\title{
EARLY MYSTICS IN TURKISH LITERATURE
}

\section{Mehmed Fuad Köprülü}

Translated, edited and with an introduction by Gary Leiser and Robert Dankoff 


\section{EARLY MYSTICS IN TURKISH LITERATURE}

Early Mystics in Turkish Literature is a translation and edition of Mehmed Fuad Köprülü's (1890-1966) Turkish masterpiece Turk edebiyatinda ilk mutasavviflar, originally published in 1918 and republished numerous times. Focusing on two great medieval poets, Ahmad Yasawī in Central Asia and Yūnus Emre in Anatolia, it examines the origin and early evolution of Turkish literature.

Using Arabic and Persian as well as Turkish sources, Köprülü describes the origin of Turkish literature and then attempts to show the continuity in its development between Central Asia and Anatolia. Furthermore, he studies these issues within the broader contexts of:

- Islam

- $\quad$ Sufism

- The genesis of Turkish culture in the Muslim world

The Turkish edition of this book was a major contribution to the study of Turkish literature, enjoying iconic status. The English edition updates and clarifies its detailed references, describes the influence of this book on subsequent scholarship, and includes a critique of the author's methods. Early Mystics in Turkish Literature is essential reading for scholars of Turkish literature and history, Islam, and Sufism.

This book has been translated into English by Gary Leiser and Robert Dankoff.

Gary Leiser is the Director of the Travis Air Museum at Travis AFB, California. He received a doctorate in Middle Eastern history from the University of Pennsylvania in 1976. He has been engaged in a long-term project of translating into English the major historical works of Mehmed Fuad Köprülü. Among those to have appeared are Origins of the Ottoman Empire and Some Observations on the Influence of Byzantine Institutions on Ottoman Institutions. His other works include the edition and translation, with Noury al-Khaledy, of al-Sulamī's thirteenth-century medical text Questions and Answers for Physicians: A Medieval Arabic Study Manual.

Robert Dankoff is Professor of Turkish and Islamic Studies at the University of Chicago. His publications include Mahmūd al-Kāshgharī, Compendium of the Turkic Dialects (D̄̄wān Lughät al-Turk), edited and translated with introduction and indices in collaboration with James Kelly; Yūsuf Khāss Hājib, Wisdom of Royal Glory (Kutadgu Bilig): A Turko-Islamic Mirror for Princes; The Intimate Life of an Ottoman Statesman, Melek Ahmad Pasha (1588-1662); Evliya Çelebi in Bitlis; and An Ottoman Mentality: The World of Evliya Çelebi. 


\section{ROUTLEDGE SUFI SERIES \\ Series Editor: Ian Richard Netton \\ Professor of Arabic Studies \\ University of Leeds}

The Routledge Sufi Series provides short introductions to a variety of facets of the subject, which are accessible both to the general reader and the student and scholar in the field. Each book will be either a synthesis of existing knowledge or a distinct contribution to, and extension of, knowledge of the particular topic. The two major underlying principles of the Series are sound scholarship and readability.

\section{BEYOND FAITH AND INFIDELITY}

The Sufi poetry and teaching of Mahmud Shabistari Leonard Lewisham AL-HALLAJ Herbert W. Mason

RUZBIHAN BAQLI

Mysticism and the rhetoric of sainthood in Persian Sufism Carl W. Ernst

ABDULLAH ANSARI OF HERAT

An early Sufi Master A. G. Ravan Farhadi

THE CONCEPT OF SAINTHOOD IN EARLY ISLAMIC MYSTICISM Bernd Radtke and Fohn O'Kane

SUHRAWARDI AND THE SCHOOL OF ILLUMINATION Mehdi Amin Razavi

PERSIAN SUFI POETRY

An introduction to the mystical use of classical Persian poems 7. T. P. de Bruijn

\section{AZIZ NASAFI Lloyd Ridgeon}

SUFIS AND ANTI-SUFIS

The defence, rethinking and rejection of Sufism in the modern world Elizabeth Sirriyeh

\author{
REVELATION, INTELLEGTUAL \\ INTUITION AND REASON \\ IN THE PHILOSOPHY OF \\ MULLA SADRA \\ An analysis of the al-hikmah \\ al-'arshiyyah \\ Zailan Moris \\ DIVINE LOVE IN ISLAMIC \\ MYSTICISM \\ The teachings of al-Ghâzalî and \\ al-Dabbâgh \\ Binyamin Abrahamov
}

STRIVING FOR DIVINE UNION Spiritual exercises for Suhrawardi Sufis Qamar-ul Huda

A PSYGHOLOGY OF EARLY SUFI SAMÂ

Listening and altered states Kenneth S. Avery

MUSLIM SAINTS OF SOUTH ASIA

The eleventh to fifteenth centuries Anna Suvorova

SUFI VISIONARY OF OTTOMAN DAMASCUS

'Abd al-Ghani al-Nabulusi, 1641-1731 Elizabeth Sirriyeh SUFI RITUAL

The parallel universe Ian Richard Netton

EARLY MYSTICS IN TURKISH LITERATURE

Mehmed Fuad Köprülü

Translated, edited and with an introduction by Gary Leiser and Robert Dankoff 


\title{
EARLY MYSTICS IN TURKISH LITERATURE
}

\author{
Mehmed Fuad Köprülü
}

\author{
Translated, edited and with an \\ introduction by Gary Leiser and \\ Robert Dankoff
}

Foreword by Devin DeWeese

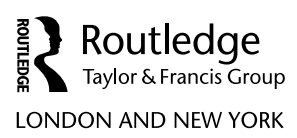


First published 2006

by Routledge

2 Park Square, Milton Park, Abingdon, Oxon OX14 4RN

Simultaneously published in the USA and Canada

by Routledge

270 Madison Ave, New York, NY 10016

Routledge is an imprint of the Taylor \& Francis Group

C 2006 Gary Leiser and Robert Dankoff

This edition published in the Taylor \& Francis e-Library, 2006.

"To purchase your own copy of this or any of Taylor \& Francis or Routledge's collection of thousands of eBooks please go to www.eBookstore.tandf.co.uk."

All rights reserved. No part of this book may be reprinted or reproduced or utilised in any form or by any electronic, mechanical, or other means, now known or hereafter invented, including photocopying and recording, or in any information storage or retrieval system, without permission in writing from the publishers.

British Library Cataloguing in Publication Data A catalogue record for this book is available from the British Library

Library of Congress Cataloging in Publication Data A catalog record for this book has been requested

ISBN10: 0-415-36686-0 (Print Edition) ISBN13: 978-0-415-36686-1 


\section{GONTENTS}

Acknowledgments

Foreword by Devin DeWeese

Translators' introduction

viii

Abbreviations

xxviii

Preface to the third edition

xxxvii

Preface to the second edition

xxxviii

Preface to the first edition

\section{PART I}

Ahmmad Yasawī and his influence on Turkish literature

1 Turkish literature before Aḥmad Yasawī 3

2 The legendary life of Aḥmad Yasawī 20

3 The historical life of Ahmad Yasawī 57

4 The khalîfas and tarīqa of Ahmad Yasawī 89

5 The work of Ahmad Yasawī 127

6 Aḥmad Yasawīss literary influence 171

\section{PART II}

Yūnus Emre and his influence on Turkish

literature

7 Turkish literature in Anatolia before Yūnus Emre 191

8 The life of Yūnus Emre 268

9 The work of Yūnus Emre 302 


\section{G ONTENTS}

10 Yūnus Emre's influence on Turkish literature and his imitators

Appendix 1: Chains of authority

385

Appendix 2: Some hymns of Yünus Emre

388

Glossary

395

Bibliography

Index

430 


\section{ACKNOWLEDGMENTS}

Presented here is a translation of Mehmed Fuad Köprülü's classic work Türk edebiyatnda ilk mutasavonflar or Early Mystics in Turkish Literature, which was first published in Ottoman Turkish in 1918. Subsequently revised and republished in the Latin alphabet of modern Turkish, it is a complex work of great range and depth relying on an array of Arabic, Persian, and Turkish sources and incorporating secondary works in several European languages. Indeed, in light of Köprülü's erudition, his son Orhon Köprülü, who edited the third edition, recommended that if a future edition were published a committee composed of scholars in various fields should be formed to bring it up to date. Translating this work into English and editing it have thus not only taken many years but also presented a number of challenges. We gratefully acknowledge the assistance, above all, of Devin DeWeese at Indiana University who wrote the foreword, provided most of the commentary on Köprülü's assessment of Ahmad Yasawī, and helped to update many of the notes. In addition, Heshmat Moayyad and John Woods at the University of Chicago clarified a number of passages in Persian. We also wish to thank Beca Lafore for preparing the maps, Kathy Kruczek for preparing the charts, Nicholas Ruiz for preparing the musical scores, Jonathan Bloom for providing a photograph of Ahmad Yasawı̄’s shrine, Berrin Dirim for providing photographs of one of Yūnus Emre's reputed burial sites, and the Mongol papercut artist Norovsambuugiin Baatartsog for making the illustrations. The Turkish Ministry of Tourism granted permission to reprint a photograph of Ahmad Yasawī's shrine from its edition of Naim-Bek Nurmuhammedoğlu's Hoca Ahmed Yesevî Türbesi (Ankara, 1991).

G. L. and R. D. 


\section{FOREWORD}

Perhaps the greatest testament to the importance of Mehmed Fuad Köprülü's Türk edebiyatinda ilk mutasavveflar (Early Mystics in Turkish Literature) is the remarkable degree to which it has shaped, during the nearly 90 years since its publication, both popular and learned ideas about the historical links between religious and literary currents in Central Asia and their counterparts in Anatolia. Ironically, therein lies also the key to both the positive and negative aspects of the work's scholarly legacy: it led the way in exploring the impact, in Anatolian Turkish society, of Central Asian Turkic religious and literary developments, yet in so doing it helped to cement a tendency to view Central Asia through an Anatolian prism, rather than on its own terms and through its own sources. The fact that such a tendency was only exacerbated by the long isolation of Central Asia, and of the sources of its religious history, during most of the twentieth century can hardly be blamed on Köprülü's work, of course. In a sense, Early Mystics may be regarded as the first substantial statement of a "western" perspective on the continuities and discontinuities of Central Asian and Anatolian cultures, and this statement should have followed, or prompted, an equally substantial statement from an "eastern" perspective; the isolation of Central Asia during the Soviet era, however, and the impact of Soviet ideology - which stunted the academic study of religious life and straitjacketed the evaluation of "national" literature ensured that there was no significant response to Köprülü's work from a Central Asian perspective. We are thus left with only one voice from what might have been, and should have been, an ongoing dialogue; and precisely because of the prominence of that one voice, and the expectation it fostered that Turkic civilization in Central Asia could be understood on Anatolian Turkish terms, a fundamental imbalance remains.

Having spent considerable time with Köprülü's Early Mystics while working on my own study of the Yasawī Șüfī tradition, I had some misgivings when I first learned that plans were under way to prepare an English translation of the book. I had decided early on that a fresh approach to the Yasawi tradition was long overdue, and that a new evaluation of that tradition would require starting from the ground up, with a substantially enlarged body of sources, new questions to ask of them, and a willingness to challenge everything that had become the 
"accepted wisdom" about Aḥmad Yasawī and his legacy; revising or updating Köprülü was precisely not the way to proceed. I am still firmly convinced of this, and I hope that the results of my efforts will soon be available; but I also became convinced that Köprülü's work had attained an iconic status that made it essential to acknowledge and take stock of the assumptions, arguments, and conclusions advanced in the book, even if wholly in the context of rejecting or challenging them. Simply put, Köprülü's Early Mystics underlies, in some measure, nearly every treatment of the Yasawī Șūfì tradition in both scholarly and popular literature that has appeared during the past 85 years; while I believe it should no longer be regarded as authoritative, its influence is undeniable, and having it available in English translation might underscore the usefulness of a fresh evaluation of where, in my view, Köprülü had gone astray, and where his pioneering work was still of value. I also recognize that Köprülü himself, naturally, was not to blame for the often uncritical repetition of his views that came to dominate scholarship, especially in Turkey, on the Yasawi tradition, and that there would be merit in revisiting what, precisely, Köprülü said and what he did not say - not only from a historiographical standpoint, but from the standpoint of marshalling evidence and arguments for or against particular aspects of Köprülü's treatment - and in this way resuming that interrupted dialogue.

So, when Gary Leiser and Robert Dankoff graciously asked me to contribute a foreword to the present English translation (and thereby gave me the opportunity to review the entire work without wading again through the 1918-era Turkish), I readily agreed. My conviction that many of Köprülü's views are in serious need of revision cannot lessen the impact of the book in its time, or the value of making it more widely accessible through a translation that is both remarkable for its clarity and an improvement, in many respects, over the original.

It should be noted at the outset that my comments are necessarily restricted to Köprülü's treatment of the Yasawī tradition, to which less than half of Early Mystics is devoted; I must leave it to others to assess the continued value of Köprülü's study of Yūnus Emre and his oeuvre, which comprises the bulk of the work, and serves as its real, central focus, for which discussion of the Yasawi tradition was preparatory. Yet Köprülü's work has in many respects held a more central place in the study of the Yasawi tradition than in the study of Yūnus Emre and other Anatolian Turkish poets and Șūīs; scholarship on the latter has grown steadily since the appearance of Early Mystics, but scholarly attention to the legacy of Ahmad Yasawī largely stagnated for nearly 70 years, with few new sources brought to light, and few new approaches adopted, beyond what Köprülü already employed. It is, moreover, in connection with the Yasawī tradition, and its presumed legacy in Anatolia, that the absence of a Central Asian perspective has been particularly unfortunate, and that imbalance of voices referred to above may in itself justify limiting my remarks to the Yasawī tradition.

The pioneering character of Köprülü's work was evident soon after its publication, in its warm reception by European scholars; the remarkable range of summaries and reviews in European languages attests to the interest and 
admiration the work evoked. It had less impact, initially, in Turkey, as is discussed in the preface to the work's second edition, in Latin script (which appeared only in 1966, nearly half a century after the original publication), but its reputation and influence grew along with Köprülü's status as the pre-eminent scholar of Turkey's new republican era. Köprülü himself understood the work as an important model for the application of critical methods developed in European scholarship, and he stressed the value of the many primary sources first brought to light in Early Mystics; the methods adopted and the sources utilized remain among the most important and enduring contributions of the work (far more than specific arguments and conclusions), and Köprülü's achievement is all the more remarkable when we consider that he was only 28 years old when he completed it.

Ironically, some of the clearest reminders of the pioneering character of Köprülü's work are to be found among the most obsolete of his long footnotes. When he wrote, he could not draw upon an extensive scholarly literature on Șūfì mystical philosophy, or on the history of the Turks, or on Central Asian poetry; such issues had not been explored, in some cases, any more thoroughly than had the life and legacy of Ahmad Yasawī, and while few would today cite much of the secondary literature he was compelled to consider on these and other subjects, much of which has been entirely superseded, we must acknowledge the breadth of his scholarship, as he addressed issues into which few had ventured before him, often supplementing his references to the relatively rare scholarly treatments of these topics with explorations in primary sources that up to his time had remained largely unexamined. The same need to prepare ground that then remained unworked no doubt reduced the time and space he could devote to the more specific subjects of his work; if we wish that Köprülü had delved more deeply into specific narratives or issues raised in the work, for example, we must remember that he felt constrained to deal with literary and religious developments and currents for which a few citations to standard treatments not yet created in 1918 would suffice today.

With due homage to the work and its impact, however, it will perhaps be useful to outline what were, in my view, the chief shortcomings in Köprülü's Early Mystics, and to indicate where and how the most substantial corrections or additions to Köprülü's presentation are to be made; doing so will not only suggest where scholarship has gone since his work appeared - or, more often, where it still needs to go - but also suggest the extent to which the flaws in the book were virtually inevitable given the state of scholarship at the time it was produced, rather than the result of scholarly deficiencies on Köprülü's part.

To begin with, there is little point in faulting Köprülü for the frequent nationalist tone in the work, and the emphasis upon asserting the intrinsically Turkish character of the cultural trends he sought to trace from Anatolia back to Central Asia; he was quite open about the "national" purpose of his endeavor, insisting that the "popular Șūfi literature" he believed was represented by both Aḥmad Yasawī and Yūnus Emre was an important element of the distinctive "national character" of the Turks, whose noble cultural heritage had been too long 
submerged, first by the dominance of Persian influence and later by European influence. While we may disagree with that stance, with the conscious insertion of such views into scholarly research, and with specific approaches or conclusions or judgments that seem to arise from these ideological foundations rather than from a sober assessment of the sources, Köprülü was straightforward about his agenda, and readers can easily ignore or suspend the obviously nationalist interpretations while still profiting from his analysis and the sources he adduced.

It is also to Köprülü's credit that he called, in his preface, for his work to be received as "a modest guide for future research"; this reminds us that he is hardly to be held accountable for what was perhaps the most unfortunate and pernicious aspect of his work's legacy, namely the slavish repetition of his views and the material he brought forward. No doubt Köprülü himself would have been dismayed at the elevation of his work as an unassailable scholarly icon, and at the tendency of later scholars to cite his "guide" as the final word on many subjects; at its worst, this tendency has led many writers to ignore, and thereby dishonor, Köprülü's own example of seeking and bringing to light new primary sources, and has even seemed to discourage the re-examination of sources already consulted by Köprülü, as if nothing more could be learned from them. Again, Köprülü can scarcely be criticized because the pioneering character of his work prompted the uncritical repetition of his views, and the wide-scale neglect, especially among Turkish scholars, of sources on the Yasawi tradition beyond those already cited by Köprülü; yet because so much of the subsequent discussion of Ahmad Yasawī and of the Yasawi tradition is simply derivative and uninspired, it is inevitable that a critique of the prevailing views will be targeted at Köprülü's Early Mystics, the source, rather than at the more easily dismissible rehashings of his work.

By far the most important factor limiting the value of Köprülü's presentation of the Yasawi tradition (including the life and legacy of the tradition's eponym) was one largely beyond his control or remedy, namely his lack of access to the vast majority of essential sources produced in Central Asia among Yasawī Sụ̂ī communities and their Naqshbandī and Kubrawī rivals. For his material on Yasawī history and the life of Ahmad Yasawī, Köprülü's chief source was a manuscript, preserved in the library of Istanbul University, that contains, I believe, two works from the late sixteenth century by a Yasawī shaikh known as Hazinn̄, a native of Hișār (west of Dushanbe in present-day Tajikistan) who established himself in Istanbul; ${ }^{1}$ in addition, Köprülü made extensive use of the important Naqshbandī hagiographical compilation from the beginning of the sixteenth century, the Rashahāt-i 'ain al-hayāt (though only through an Ottoman translation from the end of the same century), as well as a few small treatises produced in Central Asian Naqshbandī circles, and he had access to the sixteenth-century poetic anthology of Khwāja Hasan "Nithārī”" Bukhārī, the Mudhakkir-i aḥbāb, which includes interesting material on the Yasawi tradition. He was also able to consult a printed version of an important popular hagiography devoted to Hakīm Ata, a figure typically cast as one of Ahmad Yasawī’s chief disciples. Otherwise, 
Köprülü relied on Bektashī narratives about Aḥmad Yasawī as well as on Ottoman accounts claiming Aḥmad Yasawī’s spiritual ancestry of various Anatolian saints, and, of course, on the collection of poetry ascribed to Ahmad Yasawī, the Dīwān-i Hikmat.

These sources retain their importance for the study of Yasawi history, but entire Yasawī lineages, and entire narrative cycles surrounding Ahmad Yasawī, would remain unknown (as they were to Köprülü) without access to a host of other works. At the top of the list of sources whose absence from Köprülü's purview severely limited his treatment of the Yasawi tradition is undoubtedly the most important single source on Yasawī history, the Lamaḥät min nafahăt al-quds, completed in 1035/1626 by an important Yasawī shaikh, Muhammad al-'Álim al-Șiddīqī al-'Alawīe known as 'Ālim Shaikh of 'Alīyābād; this work, though occasionally cited from manuscript or lithograph copies, and published in facsimile in $1986,{ }^{2}$ remains largely unexplored, but is of vital importance for the history of the Yasawī Sūfī communities of Mawarannahr (Transoxiana), and for traditions about Ahmad Yasawī himself. ${ }^{3}$

Köprülü was also unaware of several sources produced before the sixteenth century, i.e. before the Rashahăt, whose account of the Yasawī silsila (genealogy of spiritual affiliation) shaped the presentation found in nearly every subsequent source produced outside Yasawī circles themselves. For instance, Köprülü wrote Early Mystics without consulting the important Chaghatay Turkic work of Mīr 'Alī-Shīr Nawā' $\overline{1}$, the Nasā'im al-mahabba, a translation, with additions (including precisely the valuable accounts of the Turkic shaikhs), of Jāmī's Nafahāt al-uns; Köprülü later learned of Nawâ' $\overline{1}$ 's work and wrote a brief article outlining its information on saints of the Yasawi tradition, ${ }^{4}$ but its material was not incorporated into, or even acknowledged in, later editions of Early Mystics. Köprülü was also unfamiliar with many other works, of hagiographical and doctrinal orientation, produced within various Șûfi communities of Central Asia during the fourteenth and fifteenth centuries, which must be taken into consideration when outlining this early phase of Yasawi history; of special importance are works produced within Khwājagānī communities, precursors to the Naqshbandiyya, which shed crucial light on the extremely complicated question of the relationship between the Yasawī and Naqshbandī traditions.

Another extremely important early source on the Yasawi tradition is the Turkic work of Ishāa Khwāja, the son of Ismā'îl Ata, which survives in two redactions, one of which bears the title Hadiqqat al-'arifin. This work, from the middle of the fourteenth century, is not only an important (and still virtually unknown) example of Central Asian Turkic prose, but is a vitally important source on one prominent Șūfì community that traced its origins to Ahmad Yasawī. Manuscripts of the two redactions are preserved in Tashkent and Kabul, and a fragment of the work, preserved in Uppsala, was mentioned by Köprülü in his later article on Ahmad Yasawī in the Turkish edition of the Encyclopaedia of Islam. ${ }^{5}$ The important Kabul manuscript was noted briefly by Zeki Velidi Togan, ${ }^{6}$ but the Tashkent copies have not even been described in a published catalogue (I first 
learned of them in 1984 while working in Tashkent, and published an article in 1990 citing one copy; ${ }^{7}$ I have noted the work in two other articles on the Yasawi tradition, ${ }^{8}$ and another copy has been cited in works by Ashirbek Muminov, ${ }^{9}$ but a full discussion of the work will appear in my forthcoming study of the Yasawi tradition). The Ismā $\overline{1} l$ Atā' $\overline{1}$ tradition reflected in the two redactions of this work is in fact reflected in a wide range of Central Asian hagiographical works produced from the fifteenth century to the nineteenth, but was completely unknown to Köprülü, and remains largely unknown in scholarship that has looked to Köprülü for the last word on the Yasawi tradition; its study offers many correctives to our understanding of Yasawi history, however, and I would argue that the work of Ishạa Khwāja b. Ismā̄îl Ata should, and will, displace the problematical Dĩwān-i Hikmat as the most prominent Turkic-language legacy of the Yasawī tradition.

Considering its continued obscurity, Köprülü can hardly be faulted for not knowing the work of Ishāq Khwāja, and the Lamaḥāt too appears not to be represented in the rich manuscript collections of Istanbul; nevertheless, either one of these sources alone adds sufficient new material, and new perspectives, to render much of Köprülü's treatment of Yasawī history utterly obsolete.

While the body of sources produced within other (i.e. non-Ismā' $\overline{1} l$ Atā' $^{\prime}$ ) Yasawī lineages of Central Asia is not large, these sources too are obviously important for an internal perspective on the Yasawī tradition; none of them, however, was known to Köprülü. The earliest such work, produced within the best-known Yasawi silsila, is a treatise in defense of the vocal dhikr (remembrance of God in a Șūfì séance), the Ta'ťm al-dhäkirīn, completed in 947/1541, by a disciple of the pivotal Yasawī shaikh Khudāidād, and preserved in manuscript in St Petersburg and Bukhārā; the corpus of specifically Yasawī hagiographical literature from Central Asia includes, beyond the Lamahāt, the Hüjat al-dhākirīn of Mawlānā Muhammad Sharīf of Bukhārā, completed in 1080/1669-70 (represented in manuscript collections of St Petersburg, Tashkent, and Istanbul), as well as the Manāqib al-akhyār, produced in 1036/1626 within a lineage descended spiritually as well as naturally from the Yasawī saint Sayyid Ata, and known from two manuscript copies, in London and Rampur. ${ }^{10}$

Yet another body of important "internal" Yasawī sources is the larger repertoire of works, in Persian and Turkic, by the same Hazīnī who wrote the Turkic Jawāhir al-abrār and the acephalous Persian work preserved in the manuscript from the library of Istanbul University that Köprülü used long ago; that manuscript has now been published ${ }^{11}$ (the Fawähir in transcription, the Persian work in facsimile), but Hazīn̄'s other works remain unpublished. They include the early Jāmi' al-murshid̄̄n (in Persian, commissioned in Damascus by 'Alī Chelebī Qïnalïzāde (d. 979/1572), finished in 972/1564-5, and preserved in a unique manuscript in Berlin); the Hujjat al-abrār (in Persian, completed in 996/1588, and preserved in a unique manuscript in Paris, which contains also other short works by Hazīn̄ of biographical interest but less important for Yasawī history); and the Turkic Manba' al-abhār (written in 995/1587, preserved in a single manuscript in the Süleymaniye Library in Istanbul). 
Later non-Yasawī hagiographical works produced in Central Asia are also vital for tracing the Yasawiyya into the middle of the eighteenth century (when it essentially disappears from our sources as a distinct Șūfì community); chief among these are the Thamarāt al-mashä'ikh from late seventeenth-century Bukhārā; the Ashjār al-khuld, completed in 1139/1726 by a Kashmīrī author; the Tadhkira-i Tāahir İshān, compiled by a Khwārazmian author from the mid-eighteenth century; and the untitled work of Mīr Musayyab Bukhārī, from the middle of the nineteenth century. Most of these works are preserved only in manuscripts held in collections of the former Soviet Union, and were thus long inaccessible to scholars from outside the USSR; they were also generally uninteresting to Soviet scholars, given Soviet attitudes to religious matters, and the resulting neglect of such sources, which continued into the 1980s, was clearly as much a factor in the slow pace of Yasawī studies as the dominance of Köprülü's presentation of the Yasawi tradition.

To these sources, finally, we may add the growing body of texts reflecting genealogical traditions linked to the family of Ahmad Yasawī; these texts, preserved chiefly in private hands in Kazakhstan and Uzbekistan, have only recently begun to be discovered and published, thanks largely to the efforts of local scholars (above all Ashirbek Muminov and Zikiriya Zhandarbekov).

Perhaps less consequential than the many primary sources unknown to Köprülü, but worth noting in any case, was his lack of access to important publications in Russian, in which the most substantial information on Central Asia, and on the Yasawi tradition there, available in the years preceding the completion of Early Mystics was published; Russian, naturally, was the language of scholarship in the state to which Ahmmad Yasawī’s homeland belonged when Köprülü was preparing his work. Köprülü did occasionally have access to Russian scholarship through translations into French (as in the case of Bekchurin's important description of the Yasawi shrine complex) or German (as with some of Barthold's works), but he could not consult, for example, the extensive discussions of Yasawī's shrine and the practices related to it preserved in works of N. S. Lykoshin, and expressly lamented the inaccessibility of what was undoubtedly the most important product of the pre-Köprülü phase in the study of the Yasawī tradition, the article of the Russian Orientalist K. G. Zaleman, in which he published, together with the entire text of an important and popular Turkic hagiography on Ahmad Yasawī's disciple Hakīm Ata, excerpts from several Persian hagiographies dealing with Yasawi saints. ${ }^{12}$

In addition to the essentially bibliographical shortcomings noted so far - which one might reasonably argue were more than offset, for its time and for the first serious, if tentative, examination of the Yasawi tradition, by the previously unstudied sources first introduced to scholarship in Early Mystics - there are other problems, of approach and method, that deserve to be noted.

(I) In utilizing the material he was able to consult, Köprülü sought to apply the critical methods of European historical scholarship; in this he largely succeeded (though occasionally his handling of the sources is less than transparent), but 
inevitably, of course, the approaches and attitudes of 1918 seem dated today. This is especially true in the case of Köprülü's approach to the material he casts as legendary; it combines a positivist historian's clear demarcation of sources deemed "legendary" from those deemed "historical," on the one hand, with, at times, a surprisingly uncritical attitude to sources of both (essentially artificial) classes. For instance, he immediately denounces the miraculous as a sign of a merely "legendary" narrative and source, but accepts straightforwardly stories affirming a relationship between two shaikhs, or presenting a chain of transmission, or asserting a particular practice as normative; he seems not to have considered that the retrospective construction of silsilas and relationships, for polemical or even merely didactic purposes, might be as injurious to "historicity" as the polemical or didactic use of miracle stories, and time and time again he misses opportunities to explore genuinely important and revealing historical issues by asking more fruitful questions of the rich narrative material to which he alludes (more fruitful, that is, than "did it really happen?"). In the same vein, he often lets literary merit and reputation cloud his approach to source criticism, as when he trusts the illustrious Jāmī's accounts from the Nafahāt al-uns over accounts by less exalted (or anonymous) hagiographers, without recognizing that Jāmī himself adopted many of his accounts from precisely such hagiographical works (and often with evident disregard for fidelity to his source); likewise, one senses that Köprülü regarded "legends" recorded by Evliyā Chelebi or Muṣtafā 'Ālī as somehow more valuable than their counterparts recorded in the anonymous velāyetnāmes of Bektashī saints.

We are fortunate, to be sure, that Köprülü had sufficient respect even for "legendary" sources, as evidence of the popular apprehension of a saint's legacy, to recount the stories in his work (however much he abbreviated or "rationalized" the narratives); but by casting such narratives only as indications of a saint's popular appeal, Köprülü evidently felt freed from the need to analyze them seriously, and so failed to explore the actual structure and content of the narratives for clues to the issues that mattered to those who created and circulated the stories.

At times, moreover, Köprülü's handling of his sources is frustratingly vague and imprecise. His presentations of Ahmad Yasawī's "legendary" life, for instance, and many other expositions of narrative accounts, typically skip from one source to another without specifying which he is following at a given time; by failing even to distinguish elements preserved in Bektashī tradition from those found in Hazīn̄’s work, Köprülü not only abdicated his own responsibility to contextualize each source and the material it adds to Ahmad Yasawī's persona, but prevented even his reader from taking up that task. Instead, he lumped together various sources as "books of legends" and implied that their accounts are in agreement, or are fundamentally harmonizable: thereby he ignored, and obscured, the important historical evidence that may often be derived from the discrepancies and contradictions among sources. A similar tendency is evident in his argumentation on literary history; he frequently insists, for example, that the "influence" 
of one poet on another is "obvious," and so never takes time to demonstrate it, or to explain the precise nature of the "influence" he has in mind.

(II) The Anatolian Turkish prism used by Köprülü for viewing Central Asia was noted at the outset of these remarks, but its consequences are worth fuller consideration. His lack of knowledge of the history of Central Asia, and especially of its religious history (above all in the period from the fifteenth century to the nineteenth) is understandable given the time when he wrote, but it left Central Asia essentially a blank screen upon which Köprülü felt free to project religious, cultural, and literary developments known to him from Anatolia; in this way he could insist that features of religious or cultural life among the Turks of Anatolia and the Ottoman realm that could not be traced to an essentialized "Islamic" source must go back, if not always to the pre-Islamic traditions of the Turkic nomads of the steppe (a source in fact invoked quite often), then at least to the synthesis of Turkic and Islamic traditions (equally essentialized, in both cases) that Köprülü imagined had taken place in Central Asia. It is immediately evident that such an approach is faulty, but the reconstruction of Islam's history in Central Asia on the basis of such projections from the Turkish experience in Anatolia has been far more common than the use of actual sources from Central Asia itself certainly in Turkish scholarship, but also in European and American academic circles, where familiarity with the Ottoman world was, and remains, far more widespread than any direct acquaintance with Central Asia's Islamic heritage.

This approach continues to predominate among Turkish specialists, and colors our understanding not only of the Yasawi tradition, but of the entire religious history of Central Asia as well. It was adopted even by scholars who followed not the views presented by Köprülü in Early Mystics (where he emphasized the Yasawī tradition's place in the mainstream of Sunnī Șūfì movements), but those he championed later, namely the notion that the Yasawī tradition, like the Bektashiyya that supposedly sprang from it, was from its inception a "heterodox" movement shaped more by antinomian disregard for juridical norms, and by an eager receptivity to non-Islamic "influences," than by "normative" Islam. To some extent it is Köprülü's very use of such terms as "orthodox" and "heterodox" that is disturbing today, as students of Islamic religious history struggle to shake off the simple dichotomies such terms imply, but there is a more substantive issue involved here even if we grant him his terminology: Köprülü was paving the way for projecting a "tainted" Islam, either rife with "shamanic" holdovers from pre-Islamic Turkic religion or colored by excessive compromises with presumed "popular" religious tastes, as the wellspring of the Yasawī tradition, and, by extension, as the central religious profile of the Turks of Central Asia. Such a view is utterly indefensible from the standpoint of Central Asia's religious history, and of the Yasawī tradition's own sources, but it has nevertheless been remarkably persistent in some scholarly circles (no doubt because it harmonized well with certain approaches to Islam in twentieth-century Turkey).

(III) Through the sources he was able to use, his approach to those sources, and his lack of grounding in the Central Asian environment in which the Yasawī 
tradition took shape, Köprülü in effect fixed in scholarly literature the key elements of what became the standard view of Ahmad Yasawì's life and legacy. Each of these elements would require extensive evidence, and extensive argumentation, to challenge; it may nevertheless be worthwhile briefly to review the most important of them, and why they need revision, without here marshalling the evidence and arguments to be assembled elsewhere.

(1) Chronology. Köprülü appears never to have questioned the reliability of the date, 562/1166-7, given in some sources as that of Ahmad Yasawī's death; at one point he credits "tradition" for this date, while elsewhere he claims that "all the different biographical dictionaries" are in agreement on this date. Of the sources Köprülü used, however, only the late (nineteenth-century) Indian hagiographical compendium of Ghulām Sarwar Lāhawrī, the Khazinat al-asfiyā, gives that date (neither the Rashahāt nor Hazīnī gives any date at all); the date does appear in earlier sources unknown to Köprülü (though in none of Yasawī provenance), but can be traced back no further than the second half of the sixteenth century (i.e. four centuries after the claimed date of the saint's death). Köprülü's lack of skepticism about this date, especially considering the source in which he must have found it, is remarkable; there has never been any good reason to assume that it is reliable, and substantial evidence bespeaks a somewhat later date for Ahmmad Yasawī’s death. Nevertheless, Köprülü's affirmation of 1166-7 did much to entrench this date in subsequent literature ever more firmly, and still today, following Köprülü's example, scholars continue to make arguments about other issues - the political environment in which Ahmad Yasawī lived, the reliability of specific traditions about his spiritual training, the linguistic and literary peculiarities of the poetry ascribed to him, the direction of literary or religious influence, etc. - as if this date were incontrovertibly established.

(2) Ahmad Yasawī's family. In his discussion of the saint's immediate family, Köprülü not only glossed over important, and telling, discrepancies between Hazīn̄'s account and that of the Rashahăt, for instance, but failed to consider the impact of subsequent familial groupings on the presentations of Ahmad Yasaw $\overrightarrow{\mathbf{1}}$ 's family that came to be preserved in various sources. It is typical of Köprülü's treatment of the sources that Hazīnī's account of Ahmad Yasawī's father, mother, and sister is accepted at face value, while the miracle tale for which these relationships merely set the stage is relegated to the purely "legendary" material; a fruitful interpretation of hagiographical narratives, however, must not only explore the historical circumstances reflected in accounts of the miraculous, but also envision the possibility that specific formulations of familial connections, or of genealogy, or of spiritual lineages, might distort historical reality every bit as much as (or more than) miracle stories.

(3) The role of Arslan Bābā. Köprülü accepted the story that Aḥmad Yasawī received his initial spiritual training from Arslan Bābā, and regarded the latter as a historical Șūfì teacher. While Köprülü did not explicitly support some of the more egregious transformations of Arslan Bābā - into a quasi-shamanic purveyor of pre-Islamic Turkic religious practices, or, more recently, into a representative 
of a particular sectarian movement in Central Asia - his insistence that he was, in effect, a venerable teacher who trained Ahmad Yasawī in his youth helped to set the tone of most subsequent treatments of Arslan Bābā. In fact the extant traditions about this figure most likely reflect very different religious currents, and it is quite unlikely that Arslan Bābā should be thought of as a historical Șūfì teacher.

(4) Aḥmad Yasawī’s spiritual training and Șūfì silsila. Köprülü accepted the story, found in the Rashahāt (and other sources), that Aḥmad Yasawī’s Ṣūî master was Yūsuf Hamadānī, and that the latter was also the master of the spiritual ancestor of the Khwājagān and the Naqshbandiyya, 'Abd al-Khāliq Ghujduwānī. This in itself is not surprising, since nearly every scholar who has had occasion to refer to Aḥmad Yasawī’s place in Șūfì tradition has accepted the same story. What is disturbing, however, is that Köprülü ignored the clear assertion by Hazīn̄i that Ahmad Yasawī belonged to a Suhrawardī lineage (a point underscored by other "internal" Yasawī sources as well). The likelihood that the Rashahăt's account reflected a contrivance to show Ghujduwānī's superiority over Yasawī seems clear enough from the story itself, but even if Köprülü did not think to question this, he certainly should have acknowledged the possible significance of a quite different view of Ahmad Yasawī's silsila affiliation, as found in the very "internal" Yasawī source whose importance Köprülü rightly recognized; that he did not was clearly connected with his acceptance of the death-date discussed above, and here we can begin to appreciate the web of interwoven assumptions and conjectures, which seem to support one another but in fact have no firm foundation, that fill Köprülü's treatment of the Yasawī tradition. In fact, Ahmad Yasawī is portrayed as a pupil of at least two other shaikhs, besides Yūsuf Hamadānī, and the tradition surrounding his relationship with Yūsuf Hamadānī is in many respects the most problematical of these, for a host of chronological, historical, and textological reasons.

(5) Aḥmad Yasawī's life as a Ṣūî teacher. As noted, Köprülü weaves together traditions from several sources to create a seemingly seamless biography for the saint; after returning to his hometown of Yasī/Turkistān and there training his disciples, the story goes, Ahmad Yasawī withdrew from worldly attachments at the age of 63 and lived in his "retirement" cell (where he wrote much of his poetry) until his death at an advanced age. Köprülü treats this as a relatively straightforward account of the course of Ahmad Yasawī's life, extracting it from a rich body of narratives circulated, in all likelihood, more to advance specific competitive or didactic agendas than to provide a simple biographical account; moreover, he presents it shorn of the miraculous elements he found so disturbing. For instance, what Köprülü interprets as the saint's "retirement" is actually presented in the sources as his enclosure in a subterranean cell, in which he continues to perform various miracles; Köprülü mentions the miracles as part of Aḥmad Yasawī's "legendary" life, assigns his "retirement" to his "historical" life, and invents the idea that he wrote his poetry in this historical retirement, without considering that the entire body of narratives might be explored not as a mixture 
of purely legendary elements and elements rooted in historical fact, but as a multivalent complex of symbols and traditions combined for specific religious purposes that did not include the confirmation of external biographical details.

(6) The Yasawī order. Köprülü took it for granted that Ahmad Yasawī consciously intended to create a Șūfì order, which was maintained in an unbroken line from the founder down to the latest affiliates Köprülü could find in sources available to him; thus he assumed that the principles and practices of the order outlined by Hazīnī existed largely unchanged from the time of Ahmad Yasawī himself. In fact, the silsila of the Yasawī order known from the fifteenth to the eighteenth centuries is extremely problematical in its earliest phases, leaving the question of the order's continuity, and the possible retrospective formulation of the silsila, fraught with uncertainty. To be sure, Köprülü's treatment of the Yasawī order in Central Asia was perfunctory at best, comprising less than a single page in his text, and the full ramifications of the various lineages could have been understood only through the use of sources unavailable to him; but it is unclear why Köprülü did not explore more carefully the information available to him in Hazīnī's acephalous Persian work, and in the Rashahāt, about the Yasawī silsila in the fifteenth and sixteenth centuries.

(7) The Yasawī presence in Anatolia. Köprülü laid the foundations for the most unfortunate aspect of what became the standard view of the Yasawi tradition, namely the view that Aḥmad Yasawī’s real legacy, both in Ṣufism and in poetry, lay not in Central Asia, but in the Betkashī tradition of the western Turkish cultural sphere, where it spread through the arrival, in the west, of "refugees" from the Mongol invasion. Köprülü was careful, in Early Mystics, to distance the historical Aḥmad Yasawī from the later Bektashī tradition (and, indeed, to distance Hajjī Bektash from that tradition); nevertheless, his emphasis upon Bektashī sources, and upon Anatolian traditions about saints incorporated into the Bektashī tradition, as the prime repository of Ạmad Yasaw's's memory and legacy - an emphasis that was itself an artifact of the inaccessibility of Central Asian sources - served to cement the assumption that the way to study the Yasawī tradition was to study the Bektashiyya, and more generally the currents of Anatolian Șufism that were believed to have been shaped in Central Asia. Inevitably, this tendency was only intensified by Köprülü's much-heralded - but certainly, in my view, misguided - change of mind, when he concluded that Anatolian works of Bektashī, Haidarī, and Bābā' provenance were more reliable sources on Aḥmad Yasawī and his legacy than were other works he implicitly dismissed as dominated by Naqshbandī influence. This view, though challenged in an important article ${ }^{13}$ continues to shape the predominant understanding of the Yasawī tradition in Turkish scholarship, and in much European and American scholarship as well (it is perhaps best represented today in the works of Ahmet Yaşar Ocak and Irène Mélikoff); it is at present a key obstacle, in my view, to improving our understanding of the Yasawī tradition.

(8) Aḥmad Yasawī’s poetry. The centerpiece, finally, of Köprülü's treatment of the Yasawi tradition is, of course, the Dīwān-i Hikmat. It was through this 
compilation that Köprülü sought not only details of Aḥmad Yasawī’s life and spiritual training, but the substance and spirit of his religious message; the Dĩwann was, for Köprülü, the encapsulation of Ahmmad Yasawī's central mission, namely the spread of Islam among the Turks (and its adaptation to Turkic tastes). The Dīwān, indeed, underlies the whole of Early Mystics, for the presumed influence of Ahmad Yasawī's poetry on that of Yūnus Emre, which was in fact Köprülü's central concern, provided the rationale for the entire book.

Köprülü's understanding of the Dīwān is problematical in many respects. His assumption of a "missionary" purpose for a book of Șūfì poetry has been influential, but is unconvincing, and in all likelihood obscures the actual audience for which the Dīwān was compiled. Similarly, his emphasis on a religious mission defined in purely "national" terms is as anachronistic as his attitude to the Dīwān's presumed audience is condescending. We are repeatedly reminded that the Turks whom Ahmad Yasawī was seeking to reach through the Dīwān were simple and unsophisticated, and needed a dumbed-down version of Islam and Șūfism - which, luckily, Aḥmad Yasawī was perfectly suited to provide, since he was, as Köprülü uncharitably characterizes him, not only a poor poet with a "very simple" imagination, but also a poor representative of what is best in Șūfism. Indeed, Köprülü seems less intent upon a serious study of the Dīwān, which, he declares, lacks any "significant aesthetic value," than upon holding it up, at a distance, as the presumed inspiration for - yet, ironically, as but a pale foreshadowing of - the vibrant poetry of Yūnus Emre. Such a conclusion is borne out if we compare his treatment of the verse he ascribes to Ahmad Yasawī with his treatment of Yūnus's poetry; the latter is quoted at length and subjected to considerable stylistic and semantic analysis, but Köprülü never fully engages with the Dīwān as a whole or even with a single poem contained in it (his citations from the $D \bar{\imath} w \bar{a} n$ are quite sparse, in fact, and are rarely analyzed in any depth). Köprülü's dismissal of the aesthetic quality of the poetry ascribed to Ahmad Yasawi is naturally at odds with the contemporary rediscovery, or reassertion, of the presumed role of the Yasawī tradition as a bridge between Turkey and Central Asia, and it underscores a somewhat discordant parochialism (shaped, perhaps, more by Köprülü's views on Islam and Șufism than by any conscious deprecation of Central Asian culture); yet as Köprülü contrasts what he sees as the rigid pieties and choked asceticism of the Dīwān-i Hikmat with the sort of freewheeling and "broadminded" Șūfì poetry he obviously prefers, as exemplified by Yūnus Emre's verse, we may rightly suspect that the "national" mission he set for himself was indeed restricted to the western Turks, and did not include the Turks of Central Asia, whose love for the dry and artless poetry ascribed to Aḥmad Yasaw̄i is implicitly belittled in Köprülü's presentation. ${ }^{14}$

Alongside all these problems in his treatment of the Diwann-i Hikmat, however, Köprülü failed to come to terms with a much more basic question: is the Dīwān indeed the work of Ahmad Yasawī? My own study of the Yasawī tradition has convinced me that it cannot be regarded as such in any meaningful sense; more decisive, in my view, than the issues many others have pointed out - the clearly 
compilative character of the Dīwān, the late date of surviving manuscripts, the anachronistic references to Yasaw's shrine, the inclusion in it of verse by many poets, and the wholly Chaghatay character of its language - is the simple fact that, until the nineteenth century, none of the many sources through which the history of the Yasawi tradition can be reconstructed ever affirms that Ahmad Yasawī was regarded as the author of an extensive body of mystical verse, or of aphoristic sayings, much less of a collection of poetry called the Dīwān-i Hikmat (by contrast, many sources affirm, quite early and consistently, that Hakīm Ata, who is typically cast as Ahmad Yasawī's disciple and whose very appellation links him, etymologically, with the utterance of hikmats, was widely known for his aphoristic sayings and mystical verse, and we can trace in the sources a number of aphorisms ascribed first to Hakīm Ata, or to the masha'ikh-i turk in general, for which credit is later transferred to Aḥmad Yasawī).

Köprülü seems to have at least been aware of the irony to which he in fact never explicitly calls attention, namely that Ahmad Yasawī the poet, and his Dĩwān-i Hikmat, go strangely unmentioned in the many Turkic literary works from Central Asia that one might expect to have paid homage to the earliest Turkic Șūi poet. His response to this silence is in effect an appeal to class warfare. In an extreme version of the two-tiered view of "high" and "low" culture, Köprülü insists that Ahmad Yasawī’s verse reflected folk tastes, and that the court poets (and their anthologists) held those tastes in contempt and so failed to mention the poets, or repeat the poetry, that appealed to them. ${ }^{15}$ Such a claim is nonsense in many regards, but perhaps it will suffice to recall the silence of Mīr 'Alī Shīr Nawā' the richness of Turkic as employed among all classes - about any poetic legacy of Ahmad Yasawī; as his Majālis al-nafă'is shows, Nawā' $\overline{1}$ was more than happy to name a poet and cite his verse while belittling his metric skill. Similarly, though Köprülü did not know the work when he wrote Early Mystics, Nawā's's Nasā'im al-mahabba - like the Rashahāt, which Köprülü did know - stresses Hakīm Ata's renown for aphoristic sayings, but mentions neither verse nor sayings in connection with Aḥmad Yasawī.

Köprülü, to be sure, went further than any of his predecessors in "distancing" Aḥmad Yasawī from the Dīwān, acknowledging that not all of the poems in it, or even all the poems in it ascribed to "Ahmad," could be the work of Ahmad Yasawi; he expressly rejected the naive tendency to accept the extant Dīwān-i Hikmat as a simple collection of Ahmad Yasawī's poetic production. Yet he never seems to have questioned whether Ahmad Yasawi in fact wrote any poetry at all; on the contrary, Köprülü assumed not only that he did, but that poems added to the $D \bar{\imath} w a \bar{n}$ by later poets were inevitably modeled on Ahmad Yasawī's verse, in form and content. Herein lies, I believe, the most breathtaking leap, and the most serious problem, in Köprülü's treatment of the Dīwān - which, again, colors his entire discussion of that work's presumed influence on Yūnus Emre and Turkic poetry in general: even if we suspend our skepticism and accept that Aḥmad Yasawī must have written poetry of some sort, we might still protest that 
Köprülü never indicates how, precisely, we may judge which poems were Ahmad Yasawī's and which reflected the work, or adjustment, of later poets; ${ }^{16}$ Köprülü's answer, in essence, is to insist that we need not trouble ourselves to make such a judgment, for even if we cannot identify a single poem that has survived unchanged as the work of Ahmad Yasawī, we can be sure that the verse in extant versions of the Dīwān-i Hikmat genuinely reflects the "spirit" and "literary personality" of Ahmad Yasawī.

In this way Köprülü formulated a mechanism for, in effect, saving the connection between Ahmad Yasawī and the extant Dīwān: starting from the assumption that Ahmad Yasawī wrote poetry (an assumption he never examines or questions), he declares that even if we do not have direct access to that poetry, we can know what it was like on the basis of other poets' contributions, since, Köprülü is sure, those other poets modeled their verse on Ahmad Yasawī's. The reasoning is circular, of course: Ahmad Yasawī wrote poetry, his poetry influenced his followers' poetry, their poetry appears and may even predominate in the Dīwān, and so even if we cannot point to a single poem from the Dīwān as demonstrably the work of Ahmad Yasawī (as in fact Köprülü never does), we can be certain that the verse in the Dīwān closely reflects the missing verse of Ahmad Yasawī.

It is, of course, doubly ironic that Köprülü takes the trouble to pursue this dubious argument, with the aim of linking the Dīwān to Ahmad Yasawī, only to disparage the Dīwān as aesthetically deficient, and Aḥmad Yasawī as an inferior poet. But by maintaining that the Dīwān reflects the "literary personality" of Aḥmad Yasawī, Köprülü felt justified, we may presume, in a wide range of assertions about the place of the Dīwān in Turkic literary and cultural history. Thus, for instance, Köprülü writes with unblinking certainty that when (not if) an early copy of the Dî̄an-i Hikmat is discovered, it will reveal linguistic features characteristic of the eleventh-century Kutadgu Bilig; but until such an early copy is brought to light, Köprülü insists that we can still discuss the linguistic features it must have reflected on the basis of the period and environment in which Ahmad Yasawī lived, and of our certainty that he wrote the "original" poetry that inspired later additions to the Dīwān.

In the final analysis, it is not Köprülü's argument by itself that is particularly lamentable; had it provoked the debate that he himself no doubt would have welcomed, it would not have had the stultifying effects on Yasawi studies that it in fact did have. However, the conclusions based on this argument were repeated again and again, with reference to the by-then-iconic Köprülü, in countless surveys of Turkish history, literature, and religion, in Turkish as well as in European and American scholarship, and with only rare exceptions, the question of the authorship of the Dīwann-i Hikmat was never seriously addressed. Indeed, on the contrary, the $D \bar{\imath} w \bar{a} n$ became ever more inextricably linked with the name of Ahmad Yasawī, and the assumption that he wrote poetry - and that, however we choose to finesse the issue, the Dĩwan-i Hikmat is that poetry became his central claim to fame, eclipsing not only the actual history of the Central Asian Șūfì lineages, familial groups, and shrine constituencies that took 
their inspiration from Aḥmad Yasawī (in most cases without ever paying attention to the poetry he was supposed to have written), but even the rich body of narrative evocations of Ahmad Yasawī's saintly persona preserved in literary hagiographies and oral tradition from Central Asia.

As a final indication of the importance of Early Mystics, and of the unfortunate state of Yasawī studies resulting from the long reluctance to engage Köprülü's work critically from a Central Asian perspective, we may note briefly how thin scholarly production on the Yasawī tradition has been since the work's appearance. Between 1918 and the late 1940s, little of note was added to international scholarship on the Yasawi tradition except for two articles, both by Soviet scholars, focused on the shrine of Ahmad Yasawi ${ }^{17}$ Both studies included information on oral tradition connected with the shrine, and on the organizational aspects of the activities associated with it; they are of particular importance for reflecting the period before the intense assault against Islamic institutions begun by the Soviet government in the later 1920s.

Two important articles from the late 1940s and early 1950s, one from the Soviet Union and one from Turkey, mark the next significant scholarly contributions on the Yasawi tradition. The first, a study of the language of the Dīwann-i Hikmat by A. K. Borovkov, ${ }^{18}$ formulated major elements of the case for rejecting

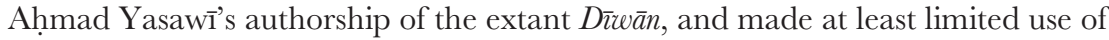
several important Central Asian sources (the Lamahät and the Thamarāt al-mashä'ikh) on the Yasawi tradition; unfortunately, this article was largely ignored in Turkey and elsewhere, though its arguments were summarized in H. F. Hofman's survey of Chaghatay literature, from 1969. ${ }^{19}$ The other seminal article from this era, by Zeki Velidi Togan, ${ }^{20}$ discussed several previously unknown sources, including the Hüjat al-dhäkimin and another source, seemingly of great interest, that has unfortunately been lost; Togan's work, like Borovkov's, pointed to important new directions for research on the Yasawi tradition, but there appears to have been virtually no serious response to the promise of either contribution.

For nearly 40 years after this period, the Yasawi tradition suffered a particularly severe drought in substantive scholarly attention. In the Soviet Union, not unexpectedly, Ahmmad Yasawī came to be decried, along with other Șūfìs, as an obscurantist deceiver of the masses, and the most substantial publication devoted to him was an antireligious tract entitled "The Shadow of the Middle Ages."21 Some attention was occasionally given to literary aspects of the Dīwān-i Hikmat, and Ahmad Yasawī's shrine was studied as an archeological and architectural site, but there was virtually no serious attention to the history and legacy of the Yasawī tradition until the end of the Soviet era. In Europe and America, study of the Yasawī tradition largely fell through the cracks of academic divisions that also harmed the broader study of Central Asia as a whole. Although the hagiographical legacy of the Yasawī order is overwhelmingly in Persian, Iranists largely ignored what was repeatedly (if wrongly) cast as a purely "Turkic" tradition; meanwhile, students of Turkic language, history, or religion remained largely unfamiliar (in part due to their reliance upon Köprülü) with the larger body of 
sources relevant to Yasawī history, and limited their interest in the Yasawī tradition to the Dīwān-i Hikmat. Specialists in Șūfì studies, meanwhile, began to turn their attention to the Yasawi tradition in the 1970s, but almost entirely in connection with its presumed links to the Naqshbandiyya.

In Turkey, the Yasawī tradition continued to be noted as an important element of a Turkish religious and literary heritage, but writers were mostly content to parrot the conclusions of Köprülü, and there was little original work done, even on the sources already identified by Köprülü. The manuscript containing works of Hazīn̄̄ that was used and cited so extensively by Köprülü, for instance, remained largely unstudied by scholars in Turkey, from the time Köprülü wrote down to the 1990s. It was not until 1983 that a substantial selection of poems from the Dīwān-i Hikmat was published, edited by Kemal Eraslan $^{22}$ (whose 1979 publication of a transcribed edition of Nawà's's $\mathcal{N a s} \bar{a}^{\prime} i m$ al-mahabba was noted earlier); like Köprülü, Eraslan effectively dodged the issue of the Dīwān's authorship, and like Köprülü's work, Eraslan's selections from the $D \bar{\imath} w \bar{a} n$ seemed almost to discourage original work on the poetry ascribed to Aḥmad Yasawī, as scholar after scholar chose to cite these selections for a wide range of conclusions (about the Dīwān's language, style, philosophical and religious foundations, etc.), instead of exploring fuller printed versions, or actual manuscript copies, of the Dīwān (this tendency continued even after the publication of fuller versions of the Dīwān in the 1990s). European and American Turkologists, it may be added, seem largely to have concurred with Turkish scholars on the virtual identification of Yasawi studies with the study of the Dīwān-i Hikmat, and in any case cannot be said to have contributed significantly to the study of any aspect of the Yasawī tradition.

Since the collapse of the Soviet Union and the expansion of contacts with scholars, and scholarly resources, in Central Asia, attention to the Yasawī tradition has grown dramatically in terms of sheer bibliographical weight, but less so in terms of new approaches or the use of new sources. Several new versions of the Dīwān-i Hikmat have been published in the former Soviet Union, with transcriptions based on modern Uzbek, Qazaq, Türkmen, and Tatar, and two Latin-script transcriptions have appeared in Turkey (the Türkmen publication, issued in Moscow, and one of the Turkish versions are based on actual manuscript copies, while the others are based on earlier printed versions of the Dīwān); the fundamental issues surrounding the Dīwān's origins and development, however, remain essentially ignored. As for other aspects of the Yasawi tradition, the most important developments inevitably involve an increased attention to previously unavailable Central Asian sources. Scholars in Uzbekistan and Kazakhstan - above all Ashirbek Muminov and Zikiriya Zhandarbekov - have begun uncovering valuable genealogical texts dealing with an important and still unappreciated aspect of the Yasawi tradition, as noted above; at the same time, some increased attention to the study of Yasawi hagiographical literature from Central Asia is evident in works of Bakhtiyar Babadzhanov in Uzbekistan, Florian Schwarz in Germany, and Thierry Zarcone in France. My own publications on 
various aspects of the Yasawi tradition likewise reflect the study of Central Asian materials, and stem from ongoing work aimed at a thorough re-examination of the history of Yasawī Șūfì communities.

In Köprülü's native country, lastly, the disconnect between quantity and quality in recent Yasawī studies is regrettably quite stark; the flood of publications on Ahmad Yasawi that has appeared in Turkey since the early 1990s (partly in connection with the declaration of 1993 as the "Year of Ahmad Yasawī," on the misguided assumption that his birth could be dated to 1093) is full of largely unoriginal and repetitive works that rarely go beyond Köprülü's approaches and conclusions of long ago. A bright spot in this regard is the promising work of Necdet Tosun, who has recently published two important sources relevant for Yasawi studies. ${ }^{23}$ In his introduction to one of these, especially, Tosun reveals alongside a persistence in several assumptions about the Yasawī tradition that will take some time to abandon - a far greater acquaintance with the broader body of sources from Central Asia than is evident in any other product of Turkish scholarship on Ahmmad Yasawī. His approach, rather than the uninspired repetition of ideas that were fresh some nine decades ago, is what I firmly believe Köprülü would be pleased to see today.

Devin DeWeese

Bloomington, Indiana

\section{NOTES}

1 Köprülü, and others following him, have referred to this manuscript as containing a single work, the Fawāhir al-abrār, in which the author changes from Turkic to Persian in the midst of the text; in fact the change of language coincides with a clear break in the text between two folios, and it seems clear that several sheets containing the end of the Fawähir and the beginning of a second work have been lost.

2 Muḥammad 'Ālim Șiddīqī, Lamahāt min nafahăt al-quds (Islamabad, 1406/1986).

3 See my preliminary discussion of this work in "The Yasavī Order and Persian Hagiography in Seventeenth-Century Central Asia: 'Ālim Shaykh of 'Alīyābād and his Lamahāt min nafahāt al-quds," in The Heritage of Sufism, vol. III: Late Classical Persianate Sufism (1501-1759), The Safavid and Mughal Period, ed. Leonard Lewisohn and David Morgan (Oxford, 1999), pp. 389-414.

4 “Orta-Asya Türk dervişliği hakkında bazı notlar," TM, 14 (1964), pp. 259-62.

5 "Ahmed Yesevi" in $\dot{I} A$, I, p. 212. citing Zetterstéen's catalogue of the Uppsala collection, whence the manuscript was mentioned also in H. F. Hofman's Turkish Literature: A Bio-bibliographical Survey: Secton III (Chaghatai), Part 1 (Authors); 6 vols in 2 (Utrecht, 1969), III, pp. 316-18.

6 A. Zeki Velidî Togan, Oğuz destan: Reşideddin Oğuznâmesi, tercüme ve tahlili, 2nd edn (Istanbul, 1982), pp. 81, 104, 125; and Togan, Umumî Türk tarihine giriş, I, 3rd edn (Istanbul, 1981), p. 497.

7 "Yasavian Legends on the Islamization of Turkistan," in Aspects of Altaic Civilization III (Proceedings of the Thirtieth Meeting of the Permanent International Altaistic Conference, Indiana University, Bloomington, June 19-25, 1987), ed. Denis Sinor (Bloomington: Indiana University, Research Institute for Inner Asian Studies, 1990), pp. 1-19. 
8 "Yasavi Šayhs in the Timurid Era: Notes on the Social and Political Role of Communal Sufi Affiliations in the 14th and 15th Centuries," in La civiltà timuride come fenomeno internazionale, ed. Michele Bernardini [= Oriente Moderno (Rome), N.S., 15 (76), No. 2 (1996)], pp. 173-88 [pp. 175ff]; and "The Mashä'ikh-i Turk and the Khojagann: Rethinking the Links between the Yasavī and Naqshbandī Sufi Traditions," Fournal of Islamic Studies (Oxford), 7/2 (July, 1996), pp. 180-207 [p. 187].

9 Aširbek K. Muminov, "Veneration of Holy Sites of the Mid-Sirdar'ya Valley: Continuity and Transformation," Muslim Culture in Russia and Central Asia from the 18th to the Early 20th Centuries, ed. Michael Kemper, Anke von Kügelgen, and Dmitriy Yermakov (Berlin, 1996; Islamkundliche Untersuchungen, Bd 200), pp. 355-67 [p. 364]; Aširbek K. Muminov, "Die Qožas: Arabische Genealogien in Kasachstan," Muslim Culture in Russia and Central Asia from the 18th to the Early 20th Centuries, vol. 2: Inter-regional and Inter-ethnic Relations, ed. Anke von Kügelgen, Michael Kemper, and Allen J. Frank (Berlin, 1998; Islamkundliche Untersuchungen, Bd 216), pp. 193-209 [pp. 207-8].

10 See my "A Neglected Source on Central Asian History: The 17th-century Yasavī Hagiography Manāqib al-akhyār," in Essays on Uzbek History, Culture, and Language, ed. Denis Sinor and Bakhtiyar A. Nazarov (Bloomington, IN: Research Institute for Inner Asian Studies, 1993; Uralic and Altaic Series, vol. 156), pp. 38-50.

11 Hazīn̄i, Cevâhiru'l-ebrâr min emvâc-ı bihâr (Yesevî Menâkıbnamesi), ed. Cihan Okuyucu (Kayseri, 1995).

12 K. G. Zaleman, "Legenda pro Khakim-Ata," Izvestiia Akademii nauk (St Petersburg), 9/2 (1898), pp. 105-50.

13 Ahmet T. Karamustafa, "Early Sufism in Eastern Anatolia," Classical Persian Sufism: From Its Origins to Rumi, ed. Leonard Lewisohn (London/New York, 1993), pp. 17598.

14 Copies of Latin-script editions of Early Mystics were eagerly and gratefully received by Uzbek intellectuals during two of my visits in the mid-1980s; the work had then the triple cachet of being inaccessible and forbidden, of dealing with a figure who was both beloved as poet and typically disparaged by Soviet propaganda, and of highlighting a Turkic consciousness that transcended national boundaries. The sense of deflation, upon discovering the eminent Turkish scholar's dismissal of Ahmad Yasawī's poetic gifts, was quite palpable.

15 In fact, however, Köprülü's hostility to the Persian influence in court poetry, and his preference for the "simple Turkish" of the "folk poets," reflected a dichotomy that was central in his time, but is increasingly recognized as overdrawn today; and in any case, it was not a meaningful dichotomy in Central Asia (especially for poets, and their audiences, who had not yet learned the importance, so much a part of Köprülü's age, of extracting the Persian and Arabic elements from their lexicons). In this regard it is worth recalling the appraisal, half a century before Köprülü wrote, of Vambéry, who said that the Persian and Arabic element was sufficiently strong in the poems of the Diw $\bar{\imath}$ n-i Hikmat to cause the "uninstructed nomads" difficulty in understanding them (A. Vambéry, "Muhammadanism (in Central Asia)," Encyclopaedia of Religion and Ethics, ed. James Hastings (1908-26; rpt New York, 1961), vol. 8, pp. 885-8 [p. 887]).

16 Köprülü often implies that use of the syllabic meter is a marker of the early and more primitive stage of Turkic poetry supposedly represented by Ahmad Yasawī's verse (even though Köprülü himself notes some confusion over whether certain poems reflect syllabic meter or poorly executed 'arü d meters). It is interesting, in this regard, that the earliest version we have of a poem ascribed directly to Ahmad Yasawī and found, still, in extant versions of the Dīwān-i Hikmat appears in one of Hazīnī's works from the latter sixteenth century; yet Köprülü himself acknowledged that this poem reflected the principles of the 'arüd system supposedly introduced only after the time of Ahmmad Yasawī. Köprülü would no doubt argue that this poem had been modernized 
and its meter adjusted; indeed, much else has been adjusted, inasmuch as extant versions of the poem differ substantially in structure and wording, and in Hazīnīs work it appears in distinctly Ottoman orthography, rather than in the Chaghatay form we would expect it to have if indeed written down in Central Asia. But when our earliest known recording of a poem ascribed to Ahmad Yasawi reflects the 'arūd system, the rationale for using that system's presence or absence as evidence of the "originality" of specific poems is obviously dissolved.

17 M. E. Masson, Mavzolei Khodzha Akhmeda Iasevi ([Tashkent, 1930], 23 pp.; this work has now been republished in Goroda Turkestana: Sbornik nauchnykh statei, ed. K. M. Baipakov [Almaty, 1999], pp. 9-29); W. Gordlevsky, "Choğa Ahmed Jasevi" [in German], in Festschrift Georg Facob, ed. Theodor Menzel (Leipzig, 1932), pp. 57-67 (in Russian, with some additional material, in V. A. Gordlevskii, Izbrannye sochineniia, II [Moscow, 1962], pp. 361-8).

18 A. K. Borovkov, "Ocherki po istorii uzbekskogo iazyka (opredelenie iazyka khikmatov Akhmada Iasevi)," Sovetskoe vostokovedenie, 5 (1948), pp. 229-50; Borovkov unfairly dismissed Köprülü's entire work as uncritical (p. 229) and ignored it altogether.

19 H. F. Hofman, Turkish Literature, vol. VI, pp. 110-28 (on Ahmad Yasawī; Hofman's study also includes useful discussions of other figures from the Yasawi tradition).

20 Zeki Velidi Togan, "Yeseviliğe dair bazı yeni malûmat," in Osman Turan et al. (eds) 60 Doğum ynl münâsebetiyle Fuad Köprülü armağanı (Mélanges Fuad Köprülï) (Istanbul, 1953), pp. 523-9.

21 Iu. G. Petrash, Ten'srednevekov'ia (Alma-Ata, 1981).

22 Ahmed-i Yesevî, Dîvân-ı Hikmet’ten sę̧meler, ed. Kemal Eraslan (Ankara, 1983).

23 Necdet Tosun, "Yesevilliğin İlk Dönemine âid bir Risâle: Mir’âtü'l-kulûb," ILLAM Araştırma Dergisi, 2/2 (Temmuz-Aralık, 1997), pp. 41-85; idem, "Ahmed Yesevî̀nin Menâkıbı," ILAM Araştırma Dergisi, 3/1 (Ocak-Hazıran, 1998), pp. 73-81. 


\section{TRANSLATORS' INTRODUGTION}

In an article entitled "Attempts at Self-interpretation in Contemporary Islam" published in 1955, Gustave von Grunebaum, one of the leading twentiethcentury scholars of the Middle East, quotes his equally renowned colleague H. A. R. Gibb as stating regretfully in 1942: "I have not yet seen a single book written by an Arab of any branch in any Western language that has made it possible for the Western student to understand the roots of Arab culture. More than that, I have not seen any book written in Arabic for Arabs themselves which has clearly analyzed what Arabic culture means to the Arabs." Von Grunebaum then goes on to say: "This statement could be extended to include the non-Arab Muslim and his failure to interpret his culture to both himself and the West. It holds good today as it did when it was written, and it is likely to hold good for some time to come."

Gibb's assertion was, perhaps, debatable, but von Grunebaum's was mistaken, for in 1918 Köprülü had published Early Mystics in Turkish Literature, which, among other things, was meant to help establish the modern Turkish national identity. ${ }^{2}$

\section{Mehmed Fuad Köprülü}

Our author was born in Istanbul in 1890. Through his father İsmail Faiz Bey, he was related to the sister of the famous Ottoman Grand Vizier Köprülü Mehmed Pasha (d. 1661). She was also the wife of Kıbleli Mustafa Pasha, a vizier of Mehmed IV. His father was a civil servant and his mother was the daughter of a religious scholar from İslimiye, present-day Sliven in Bulgaria.

Köprülü attended the Ayasofya junior high school (rüsdiyye) and then Mercan high school (idâdî) in Istanbul. Between 1907 and 1910, he attended the School of Law at Dârülfünûn, which later became Istanbul University, but he did not complete the course of study. Indeed, while in law school, he became interested in Turkish literature, which soon became his passion and contributed to his decision to abandon law. In 1909 he joined the literary society Fecr-i Âtî, which was strongly influenced by French literature, and wrote poetry for the illustrated weekly Servet-i Fünûn. He also wrote about contemporary literary issues and, 
taking a conservative position, was critical of the national literature and language movement. He later changed his position, however, under the influence of Turkish nationalism. Between 1910 and 1913, he taught Turkish and Turkish literature at various high schools in Istanbul. He was the first to organize a program in literature at Istanbul Lisesi and Galatasaray Lisesi. Meanwhile, he joined various political associations, such as Türk Derneği (The Turkish Association), Türk Yurdu Cemiyeti (The Turkish Homeland Society) and Türk Ocağ1 (The Turkish Hearth). Coming under the influence of Ziya Gökalp (1875 or 1876-1924), the Turkish nationalist ideologist of the Ottoman Empire and exponent of the Turkism movement, he identified himself with the Turkish national literature movement. Parallel to Gökalp's establishment of the bases of Turkish nationalism, Köprülü carried out scholarly research on the origins of Turkish literature, or what he called Turkish national literature. He thus went back to the earliest periods of Turkish history and examined the history and literature of various Turkish societies. Contemporary political and social conditions in the Ottoman Empire, the teachings of Gökalp, and the policies of the Committee of Union and Progress all influenced him in this regard. In 1913 with Gökalp's help, he became instructor - at the age of 23 and almost completely self-taught - of the history of Turkish literature in Dârülfünûn. Intensifying his research, he published in the same year his ideas about how Turkish literature should be studied using European methods in an article entitled "Türk edebiyatı tarihinde usûl" (Method in the history of Turkish literature).

With several friends, Köprülü tried to found the Türkiyat Cemiyeti (Society for Turkish Studies). He had Gökalp's support, but the grand vizier, Sait Halim Pasha, was opposed to the name, which was changed to Âsâr-i İslamiyye ve Milliyye Tetkik Encümeni (The Society for the Study of the Islamic and National Culture). This society was launched in 1915. Its publication was Milli Tetebbüler Mecmuası (The Fournal of National Research). For the first issue, Köprülü contributed 'Türk edebiyatında âşık tarzının menşe' ve tekâmülü hakkında bir tecrübe" (An essay on the origin and development of Turkish minstrel poetry). Indeed, he began to publish on a wide variety of historical, literary, and intellectual subjects in many journals and newspapers. His first major work, Early Mystics in Turkish Literature, which proved to be his masterpiece, appeared in 1918, when he was only 28, and earned him an international reputation. In 1920-1, he published the first edition of Türk edebiyat tarihi (The History of Turkish Literature), which further established him as a leading authority in Turkish studies. In 1922, he published "Anadolu'da islâmiyet" (Islam in Anatolia) and in 1923 Türkiye tarihi (The History of Turkey). Also in 1923, he became dean of the Faculty of Literature at Istanbul University. In the same year Gökalp published Türkçülügü̈n esaslarn (The bases of Turkism) and stated that Köprülü was very learned and a great scholar in the field of Turkish studies and that he would shed light on Turkism. In 1924, Köprülü served for eight months as under-secretary in the Ministry of Education on the insistence of its minister, Vasıf Çinar. In the same year, he became director of the Türkiyat Enstitüsü (Institute of Turkish Studies), which 
was established by a decree of the Council of Ministers. In 1925, he began to publish Türkiyat Mecmuase (The Journal of Turkish Studies), its scholarly journal.

As Köprülü's fame spread abroad, he attended a number of international congresses as Turkey's representative: Paris, 1923; Leningrad, 1925; Baku, 1926; Oxford, 1928; London, 1929; and Tehran 1934. In 1925 he was made a corresponding member of the Soviet Academy of Sciences on the recommendation of W. Barthold, I. Krachkowsky, and S. Oldenburg. He received honorary degrees from the University of Heidelberg, 1927; the University of Athens, 1937; and the Sorbonne, 1939.

In 1927 Köprülü was elected president of Türk Tarih Encümeni (The Turkish Historical Society). The following year, he published, among other things, several studies on the pre-Ottoman Turkish principalities in Anatolia. In 1931 he founded the short-lived Türk Hukuk ve Iktisat Tarihi Mecmuası (Journal of Turkish Legal and Economic History), in which appeared his long article "Bizans müesseselerinin osmanlı müesseselerine te'siri hakkında bâzı mülâhazalar" (Observations on the influence of Byzantine institutions on Ottoman institutions). In 1935 he published Les origins de l'Empire Ottoman, which was a series of lectures given at the Sorbonne the previous year. In 1937 he became ordinarius professor at Istanbul University, where he served from time to time as a dean.

In 1935 Köprülü began his political life. While still a university professor, he was elected representative from Kars in eastern Turkey. Shortly thereafter he moved to Ankara, where he taught medieval history in the Faculty of Language, History and Geography at Ankara University (1935-41). After 1941 he devoted much of his scholarly energy to the Íslâm Ansiklopedisi, the expanded Turkish version of the first edition of the Encyclopaedia of Islam, but still contributed to various journals, notably his "Anadolu Selçukluları tarihinin yerli kaynakları" (Local sources for the history of the Seljuks of Anatolia) and "Osmanl imparatorluğu'nun etnik menşei meseleleri” (Problems of the ethnic origin of the Ottoman Empire), both of which appeared in Belleten in 1943. In the same year he retired from his professorship and entered politics full time. He was one of the founders of the Democratic Party in 1945. The following year he was elected deputy from Istanbul. When the Democratic Party came to power in 1950, he became Minister of Foreign Affairs. With the exception of a brief period in 1955, he held this position until May 1956 and played an important role in Turkey's accession to NATO. After a falling out with party officials, he resigned from the Democratic Party in 1957. Several months after the coup against Prime Minister Adnan Menderes on 27 May 1960, he was arrested and held on Yassiada for four months. Upon his release in 1961, he briefly re-entered politics and then withdrew completely.

Meanwhile Köprülü's scholarly work continued to be recognized abroad. In 1947 he was elected a member of the American Oriental Society. In 1959 he was made an honorary member of the American Historical Society. Between September 1958 and July 1959, he was a visiting professor at Harvard. In 1964 he was made a corresponding member of the School of Oriental and African 
Studies at the University of London. Indeed, he never really ceased pursuing his scholarly interests. Toward the end of his life, he worked with F. A. Tansel on updating some of his earlier publications, including the one presented here. On 15 April 1965 he was involved in a traffic accident in Ankara and on 28 June 1966 died from complications arising from that accident. He was buried in the Köprülü burial plot opposite the tomb of Sultan Mahmud in Istanbul.

Taking Turkish literature beyond the boundaries of the Ottoman state, Köprülü approached it as a whole, from the heroic era to the present. In the process, using modern scholarly methods, he shed light on the main features of Turkish literature. He introduced many poets and writers, such as Shayyād Hamza, Aḥmad Faqīh, and Khwāja Dehhāni, to the scholarly world. His books and articles touched on many subjects: the history of Turkish literature, literary criticism, Oriental studies, the history of Turkish civilization and culture, language, religion, art, music, political history, and ethnology. As with literature, he believed history should be approached as a whole. He worked to make the old concept of history in Turkey, which was military and political history, more inclusive, incorporating religious, legal, economic, and social history as well. He generally saw literary history as part of the history of civilization, and believed that by studying all the literary products that revealed the intellectual evolution of a nation over the centuries one could shed light on its spiritual life. Thus, because literary works were created by artists under the moral and material influence of the society in which they lived, literary history included not only a work itself but also the life of the artist and the society to which he belonged. Altogether, Köprülü established the basis for the modern study of Turkish literature and showed Turks how to do this themselves. He was a master at synthesizing great amounts of information and published some 1500 books, articles, essays, and other writings. ${ }^{3}$

\section{Early Mystics in Turkish Literature}

The appearance of Köprülü's Early Mystics in 1918 caused a sensation among knowledgeable European scholars. They had never seen anything like it. For the first time, a native Middle Eastern scholar had applied modern Western methods of research and analysis to sources that were, up to then, unknown or poorly known in both Europe and the Middle East in order to study a number of fundamental aspects of the origin of his own culture. As a consequence, he published a major work in his own language that shed light on many little known or obscure subjects. At the same time, by describing the sources for his work, he opened new areas of research.

What exactly did Köprülü do in this book? Briefly put, he described, by marshalling a vast array of Arabic, Persian, and Turkish sources, the virtually unknown subject of the origin of Turkish literature and the role of mystics or Șūfîs in the development and spread of this literature in the area stretching from Central Asia, the original homeland of the Turks, across Iran to Asia Minor or 
Anatolia. In the process, he showed how this literature helped to create a national identity for the Turks, and thus played a seminal role for Turkish culture in the Muslim world. This last point was very important. Köprülü had a national objective in mind when he wrote this book. It appeared at the time of the collapse of the Ottoman Empire and at the beginning of the Turkish nationalist struggle for independence, which soon resulted in the emergence of the modern Republic of Turkey. Köprülü sought to give the Turks, for the first time, a proper historical identity through their literature, one that was not lost or obscured in Ottoman or traditional Islamic history. In short, he wanted to present to the Turks their true history as far back as the literary sources would allow. With Early Mystics, Köprülü became the founder of the modern study of Turkish literature and history in Turkey. Indeed, this work had an important effect on Turkish studies internationally.

Köprülü divides Early Mystics into two distinct parts. He devotes the first to Aḥmad Yasawī, whom he identifies as the first great Turkish popular Ṣūī poet. According to Köprülü, Aḥmad Yasawī was born in Sairām (Isfîjāb), in modern Kazakhstan, in the latter part of the eleventh century and died in 1166-7. In the course of his life, he established a new genre in Turkish literature, namely mystical folk poetry, and founded a Șūfi brotherhood or țarqqa that spread his teachings. This brotherhood, the Yasawiyya, was the first to flourish among the Turks, and eventually gave rise, again according to Köprülü, to one of the most powerful tarīqas in the Muslim world, the Naqshbandiyya. After Ahmad Yasawī’s death, his tomb in Yasī, which was greatly embellished by Tīmūr (Tamerlane), became an important place of pilgrimage for the Turks of Central Asia and the Volga region.

Köprülü begins by describing the various cultural influences on the Turks in Central Asia and what was known of Turkish literature before the appearance of Aḥmad Yasawī. He focuses on the spread of Șūfī mysticism among the Turks how it was adapted to traditional beliefs and its role in the conversion of the Turks to Islam. Then he presents an account of the legendary life of Ahmad Yasawī as reflected in popular traditions and later Șūî̀ religious biographies. Köprülü follows the spread of the legends about Ahmmad Yasawī throughout Turkistan (modern Kazakhstan, Uzbekistan, Turkmenistan and Kyrgyzstan), along the Volga, and eventually to Anatolia and the Balkans - spreading to the latter two regions mainly as a result of the Mongol invasion and then being incorporated into the Bektashī tradition. All this is evidence, asserts Köprülü, of the very strong impression that Ahmad Yasawī made on Turkish literary and religious life. Our author then concentrates on Ahmad Yasawī's literary imitators and spiritual successors to show how they compounded and magnified his influence among the Turks.

Köprülü next describes Ahmad Yasawī’s literary works, i.e. his collection of religious poems known as Dīwān-i Hikmat. He discusses its linguistic and literary features, comparing it to earlier Turkish works, such as the Kutadgu Bilig, as well as to contemporary works. Köprülü emphasizes in particular how Aḥmad Yasawī 
addressed the common people in their own language. He also takes careful account of the Sūfì element in the $D \bar{\imath} w \bar{a} n$, which was critical in making it a new genre of Turkish literature.

After this, Köprülü attempts to describe what was known of the actual historical life of Aḥmad Yasawī: his childhood, religious training, travels, and family. Then he discusses his historical spiritual successors. This naturally leads to a detailed account of the rules and religious practices of the Yasawi tariqqa, which in turn allows Köprülü to present a synthetic view of the origin and nature of Turkish mysticism in Central Asia. He then shows how Ahmad Yasaw $\overline{\mathbf{1}}$ 's influence, spread by the Yasawiyya, prevailed for centuries among the Turks.

Köprülü devotes the second part of his book to Yūnus Emre, the greatest of all Turkish Sūfì poets, whose work has influenced Turkish literature up to modern times. Yūnus Emre lived in the second half of the thirteenth century in Central Anatolia. Like Ahmad Yasawī, who had a strong influence on him, this poet spoke to the people in a language they could understand, but, according to Köprülü, he was a much greater artist. His sublime poetry, which expounds the most difficult metaphysical problems in plain and unembellished language, not only furthered the development of Turkish mystical folk literature but also helped to spread Șüfism among the Turks in Anatolia.

Köprülü begins by describing Turkish literature in Anatolia before Yūnus Emre, the development of the Șüfi movement in that region, and such notable mystics as Jalāl al-Dīn Rūmī. Then he focuses on the rise of Turkish in Anatolia as the national language of the Turks and on the appearance of folk literature, including such works as the Dede Korkut and Oghuznāme. Next Köprülü discusses the life of Yūnus Emre. He starts with the view of Yūnus in the Bektashī tradition and then examines the historical person, assessing among other things his supposed illiteracy and his fame, which was already considerable by the fourteenth century. Then Köprülü provides a detailed account of his collected poetry, comparing its linguistic and literary features to earlier works, including those of Ahmad Yasawī, and contemporary products. Altogether, he shows how Yūnus Emre created a new style of Turkish literature that had a profound effect on later poets. Köprülü stresses Yūnus Emre the moralist and supreme artist who was able to grasp and eloquently explain Șūfi principles and profound metaphysical questions in simple language. For Köprülü, the plain yet eloquent language in the style of Yūnus Emre represents the epitome of Turkish literary taste. Thus Yūnus Emre embodied the Turkish "national” genius. Finally, Köprülü describes Yūnus Emre's continuous influence on the development of Turkish literature, his many spiritual successors and literary imitators, his key role in the development of the poetry of the Turkish Sūfì lodges, especially those of the Bektashīs, and the creation of ' $\bar{s} h$ h $q$ literature (that of wandering minstrels after the fifteenth century).

Köprülü firmly believed that one had to study Turkish literature, from Central Asia to Anatolia, as a whole, and that without understanding pre-Islamic Turkish literature, it was impossible to describe that of the post-Islamic periods. And 
without knowing how Turkish literature developed in Central Asia and Anatolia up to the formation of the Ottoman state, it was impossible to comprehend the development of Ottoman literature. With Early Mystics, Köprülü attempted to lay the foundation for the modern study of Turkish literature, from its very beginning, within such a framework. He was remarkably successful in this attempt. Indeed, despite some serious flaws, which have been highlighted in the Foreword and the commentary in the notes, his book became a milestone in the modern study of Turkish literature and cultural history. It also stimulated many subsequent works, such as those of Abdülbaki Gölpınarlı on Yūnus Emre. Today much of the background information in Early Mystics, such as that on the Turks, Islamization, and Sufism, is, of course, dated, but its assessments of Ahmad Yasawī and, especially, Yūnus Emre are still central to modern research; although recently, as mentioned in the Foreward and the commentary in the notes, Köprülü's analyses of Ahmad Yasawī and his work have been seriously challenged. Nevertheless, for almost a century, this work has remained a standard of modern Middle Eastern studies. It is still the starting point for research on the cultural genesis of the Turks. Furthermore, this book is also of great importance for the study of the evolution of Islam in general and Șufism in particular, and of the interrelationship and differences between Turkish literature and Arabic literature, and especially between Turkish literature and Persian literature. It lies at the heart, therefore, of the most fundamental areas of research in Central Asian, Middle Eastern, and Islamic studies. Its significance to specialists and general readers goes well beyond the scope of Turkish studies.

\section{Translators' note}

As mentioned, Early Mystics was originally published in Istanbul in Ottoman Turkish in 1918. A second edition, revised by Köprülü and transcribed into the Latin alphabet, appeared in 1966. A third edition prepared by his son Orhon Köprülü, who simplified the language a bit, corrected a few things, and made some additions to the notes, was published in 1976. Since then, this third edition has been reprinted a number of times. The translation presented here is based on this edition, although we frequently compared it with the first edition, especially to clarify problems arising from changes in alphabet.

We have attempted to translate this work into colloquial English. This means in particular that we have tried to eliminate the redundancies and wordiness in Köprülü's style, although some vestiges of these characteristics may remain. In a few cases, we have broken long paragraphs into shorter paragraphs; and we have rearranged the order of a few notes required by the differences in English and Turkish syntax.

Furthermore, the translation that follows differs in several other respects from the way in which the original text was presented. At the very beginning, in the table of contents, Köprülü included the subheadings from all chapters. We have eliminated them as unnecessary. In the narrative and notes - apparently believing 
that his readers were equally multilingual and well read - Köprülü frequently included passages in medieval Arabic, Persian, or Turkish without translating them and with little or no comment. We have translated all such passages into English with the exception of some chronograms in Chapter 4, some first lines from Dīwān-i Hikmat in Chapter 5 that are cited for identification purposes, and the poem cited in Chapter 9, notes 3 and 6 , in order to illustrate textual and linguistic matters.

In addition, and just as annoying, Köprülü was inconsistent in his method of citing sources, sometimes even giving different names to the same source. In other instances, he was so brief or vague as to leave even a specialist reader in doubt. He also had a tendency to merge his sources and to make sweeping generalizations without proof. It is difficult to determine if these are signs of haste or simply carelessness. In any case, we have recast all of Köprülü's footnotes according to modern English usage, giving a full reference to a work when first cited, and author and short title thereafter. The full reference can, of course, also be found in the Bibliography.

We have checked many of the original sources that Köprülü cites and have made a number of corrections. Furthermore, we should point out in particular that the use of quotations from Aḥmad Yasawīs Dīwān-i Hikmat in "Westernized" form are not meant to imply that this work was in Ottoman rather than Chaghatay. This is the way in which they appear in the Latinized editions of the Early Mystics. We should also state that for Evliyā Chelebi's Seyāhatnāme, Köprülü used the Istanbul edition of 1314-18/1896-1900, which is unreliable for scholarly purposes. We have cited instead the original Bağdat Köşkü manuscripts. Köprülü frequently mentions the Kirghiz, following Russian usage of the time, but with rare exceptions he really means the Qazaqs. Where appropriate we have changed this designation to the latter. Lastly, we have added a minimum number of new references in an attempt to bring Early Mystics up to date. This minimalist approach will not satisfy all readers, but given the breadth and complexity of this work, it would be impossible to introduce all the subsequent work on the subjects raised by Köprülü that have appeared in many languages over the past century.

As will be seen in the prefaces, Köprülü included in the first edition a "select," rather than a complete, bibliography. In the second and third editions, it was merged it with the index. We have provided a separate and complete bibliography of all works cited and a separate index. In the bibliography we have also translated the titles of all Russian and modern Turkish works. Except for the correction of minor oversights, we have placed all changes and additions to, or clarifications of, the narrative and notes in braces \{\} . We have also added a glossary, two maps, and several photographs.

Because Early Mystics covers both a vast period and a vast cultural area, and employs so much Arabic and Persian technical terminology, not to mention, of course, Turkish, and because the same words frequently appear in all of these languages but often with different pronunciations, there is no satisfactory system of transliteration of this terminology into English that would reflect these 
differences and not cause confusion for the lay reader when moving back and forth among these languages. As a general rule, therefore, we have "Arabized" technical terms where possible and followed the system of transliteration used in the Encyclopaedia of Islam, with the exceptions of $\mathrm{q}$ for $\mathrm{k}$ and $\mathrm{j}$ for $\mathrm{dj}$, until the modern period, for which we have "transitioned" to modern Turkish orthography for Turkish names and words. Thus ö and ü are the same as in German, $\mathrm{c}=\mathrm{j}, \mathrm{c}=\mathrm{ch}, \breve{\mathrm{g}}$ is not pronounced but lengthens the preceding vowel, $\mathrm{s}=\mathrm{sh}$, and $1=$ gh in Edinburgh. It should also be mentioned that in modern Turkish a circumflex is used to indicate long vowels, but it is often left out. Thus a word may appear with this accent in the title of one work but appear without it in another. Inconsistencies were thus inevitable, especially because we have also used the conventional English spellings for certain words, but should not bother the specialist or lay reader.

Finally, we should mention that this is the first attempt to translate Early Mystics into another language. ${ }^{4}$ Theodor Menzel published a very detailed summary of the narrative part of this work as "Köprülüzade Mehmed Fuad's Werk über die ersten Mystiker in der turkischen Literatur," in Körösi Csoma Archivum, 2 (1926-32), 281-310, 345-57, 406-22, but the narrative constitutes only one-third of the work. The remainder consists of the notes.

\section{NOTES}

1 In Islam: Essays in the Nature and Growth of a Cultural Tradition, Memoire 81 of The American Anthropologist, p. 185.

2 Von Grunebaum's oversight is curious. He knew Köprülü and contributed to his Festschrift in 1953, by which time, as we shall see below, Köprülü had published a stream of fundamental articles and monographs in Turkish that laid the basis for the modern study of Turkish civilization in its broadest sense. Moreover, a detailed German summary of the narrative part of Early Mystics had been published in 1932, on which see below.

3 This sketch of Köprülü's life comes from Gary Leiser's introduction to his translation of "Bizans müesseselerinin osmanlı müesseselerine tesiri hakkında bazı mülahazalar," as Some Observations on the Influence of Byzantine Institutions on Ottoman Institutions (Ankara, 1999), and from "Köprülü, Mehmed Fuad," in Türk Dili ve Edebiyat Ansiklopedisi (Istanbul, 1982-98). For additional works on his life see the prefaces, n. 1. The best study of Köprülü is George Park, "The Life and Writings of Mehmet Fuad Köprülü," dissertation, Johns Hopkins University, 1975.

4 The translators have previously published a slightly modified version of Chapter 10 in Mésogeios, 17-18 (2002). 


\section{ABBREVIATIONS}

EI Encyclopaedia of Islam, 1st edn (Leiden, 1913-42)

EI $I^{2} \quad$ Encyclopaedia of Islam, 2nd edn (Leiden, 1960-2004)

EIr Encyclopaedia Iranica (London, 1985-)

IA Islâm Ansiklopedisi (Istanbul, 1940-88)

$7 A \quad$ Fournal Asiatique

MTM Milli Tetebbûlar Mecmuası

RHR Revue de l'Histoire des Religions

TM Türkiyat Mecmuası

TOEM Tarîh-i 'Osmânî Encümeni Mecmuası

IM Teni Mecmua

ZDMG Zeitschrift der Deutschen Morgenlandischen Gesellschaft

ZKV Zapiski Kollegii Vostokovedov

ZVO Zapiski Vostochnago Otdyeleniya Imperatorskago Russkago Arkheologischeskago Obshchestva 


\section{PREFACE TO THE THIRD EDITION}

The third edition of Ordinarius Professor M. F. Köprülü's book entitled Early Mystics in Turkish Literature is being published by the Office of the Chief of Religious Affairs, which also published the second edition in 1966. This new edition has a history of four or five years. At first the Ministry of National Education considered publishing it in the series One Thousand Basic Works, but when this series was ended the Cultural Secretariat of the Office of the Prime Minister decided to issue this book among its publications. Upon this decision, I was asked to prepare this new edition. The Secretariat and I came to a mutual understanding on certain conditions and toward the end of 1973 the work was ready to be given to the press. At that point, the Office of the Chief of Religious Affairs made persistent entreaties to both me and the Cultural Secretariat of the Office of the Prime Minister as a result of which all parties mutually agreed that the third edition would also be published by the Office of the Chief of Religious Affairs.

My late father had prepared the second edition of Early Mystics, but because of his untimely death resulting from a traffic accident, the final proof reading was done by Fevziye Abdullah Tansel, who also wrote the preface to that edition. In her preface, which I have included verbatim in this new edition, Tansel accurately describes the conditions under which Early Mystics was written in 1918, the great interest the book aroused at that time in Europe, the special characteristics of the work that Köprülü did in various fields, ${ }^{1}$ and how the second edition came about. Consequently, there is no need for me to say anything more in these respects.

I will simply try to describe here the principles that I followed while preparing the third edition of Early Mystics. I have basically adopted the editorial method that Tansel used in the second edition, but I have taken a bit further her simplification of the language and carried the process as far as one could with a work of this sophistication. For example, in place of the term müsteşrik \{Orientalist\}, which would be difficult for today's youth to understand, I preferred the word şarkiyatcl, the meaning of which could at least be inferred by deduction. Instead of the term muakkip \{imitator\}, I found it appropriate to say takipçi. And I used doğu \{east\} and batu \{west\} rather than şark and garp. If he were alive today, my 
father would have readily adopted virtually all the changes that I made in the language of the third edition.

Another way in which this edition differs from the second is that I have extended Tansel's effort to write the names of foreign books and articles in their original form. The names of a number of foreign books and articles were, in fact, left in their Turkish form in the second edition. With certain exceptions, I have tried to give all of these titles in the language in which they were written. In order to distinguish the Leiden edition of the Encyclopaedia of Islam from the Istanbul edition (i.e. the Islâm Ansiklopedisi), I have written the former as Encyclopédie de l'Islam \{in the translation, we refer to the English version throughout\}.

While preparing the second edition, my late father added to the original notes only a few of his publications that appeared after 1919. For the third edition, I have made additions to many of these notes. ${ }^{2}$ Thus, this new edition of Early Mystics represents, to a certain extent, an improvement over previous versions. In the additions that I made to the notes, I followed two main principles. First, I concentrated on the works of Köprülü that appeared after the first edition of Early Mystics and I added to the relevant notes the results of those works to which, if he were alive, he too would most naturally have referred. Second, as far as I could, I have added, where necessary, references to the works of other writers that are relevant to the original notes of the book.

It will be understood from my brief comments here that the most noteworthy features of the third edition are the additions that I have made to the notes. In order to distinguish them from the original notes, I have placed them within brackets [ ] \{which have been retained in the translation .

As a result of the research that Köprülü carried out after completing the first edition of Early Mystics, he changed his mind about certain ideas that he had previously advanced. One change was the view he later held about Ahmad Yasawī and his tarīqa \{Ṣ̂̄ī brotherhood, mystical path\}. As Köprülü himself expressly stated, "I originally described both the Șūfi personality of Ahmad Yasawī and the nature of the Yasawī tarīqa exactly as the Naqshbandī sources portray them. However, the accounts of the Bābā'̄ , Haidarī, and Bektashī traditions concerning Aḥmad Yasaw̄̄ are closer to historical reality." Despite Köprülü's change of view, it was not incorporated in the second edition of Early Mystics. In this new edition, though, I have used the occasion to clarify this matter.

In his later writings, Köprülü also advanced views that differed from those in the first edition on certain secondary problems, but there was no reflection of them in the second edition. He wrote in the first edition, for example, that the pen name of Mehmed Giray IV was 'Ârif, but in an article that appeared in 1928, he stated that it was not 'Ārif but Kāmil. ${ }^{4}$ This minor error was left in the second edition, but in the present version I have corrected it in the relevant note.

In the first edition of Early Mystics, the name of a certain work is given as Hibat al-haqā'iq. Although well known by this name at that time, it has now been 
shown that this title was the result of a misreading. Reşid Rahmeti Arat later carried out research in which he established that the name was 'Atabat al-haqa' iq and this reading has been universally accepted. Nevertheless, in the second edition the title of this famous book is still given as Hibat al-haqa' $i q$. In the third edition, I have given the correct name in both the text and the notes. Throughout the work, I have also found it appropriate to write certain personal names the way Köprülü later accepted them. For instance, in an article that he published many years ago, he went to great length to explain that the name "Kutulmuş," as it appeared in the second edition, must be read as "Kutalmıs,", and many of our other historians have agreed with him. In this new edition, I have therefore used Kutalmış as the form of this name.

I should like to state immediately here that the additions that I have made to some of the notes in the third edition of Early Mystics are just a beginning. I hope and wish that for a future fourth edition a commission of specialists on various subjects will be formed who will be able to make additions to a great many more notes. I am sure that my father's spirit would rejoice at such a project.

Another difference between the second and third editions of Early Mystics is the method of transcription. In the new edition, proper names have been written as they are pronounced. In ending this brief description of the third edition, I should mention that I was in Istanbul while the book was published in Ankara and thus pages were sometimes sent to the press without being proof read and this led to a number of unavoidable printing errors. Those mistakes that cannot be deduced from the context have been listed with their corrections at the end of the book \{not included, of course, in this edition\}.

Istanbul, January 20, 1976

Dr Orhan F. Köprülü

\section{NOTES}

1 The following works, listed chronologically, should be added to the bibliography \{of the works\} of Köprülü given by Tansel in her preface to the 2nd edn (see below n. 2 to Preface to 2 nd edn): S. N. Özerdim, "Bibliyografya - F. Köprülü'nün yazılarına ek ve bâzı düzeltmeler," Belleten, 30 (1966), 661-5; F. A. Tansel, "Memleketimizin acı kaybı Prof. Dr Fuad Köprülü," Belleten, 30 (1966), 633-5; Tansel, "Prof. Dr Fuad Köprülünün yazıları için basılmış bibliyografyalar," Türk Kültürü, 6 (1968), 543-56; Orhan F. Köprülü, "Prof. Fuad Köprülü için yazılmış bibliyografyalar ve bunlara bâzı ilâveler," Türk Kültürü, 8 (1970), 616-20; Köprülü, "Fuad Köprülü bibliyografyasına yeni ilâveler," Türk Kültürü, 10 (1972), 1242-5; Köprülü, "Köprülü bibliyografyası'nda yeni gelişmeler," Türk Kültürü, 14 (1975), 52-5. \{See also Köprülü, Fuad Köprülü (Ankara, 1987). $\}$

2 We can list here articles like "Çagatay edebiyatı," "Âzerî edebiyatı" \{rather, "Âzerî," which includes a long subsection entitled "Âzerî edebiyatının tekamülü\}, and "Bektaş" in $\dot{I A}$; "Abdal" in Türk halk edebiyat ansiklopedisi \{Istanbul, 1935\}; and "Misır'da bektaşîlik" in TM \{6 (1936-40), 13-31\}. \{Orhon Köprülü's additions to the notes were relatively few. 
$3 \dot{I A}$, s.v. "Ahmed Yesevî," I, 212a. For more on this matter, see n. 52 which I added to pp. 116-17 of the 3rd edn \{i.e. n. 70 of Chapter 4 of the present translation\}.

4 \{"XVII. asır saz şairlerinden Kâmil kırım hanı IV. Mehmet Giray,"\} Hayat Mecmuası, 1928, no. 134; \{reprinted in Orhon Köprülü ed. Köprülü'den seçmeler (Istanbul, 1972), pp. $93-8\}$.

5 "Türk onomastique'i hakkında," İstanbul Üniversitesi Edebiyat Fakültesi Tarih Dergisi, 1 (1950), 227-30. 


\section{PREFACE TO THE SECOND EDITION}

The Office of the Chief of Religious Affairs has decided to publish a second edition of Professor Dr Fuad Köprülü's book entitled Early Mystics in Turkish Literature. The author of the work has greeted this decision with pleasure. Not only has it long been out of print - and when rarely found in second-hand bookshops the price is high, 150 or sometimes even as much as 700 liras $\{\$ 1=14$ liras $\}-$ but it is also the publication to which he devoted the most work and therefore the one to which he gives the most value.

Köprülü began his publishing career when only eighteen years old with a poem entitled "Şeyh Gâlibe." Between 1908 and 1918 - before the appearance of Early Mystics - he published a number of poems as well as articles on language, history, literature, literary history, and other fields. Although some twenty of these articles were translations from French, they are noteworthy for shedding light on his artistic talent and his intellectual development and inclinations. ${ }^{2}$ The preparatory phase of the studies that, in the event, formed a nucleus for the scholarly work that he would later produce occurred in particular between the years 1913 and 1918. In 1913, at the age of twenty-three, Köprülü was chosen for the position of Professor of the History of Turkish Literature at Istanbul's Dârülfünûn \{later Istanbul University\}. In the same year, he published an article entitled "Türk edebiyatı tarihinde usûl" \{Bilgi Mecmuası, 1 (1329/1913), 3-52; reprinted in his Edebiyat araştrmalan (Ankara, 1986), pp. 3-47\} in which he not only critically examined and explained the scholarly methods on which the Western world relied, but also established, based on his personal experience, the scholarly methods that were appropriate to the national structure of Turkish literary history. The ability to use these scholarly methods to their full extent, and the knowledge that he acquired from his personal studies of our popular poets, are conspicuous in, among others, his articles "Ahmed Yesevî ve Çağatay ve Osmanlı edebiyatları üzerinde te'sirleri," which was published in Bilgi Mecmuası, 1 (1330/1914), 61145, "Türk edebiyatı'nın menşe'i”" and "Türk edebiyatı'nda âşık tarzının menşe' ve tekâmülü \{hakkında bir tecrübe\}," both of which appeared in MTM in 2 (1331/ 1915), 5-78, and 1 (1331/1915), 5-46, respectively, ${ }^{3}$ whose director he became in the same year. All this prepared him to establish the study of popular Șūfì literature on a sound foundation and made it possible for him to write Early Mystics. 
Composed, therefore, after such a preparatory phase, Early Mystics attracted the attention of European scholars to Köprülü, the founder of the science of Turcology in our country, and his work. Professor Cl. Huart, a member of the Institut Français, wrote the first review of this book. He begins his critical article by saying "There is certainly something that has changed in Turkey. Less than two years ago, a large volume was published that is unlike anything that we have previously known. Not only does it reveal to us new events or fill gaps in our insufficient knowledge \{ of the history of Turkish literature , but it is also presented in an impressive manner. We discover here, with amazement bordering on admiration, the application of the strictest principles of historical and literary criticism as they are taught in the universities of Western Europe. Although written in Ottoman Turkish, one could say that it was thought in French. Indeed, alongside technical expressions taken largely from Arabic, which is the scholarly language for the Muslim East as Greek is for us, one encounters others that are simply calques on French terms." Describing Köprülü in his article as "a writer known for his patriotism," Huart then presents his analysis of the book. He points out that it focused on a field of early Turkish literature that had been very little studied since the conquest of Istanbul. He mentions other documents that confirm the information provided in this work and, thanks to it, shows how erroneous \{our knowledge\} has been of certain matters and would have to be corrected. Commenting on the richness of the published and unpublished sources in various languages that Köprülü used, Huart expresses a desire for the immediate publication of the unpublished works that he mentioned and, at the end of his article, reaches the following conclusions: "Not only the history of Asia Minor from the thirteenth to the fifteenth centuries, but also that of the ideas in circulation throughout the immense domain of the Muslim world during this and earlier periods are still so little understood, even by Orientalists, that any serious work that contributes to our knowledge can only be welcomed. Consequently, we are happy to greet the publication of a volume, like the one Köprülü-Zâde Mehmed Fuad has written, which by its nature focuses attention on the problems that need resolving and that one can be optimistic about resolving, thanks to the new sources that he presents, which until recently have been inaccessible to research." In another review of this work, Huart states his opinion that "its author has adopted the principles of European science; he knows French and probably also German; he knows our methods of criticism and applies them; he translates into Turkish our scholarly terminology whenever the language is appropriate and, if not, introduces it with Latin letters directly into his text. His work will open a new era." 7

After Huart, J. H. Mordtmann published a critical review of Early Mystics. In his analysis of the book, the heart of his article, he cites a few documents that escaped the notice of our author and are related to \{certain $\}$ details. Mordtmann describes the characteristics of Köprülü's method and how his book was written from a new point of view, saying, "Among the exponents of the humanities in the new Turkey, the author merits the rank of müctehid an independent scholar 
of great erudition and diligence\}. He approaches, with broad perspectives, various and great problems. He commands the relevant Western and Eastern literatures on an astonishing scale and establishes himself as a master in specialized research. He has the skill to present the subject matter in an easily comprehensible style that does not weary the reader. With special gratitude, we must acknowledge that he, by means of accurate citations and detailed references, has met the demands placed on such works in the West. Notes of various length, which accompany the entire text, complete the presentation in the manner in which European philology has been practiced for centuries. In contrast to his predecessors in the East and West - the Ottoman tezkirecis \{biographers\}, Hammer, Gibb, and others - he considers Ottoman literature as the result of the general literary development of the Turkish peoples during the thirteenth and fourteenth centuries." Mordtmann also describes the very rich contents of this work and then adds that "because of its size, which would surely make a full translation prohibitive, certain parts should at least be made accessible to European colleagues." 9

Let me state that, unfortunately, when Early Mystics appeared not a single review of it was published in our country. One reason for this is that the book constituted as much a turning point in our scholarly research in Turcology as it did in the scholarly life of the author, and consequently our scholars had not yet attained a level of competence that would allow them to evaluate it. In the Western scholarly world, however, following Huart and Mordtmann, J. Németh, Professor of Turcology at the University of Budapest, evaluated this work. The latter states, "In this work, Köprülü-Zâde Mehmed Fuad, Professor of the history of Turkish literature at the University of Constantinople, has, on the one hand, provided a synthesis of knowledge on the origin and early development of Turkish mystical poetry and, on the other, presented all the basic and a great many secondary problems of early Turkish literature related to his subject, which he has studied in a detailed and most critical manner. In both parts of the work, he has succeeded to a degree that one would hardly expect given the present state of research. European education, extensive study of Turkish literature, mastery of philology, ability to express oneself clearly, rich resources (the libraries and manuscript collections of Constantinople), and the results of earlier research have all contributed to the creation of this distinguished book. Köprülü-Zâde has produced a guide to this difficult field. It presents many problems in a clear light and will facilitate to a significant degree future research." In the same review of Early Mystics, which he considered to be the harbinger of a bright future for research in Turkey on the history of Turkish literature, Professor Németh acknowledges Köprülü's authority and ends by saying, "Altogether, thanks to Köprülü-Zâde and his school in Constantinople who have made accessible to us the bases of their research (texts and other sources) in a philologically reliable manner, we hope that the history of Turkish literature will thus finally occupy its proper place as a worthy discipline in the ranks of the historical studies of other literatures. No one is more competent to lead this 
work, on the basis of his abilities and because of his position, than Professor Köprülü-Zâde."10

In 1925, Th. Menzel published an article entitled "Die ältesten türkischen Mystiker," based on Early Mystics. ${ }^{1}$ And in the same year, Köprülü was elected a member of the Academy of Sciences of the USSR. Before his election, professors W. Barthold, S. Oldenburg, and I. Krachkovsky prepared a report in which they described the value and originality of his scholarly books and articles published up to 1925 and gave perhaps the most prominent place to the ideas in Early Mystics. ${ }^{12}$ In this report, they cite the opinion of the late Martin Hartmann, who had usually been a severe critic of Turkish scholarly works, about the articles on popular literature that Köprülü had first published in MTM and used as a basis for writing Early Mystics. In Hartmann's view, Köprülü's works were in complete conformity with the European scientific method and contained profound scholarly thought. Other characteristics of his works were his success in showing everywhere in excellent fashion the relationships between the history of literature and social life, and in providing new theories to shed light on historical events. Turning to the new ideas presented in Early Mystics, the report notes that the work was well received by French, German, and Hungarian reviewers. It goes on to state that the work was very important for revealing the close relationships between the Șūfị tañqa of the Central Asian Turk Aḥmad Yasawī and the Bektashī tarīqa of Asia Minor. And according to the French reviewer Huart, Köprülü's study would require a major revision in the ideas of European scholars about the Bektashīs - as portrayed in both Georg Jacob's famous book \{Die Bektaschïje in ihrem Verhältnis zu verwandten Erscheinungen (Munich, 1909)\} and R. Tschudi's article in the $E I^{1}$ on this subject \{s.v. "Bektāsh" ". The report then goes on to analyze Early Mystics.

I believe that the material that I have presented to this point has revealed the importance of Early Mystics with respect to its repercussions in France, Germany, Hungary, and Russia. ${ }^{13}$

When our author wrote Early Mystics, he was twenty-eight years old. He had not yet established his rich library, which today is connected by a corridor to the top floor of his house in the Akbiysk section of Istanbul and which is also reached by a stairway from the garden. ${ }^{14}$ At that time, his library was in the large room on the second floor of this house opposite the stairs. Köprülü has stated that he wrote Early Mystics in this room in a year and a half and then spent more than another year revising it. In this work, which focused on subjects and problems that had been virtually unexplored up to that time, the author, following the most rigorous scholarly methods, demonstrated the ability to synthesize and present in Turkish the rich material that he had obtained not only from published sources in Oriental and Western languages but also from manuscripts in the libraries of Istanbul and Europe and his own unique manuscripts and 
those of his friends. Early Mystics constituted, in fact, a beginning, a turning point, for his subsequent scholarly research.

Professor Köprülü always had a national objective in his research and it was for this reason that he divided Early Mystics into two parts: "Ahmmad Yasawī and His Influence \{on Turkish Literature\}" and "Yūnus Emre and His Influence \{on Turkish Literature\}." In this way, he wanted to prove that "the Turkish literature of Anatolia had not developed separately and independently from the literature of the Turks in other regions, that it was a continuation of the past \{i.e. earlier Turkish literature $\}$, and that, consequently, one could only write a history of Turkish literature by studying it as a whole" (p. 3 of the first edition). Let me immediately state that while the life, work, and influence of Ahmad Yasawī and Yūnus Emre - the first of whom lived in Turkistan in the sixth/twelfth century and the second of whom, who continued his tradition, lived in Anatolia - are studied in Early Mystics, the book also sheds light on their milieus and on their ethnic, religious, linguistic, literary, and political characteristics. Indeed, although Șüfi literature from the sixth/twelfth century to recent times constitutes the core of the book, the material presented on the influence of these two great Turkish mystics and their imitators includes information on the history and social, linguistic, and literary life of the period in general. Another valuable feature is that, as in subsequent studies, the author is not content with simply providing information on these various topics, but also draws attention to scholarly problems that have not been investigated and need to be studied. For all these reasons - its comprehensive coverage of the subject, the rich information that it contains, and its masterful composition based on the most rigorous methodology - Early Mystics is a milestone of scholarship.

It is appropriate to give a brief account of how the second edition of Early Mystics was prepared and to describe the differences between it and the first edition.

Köprülü worked continuously between September and December of 1963 to prepare the second edition of this book. While I read the text that was typed with the new letters \{Latin alphabet\}, Köprülü would follow along in the original work. On some subjects - for example, the linguistic characteristics of the Dīwān-i Hikmat (pp. 107-24 of the second edition) - he would say, "What difficulties I encountered while writing this! At that time there was nothing written on this subject." Furthermore, he placed marks at the required places for the additions that he was planning to make at the end of the book. In fact, he had already put such marks in his personal copy and had even entered some notes. He said, for instance, that he had made a lot of notes on Luqmān-i Paranda. Because of the essentially plain language of the book, we changed certain Persian phrases and foreign words that are no longer used today \{in Turkish\}. The revisions and additions that Köprülü was going to make were to be placed at the end of the book, so nothing was added to the main body of the work except 
some limited bibliographic information. \{Fortunately,\} almost all the books in foreign languages that Köprülü had used were in his library in Istanbul. Nevertheless, writing the names of these books and their authors, all of which had been in the Arabic alphabet in the first edition, in their original form proved to be an enormous task. After four months of continuous work, the text was ready for the press. At the beginning of 1964, it was delivered to the Office of the Chief of Religious Affairs.

The following are the major differences between the first and second editions of Early Mystics:

1 As the author stated in the preface \{to the first edition\} of his book, he was not able to see certain studies despite making every effort to do so. After indicating that some of them were important, he said, "If I come across any of these sources while my book is in press, I will not hesitate to include them at the last minute in the Corrections and Additions section." It is clear from this that he planned to work on the book even after it was given to the press. Indeed, in the Corrections and Additions section that he attached to the end of the book, he explained, "The number of printing errors in my book was very low and, on the whole, so obvious to the reader as to be of no significance. However, more than a year passed between the time the book went to the press and the time it appeared from the press. During this period, I continued my research and noticed some mistakes in both the typescript and published text as well as a few rather important omissions. It was possible, of course, to leave them to the second edition of the book, but there was considerable doubt about when there might be a second edition. Consequently, I was compelled to add this short section containing major errors and omissions in order for the first edition of my book to have as few deficiencies as possible when presented for criticism. Nevertheless, in a study of this nature, which covers a broad and completely unknown subject for the first time, there is no doubt that many errors and deficiencies will remain. I hope to make up for them by benefiting from the criticism to which my work will be subject." After this, thirty-five entries are given (pp. 395-400). In the second edition, these corrections and additions have been inserted in their proper place in the text and notes, and therefore have been deleted from the end of the book.

2 The author also continued his research while the section called "Corrections and Additions" was being set in type. As he states, "After the 'Corrections and Additions' section was printed, I came across some information on the famous cauldron in the türbe \{mausoleum\} of Ahmad Yasawi and I could not avoid inserting it here." He then attached one more page under the heading "Appendix" (p. 401). In the second edition, this section has been removed and placed where it belongs in the book.

3 In the first edition, under the heading "Bibliography," which was arranged alphabetically, Köprülü explained, "While writing my book, I provided sufficient information on every page concerning the various sources to which I referred. There were, however, some works, mainly manuscripts, about which no 
information was given in the text . I therefore found it appropriate to give a brief description of them here. The works next to which there is an asterisk are manuscripts. In my bibliographic entries, I did not consider it important whether works were in manuscript or published, or written in different languages. I listed them alphabetically according to the name of the author. Works whose authors are unknown were entered alphabetically according to their titles." Then comes the bibliographic data (pp. 403-16). In the second edition, the author thought it better to place the information given on a work in the bibliography within brackets next to its title in the general index. This information comes immediately after the numbers referring to the pages on which the work is mentioned in the book. In this way, the information that had been given in the bibliography, which we have deleted, can be more extensively and easily used.

4 In the first edition, the bibliography was followed by the table of contents (pp. 417-24). The author had taken great pains to arrange this section in order of subject rather than by heading; and for the second edition he has placed it verbatim at the beginning of the book under the heading "Contents." The page numbers for the table of contents have, naturally, been changed to correspond to the new edition.

5 In the first edition, under the heading "General Index," which contained the proper names in the text in alphabetical order, Köprülü stated, "The names of authors, whose works can be found directly under their names in the Corrections and Additions \{i.e. bibliography section are not included in this list. As I said in the preface, I had originally decided to have two separate lists, one for personal names and one for place names, but I later came to prefer the present arrangement." Thus the General Index contained historical names, with the exception of the names of authors, and geographical names (pp. 425-46). This index also contained a limited number of technical terms. Alpler devri, for example, is included but alp-erenler is not. Following the author's suggestion, this General Index was removed and replaced at the end of the second edition with one that contains everything that had been in the General Index plus the names of all works and authors that were in the text or had been in the Corrections and Additions and Appendix sections as well as all expressions and technical terms concerning history, literature, language, religion, mysticism, etc.

In both editions, the arrangement of the remaining parts is the same. Two diagrams, entitled "The Yasawiyya Chain of Authority" and "The Zangì Ata Chain of Authority," and the musical scores for twelve of the hymns of Yūnus Emre are placed at the end of the book and separated from the text. In the first edition, the illustrations "Turkistan: The City of Yası̄" and "The Tomb of Ahmad Yasawī in Turkistan" were published as a supplement to the text \{i.e. separately\}.

$*$

The proofs of the book were first corrected by the Office of the Chief of Religious Affairs. Around the middle of September 1965, Professor Köprülü began to 
work on correcting them a second time. As I read and corrected the proofs, he followed along in the first edition of his book. On Friday, October 15, he had worked more than three hours in this fashion at Türk Tarih Kurumu the Turkish Historical Society, in Ankara\}. On that day, we had reached the end of the section on the rules $\{\bar{a} d \bar{a} b$, etiquette, protocol $\}$ of the Yasawi $\tan q a$, which began on page 80 , in our corrections. In this section the duties of murids \{novices, disciples\} to their murshid \{spiritual guide\} were discussed. Once while correcting this section, Köprülü assumed a joking manner as he spoke of unpleasant matters and said, "Do you see? The paths of discipleship are difficult." And he added, "You shall complete what I have left half finished." On Monday we were going to continue the corrections, but that evening while walking home from the Turkish Historical Society, he suffered that regrettable traffic accident. I visited him many times in the hospital and, although he said that I should continue the job of making the corrections and that, in any case, he would soon be on his feet and then be able to work again, he was never able to get beyond the subject of the rules of the Yasawī tariqa. To be sure, Early Mystics was a solid work with respect to the fundamental material on which it was based and very little criticism of any kind was directed toward it that would cause any change in this material. Nevertheless, Köprülü had continued his research \{on this subject\} during the almost fifty years that had passed since the book was published; and he said that he had thought about providing an appendix at the end of the book for the notes that he had taken from this research because they would enrich the present material. What a pity that this was not possible!

In 1964, while we were organizing his library in his home in Ankara, Professor Köprülü took Early Mystics from a shelf and, opening it to the first page, said, "Do you see? I wrote the death dates of my relatives here. This is the date of my father's death ..." Because of its religio-mystical subject, this book had a spiritual value for him. This famous work, which attracted the attention of Western Turcologists to our country, was truly a turning point in his scholarly life. Exerting an enormous effort, he had written it at the age of twenty-eight, an age that was young for one to be called a true scholar. On April 27, 1966, he signed off on the proofs for the text of the second edition. This was the last work on which he was able to sign off for publication. Around the middle of the following May, he was able to see the first volume of his Edebiyat araştrmalar, which was published by the Turkish Historical Society, ${ }^{15}$ but he was not able to see the second edition of Early Mystics, which he had wished so much to be completed.

Our esteemed and great teacher! The second edition of Early Mystics is now finished and has been published by the Office of the Chief of Religious Affairs, which is responsible for administering the religious affairs of our country. May your soul rejoice! May God's mercy be upon you! Rest in the light!

Ankara, July 9, 1966 Fevziye Abdullah Tansel 


\section{NOTES}

1 Mehâsin Mecmuası, Sept. 1324/1908, no. 1.

2 Although they are incomplete in certain respects, see the following bibliographies of the author's publications: Şerif Hulûsî \{Sayman\}, Ord. Prof. Dr Fuad Köprülü’nün yazılar için bir bibliyografya (1913-1934) (Istanbul, 1934), 19 pp.; Hulûsî, Ord. Prof. Dr Fuad Köprülü'nün yazılan için bir bibliografya (1912-1940), 2nd edn (Istanbul, 1940), 24 pp.; S. N. Özerdim, "F. Köprülü’nün yazıları, 1908-1950," in Türk Dili ve Tarihi hakkrnda Araştrmalar - 1, published by Türk Tarih Kurumu and Türk Dil Kurumu on the occasion of Köprülü's sixtieth birthday and edited by Hasan Eren and Tibor HalasiKun (Ankara, 1950), pp. 159-248; and "Fuad Köprülü'nün ilmî neşriyatı," in Turan et al. (eds) 60 Doğum yılı münâsebetiyle Fuad Köprülü armağanı, pp. xxvii-1.

3 Both these and a number of Köprülü's other scholarly articles can be found in a recently published collection of his works, Edebiyat araştrmalan (Ankara, 1966 \{reprinted Ankara, 1986\}). \{These two articles are on pp. 49-130 and 195-238 respectively.

4 \{"Les Anciens derviches turcs,"\} Journal des Savants, new series, 20 (1922), 5. For a Turkish trans. by Râgip Hulûsî, see TM, 1 (1925), 267-80.

5 \{Huart citing L. Bouvat in "La Presse Ottomane" in\} Revue du Monde Musulman, 38 (1920), 242.

6 "Les Anciens derviches turcs," p. 18.

$7 \mathcal{F A},\{202\}$ (1923), \{147\}. In this article, Huart mentions the founding of the Historical Society \{Tarih Encümeni\} in Istanbul and the beginning of research on new documents, and then draws our attention to a very important point, namely that this work, which was written when the Ottoman Empire was on the verge of collapse, was prepared with a national objective in mind, that of investigating the problem of the origins of this powerful state. Let me point out an error that has appeared in certain \{Turkish\} works with respect to Huart's reviews mentioned here and the one in n. 5: the passages cited from both of Huart's reviews have been presented as being from only the one in $\mathcal{F A}$ with no reference to Fournal des Savants (see, e.g., the brochure issued on the occasion of Köprülü's fortieth birthday, p. 4: N. S. Banarl, Resimli Türk edebiyatı tarihi \{Istanbul, 1948\}, p. 362).

8 Orientalistische Literaturzeitung, $\{26\}$ (1923), $\{122-3\}$. For a Turkish translation by Mübârek Galib, see TM, 1 (1925), 281-7.

9 Ibid., p. 129.

10 Körösi Csoma-Archivum, $\{1\}$ (1924), $\{330-2\}$. For a Turkish translation of this article by Köprülü-Zâde Ahmed Cemal, see TM, 1 (1925), \{in the review section\} 288-9. In addition to the information given by Németh here on Köprülü's book, he also states that among the manuscript collections of the Hungarian Academy there is a recent MS belonging to Aḥmad Yasawī of which Köprülü was unaware. According to the catalogue, it consists of 81 folios of 17 double lines and was written in 1124/1712.

$11 Z D M G$, which is Germany's oldest journal of Oriental studies, new series, 4 (1925), 269-89.

12 Köprülü was elected to membership in the session of the aforesaid academy held on November 5, 1925 and was informed of his election by a letter dated November 20, 1925. Later he was also sent a diploma of membership. (For more information and the text of the report, see TM, 2 [1926], 555-9.) In 1948, Köprülü was expelled as a corresponding member because of his nationalism and the communist bias of certain members of this academy. This action stemmed from a letter - which was first published in the communist newspaper in Tbilisi \{in Georgia\} and then in the major Soviet newspapers, and broadcast on Soviet radio - signed by two members of the Georgian Academy. Supposedly based on historical facts, it demanded that a large section of Turkish territory be given to Soviet Georgia. Subsequently, in a series of 
articles, Köprülü attacked this letter, which was having repercussions in the world press. (See "Gürcü âlimlerine cevap - I. Tarih, yalancı şâhit olamaz"; "II. Tarih değil, efsâne"; "III. Efsâne değil, tarih," which appeared, respectively, in the newspaper Vatan, December 17, 19, 20, 1946; see also Köprülü, On the Way to Democracy, trans. Tibor Halasi-Kun [London, 1964], pp. 79-90.) Köprülü used to say that he considered it an honor to be expelled.

13 Alî Emirî Efendi, in his response to Alî Rıâ Bey's letter criticizing \{Sahabeddin Süleyman and Köprülü's\} Yeni Osmanl tarih-i edebiyatı \{Istanbul, 1916\}, referred to Early Mystics, asked if the Ministry of Education had published this work out of love of ignorance, and said that it was meaningless to write a book about Ahmad Yasawi and Yūnus Emre, whose death dates were unknown and whose dīwāns \{collections of poems $\}$ were no longer extant, and to give a place to legends. This article, which descends to the level of personalities, is virtually devoid of constructive criticism \{"Cevap,"\} (Tarih ve Edebiyat Mecmuası, year 3, no. 25, March 31, 1336/1918, pp. $635 f f)$.

14 KKöprülü's library is now in the possession of the Yapı Kredi Sermet Çifter Araştırma Kütüphanesi in Beyoğlu, Istanbul.\}

15 See above n. 3. 


\section{PREFACE TO THE FIRST EDITION}

In order to understand the $\{$ Turkish $\}$ national spirit and taste in Muslim Turkish literature, the period most worthy of study is that of the great mystics \{Ṣūîs \} who spoke to the masses using the popular language and meter and whose works have endured for centuries. One must distinguish this popular $\{k h a l q\}$ Șüfì literature, which was clearly related to the pre-Islamic folk $\{$ qawm $\bar{\imath}\}$ literature, from the abundant and artful compositions that Turkish poets - who translated, and skillfully and enthusiastically imitated, the Șūfi works of the Persians - wrote in the 'ar $\bar{u} d$ meter $^{1}$ and most often in pompous language. Because these two currents continued parallel to each other for centuries, they naturally influenced each other. Nevertheless, despite such mutual influence and the many Persian elements that were incorporated, it is possible, indeed essential, to study the popular Suufì literature - if one can use this expression - as a separate phenomenon. ${ }^{2}$

Because we $\{$ Turks forgot our distinctive national character in the middle ages under Persian influence and, since the Tanzimat the Ottoman reform movement between 1839 and 1878\}, under European influence, popular Șūî̀ literature, like everything related to, or derived from, the people, has been neglected, even regarded with contempt. Unlike the artists who wrote pompous works in imitation of the Persians, the popular mystics, who tried to impart, with simple and sincere hymns, the sacred fire that burned in the depth of their souls, were forgotten. Earlier generations, even if they did not allow these hymns any aesthetic value, at least attributed to them a sacred quality. In recent times, because this view also has disappeared, no one even remembers who wrote them. Among the trifling things that have been written on our literary history since the Tanzimat, and that do not have any scholarly value, not a single line mentioning the existence of the popular mystics can be found. However, this Sûfî literature of the common people, which is closely related to early popular literature and is very valuable in revealing the national spirit, has a long history.

The Turks embraced Islam within a short time and of their own free will, unlike many others who were converted by the sword. And these Muslim Turks did not refrain from making religious propaganda among their brothers who had not yet entered the Islamic fold or, if they had, did not properly conform to its beliefs and principles. These then were the spiritual conditions under which 
early Turkish literature spread in Islamic form. A number of Turkish dervishes, animated by the desire to spread the new religion and its tariqas, moved among the nomadic Turks and tried to propagate this new religious ideal in a language they could understand and in an aesthetic form they would appreciate. This is the reason why the popular literature, which had prevailed among the Turks for centuries, served as a model for the mystical literature whose foundation was being laid. This mystical literature, which produced works that were rather dry and simple in the earliest stages that we can discern - probably because it pursued a propagandistic goal - was increasingly refined over the centuries to the extent that it acquired a special quality that revealed the Turkish national genius. In fact, works were created that could compare with the most sublime Persian mystical compositions. This popular Sūfì literature, which is so characteristically Turkish that nothing like it is found among the Arabs and Persians, is therefore worthy of special and careful study.

Up to now, the few general works and monographs that have been written in the East and West on our literary history have been largely devoid of scientific value. Consequently, the problem of the general development of Turkish literature is still an unsolved mystery for the scholarly world. I must say that, unfortunately, no one - from Joseph von Hammer(-Purgstall) to E. J. W. Gibb, or from our old official biographers to the few rare scholars of today - has realized that it is necessary to study as a whole the literary development, over at least thirteen or fourteen centuries, of the entire Turkish nation from Inner Asia to the shores of the Mediterranean. In the hands of researchers who consider the various branches of the Turks to be separate nations with no connection to each other, who do not understand the bonds and relationships among them, and who see no need to study the general history of the Turks in a comprehensive fashion, this important part of world history will remain a mystery forever. Fortunately, the historical research that has modestly begun in our country in the past six or seven years has revealed the error of this point of view, to which Orientalists have been bound up to now, as well as the path that must be followed in order to study the past and bring it to life. ${ }^{3}$ We will see in the future what important results this approach will have in the study of all branches of Turkish history.

When a group of events are connected and have influenced each other, it will always produce mistaken results to take into account some of them while ignoring the rest, or to try to understand any series of events by completely neglecting their origin. Without understanding pre-Islamic Turkish literature, it is impossible to explain that of the Islamic periods. Without knowing how Turkish literature developed in Central Asia and Asia Minor up to the formation of the Ottoman state, it is impossible to comprehend the development of Ottoman literature. Indeed, it is a mistake to ignore any of the literatures that have appeared in each period in the different geographical areas where the Turks have lived, and the relationships among these literatures. It is meaningless to try to understand, for example, the period of Ahmad Pasha \{Bursall, d. 902/1496-7\} without knowing $\{$ Mīr 'Alī Shīr\} Nawā'̀̄ \{d. 906/1501\}. In like manner, in order to grasp 
scientifically the development of Turkish literature, it is also necessary to understand the special developments of popular literature and ' $\bar{a} s h q$ \{minstrel $\}$ literature in every period and region and the influences and reactions upon each other of the classes of literatures addressed to all these different levels of taste. ${ }^{4}$

Once these requirements are clear - i.e. once these new points of view are accepted - the first task is to write monographs on the different periods of our literary history, on the literatures in the various Turkish dialects and on various important figures, in other words, to conduct meticulous and systematic analyses on literary phenomena, undertaken with a synthetic goal in mind. Indeed, history today is not a mass of endless and unconnected data, but a product of synthesis and composition. For historians who accept the notion that social factors determine the course of events, history is neither a work of art nor simply an exercise in erudition. Consequently, in order for a historian not to be left bewildered when faced with a mass of important events, he must rely on a set of hypotheses derived from the systematic study of these events, i.e. he must combine, classify, and compare the data that he collects and then establish certain frameworks in his mind in order to be able to reach any conclusions from them. This approach - which is also what we call intuition - is possible as a result of a historian's familiarity with, and affinity for, his subject over many years and is completely scientific. It has no connection with preconceived ideas, because these hypotheses and frameworks arise out of lengthy and systematic study of the events themselves, i.e. from meticulous and profound analyses. Given that even mathematicians and specialists in the natural sciences have accepted the necessity and importance of hypotheses in their work, it is impossible for any scholar not to perceive the need for them in a more complex field like the social sciences. Taking all these observations into account, it is easily conceded that for a true historian, who has complete command of his subject, erudition is not a goal, but it is a requisite condition. Simple syntheses that are not based on extensive and rigorous analyses, no matter how bright their apparent scientific luster, are doomed to collapse in the face of serious criticism.

After this brief explanation of my views on literary history, I would like to say a few words about the nature of this modest monograph that I have presented for criticism. Some four or five years ago, I published a rather long study on Khwāja Ahmad Yasawī, the herald of popular Șūfì literature among the Eastern Turks and their greatest representative, and another on Yūnus Emre, who is considered the earliest and greatest popular Șūfì poet of the Western Turks. ${ }^{5}$ The major thesis of those studies was that popular Șufi literature among the Western Turks was influenced by Aḥmad Yasawī. In the study on Ahmad Yasawī in particular, I tried to support this hypothesis with the help of historical documents, in addition to literary and linguistic comparisons, and I presented considerable material relating to his fame, his disciples, his miracles, etc. among the Western Turks. In this way, I wished to demonstrate that the Turkish literature of Anatolia had not developed separately and independently from the literature of the Turks in other regions, that it was a continuation of the past \{i.e. earlier 
Turkish literature $\}$, and that, consequently, one could only write a history of Turkish literature by studying it as a whole. During this time, I was not even aware that Mr E. J. W. Gibb had discovered some common points between Ahmad Yasawī and Yūnus Emre. Nevertheless, I set out to prove a much broader claim than his and put forward the bold hypothesis that the popular Șūfì literary movement among the Western Turks originated from the Eastern Turks and especially Aḥmad Yasawī.

As a result of continuous work over the past four or five years, and as the fruit of investigating Turkish literature as a whole, I have arrived at some clear and specific ideas regarding the literary development of the Turkish nation. I have also engaged in detailed studies on the pre-Islamic literature of the Turks, the scholarly study of which up to now had been regarded as impossible. All of this has made it possible to defend much more forcefully and definitively the hypothesis that I made five years ago. For a historian, nothing more gratifying can be imagined than to be able to support a hypothesis made years earlier with new documents that were discovered later. While studying the different periods and branches of Turkish literature, I obtained a number of documents on Ahmad Yasawī, Yūnus Emre, and popular Șūî literature among the Turks. Thus I felt obliged to combine and synthesize these materials and to write this monograph on an aspect of Turkish literature that displays most clearly its national spirit and taste.

I have published this book under the title Early Mystics in Turkish Literature mainly because I have included extensive material on the life and works of these two great personalities in addition to showing, in general, how popular Șūfì literature began among the Turks and the various causes and influences under which it developed. The work is thus divided into two parts. In the first, I describe broadly Turkish literature up to Aḥmad Yasawi and the spread of Islam and Șuffism among the Turks. Then I provide more detailed information on the legendary and historical life of Ahmad Yasawī, on the rules of his tariqqa, on his spiritual successors $\{k h a l i f f a s\}$, on his works and influence. Because this part constitutes in itself a monograph on Ahmad Yasawī, all issues connected with him - even a number of secondary topics that at first glance might seem extraneous - are dealt with in full detail. Those who believe that such minute details are appropriate for any monograph will excuse the author. On matters not directly concerned with Ahmad Yasawī, such as his khat̄fas and his poetic imitators, naturally I have not maintained the same degree of detail but have treated them in a more general manner. Nevertheless, this first part clearly shows the general outline of popular Șūfì literature among the Eastern Turks and its historical development.

As for the second part, which describes the origin and development of this type of literature among the Western Turks, it constitutes a monograph on Yūnus Emre and, following the format of the first part, gives a fully detailed account of all issues connected with him, even if not touching directly on literary history. An extensive description is given of Yūnus Emre's legendary life, his 
historical life, his poetry and its different characteristics, and his influence. Then a brief general account is given of his principal followers, their lives and works. But as with the first part, this second part also clearly explains the origin and development of popular Șuffi literature among the Western Turks. Although all sources and documents are given individually in the footnotes, I have found it necessary to add a bibliography at the end of the book to facilitate the work of researchers and especially university students. Furthermore, I give short descriptions there of manuscripts, some of which are completely unknown to the scholarly world, as well as information that I regard as necessary and useful on many \{published\} sources or studies in different languages. Finally, I have added two indexes \{subsequently changed to one in the first edition of Early Mystics\}, in alphabetical order, of personal names and place names, which should be of further assistance to those working in various fields of history.

A quick perusal of the bibliography will indicate how much attention to detail I have given in my book, even regarding secondary and tertiary issues, and how many and varied sources I have consulted. Indeed, I can state that my book presents a canvas of many important historical problems that are still unknown to the scholarly world but are worthy of study, and that it provides the primary sources for studying them. If my book can serve in this fashion as a modest guide for future research, this would be the greatest satisfaction that I could receive from my work. I must attribute the deficiencies in my book especially to the fact that there are very few works on the Eastern Turks in the libraries of Istanbul and that it was also almost impossible to find there works published in Europe. For example, Zeki Velidi \{i.e. Ahmed Zeki Velidi Togan\} stated in his Türk-Tatar tarihi \{Kazan, 1912\} that the Russian Orientalists S. E. Malov, N. F. Katanov, and S. M. Matveev had made studies on Ahmad Yasawī and his khalīfas, but despite all my efforts, I was not able to see them. Furthermore, I was unfortunately unable to examine K. G. Zaleman's article on Hakīm Ata and N. I. Veselovskii's work on the türbe and mosque of Ahmad Yasawī, both of which are mentioned by P. M. Melioransky in the Encyclopaedia of Islam $\left\{E I^{I}\right.$, s.v. "Ahmed Yesew $\left.\vec{\imath} "\right\}$. Since Melioransky is silent about the Russian sources mentioned by Zeki Bey, this could be an indication that they are not of great importance. Whatever the case, to see and review these sources would not have been without advantage. If I come across any of these sources while my book is in press, I will not hesitate to include them at the last minute in the Corrections and Additions section. I can claim, nevertheless, with strong conviction that any deficiencies arising from not having seen the aforesaid sources could not have a great effect on the work as a whole. If this small product of five or six years work sheds light on, and explains in broad outline, a problem that has remained unknown up to now, namely the problem of the origin and development of popular Șūfi literature among the Turks, I hope readers will excuse any errors and deficiencies in the details. 


\section{NOTES}

1 On this topic, see $\dot{I} A$, s.v. "Arûz," the sections on Persian and Turkish literature (M. F. Köprülü); and EIr, s.v. "'arūż” (L. P. Elwell-Sutton).\}

2 Here the word khalq is used as the equivalent of French populaire. It would be wrong to conclude, as some have done, that this term is used pejoratively. The works created by this literature, which should not be confused with the products of folklore, were greeted enthusiastically not only by the common people, but also by the scholarly and refined circles of the upper classes. See the narrative of this book. \{Köprülü's distinction between "popular" and "folk" literature is not always clear. He often uses khalq to mean both.\}

3 This view was described and defended in detail for the first time in my article "Türk edebiyatı tarihinde usûl," Bilgi Mecmuası, 1 (1329/1913), 3-52. This same view was also clearly expressed in the introduction to my book Türk edebiyat tarihine medhal no such book was published, but the first part appeared as the article "Türk edebiyatının menşe'i" - see the bibliography\}, but in another fashion.

4 For an understanding of my thoughts on this matter in broad measure, see the introduction to my article "Türk edebiyatında âşık tarzı'nın menşe' ve tekâmülü hakkında bir tecrübe," MTM, 1 (1331/1915), pp. 35-46. \{Reprinted in his Edebiyat araştırmalan.\}

5 "Ahmed Yesevî ve Çağatay ve Osmanlı edebiyatları üzerinde te'sirleri," Bilgi Mecmuası, \{vol. 1\}, 1330/1914, 611-45; and "Yūnus Emre," Türk Yurdu, 4 \{1329/1913\}, 61221, and "Yūnus Emre, âsârı," 5 \{1329/1913\}, 922-30. 



\title{
Part I
}

\author{
AHMAD YASAWI AND \\ HIS INFLUENGE ON \\ TURKISH LITERATURE
}




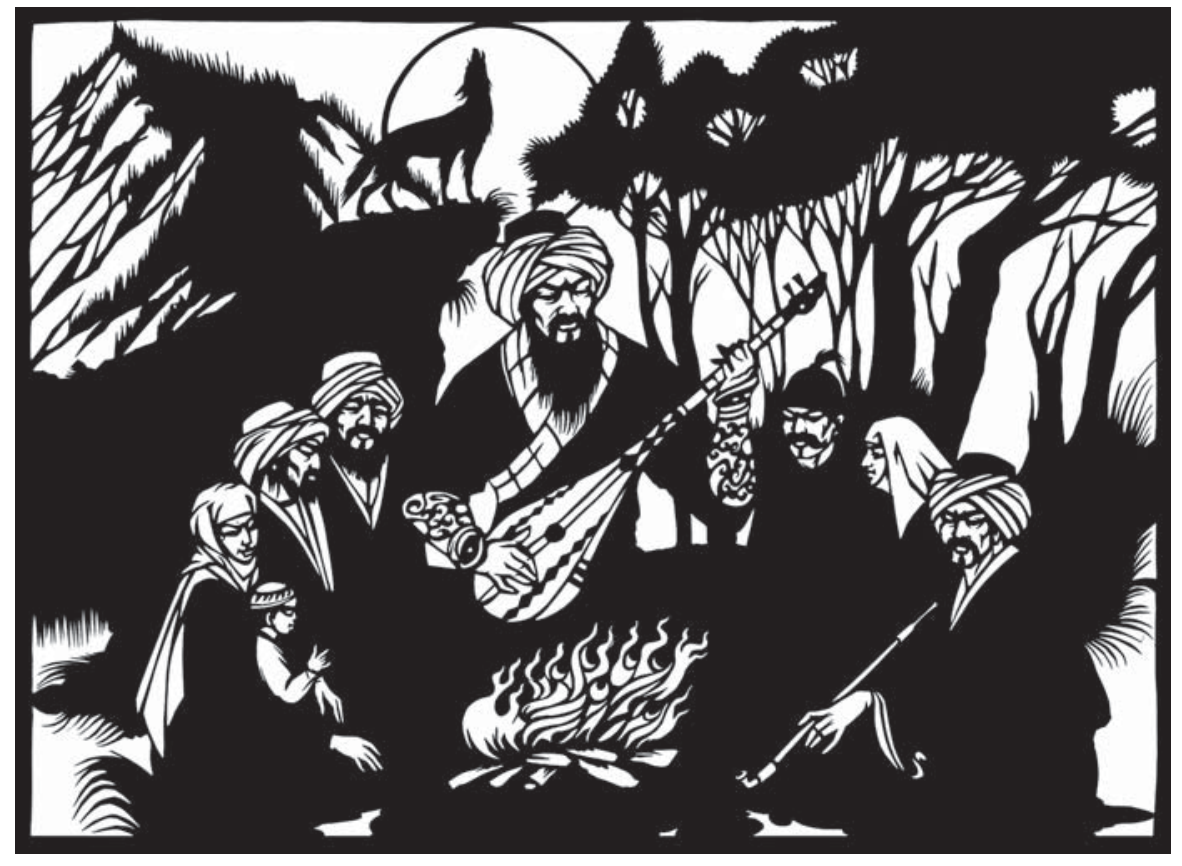




\section{TURKISH LITERATURE BEFORE AHMAD YASAWI}

\section{A Pre-Islamic literature}

The literature produced by the Turks before their adoption of Islam consisted with the exception of some insignificant translations made under Chinese, Indian, and Iranian influence - of popular poetry sung to the accompaniment of the saz $\left\{\right.$ a Turkish stringed instrument, see $E I^{2}$, s.v. "Saz" (J. Cler)\}. In all the social institutions of the Turks at that time, there was, moreover, a primitive genuineness that revealed the spirit and personality of the people in language, religion, ethics, customs, and legal practices. Although the civilizations of China, India, and Iran had begun to have an influence on the Turks in some fields, this $\{$ cultural\} penetration was very piecemeal and superficial. Because it never spread from the center to the periphery, i.e. from the enlightened elite to the mass of the people, it was not able to have a real effect on society. Thus, the works that constituted the Turkish literature of that time were also, in conformity with the other elements of society, far from foreign influence and genuinely reflected all the attributes of the people. Everyone, from the ruler to the most insignificant person, sensed himself in the \{popular\} poetry. Poets in that period were uniformly simple men with kopuz \{ancestor of the saz\} in hand. Wandering from encampment to encampment, they would appear at public or private gatherings and sing the exploits of the old heroes and recite the national epics, or fashion new \{folk\} songs $\{\mathrm{s}$. türkü $\}$ about recent events. At the same time, they might also perform magic or do fortune telling with their kopuzes. And the poets were certainly present at national hunting rites, called sigur \{properly, sagır, "royal battue" $\}$, at public banquets or şölen, and at mourning ceremonies called yoğ.

All of this poetry was recited in the syllabic meter $\{$ hece vezni\}, which was natural for Turkish. This metrical system had several varieties depending on the number of syllables, because Turkish syllables, while they are all precise and unvarying in length, naturally divide into groups with distinct pauses or caesuras. The oldest were the simplest, i.e. the ones with the smallest number of syllables. All of the poems of that period, whatever the subject, had a precise form. In these early forms of Turkish poetry, two main features are conspicuous. The first is the paucity and specificity of the forms. The reason for this is that the literary 
personality in those primitive times could not develop freely, but every poet had to respect the existing forms with a kind of religious devotion. Second, in strophes of poetry, which were usually composed of four verses \{i.e. quatrains\}, only the first three verses rhyme with each other while the fourth rhymes with \{the fourth line of $\}$ all the strophes. It seems clear that this type of poetry was written to be sung and that the fourth verse always naturally maintained the same rhyme, operating like the refrain of a folk song. In the works of this early period, when music and poetry had not yet been separated, the rules of rhyme were also very simple and basic, so much so that, in the modern sense, it would be more correct to speak of assonance rather than rhyme. For them, it was sufficient for the last syllables of the verses to have a slight similarity, in order to create a rhyme, and this similarity was usually brought about by the inflection of verbs, thus assuring the poets an ample ease of composition. In short, although the literary products of this early period were of limited scope, simple, and basic, they sprang from the spirit of an entire people and expressed their joys and sorrows. This elementary, but lively and heartfelt literature, which spread with vigor and majesty across the steppes of Asia, was rich enough to show the rough and warlike and, at the same time, refined and profound spirit of the Turk in its naked glory. ${ }^{1}$

\section{B The Turks and Islam}

In the sixth century CE, the Turks known as the Göktürks established a large empire in Central Asia, stretching from Siberia to Lake Baikal, and began, on the one hand, to threaten seriously China and, on the other, the Sāsānid rulers. They even held discussions with the Byzantine Empire \{about an alliance\} against \{the Sāsānid ruler\} Khusraw Anūshirwān. Problems of succession, however, resulted in the division of this empire into two parts, known as the Western and the Eastern Turks, in 581. In the eighth century, it almost seemed that the Eastern Turks, or T'u-Chüe, would be able to re-establish the former Turkish unity, but at that time Arab armies propagating a new religion entered Transoxiana under the command of Amīr Qutaiba $\{\mathrm{b}$. Muslim\}. Both the Western and Eastern Göktürks resisted the Muslim invasion for a long time. The new religion gradually advanced, however, sometimes by blood and iron and sometimes by peaceful means, and expanded its area \{of dominance\} toward the east.

In order to invade Soghdia and Farghānā, the Muslim armies that were marshalled in Khurāsān followed the old military road that passed through Marw and Balkh south of the Amu Darya \{Oxus\} River. Despite the great disorders that the Turkish world then faced, it occasionally struck fairly successful blows against the conquerors. In 712, a Turkish army entered Soghdia and rendered great assistance to the local population, who had risen in revolt after Qutaiba's return to Marw, and left the Arabs in possession of only the city of Samarqand. Nevertheless, the following year, the Arabs again carried out successful conquests in the region. After the death of Emperor Mo-ch'o \{716, 
the ruler of the Eastern Turks\}, the Western Turks again separated from the Eastern Turks. But Su-lu, a leader of the Türgesh, who had formed a strong government and had taken possession of the old provinces of the Western Göktürks between Talas $\{$ Tarāz $\}$ and Tokmak, did not want to give up Transoxiana easily. Consequently, for most of his life, he did not leave the Arabs in Soghdia in peace. Although the conquests of Qutaiba had advanced rather far to the north of the Amu Darya, the Turks, who had previously penetrated deeply into Iran, were able to hold out and entered the region of Gurgān via the corridor between the Amu Darya and the Caspian Sea.

During the period of the Arab Umayyad caliphate, the situation in Transoxiana remained in doubt for a long time. If the plan of Caliph 'Umar b. 'Abd al-'Azīz \{d. 101/720\} to build caravansaries and hospitals throughout his domain and establish a just administration, while not taking kharajj \{land tax on nonMuslims \} from converts, had been properly applied, Transoxiana would have been very quickly Islamized. The tyrannical and selfish policy of the Umayyads prevented this, however, and war against the Turks continued for a long time. During this interval, the Chinese unjustly killed the ruler of Shāsh \{Tashkent\}, who had surrendered to them. His son took refuge with the Muslims and sought their help. Although the Chinese dispatched a powerful army with the support of the Ikhshīd of Farghānā, the army that Abū Muslim sent under the command of Ziyād b. Șālị completely defeated it - because of the uprising of the Qarluqs. ${ }^{2}$ This battle (133/751) then sealed the fate of Transoxiana, which, henceforth, would definitely be Islamized and enter the orbit of Islamic civilization. And, indeed, so it was.

During the 'Abbāsid caliphate, the Turks were not able to carry out a major operation in Transoxiana, only some minor actions. As in the Umayyad period, there were no formidable masses of Turks to resist the Arabs. After the defeat of the Chinese and the collapse of the Türgesh state, two groups of Turks appeared. The Qarluqs conquered the entire province of Yedi-Su \{Semirechy\} and the region east of the Syr Darya \{Jaxartes\} and in 766 took the capital \{Sūyāb/ Ordukent $\}$ of the Türgesh. Meanwhile, the Oghuz took the area west of the Syr Darya. These were the remnants of the Western Turks who had scattered after the death of Su-lu. It was these Oghuz who participated in the events of the ninth century, and they should not be confused with the Toquz Oghuz \{i.e. Uighurs\} of Eastern Turkistan. Although they were unable to conduct large-scale operations, they occasionally pillaged the countryside, became involved in uprisings in Transoxiana and came to the aid of local rulers or Arabs who had rebelled. Large walls were built around cities like Bukhārā and Shāsh as protection from their depredations.

Transoxiana became completely Muslim in the Sāmānid period. Most of the people of that region were probably already Muslim by the reign of Caliph al-Mu'tașim \{d. 247/861\} and even carried out military expeditions $\{$ ghaz $\bar{a}\}$ against the unbelievers in the desert. As the people of Shāsh had done previously, the inhabitants of Isfijāab, north of the Syr Darya, also converted to Islam a short 
time after Nūḥ b. Asad, the uncle of the first Sāmānid ruler Ismā'īl b. Aḥmad, captured that city in 838. Furthermore, Caliph al-Ma'mūn, as a result of various campaigns, brought members of important local families to the capital of the caliphate $\{$ Baghdad\} and induced them to convert by bestowing upon them major gifts and other rewards. This sensible policy of Islamization was followed even more vigorously during the reign of al-Mu'tașim when Turks from the areas of Soghd, Farghānā, Ushrūsana, and Shāsh were taken directly into the caliph's imperial guard. Al-Mu'tașim built the city of Samarra for his Turkish bodyguard troops. After al-Mu'tașim's reign, not only did the number and influence of the Turks in Iraq gradually increase, but this situation also contributed to the rapid Islamization of Turkistan. ${ }^{3}$ In $350 \mathrm{AH}\{961\}$ nomads of 200,000 tents - Qarluqs, Oghuz, and the remnants of the Western Turks - who lived, without recognizing Muslim rule, in territories on the Muslim side of the fortified frontier between Shāsh and Fārāb accepted Islam. This religion also began to be firmly established in the fourth/tenth century in the areas of Kāshghar and Balāsāghūn. During the fifth/eleventh century, at any rate, virtually the entire Turkish world did become Islamized and fell under the influence of Islamic civilization. ${ }^{4}$

\section{G The Șūfĩ movement}

As early as the second/eighth century, Islam had begun to differ significantly from its original form. In fact, when various nations $\{\mathrm{s}$. millet $\}$ who had lived with their own cultures and traditions for centuries in different parts of the world entered the sphere of Islam, they inevitably introduced a great many changes even on the most fundamental points. An old and rich civilization like that of Iran was thus able to defend at least its moral independence against the irresistible force from the desert. Subsequently, because of its rapid spread, Islam also came face to face with civilizations and religions other than Iran. The influence of Indian civilization (even if indirect), Judaism, Christianity (which had completely dominated Syria), intellectual movements that resulted from the translation of the works of the ancient Greek philosophers - these and many other factors affected the development of Islam. Consequently, throughout the Islamic realm there were a great many religious doctrines $\{$ s. madhhab $\}$ and sects $\{$ s. maslak\} that clashed sharply with each other. ${ }^{5}$ The old Sāsānid dominion, which was already on the verge of collapse because of steadily increasing Turkish attacks, ${ }^{6}$ initially submitted to the Arab sword; but then the Iranian spirit $\{\dot{I} r a ̂ n i l i k\}$, by considering the descendants of Husain \{the grandson of the Prophet\} to be the inheritors and successors of the Sāsānids, struck terrible blows against the Arab nation and the Islamic religion under the screen of "defending the rights of ahl al-bait" \{the family of the Prophet\}. By insinuating Zoroastrian beliefs in a Muslim guise, the Iranian spirit asserted itself, demonstrating that an ancient civilization could not easily be destroyed. ${ }^{7}$ In the fifth/eleventh and sixth/twelfth centuries, various religious doctrines and practices held sway throughout the 
Muslim world and the personal and political ambitions of the rulers gave great scope to their development. ${ }^{8}$

One of the most striking things in many places in the Islamic world at that time was the spread of mysticism \{Ṣūfism\} and the multitude of mystics \{Ṣūfis $\}$. Șūfism hardly existed in the first centuries of Islam. It took shape under the influence of Iranian, Indian, and Greek ideas, and to some degree Christianity albeit taking most elements from Islam - and soon spread throughout the Muslim world. ${ }^{9}$ Beginning with Abū Hāshim al-Kūfî \{d. 161/777-8\}, who first took the name Șūî and founded the first zāwiya \{Ṣūî lodge\} in Syria, many great Șūfīs - including Sufyān al-Thawrī (d. 161/778); Dhū '1-Nūn al-Mișrī (d. 246/ 861), who grew up in Egypt, which had been the home of the early Christian hermits; Abū Yazīd al-Bistāmī (d. 261/874-5 or 264/877-8) from Khurāsān; \{al-Husain b. Manșūr\} al-Hallāj (d. 309/922), about whom all sorts of ideas were advanced; and al-Junaid al-Baghdādī $\{$ d. 298/910 $\}$ - succeeded in spreading their doctrines despite all forms of opposition and imputations. In his famous treatise \{al-Risāla al-Qushairiyya\}, Abū 'l-Qāsim 'Abd al-Karīm al-Qushairī (d. 465/1072) tried to demonstrate that the Șūfì way of life was compatible with Sunn̄̄ doctrine. Somewhat later, al-Ghazālī (450-505/1058-1111) succeeded, in many of his works, in convincing the Sunni establishment that this was the case. Afterwards, al-Suhrawardī al-Maqtūl \{d. 587/1191\}, the author of Hikmat al-ishrāq, Shihāb al-Dīn al-Suhrawardī $\{$ d. 632/1234\}, the author of 'Awārif al-ma'ārif, 'Abd al-Qādir al-Jīlānī (d. 561/1166), and a great many other Șūfīs who fill the books of țabaqāt al-șüfyya \{Ṣūfì biographical dictionaries\} gained tremendous spiritual authority among thousands of disciples, as well as the general public, as they expounded their doctrine. ${ }^{10}$ Many famous religious scholars \{'ulama'\} attached themselves to the great shaikhs, and many rulers and commanders $\{$ s. amir $\}$ encouraged this movement - or, rather, were caught up in it - by sponsoring the construction of zāwiyas and tekkes \{also Șūfì lodges\}. Thus, shaikhs and dervishes were trained throughout the Muslim world and new social groups were, in effect, brought into being. Moreover, after the death of every great shaikh, he acquired a miraculous aura in the popular imagination. Such flights of fancy fill not only the manaqqib works \{works of the legendary deeds of Șûfi saints\}, which are replete with superstitions of no historical value, but also those sources that are most valuable for the history of Șufism. ${ }^{11}$

\section{D Șūfism in Turkistan}

Khurāsān, which nourished the ancient traditions of Iran in its bosom, was a primary, perhaps the primary, center of the Șūfi movement after the rise of Islam. Consequently, after the Islamization of Transoxiana, it was quite natural for this movement to enter Turkistan by the routes that Islam had previously followed. And this is exactly what happened. In the third/ninth century, Șūfīs were abundant in Herat, Nīshāpūr, and Marw, while in the fourth/tenth century shaikhs began to appear in Bukhārā ${ }^{12}$ and also in Farghānā. ${ }^{13}$ Indeed, the Turks 
in Farghānā gave their shaikhs the name $b \bar{a} b$, or $b \bar{a} b \bar{a}$. Șūfis also appeared among the Turks who traveled, in whatever capacity, to and from Khurāsān. Muhammad Ma'shūq Ṭūsī, whom the famous Șūfì Abū Sa'īd Ibn Abī 'l-Khair \{d. 440/ 1049 \} greatly esteemed, and Amīr 'Alī 'Abū were pure Turks. ${ }^{14}$ In the event, influenced by various factors of this sort, the Șūfì movement slowly gained strength among the Turks as it spread from the great Muslim centers like Bukhārā and Samarqand to the hinterlands, and as dervishes, armed with an ecstatic religious love, introduced new beliefs among the nomadic Turks. ${ }^{15}$

The spread of Șuffism, which claimed roots going back to the Prophet via Abū Bakr \{the first caliph\} or 'Alī \{the son-in-law of the Prophet and the fourth caliph $\}$; the de facto official recognition that it received from the political powers through the construction of tekkes; and the high regard that a great many notables, statesmen, and even sultans paid to the shaikhs - all these factors gave the shaikhs enormous moral influence. Both the Qarakhānids, who were so observant of $\{$ Islamic $\}$ religious norms $\{$ s. h. $u k m\}$ that they would not drink wine, and the early Seljuks, who defended Islam with enthusiasm and passion, showed great respect and reverence to religious scholars and shaikhs alike. ${ }^{16}$ On the other hand, because the Turkish rulers were so devoted to Islamic beliefs, ${ }^{17}$ they had accepted Hanafism with great vigor and conviction. This tendency, which essentially arose from the social conscience of the Turkish nation, on the one hand hindered the spread of heretical Shî̀̄ and Mu'tazilī doctrines within Islam and, on the other, also as a natural result of this, created a profound and sincere harmony between legal religious norms and the Șūfi ideas that developed in Turkish circles. ${ }^{18}$

In my view, by the time Ahmad Yasawi came on the scene, the Turkish world had already been accustomed to Șūfi ideas for a rather long time - probably since the fourth/tenth century - and \{word of $\}$ the legends and miracles of the Șūfìs had spread not only in the cities but also, to some extent, among the nomadic Turks. As for the dervishes, who recited hymns and poetry, who did many good works for the people in order to please God, and who showed the people the ways to happiness and paradise, the Turks enthusiastically accepted them and believed what they said, likening them to the ozans \{troubadour poet-singers $\}$ whom they had endowed with religious sanctity since ancient times. In this manner, a number of the dervishes, who were called ata \{father\} or $b \bar{a} b$ \{spiritual leader\}, took the place of the old ozans. Well known among the people were tales of such Șūfìs as Arslan Bābā, who was depicted as a companion of the Prophet; Korkut Ata, ${ }^{19}$ the famous patron saint of the ozans who, according to legend, went from Turkistan to Arabia in order to learn about Islam and, after meeting with Abu Bakr, accepted the new faith; and Choban Ata. ${ }^{20}$ It seems certain, then, that, at the time of Ahmad Yasawī, there were dervishes trying to spread Muslim beliefs and traditions among the nomadic Turks, who lived along the banks of the Syr Darya and in the steppes, by addressing the people in a language they could understand - simple Turkish. One must assume that Ahmad Yasawi was a greater and more powerful personality than the dervishes who 
preceded him. Still, if the earlier generations had not prepared the way for him, his success could not have been as great.

\section{E The influence of Iran}

Because of their geographical location, the Turks were in continuous contact with China and Iran from very ancient times. The early Chinese chronicles, which are reliable and comprehensive, show the relationship of the Turks with China fairly clearly. The early relationship of the Turks with Iran, however, only enters the light of history - leaving aside the legends in the Shähname - at the time of the last Sāsānid rulers. After the Turks had lived under the influence of these two civilizations for centuries, Iran, which had accepted Islam, gradually brought them into its sphere of influence. ${ }^{21}$ Even during the development of the Uighur civilization, which was the \{Turkish civilization\} most strongly influenced by China, the attraction of the Turks to Iranian civilization, which had proven its worth in art, language, and thought, was virtually unavoidable, especially after it was invigorated with a new religion. ${ }^{22}$

Even before it drew the Turks into its sphere of influence, Iranian civilization had had, in fact, a major effect on Islam. With respect to the concept of government and the organization of the state, the 'Abbāsids were attached not to the traditions of the khulafä' al-rāshidūn \{the first four caliphs\} but to the mentality of the Sāsānid rulers. ${ }^{23}$ After Khurāsān and Transoxiana passed into the hands of native Iranian - and subsequently highly Iranized Turkish - dynasties with only nominal allegiance to the 'Abbāsids, the former Iranian spirit, which the Islamic onslaught was not able to destroy despite its ruthlessness, again revealed itself. In the fourth/tenth century, Persian language and literature began to grow and develop in an Islamic form. This Perso-Islamic literature was influenced, to a large extent, by the literature of the conquerors. Not only were a great many words brought into the language via the new religion, but new verse forms, a new metrical system, and new stylistic norms were also adopted in great measure from the Arabs. Indeed, almost nothing remained of the old Iranian syllabic metrical system, the old verse forms, or the old ideas about literature. Still, the Iranians, as heirs of an ancient civilization, were able to express their own personality in their literature despite this enormous Arab influence. They adopted from the 'arü $d$ meters only those that suited their taste. They created or, perhaps, revived the ruba $\bar{\imath} \imath$ form \{of verse\}. ${ }^{24}$ They also introduced novelties in the qași $d a$ form \{of verse\}, which can be considered an old and well known product of Arabic literature, and in the ghazal \{lyric "love song" \}. ${ }^{25}$ Above all, by reanimating \{their own ancient mythology, they launched an "epic cycle" that was completely foreign to Arabic literature. ${ }^{26}$ These developments were on such a scale that the fifth/eleventh century witnessed the formation of a new Persian literature in all its glory.

The Turks adopted a great many elements of Islam not directly from the Arabs, but via the Iranians. Islamic civilization came to the Turks by way of 
Transoxiana from Khurāsān, the cultural center of Iran. Indeed, some of the great cities of Transoxiana were spiritually far more Iranian than Turkish. Also, the Iranians were no strangers to the Turks, for they had known each other well before the appearance of Islam. For all these reasons, it was the Iranians who guided the Turks into the sphere of Islamic civilization. This fact, naturally, was to have a profound influence on the development of Turkish literature over the centuries.

To be sure, we do not know precisely how and to what extent Persian literature at first influenced Turkish literature, but the earliest Turkish work recognized by the scholarly world as a product of the post-Islamic period, the Kutadgu Bilig written in Kāshghar in 462/1069-70 at the time of the Bughrā Khāns \{Qarakhānids\}, clearly exhibits Persian influence in many respects. This is not the place to give a fully detailed description of this old Turkish composition, ${ }^{27}$ but the Persian influence on it is striking, especially in language, meter, and form.

Linguistically, the Kutadgu Bilig is full of Persian and Arabic words. If one takes into consideration the longstanding relations of the Turks with the Iranians, the many concepts that the new religion introduced, and the new words that were used to express them, then the number of foreign words does not appear to be excessive. As for the question of meter, this composition - despite the mistaken claims of certain European scholars - was not written in the syllabic meter but was modeled directly after the meter of the Shāhnāme and, as in all Persian works of this type, the preferred form was that of mathnaw $\bar{\imath}$ \{rhymed couplets $\}$. The verse is very defective, because the Turkish of that time could not, of course, suddenly accord with the 'arü $d$ metrical system, which was alien to its structure. This is one of the main reasons why some people considered it to have been written in the syllabic meter. With regard to subject matter, ideas, and metaphors, one encounters the influence, at the same time, of both \{Turkish\} popular literature and Chinese literature. But in the meter, especially, the strong influence of Persian literature is immediately apparent. Indeed, this influence was so strong that within a short time it eventually was able to drive out all others.

Like all Muslim works, the Kutadgu Bilig begins with a prose preface that includes the tahmīd \{al-hamdu li-'llāh, praise be to God\} and tasliya \{sallā 'llāhu 'alayhi wa sallam, God bless him (the Prophet) and grant him salvation\}. In the prologue to this work, the author Yūsuf Khāṣs Hājib finds the human aptitudes to consist of "justice, ability, comprehension, and contentment." ${ }^{28} \mathrm{He}$ then animates each one in the form of a person and presents lengthy debates among them. With regard to its subject, this book is a variation on the Persians' siyāsatnāme \{advice for rulers\} genre. One of these four aptitudes, Ögdülmish son of Qut \{rather, he is the son of Ay-toggdi who represents "Fortune" (= Qut)\}, describes to the ruler, one by one, all the officials and classes who constituted Turkish society in Kāshghar at that time and explains the qualifications they should have and how the ruler should treat them. The book is full of such questions as "How 
should one be a tapucu, i.e. a civil servant?" "How should one be a subaşs or military commander?" "How should one treat the people?" "What should one do for farmers, merchants, doctors, and sorcerers?" "How should one behave toward women?" "What qualities should be sought in a good wife?" "How should the dynasty show respect to the mission of the Prophet?" There is also a kaside in praise of Bughrā Khān, following the example of Persian mathnaw writers. Nevertheless, as regards the subject of the work - i.e. portraying the various human aptitudes through personification - as well as the simplicity and specificity of its figures of speech and metaphors, nothing like it can be found in Persian literature. For these aspects, Chinese influence on the one hand and vestiges of $\{$ Turkish\} popular literature on the other are much more significant. Even the ode in praise of Bughrā Khān is closer to the products of early \{Turkish\} popular literature than to Persian examples. ${ }^{29}$

This work, which was written in Kāshghar in 462/1069-70, should by no means be considered an isolated literary product. Indeed, there are references in the preface that clearly reveal this point. If one considers that the Turks already had \{various\} scripts before Islam and that they had books composed in these scripts, then it becomes immediately obvious that Muslim works would be written in Kāshghar, which was an old center of Turkish civilization, soon after that city accepted Islam, and that one would not have to wait centuries before this occurred. When the Turks adopted Islam, they were not a barbarian people who were strangers to writing, books, and education. ${ }^{30}$ Thus, we can assert that by the fifth/eleventh century at least, Turko-Islamic works had begun to be written in Turkistan and that they were subject to Perso-Islamic influence. If Iranian influence had made an impact so quickly and vigorously in an eastern region like Kāshghar, which was a center of the old Uighur civilization and had been under continuous and strong Chinese influence, then naturally this influence must have been felt on a much wider scale in regions further to the west and closer to the cities of Khurāsān. But unfortunately, ruinous invasions, wars, and a thousand other things over the centuries have destroyed the products of those early periods and virtually nothing remains in our possession. Let me state clearly here, however, that such Turkish works that imitated Persian forms and were written under the influence of Persian literature in Muslim centers were not widespread among the masses. They were only circulated among the learned who received a Muslim education in the madrasas \{these colleges of Islamic law began to spread in the fifth/eleventh century\}.

\section{F Popular literature}

We know that the Turks possessed a rich popular literature in the fourth/tenth and fifth/eleventh centuries, and we also have some valuable examples of it. These works allow us to explain how, and with what kinds of compositions, the Turks were able to express their literary impulse in the time before Ahmad Yasawī. While the Kutadgu Bilig and similar works were read and studied by men 
educated in the madrasas of the cities of Turkistan, which had become strong centers of Islam, the needs of the popular masses were met, as they had been for centuries, by the simple products of the popular poets. ${ }^{31}$ Because popular literature, for various reasons, underwent hardly any perceptable change over the centuries, it preserved its basic pre-Islamic features into the Islamic period.

Some of the surviving works from that period can be regarded as codes of ethics of a didactic nature. The evil of stinginess and envy, the obligation to gain a reputation for generosity among one's people, the qualities of the hero, the greatness of God, and the need to respect and obey one's parents and elders are among the items dealt with in these pieces in a simple and straightforward manner. The most valuable of these works, however, are the lamentationselegies $\{$ s. sagu-mersiye $\}$. These elegies were sung during mourning ceremonies or in general assemblies - regarded in pre-Islamic times as only a religious practice but afterwards as more of an aesthetic one - to the accompaniment of the kopuz and were usually rather long. They describe the merits of the deceased, the various stages of his combats, how he attacked the enemy, where the battles occurred, and how grieved all the people were - indeed, all of nature was because the hero died. The metaphors are simple and primitive but sincere and colorful. Sometimes summer and winter are personified and, as in the Kutadgu Bilig, engage in a debate. We find in them a rapturous feeling, not only toward nature but toward all manifestations of life. Saying that when summer comes the snows will melt, the nightingales will sing, and happy couples will make love, the reciter of the elegy dwells on the joy of life. When he sees a beautiful slave girl, he likens her face to the moon and her neck to the juniper tree. Like all lovers, he speaks of the beauty of his beloved, her cruelty, and her bewitching eyes and he weeps profusely. The beauty of the countryside and the plains, the frosty nights, the wild steppes, the misty hills, the ducks, geese, and small water fowl are all described in these elegies with a lively affection. ${ }^{32}$

These elegies are expressed in quatrains, each verse having seven or eight syllables. Sometimes the verses of the first quatrain all rhyme $\{a a a\}$, sometimes all but the third rhyme $\{a a b a\}$. As for the following quatrains, the first three verses rhyme while the fourth returns to the rhyme of the initial quatrain \{ccca, ddda, etc. $\}$, thus forming a larger unit, whose rationale I explained above (section A \{i.e. that this type of poetry was written to be sung and the fourth verse maintained the rhyme, like the refrain of a folk song\}). The other poems, of a didactic nature, are occasionally in the form of quatrains with five, six, or seven syllables per verse, but more often consist of couplets of 10, 12, 14, or 15 syllables per verse \{Köprülü is mistaken here. This should be 11 or 12 \}.

Aside from poems, there existed among the people legends or sagas, such as the Oghuz menkabesi \{Legend of the Oghuz $\},{ }^{33}$ that had survived from very early times. Although they belonged fundamentally to the pre-Islamic period, a number of these legends acquired an Islamic form and circulated in that fashion thanks to the efforts of the dervish poets who made religious propaganda in the Islamic period. 
This, then, was the level of literary development of the Turkish people when Ahmad Yasawī appeared on the scene in the fifth/eleventh and sixth/twelfth centuries.

\section{NOTES}

1 For detailed information with full documentation on the music, literature, and literary life of the Turks before Islam, see the first part of my article "Türk edebiyatı tarihine medhal" \{only the first part of this study ever appeared, as "Türk edebiyatının menşe'i," MTM, 2 (1331/1915), 5-78, reprinted in his Edebiyat araştrmalan, pp. 49-130\}. There is also brief and general information on this subject in my book Küçük Türk edebiyat tarihi \{apparently part one of his Türk edebiyat tarihi (Istanbul, 1920-1), cf. his Türk edebiyat tarihi (1926; reprinted Istanbul, 1981), Chapters 1-4\}.

2 For the information in Chinese sources on this war, see E. Chavannes's book Documents sur les Tou-kioue (Turcs) Occidentaux (St Petersburg, 1903), pp. 297-8.

3 As will be seen, Köprülü sometimes uses Turkistan to mean the historical region of the middle (and sometimes lower) Syr Darya valley and sometimes to mean the Russian holdings in Central Asia in the nineteenth and early twentieth centuries.\}

4 Al-Tabarī \{Ta'rn̄kh, i.e. Ta'rn̄kh al-rusul wa 'l-mulük (Leiden, 1879-1901), Eng. trans. under the general editorship of Ehsan Yarshater as The History of al-Tabari (Albany, NY, 1985-)\}; Ibn al-Athīr \{al-Kämil fì 'l-ta'rūkh, Thornberg edn (Cairo, 1303/18856)\}; al-Balādhurī, Futūh al-buldān \{(Leiden, 1866), Eng. trans. Philip Hitti and F. C. Murgotten as The Origins of the Islamic State (New York, 1914-24)\}; W. Barthold, Turkestan down to the Mongol Invasion (London, 1928); Jurjī Zaydān, Medeniyyet-i islâmiyye tarihi, \{Turkish\} trans. \{of the Arabic original (Istanbul, 1328-30/1910-12)\}; Necib Âsım and Mehmed Ârif, Osmanh tarihi \{Istanbul, 1335/1916-17\}; Chavannes, Documents. \{On the Göktürks, see Wolfgang Scharlipp, Die frühen Türken im Zentralasien (Darmstadt, 1992) and Ahmet Taşağıl, Gök-Türkler (Ankara, 1995).\}

5 Bernard Carra de Vaux, Gazali (Paris, 1902) \{reprinted Amsterdam, 1974\}, Chapters $7,8$.

6 Chavannes, Documents, p. 302. The major role that the Turks played in this important event in world history has not been considered at all by specialists in Islamic history.

7 In order to understand the influence of the Iranian national spirit on Islam, see R. Dozy's Essai sur l'histoire de l'Islamisme (Leiden, 1879), Köprülù apparently used the Turkish trans. by Abdullah Cevdet (Cairo, 1908)\}; and \{vol. 2\}, Chapter 34, "Le Mahdi," in Cl. Huart's Histoire des arabes (Paris, 1912-13). E. Blochet provides strong evidence that Iranian culture had already exerted an influence on the Arabs before Islam, "Études sur l'histoire religieuse de l'Iran" \{part 2, "L'ascension au ciel du prophète Mohammed," RHR, 40 (1899)\}, p. 20. Jurjī Zaydān, like all other Arab historians, is of the opinion that "Abbāsid rule was nothing but Iranian oppression (Medeniyyet-i islâmiyye, vol. 1, p. 84). A great many Iranian poets from Firdawsī \{d. $411 / 1020\}$ to Khāqānī \{d. 595/1199\} were Zoroastrians \{zerdüştî\} in spirit. Indeed, Shaikh Abū 'l-Qāsim Jurjānī did not want to perform Firdawsî̀s funeral prayer because he had filled his Shähnāme \{Book of Kings\} with eulogies for all the Zoroastrians \{mecûsîler\}, Dawlat-Shāh, Tadhkirat al-shu' $\operatorname{ară}$ ', \{ed. E. G. Browne (London, 1901)\}, p. 58.

8 On this subject, see al-Shahrastānī, Milal wa 'l-nihal \{Turkish trans. Nūh b. Muștafā (d. 1070/1660), published in Cairo, 1263/1847 and then Istanbul, 1279/1862; French trans. D. Gimaret et al., as Livre des religions et des sectes (Louvain, 1986-93)\}.

9 Carra de Vaux, Gazali, \{Chapter 7,\} "La mystique avant Gazali," pp. 175-200. The ideas advanced on the origin of Șüfism are still very divergent. Carra de Vaux, who is a devout Catholic and a fine Orientalist $\{$ d. 1953\}, presents Christianity as the prime 
source, but he is partisan in this regard. In his article "Perse" (Iran) in La Grande Encyclopédie \{Paris, 1886-1902\} and in the section on Șūfism (pp. 268-77) in his $\{$ Histoire de la $\}$ littérature arab $\{$ (Paris, 1902), English trans. A History of Arabic Literature (London, 1903; (reprinted Beirut, 1966)\}, Huart says the question has not yet been resolved whether this movement came from India, from Christian monks, or directly from Iran, but he gives primacy of place to Iranian influence. In his article "Soufisme" in La Grande Encyclopédie, Georges Salmon gives the opinion that this movement arose under the influence of the Alexandrian school, i.e. Neoplatonism, but that pantheism, which later spread among the Șūfìs, arrived from India via Iran. Carra de Vaux, however, while discussing the Süfi poets of Iran, explains at great length that most of them were not pantheistic and that there is absolutely no connection between the \{concept of \} fan $\bar{a}$ ' annihilation, passing away from self and its replacement by a pure consciousness of God\} in Șüfism and nirvana in India (Gazali, p. 287) \{see EIr, s.v. "Baqā' wa Fanā'”" (G. Böwering)\}.

There are also those, like Blochet, who claim that Christianity had no influence whatsoever on Islam, and those who think that the principles of Șufism were wholly derived from the Koran and Hadith \{Prophetic tradition\}. Thus we can see how far we are from solving this problem. Huart, unable to give a definite answer based on historical documents, makes very vague and general assertions, such as "The Șûfì movement represents the victory of the Arian spirit over the Semitic mentality." This is utter nonsense. The views of Dozy, A. I. Silvestre de Sacy, E. Trumpp, and F. A. D. Tholuck \{Sufismus (Berlin, 1821)\} on this subject cannot even be considered as significant as those given above because they belong to earlier periods of Orientalism. There is certainly a great need in the scholarly world for a general history of Sūfism that would show the influence of various sources on the different Sūfis in their proper proportions. Unfortunately it appears to be difficult to meet this need. \{Since Köprülü wrote, an enormous amount of scholarly work has been done on Șūfism; see, e.g., $E I^{2}$, s.v. "Tașawwuf" (L. Massignon [B. Radtke et al.]).\}

10 The first biographies of Șūfìs were written in Arabic. In his introduction to $\{R$. A. Nicholson's edition of Farīd al-Dīn 'Atțār's\} Tadhkirat al-awliyā' \{London, 1905-7\}, Mīrzā Muhammad b. 'Abd al-Wahhāb al-Qazwīnī mentions, p. ¿̌-, as the earliest works of this kind 'Abd al-Raḥmān Muhammad b. al-Husain al-Sulamī's (d. 412/ 1021) Ṭabaqāt al-șūfìyya, Abū Nu'aim Aḥmad b. 'Abd Allāh al-Iṣfahān̄’s (d. 430/1038) Hilyat al-awliy à ', Ibn Khamīs al-Ka'bī \{al-Mawșilī al-Shāfi'̄’s\} (d. 552/1157-8) \{Manāqib al-abrār min \} mahāsin al-akhyār, and Jamāl al-Dīn Abū 'l-Faraj al-Baghdādī al-Hanbalī's \{i.e. Ibn al-Jawzī\} (d. 597/1200-1) Șafiwat \{or Sifat\} al-șafiwa. The first two of these works are in our libraries \{al-Sulamī ed. J. Pedersen (Leiden, 1960); al-Ișfahān̄̄ ed. (Cairo, 1932-8); Ibn al-Jawzī ed. (Cairo, 1411/1991)\}. Furthermore, al-Sulamī adapted his work from that of his master Abū Bakr Muhammad b. 'Abd Allāh \{al-Bajalī\} al-Rāzī \{known as Ibn Shādhān, d. 376/986\}, \{Jāmī, \} Nafahāt \{al-uns\}, \{ed. (Calcutta, 1859)\}, \{Turkish\} trans. \{Lāmi'î́, \{Istanbul, 1289/1872-3\} p. 274. The earliest biographical dictionary of the $\{$ Sūfî $\}$ saints written in Persian was the Kashf al-mahjūb li-arbāb al-qulūb of Abū 'l-Hasan 'Alī b. 'Uthmān al-Ghaznawī al-Jallābī \{al-Hujwīrī\} (d. 465/1072 or 469/1076), a very poor edition of which was published in Lahore. There are some manuscript copies in the Istanbul libraries. Before the Great War \{the First World War\}, the Russian Orientalist V. A. Zhukovskii was preoccupied with preparing a new critical edition of it (\{Huart, a review of Nicholson's The Kashf al-mahjūb, The Oldest Persian Treatise on Súfis, $\}$ FA, 11th series, 3 \{1914\}, p. 187) \{ed. Zhukovskii (Leningrad, 1926)\}. Nicholson has translated this work into English \{Leiden and London, 1911\}. In addition to this work, Shaikh al-Islām Abū Ismā'îl 'Abd Allāh b. Muḥammad al-Anșārī al-Harawī (d. 481/1089) translated al-Sulamī’s Ṭabaqāt al-sūfinya \{into Persian\}, with certain additions, and this forms the basis of Jāmī's 
Nafahāt al-uns. The author of Kashf al-mahjūb made great use of al-Sulamī's Tabaqāt and al-Qushairī's Risāla. If we add to the aforesaid works Farīd al-Dīn 'Atțār's Tadhkira-i awliy $\vec{a}$ ' and al-Qushairî's Risăla, we will have presented almost all the major sources that were written up to the sixth/twelfth century. \{On Șūfì biographical literature, see the survey by Jawid A. Mojaddedi, The Biographical Tradition in Sufism: The Tabaqāt Genre from al-Sulamī to $\bar{f} \bar{a} m \bar{\imath}$ (Richmond, Surrey, 2001).\}

11 For example, al-Qushairî’s Risāla \{Turkish trans. Nâfî Efendi as Risâle-i Kuşayrîye (Istanbul, 1307/1889-90), eds 'Abd al-Halīm Mạ̣mūd et al., as al-Risāla al-qushairiyya (Cairo, 1966), English trans. Rabia Harris as The Risalah: Principles of Sufism (distributed by KAZI Publications, Chicago, 2002)\}, 'Attāar's Tadhkira, \{Jāmī's\} Nafahāt, and \{'Alī b. Husain Wā'iz Kāshfî Șafî̀'s\} Rashahāt-i \{'ain al-hayāt (Lucknow, 1308/1890), ed. 'A. A. Mu'īniyān (Tehran, 2536/1977-8)\}. The section that 'Aț̣ār devoted to al-Hallāj is very significant in this respect (Nicholson ed., pp. 135-45).

12 \{Jāmī, $\}$ Nafahăt, \{Turkish\} trans., p. 275.

13 Ibid., p. 323.

14 Ibid., pp. 348-50.

15 Barthold, Turkestan \{down to the Mongol Invasion, Russian edn (St Petersburg, 18981900), English trans. (London, 1928), revised English trans. (London, 1968). Köprülü could not read Russian and apparently relied to some degree on Turkish emigrés from Russia to inform him of the contents of various Russian works.

16 Ibid.

17 The Seljuk ruler Toghrl Beg \{d. 455/1063\} was a zealous Hanafí. Ibn al-Athīr writes that his vizier 'Amīd al-Mulk \{al-Kundurî\} even had permission from him to curse both the Rāfidīis and Ash'arīs in the mosques of Khurāsān and that Toghrıl Beg was very fanatical against the Shāfi'īs (al-Kämil, vol. 10, p. 11). Alp Arslan \{the nephew of Toghrıl Beg\} ordered Abū Sa'īd Muhammad b. Manșūr Sharaf al-Mulk al-Khwārazmī to repair the türbe and mosque of Abū Hanīfa in Baghdad and establish a Hanafì madrasa \{Islamic law school\} there (\{Nizāam al-Mulk, $\}$ Siyāsatnāme, ed. and French trans. Ch. Schefer \{Paris, 1891-3\}, trans., p. 2.) \{English trans. H. Darke as The Book of Government, or Rules for Kings (London, 1960)\}. In Nizām al-Mulk's Siyāsatnāme, there is important information showing how severely Alp Arslan acted against the Shāfi'is and especially the Rāfidīs (see Chapters 21 and 42). Dozy also recognized that the Turks were ardent Sunnīs (Essai, Turkish trans., vol. 2, p. 495). Indeed, we find this \{attitude\} among the Turks in Baghdad even before the Seljuks. The Turks did not refrain from using any means to defend Sunnism against the Buwaihids who supported Shī ism in Baghdad (\{Zaydān, \} Medeniyyet-i islâmiyye, vol. 4, p. 263). The other Turkish states in Turkistan also always defended Hanafìsm (Barthold, Turkestan).

18 See the mystical views of the Turkish Sūfîs in \{Jāmī's\} Nafahāt and \{Ṣafìs\} Rashahät. Very significant in this regard is the danger that Farīd al-Dīn 'Atțār incurred in Samarqand around the end of the sixth/twelfth or beginning of the seventh/thirteenth century. In his Mazhar al-'aja'’ib he had been very excessive in his praise of the Twelve Imāms \{supreme leaders of Twelver Shī'ism\}, especially 'Alī, and had demonstrated his belief in the expected mahd $\{$ an eschatological figure similar to a messiah\}. Consequently, one of the great jurists of Samarqand accused him of being a Rāifị̄ \{heretic\} and issued a fatwa $\bar{a}$ \{legal opinion\} that his book should be burned and that he should be executed. Farīd al-Dīn was able to save himself from this accusation only with difficulty (introduction to his Tadhkirat al-awliy $\vec{a}$, p. $)$ ). \{It is now recognized that Mažhar al-ajā’ib was not among 'Aț̣āar's authentic works. See Sa'īd Nafî̀sī, Justujū

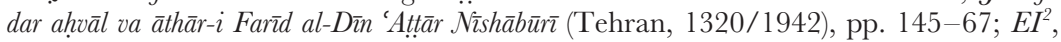
s.v. "Aț̣āar" (H. Ritter).\}

19 For information on the legend of Dede Korkut $\{$ dede $=a t a\}$, which was known on the banks of the Syr Darya (the old territory of the Oghuz), among the Turkmen, around 
Derbend in Azerbaijan, in Anatolia, in short, all the areas to which the branches of the Oghuz spread, see my Türk edebiyat tarihine medhal \{i.e. "Türk edebiyatının menşe'i," $\}$, pp. 61-2. \{See $E I^{2}$, s.v. "Dede Korkut" (Fahir İz), and Geoffry Lewis trans. The Book of Dede Korkut (Harmondsworth, UK, 1974).\}

20 E. Schuyler, \{Turkistan, Notes of a Journey in Russian Turkistan, Khokand, Bukhara, and Kuldja, 6th edn. (London, 1877), (abridged reprint London, 1966)\}, Turkish trans. \{Ahmet Efendi\} as \{Musavvar\} Türkistan \{tarihi ve\} seyâhatnâmesi \{Istanbul, 1294/1878\}, p. 302.

21 Blochet, "Mazdeism ve Türkler" \{rather, "Madza'izmin Türk kavimlerinin i'tikadları üzerinde tesiri," which is the Turkish trans. of the first part of his "Études sur l'histoire religieuse de l'Iran: (1) De l'influence de la religion mazdéenne sur les croyances des peuples turcs," RHR, 38 (1898), 26-63\}, MTM, 1 (1331/1913), 128ff. \{See also his "Christianisme et mazdéisme chez les Turks orientaux," Revue de l'Orient Chrétien, 27 (1929-30), 31-125.\}

22 \{Köprülü,\} Türk edebiyat tarihi, Chapter 1.

23 See my "Selçukiler zamanında Anadoluda Türk medeniyyeti," MTM, 2 (1331/1916), 193-232. \{English trans. Gary Leiser as "Turkish Civilization in Anatolia in the Seljuk Period," Mésogeios, 9-10 (2000), 37-82.\}

24 Ağa Aḥmad 'Alī Aḥmad, Risāla-i tarāna (Calcutta, 1867), cited from Majma' al-șanāyic, p. 2. On this subject, see also \{Shams al-Dīn Ibn Qays al-Rāzī or Shamsī Qays, \} al-Mu'jam fì ma'āâñ ash'ār al-'ajam, \{eds Muhammad Qazwīn̄i et al. (Tehran, 1314/ 1935)\}. \{See $E I^{2}$, s.v. "Rubā'î," (C.-H. de Fouchecour et al.).\}

25 See the section "Acemler'de mersiye" in my article "İslâm edebiyatında mersiye" \{rather, "Bizde mersiye ve mersiyecilik,"\} $Y M, 1$ \{1917\}, no. 18, pp. 344-8. \{See $E I^{2}$, s.v. "Kașīda," (F. Krenkow [G. Lecomte], et al.), and "Ghazal" (R. Blachère et al.).\}

26 See the foreword by J. Mohl to the French translation of \{Firdawsī's $\}$ Shāhnāme (Paris, 1876-8) \{as Le Livre des Rois... $\}$.

27 See the version edited by W. Radloff in three large vols \{Das Kudatku-Bilik... (St Petersburg, 1891-1910)\}. [After Radloff's facsimile edn of the Kutadgu Bilig, which was based on the Herat MS currently in Vienna, Türk Dil Kurumu also published a facsimile edn of the same MS (Istanbul, 1942). The second MS of the Kutadgu Bilig, which is in the Khedival Library in Cairo, and which the Dil Kurumu also published as a facsimile edn in Istanbul in 1943, was very similar to this one. As for the third MS of the Kutadgu Bilig, which was written in the city of Farghānā in Turkistan and is much more important than the other two, it was first made known to the scholarly world by the late Reşid Rahmetî Arat. This was also published in a facsimile edn by Dil Kurumu in 1943.

Arat prepared a critical edn of the three currently known copies of the Kutadgu Bilig and the Türk Dil Kurumu published it in Istanbul in 1947. Arat also wrote a translation of the Kutadgu Bilig into Western Turkish (the Turkish of Turkey), which Türk Tarih Kurumu published in Ankara in 1959. This work, which is composed of 6645 couplets, has great value for Turkish intellectual history. In a number of respects, it is still in need of analysis. For more information on the Kutadgu Bilig, see issue $98\{9(1970)\}$ of Türk Kültürü, which was devoted to it.] \{Now see $\dot{I} A$, s.v. "Yûsuf Hâs Hâcib" (Kemal Eraslan), and $E I^{2}$, s.v. "Yūsuf Khāsș Hạājib" (R. Dankoff). English trans. of the Kutadgu Bilig by Robert Dankoff as Wisdom of Royal Glory (Chicago, 1983). $\}$

$28\{$ Köprülü is mistaken here. The verse prologue, which is not by Yūsuf Khāṣs Haajib, asserts that the work is based on four fundamental principles: justice ('adl, könilik), fortune (dawla, qut, iqbāl), wisdom (khirad), and contentment (qana' at wa' afyat). The prose prologue, which is a summary of the verse prologue, renders these as justice, fortune, intellect, and contentment ('adl, dawlat, 'aql, qana'`at). Yūsuf himself (lines 355-7) gave 
them as justice (köni törü), fortune (qut), wisdom or intellect (uqush), and man's last end $\left.\left({ }^{\prime} \bar{a} q i b a t\right).\right\}$

29 Türk edebiyat tarihi (Istanbul, 1926), Chapters 6, 2 (VI. Bab, 2). Iran edebiyatr not further identified\}, pp. $131 \mathrm{ff}$.

30 Both Byzantine and Chinese sources state that the Turks had their own writing before Islam and wrote books with it. According to Chinese historians, the Uighur Turks had quite a brilliant and extensive literature in the fifth century CE \{They do not fully emerge in history until the eighth century; see Peter Golden, An Introduction to the History of the Turkic Peoples (Wiesbaden, 1992), p. 157.\} Not only did they have prose and poetic works, but there were also chroniclers at the courts of their khāns \{rulers\}. Indeed, by this means all events were recorded from the earliest periods of the Uighurs until almost the time of Chingiz Khān $\{$ d. 1227\}. While mentioning that he came across a great many public libraries in the country of the Uighurs, the tenth-century CE Chinese traveler Wang Yen-te does not state that this was anything remarkable. In fact, despite all the invasions that have befallen Turkistan, translations of a great many stories and religious works have survived from those early periods, and the Orhan Inscriptions, which the old Göktürks had written, also bear witness to the early civilization of the Turks. Because the Turks who went to the 'Abbāsid court in Baghdad were mostly desert people who lived a primitive life, they did not occupy themselves with learning and education. Thus, the Arab historians believed that the Turks were generally unfamiliar with learning and art. Ibn al-Athīr, for example, is surprised to find that Qutalmısh, the founder of the Seljuk dynasty of Anatolia, was interested in astronomy even though he was a Turk (\{Zaydān, \} Medeniyyet-i islâmiyye, trans. vol. 4, p. 294). [In his article, "Türk onomastique'i hakkında," Tarih Dergisi, 1 (1950), $227-$ 30, Köprülü shows that the proper pronunciation of this name was Qutalmısh rather than the other forms \{Qutulmush $\}$ in which it had previously been read.] The fact is, there were Turks who had preserved their early civilization at that time and lived a civilized life, and who had not left their country to enter the courts of the caliphs. The errors of the Arab historians are most obvious in this respect.

31 While the Persian poets of the Turkish rulers who were under Iranian influence, such as those at the court of Mahmūd of Ghazna \{d. 421/1030\}, tried to develop Islamic Persian literature and raise it to a high level, the army, which was composed mostly of Turks, satisfied its \{literary\} taste with popular folk songs \{s. türkü $\}$ and epics \{s. dastān $\}$. The same situation pertained in other Turkish armies. Gardīzī $\{f$. midfifth/eleventh century\} reports that during a battle between Mahmūd of Ghazna and the Qarakhānids, Mạ̣mūd's troops began to sing Turkish songs when they saw the Turkmen (Barthold, Turkestan, \{English trans., p. 273, "Mahmmūd's soldiers 'sang a Turkish song to a Khotanese melody'; on hearing the sounds the Turks threw themselves in terror into the river, where part were drowned"' $)$ ).

32 For these works, see Mạ̣mūd al-Kāshgharī’s Dīwān lughāt al-turk \{(Istanbul, 1333-5/ 1915-17), English trans. Robert Dankoff and James Kelly as Compendium of the Turkic Dialects (Cambridge, MA, 1982-5)\} written in 1077 \{he began it in 464/1072 and completed it in $469 / 1077\}$.

33 The Oghuz menkabesi, which had long been well known among the Turks, survives in two main written versions. One is a piece written in the Uighur alphabet far from Islamic influence. It reveals the earlier form of this legend (Radloff, ed. Das KudatkuBilik, vol. 1, pp. x-xiii). The Islamic form is first mentioned by Rashīd al-Dīn \{d. 718/ $1318\}$, the vizier of Ghazan Khān, in his Jāmi al-tawärīkh, and from there was transmitted to other works. If we take into consideration the similarity between the Uighur text and the version recorded by Rashīd al-Dīn and the fact that Rashīd al-Dīn had recourse to early Turkish sources while composing his work, we can conclude that this and similar legends have been recorded and written down from a very early period. 
Indeed, before the appearance of the Ottomans, Abū Bakr 'Abd Allāh al-Dawādārī, an official of the Egyptian \{Mamlūk\} ruler Muhammad Qalāwūn \{678-89/127980 \}, says in his Durar al-tījan that there were two ancient sacred books, the Ulu Han Ata Bitigi i of the Qipchaqs and Mongols and the Oghuznäme of the other Turks. He states that he saw a copy of the Oghuznamme that had first been translated from Turkish into Persian and then later, in 211/826-7, was translated into Arabic by Jibrä'îl b. Bakhtīshū', the chief physician of Hārūn al-Rashīd. It had come from the treasury of Abū Muslim al-Khurāsānī. According to the information provided by this author, the work contained such things as the legends of "Ulug Karadağ," "Altun-Han," "Ulu Ay Ataj1," "Ulu Ay Anaj1," "Türkler yemini," "Chojuk," and "Arslan." It seems clear that Kitab-ı Dede Korkut \{Book of Dede Korkut\} was a later extract from this Oghuznāme, and that the Islamic version found in the work of Rashīd al-Dīn and the Oghuz menkabesi surviving in an Uighur text derived from the same source. Hence it is clear that the Oghuznāme is not, as some believe, a history, but a collection of legends. The Jām-i jam āyzn, which was said by its author \{Beyâtî Shaikh Mahmûd\} to have been compiled from the Oghuznāme, is confirmation of this. In fact, already a century ago, J. Klaproth mentioned the striking unity in the Chinese and Persian accounts of the Turks as evidence for the existence of early Uighur chronicles recording all such legends and traditions. For additional information on the Oghuznāme, see Chapter 7, section G below. \{See $E I^{2}$, s.v. "Oghuz-nāma" (Irène Mélikoff).\} 


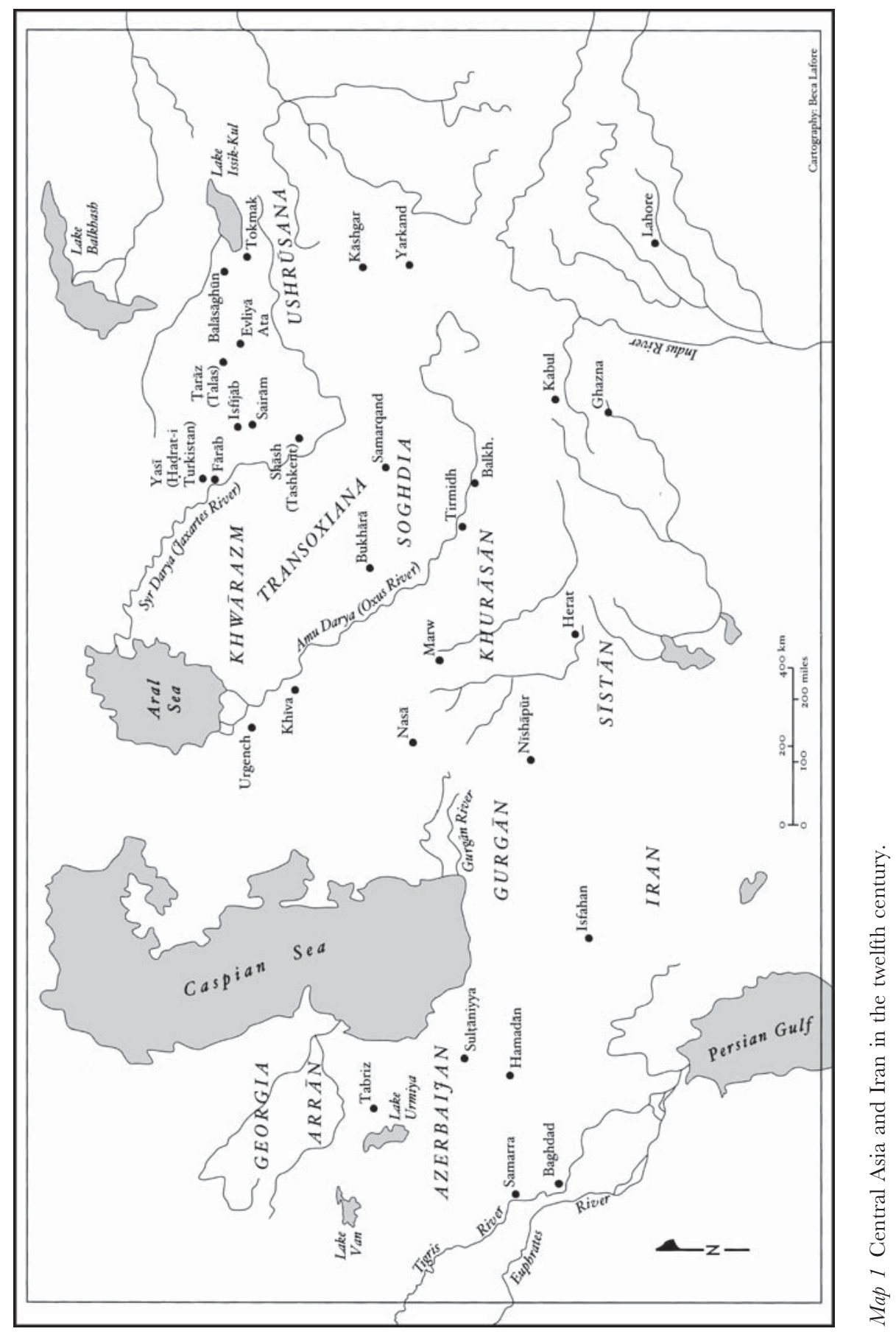




\section{THE LEGENDARY LIFE OF AHMAD YASAWI}

It seems that every personality who leaves a strong impression on the popular imagination has legends created about him even while he is still alive. Over the centuries, as they pass from generation to generation, these legends grow larger and larger until it is difficult to distinguish the true character of the original personality. In the Orient in particular, the Șūfìs had such a powerful influence on the popular imagination that with each passing century new legends were fabricated about them while each day more was forgotten about their true historical characters. Because the early Oriental historians were not able, for the most part, to distinguish history from legend, they simply transferred to their books verbatim the fanciful accounts that had been created in the popular imagination. Therefore, although my ultimate goal is to try to establish the historical character of Khwāja Aḥmad Yasawī, I will first describe the legendary personality that tradition has handed down to us. Being a creation of the social consciousness, this personality, even if it does not correspond to the historical personality, has great social value and is worthy of study.

\section{A His childhood}

In the city of Sairām in Turkistan \{Sairām is just east of Shymkent in modern Kazakhstan\}, there was a shaikh named Shaikh Ibrāhīm, a descendant of 'Alī. When he died, he left a grown daughter named Gawhar Shahnāz and a sevenyear-old boy named Ahmad. ${ }^{1}$ From the time he was very young, Ahmad received various manifestations \{of God's grace \} and displayed extraordinary qualities that belied his age. In his work entitled Dīwān-i Hikmat, he recounts successively, in a language appropriate to the Șufīs, the spiritual powers that he had received. ${ }^{2}$ At age seven, when he was orphaned by the loss of his father, Ahmad, who since childhood had received the guidance of Khadir a popular figure in Muslim legend, often identified with Elijah, see $E I^{2}$, s.v. "al-Khadir" (A. J. Wensinck); Ahmet Yaşar Ocak, İslâm-Türk inançlarnnda Hızır yahut Hızır-İlyâs kültü (Ankara, 1985); and Patrick Franke, Begegnungen mit Khidr (Beirut, 2000)\}, was raised by another, spiritual father. This was Shaikh "Bābā Arslan" \{Köprülü subsequently refers to him as Arslan Bābā\}, one of the Companions of the Prophet. Guided 
by spiritual direction \{mânevî işâretiyle\} from the Prophet, he went to Sairām to become Ahmad's teacher. ${ }^{3}$

According to legend, Arslan Bābā was one of the foremost Companions \{ of the Prophet\}. One well known report states that he lived to age 400, and another to age 700. His traveling to Turkistan and being charged to teach Ahmad Yasawī were based on spiritual direction. It seems that during one of the Prophet's military expeditions, his noble Companions came to him hungry and pleaded for something to eat. The Prophet uttered a prayer and \{the angel\} Gabriel brought a dish of dates from paradise. One of the dates fell on the ground, whereupon Gabriel said, "This date is the portion of a member of your religious community named Ahmad Yasawī." Because anything held in trust was naturally to be given to its owner \{cf. Koran IV:58\}, the Prophet proposed to his Companions that one of them undertake this duty. But none of them responded except for Arslan Bābā, who said that by apostolic favor he would be able to undertake this task. The Prophet then put the fallen date into Arslan Bābā's mouth with his own hand and added a bit of his own blessed saliva. A covering immediately formed over the date and the Prophet instructed Arslan Bābā how he would find Ahmad Yasawī and commanded him to devote himself to his education. ${ }^{4}$ Arslan Bābā then went to Sairām (or Yasī) and, after completing there the task that he had taken upon himself, died the following year. It is recorded in the Dīwān-i Hikmat that "the Angel of Death took his soul, the hüris \{female denizens of paradise\} cut out a shroud from silk garments, and 70,000 weeping angels appeared and transported him to paradise."

By age seven, Aḥmad Yasawī had already advanced through a series of high spiritual stages and then, under the direction of Arslan Bābā, the young Aḥmad reached a high level of maturity and slowly began to win fame from every quarter. His father Shaikh Ibrāhīm had already been renowned in that region for performing countless miracles $\{$ s. karāma $\}$ and many legends were told of him. ${ }^{6}$ Consequently, it was recognized that, with respect to his lineage as well, this quiet and unassuming young boy, who always did his sister's bidding, held a spiritually important position. Around that time an extraordinary event occurred that spread Ahmad's fame throughout Turkistan. A ruler named Yasawī was ruling as sultan in Transoxiana and Turkistan. He spent the winters in Samarqand and the summers in the mountains of Turkistan. Like all Turkish rulers, he was fond of hunting and used to pass the time in this pursuit in the mountains of Turkistan. One summer he wanted to go hunting on Qarachuq Mountain, but because it was so rugged, he gave up hope of doing so. He was never able to hunt on Qarachuq. ${ }^{7}$ Consequently, he wanted to get rid of the mountain. $\mathrm{He}$ gathered together all the friends of God \{i.e. the saints\} in the lands that he ruled and requested them to remove this mountain by the blessing of their prayers. The saints of Turkistan agreed to the ruler's request. They wrapped themselves in ihrāms \{the garb of pilgrims going to Mecca\} and for three days prayed and pleaded for this mountain to disappear. Contrary to expectation, however, all their prayers were in vain. Searching for the reason, they asked, 
"Was there anyone among the 'arifs \{those who have knowledge of God\} and saints of the country who did not come?" It turned out that Shaikh Ibrāhīm's son Aḥmad Yasawī had not been summoned because he was still very young. They immediately sent men to Sairām to summon him. The boy consulted with his older sister and she said to him, "Our father had some testamentary advice \{for you\}. The thing that will show whether or not your time to appear has come is a table cloth that is tied \{in a knot\} in our father's place of worship. If you can untie it, then go ahead \{in response to the ruler's summons\}, for that means the time of your appearance has come." The boy then went to the place of worship and untied the table cloth. This meant that his time to appear had come. He immediately took the table cloth and went to the city of Yasī. ${ }^{8}$ All the saints were present there. He indicated \{they should\} pray over a piece of bread that was on the cloth. They agreed and recited the Fätiha \{opening süra of the Koran \}. He divided the bread among those who were assembled and there was enough for everyone. There were 99,000 people present composed of the saints, the ruler's officers $\{u m a r a \bar{a}\}$, and troops. When they saw this miracle, they had a better understanding of the greatness of Ahmad Yasawī. \{Meanwhile\} Ahmad Yasawi expected that the answer to his prayer was inside his father's dervish cloak. Suddenly, torrents of rain burst from the sky and all the land was flooded. When the prayer rugs of the shaikhs began to float on the waves, they pleaded and cried out. Ahmmad Yasawī stuck his head from the cloak. The storm immediately subsided and the sun appeared. And what should they see! Qarachuq Mountain had disappeared. Where the mountain once stood there is now a town called Qarachuq, where most of Ahmad's descendants reside. The ruler Yasawī, who had witnessed this miracle, entreated Ahmad to ensure that his name would remain on earth until the Day of Judgment. Ahmad accepted his wish and said, "Whoever in the world loves me, may he recall me together with your name." Thus, from that day forward, he has been called "Khwāja Aḥmad Yasawī."

\section{B His fame}

The books of legends \{manāqib\} agree \{Köprülü assumes this $\}$ in stating that Aḥmad Yasawī went to Bukhārā for a while on the advice of Arslan Bābā and attached himself to Shaikh Yūsuf Hamadānī, that city's most renowned spiritual guide, and that after his death he spent some time in Bukhārā carrying out religious propaganda $\{$ halkı dâvete meşgûl $\}$ and then, commending all of his companions to Khwāja 'Abd al-Khāliq Ghujduwān̄̄, went to Yas̄ī on the spiritual direction of the Prophet. ${ }^{10}$ While recounting successively, in a Șūfì manner, the kinds of spiritual manifestations that he exhibited between ages seven and fifty, Aḥmad Yasawī says in the Dīwān-i Hikmat "that he fell in love \{spiritually, i.e. with God $\}$ at age twenty-six, that he fought on behalf of the divine countenance $\{d \bar{\imath} d \bar{a} r\}$ like Manșūr \{al-Hallāj\}, that he suffered various torments because he was not able to find a $p \bar{\imath} r$, and that he finally found a $p \bar{\imath} r$ at age twenty-seven and then he escaped from his torments, and that it was then that he could be worthy 
of that dervish convent." Indeed, one of the hikmats \{religious poems\} has the following refrain: "My great teacher, I came to take refuge with you" \{Zâtı ulu hoca'm, sana sığnı geldim\}. One could guess that this refers to Yūsuf Hamadānī and that Ahmad attached himself to him at age twenty-seven. ${ }^{11}$

Ahmad Yasawī was occupied continuously with teaching and providing guidance in the town of Yasī. The number of disciples who gathered around him increased daily and his fame gradually spread throughout Turkistan, Transoxiana, Khurāsān, and Khwārazm. He was superior to all the saints of his time in both exoteric and esoteric knowledge. He lectured to his disciples on both types of knowledge. He spent \{virtually\} all his time worshipping God and doing pious acts. In his free time, he carved spoons and ladles and sold them to earn a living \{Köprülü takes this from Bektashī lore without citation\}. He always kept company with Khadir, who had been his father's old companion. Indeed, one day, Khadir said to Ahmad, "I travel the seven climes seven times a day searching for a companion and there is no companion more capable and finer than you." 12 Ahmad would not accept a single morsel from the endless gifts and votive offerings that were donated to his tekke \{this term was not used in Central Asia\}. Every day \{word of $\}$ his saintly powers spread a little further among the people. "It is reported that the celebrated khwajja \{master\} had an ox. It would go about the city market with a saddle bag \{on its back $\}$ in which spoons, ladles, and begging bowls were visible. Those who wanted to purchase them would take a certain amount \{of these goods\} and leave what they cost in the saddle bag. The ox would wander about every day until nightfall. Then it would go to the khwaja. He would take the contents \{of the bag\} in his blessed hand. If someone were to take something from the saddle bag without paying for it, the ox would follow him and would not go to another quarter \{of the city\} until he had returned the merchandise or paid for it."13

According to tradition, the erens \{saints\} of Khurāsān held Ahmad Yasawī in high esteem, but they didn't realize the true magnitude of his greatness. One day they decided to hold a large assembly and invite the khwäja to it. One of them took the form of a crane and set out to inform the khwajja. Learning of this matter through his inner power, the khwajja told his disciples that seven saints were coming and took some of his dervishes with him \{to meet them\}. He also took the form of a crane and came out to greet the saints. At a large river on the border of Samarqand, the two groups met. The erens of Khurāsān were amazed and humbled by the khwajja's power. While they were all together, the khwajja looked at the river. A merchant was crossing it with all of his goods and animals. Suddenly, the water swept them all away. The merchant vowed that if he were rescued he would donate half of his goods \{to his rescuer\}. Hearing this, the khwäja immediately stretched out his hand and saved the merchant. He then immediately changed form and assumed the attire of an ordinary man. The merchant immediately clasped the hand of his rescuer and gave him half of his goods. Ahmad took this merchandise and wealth and went to Khurāsān where he gave all of it away to the erens. He thus became the object of boundless reverence. ${ }^{14}$ 
As the fame of Ahmad Yasawī spread and the number of his disciples grew into the thousands, the number of his opponents and rivals, of course, also increased. These hypocrites finally ventured a grave slander. Supposedly, women who did not cover themselves were attending the khwäja's majlis \{religious assembly, course of instruction $\}$ and mingled with men in the dhikr \{Ṣūfì séance $\}$. The religious scholars of Khurāsān and Transoxiana, who strictly abided by the stipulations of Islamic law $\left\{\operatorname{Shar}^{c} a\right\}$, sent an investigator to determine if there was any truth to this rumor. The information that he collected made it clear that this was simply a case of slander. Still, Ahmad Yasawi wanted to teach them a lesson. One day, while sitting in a majlis with his disciples, he brought out an inkstand closed with a seal. Addressing the whole congregation he said, "Who among the saints has never, since reaching the age of discretion, touched a woman with his right hand?" No one was able to answer. While the shaikh was saying this, one of his disciples, Jalāl Ata, stepped forward. Aḥmad Yasawī put the inkstand in his hand and sent him in care of it with the investigators to the countries of Transoxiana and Khurāsān. All the religious scholars and upholders of Islamic law in those countries got together and opened the inkstand. Inside were a fire and some cotton, neither of which had any effect on the other. The fire did not burn the cotton nor did the cotton extinguish the fire. At that moment, the religious scholars, who had sent out the investigators when the $k h w \overline{a j} a$ was under suspicion, understood the lesson that he wanted to give them in all its clarity. Even if men and women gather in a meeting of the people of God and attend the dhikr and worship together, God Almighty is able to cleanse their hearts of all spite and enmity. All the scholars were exceedingly ashamed and fearful and they tried to get their offense forgiven by sending gifts and votive offerings. $^{15}$

\section{His khalīfas}

Ahmad Yasawī had 99,000 disciples who came from the four corners of the world. ${ }^{16}$ According to another tradition, he had 12,000 "dervish disciples who were initiates of his sainthood, had the power to perform miracles, and who were perfect and excellent $\{$ in all respects\}" \{velâyet-meâb, kerâmât-iktisâb, kâmil, mükemmel

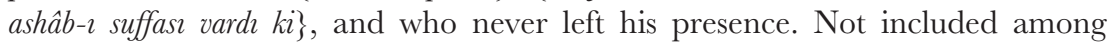
them were the khaliffas and shaikhs who were sent in all directions under his guidance and by his permission. The following were his leading khal̄̄fas: Șūfì Muhạmmad Dānishmend Zarnūqī, Sulaimān Hakīm Ata, Bābā Māchīn, Am̄̄r 'Alī Hakīm, Hasan Bulghānī, Imām Marghuḍ̄i, and Shaikh 'Uthmān Maghribī. ${ }^{17}$ The attachment of some of them to Ahmad Yasawī came about in a very unusual manner. For example, before Bābā Māchīn joined Aḥmad Yasawī, he was, at age 400, a famous saint from among the Șūfì leaders of Khurāsān. Every day, in plain view, he would fly a distance of 24 parasangs \{this is from the Dīwān-i Hikmat\}. Deluded by the spiritual level that he had attained, he was about to reprove Ahmad Yasawi for having men and women together in his majlis. On 
Aḥmad Yasawī’s order, however, Hakīm Ata and Șūfì Muhammad Dānishmend seized him and, tying him tightly to a column of the tekke, gave him 500 blows. But they had no effect, so they beat him again. A mark became visible on his back and he began to weep. They then untied him from the column and he paid allegiance to his excellency the pir and repented. "A powerful jinn invisible beings, harmful or helpful, that interfere in the lives of mortals $\}$," they said, "had settled on Bābā Māchīn's back. Every day, he \{the jinn \} used to fly a distance of some parasangs \{carrying Bābā Māchīn\}. Hurt by the 500 blows, he finally left Bābā Māchīn's back and fled. The last blow therefore struck Bābā Māchīn and thus he was saved." Afterwards, Bābā Māchīn underwent 40 days of penitence $\left\{\operatorname{arb}^{\prime} \bar{\imath} n\right\}$ and solitary religious devotions $\{k h a l w a\}$. In fact, he retired privately with Ahmad Yasawī three times. Eventually, he became one of the most \{spiritually\} advanced of the shaikh's famous khalīfas. ${ }^{18}$

Another important khah̄efa was Imām Marghuḍ̄i (or Marghaḍ̄ị, Marwaz̄i, i.e. from Marw \{rather, Marghuzī, as in other works by Hazīnī, which may refer to Marghah near Marw\}). At first, he did not want to admit to the greatness of the khwajja, but later he could not escape his magnetism. At the time when the khwāja's fame was spreading in all directions, four students from Yasi settled in the city of Urgench in the land of Khwārazm to study. Imām Marghuḍī was the most renowned and learned professor \{mudarris\} in Urgench. These students naturally went to his lectures. When the Imām learned where the students were from, he said to them, "We have heard that in Yasī Khwāja Aḥmad Yasawī is behaving contrary to the Shari $a$. I wonder if there is any truth to this rumor." In response to this grave question, the young students said that they knew nothing about the matter, only that the khwäja was a pious man and an upholder of the Shari $a$ and that he had 12,000 dervish disciples. The Imām could not allay his doubts and decided to go there himself and try to learn \{the truth of $\}$ this matter. Saying, "Up to now, I have memorized 12,000 mas'alas \{points of law\}. Surely I can go and ascertain \{the truth of $\}$ this matter," he set out on the road taking with him 400 eminent legal scholars \{s. dānishmand\} and 40 muftīs \{those who give formal legal opinions $\}$. While this caravan was en route, Ahmad Yasawī, with the help of God, learned what was happening and said to his first khaliffa Ṣūfì Muhammad Dānishmend, "Go see what is coming to us over the horizon!" Șūfì Muhammad informed him that Imām Marghuḍ̄ was coming with 3000 mas'alas in his memory. On the order of the shaikh, Sūfì Muhammad then erased 1000 of those mas'alas from the memory of the Imām. Later, he also asked Sulaimān Hakīm Ata the same question. He said that Imām Marghuḍī of Khwārazm had set out with 3000 mas'alas, but 1000 had been removed, so now he was coming with the remaining 2000 mas'alas. Aḥmad Yasawī ordered him to erase 1000 more and he did so. Thus when the Imām arrived in Yasī only 1000 mas'alas remained in his memory. When Imām Marghuḍī saw Aḥmad Yasawī, the latter was wearing an old fur inside out on his back and a black conical hat made of sheep skin on his head, and he asked him, "Are you the one who leads God's slaves astray?" Unperturbed, Aḥmad Yasawī replied that the Imām would 
first be his guest for three days and that afterwards they would be able to discuss matters. Three days later, they brought out a chair, which the Imām sat in. The shaikh ordered Hakīm Ata to erase his remaining 1000 mas'alas. Seated in the professorial chair, Imām Marghuḍ̄ could not remember a single maśala. He leafed through his notebooks page by page, but every page was completely blank. He then realized his own fault and got off the chair. He begged the shaikh's forgiveness, and in the company of all his legal scholars and muftīs, was initiated into the order. After five years of retiring for solitary religious devotions, spending forty-day periods of penitence, and undergoing severe mortification of the flesh, he completed all stages \{of spiritual development\}. Finally, Ahmad Yasawī sent him and five of his other khalîfas to carry out religious propaganda among, and instruct, the people of Khurāsān. These five were Shaikh Muhammad Baghdādī, Saif al-Dīn Bākharzī, Shaikh Kamāl Shaibānī, Shaikh Sa'd al-Dīn, and Shaikh Bahā' al-Dīn. ${ }^{19}$

\section{Chilla-khāne}

Since childhood, Aḥmad Yasawī had never fallen short in his attachment to any sunna \{a saying or action\} of the Prophet. Consequently, because the Prophet migrated from this transitory world at the age of 63, Ahmad Yasawi wished to be buried as soon as he reached that age because he was attached to this sunna. At one side of the tekke, they dug a pit into which one could descend by a ladder. They cleared a path and built a cell from crude sun-dried bricks. Thanks to the spiritual succor of \{the prophets\} Ilyās \{Elias\} and Khadir, nothing has disturbed that structure for hundreds of years. Ahmad Yasawī dug out a place there in the shape of a sarcophagus and made it his abode. The more he chanted religious formulas or prayers in that tight place, which resembled a sarcophagus, the more his knees rubbed against his breasts until both were worn through. For this reason, they called them سرحلقة سينه ريشان \{Chief of the HeartWounded $\}.{ }^{20}$ According to one report, Ahmad Yasawi remained in that place until age 120, according to another until age $133,{ }^{21}$ and according to another, in circulation today in Yasī, until age 125; \{in any case $\}$ he spent the rest of his life in that tight narrow chilla-khāne \{place where religious devotees shut themselves up, lit. place of 40 (days)\} exactly like the ash $\bar{a} b-i$ qubur \{people of the tombs, i.e. the dead\} engaged in mortification of the flesh and worshipping God. ${ }^{22}$

Even while he was living in this chilla-khāne, there was no end to the miracles that Ahmad Yasawī performed. One day "that place of worship, which was like a sarcophagus, left a kind of fire and thirst in the bellies of the dervishes and mystics, and this made those in the majlis anxious. Hakim Ata was enjoined to provide them with water. As he rose to get the water, the sound of streaming water reached his ears. Amazed, he turned around and looked. The center of the majlis was like an oven or the stokehold of a bath. Flames were everywhere and the mystics and dervishes were roasting in that fire. Hakīm Ata stood there overwhelmed and delirious \{at the sight\}. At that moment Ahmad Yasawī 
suddenly appeared with a drinking glass in his hand. He plunged the drinking glass into the fire and gave everyone there a drink. Hakim Ata, who drank water from that glass, reported 'It was sweet as honey and cold as snow.' In this manner, the thirst of those in the majlis abated and then the shaikh of shaikhs lowered the palm of his hand over the fire and it immediately disappeared. By the wisdom of God, however, an earthen jar appeared. The Yasawīs call it 'khum-i 'ishq' \{the jar of love and use it to derive omens. If one's wish is to be granted, the wisher's hand, no matter how short his arm, reaches the bottom and grasps a stone, a piece of straw, or the like. On the other hand, if the wish is not to be granted, the hand of the seeker, no matter how long his arm, cannot reach the bottom." 23

Another legend describes an incident between a ruler named Qāzān Khān and Aḥmad Yasawī. Qāāān Khān noticed that Aḥmad Yasawī did not come to the mosque for Friday prayer and sent word to him about this via the shaikh's chief confidant Ṣūfì Muhammad Dānishmend Zarnūqī. At that moment, the call was being given from the minaret for the Friday prayer. Quickly and fearfully, Șūfì Muhammad entered the shaikh's presence and was told, "Oh, Ṣūî̀ Muhammad, come! Stick with me! Let us go together to the Friday prayer." Șūî̀ Muhammad obeyed the khwäja's command. Instantly, he found himself sitting in a row inside a mosque. As soon as the Friday prayer was finished, Șūfì Muhammad, bewildered by this extraordinary event, looked for the shaikh but could not find him. He went in and out of the mosque door seven times without success. The caretaker of the mosque was cognizant of this mystery, however, and said to Șūfi Muhammad, "Hey there, dervish! This place is Cairo and this mosque is the Mosque of al-Azhar. The friend for whom you search has performed the Friday prayer for a long time now." After spending a week there, Șūfì Muhammad found his shaikh and immediately was returned to his cell. The khwāja ordered him to go and relate what he had seen. Sūfī Muhammad came \{back to Qāzān Khān\} and recounted everything that had happened to him. The muezzins, however, had not yet finished making the call to prayer. Qāaān Khān and those in his retinue then properly understood the greatness of the khwäja. ${ }^{24}$

The people of the town of Șūrī (Savrān, Sabrān \{Ṣūrī and Savrān/Ṣabrān are two different toponyms $\})^{25}$ in the environs of Yasī had concentrated their hatred of the people of Yasī especially on the person of Ahmad Yasawī. As the fame of Aḥmad Yasawī spread abroad, they became enraged. Finally, they hatched a plot by which they could accuse him of theft. They butchered a cow and secretly took it to the tekke, where they left it. Because it was the summer season, the disciples were spending time outside. Thus no one saw the butchered cow. Early the next morning, on the pretext of searching for their cow, the people of Șūrī gathered in front of the tekke and told the shaikh that they wanted to look inside. Addressing these hypocrites, Ahmmad Yasawī said, "Enter, curs! Enter, dogs!" They went inside, but by the wisdom of God they were all immediately transformed into dogs and began to eat the cow, which they had butchered and 
placed inside the tekke. Their friends, who were observing all this from outside, became terribly frightened and immediately repented and begged the shaikh for forgiveness. The others were immediately returned to human form except for their tails, which remained in place as a memento of their evil deed and were passed on to all of their descendants. ${ }^{26}$

Despite all the spiritual blows that they suffered, the people of Sūrī simply could not refrain from fighting against the khwäja. The khwäja had a son named Ibrāhīm and also a beautiful horse. He said, "Whoever should bring word of the death of my son, I will give him this horse in thanks." ${ }^{27}$ The people of Șūrī learned of this. One day, they found Shāhzāde Ibrāhīm sleeping beneath a tree. They cut off his head, wrapped it in a towel, and laid it before the khwajja. The khwāja asked those who brought it, "What's this?" They said it was a gift of fresh melon. Although the khwajja understood what was going on, he nevertheless gave the murderer that horse and also his daughter so that no blood feud would remain between them nor would any hatred or blood money ensue. According to the account of Hazīnī, Shaikh \{Farīd al-Dīn\} 'Atțār reported this anecdote in his book Mantiq al-tair. Now, every year blood is seen flowing from the place below the tree where Ibrāhīm was murdered. The khwäja's disciples and those who believe in him take that blood and, with God's permission, use it to cure all sorts of illnesses. ${ }^{28}$ Among the Yasawī dervishes, there are many oral traditions like this about the khwāja.

\section{E The miracles he performed after his death}

Khwāja Aḥmad Yasawī died after spending a long life in his chilla-khāne. Nevertheless, he continued to perform miracles. Of these countless miracles, only a few were able to pass into the histories and books of legends. For example, according to one old legend, Tīmūr's \{Tamerlane \} building of a türbe and mosque over the khwäja's grave was the result of one of the khwäja's miracles. The work entitled Risāla-i tawā̄inkh-i bulghāriyya records this legend in the following manner: "Finally, His Excellency Am̄̄r Tīmūr intended to go to Bukhārā with Khaḍir, peace be upon him. On the way, he stopped in Turkistan \{i.e. Yasī\}. Khwāja Aḥmad Yasawī of Turkistan appeared in Amīr Tīmūr's dream and said, 'Here there, brave young man! Go quickly to Bukhārā! God willing, the death of the ruler $\{s h \bar{a} h\}$ there is in your hands, and many things are bound to happen to you. In any case, all the people of Bukhārā are waiting for you.' Amīr Tīmūr awoke from this dream and thanked God. The next day he summoned Nūghāibāq \{Noghay Beg\} Khān, the ruler of Turkistan, and gave him a lot of money to build a shrine at the tomb of Ahmad Yasawī. As instructed, the ruler of Turkistan built an ornate shrine that still stands in all its beauty." ${ }^{29}$

We know from other sources, in fact, that Tìmūr believed very much in Aḥmad Yasawī. Indeed, when he marched to Anatolia to wage war against Sultan Bayezid I \{1402\}, he took omens from the khwäja's maqāmāt \{ "assemblies," a literary genre $\}.{ }^{30}$ 
Naqshbandī tradition attributes the fact that the famous Sultan Abū Sa'īd Mīrzā \{r. 1451-69\}, of the Tīmūrid dynasty, was honored by the favor of Khwāja 'Ubaid Allāh \{Ahrār \} to a miracle of Ahmad Yasawī. At a time when Sultan Abū Sa'īd Mīrzā had still no reputation or fame, Khwāja 'Ubaid Allāh wrote his name on a piece of paper and inserted it in his turban. His disciples asked him who this Abū Sa'īd Mīrzā was. He answered, "The man who will be my ruler, your ruler, and the ruler of Taskhkent, Samarqand, and Khurāsān!" In fact, a very short time later, this came about as follows: around that time, Sultan Abū Sa'̄̄d Mīrzā had a dream in which Khwāja 'Ubaid Allāh recited the Fātiha to him as instructed by Aḥmad Yasawī. Abū Sa'īd Mīrzā asked Aḥmad Yasawi the name of the khwäja who was reciting the Fätiha to him and learned who it was. When he awoke the next morning, he asked those in his retinue if they knew anyone named Khwāja 'Ubaid Allāh. He learned that there was a shaikh with that name in Tashkent and immediately set out for that city. Eventually, he had an audience with the khwajja in Farkat and begged him for one Fätiha. The khwäja laughed and said, "The Fätiha is one \{Fâtiha bir olur\}."

In Fawähir al-abrār, there is a description of one of the khwäja's miracles concerning Humāyūn \{the Mughal emperor, d. 1556\}. Sayyid Manșūr Ata, the author's shaikh and a khalīfa of the Yasawīs, ${ }^{32}$ once went to Turkistan, i.e. Yasī, and, visiting the khwäja's türbe, spiritually had an audience with him. During the audience, Aḥmad Yasawī said, "The Chaghatay ruler - i.e. Humāyūn the son of Bābur - wants to capture Samarqand and take control of that country, but the good spirits \{saints?\} are not pleased with this and want to direct him toward India. Remove an 'alam \{standard, badge\} from my türbe and take it for his victories in that region." Upon this order from the khwāja, Sayyid Manșū removed an 'alam and went to Kabul, the center of Humāyūn's government. Indeed, Humāyūn wanted to take Samarqand, the burial place of his grandfather Tīmūr, and destroy the Chingizids. The ruler's brother, Hindāl Mīrzā met with Sayyid Manșūr for a rather long time in Kabul and, realizing his greatness, became a disciple. When Hindāl Mīrzā went back to Humāyūn, he related to him what had happened to him. Humāyūn also had had a dream in which he saw a wonderful vision presaging this occurrence. They then summoned Sayyid Manșūr. He came bringing the 'alam that Ạ̣mad Yasawī had given him. The ruler received him. Then a dhikr circle was organized and verses \{s. manzūma\} from the hikmats of the pirs of Turkistan were recited. Those who were listening reached a state of ecstasy. Afterwards, he said to Humāyūn, "The saints of Transoxiana bring you good news of the conquest of India. His excellency Aḥmad Yasawī sent this for victory. Please accept it." Humāyūn was very pleased with this good news. He marched on India, invaded and captured it. ${ }^{33}$ In this manner, Aḥmad Yasawī performed another great miracle.

In his fawāhir al-abrār, Hazīnī describes another miracle of Ahmad Yasawī that he cites from his shaikh Sayyid Manșūr Ata \{rather, Sayyid Manșūr\}. When Sayyid Manșūr first saw Aḥmad Yasawī’s chilla-khāne, he was very astonished how he had endured living in this very depressing, small and narrow place for 
years. But suddenly, he looked around and noticed that one end of that chillakhane that he thought was very small was in the East and the other end was in the West! He realized that what he had previously thought was mistaken and he once again thoroughly understood that God never causes his beloved servants to suffer from distress. He could make a small and narrow place that was a few spans wide bigger than the whole world. ${ }^{34}$

An American traveler named Schuyler, who stopped in Yasī while journeying in Turkistan shortly after the Russian invasion, recorded another legend about Ahmad Yasawi that was in circulation among the people there. According to this legend, Ahmad Yasawī, while still alive, went up the minaret of the mosque of Hazret \{i.e. Hadrat-i Turkistan\}, took the white turban from his head, and showed it to the people. The people interpreted this to mean that the city would soon fall into the hands of the Russians and therefore they did not put up any resistance to the Russian army. ${ }^{35}$ On the other hand, the same traveler writes that because that mosque was considered to be the holiest mosque in Central Asia, all the religious scholars and the populace gathered there before the Russian invasion and entreated God to drive away the enemy who was about to fall on them. ${ }^{36}$ Furthermore, there is a very famous Noghay legend that presents Edigü, one of the ancient folk heroes of the Turks, as a descendant of Aḥmad Yasawī. ${ }^{37}$ And in the famous legend of Satuk Bughrā Khān published by R. B. Shaw, there is mentioned a ritual that was held at the türbe of Sultān Khwāja Aḥmad Yasawī. ${ }^{38}$

There are many such legends concerning the miracles that Ahmad Yasawī performed while he was alive and after his death. If we consider the profound spiritual influence that he exerted, not just in Central Asia and among the Northern Turks \{this expression is no longer used and the Qirghiz but in all the Turkish countries, then we can better understand the origin and nature of the legends concerning the many miracles that he performed even after his death.

\section{F His khalīfas among the Qipchaqs}

It can easily be seen from the Risāla-i tawārīkh-i bulghāriyya, ${ }^{39}$ written by Husām al-Dīn b. Sharaf al-Dīn \{Muslimī $\}$ in 992/1584, that Ahmad Yasawī enjoyed great fame among the Qipchaq Turks from a very early time and that the earliest shaikhs who appeared among them were directly or indirectly connected with him. In this work, which contains material of a legendary nature rather than of historical value, a number of the early shaikhs who were khalifas of Aḥmad Yasawī are mentioned. One of them is Bayrāsh b. Ibrāsh Ṣūfî, an early shaikh of the Qazaqs. He was from the Jahriyya tarnqa and a student of Ahmad Yasawī. He was sent to the region of the Bulghars on the shaikh's instructions. Ish-Muhammad Tūq-Muhammad-oghlu from the avul \{nomadic settlement\} of Aday-Chermish on the banks of the Buri River was a disciple of Bayrāsh Șūfi. Bayrāsh Șūî̀ was a shaikh for 36 years and attracted many disciples. He won fame under the byname Shaikh Bābā. After this famous representative of the 
Jahriyya tarīqa in the north died, that entire region was without a murshid for a full 20 years. There was no longer anyone who knew the rules of the Șūfi way. During this time, Shaikh Hidāyat Allāh, a disciple of Ahmad Yasawī, was in Yarkand at the head of the Jahriyya tarīqa. One of his Bulghar followers was Idrīs Dhū al-Muhammad-oghlu from the avul of Terberdi Chāllı. He went to Yarkand and stayed with that shaikh for fifteen years. Twenty years after the death of Sunfi Ish-Muhammad, Shaikh Hidāyat Allāh ${ }^{40}$ sent Idrīs Khalīfa to the region of the Bulghars. Qāsim Shaikh Ibrāhīm-oghlu from Kazan was his khaîfa. In the avul of Bay Chura-Chermishi on the shore of the Aq-İdil \{Volga\} is the tomb of Khwāja Amīr Kalāl another disciple of Aḥmad Yasawī. This brief account clearly indicates the place of Ahmad Yasawī among the Northern Turks. ${ }^{41}$ In order to convey the significance of Aḥmad Yasawī among the Northern Turks, let me add that there is an oral legend in that region that even attributes to him the first use of tea among the Turks. ${ }^{42}$

The fact that we have so little information on the khalīfas of Ahmad Yasawī who spread from the Qazaqs to the banks of the Volga results from the almost complete absence of documents that have survived from early times concerning the history of that region. Otherwise, we might have had considerable information on the legends and miracles of Ahmad Yasawī's disciples along the banks of the Volga. While simple and general works, like \{the anonymous\} Sharä'it al-imann, which are very widespread in that area, show that the khwäja is still important for the \{local\} people, it is also clear from the famous Hakîm Ata kitâbı that a number of legends about Yasawī dervishes have been current there for a long time. ${ }^{43}$

\section{G Khalifas in the lands of the Western Turks \{Rūm Diyārı\}}

According to tradition, the spiritual influence of Ahmad Yasawī continued for a long time in all of the Balkans \{Rumelia\}, Asia Minor, Azerbaijan - in short, among the Western Turks generally - as a great many dervishes who claimed to be attached to him gradually began to enter those regions. In the various countries to which he traveled, Evliyā Chelebi $\{$ d. c.1685\} visited the türbes of a number of saints who were considered to be connected with Ahmad Yasawī and he lists them one by one: ${ }^{44}$ Avshar Bābā, whose türbe in Niyāz-ābād was a place of pilgrimage; ${ }^{45}$ Pīr Dede, who was buried in, and had a tekke in, Merzifon; ${ }^{46}$ Akyazılı, whose great tekke was in the Bat-ova plain on the Black Sea coast and whose legends were famous; ${ }^{47}$ Kademli Bābā Sulțān, who was buried in Adatepe on the Filibe road; ${ }^{48}$ Geyikli Bābā, who was buried in Bursa; ${ }^{49}$ Abdāl Mūsā; ${ }^{50}$ and Horos Dede, who was buried in Unkapanı \{in Istanbul $\}.{ }^{51}$ All of them were khaliefas of Aḥmad Yasawī. In addition to the faqīrs of Aḥmad Yasawī who are mentioned by Evliyā Chelebi, the historian 'Ālī mentions someone named Amīr Chīn Osman in a series of shaikhs from the reign of Sultan Orhan. Another khalêfa of Aḥmad Yasawī, he went to Rūm after 600/1203-4 and built a famous 
tekke, called the Osman Bābā Tekke, in the vicinity of the sancak \{district\} of Bozok. ${ }^{52}$ Evliya $\bar{a}$ Chelebi, who says in various places in his book that he \{himself\} was a descendant of Ahmad Yasawī, also describes the tekkes and tombs of two other Yasawī khalifas who went to Rūm. One was the tekke of Shaikh Nușrat. It was located on the plain of Zile, which was north of Arik-ova and just past Çamlıbel. Shaikh Nușrat, who was from Khurāsān, had once gone to this place in Rūm on the order of his pīr \{Ahmad Yasawī $\}$. Evliyā Chelebi says that his extensive and flourishing tekke had about 70 faqirs and all the people in the region believed in the shaikh. Indeed, in front of the tekke stood an ancient mulberry tree that was used as a cure for fever (Seyāhatnāme, Book 3, fo. 91a; \{Evliyā explains that they used a splinter from the bark of the rotted part of the trunk to make a fumigatory\}). The second tekke was that of Gajgaj \{rather, Gijgij\} Dede in Tokat, located on a small mountain that overlooked the city, a place to which people made excursions. When Evliyā Chelebi visited this tekke, it had a few dervishes who were satisfied with very little. The founder of the tekke was Gijgij Dede, a saintly disciple of Ahmad Yasawī, who had gone to this place on his master's instruction. He took the name Gijgij "because he looked terrifying and roared (gyjlda-) like a dragon" (ibid., Book 5, fo. 21b).

\section{H The Bektashī tradition}

It is fairly clear from the reports of Evliyā Chelebi that the early arrival among the Western Turks of a number of dervishes connected with the Yasawi tariq a - which is definitely confirmed before the tenth/sixteenth century \{Köprülü apparently assumes this $\}$ - resulted in the creation of a Bektashī legend about Ahmad Yasawī and Hājjī Bektash. Only in books that were written in the tenth/ sixteenth or subsequent centuries - like \{'Ālī's\} Kunh al-akhbār and Evliyā Chelebi's Seyāhatnāme - does one come across stories that Hājjī Bektash was a disciple of Ahmad Yasawī. This fact confirms the accuracy of the report that 'Āshıq PashaZāde gives about Hāijjī Bektash. ${ }^{53}$ In any case, not a single word is to be found on the relationship of Ḥājjī Bektash with Aḥmad Yasawī in either 'Āshıq PashaZāde or Tashköprü-Zāde. ${ }^{54}$ Nevertheless, whatever its historicity, the Bektashī tradition \{i.e. the Veläyetnāme\}, which, as mentioned, took form in the tenth/ sixteenth century \{more likely in the late ninth/fifteenth century\}, provides considerable legendary material on Ahmad Yasawi. If it is combined with the reports by the historian 'Ālī and Evliyā Chelebi, it clearly shows that Ahmad Yasawi had exerted a great influence on the Western Turks for a long time. Therefore, in order to complete \{our treatment of $\}$ the legendary life of Ahmad Yasawī, we must describe his place in Bektashī tradition.

Present-day Bektashi tradition is still, for a variety of reasons, in a state of disorder. The various hagiographies (velāyetnāmes) that were written about Hiājjī Bektash, and later about his many disciples, sometimes differ greatly from each other. In the Velāyetnāme-i Hājojim Sultān, for example, it is stated that Hājjī Bektash was a direct khalifa of Ahmad Yasawī, while in the complete prose copies of the 


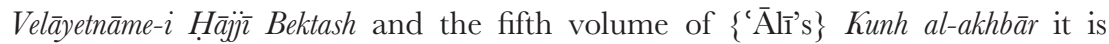
related that Hājjī Bektash was a disciple of Shaikh Luqmān-i Paranda and that this Luqmān-i Paranda received permission to initiate people into Șūism from Ahmad Yasawī or, according to another, rather weak, report from the khwäja's ancestor, the famous 'Alid Muhammad Hanafī \{i.e. Muhammad Ibn al-Hanafiyya\}. Thus, the legendary accounts that in the Velāyetnāme-i Häjom Sultān, for instance, take place directly between Aḥmad Yasawī and Hājjī Bektash are shown in other works as taking place between Luqmān-i Paranda and Hājjj̄̄ Bektash. Furthermore, the velāyetnāmes of Hājjī Bektash that contain the latter version of this story also record a number of legends that directly involve Ahmad Yasawī and Hājjj̄̄ Bektash. ${ }^{55}$

According to one legend in the velāyetnāmes of Hājjī Bektash, Bektash Veli was presented to Shaikh Luqmān-i Paranda for his education while he was still a child. Luqmān-i Paranda was a khalîfa of Ahmad Yasawī and was a man thoroughly versed in exoteric and esoteric religious knowledge. He was initiated into the perendelik \{flying like a bird\} by Ahmad Yasawī, or, according to a report by Muhammad Ibn al-Hanafiyya. Bektash Veli performed many miracles while still a child. One day when Luqmān-i Paranda entered his presence, he was amazed to see the room full of light. Looking around, he saw two luminous persons, one to the left and the other to the right of Bektash. They were teaching him to recite the Koran. As soon as Luqmān entered, they disappeared. Luqmān asked the boy, "Who were they?" He explained that one was the Prophet and the other was 'Alī. ${ }^{56}$ On another occasion, Bektash Veli was reciting a lesson for Luqmān. The time for prayer arrived and Luqmān asked his pupil for some water with which to perform the ablution. Bektash said to his teacher, "Why don't you arrange it so that a stream flows in here? Then there will be no need to go outside." When his teacher said that his own power did not suffice for this, Bektash Veli immediately prayed to God, and Luqmān-i Paranda said, "Amen." At that moment, a little stream emerged from the middle of the school and flowed toward the door, and some beautiful irises $\{s \underline{u} s \bar{a} m\}$ bloomed at the source of the spring. ${ }^{57}$

A short time after this event, Luqmān went on the pilgrimage. He went up to 'Arafāt \{a hill near Mecca\} and while his disciples turned toward the qibla \{direction of Mecca\} he said to them, "Friends! Today is the day before the religious feast $\{$ arefe günü $\}$. Now in our country foods ${ }^{58}$ are being cooked!" These words, by the power of God, were made known to Bektash. Just then various dishes were being cooked in the shaikh's house. Bektash took a tray of the food and instantly served it to Luqmān. When they \{Luqmān and his disciples\} returned to Nīshāpūr, Luqmān told everyone of this miracle performed by the boy and gave him the byname Hājj̄̄ \{"Pilgrim"\}. At about that time, the erens of Khurāsān came to congratulate Luqmān on his pilgrimage. When they saw the stream flowing in the school, they were amazed and asked about it. Luqmān said, "This is a miracle of Hājj̄i Bektash" and he told the erens his numerous miracles one by one. The erens of Khurāsān thought that it was strange for such 
extraordinary things to be done by a child. Haajjī Bektash, who was present, said to them, "I am a descendant of 'Alī. Don't think such things are too much for me. They are a divine gift." The erens of Khurāsān then asked, "If you are the 'possessor of the mystery' where is your sign?" Hājjī Bektash showed them two green moles on the palm of his hand and on his forehead. They all were dumbfounded and finally had to concede his greatness. ${ }^{59}$

One day the erens of Khurāsān assembled and asked Hiājjī Bektash who his pīr was. Hājji Bektash replied that whoever spread a prayer rug over iris petals and prayed, he would become his disciple. They all laughed at this proposition and asked if he would be able to perform this miracle himself. When he performed this miracle for them as well, they all removed their garb from their heads. His teacher Luqmān also removed his. Saying, "Allähu akbar" \{God is most great\}, Hājjī Bektash had them put their headgear back on. Around this time, Sultān Ibrāhīm-i Thānī died. They offered the \{spiritual\} sultanate to Hiājjī Bektash, but he would not accept it. He left it to one of his uncles, Hasan, and withdrew, preferring to do religious exercises \{khalwa and 'uzla\} at a place of worship. After reaching the age of discretion, he remained in this state for forty years. ${ }^{60}$ After this, there is no longer any mention of the name Luqmān in the Velāyetnāme. Subsequently, we find Hāijjī Bektash associated with the aged shaikh Ahmad Yasawī. ${ }^{61}$

In the Velāyetnāme, Ḥājjī Bektash's meeting with Ahmmad Yasawī is presented in a very unusual manner. According to this legend, Ahmad Yasawī was the saint of all Khurāsān and the shaikh of 99,000 disciples. Now, the territory of Badakhshān was completely in the hands of unbelievers who continuously raided the realm of Islam. Finally, the people \{of Khurāsān\} became tired of this and went to Ahmad Yasawī, imploring him to help them. So he placed a tāj \{ "crown," dervish headgear $\}$ on the head of his son Haidar, ${ }^{62}$ who was only twelve years old, girded his waist with a sword and gave him horsetails and a standard. Haidar then went to war with 5000 warriors. While sending his son, the shaikh for some reason failed to mention the name of God, and so his army was defeated. Haidar was taken prisoner and all of his men were put to the sword. Haidar spent seven years in prison and the people of Khurāsān were spared no sufferings from the unbelievers of Badakhshān. At last, they went to Ahmad Yasawi and implored him to help them. He made a fervent silent prayer to God and suddenly Hājjī Bektash appeared at the gate of his tekke. He entered, saluted the Shaikh, and rubbed his face on the threshold. Ahmad Yasawi was very glad and said, "Behold! The possessor of the Kingdom has come." After a meal, Ahmad Yasawī recounted all that had occurred. Hājjī Bektash immediately turned into a falcon and flew away. Ahmad Yasawī's disciples were angry that he had shown favor to that naked abdāl \{dervish\} and left the tekke. But Hājjī Bektash instantly appeared with Haidar, whom he had rescued from prison, and handed him over to his father. All the dervishes then acknowledged his greatness. ${ }^{63}$ Haajjji Bektash was not satisfied with this, however, and by performing many wonders he converted the people of Badakhshān to Islam. ${ }^{64}$ 
After this, Hājj̄̄i Bektash was no longer going to remain in Khurāsān. On the order and instruction of Ahmad Yasawī, he was going to go to Rūm. But the Velāyetnāme explains at length that he acquired, by performing a number of miracles, some things that Ahmad Yasawi had held in trust, i.e. the tāj, khirqa \{dervish cloak\}, sofra $\left\{\right.$ table cloth\}, and sajjäda \{prayer rug\} ${ }^{65}$ In this manner, Ahmad Yasawi turned these things, which he had kept for years, over to their rightful owner, saying, "Oh, Hājjī Bektash, you have now received your lot $\{$ nasibini aldin\}. Congratulations that you have the rank of the chief of the greatest saints \{qutb al-aqtāb, "pole of poles"\} and your authority will last forty years. Up to now authority has been mine. Henceforth, it is yours. In fact, the time for my death has come. Now then, go! I have sent you to Rūm and placed you at the head of the abdāls of Rūm and appointed you their leader."

In the Velayyetname-i Häjoim Sultān, there is another legend that shows the relationship between Hājjī Bektash and Aḥmad Yasawī: "His excellency Sulțān Khwāja Aḥmad Yasawī had a wooden sword. He brought it out, pronounced 'Allāhu akbar,' and girded the waist of Sulțān Hājjī Bektash Veli of Khurāsān with it. In the hearth, wood from a mulberry tree was burning. He grabbed a half-burned piece of wood and flung it toward Rūm. Then he said, 'Be it known that I have sent this half-burned piece of wood in Khurāsān, as an er, to Rūm. Let them receive it in Rūm." So that piece of wood was hurling through the air. Meanwhile, in Konya, there was a saint known as Sulțān Khwāja Faqīh. He seized the wood and planted it in front of his cell. By the power of God, the halfburned piece of wood began to grow. The top of it was burned, but the bottom was mulberry. Even now it is still bearing fruit. That night Hājjim Sultān and Hājjī Bektash Veli lay down on the prayer rug. A divine voice cried, 'Don't tarry! Go to Rūm!' They arose, performed the morning prayer, and completed their litanies, saying (فاينما تولوا فتم وجه اللَه (Wherever you turn, there is the face of God, Koran 2:115\} and prostrated themselves to the friend Ahmad Yasawī\}. They requested permission $\{\ddot{j} \bar{a} z a\}$ from him. Then Khwāja Ahmad Yasawi b. Muḥammad Hanafī \{i.e. Muḥammad Ibn al-Hanafiyya\} b. 'Alī 'l-Murtaḍā and 99,000 khaliffas blessed them and at that hour on a blessed Wednesday they set out on the road to the Ka'ba." ${ }^{\prime 67}$

\section{The legend of Sari Saltuk}

It is clear from Evliyā Chelebi's researches that there must have been a great many more legends telling how the great saint of Turkistan, Ahmad Yasawī, never forgot the Turks who went to Rūm and continuously sent them assistants. The "Sarı Saltuk legend," which has long been very famous among the Western Turks, is very suggestive in this respect. According to the form of the legend recorded by Evliyā Chelebi, Aḥmad Yasawī first sent Hājj̄ì Bektash \{to Rūm\} and then sent Muhammad Bukhārī, known under the byname Sarı Saltuk, to assist him with 700 erens of Khurāsān. Girding Sarı Saltuk's waist with his famous wooden sword, he gave him the following advice: "My Saltuk Muhammad! 
May my Bektash send you to Rūm. Disguise yourself as Sarı Saltuk, the heretic, in the country of Poland, and kill that cursed one with a wooden sword! Earn a name for yourself and fame in Macedonia, Dobruja, and the land of the seven kingdoms!" When Sarı Saltuk arrived in Rūm, Hājjī Bektash carried out his shaikh's order and sent him to Dobruja. Sarı Saltuk performed a great many miracles in that region. He captured many places and converted their inhabitants to Islam. Evliyā Chelebi visited the tekke of this Sarı Saltuk, whose legends he narrates at length, in Silistria on the Black Sea coast. ${ }^{68}$

\section{J Conclusion}

It is possible to reach some historical conclusions from the information that I have provided on the legendary life of Ahmad Yasawī. Until confirmed by other historical evidence, however, these conclusions must be considered tentative \{indeed, Köprülü's dating for the spread of Ahmad Yasawī's legend in various regions is pure conjecture\}. According to the information currently available, the legends about Ahmad Yasawī spread to three major Turkish areas: Turkistan and Qazaqstan (eastern central region), along the Volga (northern region), and Anatolia and Rumelia (western region).

The legends in \{Hazīnı̄'s\} Fawähir al-abrār, which was written by a Yasawī dervish from Turkistan, and those that passed via the Qazaqs and spread to the Northern Turks, and which exist in old, very simple popular books, like the Hakim Ata kitâbr, and the traditions that have been preserved to this day in the dervish convent in Yasī represent the oldest version of the Ahmmad Yasawī legend and are the closest to historical reality. ${ }^{69}$ This influence passed through the region of the Qazaqs and from there went even as far as the old Bulghar Turks and left prominent traces among them. It is a pity that so few historical documents have survived from these Northern Turks. Consequently, we cannot adequately determine the form in which the legend of Ahmad Yasawī spread among them. A number of works that have probably been in circulation among the Northern Turks since fairly early times, such as \{Husām al-Dīn Muslimī’s\} Risāla-i tawārn̄kh-i bulghāriyya, the famous \{anonymous\} Hakîm Ata kitâbı, Bâqirghân kitâbı, and Âhir-zamân kitâbı \{the last is attributed to Sulaimān Hakīm Ata\}, have kept the legends of Ahmad Yasawī and his disciples alive in that region for centuries. And finally, when the legend of Edigü took shape among the Noghays, Ahmad Yasawī was incorporated into that legend as the grandfather of the hero \{again, not exactly\}. One can conclude from all of this evidence that by the ninth/fifteenth century, the legend of Ahmad Yasawī was thoroughly familiar to the Northern Turks.

The legend of Ahmad Yasawī spread rapidly in the Syr Darya region, i.e. in Yasī, Shāsh \{Tashkent\} and its environs, but this was not the case in Farghāna, Bukhārā, Samarqand, Khīva, and Khurāsān. In these areas, we find that the legend of Ahmad Yasawī only began to spread after the eighth/fourteenth century, i.e. after the growth and spread of the Naqshbandī tariqa. The fact that Tìmūr 
had a türbe and mosque built and dedicated to this great shaikh in 800/1397-8 does not contradict this assertion. Tìmūr pursued a policy of supporting the khwajjas and shaikhs in order to establish fully his influence over the people. With this goal in mind, he catered to the beliefs of the people in the Syr Darya region. Many of the shaikhs who appeared during the reigns of Tīmūr and his descendants were members of the Naqshbandī tarīqa. It was only when they became active that the Yasawi legend began more or less to make itself felt in the regions that had been thoroughly imbued with Iranian culture - such as Khurāsān and Bukhārā. But in the areas to the northeast where Turkish culture was more predominant, the influence of Ahmad Yasawī spread, along with the fame of Șūfîs who wrote excellent poetry in Persian, even before the establishment of Naqshbandism. ${ }^{70}$

The legend of Ahmad Yasawī had already spread among the Western Turks well before the formation of the Ottoman Empire. The Mongol invasion, as it swept like a flood from east to west, resulted in the transfer of many things from their original homeland to the Turks in Anatolia. Indeed, this invasion drove thousands of refugees before it. Among the people who went to Anatolia via Khwārazm, Khurāsān, and Azerbaijan, there were certainly dervishes and travelers who belonged to the Yasawī tariqa. And for this reason the Yasawī legend also began to thrive in Anatolia and spread among its people. Nevertheless, because the documentation related to life in Anatolia in the seventh/thirteenth and eighth/fourteenth centuries is so meager, we do not find the Yasawī legend there in written form until after the ninth/fifteenth century, i.e. until after the Bektashī tradition had firmly taken hold and become established. ${ }^{71}$ The Bektashīs followed a simple policy of taking over traditions that already existed among the people and inserting Hājjī Bektash into them. In this way, they skillfully ensured that the legend in its new form did not appear completely foreign to commonly held ideas. Therefore, by taking over the traditions that existed concerning Ahmad Yasawī, the Bektashīs created a tie between him and Hājj̄ī Bektash. ${ }^{72}$ We can vigorously assert that the legend of Ahmad Yasawi flourished among the Anatolian Turks since probably the second half of the seventh/thirteenth century and that, in this Western area, the legend was more confused and further from historical reality than it was in the Eastern and Northern areas. ${ }^{73}$

\section{NOTES}

1 Hazīn̄̄s Fawāhir al-abrār min amwāj al-bihār, which describes the legends of Ahmmad Yasawī \{Hâlis Efendi Library now in the Süleymaniye Library in Istanbul\}, unique MS, p. 66. See the bibliography for additional information on this work. \{Now edited by Cihan Okuyucu (Kayseri, 1995). The manuscript containing the Fawāhir al-abrār is now preserved in the Istanbul University Library (TY 3893). Köprülü assumes (as everyone following him, including Okuyucu) that the manuscript contains a single work with this title, in which the author shifted from Turkic to Persian. This manuscript undoubtedly contained two of Hazin̄ī's works bound together, first the Turkic Fawähir, and then a Persian work whose title remains unknown; one or more folios were lost, 
and with them the end of the Turkic work and the beginning of the Persian work. See Devin DeWeese, "The Yasavī Order and Persian Hagiography in Seventeenthcentury Central Asia: 'Ālim Shaykh of 'Alīyābād and his Lamahăt min nafahāt al-quds," in Leonard Lewisohn and David Morgan (eds), The Heritage of Sufism, vol. 3, Late Classical Persianate Sufism (1501-1705), The Safavid and Mughal Period (Oxford, 1999), pp. 389-414, especially p. 392, n.3.\}

2 \{Ahmad Yasawī,\} Dīwān-i Hikmat, Istanbul edn $\{1299 / 1881-2\}$, p. 6. The same information is found with very few differences in wording on pp. 183-6 of the same

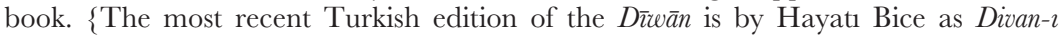
hikmet (Ankara, 1993). Versions of this work have been published in Cyrillic Uzbek and Qazaq and Tatar. Facsimiles of manuscript versions have been published in Moscow (with a Cyrillic Türkmen transcription) and in Istanbul (by Yusuf Azmun in 1994). No critical text edition has yet been undertaken. Turkish scholars continue to cite the selection of poems published by Kemal Eraslan, Ahmed-i Yesevî, Divânn-ı Hikmet'ten seçmeler (Ankara, 1983).\}

3 Ibid., p. 7. \{Fakhr al-Dīn 'Alī Șafì - although in the original bibliography Köprülü gives his father Husain b. 'Alī Kāshifì al-Wā'iz as the author\} Rashahăt, Turkish trans. $\{$ (Istanbul, 1291/1874)\}, p. 14, but the account in the Rashahät itself is a bit

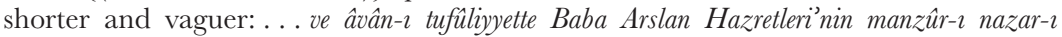
kimya-eserleri, olmuşlardrr. Rivâyet ederler ki Baba Arslan İ̧âret-i pür-beşâret-i Hazret-i Risâlet ile Hâce-nin terbiyetine mesgûl olmuşlar ve Hâce’ye anlarn mülâzemet ve hizmetlerinde küllt terakkryât-ı 'aliyye müyesser olmuş. \{And during (his) childhood, he was under the elixer-like gaze of His Excellency Bābā Arslan. It is reported that Bābā Arslan became preoccupied with Ahmad's upbringing on the felicitous instruction of the exalted personage of the message (the Prophet Muhammad), God bless him and grant him salvation, and that in his attendance and service Ahmad was vouchsafed perfect spiritual progress. $\}$ On this matter, see the details that I have given in the text.

4 Sayyid \{Bahā’ al-Dīn\} Hasan Khwāja Naqī̄b al-Ashrāf \{Nithārī\} Bukhārī, Mudhakkir$i$ ahbāb, \{Königliche Bibliothek Berlin\} MS, pp. 299-301 \{ed. Najīb Māyil Haravī (Tehran, 1377/1999)\}. After relating this legend, the author says, "This story is recounted at length in books and is narrated by trustworthy authorities." In fact, in both the \{Turkish $\}$ translation of \{Ṣafi's\} Rashahat and other books on the legends of the saints, such as \{Harīrī-Zāde\} Kamāl al-Dīn \{Muhammad's\} Tỉbyān-i wasă’il \{al-haqa à iq, Mulhak Fatih Library MSS 430-2\} and \{Ghulām Sarwar Muhammad Lāhawrī’s\} Khaz̄nat al-asfiya a $\{$ Lucknow, 1322/1904-5)\}, it is related that Arslan Bābā carried out this duty of providing guidance \{i.e. religious instruction \} on the order of the Prophet Muhammad (see the bibliography for information on these books). Indeed, it states in \{Ahmad Yasawī's\} Dī̌ān-i Hikmat that Arslan Bābā was Sahâbeler ulusu hâss-ı bende-i Kird-gâr \{the greatest of the Companions and the noblest of God's servants\}, p. 173. This legend circulated for centuries among the Yasawīs. A Yasawī poet named Shams tells this legend in a poem $\{$ manžuma $\}$ that he wrote about Arslan Bābā: "One day the Prophet summoned Arslan Bābā and gave him a date. Then he said, 'After I die a child named Ahmad will come into the world. He will be the quintessence of my religious community. Go see him and give him this date.' With the blessing of the Prophet's prayer, Arslan Bābā lived a long life. He searched continuously for the one whose date he held in safekeeping. Finally, 400 years later, he arrived in Turkistan. As usual, he sent word of his search in all directions. At last, he found him while on his way to school in Yasī. Arslan Bābā greeted the child and after the child returned the greeting he asked, 'Oh Bābā, where is the object you hold in trust?' Not expecting this question, Arslan Bābā was surprised and said, 'Oh saint, how did you know about this?' The child replied, 'God informed me.' Arslan Bābā then asked him his name. 
He said that it was Aḥmad and Arslan Bābā surrendered to him what he had held in trust," Dīwān-i Hikmat, pp. 75-7. It appears from this poem that Arslan Bābā was from Utrar and that Māchīn Bāb $\{\bar{a}\}$ was buried to the right of him and Qārgha Bāb was buried to the left of him \{the former is mentioned below while the latter is not further identified\}. However, we know that Māchīn Bābā was buried in the village of Farkat $\{$ فركت (Hazīnī, Gawähir, p. 77) and that there was a tradition that Arslan Bābā was buried in the tomb \{türbe of Ahmad Yasawi (the article entitled "Khalwa" \{in Russian and not further identified $\}$ in the journal Shürā, \{Orenburg, March 1914\}, p. 146).

5 A Aḥmad Yasawī, \} Dīwān-i Hikmat, p. 7. However, neither \{Safî̀s\} Rashahät nor the other books of legends confirm the story in the Dīwān-i Hikmat that Arslan Bābā died the following year. For information on the descendants of Arslan Bābā, see the details on Manșūr Ata in Chapter 4, p. 89.

6 Khaḍir was the companion of Ahmad Yasawī’s father Shaikh Ibrāhīm and his 10,000 disciples. Shaikh Ibrāhīm married 'Â'isha Khātūn, the daughter of Mūsā Shaikh, one of his leading khaliffas, and Khadir in particular was the cause of this marriage, \{Hazīnī, \} Jawāhir, p. 74.

7 The "Qarachuq" Mountain, which is frequently mentioned in the Oghuz legends, and memory of which has been preserved for centuries, also appears here. This is quite natural because the Syr Darya region, which is where this legend flourished, was the early country of the Oghuz. \{Qarachuq is close to Yasī/Turkistān. This name was applied to the mountains now called Qaratau/Karatau, but is now borne (in the Qazaq form Qarashıq) by a stream west of Turkistān.\} See $E I^{l}$, s.v. "Ghuzz" (W. Barthold) \{now see EI ${ }^{2}$, s.v. "Ghuzz" (Cl. Cahen et al.) and Golden, An Introduction to the History of the Turkic Peoples, pp. 205-11\}.

8 The following tradition about this famous table cloth is widespread among the Bektashīs, who are a branch of the Yasawi tarīqa: "that dome-shaped Bektashī headgear \{qubba$i$ alif-tāj\}, the dervish cloak $\{k h i r q a\}$, lamp, table cloth, standard, and prayer rug that \{the angel\} Gabriel brought to the Prophet, God bless him and grant him salvation, by order of God, praise be to Him; the Prophet gave all these things and the regulations governing them to \{his son-in-law\} 'Alī. 'Alī gave them to \{his son\} Husain. Husain gave all this to \{his son\} Zain al-'̄Abidīn. When Zain al-'Ābidīn was in the prison of Marwān, Abū Muslim \{the leader of the revolutionary 'Abbāsid movement in Khurāsān, cf. EIr, s.v. "Abū Moslem . . K Korāsānì”" (Ḡ. H Yūsofì)\} came and asked permission to emerge and he gave the dome-shaped headgear, cloak, lamp, table cloth, standard, and prayer rug and the regulations governing them to Abu Muslim \{Zain died in 95/714, long before Abū Muslim and the 'Abbāsids overthrew the last Umayyad caliph, Marwān II in 132/750\}. Abū Muslim gave them to Muhammad \{b. 'Alī al-\}Bāqir \{the son of Zain al-'Ābidīn\}. Imām Muhammad Bāqir gave them to his son Imām Ja'far al-Ṣādiq. Imām Ja'far al-Ṣādiq gave them to his son Mūsā Kāzim. Imām Mūsā Kāzim gave them to his son the Sultān \{figuratively, i.e. this is an honorific title\} of Khurāsān 'Alī al-Riḍā. The Sulțān of Khurāsān 'Alī al-Riḍā gave them to Sultān al-'Ārifin \{an honorific title: the sultan of those who have knowledge of God\}, the fountainhead of the merdan \{heroes, the seven spiritual beings held to be the guides and rulers of the faithful\} of the \{ninty-nine\} thousand pirs \{shaikhs, i.e. Șūfì masters, elders \} of Turkistan, Khwäja Aḥmad Yasawī. Ahmad Yasawī, may God have mercy on him, did not give them to any of the 99,000 khaliffas. When they requested these things, he said that their \{rightful\} owner would come - thereby indicating the coming of His Excellency Sulțān \{again, this is a figurative title\} Hājjī Bektash Veli. Finally, His Excellency Sulțān Hājjī Bektash came and he gave him those things," Velāyetnāme-i Häjjizm Sultān, ed. R. Tschudi \{as Das Velayet-name des Hadschim Sultan (Leipzig, 1914)\}, pp. 7-8. This information in Hājjim Sultān's Velāyetnāme was taken from the famous work Velayyetnamme-i Häjji Bektash Veli. This story \{which of course 
connects Ahmad Yasawi with the first eight of the Twelver imāms\} is the same in both the sixth chapter of the versified version of this work and the prose version. The author \{Hazīnī\} of Jawāhir al-abrär also says Hoca Ahmed Yesevînin horkat ve revâcı Resûl-i Ekrem صلي الله عليه و على آله و سلم horka-ı mi râcondan ve hâsiyyet-i mi râc ve hurmâ-i latifflerindendir \{The cloak of Ahmad Yasawi and its being in demand derived from the cloak of the ascent (to heaven) of the most noble Prophet, may God bless him and his family and grant him peace, and from the special nature of the ascent and his gracious date\}, p. 27. \{Köprülü assumes that the tablecloth of Hazīnī's story must be that in the Velayetname. $\}$

9 \{Hazīnī, $\}$ Fawāhir, pp. 67-70.

10 \{Ṣafī's\} Rashahāt, \{Turkish\} trans.; \{Muștafā 'Ālī's\} Kunh al-akhbār \{Istanbul, 18619\}; Bahr al-wilāya \{MS in the Hâlis Efendi Library in the Süleymaniye Library, not further identified\}; Süleymân-ı Köstendili \{not further identified\}; \{Harīrī-Zāde's\}

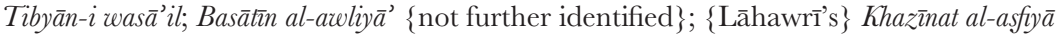
and various other books on the lives of the saints. No reference can be found at all, however, to Arslan Bābā in \{Hazīn̄̄'s\} Fawāhir \{but Hazīn̄̄ does mention him in another of his works, unknown to Köprülü\}. There is also no mention of Yūsuf Hamadānī in Bektashī tradition. In the Fawähir, as in all the biographical dictionaries, it only states that Ahmmad Yasawī was attached to Yūsuf Hamadānī and was one of his four khaliffas, pp. 225-9 \{in the Okuyucu edn, pp. 133-6, 113a.13-14, 113b.4, 8, and 115b.3-6. Surprisingly, Köprülü does not mention the silsila cited by Hazīn̄ in the Fawāhir leading back from Aḥmad Yasawī to the Prophet through Shihāb al-Dīn al-Suhrawardī! Hazīn̄i does give a verse recapitulation of the Yūsuf Hamadānī story, with Ahmad Yasawi as one of four khaliffas (though this appears in the acephalous Persian work bound with the Fawähir, which, as mentioned, Köprülü took together as a single work), and Köprülü cites this (without comment on Hazīn̄̄'s reference to "Abū Yūsuf" instead of "Yūsuf"), but he ignores al-Suhrawardī's lineage altogether\},

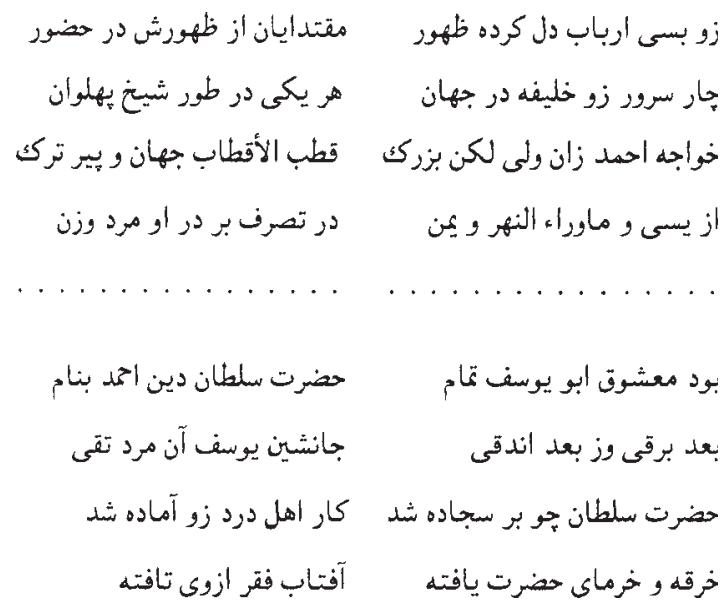

\{From him many spiritual masters appeared.

From his presence, many spiritual guides are present.

From him four leading khalifas are in the world.

Each one of them following the manner of the warrior shaikh. 
But Khwāja Ahmad is the greatest khaliffa from that saint.

Pole of Poles of this world and Pīr (shaikh, spiritual guide) of the Turks.

From Yas̄i and Transoxiana and Yemen

Men and women serve at his gate under his command.

$\cdots$

There was one greatly beloved of Abū Yūsuf,

One named Ahmad, sovereign of the Religion.

Following (Shaikh 'Abd Allāh) Baraq̄i and (Shaikh Hasan) Andaq̄̄

That pious man became Yūsuf's successor.

When that majestic sultan assumed the prayer-rug

He assumed the task of caring for the people of love-pain (i.e. the dervishes).

He received the cloak and the date of his majesty (the prophet Muhammad)

From him shone the sun of poverty (i.e. being a faqī or dervish).\}

11 Dĩwan-i Hikmat, pp. 11-12. \{As noted in the introduction, the quotations from this work in "Westernized" form in Early Mystics are not meant to imply that the Dĩwān-i Hikmat was in Ottoman rather than Chaghatay.

12 \{Hazīn̄i, Fawāhir, p. 72. On the relationship of Ahmad Yasawī to Khadir, see also the pages below. This issue of friendly conversation with Khadir is not confined to Ahmad Yasawī. If we take a look at the Sūfí biographical works, we would find a great many stories about Șûfis who met Khadir. If we look, for example, at the contemporaries of Ahmad, not only did Shaikh Yūsuf Hamadānī continuously meet with Khaḍir (see 'Abd al-Khāliq Ghujduwānī, Maqāmāt-i Yūsuf Hamadāñ̄ \{this work is appended to Harīrī-Zāde's Tibyān-i wasă'il al-haqā'iq, Ibrahim Ağa MS. 432 in the Fatih Library in the Süleymaniye Library in Istanbul; see Chapter 3, p. 75, n.20 for more on this author and his work, but we should note here that the attribution of the Maqāmāt-i Yūsuf Hamadāñ̄ to Ghujduwānī is doubtful\}) but 'Abd al-Khāliq Ghujduwānī also learned the dhikr-i khafiyya from him (\{Ṣafī,\} Rashahăt, \{Turkish\} trans., p. 25). Indeed, he was also the one who taught the dhikr-i arra to Ahmad Yasawi (see Chapter 4, pp. 101-2) \{these are silent and vocal dhikrs\}.

$13\left\{{ }^{\mathrm{A}} \mathrm{l} \overline{1},\right\}$ Kunh al-akhbār, vol. 5, p. 54. This legend was taken completely from the Velāyetnāme-i Häjj̄i Bektash Veli.

14 Velāyetnāme-i Ḧäjji Bektash Veli \{Köprülü used the MS in his private library, for editions see the bibliography; German trans. E. Gross as Das Vilâyet-nâme des Haggi Bektasch (Leipzig, 1927)\}, دربيان اوصاف خوإجه أمد يسوى قدس سره SDescription of Ahmad Yasawī, may (God) hallow his heart\}." "Taking the shape of a bird and flying" is a motif frequently encountered in the legends of Turkish saints, as in this legend of Ahmad Yasawī. One can find many examples in Bektashī legends. F. Grenard reports that such legends are found among the Eastern Turks of Turkistan (Le Turkestan et le Tibet (\{part 2 of J.-L. Dutreuil de Rhins (ed.), Mission scientifique dans la haute asie (Paris, 18978)\}, p. 240). They belong to many saints whose shrines are places of pilgrimage in that region. He states that according to the legend of Imām Ja'far Țayyār \{the flyer\}, whose \{shrine - he has many - and\} place of pilgrimage is in Chīrā in the environs of Khotan, he flew to that place from Mecca. According to Grenard, there is a great similarity between these miracles and the legends of the Buddhist saints described by \{the Chinese Buddhist pilgrim $\}$ Hsüan Tsang $\{f$ l first half of the seventh century\}. In fact, he narrates a Buddhist legend resembling this flying story and also states that some of the tombs of Muslim saints were originally Buddhist convents. While it is true that Buddhism influenced the early beliefs of the Turks in this region, 
it would nevertheless be mistaken to allege that the legends of the Muslim saints derived exclusively from the Buddhists. In any case, these are issues of religious sociology that require \{further\} research.

$15\{$ Hazīnī, \} Jawāhir, pp. 82-4.

16 Velāyetnāme-i Hǟjō Bektash Veli. All Bektashī traditions agree on this point.

$17\{$ Hazīn̄i, J Fawāhir, p. 75. According to this source, there is no reference at all in the other biographical dictionaries to Sūfì Muhammad Dānishmend who was the first khal̄̃fa. \{Hazīn̄i simply names Șūfì Muhammad Dānishmend. He does not say that biographical dictionaries do not mention him. If Köprülü meant to say that he could find no reference to Sūfì Muhammad Dānishmend in such sources available to him, he is closer to the truth. In fact, Sūfì Muhammad Dānishmend was the chief silsila link, as Yasawī's direct disciple, for the lineage that produces the earliest known Yasawī source, which was unknown to Köprülü; the work is the fourteenth-century Turkic work of Ishāa Khwāja b. Ismā'îl Ata, which survives in two redactions, one

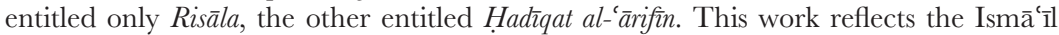
Ata tradition that seems to have been a rival of the Yasawi lineages traced through Hakīm Ata (hence the story from the Hakim Ata kitābl, which Köprülü alludes to by saying that the work shows Ṣufī Muhammad Dānishmend as the "second khalifa," but which actually makes Hakīm Ata the "full" disciple and Șūî̀ Muḥammad Dānishmend a "half" disciple - a story also found in an earlier source, but with the two figures reversed in status). Șūfì Muhammad Dānishmend also appears in some versions of the Rashahät, whose presentation of Ahmad Yasawì's four disciples is in fact more complex than is often recognized and than Köprülü allowed. Șūfì Muhammad Dānishmend also appears in the Lamahăt, but is simply called "Sūfì Dānishmend." Yasawi dervish, reveals his presence in the tradition by mentioning his name in a poem that he wrote about Zangī Bābā, Hak Mustafần nin peyrevî Sultân Hoc(a) Ahmed Yesevî/Sûfì Muhammed Mevlevî Yâ Zengî Bâbâ himmetî \{the true follower of Mustafāa is Sulțān Khwāja Aḥmad Yasawī/Șūfì Muhammad Mawlawī, or the spiritual ambition of Zangī Bābā \}, Dī̌ān-i Hikmat, p. 258. Furthermore, Șūî̀ Muhammad Dānishmend in the \{anonymous\} Hakim Ata kitābr (Kazan, 1901) is shown as the second khalīfa after Hakīm Ata. For some reason, this person whose historical existence was probably genuine did not become sufficiently renowned to enter the Șûfi biographical works. See Chapter 4, pp. 89-92 on Sulaimān Hakīm Ata. We have no other historical or legendary information on Shaikh 'Uthmān Maghribī \{whose name recalls that of a tenth-century Șūî̀ known already from Hujwīrī and later hagiographies, but remains unidentified\} or Imām Marghuḍ̄ \{his nisba is problematical, as noted below in the narrative, and the same figure (i.e. he plays the same role in the story below in the narrative of the erasure of the scholar's books and mind) is called "Imām Marāgh $\bar{\imath}$ " in the Lamahāt. His memory has apparently survived in the local tradition of Turkistān, which calls him "Imam Marghuz" or "Imam Markozi" and identifies him with the Kök Tondï Ata" whose shrine still stands north of Turkistān in the village of Shobanak. On local tradition about him, see R. M. Mustafina, Predstavleniia kul'ty, obriady u kazakhov (V kontekste bytovogo islama v Iuzhnom Kazakhstane v kontse XIX-XX vv.) (Alma-Ata, 1992), pp. 89-90, 111; and Sadïq Sapabekŭli, "Türkǔstandaghï tarikhi ziyarat," in Yäsaui taghilimï, eds Khamid Imanzhanov and R. Zhüzbaeva (Turkistan, 1996), pp. 123-32\} whose legend is mentioned with Amīr 'Alī Hakīm \{whose name recalls the one assigned, in various later traditions, to Yasawî̀'s son-in-law and to a descendant of Yasawī’s brother $\}$ and with Ahmad Yasawī below. As for Hasan Bulghānī, it is likely that the form in which his name is shown is mispelled and is corrupted from Hasan Bulghārī \{more likely Balghān̄̄, perhaps linked to the Balqān mountains in southwestern Turkmenistan\}. This shaikh, who came from the land of the Bulghars \{the Hasan Bulghārī to whom Köprülü refers derived his nisba from a seven-year sojourn 
in Bulghār, but was actually a native of Nakhchivan $\}$ and met Saif al-Dīn Bākharzī and others, was a famous Șūfì of that era, \{Ṣafī, $\}$ Rashahăt, \{Turkish\} trans., p. 38. See the information given a little further below on Saif al-Dīn Bākharzī.

$18\{$ Hazīn̄i, \} Fawāhir, pp. 75-7; \{Ahmad Yasawī, $\}$ Dĩwān-i Hikmat, 3rd Kazan edn \{1311/ $1893-4\}, 47$ th hikmat. With the exception of this very valuable work $\{$ Fawähir $\}$, which was based on Yasawī tradition, the khalîfas of Ahmad Yasawī are presented in a different manner in the other books on the legends of saints. See Chapter 4, pp. 8994 for critical information on this matter. Suffice it to say here that Bābā Māchīn is not mentioned in them \{but he is found in Central Asian Yasawi sources unknown to Köprülü, especially the Lamahāt $\}$. Nevertheless, the tradition is clear in this respect. In fact, Sulaimān Ata confirms this by saying Baba Maçin ol Sultân / Mürîd boldi bî-gümân \{Bābā Māchīn, that sultan / became his disciple without doubt\}, Dī̌ān-i Hikmat, p. 271. The 47th hikmat in the 3rd Kazan edn of the Dĩwan-i Hikmat relates this legend in exactly the same way. After Bābā Māchīn died, he was buried in the town of Farkat. During a battle with the unbelievers, his foot sank into a stone and left a print that could be seen in the tenth/sixteenth century. Pilgrims visited it and made various requests that were granted, Jawähir, p. 77.

19 \{Hazīn̄, \} Fawähir, pp. 78-81. Among them only the name and biography of Saif al-Dīn Bākharzī have been confirmed in the books of legends. This Ș̣̂fî̀, who wrote some noteworthy Persian quatrains, was a khalīfa of the famous shaikh Najm al-Dīn Kubrā. The shaikh, after himself extracting him from the khalwa during the second forty \{days\}, sent him to Bukhārā. Saif al-Dīn lived there a long time after the shaikh's martyrdom and died in 659/1261. His tomb is in Bukhārā (\{Amīn \} Ahmmad Rāzī, Haft iqlīm \{Köprülü used the MS in the Hâlis Efendi Library in the Süleymaniye Library in Istanbul; ed. Javād Fāḍil (Tehran, 1960)\} and \{Jāmī, Nafahăt, \{Turkish\} trans., pp. 487-8). Bākharz is a region between Nīshāpūr and Herat that had 168 towns (\{Yāqūt,\} Mújam al-buldān, \{ed. F. Wüstenfeld (Leipzig, 1866-73)\}, vol. 2, p. 28; Barbier de Meynard, Dictionnaire géographique, historique et littéraire de la Perse et des contrées adjacentes \{Paris, 1861\}, p. 74). As for the others: Shaikh Sa'd al-Dīn could be Sa'd al-Dīn Hammūyī, one of the khalîfas of Najm al-Dīn Kubrā; Shaikh Kamāl Shaibānī could be the famous Kamāl Khujandī \{no, Kamāl Khujandī was a fourteenthcentury poet; Köprülü may mean Kamāl Jandī, a disciple of Najm al-Dīn Kubrā, but the person in question was more likely Kamāl al-Dīn Husain b. Muzaffar al-Shaibān̄̄ al-Baladī, a disciple of Jandī; see DeWeese, "Bābā Kamāl Jandī and the Kubravī Tradition among the Turks of Central Asia," Der Islam, 71 (1994), 58-94\}; and Shaikh Muhammad Baghdādī could be Shaikh Majd al-Dīn Baghdādī, but these identifications are very unlikely. There is absolutely no record of any of these legends in the biographical dictionaries, and also no account of Saif al-Dīn Bākharzī's relationship with Ahmad Yasawī. In the Nafahät, \{Turkish\} trans., p. 173, it is only mentioned that Shaikh 'Alī Lālā, a khalîfa of Najm al-Dīn Kubrā, was attached to Ahmmad Yasawī before joining him. See Chapter 3, p. 62 on this question. Some fifty Persian quatrains of Shaikh Saif al-Dīn Bākharzī were published in \{S. Khuda Bakhsh, "Saifuddīn Bākharzī,"\} ZDMG, 59 (1905), 345-54. On his tekke in Bukhārā, see Ibn Bațtūța, Seyāhatnāme \{i.e. his al-Rihla, Turkish trans., Şerîf Pasha, (Istanbul, 1333-5/ 1914-17)\}, vol. 1, p. 416, \{English trans., H. A. R. Gibb as The Travels of Ibn Battunta (Cambridge, 1956-72), vol. 3, p. 554. And see $E I^{2}$, s.v. "Sayf al-Dīn Bākhharzī” (Hamid Algar). $\}$

$20\{$ Hazīnī, $\}$ Fawāhir, pp. 88-90.

21 Ibid., p. 90.

22 See the article "Khalwa" in the journal Shürā, March 1914; \{see $E I^{2}$, s.v. "Khalwa" (H. Landolt).\} In the Dīwān-i Hikmat, p. 81, he also says, Yüzyigirmi brşka \{as in 1st edn, more correctly beşkä $\}$ kirdim bilalmadrm/Erenler'din feyz-u fituh alalmadım \{I became 
125 years old and learned nothing/I did not acquire from the saints enlightenment and conquest\}. \{See DeWeese, 'Sacred Places and 'Public' Narratives: The Shrine of Ahmad Yasavī in Hagiographical Traditions of the Yasavī Sufi Order, 16th17th Centuries," Muslim World, 90 (2000), 353-76.\}

$23\{$ Hazīnī, \} Fawähir, pp. 91-4. One frequently encounters allusions to this "اخم عشَق in Aḥmad Yasawī's poetry, Dīwān-i Hikmat, Kazan edn, p. 262. \{See DeWeese, "Sacred Places." $\}$

$24\{$ Hazīnī, \} Jawāhir, pp. 98-100.

25 There is no reference at all to this small town in \{Yāqūt's\} Mújam al-buldān, but the legend given above indicates that it was around Yasī. The poet Muhammad Șālih indicates in his Shaibāñ̄namme that Yasī and Savrān were two towns close to each other. This conforms to the account in the legend given above (Shaibāninnamme, \{German trans. and \} ed. Arminius Vambéry \{as Die Sheïbaniade (Vienna, 1885)\}, p. 444 nnew ed. E. Shādīev (Tashkent, 1989)\}). Indeed, according to the information given by É. Reclus, Savān or Sāvrān is a town west of Yasī, currently in a desolate and ruined state. Reclus writes that it possessed two graceful minarets, known to be ancient monuments, and that one had collapsed and the other was on the verge of collapse (Reclus [ed.], Nouvelle géographie universelle \{Paris, 1881-94\}, vol. 6, p. 554). The American traveler Schuyler, who visited these places during the Russian occupation, gives quite a lot of information on this town because he passed through it on the way to Yasī. According to this account, the remains of rather large buildings and some ruins of a fortress were found there. The local people had fled to the east in the years corresponding to the Russian invasion. The same traveler writes that a very tall mosque built of brick had previously been there, but it had collapsed and the two remaining minarets had been destroyed by the Russians, so he could see nothing but their bases (Schuyler, Turkistan, \{Turkish\} trans., p. 90). K. Ujfalvy, who also saw Savrān, reports that this town had a fortress with thicker walls than had the other nearby towns and that a great many ancient monuments were excavated from there (Ujfalvy, Le Syr-Daria ... \{Paris, 1879\}, p. 47).

$26\{$ Hazin̄ī, Fawāhir, pp. 101-2. The author also records a custom that survived as a memento of this legend, Muhlislerden herkim rûh-i şerifflerinden istihâre için bir siğır cum'a gecesi def'-i beliyyât ve ref'-i âfât ve kazâ-y hâcât için kurbân eylese ve ervâh-ı tayyibe için helva ve zâkirler için gül-suyu ve buhûr ve balmûmu yaksa ve bu silsile-i Yesevîye ehl-i irşâdona ihyâ-i leyl istid'â eylese murâd hâssl ve duâ ve münâcât müstecâb olur \{Any sincere individual who sacrifices a cow on Friday eve (Thursday night) to obtain a dream-omen from the noble spirit (of the Prophet?) in order to repel calamities and remove disasters and attain wishes, and who makes sweetmeats for the good spirits (of the saints?) and makes rose-water and burns incense and candles for the performers of the dhikr, and who seeks a benediction by nightime prayer on behalf of the spiritual guides of the Yasawiyya order, his wish will be granted and his benediction granted and his prayers answered\}, p. 102. In the Velāyetnāme of Hājjī Bektash, we come across this legend in slightly different form: "There was a meeting of those who were envious of his esteem and fame among the people and wanted to harm the khwajja in some manner or other. They butchered the ox of one of them and left only the feet of the animal in the slaughter house. They took the skinned ox directly to the khwäja's kitchen and hung it there. The next day, these hypocrites went to the judge $\{$ hăkim $\}$ and complained. They searched every house for the ox. Finally, they produced evidence of a trail of ox blood and demanded to see the shaikh's kitchen. This unexpected accusation threw everyone into a state of bewilderment. Khwāja Ahmad, who knew of this issue in advance because of his mystical power, gave them permission to enter. They entered the kitchen and found the ox. So they got their wish, but the shaikh suddenly performed a miracle: his accusers suddenly took the form of dogs and they devoured the flesh of 
the ox" (from the versified version of the Velāyetnāme \{see Bedri Noyan (ed.), Firdevsi-i Rûmi, Manzûm Hacı Bektâş Veli Vilâyetnâmesi (Aydın, 1986), pp. 113-14\}). \{On Ahmad Yasawī's troubles with the people of Șūrī, see DeWeese, "Aḥmad Yasawī and the Dog-Men: Narratives of Hero and Saint at the Frontier of Orality and Textuality," forthcoming in the proceedings of the conference on "Theoretical Approaches to the Transmission and Edition of Oriental Manuscripts" (Orient-Institut der Deutschen Morgenländischen Gesellschaft, Istanbul).\}

27 The khwäja's purpose in this was to follow the model of the Prophet $\{$ sunnat-i nabawiyya\}, because the male children of Muhammad also did not survive childhood.

28 Fawāhir, pp. 103-5. I was not able to find such a story in 'Aț̣ār's Mantiq al-tair. \{Köprülü found it later. See his "Ahmed Yesevî," İA, vol. 1, p. 210.\} The death of this Șūfì poet, who says with the verses
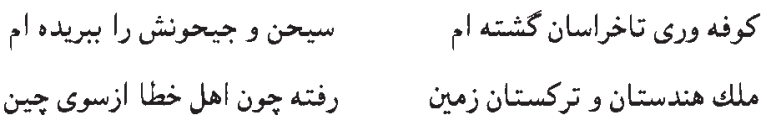

\{I have traveled to Kūfa and Rayy and as far as Khurāsān.

I have crossed over the Syr Darya and the Amu Darya.

I have gone to the realms of India and Turkistan.

By way of China, like the people of Cathay\}

that he also visited Turkistan among a great many other places in the world, and who was accused of Shīi heresy at one time in Samarqand, was probably after 618/12212 (it cannot be determined for certain), i.e. 619-33/1222-34 according to various accounts. The miracle of someone whose name 'Atțār did not even mention in his Tadhkirat al-awliy $\vec{a}$ ' (he had not yet gained, of course, great fame) would naturally not be mentioned in the Mantiq al-tair (in Nicholson [ed.], Tadhkirat al-awliy $\vec{a}$, see the introduction written by Muhammad b. 'Abd al-Wahhāb Qazwīnī. \{See $E I^{2}$, s.v. " "Aț̣āro" (H. Ritter); English trans. of the Mantiq al-tair by Afkham Darbandi and Dick Davis as The Conference of the Birds (London: Penguin, 1984), p. 129.\}

29 \{Husām al-Dīn Muslim̄i, \} Risāla-i tawā̄īkh-i bulghāriyya \{Kazan, 1902\}, p. 26. On this treatise, see the bibliography \{and n.39 below $\}$.

30 "When I went to the capital of Rūm \{Anatolia\}, I sought a good omen from the maqāmāt of His Excellency Shaikh Yasawī. I found the following good tidings: whenever you encounter difficulties, recite this quatrain:

Yeldâ giceni șem ${ }^{-}-i$ șebistân itkân

Bir lâhzada'alemni gülistân itkân

Bes müşkil işim tüşübdür âsân itkân

Ey barçanı müşkilini âsân itkân

\{You who make the night of the winter solstice a candle for the bedchamber

You who in a single glance make the world a rose garden

Then, when I have a difficult task, make it easy

You who make every difficult thing easy.\}

I memorized this quatrain. When I confronted the army of the emperor of Rūm \{i.e. Bayezid I\}, I recited it 70 times and victory was achieved," Vâki'ât-i Tîmûr, Turkish trans. by Qāọī Makhdūm Nabī Jān Khāṭif Khujandī (Tashkent, 1308/1890-1) \{also 
known as the Malfüzăt of Tīmūr, this work is a seventeenth-century compilation from Moghul India\}.

31 \{Ṣafī,\} Rashahāt, \{Turkish\} trans., p. 232. \{In the Persian original Khwāja Ahrāar does not laugh. The text reads fätiha yaki mībasshad = the Fätiha is given once, i.e. he had already done it. $\}$

32 \{By calling Hazīn̄̄s master "Sayyid Manșūr Ata,” Köprülü is conflating two separate figures, namely the "Sayyid Manșūr" known from Hazīnì's works as his own master, and the "Manșūr Ata" known from Șafì's Rashahāt as a son of Arslan Bābā and as the first of (a contrived) four khal̄ffas of Ahmad Yasawī (aside from sources clearly dependent on Șafī's account, Manșūr Ata appears only in Nithārī's Mudhakkir-i ahbāab, and there only as a son of Arslan Bābā, and hence as Nithārî̀s own ancestor).\}

$33\{$ Hazīn̄̄, Jawāhir, pp. 308-14. After Humāyūn Shāh lost his dominion and took refuge with the Safavids, he captured Kabul from his brother Kāmrān Mīrzā with their help in 952/1448-9 and from there he set out to capture India in 961/1553-4 (Mullā 'Abd al-Hamīd Lāhawrī, Pādishāhnāme \{Calcutta, 1866-72\}, vol. 1, pp. 64-5). As for the death of Hindāl Mīrzā, it occurred in 958/1551 (Badā'ūn̄̄, Muntakhab al-tawārīkh \{Calcutta, 1868 \}, vol. 1, p. 454 \{partial English trans. of the 1925 Calcutta edn, George Ranking et al. (Karachi, 1976-8)\}). Consequently, Sayyid Manșūr must have met Hindāl Mīrzā and Humāyūn Shāh in Kabul between the years 952/1545 and 958/1551. The information given in the Fawähir on the life of Sayyid Manșūr in fact supports this.

34 Jawāhir, pp. 97-8.

35 Schuyler, Turkistan, Turkish trans., p. 97. \{In the original English version, 6th edn, vol. 1, p. 72, "It is probable that this ancient monument would have been entirely ruined had it not been that the Sheikh-ul-Islam mounted the minaret and showed the white flag, which was the precursor of the surrender." Köprülü misinterprets the Sheikh-ul-Islam to mean Ahmad Yasawī, but he was simply an official in the town. Thus this comment has nothing to do with Ahmad Yasawi. \}

$36 \mathrm{Ibid}$. \{In the English version, vol. 1, p. 72, "This mosque is considered the holiest in all Central Asia, and had very great religious importance, as previous to the capture of the city by the Russians pilgrims of all ranks, even khans and amirs, assembled there from all quarters."

37 See $E I^{I}$, s.v. "Aḥmed Yesewī" (Melioransky), p. 209. See the Edigü legend collected by Radloff from the Baraba, Tobolsk, and Tümen Tatars (W. Radloff, Proben der Volkslitteratur der türkischen Stämme Süd-Siberiens \{St Petersburg, 1866-70; reprinted Leipzig, 1965\}, vol. 4 of the \{German\} translation, pp. 35, 134, 241). \{The "Noghay legend" makes Edigü a descendant of Aḥmad Yasawī only if we assume that Edigü's ancestor Bābā Tükles, whom Köprülü does not mention, is to be identified with Ahmad Yasawī. On the Edigü legends, see DeWeese, Islamization and Native Religion in the Golden Horde: Baba Tükles and Conversion to Islam in Historical and Epic Tradition (University Park, PA, 1994); and Andrea Schmitz, Die Erzählung von Edige: Gehalt, Genese und Wirkung einer heroischen Tradition (Wiesbaden, 1996).\}

38 See Grenard, "La Légende de Satok Boghra Khân et l'histoire," 7A, 9th ser., 15 $\{1900\}$, p. 14, who cites Robert Barkley Shaw, A Sketch of the Turki Language as Spoken in Eastern Túrkistán \{Káshghar and Tarkand, Together with a Collection of Extracts (Lahore, 1875)\}. This legend is very famous among the people of East Turkistan.

39 The Tawärikh-i bulghäriyya is a controversial work whose sixteenth-century dating, accepted by Köprülü, is obviously erroneous; the work was clearly compiled in the very late eighteenth century or the early ninteenth century. See Allen J. Frank, Islamic Historiography and "Bulghar" Identity among the Tatars and Bashkirs of Russia (Leiden, 1998); Michael Kemper, Sufis und Gelehrte in Tatarien und Baschkirien, 1789-1889: Der islamische Diskurs unter russischer Herrschaft (Berlin, 1998); and M. A. Usmanov, Tatarskie istoricheskie istochniki XVII-XVIII vv. (Kazan, 1972). The work's references to supposed followers of 
Ahmmad Yasawī are also anachronistic and are discussed in Frank's book and his "Islamic Shrine Catalogues and Communal Geography in the Volga-Ural Region: 1788-1917," Journal of Islamic Studies, 7 (1996), 265-86.\}

40 \{The "Hidāyat Allāh" mentioned here is an echo of the famous seventeenth-century Naqshbandī shaikh of Yarkand, Khwāja Hidāyat Allāh Āfāq. See Frank, Islamic Historiography and "Islamic Shrine Catalogues." The name Kalāl also appears as Kalān̄̄, which has been interpreted as "Kulāl" in some texts.

41 Risāla-i tawārn̄kh-i bulghāriyya, pp. 22-4. This work, which has long been widely read among the Northern Turks, is not of great historical value. \{See n.39 above.\}

42 One day Ahmmad Yasawī visited a village in Turkistan on the border of Khițāy. He was exhausted because of the freezing weather and of the long distance that he had traveled by donkey. As it happened, just at that time the wife of the farmer in whose home he was staying as a guest was about to give birth. For this reason, the farmer asked Ahmad Yasawi to pray for her. The khwajja wrote a prayer and they attached it to the woman's waist and there immediately occurred what he had wished. The farmer was very happy because his wife had given birth \{without difficulty\} and he prepared some tea. The khwäja perspired from drinking the very hot tea and it made his fatigue disappear. He then prayed, saying "This had a healing quality. Have your ill ones drink this that they may be cured. May God make this available until the Day of Judgment!" Then, according to tradition, tea has continued to be used among the Turks from that time and it has been a curative to everyone ('Abd al-Qayyūm Nāṣirī, Fawāgih al-julasā' [Kazan, 1884], p. 658). After this, 'Abd al-Qayyūm Nāṣirī says, "The village of Yasa is east of Kāshghar; Khwāja Aḥmad died in the year 369 of the Hijra." He goes on to give other historical and geographical information - all of which is, needless to say, totally without value. \{The tea story appears in N. Katanov, "Materialy k izucheniiu kazansko-tatarskago narechiia," Uchenye zapiski Kazanskago Universiteta, 7-8 (1898), pp. 36-7 (trans.), 80-1 (text).\}

43 Togan, Türk-Tatar tarihi, p. 62. The Sharä'it al-īmān (Kazan, 1901), which is very widespread among the Northern Turks, is a work that explains in simple terms the Arabic alphabet, the ritual prayers, and the stipulations of Islam. At the end, after the topic of madhhab \{"law school"\}, the following catechism is found: "To whose silsila \{chain of authority\} do you belong?" "I am from the silsila of Khwāja Ahmad Yasawī." "How many silsilas are there?" "Four." "What are they?" "First, that of Khwāja Aḥmad Yasawī; second, of 'Abd al-Khāliq Ghujduwānī; third, of Shaikh Najm al-Dīn Kubrā; fourth, of Abū 'l-Hasan 'Ishq," p. 20. In Shams al-Dīn Muhammad b. Nūr Muhammad al-Ṭāhirî̀s short work Köylü imân (Kazan, 1903), which is also of this type and was written in verse especially for a popular audience, the following simple lines of poetry are found that also reveal the fame of Ahmad Yasawi among the Northern Turks, p. 12:

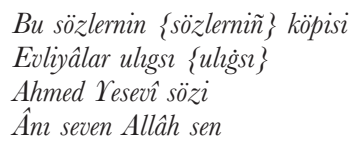

\{All of these words are the words of Ahmad Yasawī, greatest of The Saints, whom God Loves.

44 \{See Müjgân Cunbur, "Evliyâ Çelebi Seyâhatnâmesi'nde Ahmed Yesevî," Erdem, vol. 7, no. 21 (1995), 887-917.\}

45 Evliyā Chelebi, Seyāhatnāme, Book 2, fo. 312a.

46 Horâsân'dan Türk-i Türkân Hoca Ahmed Yesevî izniyle Rûm'a gelüp şehr-i Merzifon'un cânib-i şimâlîsi hâricinde şehre nâzur bir mürtefi zemînde sâkin olup kâhî̀e hamâmlarda yatup, meczûb-i 
Hudâ bir ârif-i billâh kimesne idi kim Orhân Gâzî asrndan tâ Ebü'l-feth'e ermiş bir zât-i şerîf idi. Bâlâda menâkıbı vardır. Hâlâ âsitânesi Osmâncık'da Koyun Baba tekyesinden ziyâde binâ-yı azîm kıbâb-ı âlîler ile ârâste ve müte'addid meydânlar ve matbah u kilar ve dervîşân hücretleriyle pîrâste olmuş her şeb iki yüz ve üç yüz âdem konup göçer mihmân-sarây-ı Bektâşiyân'der iki yüzden mütecâviz

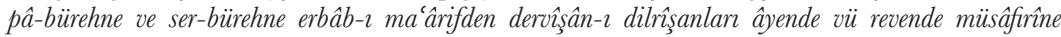
hizmet ederler. \{With the permission of Türk-i Türkān Khwāja Ahmad Yasawī, he came from Khurāsān to Rūm and settled north of Merzifon on a high spot overlooking the city. Sometimes he would pass the night in the baths. He was someone who had true knowledge of God and was ecstatic with divine love. He lived from the time of Orhan Ghāzī until that of Sultan Mehmed II. There are thousands of legends about this $p \bar{r} r$, aside from those given above. His dervish convent is a large building even larger than that of Koyun Bābā in Osmancık - outfitted with lofty domes and numerous squares, kitchens, pantries, and dervish cells. Every night 200 or 300 men are put up there, and over 200 barefooted and bareheaded wandering dervishes are served as guests.\} Ibid., Book 2, fo. 347b. \{On Pīr Dede, see Suraiya Faroqhi, "The Life Story of an Urban Saint in the Ottoman Empire," Tarih Dergisi, 32 (1979), 655-78, 1009-18.\}

47 Belh u Buhârâ ve Horâsân' da cedd-i izâmmmz Türk-i Türkân Hoca Ahmed Yesevî halîfelerindendir. Hattâ Hacı Bektaş-ı Velî Horâsân'dan Rûm'a teveccüh etdiklerinde yetmiş aded kibâr-ı kümmelîn

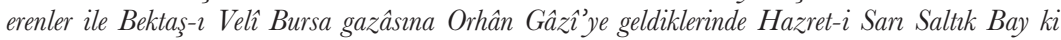
ism-i serî́fi Muhammed Buhârî̀dir anlar ve Keligra Sultân ve bu Akyazıl Sultân Bursa'ya bile gelüp ba'de'l-feth mezkûr erenler Rûm diyârnda Bektaş-ı Velî izniyle post sâhibi olurlar. \{He was one of the khalīfas of our illustrious ancestor Türk-i Türkān Khwāja Ahmad Yasawī in Balkh, Bukhārā, and Khurāsān. In fact, when Hājjī Bektash came from Khurāsān to Rūm and joined Orhan Ghāzī in his campaign against Bursa with seventy great saints, Sarı Saltuk Bay - whose name was Mụhammad Bukhārī - and Keligra Sultān and this Akyazılı Sulțān came to Bursa together and after the conquest became shaikhs in Rūm with Hājjīi Bektash's permission \}. Ibid., Book 3, fo. 122b. In the pages following this, there is important information on the legends of Akyazılı and details about the tekke. According to Bektashī tradition, Akyazılı was a Bektashī. Indeed, among the Bektashīs there is also a biography of Akyazılı, as there is of Q1zıl-Deli Sultān (copy in my private library). In another Bektashī treatise, we find two separate biographies and a gülbang \{collective prayer of the Bektashīs\} attributed to Akyazilı (copy in the library of the late Hâşim Pasha).

48 Anın tâ zirve-i a'lâsında Ziyâret-i Hazret-i Kademli Baba Sultân: Hacı Bektaș-ı Velì hizmetiyle tâ Horâsân'dan bile Rûm'a gelmiş Fağfûr diyârn hâkinde Kozak kavmi memlûklarndan bir çâker-i

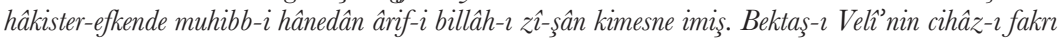

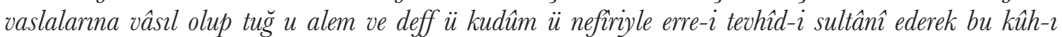
bülendi cây-ı me'men edinüp ber-seccâde olup yedi sene niçe bin cânlar andan mèzûn olup âhir dâr-ı âhirete min mahabbetillâh yönelüp bu mürtefic cihânnümâ püste üzre fukarâlarn cesed-i azizzi defn ederler. \{At the very summit of this place (Adatepe) is the shrine of Kademli Bābā Sultān. He came in the service of Hājjī Bektash together with him all the way from Khurāsān to Rūm. He was a humble servant among the slaves of the Kozak people in the land of China, a lover of the family of the Prophet, one who had true knowledge of God. Accepting the trappings of poverty from Hājjī Bektash - horsetail and standard, tambourine and drum and trumpet - and performing the royal saw-like tawhìd (i.e. dhikr) he took refuge on this high mountain and assumed the prayer-rug. In seven years thousands of people received orders from him. Finally, out of love for God, he departed for the afterworld and his dervishes buried his blessed body on this lofty summit.\} Ibid., Book 3, fo. 132a.

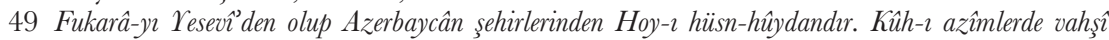
sığgnlara süvâr olup Orhân Gâż̂̀ ile sefer eşüp at tavlası gibi bir tavla siğınlan var idi, bârhânesin 
bile vahşı̂ gazâllara yükledirdi. \{He was a Yasawī dervish from the city of Khūy of fine

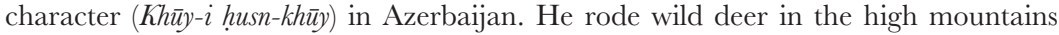
and went on campaign with Orhan Ghāzī. He had a stable for deer like a horse stable, and he even had his baggage loaded on wild gazelles.\} Ibid., Book 2, fo. 237b. Nevertheless, Bursalı \{̇́smail\} Belig considers him to be a mur̄̄d of Bābā Ilyās and from the tarīqa of Shaikh Abū '1-Wafā' Baghdādī (Güldeste-i riyâzı irfân \{Bursa, $1302 / 1884\}$, p. 220). Indeed, the information provided by \{Tashköprü-Zāde in his\} al-Shaqā'iq \{al-nu'māniyya, on the margins of Ibn Khallikān's Wafayāt al-a'yān (Būlāq, 1300/1882), new ed. Ahmet Furat (Istanbul, 1985)\} shows that Geyikli Bābā was from Khūy \{in Azerbaijan\} and was a mur̄e of Bābā Ilyās, al-Shaqā'iq, \{Turkish\} trans. \{Mecdî (Istanbul, 1269/1852-3)\}, pp. 31-3. The information in $\left\{S^{\prime}{ }^{\prime} d\right.$ al-Dīn's $\}$ Täj al-tawārīkh \{Istanbul, 1280/1863-4\}, vol. 2, p. 406, and in \{Joseph von\} Hammer \{-Purgstall, Geschichte des osmanischen Reichs (Budapest, 1827-35), Turkish trans. Mehmet Ata as Devlet-i osmaniyye tarihi (Istanbul, 1329-37/1911-19)\}, vol. 1, p. 160, who cites all of it, corroborates al-Shaq à iq. This Geyikli Bābā is somewhat reminiscent of the famous Zāhid-i Āhū-Pūsh \{i.e. the hermit clad in deerskin\} (Juvain̄̄, \{Ta'rīkh-i\} Jahān-Gushā, \{ed. Mīrzā Muhammad Qazvīnī (London, 1912-37)\}, vol. 2, p. 10) \{English trans. J. A. Boyle as The History of the World Conqueror (Manchester, 1958), vol. 1, pp. 283-4\}. \{See M. Köhbach, "Vom Asketen zum Glaubenskampfer; Geyiklü Baba. Ein Beitrag zur osmanischen Hagiographie," Joumal of Ottoman Studies, 3 (1982), 45-52.\}

50 Bu dahi Hoca Ahmed-i Yesevî fukarâsı idi. Horâsân'dan Hacı Bektaş ile Rûm'a geldi. Niçe yüz keșf u kerâmetleri zâhir olmuşdu. \{He was also a Yasawī dervish. He came from Khurāsān to Rūm with Hājjī Bektash and performed numerous miracles.\} Evliyā Chelebi, \{Seyāhatnāme,\} Book 2, fo. 237b. Abdāl Bābā $\{$ Mūsā $\}$ was also a contemporary of Geyikli Bābā, \{Tashköprü-Zāde, $\}$ al-Shaqāiq, \{Turkish\} trans., p. 33. The information in al-Shaq $\bar{a}^{\prime} i q$ is the same as that in \{Sa'd al-Dīn's\} Täj al-tawārikh, vol. 2, p. 407, and the $\{$ Turkish $\}$ trans. of Hammer, $\{$ Devlet-i osmaniyye tarihi $\}$, vol. 1, p. 161. Ayakch1 Shāh Abdāl Mūsā Sulțān was the eleventh of the twelve posts \{spiritual successors\} in Bektashī tradition (\{anonymous,\} Risāla-i bektāshiyya, MS copy in my private library). Under his influence, Bektashī poets also wrote nefeses \{folk religious poetry\} about Abdāl Mūsā. Husain̄̄'s nefes, which begins with the line Abdal Mûsa Sultan gazaba geldi \{Abdāl Mūsā Sulțān became angry\}, is famous (the collection of Bektashī poetry in my private library). The legends of Qayghusuz Sultān recount in detail how Qayghusuz, whom the Bektashīs considered one of their own, went to the dervish convent of Abdāl Mūsā and, thanks to that, obtained guidance (Manāqib-i Qayghusuz Abdāl [Sulțān], MS copy in my private library). I can state that this story by no means conforms to historical reality, as is the case with other Bektashī traditions. In order to understand why Abdāl Mūsā was considered to be connected with Hājjīi Bektash, see 'Āshıq Pasha-Zāde, Tawān̄ikh-i āl-i'uthmān, \{ed. 'Ālī Bey, (Istanbul, 1332/1914)\}, p. 205 \{new ed. H. Nıhal Atsız as Tevarih-i âl-i Osman, Aşıkpaşaoğlu tarihi (Ankara, 1985)\}. [For additional information on Abdāl Mūsā, see Türk halk edebiyatr ansiklopedisi, s.v. "Abdal Mûsâ" (M. F. Köprülü). The article on Abdāl Mūsā in this encyclopedia, only the first fascicle of which appeared, was left unfinished. The remainder of the article was published by Orhan Köprülü based on his father's draft. See Köprülü'den seçmeler (Istanbul, 1972), ed. Orhan Köprülü. This article, with notes and bibliography, was also included in a second edition by Orhan Köprülü as M. F. Köprülü, "Abdal Mûsâ,” Türk Kültürü, 11 (1973), 198-207.] \{Now see also Abdurrahman Güzel (ed.), Abdal Mûsâ velâyetnâmesi (Ankara, 1999).\}

51 Horosî Dede, ceddimiz Türk-i Türkân Hoca Ahmed Tesevî hazretlerinnin fukarâlarnndan olup Hacı Bektaş Velî ile Horâsândan gelüp bir pî̀-i fânî olup Ebü'l-feth ile Islambol'a gelirken asâkir-i Islâm içre şeb ü rûz yigirmi dörd sấatde yigirmi dörd kerre bâng-i horos urup Kum yâ gâfiliun deyü 
guzât-i müslimîni âgâh etdiüryçün Horos Dede derlermiş. \{Horos Dede was one of the dervishes of our ancestor Türk-i Türkān Khwāja Aḥmad Yasawī. He came from Khurāsān with Hâjjji Bektash Veli and became a saintly old man. While coming to (conquer) Istanbul with Mehmed II, he used to crow like a rooster every hour for twentyfour hours day and night, keeping the soldiers alert, and say "Get up, oh neglectful ones!" So he was called Horos Dede ("Grandfather Rooster").\} Seyāhatnāme, Book. 1, fo. $26 \mathrm{~b}$.

52 Kunh al-akhbār, vol. 5, pp. 58-61. 'Âli attributes the coming of the ers \{saints\} of Khurāsān to Rūm on spiritual advice $\left\{m a^{i}\right.$ nevî işâretlerle $\}$ to the fact that the domain of Rūm was the place of manifestation of God \{nazar-gâh-ı Hudâ\}. As for Amīr Chīn Osman, he came into the world in extraordinary fashion, as in the legends of a great many other saints. \{Later, $\}$ according to their vows, his parents dedicated him to the service of Ahmad Yasawī. He performed miracles like finding fresh grapes in the middle of winter and taking them to his shaikh. At last, some merchants from China came to the shaikh and pleaded for his help to get rid of a dragon that had appeared in their country. The shaikh girded the waist of Osman, who was still a child, with a wooden sword and sent him off. He went \{to China\} and killed the dragon. Subsequently, Osman was given the byname Amīr Chīn \{Commander of China\} and he was sent to Rūm by his shaikh. There he guided a great many people to Islam. While serving the warden \{muhäfiz\} of the sancak of Bozok in 1005/1596-7, 'Āli heard and recorded this legend (which closely resembles Bektashī legends but is not found in the velāyetnāmes) from the shaikh of the tekke of Osman Bābā, 'Umdat al-Māchīn. Evliyā Chelebi, \{Seyāhatnāme,\} Book 3, fo. 90b, says that he was buried in the town of Husain-ova, which was part of the sancak of Bozok, and also mentions that he received the byname Amīr-i Chīn because he killed a dragon in China with a wooden sword. He states too that he was the seventh khalifa of Ahmad Yasawī. \{Ocak tries to identify him further, "Un cheik Yesevī et Babaī dans la première moitié du XIII' siècle en Anatolie: Emīrci Sulțān (Şerefu'd-Dīn İsmā̄îl b. Muhammed)," Turcica, 12 (1980), 114-24, and also his "Emirci Sultan ve Zaviyesi: XIII. yüzyllın ilk yarısında Anadolu (Bozok)'da bir Babâî şeyhi: Şeref'ud-Din İsmail b. Muhammed," Tarih Enstitüsü Dergisi, 9 (1978), 129-208.\}

53 According to the information provided by 'Āshıq Pasha-Zāde, one of the earliest Ottoman historians, Hājjjī Bektash went from Khurāsān to Sivas with his brother Mentesh, then from there to Bābā Ilyās, from there to Kırşehir, and from there to Kayseri. When Mentesh \{later\} went from Kayseri to Sivas, he was martyred there. Hājjj̄ Bektash went from Kayseri to Kara-öyük where he married Khātūn-ana and \{later\} died. This historian, who states rather clearly that he knew, in particular, the entire life of Häjjī Bektash and his brother, says Kendi bir meczûb-ı budala azîzdi; seyhlikten ve müridlikten fârigdi \{he was a saint ecstatic with divine love and had no interest in being a shaikh or having disciples\}. He rejects categorically the reports that had no historical basis, such as the one that Hājjī Bektash met Orhan and that he prayed for the janissary corps. The numerous notes that 'Âli Bey added to this subject in his annotations to 'Āshıq Pasha-Zāde's Tawārn̄kh - for example, that Hājjī Bektash went to Rūm in 680/1281-2, that he lived for ninety-two years, that he died in 738/13378, that Khātūn-ana was engaged to Khwāja Idrīs who was a member of the 'ulama', that during his life Hājjī Bektash gave the position of shaikh in the convent built by Sultan Orhan to the children of Khwāja Idrīs, that his father's name was Sayyid Muhammad Ibrāhīm-i Thānī and his mother's name was Khatme Khātūn, and that he was born in Nīshāpūr in 646/1248-9 - are all based on Bektashī traditions. Unfortunately, they have no historical value. To compare legendary stories like these, drawn from the velāyetnāmes, with the clear and precise statements in 'Āshiq PashaZāde's history (pp. 204-6) can never be considered correct behavior for a historian. 
Indeed, 'Āshıq Pasha-Zāde's remarks on Ḥājjī Bektash can be easily corroborated by other evidence. Prof. Jacob has also reached virtually the same conclusion in his research on Hājjjī Bektash \{see his Die Bektaschïje\}. On this subject, see Chapter 4, p. 104.

54 See respectively their Tawā $\bar{n} k h$, pp. 204-6, and al-Shaq $\bar{a}^{\prime} q$ \{Turkish\} trans., among the shaikhs of Murad I, vol. 1, p. 44.

55 Velāyetnāme-i Häjji Bektash Veli, MS in my private library. There are many manuscript copies of this famous work.

56 Ibid., p. 6.

57 Ibid., p. 7. This legend is found in almost the same form in the velāyetnāme of Haajjīm Sultān. We find there, however, Aḥmad Yasawī in place of Luqmān-i Paranda.

58 In the original, the food is specified as bisi, a special kind of pastry. See Gölpinarlı (ed.), Vilâyet-Nâme, p. 6.$\}$

59 Velāyetnāme-i Hǟjjì Bektash Veli, MS in my private library, p. 8.

60 Ibid., p. 9.

61 No one named Luqmān-i Paranda is found in the precursors of the Naqshbandīs \{hâcegân silsila\} in \{Ṣafî's\} Rashahạt \{it is difficult to know why Köprülü thought he should be , nor is this title found in the works mentioning the legends and lives of the saints. Only the historian 'Âli presents some of the legends mentioned above as if they had taken place between Hājjjī Bektash and Luqmān-i Paranda, but he gives no information about Luqmān, Kunh al-akhbār, vol. 5, p. 53. In like manner, Luqmān is shown as a murshid of Hāājjī Bektash in such books as \{'Abd al-Ghaffār b. Hasan Kirimì's\} 'Umdat al-tawārink, which doubtless indicates that Kunh al-akhbār was the source of these works in this respect. 'A $\mathrm{A} l \overline{1}$ certainly took this story from Bektashī tradition. We learn from \{Mīrkhwānd's\} Rawdat al-șafā \{ed. Rị̣ā Qul̄̄ Khān (Tehran, 1270-4/1853-6; new edn, Tehran, 1338-9 sh./1960)\} that Shaikh Luqmān-i Paranda was not completely imaginary, like a number of other personalities in the Velayetnāme, but actually existed. While mentioning him among the famous people from the reign of \{the Tìmūrid\} Sultan Husain Bāiqarā $\{1469-1506\}$, this work states that he had a very well known tekke and shrine \{mezarlkk\} in Herat. The literary scholar Mawlānā Yūsuf Badīì Andijānī (d. 898/1492-3), who wrote a treatise on the rules of the ти' атта̄ \{a genre of verse\}, was buried in the cemetery of Luqmān-i Paranda, Rawdat al-safä, vol. 7, p. 122; \{Khwāndamīr,\} Habīb al-siyar \{Bombay, 1273/1857\}, vol. 3, p. 327. We also learn \{from Rawdat al-safā \} that the famous Sayyid Shams al-Dīn Muhammad Andijānī, a contemporary who had the byname Mīr-i Ser-Burehne \{Bareheaded Amīr , was placed in charge of this tomb and was appointed the shaikh, and that every year this shrine received 150,000 kepeki dinars from waqfs \{pious endowments $\}$ and votive offerings, Rawdat al-safā, vol. 7, p. 116. This brief report shows us that Shaikh Luqmān-i Paranda was a great and famous shaikh buried in Herat \{Mīrkhwānd does not clearly show this\}, that his tekke and tomb were renowned among the people in that region in the ninth/fifteenth century, and that it possessed rich waqfs. Most probably this shaikh was a member of Ahmad Yasawī's tarña, but one could state with great likelihood that he, like a number of the other shaikhs mentioned in the Velāyetnāme, had absolutely no historical connection with Hājjī Bektash. If more information were available on the life of this shaikh, it would probably shed light on a number of points that have remained obscure up to now. In any case, I have not been able to find any information on Luqmān-i Paranda in either the description of Herat in \{Zāhir al-Dīn Bābur's $\}$ Bāburnāme \{ed. A. S. Beveridge as the Bábár-náma (Leiden, 1905); new ed. Eiji Mano, Bâbur-nâma (Vaqâyì) I: Critical Edition Based on Four Chaghatay Texts, II: Concordance and Classified Indexes (Kyoto, 1995-6); English trans. Wheeler Thackston (Oxford, 1996)\} or under "Herat" in Barbier de Meynard's Dictionnaire géographique. The references in Rawdat al-ṣafā and \{Khwāndamīr's\} 
Habīb al-siyar that reveal the historical existence of Luqmān-i Paranda have, to date, not attracted any attention. There is also some brief information on this person in

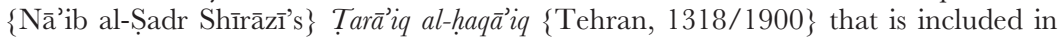
the work that I will publish on the Bektashiyya. \{Never published. See his article "Bektaş" in $\dot{L} A$. $\}$

62 CCuriously, Köprülü does not mention that the Haidar who is mentioned as Ahmad Yasawī's "son" in the Velāyetname's account is expressly identified there as Quṭ al-Dīn Haidar, eponym of the Haidarī dervishes and a figure linked to Aḥmad Yasawī also by Nawâ'’'s $\mathcal{N}$ asä’im al-mahabba.\}

63 Velāyetnāme-i Häj̄ji Bektash Veli, pp. 10-15. This legend is not found in the Velāyetnäme-i Hā̄joim Sultān.

64 Velāyetnāme-i Häjoj Bektash Veli, pp. 15-21. This legend is also not found in the Velāyetnāme-i Hǟjöm Sulțān.

65 See section A above for information on these items with which Ahmad Yasawi had been entrusted. When the khaliffas of Ahmad Yasawī requested these entrusted items from him they usually received the answer "sâhibi varder, gelir" \{their rightful owner will come to claim them\}. One morning they resolved to take them, so after the morning prayer they sat down and lit a big fire. At that moment, Ahmad Yasawī appeared and knew their intention. There was a heap of millet grain \{Köprülü misread çeç = heap as çiçek $=$ flower. The test was to perform the prayer on a millet heap without disturbing a single grain. See Gölpınarlı (ed.), Vilâyet-Nâme, pp. 15-16\} at one side of the square at that place. Ahmad Yasawī said Kim bu dan çeçinin üstüne seccâdesini koyup namaz kularsa, o emânetler gelip onun bașı ucuna dikilirler. Hem zâten nâfile zahmet çekmiyin, sâhibi nerede ise buraya gelir! \{Whoever places his prayer rug over this heap of millet and prays, those entrusted things will come and station themselves at his head. Anyway, don't trouble yourselves in vain. Their owner will be here soon!\} At that moment, Hājjī Bektash appeared and greeted them. The khwāja and his muñds rose to their feet. Shortly afterwards, Ahmmad Yasawī shouted, "Yâ Bektaş̣!" \{Oh, Bektash!\}. On this signal, Hājjī Bektash placed his prayer rug on the heap of millet and performed two prostrations. Not one grain of millet moved from its place. The crown in trust then immediately took flight and moved to Bektash's head. The cloak rose in the air and settled on his back. The lamp rose from its place, lit up, and stood before him. The Prophet's standard rose from its place and stationed itself above his head. The prayer-rug rose from its place and spread itself underneath him Veläyetnāmei Hǟji Bektash Veli, pp. 24-5. \{Köprülü made a jumble of this passage. We have followed Gölpınarlı's edn, p. 16\}.

66 Ibid., p. 25. This tradition was so widespread among the Western Turks that even Evliyā Chelebi described Hājjī Bektash's coming to Rūm in the same manner, Yine bunlarn zamân-ı hilâfetinde cedd-i 'izâmmm Türk-i Türkân Hoca Ahmed Tesevî hazretleri Horâsân'dan halîfesi olan Hacı Bektaş Velìyi ücyüz fukarâsyyle sâhib-i seccâde edüp deff ü kudûm ve 'alem u çrrâğ verüp... Orhân Gâzî̀ye gelüp mülâkât olduğu gibi Bursa üstüne gelüp fethetdiler \{At the time of his (i.e. Sultan Orhan's) sultanate, our illustrious ancestor Türk-i Türkān Khwāja Ahmad Yasawī placed his khal̄̃fa Hājjīi Bektash in charge of 300 dervishes and gave him the tambourine and drum, standard and lamp ... He came from Khurāsān to Orhan Ghāzī and met with him. Then they went to Bursa and conquered it.\} Seyăhatnāme, Book 1, fo. 23b. In a nefes on the qualities and miracles of Hājjīi Bektash, a Bektashī poet named Dīdārī stated in the following lines of verse that he was associated with Aḥmad Yasawī, Hâce-i Yesevî onun pîridir / Kerâmeti dağlar taşlar yürütür \{Khwāja Yasawī was his pīr / His miraculous grace moved mountains and rocks $\}$. In a MS that I have of a collection of Bektashī works, the chain of authority of the tarīqa of Haajjī Bektash is given as follows: Hạajjī Bektash Veli, Khwāja Aḥmad Yasawī, Mumshād Dīnawarī \{a well known figure from the early generations in 
reconstructed Șūfì silsilas\}, Quṭb al-Dīn Haidarī \{he is indeed linked to Aḥmad Yawawī by Nawā'ī and in Bektashī tradition\}, Imām Mūsā Riḍā, Imām Mūsā Kāẓim, Imām Ja'far al-Ṣādiq, Imām Muḥammad Bāqir, Imām Zain al-'Ābidīn, Imām Hụain, Imām 'Alī 'l-Murtadiā, the Prophet Muhammad, \{the angel $\}$ Jibrā'îl, \{the angel $\}$ Mikhā'īl, \{the angel\} Isrāfil, \{the angel\} 'Azrā'īl. There is no need to state that this chain has absolutely no historical value. \{This list may not, in fact, have been intended to be understood as a silsila in any real sense.\} However, it is clear from this as well that all Bektashī traditions wanted to trace Bektashism back to Ahmad Yasawī.

67 Velāyetnāme-i Häjjim Sultān, pp. 15-16. This legend is also found in somewhat abbreviated form in the Velāyetnāme-i Hājji Bektash Veli, but according to this version it was not Ahmad Yasawī who hurled the piece of wood, but rather one of the erens of Khurāsān, and the one who caught it in Konya was named Ahmad. He planted it at the convent of Bektash Veli, p. 26. In the Velāyetnāme we also learn that Ahmad Yasawī gave a giant \{or demon?) to the service of Hājjī Bektash and, after Hājjī Bektash went to Rūm, he gave it in turn as a gift to Qaraja-Ahmad, p. 30.

68 Evliyā Chelebi, \{Seyāhatnāme\}, Book 1, fo. 212b; Book 2, fos 266a-267b. Sarı Saltuk, i.e. the legend of Kaligra (Kalliakre) Sultān, is described at length in these pages. Evliyā Chelebi not only says that Sarı Saltuk had a shrine in Bābāeski (Book 3, fo. 170a), but he also states, while mentioning Babadağ1 \{in Dobruja\} in the same volume, that Sarı Saltuk had a maqām \{tomb\} there; and he adds that Yazıcı-oğlu \{Mehmet Chelebi, d. 1451\} and the governor of Ochakov \{Özi\} Kenan Pasha \{d. 1659\} each wrote a work on his legends, Book 3, fo. 127b. Unfortunately, we have no information about these two works. In any case, Sarı Saltuk was a very well known hero among the Western Turks. The poet Naw'i $-Z \bar{a} d e$ 'Ațâ' $\overline{1}\{$ d. 1635$\}$, the author of Khamsa, tells of one of his great miracles in his Kitāb-i Nafhat al-azhār der jawāb-i mahzan al-asrār (copy in my private library) and Kemāl Pasha-Zāde \{d. 1534\} speaks of his spiritual height in his Mohaçnāme \{book 10 of his Tarih-i äl-i osman, ed. and French trans. Abel Pavet de Courteille as Histoire de la campagne de Mohacz par Kemal Pachazadeh (Paris, 1859)\}, saying Dobruca Kin dedikleri yerde sâhib-i serîr-i velâyet, tâcdâr-ı

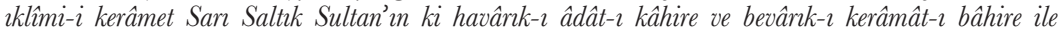
zâhir olan emîr-sûret, fakîr-sîret azizzlerdendi ... \{ In the place they call the land of Dobruja, the possessor of the throne of sainthood, king of the realm of miracles, Sarı Saltuk was one of the saints who were amirs in appearance and faqìrs in character, and who manifested extraordinary marvels and superior miracles ... \}, pp. 80-3. There is in fact a historical basis to this legend. In 662/1263-4 a number of Turks went to Dobruja in the company of Sarı Saltuk and later, at the time of 'İsā Bey, one of the Karası-oghulları at Balıkesir, they emigrated to the area of Karası. This migration is mentioned in the MS of \{Yazıc1-oğlu 'Ali's\} Saljūqnāme in the Revan Köşkü \{in Topkap1 Saray1; this work was edited by Th. Houtsma as vol. 3 of Recueil de textes relatifs à l'histoire des seldjoucides (Leiden, 1902)\}, which states Dobruca İli'nde duran Müsülmanlar dahî kâfirden uşinen, göçüp Karesi iline geçtiler \{the Muslims, who were in the land of Dobruja, were harried [?] by the unbelievers, they emigrated and went to the land of Karası\}, Ahmed Tevhid, "Rum selçuki devletinin inkiraziyle teşekkül eden tevâif-i mülûkdan Kara Hisar-i Sahibde Sahib Ata Oğulları,"\} TOEM, 9 \{1327/ $1910\}, 565$. Tevhid says that there is a work in the Imperial Library in Vienna by the shāhnāme writer \{şehnâmeci\} Sayyid Luqmān on the conquests of Sarı Saltuk Ghāzī. It is a treatise mentioned in G. Flügel's catalogue \{Die arabischen, persischen und türkischen Handschriften der Kaiserl.-Königl. Hofbibliothek zu Wien (Vienna, 1865-7)\}, vol. 2, p. 225. A short treatise bearing the title Ijmāl-i ahwōal-i āl-i saljūq ber müjib-i naql-i oghüznāme-i Sayyid Luqmān was published by Dr. J. J. W. Lagus in Helsinki in 1854. The traveler Ibn Batțūta, who was a contemporary of Sultan Orhan, mentions Sarı Saltuk in his Rihla 

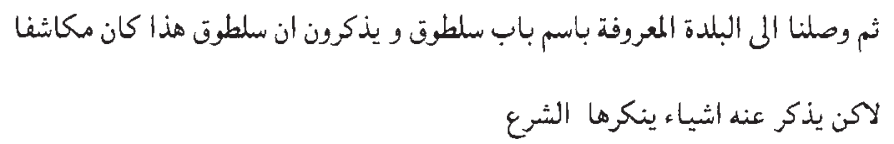

\{We came to the town known by the name of Bāb Salțūq. They relate that this Salțūq was an esctatic devotee, although things are told of him that are reproved by divine law; cf. Gibb, trans. vol. 2, pp. 499-500\} (\{eds C. Defrémery and B. R. Sanguinetti as Voyages d'Ibn Batoutah\} [Paris, 1853-8], vol. 2, p. 416). While providing information on Sarı Saltuk in the annotations to his translation of the Mohaçname, Pavet de Courteille says that his tomb was in Babadaği, that it was widely venerated, and that it was visited by Sultan Süleyman in 945/1538, p. 177. In any case, these historical works mention no connection whatsoever between Sarı Saltuk and Hājjī Bektash. Nevertheless, it is recorded in detail in Bektashī tradition, which is always completely contrary to the historical facts, that Sarı Saltuk was a shepherd, that on the order of Hājjī Bektash he took Ulu Abdāl and Kichi Abdāl with him and traveled from Sinop to Georgia on a prayer rug, that he converted the Georgians to Islam, that he then went to the fortress of Kaligra in Dobruja where he killed a dragon, that he then invited the people of the surrounding region to Islam, and that he established a tekke. Sarı Saltuk returned for a time after Hājjī Bektash's death, but he went back again to Dobruja and died there. In accordance with his will, when he died seven coffins were laid out. His murids and those who believed in him came from various cities and took one of them and looked in it. They saw Saltuk Bābā in each one and thus they happily took him to their own cities where they buried him. According to Bektashī tradition, this was why he had a maqūm in seven places (Velāyetnāme-i Hājji Bektash Veli, pp. 62-7). In the versified version of the Velayetname, the legend is the same, lacking only the trip to Georgia and his return to the mother lodge. Naw'î-Zāde 'Ațâ' $\overline{1}$ shows quite clearly in his Khamsa that in the eleventh/seventeenth century the Bektashīs considered Sar1 Saltuk to be a great member of their order, just like Qizıl-Deli Sultān (MS in my private library). [For Köprülü's subsequent work on Sarı Saltuk and the Saltuk-nāme, see the text and notes of his "Anadolu Selçukluları tarihinin yerli kaynakları," Belleten, 7 (1943), 430-41 \{English trans. Gary Leiser as The Seljuks of Anatolia: Their History and Culture According to Local Muslim Sources (Salt Lake City, 1992), pp. 43-52\}. See also Orhan F. Köprülü, "Tarihî kaynak olarak XIV. ve XV. asırlardaki bâzı Türk menakıbnâmeleri," Dissertation Istanbul University, \{1951,\} Tarih Semineri, ktp. no. 512, pp. 21-83.] \{Now see $E I^{2}$, s.v. "Ṣarı Șalțūk Dede" (G. Leiser); and Ahmet Yaşar Ocak, Sarn Saltık (Ankara, 2002).\}

69 Hazīn̄in, who was originally from Turkistan \{from Hișār west of Dushanbe in modernday Tajikistan but wrote his work to be presented to Sultan Murad III in Istanbul, also shows Hājjī Bektash as one of his khaliffas, but by using the phrase diyorlar ki \{they say that\}, he does not make this claim himself, p. 75. Because his Jawähir does not include all sorts of legends from the Bektashī tradition, provides rather plausible information on the family of Ahmad Yasawī, and incorporates much material on the rules of the Yasawi tañqa, we can regard this work as being uniquely important in preserving the version of the legend of Ahmad Yasawī found in Turkistan \{but Köprülü was unaware of the substantial literary legacy produced by Yasawi tradition, or reflecting it, in Central Asia\}. Speaking of Ahmad Yasawī in the versified version of the Velāyetnāme of Hājjī Bektash, the verse Murâd îden menakıbnda göre / Olan pervâne îren şem $-i$ nûrâ $\{\mathrm{He}$ who wishes may consult his Manāqib; it is the moth that attains the candle of light $\}$ could be evidence, although not very definitive, that some kind of legend about him had appeared in that region and that he was known there. 
70 There is nothing on Ahmad Yasawī in any of the works of Bābur Shāh or Nawā'ì or in \{Mīrkhwānd's\} Rawdat al-safā, or \{Khwāndamīr's\} Habīb al-siyar. Only \{Ṣafî̀'s\} Rashahatat, which was written in the early years of the tenth/sixteenth century, contains a little information on him. Even Jāmī's Nafahāt has no reference to him. \{Bābur, indeed, does not mention Ahmad Yasawī; but Mīrkhwānd does mention his shrine, as does Khwāndamīr. Nawă $\overline{1}$, of course, gives the extremely important account of Ahmad Yasawī in his Nasä'im al-mahabba, along with several other figures who may be linked with the Yasawi tradition; the work was a Chaghatay translation, with expansion (especially a section on the Turkic shaikhs) of Jāmī’s Nafahăt. Köprülü's failure to use it for Early Mystics was remedied in a later article, "Orta-Asya Türk dervişliği hakkında bazı notlar," TM, 14 (1964), 259-62, in which, however, he merely paraphrased the work's accounts without adding any analysis or comparison. On the earliest edition of the additions, see Carl Brockelmann, "Newa' is Biographien türkischer und zeitgenössischer Mystiker," in Documenta Islamica Inedita (Festschrift R. Hartmann), ed. J. Fück (Berlin, 1952), pp. 221-49 (full of misprints and based on a manuscript with many problems) and Kemal Eraslan's edition in Turkish-based transcription, Alî Şîr Nevâyî, Nesâyimü'l-mahabbe min şemâyimi'l-fütüvve (Istanbul, 1979), 2nd edn (Ankara, 1996). Eraslan does not mention Brockelmann's work. As for the Rashahăt, it is indeed an important source on Ahmad Yasawī and the Yasawī tradition, but it garbles or over-systematizes the tradition's silsila, among other things. Jāmī's Nafahăt does not accord a separate biographical entry to Aḥmad Yasawī, but it does mention him in its account of the four successors of Yūsuf Hamadānī. See the critical edition of Nafahāt al-uns by Mạ̣mūd 'Ābidī (Tehran, 1370/1991), pp. 382, $388,438$.

71 Setting aside the Velāyetnāme, we first encounter the tradition of Hājji Bektash in written form in \{'Ālī's\} Kunh al-akhbār and Evliyā Chelebi's Seyāhatnāme. It is quite obvious that the tradition of Hājjī Bektash was fixed and established, and the Velāyetnāme was created, in the tenth/sixteenth century, which we consider to be the period in which the present-day Bektashiyya took form and developed, and that both 'Āli and Evliyā Chelebi made use of it. 'Ālì summarized the information on Hājjī Bektash, apart from the section on Chīn Osman, from material wholly derived from the Velayyetname. The fact that the arrangement of the material in the Velayyetnāme is the same as that in the Kunh al-akhbār, and the fact that there is not even the slightest difference between the legends, are sufficient proof of this. Furthermore, 'Āli states that he saw the \{spiritual? \} genealogy of Hājjī Bektash (vol. 5, p. 53) and informs us that he visited his convent in 1005/1596-7 and met there with Iskender Chelebi, a descendant of Balım Sultān. All of this is sufficient evidence to confirm that the Velāyetnāme of Hājjī Bektash existed at that time and was commonly known.

72 The legend of Sarı Saltuk is evidence for this Bektashī practice. In addition, the fact that historical personalities like Yūnus Emre, Sayyid Maḥmūd Hairān̄̄, and Mawlānā Jalāl al-Dīn Rūmī, whose legends were widespread among the people, were mixed with the Bektashī legend in various ways is also evidence for this practice. If we possessed Yazıcı-oğlu's San Saltuk menkabesi, which Evliyā Chelebi says was extant, we would surely learn the extent to which he was associated with Ahmad Yasawī. I wonder if this relationship, which is mentioned by Evliyā Chelebi, had long existed as a legend among the people or if it was created later under the influence of the Bektashī legend. For now no definite answer can be given to this question. The second possibility appears to be more likely, but because certain dervishes like Chīn Osman and numerous Yasawī khalīfas mentioned by Evliyā Chelebi - who are not included in the Bektashī tradition are associated with Ahmad Yasawī in early legends among the Western Turks, the first possibility cannot be completely rejected. \{Köprülü, however, has no evidence of these legends' early attestation.\} 
73 Another possibility arises here. I wonder if the legend of Ahmad Yasawī spread among the Western Turks after the spread of the Naqshbandiyya. The spread of the Naqshbandiyya among the Western Turks took place in the second half of the ninth/ fifteenth century after Shaikh Ilāhi-i Simāvī, or more correctly in the tenth/sixteenth century, \{Tashköprü-Zāde,\} al-Shaq $\bar{a}^{\prime} i q$, \{Turkish\} trans., vol. 1, p. 262; \{İsmâ'̂̂l Belig,\} Güldeste-i riyâz-ı irfân, p. 144; \{Lațî̄, \} Tadhkira, \{ed. Ahmed Cevdet as Tadhkirayi Latîfi (Istanbul, 1314/1896)\}, p. 50. In any case, the present form of the legend of Hāàj]̄̄ Bektash, 'Ālī's history, Evliyā Chelebi’s Seyāhatnāme, and even \{Hazīn̄̄'s\} Jawähir all came into being after the ninth/fifteenth century, in the tenth/sixteenth century, i.e. after the spread of the Naqshbandiyya. By dismissing all this evidence as coincidence, could it not be a mistake to assert that the legend of Ahmad Yasawi had already spread among the Western Turks before the formation of the Ottoman state?

In my view, this possibility is not very strong. The aforesaid annotations can be cause to reject it and several other factors could be considered in this regard. For example, if 'Ālī and Evliyā Chelebi had taken the legend of Ahmad Yasawī from \{Hazinn's \} Fawähir, then we could conclude that this legend had come to the Western Turks as a result of the spread of the Naqshbandiyya, but the fact is that they both took this legend from the Bektashī tradition. Indeed, because it is not mentioned in Kātib Chelebi's Kashf al-zunūn, we could conclude that the Fawähir cannot have been well known at that time. Although it is true that the Bektashi tradition was fixed in the tenth/sixteenth century, this does not prove that the Yasawi legend had appeared at that time. If it had, then one would have to believe that the legends of Yūnus Emre, Sayyid Mạmmūd Hairānī and others had also come into existence in the tenth/ sixteenth century. I have explained above, however, that Ahmad Yasawī legends are to be found in 'Âlī and Evliyā Chelebi, which differ from those derived from the velāyetnāmes. As will be described in the second part of this book, there is a definite resemblance between the work of Yūnus Emre and his associates and the Dǐwa $n-i$ Hikmat, which further strengthens my aforesaid assertion. In any case, until new documents provide proof to the contrary, we can state categorically that the legend of Ahmad Yasawī had already existed among the Western Turks before the formation of the Ottoman state. \{Köprülü was on to something in suggesting that the Naqshbandīs had a role in spreading Ahmad Yasawī's fame among the "Western Turks," but that role probably came later. His argument against his suggestion stresses the weak arguments and misses the main one, namely that the Veläyetname of Haajjī Bektash was undoubtedly compiled before the end of the fifteenth century (the notion that Evliyā Chelebi could have gotten his information on Ahmad Yasawī from Hazīnī's work makes no sense). Finally, he goes too far in claiming that the circulation of legends about Ahmad Yasawi in Anatolia before the formation of the Ottoman state is "categorically" affirmable without negative proof!\} 


\section{THE HISTORIGAL LIFE OF AHMAD YASAWI}

Legends created by the popular imagination always contain an element of truth, i.e. they faithfully represent the form in which any personality or event is reflected in the general consciousness. It is the duty of the historian first to describe the legendary form of this personality or event and then to establish and animate its historical reality. If the first duty has been adequately done, it will greatly facilitate translating and reducing the myth to its true proportions.

\section{A His childhood}

Ahmad Yasawī was born in the town of Sairām, which today is part of the district of Aqsu in the region of Eastern Turkistan in China. It is located $176 \mathrm{~km}$ northeast of \{the town of Aqsu. ${ }^{1}$ Sairām is a small town on the stream called the Qara-su, which flows into the Shāhyār River, a tributary of the Tarim River. ${ }^{2}$ Although the date of Ahmad Yasawī's birth is not known for certain, we can estimate that it occurred around the middle of the fifth/eleventh century. ${ }^{3}$ Ahmad's father, Shaikh Ibrāhīm, was one of the most famous shaikhs of Sairām. He married ' 'A'isha Khātūn, the daughter of Mūsā Shaikh, one of his khal̄̄fas. From this union, a daughter, Gawhar-Shahnāz, and later a son, Ahmad, were born. Their mother predeceased their father, who died when Ahmad was seven years old. ${ }^{4}$ Thus we find him under the guardianship of his sister. According to tradition, Shaikh Ibrāhīm's family was traced back to Imām Muhammad Ibn al-Hanafiyya b. 'Alī al-Murtad̄a in the following manner: Shaikh Ibrāhīm b. Shaikh Ilyās b. Shaikh Maḥmūd b. Shaikh Maḥmūd (?!) b. Shaikh Muhammad b. Shaikh Iftikhār b. Shaikh 'Umar b. Shaikh 'Uthmān b. Shaikh Husain b. Shaikh Hasan b. Shaikh Ismā'īl b. Shaikh Mūsā b. Shaikh Mu’min b. Shaikh Hārūn b. Shaikh al-Shuyūkh Baḥr al-'Irfān Jabal al-Ițmi'nān Quṭb-i Turkistān Khwāja Isḥāq Bāb b. 'Abd al-Raḥmān b. 'Abd al-Qahhār b. 'Abd al-Fattāh b. Imām b. al-Hanafiyya b. 'Alī al-Murtaḍā.

It can be supposed that, for unknown reasons, Aḥmad Yasawī went to Yasī when he was still young and settled there. The traditions about how he took the byname Yasawī and about how Arslan Bābā met him in Yasī both support this notion. Because the city of Yasī - as it is called today \{Hadrat-i\} Turkistan - was 
the center of government of Oghuz Khān, it was a famous place that had already passed into Turkish legend. ${ }^{6}$ And the fact that Khwāja Ahmad took the byname Yasawī, based on residence in this city, further increased its historical importance in the Turkish world. In any case, Ahmad, who went to this city and settled there with his sister, received there the favor, kindness, and blessing of the well known Turkish shaikh Arslan Bābā. ${ }^{7}$ Because the latter died while Ahmad was quite young, the tradition that Arslan Bābā had a strong influence on his personality cannot be regarded as historically correct. \{In any case, $\}$ it is likely that Ahmad did spend the first years of his education in Yasī, for we find him, while he was still a youth, going to Bukhārā, which was a great Islamic center, in order to complete his education.

\section{B Khwāja Yūsuf Hamadānī in Bukhārā}

In the sixth/twelfth century, Bukhārā was under the political control of the Qarakhānids. This city had lost the political significance that it had had in the Sāmānid period, but it maintained its fame as the most important center of the Islamic sciences in Transoxiana. Its madrasas were full of students coming from throughout the Muslim world, and especially Turkistan. The city was ruled by a very rich family of 'ulama' known as the Āl-i Burhān. All the learned members of this family, who were Hanafīs, were given the byname Șadr-i Jihān. The founder of the family was Burhān al-Milla wa 'l-Dīn 'Abd al-'Azīz b. 'Umar, who was well known under the byname Nu'mān-i Thānī. He lived from about the second half of the fifth/eleventh century to the early years of the sixth/ twelfth century. Although subordinate to the Qarakhānids, this șadr \{paramount or foremost person $\}$ usually lived like an independent ruler. He was succeeded by his son, Husām al-Dīn 'Umar, who held the reins of power in Bukhārā until he was killed by the Qara Khitāay in 536/1143-4. ${ }^{8}$ In any case, it is rather easy to guess what kinds of religious currents were prevalent in the madrasas of Bukhārā during the rule of these sadrs who were Hanafì religious scholars and supported 6000 faqīhs \{jurists\}. It was at such a time and into such a milieu that Aḥmad Yasawī arrived. He attached himself to Shaikh Yūsuf Hamadānī, one of the leading religious scholars and Sūfīs of the period, and his personality was formed under his influence. ${ }^{9}$

Abū Ya'qūb Yūsuf b. Ayyūb b. Yūsuf b. al-Hasan b. Wahara ${ }^{10}$ was born in 440 or $441 / 1049-50$ in the town of Būzanjīrd in the region of Hamadān. ${ }^{11}$ Sometime after 460/1067-8, he went to Baghdad, ${ }^{12}$ where he attached himself to Shaikh Abū Ishāa Shīrāzì and in a short time surpassed his friends in the study of \} usül al-fiqh \{the principles of jurisprudence\} and khiläf \{divergences among the legal schools $\}$ and won the respect of his master. According to the information given by al-Sam'ān̄̄, who was in Yūsuf Hamadan̄̄'s tekke in Marw and who met there and later in Bukhārā with Hasan Andāqī, he had extensive knowledge of figh and, above all, 'ilm-i nazar. Later he studied Hadith with the great traditionists of the age in Baghdad, Isfahan, and Samarqand. Finally, after 
acquiring great knowledge and erudition in the religious sciences, he abandoned them on the impulse of his mystical temperament and studied Sūfism directly from the famous Shaikh Abū 'Alī Fārmadī. It is reported that he also conversed with Shaikh 'Abd Allāh Juvainī and Shaikh Hasan Simnānī. ${ }^{13}$

After following the path of asceticism and struggle against his carnal self, Yūsuf Hamadānī went to live in Marw. A short time later, he left for Herat. He stayed there for a fairly long time, but when the people of Marw asked him to return to their city, he did so. \{Nevertheless, \} he left a second time for Herat. In Rabī' I 535/October-November 1140, while on the way back to Marw from Herat, he died in the town of Bāmiyīn. ${ }^{14}$ According to one report, Ibn al-Najjāar, one of his disciples, later had his body taken to Marw, where his tomb now is. ${ }^{15}$

Khwāja Yūsuf Hamadānī was a very ardent follower of the "Greatest Imām" $\{$ Abu Hanīfa\} and was a follower of his madhhab \{the Hanafī school of law\}. He lived in different cities in Iraq, Khurāsān, and Transoxiana where he was occupied with providing spiritual guidance to the people. He spent a rather long time in Bukhārā and even lived for a while on Kūh-i Zar \{near Mt Dāmghān\}. ${ }^{16}$ It seems that Aḥmad Yasawī joined Yūsuf Hamadānī when he was in Bukhārā or, according to another tradition, when he was in Samarqand - and learned from him the rules, as well as the sciences (both exoteric and esoteric), of the mystical way. He may also have traveled about various countries with his shaikh. In any case, Yūsuf Hamadān̄̄ spent most of his time in Marw al-Rūd. Abū 'l-Sa'd al-Sam'ānī says that he had a tekke in Marw, ${ }^{17}$ and other sources report that his tekke in that city was so famous and important at that time that it was regarded as the Ka'ba of Khurāsān. ${ }^{18}$ Yūsuf Hamadānī, who won widespread fame in the Muslim world for his erudition and virtue and for the miracles that he performed, went to Baghdad in 515/1121-2. In the famous Nizāmiyya Madrasa founded by the Seljuk Vizier Niẓām al-Mulk, he gave sermons and spiritual counsel to a select assembly who had hastened there from all directions. During one sermon, a famous faq̄h named Ibn al-Saqqā' stood up and asked the khwäja a question. In reply he said, "Sit down! I detect the odor of unbelief in your words. It is likely that your death will not be within the Muslim faith." This in fact came to pass. Ibn al-Saqqā' went to Constantinople with the Byzantine ambassador who had come to Baghdad and he became a Christian. ${ }^{19}$ Yūsuf Hamadān̄̄ performed a great many similar miraculous and marvelous deeds.

Khwāja 'Abd al-Khāliq Ghujduwān̄̄, in his treatise Maqāmāt-i Yūsuf Hamadān ${ }^{20}{ }^{20}$ provides considerable information that shows, in the most sincere manner, the life and character of the shaikh. Thanks to this work, the figure of the learned Șūfî, which al-Sam'ānī, whom we can consider to be the earliest source on this subject, and various other sources only vaguely bring to life, takes very clear and lively form. We learn not only of Yūsuf Hamadānī's physical appearance, character, and habits, but also the full essence and depth of his spirit.

\{According to the Maqāmāt, \} Yūsuf Hamadān̄ was a tall, thin man with pockmarks and a long, light-brown beard. He wore wool clothing that was always patched. He gave no importance to worldly affairs and would not visit the homes 
of rulers or great men. Whatever he acquired, he gave to the needy. He would not accept anything from anyone. He did not know Turkish. He was single for seventy-five years and then finally married. His wife died forty days before he did. He was very kind to everyone. He was patient and tender-hearted and would ask visitors about the dervishes in their provinces. As he silently performed the $d h i k r$, he would imprison his carnal self and therefore sweat profusely. ${ }^{21} \mathrm{He}$ was always occupied with reading the Koran. From the place called Khosh-dūd, which was within the Ghätfar quarters, to the mosque he would make a complete recitation of the Koran. From the door of the mosque until he arrived at the home of Khwāja Hasan Andāqī and Khwāja Aḥmad Yasawī, he would recite Sürat al-Baqara. On the way back, he would complete Sürat Āl 'Imrān. While going from his mosque to the dervish cells, a distance of 700 feet, he would also recite part of the Koran. In between, he would turn his face toward Hamadān and weep profusely. He possessed the staff and turban of Salmān Fārsī \{a Persian barber who was taken into Muhammad's household and became the model of spiritual adoption\}. At the beginning of every month, he would summon the mullās of Samarqand and discuss the Sharī' $a$ with them. Khadir was his constant companion. He would apply medications to pains and wounds, write nuskhas (amulets) for fevers, and try to alleviate everyone's suffering. He was never loath to teach the obligations of the faith to all the villagers, Turk and Tajik alike. He was always preoccupied with teaching. He accepted all the basic dogmas of Islam without esoteric interpretation. He lived in a continuous state of asceticism and spiritual struggle \{against his carnal self \}. He advised his disciples to follow the ways of the Prophet and his Companions. His heart was full of deep affection for all creatures. He would go to the homes of Christians and Zoroastrians and recount to them the splendors of Islam. He was patient and forbearing with everything. He showed respect and affection to everyone. A harsh word never passed his lips. He never called a Muslim an unbeliever. He was inclined to poverty and would not use anything made of gold or silver. He regarded the poor more highly than the rich. In his room, there was a rush mat, a felt, a water jug, two cushions, a saucepan and nothing else. He would always speak to his disciples of the legends and virtues of the Chahār yār \{the first four caliphs\} and advise them to pray, fast, hold dhikrs, practice asceticism, and struggle against their carnal desires.

On Wednesday, 11 Ramaḍān 504/March 25, 1110, Sultan Sanjar sent a letter to Qāsim Jūkī in Samarqand. In this letter, he made known his respect and deference toward Shaikh Yūsuf Hamadānī. He also sent 50,000 gold pieces to the dervishes of his tekke and added that "they should inform him about the way of life of this great shaikh, who did not deviate from the path of the Aṣhāb-i Kirām \{Companions and disciples of the Prophet\}, and should request for himself \{the recitation of $\}$ the Fätiha from the Shaikh." "22 Meanwhile, Shaikh Yūsuf had gone to the cell of Khwāja 'Abd Allāh Baraqī in order to meet his disciples. Khwāja Hasan Andāqī, Khwāja Aḥmad Yasawī, Khwāja 'Abd al-Khāliq Ghujduwānī, and several others were all there. The disciples informed him of 
Sultan Sanjar's offering, and Shaikh Yūsuf recited a Fātiha for his deed. He then said that he had no deeds that Sanjar should be informed of except for moral slips and errors. When his dervishes pressed him, he said, "Write down whatever you see me do that is in conformity with the prophetic Sharn'a!" Granted this permission, the dervishes wrote his biography and sent it \{to Sanjar\}.

Before he died, 'Abd al-Khāliq Ghujduwān̄̄ asked him about his khal̄̄fas and received the following answer: "My khal̄efas will be Khwāja 'Abd Allāh Baraqī, and after him Khwāja Hasan Andāqī, and after him Aḥmad Yasawī. When the turn of khalīfa has come to Ahmad Yasawī, he will travel to the province of Turkistan and you will become the khaliffa." This in fact came to pass. On the day of his death, he turned his back to the mihrāb \{niche indicating the direction of Mecca\} and ordered his companions to heat some water \{to wash his corpse\}. Then he turned his face to his four khaliffas and the others who were present and said, "I have left my place to 'Abd Allāh Baraqī. Follow him! Do not oppose him! State the rules of behavior that we wrote for Sultan Sanjar to our disciples and companions!" Turning to Aḥmad Yasawī, he asked him to read the Sürat al-Fätitir, Sürat $Y \bar{a} s \bar{n}$, and Sürat al-Nāzi' $\bar{a} t$. When this was finished, a cry broke out. ${ }^{23}$ When Yūsuf Hamadān̄̄, who had won great fame during his life for his strict observance of the stipulations of the Shar ' $a$ and the sunna of the Prophet and for his erudition in the religious sciences, closed his eyes, many of the attributes that contributed to his fame passed to his khalnfas and within a short time they too won great renown. ${ }^{24}$ Y ūsuf Hamadānī was often cited in books on Șūfism. ${ }^{25}$ These references as well as some legends confirm that he wrote several works, ${ }^{26}$ but unfortunately none has come down to us. ${ }^{27}$

Thus, Khwāja Aḥmad regarded his spiritual guide and teacher Yūsuf Hamadān̄̄ as a model of knowledge and learning, excellence and virtue. In this period, which was dominated by Turkish rulers who closely adhered to the stipulations of the $\operatorname{Shari}^{\prime} a$ and were opposed to Mu'tazilism \{theological doctrine stressing rationality $\},{ }^{28}$ he acquired, like his teacher, a great knowledge of the sciences of the Shar $\bar{\imath}^{\prime} a$ and became so renowned for his religious knowledge, asceticism, and piety that, in his old age, Yūsuf Hamadānī selected him to be a khal̄̄fa together with his other three murīds. ${ }^{29}$ For a while after the deaths of the first two khalīfas, Khwāja 'Abd Allāh Baraqī (d. 555/1160-1) and Khwāja Hasan Andāqī (466552/1073-1157), he was the head of the tekke in Bukhārā. However, after serving in this post for a time - how long we do not know, but it was probably not very long - he left all his disciples to the fourth khal̄efa Khwāja 'Abd al-Khāliq Ghujduwān̄̄ and went straight to Turkistan, to Yasī. ${ }^{30}$

\section{G His return to Yasī}

After completing his training in the Șūfì path with the most famous shaikh of the age and acquiring the position of khaliffa, Ahmad Yasawi did not remain in Bukhārā, but returned to Yasī for unknown reasons. Although we do not know exactly when he returned, it was probably after the death of the first khalinfa 'Abd 
Allāh Baraqī, i.e. after 555/1160-1. If so, we must conclude that Ahmad did not reside very long in Yasi and that he died about ten years after his return, because all the different biographical dictionaries agree that his death occurred in 562/ 1166-7 the "first" khal̄ fa, Baraqī, died in 555, and the "second" khal̄ fa, Andāqī, died in 552. Köprülü has the latter in mind when he says "ten years".$^{31}$ If we compare the very few historical documents in our possession to the legendary accounts, we must conclude that either the tradition according to which Khwäja Ahmad lived 125 or more years, or else his historical death date, is mistaken. If the tradition were accepted as correct, this would require advancing his death date into the early years of the seventh/thirteenth century, but this would obviously be absurd.

The report on Shaikh 'Al̄̄ Lālā in $\{$ Jāmī's $\}$ Nafahạt indicates that Aḥmad Yasawī was a contemporary of the famous Najm al-Dīn Kubrā. ${ }^{32}$ A point on which all the historians agree is that Najm al-Dīn Kubrā was martyred in 617/ 1220 during the Mongol invasion. ${ }^{33}$ Even if this story of contemporaneity were accepted as correct, we would still not have to conclude that Ahmad Yasawī died around the end of the sixth/twelfth century or the beginning of the seventh/ thirteenth century, because if we consider that Najm al-Dīn Kubrā \{b. 540/1145\} was still young when he met Ahmad Yasawī, we can easily admit that Khwāja Ahmad could then have been nearing the end of his life. In this case, however, we would have to conclude that Shaikh 'Alī Lālā lived for almost a century (d. 3 Rabī' I 642/August 9, 1244). Despite the long lives of most Șūfìs, when we take into account the birth date of Shaikh 'Alī Lālā this story is unacceptable. ${ }^{34}$ When we consider the fact that, in \{Hazin̄is's\} Fawāhir, which has the best record of the Yasawī tradition, Shaikh Saif al-Dīn Bākharzī, who was a khalîfa of Najm al-Dīn Kubrā, is also mentioned as a khatîfa of Ahmad Yasawī, then it appears probable that there was some basis to this story in $\left\{\mathrm{Jām}^{\prime} \mathbf{s}\right\} \mathcal{N}$ Nafahăt and that Shaikh 'Alī, for example, was in a Yasawī tekke - perhaps in Yas̄i - where the \{living\} memory of Ahmad Yasawī had not yet been forgotten. Thus, based on these extrapolations, I see no reasonable justification for now to reject the report that Ahmad Yasawī died in 562/1166-7. ${ }^{35}$

Yūsuf Hamadānī's learned khal̄̄fa gathered around him thousands of disciples from Turkistan during the years that he lived in Yasī. The general situation at that time was very conducive to \{the spread of $\}$ religious and Sūfī propaganda. Sultan Sanjar, who had united Transoxiana and Khurāsān under the same political rule after Malik-Shāh, had died (552/1157) and the Khwārazm-Shāhs had begun to show signs of creating a large Muslim state. At exactly the same time, a powerful Islamic movement was developing around Yedi-Su \{Semirechy\} in the vicinity of Qūlcha $\{$ Kulja $\}$ in Eastern Turkistan. ${ }^{36}$ During this period, when the shaikhs possessed enormous influence throughout Muslim Asia and tekkes were being built everywhere, Aḥmad Yasawī won fame along the Syr Darya, around Tashkent, and even in the steppes to the north. He gathered around him not the educated men who had a knowledge of Persian language and literature and were familiar with Iranian customs, as was the case in Bukhārā, Samarqand, 
or the cities of Khurāsān, but the simple and naive Turks who were newly, but very strongly, attached to Islam. Consequently, although he knew, of course, the Arabic religious sciences and Persian literature quite well, he had to address his disciples in a language they could understand. Instead of writing in Persian, like other Șūfiss who had lived within the Persian cultural milieu, he used Turkish; and in order to expound the rules of the Șūfi path to Turkish dervishes who did not know Arabic and Persian, he wrote moralizing and mystical verses using the simple forms derived from Turkish popular literature this is all speculation based on no sources whatsoever\}.

According to tradition, after Ahmad Yasawi reached the age of sixty-three, he had a chilla-khāne that was three yards deep made to one side of his tekke and withdrew to it. Unfortunately, we do not know when this took place. Using mystical language, he recounts at length in many passages in the Dīwān-i Hikmat how he withdrew to his chilla-khāne, and the reasons for his seclusion. His life in this chilla-khanne was probably not as long as was reported, nor did he collect about him 99,000 disciples as was claimed in the traditional stories. This great age and large number are simply meant to indicate the wide fame that he enjoyed at that time. Until his death, Khwāja Aḥmad continued to write Suufī verses under the heading of hikmat. In this fashion he expounded to his disciples the rules of Șüfi behavior and discipline, mystical truths, the need for the purification of the inner self and moral betterment, and religious traditions. He used his hikmats to explain these things to those who could not read about the primary religious sciences in Arabic or Persian. Because Ahmad Yasawī was a Hanafī faqīh and a scholar of the Sharī a just like his teacher, he continuously welded the tariq a with the $\operatorname{Sharī}^{-} a$. He tried to propagate the idea that neglect of religious obligations did not accord with the rules of behavior of the tariqa. ${ }^{37}$

After the sections that he abridges and cites from 'Abd al-Khāliq Ghujduwān̄̄'s Maqāmāt, Aḥmad b. Mawlānā Jalāl al-Dīn Kāsānī \{Makhdūm-i A'ẓam\} gives the following information on the khalīfas of Yūsuf Hamadānī: "Oh holy ones \{azizler\}, you should know that his Excellency Khwāja Abū Yūsuf ${ }^{38}$ Hamadān̄̄ had four khalîfas. The first was 'Abd Allāh Baraqī who was his immediate successor. His noble tomb is outside the gate of Gülābād \{rather, Kalābādh\} in Bukhārā, on Shūristān hill and near the tomb of his Excellency Khwāja Ishāq-i Gülābād̄̄. The second was Khwāja Hasan Andāqī, who was immersed in the world of ecstatic contemplation and beatitude. His tomb is also near that of Khwāja Ishāa. Andāq is a village six parasangs from Bukhārā. The third was Khwāja Aḥmad Yasawī. One of his miracles and wonders was that whoever, with sincere intention, had the honor of his company would become a saint. In fact, he used to say, 'Your intentions are your companions' $\{$ Niyyâtın koldaşın\}. He departed from this world in 512/1118-19. His blessed tomb is in Turkistan. His sublime dervish convent is enormously prosperous." It is obvious that the date of 512 given here is a copyist's error for $562 / 1166-7 .^{39}$

As is clear from an examination of the Dīwann-i Hikmat and the milieu in which his personality was formed, Khwāja Aḥmad Yasawī was a serious, far-sighted, 
discerning Turkish Șūfî \{this characterization is Köprülü's own\}. Junaid of Baghdad said that Șufism consisted of "the abandonment of pretensions and concealment of accomplishments" \{terk-i deâvi ve kitmân-i meâni\}. These words apply perfectly to Ahmad Yasawī. In his works, one finds no hints that might upset common beliefs. The ideas and tendencies of many Iranian Șūfis who behaved somewhat carelessly with regard to the $\operatorname{Shari}^{\prime} a$ are virtually absent from this great Turkish shaikh. Khwāja Ahmad was so devoted to the stipulations of the $\operatorname{Shari}^{c} a$ that he once exclaimed: "There is no difference between someone who neglects even one of his prayers and a pig." In every poem he mentions his sins and asks forgiveness, or he speaks of heaven and hell and Șûfì legends and concludes by humbly asking God to forgive his sins. Even when he becomes most absorbed in the philosophy of the unity of God and speaks most often of the stage $\{m a q \bar{a} m\}$

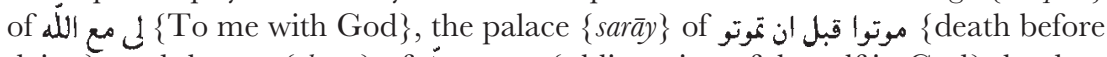
dying\}, and the sea $\{$ derya $\bar{a}$ of فن في الله not forget the weapon of the Shar ${ }^{c} a .{ }^{40}$ His ability to attract so many disciples was not only due to the great care that he exercised with respect to the Shari ${ }^{-} a$ and the depth of his knowledge of the religious sciences; it was also aided very much by his speaking to the people simply and categorically of the principles that he defended, and addressing them in a language that they more or less understood and in a form of verse to which they were accustomed. In short, Aḥmad Yasawi profoundly understood the needs of his milieu and tried to meet them. The dense fog of legends that still envelops his historical personality is an indication of the great sanctity in which he has been held in the popular imagination over many centuries.

\section{His children and grandchildren}

Both a present-day tradition in Yasī and a legend in \{Hazīn̄̄'s $\}$ Fawāhir agree that Aḥmad Yasawi's son named Ibrāhīm died during his father's lifetime. According to the tradition in Yasī, the khwäja also had a daughter named Gawhar Khūshnās or Gawhar Shahnāz. The lineage of a great many people who, over the centuries, considered themselves to be the descendants of Khwāja Ahmmad Yasawī is traced to this daughter. ${ }^{41}$ Even today, many people among both the Eastern and Western Turks claim that they are descendants of Ahmmad Yasawī. ${ }^{42}$ Khwāja Hasan Naqīb al-Ashrāf \{Nithārī\} of Bukhārā says that Shaikh Zakariyyā', a tenth/sixteenthcentury notable from Transoxiana who for a while was in the company of 'Abd Allāh Khān, recited poetry from time to time, and lived in Samarqand, was a descendant of Ahmad Yasawī. ${ }^{43}$ We find among the Western Turks as one of the descendants of Ahmad Yasawī the poet Mevlidji Üsküplü 'Ațā, who wrote a work entitled Tuhfat al-'ushshāq in the style of the Tajn̄̄sāt of Kātibī. ${ }^{44}$ In addition, the famous eleventh/seventeenth-century Ottoman traveler Evliyā Chelebi states in several places in his book that he too was a descendant of Ahmad Yasawī. ${ }^{45}$

We learn very clearly from \{the Ottoman admiral\} Sayyidī 'Alī Ra' $\overline{1}$ ' Mir'āt al-mamālik that there were found across the great expanse of Asia in the tenth/ 
sixteenth century a great many Ṣūîs who claimed kinship with Khwāja Aḥmad Yasawī. Sayyidī 'Al̄̄ Ra'īs was a famous poet with the pen name Kātibī. While passing through the regions of Sind, Punjab, Afghanistan, Transoxiana, Khurāsān, Azerbaijan, and Iran during a long journey that he made in 961-4/1553-7, he came across the following Șūfis who claimed to be related to Ạ̣mad Yasawī: the first was Sadr-i 'Ālam Shaikh. Baraq Khān, whom Sayyidī 'Alī Ra' ìs met in Samarqand, had this man accompany him as an envoy (Mir'ät al-mamālik \{Istanbul, 1313/1895-6\}, pp. 65, 72 \{new Turkish edn, Mehmet Kiremit (ed.), Mir'âtülmemâlik (Ankara, 1999); English trans. A. Vambéry as The Travels and Adventures of the Turkish Admiral Sidi Ali Re' is in India, Central Asia and Persia in the Years 15531556 (1899; reprinted Lahore, 1975)\}. The second was Bābā Shaikh, who was to be killed by the Circassians while on the way to Astrakhān (ibid., p. 89). The third was Shaikh Muḥammad Dam-tīz b. Khwāja Aḥmad Yasawī, whom he visited in Gurgān, which he reached after passing through Abhar near Sulțāniyya on the Qazwin-Baghdad road (ibid., p. 92) \{actually the admiral mentions only his grave $\}$. These details indicate how extensively and vigorously Yasawism and Yasawī influence had spread in Muslim Asia in the tenth/sixteenth century.

After the eleventh/seventeenth century, we only encounter a Ṣūî named Khwāja Hāạı Aḥmad Yasawī Naqshbandī who claimed to be related to Aḥmad Yasawī. According to a statement by the author \{Lāhawrī $\}$ of Khazinnat al-asfiy $\bar{a}$, this dervish "was a performer of wonders and miracles and a source of illuminations and epiphanies." Separated from his homeland by the hand of fate, he spent time in Arabia, Mecca, Medina, Jerusalem, Damascus, Iraq, Anatolia, and Russia, and then went to India and Kashmir where he went into seclusion. He would not meet with anyone. Sometimes, however, he would go to the tekke of Shaikh Āgāh Mullā Shāh. A few years later, Khwāja Niẓām al-Dīn b. Mu'īn al-Dīn recognized his spiritual superiority and entered his service. With great difficulty he convinced him to come to the city with him. After the death of Nizāam al-Dīn, Khwāja Nūr al-Dīn Muhammad Āftāb entered his service and became his disciple. In this manner, he acquired great fame in the region. This Naqshbandī - or more correctly Yasawī - shaikh, who was a descendant of Ahmad Yasawī, died in 1114/1702-3 or 1116/1704-5 and was buried in Kashmir. ${ }^{46}$

\section{E His türbe and mosque}

The world conqueror Tīmūr, who throughout his life followed an Islamist political policy aiming to take advantage of the spiritual influence that the khwajjas and shaikhs had over the people, ${ }^{47}$ who abolished the old yasa \{"law," tribal custom\} of Chingiz Khān, and who established a new \{religio-political\} organization inspired by Twelver Shī ism, ${ }^{48}$ built the Dilgushā Garden in 799/1396-7 in Samarqand $\}$ and then headed toward Tashkent. Crossing the Syr Darya River, he ordered his army to take up winter quarters in the towns in the vicinity and he himself went to Yasī to visit the grave of Ahmad Yasawī, whose great fame 
had spread throughout Turkistan and the Qazaq steppes. According to the account of Sharaf al-Dīn 'Alĩ Yazdī, the author of the Zafarnāme, he ordered the construction of a lofty shrine over his grave "out of respect for this great Muslim who was a descendant of Muhammad Ibn al-Hanafiyya" and issued a ferman $\{$ edict $\}$ to this effect. ${ }^{49}$ This project was placed under the control of Mawlānā 'Abd Allāh Șadr and it was begun under the architectural direction of one Khwāja Husain Shīrāzī. ${ }^{50}$ A magnificent building, including a large dome, two minarets, and innumerable anterooms, cells, and cupolas, was completed in two years. ${ }^{51}$ As required by Timmūr's orders, the dome and walls of the building were decorated with tiles and the tombstone of the khwäja was made of marble and embellished with superb carving. Thus both the exterior and interior of this building were created in a form that was virtually flawless. On each side of the mihra $b$ were enormous lamps, made in Tìmūr's name in 899/1493-4 by an artisan from Isfahan. ${ }^{52}$ There was also inside the shrine ${ }^{53} \mathrm{a}$ huge cauldron inscribed with verses from the Koran, which apparently was donated as a waqf in 801/1398-9. ${ }^{54}$ The carvings on the door were of exceptionally fine and elegant detail. After this great building was completed, Tīmūr bestowed many gifts and gave many alms to the poor and needy in the city. When these ceremonies were finished, he returned to his army. According to \{Schuyler's\} report, this architectural monument was last repaired by 'Abd Allāh Khān. ${ }^{55}$

According to Ujfalvy $\{$ Le Syr-Daria $\}$, who made a scientific exploration of that region about a half century ago $\{c .1875\}$, this shrine was an architectural monument in the full sense. Both Mir-Salikh-Bekchurin and Schuyler indicate that the shrine was not only the principal monument of the city of Turkistan but was also an artistic work that could perhaps take its place among the architectural masterpieces of the entire world. I feel compelled to cite briefly here the valuable information that Schuyler provides on this shrine.

The mausoleum is an immense building, crowned by a huge dome, and having annexed to the rear another small mosque, with a melon-shaped dome. The front consists of an immense arched portal, at least a hundred feet high, flanked by two round windowless towers with crenelated tops ... The archway there is a large double door of finely carved wood, and over this a small oriel window, dating from the last reconstruction by Abdulla Khan. The walls are of large square-pressed bricks, well burnt, and carefully put together. Only the rear and side still bear the mosaic facings of enamelled tiles, though in a very injured condition. The blue tiles which covered the dome have nearly all fallen off, and of the inscriptions in large Cufic letters which surround it only the end can now be deciphered. ... Similar inscriptions - gigantic ornamental texts from the Koran, in blue on a white ground - run around the frieze, and the building, which is still grand in its decay, was evidently once wondrously beautiful. Earthquakes and despoilers have ruined it, leaving 
THE HISTORICAL LIFE OF AHMAD YASAW

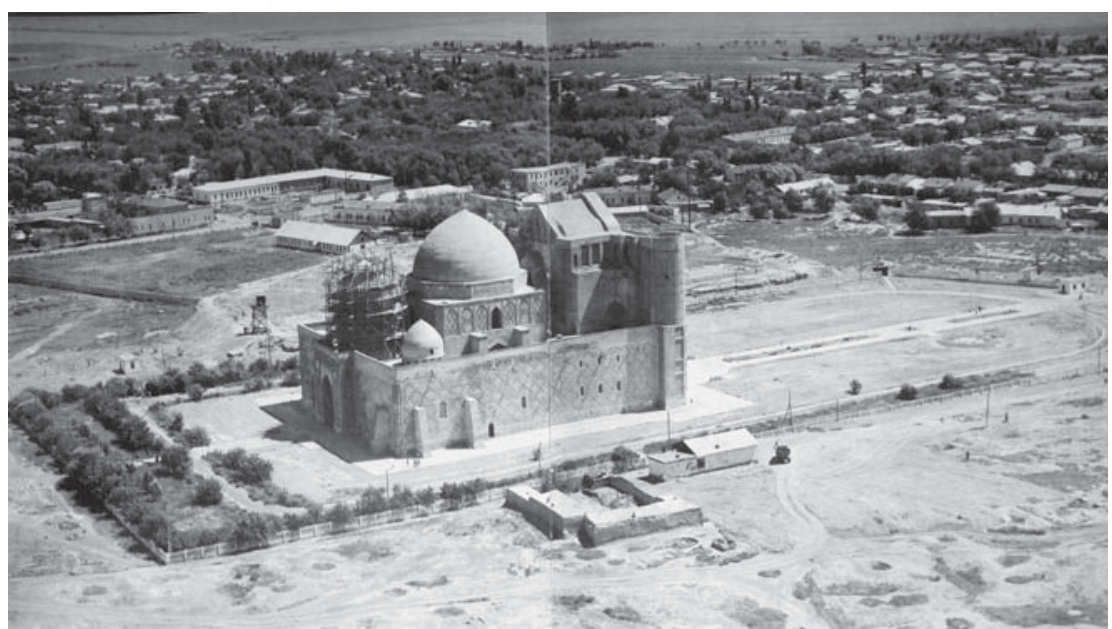

Figure 1 The shrine of Ahmmad Yasawī in Haḍat-i Turkestan, Kazakhstan, during restoration. (Photo courtesy of the Turkish Ministry of Culture.)

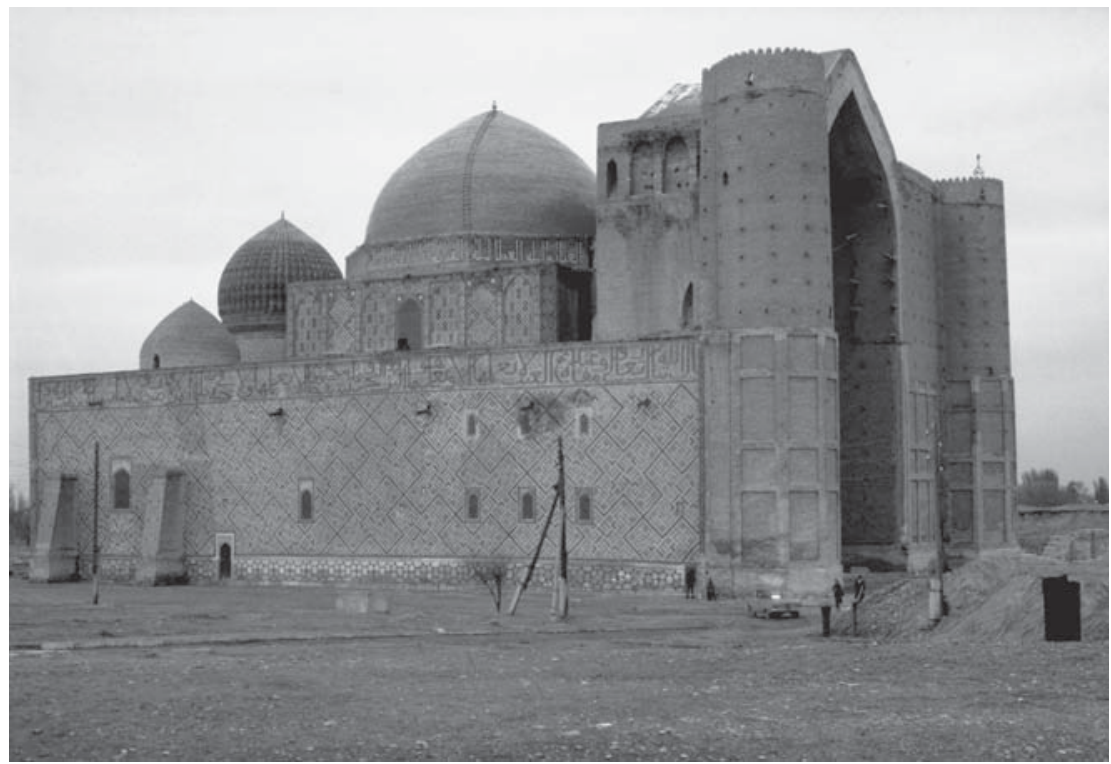

Figure 2 The shrine of Ahmad Yasawī in Haḍrat-i Turkestan, Kazakhstan, after restoration. (Photo courtesy of Jonathan Bloom.) 
large cracks, now filled up in many places with coarse plaster. The front was apparently never completed, for the old beams which once served as scaffolding, remain standing in the walls, occupied now by immense storks' nests. . . . In the middle of the mosque \{i.e. shrine\} is an enormous hall, under the lofty dome which rises to a height of over a hundred feet, and is richly ornamented within with alabaster work in the style common in Moorish buildings, and especially seen in the Alhambra. On the right and left are rooms filled with tombs of various Kazak sultans of the Middle and Lesser Hordes, among them the celebrated Ablai Khan. One room answers for a mosque, where the Friday prayers alone are said, while under the small dome at the back of the building are the tombs of Ahmed Yasavi and his family, ${ }^{56}$ and opening out of a long corridor full of tombs is a large room with a sacred well. Next to the tomb of the saint the most interesting monuments are those erected to a great-granddaughter of Timur, Rabiga-Sultan-Begim, daughter of the famous Ulugh-Bek. She was married to Abulkhair-Khan, and died in 1485. One of her sons lies next to her.

The walls of the first room are covered with numbers of inscriptions, chiefly short prayers or verses from the Koran, one of which is said to have been written by Muhammed Ali Khan of Khokand, who was killed by the Amir of Bukhara in 1842; and in the middle, standing on a pedestal, there is a large brass vessel like a kettle, which would contain at least fifty gallons of water ${ }^{57} \ldots$

In the little enclosure in front of the portal are numerous tombs bearing inscriptions, and in a corner of the large court-yard is a small and very elegant mosque, with a lemon-shaped cupola, covered with blue tiles. The local legend runs that this was the temporary restingplace of the body of Rabiga-Begim, whose early death caused Timur such grief that he built the great mosque \{shrine $\}$. Unfortunately history shows that she died some eighty years after him, and it is very doubtful if he ever saw her.

The termination of the great mosque \{shrine\} called Hazret was almost contemporaneous with Timur's death. The word Hazret, an Arabic word, meaning literally "presence," is used in the sense of "majesty" for rulers, and with the meaning "sanctity" is frequently applied to saints, especially to those most reverenced, and in this case the celebrity of the saint has given a name to the town, which is often called "HazretiTurkestan," or even simply "Hazret."

Besides the mosque \{shrine there is little in Turkestan to interest one. The city has much fallen off, and barely numbers six thousand souls. $^{58}$

With regard to its architectural style, this work follows the same basic lines as the others built in Central Asia during the reign of Tīmūr. 


\section{F Present-day Yasī}

Still retaining its historical repute, Yasī, today called Turkistan, is a small dilapidated Turkish \{rather, Qazaq\} town on the Orenburg-Tashkent railway. It is the capital of the district of Turkistan, which constitutes the sixth division of the province of the Syr Darya, which was divided into eight divisions in the Tsarist period. About a century ago $\{c .1820\}$, it had 965 houses and a population of 5223 composed of Sarts \{rather Uzbeks\} and Qazaqs. The city's ruined fortress and its only monument, the Jāmi'-i Hadrat, which is in the middle of the fortress, are visible. Ascending to a high point on this building, one is greeted by a very picturesque landscape. First, the dilapidated Sart city spreads round about with its dirty tangled streets and gloomy houses. Among the confused mass of streets and buildings, the ruins of the old palace of the Khān and the Russian church stand out. Then, beyond the limits of the city and past the well tended arable fields lie the town of İān and other Qazaq villages and in the distance the snowcapped peaks of the Karatau range. This part of Asia, in fact, is covered with ruins. The fortresses that served to defend the fords of the Syr Darya have long been abandoned and mounds are scattered about the plain. South of Yasi are Utrar, where Tīmūr died, and Savrān \{actually northwest of Yasī , each of which is nothing but a heap of ruins. ${ }^{59}$

After belonging to various dynasties of Asia at different times, Yasī became for a while the capital of the Qazaqs ${ }^{60}$ and finally in 1864 it was taken by the Russians. The walls of Jāmi'-i Hadrat still bear marks of the terrible Russian artillery bombardment. ${ }^{61}$ Nevertheless, thanks to the mosque and to Khwāja Aḥmad Yasawī who lies beneath its dome, this small city still retains its sacred character among all the Eastern and Northern Turks. Over the centuries, not only have a great many rulers visited it but poets have also never stopped praising its holiness. ${ }^{62}$ Even today, throngs of people come from various places in Turkistan to visit \{i.e. make a pilgrimage to $\}$ the tomb of the khwajja. This tomb is visited continuously, but once a year on 10 Dhū 'l-Hijja \{' $\bar{I} d$ al-aḍā $\}$, the Șūfîs withdraw into seclusion with extraordinary ceremonies. ${ }^{63} \mathrm{Up}$ to recent years, 5000-6000 people used to gather there solely for this purpose. ${ }^{64}$ Visiting the tomb of Ahmad Yasawī, whose legends and miracles are related in popular works among the Northern Turks and throughout the steppes, and about whom many eulogies and hymns are sung, ${ }^{65}$ is considered in that region to be of greater merit than making the pilgrimage to Mecca.

The khwajja's greatest influence is over the people of the steppe. Throughout this area, one finds numerous legends, as well as tombs of the khwäja's disciples, which testify to this influence. For example, the name of the town of Awliyā Ata, which Howorth claims to be identical with the old city of Tarāz, was taken from the byname of a Șūfì named Qarakhān, who was a descendant of Ạ̣mad Yasawī. His türbe, which is a ruined building made simply of bricks, has given its name to the entire town. Also, according to a local tradition, the great türbe of Asa Bibi, a kinswoman of Qarakhān, is next to the road ten miles west of the town of Awliyā Ata. ${ }^{66}$ 
According to the report of a Russian traveler, if a rich Qirghiz or Qazaq belonging to the Great or Middle horde dies in the winter, he is not immediately buried. Instead, his corpse is tightly wrapped in a piece of felt or cloth and then hung from a tree. As soon as spring arrives, his corpse is taken to Yasī and buried near the tomb of Qara Ahmad - their name for Ahmad Yasawī. ${ }^{67}$ Indeed, the rich, while still alive, buy a plot of land near the türbe and place feathers on it, and when they die they are buried there. ${ }^{68}$ Qazaqs who do not have children go to the shrine and sacrifice sheep to the spirit of the khwajja next to the great cauldron. ${ }^{69}$ All of these reports show that this early influential leader of Turkish Sunfism in the Syr Darya region and throughout Central Asia has still maintained over the centuries his legendary greatness in all its former glory. ${ }^{70}$

\section{NOTES}

1 \{Hazīnī, Fawähir, p. 49. This account is found only in this book. All other sources state that the khwajja was born in Yasī. Nevertheless, it would not be wrong to prefer this work to the other sources, which all transmit the same material, because it contains the most plausible accounts of the khwäja and was written by a Yasawi dervish who was most familiar with the Yasawi tradition. There are a number of other historical reasons for preferring this narrative. According to tradition, Sairām had long been an important Islamic center and its inhabitants were divided into three clans (uruğ), i.e. three divisions: the Shāh clan, who traced their descent to the early Tajik shāhs; the Amīr clan, who traced their descent to the early amīrs and mīrzās \{princes\}; and the Khwāja clan, who were the descendants of 'Alī. Naturally, this third uruğ, who were related to the family of the Prophet, were held in greater esteem than the others. This tradition, which has been current among the people of Sairām up to recent times, considers all the khwäjas to be descendants of Imām Muhammad Ibn al-Ḥanafiyya (Mullā Mūsā b. Mullā 'İsā Sairāmī, Ta'rīkh-i amaniyya [Kazan, 1905], p. 286). \{This is a rather garbled version of local Sairāmī tradition.\} Indeed, the author of this history traces his own genealogy from Kamāl al-Dīn Bāb Shaikh, whose descent from the Prophet was confirmed in a yarly̆g \{edict\} given by 'Abd Allāh Khān in 945/1538-9 to Imām Muhammad Ibn al-Hanafiyya in the following manner: Kamāl al-Dīn Bāb, Sayyid Ibrāhīm Bāb, Sayyid 'Abd al-Jabbār Bāb, Sayyid 'Abd al-Karīm Bāb, 'Abd al-Majīd Bāb, 'Abd al-Wudūd Bāb, 'Abd al-'Azīz Bāb, Arslan Bāb, Ilyās Bāb, Mahmūd Bāb, Iftikhār Bāb, 'Uthmān Bāb, 'Umar Bāb, Ismāêil Bāb, Ishāq Bāb, 'Abd al-Karīm Bāb, 'Abd al-Jalīl Bāb, 'Abd al-Rah̄ìm Bāb, 'Abd al-Raḥmān Bāb, 'Abd al-Jabbār Bāb, 'Abd al-Fattāḥ Bāb, Imām Muḥammad Ibn al-Hanafiyya; ibid. If we compare this genealogy with that of Ahmad Yasawi mentioned above, we find a very close similarity. Ilyās Bāb was Aḥmad Yasawī’s grandfather. Thus it appears that Arslan Bāb Ibn Ilyās Bāb, who was the grandfather of Kamāl al-Dīn Bāb, was the brother of Shaikh Ibrāhīm, Ahmad Yasawì's father. The fact that there were others in Sairām who claimed that they were descendants of Muhammad Ibn al-Hanafiyya - or, rather, that there were enough of them to constitute a clan - fully corroborates the birth of Ahmad Yasawī in Sairām. On Imām Muhammad Ibn al-Hanafiyya, see $\left\{\right.$ al-Sam' $^{\prime} \bar{n} n \overline{1}$, \} al-Ansāb \{facsimile ed. D. S. Margoliouth (London, 1912), eds al-Mu'allimī et al. (Hyderabad, Deccan, 1952-82)\}; and especially Ibn Khallikān, \{Wafayāt al-a'yān (Būlāq, 1299/1881-2), new ed. Iḥsān 'Abbās (Beirut, 1968-72), vol. 4, pp. 169-73, English trans. MacGuckin de Slane as Ibn Khallikān's Biographical Dictionary (Paris, 1842-71); see also $E I^{2}$, s.v. "Muhammad Ibn al-Hanafiyya" 
(Fr. Buhl) $\}$. \{In the text, Köprülü was in error in placing Sairām in Eastern Turkistan. He later corrected this in his article "Ahmed Yesevî" in $\dot{I} A$. In the note above, Köprülü states that "all other sources" affirm Ahmad Yasawī's birth in Yasī. This is not quite true. In so stating, Köprülü ignores the fact that the earliest sources (the Rashahāt and Nawa'ì) say this, and he goes on to defend Hazīn $\overline{1}$ 's account on the basis of a nineteenth-century source by a native of Sairām! There seems to have been some competition for the distinction of being Ahmad Yasawī's birthplace, and there are good grounds for claiming that Sairām's claim came later. In addition, there is no basis for dividing Hazīnī's account of Ahmad Yasawī's youth into "historical" and "legendary" elements. Finally, on genealogical traditions linked to Ahmad Yasawī, see DeWeese, "The Politics of Sacred Lineages in 19th-century Central Asia: Descent Groups Linked to Khwaja Ahmad Yasavi in Shrine Documents and Genealogical Charters," International Fournal of Middle Eastern Studies, 31 (1999), 507-30, with further references.

2 Shams al-Dīn Sāmī, Qāmūs al-âlām \{Istanbul, 1889-98, reprinted Ankara, 1996\}. Chavannes (Documents, p. 238) says that the information given by Arab authors on this city, which is not mentioned in \{Yāqūt's\} Mújam al-buldān, was collected and summarized by É. Quatremère, \{"Notice de l'ouvrage qui a pour titre Mesalik Alabsar fi Memalik Alamsar, Voyages des yeux dans les royaumes de différentes contrées,"'\} Notices et Extraits des Manuscrits \{de la Bibliothèque de Roi\}, 13 (1838), p. 224, n.1. See the detailed information on this city in Chapter 5, p. 133.

3 According to tradition, he died in 562/1166-7 after the age of 120. Also according to tradition, Arslan Bābā took upon himself his education in the fifth/eleventh century. \{Köprülü never seriously grapples with the date of Ahmad Yasawī's death. This issue is more complicated than he suggests. Indeed, there is little reason to give credence to the notion that Ahmad Yasawi died in 562. The invocation here of "tradition" as a source for this death date or for his "training" by Arslan Bābā makes no sense; the first comes from a specific source, while the second is based on a source that never gives any kind of date. $\}$

4 \{Hazīnī, \} Jawāhir, p. 66. When speaking of his father's tomb, Ahmad Yasawī gives it the name Aq-türbet (Dīwān-i Hikmat, p. 33). \{Note: this same account of Ahmad Yasawì's family is presented in the previous chapter from the same source as "legendary."

5 Ibid., pp. 48-9. I mentioned above that Bektashī tradition also presents Aḥmad Yasawī as a descendant of Muhammad Ibn al-Hanafiyya. No such detailed genealogy is found, however, in any other source. \{Ạmad Yasawī's descent from Muhammad Ibn al-Hanafiyya is attested, for example, in Sharaf al-Dīn 'Alī Yazdī's work from the early fifteenth century; and a full genealogy appears already in the Turkic work of Ishāq Khwāja b. Ismā'ill Ata from the fourteenth century.\} Yet there are some things that corroborate this in a number of verses in the published version of the Diw $\bar{a} n-i$ Hikmat, which was written by Yasawī dervishes in different periods based on early tradition, on his belonging to the lineage of Haidar (Dĩwan-i Hikmat, p. 267), and on Isḥāq Bābā and Shaikh Ibrāhīm (ibid., p. 270). It is not particularly difficult to investigate the origin of these legends. Even today there are several legends in Turkistan about how some of the descendants of 'Alī, and especially those related to Ja'far al-Ṣādiq and Muhammad Ibn al-Hanafiyya, went as far as that region. Mullā Mūsā of Sairām states that Ja'far al-S̄ādiq had a place of pilgrimage in Khotan; that Imām 'Abd al-Raḥmān 'Alawī, who was renowned under the name Bațtāl Ghāzī and was buried in Aqsu, was the fourth grandson \{removed\} of Muhammad Ibn al-Hanafiyya; that the tomb of Alp-Ata the sixteenth grandson \{removed\} of Muhammad Ibn al-Hanafiyya was in Turfan; that the tomb of Bābā Qanbar Walī, 'Alī's master of the horse $\{$ mirahor\}, was in Kūchā; that those of a number of imāms were in Ush-Turfan; 
and even that there was a tradition in the latter place that 'Alī had visited it (\{Mullā Mūsā,\} Ta'ñ̄kh-i amaniyya, pp. 316-19, 358). There are a great many legends similar to these in other places in Turkistan. Needless to say, they have no historical value. \{On the narrative of Islamization focused on Ishāq Bāb, an ancestor of Ahmad Yasawī, see DeWeese, "Yasavian Legends on the Islamization of Turkistan," in Denis Sinor (ed.), Studies in Altaic Civilization III (Bloomington, IN, 1990), pp. 1-19, and Safi ad-Din Orïn Qoylaqï, "Nasab-nama”, ed. Äshirbek Qŭrbanŭlï Muminov and Zikiriyä Zamankhanŭlï Jandarbekov (Turkistan: "Mŭra," 1992).\}

6 While discussing the region of "Turkistan and the Steppe" in Chapter 27 of his Fihān-numā, Kātib Chelebi gives the following information on Yasī: Yüzbir derece tûl,

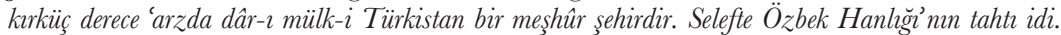
Meşâyih-i nakşbendîye'den Hoca Ahmed bu şehire mensûpdur \{ It is a famous city in the country of Turkistan at 101 degrees longitude and 43 degrees latitude. At a former time it was the capital of the Özbek khānate. Khwāja Ahmad, who was a Naqshbandī shaikh, got his byname from this city\} (published version \{apparently Istanbul, 1145/ $1732\}$, p. 367). Ahmad Vefik Pasha, under the rubric "Turkistan" in his Lehce-i osmân $\hat{\imath}$ \{2nd edn (Istanbul, 1306/1890)\}, says Semerkand şimâlinde sâbıkâ Kazaklar' ın şehri, Nesâ,, Ahmed Nesầ $\hat{\imath}$ makâm, türbet-i hazret \{formerly the city of the Qazaqs north of Samarqand, Nasā', the tomb of Ahmad Nasā' $\overline{1}$, the türbe of the exalted one\}, thus confusing Nasa $\bar{a}^{\prime}$ with Yasī. Similarly, Yasī appears as Nasā' in the published edition of \{Mīrkhwānd, \} Rawdat al-safa (vol. 6, p. 126). The reason for this is that the authors, or those who copied them, confused these two names. Kātib Chelebi mentions two Nasā's, an upper Nasā' and a lower Nasā', in Farghāna, and another, a third, in Khurāsān and says that the last one was famous (Fihān-numā, p. 357). A great many 'ulam $\bar{a}$ ', in fact, came from this Nasā' in Khurāsān. Yāqūt mentions four more cities with this name (Mújam al-buldān, Chapter 8, pp. 282-3); Barbier de Meynard, Dictionnaire géographique, p. 564). The French Orientalist Louis Dubeux, while discussing Yasī, reports that it had previously been called Țarāz (Tartarie \{Béloutchistan, Boutan et Népal\} [Paris, 1848], p. 113), which is totally mistaken, however. This old historic city $\{$ TTarāz $\}$, which was very well known to both Chinese travelers and historians and to the Arabs, indeed, even to the Byzantine ambassador Zemarchus, had long had great importance because it was at a pass at the junction of two major trade routes between Iran and Turan. The \{sixth-century\} Byzantine historian, Menander Protektor, who cited the embassy of Zemarchus, called this city "Tālās." The Chinese traveler Hsüan Tsang called it "Ta-lu-si" and some Chinese historians called it "Ta-la-za." The Arabs called it "Tarāz." According to H. Howorth, it is none other than the present-day Awliyā Ata (History of the Mongols [London, 1880-8], vol. 2, part 1, Chapter 4, n.1 \{i.e. part 2, division 2, pp. 284-7\}. Virtually all the information on this city is collected here \{Howorth\}. Chavannes, Documents, p. 238). It is clear from all of this that Tarāz, which had been known since the sixth century GE, is completely different from Yasī. Detailed information is given on these cities in Chapter 5, p. 154, n.28.

7 See Chapter 4, p. 92 for information on the historical existence of Arslan Bābā and on his family.

8 After Bukhārā passed into the hands of the non-Muslim Qara Khițāy, the influence of these sadrs continued, however, in a different form. Alptigin, the governor appointed by the Qara Khițāy ruler, was obliged to refer all questions to Sadr-i Imām Ahmad b. 'Abd al-'Azīz (see Barthold, $E I^{l}$, s.v. "Bukhārāa" and "Burhān," who cites Niẓām-i 'Arūḍī). For the information on the șadrs provided by Mīrzā Muhammad b. 'Abd al-Wahhāb Qazvīn̄i, see the first vol. of \{Muhammad 'Awfî's\} Lubāb al-albāb, eds E. G. Browne \{and Qazvīnī (London, 1903)\}, vol. 1, pp. 332-3. The most important research on sixth/twelfth-century Bukhārā, based on Arabic and Persian sources, is found in Barthold's Turkestan. For the summary above, I was content with referring to 
this book and his $E I^{I}$ articles "Bukhāāā" and "Burhān." These șadrs are also mentioned in one of the Mathnaw ${ }^{2}$ stories \{of Rūmī\}. \{See $E I^{2}$, s.v. "Șadr" (J. Calmard et al.).\}

9 An important treatise entitled Maqāmāt-i Yüsuf Hamadānī, attributed to Khwāja 'Abd

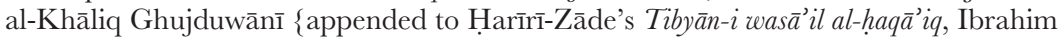
Ağa MS 432 in the Fatih Library in the Süleymaniye in Istanbul\}, states clearly that eleven people - Ghujduwānī among them - went with Khwāja Yūsuf from Hamadān to Samarqand; also that Yūsuf Hamadānī went to Samarqand at the direction of Khaḍir; and that while he was residing at Mahalla-i Khūsh, Khwāja Hasan Andāqī and Khwāja Aḥmad Yasawī arrived and nine months later were joined by Khwāja 'Abd Allāh Baraqī. But \{Muhammad Pārsā's\} Faṣl al-khițāb, and also \{Ṣafî̀s\} Rashahāat and \{Jāmī's\} Nafahāt, which cite it, report that 'Abd al-Khāliq Ghujduwānī became an adherent of Khwāja Yūsuf in Bukhārā - indeed, that Aḥmad Yasawī also became an adherent of him there (Fasl al-khita $\bar{b}$, MS in the \{Istanbul\} University Library). Still, Imām \{'Abd Allāh b. As'ad\} al-Yāfi'î̉s history \{Mir'ät al-janān wa 'ibrat al-yaqzan fi márifat hawädith al-zamān (Hyderabad, 1337-9/1918-21, and Beirut, 1984)\} and al-Sam'ānī's al-Ansāb specify that Khwāja Yūsuf had previously resided in Baghdad, Isfahan, Bukhārā, and Samarqand for the purpose of learning Hadìth, and if we take into consideration contemporary dervish life, the possibility that he could also have been in those places later cannot be completely ruled out. In any case, the story in the Maquamat is not implausible enough to be rejected outright or be regarded as a fabrication. \{Wilfred Madelung, in his "Yūsuf al-Hamadān̄ī and the Naqšbandiyya," Quaderni di Studi Arabi, 5-6 (1987-8), 499-509, highlights the discrepancies between the early and reliable biographical tradition about Hamadānī, on the one hand, and the version of his biography incorporated into Naqshbandi tradition, on the other. Köprülü himself already noted the discrepancies, but he did not explore them in depth, and was unable to get out from under the assumption that Ahmad Yasawī was a disciple of the historical Yūsuf Hamadānī. In any case, Madelung's study demolishes the synthetic view of Hamadānī accepted in nearly all secondary literature, including Köprülü.\}

10 \{Yāqūt,\} Mújam al-buldān, vol. 2, p. 302. This lineage was taken from there. Ibn Khallikān says that he did not know the meaning of the name Wahara at the end of this genealogical chain \{Wafayāt, 'Abbās edn, vol. 7, p. 80\}.

11 On Yūsuf Hamadānī, Ibn Khallikān made use of al-Sam'ānī's al-Ansāb and Ibn al-Najjār's Ta'rīkh Baghdād (\{Wafayāt, \} vol. 2, pp. 464-5 \{'Abbās edn, vol. 7, pp. 78$81\})$. \{See $E I^{2}$, s.v. "Ibn al-Nadjdjār" (C. E. Farah).\}

12 Based on the information that Khwāja Muhammad Pārsā gives in his Fașl al-khițāb, which was taken from Mawlānā Sharaf al-Dīn 'Aqīīin, the author $\{$ Șafî̀ of the Rashahāat writes that Yūsuf Hamadān̄ was eighteen years old at that time (p. 13). Khwāja Muhammad Pārsā's verbatim account of this matter is as follows:

$$
\begin{aligned}
& \text { مولانا شرف الملة والدين العقيلى الانصارى البخارى روح اللَّه تعالى روحه كه از كبار علما اند } \\
& \text { واز خاندان خواجكان بخط مبارى ايثًان مكتوب است كه شيحخ يوسف همدانى قدس الله روحه هزده } \\
& \text { ساله بودندكه بيغداد رفتتد و أز ابو اسحاق فقيه علم فقَه آموختند و در علم نظر بدربة كمال } \\
& \text { وسيدند وبر مذهب امام اعظم ابو حنيفه رضى اللّه عنه بودند ودراصبهان وبخارا تعلم كردند } \\
& \text { ودرعراق وخراسان وخوارزم وماوراء النهر صاحب قبول بودند }
\end{aligned}
$$

\{Mawlānā Sharaf al-Milla wa 'l-Dīn al-'Aqīī̄ al-Anșarī al-Bukhārī, may God rest his soul, one of the great 'ulama', of the dynasty of the Khwājagān (Naqshbandiyya), has 
written in his own hand that Shaikh Yūsuf Hamadān̄, may God sanctify his soul, was eighteen years old when he went to Baghdad. He studied fiqh with Abū Ishāa Faqīh, and reached perfection in philosophical speculation (' $i l m-i$ nazar). He was a Hanafī by madhhab. He studied in Isfahan and Bukhārāa, and became an authority (șāhib-qabūl) in Iraq, Khurāsān, and Transoxiana, \} Faṣl al-khițāb, MS in the \{Istanbul\} University Library). Nevertheless, Ibn Khallikān, whose information is credible given the sources on which he relied, indicates that he went to Baghdad after 460/1067-8 \{Wafayat, 'Abbās edn, vol. 7, p. 78\}. Taking this into consideration, we would have to admit that Yūsuf Hamadānī probably went to Baghdad after age twenty. \{Again, see Madelung, "Yūsuf al-Hamadān̄ī." On the Khwājagān, see $E I^{2}$, Supplement, s.v. "Khwādjagān" (Th. Zarcone)\}

$13\{$ Șafī, Rashahāt, \{Turkish\} trans., p. 12; and \{Jāmī,\} Nafahāt, \{Turkish\} trans., p. 409. This story is also based on the information that Khwāja Muhammad Pārsā $\{$ Fașl al-khitāb $\}$ derived from Sharaf al-Dīn 'Aqīīi.

14 Ibn Khallikān, \{Wafayāt, $\}$ vol. 2, p. 465; \{Yāqūt,\} Mu'jam al-buldān, vol. 2, p. 303; \{Ṣafī,\} Rashahāt, \{Turkish\} trans., p. 13; \{Jāmī,\} Nafahăt, \{Turkish\} trans., p. 409. Ibn Khallikān indicates that Bāmiȳ̄n \{Bāmayīn $\}$ is between Herat and Baghshūr, while Yāqūt makes it a place subordinate to Bādhghīs. According to the explication in the Mújam, Bāmiȳn was the center of the qașaba \{district\} of Bādhghīs between Marw al-Rūd and Herat. The same source also states that Baghshūr was between Herat and Marw al-Rūd (see Mújam, vol. 2, and Barbier de Meynard, Dictionnaire géographique).

15 \{Safí,\} Rashahāt, \{Turkish\} trans. p. 13. \{The Rashahāt's identification of Ibn al-Najjār as one of Yūsuf Hamadānī's disciples is an example of garbled transmission. Ibn al-Najjār was a thirteenth-century author of a work that incorporated biographical traditions about Hamadānī, but through Pārsā, Jāmī, and the Rashahăt, he became a disciple of Hamadānī. $\}$

16 Ibid., p. 12, citing \{Muhamad Pārsā,\} Faṣl al-khițāb. \{Madelung, "Yūsuf Hamadān̄̄," points out that Hamadān ī is shown as a Shāfí̄ in the early biographical tradition, but becomes a Hanafi in the (no doubt spurious) texts circulated about his role in the Khwājagānī silsila.\}

17 Ibid., p. 13, citing al-Sam'ānī, \{al-Ansāb\}. \{The issue of whether Ahmmad Yasawī "joined" Hamadānī in Bukhārā or Samarqand is, in fact, an important point that helps to delineate the separate textual traditions that contributed to the Rashahät's composite account of Aḥmad Yasawī as a disciple of Hamadānī.\}

18 The famous Iranian Șūfì poet Hakīm Sanā'ì \{d. c.525/1131\} went from Ghaznīn \{Ghazna\} to Khurāsān, became an adherent of Yūsuf Hamadān̄̄, and resided for a time in his tekke in Marw (Dawlat-Shāh, Tadhkira, p. 97). Dawlat-Shāh, p. 95, also states the following about the fame of the tekke of Yūsuf Hamadānī: \{ خانقاه اورا از تعظيم و قدر كعبه خراسان مى كفته اند (dervish convent) "the Ka'ba of Khurāsān"\}. In \{'Abd al-Waḥ̣āb al-Sha'rānī's\} al-Tabaqāt al-șuffyya \{Cairo, 1305/1887-8\} his importance, some of his legends and sayings are mentioned in exceedingly reverential fashion as well, vol. 1, p. 135 \{published as al-Tabaqāt al-kubrā (Cairo, 1898; reprinted Cairo, 1965)\}.

19 Ibn Khallikān, \{Wafayāt,\} vol. 2, p. 464; \{Jāmī,\} Nafahăt, \{Turkish\} trans., p. 411. On this matter, Ibn Khallikān relies on Abū 'l-Faḍl Șāfî̀ b. 'Abd Allāh's account and those of Hāâz Abū 'Abd Allāh Muhammad b. Mạ̣mūd, well known as Ibn al-Najjār. In the Nafahāt trans. (p. 411), we find the note Bâzzlar İbnü's-Sakkâ hikâyesini buna muhâlif naklettiler \{Some cite the story of Ibn al-Saqqä' in opposition to him\}. This legend of Yūsuf Hamadānī was so famous that Ibn al-Athīr briefly relates it while mentioning Yūsuf Hamadānī among those who died in 535/1140-1 (al-Kämil, vol. 2, p. 31). 
20 I was not able to obtain an old copy of this Persian treatise that was appended to the third volume of \{Harīīi-Zāde's\} Tibyān-i wasa $\bar{a}^{\prime} i l\left\{a l-h a q \bar{a}^{\prime} i q\right\}$. There are some treatises belonging to 'Abd al-Khāliq Ghujduwān̄ in the Esad Efendi Library \{in the Süleymaniye in Istanbul $\}$, MS 3702, but despite all my efforts it was not possible to see them. Perhaps the original of the Maqūmāt-i Yüsuf Hamadān $\bar{i}$ is there. I have carried out considerable research to determine if this treatise is a complete fabrication or if it is really a work by 'Abd al-Khāliq Ghujduwānī and has some historical value. There are, in fact, clear contradictions between the information provided by this treatise and the reports in al-Sam'ānī and other sources. For example, Khwāja Yūsuf's lineage, in a wholly fictitious manner, is traced to Abū Hanīfa. Then, not only is his birth date erroneous but we also find, for example, a report to the effect that he never cursed Chingiz Khān, whereas Chingiz Khān appeared only after the death of the khwäja. In addition, there are a number of exaggerations, such as "that he made the pilgrimage to Mecca 32 times on foot, that he made 10,000 complete recitations of the Koran, that he memorized 700 books of fiqh, tafsīr \{exegesis, especially Koranic \} and kaläm \{scholastic theology\}, and that he converted 8000 idolaters to Islam." For a muñd who believed in his shaikh, however, these exaggerations were of no consequence. A number of things like this, which cast doubt on the \{historical\} reliability of the treatise, may have been introduced through the process of copying and recopying over the centuries, or could have been added by a later copyist for various reasons. If we take into consideration how much the "dynasty" (suläla) of the Khwājagān \{Naqshbandiyya\} was in demand and respected in Central Asia at the time of the rulers who were descendants of Chingiz Khān, then we could readily grant that any dervish could add such things in order to curry favor with the ruler. Otherwise, the information that 'Abd al-Khāliq Ghujduwānī gives in his own biography and the descriptions that he gives of the khalifas of the khwäja, their actions and character, conform exactly to the other sources and complement them in an exceptional manner. If this treatise had been completely fabricated, then its author would be someone so unfamiliar with chronology as to consider Chingiz Khān a contemporary or predecessor of Khwāja Yūsuf Hamadānī, and he would not have known that period of history and the khwäja's spiritual personage so completely and accurately, and so would have filled this treatise with a bunch of wild legends. In light of all these observations, we can conclude that this treatise, which portrays Yūsuf Hamadānī in such a manner, was written by 'Abd al-Khāliq Ghujduwānī, but that the version that has come down to us was corrupted and altered as it was copied and recopied [on Ghujduwāni and the Maqāmāt-i Yūsuf Hamadānī, see $\dot{I}$, s.v. "Gucduvânî" (Kasım Kufralı), \{cf. EI ${ }^{2}$, s.v. "Ghudjduwān̄̄" (S. Naficy)\}].

In the rich and truly valuable library of Bağdadlı Vehbî Efendi \{in the Süleymaniye Library in Istanbul\}, there is a Risāla-i bāburiyya by Aḥmad b. Jalāl al-Dīn al-Kāsānī \{known as Makhdūm-i A'ẓam, d. 1542-3, see EIr, s.v. "Ahmmad $\underline{K}^{\mathrm{v} a ̄ j a g i ̄ ” " ~(J . ~ F l e t c h e r)\} ~}$ on Șūî̀ rules and another treatise on Yūsuf Hamadānī. \{These two works are bound together. The latter is ascribed to Makhdūm-i A'zam and stands as sixteenth-century evidence for the circulation of a work similar to the Maquāma t of Hamadānī ascribed to Ghujduwāni. . As the author clearly states, part of this treatise was abbreviated from 'Abd al-Khāliq Ghujduwān̄̄'s Maqāmāt-i Yüsuf Hamadān̄̄. At the end of it, there is rather abundant information on the khal̄̄fas of Yūsuf Hamadānī and on the chains of authority of Bahă' al-Dīn Naqshband and Sa'd al-Dīn al-Kāshgharī. The first part of this treatise, equivalent to an abridged version of one section of the copy of the Maqāmāt that I have studied, indicates that this work was not fabricated, but that it had been current among the Naqshbandī dervishes for centuries. There is nothing so incongruous here as the issue of Chingiz Khān as to undermine one's confidence in the text. Clearly, such details as this were added by various people as the treatise 
passed from hand to hand. It is stated in this work too, however, that Yūsuf Hamadānī died in Samarqand in 505/1111-12. The year 505 could well be a mistake for 535/ 1140-1. As for his death in Samarqand, this contradicts Ibn Khallikān. Nevertheless, these details show that the work attributed to 'Abd al-Khāliq Ghujduwānī cannot be simply rejected. The author \{al-Kāsān̄î of the treatise says, "Although Khwāja \{'Ubaid Allāh\} Ahrār had a great many khalîfas, the last of whom was Aḥmad b. Jalāl al-Dīn al-Kāsānī, the real khal̄ fa of khal̄̄fas was his \{the latter's\} own murshid Mawlānā Muhammad al-Qāḍ̄ and this man was buried at the feet of Khwāja Ahrrār." This treatise, which was apparently copied in India in 1184/1770-1, includes the following biographical note on the author: "The shaikh of shaikhs, his excellency Shaikh Burhān al-Dīn Q1lıch was a companion of Shaikh Abū 'l-Qāsim Gurgānī and Khwāja Yūsuf Hamadānī. He died in $490\{1096-7\}$. His excellency my father used to say 'My son has become an adherent of his excellency Shaikh Burhān al-Dīn Qılıch and they will call his son Q1lichlığ Ata.' If this shaikh looked at a withered tree, it would turn green. If he saw someone deviating from the path of the Shari' $a$, one look from him would behead him. He was very awe inspiring and quick tempered." \{This detail confirms the identity of the treatise that Köprülü saw with a treatise, ascribed to Makhdūm-i A'zam (who was a descendant of "Q1lich Ata"), found in some, but not all, collections of Makhdūm-i A'żam's treatises. In some collections it is called the Risāla-i 'ilmiyya.\}

\{On the problems with the Maqāmāt, see Madelung, "Yūsuf al-Hamad̄ān̄̄" and DeWeese's forthcoming analysis. A version of this work was published by Sa 'īd Nafìsī as "Risālah-i șāhibiyah," Farhang-i İān-zaminn, 1/1 (1332/1953), 70-101. This work cannot be by Ghujduwānī. It survives in fuller manuscript versions and is paralleled by another set of traditions about Ghujduwānī and Hamadānī that probably reflect communal splits in the early Khwājagānī tradition. It cannot be used at face value as a source on Hamadānī. The dates mentioned in the work (and the supposed letter from Sanjar mentioned below) are also completely unreliable. It is worthy of note that the text credits Hamadān $\overline{1}$ with going on holy war and converting unbelievers to Islam. Depending on the version, they are identified as "Jete" or "Toqmaq," which are fourteenth and fifteenth-century terms for Mongol groups, or as Russians, which is evidence of the late date of the text.\}

21 It is also mentioned in the Maqāmāt that Yūsuf did not do the dhikr aloud and, indeed, that at that time there was no audible dhikr. Somewhat different information is given on this, however, in the translation of \{Ṣafî's\} Rashahăt. See Chapter 4, p. 101.

22 Malik Shāh's son Sultan Sanjar was appointed governor of Khurāsān by Barkyārūq who had taken possession of the entire sultanate on the death of his brother Mahmūd in 487/1094 and then became involved in the fighting between him and their other brother Muhammad. From the death of Barkyārūq in 498/1105 to the death of Muhammad in 511/1118, he ruled Khurāsān independently. According to the aforesaid story, his sending a letter to Khwāja Yūsuf Hamadānī thus occurred during this time. From Sanjar's attitude toward al-Ghazālī \{see below, n.28\}, we can suppose that he would certainly have had a great interest in legal and mystical questions and in particular that he would want to learn about the lifestyle of a shaikh famous for his great devotion to the sunna of the Prophet. We learn from a very amusing and clever episode that Dawlat-Shāh cites from Suwar al-aqātìm \{not further identified\} how contemptuous Sanjar was of Shī̄i beliefs (Dawlat-Shāh, Tadhkira, p. 66).

$23\{$ Ghujduwānī, \} Maqāmāt-i Yūsuf Hamadānī. According to this account, Khwāja Yūsuf must have died in Samarqand. Other sources, however, are unanimous in giving a much different report. To be sure, even in the Maqāmāt, it is not explicitly stated that his death occurred in Samarqand; rather, this can only be inferred from the context. \{More tellingly, the Maquamat insists he was buried in Samarqand, while Yūsuf Hamadānī's shrine in Marw is well known.\} 
24 Among these khal̄̄fas, Aḥmad Yasawī and 'Abd al-Khāliq Ghujduwān̄̄ in particular won great fame. The first two khalif fas did not become very famous.

25 In his Faṣl al-khitāb, for example, Muhammad Pārsā cites him frequently and uses phrases that express deep respect for him. Al-Sam'ānī $\{a l-A n s \bar{a} b\}$ also says that he was a well known traditionist $\{$ muhaddith .

26 Shaikh Najīb al-Dīn Shīrāzī states that he came across some of the khwäja's works and that the khwaja appeared in one of his dreams and told him that these works, the name of the author of which was not clear, belonged to him (\{Jāmī $\}$ Nafahăt, \{Turkish\} trans., p. 410). \{The subject of the story mentioned here from Jāmī's Nafahăt actually refers to himself (in the dream) as Abū Yūsuf, not Yūsuf Hamadānī.\}

27 An Arabic work by Yūsuf Hamadānī under the title Nahj al-asrār wa má dan al-anwār fì manāqib li-sādāt al-akhyār min al-mashāyikh al-abrär is mentioned with the number 4340 in the catalogue of the Ayasofya Library, but this work is nothing but Nūr al-Dīn 'Alī Ibn al-Jawzī's Kitāb-i Bahjat al-asrār wa ma'dan al-anwār, which describes the legends of 'Abd al-Qādir Jīlānī. \{A Șūfī work entitled Kashf al-asrār is ascribed to Yūsuf Hamadānī, but apparently it has not survived. $\}$

28 Because both the Qarakhānids and Seljuks were simple Muslims, they showed great respect to the 'ulam $\bar{a}$ ' and Șūfìs. The members of these two dynasties were extreme in their support of Sunnism - downright fanatic, in fact. Nevertheless, the Shīi movement, which had already appeared in Khurāsān in the Sāmānid period, was secretly present in Transoxiana. The 'ulam $\bar{a}$ ' in Bukhārā, which was the most important center of Sunnism in Transoxiana, fought continuously against Shî' ism. In 436/1044-5, a great Shī̄ì movement broke out in Transoxiana. Bughrā Khān crushed it by massacring the Ismā'îlīs (Ibn al-Athīr, \{al-Kämil, $\}$ vol. 8, p. 180). In any case, according to the information provided by Barthold, we can say that in the fifth/eleventh and sixth/ twelfth centuries the rulers of Transoxiana and the șadrs of Bukhārā were fervent Hanafîs. In this regard, see Chapter 1, p. 15, n.17 (Barthold, Turkestan). Nizām al-Mulk clearly shows what a fanatical Sunnī Alp Arslan was (Siyāsatnāme, sections 21 and 42). We also know very well how Sultan Sanjar dealt with al-Ghazālī for a while over an accusation of Mu'tazilism (\{Mehmed\} Şerefeddin \{Yaltkaya\}, "Sencer ve Gazzâlî," \{Darülfünûn Illâhiyat Fakültesi Mecmuasi, 1 (1341/1925), 39-57\}). Recent research on the subject of the madhhabs in the Seljuk period has corroborated all this (Şerefeddin, "Selçukiler devrinde mezâhib," $\{$ TM, 1 (1925), 101-8\}).

29 \{Ghujduwānī's\} Maqāmāt, \{Ṣafī's\} Rashahāt, \{Jāmī’s\} Nafahāt, and all the other biographical dictionaries that rely on them are unanimous on this point.

30 It is certain that Ahmad Yasawī became shaikh in Bukhārā, probably after the death of Yūsuf's first khaliffa, i.e. after 555/1160-1 (on the date of the death of 'Abd Allāh Baraqī, see $\{$ Lāhawrī, $\}$ Khazinnat al-asfiy $\bar{a}$ ', vol. 1, p. 531), because it is evident that both the first and second khalêfas were in Bukhārā and both were buried in Bukhārā near the tomb of Shaikh Abū Isḥ̄à Gülābādī (\{Șafī,\} Rashahāt, \{Turkish\} trans., pp. 1314). \{Köprülü is apparently not bothered by the fact that Lāhawrī (whose dates are mostly worthless) has Baraqī, the first khaliffa, dying in 555, but Andāqī, the second khalîfa, dying in 552. The accounts of the succession to Hamadāni all affirm that succession came upon the death of the prior successor (until Ahmad Yasawī broke the practice). Hence the curious death dates of Baraqī and Andāqī. On Ahmad Yasawī’s abdication of leadership to Ghujduwānī, see DeWeese, "The Mashä'ikh-i Turk and the Khojagān: Rethinking the Links between the Yasavī and Naqshbandī Sufi Traditions," Fournal of Islamic Studies, 7 (1996), 180-207. Here DeWeese shows that the depiction of Ahmad Yasawī handing his disciples off to Ghujduwānī is clearly a story contrived to favor the Khwājagān and Naqshbanidyya in competition with the Yasawiyya, etc.\}

31 Mawlānā Ghulām Surūr Lāhawrī, a religious scholar from India \{i.e. Lahore in modern Pakistan\}, describes the Naqshbandī silsila, cited from \{Șafì's\} Rashahāt, in his 
famous biographical dictionary of saints called Khazinnat al-asfiy $\bar{a}$ ', and while doing so provides information on Ahmad Yasawī. As an addendum, he mentions the following chronogram of his death, which is equivalent to 562/1166-7 (Khazinat, p. 532),

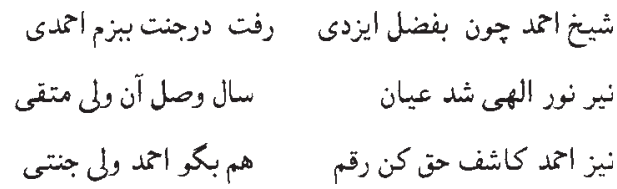

\{The Shaikh Ahmad, by divine grace, went to Paradise in the party of Muhammad The divine luminary became visible: the year that pious saint died

And Ahmad, revealer of Truth, add the numbers and say: "Ahmad saint of Paradise"

(the letters in =562). There are, in fact, other chronograms given in the Khazinnat al-asfiya $\bar{a}$, which were cited already in K. G. Zaleman (ed. and Russian trans.), "Legenda pro Khakim-Ata," Izvestiia Akademii nauk (SPb.), 9/2 (1898), 105-50.\} Melioransky, in $E I^{l}$, s.v. "Ahmed Yesewī," says "The year of his birth is not known, but in his Dīwān it is stated that he was 63 years old when he died." This remark can be refuted on several grounds. First, absolutely no one can state his own death date in his own dīwān! Second, not only does the existing tradition indicate that Ahmad Yasawi probably lived more than sixty-three years, but his poetry proves it. It is obvious that Melioransky did not understand that "entering the earth" in the line "ol sebepden altmişücte kirdim yirge" \{for that reason at age sixty-three I entered the earth\} meant "withdrawing from the tumult of the world," i.e. "entering the chilla-khanne," and thus he interpreted it to mean death. \{Köprülü actually pictures Ahmad Yasawī "entering the earth" at age sixty-three and continuing to write there. It did not occur to him that perhaps some later devotee of Ahmad Yasawī wrote the verse about entering the earth as a reflection of the traditions about him.\}

32 Nafahăt, \{Turkish\} trans., pp. 492-4. Shaikh Raḍ̄ 'l-Dīn 'Alī Lālā was in Ahmad Yasawī’s tekke in Turkistan. One day a man came from Khwārazm. Shaikh Lālā was in a cell doing his religious retreat $\{k h a l w a\}$. Shaikh Ahmad asked the man "Is there a dervish occupied with guiding people on the mystical way in Khwārazm?" The man answered, "A new young man has come. He is guiding people on the mystical way and has attracted a great many murīds." Ahmad Yasawi asked his name. The man said, "Najm al-Dīn Kubrā." Shaikh 'Alī Lālā had once seen Najm al-Dīn Kubrā in a dream and, interpreting this to mean that he $\{$ Najm al-Dīn $\}$ would guide him \{'Alī Lālā $\}$ on the mystical way, had searched for him for years. As soon as he heard his name during his retreat, he leapt up and girt his loins for a journey. Because it was winter, Khwāja Ahmad advised him to wait. But the exuberant dervish could not wait another day. He immediately went to Khwārazm and joined the service of Najm al-Dīn (p. 493). \{Köprülü did not know that Jāmī took this story from a much earlier source, the Chihil majlis of Amīr Iqbāl Sīstānī, a collection of sayings he compiled from his master, 'Alā' al-Dawla Simnānī, and dates from c.1325. It is the earliest reliably datable source to mention Ahmad Yasawī. \}

33 Mīrzā Muhammad b. 'Abd al-Wahhāb Qazvīnī, introduction to \{'Aț̣ār's\} Tadhkirat al-awliy $\bar{a}$ ', citing various sources like Yāfi'îs $\{$ Mir'ät al-janān $\}$, \{Nūr Allāh al-Shustarî’s\} Majālis al-mu'min̄̄n, \{Rāzī’s\} Haft iqtīm, \{Dārā Shukōh's\} Șāfinnat al-awliyā', \{Hidāyat's\} Riyāed al-'ārifiñ, and \{Jāmī's\} Nafahăt, \{Turkish\} trans., p. 480.

34 Shaikh Raḍī 'l-Dīn 'Alī Lālā died in 642/1244 during the caliphate of al-Musta'șim and was buried in Khurāsān (\{Hamd Allāh Mustawfī Qazwīn̄̄,\} Ta’rīkh-i Guzīda, 
facsimile ed. E. G. Browne [London, 1910], p. 751 \{new ed. 'Abd al-Husayn Navā'ì (Tehran, 1362 [1983 or 1984]\}). Originally from Ghazna, he was a cousin of Hakīm Sanā'̄̄. According to \{Jāmī's\} Nafahăt, his father Shaikh Sa'īd was a cousin of Sanā'ì. His father and Sanā'ì went on the pilgrimage to Mecca together. Also according to the Nafahăt, he had been in the company of Yūsuf Hamadānī. We showed above $\{n .18\}$ that Hakim Sanā'ì spent some time in Marw and in the tekke of Yūsuf Hamadānī. It is highly likely that Shaikh Sa'īd's meeting with Yūsuf Hamadānī occurred at that time. Raḍī 'l-Dīn 'Alī Lālā was born in $563 / 1167-8$ or 566/1170-1 in Khusraw-i Shīrgīr in the province of Juwain. Later he wandered for years as a dervish, visiting many countries in Asia. He was famous for having obtained $i j \bar{a} z$ as \{permission to teach a work on the authority of its author from 400 great shaikhs and for meeting in India with the legendary Abū 'l-Riḍā Bābā Ratan Hindī - who, just like Arslan Bābā, was a companion of the Prophet or, according to another story, was an apostle of Jesus, and lived 1400 years - from whom he received the comb of the Prophet (Dawlat-Shāh, Tadhkira, p. 222). On Bābā Ratan, see \{Muhammad b. Ya'qūb al-Fīrūzābādī, \}

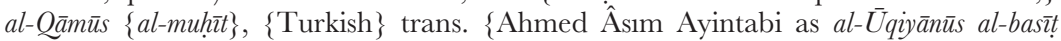
fì tarjamat al-qāmūs al-muhīt (Istanbul, 1268-72/1851-5)\}, vol. 3, p. 636. Bābā Ratan Hindī is a well known personage throughout the Eastern world. There are numerous references to him in various sources. See above all, for example, Evliyā Chelebi, \{Seyāhatnāme,\} Book 3, fo. 67a \{now see German trans. of this section by Korkut Bugday as Evliya Çelebis Anatolienreise aus dem dritten Band des Seyahatname (Leiden, 1996), p. 130\}; and in the dhail \{supplement\} to \{Tashköprü-Zāde's\} al-Shaq $\vec{a}^{\prime} i q$ \{i.e. Hadà'iq al-shaq $\vec{a}^{\prime} i q$ (Istanbul, 1268/1852 and 1269/1852-3)\}, vol. 1, p. 66, there is very good information cited from different sources. There is a poem of 4000-5000 couplets entitled Qissa-i Bāb $\bar{a}$ Ratan by the famous Indian poet Shāh Muhammad Walī Allāh Dakkān̄i. See Garcin de Tassy, Histoire de la littérature hindoui et hindoustani \{Paris, 1870-1\}, 2nd edn, vol. 3, p. 287. \{Now see $E I^{2}$, s.v. "Ratan" (Mohammad Shafi').\}

35 In fact, there is greater uncertainty over his death date than Köprülü allowed. The generally accepted date is not attested until the latter sixteenth century and was itself clearly contrived in connection with the equally contrived story of Ahmad Yasawī's succession to Hamadānī. The story of Aḥmad Yasawī's link to 'Alī Lālā, moreover, is not just from Jāmī. He took it from a source from the early fourteenth century and that source contains the earliest reliably datable reference to Ahmad Yasawī. See above, n.32.\}

36 Barthold, Turkestan, \{English trans., p. 353.\}

37 On the traditions surrounding Ahmad Yasawī's "retirement" underground, see DeWeese, "Sacred Places and 'Public' Narratives." Treating the story of Ahmad Yasawī's withdrawal as part of his historical biography (and to take the Dĩwan-i Hikmat as an "autobiographical" source on it, rather than as an echo of the traditions from several centuries later) was irresponsible even on the basis of the sources that Köprülü had on hand. Furthermore, claiming that Ahmad Yasawī was a Hanafí jurist again has no basis. $\}$

38 Note that Abū Yūsuf is not the same as Yūsuf, which is another clue to problems in the traditions about Hamadānī. $\}$

39 In fact, other manuscripts of this work by Makhdūm-i A'zam give other dates that are not so easily construed as errors for 562.$\}$

40 Dīwān-i Hikmat.

41 "Khalwa," in the journal Shūrā, March 1914, p. 14.

42 On traditions of familial descent from Ahmad Yasawī, see DeWeese, "The Politics of Sacred Lineages." $\}$ 
43 Nithārī Bukhārī, Mudhakkir-i ahbāab, among the poets whom the author knew and who were alive when he wrote about them, and who lived in places other than Bukhārā, p. 252.

44 'Āshıq Chelebi, Tadhkira \{i.e. his Mashā'ir al-shu'arā', MS in Köprülü's private library\}, pp. 250ff. \{now ed. G. M. Meredith-Owens (London, 1971).\} 'Āshiq Chelebi says that his grandfather was this Naqshbandī poet who had come from Iran and had written two works, Tajnīsāt and Tuhfat al-'ushshāq. \{Kınalı-Zâde\} Hasan Chelebi only mentions that he wrote the treatise Tajnīsatt, although he says that he was from the Yasawī lineage, \{Tadhkirat al-shu'arā', MS.TY 1737, Istanbul University Library\}, pp. 137ff. \{now ed. İbrahim Kutluk (Ankara, 1979-81)\}; Lațifi does not describe his lineage, but apart from that gives the same information, $\{$ Tadhkira, $\}$ p. 246. There exists a copy of the Tuhfat al-'ushshāq that 'Ațā wrote in 911/1505-6 in imitation of Kātibī's Tajn̄̄săt in my private library; thus it appears that 'Āshıq Chelebi mistakenly considered the imitation of the Tajn̄isăt and the Tuhfat al-'ushshāq to be two different works. 'Ațā tells of his own lineage in this work in the following couplets,

Niceyedek ey 'Atâ bu kîl-ü kâl

Hâl iste kim olasin nîk-hâl

Kâtibînin șehri Nîşâbûr ise

Melce'-i 'Attâr gibi nûr ise

Sen Yesüdan Şeyh Ahmed Pûr'sun

Máni yüzünde o şemsin nûnsun

Gerçi hak-i hitta-î Üskûb'sün

Ma'denî sen zer gibi üsküb'sün

Resmini haddim değil tavsîf edem

Gün gibi rûşsen nice ta'rîf edem

Her sözünü nisbet et ol merde sen

Dirilüb tâ olmayasin mürde sen

Çün o deryâdan ola sana grdâ

Pes mu'înindir hakikat mấadâ

\{For how long, Oh 'Ațā, will you depend on hearsay?

Seek out ecstasy, so that you become well-off.

If Kātibī's city is Nīshāpūr

- city of light, refuge of 'Attāar -

You are Shaikh Ahmad Pūr from Yasu

- spiritually, you are the light of the sun.

Although you are from the soil of Üsküb,

Your ore is gold, like a golden head-dress

Describing his form is beyond my capacity.

How can I portray what is bright as the sun?

Relate each of your words to that saintly man.

You are dead until you come back to life.

Since your nourishment is from that sea,

$\mathrm{He}$ is your helper, other than the Truth.\}

45 \{Seyāhatnāme,\} Book 1, fos 23b, 26b, Book 3, fo. 122b. Dr Mordtmann does not mention, for some reason, that he was from the family of Ahmad Yasawi in his article "Evliyā C̆elebi," in $E I^{I}$ \{cf. İA, s.v. "Evliya Çelebî" (Cavid Baysun)\}.

46 Khazinnat, vol. 1, p. 657. The author always identifies the Yasawīs as Naqshbandīs. \{The account of Khwāja Hāfiz Aḥmad Yasawī mentioned by Köprülü, citing the Khazinnat al-asfiy $\bar{a}^{\prime}$, was taken by the latter work from an earlier history of Kashmīr, so the date is more reliable. But both versions of the account leave no doubt that he was 
regarded as a Naqshbandī shaikh, whatever his natural descent. Köprülü's insistence that he was a Yasawi underscores his confusion about (or blurring of) the distinction between silsila and natural descent. He does so because he adopted the version of the Yasawī silsila preserved in the Rashahāt and thus repeated in general Naqshbandī works, and by the time he wrote there was no Yasawiyya as such.\}

47 All the historians who have done research on Tīmūr - including Léon Cahun, although we cannot consider him to be a true historian - agree on this (Léon Cahun, Introduction à l'histoire de l'Asie, les Turcs et les Mongoles, [Paris, 1896], p. 471). \{Köprülü's description of Tīmūr's "Islamist policy" and Shī̄ leanings was unfounded. Cf. Beatrice Forbes Manz, The Rise and Rule of Tamerlane (Cambridge, 1989), pp. 17-18.\}

48 See the Persian text of the \{anonymous\} Tüzunkāt or L. M. Langlés's translation \{as Institutes politiques et militaires de Tamerlan, proprement appellé Timour... (Paris, 1787); English trans. and Persian text by Major Davy as Institutes, Political and Military (1783; reprinted Tehran, 1342/1963)\}. In a letter that he sent to the emperor of China, Sultan Shāh Rukh states that "Tīmūr abolished the yasa of Chingiz Khān and the yarghu \{tribunal\}; he put into force in all countries the maxim amr-i ma'rüf wa nahy- $i$ munkar \{commanding the good and forbidding the bad\} according to the commands of the Sharī $a$; and in his time the Muslims reached their full splendor" (Hāfiz-i Abrū, Zubdat al-tawārikh \{MS in the Damad Ibrahim Pasha Library in the Süleymaniye in Istanbul $\}$ among the events of $815 / 1412-13$ ). There is a full translation of this important letter in my critical article on 'Aja'ib al-lat $\bar{a}$ ' if $\{$ i.e. his review of the Turkish trans. of Khwāja Ghiyāth al-Dīn Naqqāsh's 'Ajā'ib al-latăâi: Hatây (i.e. Khațā̄î̀) seyâhatnâmesi by Çelebi-Zâde Âsım, $\}$ (MTM, 2 \{1331/1915\}, 356-7).

49 There is a minor discrepancy among historians about the date on which this building was constructed. Sharaf al-Dīn says in his famous Zafarnāme \{Calcutta, 1887-8\} that the order was given to build the türbe in 799/1396-7 after the construction of Dilgushā Garden and its pavilions (among the events of 799, and in Muhammad 'Alī b. Darwīsh 'Alī Bukhārī, \{Chaghatay\} trans., Zafarnāme-i Tìmūr, \{MS 3268 Nuruosmaniye Library in Istanbul; French trans. of the Persian MS Pétis de la Croix as Histoire de Timur-Bec (Paris, 1722), English trans. as The History of Timur-Bec . . (London, 1723)\}). We see this story, which is not found in Hātifî's work \{Tìmūrnāme, also known as Zafarnāme, various MSS \} nor in \{Ibn 'Arabshāh's\} 'Ajä'ib al-maqdūr, in Mīrkhwānd in a special chapter entitled
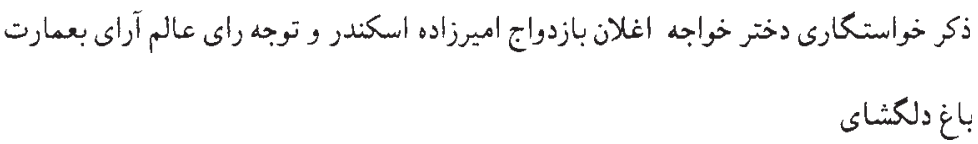

\{Proposal of marriage of Khwāja Oghlan's daughter to Amīr-Zāde Iskandar and the intention of the World-Adorner (= Tīmūr) to build the Dilgushā Garden $\}$ among the events of 800/1397-8 (Rawdat al-safä, vol. 6, pp. 127-8). Melioransky indicates, perhaps also based on this, that this shrine was constructed in 800/1397-8 (see $E I^{l}$, s.v. "Ahmed Yesewī"). This date is also given in Schuyler's Turkistan (Turkish trans., p. 93). Mir-Salikh-Bekchurin \{"Opisanie mecheti Azreta, nakhodiashcheisia v Turkestane," Voennyi sbornik, 9/8 (1866), 209-19; French trans. L. Leger as "Description de la Mosquée de Hazret (Khodja Ahmed Yessevy)," Recueil d'itinéraires et de voyages dans l'Asie Centrale et l'Extrême-Orient (Paris, 1878), pp. 245-58\} and Ujfalvy accept the date of 806/1404 without giving a source (Ujfalvy, Le Syr-Daria, pp. 17, 50). In the second volume $\{$ sic, only one volume\} of his work Manuel d'art musulman \{Paris, 1907\}, which discusses architecture, Henri Saladin says, while discussing the monuments of 
Turkistan, that the türbe - with the famous name Jāmic-i Hadrat - was constructed in 806/1404 (p. 359). In any case, the most accurate of these accounts is what I have mentioned above.

50 The name of this architect is not found in the Oriental sources; but Ujfalvy and N. I. Veselovsky, who personally visited the shrine, and the author \{Saladin\} of Manuel d'art musulman, who cites them, all agree on this point.

51 Both Sharaf al-Dīn \{Yazdī $\}$ and Mīrkhwānd give almost the same description of this building. Because Mīrkhwānd most certainly copied Sharaf al-Dīn, I will cite verbatim the description in the Zafarname (Zafarnāme MS) \{we have used the edn by Muhammad 'Abbāsī (Tehran, 1336/1957), vol. 2, p. 16\},

$$
\begin{aligned}
& \text { وحضرت صاحبقرانى بقرية يسى بزيارت شيخ اتمد يسوى توجه فرمود كه از فرزندان امام زاده محمد } \\
& \text { حنفية است عليه وعلى آبائه السلام وبتعميرآن مزار متبرك أشارت عالى ارزانى داشت وعمارتى } \\
& \text { همتبر اساس انداختند مشتمل برطات وسيع رفيع با دو منار ركتبد مربع سي كز لو سي كز وكنبد ديكر } \\
& \text { يوازده كزدر دواز ده كز با جهار صفه براى مرقد منوردر قبلى كنبد بزركى متصل بآن ودر دو جانب كنبد دو } \\
& \text { جهار صفة ديكر هر يكي سيز ده كز ونيم در شانزده كز ونيم جهت بحاعت خانه وديكر حجرات وتوابع ولواحق } \\
& \text { زفرمان شُد تا ديوار وقبة آنرا از كاشى كارى تزيين دهند وقبر از سنكك سفيد بتكلف تراشيده } \\
& \text { نقثهاي بديع بر آن نكارند واتمام آنرا بعهدة اهتمام مولانا عبيد الله صدر -- روضة الصفاده } \\
& \text { زظفرنامه ترجمه سنده "عبداللَّ" - فرمود وبر حسب فرموده بعرض دو سال باتمام يبيوست وجون ميامن } \\
& \text { اقامت رسم زيارت قرين روزكار سعادت آثار كشت همت يادشاهانه صلات وصدقات بسيار } \\
& \text { بكجاوران مزار وساير ارباب استحقات وافتقار تصدق فرمود واز آنمجا باز كشته باردوى همايون } \\
& \text { عباودة فرمود. }
\end{aligned}
$$

\{His majesty, lord of the auspicious conjunction (i.e. Timūr), visited the tomb of Shaikh Ahmad Yasawī in the town of Yasī; he was a descendant of Imām-Zāde Muhammad Ibn al-Hanafiyya - peace be upon him and upon his ancestors. Tīmūr issued the order to repair that holy tomb. The foundation was laid of a great edifice, with a wide and tall arch; two minarets; a square cupola 30 cubits by 30 cubits; another cupola 12 cubits by 12 cubits; a rectangular room for the resplendent sepulchre to the south of the great dome adjoining it; two other rectangular rooms on the two sides of the cupola, each $13^{1 / 2}$ cubits by $16^{1} / 2$ cubits, as the congregational prayer-hall; and other chambers and appurtenances. It was ordered that the walls and the dome be ornamented with tilework and the tomb be made of carved white stone etched with fine designs. The Sadr, Mawlānā 'Ubaid Allāh ('Abd Allāh according to Rawdat al-safā and Zafernâme Tercümesi \{this comment inserted by Köprülü in Turkish\}), was charged with carrying out this task, and work was completed in two years, as ordered. When the visitation ceremonies were completed, Tīmūr performed the ritual prayer and gave many alms to the residents at the tomb and to the other worthy dervishes. He then departed from there and returned to his camp.\}

52 \{ See A. A. Ivanov, "O bronzovykh izdeliiakh kontsa XIV v. iz mavzoleia Khidzhi Akhmeda Iasevi," in B. A. Litvinskii (ed)., Sredniaia Aziia i ee sosedi v drevnosti i srednevekov'e 
(Moscow, 1981), pp. 68-84; Thomas Lentz and Glenn Lowry, Timur and the Princely Vision: Persian Art and Culture in the Fifteenth Century (Los Angeles, 1989), pp. 29-31 and catalogue no. 4.; and Linda Komaroff, The Golden Disk of Heaven: Metalwork of Timurid Iran (Costa Mesa, CA, 1992), pp. 17-49, 237-49.\}

53 \{Köprülü calls it a mosque after its popular name Jāmi ${ }^{\complement}-1$ Haḍrat. Shrine makes more sense, although the complex does contain a small mosque as well. There is enormous literature on this shrine complex. See especially L. Iu. Man'kovskaia, "K izucheniiu priemov sredneaziatskogo zodchestva kontsa XIV v. (mavzolei Khodzhi Akhmada Iasavi)," Iskusstvo zodchikh Uzbekistana, 1 (1962), pp. 93-142, English paraphrased translation with additional references by Lisa Golombek as "Towards the Study of Forms in Central Asian Architecture at the End of the Fourteenth Century: The Mausoleum of Khvāja Aḥmad Yasavī," Iran, 23 (1985), 109-27; and Türkiye Diyanet Vakfi İslam Ansiklopedisi, s.v. "Ahmed Yesevî Külliyesi" (Emel Esin).\}

54 Schuyler, Turkistan, \{Turkish trans.\}, p. 96.

55 Ibid., p. 94.

56 The khwäja's tomb is currently under the building erected by Amīr Tìmūr. There is no inscription or anything of the kind on the tomb. Next to the khwaja is the tomb of his wife. There are quite a few who believe that those who visit these two tombs will acquire more merit than that obtained from going on the pilgrimage to Mecca. They make visiting the khwäja's tomb the top priority for those who visit such tombs. The $k h w \bar{a} j a$, who encouraged the visiting of tombs, mentioned them as follows, "Bu Arslan Bāb Evliyā, Bu Abū 'l-Khair, Bu Āblāy, Bu Muhammad Hanafì \{i.e. Muhammad Ibn al-Hanafiyya\}, Haḍrat-i Sulțān al-'Árifīn, so that there are 77,000 shaikhs and 88,000 servers (princes, saints) . . etc. This visiting is continuous" "Khalwa," in the journal Shürä, March 1914, p. 140). \{Claiming that "the khwäja" is known to have encouraged the visitation of tombs, and even commended going to his own - since "Haḍrat-i Sulțān al-'Ārifīn" refers to Aḥmad Yasawī - and to the eighteenth-century Qazaq khān Ablay makes no sense of course. The article from Shūrā, signed by a certain "T," recounts a visit to Ahmad Yasawī's shrine in January 1914. The listing of graves comes as the caretaker - who belonged to the social/familial group known as khwäjas (who claimed descent from Yasawī's daughter, see DeWeese, "The Politics of Sacred Lineages"), hence perhaps Köprülü's confusion over who was encouraging the visitation of these shrines - was identifying particular graves. The "Bu" in these phrases simply means "this," in the sense of "here lies."

57 There was water in this vessel "for the the use of the persons who live in the mosque \{i.e. shrine and the pilgrims and students who come there. It is said to have been cast in Churnak \{rather, Qarnaq\}, now in ruins, about fifty miles from Turkestan $\{25$ $\mathrm{km}$ north of Turkistan\}. Around this vessel there are several lines of Arabic inscriptions, in different characters ..." These inscriptions concern the importance of water. It appears from them that, on the order of Tamerlane, the vessel was made by Ustādh Abū 'l-'Azīz Ibn Sharaf al-Dīn al-Tabrīzī and placed there (Howorth, citing Schuyler, History of the Mongols, from notes at the end of part 8 of Chapter 2 \{i.e. part 2, division 2, pp. 682-3, corresponds to Schuyler, vol. 1, pp. 71-2\}). \{All citations from Howorth (Schuyler) here and below are given in the original English, which differs a bit from the Turkish translation.\} Today people in Yasi believe that this cauldron also survives from the time of Ahmad Yasawī ("Khalwa," \{in the journal Shürāa\} p. 147). \{According to a Soviet-era report, the inhabitants of Qarnaq still showed the nearby site where the cauldron had been cast. See M. E. Masson, Mavzolei Khodzha Akhmeda Iasevi (Tashkent, 1930), p. 16, n.1. Masson's article is one of the most valuable early descriptions of the shrine. It has been reprinted in K. M. Baipakov (ed)., Goroda Turkestana: Sbornik nauchnykh statei (Almaty, 1999), pp. 9-29.\} In the ZDMG, 51 (1897), Vambéry has an article on the legends of Tīmūr (\{"Eine legendäre Geschichte 
Timurs," , pp. 215-32) that includes the text and translation of a Persian historical document entitled

$$
\text { :استان يورش حضرت صاحبقران بدشت قيهّاق بر سر توقتمش خان }
$$

\{Account of the campaign of His majesty the Șāhib-qirān into the Qipchaq Steppe against Toqtamish Khān\}. This document, which was apparently written in 1192/ 1788 at the time of Abū 'l-Ghāzī Bahādur Khān, is of much more legendary than historical value. \{The text cited here from Vambéry's article in $Z D M G$ comes from a work known as the Kunūz al-a'zam, compiled by a certain 'Abd al-Raḥmān Sīrat in the early eighteenth century. See DeWeese, "The Descendants of Sayyid Ata and the Rank of Naq̄ib in Central Asia," Journal of the American Oriental Society, 115 (1995), 612 34.) Legendary works of this kind are very common to both Chingiz Khān and Tìmūr. Indeed, I have mentioned above, while describing the feelings of respect that Tìmūr had for Aḥmad Yasawī, certain legends and legendary works \{of this kind\}. We find one of these legends, which derived from the fact that Tìmūr had a türbe built for Ahmad Yasawī, at the beginning of this document that Vambéry published. It indicates - naturally in a purely legendary fashion - the origin of this famous cauldron in the türbe and how it came to be there. Let me quote this part verbatim, with the addition of a few minor, but necessary, corrections and emendations \{he actually left out some fairly important things\},

$$
\begin{aligned}
& \text { جون حضرت صاحبقران به يورش دشت قيتهاق آمـاده شد بقلعة تركستان (يسى) } \\
& \text { آمد امير ملك خواجه احمد يسوى را ملازمت كرد كفتند اينجا قلعه است قبا نام هفت روزه } \\
& \text { دورتر طليفة تركمان يوز (غوز، اوغوز ) مى نشيند كه انها خود را نسل افراسياب ميكيرند } \\
& \text { هيسران ارغون خان توركمانند ينج برادرند بركسى انقياد ندارند در ينوقت ايلجِيان آن ينج } \\
& \text { برادر در نامة ايشان اين قطعه بود كه. }
\end{aligned}
$$

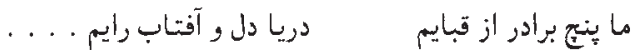

$$
\begin{aligned}
& \text { هر كدام خنده ها كردند عقيده كرده اند كه غير از قبا جاى ديكر نباشد ميرزا عمر سير } \\
& \text { شيخ جواب داده فرستاد كه }
\end{aligned}
$$

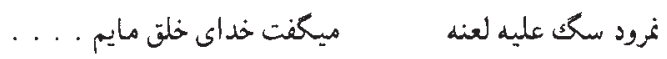

$$
\begin{aligned}
& \text { صاحبقران از تركستان سوار شده رفته قبل كرد اول ايشانان بجنكك بر آمدند بعد كه } \\
& \text { كترت سياه صاحبقرانرا ويدند قبل شدند جهل روز قافيئ ايشانان تنكك شد نوشته فرستاككد }
\end{aligned}
$$

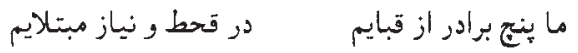

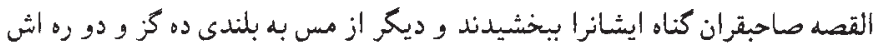

$$
\begin{aligned}
& \text { ده كز از زمان افراسياب مانده بود بصاحبقران بيشكث كردند صاحبقران بر سر مزار } \\
& \text { حضرت خوأجه اتحد يسوى فرستادند كه آن ديكى هنوز آنجاهست. }
\end{aligned}
$$


\{When his majesty, lord of the auspicious conjunction (i.e. Tīmūr), during his campaign to the Qipchaq Steppe, arrived at the fortress of Turkistan (Yasī), he paid his respects to the amīr-i mulk (commander of the kingdom) Khwāja Ahmad Yasawī. He was told that there was a fortress nearby called Qaba, and that a seven-day journey further on there dwelt a tribe of Turkmen Yuz (i.e. Oghuz) who traced their descent back to Afrāsiyāb. They are descendants of Arghun Khān Turkman, five brothers, and are obedient to no one. Now envoys came from those five brothers with a letter containing the following verses:

We are five brothers from Qaba;

Our hearts are like the sea, our minds like the sun ...

Everyone broke out laughing, for they truly believed that there was no place like Qaba [and that they were masters of the entire world]. Mīrzā 'Umar Shaikh sent the following reply:

Nimrod, the dog, God's curse be upon him,

Said: "I am the lord of creation."

[God drove him mad with half a flea.]

The lord of the auspicious conjunction mounted, left Turkistan, and laid siege [to Qaba]. At first they fought back, but when they saw the great number of Tìmūr's forces, they withdrew into their fortress. After forty days they began to weaken, and sent the following message:

We are five brothers from Qaba;

We are straightened from hunger and need...

In short, Tìmūr forgave them their fault, and they presented him with a copper kettle, ten cubits high and ten cubits in circumference, which had come down to them from the time of Afrāsiyāb. Tìmūr sent it to the tomb of Khwāja Aḥmad Yasawī, and it is still there.\}

According to this legend, this copper cauldron, which was ten arşıns \{cubits\} high and ten arşıns in diameter and survived from \{the time of $\}$ Afrāsiyāb, was given as a gift to Tìmūr in Qaba by five brothers from a Turkmen family. There is some information in this text about the cauldron, the name of the maker of which was inscribed on top, and its correct size. But this document only confirms the continuous influence Ahmad Yasawī had in Central Asia.

58 Howorth, citing Schuyler, History of the Mongols, vol. 2, notes at the end of the eighth part of the second chapter \{i.e. part 2, division 2, pp. 681-3, corresponds to Schuyler, vol. 1, pp. 70-3\}. According to the information provided by Schuyler, "The Sheikhul-Islam has several documents from various rulers of Central Asia in whose possession Turkestan has been, conferring privileges on the shrine, one of them of the year 1591, signed by Abdulla Khan" (ibid., \{i.e. part 2, division 2, p. 683, corresponds to Schuyler, vol. 1, p. 72\}). \{Here Köprülü seems to understand that Schuyler's "Sheikh-ul-Islam" was not Ahmad Yasawī.

59 Ujfalvy, Le Syr-Daria, pp. 17, 51; Reclus, Nouvelle géographie universelle, vol. 6, pp. 553-4.

60 Sığnak was the government center of the state of the White Horde founded by Jūjīs \{d. 1225 \} oldest son. Subsequently, however, during the period of the Qazaqs, this state was divided into three parts, the Great, Small, and Middle \{hordes\}. Yasī was the capital of the strongest of them, the Middle Horde (Howorth, History of the Mongols, vol. 2, Chapter 2, p. 647). 
61 Reclus, Nouvelle géographie universelle, p. 554. According to Mir-Salikh-Bekchurin's account, the Shaikh al-Islām, who saw that the shrine was in ruins, ascended the minaret with great difficulty and waved the white flag to the Russians, and in this way the most beautiful monument in the region of the Syr Darya was saved from complete ruin (Ujfalvy, Le Syr-Daria, p. 18). The current state of the shrine, however, is one of utter ruin. In recent times several attempts have been made to raise funds to repair it, but nothing has come of this (\{"Khalwa" in \} the journal Shürā, March 1914, p. 145). The Russian committee that has been preoccupied with research on Central and East Asia sent N. I. Veselovskii to make a special study of this monument, but it is probably doomed to destruction. \{Later, when the territory now called Kazakhstan became part of the Soviet Union, repairs were carried out from time to time beginning in 1928. It was eventually almost completely restored, although not without some problems. See Naim-Bek Nurmuhammedoğlu, Hoca Ahmed Yesevî türbesi (Ankara, 1991), pp. 51-3. This work, with many photographs, was originally published in Alma-Ata in 1980 and then republished in Ankara with the addition of a Turkish translation of the text.\}

62 Muḥammad Șāliḥ Mīrzā, the well known Central Asian Turkish poet of the tenth/ sixteenth century, wrote a famous poem entitled Shaibanninamme to spread the word about the events of the sultanate of Shaibānī \{now generally read as "Shībānī"\} Khān, and at the end of it he mentions Ahmad Yasawī and Yasī while praying for Shaibānī Khān (Shaibān̄̄nāme, Vambéry [ed.], p. 444),

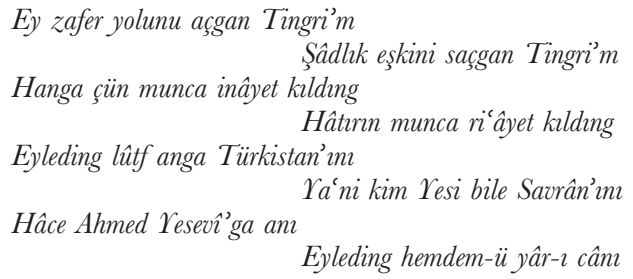

\{Oh God, who opens the way to victory,

God, who scatters the tears of joy

You have shown such care for the Khān,

You have been so solicitous on his behalf

You have favored him with Turkistan,

That is, with Yasī and Savrān

You have made him the companion

And sincere friend of Khwāja Aḥmad Yasawī.\}

On this poet, see my still unpublished work Tìmūrlular devrinde Orta-Asya Türk edebiyatn \{never published, but see his article in $\dot{I} A$, s.v. "Çagatay edebiyat1," pp. 312-13\}. Neither Vambéry nor Melioransky, who published a more accurate and reliable edition of this work, was able to provide adequate information on him.

63 "Khalwa" in the journal Shürä, March 1914. In order to understand the meaning and nature of khalwa in the Yasawi tarīqa, see the next chapter.

64 Ibid., p. 148.

65 Passages in the simplest works, such as \{the anonymous\} Sharäit al-imañn, reveal the significance of Ahmad Yasawī (see Chapter 2, p. 30), and works like Fawz al-najāt by Șūfì Allāhyār (written in 1180/1766-7), which were quite famous in Central Asia, also speak of him with respect. In one place in his mathnaw the aforesaid Fawz al-najāt\}, Șūfì Allāhyār delivers a eulogy to him (Istanbul edn, \{n.d.\}, p. 111), 


\section{Türk içinde Hâce Ahmed Yesevî}

Olar irür köp meşâyzh serveri

\{Among the Turks Khwāja Aḥmad Yasawī

Is the leader of all the shaikhs.

In the section entitled ر بيان ختم يازده أحمد: \{Concerning the Eleven Seals of Ahmad\}, he mentions him again in a couplet (Kazan edn, 1895, p. 79),

Birisidür Hâce Ahmed Tesevî

Zâhir-ü bâtında ol erdi kavî

\{One of them is Khwāja Aḥmad Yasawī

He was powerful in the exoteric and esoteric matters.

The famous Khwāja Sulaimān, known as Hakīm Ata, also wrote a description of him in a famous hymn, the relevant passage of which states (Dīwann-i Hikmat, Istanbul edn, p. 111),

Baksa Ka'be görüngân bassa yirler türülgân

Ledün ilmi birilgân Hâcem Ahmed Yesevî

Ash irür hânedân bilmez an göb nâdân

Bilür an Hak Yezdân Hâcem Ahmed Yesevî

\{When he looks, the Ka'ba appears; when he steps the ground folds up.

He has been given the science of ladun (nearness to God); my Khwāja Aḥmad Yasawī.

His lineage is the family of the Prophet.

Many ignorant ones do not know him.

But God knows him; my Khwāja Aḥmad Yasawī.\}

66 \{The Qarakhān, or Awliyā Qarakhān, whose shrine gave the town one of its many names, was regarded in local tradition as a descendant of one of the three Islamizing figures descended from Muhammad Ibn al-Hanafiyya (Ahmmad Yasawī was a descendant of another of the three). See DeWeese, "Yasavian Legends on the Islamization of Turkistan," in Denis Sinor (ed.), Aspects of Altaic Civilization III (Bloomington, IN, 1990), pp. 1-19. The same tradition plays a prominent role in the genealogical texts collected recently by Ashirbek Muminov and Zikiriya Zhandarbekov mentioned above in the Foreword. Finally, Köprülü is relying on Schuyler here in referring to the shrine west of town as that of "Asa Bibi" (in Schuyler "Assa Bibi"). In fact the shrine of 'A 'isha Bībī is relatively well known. See Robert Hillenbrand, "The Mausoleum of 'A'isha Bibi and the Central Asian Tradition of Funerary Architecture," Fournal of Turkish Studies, 18 (1994), 111-20.\}

67 Cited from Description des hordes et des steppes des Kirghiz-Kazaks ou Kirghiz-Ka'issaks by a Russian scholar named \{A. I. Levshin \{or Levchin\} and translated \{from Russian\} by Ferry de Pigny \{Paris, 1840\} (Dubeux, Tartarie, pp. 135-6). Not only Āblāy-Khān, the Qazaq ruler of the Middle and Great hordes, was buried there, but Ondan Sultān, one of the most famous of the White Horde amīrs and a descendant of Chingiz Khān, was buried there as well (Howorth, History of the Mongols, vol. 2, part 2, pp. 636-47). \{Köprülü's identification of Ondan Sultān as a Chingizid implies that Ablay was not a Chingizid. All the khāns of the Qazaqs were Chingizids, or at least claimed to be. There are, in fact, many other Qazaq khäns said to be buried at Ahmad 
Yasawī's shrine complex.\} Such Qazaq customs as keeping the corpse unburied until spring are vestiges of pre-Islamic Turkish funeral rites.

68 Ujfalvi, Le Syr-Daria, p. 52.

$69 \mathrm{Ibid}$., p. 51. \{On the role of Ahmad Yasawī's shrine and of stories and practices connected to it, in the context of contemorary Qazaq religion, see Bruce G. Privratsky, Muslim Turkistan: Kazak Religion and Collective Memory (Richmond, Surrey, 2001).\}

70 According to Schuyler, the expenses of the shrine were managed by its waqfs. Before the city was conquered by the Russians, the Khān of Khokand used to send 500 gold coins $(t z l a)$ every year to help to cover the expenses of the mosque. In addition, those who visited the mosque always gave some \{monetary\} assistance to its employees and distributed the sacrificial animals that they slaughtered to the poor (Howorth, History of the Mongols, vol. 2, cited from Turkistan). Mir-Salikh-Bekchurin also says that this mosque was managed by waqfs. Those who trained the murids who looked after the türbe and who considered themselves to be descendants of Ahmad Yasawī benefited in particular from this. In the popular language, these men were given the title azlar, a corruption of "azizler \{holy ones\} ("Khalwa" in the journal Shūrā, March 1914, p. 145). 


\section{4

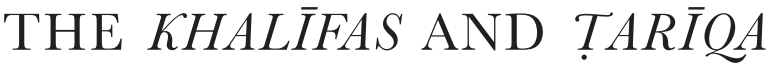 OF AHMAD YASAW $\overline{\mathrm{I}}$}

\section{A His first khalīfas}

As I have stated above (Chapter 2, pp. 24-6), it is certain that Khwāja Aḥmad Yasawī sent many khalīfas throughout Turkistan. Although most of them have been forgotten among the thousands of complex events in life, the memory of some of them who had strong personalities has survived until today and the Yasawi silsila has continued with them. It would be useful, therefore, to review the most famous of these first khaliffas and those with whom the Yasawi silsila was maintained until around the end of the tenth/sixteenth century.

Khwāja Aḥmad Yasawī's first khal̄̄fa, to whom an important and prominent place was given in $\{$ Yasawī $\}$ tradition, was Manșūr Ata, the son of Arslan Bābā. Manșūr Ata was succeeded by his son 'Abd al-Malik Ata, who was replaced by his son Tāj-Khwāja, who in turn was the father of the famous Zangī Ata. ${ }^{1}$ The second khal̄ffa, about whom we have little information, was Sa'̄id Ata of Khwārazm, who died in 615/1218-19. ${ }^{2}$ As for the third khal̄ fa, Sulaimān Hakīm Ata, not only do we know that he uttered "wisdom-filled and moral-pointing anecdotes about the conditions of the dervishes in the Turkish language" \{dervişler ahvâlinden Türkî dilde kelimât-i hikmet-âmiz ve latâif-i ibret-engîzleri\}, but we also possess detailed information about his deeds and khalīfas. Based on this, we can show that Sulaimān Hakīm Ata was the most well known khal̄ fa of Ahmad Yasawī among the Turks. Hakīm Ata lived in Khwārazm providing spiritual guidance to the people in that region. Although he died before the other khatiffas of Ahmad Yasawī, he remained a source of spiritual authority for a rather long time and gathered about him most of the disciples who were attached to the tariqa. According to tradition, his wife, 'Anbar Ana, was the daughter of the ruler Bughrā Khān. ${ }^{3}$ According to another story, he died in 582/1186-74 and was buried in Aq Qūrghān. ${ }^{5}$

We know of the legend of Hakīm Ata because it circulated among the Northern Turks for centuries in a book of legends with the title Hakim Ata menkabesi \{i.e. The legend of Hakīm Ata\}. ${ }^{6}$ Hakīm Ata's original name was Sulaimān. When he was a boy, he used to go to school holding the Koran in his hand out of respect and would not dangle it on his neck like the other boys. When he left 
school, he used to turn his face to the school and his back to his home. One day, while sitting at the threshold of his masjid \{mosque\}, Khwāja Ahmad Yasawī observed this behavior and it pleased him. With the consent of the boy's mother and his teacher, Ahmad Yasawī took him into his service and instructed him in the Koran. After reaching age fifteen, Sulaimān became a disciple of the khwäja. One day Khadir, peace be upon him, came to visit the khwäja who sent the boys out to fetch some firewood in order to cook dinner. While they were returning with the firewood, a terrible rainstorm began and all the wood got wet. Only the wood that Sulaimān had brought was dry because he had taken off his clothes and used them to wrap it. Thanks to this, they were able to ignite the other wood. Khaḍir, peace be upon him, asked Sulaimān how he had kept his wood dry and Sulaimān told what he had done. Khadir was very pleased with this and said to the boy, "Henceforth may your name be Hakīm \{wise\}!" He then placed some of his blessed saliva in Sulaimān's mouth and the boy's heart was filled with light. Khadir then said, "Come on! Don't stop! Show your spiritual power!" At that moment, Hakīm Ata began to recite some wisdom quatrains \{hikmats\} and other verses $\left\{\right.$ manzumas\}. . $^{7}$

One day in the month of sacrifice $\{$ Dhū 'l-Hijja\}, 99,000 shaikhs were present in the tekke of Khwāja Aḥmad Yasawī. The khwāja acted as the prayer leader $\{i m \bar{a} m\}$ and they began to pray. At his right was Hakīm Ata and at his left was Ṣūfì Muhammad Dānishmend. During the prayer, a noise emerged from the khwāja. The congregation said, "The imām has broken wind" and abandoned the prayer because it was not ritually acceptable. The khwajja, however, paid no attention. He continued the prayer. Without hesitation, Hakīm Ata followed suit. Șūì Muhammad took his cue from Hakīm Ata and also continued. Finally, after all greetings were finished \{following the prayer\}, the khwajja said, "I did this on purpose to see what level you had reached in your religious training. That sound did not emerge from me. It came from a piece of wood that I had inserted at my waist. It is apparent that I have one disciple who has reached perfection and one who has come half way to perfection. The others are all ignoramuses." He then gave Hakīm Ata an order saying, "Tomorrow just before dawn a camel will come to you. Mount it and wherever it stops that will be the place where you will dismount."

The next morning just before dawn, Hakīm Ata mounted the camel that appeared and gave it free rein. The camel headed out of Turkistan \{i.e. Yasī toward the east. Just west of the city of Khurāsān, it came to a place called Bī-nawā Arkası \{Behind the Beggar\} and stopped. They tried with all their might, but the camel would not budge. It only brayed. For this reason, they called that place Bāqirghān \{"It brayed"\} ${ }^{9}$ When the camel stopped, Hakīm Ata dismounted. This was a place where Bughrā Khān's herd of horses grazed. The horse herders wanted to drive him away from there. "I am a dervish. I won't go anywhere," he said. They then attacked him with the sticks that they used to herd the horses. Hakīm Ata gave an order to the trees that were there, saying, "Hold them!" The trees seized three of them tightly, while two others fled and reported to Bughrā 
Khān what had happened. The Khān was very pleased with these events and said, "For three days I have been getting whiffs of the odor of erens. This means that an er \{saint\} has appeared in our country." He sent someone named 'Abd Allāh Sadr to ascertain the matter. 'Abd Allāh Sadr asked the dervish who he was and what he wanted, and learned that he was Hakīm Sulaimān, a Yasawī disciple. When he realized why the herdsmen were left in the trees, a voice came from the trees, saying, "This is what happens to those who act like this." Convinced of the sublimity of this dervish, 'Abd Allāh then returned to inform the Khān. ${ }^{10}$ In order to conciliate the dervish, Bughrā Khān gave him one of his very beautiful daughters named 'Anbar and also sent him many camels, sheep, and horses. Hakim Ata accepted all of these things and made his residence at the place called Bāqirghān. Bughrā Khān and all his viziers became his disciples and followers. Hakīm Ata's fame spread in all directions.

Hakīm Ata had three children by 'Anbar: Muhammad Khwāja, Aṣghar Khwāja, and Hubbī Khwāja. When the first two had grown up, they were sent to Khwārazm to study with a very famous religious scholar \{ $\{\bar{a} l i m\}$ named Jārullāh 'Allāma Shaikh. They performed many miracles there and attracted hundreds of disciples. ${ }^{11}$ As for the youngest, Hubbī Khwāja, every day he would ride about the mountains and plains on horseback hunting deer and would bring them to his father. Hakīm Ata had no idea what a high level of spirituality his youngest son had attained.

One day, by a strange turn of events, he learned of this fact. Hakīm Ata had a disciple named Shaikh Sā'at from the town of Ṭarādīkān (طراديكان) \{rather, Turā, so far unidentified in the province of Junūq \{rather, Khīvaq or Khīva\}. Hakīm Ata summoned him and he immediately came running. A little later he also summoned Hubbī Khwāja. He was a bit late and, as usual, brought his father a deer. The boy's late arrival annoyed his father. Perceiving this, Hubbī Khwāja explained the reason for his delay, saying "Two ships in the ocean were sinking and requested my help. I am late because I was busy with them." His father did not believe this. "If you don't believe me," his son continued, "in exactly five months they will bring 10,000 gold pieces here as a token of gratitude. Then you will see." And truly it happened that way. All the men who brought the money became disciples of Hubbī Khwāja. Hakīm Ata now began to understand his son's high degree $\{$ of spirituality\}.

Again, one day his son posed the following question: "I see that you always perform here recommended acts $\{$ sunna $\}$ of the ritual prayer, but where do you perform its obligatory acts $\{$ fard $\}$ ?" In response to this question, his father said that he performed the obligatory part at the Ka'ba. "Very well," he said, "but it is a lot of trouble to go that far. Can't you bring the Ka'ba here?" Hakīm Ata confessed that he did not have that much power. The next day, however, he was suddenly shocked to find that his son had brought the Ka'ba to Bāqirghān and he became somewhat jealous. Now, two saints certainly cannot occupy the single official position of the shaikh in a Șūfi order $\{$ post $\}$. One day Hakīm Ata assembled his disciples. They sacrificed nine oxen ${ }^{12}$ and held dhikrs and sama $\bar{a}^{c}\{$ S S ūfî séance 
with music\}. Everyone was summoned except Hubbī Khwāja. Meanwhile, he returned from the hunt with the deer he had caught. When he saw that everyone had been summoned but no word had been sent to him, he was upset and asked his father the reason for this. By means of a miracle, he then brought back to life the oxen that had been slaughtered. All the people who witnessed this became his followers. Consequently, his father called him and said that the two of them could not remain together in the same place. ${ }^{13}$ Hubbī Khwāja understood the meaning of these words very well and said to his father, "You stay!" He went out and bade farewell to his mother. He put on his burial shroud and stood in the middle of his cell. He told his mother not to weep for him but to try to please his father. He pulled in his head, and disappeared except for his shroud, which remained in the cell. His father and mother wept profusely over this. Hakīm Ata recited many hikmats about his grief for his son.

Hakīm Ata's behavior toward his son required divine punishment. It was revealed to him that if Hubbī Khwāja had lived, sixty saints would have appeared among his descendants. Because they were prevented from coming into the world, as an atonement, water would flow over him for forty years, and only in this way would he be cleansed of his sin. And in fact this is what happened. After his death, the Amu Darya flooded the city of Bāqirghān, and water flowed for forty years over Hakīm Ata's türbe. Then the water receded, but no one knew what had become of his türbe. Finally, by the spiritual direction of Hakīm Ata, someone named Khwāja Jalāl al-Dīn found his grave and erected a tall building over it. People flocked to visit it from all directions. ${ }^{14}$

The best known of Hakīm Ata's many khalīfas was Zangī Ata. When he was in Tashkent, he learned of his shaikh's death and immediately went to Khwārazm to visit his tomb and offer his condolences to his family. Because he was a descendant of the Arab Arslan Bābā, he was an ugly man with black skin \{Arab can mean "African," "black" $\}$. After the canonically prescribed waiting period for an engagement had ended \{to see if she were pregnant\}, he asked for the widow 'Anbar Ana as a result of the spiritual direction of her deceased husband. 'Anbar Ana was very loath to remarry, but finally, as a result of one of Zangī Ata's miracles, she was compelled to give her consent. ${ }^{15}$

Zangi Ata was a thick-lipped negro $\left\{z^{\prime} a n j \bar{\imath}\right\}$ cattle herder in the mountains of Tashkent. He used to support himself and his family with the meager wages he received from the people of Tashkent for herding their cows. Because he spent his life in the countryside, he would do his prayers on the plains or in the valleys. Afterwards, he would begin a loud dhikr. According to tradition, whenever he did this, all the cattle would stop grazing, form a circle around him, and listen. One day, Zangi Ata collected a huge pile of thorny brush from among the thickets in the mountains and was tying it with a rope in order to take it home. At that moment, four young men appeared before him. They greeted him and he acknowledged their greeting and asked where they had come from and where they were going. \{They replied that\} while studying in a madrasa in Bukhārā, they resolved to follow the path of God and were now searching for a shaikh 
who could give them guidance. "Wait a bit!" said Zangī Ata. "Let me sniff in the four directions. Wherever I perceive the fragrance of the perfect guide, I will inform you." The youths waited with pleasure. Zangi Ata turned his face to the four directions and sniffed. At last he said, "No one but me is capable of making you reach perfection."

These four youths who had come from Bukhārā in search of a shaikh were Uzun Hasan Ata, Sayyid Ata, Șadr Ata, and Badr Ata. They eventually became Zangī Ata's four great khalifas. Uzun Ḥasan and Șadr were the first of the four to become his followers based on his promise. For this reason, they were the first to reach the level of perfection. Sayyid Ahmad, ${ }^{16}$ because he had some education and came from a respected family, found it rather strange that a black cowherd would undertake to guide him. This conceit, however, only blocked his path, and his efforts proved fruitless. Finally, he implored 'Anbar Ana to intervene with Zangī Ata on his behalf in this matter. 'Anbar Ana promised to help him, saying, "Tonight wrap yourself in a black felt and wait by Zangī Ata's path. Just before dawn, when he goes out to relieve himself, he will see you in this condition and pity you!' Indeed, that night, this very kind-hearted woman asked her husband why Sayyid Ahmad had not received his favor and said that he was worthy of it. Zangī Ata smiled and explained that when Sayyid Ahmad first saw him, it had awakened conceit in his heart. He added that, as a result of 'Anbar Ata's intercession, he would forgive his original fault. The next morning just before dawn, when Zangī Ata went outside, he saw a black object lying in his path. When he touched it with his foot in order to discover what it was, Sayyid Ahmad prostrated himself at the shaikh's foot and begged forgiveness. In response to this, Zangī Ata treated Sayyid Ahmad with such favor that everything that he wished for was revealed to him at that moment. ${ }^{17}$

As for Sadr Ata and Badr Ata, who were the third and forth khalifas of Zangī Ata, their names were Șadr al-Dīn Muhammad and Badr al-Dīn Muhammad. When they were in Bukhārā, they lived in the same cell, studied the same lessons, and never left each other's company. After becoming a disciple of Zangī Ata, Sadr al-Dīn's level \{of spirituality\} rose. In contrast to this, that of Badr al-Dīn continuously declined. Finally, grieved by this, Badr al-Dīn went to 'Anbar Ana weeping profusely and explained his dilemma. When her husband was in a light-hearted mood, she described Badr al-Dīn's anxiety to him. Zangī Ata laughed and said, "When he first met me, Badr al-Dīn said to himself that this negro with camel lips was claiming too much. That is the reason he has not yet been able to attain enlightenment. But since you have intervened, I have forgiven this fault of his." Afterwards, in fact, there was no difference in the progress of the spiritual training of these two friends. ${ }^{18}$

The tomb of this famous Turkish shaikh, whose memory was sung for centuries by the Sūfì poets of Central Asia, ${ }^{19}$ is eight miles from Tashkent on the Samarqand road. ${ }^{20}$ Khwāja 'Ubaid Allāh Ahrār, the great and renowned Șūfì of Central Asia, held Zangi Ata in very high regard and used to say that whenever he visited his tomb he would hear the cry of "Allāh Allāh" from within. ${ }^{21}$ 
The Yasawiyya spiritual chain traces back above all to the two disciples of Zangī Ata, Sayyid Ata and Sadr Ata. After receiving his shaikh's forgiveness, with the intervention of 'Anbar Ana, Sayyid Ata made great spiritual progress and had many debates with his contemporary Khwāja 'Azīzān. ${ }^{22}$ The most famous khaliffa of Sayyid Ata, many of whose miracles are mentioned in the books of legends, was Ismā'īl Ata from Hūziyyā. ${ }^{23}$ A pure Turk, Ismā'īl Ata paid no attention to the attacks on him by the mullās and would not give up his duty as a spiritual guide. ${ }^{24}$ One day, however, while passing in front of the tomb of Khwāja Muḥammad al-Nāmī, the ancestor of Khwāja 'Ubaid Allāh Aḥ̂ār Tashkandī, he said, "Rotten straw is good for nothing," alluding to the fact that Muhammad al-Nāmī had died long ago and therefore could no longer have any influence. Suddenly a piece of straw came through the air and struck him in the eye. As a result, he lost the eye. ${ }^{25}$ Nevertheless, Khwāja 'Ubaid Allāh always spoke highly of him. As for Ismā'īl Ata's son Ishāq Khwāja, he spent a rather long time in Isfijjā $b^{26}$ providing the people with guidance. Some of the exploits of this shaikh, who gained fame among the Turks, were firmly proven and famous. ${ }^{27}$ Khwāja Bahā' al-Dīn Naqshband appeared shortly after him, but the Yasawi spiritual chain maintained its fame with the original khaliffas of Sadr Ata.

Another khalīfa of Șadr Ata was Ayman Bābā, whose khalīfa was Shaikh 'Alī, whose khalīfa was Mawdūd Shaikh. The latter's two leading khal̄ffas were also famous: Kamāl Shaikh and Khādim Shaikh. Kamāl was a contemporary of Khwāja 'Ubaid Allāh Aḥrār. Khādim already had many disciples in Tashkent and Transoxiana when the khwäja appeared on the scene and subsequently had an audience with him. The author $\{$ S Safi $\}$ of the Rashahāt reports a number of sacred words of this shaikh cited from Khādim Shaikh's khal̄ fa Jamāl al-Dīn Bukhārī. ${ }^{28}$ According to \{Harīrī-Zāde's\} Tibyān-i wasā'il, the Yasawī chain of authorities that derived from Khādim Shaikh was as follows: $:^{29}$ Khādim Shaikh, Shaikh Jamāl al-Dīn Bukhārī, Shaikh Khudāidād 'Azīzagī, Mawlānā Kūh-i Zarrī (Kūh-i Zarī), Shaikh Garmīnī, Muhammad Mu’min Samarqandī, Shaikh Ākhūnd, and Mullā Khurd 'Azīzān. The same source records the chain of authorities from Kamāl Shaikh as follows: Kamāl Shaikh İqān̄̄, Shaikh 'Alīyābād̄̄, Shaikh Shams Özkendī, Abdāl Shaikh, Shaikh 'Abd al-Wāsi', and Shaikh 'Abd al-Muhaimin who was alive in Tashkent in 974/1566-7. Haz̄̄n̄̄, however, gives a rather different chain than this from Zangī Ata. ${ }^{30}$

\section{B Yasawī rules of behavior}

Like all tariqas, the Yasawiyya had a number of rules. The fundamental principles of these rules did not differ from those of the other Șūfi paths, but they had their own special features that are worthy of study. The basic number of rules that a disciple who entered the Yasawiyya tariqa was required to observe can be reduced to ten \{these ten are actually listed by Hazīnī\}. (1) He must not recognize anyone as superior to his shaikh and must submit to him unconditionally. Spending 
the days eating all sorts of food and the nights sleeping in the presence of the Guide cannot close the doors to esoteric spiritual knowledge. But a dervish who left his shaikh, \{even though he $\}$ fasted and stayed awake to his own satisfaction, and carried on naked and weeping, would have the door to progress closed. (2) The disciple should be intelligent and perceptive and be able to understand the shaikh's allusions $\{r u m \bar{u} z\}$ and directions $\{i$ shārāt $\}$. (3) He must submit to and obey all words and actions of the shaikh. (4) In all service to the shaikh, he should not be lazy but be quick and nimble, so that he may obtain his approval, because the approval of the shaikh is tantamount to the approval of God. (5) He should speak the truth and keep promises, so that if the shaikh's temperament changes, this may not be a reason for rejection. He should never feel uncertainty or doubt. Otherwise, disappointment would be inevitable. (6) He should be faithful and firm in his oath of allegiance. (7) The disciple should be prepared to place all his property at the disposal of his shaikh. The way to inner spirituality can be opened in no other manner. (8) He should keep the shaikh's secrets and beware of disclosing them. (9) He should keep in mind all the shaikh's suggestions, admonitions, and counsels and never neglect them or try to circumvent them. (10) For the sake of divine union, he should be prepared to give his heart and soul for the sake of the shaikh. He should be the friend of his friend and the enemy of his enemy. If necessary, in order to meet the shaikh's needs, he should be willing to sell himself as a slave. ${ }^{31}$

The principles of the fortified city \{shahristān\} of the tariqa are six: knowledge of God, absolute generosity, true honesty, absorption in certainty, trust in God pending bestowal of spiritual or material possessions, and critical meditation. The pillars of being a shaikh and role model are also six: knowledge of the true faith, true manifest forbearance, praiseworthy patience, sublime contentment, Abrahamic sincerity, and bountiful nearness. ${ }^{32}$ The duties of the tariqa are also six: seeking the Possessor of Perfection and approaching the Possessor of Glory, longing for union with the Everlasting, fearing the imperishable King day and night, being hopefully expectant under all conditions, mentioning continually \{God's name\}, and contemplating union with the transcendent everliving God. The customary practices of the tarīqa again are six: congregational prayer, staying awake until just before dawn \{seherlerde uyanılkk\}, maintaining a state of spiritual purity, \{seeking\} the presence of God, invoking God, and obedience to the righteous and to the guides. ${ }^{33}$ Laudable \{but not required $\}$ actions are also six: to look after a guest cheerfully and with pleasure, to accept a guest just as he is, no matter how long a guest remains to regard this as a Godsend, to extend hospitality, to try to do whatever a guest wishes, and to pray for Ahmad Yasawī and the shaikh. The rules of the tariqa are also six: to fall to one's knees and sit in a humble, well behaved manner, to see oneself as inferior to all others, to see everyone else as superior to oneself, to know all the shaikhs and saints ${ }^{34}$ and to remain quiet in their presence, not to speak without permission in the sessions of the shaikhs, and to keep in one's memory the saintly \{veläyet $\}$ secrets and miraculous signs of one's own shaikh and other shaikhs. ${ }^{35}$ 
According to Khwāja Aḥmad Yasawī, the passing \{murūr\} of the novices $\{$ s. mubtadi $\}$, the rise $\{s u d \bar{u} r\}$ of those of middle range $\{$ s. mutawassit $\}$, and the appearance $\{z u h \bar{u} r\}$ of those who have reached the goal $\{$ s. muntah $\bar{\imath}\}$ are dependent upon four conditions. The first is place. The second is time. The third is the brethren of the order\}. And the fourth is attachment to the ruler. ${ }^{36}$ In order for the devotees to be free from distraction and to be preoccupied with litanies $\{a w r \bar{a} d\}$, it is necessary first of all for the place to be flourishing. In order for there to be no boredom ${ }^{37}$ among the $\{$ religious $\}$ students and ordinary people, which could result in idleness and neglect \{of duties\}, it is necessary to be protected from the disturbances $\{\mathrm{s}$. 'ârida $\}$ of the time. In order for the required ardent yearning to be present at all spiritual levels $\{m a q \bar{a} m \bar{a} t\}$, in the khalwa \{retirement for devotions\}, and in the forty-day periods of penitence, one needs true brethren who are seekers of poverty \{faqr, i.e. the dervish life $\}$ and passing away $\{$ fan $\vec{a}$, see glossary $\} .^{38}$ Finally, it is also necessary to be attached to the ruler, for control by the ruling authorities assures the privileges of those who possess spiritual knowledge. ${ }^{39}$ According to the Yasawīs, the ultimate goal $\{$ muntah $\bar{a}\}$ for devotees and the final stage of all strivers $\{$ s. mujāhid $\}$ is the road of poverty. Hazin̄ī describes the hardships of this road in the following manner:

Fakr yolunda lâ yu'ad velâ yuhsâ seferler olur. Ol cümle seferlerden âlem-i bâtrn ve kişver-i gaybü'lgayb içinde ücyüzaltmış deryâ ve kurkdört berzah ve perde ve hicâblar açılır ve her berzah ve perde ve hicâb tahtından ve zımnindan ve zuhûrundan kırkdört yol çıkar ve dokuz taht ve her taht üzre bir müstakıl sultân-ı mütecemmil emrü fermân ve hükmeder. Çün ol taht-gâh ve sultânlardan geçilse, iki azîm kapr \{kuyu in Okuyucu's edn\} ve refiül-bünyân bâb-ı hümâyûn ve der-i meymûn zuhûr eder ve herbir kapı ve bâb-ı hümâyûn ve der-i meymûn karşısında üç deryâ-yi mehib ve 'amîk mevc urur. Bu kapi ve deryâ-yi mevvâcdan 'ubûr olup geçilse, nâgâh bir kubbe peydâ olur ve altr yol ki onsekizbin âlem, ol altr yolu başında mütahayyir ve mütegayyir ve muztar kalmışlar fakrü fenâ ile. İs bu menâzil ve merâhil beyâbân-i fakrü fenâ ki mehip ve acîbdir; muktedâsız ve kilağuzsuz sülûk ve 'ubûr ve mürûr kılmak müteazzir ve \{belki in Okuyucu's edn $\}$ muhaldir. Bu menâzili geçmeyince fakr idrâk olunmaz \{olunmaya in Okuyucu's edn $\}$.

\{There are innumerable journeys on the road of poverty. From all these journeys 360 seas and 44 obstacles, screens, and barriers are open to the inner world, the country of the invisible of the invisible. And from beneath every obstacle, screen, and barrier, from within and from without, 44 roads emerge. There are nine thrones on each of which sits an independent and splendid sultan who commands and rules. When those thrones and sultans are passed, two great and lofty gates, the gate of fortune and the gate of auspiciousness, appear. The waves of three dreadful deep seas strike against each door and the gate of fortune and the gate of auspiciousness. When one passes this door and across this rough sea, suddenly a dome appears, and six roads, at which the 18,000 
worlds are dazzled, transformed, and constrained (muztar) with poverty and passing away. These stages and levels of the wilderness of poverty and passing away, which is awful and wondrous, are impossible and inconceivable to traverse without a guide. If one does not traverse them, it is impossible to understand (true) poverty. $\}^{40}$

According to Aḥmad Yasawī, a true Șūfì must become accustomed to asceticism and striving \{for union with God\}. He must distance himself from the comfort of eating and drinking, from khalwa, ${ }^{41}$ sexual desire, and carousing. Abandoning the pomp of this world, he should make it a practice to turn toward God and to meditate, so he may become a genuine Șūfì. For this reason, three different \{forms of asceticism and striving are stipulated for the followers of the Yasawi tarīqa. According to them, if voluntary fasting is done for three days, dust and darkness will be lifted from the inner self; if done for five days, the divine secrets $\{$ mughayyabāt\} of the jinns and the good spirits will be subdued \{i.e. made obedient\}; if done for six days, the springs of the heart's seas will open and begin to flow; if done for nine days, it results in the revealing of hearts $\{q u l \bar{u} b\}$ and the uncovering of tombs $\{q u b \bar{u} r$. But all these ascetic practices and strivings must be done with the permission and approval of the shaikh. If not, they are of no use. Indeed, they will cause harm. ${ }^{42}$

In the Fawähir, there are more descriptions of the Yasawiyya that provide details about its procedures and rules. These are very important in demonstrating the characteristics of the tariqa. We can relate their general outline as follows. In the Yasawi tarīqa, it is the custom, while offering greetings in every encounter, to place the back of the left hand on the ground and to cup the right hand behind one's back. The dervish places his left foot on the ground and, also placing the left side of his face on the ground, extends his right foot, heel first, like a sheep to be sacrificed. With humility and contrition, he describes his faults with a hundred griefs in the presence of the Șūfì master $\{p \bar{\imath} r\}$. Finally, the master says Allāhu akbar and thus makes his devotee, who has taken the form of a sacrificial sheep, reach the state of "death before dying." In like manner, according to the Sharic $a$, it is prophetic custom $\{$ sunna $\}$ for a superior to initiate the greeting to an inferior, and not vice versa. If his excellency the $p \bar{\imath} r$ does not state his faults, he increases the number of sacrificial \{kurban\} takbirs \{to say "God is most great"\} as an answer. The dervish, thanking the pīr for the favor of pronouncing the takbīr, must withdraw with his left hand and depart, while again asking forgiveness for his faults. If there is something in his hand, he makes an entreaty and presents it. If nothing is present in his hand, it suffices to make an entreaty. In order to open the way to esoteric knowledge, he must ask for forgiveness for his faults and in this manner his entreaty before the guide results in nearness to God. The guide's prayer in response to his entreaty is acceptable. As long as the Șūfì devotee does not dwell at the door of faults and entreaty and is not upright, the door of acceptance and the gate of nearness to God are closed to him and his wish will not be fulfilled. It is as Ahmad Yasawī said, "Prayer opens the way." 
The dervish should spend the night in prayer by reading the short süras \{chapters of the Koran\}, because not everyone is able to read the long süras. After doing night vigil prayers of sixteen rak'as \{bending of the torso while upright followed by two prostrations $\}$ with special rules, he should recite the tamjī

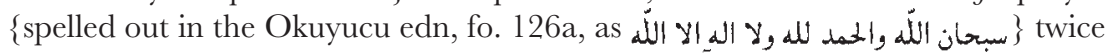

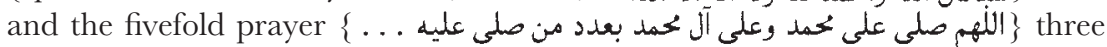
times. After this, istighfär Allāh \{i.e. the prayer astaghfiru'llāh "I ask God's forgiveness"\} is said 101 times in a sad voice and with humility and anguish, and Sufficient for me is my glorious Lord; there is nothing in my heart but God\} is recited five times, and the istighfär is recited five times, and the kalima-i istighfär is recited three times, and the kalima- $i$ faläl is recited 101 times in a loud strong voice. Then he is occupied with the dhikr-i arra \{of the saw, see below\}. This dhikr must also be performed forcefully and vigorously so that the dervish breaks into a sweat. As the Sūfīs have confirmed, only in this way can the ritual impurity of the tariqa be cleansed. Then, the length of the

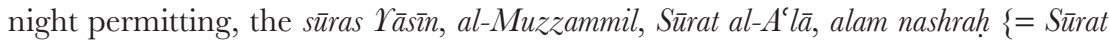
al-Sharh $\}$, innā anzalnā $\{=$ Sürat al-Qadr $\}$, and li $\bar{l}$ āf Quraish $\{=$ Sürat Quraish $\}$ are chanted. Just before dawn, a silent fervent prayer to God, done sorrowfully and with weeping, is accepted by Him. After the dawn prayer, subhān Alläh is repeated twenty-five times, al-hamdu li'lläh is repeated twenty-five times, lā ilāha illā 'llāh is repeated twenty-five times, and Allahhu akbar is repeated twenty-five times. The great name of God $\{i s m-i \mathcal{F} a l a l\}$ is recalled 101 times and the dhikr-i arra is continued with love, passion, and enthusiasm, for the dhikr-i arra leads to the annihilation and passing away, and to poverty and eternal union with God $\left\{b a q \bar{a}^{\prime}\right\}$. Then one reaches a state of pleasurable meditation and chants the $Y \bar{a} s \bar{n}$ $\{s \bar{u} r a\}$ with full reverence. Then one asks God's forgiveness. The Fätiha is recited for the spirits of the shaikhs and the ancestors. Then one shakes hands with everyone in the gathering $\{$ majlis $\}$.

According to the interpretation of a noble tradition $\{$ Hadith-i sharif $\}$ which was handed down from Haḍrat-i Anas \{b. Mālik\}, "Whoever does the morning prayer with the congregation, then sits to perform the dhikr until sunrise, and then does two rak'as, he receives a reward equal to that of a pilgrimage and a full minor pilgrimage \{to Mecca, 'umra\}." For this reason, after the tasbih \{saying subhāan Allāh\}, tahlīl \{saying lā ilāha illā 'llāh\}, qirā'at \{reading the Koran\}, khatm \{complete reading of the Koran\}, prayer, and greeting each other, a two-rak' $a$ morning $\{i s h r \bar{a} q\}$ prayer is done with complete supplication and humility. In each rak'a, the Fätiha is recited followed by \{saying\} five \{times\} qul huwwa 'llahh $\{=$ Sürat al-Ikhlās $\}$. Then a two-rak'a asking for forgiveness $\{$ istakhāra $\}$ prayer is done saying qul yā $\{=$ Sürat al-Käfirūn $\}$, and qul huwwa 'lläh. Then a four-rak'a forenoon prayer is recited: in the first, wa 'l-duha is recited, in mu'awwadhatain the second alam nashrah lak, and in the third and fourth.

For the noon prayer, the custom is four rak'as in which four quls are recited; and for the afternoon prayer the custom is also four, in which ten wa ' l'așr are recited: four in the first $r a k^{c} a$, three in the second, two in the third, and one in the 
fourth. After reciting the prayers, istighfär Alläh is said seventy-one times and the great name $\{$ of God $\}$ is said 101 times with modesty and humility and then one begins the dhikr-i arra \{on this, see section D below\}. In the evening at nightfall, one prays and beseeches God while recalling the darkness and solitude of the grave. After each of the five daily prayers, the five well known süras that are the obligation of the superiors $\{w a z \bar{\imath} f a-i$ buzurgān $\}$ must be chanted. If this is not feasible, one Fātiha, one Āyat al-kursī and three Ikhlās sūras must be recited. This is to receive God's mercy and forgiveness for one's sins. It is meritorious to fast on Mondays that coincide with the birthday of the Prophet. It is also meritorious to fast on Thursdays, which is the day on which people's deeds are presented before God for judgement. ${ }^{43}$

\section{Khalwa \{retirement for religious devotions\}}

Khalwa has a special significance in the Yasawiyya tariqqa and has its own special rules. According to Khwāja Aḥmad Yasawī, a number of subtle meanings are found in the letters in the word khalwa: $k h \bar{a}^{\prime}$ derives from $k h \bar{a} \bar{\imath}$ \{empty, devoid of everything\}, lām from lail \{night\}, wāa from wușla \{union with God\}, and $t \vec{a}$ \{i.e. $h \bar{a}^{\prime}$ as $t \bar{a}^{\prime}$ marbut $\left.t a\right\}$ from hidāya \{guidance\}. \{A similar, but not identical, explanation of the letters in this word is found in the Lamahāt.\} During the khalwa, pleasures pertaining to the senses and to satan are burnt away and disappear. Fire and light appear from divine ecstacies. The gloom and other afflictions of humanity are removed. The layers of the inner self are illuminated and cleansed and many \{other forms of $\}$ divine favor $\{$ faid $\}$ like this are acquired.

There are two khalwas. One is the canonical $\left\{\operatorname{Shari}^{c} a\right\} k$ khalwa and the other is the mystical $\{$ tariqa $\}$ khalwa. Without the canonical khalwa, the mystical is impossible. The canonical khalwa is based on complete repentance for all actions that can be considered shameful, all inauspicious words and all other faults and sins. If this is not done, the devotee of the tarnqa is not worthy of its khalwa. Furthermore, the fast must be done in a manner in which the limbs and sensory organs are guarded and preserved from the things that are canonically forbidden. The early great Șūis had a number of views about the tariqa khalwa \{in the Okuyucu edn, p. 22, "about khalwa and arba' $i n$ " $\}$ and various principles and rules were established according to these views. ${ }^{44}$ Only the perfect spiritual guide can determine how the devotee who will do the khalwa should behave during this period in accordance with the devotee's nature. Otherwise, harm is bound to occur.

Hazinn̄ describes the traditional forms and ceremonies of the khalwa in the Yasawi tariqa in the following manner. One day beforehand, with the consent of their guide, the devotees must fast to purify themselves for the khalwa. After the morning prayer on the eve of the khalwa, they repeatedly say subhän Alläh and $l \bar{a}$ iläha illā 'llāh and recite the dhikr-i mulaqqin \{in the Okuyucu edn, p. 33, "mulaqqan"\} and wird-i murakhkhas. After pronouncing the dhikr Alläh, they stand in line and, in a loud voice, say Allāhu akbar eight times in the direction of Mecca. The purpose of this is to ask for succor and victory from God at the beginning of the war to be 
waged against the army of carnal desires. After the afternoon prayer on the day before the khalwa, the holes, doors, and chimneys of the place of worship and the khalwa cell are closed so that no wind or cold may spoil the training $\{s u l \bar{u} k$, but in the Okuyucu edn, p. 34, harara = heat, adding "and so that they may progress on their path $\}$ of the disciples who are going to begin the khalwa. Then, until the sun sets, while imploring God and shedding tears, the disciples devote themselves to the awräd \{litanies\}, istighfär and dhikrs, which have been authorized and ordered for this. After the evening \{sunset\} prayer, they wash hands \{in preparation \} for a meal. Whoever is serving brings hot water in a jug for breaking the fast. The fast is broken with it and then no additional water is brought. Afterwards, khalwa soup is provided, made from black millet $\{k a r a d a n\}$ that sprouted thanks to the miracles of Ahmad Yasawī. If this cannot be found, red millet can be used. The soup is served to everyone individually. The purpose of this is to ensure that a situation does not arise in which someone does not participate and thus fails to attain divine favor. Then, in order to counteract the heat, a bit of watermelon or some ayran \{a cool drink made of yogurt and water\} may be served. After eating, a süra or a number of verses of the Koran are chanted. Standing in line, they say three takbirs in a loud voice. Then all are seated and occupied with invoking God's name $\{$ dhikr Allah $\}$ with reverence and respect until midnight. During this time, hymns of the Yasawi shaikhs, called hikmat, are read solemnly and in an inspirational manner $\{$ telkinlerle $\}$ in order to encourage and excite the dervishes. ${ }^{45}$ After this, they go to another place to have their heads shaved. When the razor and whetstone are ready, another three takbirs are recited. After shaving, they line up in the khalwa cell and give three takbirs to the four directions, beginning with the direction of Mecca. When this is finished, they form a circle and begin the dhikr. This continues until the candles go out. When this occurs, several hours are spent resting "in order to remove hardship and repel fatigue." During this period, many veils are lifted and divine lights are uncovered. With permission, the dervishes recount their dreams to the shaikh and solicit his interpretation. If the dream is auspicious, they perform supplication; if inauspicious, they admit fault, and thus the dream is annulled and made auspicious, by the grace of God. If supplication and admission of fault are delayed or neglected, this is evidence of a lack of progress and decline.

In this manner, day and night, the khalwa and arba' $\bar{\imath} n$ are completed. With permission, kitchen servants are the first to leave the khalwa cell and they slaughter sacrificial animals. It is the custom not to give the blood of these animals to dogs, but to bury it and preserve the bones. ${ }^{46}$ The esophagi of the slaughtered animals are roasted and given to the participants in the khalwa along with cold water or ayran. No one spends that night in the khalwa cell. The dervishes rest in the houses of the other friends and Sūfīs. Then they gather for the morning prayer and chant religious formulas. They pray that their khalwa be acceptable \{khair $y \bar{a} d$ misread for khair bād in Okuyucu edn, p. 35\} with three takbirs and make supplication. Then all disperse to their homes with tranquil hearts. This then is the character and form of the khalwa that is very famous in the Yasawi tariqa. ${ }^{47}$ 


\section{Dhikr-i arra}

One of the features of the Yasawī tariqqa and of the Turkish Șūfis whose religious training was traced to Khwāja Aḥmad Yasawī is a dhikr known as dhikr-i arra \{i.e. of the saw . They gave it this name because the sound that emerges from the larynx of one performing the dhikr resembles the sound of a bucksaw. One day, according to legend, Khaḍir came to have a chat with Ahmad Yasawī. He had always found the khwäja to be cheerful and light hearted, but on that day he saw that he was distressed and worried. With surprise and astonishment he asked the reason for this, saying, "Having attained these lofty states and stages \{ of spirituality \}, what is the cause of your affliction?" Aḥmad Yasawī gave this reply: "Sorrow has seized the hearts of the companions and dervishes. I am grieved and distressed because I see no way to remove it." Khadir then began to mention the name of God \{dhikr Allahh\} saying, "Ah, ah!" The anxiety disappeared and this dhikr, by his command, became a litany \{wird $\}$ throughout the silsila. This, therefore, according to legend, was the basis and nature of the dhikr-i arra in the Yasawi tariqa and how it entered the Yasawiyya. ${ }^{48}$ The Yasawi tariqa is, in fact, from the Jahriyya \{i.e. those who recite the dhikr aloud\}. ${ }^{49}$

There are a number of stories about the effect and spiritual power of the dhikr-i arra. \{For example,\} Shaikh Maḥmūd Khalwatī Zāwrān̄̄, a disciple of the Turkistan̄̄ Shaikh Mawdūd, was once near Khwāja 'Ubaid Allāh in one of the districts of Samarqand. Because the loudness of his public instruction and the clamor of his dhikr-i arra clashed with Khwāja \{'Ubaid Allāh\} Ahrāar's meditation and silent dhikr, Ahrār wrote a letter specifically asking him to abandon this practice. As soon as Shaikh Mahmūd received this letter, he kissed it and placed it to his head. Heaving a heart-burning sigh, he began such a dhikr-i arra and loud public instruction that the man who had brought the letter and the other partisans of silence were overcome with dread and amazement. Khwāja Aḥrār was offended by this and tried to change Mahmūd's mind by spending the night in prayer and seeking divine guidance in dreams. He was not, however, able to accomplish anything. Finally, he revealed his greatness by admitting that Mahmūd was not defeated but, rather, was victorious. They met and had a friendly discussion and a strong friendship developed between them. ${ }^{50}$

As described in detail in \{Ṣafì's\} Rashahāt, Kamāl Shaikh, one of the leading khalīfas of Mawdūd Shaikh, used to live in the region of Shāsh \{Tashkent\}. Khwāja 'Ubaid Allāh Aḥrār, when he went to Tashkent from Khurāsān, frequently met with him. One day in Tashkent, Kamāl Shaikh visited Khwāja 'Ubaid Allāh, who asked that he perform a dhikr-i arra for him. Kamāl Shaikh, in agreement with his disciples, performed the dhikr forcefully seven or eight times. 'Ubaid Allāh then said, "Enough! It has infected my heart with suffering." He thus acknowledged the powerful spiritual effect of this dhikr. ${ }^{51}$

On this type of dhikr, which was also called dhikr-i minshāri \{saw-like\}, Shaikh Muhammad Ghawth \{Gwaliyārī, d. 1562\} gives the following information. For the dhikr-i minshāri, one must put his two hands on his two thighs and exhale 
toward the navel saying "Ha!" Then, he prolongs this by causing the breath \{to be squeezed\} from below the navel, and as his head, waist, and back come parallel, he must say "Hay!" forcefully and then repeat all of this. Just as a carpenter makes a sound when he draws a bucksaw over wood, the person performing the $d h i k r$, in order to get his heart in the right condition and to attain ease, must draw the dhikr over the tablet of the heart $\{l a w h-i$ qalb $\}$. Some shaikhs perform the dhikr-i minshār saying "Allāh!" As is known to those who acquire it, the benefits of this $d h i k r$ are beyond calculation. ${ }^{52}$ The description that Shaikh Sālim b. Aḥmad Shaikhān Bā-'alawīī Hadramī gives of the performance of the dhikr-i minshân $r \bar{i}$ is clearer and more detailed:

The dhikr-i minshār $\bar{\imath}$ is performed in five manners. In each one, the person doing the dhikr presses a little on his belly and draws his breath upward from below his navel. Then, relaxing his belly a little, he extends his breath toward his navel and exhales. This aspect $\{$ of the $d h i k r\}$ is very much like a carpenter sawing back and forth with a bucksaw on a piece of wood. In the first of the five manners, the person doing the dhikr sits on his knees, places his hands on his thighs, begins to draw his breath from his navel toward his palate, and says "Ha!" Then, extending his breath toward his navel, he forcefully exhales downwards in such a way that his head, waist, and back are parallel and says "Hay!" These cries actually resemble the sound that a carpenter makes when he pushes and pulls the bucksaw over a piece of wood. "Ha!" points to Äyat-i nafs and "Hay!" points to Ayyatt-i ājäk \{allusion to Koran 41:53, i.e. one signals the signs of God within oneself, and the other the signs of God outside oneself "on the horizons" \}, or the reverse. This aspect in the first is according to the victory of necessity over possibility or in the second according to the victory of possibility over necessity. In the second manner, the person says "Hu!" while drawing his breath and "Hay!" while exhaling downward. Or, in both instances \{in and out\}, he says "Allāh!" In the third manner, he says "Allāh!" while drawing his breath and "Hu!" while exhaling downward. In the fourth manner, he says "Hay!" in both instances. In the fifth manner, he also says $d \vec{a}$ 'im, $q \bar{a}{ }^{\prime} i m$, hădir, nāazir, and shähid in both cases. The benefits of this dhikr are many. It was handed down from Zacharia, peace be upon him. ${ }^{53}$

\section{E Tarīqas originating from Ahmad Yasawi}

With respect to the pedigree of the religious order $\{$ sülukk silsilesi $\}$, the most important tarīqas connected with Aḥmad Yasawī are two: the Naqshbandiyya and the Bektashiyya. In addition, there are a few small branches that also originated from Ahmad Yasawī, such as the İqāniyya, but they cannot be considered as truly separate tarīqas. In each of the major tarīqas a number of minor branches 
also sprang up, but they did not depart from their basic features. Many such branches cannot yet even be properly identified. ${ }^{54}$

The Naqshbandiyya is considered to be traced back to Ahmad Yasawī because the pīr of this țar̄qa, Muhammad b. Muhammad al-Bukhārī, known as Khwāja Bahā' al-Dīn Naqshband \{d. 1389\}, spent some time with Qutham Shaikh and Khalī Ata, both Yasawī shaikhs, and was enlightened by them. In his youth, Khwāja Bahā' al-Dīn was instructed by Amīr Sayyid Kalāl to join the company of Qutham Shaikh and he spent more than two or three months with him. Then Qutham Shaikh bestowed an honor on him, saying, "I have nine sons. You are the tenth and are preferred to all of them!" After this, when Qutham Shaikh went from Nakhshab to Bukhārā, the khwāja paid him extraordinary respect. ${ }^{55}$

Khwāja Bahā' al-Dīn has a second connection with the Yasawiyya because be was also initiated into this order by the Yasawī shaikh Khalī Ata. He personally describes his discussions with him in the following manner:

In my youth, I had a dream in which Hakim Ata commended me to a certain dervish. I had a pious grandmother to whom I related my dream. She explained it \{by saying\} that I would be initiated into a dervish order by a Turkish shaikh. One day in the Bukhārā market, I encountered the dervish whom I had seen in my dream, but I was not able to meet with him. That evening someone came to my house and he told me that that dervish, whose name was Dervish Khalil, wanted to see me. With supplication and eagerness, I immediately went to his majlis. I started to tell him my old dream. He stated in Turkish that this had, in fact, been known to him from the beginning. \{Now, $\}$ chance made that dervish the ruler of Transoxiana. He took the title Sultān Khalil. He also met with me at that time and showed me great kindness. Sometimes gently, sometimes harshly, he taught me the rules of the tarīqa. I remained in his company in this manner for about six years. I made great progress in religious training and in acquiring spiritual power. I used to be in his service among the people. When we were alone, I was his special confidant. Subsequently, the sultanate of Sulțān Khalil took a turn for the worst. In an instant, nothing remained of that former reign. When I saw this, my heart completely lost its enthusiasm for the affairs of this world. I went to Bukhārā and settled in one of the neighboring villages. ${ }^{56}$

Khwāja Bahā' al-Dīn Naqshband, in fact, received his spiritual training from Khwāja 'Abd al-Khāliq Ghujduwānī. For this reason, it is by no means a mistake to regard the latter as part of the Khwājagān \{i.e. Naqshbandiyya\}. Thus, the Naqshbandiyya naturally resembles the Yasawiyya in many respects because it was influenced by the Yasawiyya, on the one hand, via Qutham Shaikh and Khalī Ata and, on the other, via Khwāja 'Abd al-Khāliq Ghujduwānī, who was 
the khalîfa of Yūsuf Hamadānī, after Aḥmad Yasawī. After Bahā' al-Dīn, the Naqshbandiyya spread widely among the Turks of Transoxiana and Khurāsān and from one point of view restricted the area of influence of the Yasawiyya. With respect to the general features of the Naqshbandiyya, however, we must add that they differed little from those of the Yasawiyya ${ }^{57}$ and that it was indebted to the Yasawiyya for laying the groundwork that allowed it to spread throughout Central Asia in a short time. ${ }^{58}$

The second great tariqqa that originated from Ahmad Yasawī is the Bektashiyya. While discussing the legendary life of Ahmad Yasawī, I have described the place given to him in Bektashī tradition (Chapter 2, pp. 32-5). In some Ṣūfì genealogies, the silsila of the tarīqa of Hājjī Bektash Veli is presented in a totally different manner, but none of these has any historical value. ${ }^{59}$ The reason is, as I explained above based on 'Āshıq Pasha-Zāde, that Hājjī Bektash Veli was a dervish obsessed with divine love who went to Anatolia and settled there before the founding of the Ottoman state and he did not by any means establish a tariqa. Indeed, his personality militated against founding such a great order. Like many other madhhabs and tariqas of various types that were involved in the religious upheavals that began among the Turks in Anatolia in the seventh/thirteenth century and continued vigorously in the eighth/fourteenth, ninth/fifteenth, and even the tenth/sixteenth centuries, the Bektashi tarīqa proper most likely took shape in the

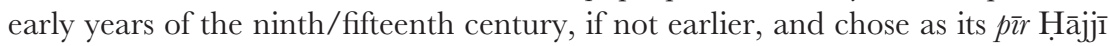
Bektash Veli, whose historical character had been forgotton and whose legends had grown up among the people since the seventh/thirteenth century. ${ }^{60}$

The tradition in those legends that Hājj̄i Bektash Veli was a Yasawī disciple has two possible explanations. One is that, because numerous Yasawī disciples did go to Anatolia before the founding of the Ottoman state, Hājjī Bektash Veli was considered to be one of them. The other is that Hājji Bektash Veli was indeed a Yasawī disciple. Whichever of these is true, it would not indicate that the Bektashī țanqa is related to the Yasawiyya, because this tariqa is not something that Hājj̄i Bektash himself established. Despite some external similarities, such as the use of Turkish rather than Arabic and Persian in the religious ceremonies of the Bektashīs and the widespread use of hymns written in plain Turkish and in the popular meter and language, exactly as among the Yasawīs, there is no factual connection between the two orders. From the very first appearance of the Bektashī tariqa those who joined it were regarded as heretics $\{z$ indīqs $\}$ who considered everything that was religiously unlawful to be religiously permissible, ${ }^{61}$ or they were deemed part of the Hurūfì sect ${ }^{62}$ and thus outside the $\operatorname{Shari}^{\prime} a$. This state of affairs, which pertained from the very first appearance of the tariqa, strengthens the notion that the generally held opinion that the Bektashiyya was originally a Șūî maslak \{path \} within the scope of the Sharī $a$ like other tariqqas, but later was taken over by Hurūfīs, mulhids \{heretics, unbelievers\}, and zindīqs and thus lost its original character, is historically mistaken.

The author $\{$ Harīî̄-Zāde\} of Tibyān-i was $\bar{a}$ il indicates that, in addition to these two great tariqas, there are two other tariquas that are branches of the 
Yasawiyya, but, in fact, they are not individual tariqas but subdivisions of the same tarnqa. The first of these two subdivisions is the Iqaaniyya. It goes back to Shaikh Kamāl Īqān̄̄, a khal̄̄fa of Mawdūd Ata. ${ }^{63}$ Khwāja 'Ubaid Allāh Ahrā̄r met this shaikh, who lived in the region of Tashkent, when he went to that city from Khurāsān and showed him great respect and affection. Indeed, as a result of their mutual affection, they were constantly engaged in discussions. Because I have described above the pedigree of the İāniyya, which derived from Kamāl Shaikh, there is no need to repeat it here (see section A, p. 94). As for the second of these two subdivisions, Harīri-Zāde, without ever mentioning it by name, is content with stating that it extended via a silsila, which I mentioned above, from Khādim Shaikh to Shaikh Ākhūnd Mullā Khurd 'Azīzān, who died in 975/1567 and was a khal̄ffa of Shaikh Khwājagīi Kāsānī \{Makhdūm-i A'ẓam\}.

\section{F Conclusion}

In light of the analytical details that have been given to this point about Ahmad Yasawi and the Yasawiyya, it is possible to present a synthetic view of the origin and nature of Turkish Șufism in Central Asia and its basic features and characteristics. The significance of Aḥmad Yasawī in Turkish history does not derive, in fact, from his being an early poet who wrote only five or ten pieces or \{even\} a few volumes of Șūfì verse $\{$ manzuma $\}$. Instead, it derives from his holding sway for centuries over the $\{$ Turkish $\}$ spirit by creating for the first time among the Turks, in the centuries during which Islam was beginning to spread among them, a Șūfi maslak. It is not that prior to him no one among the Turks had entered the Șūfi maslaks (Chapter 1, pp. 7-8), but those who did had been Persianized as a result of Iranian cultural influence in the great cities of Islam or, because of the general acceptance of the new religion, were forgotten after being absorbed among the great masses of the Turks. Not one of them left a lasting legacy or succeeded in establishing anything of permanence, whereas Ahmad Yasawī, thanks to his powerful personality, founded a great tariq a among the Turks that lasted for centuries. And this tariqa was the first to be founded by a Turk among the Turks. Thus, by critically examining the Yasawiyya and Ahmad Yasawī, we can shed light on a number of the oldest and most original aspects of Turkish Șūfism.

The Yasawiyya, i.e. Turkish Șuffism, was born under the powerful influence of a great Persian Șūfi in an area that was dominated by Persian culture. Shaikh Yūsuf Hamadānī, the scion of a Zoroastrian family from Hamadān that had been Muslim for only three generations, was not, however, one of those broadminded, free-thinking, Persian Șūfìs who tried to reconcile and interpret ancient Indian and Iranian beliefs on the basis of Islam. Instead, because he was a Hadith scholar, in the full sense of the term, who was deeply imbued with the sciences of the Shari' $a$, he held the Koran and sunna above everything and did not advance interpretations that would be unacceptable to the upholders of religious law. ${ }^{64}$ It is here that one will find the basic principles that later dominated the Yasawiyya. 
Ahmad Yasawī, who was completely imbued with the ideas of his shaikh and who was fundamentally a great religious scholar, tried to propagate and instill his shaikh's ideas when he returned to Yasī and, within a short time, he had great success. This success of a Șūfì maslak that instilled simple and plain religious and ethical principles - or, more correctly, that made religious and ethical propaganda - in an equally simple and plain environment, which had recently entered the Islamic milieu and in which philosophical subtleties were not yet understood, is quite natural. Moreover, Ahmad Yasawī addressed the people in a language that they understood and in literary forms to which they were accustomed, and so his success was all the greater. ${ }^{65}$

Just as the Yasawiyya never attempted to propagate or instill a subtle and profound "pantheism," so it never allowed certain \{eclectic\} ideas and views produced by the coalescence of various beliefs and deriving from various sources. ${ }^{66}$ The spiritual and intellectual history of the area in which it developed, not to mention the personality of its founder, was never conducive to such things. These things were possible, indeed natural, in milieus that, over the centuries, had become accustomed to an ancient religion and to a high philosophy to which it gave rise, and that, long remaining under the ebb and flow of various civilizations, took a keen interest in their spiritual sediments. But they were almost completely impossible for the Turkish milieu at the time that Ahmad Yasawī flourished.

Up to that time, the Turks had been in contact with the ideas and beliefs of India, China, Iran, and even, to some degree, Christianity, but they had never adopted them as their own. They were content with the simple views of the ancient primitive religion that was peculiar to them. For this reason, they felt no need to go beyond the fundamental beliefs of Islam, with which they were just becoming familiar, or to exceed that framework. ${ }^{67}$ The fact that a number of Buddhist monasteries were located in the Syr Darya region where the spiritually guiding voice of Ahmad Yasawī first resounded did not and could not lead to even a slight Indian influence on the Yasawiyya. ${ }^{68}$ We do find, however, some traces of the ancient primitive religion - not, to be sure, in the fundamental Yasawī teachings propagated by Aḥmad Yasawī and his khal̄ fas, but in a number of Yasawi legends that became current among the people. This is a natural phenomenon that commonly occurs in the history of the religious development of mankind. ${ }^{69}$ We can also say that the Naqshbandiyya, which was founded and spread a rather long time after the Yasawiyya and had very close connections with it and similarities to it, possesses the same basic characteristics as the Yasawiyya. ${ }^{70}$

The reference by Sayyidī 'Alī Ra' is shows that in the tenth/sixteenth century Yasawī shaikhs \{he actually says Yasawī descendants\} were found in Khwārazm, Astrakhān, and Western Iran in addition to the places that I have mentioned. Furthermore, I can mention an Indian Yasawi dervish named al-Shaikh al-Sharîf Muhammad al-Hindī who died in the fortress of Lippa in Temeshvar \{in modern Romania\}. According to 'Ațầ' $\overline{1}$, this shaikh, who was originally from

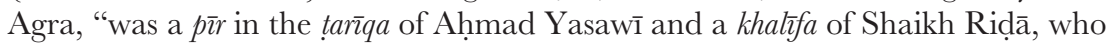


recovered his health in the service of Shaikh Hājjī Bektash.” He was a vizier of Shāh Humāyūn \{the Moghul emperor\} and the two took refuge together at the court of Shāh Tahmasp in 960/1552-3, but when his Sunnism was detected and he realized that his life was in danger, he fled to the Ottoman Empire. After living for four years in Istanbul, where Sultan Süleyman granted him a daily allowance of 120 akchas, he went to the fortress of Lippa in Temeshvar with a zeamet \{land grant\} of 20,000 akchas and died there in 974/1566-67 the supplement to \{Tashköprü-Zāde's\} al-Shaqā'iq \{i.e. Hadā’iq\}, vol. 1, p. 191). The information that Evliyā Chelebi provided above on "the Yasawī dervishes in Rüm" can also show very well the areas to which this order spread.

Historically, it is not possible to follow precisely the development and spread of the Yasawiyya in Central Asia. Nevertheless, I can give some details about it that are probably fairly accurate. ${ }^{71}$ According to what can be gleaned from existing documents, this tarīqa first took hold in Tashkent and its environs in the Syr Darya region, and then spread to Khwārazm, while also beginning to grow in strength in Transoxiana. I have also given some information above, deduced from surviving legends, on the historical development of this tariqa, which spread from the Syr Darya Valley and Khwārazm toward the northwest and the Qipchaq regions and, by means of various dervishes, went as far as Khurāsān, Azerbaijan, and Anatolia (Chapter 2, pp. 36-7). Let me add here that this tariqa, which we can regard as exclusively Turkish, generally held sway in the Turkish countries until the appearance of the Naqshbandiyya. ${ }^{72}$ After the appearance of this new order, it won a major place among the Turks of Transoxiana in particular and also spread to all of Khurāsān and Khwārazm. Because of the close relationship between the Yasawiyya and Naqshbandiyya, this state of affairs naturally caused no injury to the fame of Khwāja Ahmad Yasawī and was no obstacle to the spread of Yasawi shaikhs throughout the Turkish world. In fact, in the tenth/ sixteenth century, we not only find Yasawī khal̄ffas in Khurāsān, ${ }^{73}$ but we also find Yasawī shaikhs in various places in Central Asia and even in Kabul, Diyarbakir, the Hijaz, and Istanbul. ${ }^{74}$ Nevertheless, by that time, the Naqshbandiyya had acquired much greater importance than the Yasawiyya. ${ }^{75}$ The overriding influence and importance of Khwāja Aḥmad Yasawī was only maintained in the Syr Darya region and in the Qazaq steppes, where it was never supplanted by another tarīqa. As I have explained above (Chapter 3, pp. 69-70), the enormous respect and reverence for this great $p \bar{\imath} r$ that the Qazaqs have nourished for centuries is of a different order and much stronger than the respect and reverence they have felt for any other saint or spiritual guide. We can safely say that of all the various tariqqas that have taken shape over the centuries, the one that is most characteristically Turkish is the Yasawiyya. ${ }^{76}$

\section{NOTES}

1 \{Ṣafî,\} Rashahāt, \{Turkish\} trans., p. 15. Manșūr Ata died in 594/1197-8. \{Lāhawrī,\} Khazinat al-asfiy $\bar{a}$, records the following chronogram for him (vol. 1, p. 535): 


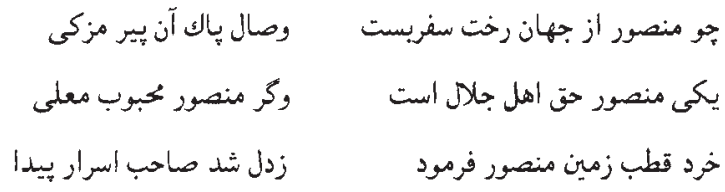

Tāj-Khwāja died in 596/1199-1200. The same work (vol. 1, p. 535) has the following chronogram for him:

$$
\begin{aligned}
& \text { جو تاج آتاشه وين تاج عزت زحق شد تاجدار خلد اعلى } \\
& \text { عيان كرديد سال ارتحالش تاج اوليا محبوب مولى }
\end{aligned}
$$

\{These dates are meaningless and appear for the first time in the Khazinnat al-asfiy $\vec{a}$ from the mid-nineteenth century.\} Nithārī Bukhārī, the author of the biographical dictionary Mudhakkir-i aḥbāb and member of the family of Arslan Bābā via Zangīä Ata, shows in the following manner the material and spiritual \{madd̄ wa ma'nawē silsila of his own grandfather 'Abd al-Wahhāb Khwāja: 'Abd al-Wahhāb Khwāja, Sulaimān Khwāja, Yahyā Khwāja, Hārūn Khwāja, Șadr Khwāja, Zangī Ata, Tāj-Khwāja, 'Abd al-Malik Khwāja, Manșūr Ata, Arslan Bāb (pp. 299-300). Hazīnī, Jawāhir, also indicates that he was a descendant of Manșūr Ata (p. 231). It is apparent that the legendary account that I recounted at great length in Chapter 2 (pp. 20-1) was formed around these details, because Arslan Bābā was certainly a historical figure and from the black race. \{Köprülü relied completely on the Rashahät's account of the succession to Ahmad Yasawī, which is completely contrived, in order to assign him four khalnfas (requiring the insertion of two ciphers, one of whom is never anything more than a name). It is odd that he did not trust Hazīnī, whose work he emphasizes for so much else. As it stands, he failed to use fully Hazīn̄'s extensive information on the Yasawī lineage leading to his own master, Sayyid Manșūr, and failed even to consider the other successors of Ahmad Yasawī, as named by Hazīn̄i, whom he mentioned earlier. Also, even if we could accept Arslan Bābā as historical (which is not clear), there is no evidence that he was "from the black race." One of his descendants is called "Zangi Ata," but elsewhere Arslan Bābā is called an Arab.\}

2 The date given for Sa ${ }^{\top} \overline{1} d$ Ata is meaningless. It is found no earlier than the nineteenth-century Khazinnat al-asfiy $\bar{a}^{\prime}$.

3 Although $\{$ Safī, $\}$ Rashahāt, $\{$ Turkish $\}$ trans., indicates that the wife of Hakīm Ata, the famous 'Anbar Ana, was the daughter of Burāq Khān (p. 16), the author \{Nithārī Bukhārī $\}$ of Mudhakkir-i ahbāb especially makes the point of correcting this to the daughter of Bughrā Khān (p. 299).

4 The death date for Hakīm Ata never appears in "a story." It too appears no earlier than the Khazinat al-asfiy $\vec{a}$. The date was probably chosen to yield a round twenty years from the death date of Ahmad Yasawī. Our earliest source to give a death date for Hakīm Ata, from the sixteenth century, says he died in $523 \mathrm{AH}$, and is thus also clearly meaningless.\}

$5\{$ Șafī, Rashahāt, \{Turkish\} trans., p. 16. The author $\{$ Lāhawrī $\}$ of Khazinnat al-asfyya records the death date of Hakim Ata in the following chronogram (vol. 5, p. 534):

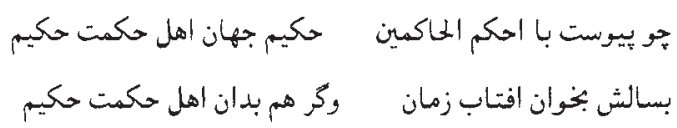


As for Aq Qūrghān, where Hakīm Ata was buried, we know of two towns with this name in the region of Central Asia and Turkistan where the Yasawiyya spread. One is a winter pasture $\{k$ şlak $\}$ in the environs of the town of Shīr-ābād near the presentday Bukhārā and Afghan border. The French Traveler G. Capus gives considerable information about it (A travers le royaume de Tamerlan... [Paris, 1892], pp. 120, 140). The other one is a ruined site that the Qazaqs today call Aq Qūrghān in the Tekesh valley southeast of Qūlcha (Kulja). It was a government center of the former Mongol khāns (Reclus, Nouvelle géogrqphie universelle, vol. on Russian Asia, p. 562). Because tradition puts Hakīm Ata in the vicinity of Khwārazm, it is more likely that the Aq Qūrghān in question was the town visited by Capus. Nevertheless, because the name Aq Qūrghān was a common designation that could be given to the türbe of any saint, just as the türbe of Ahmad Yasawī's father Shaikh Ibrāhīm was called Aq Türbet, it is also possible that Hakīm Ata is buried in an Aq Qūrghān that has nothing to do with these two towns. \{The problem here is that there are two apparently different stories about the burial place of Hakīm Ata. The anomalous one is also the most influential, since it is from the ubiquitous Rashahāt: it calls his burial place Aq Qurghān, further explaining this name in Persian as qal'ah-i safìd, leaving no doubt that the form "Aq Qurghān" was indeed intended, at least by the author of the Rashahāt. The author may, however, have had written material at hand in which his burial place was given as "Bāq.rghān" or the like, and interpreted the initial $b \bar{a}$ as the Persian prefix, and the rest as a garbled $\bar{a} q-q . r . g h \bar{a} n$. In any case, the name "Bāqırghān" (i.e. the form "Bāgh.r.ghān") is attested as the burial place of Hakīm Ata already in the early sixteenth century, i.e. not long after the Rashahāt was compiled, and that name is widely associated with Hakīm Ata. We have, of course, the other etymology of the place name, as the site where the saint's camel bellowed. Köprülü could not have read Barthold's brief article "K voprosu o rodine Khakim-Ata," Sochineniia, II/2, p. 361 (originally published in 1902), whose title was somewhat misleading since the legend of Hakim Ata says nothing of his "native land" (and in fact implies that he was in the same town as Ahmad Yasawī already in his boyhood). Köprülü does point out the similarity in pronunciation below in n.9, but in any case his long discussions of two places called Aq Qurghān are in vain.\}

6 The work to which Köprülü refers is actually known as Hakim Ata kitäbr (as he himself acknowledges below in $\mathrm{n} .7$ and elsewhere).\}

7 \{Anonymous, \} Hakìm Ata kitâbı (Kazan, 1901). \{The best known published version of this work was one that Köprülü evidently knew but never obtained: K. G. Zaleman (ed. and Russian trans.), "Legenda pro Khakim-Ata," Izvestiia Akademï nauk (SPb.), 9/2 (1898), 105-50. Zaleman's version was based on the earliest known manuscript and is much better than the 1901 printing. What Köprülü proceeds to give above in the text is a much-paraphrased rendering of the eleven stories of this work. He leaves out a great deal and does not, or could not, compare the stories with other versions in independent sources. Moreover, much of the work only makes sense with an understanding of the hereditary Șūfì traditions linked to Hakīm Ata, Sayyid Ata, and others, in Khwārazm, but Köprülü could not have known of those.\} In the most important works like \{Ṣafī's\} Rashahạt, Sulaimān Ata and Hakīm Ata are described as two different people, but this is not correct. Not only does the Hakim Ata kitâbr testify to this, but even a book like \{Hazin̄îs\} Fawähir, which is one of the most important works on this subject, describes Sulaimān Hakīm Ata as a single person. For more detailed information on the works of this important Yasawi khaliffa, see Chapter 6, pp. 175-6 of this work. \{Köprülü glosses over a very real problem: it is quite true that many other sources affirm the status of Șūfì Muhammad Dānishmend as Aḥmad Yasawī's disciple, but the fact that early versions of the Rashahāt replace Sūfì Muhammad among Aḥmad Yasawī’s four successors by splitting Hakīm Ata into two people is significant nonetheless.\} 
8 The term tekke is virtually never used in Central Asia, and in this particular instance it is not mentioned in the text of Hakim Ata kitäbr. Its use has the effect of imposing a Turkish form (institutionally, even) on a Central Asian reality it does not fit. Köprülü's rendering of the story here, moreover, obscures the difference between what he is translating and what he is explaining or interpreting, and is very unfortunate. Zaleman's text makes it clear that what Ahmad Yasawī fastens at his waist is a sheep's bladder, from which he both expels air audibly and pours water.\}

9 \{Anonymous, \} Hakim Ata kitâbı. This was the reason the name Sulaimān Bāqirghānī was given to Hakīm Ata; but it is nevertheless apparent that this resulted from a folk etymology rather than from a historical tradition. The similarity in pronunciation between Aq Qūrghān and Bāqirghān is evidence to support this.

10 It should not be forgotten that the man whom Tìmūr ordered to build the türbe of Khwāja Aḥmad Yasawī was also named 'Abd Allāh Șadr. It seems very likely that the 'Abd Allāh Sadr in this legendary account represents an altered version of this historical personality.

11 \{Here Köprülü leaves out major elements of two stories: the Jārullāh with whom the two sons go to study in Khwārazm is the famous scholar al-Zamakhsharī (d. 538/ 1144); and the story recounts the profligacy of the two sons in the city, where they drink wine and miraculously evade the punishment recommended by their father.\}

12 The sacrifice of these nine oxen was also a vestige of the pre-Islamic religious traditions of the Turks. For considerably more information collected on the sanctity of the number nine among the Turks and Mongols, see my "Türk edebiyatı tarihine medhal" \{never published, see his "Türk edebiyatının menşe'i," \}, pp. 101-2. This sacrifice and inviting everyone to the feast are reminiscent, in fact, of the old şölen (public feast); see ibid.

13 The point of the story is again obscured by Köprülü's rendering: it shows the increasing tension between father and son, which culminates in the son showing up his father by reviving the slaughtered oxen. It is surprising that Köprülü omitted the proverb uttered by Hakim Ata to explain why his son had to get lost, namely that "two rams' heads cannot be boiled in the same cauldron" (to which the son replies that even three will fit, if you just remove the horns!). This proverb is found already in al-Kāshgharī, Dankoff and Kelly (trans.), Compendium, vol. 2, p. 345.\}

14 One night Hakīm Ata appeared to Khwāja Jalāl al-Dīn in a dream. He said, "Seek me out! Build a mausoleum over me!" Based on this spiritual guidance, Khwāja Jalāl al-Dīn went to Turkistan with many goods and returned from there to Bāqirghān. Just then, however, the weather suddenly turned very bad. The sky darkened and a terrible wind blew. When the weather cleared, the goods and animals of the merchants had all been swept away. Khwāja Jalāl al-Dīn went up a hill and looked around. Opposite him, he saw a mountain and on top of it he saw a woman. He went over and greeted her and asked the location of Hakim Ata's türbe. The woman didn't know. She suggested that the khwäja go with her to her old mother and ask her. The old woman told them that that area was under water and the türbe was lost, and she said, "Near the water is an ornamental tree \{süs ağacı, i.e. not fruit bearing\}. Every night deer gather around it and remain there until dawn paying homage. Those who pass by hear the sound of a dhikr. Perhaps that is the place." Khwāja Jalāl al-Dīn traveled there that very night. He saw the deer, listened to the sounds of the $d h i k r$, and fell asleep. Hakīm Ata appeared to him again in a dream, saying "Go forward seven paces from the place where you lay down! Dig there! A reed mat will emerge and, under it, a bouquet of roses. That place is my türbe. Don't worry about your lost goods because all of it is in the caravanserai. Retrieve it and come! Build a mausoleum over me and take up permanent residence at my tomb!" When Khwāja Jalāl al-Dīn awoke, he did as he was instructed, found the tomb and set up a marker. Then he departed 
and retrieved his goods. Later he had skilled craftsmen brought from Khwārazm and 100,000 gold tenges were spent to build the mausoleum. He took the name Shaikh Jalāl al-Dīn and lived on the site. Everyone in the region rushed to visit him (Hakim Ata kitâbr \{a paraphrase of the original Chaghatay\}). On the sanctity of trees among the Turks, see the Uygur menkabesi of Juvain̄i \{probably a reference to J. Marquart, "Ğuwaini’s Bericht über die Bekehrung der Uiguren," Sitzungsberichte der Preussischen Akademie der Wissenschaften, 1 (1912), 486-502. Cf. Boyle's translation of Juvainī, vol. 1, pp. 53-61\}, Radloff's famous work on Shamanism \{Das Schamanenthum und sein Kultus, eine Untersuchun (Leipzig, 1885)\}, and Grenard $\{$ Le Turkestan $\}$. Ancient deer legends and popular folk tales clearly show the importance of deer in popular beliefs. \{Köprülü's continuous search for "survivals" is noteworthy.

15 Because Hakīm Ata was very dark skinned, 'Anbar Ana one day somehow thought to herself, "I wish my husband were not so black." Hakīm Ata learned of this through the miraculous light of saintliness and prayed, saying, "May it happen soon that you be the companion of one blacker than me." And, indeed, a short time later Hakim Ata died and Zangī Ata came and asked 'Anbar Ana for her hand in marriage. 'Anbar Ana, turning away her face with rage, rejected this proposal, saying "I will not marry anyone after Hakīm Ata, least of all such a negro," but her neck remained in that position \{i.e. twisted\}. Zangi Ata then sent her a message reminding her of what had previously passed between her and her deceased husband. When she learned that this proposal of marriage had simply resulted from a saintly miracle, she wept and had to accept (\{Ṣafi, $\}$ Rashahăt, \{Turkish\} trans., pp. 16-17). The Hakîm Ata kitâbr presents this legend in a different manner: Hakīm Ata was black, while 'Anbar Ana was white and beautiful. One day, while Hakīm Ata was washing \{himself\}, 'Anbar Ana was in bed. She looked at him and wondered why she, the daughter of Bughrā Khān, had become the wife of \{lit. fallen to $\}$ this black man. Hakīm Ata knew what she was thinking and he said to her, "You do not like my looks. But after me you will become the wife of one so black that he has nothing white except his teeth!" 'Anbar Ana then regretted what she had thought and wept. But it was too late. When the time approached for Hakīm Ata to pass away, he sent for his sons from Khwārazm and said to them, "After my death, when you serve the funeral banquet on the fortieth day, forty abdāls from the people of the Ka'ba will come from the East $\{s i c\}$. Among them will be a black abdāl blind in one eye and lame in one leg. After the required waiting period before remarrying has passed, marry your mother to him!"' And indeed, forty days after Hakīm Ata's death, the abdāls arrived, but there was no black abdāl among them. The sons asked about him. They learned that he had remained behind and they sent for him. His name was Zangī \{i.e. "Negro"\}. They married their mother to him according to their father's will. At that time, no one knew of the saintliness of this Zangī. Zangī Bābā took his wife and departed for his native country. 'Anbar Ana suffered great distress because of this Zangī as a result of her former husband's saintly miracle, but she put up with it and gave advice to other women on this subject (Hakîm Ata kitâbı). \{See $E I^{2}$, s.v. "Zangī Ātā" (Th. Zarcone). In the narrative, Köprülü switches from Hakīm Ata kitābr to the Rashahāt's account of Hakīm Ata and Zangī Ata (who are not portrayed in the former work as ever meeting one another!), but mixes the two accounts together for a while. Zangī Ata is made a descendant of Arslan Bābā in the Rashahāt and in Nithārī's work, but the Hakīm Ata kitābr says nothing of this. The idea that Zangī's black skin (or ugliness!) was because he was a descendant of Arslan Bābā (who does not appear to be identified as an Arab in any source) is Köprülü's own invention.\}

16 \{The saint Köprülü usually calls "Sayyid Ahmad," using the Rashahăt, is more often known as "Sayyid Ata," who stands at the head of an enormously important Șūfi and familial tradition in Central Asia. See the following articles by DeWeese: "A 
Neglected Source on Central Asian History: The 17th-century Yasavī Hagiography Manāqib al-akhyār," in Denis Sinor and Bakhtiyar A. Nazarov (eds), Essays on Uzbek History, Culture, and Language (Bloomington, IN, 1993), pp. 38-50; "The Descendants of Sayyid Ata"; "The Sayyid Atā'̄̄ Presence in Khwārazm during the 16th and Early 17 th Centuries," in DeWeese (ed.), Studies on Central Asian History in Honor of Yuri Bregel (Bloomington, IN, 2001), pp. 245-81; and EIr, s.v. "Atā'ìya Order."

17 SṢafī, Rashahāt, \{Turkish\} trans., pp. 17-19. The Hakim Ata kitâbı mentions certain legends about Sayyid Ata that are not found in the Rashahät and describes his relationship to Hakīm Ata as follows. One day Hakîm Ata kitâbr was being read in Sayyid Ata's teaching circle and his legends and miracles were being discussed. Sayyid Ata asked if any of the sayyids had taken up residence at his tomb. When he learned that none had done so, he went to Bāqirghān taking three people with him. Sayyid Ata asked Shaikh Jalāl, who was there, if he would cede the post of resident $\{$ mujäwir $\}$ to him. Shaikh Jalāl, who had been personally hurt by his coming, stated that he had come there on the order of Hakīm Ata. Sayyid Ata then made the following suggestion: "Tonight let the two of us go and petition \{Hakim Ata\}, and whomever Hakīm Ata wants will stay." Shaikh Jalāl agreed to this and that night they went. Hakīm Ata said, "Oh, my son Shaikh Jalāl, Sayyid Ata came here on the order of the Prophet. Cede the post of mujäwir to him. Near Khwārazm is a place called Aqtash. Go there and establish a halting place \{or caravansarai\}. Let whoever comes to visit me, visit you first. I will not accept those who have not gone to you first." Shaikh Jalāl happily ceded the post of mujäwir and went straight to Aqtash. Sayyid Ata spent a long time there as mujāwir. Finally, his time to pass away arrived. His murids asked him, "Shall we take you to the Ka'ba or bury you here?" He answered, "Put my coffin on a large cart and depart \{with it\} from Bāqirghān in the direction of the Ka'ba. That night, however, firmly tie up your animals. Don't make any noise. Stay in your homes. If you hear a sound, beware. Don't go outside. When dawn breaks, look outside. Wherever the cart has stopped, bury me on that spot." All of this, in fact, happened. The next day they saw that the cart had stopped next to the türbe of Hakim Ata. They immediately buried Sayyid Ata there. That night the spirits of the Ka'ba erens fought with the spirits of the Bāqirghān erens for possession of Sayyid Ata. The latter were victorious. Now those who come to Bāqirghān first visit the tomb of Hakīm Ata, then that of Sayyid Ata, and afterwards the other tombs (Hakîm Ata kitâbl). We find the death date \{chronogram\} of Sayyid Ata, who died in 702/1302-3, as follows in \{Lāhawrî̀s\} Khazīnat al-asfyā (vol. 1, p. 540) \{again, a meaningless date\}:
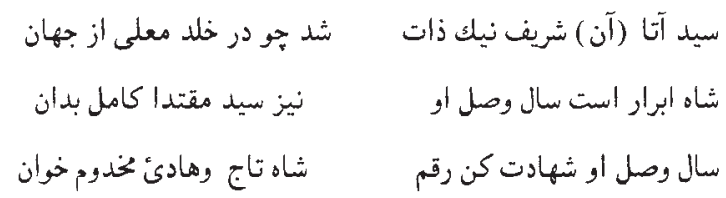

Sayyidī 'Alī Ra'īs says that he visited the tombs of Hakīm Ata and Sayyid Ata while going from Khīva to Khwārazm and that both were in the same place (Mir'āt al-mamāik, p. 71).

Riḍa Qulī Khān gives the following information on Hakīm Ata and his tomb in his famous Safarnāme-yi Khwärazm \{ed. and French trans. Ch. Schefer (Paris, 1879)\}: "Hakīm Ata is the name of a place on the bank of the Amu Darya. Hakīm Ata, who is buried there, was a Turkish shaikh of the Naqshbandī silsila. Khwārazm stretches along the banks of the Amu Darya and most of its villages are on its banks. All of them are a distance of three or four parasangs or a little more from the banks of the 
Amu Dayra. Hakim Ata is at the extreme limit of the cultivated and inhabited part of Khwārazm. Beyond it one encounters the Qazaqs and Qaraqalpaqs who are subject to the Khān of Khīva. They live in this arid region between the Syr Darya and Amu Darya, which takes twenty days to cross" (Persian text, p. 101). Schefer, who made an annotated trans. of the Safarname, corrects and supplements this information, based on \{Lāhawrī's\} Khazinnat al-asfiyan, by stating "Hakīm Ata was buried in Aq Qūrghān." He also says that there was an early copy of the story of Hakim Ata and that it was published in Kazan by I. Gottwald (Schefer trans., p. 101). Furthermore, Riḍā Qulī Khān mentions an Adun-Ata Fountain among the halting places of the Turkmen and states that this Adun-Ata was a murīd of Zangī Ata (Persian text, p. 41; Schefer trans., p. 65). This would again confirm that the influence of the Yasawi murinds had expanded widely in the the Turkmen region.

$18\{$ SSafī, $\}$ Rashahāt, \{Turkish\} trans., pp. 20-1. According to one tradition, Sadr Ata died in 656/1258-9 (\{Harīīi-Zāde,\} Tibyān-i was à'il). This, however, is clearly a mistake, for 656 was the year of Zangi Ata's death \{again, a meaningless date\}.

19 A poet named Shams wrote a munāja \{supplication\} in the musammat mode \{"pearl stringing," see Walter Andrews, An Introduction to Ottoman Poetry (Minneapolis, 1976), pp. 59-60\} addressed to Zangī Ata. It is published in Ahmad Yasawī's Dīwān-i Hikmat. This work, which was written in the 'arūd meter and begins with the verse

Ol Seyyid-i âdem hakkı yâ Zengî Bâbâ himmeti

Ol mefhar-i âdem hakkr yâ Zengî Bâbâ himmeti

\{For the sake of that chief of mankind, O spiritual guidance of Zangī Bābā!

For the sake of that pride of mankind, O spiritual guidance of Zangī Bābā!\}

has very defective versification (Dīwān-i Hikmat, Istanbul edn, p. 285). Far superior is the eulogy of Kemmī Tāshkandī, a fellow countryman of Zangī Ata, which includes the passage,

\section{Dergeh-î Hak pâsbân Hazret-i Zengî Atâ \\ Sirr-ı gaybî râzdânî Hazret-i Zengî Atâ \\ İdiler zâhir siyeh-fâm-ü likin bâtrnen \\ Tabtılar nûr-ü ziyần Hazret-i Zengî Atâ \\ Turfa bir keșf-i kerâmet görgüzüb dehr ehligâ \\ Aldılar Anbar-Anần Hazret-i Zengî Atâ}

\{Guardian of the court of God, his majesty Zangī Ata

Confidant of the mystery of the unseen, his majesty Zangī Ata

Outwardly he was black, but inwardly

He found the Light of Light, his majesty Zangī Ata

Demonstrating a wondrous miracle to the people of the age

He married 'Anbar Ana, his majesty Zangī Ata\}

(Meстиа-i Hazin̂̂, Tashkent lithograph edn $\{1329 / 1911\}$, p. 47).

20 Schuyler, Turkistan, \{Turkish\} trans., p. 189. It is also recorded in \{Safî's\} Rashahät that Zangī Ata's home and burial place were in Shāsh (Tashkent), p. 16. As for his death date, Zangī Ata died in 656/1258-9. \{Lāhawrîs\} Khazinat al-asfiya records the following chronogram for him (vol. 1, p. 539) \{again, a meaningless date\}:

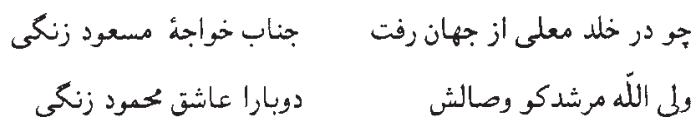


While traveling from Khīva to Krasnovodsk, Capus says that the places between Zamakhshar and Cherechelī (يحر ه جلى ) were still abandoned because of the depredations of the Turkmen. \{He adds that $\}$ there is a town of Zangī Bābā among these old towns that today only appear as ruins because they were thus abandoned (Capus, $A$ travers, pp. 405, 406, 410, 412).

$21\{$ Șafì, $\}$ Rashahăt, $\{$ Turkish $\}$ trans., p. 16. Hazīn̄̄ \{ Jawähir $\}$ mentions this famous story in the following manner:
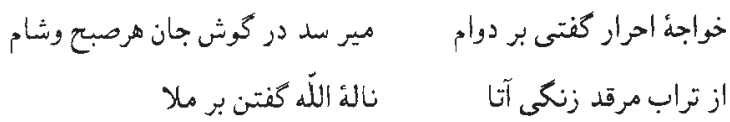

\{Khwāja Ahrāar used to say: There comes to the ear of my soul every morning and evening,

From the tomb of Zangī Ata, the cry "Allāh" spoken for all to hear.\}

Kemmī Tāshkandì's eulogy also refers to this with the couplet

Eylegaylar tâ memâtidan beri vird-i zebân

Allâh Allâh Rabbenần Hazret-i Zengî Atâ

\{Ever since his death, he will utter this litany:

"God, God, Our Lord. His majesty Zangī Ata."\}

22 \{This is Khwāja 'Alī 'Azīzān Rāmītanī, a prominent figure from the Khwājagānī silsila. See DeWeese, "Khojagānī Origins and the Critique of Sufism: The Rhetoric of Communal Uniqueness in the Manāqib of Khoja 'Alī 'Azīzān Rāmītanī," in Frederick De Jong and Bernd Radtke (eds), Islamic Mysticism Contested: Thirteen Centuries of Controversies and Polemics (Leiden, 1999), pp. 492-519.\}

$23\{$ Șafī, $\}$ Rashahāt, \{Turkish\} trans., indicates this town between Sairām and Tashkent, p. 19. \{Ismā'îl Ata is portrayed in the Rashahăt as hailing from an unidentifiable town called there "Kharzīyān." The reading is uncertain, but it is definitely not Hūziyyā. The same source also makes Ismāîl Ata a disciple of Sayyid Ata, but this is in all likelihood wrong. It is not supported by the work of Ismāîl Ata's own son, mentioned earlier. The story of the straw in Ismā'il Ata's eye, in the narrative below, involves an ancestor of Khwāja 'Ubaid Allāh Ahrār, who was indeed a Tāshkandī. Ismā'îl Ata begins an important Yasawi Șūfi lineage, primarily hereditary, that was entirely unknown to Köprülü. For a discussion of it, see DeWeese, "Yasavī Sayhs in the Timurid Era: Notes on the Social and Political Role of Communal Sufi Affiliations in the 14th and 15th Centuries," in Michele Bernardini (ed.), La civiltà timuride come fenomeno internazionale [= Oriente Moderno, Rome, NS, 15 (76), No. 2 (1966)], pp. 175-9, 185-6.\}

24 Ibid.

25 Ibid., p. 242.

26 The people in the area between Sairām and Tashkent had converted to Islam very early; see Chapter 1, pp. 4-6. On this city, see the detailed information in the discussion of Khwāja Aḥmad Yasawì’s work in Chapter 5, p. 133.

$27\{$ Șafī, $\}$ Rashahāt, $\{$ Turkish $\}$ trans., p. 20.

28 Ibid., pp. 22-3.

29 \{Here Köprülü dispenses with the entire Yasawī silsila after the fifteenth century. He uses unreliable sources, gives the wrong form of names, and sometimes splits people into two or fails to recognize specific appellations. Access to the Lamahät would have 
spared him these errors, but he could have done much better had he truly used the works of Hazīnī to which he had access. In order: Khudāidād's nisba was "Ghazīragī," though "'Azīzagī" is easy to understand and shows up in manuscripts as well (Ghazīrah is/was a town near Samarqand). "Mawlānā Walī Kūh-i Zarì" is the best form of the next person's name. "Shaikh Garmīn $\vec{\imath}$ " clearly refers to the most important Yasawī shaikh of the second half of the sixteenth century, Qāsim Shaikh Karmīnagī (Karmīnah is a famous town between Bukhārā and Samarqand). Muḥammad Mu'min Samarqandī was the father of 'Ālim Shaikh, who wrote the Lamahāt; this was as close as Köprülü got to him. It is not clear whom Köprülü had in mind with "Shaikh Ākhūnd, Mullā Khurd 'Azīzān." All this probably refers to one person, not two, namely Mawlānā Khūrd 'Azīzān (a son and successor of the Naqshbandī Makhdūm-i A'żam), who died in 977/1569-70 in Balkh, and who is mentioned later by Köprülü in this chapter of the narrative. As for the lineage of Kamāl Shaikh İqānī, the latter's disciple is shown in better sources as "Shaikh Sayyid Ahmad," and it is not clear why Köprülü (or the Tibyān) gives "Shaikh 'Alīyābādī." This Ahmad was one of the figures to whom A. K. Borovkov suggested ascribing some of the poems from the Dīwān-i Hikmat ("Ocherki po istorii uzbekskogo iazyka (opredelenie iazyka khikmatov Akhmada Iasevi)," Sovetskoe vostokovedenie, 5 (1948), 229-50). Shams Özkendi (Uzgandī) is known most extensively from the Lamahāt. Köprülü took the three names following him from the late Tibyann, but that work's source must have been, directly or indirectly, another work of Hazin̄ī that was unknown to Köprülü, the Fāmic al-murshidīn (preserved in a unique manuscript in Berlin). For the most extensive discussion of the post-fifteenth-century Yasawi silsila lines to date, see DeWeese, "The Yasavī Order and Persian Hagiography in Seventeenth-Century Central Asia: 'Ālim Shaykh of 'Alìyābād and his Lamahāt min nafahāt al-quds," pp. 389-414.\}

30 The silsila given in \{Hazīn̄̄'s\} Fawāhir is as follows: Zangī Ata, Șadr Ata, Jamāl Shāshī (in Khwārazm), his son Ḥasan Shaikh, 'Alī Khwāja, Khwāja 'Alī $\{$ sic \}, who had two khal̄fas, Shaikh Pehlivān \{just an epithet\}, and Shaikh Mawdūd (the shaikh of Sultan Abū Sa '̄id). Shaikh Mawdūd's khalñfa Khādim Shaikh, Shaikh Jamāl al-Dīn (in Bukhārā, his tomb was in Herat), Shaikh Sulaimān Ghaznawī (he studied first from 'Ubaid Allāh Aḥrār and then Jamāl al-Dīn), Shaikh Khudāidād, Mullā Walī Kūh-i Zarī (Kūh-i Zarrī), Qāsim \{sic\} Shaikh, and Shaikh Khudāidād's other khal̄̄fa Shaikh Matīn \{an epithet\}, from whom Shaikh Amīn \{an epithet\} received permission to initiate others, and from whom in turn Sayyid Manșūr Ata received this permission, and from whom in turn Hazini the author of this work received this permission (summary of the rhymed Persian \{Ṣūî́ genealogical tree \{silsilanāme\} at the end of Fawähir, pp. 23243). The reason for these differences is obvious. A given shaikh had numerous khalffas, only some of whom were recorded in the genealogical tree. Many were forgotten or their correct genealogical trees were later lost. The author $\{$ S Safi $\}$ of Rashahät, so it would seem, took the Yasawi khaliffas who had won fame up to his time from Jamāl al-Dīn Bukhārī. As for Hazīnī, he seems to have recorded the genealogical tree of his

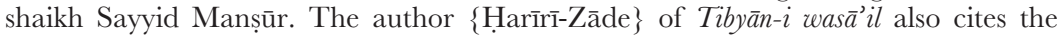
genealogical tree of some dervish or other that resembles this one. \{Köprülü misunderstood Hazīn̄̄'s account of the Yasawī silsila in several respects. His silsila chart has often been repeated and cited in other works, but it is thoroughly misleading and incomplete and thus should no longer be used. The problems posed by Hazīnī's account in the earliest stage of this silsila are indeed confusing, and cannot be sorted out on the basis of his accounts alone. Adding the data in the Lamahät is essential. Köprülü is to be criticized primarily for implying that the presentation is straightforward, not for misunderstanding a confusing account. The more important errors begin with Shaikh Sulaimān Ghaznawī and Khudāidād. Köprülü implies that the latter was the disciple of the former - and there are, in fact, the sort of conflicting 
accounts that should tell us that two separate lineages claimed supremacy for their own spiritual ancestor - but there is abundant evidence (some from Hazīnī himself) that Khudāidād was a direct disciple of Jamāl al-Dīn. Next, Mawlānā Walī Kūh-i Zarī is indeed consistently shown as a disciple of Khudāidād and as a master of Qāsim Shaikh; but Hazīnī's account then goes on to say that another of Khudāidād's disciples was Darwīsh Shaikh (to whom the epithet "Shaikh-i Matīn," i.e. "the firm master," is applied), and that after Darwīsh Shaikh came "the powerful shaikh, Mullā Amīn," from whom Hazīnī himself obtained guidance, in addition to his relationship with his principal master, Sayyid Manșūr (who was a disciple of Sulaimān Ghaznawī). The Mullā Amīn mentioned here may be another epithet referring to a known disciple of Khudāidād who came to prominence after Darwīsh Shaikh. In any case, "Darwīsh Shaikh" was not recognized as a proper name, in effect, by Köprülü (or Okuyucu), primarily because they did not know the Lamahāt (Darwīsh Shaikh was a grandfather of that work's author, 'Ālim Shaikh). Finally, it is worthy of note that Hazīn̄'s master is never called "Sayyid Manșūr Ata" (except by Köprülü).\}

$31\{$ Hazīn̄ī, Jawāhir, p. 120. Here it suffices for us to cite briefly from Hazīnī's work the rules $(\bar{a} d \bar{a} b)$ of the Yasawi tariq $a$. The details given on this subject in this work, which was written in the tenth/sixteenth century, are not found in other sources, so they are also very valuable with respect to the general history of Sunfism. Comparing these details with the rules and principles of other tariqas, however, is a subject completely beyond the scope of the present work. On the rules of the tarīqa, Hazin̄in cites a work called Bustān al-'ärifinn (Jawāhir, p. 137), but I know of no work by Khwāja Aḥmad Yasawi with this title. The work with this title that is renowned throughout the Muslim world is one on Hadith transmission, canonical rules and ethics by Imām Abū 'l-Laith Nașr b. Muhammad Samarqandī Hanafí who died in 375/985-6 \{rather, between 373/983 and 393/1003\}. There are many copies in our libraries. Kātib Chelebī adds that there were three versions of this work, large, medium, and small, and that the small one was the version commonly found throughout Rūm and the Arab countries (Kashf al-zunūn [Būlāq, 1274/1857], vol. 1, p. 153). Kātib Chelebi also states that Imām Muhȳī 'l-Dīn Yahyā b. Sharaf al-Dīn al-Nawawī al-Shāfí̄ (d. 676/1277) had a work with this title. \{It is not quite clear that Hazīni intended to ascribe the Bustān al-'arifîn to Ahmad Yasawī. He mentions it twice, once without ascription, and once ascribed to the shaikh al-masha' $i k h$, a phrase typically used to refer to Yasawi, but nevertheless somewhat ambiguous.\}

32 According to Ahmad Yasawī's declaration, one could not become a shaikh without studying seventy sciences and passing through seventy stages $\{m a q \bar{a} m s\}$. One gradually attained these sciences through forty-four stages. One who set out to be a shaikh without studying them would be detested by the men of God \{ahl Alläh; in the Okuyucu edn of Hazīn̄i, p. 63, awliy $\bar{a}^{\prime}$ Allāh, i.e. the saints $\}$. The stages are as follows: sincere repentance, beneficial knowledge, lofty forbearance, perfect discernment, comprehensive knowledge, whole-hearted submission, humble dignity, complete contentment, being as truthful as Caliph Abū Bakr, being as certain of what is right as Caliph 'Umar, being as pious as Caliph 'Uthmān, praising God like Caliph 'Alī, being as piously ascetic as Hasan, being as obliterated \{in God\} as Husain, placing complete trust in God like Imām Muhammad Ibn al-Hanafiyya, perfect endurance \{of this world\}, giving thanks for divine benefaction, submission to one's fate, fortitude in the face of tribulation, enjoyment of blessings, generosity from what one possesses, sincerity towards people of distinction, praisworthy ethics, abstinence from what is religiously forbidden and cleanliness and fasting, general humility, permanent fear $\{$ of God\}, wishing for all contingencies and terrors, compassion and weeping, longing for and being perceptive to God, ecstasy of God, goodness and virtue, 
kindness and generosity, the guidance of God, being fearful \{of God\} in outward reverence, being fearful \{of God\} in inward submission, devoutness in rejecting what is forbidden and resolution in conforming to what is commanded, wisdom and experience in word and deed, being innocent of great sins, being innocent of minor sins, the illumination of separation \{from God\} and the ardor of yearning \{for God\}, melancholia and madness \{as a form of love $\}$, love and affection \{for God\}, modesty before God and men \{in the Okuyucu edn followed by wa ' $l$-dawabb, and animals\}, signs of union, and approaching and drawing near God. In the words of this shaikh, the following eight stages are the bases of these forty-four stages: (1) the stage of the penitent ones - asceticism and striving \{for God $\}$ - the master of the penitent ones is Adam; (2) the stage of the learned ones - humility and supplication and turning toward God and seeking the five hadaras \{presences\} - the master of the learned ones is Idrīs; (3) the stage of the ascetics - compassion and attention and love and affection - the master of the ascetics is Jesus; (4) the stage of the patient ones - forbearance and putting trust in God and reflection - the master of the patient ones is Job; (5) the stage of the contented ones - joyfulness and sociability and attachments - the master is not specified; (6) the stage of the grateful ones - declaring the unity of God and chanting in praise of God and praising God - the commander is Noah; (7) the stage of the lovers - reciting and private worship and dhikrs and asking God's pardon - the one who asks the lovers to bear witness is Abraham; (8) the stage of those who know God - fasting, and praying and meditation - the supporter of those who know God is our Prophet and master \{i.e. Muhammad\} (\{Hazīnī, \} Jawāhir, pp. 108-14).

33 \{In the Okuyucu edn of Hāzīn̄̄, p. 73, the last word is 'urafă', mystics.\}

34 \{In the Okuyucu edn of Ḧāzin̄in, p. 74, we find "to know that all the shaikhs and pĩrs are holy and saintly" instead of "to know all the shaikhs and saints."

$35\{$ Hazīnī, \} Fawāhir, pp. 129-31.

36 A similar formula, with ikhwān (brethren), makān (place), and zamān (time) noted first and then táalluq be-pädshähän (attachment to the ruler) added as the essential ingredient to ensure the first three, is articulated in a treatise of the Naqshbandi Makhdūm-i A'zam, entitled Tanbīh al-salāținn, written most likely around 1530, and his treatment has been discussed briefly in Baxtiyor M. Babadžanov, "On the History of the Naqšbandīya Muğaddidīya in Central Māwarā’annahr in the Late 18th and Early 19th Centuries," in Michael Kemper, Anke von Kügelgen, and Dmitriy Yermakov (eds), Muslim Culture in Russia and Central Asia from the 18th to the Early 20th Centuries (Berlin, 1996), p. 406.\}

$37\{$ Usanç (boredom) is Köprülü’s rendering of Hazīn̄̄s fütûr u nüfûr (disquiet and fear), Okuyucu (ed.), p. 110, that could arise because of current events.\}

38 The Okuyucu edn is much more explicit. "One needs brethren who will reinforce and support the rules and regulations of the khalwas and the forties in order to attain the mystical states and to complete the mystical stations," p. 111.\}

39 Hazīnī, Jawāhir, pp. 181-4.

40 Ibid., pp. 116-17. In order to understand the expression faqr wa fan $\bar{a}$ \{poverty and passing away\} among the Șûfîs, see al-Qushairì's al-Risăla. There are also highly detailed discussions of it in \{Shihāb al-Dīn al-Suhrawardī's\} 'Awärif al-ma'ārif and \{Muhammad Pārsā's\} Faṣl al-khițāb. One can refer as well to al-Ghazālī and the works of other Șūfis. According to the great Șūiss, a dervish had to serve his shaikh with sincerity and devotion for at least forty years before he could wear the dervish cloak.

$41\{$ Köprülü seems to have gotten confused here. The original passage that he cites recommends khalwa, along with hunger, etc., as part of ascetic discipline.\}

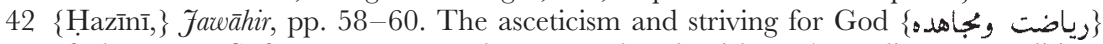
of the great Șūfis was renowned among the dervishes. According to tradition, 
Abū Yazīd Bistāmī ate just one morsel of food every sixty days. In the Yasawī tarīqa, Maḥmūd Khwāja ate one morsel every thirty days, Ulug Khwāja ate two morsels every forty days, Zangī Ata ate one morsel every nineteen days, and Sadr Ata ate one every fifteen days (ibid., p. 57). \{There is a remarkable, if not exact, parallel to this passage from Hazinnì's Fawähir on the number of days through which one morsel sufficed the various saints. It appears in a Turkic work known as the Mir'ät al-qulūb and is ascribed to Sūfì Muhammad Dānishmend. A version has been published by Necdet Tosun, "Yesevîliğin ilk dönemine âid bir risâle: Mir'âtü'l-kulûb," İLAM Arasstrma Dergisi, 2/2 (1997), 41-85. This parallel, shared by these sources from two independent traditions, suggests that for once we are close to something that, in fact, goes back fairly close to the time of Ahmad Yasawī himself.\}

43 Ibid., pp. 244-55.

44 Ibid., pp. 30-4. The words khalwa and 'uzla have long been special Șūfì terms and are used synonymously. The object of khalwa is to withdraw from the world in a relatively deserted place. 'Uzla is the attribute of one pure in heart; khalwa is the mark of union with God. With regard to the murid, he first has to withdraw \{'uzla\} from his fellow men and finally he has to choose khalwa for uns-i Haqq \{intimacy with God\}. However, whoever chooses 'uzla must believe that he has chosen this action in order to protect the people from his own wickedness, not to be protected from the wickedness of the people, for the contrary would cause vanity and conceit. Abū Bakr \{Muhammad b. 'Umar\} Warrāq \{al-Tirmidhī\} said, "I found the goodness of this world and the next in khalwa and scarcity \{qilla $\}$ and I found wickedness and harm in this world and the next in mixing with people and in abundance" (al-Qushairī, al-Risāla, \{Turkish\} trans., pp. 82-5) \{vol. 1, p. 273 in the Mahmūd et al. Cairo edn \}. Shihāb al-Dīn al-Suhrawardī, whose works on Șufīsm were of great value and importance, discusses khalwa at length in the chapter Futüh al-arba' $\bar{\imath} n$ in his 'Awärif al-ma'ärif and gives its rules and conditions. According to him, the object of khalwa is not to witness a number of strange and wondrous events or make discoveries. Whoever prefers khalwa over mixing with people has to desist from all dhikrs except dhikr Allahh, from all desires except the desire for God, and from seeking all intermediate causes $\{k \bar{a} f f a-i a s b \bar{a} b$; as opposed to God, the ultimate cause $\}$. Otherwise khalwa would lead to dissention or disaster. On this matter al-Suhrawardī says, "Some people enter the khalwa without observing its conditions; they continually recite one of the dhikrs, focus their spiritual faculties on one point and block their outward senses from external affairs. Monks, brahmans, and philosophers, in fact, do this. This state of affairs can certainly have an influence in bringing about inner peace. But the khalwa that is done by following the stipulations of the Shari $a$ and sunna results in illumination of the heart, asceticism, a refined dhikr, and acting with sincere devotion in prayer and chanting the Koran. Those who do not observe the canonical principles on this matter and do not follow the sunna will only fortify (?) the carnal self," Mehmed Alî Aynî, citing Carra de Vaux, Hüccetü'l-İslâm-ı Gazâlî \{Istanbul, $1908\}$, pp. 272-3.

45 There are details in Chapters 5 and 6 below on the hikmats of the khwäja and his followers and on how they were composed and read in the dhikr sessions.

$46\{$ Hazin̄i,$\}$ Fawähir, pp. 51-5. The custom of burying the blood of the sacrificial victim and preserving its bones is not Islamic. It would be more correct to look for the influence of the pre-Islamic religious traditions of the early Turks in this matter. Perhaps this was a vestige of early Buddhism.

47 Ibid., p. 56.

$48 \mathrm{Ibid}$., pp. 72-3. The same legend is repeated in a Persian poem in this work, p. 229. \{There are several other legends recorded about the origin of the dhikr-i arra. One links it with lamentation over the murder of Ahmad Yasawî’s son. See A. L. Troitskaia, 
"Zhenskii zikr v starom Tashkente," Sbornik Muzeia antropologii e ètnografii AN SSSR, 7 (1928), 189-92.\}

49 The dhikrs of Yūsuf Hamadānī and other khwäjas are the dhikr-i 'alāniyya \{public or loud dhikrs\}. Only 'Abd al-Khāliq Ghujduwānī was charged with the dhikr-i khafiyya \{private or quiet dhikrs\} by Khaḍir. Yūsuf Hamadān̄, who was his shaikh, did not change this (\{Ṣafī,\} Rashahăt, \{Turkish $\}$ trans., p. 25). Shaikh Rukn al-Dīn 'Alä' al-Dawla Simnānī asked the famous Khwāja 'Azīzān about the nature of the dhikr-i jahr. Answering him, he said, "I also heard you do the dhikr-i khafiyya. The purpose of the khafiyya, however, is that other people be unaware. Once people know about it, both are equal. Indeed, a reputation for khafiyya is tantamount to hypocrisy." According to the noble Hadith ... لقنوا موتاكم, it is lawful to do the dhikr at the last breath with a shout and teach it \{telkin etmek\} to a novice. Every breath of the dervish is the equivalent of the last breath. For this reason the dhikr-i jahr is regarded as inappropriate for them. Khwāja Maḥmūd Inj̄̄r Faghnawī also said that "the dhikr-i 'alāniyya is for him whose tongue is free of lies and gossip, whose throat is free of what is unlawful and suspicious, and whose heart is free of hypocrisy and vanity, and whose head is free from turning away from God to what is other than God." \{Köprülü presents here a few of the many claims and counterclaims about who did what kind of dkhir that can be found in the Khwājagān and Naqshbandī literature from the fourteenth to the sixteeth centuries as "evidence" that seems to favor a particular claim, when what they actually reflect is a long process of polemics.

$50\{$ Hazīn̄i, $\}$ Fawähir, pp. 157-8.

51 Rashahāt, \{Turkish\} trans., p. 21. According to another story, Khwāja 'Ubaid Allāh said, "Enough! He has burned from Heaven to Earth," and then "I thought if an unbeliever asks what kind of dhikr this is, how should one answer him?" And he recited the couplet,

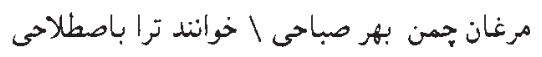

\{The birds of the field, every morning, Address you with technical terms (i.e. in language that others do not understand).\}

52 The author \{Harīrī-Zāde\} of Tibyān-i was ä'il (vol. 3, p. 265) cites this passage from a work by Shaikh Muhammad Ghawth entitled Fawähir-i khams \{or al-Jawähir al-khamsa in the original Arabic $\}$.

53 Ibid., vol. 3, p. 266. This passage was also taken from Shaikh Sālim's work entitled al-Sifr al-manthür li 'l-dirāya wa 'l-dhikr al-manshūr li 'l-wilāya. It is evident that this author saw Fawähir-i khams and made use of it. At the end of the information that he provides, Shaikh Sālim says, "according a well known tradition $\{$ qawl\}, this dhikr goes back to Sayyid Ahmad Badawī. The attribution is so well known that it has become known as dhikr-i Badawñ." This is not correct. The author \{Harīrī-Zāde\} of Tibyān-i wasă’il, in fact, quite rightly criticizes and corrects this by saying, "Tracing this dhikr back to Sayyid Ahmad Badawī is an error by either the copyist or author. In truth, it must be Ahmad Yasawī, because he used this dhikr before Ahmad Badawī, and after him numerous shaikhs also imitated it and Ahmad Badawī was among them" (Tibyān-i was $\left.\bar{a}^{\prime} i l\right)$. There is also a report in the Diwañ-i Hikmat about how the dhikr-i arra derives from Zacharia. I cite verbatim the information that \{Hazīn̄’s\} Fawähir gives (pp. 2301) on this type of dhikr in order to complete the explanation above:

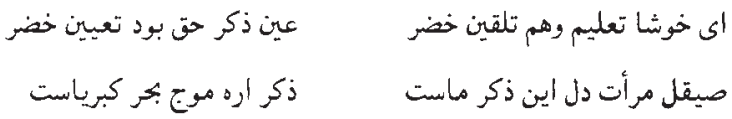




$$
\begin{aligned}
& \text { روح را زين زكر باشد بس فتوح } \\
& \text { اشك ريزان ناله كن باياد وى } \\
& \text { اشكك ريز درد مند سوخته } \\
& \text { كز دو عالم ناله وغم بايدش } \\
& \text { بحر بخشايش كجا آيد بجوش } \\
& \text { تا نكريد ابر كى خندد جمن } \\
& \text { كاه حى وهو وكاه اللّه وآه } \\
& \text { يافت مذكور آنكه آمد غرق ذكر } \\
& \text { ور وصل آيد بكف زو دمبدم } \\
& \text { ابتدا وانتها فقر وفنا }
\end{aligned}
$$

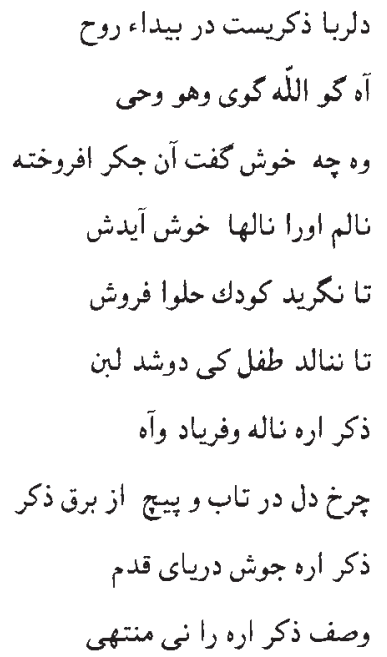

\{What fine instruction and suggestion of al-Khadir,

The very remembrance (dhikr) of God, the determination of al-Khadir.

This dhikr of ours is the polisher of the mirror of the heart.

The dhikr-i arra is a wave of the sea of divine glory.

It is a heart-stealing dhikr in the desert of the spirit.

Many an opening comes to the spirit from this dhikr.

Say "Āh" and "Allāh" and "Hū" and "Hayy,"

Shedding tears and crying out with remembering Him.

Oh how fine spoke that one with ardent heart,

Shedding tears and burning with the pain of love:

"I cry out to Him. My cries are pleasing to Him

Because He must have cries and grief from both the worlds."

If the child selling sweets does not cry out

How will the Sea of Giving be set in motion?

If the baby does not cry, when will it get milk?

If the cloud does not weep, when will the meadow bloom?

The dhikr-i arra is crying out and sighing,

Now "Hayy" and "Hū," now "Allāh" and "Āh."

The sphere of the heart twists and turns from the lightning of dhikr.

He who is drowned in Remembrance (dhikr) has found the one Remembered.

The dhikr-i arra is a motion of the sea of pre-eternity.

From it the pearl of joining-to-God comes every moment to hand.

There is no end to the description of the dhikr-i arra:

The beginning and end of it is poverty (or, being a dervish) and annihilation.\}

54 In this paragraph are additional errors that have unfortunately been frequently repeated: the idea that the Naqshbandiyya can be "traced back" to Ahmad Yasawī is more immediately preposterous than a similar claim about the Bektashiyya only because there is so much better, and earlier, documentation about the former. And there is no "branch" of the Yasawiyya known as the $\overline{\mathrm{I}} \mathrm{q} \overline{\mathrm{an}}$ iyya. This is a later invention 
of systematizers who knew of Kamāl İqānī but not of any of his successors and merely assumed there must have been some who thereby constituted a branch.\}

$55\{$ Jāmī, $\}$ Nafahāt, \{Turkish\} trans., pp. 416-17. Khwāja Bahā' al-Dīn's first meetings with Qutham Shaikh are described as follows: şöyle düştü ki Kasam Şeyh kavun yerdi. Kabuğunu Hoca'dan yana itti: Hoca'nnn dahî taleb-i harâreti nihâyette olmağ̀n ber sebîl-i teberrük ol kabuğu tamâmca yediler. $\ddot{U}_{c}$ def'a ol mecliste öyle vâki oldu. Hemen mecliste Şeyh'in hâdimi içeri girip üç deve dört at yavu-kuldım dedi. Şeyh Hoca Hazreti’ne Türkşe işâret edip antth ki at yahşı tutunuz. Mürîdlerden dört kimse şöyle heybet ile Hoca'ya bakıp, incindiler ki gûyâ ortalarnda kan vâki' olmuştu. Hazret-i Hoca buyurmuşlar ki, Meşâyih-i Türk'ün her kim sıfaton anlamaya, elbette onlarn tarikkndan ötürü onlardan nevmîd olur ve i tirâzz eyler. Pes Hazret-i Hoca, iki dizi üzerine oturup murâkabe ettiler ve müteveccih olup akşam namazım kıldıktan sonra, hâdim yine içerü girup ayntt: Develer ve atlar kendileri geldiler... Kasam Şeyh âhir Buhâra pazarlarndan birine gelip, türlü türlü alış-veriş etti ve çıkıp gitti. Âsâr-i mahabbet üzerinde zâhir idi. Bir dükkânda oturdu ve oğullarnndan ve mütâbi lerinden kendi ile berâber olanlan dâvet eyledi ve antth: Bizim naklimiz zamân erişmişstir: tevhîd kelimesin muvâfakatle divelim. Pes kendisi dedi ve cümlesi dediler. Fì'l-hâl teslîm-i rûh eyledi \{It so happened that Qutham Shaikh was eating a melon. He pushed its rind toward the khwäja. Because the khwäja's quest for (religious) fervor was very great, as a way of receiving a blessing he ate the entire rind. This happened three times at that majlis. The shaikh's servant entered that same majlis and said, "I have lost three camels and four horses." The shaikh indicated this to the khwajja in Turkish and said that he should keep a good hold on the horses. Four of the muñds looked at the khwäja in dread. They were pained, as though a matter of blood-guilt had arisen between them. The khwäja said, "Anyone who does not understand the character of the Turkish shaikhs will surely despair of them and will find their way objectionable." Then his excellency the khwäja rested on his knees and went into a state of meditation. He turned his face (toward Mecca) and performed the evening prayer. Afterwards the servant entered again and said, "The camels and horses returned on their own ..." Finally Qutham Shaikh went to one of the markets of Bukhārā, made various purchases and departed. Tokens of love were visible upon him. He sat in a shop. He summoned his sons and followers who were with him and said, "My time to pass away has arrived. Let us pronounce the tawhīd in concord." Then he uttered it and they all uttered it, (and) he immediately surrendered his soul $\}$ (ibid.). \{On the stories of Bahā' al-Dīn Naqshband's links with Qutham Shaikh, see DeWeese, "The Mashä'ikh-i Turk and the Khojagān."

56 Șalāh al-Dīn b. Mubārak al-Bukhārī, Maqāmāt Muhammad Bahā’ al-Dīn Naqshband, \{Turkish\} trans. Süleyman Azmî (Istanbul, 1328/1910), pp. 19-20, and \{Jāmī, \} Nafahāt, \{Turkish\} trans., pp. 417-18. \{On the stories of Bahă $\overline{\text { al }}$ al-Dīn Naqshband's links with Khalīl Ata, see Zeki Velidi Togan, "Gazan-Han ve Hoca Baheddin Nakşbend," in Necati Lugal Armağan (Ankara, 1968), pp. 775-84, and Jürgen Paul, "Scheiche und Herrscher im Khanat C̆agatay,” Der Islam, 67 (1990), 278-321.\}

57 Compare the details given here on the rules of the Yasawiyya with the maqāmāt and sulūk books, such as \{Nașr Allāh Efendi's\} Risāla-i Bahä'iyya (Istanbul, 1328/1910), on the rules of the Naqshbandiyya. Their many common points are immediately apparent.

$58\{$ Köprülü's assertion here is belied by the long Yasawī-Naqshbandī rivalry in Central Asia.

59 Bursalı Ahmed Lütfî Efendi, a Khalwatī shaikh, gives the silsila of Bektash Veli in the following manner: Hājjj̄i Bektash Veli of Khurāsān received the tañqa from Shaikh Luqmān-i Paranda, who received it from Khwāja Ahmmad Yasawī, who received it from Shaikh Naṣr Allāh Hasan Sanjarī, who received it from Shaikh Rukn al-Dīn Abū Muhammad Jurjānī, who received it from Shaikh Quṭb al-Dīn Sānābādī, who received it from Qāẹī Muhammad Bukhārī, who received it from Abū Bakr Muhammad Hāàilī, who received it from Shaikh 'Abd Allāh Wāsiți, who received it 
from Abū Ja'far Shahīd Țāhir Mashhadī, who received it from Shaikh Muhammad Aslan Ṭ̂ūî̀, who received it from Imām 'Alī Riḍā, who received it from his father Imām Mūsā Kāzim, who received it from his father Imām Ja'far Șādiq, who received it from his father Imām Muhammad Bāqir, who received it from his father Imām Zain al-'Ābidīn, who received it from his father Imām Husain, who received it from 'Alī; \{Harīrī-Zāde, \} Tibyān-i wasă'il, vol. 1, chapter on the Bektashiyya. While the section down to Ahmad Yasawi in this chain of transmission follows tradition, the section after him $\{$ i.e. to 'Ali $\}$ is completely unfounded. It has neither legendary nor historical value. In another chain of transmission written by Selânikli Muhammed b. Osman Efendi in 1140/1727-8, we have the following: Bektash Veli received the tarīqa \{from\} Nu'mān Sarīn (a corruption of Luqmān-i Paranda), who received it from Sayyid Ahmad Badawī, who received it from Shaikh Quṭb al-Dīn Ejder (Haidar), who received it from Khwāja 'Abd al-Rabb, who received it from Khwāja Yūsuf Hamadānī (Tibyān-i wasă’il, same vol. and chapter). Although this chain concludes with Yūsuf Hamadānī, Aḥmad Yasawī's shaikh, it too certainly has no value. Indeed, the author Kamāl al-Dīn \{i.e. Harīrī-Zāde\} says that the Bektashī way $\{\tan \bar{q}\}$ was not a branch of the Badawiyya - despite Bektash Veli's meeting with Sayyid Ahmad Badawī as cited from \{Hüdā' $\overline{1}$ 's $\}$ Wāqi ${ }^{i} \bar{a} t-i$ Uftäda - and that the link with the Badawiyya here is different from, and contradicts, the well known link, i.e. the \{traditional\} chain of transmission. Adhering to the ideas and reflections of the majority, he considers the Bektashiyya as a branch of the Yasawiyya (Tibyān-i wasa $\bar{a}^{\prime} l$, vol. 3, chapter on the Yasawiyya). \{To declare that divergent versions of the Bektashī silsila have no value ignores the potential clues they provide to differing traditions, rivalries, and the like.\}

60 In his research on the Bektashiyya, Jacob writes that this tanq $a$ was founded by Balım Sulțān who died in 922/1516 and that this tariqa has definitely been in existence only since the beginning of the tenth/sixteenth century (Bektaschijje, p. 24, and $E I^{1}$, s.v. "Bektāsh" [R. Tschudi]). Shams al-Dīn Sāmī, while attributing historical value to the legendary stories about Hājjī Bektash, also confirms that the official religious cere-

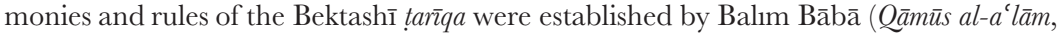
s.v. "Bektash Veli"). However, based on a number of new documents currently in our possession, which Jacob did not see, we must date the founding of the Bektashī tañqa to at least a half century or a century earlier. In fact, Khunkār Hājjjī Bektash Veli is mentioned in a poem $\{$ manzūma $\}$ entitled Khadirnāme written by a Bektashī poet named Muhȳī al-Dīn in 880/1475-6. And even famous personalities like Sarı Saltuk, Yūnus Emre, Aḥmad Badawī, Mawlānā \{Rūm̄̄ $\}$, Sulțān Walad, Mạ̣mūd Hairān̄̄, Qarāja

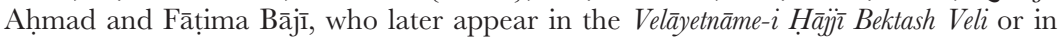
the chains of transmission, and a large number of Anatolian erens are presented as followers of Bektash Veli (unique MS in my private library). While discussing the symbols (s. 'alāma) on the headgear $(t \bar{a} j)$ of the shaikhs, Amīn al-Dīn Bābā b. Dāūud Faqīh, in his Risāla-i Qudsiyya (from a unique MS belonging to Kilisli Rifat Bey) addressed to Sultan Bayezid II in 903/1497-8, also mentions the "alifi tāj" \{tall headgear\}, which is famous in Bektashī tradition: Ve bir dahi meczûb-ı mutlak ve mahbûb¿ $H^{w}$ ond-kâr Hacı Bektaş Hazreti dir kim ol dahî şol makâma cezb olmuştur kim aşk âlemidir ve aşknn kisvelerinden bir kisve ann başında elifí tacdır. Şol ma'nâya delâlet eder kim bu cümle mahlûkâtın îcâd olmasmin ash bir elifdendir ve elif hem cemî hurîfun ashdır ve ben ol makâma vardim ve anın sırmna mahrem dïşı̈m. Ann alâmetin başında komuştur \{And there was another, obsessed with absolute divine love and beloved of the Ruler \{i.e. God\}, his excellency Hājjī Bektash. He was attracted to that mystical stage, which is the world of love, and one of the garments of love is the aliff tāj on his head. The meaning of this is that the origin of the creation of all creatures is from an alif \{the first letter of the Arabic alphabet $\}$. The alif is the origin of all letters and he reached that stage and became privy to its secret. For this reason, he put the symbol of it on his head\}. These two 
documents thus demonstrate that not only the Bektashī legend but also the Bektashī tañqa with all its religious ceremonies and rules - even up to the shape and nature of the $t \bar{a} j$ - were established in the ninth/fifteenth century. The most accurate information on Hājjji Bektash and the historical nature of the alif $t \bar{a} j$ is found in the reports of 'Āshıq Pasha-Zāde, one of the leading figures of the ninth/fifteenth century, which shows that this tañqa definitely was founded in that century ('Āshıq Pasha-Zāde, Tawārīkh-i a al-i 'uthmān, pp. 204-6). In light of these documents, therefore, the opinion embraced by Jacob that the Bektash $\operatorname{tar} q q a$ has only been in existence since the tenth/ sixteenth century (Bektaschijje, vol. 2, p. 20) collapses, and it is obvious that its origin must be pushed further back. [For more extensive and bibliographic information on the Bektashī tariqqa and the views and research on this matter, see, $\dot{I} A$, s.v. "Bektaş" (F. Köprülü).] \{Now see, for example, Suraiya Faroqhi, Der Bektaschi-Orden in Anatolien (Vienna, 1981); Irène Melikoff, Hadji Bektach un mythe et ses avatars (Leiden, 1998); and EIr, s.v. "Bektāš" and "Bektāšs̄ya" (H. Algar).\}

61 'Āshıq Pasha-Zāde, one of the great figures of the ninth/fifteenth century, says Bengî ve zenkî, toplak ve zaplak ve şeytânî âdetler bunlarda çoktur ve bu halk bilmezler ân şseytânî midir? $\{$ Drug addiction and satanic practices are common among them and the people are uncertain whether or not it is satanic\} ('Āshıq Pasha-Zāde, Tawārīkh-i äl-i 'uthmān, p. 206). The comment of the author \{Tashköprü-Zāde\} of al-Shaq ä'iq on the meaning of this belongs to a later period. Amasyalı Hüseyin Hüsâmeddin \{Amasya tarihi (Istanbul, 1328/1910)\} alleges, based on waqf documents, that Hājjī Bektash Veli died before 691/1292 (see Chapter 7, p. 228, n.30 of the present work). There are supplementary details on the Bektashiyya below in Chapter 10, pp. 366-7.

62 During the ninth/fifteenth century, disciples of Faḍl Allāh Hurūfî spread to Anatolia. We know that among them was the famous 'Alī ' $1-A$ ' lā who went to Anatolia where he established himself in a Bektashī tekke and then propagated Hurūfì beliefs in the name of the Bektashiyya. He died in 822/1419 (see İshak Efendi's Kâşifül-esrâr ve dâfi 'ü'l-eşrâr \{Istanbul, 1290/1873-4\}. Prof. Browne and Dr Jacob have also accepted this opinion about the Hurūfiyya's penetration of the Bektashiyya). The author \{HarīrīZāde\} of Tibyān-i wasă'il also agrees with this, "Hājjī Bektash named no one as his khalîf $a$ while he was alive. Later, someone belonging to the Hurüfì sect named 'Alī 'l-A'lā, known by the title 'Ishıq,' arrived and claimed to be Hājjī Bektash Veli's khaliffa.' Many people adopted his tarīqa and thus went astray and led others astray. They were a troop of zindīqs who regarded as \{religiously\} permissable the renunciation of prayer and \{other\} things that are forbidden" (vol. 1, art. "Bektâşîye"). I will describe in the second part of this book a number of men who had propagated beliefs contrary to the Shari ${ }^{c} a$ under the name of Șüfism in Anatolia before the Ottomans. Furthermore, we know very well that a forceful political policy was pursued against the Hurūfis with the encouragement of the 'ulam $\vec{a}$ ' in the ninth/fifteenth century (\{Tashköprü-Zāde,\} al-Shaqā'iq, \{Turkish\} trans., vol. 1, art. "Fakhr al-Dīn 'Ajamī," pp. 82-3), and we also encounter numerous similar actions in subsequent periods. There are also some important references in tenth/sixteenth-century documents to

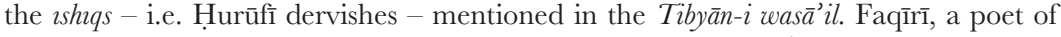
that century, describes them in his famous work, Risāla-i ta'riffat in the following manner, which can serve to indicate the general opinion about them:

\footnotetext{
Işı oldur ki olamaz hep de hâric

Kamu lûtî ve bengî vü havârîc

'Alî aşknda yanub şöyle pismiş

Cihânda onsekiz kez ton değişmiş

Taninda cür'adan yanckklander

Sanasin Kerbelâ kancıklardır
} 
$\left\{I_{\text {şz }}\right.$ s are those who ...(?) are outside.

They are all pederasts and drug addicts and heretics.

They are so ardent in their love for 'Alī,

They have changed garments eighteen times in the world.

They wear small water skins:

You would think they are the bitches of Karbalā'\}

(From the MS in my private library. For detailed information on Faqīīi and his work, see my article "X. asır hayatına âit bir vesika" in the newspaper İkdam, 1332, June 10 and 12. \{Reprinted as "Onuncu asıra âit vesikalar: Fakîri'nin Risâle-i tarîfâti" in Hayat Mecmuası, 1 (1927), 22-3\}). Absolutely no historical study has been done to date on the spread of the Hurūfiyya in Anatolia. Rızâ Tevfik's studies on this subject and the information provided by Huart are not really critical historical studies (Textes Persans relatifs à la secte des Houroufis [Leiden, 1909]). Details on this word $\imath$ sh $q$, which had appeared by the eighth/fourteenth century, can be found in my still unpublished work on the Bektashiyya. One can show that this word existed before the establishment of the Hurūfiyya and that it meant not only Hurūfí, but also more generally bătinī. [Because Köprülü's detailed research on the Hurūfiyya was never published, see for now the following studies: Rıfkı Melûl Meriç, "Hurûfilik," Istanbul University, Edebiyat Fakültesi, unpublished graduate thesis, 1936 (university library, no. 305); $\dot{I} A$, s.v. "Hurûfilik" (eds), especially its bibliography; Abdülbaki Gölpınarl, "Hurûfilik ve Mîr-i 'alam Celâl Bek'in bir mektubu" TM, 14 (1965), 93-110.] \{See also Gölpınarlı's Hurûfilik metinleri kataloğu \{Ankara, 1973); EI ${ }^{2}$, s.v. "Hurūfiyya" (A. Bausani); and Shahzad Bashir, "Enshrining Divinity: The Death and Memorialization of Fażlallāh Astarābādī in Hurūfī Thought," Muslim World, 90 (2000), 289-308.\}

$63 \overline{\mathrm{I}} \mathrm{q} \overline{\mathrm{a}} \mathrm{n}$ is the name of a town in the vicinity of Yasī (see Chapter 3, p. 69). Kamāl Shaikh would have taken the byname \{laqab, rather nisba\} İānī probably because he was from there. This byname Īqānī has no relationship to the word $\bar{\imath} q \bar{a} n$, whose meaning - certain knowledge, knowing without doubt - is well known.

64 See above (Chapter 3, pp. 58-61) for all the details corroborating this. According to the information provided by legendary accounts and history books, which are unanimous in this respect \{this is not the case\}, Shaikh Yūsuf Hamadānī was a murīd of Shaikh Abū 'Alī Farmadī, so that he was an associate of the same shaikh as the famous al-Ghazālī \{d. 1111$\}$, the author of Ihy a' 'ulūm al-dīn. Just as the Șūfism of Imām al-Ghazālī was based completely on the Koran and the sunna, the opinions about Sūfism of Yūsuf Hamadānī, who was brought up under the instruction of the same shaikh, are essentially no different. In order to see clearly and categorically the fundamental points of similarity between numerous ideas and teachings of Shaikh Yūsuf Hamadānī, who felt great reverence toward Abū Hanīfa, and the ideas of Ahmad Yasawī, see Chapter 5 below.

65 Most of this is Köprülü's invention.\}

66 'Of the two forms of Șüfism, the 'Western = Arab' and 'Eastern = Irano-Indian,' the latter is more original. Central Asian Șüfism is connected to this second form of Șufism, the creation of which was owed to Arians or Indo-Iranians. Both forms of Șufism were propagated in the Middle Ages by profound and elegant philosophers like Ahmad Yasawī (sixth/twelfth century) and Bahä' al-Dīn Naqshband (eighth/fourteenth century). The murid was slowly made cognizant of absolute wisdom \{hikmat-i mutlaq $\}$ as he went from the Shañ ${ }^{-} a$ to the tañqa, to spiritual knowledge $\left\{m a^{c} r i f a\right\}$, and finally reached the spiritual vision of God $\{$ haquqa $\}$ " (Pierre Kouznietsov, La Lutte des civilizations et des langues dans l'Asie Centrale [Paris, 1912], pp. 131-2). These superficial observations on Central Asian Sūfism and Ahmad Yasawī, which are found in this 
work - the historical sections of which are generally quite weak although based on numerous Russian sources - are not at all trustworthy.

67 All historians who have specialized in Turkish history have recognized that the Turks generally remained faithful to the basic principles of the religions that they adopted and did not participate in sectarian $\left\{M u^{c} t a z i l \bar{i}\right\}$ movements. The explanations given above clarify to some extent the reasons for this $\{!\}$.

68 For the main details on this subject, see Howorth's History of the Mongols (vol. 2, k. 2, first note of section 4); and Reclus's Nouvelle géographie universelle, vol. on Russian Asia, p. 556.

69 Grenard, in his important book Le Turkestan et le Tibet, says that certain things that are vestiges of the ancient primitive religions have become mixed with Buddhist legends (p. 240). Certain phenomena like this, which are immediately noticeable and worthy of attention, were alluded to in the second chapter of the present book. As studies on Turkish ethnography and history gradually increase, it will be possible to do serious research on such phenomena.

70 [Köprülü stated for the first time in his Les Origines de l'Empire Ottoman (Paris, 1935), pp. 118 ff, Turkish trans., Osmanl devleti'nin kuruluşu (Ankara, 1959), pp. 98 ff, 2nd edn (Ankara, 1972), based on his recent research, that it was necessary to change his opinion according to which he had described the Naqshbandiyya and Yasawiyya as having the same basis \{Köprülü mentions only the Qalandariyya, cf. the English trans., pp. 104-5\}. Later, in his article "Ahmet Yesevî" in $\dot{I} A$, he pointed out, based especially on the research he had done on the origins of the Bektashiyya and new documents that he had acquired, that the Bābā's, Haidarī, and Bektashī traditions and the stories about Ahmad Yasawi were much closer to historical reality than the way he had described both the Șūin personality of Ahmad Yasawī and the character of the Yasawi tarīqa in Early Mystics. For more extensive bibliographic information on Ahmad Yasawi than that found in Early Mystics, see the aforesaid article in $\dot{I} A$.] \{Köprülü's newer views have been followed by Irène Mélikoff, Ahmet Yaşar Ocak, and most other Turkish writers. See, for example, Ocak's collected studies Türk sufiligine bakışlar (Istanbul, 1996). Nevertheless, these views do not reflect Central Asian sources.\}

71 Köprülü's account of the spread of the Yasawìya in Central Asia is pure fantasy.\}

$72\{$ Köprülü does not prove any of this. He only insists on it. The historical Yasawī order is found above all in the Persophone parts of Central Asia, and its literary legacy is almost entirely in Persian.

73 'Ālī, Kunh al-akhbār, rukn-i thālith, juz'-i thälith, p. 11.

74 \{Hazīnī, \} Fawāhir, biography of Sayyid Manșūr.

75 It suffices to take a quick glance at \{Ṣafì's\} Rashahāat in order to understand this obvious fact. A long and separate study is required in order to explain the importance of the Naqshbandiyya in Central Asia, especially in the ninth/fifteenth and tenth/ sixteenth centuries. In order to give a general idea about this, let me simply say that not only did the Tìmūrid family give great importance to the Naqshbandī shaikhs in the ninth/fifteenth century (see \{Jāmī, $\}$ Nafahăt; Rashahăt, \{Turkish\} trans.; Jāmī’s biographical dictionary \{sic, i.e. Nafahät\} and other works \{such as Tuhfat al-ahrār $\}$ ), but during the reign of the Shibannids in the tenth/sixteenth century - thanks to the fact that all members of the ruling family were murids of Naqshbandī shaikhs - the Naqshbandiyya also gained very great importance throughout Transoxiana (see the descriptions given of the Shibānid rulers in \{Nithārī Bukhārī's\} Mudhakkir al-aḥbāb). \{See $E I^{2}$, s.v. "Nakshband" (H. Algar) and "Nakshbanidyya" (H. Algar et al.\}

76 The dhikr-i arra, for example, constituted one of the chief characteristics of the Yasawiyya. We can see clearly in this dhikr the vestiges of certain types of behavior that were peculiar to the Qazaq bakhshis \{saint, sorcerer, popular poet\}. \{Köprülü is certain that something in the "behavior" of Qazaq bakhshis shaped the Yasawi dhikr-i 
arra; even assuming that what he meant to say was that the Qazaq bakhshis continued a tradition that went back to earlier Turks whom Ahmad Yasawi wanted to reach by adjusting the dhikr to suit their tastes. Köprülü seems intent on seeing the bakhshis as more Turkic than Muslim, and never seems to have considered that perhaps the bakhshis' chants resemble the dhikr because the Qazaqs adopted the latter.\} The information given by the author of Risāla-i Bäburiyya, one Aḥmad b. Mawlānā Jalāl al-Dīn al-Kāsānī, is very worthy of note in this regard: Sâdât-ı Nakşbendîye zikr-i hafîyi ihtiyâr buyurmuşlarder; fakat bâzılan muktezâ-yn hâl olarak zikr-i cehrî de yaparlar. Nasıl ki Hoca Ahmed Yesevî Türkistan cânibine azîmetle me’mûr oldukta gördüler ki ora ahâlîsi zikr-i hafì ile yola gelmiyorlar, derhâl zikr-i cehrî tarikmn tuttu ve bundan zikr-i erre vücûde geldi. Birçok kimseler bu saâdetle müsserref oldular \{the Naqshbandī sayyids preferred the dhikr-i khafiyya, but some of them did the dhikr-i jahri when required. In fact, on being authorized to depart for Turkistan, Khwāja Ahmad Yasawi saw that the people there did not think much of the dhikr-i khafi and he immediately took the way of the dhikr-i jahri and from this the dhikr-i arra was created. Many people were honored by this good fortune\} (from the unique MS in the Bağdadlı Vehbî Library \{in the Süleymaniye in Istanbul\}). Mahmūd al-Kāshgharī states, in fact, that the shaikhs were in great demand among, and were shown great respect by, the Turks in the fifth/eleventh century (Dīwān lughät al-turk, vol. 1, p. 294). It would be quite natural that a tañqa founded by a Turk among the Turks would acquire the imprint of the environment in which it developed. \{The manuscript of the Risāla-i Bäburiyya is not unique, but it was no doubt the only copy known to Köprülü. He was unfamiliar with the substantial body of hagiographical literature produced in Central Asia within Sūfì circles linked to the Naqshbandī, Yasawī, and Kubrawī traditions. Work on the Naqshbandiyya has expanded dramatically in the past thirty years. For Central Asian developments, see, for example, Hamid Algar, "The Naqshbandi Order: A Preliminary Survey of Its History and Significance," Studia Islamica, 44 (1976), 123-52; idem, "A brief history of the Naqshbandî order," in Marc Gaborieau, Alexandre Popovic, and Thierry Zarcone (eds), Naqshbandîs: Cheminements et situation actuelle d'un ordre mystique musulman (Istanbul, 1990), pp. 3-44; Jo-Ann Gross, "Multiple Roles and Perceptions of a Sufi Shaikh: Symbolic Statements of Political and Religious Authority," in Naqshbandîs: Cheminements et situation actuelle, pp. 109-21; Paul, Die politische und soziale Bedeutung der Naqšbandiyya in Mittelasien im 15. Fahrhundert (Berlin, 1991); Babadžanov, "On the History of the Naqšbandīya Muğaddidīya"; and von Kügelgen, "Die Entfaltung der Naqšbandīya Muğaddidīya im mittleren Transoxanien vom 18. bis zum 19. Beginn des 19. Jahrhunderts: Ein Stück Detektivarbeit," in von Kügelgen, Michael Kemper, and Allen J. Frank (eds), Muslim Culture in Russia and Central Asia from the 18th to the Early 20th Centuries (Berlin, 1998), vol. 2, pp. 101-51.\} 


\section{THE WORK OF AHMAD YASAWI}

\section{A The Dĩuān-i Hikmat}

The famous work that contains the Șūfì poems \{manzūmas\} of Aḥmad Yasawī is called the Dĩwan-i Hikmat Anthology of hikmats\} because each poem is a distinct hikmat. Among the Turks of Anatolia, these kinds of Șūfì poems were known as hymns $\{i \bar{a} h \bar{\imath}\}$, but among the Eastern Turks the works of Ahmad Yasawi and those of other dervishes who wrote this kind of poetry were usually called hikmats. Dīwān-i Hikmat was not, therefore, a title that was used exclusively for the collection of Ahmad Yasawī's poetry. In fact, we can presume, with a high degree of likelihood, that this title was given to it later. We know for certain that this type of poetry was called hikmat at least since the fourth/tenth century, given that we do not have any clear documentation of the term before then. ${ }^{1}$

The Dīwān-i Hikmat has great importance among the literary works produced by the Turks in several respects. First, because Ahmad Yasawi died in the sixth/ twelfth century, this work is the oldest example of Muslim Turkish literature \{to come down to us\} after \{Yūsuf Khāṣs Hājib's\} Kutadgu Bilig. Such a work, belonging to a period for which we have few linguistic and literary products, naturally has very great linguistic as well as literary historical value. ${ }^{2}$ Second, because the Dīwan-i Hikmat was the first work to take many elements of the old folk literature and express the spirit of Islam through them, i.e. by means of the ancient national forms and meters, we must consider it to be the oldest and most important monument of Turkish Șūfi literature. It is for this reason that the Diwwan-i Hikmat has long attracted the attention of Orientalists and, although the proper study of it could not be undertaken until now, some piecemeal research has been done on it and some sections have even been published and translated into Western languages. ${ }^{3}$

Because the Dīwan-i Hikmat circulated for centuries, especially among the Eastern and Northern Turks - the Uzbeks, Qazaqs, and Volga Tatars - virtually as a sacred text, we can find innumerable manuscripts of it and, more recently, even some printed editions. Unfortunately, my analysis of many of the manuscripts has not yielded any positive result with regard to linguistic and literary history, i.e. it has been impossible to find an early manuscript of this important work. ${ }^{4}$ 
With respect to the printed editions, as far as I know, this work was published once in Istanbul, four times in Kazan, and once in Tashkent in a lithographic edition. ${ }^{5}$ However, all these editions were based on recent manuscripts that are by no means trustworthy, so we currently possess no edition derived from an early accurate manuscript on which reliable research can be done. ${ }^{6}$

It is immediately obvious \{for example $\}$ that the present Istanbul edition of the Dìwän-i Hikmat, even when examined superficially, consists of a hodgepodge of pieces written by very different authors at different times; for one thing, pen names of the poets suffice to show this. In the Istanbul edition, there are works of different poets like Shams, Shāh-Mashrab, and Hakīm Sulaimān Ata, while in the Kazan editions there are also two pieces by another poet with the pen name Qūl Gharīb (hikmats number 102 and 126 in the fourth Kazan edition). With the exception of these five or six pieces in the Istanbul edition and the others in the Kazan editions, all the remaining sections belong to poets who used several very closely related pen names, like Qūl Khwāja Aḥmad, Khwāja Aḥmad Yasawī, Yasawī, and Ahmad Miskīn; or, much more likely, to a single poet who used all these closely related names. Indeed, according to the current general view, the person who used all these pen names was Ahmad Yasawi and all of these poems were very early products of sixth/twelfth-century Turkish. This view, which is not based on definitive proof, has been so pervasive up to the present as to have been accepted as an absolute fact in both popular and scholarly circles.

I do not hesitate, even if it at first seems strange, to assert my opposition to this general view. For one thing, we possess historical and literary evidence to show that all the works written under the pen names mentioned above, i.e. Qūl Khwāja Ahmmad, Aḥmad Miskīn, etc., cannot be attributed to Ahmad Yasawī. Unfortunately, in one of these many poems (hikmat number 88 in the fourth edition), the famous poet and Șūfì Nesīmī is mentioned! A poet who died in 562/1166-7 would not, of course, be able to mention a Șūfì poet who appeared two centuries later, even with his miraculous power!' In two other poems in the Diweann-i Hikmat in our possession, two famous disciples of Aḥmad Yasawī, Bābā Māchīn (hikmat number 47 in the Kazan edition and number 131 in the Istanbul edition), and Sulaimān Hakīm Ata (hikmat number 77), about both of whom we spoke at length above, are mentioned, whereas the likelihood is so remote as to be virtually impossible that Ahmad Yasawī himself would speak of his disciples. In addition to this varied historical evidence, which is categorical and incontrovertible, there are also a number of linguistic and literary considerations that strongly support my previous assertion. Among the poems that constitute the Dīwän-i Hikmat, there are some very well composed \{muntazam\} poems written in the various 'arüd meters, which, for those who have studied even a little the development of the literary language, are impossible to accept as products of the sixth/twelfth century. ${ }^{8}$

What can we deduce from all these considerations? Given the present extent of our knowledge and the fact that we do not possess a manuscript of the Diwann-i Hikmat from the sixth/twelfth, seventh/thirteenth, or eighth/fourteenth centuries, it is not possible to reach a definite judgment in this matter. Did this diwwän, 
which we today attribute to Ahmad Yasawī, actually belong to another poet named Ahmad who was a Yasawi dervish? Based on what we have said above, we would surely have to attribute an important part of the Dīwann-i Hikmat, especially the poems written in the 'arü meters to such a person. Because he mentions Nesīmī, this poet must not be from a time prior to the ninth/fifteenth century, but neither could he be much later. In order to be able later to attribute the hikmats that he wrote to Ahmad Yasawī, this poet would surely have had to have lived in the ninth/fifteenth century or early tenth/sixteenth century.

Would it not be correct to attribute the entire Dīwann-i Hikmat to a poet other than Ahmad Yasawī and, because of a similarity in name, to conclude that he was later confused with Ahmmad Yasawī? In my view, this possibility cannot be wholly rejected. We know for certain that Ahmad Yasawī wrote hikmats in forms taken from popular literature ${ }^{9}$ and that subsequently the writing of poems in this style actually became a tradition among the Yasawī dervishes. It is very likely, however, that the hikmats that Ahmad Yasawī wrote have been lost over the centuries and that the works of a poet of the same name who appeared later have been attributed to him because of his fame and spiritual influence among the people. Indeed, in the manuscripts presently in our possession, it is stated in several places that this work is the Daftar- $i$ than $\bar{\imath}$ \{the Second Notebook\}. ${ }^{10}$ Perhaps the Yasawī poet who compiled this dīwān considered the work of Khwāja Ahmad Yasawī to be the "first daftar," and because his own work was composed of hikmats in the same form and style and was given the same name, i.e. Dīwān-i Hikmat, he regarded it as the "second daftar." If the names of both dīwans and both authors were the same, and if there was a profound and genuine similarity in the poems of both poets with respect to form, style, and spirit, the work of the more recent poet could quite easily have been later attributed to the famous older Șūfì.

Still, we might conclude that even if the hikmats presently in our possession do not belong to Ahmad Yasawī, they are completely indistinguishable in form and spirit from those that did belong to him, because, as will become quite apparent when we discuss the followers of Ahmad Yasawī, even centuries after him hikmats of the same kind were written in the same form, style, and spirit. Nevertheless, we should not think that this was something peculiar to Ahmad Yasawī and his followers. This uniformity sometimes continued for centuries in the Șūî̀ literature written in the popular meters and forms. The reason for this is not only that the products of popular literature continued for centuries to be indistinguishable from each other, but also that later writers tried to imitate their predecessors, and that the followers of the great pirrs ascribed a virtual sanctity to the forms that they had established. Nevertheless, despite all these considerations, there also exists the strong possibility that the text of the Dīwann-i Hikmat in our possession is a mixed product composed of works belonging to both Ahmad Yasawī and to a Yasawī dervish named Ahmad who lived in the ninth/fifteenth or tenth/ sixteenth century. In any case, no matter which of the various possibilities that we have considered is preferred or accepted, the literary personality of Ahmad 
Yasawī and the early unknown stages of Turkish Șūfì literature can be illuminated by studying the Dīwān-i Hikmat in our possession. ${ }^{11}$

\section{B Linguistic character}

I have briefly recounted above the very rapid spread, via Iran, of Islam to Central Asia, to the Syr Darya region, and even to countries further east, such as Kāshghar and its environs. I also described how Transoxiana became completely Muslim in the Sāmānid period and how the people of Isfījāj ${ }^{12}$ adopted Islam under the very first Sāmānid ruler (Chapter 1, pp. 5-6). Because we do not possess an early reliable copy of the Dîwān-i Hikmat, it is necessary to study in particular some linguistic history and provide some brief information on the geographic areas of the Turkish dialects in the fifth/eleventh and sixth/twelfth centuries in order to place the Dīwān-i Hikmat in its proper linguistic sphere. In addition, by clarifying the meaning of "Chaghatay" and "Uighur" \{as adjectives describing languages $\}$ - terms that have been used continuously up to the present - it will also be useful to show the extent to which the Dīwān-i Hikmat justifies its appraisal, with respect to its linguistic and literary features, as the earliest work of Chaghatay literature. Until now, Turkish linguistic history has been almost completely neglected in scholarly studies, and so there has been no serious research on these questions to which one can refer. At the same time, because linguistics is outside my area of expertise, I expect that the information that I will present on this matter, and some of the ideas that I will advance, will \{later\} have to be re-examined and criticized by specialists in this field.

Maḥmūd al-Kāshgharī provides information in his Dīwān lughāt al-turk, compiled in the years during which the Kutadgu Bilig was being written in Kāshghar, on the contemporary dialects and geographical locations of the various branches of the Turks. According to him, the Turks were distributed from west to east in the fifth/eleventh century in the following manner: first came the Pechenegs, who were closest to the Byzantine lands, and then the Qipchaqs, Oghuz, Yimak, Bashqird, Basmil, Qay, Yabaqu, Tatars, and Qirghiz. From north to south, they were distributed as follows: Chigil, Tokhss, Yaghma, Ughraq, Charuq, Chomul, and Uighur. After all of these, \{further east\} came the Tangut, Khitāay, and Machin. ${ }^{13}$ According to al-Kāshgharī, who knew all these branches and their languages very well, the most eloquent form of Turkish was that used by those who knew only one language, who did not mix with the Persians, and who did not settle in the cities, whereas the languages of those, like the Sughdaq, Ganjak, and Arghu, who knew a second language and lived with city people, became enfeebled. ${ }^{14}$ According to al-Kāshgharī, nomads like the Chomul, Qay, Yabaqu, Basmil, and Tatars had separate languages, but they also knew Turkish well. As I explain at length in the note below, ${ }^{15} \mathrm{I}$ believe it is necessary to interpret and clarify this report to mean "they did not have separate languages but their own distinct dialects that could be included within the general Turkish linguistic sphere and, in addition, they knew the common Eastern Turkish that was called 
Khāqāniyya Turkish.” As for the other branches of the Turks whom al-Kāshgharī discusses, the Qirghiz, Qipchaqs, Oghuz, Tokhsı, Yaghma, Chigil, Ughraq, and Charuq had a common language that was pure Turkish; ${ }^{16}$ the language of the Yimak and Bashqird/Bashghırd was also close to theirs; the language of the Bulghars, Suwars, and Pechenegs, who extended toward the west, was uniformly Turkish but had a slightly different pronunciation $\{$ takhfif $\} .{ }^{17}$ Among these various dialects, that of the Oghuz was the most khafif \{lightest\}; that of the Yaghma, Tokhsı, and those who lived along the banks of the Ila, Irtish, Yamār, and Volga rivers in the direction of Uighuristan was the most correct; and that of the Mulūk-i Khāqāniyya \{Khāqān̄̄ kings\} and those who lived with them was the most eloquent. $^{18}$

These brief characterizations by al-Kāshgharī, as obscure as they are important, \{at least\} give us a fairly clear and concise idea of the number of Turkish dialects in the fifth/eleventh century and their relationships and resemblances to each other. It seems quite clear that Turkish was divided into two major linguistic groups in that period, Eastern and Western. Eastern Turkish, which the author calls Khāqāniyya Turkish or Turkish in general, was the literary dialect that was spoken in Kāshghar in particular and was used throughout that region. It was very close to the Chigil, Yaghma, Arghu, Tokhs1, and Uighur dialects. As for Western Turkish, which constituted the second major group, it was the dialect of the Oghuz, which was extremely close to the dialects of the Qipchaqs and Yimak, and also close to those of the Pechenegs and Bulghars. It is quite clear from the Dīwān lughāt al-turk that by the fifth/eleventh century, there were a number of specific and significant differences between these two great groups, i.e. Khāqāniyya Turkish and Oghuz Turkish, with regard to grammar and phonology. ${ }^{19}$

Among these two dialects, the Eastern dialect, i.e. the language of Kāshghar, had especially great importance in the fifth/eleventh century. The languages of the other Eastern Turks who lived further to the east and who had not entered the milieu of Islam were naturally also very close to the language of Kāshghar with respect to grammar and phonology. Al-Kāshgharī mentions them under the name "Uighur" and states clearly that their languages were pure Turkish and that they used the Uighur script. Only because they had not entered the Muslim milieu was there no discernible Arabic or Muslim Persian influence among them. ${ }^{20}$ Both the Oghuz and the Khāqāniyya Turks employed the Uighur script; but because the level of civilization of the Oghuz at that time was lower than that of the Khāqāniyya Turks, the literary language in the Oghuz region was Khāqāniyya Turkish, i.e. the dialect spoken in Kāshghar and its vicinity. While discussing the Uighur script, al-Kāshgharī says, "All the Turkish countries from Kāshghar to Upper China have used this script, from the most ancient times up to today (i.e. around the end of the fifth/eleventh century), in the correspondence of their khāqāns and sultans and in their books." This brief passage shows that much was written in Khāqāniyya Turkish since rather early times and that the Uighur script was used for it. ${ }^{21}$ Al-Kāshgharī adds that the same spelling system was used for all documents written in this script. ${ }^{22}$ 
According to the Russian scholar V. Grigor'ev and the French Orientalist Grenard, who relied on him, the language of Kāshghar, i.e. Khāqāniyya Turkish, was Qarluq Turkish, ${ }^{23}$ because the founders of the Kāshghar Khāqānate, according to their research, were not Uighurs, i.e. Toquz Oghuz, but Qarluqs. These Qarluqs, who lived among the Göktürk tribes north of the T'ien-Shan Range, migrated to the west of Issik-Kul with some other Göktürk tribes who would not accept Uighur rule after the collapse of the Göktürk state in the second/eighth century and occupied Tashkent and Farghāna. The descendants of their chiefs expanded \{their authority\} like the Göktürks as far as China, i.e. as far as the Wolf clan. ${ }^{24}$ Supplementing the information provided by al-Mas' $\bar{u} d \overline{1}$, but from another point of view, Istakhrī states unequivocally that these Qarluqs, who were referred to as Turks, had spread toward the east and that it took a month's journey, starting at Farghāna and passing through the Qarluqs, to reach the country of the Toquz Oghuz. ${ }^{25}$ This report, which shows that the Khāqaaniyya Turks in \{al-Kāshgārīss Dīwān lughāt al-turk were Qarluqs and that we must consider them to be a Turkish tribe separate from the Uighurs but related to the old Göktürk social structure, also clearly indicates that the Kutadgu Bilig is linguistically related to the Orkhon Inscriptions, which belong to these same Göktürks. ${ }^{26}$ This clear connection, which was first proposed by Thomsen and later confirmed by Radloff, can also be considered as linguistic evidence to support the historical analysis that I have been giving here. ${ }^{27}$

In the fifth/eleventh century, while Kāshghar Turkish, i.e. Eastern Turkish, prevailed in the eastern areas where the Qarluqs lived - from Kāshghar to the environs of Farghāna, Tashkent, and Samarqand - Oghuz Turkish, i.e. Western Turkish, which constituted the other great linguistic domain, had spread to a wide area in the west, especially from the Syr Darya region south as far as Khurāsān. According to al-Kāshgharī, in the fifth/eleventh century the principal cities of the Oghuz were along the Syr Darya and the nomads among them also lived on both banks of this river. ${ }^{28}$ According to the accounts of the other Arab historians and geographers, these Western Oghuz, who had separated from the Eastern Toquz Oghuz, had spread to the Syr Darya region from Gurgān $\{$ sic $\}$ to Fārāb and Isfijjāb. There were Khazar and Bulghar Turks to the west of them, Qarluqs to the east, and Kimeks to the north. ${ }^{29}$ Also, during this century, some of the Oghuz migrated to Mangishlak and settled there. ${ }^{30}$ Some of these Oghuz Turkmen who had already entered the Islamic realm in the fourth/tenth century also descended upon the area around Bukhārā toward the end of the fourth/ tenth century. Among them appeared the Seljuk dynasty that founded a powerful sultanate in Asia. During the period of their sultanate, Asia Minor and Azerbaijan were strongly Turkified by this Oghuz migration. After this, no great movement of the Oghuz who remained in the East has been recorded. We only know that in 548/1153-4, the Oghuz who lived around Balkh revolted against Sultan Sanjar and wreaked havoc on Khurāsān and the surrounding area, but this was neither ethnographically nor linguistically significant. The places that were abandoned by the Oghuz north of the Caspian and Aral seas in the Syr Darya 
area were filled by the Qipchaqs, who were a large branch of the Kimeks. By 421/1030-1, we find the Qipchaqs adjacent to Khwārazm. ${ }^{31}$

This then was the linguistic situation in the Kāshghar and Syr Darya areas of Central Asia in the fourth/tenth and fifth/eleventh centuries, i.e. before the Mongol invasion. Given the paucity of contemporary historical and linguistic documents and the confusing and obscure references of the early historians and geographers, this summary \{of the available material\} that I have presented is certainly not very clear. Nevertheless, despite this vagueness, in light of the analysis given above, I think the linguistic character that must be ascribed to Aḥmad Yasawī's Dīwān-i Hikmat is fairly clear. Ahmad Yasawī was born in the city of Sairām/Isfíjāb in the vicinity of Isfijjāb $\{$ sic $\}$, which early on had adopted Islam. ${ }^{32}$ If we consider that al-Kāshgharī regarded the places that stretched from Isfījāb to Balāsāghūn to be the Arghu region, ${ }^{33}$ then it would appear that Ahmad Yasawī was also an Arghu Turk. The same writer adds that the people of Balāsāghūn, Țarāz, and Madīnat al-Baiḍā, i.e. Sairām, spoke both Soghdian and Turkish and hence - because of foreign influence - the language of the inhabitants of the Arghu region had to some degree lost its vigor. ${ }^{34}$ Because the Arghu dialect can be included in the same linguistic domain as that of the Khāqāniyya Turks, it is certain that Ahmad Yasawī's mother tongue was not the Oghuz dialect. ${ }^{35}$ To be sure, he might have encountered Oghuz in places where he subsequently traveled, in Bukhārā, for example. We do not know the extent to which the Oghuz, after they descended from the Syr Darya region, mingled with the local people in Central Asia and Khurāsān and, at the same time, with other branches of the Turks and whether they had any linguistic influences on each other. ${ }^{36}$ We can only say for certain that when Ahmad Yasawī later went to Yasī a significant number of Oghuz had already migrated from that region, and those who had remained had mixed with Qipchaqs who had come down from the north and with other Turks who had come from various directions. Therefore, even if there might have been some Oghuz influence on his language, we cannot include it in the Oghuz linguistic sphere generally. In other words, we must definitely accept his work as a product of Eastern Turkish. If we possessed an early and trustworthy copy of the Dīwān-i Hikmat, it would surely show a number of linguistic features very similar to those in \{Yūsuf Khāṣs Hājib's\} Kutadgu Bilig; although it was under much stronger Arab and Persian influence - and even perhaps a bit under the influence of the old Oghuz dialect - it would belong, broadly speaking, to the same language domain as the Kutadgu Bilig. However, even if the copies that we currently possess contain some genuine pieces of Ahmad Yasawī's work, they will have been corrupted as they passed through the hands of various copyists over the centuries and will have lost almost all their original character. Such pieces, if they exist, would thus have no serious value for linguistic history. ${ }^{37}$

Some researchers - including, first of all, Vambéry and then Thúry - jumped to conclusions about the linguistic character of the Dīwann-i Hikmat, although they did not make a proper analysis of it and were ignorant of the historical personality 
of Ahmad Yasawī. They claimed that the language of the Dīwān-i Hikmat was the dialect of the Khānate of Khokand. ${ }^{38}$ Later, certain other researchers - Thúry also among them - considered it to be, along with Rabghūzî̀'s Qisas al-anbiy $\vec{a}^{\prime}$, one of the early works in the Chaghatay dialect, and regarded it as an intermediate work between the Kutadgu Bilig and the language of Nawā' ${ }^{39} .{ }^{39}$ Prof. Hartmann also considers the work of Ahmad Yasawi to be in Chaghatay, \{defined as\} the literary language of the area extending from the Caspian Sea to Kansu, and states that even later poets, like Chimyanlı Hüveyda, remained linguistically faithful to it as much as possible. ${ }^{40}$ In light of the thorough description that I have given above of the copies of the Dîwan-i Hikmat in our possession (section A of this chapter), however, I hope it is clear that in order to truly determine the linguistic character of this important work, we must not study the printed editions or recent manuscripts, but must find a very early manuscript or, if this is not possible, investigate the milieu in which Ahmad Yasawi lived and wrote his hikmats and the linguistic area to which it belonged. I reported briefly in the previous paragraph the results of my research in this respect and said that we must consider the Diw ān-i Hikmat as belonging to the same linguistic domain as the Kutadgu Bilig, i.e. to be a work in the Eastern dialect connected with the Qarluqs. Until the appearance of an early and trustworthy copy of the Dīwann-i Hikmat written before the Mongol invasion, the current state of our knowledge will not allow us to state categorically the linguistic area to which it belonged. The fact that the recent unreliable copies currently in our possession belong completely to the dialect that we call Chaghatay means nothing. Nevertheless, despite the continuing lack of an early and accurate copy of the text and the rather astounding primitive character of the current research on Turkish linguistic history, I am of the opinion that the hypothesis that I have advanced on this question is based on a rather strong foundation. ${ }^{41}$

\section{G Literary character}

In order to explain properly the literary nature of the collection of poetry that we possess today under the general title of Dĩwan-i Hikmat, we must subject it to a minute analysis with respect to both subject and form. The subject matter in the Dîwan-i Hikmat is very simple and limited: countless eulogies of the virtues of dervishes and the dervish life; the most famous Muslim legends, from which, finally, ethical and religious morals are inevitably drawn; various pieces on the life and miracles of the Prophet Muhammad; anecdotes; complaints about the state of the world and ascetic complaints written to remind \{the reader that the Day of Judgment is near; and finally simple and primitive, yet lively, accounts told with a simple-hearted appeal about conditions in heaven and hell, the demons of hell, and the female and male denizens of paradise \{s. hiurn and ghulām $\}$, and the gardens of paradise. At a time when Islam was just beginning to spread among the Turks, it was quite natural that works written by a Șūfi for a mass of people with simple and primitive tastes - and who had not yet succeeded 
in completely escaping from the customs and beliefs of the ancient pagan period - would not go beyond these subjects.

Ahmad Yasawi was by no means a stranger to the Islamic sciences and Persian literature. Much of his education and religious training took place in Muslim Persian intellectual centers, so he knew very well the mystical works of the great early Persian Șūî poets. However, given the need to address the Turks, who had sincerely but still superficially adopted Islam, and who would not easily abandon their national culture, it was necessary, willy-nilly, to conform to their tastes and customs and to address them in a simple language whose meaning they would understand and in a meter to whose music they were accustomed. It was simply under the influence of such powerful factors as these that Ahmad Yasawi adopted the national syllabic meter, which the people loved and the popular poets had used for centuries, rather than the harmonious 'arü $d$ meters cultivated by the Persians. He wrote all his hikmats in this meter and in the old national forms that were also taken from popular literature. In this regard, it is not pertinent to claim that the language had not been cultivated to an extent that it was comfortable with the 'arü d meters, because the Kutadgu Bilig clearly demonstrates that the 'aru $\bar{d}$ metrical system had been employed in Turkish literature some sixty or seventy years earlier. The single reason for this phenomenon was, as I stated above, the desire of the poet to address the mass of the people directly. ${ }^{42}$ Nevertheless, if we had an early copy of the Dīwann-i Hikmat, it is almost certain that its language, despite the author's desire to compose it in a very plain manner so that it could be understood by the greatest possible number, would contain a much greater mixture of Arabic and Persian words than the Kutadgu Bilig, which was bound to the Persian meter. ${ }^{43}$

Ahmad Yasawī wrote most of his hikmats in the seven- or twelve-syllable meters long used and much beloved among the people of Central Asia. These meters, which have a strange somewhat monotone harmony, and, at the same time, a somewhat primitive and crude but "original" flavor, do not reveal anything extraordinary in his hands. Even in passages requiring the greatest display of emotion, he is very cool and calm. The plodding nature of his admonitions, the simple and monotonous expression of his narratives, and the calm and dignified manner of his prayers almost never change. The staid and rigid personality of this Central Asian Turk, usually indifferent to the rapture and excitement of the inner life, but outwardly completely faithful to the fundamental principles of the $S_{\text {Shar }}$ ' $a$, is immediately apparent in the Divwān-i Hikmat. In order to provide some movement and excitement in the heavy monotonous harmony of the seven- and twelve-syllable meters, an artistic and emotional soul would have had to breathe life into it. In the meters that he selected, Ahmad Yasawi conformed to the common taste of the period and completely avoided any personal innovations.

With regard to rhyme as well, he had no attachment to Arabic and Persian and remained completely faithful to the national literary tradition. Rather than use full rhymes, he followed popular literature and used half rhymes, usually composing them from the inflections of the verbs, and for the most part stuck to 
the old $\operatorname{rad} \bar{f} f$ \{repetition of the word at the end of each couplet\} method. ${ }^{44}$ His interest in respecting the early folk literary tradition fully reveals itself in his form of versification. Ahmad Yasawī, who said

Ücyüzaltmıs hikmet aytıb dâstân aytı

Dâstân aytı bûstân içra oymak ucun

\{He uttered 360 hikmats and dastāns

in order to penetrate (?) in the garden

arranged all of his hikmats according to this ancient and thoroughly national form. In these dastāns, composed of four-verse stanzas or quatrains, the last verse of the first stanza is sometimes repeated in all the stanzas like a refrain. The first three verses of each stanza rhyme, while the last verse rhymes with the last verses of all the stanzas. Usually the first stanza differs from the others with the first verse rhyming with the third and the second with the fourth \{thus: abab cccb dddb etc.\}. This form of versification, which is very limited and primitive, is apparently the native form and completely devoid of foreign influence. The repetition at the end of each stanza, either of an entire verse or of a rhyme, shows that it was written not for the purpose of being read privately like works belonging to later periods of development, but in order to be recited publicly in religious gatherings. In other words, Ahmad Yasawī’s work was in this respect no different from the products of the early folk literature. ${ }^{45}$

\section{Yasawī, Șūfi}

In the chapters above, I have discussed the time when Khwāja Aḥmad Yasawī lived, his milieu, the various influences under which he developed, and the basic characteristics of the tanqqa that he established. If readers will recall these descriptions, they will easily grasp the extent to which Ahmad Yasawī can be called a "Ṣūfì poet" and the degree to which this title, when applied to him, is comprehensive and all encompassing. This great Turkish shaikh, who, from childhood until his last years, lived a vigorous and sincere Șuffi life, wrote poetry for the enlightenment of the Turks who could not understand the Șûfî works in Arabic and Persian and for the purpose of confirming the mystical truths and instilling them in his disciples. It was therefore quite natural that the mystical character of his poetry should come to the fore. As I explained above (section A of this chapter), even a superficial analysis of the Dīwān-i Hikmat - which, even if it does not belong to Ahmad Yasawī, we naturally concluded that in form and spirit it would be identical with those works that did belong to him - proves this point sufficiently. This Șūfī, who had a very simple imagination and was almost completely unfamiliar with literary art, was, like all other Șūfìs, indifferent to the external world and its manifestations. Engrossed as he was in the world of monism, he could, in the end, liken this world and the next world "to two poppy 
seeds." ${ }^{46}$ The only thing that preoccupied him was the thought of guiding the people and encouraging them along the right path. The religious legends that he recounted, the prayers, pleas for God's help, and requests for God's forgiveness, were all written with this noble thought in mind. In the various poems that he wrote about the Prophet and in the hikmats that deal with eschatological subjects, he called upon everyone to follow the right path and begged God's forgiveness for his own shortcomings and sins. His most common recommendations were to listen to the words of the saints, to conform to the stipulations of the Koran and Hadīth, to combine Sharìa with tarīqa, to abandon this world of vanity, and to turn to the path of asceticism and religious striving $\{$ mujāhada $\}$. Like all the Șūfìs, he complained of the condition of this world. With a very sincere and consuming passion he bemoaned the fact that no one heeded the words of the true saints and that everyone was a captive of his own base desire $\{$ nafs-i ammāra $\}$.

Because he was of the Hanafi madhhab, he always venerated and praised the "Imām A'zam" \{the most magnificent imām, i.e. Abū Hanīfa\} and the founders of the other Sunnī madhhabs. Indeed, there is a long and noteworthy legend in the Dīwān about how Abū Hanīfa had miraculously solved a number of complicated problems of Islamic law at the age of six and how he received his title. On the other hand, there is absolutely nothing in the Dīwān-i Hikmat to suggest Shi' 'ism or any form of Mu'tazilism, even to the extent found, for example, in Farīd al-Dīn 'Aț̣ār. ${ }^{47}$ Indeed, as I have also explained above, this \{i.e. strict Sunnism $\}$ was one of his governing ideas. Even when he discoursed on the passion of Manșūr al-Hallāj and the mystery of anā 'l-ḥaqq \{al-Hallāj's utterance, "I am the Divine Truth" $\}$ and when he said that the mullās did not understand the mysteries of the tariqa \{i.e. of mysticism\}, he would never go beyond a certain point. He strongly promoted renunciation and ascetical exercises as steps on the Șüfi path. Asceticism, piety, mortification of the flesh, and spiritual striving were all most necessary in order to reach the level of truth. It was not easy to follow the path to Divine Truth $\{H a q q\}$. The path of \{ecstatic or spiritual $\}$ love of God was very blessed, but it was full of endless difficulties. "The \{psychological and physical $\}$ state of one who enters these tortuous paths is desperate. Many a lover has become dust on these paths . .."48 "In order to become a devotee, one must enter the garden of love. For its sake, however, one must first kill the self. One must endure many long torments and great tribulations in order that this be possible. He who wants to find the pearl of love should be content with one drop. The true lover who burns with the fire of love loses his own color. His soul is bewildered, his heart is desolate and his eyes are flooded with tears. As the Prophet said, الدنيا جيفة وطلابها كلاب \{The world is carrion and those who hanker after it are dogs $\}$. The true lovers are those who give up their own souls and seek the beloved, union with God. Oh, Khwāja Aḥmad, always think of God and weep. Pray morning and night and keep the fast, so that you may reach your goal." Asceticism and spiritual striving, which occur in this sense in most of the hikmats, indicate the need to withdraw from all worldly matters. For the Șūī, in fact, this is the meaning of the Koranic verse (2:278) يا ايها الذين امنوا اتقو اللّ 
\{Oh you who believe, fear God! $\}$. If not, one's heart cannot become "the place of divine manifestation" $\{$ nazar-ga $\bar{a} h-i$ ilāh $\bar{\imath}\} .{ }^{49}$ And although Ahmad Yasawī tells us that after all these hardships "he drank the wine of union, received precedence $\{s a b q\}$ from God, and was aware of the mystery of anā 'l-haqq," he still did not reveal the mystery. ${ }^{50}$

In addition to many poems on such themes in the Dīwann-i Hikmat, there are a number of hikmats on the life of Khwāja Ahmad Yasawī. This Turkish shaikh recounted the important events of his life in simple and artless language: how he had become a friend of Khadir, in what manner he received blessings from Arslan Bābā, and how he had been seized by the love of God since childhood. Stating that he wandered about as an exile in Khurāsān, Iraq, and Syria for a long time, and then, missing Arslan Bābā, that he returned to his own city of Turkistan $\left\{Y_{a s} \overline{1}\right\}$ and wanted to die there, he mentions his birthplace with great ardor: "Fastening a stone to my heart, I left that blessed Turkistan where I was born." Just as his shaikh, Khwāja Yūsuf Hamadānī, became homesick whenever he thought of Hamadān, so too did Aḥmad Yasawī harbor a great affection for his hometown. The Dīwann-i Hikmat also clearly relates that, after passing through various cycles \{dawra, of religious learning\} up to age sixty-three and reaching various spiritual stages $\{m a q \bar{a} m\}$ in the mystic path, he realized that he had become a great "sultan" in the eyes of his disciples and, attributing this to the dictates of the carnal soul $\{n a f s-i$ ammāra $\}$, he went underground - i.e. entered the chilla-khāne - and wrote his hikmats in isolation from the people. ${ }^{51}$

Now that we have analyzed the contents of the poems in the Dīwān-i Hikmat, we can broach the topic of the extent to which it would be suitable to call Aḥmad Yasawī a Șūfì poet. He cannot be regarded as one of the 'āshıq Șūfìs who tried to record the candid outcries that burst from their souls and did not pause to consider whether these outbursts were reconcilable with the external ordinances of Islamic law. To the contrary, he always took into consideration the mentality and spiritual state of the community he was addressing. He communicated to them not the subtleties of Șūfi philosophy, which they could not understand, but rather a number of legal and ethical principles in a hortatory manner, urging them to follow these principles faithfully in order to achieve happiness in the next world. His lengthy eulogies of the first four caliphs, his ascetic exhortations to the dervishes to follow the tariqa, and his bemoaning the evils at the end of time do not reveal Aḥmad Yasawī to us as a true Șūfì poet. Yūnus Emre said, "He who does not regard the seventy-two sects with the same eye $\{$ i.e. as indistinguishable $\}$ rebels against truth even if he is a madrasa instructor." One can find nothing at all in the Dīwan-i Hikmat that recalls this broadmindedness and nothing of the pantheist philosophy of Jalāl al-Dīn Rūmī. ${ }^{52}$ In this respect, rather than being a profound poetical Șūfì work, the Dīwān-i Hikmat can be better characterized as a simple work composed of religious and ethical sermons and narratives as well as didactic poems concerning the principles of the tariqa and the rules of the mystical discipline. Aḥmad Yasawī had many Șūfi ideas, but despite this he was a dry moralist who lacked true poetic ability or lyrical gift. 
We can get a clearer idea about this if we compare Ahmad Yasawī to the moralist Șūî poets of Iran who had diverse abilities and talents. In the sixth/ twelfth century, when the Dīwān-i Hikmat was written, the magnificent Șüfi literature of Iran was still in the process of formation. After epic literature, epitomized by Firdawsī, it was the turn of moralistic Șūfì literature to develop and become refined. Among the Șūfìs who had thrived up to that time, there were some who wrote a few quatrains or ghazals from time to time. The famous Șūî Shaikh Abū Sa'īd b. Abī 'l-Khair, who died after the age of eighty in 440/1049 - the admiration that he and Ibn Sinnā expressed for each other from the moment of their first meeting is well known - recited beautiful quatrains with a lofty and sincere Șūfî feeling. In the poetry of this great Șūfì, who says in a famous quatrain

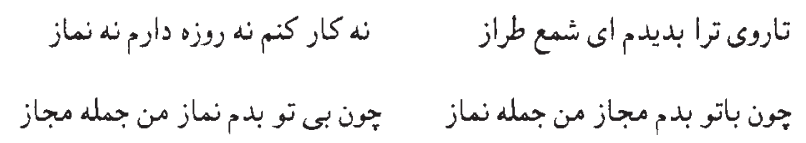

\{Since I beheld you, my candle of Țarāz,

I have ceased all work, keep not the fast, nor pray.

With you my figurative speech becomes prayer.

Apart from you my prayer becomes a mere figure, $\}^{53}$

there is a vague pantheistic streak and a free and candid expression of mystical love, in short, a divine breath. ${ }^{54}$ Although subsequent Șūfīs wrote innumerable commentaries on some of his quatrains, ${ }^{55}$ Shaikh Abu Sa ${ }^{c} \overline{1} d$ was generally known much more as a Șüfi than as a poet. Thus, we can say that great poets who were directly inspired by Șūfism had not yet appeared.

Hakīm Sanā'̄ and Farīd al-Dīn 'Ațtār opened the period of great Ṣūî̀s in Persian literature in the sixth/twelfth century. Following them, Sa'dī, Jalāl al-Dīn Rūmī, Jāmī, and numerous other such poets extended this period. I have examined the moralistic Șūfì works of Hakīm Sanā'̄i (d. 545/1150-1 \{probably d. 525/1131\} and Farīd al-Dīn 'Atțār, who are virtual contemporaries of Ahmad Yasawī, and I do not believe they had any influence on him. ${ }^{56}$ Apart from such common elements as encouraging people to join the tariqa or abandoning the affairs of $\}$ this world, there is no connection whatsoever in form or style between his hikmats and the Șūfì works of these great Persian poets. Hakīm Sanā'̄̄ and 'Atțār were not merely Șūîs. They were at the same time great poets, possessing refined language and a rich imagination. Ahmad Yasawī, on the other hand, was not a great poet, only a Șûfi. Unlike the Persian poets who were his contemporaries, he addressed not an audience that was prepared to understand all the subtleties of Șūfism, but rather an audience of simple and primitive folk. Yet neither Hakīm Sanā'ì nor Farīd al-Dīn 'Aț̣ār, despite all their artistic power, can be regarded as consummate Șūfì poets. It is not possible to deny the value of their works and the importance they have had among the Șûfīs, but we must 
admit, nevertheless, that they were not able to reach the sublime level of pantheist philosophy found in the work of Jalāl al-Dīn Rūmī. ${ }^{57}$ Farīd al-Dīn 'Atțār, who in his Pandnāme was a moralist - exactly like $\mathrm{Sa}^{\prime} \mathrm{d} \overline{\mathrm{i}}$ - can also be regarded as a moralist poet in his famous Mantiq al-tair, because this work is, above all, a collection of Șūfì ethics. The same is true for 'Ațtār's other works as well as those of Sanā'̄. Even as moralists, however, they were superior to Ahmad Yasawī and taught a much more systematic system of Șūfì ethics. But the unsystematic character of the Șūfì ethics taught by Aḥmad Yasawī is not due to the weakness of his doctrines. If we take into consideration not only his lack of artistry but also the simplicity and primitiveness of the community that he was addressing, then his excuse in this respect is obvious. Otherwise, Ahmad Yasawī was an important figure who fully grasped the entire mystical world-view of his age. Because he fully believed in the need to reveal Șūî realities, but tailored to the ability and comprehension of his audience, he avoided pantheistic teachings, even to the extent found in the Mantiq al-tair. ${ }^{58}$

If we compare the Dīwan-i Hikmat to other famous Turkish works of a didactic nature that were written before or a short time after it - for example, to the Kutadgu Bilig - we find a significant difference with respect to their ethical views. The Kutadgu Bilig resembles the Persian mirrors-for-princes in giving attention mainly to social ethics, while the Dīwān-i Hikmat is a Sūfī digest of personal ethics. As for \{Ạmmad b. Maḥmūd's\} 'Atabat al-haqā'iq, which is reminiscent above all of 'Atțār's Pandnāme, it does not have even as much Șūfī character as the Pandname. In very dry language, it expounds on the merits of patience and contentment; teaches that this world has no value other than as a place to sow and reap for the next world; enumerates the terrible consequences of miserliness, talkativeness, joking, keeping bad company, covetousness, and greed; and states that the world is full of evil men and evil deeds. The poet, who was always bound to the text of the Koran and Hadith, saw no need to give an allegorical sense to the "taverns," 59 for which all the Șūfìs felt the most sincere and ardent reverence, and related with profound chagrin that while the mosques were empty the taverns were full. The only point that reveals a slight Ṣufī influence in all these moralistic views is his insistence on not hankering after the transitory world but, instead, being resigned to fate - obviously such teachings could only derive from a mystical system. ${ }^{60}$ It is clear, therefore, that there is no connection or similarity between the Șūfi ethics propounded in the Dīwān-i Hikmat and either the Kutadgu Bilig or the 'Atabat al-haqā'iq. Aḥmad Yasawī was by no means influenced by the Kutadgu Bilig, which was written earlier; by the same token, he did not influence the poet of the 'Atabat al-haqa' iq.

\section{NOTES}

$1\{$ Hazin̄ī, \} Fawăhir, p. 53. \{The fact that Köprülü assumes that Aḥmad Yasawī’s authorship of the Diwan-i Hikmat is a given colors the rest of his discussion. It is especially remarkable that he should cite Hazīnī as evidence on the late fourth/tenth-century 
currency of the term hikmat, and that he ignores non-Turkic Șūfi hikam. In the next paragraph in the narrative, Köprülü goes on to use Ahmad Yasawī's death date, which he never seriously examined, as the basis for declaring the Dĩwän-i Hikmat to be the oldest example of Muslim Turkic literature after the Kutadgu Bilig!\}

2 The problem of the date of the Dīwän-i Hikmat and the personality of Ahmad Yasawi have long been the cause of many protracted disputes among Orientalists. When Vambéry published certain selections from this work for the first time in Cagataische Sprachstudien \{Leipzig, 1867\}, he provided no information on its date or the personality of Khwāja Aḥmad Yasawī. Russian Orientalists, including Melioransky, have carried out some more or less critical studies on the Khwāja based on the editions of the Dĩwan-i Hikmat printed in Russia. They know that he died in 562/1166-7 and thus realize the early date of this work with respect to the history of the Turkish language. Prof. Brockelmann, in an important study entitled Ali's Qissai fusuf, der älteste Vorläufer der osmanischen Litteratur, recently published in the journal of the Prussian Academy \{Abhandlungen der Königlichen Preussischen Akademie der Wissenschaften, no. 5 \} (Berlin, 1917), states, based on Melioransky, that the Dĩwan-i Hikmat is a sixth/twelfth-century Turkish work. In his critique of Brockelmann, Túrán, 2 (1918), 111-18, J. Németh, professor of Turkish linguistics at the University of Budapest, discusses the late Hungarian Orientalist Jozef Thúry's great knowledge of the literature of the Eastern Turks and, based on this, strongly criticizes Melioransky and Brockelmann's opinion that Ahmmad Yasawī belonged to the sixth/twelfth century. Because Thúry's article, which includes his observations on Ahmad Yasawī, has been translated into Turkish, as "Ondördüncü 'asır sonlarına kadar Türk dili yâdıgârları," \{trans. from the Hungarian by Râgip Hulûsî, MTM, 2 \{1331/1913\}, pp. 81-133, we are able to refute the ideas advanced by Prof. Németh that are based on it. According to Thúry, "Ahmad Yasawī was a shaikh of the Naqshbandī tariqqa. We do not know when he died, but it is well known that the founder of the Naqshbandiyya, Pīr Muhammad \{better known as Bahā' al-Dīn Naqshband, died in 719/1319 and that Tìmūr had a magnificent building erected over the tomb of Ahmad Yasawi in 799/1397. Therefore, Aḥmad Yasawi must have died between 719/1319 and 799/1397 and consequently the Diwwan-i Hikmat is a work of the eighth/fourteenth century" (MTM, pp. 97-8). Thúry cites \{Ṣafi's\} Rashahāt, \{Turkish\} trans., as a source on this subject. If he had properly studied the information about Ahmad Yasawī given by Șafì, however, he would have realized that Khwāja Yūsuf Hamadānī's third muñd could not have belonged to the eighth/fourteenth century. It is evident that, just as he made a poor analysis of the Rashahāt, academician Thúry also completely ignored all the sources on Ahmad Yasawī. Indeed, the most curious thing is that he was not even aware that this work had been printed in several editions. Vambéry too claims that it was unpublished except for 310 lines of verse found in Shaikh Süleyman's Chaghatay

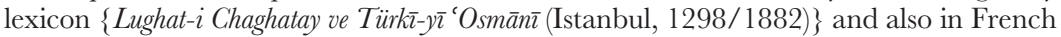
Orientalist Abel Pavet de Courteille's dictionary \{Dictionnaire turc-oriental (Paris, 1870)\}. In light of these remarks, Prof. Németh should understand how ignorant the late Hungarian Orientalist \{i.e. Thúry\} was of the sources on this subject. \{Köprülü's critique of Németh's and Thúry's ideas about the dates of Ahmad Yasawī was in some respects correct. The fullest discussion of the issues here, and of Thúry's error-filled arguments, came in a series of brief notes published in Der Islam: Franz Babinger, "Zur Frügeschichte des Naqschbendi-Ordens," 13 (1923), 105-7; Brockelmann's note in the same volume, 282-3; and the notes of Barthold and Babinger, 14 (1925), $112-14$.

3 The first Orientalist to mention the existence of the Dīwann-i Hikmat and, in fact, to publish and translate selections from it was Vambéry (Ćagataische Sprachstudien, pp. 115-23). However, in the introduction to his work, he is not able to give any 
historical information apart from citing a few lines from Levshin, \{Description des hordes\}, pp. 36-7.

4 I found no manuscripts of the Dĩwan-i Hikmat in the waqf libraries of Istanbul. One of the two manuscripts that I personally was able to study in Istanbul is today found among the books acquired from N. Katanov. This copy, which was made in 1290/ 1873-4, is composed of 331 pages. Each page has an average of eleven lines and there are ninety-nine hikmats altogether. This copy, which is full of mistakes and is corrupt in every sense, cannot be used as the basis of scholarly study - even less so than the printed texts. The other copy, which is among the books acquired by the Ministry of Education from Hâlis Efendi, was made in 1260/1844-5. It contains much poetry that does not belong to Ahmad Yasawī, even Nawā's's famous Tarji $\bar{\imath}^{\prime}-i$ bend, which was included in the Kharābāt \{or Harâbât, i.e. a famous anthology published by Ziyâ Pasha (Istanbul, 1291-2/1874)\}. Melioransky writes that there are four different manuscripts, all with number 239, in the Asia Museum in Saint Petersburg, but that they are all recent and that no trustworthy early copy of this work can be found. I was not able to find copies of it among the Turkish works in the Berlin, Vienna, or Gotha libraries or in the British Museum. (I have depended on the \{manuscript\} catalogues of G. Flügel, W. Pertsch, and Ch. Rieu. It is possible that the Dĩwān-i Hikmat might be found among the recent acquisitions of these libraries, i.e. since those catalogues were published.) A manuscript of the Dīwān-i Hikmat is known to be in the Library of the Hungarian Academy, but we do not possess sufficient information about it. Because the Dīwān-i Hikmat was very famous in Central Asia and among the Northern Turks, it is certain that other copies will be found in other libraries or in private hands. Nevertheless, most will undoubtedly belong to recent times. Strong evidence for this opinion is that the Russian Orientalists, who have the best chance of finding an early copy of the Diw añ-i Hikmat, have so far had no success. As far as I know, the oldest copy was formerly in the Vefik Pasha Library \{not further identified\}. According to the catalogue, it (number 1039) is composed of 148 folios, is four inches thick, is written in a plain but beautiful hand, has headings in red, and was made in 1105/1693-4. Unfortunately, I was not able to find it. Pavet de Courteille says that there is a manuscript of the Dīwan-i Hikmat in his private library, but he gives no information on whether it is old or new (Mirâdj-Nâme: Récit de l'ascension de Mahomet au ciel \{Paris, 1882; reprinted Amsterdam, 1975\}, in the course of the notes, p. 33). It is obvious, therefore, that there are no happy results to be reported from this long recital. \{For comprehensive information on manuscripts of the Dīwān-i Hikmat, see H. F. Hofman, Turkish Literature, a Bio-bibliographical Survey. Section III. Moslim Central Asian Turkish Literature Being in the Main a List of "Chaghatayan" Authors and Works in "Chaghatay" as Registered in Professor M. F. Köprülü's Article: "Çagatay edebiyatr," IA, Vol. 2 (270-) (with some additions, Navāāanna, however, excepted) (Utrecht, 1969-), vol. 6, pp. 11928. The earliest dated manuscript of something like the Dĩān-i Hikmat comes only from the early eighteenth century. The most extensive survey of manuscript copies of this work preserved in Tashkent, the largest repository of Central Asian manuscripts, has been done by M. M. Ishmukhamedova. See the summary of her dissertation “'Devani hikmät'ning qolyazmäläri," Filologyiyä fänläri namzadi ilmiy däräjäsini alish uchun yazilgän dissertatsiyä Ävtoreferäti (Tashkent, 1995).\}

5 \{There were many. See Hofman, Turkish Literature, vol. 6, p. 121.\}

6 The Diwān-i Hikmat was published for the first time in 1295/1878-9 in Kazan as a booklet of 125 pages containing sixty-seven hikmats and one munäjät \{supplication\} under the title Hikam-i hadrat-i sulțān al-'ārifìn Khwäja Ahmad Yasawĩ. I was not able to see a copy of the second edition, so I do not know when it was published or the nature of the edition. The third edition was published by the Kazan University Press in 1311/1893-4 under the title Dī̌wān-i hikmet-i sulțān al-'ārifín Khwäja Ahmad b. Mahmüd 
b. Iftikhär-i Yasawer. It contains on the first page a brief biography taken from the famous biographical dictionary of saints by Ghulām Muhammad Lāhawrī entitled Khazinat al-asfiy $\bar{a}$, a prose introduction of seventeen pages and 134 hikmats and one munājat. We can state that this prose introduction, which describes the rules of the $\{$ Yasawī $\}$ order, has been extracted almost verbatim from \{Hazin̄îs\} Fawähir. The fourth edition, which was also published in Kazan in 1896, has 277 pages and, together with the same biography extracted from Khazinat al-asfiy $\bar{a}^{\prime}$ and the introduction on the rules of the order as in the third edition, contains 148 hikmats, fourteen more than in the third edition. The lithographic edition published in Tashkent in 1314/1896-7 has 154 pages containing the prose introduction called Faqmāme and roughly the same hikmats and, at the end, the munajāt found in the third Kazan edition. It includes more hikmats than the other editions because of the addition, at the end, of hikmats in the same style belonging to a Yasawi dervish. The Istanbul edition,

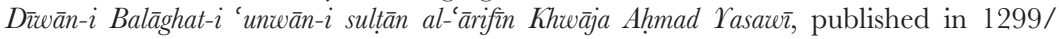
1881-2 by Hājjī Süleyman Efendi, the shaikh of the dargāh \{dervish convent\} of the Özbeks, has 276 pages with an average of twenty-six lines per page. This contains rather more material than the other published editions, and also includes, in addition to the poetry of Ahmad Yasawī, that of many other well known Șūin poets of Central Asia. This confusion is found in the other editions as well, but to a lesser degree. \{Köprülü says that the prose introduction included in the 1311/1893-4 Kazan printing of the Dīwann-i Hikmat describes the rules of the order and "has been extracted almost verbatim from (Hazīnì's) Fawähir;" that the 1896 fourth edition includes the same introduction; and then that the 1314/1896-7 Tashkent publication includes "the prose introduction called Faqmāme." Depending on one's interpretation of the definite versus indefinite article, Köprülü's phrasing can imply that the prose introduction in the earlier versions might be the same one that is called Faqranme. In other words, it is not clear if he is implying that the prose introduction in the Tashkent printing is different from the pose introduction in the Kazan versions, or merely that the same prose introduction happens to be ascribed a title in the Tashkent printing. In any case, the Faqmāme is not the same as anything from the Fawāhir.\}

7 Sayyid 'Imād al-Dīn Nesīmī, who holds a large and important place in Ottoman literature and, according to a very strong tradition, was a disciple of Faḍl Allāh Hurūfì, was put to death, as is well known, in Aleppo in 820/1417-18 (\{Kātib Chelebi, $\}$ Kashf al-zunūn, vol. 1, p. 401; Lațīfî, Tadhkira, p. 332). His Dīwān and legends, which were quite renowned in Iraq, eastern Anatolia, and Azerbaijan, had spread to Khurāsān and Transoxiana during the ninth/fifteenth century. A majlis in the Majālis al-'Ushshāq of Amīr Kamāl al-Dīn Husain \{Tabasī Gāzurgāhī\}, who was appointed grand vizier by Sultan Husain Bāiqarā in 904/1489-99, is devoted to Nesīmī. (In order to understand the error in ascribing this work to Sultan Husain Bāiqaāa, beginning with Kātib Chelebi and continuing to the present, see \{Khwāndamīr, $\}$ Habīb al-siyar, vol. 3, part 3, p. 330, and especially \{Bābur's\} Bäburnāme - the section describing the leading figures of the reign of Sultan Husain Bāiqarā. There are numerous manuscripts of the Majälis al-'Ushshāq in Istanbul and the libraries of Europe, such as Ayasofya MS 4238). \{There is a new edition of the Majālis, ed. Ghulām-riżā Tatātabā'̄̄ Majd (Tehran, 1376/1997). Remarkably Köprülü cites this work on Nesīmī, but missed a very interesting story in it that mentions Ahmmad Yasawī (called Ata Yasawī, a form clear in manuscripts, but misread in the new edition). See DeWeese, "Dog Saints and Dog Shrines in Kubravī Tradition: Notes on a Hagiographical Motif from Khwārazm," in Denise Aigle (ed.), Miracle et karāma: Hagiographies médiévales comparées (Turnhout, Belgium, 2000), pp. 464-5.\} Vambéry also states that Nesīmî’s Sūfì poetry is esteemed and in demand in Central Asia and has long been recited there (Čagataische Sprachstudien, pp. 141-3). \{See $E I^{2}$, s.v. "Nesīmī” (F. Babinger).\} 
8 For example, as the twenty-first hikmat there is a mathnawe beginning İlâh $\hat{\imath}$ Kâdirâ Perverdigârâ / Rahm kal bendenga ey Kirdigârâ; as the twenty-third hikmat there is a poem praising the Prophet in very polished language beginning Başımga tüşüb nac ra-i sevdâ-yi Muhammed / Men an ucun gûyida şsydâ-yi Muhammed; as the twelfth hikmat there is another such poem beginning Bizdin dürûd bisyâr Yâ Mustafâ Muhammed; as the thirtythird hikmat there is a smooth poem that ends with the line Ehl-i dil bolgan kişi gamkin göngülnü şâd iter; as the fifty-third hikmat there is a ghazal beginning Garîbligda garîb bolgan garîblar / Garîblar hâlini bilgen garîblar; as the fifty-sixth hikmat there is a hymn with

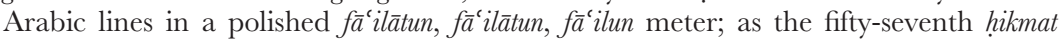
there is a mathnawĩ, beginning Muhammed'ni biling zâtı Arab'dur / Tarikatni yolu küll-i edebdür about the Prophet and in mathnaw form; as the ninety-second hikmat there is a very smooth poem in the meter maf' $\bar{u} l u$ maf $\bar{a}^{c} \bar{\imath} l u$ maf $\bar{a}^{\prime} \bar{\imath} l u ~ f a a^{\prime} \bar{u} l u n$; as the one hundredth hikmat there is a poem written in the meter of four mafát'iluns; as the one hundred and second hikmat there is a very well composed five-line stanza with the refrain, Sûfi-naks oldun veli her giz müsülmân bolmading; as the one hundred and seventh and one hundred

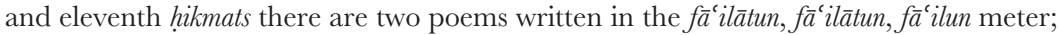
as the one hundred and twenty-seventh hikmat there is a ghazal whose first verse is Dem bu demdur özke dem nidem dime / Dünyâdin bi-gam ötärsin gam dime; as the one hundred and thirty-fifth hikmat there is a munāja ât whose first verse is Ayâ ş̧âhi du 'âlem pâdişâhı / İrürsin bendeni puşt ü penâh $\hat{\imath}$; and finally there is a long and rather polished munājāt in the meter

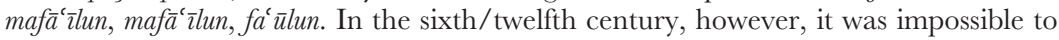
write such polished poetry in so many different 'arüd meters.

9 \{It is difficult to determine how Köprülü knew this for certain.\}

10 The Daftar-i thān is is mentioned in a number of places in the Dīwān-i Hikmat (Istanbul edn, pp. 2, 17, 28, 74, 147):

Riyâzetni katıg tartıb kanlar yutub

Min defter-i sânî sözdin actrm mana

\{I suffered hard austerities, swallowed blood;

I began to utter the Second Notebook.

Kul Hâca Ahmed men defter-i sânî aytrm

İki âlem işretlarn meyga saydım

\{I am the slave, Khwāja Aḥmad, I uttered the Second Notebook.

I reckoned the enjoyments of both worlds as wine.\}

Min defter-i sânî aytrm kani kulak

Kan-yaş töküb yıglamaslar misl-i bulak

\{I uttered the Second Notebook. Where are ears?

They weep not, pouring bloody tears like a fountain.\}

Tâze tâze Hikmet'larm sânî defter

İsiz sözüm nâdânlarka knlur ebter

\{My brand-new hikmats, the Second Notebook -

Alas! My words confound the foolish.\}

Min defter-i sânî aytım sizka yâdigâr

Ervâhimdin meded tiläb okung zinhâr

\{I uttered the Second Notebook to you as a memento.

Read them seeking help from my spirits, take heed!\}

11 After coming close to acknowledging problems in the attribution of the Dīwa n-i Hikmat to Ahmmad Yasawī - if this work includes a mix of Ahmad Yasawī's verse with that of a later "Ahmad," then the latter's contribution could presumably be close to 
100 per cent - Köprülü backs away, saying even the extant Dĩwān-i Hikmat shows us the "literary personality" of Ahmad Yasawi. \}

12 For additional information on Ispījāb or Isfijjāb, see \{Yāqūt,\} Mújam al-buldān (vol. 1, p. 230). Maḥmūd al-Kāshgharī says that the city of Sairām, which was well known

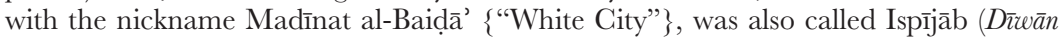
lughät al-turk, vol. 3, p. 133). Extensive and explicit information on Ispījāb can be found in all the Arab geographers. \{See Barthold, Turkestan Down to the Mongol Invasion, pp. 169-79; EIr, s.v. "Asfijāā" (C. E. Bosworth); $E I^{2}$, s.v. "Sayrām” (P. B. Golden).\}

13 Dĩwān lughāt al-turk, vol. 1, pp. 27-8. Abū Dulaf, who made a long journey from Bukhārā to China during the time of the Sāmānid ruler Naṣr II b. Ahmad \{301-31/ 914-43\} presents the Turkish tribes along the routes that he took as follows: "First the خركه (Charuq:), a month later the طحظظ (Tatars?), twenty days later the بخا/ بجيا (?), then the Pechenegs, after traveling twelve days among them the Chigil, after traveling forty days the Bughraj (Ughraq?), a month later the Tübet (تبت), forty days later the Kimek/Mimak, after traveling a month among them the Ghuz/Oghuz, after traveling a month among them the Toghuz-ghuz/Toquz Oghuz, after traveling twenty days among them the Qirghiz, after traveling a month among them the Kharlukh/Qarluq, after traveling twenty-five days among them the خطلخ (Halaj), and then the ختيـان (Khițāy?)." Abū Dulaf mentions that among these tribes the Kimek and Qirghiz had their own special writings $\{$ yazlar $\}$, indeed, that the Qirghiz had verse compositions to be recited at prayer times. (This traveler's account, the Arabic text of which was published with a Latin translation in Berlin in 1845, is found in full in \{Yāqūt's\} Mứjam al-buldān under "al-Șīn"; the Turkish trans. is in Şerefeddin, "Eski Türk memleketlerinde," $Y M$, no. 59, \{29 August, 1918, pp. 134-6\}). In any case, the information given by these sources urgently needs to be critically analyzed and expanded upon. \{Köprülü's notes on Abū Dulaf no longer have any scholarly value. The basic edition is V. Minorsky, Abu Dulaf Mis'ar ibn Muhalhil's Travels in Iran (circa AD 950): Arabic Text with an English Translation and Commentary (Cairo, 1955). Cf. Peter Golden, An Introduction to the History of the Turkic Peoples, pp. 194-211.\} Géza Kuun, while translating \{into Hungarian\} the information that Gardīzi gives \{in Persian\} on the Turks in the Hungarian Fournal of Oriental Studies \{Keleti Szemle\}, also collects with it, in the form of additional notes to the text, the information that the Arab geographers give on them and thus, by compiling all this information, makes a simple attempt to describe this subject (\{"Gurdēzī a törökökröl,"\} Keleti Szemle, 2 (1901), 1-5; 3 (1902), 32-44, 81-94, 253-61; 4 (1903), 17-40, 129-41, 257-83; 5 (1904), 130-52). However, because it was not possible to compile properly the information given by all the Muslim and Chinese historians on this subject, this attempt comes across as rudimentary. This being said, these articles were not written, in fact, with this purpose in mind. Because it would take us very far from our subject and, indeed, require a separate study, I cannot give here a detailed description of the relationship of these different tribes to each other and their geographical areas. In any case, it should not be forgotten that in subsequent periods they moved to other locations.

14 Soghdia, which already constituted an Iranian satrapy between the Amu Darya and Syr Darya at the time of the Achaemenids, had its capital at Samarqand. The Arab geographers placed this region, which they named Sughd, between Bukhārā and Samarqand and included Samarqand within it. Indeed, Abū 'Abd Allāh al-Muqaddasī states that it had twelve cities, six in the north and six in the south (\{Yāqūt, \} Mújam al-buldān, vol. 5, p. 86). The Turks began to play an important role in this area around the middle of the sixth century CE. At that time or a little later, expanding their empire toward the west, they conquered the Hepthalites and then took control of Soghdia. This brought them into close contact with Iranian peoples and civilization (V. Thomsen, "Inscriptions de l'Orkhon \{déchiffrées\}," $\{$ Mémoires de 
la Société Finno-ougrienne,\} Helsinki, 5 [1896], p. 54). Campaigns against the Sughdaqs around the Iron Gate are mentioned in the Orkhon Inscriptions. In connection with this, Prof. Thomsen says, citing \{the sixth-century Byzantine historian\} Menander Protektor and J. De Guignes \{Histoire général des huns, des turcs, des mongols et des autres tartares occidentaux (Paris, 1756-8)\}, that this country had been subject to the Turks since the time of Mūqān Khān (ibid., p. 154, no. 38). As a result of recent research on the Soghdian language, we have learned that it was a dialect of old Persian. Al-Kāshgharī, however, not only indicates that the Sughdaqs, i.e. the Soghdians, knew both Turkish and Soghdian, but adds that the people of Balāsāghūn, Țarāz, and Sairām also spoke both languages (on Persian words found in Turkish, see n.20 below). The explanation that the same writer gives of the word Sughdaq clarifies this point somewhat. According to him, the Sughdaqs who had come to Balāsāghūn had, in fact, come from Soghdia - the area between Bukhārā and Samarqand; they dressed like the Turks and adopted their habits (\{Dīwān lughāt al-turk, $\}$ vol. 1, p. 391). Evidently a group of Soghdians migrated from Soghdia to the northeast, the region of TTarāz, Balāsāghūn, and Sairām, where, although mixing with the Turks and becoming Turkified, they were able to preserve their old language to some degree. It is likely that this partial migration occurred around the time that the armies of Islam arrived in Transoxiana - because the Tukiyu Turks, having previously passed through the Iron Gate to Soghdia and reaching as far as the Indus, had had close relations with the Soghdians for a long time ‘"Tukiyu" in Western books usually appears as T'u-chüeh, the Chinese designation for the Turk steppe empire of the sixth to eighth centuries. This is probably a transcription of Türk, though some think it stands for Türküt. Below in n.15, for example, Köprülü calls them the Göktürk, which is the usual designation for this empire in Turkey - but for now we can say nothing definite about this. As for the Ganjāks, who are also described as knowing Turkish and Soghdian, there is not much information on them in the Diwwān lughāt al-turk. We only learn that the Ganjāk dialect was predominant in the area around Kāshghar, but in the city itself Khāqāniyya Turkish was spoken (vol. 1, p. 31); and that the letter $h \bar{a}^{\prime}$ (ه)), which did not exist in Turkish, was found among the Ganjāks in some words that were not of Turkish origin (vol. 3, p. 85). On the Arghu, see the details given below.

15 It is not possible to give here detailed information from Chinese and Arab sources on these different branches of the Turks. Let me just briefly present the information that al-Kāshgharī gives on them and their languages and compare it with that in various Chinese and Arabic sources.

The branches given by al-Kāshgharī that were named the Chomul, Qay, Yabaqu, Basmil, and Tatar nomads and were situated on the eastern march of the Turkish area - namely, the Chomul between the Charuq and the Uighurs, and the other four tribes among the Yimak, Bashqird, and Qirghiz - were tribes, some of which were evidently not Turks but had become Turkish speaking as a result of mixing with the Turks, while others, who were Turks, had acquired a very peculiar dialect and had not completely lost it.

Yãqūt, citing al-Bīrūnī \{d. c.442/1050\}, indicates that the area of the Qay and Qun was to the east of the Qirghiz, Kimek, and Toquz Oghuz, thus approaching al-Kāshgharî̀s report (vol. 1, p. 31). Because nomadic tribes like these easily changed their location in those centuries, al-Kāshgharī's placement of the Qirghiz in a region to the east of them should be seen as natural. On the other hand, because there is no mention in his Dīwān lughät al-turk of the type of Turkish that they spoke, they apparently were not as important as the other branches of the Turks. Based on Muhammad 'Awfî's Jāmic al-hikāyāt, Prof. Marquart has asserted the likelihood that the Qayı were in fact Mongols who were later Turkified, but he also adds that Rashīd al-Dīn reports that the Qayı were at the head of the Oghuz tribes (the bibliographical article written 
by Dr F. Giese entitled "Kumanların kavmiyetine dâir" \{this is part 2 of Giese's review article "Türk elsine ve tarihine dâir bazı yeni alman neşriyatı" in Darülfuinûn Edebiyat Fakültesi Mecmuası, 1 [1332-4], pp. 290-3\}). However, the Qayı whom Rashīd al-Dīn considers to be among the Oghuz clans, i.e. the clan whom al-Kāshgharī calls the Qayığ, and these Qay are completely separate from each other. The Dīwān lughāt al-turk clearly shows this, but, on the other hand, it also confirms 'Awfi with respect to the suggestion that the Qay were in fact not Turks but had later been Turkified. \{Köprülü later did additional work on the Qay, see his "Osmanlı İmparatorluğunun etnik menşei mes'eleleri," Belleten, 7 (1943), 219-313, and "Kay kabilesi hakkında yeni notlar," Belleten, 8 (1944), 421-52.\}

The Turkified people whom al-Kāshgharī calls the Tatars are those whom the Chinese had called Tatars since the third/ninth century, so they are indeed Mongols (Thomsen citing Klaproth \{Asia polyglotta (Paris, 1831)\} and W. Schott \{"Älteste Nachrichten von Mongolen un Tataren," Philologische und historische Abhandlungen der König. Akademie der Wissenschaften zu Berlin, 1845, pp. 445-74\}, Inscriptions de l'Orkhon déchiffrées, p. 140). Al-Kāshgarī's statement in Dīwān lughāt al-turk about their having separate languages implies, however, that the Yabaqu, Chomul, and Basmil were also not originally Turks but were later Turkified like the Tatars and Qay, whom we strongly believe were of Mongol origin. The historical information that we have on these peoples does not, however, support this.

I believe that the Yabaqu in the Dīwān lughät al-turk were an Uighur tribe subject to the Göktürks and were the nomadic Turkish tribe mentioned by the Chinese as Pa-ye-ku and in the Kültigin inscriptions as the Yırbāyīrqu (Thomsen, Inscriptions, p. 109). If this is correct, we find them in the first half of the seventh century $\mathrm{CE}$ in the Yu-Tu-Kiyun $\{=$ Ötüken $\}$ mountains with the other Uighurs and as subjects of Hsienpi Kaghan. In $716 \mathrm{CE}$, the Göktürk ruler Mo-ch'o carried out a punitive operation against them and defeated them near the Tula river. On his return, however, a number of Pa-ye-ku took advantage of his carelessness while passing through a forest, captured and beheaded him. In short, all information obtained from Chinese sources indicates they were related to the Uighurs and lived in the same areas as the Uighurs (Thomsen, ibid., p. 72; Chavannes, Documents, pp. 88, 89, 91, 95). \{Al-Kāshgarî’s\} Dīwān lughāt al-turk also states that they were with the Uighurs who had not yet adopted Islam and, indeed, that in the fifth/eleventh century a force composed of 40,000 Muslim Basmıl Turks under the command of Ghāzī Arslan Tigin, and with the help of the Prophet, defeated a force of 700,000 Yabaqu under the command of Büke (Dīwān, vol. 3, p. 173). There is a long poem in the Dĩwān lughät al-turk about this event \{see Dankoff, "Three Turkic Verse Cycles Relating to Inner Asian Warfare," Harvard Ukranian Studies, 3-4 (1979-80), part 1, pp. 151-65\}. Although the nonMuslim nomadic Yabaqu were actually a Turkish tribe ethnically related to the Uighurs, it is clear that they spoke a dialect that was quite different from the Turkish of Kāshghar because their population was undoubtedly significant - even if we consider the size of the army that they fielded to be an exaggeration. Al-Kāshgharī also states that the famous Yamār river was a great river in the area of the Yabaqu (Dĩwān, vol. 3, p. 21), that the Yabaqu river rose in the Kāshghar mountains and flowed through Farghāna to Özjand (ibid., vol. 3, p. 27), and that there was a Turkish tribe called the Edhgish in Özjand (ibid., vol. 1, p. 89).

As for the Chomul, about whom al-Kāshgharī gives absolutely no information, they must be the tribe called Cho-mi/Tch'ou-mi in Chinese sources. During the time of the T'ang, this tribe lived on the banks of the Manas river west of Urumchi (Chavannes, Documents, p. 31).

The Basmil were the Turkish tribe whom the Chinese called the Pa-si-mi, as Thomsen originally proposed. According to Chinese sources, they had ethnic ties to 
the Turks and their chiefs were related to the A-shih-na family, as was the case with the Göktürks. They originally lived along the Hopog river in Tabargatay east of Choghujhaq (Tchougutchuk). In the second/eighth century, they migrated and occupied Beshbalıg. During this century, the Basmil sometimes acted in unison with the Western Göktürks and Uighurs. Other times, they suffered from their attacks, or they united with the Toquz Uighurs and Qarluqs and became involved in political activities by creating a confederation of eleven tribes (Thomsen, Inscriptions, pp. 76, 178; Chavannes, Documents, pp. 29, 86, 94). This information, which very clearly shows the ethnic relationship of the Basmil with the Qarluqs and T'u-chüeh, describes at the same time their political relations with the Uighurs. Al-Kāshgharî̀s account states that they were Muslims in the fifth/eleventh century, that they lived a nomadic life in a region near the non-Muslim Uighurs, Yabaqu, and Chomul, and that they fought with the Yabaqu. As for the question of their having a separate language like the others, we could attribute this to the nomadic Basmil having a dialect that was different from Kāshghar Turkish.

It appears, then, that the Qay and Tatars, who were originally Mongols and later were Turkified, as well as the Chomul, Yabaqu, and Basmil, who were true Turks, all spoke separate dialects in addition to Kāshghar Turkish, which had a firm hold on all the Eastern Turks in the fifth/eleventh century, and these dialects were rather different from it. It is not possible to interpret al-Kāshgharî̀s strange statement in any other way according to the form and degree of our current knowledge.

16 From this group, I see no need to go into great detail here on the Qirghiz, Qipchaqs, and Oghuz. Historical and linguistic information on the Qipchaqs and Oghuz will be given below to the extent that it concerns our subject. As for the Qirghiz, sufficient information can be found on them in almost all the Arab geographers and a summary of the information given by Chinese sources - based on the studies of such scholars as C. Visdelou \{Bibliothèque orientale ... (Maastricht, 1780)\}, Schott, Radloff, and Klaproth - is found in Thomsen's work (Inscriptions, p. 140). This people, who extended across an area stretching from the banks of the upper Yenisey south to the Tang-nu mountains, lived separately and independently of the Göktürks. Although they were defeated by the Uighurs shortly after the first half of the eighth century CE, they later became powerful and in 840 overthrew the Uighur Empire (ibid.). According to Istakhrī, the Qirghiz were surrounded by the Toquz Oghuz, Kimek, the "sea," Qarluqs, and the lands of the Oghuz. According to Gardīzī, the Toquz Oghuz were to the south of them and the Kimek were to the west of them. Yāqūt, however, shows them to the east of the Kimek and the Toquz Oghuz. (See \{Yāqūt, $\}$ Mújam al-buldān and \{M. J. de Goeje (ed.),\} Bibliotheca Geographorum Arabicorum \{Leiden, 1870-94\}). \{This material has been collected by Ramazan Şeşen, İslâm coğrafyacılarna göre Türkler ve Türk ülkeleri (Ankara, 1985).\} Muhammad 'Awfí states that the Kimek were north of the Qirghiz (northwest) and the Yaghma and Qarluqs were to their west (Marquart, "Über das Volkstum der Komanan," \{i.e. Chapter 2 of Osttürkische Dialekstudien, \} p. 39, text).

Al-Kāshgharī gives no information on the Ughraq, but they were probably the same as the Arghu just as the Soghdians were called Sughdaqs (for more information on the Arghu, see below n.33). Among the various Turkish tribes mentioned in a Syriac text written in $569 \mathrm{cE}$ are the Bulghars, Suwars, Avars, and Ughārs (Chavannes, Documents, p. 250). I believe that the latter were the Ughraqs. Based on his name, the famous Saif al-Dīn Ūghrāq, whom we see \{in Juvainī\} as one of the greatest commanders of Jalāl al-Dīn the Khwārazm-Shāh and the chief of the Khalaj and Turkmen, must have belonged to this tribe (Juvain̄i, Jahān-Gushā, vol. 2, p. 308).

As for the Charuq, they lived in the city of Bārjūq where, according to legend, Afrāsiyāb imprisoned Bīzhān (\{al-Kāshgarī,\} Dī̌ānn lughāt al-turk, vol. 1, p. 318). 
It appears that these branches, about whose dialects virtually no details are found in al-Kāshgharì's book, did not have great importance in the Turkish world, but they are clearly listed among the Eastern Turks, namely the Qarluqs, Chigil, Tokhs1, and Yaghma. Information on the Chigil, Tokhsı, and Yaghma Turks will be given below while discussing the Qarluqs.

17 Information on the Yimak is given below. Because al-Kāshgharī gives no more information on the Bashqirds, Bulghars, Suwars, and Pechenegs than that known to date by the scholarly world, I will not go into further detail on them. In his Dĩwann lughāt al-turk, he only mentions, in addition to these Pechenegs who resided near Rūm \{Anatolia\}, another group, the Bejaneks, who were an Oghuz tribe (vol. 1, p. 404). For the dialect of the original Pechenegs, see below.

18 Dīwān lughāt al-turk, vol. 1, pp. 29-31.

19 The details scattered throughout the Dìwān lughāt al-turk allow one to form a judgment on this matter. For example, while describing dialectical differences, the author says that words beginning with $y \bar{a}^{\prime}(\boldsymbol{s})$ among the Eastern Turks are changed to alif $(\mathbf{j})$ or $\bar{j} m(\boldsymbol{\tau})$ by the Oghuz and Qipchaqs; words beginning with $m \bar{\imath} m(\boldsymbol{p})$ among the Eastern Turks change to $b \bar{a}^{\prime}(ب)$ among the Oghuz, Qipchaqs, and Suwars; words beginning with $d \bar{a} l(\mathbf{S})$ change to $t \bar{a}^{\prime}(\mathbf{U})$; and the three-dot $f \bar{a}^{\prime}(\mathbf{S})$, which is called the $f \bar{a}-i$ türkiyye among the Eastern Turks and is pronounced between a $f \vec{a}^{\prime}$ and a $b \vec{a}^{\prime}$, is replaced by wāw ( ) among the Oghuz Turkmen (vol. 1, pp. 31-3, vol. 2, pp. 154, 253). The dialectal split is invariable in nouns of time and place and in verbal nouns. For instance, while the Khāqāniyya Turks, the Chigil, Yaghma, Tokhsı, Arghu, and Uighurs say Bargu yir (the place to go), the Oghuz, Qipchaqs, Pechenegs, and Bulghars say barast yir. In like manner, while these eastern branches say bu turgu yir irmas (this is not the place to stop), the western branches say bu turasi yir tigil (vol. 1, pp. 34-5; vol. 2, pp. 56-8). The same difference occurs in the names of instruments. Whereas the Khāqāniyya Turks say yıgaç biç̧gu nang (something to cut wood), the Oghuz say yngaç bicasi nang (vol. 2, p. 58). In addition, we know that the Oghuz and Qipchaqs deleted the ghain $(\dot{\varepsilon})$ from the middle of words - for example, while the other Turks say tamgak (palate), they use tamak, and in like manner they say baran instead of bargan (the one who goes) (vol. 1, p. 35). When al-Kāshgharī mentions various Turkish dialects, he not only describes their phonological characteristics, but sometimes also records certain lexical items that were of local significance; for instance, he reports that some words belonged only to the Chigil, or Arghu, or Qipchaqs. It is obvious, however, when his book is analyzed from beginning to end, that the primary subjects are Khāqāniyya Turkish and Oghuz, i.e. Eastern Turkish and Western Turkish. Among the terms given, there are many that were particular to the Oghuz or that were unknown to them and used by other Turks. Furthermore, al-Kāshgharī reports that because the Oghuz had mingled a lot with the Persians, they had forgotten many of their own words and had replaced them with Persian words (vol. 1, p. 73). A proverb from that period demonstrates, as much as any other historical document, that the Turks were then living cheek by jowl with the Persians: Tatsiz Türk bolmas / başsız börk bolmas \{No Turk without a Tat / no hat without a head\}. Here the Persians are meant by Tat. Nevertheless, al-Kāshgharī says that the Yaghma and Tokhsı Turks also called the unbelieving Uighurs Tat because they considered them to be foreigners (vol. 2, p. 225). Börk was the famous red conical hat $\{k \ddot{u l} l \hat{h}\}$ that we also find among the Anatolian Turks up to the tenth/sixteenth century. We also learn from the same source that the Oghuz used the word Sukak to allude to the Persians (vol. 2, p. 229).

20 Persian words were also found in the Turkish language before the coming of Islam. Not only does one encounter New Persian terms like dost and dushmān in the copy of the Oghuz legend \{but this is now believed to belong to the Mongol period!\} written in the Uighur alphabet (Radloff, Das Kudatku-Bilik), but one also finds words deriving 
from the Iranian Soghdian dialect in the Old Turkish works that have recently appeared in Eastern Turkistan (Thomsen, "Ein Blatt in türkischer 'Runen' Schrift aus Turfan," Sitzungsberichte der (Berliner, d.h.) Preussischen Akademie der Wissenschaften, 1910, \{pp. 296$306\}$ ). On this subject, see the studies by F. C. Andreas \{The Book of Mainyo-i-khard ... (Kiel, 1882)\}. According to al-Kāshgharī, the people of Balāsāghūn, Tarāz, and Sairām spoke both Soghdian and Turkish (Dĩwān, vol. 1, p. 31). In any case, the reason for the appearance of Persian words in these Old Turkish works is either because this group of people were Turkified Soghdians or - much less likely - they were Turks who had been under Soghdian influence (see n.14 of this chapter). There is no need to describe here the strong influence that Islam later had on the Turkish language. Al-Kāshgharī, in fact, by clearly specifying in his introduction to his Dĩwān that he recorded only pure Turkish words, acknowledges the adulteration of contemporary Turkish. One can also clearly deduce from al-Kāshgharî's work that the dialects of the Khāqāniyya Turks and of the still non-Muslim Uighurs were very similar. Barthold quite rightly attributes this influence \{i.e. the influence of the Uighurs on the Khāqāniyya Turks\} to the fact that the Turco-Muslim rulers who reigned in Kāshghar were more learned and civilized than the early Seljuk chiefs (Barthold, Turkestan, \{English trans., p. 311\}).

21 Dĩwān lughāt al-turk, vol. 1, p. 10. While discussing the Uighurs, al-Kāshgharī says, a bit obscurely: "Not only is their language pure Turkish, but they also have a separate language in which they converse among themselves and, as I explained at the beginning of the book, they have a script composed of twenty-four letters with which correspondence is written. In addition, the Uighurs and Chinese have another different writing system with which they write holy books and registers $\{$ dawāw $\bar{n}\}$, and only the infidels can read them" (vol. 1, p. 30 \{English trans. Dankoff and James Kelly, vol. 1, p. 83$\}$ ). What could be the separate language that these Uighurs, whose language was pure Turkish, spoke among themselves? Even if we consider the script that the Uighurs shared with the Chinese, in addition to their own, to be the Buddhist \{Chinese?\}, the problem of this "separate language" still needs to be resolved. In certain respects, we find very clear Islamic influence in this Eastern Turkish of the fifth/eleventh century. For example, while the word yalavac at first corresponded to \{the Arabic term rasül in the meaning of both "prophet" and "envoy," we know that under the influence of Islam, rasül was appropriated exclusively as the equivalent of "prophet," and yalavar appeared as the equivalent of "envoy" (vol. 2, p. 231). We also know that at that time the secretaries who wrote the Turkish correspondence of the sultans - this must be the Seljuk Sultans - with the Turkish \{i.e. Uighur\} script were called almma (vol. 1, p. 127) and that the pens used to write in the Turkish script were made from the $u c$ tree (vol. 1, p. 38). These almgas of the Oghuz were none other than the bakhshis of the Uighurs. (For general information on the writing system of the Uighurs and to learn the major sources on this subject, see my Türk edebiyat tarihi \{reprinted 1981, pp. 27-31\}).

22 Dīwān lughāt al-turk, vol. 1, pp. 7-9.

23 Al-Kāshgharī dubs Qarluqs "Turkmen" (ibid., vol. 1, p. 139; vol. 3, p. 259). We know very well, however, that the Turkmen were Oghuz (ibid., vol. 3, p. 304; \{Yāqūt, \} Mújam al-buldān, vol. 1, p. 41; an abundance of sources are unanimous on this point). Now, all the Arab geographers agree that the Qarluqs were distinct from the Oghuz; so how should one interpret al-Kāshgharî's statement? In my view, the reason for this discrepancy is very clear: the word "Turkmen" was a title - the etymology of which has not yet been determined for certain - that was given to the Oghuz, in particular after Islam. It is very likely that because al-Kāshghari used this vague expression to mean Muslim Turk, he also applied it to the Qarluqs who, along with the Oghuz, had adopted Islam. In fact, the information given in his work on the Qarluqs and their 
language clearly shows that they could not be considered Oghuz, i.e. Western Turks. Other sources corroborate this. There is one aspect of this matter that is especially noteworthy. While speaking at the beginning of his work about the regions to which the Turks spread and their dialects, al-Kāshgharī never mentions the name Qarluq; and in the area to which the other Arab geographers assign them, he indicates \{only\} the Chigil, Yaghma, and Tokhsi and especially that the Chigil were the most important among them. We learn from al-Kāshgharī's clear and explicit statement where the Chigil were found in the fifth/eleventh century. (1) The nomadic Chigil lived beyond Barsghān in Qayās - al-Kāshgharī gives three towns with that name, all of them belonging to the Tokhsı and Chigil (Dìwān lughāt al-turk, vol. 3, p. 129). (2) There was a Chigil fortress near Tarāz, which was in the country of the Arghu. The Chigil were found there. Indeed, all the Arab geographers mention this city. (3) There was also a place with this name around Kāshghar. Because the country of the Oghuz adjoined that of the Chigil, they were always at war. Traces of this old hostility were found even as late as the fifth/eleventh century. The Oghuz gave this title to all the Turks who dressed like the Chigil - because they had a distinctive dress - and so they considered, erroneously of course, all the Turkish territories stretching from the Amu Darya to upper China to be Chigil (ibid., vol. 1, pp. 329-30). We gather that the Chigil had their own particular dress - even their tall felt caps $\{b o ̈ r k\}$, i.e. their conical hats $\{k u ̈ l a \hat{h}\}$, were different from those of the other Turks (ibid., vol. 3, p. 132). We also gather from a number of al-Kāshgharîs's important descriptions of the Chigil dialect that it was Eastern Turkish - very close to the language of the Orkhon Inscriptions - and that it was extremely close to the Yaghma, Tokhs1, Arghu, and Uighur dialects. Thus, what al-Kāshgharī calls Khāqāniyya Turkish was the form of this dialect spoken in Kāshghar. In the Orkhon Inscriptions, there is the term İzgil. Thomsen considered this to be the name of an unknown people and quite rightly connected it to the term İçgil-İçgül, which Rashīd al-Dīn mentions as one of the ten rivers in the country of the Uighurs. İzgil is probably nothing but Chigil (Inscriptions de l'Orkhon, p. 160, no. 52). All of this linguistic and geographical evidence suggests that the Chigil were the largest and most important branch of the Qarluqs. It will be demonstrated below that Kāshghar Turkish was Qarluq Turkish, that the Qarluqs were ethnically related to the Göktürks, and that later, by seizing their summer pastures around the Chu and Talas rivers, they forced the Oghuz to withdraw to the northwest. When all of this is compared with the information that I have given about the Chigil, it seems indisputable that the Chigil were one of the most important branches of the Qarluqs. Nevertheless, in order to prove this decisively - and also the idea, weakly advanced below by Grenard and Grigor'ev, that it was the Qarluqs who established the Khānate of Kāshghar and that Kāshghar Turkish was Qarluq Turkish - let me cite the clear account of 'Awfì and Gardīzī (from Marquart's work, \{"Über das Volkstum der Komanen,"' p. 39):

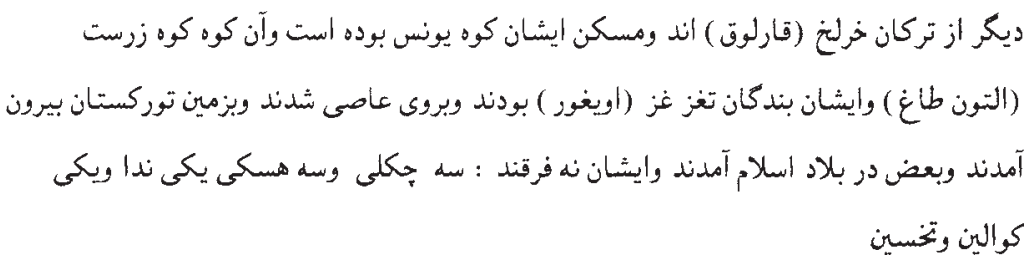

\{Another branch of the Turks are the Kharlukh (Qarluq). Their homeland was Jonah's mountain, which was Golden Mountain (Altun Tagh). They were slaves of the 
Toghuzghuz (Uighurs), against whom they rebelled. They emerged in the territory of Turkestan and the lands of Islam. They are nine groups: three Chigil, three Hsk(?), one Ndā(?), one Kwālīn(?), one Tukhsīn.\} This account, which shows that the Chigil constituted an important branch of the Qarluqs and that the Tokhs1 were also from the Qarluqs, definitely corroborates my assertion above and confirms the information that I will give below on the Qarluqs, which is cited from Thomsen and the studies of Chavannes and Visdelou. Gardīzì also says that all the Chigil were found on the road from Tumket (تش تشكت?) to Kümberket, that the area around Issik-Kul, which al-Kāshgharī also mentions under the name Lake Barsghān (Dīwān lughät al-turk, vol. 3, p. 99), was completely inhabited by the Chigil, that it was five parasangs from Issik-Kul to Tangkut and from there a three-day trip to Barsghān, and that along the way there were nothing but the tents of the Chigil (Kuun, "Gurdēzī,"\} sixth article $\{$ sic $\}$, Keleti Szemle, no. 4, 1902 \{part 6 is in 4 (1903)\}). These reports, which completely confirm the information given by al-Kāshgharī and the other Muslim geographers, tend to support and clarify my assertion.

24 Grenard, Turkestan, p. 48. It is readily apparent from the reports of Chinese historians that the Qarluqs, whom the Chinese called Ko-lo-lu, were in fact ethnically related to the Göktürks. They lived northwest of Pei-t'ing, i.e. Beshbalıg, and west of the Altun mountains. They were divided into three groups or clans. In $650 \mathrm{CE}$ or a little later, they acquired authority over a province of China and their chiefs - according to Chinese accounts - took the name Tu-tu, i.e. Tudun. The Qarluqs, who were surrounded by the Göktürks on the east and west, would tailor their movements according to the strength or weakness of the Göktürks. They slowly advanced toward the south and their chiefs took the name Shih-hu. The Qarluqs were brave and warlike. After $742 \mathrm{CE}$ they became subject to the Uighurs and migrated to the Ötüken mountains (Thomsen, who cites Visdelou, Inscriptions de l'Orkhon, p. 71, n.3. For more information, see Chavannes, Documents, pp. 85-6). The title se-kin that one comes across in Chinese sources is nothing but a form of the term sagun, which al-Kāshgharī says was given to high-ranking men of the Qarluqs (\{Dĩwän lughät al-turk, $\}$ vol. 1, p. 337). In his article on the famous city of Balāsāghūn, Barthold states that this word did not exist in the Turkish dialects $\left(E I^{l}\right.$, s.v. "Balāsāghūn," \{cf. EIr, s.v. "Balāsāgūn" (C. E. Bosworth)\}), but he is mistaken. Moreover, al-Kāshgharī records the term àtāsäghūn, meaning "physician."

25 Grenard, Turkestan, p. 94. Barthold also gives the same information based on Ibn Hawqal (EI', s.v. "Ghuzz"). In his article "Über das Volkstum der Komanen," Marquart writes that after the collapse of the state of the Western Turks, the summer pastures around the Chu and Talas rivers were seized by the Qarluqs; and the Western Turks, i.e. the Oghuz, being forced to withdraw toward the northwest, subsequently defeated the Pechenegs who lived at that time around the Aral Sea and in the valley of the Syr Darya (see Giese's bibliographical article "Kumanların kavmiyetine dâir" \{i.e. his "Türk elsine ve tarihine dâir bazı yeni alman neşriyatı"\}, p. 291).

26 Chavannes, in his valuable work on the Western Turks $\{$ Documents $\}$, basically accepts this idea, which was proposed by Grenard in his article "La légende de Satok Boghra Khân et l'histoire." According to Chavannes, it is very likely that those who succeeded the Western Turks and constituted the lineage of the Bughrā Khāns in Balāsāghūn were Qarluqs. But he adds, "Even if it is not correct to consider the Bughrā Khāns to have originated from the Uighurs, it should not be forgotten that the Qarluqs were very frequently included in the Uighur confederation. This confederation, which took the name 'the Eleven Tribes,' was composed of the Toquz Oghuz, Basmil, and also the Qarluqs. For this reason, one should not be surprised that the Kutadgu Bilig was written in Uighur. Because even if the Qarluqs were racially related to the Göktürks, they were politically bound to the Uighurs" (p. 86). It must be admitted that neither 
Grenard's assertion about the linguistic character of the Kutadgu Bilig nor Chavannes's objection to it is based on scientific evidence. However, the information that I have been setting forth here on the distribution of the various Turkish dialects in Central Asia during the fifth/eleventh and sixth/twelfth centuries and their closeness to each other supports only Grenard's assertion. The work of a Turk born in the city of Balāsāghūn, which was inhabited by the Qarluqs or the Arghu who were one of their branches, and written in Kāshghar, which was also inhabited by the Qarluqs, could certainly not have had any other linguistic character. It can be seen from the most superficial analysis of al-Kāshgharī's Dīwān lughāt al-turk that Kāshghar Turkish, which the author calls Khāqāniyya Turkish, is the same as the language of the Kutadgu Bilig. Some information is given below concerning the relationship of this Qarluq Turkish to the language of the Orkhon Inscriptions. At the same time, it should not be forgotten that this Khāqāniyya Turkish was close to Uighur Turkish and that both fall within the sphere of Eastern Turkish.

27 In an important article entitled "Sur le système des consonnes dans la langue ouïgoure," \{Keleti Szemle, 2 (1901), 241-59\} Thomsen, while giving a very important criticism of the way in which Radloff read the Kutadgu Bilig, carefully noted that the language of the Orkhon Inscriptions was extremely close to that of the Kutadgu Bilig and, as a result of this study, categorically established that the vocalic \{rather, consonantal\} system in the Kutadgu Bilig and in the Orkhon Inscriptions were, with almost no exceptions, identical ("Sur le système," pp. 244-7). Radloff also accepted this close relationship between the old Göktürk inscriptions and the Kutadgu Bilig.

Additionally, there is a point of morphology that is common to the language of these inscriptions, the Kutadgu Bilig, the old Kuman dialect, and the old Seljuk-Ottoman (i.e. Oghuz) dialect, which, although it has attracted great attention from European scholars who have specialized in Turkish linguistics and has been studied and explained quite well, also needs to be supplemented with the information provided by \{al-Kāshgharī's\} Dīwān lughät al-turk. Focusing his attention on words in the Orkhon Inscriptions that end in -daci/-deci, e.g. boldact, Thomsen asserted, in opposition to Radloff, that this form is found in the poem of Yūsuf and Zulaikhā published by Houtsma (\{"Ein alttürkisches Gedicht: (eine vorislamische Bearbeitung des biblischen Romans von Joseph und Zulaika; aus der Dresdner Handschrift herausgegeben und überstetzt),"' $Z D M G, 43$ [1889], p. 74), in a glossary published in 1894 in Leiden by the same author (Ein türkisch-arabisches Glossar, p. 42) and in the Codex Cumanicus (ed. Kuun \{Budapest, 1880; reprinted Budapest, 1981\} p. 104) and that, as far as the tense usage was concerned, it expressed the future (Inscriptions de l'Orkhon, pp. 162-3). However, words in this form also exist in the Kutadgu Bilig, as Thúry ("Ondördüncü 'asır sonlarına kadar Türk dili yâdıgârları," p. 94) and then Brockelmann ('Ali's Qissa'i Jusuf, no. 51, p. 33) have previously reported. According to al-Kāshgharī, among the Eastern Turks, i.e. apart from the Oghuz and Qipchaqs, active participles are in the form közetküci/"one who watches, guard," bititküci/"one who writes, scribe," sufgurgucil "one who waters," yükünküci/"one who prostrates." Among the Oghuz and Qipchaqs, i.e. the Western Turks, the corresponding words are: gözetici from the assimilation of közettaci, bititdaci, sufgurdaci, yükündaci (\{Dīwān lughāt al-turk, $\}$ vol. 2, pp. 131, 203, 239, 256; vol. 3, p. 232). We also clearly understand that this form, which, according to al-Kāshgharī, was unique to the Western Turks, expressed the future, as Houtsma and Thomsen have asserted. For example, öldaci sicgan meant "the mouse that is going to die" (ibid., vol. 1, p. 366). Based on its frequent appearance in eighth/fourteenthcentury Ottoman texts, this form clearly belongs to the Oghuz, i.e. the Western Turks, as al-Kāshgharī reported; thus it is worthy of study with respect to linguistic history, given its presence in the Orhon Inscriptions, and then in the Kutadgu Bilig, in the Kuman language, and in the 'Atabat al-haqa' 'iq, which I very strongly suspect 
exhibits linguistic characteristics dating before the Mongol invasion (Necib Âsm (ed.), part 1, 1334, p. 103 the reference is to Adīb Aḥmad b. Maḥmūd Yüknekī, Hibetül'-hakâyı (Istanbul, 1334/1918); this edition was superceded by R. R. Arat (ed.), Atebetü'l-hakaylk (Istanbul, 1951)\}). I know of no examples of this form in later works from Central Asia, i.e. works created after the linguistic changes that occurred subsequent to the Mongol invasion. It is quite surprising that despite the very clear statement of al-Kāshgharī, who was well aware of the characteristics of the Turkish dialects, this form occurs in works in early Eastern Turkish. For its existence in Qipchaq Turkish as well, see Abū Hayyān \{al-Gharnāțī's\} Kitāab al-idrāk \{li-lisān al-atrāk (Istanbul, 1309/1893)\}, pp. 135-6, 188 \{new ed. A. Melek Özyetgin as Eb̂̂ Hayyân, Kitâbu'l-İdrâk li Lisâni'-Etrâk (Ankara, 2001)\}.

28 In various places in his work, al-Kāshgharī clearly indicates the locations and cities of the Oghuz in the fifth/eleventh century. While discussing the word öküz \{i.e. ögüz\}, for example, he states that this word, which generally means "river," among the Oghuz specifically referred to the Syr Darya, which was also given the name Banākat; and that the cities of the Oghuz were along this river, and the Oghuz nomads lived along its banks as well (\{Dīwān lughät al-turk, $\}$ vol. 1, p. 58). Ibn Hawqal also indicates that the Oghuz centers were primarily along the lower course of the Syr Darya (\{al-Masālik wa 'l-mamālik, ed. de Goeje (Leiden, 1873),\} p. 393 \{superseded by J. H. Kramer's edn (Leiden, 1938-9)\}). According to Ibn al-Athīr, these Oghuz had separated from the Tokuz-guz, i.e. the Uighurs, during the caliphate of al-Mahdi (158-69/774-85) (al-Kämil, vol. 2, p. 117). The Dĩwān lughāt al-turk also informs us of the primary Oghuz cities. (1) Sabrān. The author writes that this was the original name of this city, which was usually called Șabrān, because there was no ص in Turkish (vol. 1, p. 364). This city, which Yāqūt in his entry on Isfijāab places in the vicinity of Țarāz, Sānīkath, and Fārāb (Yāngīkend), and which he also describes in the entry on Sabrān as being the Oghuz capital on the Syr Darya and having a fortress (Mújam al-buldān, vol. 1, p. 230, vol. 5, p. 336), was the city of Savrān near Yasī, which I discussed above (Chapter 2, p. 27). (2) Sütkent (vol. 1, p. 369). It would be natural for this city to be in the same region, although this is not specified. (3) Sughnaq (vol. 1, p. 392). This city was Sığnak, which later became the capital of the White Horde (for more details, see Howorth, History of the Mongols) $\left\{E I^{2}\right.$, s.v. "Sighnāke" (C. E. Bosworth)\}. (4) Qarnaq (vol. 1, p. 393). There is no information on it apart from being an Oghuz city. (5) Qarajuq. Al-Kāshgharī gives the following description of it اسم الفاراب وهى أسم بلاد الغزية (it is the name of al-Fārāb, which is the name of the country of the Oghuz\} (vol. 1, p. 304). We have seen above in one of the legends about Aḥmad Yasawī how he made Qaraj(ch)uq Mountain disappear miraculously (Chapter 2, pp. 21-2). We find Qarajuk Mountain, which was in the vicinity of this Oghuz city, whose name also appears frequently in the Dede Korkut, within the Oghuz region in the map in the Dīwān lughāt al-turk. There is much information on Fārāb (Otrar), which was far from Tashkent and close to Balāsāghūn, in Mu'jam al-buldān (vol. 6, p. 322) and Barthold (see $E I^{I}$, s.v. "Fārāb" \{cf. EI $I^{2}$, s.v. "Fārāb" (Barthold[B. Spuler] \}). As for the famous city called Tālās or Țarāz, al-Kāshgharī records two Ṭarāz in his book, one Ūlūgh-Tālās and the other Kiji-Tālās \{Kümi-Tālās in the first edn of Early Mystics, which is correct\} on the Islamic frontier (\{Dīwān lughät al-turk,\} vol. 1, p. 306), but he does not specify whether it is an Oghuz city. However, when defining the lands of the Arghu Turks, he says that they extended "from Tarāz to Balāsāghūn," so it appears that Țarāz was not an Oghuz city (ibid., vol. 1, p. 114). We also learn from the same work the names of a few other towns near Tarāz. One was a fortress named Qarghaligh (ibid., vol. 1, p. 433), another was the town of Yaghma, which belonged to the Qara-Yagma Turks (ibid., vol. 3, p. 26), a third was Gencak Singir on the Qipchaq border (ibid., vol. 1, p. 399), and a fourth was the town of Atluq 
(ibid., vol. 1, p. 90). I have given sufficient information on Țarāz above (Chapter 3, p. 72, n.6). For more information on old Țarāz and Awliyā Ata, which Howorth claims occupies its site, see Reclus, Nouvelle géographie universelle, vol. on Russian Asia, pp. 557-8. Although Barthold, like Howorth, asserts that old Tarāz is present-day Awliyā Ata ( $E I^{I}$, s.v. "Balāsāghūn"), Chavannes categorically rejects this and says that it must be five parasangs to the south of Awliyā Ata (Documents, p. 304). \{See EI ${ }^{2}$, s.v. "Awliyā Ata (Barthold-[B. Spuler]), and "Ṭarāz" (C. E. Bosworth).\}

29 Al-Kāshgharī says the Kimek/Yimak were Q1fchaqs, but the Q1fchaqs distinguished themselves from the Yimak by this name. His account conforms to those of the Arab geographers Ibn Hawqal (\{al-Masālik, \} p. 11) and Ișțakhrī (\{Masālik al-mamālik, ed. de Goeje (Leiden, 1870; reprinted Leiden, 1927), \} p. 222) in making the Q1fchaqs a branch of the Yimak, for it explains how these two branches were related to each other (Dīwān lughāt al-turk, vol. 3, p. 22). Furthermore, Iștakhrī says that the upper course of the Volga formed a natural border between the Oghuz and Yimak (Masälik). At the same time, al-Muqaddasī, while providing details on the seven fortresses of Savrān (Sabrān), which I indicated in n.28 above based on Dīwān lughāt al-turk was an Oghuz city, and on its other features, also says that this formed a border between the Oghuz and the Kimek (\{Ahsan al-taquāsìm fì márifat al-aqālt̄m, ed. de Goeje, 2nd edn (Leiden, 1906),\} p. 274 \{English trans. Basil Anthony Collins as The Best Divisions for Knowledge of the Regions (Reading, UK, 2001), p. 226\}). In addition, the author \{Ibn al-Faqīh al-Hamadān̄i $\}$ of Kitāb al-buldān \{ed. de Goeje (Leiden, 1885)\}, while enumerating the branches of the Turks in the entry on Shāsh (Tashkent) \{p. 329\}, lists the most important branches as the Qarluqs, Tokuz-guz, Türgish, Kimek, and Oghuz ( $\{D \bar{\imath} w \bar{a} n$ lughāt al-turk,\} vol. 2, p. 394). The Qipchaq dialect, which al-Kāshgharī considered to be closely related to the Oghuz dialect, was the same as the Kimek dialect. Indeed, we can consider these two names to be virtually synonymous despite any apparent difference between them.

30 According to the Arab geographers, this peninsula had not been previously inhabited. The Oghuz who were separated from their comrades went there and settled (Isțakhrī, \{Masālik,\} p. 219). Al-Kāshgharī in fact records that Mangishlak was "a place name in the Oghuz country" (\{Dīwān lughät al-turk, $\}$ vol. 1, p. 387, vol. 3, p. 118). \{See $E I^{2}$, s.v. "Mangishlak" (Yu. Bregel).\}

31 See the details given by Barthold in $E I^{l}$, s.v. "Ghuzz."

32 Isfijāb is a very old Turkish city. During his journey, Hieuen-Thsang stopped in this city, "which was 200 li" southwest of Tālās (Tarāz) and which the Chinese called Pe-choei and the Turks called Aksu. Although its exact location is not given, it appears that it was a bit southeast of Chimkent. In 642 CE Tūlū Khāqān took refuge in this city, where he was attacked by the Nu-shih-pi. According to Chavannes, this was the place the Arabs called Ispījāb \{sic, rather Isbījāab\} (Documents, p. 195). According to the Arab geographers and \{al-Kāshgharī's\} Dīwān lughāt al-turk, Ispījāb $\{$ sic $\}$ and Madīnat al-Baiḍā', i.e. Sairām, are the same city, but Chavannes claims that present-day Sairām is the city the Chinese called Kiu-p'i-lo (Documents, p. 8). Nevertheless, I believe, based on the Arab geographers, that this is a mistaken opinion. This region, which originally belonged to the T'u-chüeh Turks, was seized by the Qarluqs after their collapse, as I explained above, and very quickly entered the realm of Islam.

33 Dīwān lughät al-turk, vol. 1, p. 31. Nevertheless, the same author also shows the lands between Țarāz and Balāsāghūn as the country of the Arghu (vol. 1, p. 114). In his Dīwān lughāt al-turk, a city of Qabus (vol. 1, p. 308) and a city of Belu (vol. 3, p. 176), the locations of which are not specified, are shown as Arghu locations. This second city appears in the works of the Arab geographers as Balu/Bahlu and is described as a city that was a distance of a half parasang from the town of Chigil and was larger than the town of Barsgan to the left of it (Kuun, "Gurdēzî," citing al-Muqaddasī). 
These descriptions show that the Arghu area began at Ṭarāz. Considering that Tarāz/ Tālās was not an Oghuz city, and that it shared a border with the Chigil on one side and the Arghu on the other, it is clear that the Arghu must be considered, like the Chigil, to be among the Eastern Turks. While enumerating the primary Turkish tribes at the beginning of his work, al-Kāshgharī does not mention the Arghu, but later he provides considerable information on their geographical area and the characteristics of their dialect. In the same passage, al-Kāshgharī does not mention, for example, the Qarluqs, who were a great and very well known Turkish people, under this general name, but he lists the Chigil and Tokhs1, who were Qarluq tribes. Perhaps the Arghu were the same as the Ughraq \{see above, n.16\}; or else Ughraq may be the general name for the Charuq and the Chomul. Whichever of these two hypotheses may be correct, we must still inquire whether the Arghu included the Qarluqs, or were they a separate Turkish tribe? The geographical area that al-Kāshgharī indicates as belonging to the Arghu matches that assigned to the Ughraq. Although the information at hand is still not sufficient to allow us to say anything definite on this matter, we consider the Arghu, like the Chigil, Yaghma, and Tokhs1, among the Qarluqs. The information that I will give below on the Arghu dialect will suffice to prove that it was an Eastern dialect, probably very close to the language of the Khāqāniyya Turks.

34 Dĩwān lughāt al-turk, vol. 1, p. 31. On this question, see n.14 of this chapter. Balāsāghūn, which al-Kāshgharī mentions as Qoz \{i.e. Quz\}-ülüş (vol. 1, p. 60), or as the Mongols called it Gubalıg, i.e. "beautiful city" (\{Khwāndamīr, $\}$ Habīb al-siyar, see the section on the Qara Khițāy), was like other cities in that region destroyed in the innumerable struggles for power in the eighth/fourteenth century. Consequently, nothing is heard of it during the events of the reign of Tīmūr (see Barthold, EI $I^{l}$, s.v. "Balāsāghūn"). [Zeki Velidi Togan also confirms that this city had lost its importance before Tīmūr, $\dot{I} A$, s.v. "Balasagun."] Barthold indicates its location as that of present-day Awliyā Ata, i.e. northeast of old Ṭarāz. A Persian couplet also corroborates this (Habîb Efendi, Düstûr-i Suhan \{Istanbul, 1309/1891-2\}, p. 126):
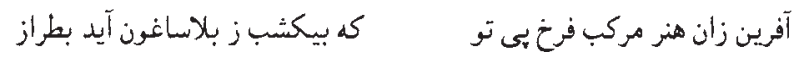

\{Bravo! For the skill of that fortunate-footed donkey of yours, which in a single night can go from Balāsāgūn to Tarāz.\} The German Orientalist Marquart claims that Gubalıg was Guzbalı, which meant "Oghuz city," but this should probably be accepted with caution. Even if the Oghuz had previously been in that region, and therefore in Balāsāghūn, it is \{still\} true that the Arghu, whom we consider a branch of the Qarluqs, occupied their territory in the fifth/eleventh century. Nizām al-Mulk states that he \{i.e. the Sāmānid ruler Nașr II b. Ahmmad (301-31/914-43)\} was considering war against the non-Muslim Turks who had captured Balāsāghūn around 330-1/941-2, which tells us that this city was regarded as being within the sphere of Islamic influence at that time (Siyāsatnāme, Schefer edn, p. 189 and Barthold who cites it \{see Darke trans., p. 215; Barthold, Turkestan, p. 243\}). However, a little later these Turks became firmly converted to Islam, and the Ilek-Khāns \{Qarakhānids\} who appeared from among them subsequently invaded and conquered Transoxiana. The first Muslim ruler from this family was 'Abd al-Karīm Sātūq Bughrā Khān (d. 334/945-6), whose legends are still famous in Central Asia. The Turks whom Ibn al-Athīr reported during the events of 349/960-1 as being a people of 200,000 tents who had adopted Islam (\{al-Kāmil $\}$ vol. 8, p. 176) were, according to the most likely probability, these Qarluq Turks (see above pp. 132ff. \{of narrative\}). Furthermore, Ibn al-Athīr writes that a Turkish tribe that had accepted Islam in Șafar 435/ 
September-October 1043 had its summer pastures around the city of Balāsāghūn, and the Bulghar Turks had their winter pastures in that area (ibid., vol. 9, p. 179); it is probable that that tribe was also a branch of the Qarluqs, namely the Arghu or Basmil. In 524-5/1130, i.e. in the first quarter of the sixth/twelfth century, when Balāsāghūn passed into the hands of the pagan Qara Khițāy, we again find the Qarluqs and Qanglı in that region (Juvainī, Jahān-Gushā, vol. 2, p. 87).

35 Because the Oghuz had a common border with the Arghu, they adopted quite a few words from them. For example, taking dag-ol from the Arghu, they transformed it into tekil/degül, "not" (\{al-Kāshgharī, Dīwān lughāt al-turk, \} vol. 1, p. 329, vol. 3, p. 114), and in like manner adopted other words from them (vol. 1, p. 316). It appears from al-Kāshgharī's account that the Arghu themselves made some linguistic borrowings from the Persians (vol. 1, p. 360). In addition, the Arghu had numerous words in common with the Yaghma and Qarluqs and at the same time with the populace of the city of Uch and the Bulghar Turks. The descriptions of the Arghu dialect given in various places in the Dĩwān lughāt al-turk definitely indicate that it was an Eastern dialect that was very close to that of the Qarluqs, i.e. to Khāqāniyya Turkish.

36 \{See Peter Golden, "The Migrations of the Oğuz," Archivum Ottomanicum, 4 (1972), $45-84$.

37 It is noteworthy that Köprülü can disallow the Dīwān-i Hikmat as a work with any value for linguistic history because of the long history of copying and recopying that he assumes to have occurred, yet he cannot imagine that this same long history could have rendered this work anything less than a key source on Ahmad Yasawîs literary personality, Șūfì thought, etc.\}

38 Vambéry, Cagataische Sprachstudien \{there is no such statement in this work as cited below in this note; cf. his article "Muhammadanism (in Central Asia)," in Encyclopaedia of Religion and Ethics (New York, 1908-26), vol. 8, p. 887\}; Thúry, "Ondördüncü 'asır sonlarına kadar Türk dili yâdıgârları." Vambéry says that this work, which had great influence among the nomads, was widely read and was in the Khokand dialect even though it was poorly understood because it incorporated foreign - i.e. Arabic and Persian - words and phrases. Thúry also concludes that "According to the sections that have been published, one could definitely assert that the language of this work is in the dialect spoken in the Khānate of Khokand," \{p. 98\}.

39 Thúry, ibid.; Togan, Türk-Tatar tarihi. The scholarly meanings of the terms "Uighur" and "Chaghatay" \{as designations for languages\} are not crystal clear even today. Their sense is vague. Because research on Turkish linguistic and literary history is still at a very preliminary stage, it is easy for anyone to use these terms at random and taking advantage of their vagueness - give them whatever meaning he likes.

Books that have been written up to now in the Uighur alphabet, like \{Yūsuf Khāṣs Hājib's\} Kutadgu Bilig, \{the anonymous\} Mi'rājnāme, \{the translation of 'Atțār's\} Tadhkirat al-awliy $\bar{a}$, and the translation of \{Niz̄āmī Ganjawī's\} Makhzan al-asrār, were considered to be "Uighur" simply because the Uighur alphabet was used. The Russian Orientalist I. Berezin, for instance, in a short treatise that he published seventy years ago on the classification of the various Turkish dialects, puts forth this observation on Uighur: "This dialect no longer exists. We know it thanks to manuscripts like those of \{the anonymous\} Bakhtiyärnāme, Mi'räjnāme, and Tadhkirat al-awliy $\bar{a}^{\prime}$ - the texts of these works in the old Uighur alphabet, the forms in which they were copied and their English translations are found in Arthur Lumley Davids's A Grammar of the Turkish Language (London, 1832) - the Kutadgu Bilig (published by the Orientalist \{Amédée\} Jaubert \{rather, he was the first to bring it to the attention of the scholarly world and to translate a section of it in his 'Notice d'un manuscrit turc, en charactères ouigours, envoyé par M. de Hammer à M. Abel-Rémusat,' JA, 6 (1825), 39-52, 78-95; see $\dot{I} A$, s.v. 'Kutadgu Bilig' (R. Rahmeti Arat)\}), the Uighur-Chinese dictionary published by 
Klaproth, and Toktamish's edict to Jagiello published with Russian translation by Qāsim Bey. This dialect had a distinct script and literature. According to these works that I have studied, Uighur is the origin of Chaghatay. Not only are the basic writing systems of both dialects similar, but they also both contain certain forms that are not found in others" (Berezin, Recherches sur les dialectes musulmans [Kazan, 1848]). This mistaken and simplistic view is naturally also found in Davids's Grammar (French trans. Sarah Davids, Grammaire turke [London, 1836]). Léon Cahun, even though he came on the scene a half century after these researchers, still followed this old erroneous view and believed that works like the Bakhtiyārnāme, Mi'räjnāme, and Tadhkirat al-awliya $\bar{a}^{\prime}$ were written in the Uighur dialect (E. Lavisse and A. Rambaud, \{Histoire général du $I V^{e}$ siècle à nos jours (Paris, 1893-1901), \} vol. 3 \{Formation des grands états, 1270-1491, \} p. 967 - Introduction à l'histoire de l'Asie, p. 508). Because these various works, which were copied in the tenth/sixteenth century, are also found in manuscripts written in Arabic script, I see no need to expound on the superficial error of this approach.

Scholars who have done somewhat more research on the Turkish language understand this error and realize the necessity of turning to history and linguistic history for information on this subject. Vambéry and Radloff, on the basis of such observations, thus consider the Kutadgu Bilig to be an Uighur work - because it was written in Eastern Turkistan, which was inhabited by Uighurs, and because it has certain linguistic characteristics different from later Central Asian works (see the introduction to Radloff's edition of the Kutadgu Bilig). Agreeing with them, Thúry and many others have also applied the name Uighur to the linguistic products from the area of Eastern Turkistan. The information that I have given above, however, on the number of Turkish dialects in the fifth/eleventh and sixth/twelfth centuries and their relationship to each other and their geographical areas, shows clearly that those who lived in the city of Balāsāghūn, where the author \{Yūsuf Khāṣs Hājib\} of the Kutadgu Bilig was born, and Kāshghar were not Uighurs but Qarluqs, whom al-Kāshgharī calls Khāqāniyya Turks. Indeed, the author of the Kutadgu Bilig specifically states that his work was not in Uighur but in Turkish. That Turkish was the Eastern dialect, which al-Kāshgharī calls "Turkish," without qualification, or "Khāqāniyya Turkish." With respect to its general linguistic features, the Dīwann-i Hikmat was also written in this dialect.

As for "Chaghatay," the banner term for the literary language of Central Asia, it derives from the name of Chingiz Khān's son Chaghatay, who ruled that region at one time, and was applied to the Turkish language of Central Asia. Thus, Central Asian and to some degree Qipchaq works, which have been written under the influence of Islamic civilization since the eighth/fourteenth century, can be subsumed under this name. Describing both the ethnographic and linguistic consequences of the Mongol invasion on the entire Turkish world is a separate and important subject requiring more lengthy research than can be presented here in even a brief outline (for details, see my article "Chagatay edebiyatı"). The simplest and most accurate definition of this Chaghatay - which includes the works of all Central Asian poets and writers, beginning with the Qișas al-anbiy $\vec{a}^{\prime}$ of Rabghūzī (which includes a number of linguistic features reminiscent of the language of the Kutadgu Bilig that are not found in Chaghatay works from subsequent periods) and even comprising the followers of Nawầ $\overline{1}-$ is as follows: "It is the Eastern Turkish literary dialect that was established under the influence of Islamic civilization after the Mongol invasion." The linguistic and historical analyses given above suffice to prove that the Dīwan-i Hikmat - not the current copy but the original version that would have displayed the linguistic characteristics of the time and milieu in which it was written - could by no means be included in this linguistic domain. \{In this note Köprülü claims to know the Dǐwān-i Hikmat's general linguistic features without having access to early manuscripts and with the acknowledgment 
that existing manuscripts are just in Chaghatay. The note culminates with his "proof" that the phantom Dĩwan-i Hikmat should not be considered a Chaghatay work.\}

40 "Der čaghataische Diwan Huwedas herausgegeben und übersetzt von M. Hartmann," in\} Berlin Universität, Seminar für Orientalische Sprachen, Mitteilungen, \{Westasiatische Studien\}, 5 (1902), p. 133. The author \{Kouznietsov\} of the Russian work entitled La Lutte des civilizations et des langues dans l'asie centrale is also among those who consider Ahmad Yasawī to be a Chaghatay poet (p. 76).

41 \{Here Köprülü's analysis becomes extremely convoluted, highlighting the untested (and untestable) assumptions that shaped his discussion of the Dīwān-i Hikmat. First he criticizes those, quite rightly, who declared the language of this work to be Chaghatay, and especially those who found its language to be quite similar to the version of Chaghatay known from ninetenth-century Qoqand. Then he insists that, failing the appearance of an old copy of the Dĩwan-i Hikmat, the way to study its language is to study the literary and lingustic milieu in which (he is sure, but without any real justification) Ahmad Yasawī lived and wrote. Finally, he admits that all known copies of the Diwañ-i Hikmat do reflect Chaghatay, but that this means nothing. In other words, the imaginary early copies of a work, and the linguistic features of other works written in the time and place we imagine the work's author to have lived, are better sources on the work's inguistic features (but not on its literary or intellectual features) than existing copies of the work!\}

42 I believe that even before the Kutadgu Bilig an attempt was made to adapt the 'arūd system to Turkish and that some works were produced in this meter, and that, especially after the Kutadgu Bilig, many Turkish works were written in those regions in imitation of the Persians. \{Ahmad b. Mahmūd's\} 'Atabat al-haqä'iq provides some idea on this matter. However, while these works, which used the 'arü $d$ meter in imitation of Persian works, were dedicated to various rulers - i.e. were written in a court milieu, naturally subject to strong Muslim Iranian influence - the fact that works that directly addressed the great mass of the people, such as the Dĩwann-i Hikmat, were faithful to popular taste and understanding should not be regarded as a coincidence. We can only explain this important phenomenon in the history of our literature by the influence of this milieu. It was possible to exhibit great skill and excellence in the Turkish palaces, which were full of men of state and scholars who knew Persian literature very well and had received a classical \{Islamic\} education, by writing in Persian, or at least by writing things that were comparable to what the Persians wrote. Whether or not the people understood such things, whether or not they considered them suitable to their own taste, was of absolutely no importance to the poet who only expected to be appreciated and rewarded by the ruler and palace officials. In contrast, the highly spiritual, idealistic Șūfîs, such as Ahmad Yasawī, who labored for the satisfaction of God and did not expect any reward from rulers and men of state, and who were trying to convey religious and mystical truths to the people, considered it their primary duty to conform to popular taste and sensibility. We can clearly and definitely see this state of affairs in virtually every period of Turkish literature. The Sūfìs sang not for the purpose of displaying their art to prominent figures and earning material rewards, but in a state of ecstasy and animated by the ideal of inspiring others with the sacred feelings overflowing from their souls and quenching \{other\} thirsty souls from the sublime springs of divinity. We should not forget how important this factor was in making them - the Șūfìs - a much better representative of the national taste than any other group.

43 Although no research has yet been done on the history of the development of the Turkish language, I can try to explain the reasons for this in general outline. First, because he took his subjects wholly from the realms of religion and mysticism, Ahmad Yasawī had to use their specific and established terminology. In general, the Turks 
were only able to extract the new concepts pertaining to sacred law and mysticism of a religion they had newly adopted from the language of the Koran \{i.e. Arabic\} and also from the works of Persian scholars, who had appropriated those concepts via Arabic. Second, loanwords from Arabic and Persian had gradually increased among the Turks after they entered the milieu of Islam and the people had become somewhat accustomed to them. Thus, even Ahmad Yasawī, taking this into consideration, was not reluctant to use words from foreign languages while addressing the mass of the people. I have shown above - based on \{al-Kāshgharī's\} Dīwān lughāt al-turk - that even in the fifth/eleventh century a number of Arabic and Persian words had entered the language of both the Eastern and Western Turks, i.e. of both the Qarluqs and Oghuz.

44 The most commonly used meters in the Dīwän-i Hikmat are seven-syllable and twelvesyllable. The oldest examples of Turkish folk literature that have come down to us were also, for the most part, written in these meters. Indeed, in these early works, the caesuras of the twelves are usually in the form $4+4+4$. In this respect too the passages in twelves in the Diwwan-i Hikmat conform to the folk literary tradition. As for rhyme, the views that I have advanced in another work concerning rhyme in the oldest examples of our folk literature can be applied to the Dīwann-i Hikmat: "The rules of rhyme that our earliest poetry followed were, naturally, of a simple and primitive character. Instead of 'rhyme' in the modern sense, it would be more accurate to call them half rhyme (assonance), because rhyme in our early poetry does not consist of the syllables at the end of the verses having the identical sound. This poetry is far from being constricted by such a narrow rule. For the existence of rhyme there suffices to be a minimal similarity in sound among the final syllables. Rhymes can be formed by a partial resemblance in sound, such as deşildi/koşuldu, kuşlatmak/dişletmek/taşlatmak. Sometimes radîf is found along with rhyme, i.e. the last element is fixed and the rhyme pertains to the elements preceding it. Sometimes - to be sure as a random effect - one also comes across passages that rhyme according to the modern view. In any case, we find this old view of rhyme flourishing in some of the folk poetry that we can consider to be a continuation of our ancient pre-Islamic folk literature. The poets of this early period usually achieved half rhymes very easily from inflections of the verb" (Türk edebiyat tarihi, Chapter 4, "İlk şiirler ve ilk şâirler"). In some of the quatrains in the Dĩwān-i Hikmat, the fourth verse sometimes falls one syllable short. We also find this feature in our earliest popular poetry.

45 The following information, which I have given in another work on the forms of versification used in our earliest folk poetry, fully applies to Khwāja Aḥmad Yasawī’s hikmats: "The sagus, or elegies, composed about great heroes, consist of four-verse stanzas or quatrains, each verse of which has seven or eight syllables. Sometimes the four verses of the first quatrain all rhyme together, sometimes all but the third verse rhyme. The first three verses of the subsequent quatrains rhyme among themselves, with a different rhyme from the other quatrains. But all of the quatrains are linked together because they have the same rhyme in the fourth verse. These sagus, which undoubtedly represented a rich and most valuable form of our early Turkish folk poetry, were generally long. In the early forms of Turkish poetry, two major points are worthy of note. First, the forms are few in number and well defined. This is because it was not possible for the literary personalities to develop freely in these early periods, and every poet had to respect the existing forms as virtually sacred. Second, in the quatrains constituting elegies, the fourth verse always rhymes. This indicates that the elegies were written in order to be sung and that the fourth lines naturally always preserved the same rhymes because they constituted a virtual folk-song refrain" "Türk edebiyatı tarihi, Chapter 4, "İlk şiirler ve ilk şâirler"). This type of verse, which evolved from the koşma and dastān of popular literature to our classical literature 
in the murabbac and şark forms under Arab-Persian influence, is wholly national. In this form, which was a vestige of the early periods when there was no separation between literature and music, i.e. between words and melody, the first three verses were to be recited by the poet-composer alone, while the refrain, which was the fourth verse, was to be sung chorus-like by the entire community. The author $\{$ Hazīnī $\}$ of the Fawähir states that the hikmats of Ahmad Yasawī were recited with special melodies in the tenth/sixteenth century \{he does not, in fact say this\}; and we know very well that today there are special melodies for the Dĩwan-i Hikmat among both the Qazaqs in Turkistan and the Turks along the Volga. In exactly the same fashion, as we will see in detail in the second part of this book, the ilâhîs \{hymns\} of Ottoman literature, and also a number of popular works, which acquired a religious value among the people and were much read, had specific melodies attached to them. \{Note: section C in the narrative is all Köprülü offers as a "minute analysis" of the Dīwān-i Hikmat, giving only one example of a poem he believes can be traced to Ahmad Yasawī, whose work he characterizes broadly as primitive.

46 One can come across this simile (tashbinh) or other such unusual similies in almost all the Șūfìs. We find the following lines from Mawlānā Jalāl al-Dīn Rūmī, for example:

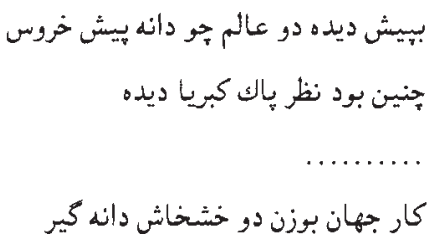

\{Before my eye the two worlds are like a seed before a rooster.

Thus is the pure vision of one who has seen divine majesty.

$\cdots$

Consider the business of this world as the weight of two poppy-seeds.

47 There are no traces of Shī ism in any form in the early famous works of Farīd al-Dīn 'Atțār, such as the Pandnāme. Around the end of his life, however, he praised 'Alī and the Twelve Imāms with great enthusiasm in the poem Mazhar al-'ajă'ib \{again, this poem is no longer considered to be an authentic work of 'Atțār\}, which he wrote and dedicated to 'Alī, and declared that he believed in the occultation \{gaybet, in 1st edn of Early Mystics; aleyhdarlk, opposition, in 3rd edn\} of the mahdī. I mentioned above that as a result of this he was banished from Samarqand as a rāfiti (Chapter 2, p. 43, n.28). Later, Farīd al-Dīn 'Aț̣ār related this incident in his poem Lisān al-ghaib, which he wrote in Mecca, and then could not resist writing these lines:
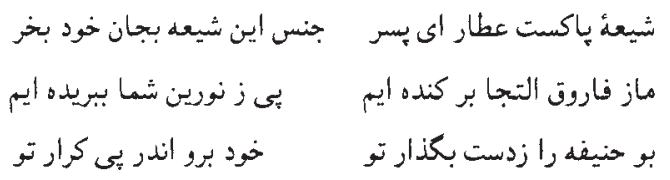

\{'Attāar is a pure Shīî, O my son. Embrace this kind of Shī' ism wholeheartedly. We have rooted out any refuge in Fārūq (i.e. 'Umar). We have stopped

following your "Two Lights" (i.e. 'Uthmān).

And you: give up Abū Ḥanīfa, and follow after Karrār (i.e. 'Alī).\} 
(from the detailed introduction that Mīrzā Muhammad b. 'Abd al-Wahhāb Qazwīn̄i wrote to the Tadhkirat al-awliy $\vec{a}^{\prime}$ published by Nicholson). Although some respect is given to Shāh Husain and Shahr Bānū \{the mother of the fourth Shī'ī imām 'Alī Zain al-'Ābidīn $\}$ in the Istanbul edition of the Dīwān-i Hikmat, (p. 205), this is by no means something that could be interpreted as $\mathrm{Sh}^{\mathrm{i}}$ 'ism, for it is common among all Muslims. Furthermore, it is highly likely that this short passage does not belong to Ahmad Yasawī but was written later. Moreover, it should not be forgotten that even Ahmad Yasawī, according to tradition, was descended from 'Alī. Because Hartmann did not know how the Bektashī tarīqa was connected with Ahmad Yasawī, he thought that the "Ahmad Yasawī b. Muhammad al-Hanafī" in the Bektashī tradition was a completely different person ("Der čaghataische Diwan Huwedas," p. 133). The accounts given above demonstrate that this is completely erroneous and that even in the Central Asian version of the legend of Ahmad Yasawī, which was the basis of the version that spread in Anatolia, he was considered to be a descendant of 'Alī.

48 Diwān-i Hikmat. The meaning of love $\{$ 'ish $q\}$ here is, of course, not "metaphorical" \{i.e. earthly\} love, but "true" love, i.e. the love of God. Only through love is it possible to be saved from non-existence and to exalt the human soul and return it to the original place of its descent. The sole reason why a number of Șüfis had a strong interest in "the beauties of earthly form" \{mahāsin-i suwariyya $\}$ was because it was only possible to attain "true" love via "metaphorical" love, according to the saying (لمجاز قنطرة الحقيقة \{metaphor is the bridge to truth\}. However, the long, hair-fine bridge leading from human love to divine love is very dangerous. Many on this path fall into the whirlpool of human passions and are drowned. But once this bridge is crossed, non-existence is itself obliterated. The lover sees divine beauty in everything. This is what our popular Șūî̀s call "becoming God with God" \{Hak ile Hak olmak\}. The endless laments of true lovers result from their desperate longing for divinity, which is the soul's original source. The moving laments that fill the Diwwan-i kabirr of Mawlānā, the poet of the famous couplet

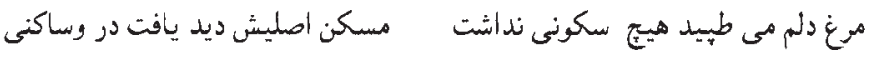

\{The bird of my heart fluttered and had no rest

It saw its place of origin and found rest there\}

and many latitudinarian views, which were considered impossible to adapt to the external meaning of the $\operatorname{Sharin}^{-} a$, were all a product of such a mad, infinite, divine love. In Ahmad Yasawī, however, such laments are very feeble - indeed, they hardly exist. 49 Mawlānā describes this mystical reality in the following manner:

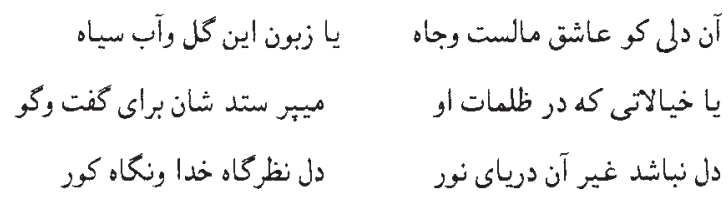

\{Is that (pure heart) the heart that is enamoured of riches and power, or is submissive to this black earth and water (the body),

Or to vain fancies which it worships in the darkness for the sake of fame, The heart is naught but the Sea of Light: is the heart the place for vision of God - and then blind? (Nicholson trans., Mathnawi, vol. 3, 2267-9.)\} 
50 According to the great Șūfiss, the common people cannot understand the realities of divine unity. The realities that were reserved for the select few could by no means be disclosed to them. Sūfìs are not heedless of the noble Hadìths "Relate and convey matters to your interlocutors in a way that they will be able to understand, because you do not wish them to give the lie to God and the Prophet" (in al-Bukhārī, $\{$ Sahịh,$\}$ citing 'Alī) and "Your relating and conveying matters to a people in a way that they will not understand will leave some of them in a state of discord" (in \{al-Shaybānī's\} Fāmic al-ṣaghīr, citing Ibn 'Abbās in comparison with Ibn 'Asākir). Qāẹ̄i Yūnus 'Abd

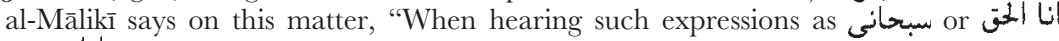

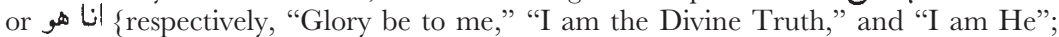
see Carl W. Ernst, Words of Ecstasy in Sufism (Albany, NY, 1985)\} from a saint, do not imagine this to be a form of self-expression, because the reference in such cases is not to one's self; instead, the 'I' that he announces is the 'I' of God. As for the 'I' of the slave \{i.e. $\operatorname{man}\}$, the proponent of this has no comprehension because this form of ' $\mathrm{I}$ ' does not exist in the mind and in the domain of the senses; and how can something that cannot be known be announced? As for the utterance that issues from his tongue, it is the divine creation of God, Who endows everything with the ability to speak, informing us of His lofty and sublime essence" (\{Mehmed Alî Aynî,\} Hüccetï'l-islâm, pp. 334-45). Ibn Khaldūn writes in his famous Muqaddima that the jurists and great Șūfis gave the order $\{f a t w \bar{a}\}$ for the killing of al-Hallāj because he spoke as in command of his senses \{husn, which is erroneous for hiss; cf. Franz Rosenthal's trans. of Ibn Khaldūn's Muqaddimah (Princeton, NJ, 1967), vol. 3, p. 102\} when ecstasy and the mystical state had not come to him (\{Turkish\} trans. \{Pirî-Zâde Mehmed Sâhib Efendi, Chapters 1-5 (Cairo, 1275/1858-9), Ahmet Cevdet, Chapter 6 (Istanbul, 1277/1860-1),\} book 1, Chapter 6, p. 96). "The great Șūfìs" here evidently refers to the traditional account according to which Junaid al-Baghdādī gave the fatwa for this. In fact, Junaid had previously warned him that he had strayed to the wrong path and, according to tradition, when they wanted him to sign the fatw $\bar{a}$ for his execution, he only signed it in the madrasa in the attire of the 'ulama' (\{'Atțār,\} Tadhkirat al-awliy $\bar{a}$ ', Nicholson edn, vol. 2, pp. 12, 137). However, the following lines from the Mathnawi \{Nicholson edn, vol. 2, 1398-9\}

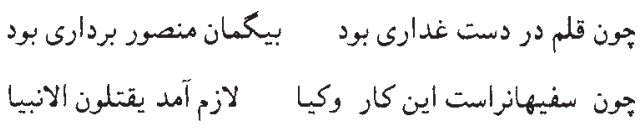

\{When the pen is in the hand of a traitor, without doubt Manșur will be on the gibbet;

When matters of state belong to fools, then certainly "they kill the prophets" (Koran 3:112)\}

show that Mawlānā did not believe this and he further expounded on his appreciation of al-Hallāj as follows, thus agreeing with the statement of Qāḍ̂̀ Yūnus 'Abd al-Mālikī,

$$
\begin{aligned}
& \text { آن انا كفت وزخود برياد شيد واين أنا كفت وزخود آزاد شد } \\
& \text { اين انا هو بود در سراي فضول اتحاد نور نه أز راه حلول }
\end{aligned}
$$

\{That one (i.e. Pharaoh) said "I" and went to ruin; this one (i.e. al-Hallāj) said "I" and was free of self.

This "I am He" was in its secret meaning, O meddlesome one, from union with the Light, not from transmigration of souls (Mathnawi , Nicholson edn, vol. 5, 2035, 2038).\} 
All the great Șūfiss, in fact, recognized al-Hallāj's greatness. The famous Șūfî Shaikh Shiblī \{d. 334/945\} said, "al-Hallāj and I were the same, but they considered me to be mad and thanks to this I was saved. \{They thought\} he was rational and this destroyed him." According to another tradition cited from Shaikh Shiblī, the great calamity that befell al-Hallāj simply resulted from his revealing to others the mystery of God \{sirr-i Haqq\} (Tadhkirat al-awliy $\bar{a}$, vol. 2, pp. 136, 145). In like manner, there is a noteworthy legend in \{Muhammad Pārsā's\} Fașl al-khitāab on why al-Hallāj suffered this sentence. The legends about this great Șūin, whose biography is also found in Ibn Khallikān (\{Wafayāt, $\}$ vol. 1, p. 183), are well known in the Muslim world and, because they spread among the people, works were written about him, including the Hallajnāme by the early Ottoman poet Mürīdī. For those who want a better understanding of al-Hallāj's ideas and beliefs about Șūfism, they can refer to Kitāb al-Ṭawāsinn (ed. L. Massignon [Paris, 1913], \{French trans. Massignon in vol. 3 of his La Passion d'al-Husayn-ibn-Mansour al-Halläj (Paris, 1922), English trans. Herbert Mason as The Passion of al-Halläj (Princeton, NJ, 1982)\}). Shaikh Mahmmūd Shabistarī \{d. c.71820/1318-21\} gives sufficient details in Gulshan-i rāz on the subject of this الخقا

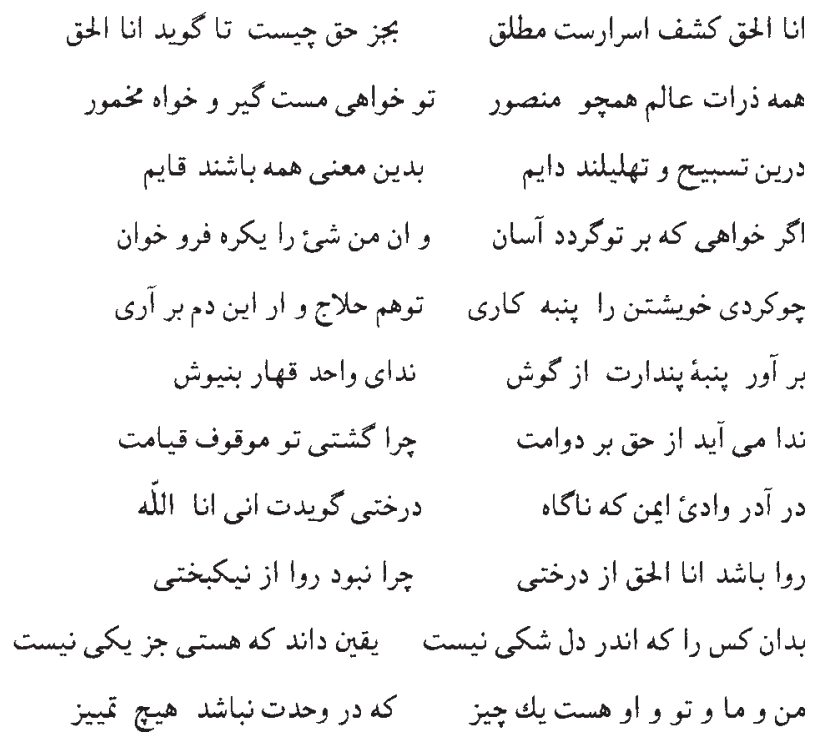

\{Verily "I am The Truth" is a revelation of absolute mystery,

Save "The Truth," who can say "I am The Truth?"

All the atoms of the world, like Mansur,

You will take to be drunken and heavy with wine;

Continually are they singing this song of praise,

Continually dwelling on this mystic verity.

If you desire that its meaning may be clear to you,

Then read the text, "All praise Allah,"

When you have carded "self" as cotton,

You, like the "wool carder," will raise this cry.

Take out the cotton of your illusion from your ears,

Hearken to the call of The One, The Almighty. 
This call is ever coming to you from "The Truth,"

Why are you tarrying for the last day?

Come into the "valley of peace," for straightaway

The bush (allusion to Moses and the burning bush at Mt Sinai, Koran 20:9)

will say to you, 'Verily I am Allah' (Koran 20:14).

The saying "I am 'The Truth"” was lawful for the bush,

Why is it unlawful in the mouth of the good man?

Every man whose heart is pure from doubt,

Knows for a surety that there is no being but 'One.'

'I,' 'We,' 'Thou' and 'He' are all one thing,

For in Unity there is no distinction of persons.

Ed. and English trans. E. H. Whinfield as Gulshan I Raz: The Mystic Rose Garden of Sa'd Ud Din Mahmud Shabistari (London, 1880; reprinted Lahore, 1978), pp. 45-6. Note: halläj means "wool-carder" in Arabic.\}

$51\{$ Köprülü accepts that these passages from the Dīwān-i Hikmat, giving a year-by-year "account" of Ahmad Yasawī's life, are the "autobiographical" work of Ahmad Yasawī himself. It is worth noting that the Dīwān-i Hikmat never mentions Yūsuf Hamadānī.\}

52 For the differences between the great popular Sūfî of the Western Turks, Yūnus Emre, and Ahmad Yasawī, see the second part of this work. In Jalāl al-Dīn Rūmī, there is a strong tendency toward pantheism under the influence of Neoplatonic mysticism. The Dīwān-i Shams al-haq à $i q$ of this Șūfì poet, who expressed ecstatic and passionate outbursts with a sublime and ardent love, is the finest indication of what sublime and divine poetry this form of inspiration could produce; indeed, people of taste and critical sensitivity are unanimous in regarding it as one of the major summits of Sūfî literature. For example, referring to Bazm-i alast \{the primordial covenant between man and God\}, which formed a perpetual subject for Ottoman poets, the following lines of Mawlānā are very suggestive and poetic:

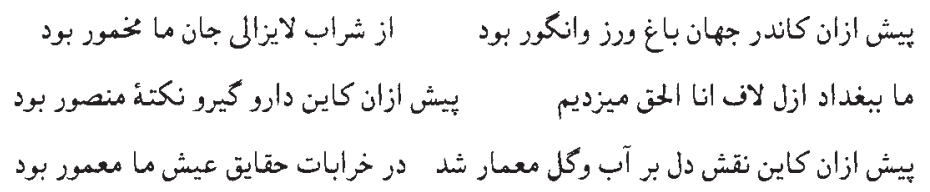

\{Before vineyard and vine and grapes were created, our soul was drunk on the wine of everlastingness.

In the Baghdad of eternity, we uttered "I am Divine Truth" before Manșūr's utterance and arrest and hanging.

Before this heart was moulded of water and clay, our life thrived in the tavern of Reality.\}

Mawlānā, who openly confessed "I am Divine Truth" \{ana al-haqq\} like Manșūr \{al-Hallāj\} in the Baghdad of eternity, does not refrain from declaring and revealing the mystical truths with a most candid ecstasy and exuberance in his Dīwann-i kabir \{i.e. Dīwān-i Shams al-haqā'iq\}. Mawlānā, who says,

$$
\text { مرد خدا زان سوى كفرست و دين مرد خدار راجه خطا وصواب }
$$

\{The man of God is beyond infidelity and religion. To the man of God right and wrong are alike. 
(R. A. Nicholson (trans.), Selected Poems from the Dīvanni Shamsi Tabrīz [Cambridge, 1898; reprinted Cambridge, 1952], p. 30)\} clearly shows his Șūfi character in his very lively ghazals:

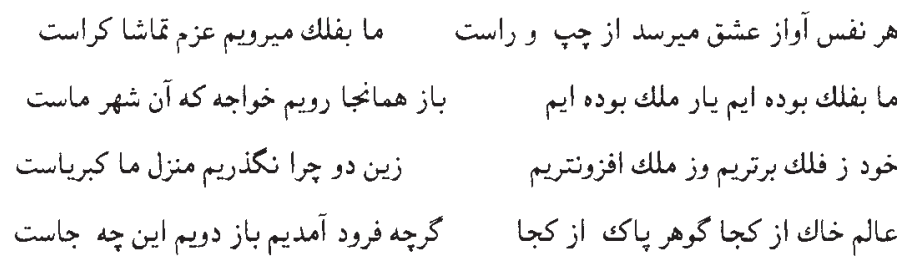

\{Every moment the voice of Love is coming from the left and right.

We are bound for heaven: who has a mind to sight-seeing?

We have been in heaven, we have been friends of the angels;

Thither, sire, let us return, for that is our country.

We are even higher than heaven and more than the angels;

Why pass we not beyond these twain? Our goal is majesty supreme.

How different a source have the world of dust and the pure substance!

Tho' we came down, let us haste back - what place is this!

(Nicholson, trans., p. 33.)\} As for the Mathnawi, this is a work of a much more pedagogic nature (see the second part of this book for more on Jalāl al-Dīn Rūmī).

53 SSee John O'Kane's trans. of Muhammad b. al-Munawwar's Asrār al-tawhīd as The Secrets of God's Mystical Oneness or The Spiritual Stations of Shaikh Abu Sa'id (Costa Mesa, CA, 1992), p. 514.\}

54 J. Darmesteter, in Les Origines de la poésie persane (Paris, 1887), advanced the following view, which is worthy of note, on this matter: "The orthodoxy of Baghdad could not long satisfy Iran's mythological and philosophical instincts. Among the people, Islam was quickly transformed by receiving to its bosom all the old popular mythology that was galvanized around the heroic figure of 'Alī. The new religion that arose from it, Shī' ism, which combined in itself the inferior elements of these two parent religions, the mythological excess of ancient Iran and the dogmatic intolerance of Islam, and which became such a factor in the moral decline of Iran, was fine for the populace and most of their priests. But it was insufficient for the souls of the elite. Some of them left Islam more or less openly through science and lack of faith. Others left by means of mysticism. At the time of Firdawsī, two poets represented these two opposite currents. One was the physician Avicenna (Ibn Sīnā) and the other was the dervish Abū Sa'īd" (pp. 59-60). \{Darmesteter goes on to say\} "Abū Sa'îd's pantheism was not as definite and clear as in subsequent poets and it was because of this that he was such a great poet. Knowledge (i.e. 'ilm), as one calls the Sūfì intuition, was not for him, as it would be for his successors, a frozen and unchanging belief, a tradition they had acquired from their masters, a matter to be put in verse. This knowledge - he created it, nourished it with his blood and tears, with the pain, doubt and contradictions in his heart" (pp. 81-2). Although not clearly stated in Darmesteter's book, we find this idea at least a quarter century earlier in J. A. Gobineau (Les Religions et les philosophies dans l'asie centrale [Paris, 1866 \{reissued, Paris, 1953\}], p. 79). On the lyric poetry of Ibn Sīnā, see the work of the Orientalist Carra de Vaux (Avicenne \{Paris, 1900; reprinted Amsterdam, 1974\}, p. 155).

$55\{$ Jāmī, $\}$ Nafahăt, \{Turkish\} trans., p. 344. On this shaikh, see also 'Atțār, Tadhkira, vol. 2, pp. 322-37, and Nāmah-i Dānishvarān \{Tehran, 1338/1959-60\}, vol. 1, 
pp. 608-15. A number of special functions have been attributed to individual quatrains of Abu Sa ${ }^{i} \mathrm{i}$. For example, there are some quatrains that were read in order to attain various goals, \{namely\} to find a perfect guide, to atone for one's sins, to be delivered from illness, to make it rain, to improve one's means of livelihood, and so forth (see the collected quatrains (Ruba'iyāt) published with Khwāja 'Abd Allāh Anșārī \{al-Harawī's\} Munājāt [Istanbul, 1301/1883-4].) \{The latter has been translated by Lawrence Morris and Rustam Sarfeh as Munäjät: The Intimate Prayers of Khwajih 'Abd Allāh Anșārī (New York, 1975). See also Fritz Meier, Abū Sa' $\bar{\imath} d-i$ Abu l-Hayr 9357-440/967-1049): Wirklichkeit und Legende (Leiden, 1976); and EIr, s.v. "Abū

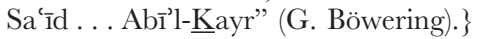

56 Hakīm Sanā'̄ was for a time in the tekke of Khwāja Yūsuf Hamadānī and toward the end of his life spoke only of tawhìd \{proclaiming the unity of God\}, ma'arif \{knowledge of God\}, and haq $\bar{a}^{\prime} i q$ \{reality of God\}. The religious scholars \{'ulam $\left.\bar{a}^{\prime}\right\}$ of Ghazna found his book Hadiquat al-haqa' $i q$ to be contrary to the stipulations of the Shari ${ }^{\prime} a$ and sent it on to Baghdad, but the 'ulama' there saw nothing objectionable in it. Mawlānā glorified him in the couplet

$$
\text { عطلار روح بود وسنائى دو جشم او مااز بي سنائى وعطار آمديم }
$$

\{'Atțār was spirit and Sanā'̄ was his two eyes. We have followed in the traces of Sanā'̄ and 'Atṭār, \} and Dawlat-Shāh described the works of this great poet as follows:

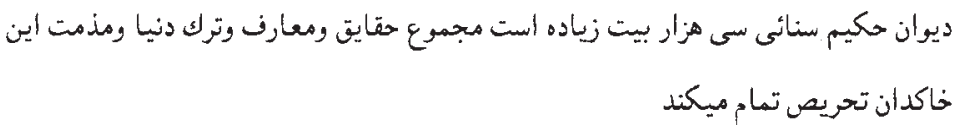

\{The dīwān of Hakīm Sanā's, consisting of over 30,000 couplets, is a gathering of $h a q \bar{a}^{\prime} i q$ and $m a^{\prime}$ a $\dot{r}$ if, urging renunciation of the world and reproaching this dust-heap of desires\} (Dawlat-Shāh, Tadhkira, pp. 95-9). As for Farīd al-Dīn 'Aț̣ār, who gained even greater fame than Sanā' $\overline{1}$, the historical sources differ considerably on the date of his death, but Muhammad b. 'Abd al-Wahhāb Qazwīn̄ rightly claims that he must have lived until the year 617/1220 (\{'Aț̣ār,\} Tadhkira, introduction. \{His death date moves back and forth. Cf. $E I^{2}$, s.v. "Ațtāar" (H. Ritter).\} We possess considerable information on the mystical life of this great poet. Dawlat-Shāh, who regarded him very highly, states (\{Tadhkira, $\}$ p. 188):

$$
\begin{aligned}
& \text { در نهايت كمال بحرى بود زاخر و همت او مصروف بود بر نفى خاطر، در كوشةٌ نشسته ودر بر روى } \\
& \text { غير بسته، هزاران ابكار اسرار دو خلوت سراي او جلوه ساز بودند و دو شبستان او عروسان حقايق } \\
& \text { ودقايق محرم راز }
\end{aligned}
$$

\{n the extreme of perfection he was a swelling sea. His ambition was directed to the banishing of self-will. He withdrew into a corner and shut the door to others. Thousands of virgin mysteries were revealed to him in seculsion, and in his bed-chamber the brides of spiritual realities lifted their veils. $\}$ In any case, if we take into consideration the time in which they lived, we can definitely assert that Ahmad Yasawī was not influenced by either Hakīm Sanā'ī or, in particular, Farīd al-Dīn 'Atțār, even though he may have been familiar with the poetry of earlier Sūfîs, such as Abū Sa'īd. 
Based on Dawlat-Shāh, the death date of Hakīm Sanā'̄i is given as 576/1180-1, but this is not correct. Hüseyin Dâniş says in Ser-Âmedân-ı Suhan \{Istanbul, 1327) $1909\}$, p. 219, that Sanā'̄̄ was a disciple of Yūsuf Hamadānī and that according to one tradition he died in 576 and according to another in 690/1291, but this is also mistaken. I have stated above that this Sūfi poet was for a while in the dervish convent of Yūsuf Hamadānī. Based on H. Ethé's catalogue \{Catalogue of Persian, Turkish, Hindustani and Pushtu Manuscripts [in the Bodleian] (Oxford, 1889)\}, the work of G. Ouseley \{Biographical Notices of Persian Poets (London, 1846)\}, and \{Jāmī's\} Nafahāt, Prof. Nicholson has lowered his death date to 545/1150-1 (Selected Poems from the Dìvāni Shamsi Tabriz, p. 259). There are many details on this in the entry on Sanā' $\overline{1}$ in the Encyclopaedia Britannica. \{His death date is given as probably 525/1131 in $\dot{I} A$, s.v. "Senâ'1̂" (Ahmed Ateş) and $E I^{2}$, s.v. "Sanā'̄̄' (J. T. P. de Bruijn).\}

57 The works of both Hakīm Sanā'ī and Farīd al-Dīn 'Ațtār were of a pedagogic nature, written to teach ethics and Șüfì rules of conduct to the people. In the famous poem Mantiq al-tair, which is the most renowned work of 'Atțār, expounding as it does the tenets of Șüfism in an allegorical form, and which was translated and extensively commented upon by Garcin de Tassy, who considered it to be one of the most important monuments of Șūfì doctrine (La Poésie philosophique et religieuse chez les persians $\{$ d'après le Mantic uttair...\} [Paris, 1860], p. 6), there are a few rare points that could be interpreted according to only the strictist pantheistic beliefs, but they are not sufficient for us to regard him as a "pantheistic Șūfì poet" (Chapter 10 of Carra de Vaux's Gazali, in which he discusses the Persian Șūfì poets, p. 289). 'Aț̣ār, certainly one of the most prolific of the early Persian poets, did compose much mystical verse, such as
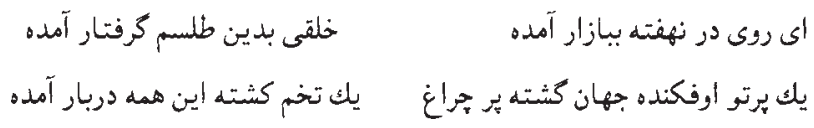

\{He came to the market place with his face covered; the people were seized by this talisman. He sent out one ray and the world became a torch; he sowed one seed and the universe produced all these fruits, $\}$ but it is impossible to find in it the divine ecstasy and exuberance of Mawlānā and his intense pantheism. Sayyid 'Izz al-Dīn Āmilī wrote numerous commentaries on these mystical odes (Dawlat-Shāh, \{Tadhkira, p. 190). Nevertheless, it would be more correct to regard the poet of the Pandname and Mantiq al-tair as a moralist just like Sa'dī. Carra de Vaux states that one must consider both of these poets as moralists and even that the Mantiq al-tair is a didactic work expounding the fundamental tenets of Șuffism (Gazali, pp. 281, 283). This is completely in accord with my view. On the subject of $S^{\prime}{ }^{\prime} d \overline{1}$, everyone agrees that he was not a Șūī poet but a great moralist (Carra de Vaux, ibid.). Barbier de Meynard, who translated the Büstān into French, says that Sa'dī had little inclination toward Șūfism, but that he had to give a slight Șūfì color to his work because of the general tendency of his time; that he was never a Șūfì poet comparable to Mawlānā or even Hāfiz Shīrāzī; and that one must view Sa'dī as one of the most charming and humane moralists to appear in the Muslim East. This view is quite correct (introduction to his trans. of Büstān \{as Le Boustan, or Verger; poem persan de Saadi; traduit pour la premièr fois en français ... (Paris, 1880)\}, p. 26; İran'da şiur \{Poetry in Iran, not further indentified\}, p. 47).

58 The one poem in the Dǐwan-i Hikmat that reveals a relatively broad-minded and unconstrained Sūfì doctrine is not in the published editions currently in our possession. It is found in \{Hazinn̄'s\} Fawāhir, and so we must recognize it as the oldest piece of 
poetry attributed to Ahmad Yasawī. I thus cite it here verbatim, although the text has been corrupted by copyists:

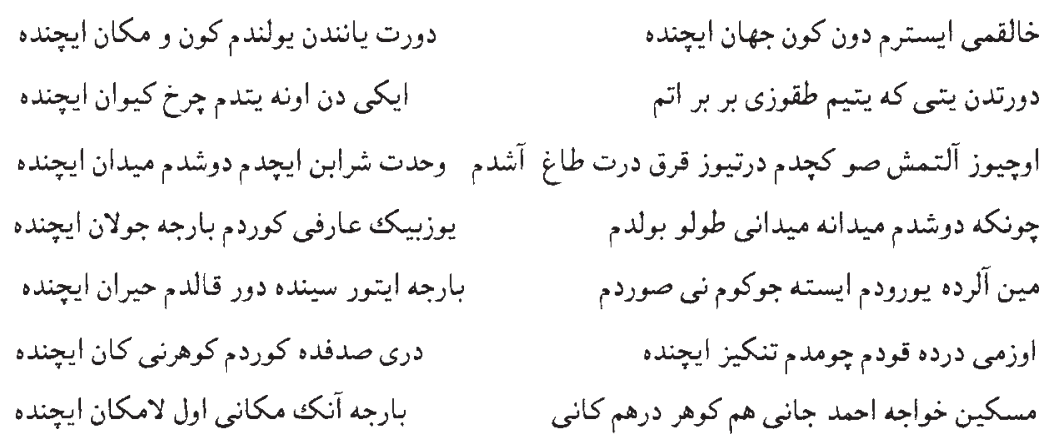

\{I seek my Creator night and day in the world.

I am freed from the four directions in the realm of being and becoming.

From four I reached seven, I did nine one by one,

From two I reached ten in the sphere of Saturn.

I crossed 360 rivers, I crossed 444 mountains,

I drank the wine of Unity, I entered the battlefield.

When I entered the battlefield, I found the field full.

I saw 100,000 gnostics, all prancing in the field.

I ran among them and asked what I was seeking.

They all said: "It is in you." I was lost in amazement.

I submitted to pain, I plunged in the sea,

I saw the pearl in the shell, the jewel in the ore.

Poor Khwāja Ahmad's soul is both the jewel and the ore.

All of his place is in no-place.

Cf. the transcription in M. Orhan Soysal (ed.), Eski Türk edebiyat metinleri (Ankara, 1978), p. 114, although it is missing the second verse,

\section{Törtdin yetige yetdim / tokuzu bir bir etdim}

İkidin onga yetdim / çarh-ı keyvan içinde.\}

The poem given by Hazin̄ī actually does appear in a published version that should have been available to Köprülü, namely the 1299 Istanbul printing, pp. 234-5, where the poem differs considerably in wording and in the order of lines. It also appears in the recent Bice edn, pp. 82-3. The text does not, in fact, explicitly state that the poem belongs to Ahmad Yasawī, but that seems to be the implication. Köprülü's claim that the text has been corrupted by copyists is interesting. The manuscript in which it is preserved in this form was copied in the same year the work was composed (1002/ 1593), and there is every reason to suppose that it reflects Hazīnì's intention. Perhaps Köprülü means that Hazīnī took it from a written version that had already been corrupted in transmission. But if so, what is remarkable is that he never draws attention to the most glaring "adjustment" in the text, namely the prevalence of "Oghuz" forms, orthographically and sometimes grammatically, over the Central Asian forms we might expect to find in an "original" Dīwān-i Hikmat. The mostly Ottoman orthography, which is replaced by Chaghatay forms in the printed versions, should at least 
remind us that what we have here is at best a poor reflection of the original Chaghatay form of the poem, no matter if it was written in the twelfth, thirteenth, or sixteenth century.

59 E. J. W. Gibb, who has beautifully summarized their Șūfì beliefs in his magnum opus, says "The early Șūfì poets had taken the current phraseology of the contemporary singers of love and wine, and by imparting a mystic signification to the terms thus adopted, they had constructed a species of symbolic language in which, for example, 'wine' represents the mystic love, 'the vintner' the teacher thereof, 'the tavern' \{i.e. the kharāba $t\}$ the place where it is taught, just as the 'Beloved' stands for God, and the 'lover' for man" (A History of Ottoman Poetry \{London, 1900-9\}, vol. 1, p. 23 \{Köprülü used a Turkish trans. by Fuad Raif of five folios of the first volume as Eş âr-i osmânîye tarihi\}). The poet $\{$ Mahmūd Shabistarī $\}$ of Gulshan-i rāz explains the "tavern" of the Șūfis in the following couplets:

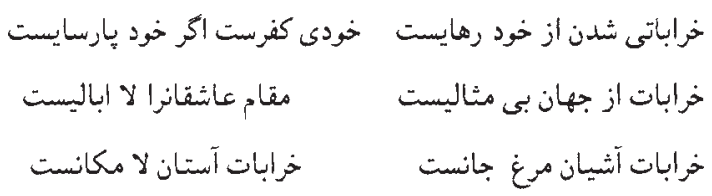

\{To be a haunter of taverns is to be freed from self,

Self-regard is paganism, even if it be in righteousness.

The tavern is of the world that has no similtude,

It is the place of lovers that reck not.

The tavern is the nest of the bird of the soul,

The tavern is the sanctuary that has no place.

(Whinfield trans., p. 81.)\}

This then is the kharābāt that Mawlānā meant in the couplet:

$$
\text { همرنك جماعت شُو تالذت جان بينى دركوى خرابات آ تا دردكشان بينى }
$$

$\{$ Be of like color with the congregation, so that you may see the soul's pleasure.

Come to the alley of the tavern, so that you may see those who swallow dregs,

and that Ḥāfiz meant in the couplet:

$$
\text { تهدم منه بخرابات جز بشرط ادب كه ساكنان درش مدرمان يادشهند }
$$

\{Do not set foot in the tavern except by the rule of good manners.

For those who dwell at its gate are the confidants of the king.\}

One should not confuse the kharābāt of the Șūfiss with the usual kharāanat of the poets (for details, see my article "Harâbât," $M M,\{1$ (1917), 186-8\}).

60 Many European researchers attribute the fatalism in the Muslim countries to the lack of the notion of free will in Islam, which is completely mistaken. On this subject, see Gobineau's famous work Les religions, p. 72. 


\section{6 \\ AHMAD YASAWI''S LITERARY INFLUENCE}

\section{A The influence of Ahmad Yasawi}

The work of Ahmad Yasawī, who had no interest whatsoever in artistic expression and who viewed poetry as simply a means of religio-Sūfì propaganda, was, as described above, an ordinary product greatly lacking in intrinsic aesthetic value. If we leave aside its historical features and examine the Dīwān-i Hikmat merely with respect to its aesthetic significance, we cannot accord it any great value according to the literary taste of today, indeed, even according to the literary taste of the past. However, when we study it from a historical point of view, i.e. with respect to its extrinsic value and influence, we must acknowledge the greatness and power of this work, which has endured for centuries. A literary work which, for almost eight \{now nine - if not actually four or five centuries, has weathered all kinds of \{social\} transformations and changes in taste, which has been the primary model to be imitated by a great many poets over these centuries, ${ }^{1}$ and which has served the purpose of providing verse to the taste of the popular masses for centuries, is unquestionably worthy of special attention with regard to literary history. ${ }^{2}$ Let me try to shed light on the reasons for this very important phenomenon so that the fact that the Dīwān-i Hikmat has had such a great extrinsic influence despite its fundamental lack of any significant aesthetic value will not remain a mystery.

As was previously explained, two fundamental elements in the work of Ahmad Yasawī are immediately apparent: the Islamic, i.e. the religio-Șūfì element, and the national, i.e. the element taken from folk literature. The Islamic element is especially strong in the subject matter, i.e. in the substance of the work, while the national element, in contrast to this, is noticeable above all in its form and meter. The Turks, who had recently entered the realm of Islam and who exhibited a great desire to understand the bases of this new religion, naturally appreciated this work, which, with regard to form, seemed to them not at all unfamiliar. And because, with regard to subject matter, the Dīwān-i Hikmat aroused their very great and sincere interest, it immediately acquired a sacred character among the mass of the people. ${ }^{3}$ Furthermore, the fact that Ahmad Yasawi was also the founder of a tarinqa, and its $p \bar{\imath} r$, and that his tarnqa spread to many different and 
extensive regions, was perhaps the most important factor in this process. For those who joined his tariqa, reading and memorizing the Dīwān-i Hikmat and, for those who were able, writing the same kind of poetry, i.e. hikmats, were virtually considered to be requirements \{of membership\}. The hikmats that were recited during the dhikrs could not, of course, simply be regarded as the work of an ordinary folk poet. They were endued with a sacred aura that overshadowed their aesthetic quality. The ability of the Dīwān-i Hikmat to remain popular over the centuries, despite all changes in taste, derived from its indisputable sacred value among the dervishes. Otherwise, if this feeling of reverence for his verses had not had the character of an indisputable principle - even an article of faith - this work would have long been forgotten. In other words, the major factor that caused the Dīwann-i Hikmat to endure for centuries and caused numerous writers to adopt it as a model was the religio-Sūfì spiritual influence of Ahmad Yasawī, which was described at length above, rather than the aesthetic value of the work.

A second factor in addition to this fundamental one was the fact that the regions in which the Dīwān-i Hikmat endured have remained under the same ruling principles \{hâkim esaslar\} for the past eight centuries and have not undergone an intellectual awakening. The religio-Șūî objectives that Ahmad Yasawī spread and instilled have not changed among the people since that time, but, to the contrary, have become more widespread and more deeply rooted. The Turkish and Persian poets, the Șûfis, the religious scholars and philosophers, and the jurists who appeared since the sixth/twelfth century were not able to create anything great or original but, instead, preoccupied themselves with a multitude of insignificant details embroidering ancient established principles. Rather than extend the intellectual horizon, they narrowed it. Indeed, they limited and restricted it. The Mongol invasion brought, for a while, some new elements from the Far East to Central Asian Muslim civilization, but this had hardly any effect on religious and mystical ideas. After experiencing its most brilliant cultural flowering during the time of Tīmūr and his descendants, Central Asia was finally subjected to a state of continuous decline from the fall of the Shibānid dynasty $\{1500-99\}$ to the Russian invasion and even up to recent years.

Moreover, despite the efflorescence during the Tìmūrid period in architecture, fine arts, music, secular literature, in short, all such manifestations of aesthetic life, in the final analysis it was still a time of the triumph of scholasticism and Șūfism. ${ }^{4}$ In fact, the ninth/fifteenth century witnessed the flourishing of a number of great poets and Șūfìs like Jāmī and 'Ubaid Allāh Aḥrār. Jāmī, in turn, exercised a tremendous mystical influence on 'Alī Shīr Nawā' $\overline{1}$, his contemporaries and followers. As Zahīr al-Dīn Bābur Shāh, the conqueror of India, perceived very clearly with his customary insight, the Șüfism of the men who gathered around 'Alī Shīr Nawā'̀̄ at the court of Sultan Husain Bāiqarā in Herat was mainly philosophical and literary in character and was naturally very unconstrained and dissolute $\{$ rindāne $\} .{ }^{5} \mathrm{~A}$ bit later, however, at the time of the Shibānid dynasty, and in subsequent centuries, this powerful Șūfì current swept through all of Central Asia and, as was explained above, assumed a religious form that was 
very ascetic and that rigorously conformed to fundamental Islamic dogmas under the name of Naqshbandism, which we can consider as a branch of Yasawism. ${ }^{6}$ In other words, the social milieu gradually developed to the point at which it could accept the work of Ahmad Yasawī with even greater enthusiasm.

Just as the first of the two elements that shaped the work of Ahmad Yasawī, i.e. the religio-Sūfĩ element, thus remained unchanging in the social milieu for centuries and conformed each day a bit more to the common \{religious\} inclination, so the national element, which is so striking in the meter derived from folk literature, also remained fixed in the social milieu. In other words, it did not deviate from the \{literary inclination of the age. Because the folk literature has remained virtually constant from the sixth/twelfth century to the present, the Dīwän-i Hikmat never went out of fashion with respect to popular taste. It endured with the same power - even with a quasi-sanctity - over the people of the steppes, the Qazaqs and Qipchaqs, who were completely unfamiliar with the classical Persian literature. Given these factors, it is no longer a mystery that the Dĩwān-i Hikmat, which essentially possesses no great aesthetic value, has endured so vigorously over such a wide area for eight centuries.

After Ahmad Yasawī, it became de rigeur for the dervishes who belonged to the Yasawi tariqga to write the same type of works that he did. ${ }^{7}$ For the Yasawi dervishes who had a modicum of poetic skill, following the road opened by the $p \bar{r} r$ of the taniqa acquired the character of a sacred duty. Thus, beginning with Sulaimān Bāqirghānī, i.e. the famous Ḥakīm Ata, numerous Yasawī and Naqshbandī shaikhs and dervishes wrote the same kinds of hikmats. These hikmats were virtually indistinguishable from each other with regard to subject, form, and style because the pattern established by the great pir had acquired a virtual sanctity and it was felt that one should not deviate from it in any way. Only after many centuries had passed and the 'arüd metrics had become thoroughly incorporated in literature did some Șūfì poets, no longer objecting to the use of a now familiar metrical system, begin to use it to write mystical poetry, prayers $\{$ munāja $\bar{t}\}$, and narratives. Still, the old type of hikmat continued to have a much stronger appeal than these other efforts and never conceded its place to the 'arüd system. Although we do not have much definite information, we can deduce that the Sunfiss, i.e. the poets in the tekkes, finally began to write works in 'arüd and that these types of works began to increase in the tenth/sixteenth century. In my view, 'arüd could not have entered the tekkes and khänqāhs until after 'Alī Shīr Nawâ'î. There had already been some occasional efforts in this direction before Nawâ' $\overline{1}$, but it was not until the tenth/sixteenth century that they were able to go beyond random individual efforts and take the form of a vigorous general movement, and that the 'arüd system assumed a more or less popular character. Still, these Șūfì poets, who saw nothing wrong with using 'arūd, at the same time were always eager to write hikmats in the syllabic meters. Among the early products of our literature, the influence of Ahmad Yasawi can also be clearly seen in the well known poem of $Y \bar{u} s u f u$ Zulaikha written by a poet named 'Alī in Central Asia in $630 / 1232-3 .^{8}$ 
Thus, on the one hand, the followers of Ahmad Yasawī, remaining faithful to his literary traditions, produced simple Șūfi works for the people. On the other hand, meanwhile, Persian influence gradually increased, and in the palaces of the Turkish rulers a number of Turkish works were composed in 'arü $d$ in imitation of the Persians. This trend, which had begun with \{Yūsuf Khāṣs Hājib’s\} Kutadgu Bilig and Ahmad b. Mahmūd's\} 'Atabat al-Haqā'iq, continued in the Seljuk period, and maintained its importance during the Mongol period. Later, in the Tīmūrid period, it began to develop with renewed vigor and, after producing poets like Amīr Saif al-Dīn, Mīr Haidar, Luṭ̂̄, and Sakkākī, reached its highest point with Nawā' $\overline{1}{ }^{9}$ These poets, who thought of nothing but skillfully imitating the perfect examples of the great Persian poets, and so gave no value to the popular language and taste and to the national meter and forms derived from folk literature, tried to display their talent in the courts by approaching those Persian models as closely as possible. It was quite natural, therefore, that Ahmad Yasawī would have absolutely no influence on them. The influence of 'Alī Shīr Nawā'̄ was paramount throughout Central Asia until the collapse of the Shibānid dynasty. Only then did there begin to flourish, among groups of local poets who appeared in various regions of Central Asia, popular Ṣūī poets who took Ahmad Yasawī as a model alongside the classicizing court poets who imitated Nawā' $\overline{1}$. In this way, the influence of Ahmad Yasawī, who had almost been forgotten in the literary world for about two or two and a half centuries, reasserted itself with a strength that was no doubt greater than it had been in the past. This important phenomenon can also explain, as I stated above, the rapidity and vigor with which the social milieu once again hankered after an ascetic Șūfism.

Thus, among the imitators of Ahmad Yasawī, in addition to the popular Șūfì poets, i.e. the tekke poets, there also appeared a group of folk poets who cannot be regarded as Șūfis in the full sense, although they took their basic literary notions mainly from the tekkes. These were the 'áshıqs or minstrels who, with saz in hand, wandered from tekke to tekke, coffee house to coffee house, and city to city. These minstrel poets, who replaced the old Turkish ozans or bakhshis \{bāqshīs, bakhshiss, bakshis, and other forms $\},{ }^{10}$ for the most part had no madrasa education, but acquired whatever learning they had on their own. Therefore they were better acquainted with the popular taste and spirit and they made use of folk literature in great measure. This being the case, and because virtually all of them were connected with either the Yasawī or Naqshbandī tarīqa, they learned by ear a great deal about the principles of Sunfism and the rules of the order, and they naturally made abundant use of words and expressions related to such things in their works. ${ }^{11}$ The works of these 'asshqs - who took their inspiration from Islamic tradition, the legends of famous saints, the old Iranian epics, or else from national subjects or contemporary events - were naturally more varied than those of the Șūfis and generally were of a semi-religious or non-religious nature. Thus, they were more satisfying to the national taste. These works were far, however, from the sanctity that was accorded to the hikmats of the Șūiss. Just as the 'āshrqs among the Western Turks had begun to use 'arü 
\{d. 820/1417-18\} and especially after Fudūlī \{d. 963/1556\}, those among the Eastern Turks did so after Nawā'̄i $\{$ d. 506/1501\}. Nevertheless, while they did make some use of 'arü - like the poets who appeared after Nawa' $\overline{1}$ - they still gave much more importance to the syllabic meter. This is the reason why Vambéry says that, in the books of minstrel poetry that he collected under the title Bakhshi kitâbr, he came across numerous works by various poets written in both 'arüd and the syllabic meters. ${ }^{12}$ In any case, it is quite clear that Ahmad Yasawi exerted a very powerful influence on these popular ' $\bar{a}$ shrqs as well as on all the poets of the Șūî̀ tekkes in Central Asia.

Among the Șūfì poets who imitated Ahmmad Yasawī and flourished in Central Asia - Qūl Shams al-Dīn, Khudāidād, Īqānī, Qūl 'Ubaidī, Faqīrī, Aḥmad Yasawī \{sic\}, Baiḍā, Bihbūdī, Shuhūdī, Qūl Sharafī, Gedā, Ghazzālī, Ṭufailī, Qāsim, Mashrab, Hüveydâ, etc. - there were many who differed not only in time but also in quality and fame. It would be outside the scope of this work to provide here even a very brief general account of all of them. ${ }^{13}$ These poets, some of whom have dīwāns (published and unpublished) and some of whom have only a few scattered compositions, wrote some poems in 'arüd as well as hikmats in the style of Ahmad Yasawī. A poet of this type from Khokand wrote, under the pen name Güldeste, an important dīwān modeled after the Dīwān-i Hikmat. ${ }^{14}$ In short, Ahmad Yasawī was a very important poet who, with his powerful personality, influenced the Turkish literature of Central Asia for centuries and created his own unique type of poetry.

\section{B Sulaimān Bāqirghān̄̄ \{Hakīm Ata\}}

In the field of literature, the first and most famous follower of Ahmad Yasawī was his third khal̄efa Hakīm Sulaimān Ata \{Bāqirghān̄̄ . We know from \{Ṣafìss\} Rashahāt that this Ṣūî, whose life and legends I discussed at length above (Chapter 4, pp. 89-94), produced a number of Turkish works ${ }^{15}$ and that they were very famous in Turkistan. ${ }^{16}$ Indeed, legend states that from his early childhood he began to recite versified hikmats thanks to the spiritual power of Khadir. Thus, the first hikmat on the first page of the famous book of Hakim Ata begins with the line Hızır-İlyas atam bar \{I have a father Khaḍir-İlyās\}. In any case, both history and dervish tradition show that Hakīm Sulaimān Ata was also a Ṣūfì poet like Ahmad Yasawī.

The major works that have been attributed to Hakīm Sulaimān Ata, such as Bâqirghân kitâbı, Âkhir zamân kitâbı, and \{Hadrat-i\} Maryam kitâbı, are popular works that are still read with great rapture and excitement in Central Asia, especially in the region of the Volga. If we leave aside Maryam kitâbr and also Âkhir zamân kitâbı - which is a rather long but simple dastān put in the tongue of an ascetic about the portents of the end of time, Gog and Magog, the messiah $\{$ mahd $\bar{\imath}$, the $d \bar{a} b b a t$ al-ard (an animal that will appear with the mahd on the Day of Judgment), and the events of the Day of Judgment - Sulaimān Ata's major work is a famous collection of poetry called Bâqirghân kitâbı. Glancing over this collection, which 
has been published in several editions, it becomes quite clear that it comprises hymns and Sūfì poems belonging to various poets of different times - exactly like the Dĩwan-i Hikmat - and that it definitely cannot be attributed to a single person. Not only the style and contents of the poems but even the pen names of the various authors $\}$ suffice to show this. ${ }^{17}$

Much of the folk poetry in the syllabic meter written by Khwāja Sulaimān Bāqirghānī under different pen names, such as Qūl Sulaimān, Hakīm Sulaimān, Hakīm Khwāja Sulaimān, and Hakīm Ata, resembles the work of Ạ̣mad Yasawī in every respect: dastāns about the Ascension and death of the Prophet; dialogue of heaven and hell; the very famous legend about how only those who repent would be able to drink from the four rivers that flow through heaven while those who do not repent would be given instead the poison from the tree that grows in hell $\{$ zakkum $\}$; events on the Day of Judgment; fear of God; Moses being a disciple of Khadir; the story of Ishmael and Abraham; some Șûfi thoughts on the virtues of dervishes and being a dervish and on the transitory nature of this world; eulogies about Ahmad Yasawī; and so forth.

The basic spirit pervading all these things is exactly that of the Dīwan-i Hikmat. The space devoted to mystical love in Sulaimān Ata, as in the work of Ahmad Yasaw $\overline{1}$, is very little, and suitable for the religious training not of true lovers \{'äshrqs\} but rather of ascetics. "If the shadow of love touches someone, he should become a lover. For the lover, the nurse of love is pain and torment. The path of love is long and its night is terrifying. One should forfeit his soul and dive into the unfathomable sea of love." The love of this ascetic, who speaks of the sweetness of mentioning $\{d h i k r\}$ God just before dawn together with the birds, is evidently no different than that of his shaikh Ahmad Yasawī. We see this identity not only in subject matter but also in form and style. For example, the meters and forms used in the Dīwān-i Hikmat, and their major characteristics, are found in exactly the same manner in the works of Hakīm Sulaimān Ata. Therefore, we can definitely say that Sulaimān Ata tried to conform completely to the personality of his shaikh rather than to exhibit an individual personality of his own, both artistically and doctrinally. He took great pains to imitate him fully in literature as well as in the rules of the order and mystical doctrines, for, as explained above, writing Șūfì hikmats like those of Aḥmad Yasawī was not an aesthetic or personal matter but was simply one of the protocols of Yasawism. Because Sulaimān Ata was the one who first established this tradition, he deserves to hold the most important place among the followers of Ahmad Yasawī. It is precisely for this reason that his work, together with that of his shaikh, has vigorously endured among the people for eight centuries. ${ }^{18}$

\section{G Conclusion}

We have seen above what a powerful moral influence Aḥmad Yasawī has long exerted on the entire Turkish world. Therefore, after describing his influence on the corpus known collectively as Chaghatay literature and in Central Asia 
generally, we should also show the scope and power of his influence in the other vast regions of the Turkish world. We may thus attain a clear and definite idea as to the extent of the Dĩwän-i Hikmat's penetration and dissemination. In order to do this, we have to search for the influence of Ahmad Yasawi in four main regions: the area of the Qipchaqs, i.e. the present-day Northern Turks; the area of the Turkmen; the area of the Azeriss; and the area of the Western Turks, i.e. Anatolia and Rumelia.

The literature of the earliest periods of the first of these different linguistic areas, i.e. the northern area, is almost entirely unknown. While a few texts of a linguistic character survive, there are hardly any of a literary character. Only a few rare and valuable works, like the Mahabbatnāme, ${ }^{19}$ reveal that a number of literary works imitating classical Persian literature appeared during the eighth/ fourteenth century under the patronage of the Turkish rulers and princes within the realm of the Golden Horde. Consequently, these were written not in the local dialect but in the literary dialect that we call Chaghatay. Still, one wonders what kind of popular literary works were created in that region at that time. How much were the hikmats of Aḥmad Yasawī and Sulaimān Bāqirghānī read among the people and how much influence did they have? Given our current paucity of information, it is hardly possible to give precise answers to these difficult questions. All we know is that there endured among the people, in addition to literature like the Mahabbatnāme that imitated Persian works, a number of works whose subjects were taken from early popular mythology, such as Husām Kātib's famous story of Kesikbash entitled Jumjuma sulț̄an ${ }^{20}$ and some other early stories and verse compositions of this sort. ${ }^{21}$ It is highly likely that the hikmats of Aḥmad Yasawī and especially Sulaimān Bāqirghānī were among them, because we know that collective works like the Dĩwān-i Hịkmat, Bâqirghân kitâbr, and Âkhir zamân kitâbl, which included the poetry of Yasawī dervishes, were very widespread and famous among the Northern Turks from an early period. ${ }^{22}$ In recent years, i.e. during the early years of the twentieth century, a new literature began to take shape among the Northern Turks under the influence of European civilization. Yet it suffices to study the earlier literature only superficially in order to detect the clear and unquestionable influence of Ahmad Yasawī and his followers and imitators. ${ }^{23}$

We can also see the influence of Ahmad Yasawī on the Turkmen tribes, most of whom were nomads living in a vast area extending from Balkh and Herat to Astarābād between the Amu Darya and the Caspian Sea. These Turkmen, whose literature, given their social level, could be no more sophisticated than folk literature and whose primitive aesthetic needs were met by various kinds of folk poetry that was composed and sung by bakhshis, or minstrels \{saz poets\}, were long familiar with the Șûfì hikmats of Ahmad Yasawī and his followers, as well as with the Dede Korkut stories. In the work of the folk poet Makhdūm Qulī $\{1733$ ? - 82?\}, which they regard as quasi-sacred, the influence of Ahmad Yasawi is readily apparent - as Vambéry has quite rightly pointed out. This Naqshbandī dervish, who lived about a century and a half ago and wandered about 
Transoxiana and northern Iran with saz in hand, is considered even today to be the greatest Șūì poet of the Turkmen. Like the 'āshrqs of Azerbaijan and Anatolia, he composed poems of a very local character inspired from daily life. These described folk heroes and accounts of alaman, i.e. tribal warfare. In his Șūfì ethical poems, this poet shows exactly the same spirit and style as Ahmad Yasawī. He says that the world is transitory, that believers should strive basically for the hereafter, that his heart pounds with the love of God, and that he wants to accompany true dervishes who sing for God's sake. He tries to instill the need to worship God, to be pious, to avoid evil deeds, to acquire good habits, and other ethical principles - exactly the same things that are stressed in the Diw wan-i Hikmat. It is quite evident, therefore, that Ahmad Yasawī also exerted a strong influence on the folk poets of the Turkmen. ${ }^{24}$

Perhaps the least known linguistic and literary region of Turkish up to the present is that lying between Central Asia, where the great literary dialect that we call Chaghatay prevailed, and Asia Minor, where Seljuk Turkish was the dominant language. This middle region, which includes the area around Baghdad, Mosul, Diyarbakir, eastern Anatolia, and Caucasian and Iranian Azerbaijan, is where Azerī was used. This language very closely resembles the Anatolian, i.e. the Seljuk-Ottoman dialect. I believe that this later dialect came about as a result of the migrations caused by the Mongol invasion and the appearance of new ethnic groupings. We know that the earliest product of this dialect was the mystical poetry of the Șūfì Hasan-oğlu, who wrote before 700/1300 and won great fame not only in his own territory but also in Anatolia because of the dialectical similarity. ${ }^{25}$ Unfortunately, almost nothing of his poetry has survived. One can surmise, however, that this Turkish poet, who was well known for writing Persian Șūfi poetry, must have been preoccupied with the subject of Șūfism and, given his wide fame, must have written many hymns in the Yasawī manner and in the syllabic meter. We can definitely conclude that the türkïs of the famous Hasan-oğlu - if they in fact belong to him (we have no conclusive evidence if they can be attributed to him or not) - which the Ottoman biographers \{tezkireciler\} of the tenth/sixteenth century spoke of rather disparagingly, no doubt because they were written in the syllabic meter in imitation of folk poetry, reveal the contemporary influence of Ahmad Yasawī. ${ }^{26}$ This hypothesis gains even more credence if we take into account that the vestiges of folk literature and mythology maintained their vigor in this middle Azeri area from a very early period. ${ }^{27}$

I have expounded in detail above \{Chapter 2, pp. 31-5\} how and when the legends of Ahmad Yasawī spread to Anatolia and how Yasawī dervishes went there without interruption. The second half of my book is devoted to analyzing the rise and development of popular Șûfi literature among the Turks of Anatolia. A comprehensive account of Ahmad Yasawì's literary influence on the Western Turks is to be found there. Thus, there is no need to say anything about this subject here. When the history of the Sūfì movement among the Turks, i.e. the history of the tañqas, is more carefully studied, when many aspects of Turkish folk 
literature and Turkish ethnography that today are unknown become clarified through serious and detailed research, and when the history of Turkish literature, which even today is regarded as a virtual enigma by the scholarly world, is scientifically established and explained, then the widespread and long-lasting influence of this early Turkish Șūî on the entire Turkish world will be much better understood.

\section{NOTES}

1 \{It did not occur to Köprülü, or others, that the "imitations" were, in fact, the model, or even the stuff out of which the Dīwän-i Hikmat was created.\}

2 Prof. Hartmann, while speaking of the Chaghatay poet Chimyanlı Hüveydâ, says that Ahmad Yasawī provided all of Turkistan with spiritual fulfillment through the dīwān that he created, and he states: "If one considers that the death of the author of the Dīwān-i Hikmat occurred only a century after the composition of the Kutadgu Bilig, the importance of this book, which lives even today among his countrymen - almost 760 years after the death of the poet - is patently obvious" (\{ "Der caghataische Diwan Huwedas," $\}$ p. 133). In fact, all European scholars who have done research on Turkish history have more or less understood the importance of Ahmad Yasawī. According to Cahun's famous history, for example, "In the time of Tìmūr, Turkish gained the upper hand over Persian. The men of Transoxiana awakened and no longer wrote in Persian but in Chaghatay. Before them, Khwāja Ahmad Yasawī of Turkistan wrote in the popular language, but as can be seen from the historical works written by Juvaini, Rashīd al-Dīn, and Vașsâf on the order of Mongol princes, the language of the court and of science was Persian. However, after Khwāja Aḥmad Yasawī in particular, Turkish gained such importance that books of religious propaganda and edification like Mirrājnāme, 'Book of the Ascension' (1442), Bakhtiyārmāme, 'Book of Fortune' (1432), and Tadhkirat al-awliy $\bar{a}$ ', 'Attestation of the Saints' were written in the Uighur dialect and alphabet" (\{Introduction à l'histoire de l'asie, \} pp. 507-8). In like manner, Rambaud in the section that he wrote on the empire of Tìmūr for Histoire général \{prepared with Lavisse\} adds to this description the following view of Ahmad Yasawī, "Khwāja Ahmad Yasawī, who was the first and in my opinion the greatest of the Central Asian Turkish poets" (vol. 3, p. 967). For some reason, however, Cahun did not record this view in the history that he later published. Nevertheless, it will be well understood by readers of this book the extent to which, and the points on which, the information he gives is deserving of criticism. Kouznietsov tries to describe the status of Ahmad Yasawī, citing Cahun and Vambéry, in the following manner: "After the conquest of Central Asia, Turkish civilization began to develop in confrontation with the Iranians and reached its zenith during the reign of Tìmūr. This development, by first asserting the idea of Turkish nationality, goaded the country's intellectual life onto this path. In this respect, the Uighurs were also of assistance in that their influence in Central Asia had already begun at the time of Chingiz Khān. Alphabets derived from Christian sources were also used in the empire of Tìmūr and it was only in the middle of the fifteenth century AD that the Arabic-Persian script was able to hold its own. According to what Vambéry states in his History of Bokhara \{2nd edn (London, 1873; reprinted New York, 1973)\} (Chapter 11), in the second half of the fourteenth century AD, the Turkish national feeling revealed itself especially when the national language called Chaghatay was used in place of Persian as the official language. Translations and imitations of Arabic and, especially Persian, works appeared and became widespread. Chaghatay writers appeared along with the Uighur author \{Yūsuf Khāṣs Hājibib of the Kutadgu Bilig. The most famous of them were Khwāja Aḥmad Yasawī, the pīr of 
the city of Turkistan, Tīmūr himself, Muhammad Șāliḥ, 'Alī Shīr Nawā'̀̄, the founder of classic Chaghatay, Bābur, and Abū 'l-Ghāzī the Khān of Khiva" (La Lutte des Civilizations, pp. 75-6). It is quite natural that such general observations based on very superficial and rudimentary analyses would be for the most part erroneous. In fact, although the studies done on Ahmad Yasawī in Europe have been so superficial and, in a great many respects, erroneous, the Orientalists still succeeded in vaguely perceiving this subject, even if they did not definitely and clearly grasp the extent of the importance of Ahmad Yasawī, which neither our older nor younger historians and researchers have been able to understand. Barthold states that in addition to the studies and translations that have been done in Europe on Ahmad Yasawī, a Russian researcher named N. Lykoshin has translated \{into Russian\}, with annotations, some of his hikmats \{in "Premudrost' Khazrat-Sultana Arifin-Khodzh-Akhmada Iassavi (mogila ego v mecheti g. Turkestana)," Sbornik materialov dlia statistiki Syr-Dar'inskoi oblasti, 9 (1901), otd. II, in 76-105\} (\{mentioned in Barthold's\} "Russische Arbeiten über Westasien: Jahresbericht für 1901," Berlin Universität, Seminar für Orientalische Sprachen, Mitteilungen, Westasiatische Studien, $5\{1902\}$, p. 44).

3 There is an important point to be considered here. It is very likely that the hikmats of Ahmad Yasawi were collected not by him himself but by his dervishes somewhat later. Because he recited his hikmats not to exhibit skill and artistic talent but to instruct and guide, it is hardly possible that he attempted to collect them in the form of a dīwān. Most probably, because of the sacred character attributed to these works \{i.e. the hikmats\}, individual hikmats were later collected and then arranged and compiled into a dīwān, and it is for this reason that we cannot find an old copy of the Dīwān-i Hikmat. We shall see in the second part of this book that Yūnus Emre's dīwān was also created in this manner.

4 Cahun's view of this subject is worthy of note. According to him, "After cutting their ties with Chinese traditions ... and firmly adopting the orthodox Transoxianan church, the Central Asian Turks began a new life. After about a century, they became so imbued with Islamic philosophy, literature, and art that they became strangers to their native soil, unable to communicate with other Turks (who had not entered the Islamic millieu). ... In accepting Islam as the religion of state, the Turks of Turkistan, Transoxiana, and Khwārazm adopted it as a whole, without reflection, without discussion, militarily like a command. ... Thus, the renaissance in Central Asia was nothing more than the beginning again of the Middle Ages. While Europeans, under the lash of Hellenism and bedazzled by the rediscovery of Antiquity, set off boldly toward the unknown, to independent research and to revolution, the Asians (i.e. Turks), who up to the fifteenth century had been their equals, let themselves be led docilely to school, such as it was conceived by the doctors and scholars of the orthodox caliphate. They discovered, as something of a novelty, Aristotelian philosophy, which the Arabs had distorted (as if they had found something unknown). They came back to the Almagest and immersed themselves in the ideas of Ibn Sinnā, their countryman, and they began to relive in Turkish the Sāmānid period and marched in place. They spent their intellectual activities, which were by no means inferior to those of others, on scholasticism, jurisprudence, and rhetoric. With great effort, they revived Euclid, Ptolemy, Galen, and Hippocrates, only barely daring to touch on Plato. Going any further would have meant getting lost. Little by little, with the help of the monks (i.e. mystics), they came to think of nothing more than their salvation and contented themselves with the Koran and the compendia that it inspired.... The Turk had abdicated spiritually to his pir and temporally to his sultan" (\{Introduction à l'histoire de l'asie, $\}$ pp. 502-3). If we leave aside the numerous historical errors in these details, and the hasty generalizations, there is in fact a great amount of truth in what Cahun says. After the time of Tìmūr and his sons, the 
Central Asian Turks went continuously backward in a regressive movement. This decline is obvious in all aspects of their lives (for more information on this subject, see my article "Çagatay edebiyat,," $\dot{I} A)$.

5 Bāburnāme, among the events of 911/1505-6 \{see the Thackston trans., pp. 205-28\}. Noteworthy information is found on this matter in my article "Çagatay edebiyat,," $\dot{I} A$. \{See also Jo-Ann Gross and Asom Urunbaev, Letters of Khwäjah 'Ubayd Alläh Ahrār and His Associates (Leiden, 2002).\}

6 \{Such a statement betrays Köprülü's ignorance of Șūfì history in Central Asia after the fifteenth century. $\}$

7 \{Köprülü provides no evidence of this.\}

8 This important Turkish work, which was studied and published by Houtsma in 1889 based on the manuscripts in the Dresden and Berlin libraries \{ "Ein alttürkisches Gedicht" $\}$ and which was later published in a new edition prepared by Prof. Brockelmann, who made a thorough examination of it \{'Ali's Qissa'i fusuf\}, was written in a twelve-syllable meter with caesuras of $4+4+4$, just like the hikmats of Ahmad Yasawī, and dastān, i.e. quatrain, form just like his dastāns \{See $E I^{2}$, s.v. "Yūsuf and Zulaykhā," part 2, Turkish Literature (Barbara Flemming)\}. In this Islamic story, which was written to be recited among the people, it is quite natural that this important Șūfì poet remained faithful to the literary traditions that were so well suited to the popular taste. The syllabic meters, which were used by folk poets and Șūfiss until 'arüd and works in imitation of Persian poetry became common in the Turkish palaces and even after they had become common - were not employed by the poets of the upper class who composed artful poetry addressed to their peers. Among the Chaghatay poets of the ninth/fifteeth and tenth/sixteenth centuries, including 'Alī Shīr Nawâ' $\overline{1}$, who demonstrated in his Muhäkamat al-lughatain that he was a genuine nationalist, we find none who gave any value to the national meter, although the period can be considered one of national revival for the Eastern Turks. Only in the Dīwān of Zahīr al-Dīn Bābur \{MS in Köprülü's private library and partly published by him in "Zahiruddin Muhammad Bâbur Şah'ın 'Risâle-i vâlidiyye," MTM, 1 (1331/1915), 113-24, 235-56, 464-80, and 2 (1331/1915), 308-26; ed. Bilâl Yüce as Babür Divân (Ankara, 1995)\}, do we find one qit'a \{piece, composition\} and also one ghazal, with a syllabic stroph of $7+7=14$ - thus, in the national meter. As I stated in another work, with the exception of the tekke poets and the folk poets, i.e. the bakhshis ('äshrqs), who wrote hikmats and hymns, the national meter and national forms had long been abandoned among the Eastern and Western Turks alike and were always met by the scorn and ridicule of the classical poets. It is not possible to explain even briefly here the reasons for this and how long this view persisted ("Türk edebiyatında âşı tarzının menşe’ ve tekâmülü,” p. 26). \{Köprülü knows of the use of the 'arūd system by the Chaghatay poets of Central Asia in the fifteenth century, before Nawă $\overline{\overline{1}}$, but he wants to evict it from the tekkes and khānqāhs until Nawā'ì somehow installs it there. Thus, he has to declare the Chaghatay poets to be slavish imitators of Persian. Then he can explain (implicitly: he doesn't call attention to the fact) why Ahmad Yasawi is never mentioned as a poet, nor is verse by him cited, by these Chaghatay poets. An easier way to explain why those writers never mention verse by Ahmad Yasawī, or his status as a poet, is to assume that neither verse nor that status were yet known. Perhaps more remarkable than Köprülü's views on literary history is his apparent assumption that Persian and Turkic poets lived and wrote in utter isolation from one another. Why was it normal for popular Șūfì poets in Persian to know and use the 'arü d system, but not for popular Șūfì poets in Turkic? As for the poem written by a certain 'Alī, Ahmad Yasawî̀'s influence is "clearly seen" only through a supposedly shared meter and Ahmad Yasawī's presumed death prior to 'Alī's work.\}

9 For further information, see my article "Çagatay edebiyat,," $\dot{I} A$. 
10 For clear and detailed information on the bakhshi-ozans and their various functions in pre-Islamic Turkish life, see my "Türk edebiyatı'nın menşe'i," pp. 1-80. [See now Köprülü's "Bahşı," $\dot{I} A$, in which he corrects some of the conclusions he reached in this earlier article.] \{Actually, here in the narrative, Köprülü is projecting Anatolian circumstances onto Central Asia.\}

11 This phenomenon is encountered in almost the same fashion in the histories of all literatures. In Europe, for example, the priest-poets of the pagan period maintained their religious aura with the establishment of Christianity. Whatever stage of European history is studied, one sees that the poets called ménestrels were regarded by the people as having a sacred nature, and even their clothing preserved the fashion of a religious dress. Virtually all the most famous troubadours, equivalent to the 'ashrqqs, of those periods spent their lives in monasteries (Herbert Spencer, The Principles of Sociology, \{3rd rev. edn (New York, 1890)\}, vol. 5, Chapter 4, pp. 48-68, which discusses professional institutions). While discussing the bakhshi-ozans in the work mentioned above, I demonstrated that the same phenomenon is also encountered in our literature. For more information on this, see my XVI. asir sonuna kadar Türk sazşäirleri (Istanbul, 1930), and Türk sazşâirleri (Ankara, 1962), vol. 1.

12 This collection of the works of saz poets, which was called Bakhshi kitâbr \{the bakhshi book $\}$, is very rich and varied: in addition to a number of popular pieces, which were mainly current among the Turkmen and Özbeks, it also includes several pieces selected from the poetry of secondary poets, and even a large section drawn from the ghazals of Nawā'ì, which were very poorly known and appreciated despite their simplicity (Vambéry, Cagataische Sprachstudien, pp. 33-4.) \{This contains a small section from the Bakhshi kitâbr, pp. 132-43, and three of Nawā'î's ghazals, pp. 177-80.\} Such collections, which also included a great many pieces from Azerī poets like Fudū̄ī and Nesīmī, were indeed highly varied and were arranged according to the taste of the compiler. Because the literary relations between the Central Asian Turks and Azeri Turks had long been very strong and close, it is quite natural that these two great Azerī poets were so well known that they were regarded as native poets in Central Asia as well as in Anatolia. Considering that there were intellectual and literary relations of long standing among the different regions of the Turkish world for example, the ties between Herat and Istanbul during the reign of Mehmet II and among the courts of Khurāsān, Iran, India, and Istanbul during the reign of Süleyman the Magnificent - it is quite evident that the history of Turkish literature can only be studied as a whole.

13 The research that has been done to date on these poets is, of course, very little and deficient. Hartmann's studies on Chimyanlı Huvaidā ‘"Der čaghataische Diwan Huwedas"\} and \{Bābā Rahīm \} Mashrab \{this is a reference to Hartmann's article "Mešreb der weise Narr und fromme Ketzer: Ein zentralasiatisches Volksbuch," Der islamische Orient, vol. 5 (Berlin, 1902); Mashrab d. 1711\}, for instance, are naturally very deficient, because some of their biographies have meanwhile unfortunately been completely forgotten. The studies on them done by certain Russian scholars, and especially the important research published by Prof. A. N. Samoilovich as "Materialy po sredneaziatsko-Turetskoi literature," \{ZVO, 19 (1909), 1-30; 22 (1913-14), 12753; ZKV, 2 (1927), 257-74\} are inaccessible to me. It is therefore apparent that, given the scanty material that we currently possess, it is impossible to make critical analyses of the Central Asian poets in the post-Nawā'i period. In order to do a proper study of these Central Asian Turkish poets who flourished after the Shibānids, it would be necessary to do research in Turkistan and to make use of Russian sources on this subject. The most extensive and reliable information on this subject was first collected in my article "Çagatay edebiyat,", $\dot{I} A$, nnow see H. F. Hofman, Turkish Literature, a Bio-bibliographical Survey. For discussion of some of the names to which poems found in 
versions of the Dīwān-i Hikmat are ascribed, see A. Saadi, "Novyi material po istorii tatarskoi literatury drevnei èpokhi," Vestnik nauchnogo obshchestvo tatarovedeniia, no. 7 (1927), p. 154; Borokov, "Ocherki," p. 236; Togan, Yesevîliğe dair bazı malûmat," in Fuad Köprülï armağam, pp. 523-9; and Hofman, Turkish Literature, vol. 6, pp. 124-5.\}

14 The historian Zeki Velidi Togan, who was sent by the Russian academic societies to Turkistan to carry out historical research about a year before the First World War, mentioned this important poet in a letter that he sent to me from there. Unfortunately, we know nothing apart from this about this poet and his work.

15 The Rashahät actually says he left "sayings," not works.\}

16 The Rashahät gives the following details on this matter: Dervişler ahvâlinden Türkî dilde kelimât-ı hikmet-âmiz ve latâif-i ibret-engîzleri Türkistan vilâytinde ma' rûf ve meșhûrdur ve ânlarn fevâid-i enfâs-i kudsiyyelerindendir. Bu mesel ki halka hüsn-i zan ile hürmet ve her vakti ganîmet bilmek bâbında buyurmuşlardır ki: Her kimi görsen Hizır bil ve her geceyi Kadir bil ve bu mesel ânlara mensûptur ki 'kesr-i nefs' te buyurmușlardır: Barca yahșı biz yaman / Barca buğgay biz saman, yani Cümle yahş biz yaman / Cümle buğday biz saman. \{His words mixed with wisdom and anecdotes pointing to lessons about the conditions of the dervishes are well known and famous in the Turkish language in the country of Turkistan and are among the beneficial products of his sacred breath. He uttered this pithy saying with respect to honoring the people highly and always regarding them as a Godsend: "Know that everyone you meet is Khadir, and every night is the Night of Power." And this pithy saying, which concerns mortification of the flesh, is also attributed to him: "All is good, we are bad / all is wheat, we are straw" (Rashahät, \{Turkish\} trans., pp. 15-16).

17 The work that has long been known among the Northern Turks under the title Bâqirghân kitâbr was first published by the Kazan Academy in 1857. \{Now edited by Ibrahim Häqqul and Säyfiddin Räf'iddin (Tashkent, 1991).\} It is composed of eighty-six pages, each of which has a double column of text. On each page are an average of fifty lines of verse. As for the text that was published by the same press in $1301 / 1883-4$, it is composed of 144 pages, each with an average of twenty-six lines of verse. There are also other editions of this work. At the end of the first edition, there are two rather long narratives written in the form of a mathnawe and in 'arüd. The author of one is 'Ubaid Allāh and the other has the pen name Khatạa'ì. In this collection, there are countless Șūin poems in both the 'arüd and syllabic meters belonging to a great many people. Those belonging to Sulaimān Bāqirghānī constitute the smallest portion. The others belong to various poets such as Rājī, Mashrab, Khwāja Aḥmad, Shams-i Özkendī, Qūl Sharīf, Khudāidād, Īqānī, 'Ubaid̄̄, Faqī̄ī, Baiḍā, Bihbūdī, Shuhūdī, Qūl Sharafī, Gedā, Qūl Nasīmī, Țufailī, and Qāsim. The works of Shams-i Özkendī are perhaps the most numerous. It is thus quite obvious that the Bâqirghân kitâbr, like the Dìwān-i Hikmat, is not the work of a single poet and is not an accurate and trustworthy text. The poems of Sulaimān Ata, like those of his shaikh, survived for a long time scattered in the anthologies of dervishes or in the popular memory, then were mixed with the works of a number of other popular Șūfìs, and finally this very confused material was attributed to Hakīm Sulaimān Ata and printed under the title of Bâqirghân kitâbı. It would have taken very little effort when the work was printed to distinguish and group together the works of the poets having various pen names. Just as the anthologies of 'äshrqs, called bakhshi kitâbl, are a hodge-podge, so this book too mixes the works of several discrete Șūfì poets. \{See $E I^{2}$, s.v. "Hakīm Ata" (Günay Alpay). As mentioned earlier, the inescapable conclusion is that Hakim Ata is ascribed poetry much earlier, and much more consistently, than is Ahmad Yasawī. And we find verse attested to Hakīm Ata quite early on that is subsequently ascribed to Ahmad Yasawī.

18 Cemalü'd-Dîn Velidî Efendi, in his short treatise Tatar edebiyatinnn barnşı, briefly mentions Bâqirghân kitâbr as the oldest Tatar work, but the views that he advances are 
completely subjective and the information that he gives is also very deficient and erroneous. For example, he is wholly ignorant of the information provided on Hakim Sulaimān Ata in the famous \{anonymous\} Hakìm Ata kitâbr and also \{Ṣafì's\} Rashahāt, and he hardly even considers the fact that the works in Bâqirghân kitâbr were written by men with different pen names. Considering that the author lacks the most elementary notion of criticism, one cannot ascribe any scientific value to this simplistic book, which contains almost nothing of historical value ([Orenburg, 1912], pp. 87-9).

19 This work MSS in the Ali Emiri Efendi Library, which is in the Fatih Millet Library in Istanbul, and in the British Museum $\}$, and which was written in $754 / 1353-4$ by a Turkish poet named Khwārazmī, in imitation of the Epistles \{nāmes\} in mathnaw $\bar{\imath}$ style composed by poets like Hakīm Sanā'̄ and 'Atțār, is linguistically Chaghatay. It was dedicated to a certain Muhammad Khwāja Big, who had an important position in the retinue of the famous Jāni Big, the ruler of the Golden Horde, and who was from the Qunğrat tribe. Rieu states in his catalogue \{of Turkish MSS in the British Museum that this person was the ruler of Andkhūd, Shībirghān, and Balkh and that he was the Amīr Muhammad Khwāja Apardī who was killed while fighting Malik Mu'izz al-Dīn Husain Kart in 759/1357-8 (\{Khwāndamīr,\} Habīb al-siyar, vol. 3, p. 75), but I cannot accept this opinion. In my view, if one considers his youth, his connection with Jān $\mathrm{i}$ Big and that he was from the Qunğrat tribe, it is certain that this person was Khānizāde Muḥammad Khwāja Big (Mehmed Remzī, Talfĭq al-akhbār . . . \{renburg, 1325/1907\}, vol. 1, pp. 555-6), who fled during the sultanate of Jānī Big's son Birdī Big Khān (758-62/1356-61), went to the court of Ivan the Terrible in Moscow and presented himself as though he had come on a special mission from the Khān (for more information on this matter, see my article "Osmanlı edebiyatının başlangıcı," YM, 3 [1918], 85-8). The Mahabbatname, which was written in a period when one finds numerous Turkish works throughout the Turkish world, is of special importance because it shows that in the eighth/fourteenth century such works were created under the patronage of the Turkish khans and princes in the realm of the Golden Horde, and that they were written in the Chaghatay dialect, which was accepted as a common literary language in the Turkish courts of Transoxiana, Khurāsān, 'Irāq al-'Ajam, Fars - in short, throughout Asia. The creation of a common literary language and its rapid development in the other areas of the Turkish world - except for Anatolia and Azerbaijan - already by the mid eighth/fourteenth century, is not such a mysterious event. While it is impossible to give even a brief explanation of this event here, we can consider it to be one of the many consequences of the Mongol invasion, which gave rise to massive migrations in Asia, unified the Turks in different regions under the same political rule, and established permanent bonds among them. One must also remember, however, that this literature appeared as a court literature in regions where the people had no connection with Turkishness and in a realm where only the rulers and military commanders were of Turkish origin. In a letter that he wrote to me shortly before the First World War, Togan informed me that Prof. Samoilovich had found and prepared for publication the poem Khusraw-u Shìrn, written in "Uighur" by a poet with the pen name Qutb in Egypt in the eighth/fourteenth century. What is meant here by "Uighur," since this work is a product of the eighth/fourteenth century, must be Chaghatay, which was the common literary language of that period. It is also possible that this Chaghatay work was written in the Uighur alphabet. When we take into consideration the fact that the rulers of Egypt had permanent ties and relations with the Golden Horde, this would not be surprising. In addition to this work, a great many others were also written in Egypt in the Anatolian dialect. On this subject, see my study Türk edebiyatı tarihi (Istanbul, 1928), "Memlûklar devri'nde Türk lisan ve edebiyat," pp. $366 f f\{=$ Chapter 13, Part 4 of the 1981 edn $\}$. \{Now see A. M. Shcherbak, Oguz-nāme. Mukhabbat-nāme (in Russian) (Moscow, 1959); Ananiasz 
Zajaczkowski, Najstarsza wersja turecka Husräv u Š̆rīn Qutba (Warsaw, 1958-61); and M. Necmettin Hacıeminoğlu, Kutb'un Husrev ü Şirin'i ve dil hususiyetleri (Istanbul, 1968).\}

20 On the first folio of a small but important work entitled Hikāyat-i jumjuma sulțān, which was translated into Turkish in 955/1548-9 on the order of Șāhib Girāy b. Hājjī Girāy, it is written that this book was composed in the "Moghul" language by Husām Kātib in $777\{1375-6\}$ and that Șạhib Girāy Khān found it in his library and had it translated into Türkī, i.e. Ottoman Turkish (from a unique copy in my private library). Unfortunately, for some reason, the name of the translator is not mentioned. In my view, what is meant here by "the Moghul language" must be the Chaghatay or the Qipchaq dialect because our Ottoman authors of the ninth/fifteenth and tenth/ sixteenth centuries readily called Chaghatay by various names: "the language of Nawā' $\overline{1}$, the Tatar language, Türkī language, and Moghul language" (see "\{Türk edebiyatında\} âşı tarzının menşe” ve tekâmülü," $M T$, p. 7, n.1). We understand from a short poem about 'Alī-Shīr Nawā'ì by the famous Șādiqī Kitābdār, author of the Tadhkira nno. 168 in Pertsch's catalogue of Turkish MSS \}, that the Azerīs also called Chaghatay "Moghul." There is a possibility that the work of Husām Kātib, or, to use the old expression, Husām Bakhshi, was a popular work written in the Qipchaq dialect because of its vulgar nature, but it is much more likely that this is a poem in Chaghatay, perhaps written in the Uighur alphabet. \{Now see Fevziye Abdullah Tansel, "Cümcüme Sultan: Ottoman Translations of the Fourteenth Century Qipchaq Turkic Story," Archivum Ottomanicum, 2 (1970), 252-69; Ia. S. Akhmetgaleeva, Issledovanie tiurkoiazychnogo pamiatnika 'Kisekbash kitaby' (Moscow, 1979); Ahmed Yaşar Ocak, Türk folklorunda Kesik Baş (Ankara, 1989); and Michele Bernardini, "Solțan Jomjome et Jesus le Paraclet" in Benjamin Lellouch and Stéphane Yerasimos (eds), Les traditions apocalyptiques au tournant de la chute de Constantinople (Paris, 1999), pp. 35-53.\}

21 Ibn al-Dawādārī, in his very valuable work Tàn rikh-i mukhtasar, states that the Mongols and Qipchaqs had a highly respected book entitled Ulu Khän Ata Bitigcī, and that it was of the nature of the Oghuznāme of the Oghuz, i.e. this book included a great many traditions and legends about them. Just as the ozans of the Oghuz sang, accompanied by the kopuz, of the legends of the Oghuzname among the people, the bakhshis of the Qipchaqs also sang, with kopuz in hand, of the legends found in their own collections of traditions (Damad Ibrahim Pasha Library \{in the Süleymaniye Library in Istanbul\}, MS 913). \{See U. Haarmann, "Turkish Legends in the Popular Historiography of Medieval Egypt," in Proceedings of the VI Congress of Arabic and Islamic Studies . . 1972 (Uppsala, 1975), 97-107.\} The traveler Ibn Bațutta, who visited the country of the Golden Horde at the beginning of the eighth/fourteenth century, says that, after eating, verses from the Koran were read and there was singing in Arabic, then singing in Persian and Turkish was promptly begun and these were called mulamma \{"macaronics," half in one language and half in another\} (Ibn Bațūța, \{Turkish trans., \} vol. 1, p. 365 \{Gibb trans., vol. 2, p. 477\}), but as will be easily understood from this word, these mulamma's were not, of course, popular works. It is also possible, however, that what Ibn Batțūta says were sung during the sultan's \{i.e. Muhammad Özbeg Khān of the Golden Horde $\}$ holiday celebrations were popular Mongol works (ibid., \{Turkish trans., \} p. 382 \{Gibb trans., vol. 2, p. 496\}).

22 Cemâlü'd-Dîn Velidî Efendi, Tatar edebiyatınn barnşı, p. 87. Because the history of the literature of the Northern Turks, and this area in general, is unknown, it is not possible to determine when this began.

23 Cemâlü'd-Dîn Velidî Efendi's aforesaid work, despite its non-scholarly nature, adequately conveys this conviction. Closer study of the literature of the Northern Turks only corroborates it.

24 Vambéry first mentioned the Turkmen poet Makhdūm Qulī in his famous travel book (Voyages d'un faux derviche dans l'Asie centrale de Téhéran à Khiva, Bokhara et Samarkand, 
French trans., 2nd edn [Paris, 1873], p. 283 \{English trans. as Travels in Central Asia (London, 1864; reprinted New York, 1970)\}). Vambéry, who briefly discussed the poetry of this Turkmen poet in his Cagataische Sprachstudien, p. 36, later published selected passages from it with a German translation. Among Russian scholars, Ostroumov published some of his poetry and Samoilovich prepared an index \{fihrist $\}$ of it. Togan informed me before the First World War that Samoilovich had prepared a complete edition of his dīwān. In any case, as is clear from all of this, Makhdūm Quli is someone who has long been familiar to the Orientalist world. \{See, $E I^{2}$, s.v. "Makhdūm Kulī" (H. F. Hofman); and Walter Feldman, "Interpreting the Poetry of Mäkhtumquli," in Jo-Ann Gross (ed.), Muslims in Central Asia: Expressions of Identity and Change (Durham, NG, 1992), pp. 167-89. The evidence that Köprülü gives for "influence" is so general as to ensure that Ahmad Yasawī influenced anyone we wish.\}

25 This Turkish poet named Hasan-oğlu is the famous Șūī Shaikh 'Izz al-Dīn Pūr-i Hasan Isfarā'in̄̄. A brief extract from one of his ghazals is included in Dawlat-Shāh's Tadhkira

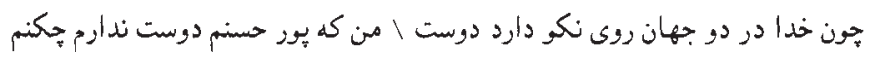

\{Because God likes beautiful faces in both the worlds / No one likes me Pūr-i Hasan. What can I do?\} This poet from Isfarā'in was one of the leading disciples of Shaikh Jamāl al-Dīn Aḥmad Dhākir \{Gūrpān̄î, who was a khā̄̂fa of Raḍī 'l-Dīn 'Alī Lālā. He wrote poetry in Turkish under the pen name Hasan-oğlu and in Persian under the pen name Pūr-i Hasan and, according to Dawlat-Shāh's account, won very great fame in Azerbaijan and Anatolia (Dawlat-Shāh, Tadhkira, p. 221). I provided some information above on the great Șūfì Shaikh Raḍi 'l-Dīn 'Alī Lālā and stated that he died in 642/1244-5 (Chapter 3, p. 62). In light of this explanation, it would not be wrong to conclude that the poet Hasan-oğlu, who was a disciple of this shaikh, won fame during the end of the seventh/thirteenth century or the beginning of the eighth/ fourteenth century. For some reason, this very early Azerī poet has not yet attracted anyone's attention. \{See Hermann Landolt (ed.), Nûruddîn Abdurrahmân-i Isfarâyinî, Le Révélateur des mystères (Kâshif al-Asrâr) (Paris, 1986), pp. 19-21 (text), 147-9 (trans.); and one of his Turkic ghazals has been published by A. Bodrogligeti, "A Collection of Turkish Poems from the 14th Century," Acta Orientalia Academiae Scientiarum Hungaricae, 16 (1963), pp. 256, 279, 291-2.\}

26 'Āshıq Chelebi, the author of the Tadhkira \{i.e. Mashā'ir al-shu'arä'\} explains, while mentioning the musician poets Maqāmī and Selmān Bursawī, that the türküs of Hasan-oğlu were very well known during his own \{i.e. 'Āshıq Chelebi's \} lifetime. However, given the long gap in time between them, it certainly would be strange if the türküs of this Hasan-oğlu, whom 'Ashıq Chelebi mentions, belonged to Shaikh 'Izz al-Dīn Pūr-i Hasan Isfarā’inī. \{See Meredith-Owens's facsimile edn of 'Āshıq Chelebi's Mashā'ir al-shu'arä', fos 126a.24, 161b.3.\}

27 The people of the linguistic area that we term Azerī - i.e. the Turks of Azerbaijan and Eastern Anatolia - preserved their old traditions much more vigorously because new waves of Turks migrated there after the original Turks of Asia Minor, i.e. after the Mongol invasion. In the second part of this book, I will provide a comprehensive discussion of the Oghuz migrations to the West and the time, strength, and intensity of these migrations. Consequently, there is no need to go into further details here. Even before the appearance of the Seljuks, a number of Oghuz tribes migrated to those regions and some of the Oghuz whom Sultan Mahmūd Ghaznawī sent from Transoxiana to Khurāsān later went there and joined them. Subsequently, in the period of the Seljuks and Khwārazm-Shāhs more groups of Turks again migrated to 
those regions and settled there. When we recall that after the Mongol invasion, during the time of the Il-Khānids, still more Oghuz tribes migrated there and commingled, then we can begin to get an idea of the ethnographic nature of this Azerī region. Almost all the Turks who went to this area were from the Oghuz, i.e. of the Turkmen type. The fact that the locus of events in the Book of Dede Korkut (in the text currently in our possession) is Eastern Anatolia and Azerbaijan confirms the views asserted above. Moreover, a slight acquaintance with the folk literature of that area would also confirm this point. Indeed, in every respect, the folk literature of that region is much richer and more genuine than that of Western Anatolia and Rumelia. As ethnographic research progresses, these subjects will be better illuminated. 



\section{Part II}

\section{YŪNUS EMRE AND \\ HIS INFLUENGE ON TURKISH LITERATURE}




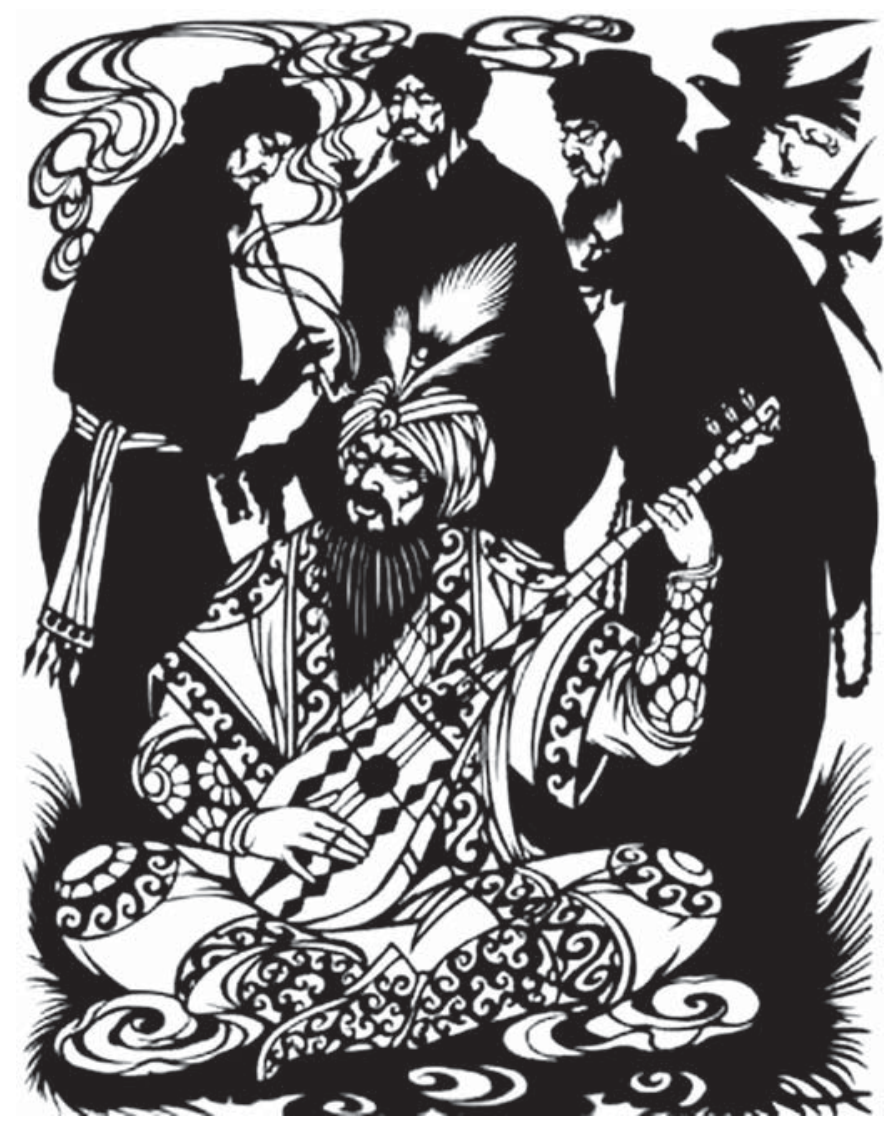




\section{7 \\ TURKISH LITERATURE \\ IN ANATOLIA BEFORE \\ YŪNUS EMRE}

\section{A The Turks in Anatolia}

In the first part of this book (Chapter 1, pp. 5-6, through Chapter 5, pp. 131-3), I provided some information on the Oghuz, who constituted a large and important branch of the Turks, and their language. Coming out of the East like an inexhaustible human flood, the Turks, who thoroughly Turkified Anatolia within a few centuries under the resolute government of the Seljuk rulers, were composed entirely of Oghuz. Consequently, before we describe in broad outline the Seljuk political structure and civilization that were established in Anatolia, it is necessary to give a bit more historical background on the Oghuz.

By the time of the reign of the 'Abbāsid Caliph al-Mahdī (158-69/775-85), the Oghuz Turks had separated from the Toquz Oghuz in Eastern Turkistan, and by the fourth/tenth century they were living in the Syr Darya region and had begun to convert to Islam. ${ }^{1}$ Around the end of that century, as the Oghuz began to migrate into Muslim territory, they first settled near Bukhārā. It was among the Oghuz that the Seljuk dynasty appeared and quickly extended its influence into the vast areas ruled by the Ghaznavid state and various minor powers. Eventually, a huge and powerful Seljuk state arose that controlled the area stretching from Chinese Turkistan to Egypt and Byzantium. This great sultanate enjoyed its most brilliant period between the reigns of Toghrll Bey (d. 455/1063) and Malik-Shāh (d. 485/1092). Subsequently, it dissolved into a number of independent states in Khurāsān, 'Irāq al-'Ajam, Kirmān, Aleppo and Damascus, and Anatolia. During the reign of Sultan Sanjar (d. 552/1157), some of the brilliance reminiscent of the earlier period returned, but it lasted only a short time. The branch of the dynasty that survived the longest was that of the Seljuks of Anatolia, because it was based on the true power of the state, the local people, while the other branches relied exclusively on the ruling family, the tribal chiefs, and the army. It is not that there were no Oghuz Turks in Khurāsān, 'Irāq al-'Ajam or Aleppo, but in Khurāsān and 'Irāq al-'Ajam in particular they were fated to assimilate gradually with the local people, or, at the very least, to assume their culture. Anatolia and Azerbaijan, on the other hand, became Turkish countries as a result of large and continuous migrations of the Oghuz tribes and 


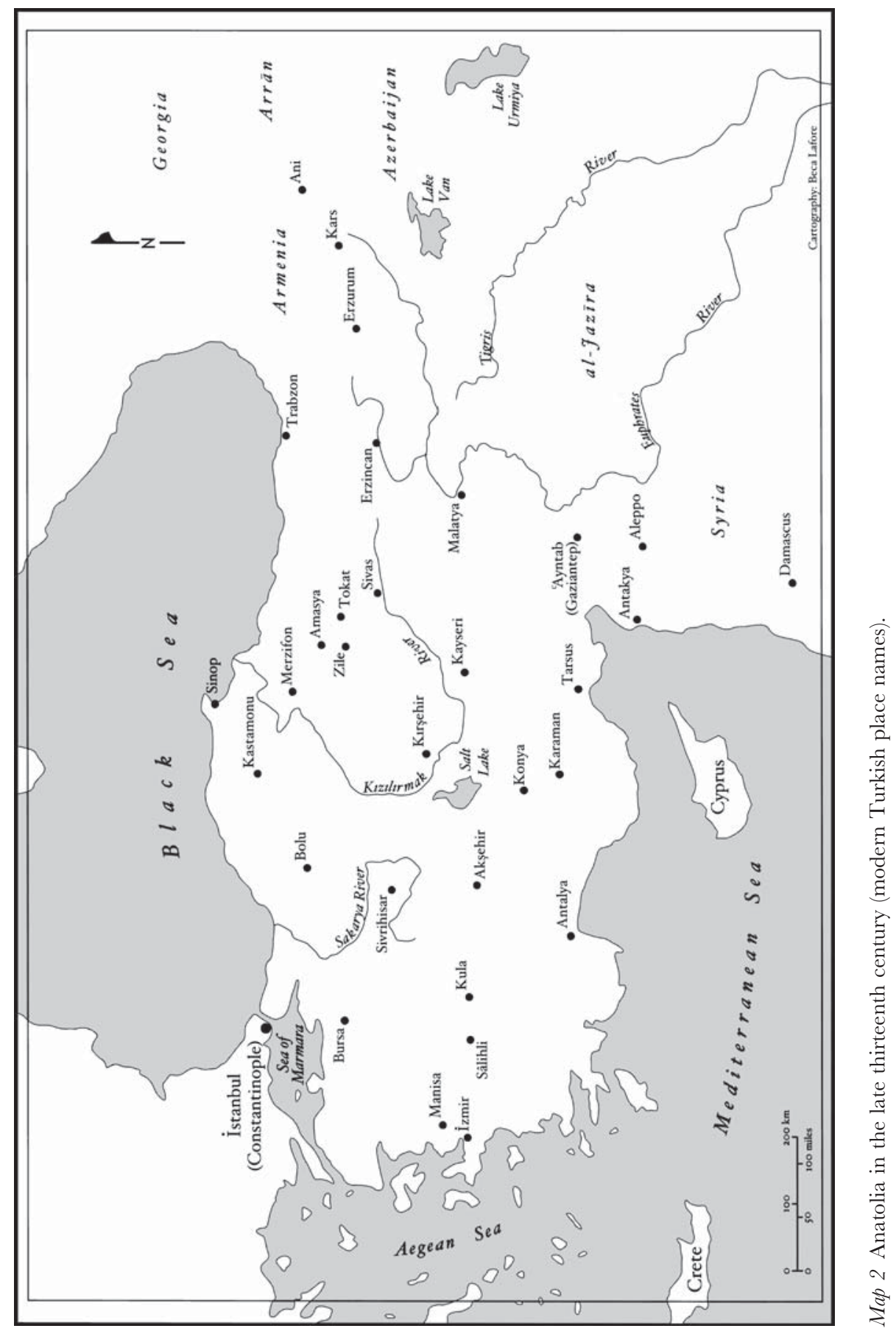


thus, despite all the political turmoil that took place, these regions became a new center of civilization for the Turks, and the Oghuz settled there permanently. ${ }^{2}$

Even before the appearance of the Seljuks, i.e. in the early years of the fifth/ eleventh century, some Oghuz tribes from Transoxiana had moved to Azerbaijan and the southern Caucasus and settled as a rather powerful presence on the frontier of the Byzantine Empire. Reinforced by some of the Oghuz whom Maḥmūd of Ghazna had transferred from Transoxiana to Khurāsān, this quarrelsome mass of Turkmen did not hesitate to attack Byzantium on occasion. Finally, just when the Seljuk state was establishing itself in Iran, Toghril Bey received a request from these Turkmen for assistance and so sent Qutalmish, one of his kinsmen, with an army against the Byzantines. Later, in order to rid himself of some Oghuz tribes who had come to Khurāsān, Toghrıl Bey also sent them, under the leadership of his brother İnal, toward the interior of Anatolia to confront the Byzantine Empire.

During the sultanate of Alp Arslan (455-65/1063-73), the Seljuks took more effective action in Anatolia. By capturing the fortresses of Ani and Kars and seizing an important part of Georgia, this ruler put an end to Byzantine rule in Armenia and Georgia. He then decisively defeated the Byzantine Emperor Romanus Diogenes at the Battle of Malāzgird $\{1071\}$ and took him prisoner, thus firmly establishing Turkish sovereignty in Anatolia. Afterward, he granted, as tamlīks \{state-owned land as freehold property\} and $i q t \bar{t}$ 's \{estates, land grants\}, all the lands of eastern Anatolia as far as the Kizıl Irmak to the leaders of the Turkmen tribes that had long been guarding the Byzantine borders. In this way, the first Turkish states were established in Anatolia, those of the Saltuqids, Mengüchekids, and Dānishmendids. They were followed by those of the Seljuks of Anatolia during the reign of Malik-Shāh, and of the Akhlāt-Shāhs during the reign of Berk-Yaruq. The most powerful and enduring of all these Turkish states was that of the Seljuks of Anatolia, which played the greatest role in the Turkification of Anatolia. ${ }^{3}$

The independent state of the Seljuks of Anatolia, which arose in Asia Minor during the dissolution of the Great Seljuk Empire after the death of Malik-Shāh, was based on a fairly sound foundation. While migrating westward in a continuous human flood from their homeland, the Oghuz Turks had come into close contact with Persian and Arab civilization, and then, mainly after the Battle of Malāzgird, settled down in Anatolia. Spreading their language, their religion, in a word their culture, they posed a constant threat to the Armenian and Byzantine rulers. Despite the attacks of the Crusaders and endless harrassments by the Greeks and Armenians, Anatolia continued to be Turkified. Thanks to a powerful army, the state of the Seljuks of Anatolia, which drew its strength mainly from the Oghuz clans, caused its neighboring Muslim and Christian states to live in a constant state of fear. Around the end of the sixth/twelfth century, however, Qilij Arslan II divided his kingdom among all of his sons according to the old Seljuk custom. This division of a great power into eleven petty and mutually hostile principalities precipitated a civil war. Eventually, Sultan Rukn al-Dīn Qāhir \{i.e. Sulaimān II 
(592-600/1196-1204)\} succeeded in re-establishing political unity after devoting his life and all his resources to this endeavor. Still, the constraints of the political system and the vagueness of the law of succession were permanent obstacles to the attainment of long-lasting prosperity and well-being for the Turks of Anatolia. The endless struggles for succession and the rumbles of independence provided opportunities for the Greeks and Armenians to rebel. They would drive out the Turks from a neighboring region, but shortly thereafter, confronting a Seljuk sultan who had established his authority over that region, they would be utterly defeated and make peace under harsh terms. In short, despite all these internal disorders, Turkish sovereignty in Anatolia proved enduring. ${ }^{4}$

During the reign of 'Alā' al-Dīn Kai-Qubād I (616-34/1220-37), which we can consider to be the high point, in every respect, of the era of the Seljuks of Anatolia, all of the minor principalities that were \{theoretically\} subject to the Seljuks were forced into obedience and submission. Nevertheless, this wise ruler realized that he could not resist the power of the Mongols, who just at that time were coming from the east like a terrible whirlwind. He formally recognized the authority of the Great Il-Khān and then made a great effort to suppress internal troubles and repel several attacks by Jalāl al-Dīn the Khwārazm-Shāh. During the reign of this prudent ruler, who brought all of Anatolia under his well ordered government, repulsed attacks from abroad, and also took political measures against the danger of the Mongol invasion, the Turks of Anatolia enjoyed great prosperity. Strong walls were erected around the great cultural centers of Konya, Sivas, and Erzincan. Mosques, türbes, madrasas, khāns, and caravansaries were built throughout Anatolia. Thanks to the correct and far-sighted policy of 'Alā' al-Dīn, the people, who, up to that time, had not been able to escape from domestic turmoil and whose lives and property were continuously threatened by aggressive armies, finally enjoyed security and prosperity. As a result, life in the great cities became refined. Aesthetic sensibility and the fine arts, which are its natural product, developed. Not content with creating a just, strong, and well ordered political structure, 'Alā' al-Dīn also gathered around him scholars and men of letters. Altogether, he was an intelligent, prudent, and skillful ruler and patron of the arts. ${ }^{5}$

'Alā' al-Dīn was killed by his son Ghiyāth al-Dīn Kai-Khusraw \{634-44/ 1237-46\} when the latter realized that the sultanate of Anatolia was going to be given to his younger brother. Upon his ascent to the throne, the previous prosperity and well-being in Anatolia abruptly disappeared. The Great Il-Khān did not approve of the murder of 'Alā' al-Dīn and dispatched Bayju Noyon, with a powerful army, ostensibly in order to administer the provinces of Anatolia. Domestic affairs were again thrown into confusion. As if the struggle for succession, the uprising of Bābā Ishạaq, the disgraceful actions of a majordomo named Sa'd al-Dīn Köpek, the intrigues of the rulers of Egypt, and the provocations of the Byzantines and Armenians were not enough, the Mongol invaders captured Erzurum, Tokat, and Kayseri, and repeatedly defeated the armies of Ghiyāth al-Dīn. These continuous military operations violently disrupted the peace and 
tranquility of the people, and oppression and poverty prevailed in place of prosperity and well-being. After Ghiyāth al-Dīn, life in Anatolia became almost unbearable for the people. His three sons sometimes ruled individually, or sometimes two or three ruled together. Amidst domestic troubles and Mongol and Byzantine incursions, the country soon fell into confusion and ruin. The people groaned under the hands of oppressive and tyrannical officials. The need to obtain the taxes that had to be given to the Great Il-Khān seemed to license every abuse. There appeared to be almost nothing left of the central government. Finally, after the execution of 'Alā' al-Dīn Kai-Qubād III on the order of Ghazan Khān, the political unity of Anatolia was completely destroyed. Upon the collapse of the Seljuk state, which had lasted from 470/1077 to 707/1307, ten small principalities arose in its place and anarchy prevailed. Not until one of these principalities, that of the Ottomans, united the Western Turks around a \{new $\}$ political center did a new era of peace and prosperity return to Anatolia. ${ }^{6}$

\section{B Seljuk civilization}

\{As they emigrated to the west, \} the Oghuz Turks who settled in Anatolia came into contact with Arab and Muslim Persian civilization and then, in the new region to which they had come, encountered remnants of ancient and non-Muslim civilizations. In the large and old cities of Anatolia, which were gradually Turkified, the Turks not only encountered earlier Byzantine and Armenian works of art and architecture, but also, as a result of living side by side with Christians, naturally participated in a cultural exchange with them. The nomadic Turks \{i.e. Turkmen\}, who maintained a tribal existence and clung to the way of life they had led for centuries, remained impervious to all such influences. Those who settled in the large cities, however, unavoidably fell under these alien influences.

At the same time, among the city people, those whose lives and livelihoods were refined and elevated usually had extensive madrasa educations and harbored a profound and genuine infatuation with Arab and Persian learning and literature. Thus, they cultivated a somewhat contemptuous indifference to this Christian civilization, which they regarded as materially and morally inferior to Islamic civilization. As a result, the influence of this non-Muslim civilization on the Turks was chiefly visible, and then only partially, in those arts, such as architecture, in which the external and material elements are more obvious. The main result of this influence was that life in general assumed a more worldly quality.

If we wish to sketch, in broad outline, the civilization created by the Seljuks of Anatolia, we must recognize that the local, i.e. non-Muslim, element was fairly insignificant compared to the Turkish and Arab-Persian elements, and that the Persian element was paramount. ${ }^{7}$ The Seljuk rulers, to be sure, who were in contact with not only Muslim Persian civilization, but also with the Arab civilizations in al-Jazīra and Syria - indeed, with all Muslim peoples as far as India also had connections with \{various\} Byzantine courts. Some of these rulers, like 
the great 'Alā' al-Dīn Kai-Qubād I himself, who married Byzantine princesses and thus strengthened relations with their neighbors to the west, lived for many years in Byzantium and became very familiar with the customs and ceremonial at the Byzantine court. Still, this close contact with the ancient Greco-Roman and Christian traditions only resulted in their adoption of a policy of tolerance toward art, aesthetic life, painting, music, independent thought - in short, toward those things that were frowned upon by the narrow and piously ascetic views of their subjects $\}$. The contact of the common people with the Greeks and Armenians had basically the same result. ${ }^{8}$

\{Before coming to Anatolia,\} the Turks had been in contact with many nations and had long shown their ability to synthesize the artistic elements that they had adopted from these nations. When they settled in Anatolia, they encountered peoples with whom they had not yet been in contact and immediately established relations with them as well. 'Alā' al-Dīn Kai-Qubād I established ties with the Genoese and, especially, the Venetians at the ports of Sinop and Antalya, which belonged to him, and granted them commercial and legal concessions. ${ }^{9}$ Meanwhile, the Mongol invasion, which caused a great number of scholars and artisans to flee from Turkistan, Iran, and Khwārazm and settle within the Empire of the Seljuks of Anatolia, resulted in a reinforcing of Persian influence on the Anatolian Turks. ${ }^{10}$ Indeed, despite all claims to the contrary, there is no question that Persian influence was paramount among the Seljuks of Anatolia. This is clearly revealed by the fact that the sultans who ascended the throne after Ghiyath al-Dīn Kai-Khusraw I assumed titles taken from ancient Persian mythology, like Kai-Khusraw, Kai-Kā’ūs, and Kai-Qubād; and that 'Alā' al-Dīn Kai-Qubād I had some passages from the Shähname inscribed on the walls of Konya and Sivas. When we take into consideration domestic life in the Konya courts and the sincerity of the favor and attachment of the rulers to Persian poets and Persian literature, then this fact \{i.e. the importance of Persian influence\} is undeniable. ${ }^{11}$ With regard to the private lives of the rulers, their amusements, and palace ceremonial, the most definite influence was also that of Iran, mixed with the early Turkish traditions, and not that of Byzantium. ${ }^{12}$

The cultural production that most clearly and forcefully represents Seljuk civilization for us even today is architecture. In the sixth/twelfth and, especially, the seventh/thirteenth centuries, Seljuk art was the sole art prevailing in Asia Minor. Various ideas have been advanced about the sources and characteristics of this important art that embellished the cities of Anatolia with madrasas, mosques, türbes, and palaces, and its highways with caravansaries. We do not possess sufficiently strong evidence to show that Seljuk art, which synthesized elements of Arab, Persian, Syrian, Armenian, Byzantine, and early Turkish art and unified them with a skill reflecting the Turkish genius, was an original art. While some older investigators, like Gustave Mendel, called into question the originality of this art, ${ }^{13}$ more recent investigators, like Heinrich Glück, are of the opinion that Seljuk art, while composed of various elements, is a high art that does reveal the Turkish spirit. ${ }^{14}$ 


\section{G The Șūfì movement}

Steadily increasing in strength and spreading in all directions, the Șūfì movement preoccupied and engulfed all the countries in the Muslim world. In the sixth/twelfth and seventh/thirteenth centuries, this movement, which, after al-Ghazālī \{d. 505/1111\}, was well harmonized with Sunnī beliefs, led to the creation of numerous tekkes in Iran, Central Asia, Syria, Egypt, and Anatolia, in short, in all Muslim lands. ${ }^{15}$ Although the actual personalities of the Șûfis who lived in these tekkes are obscured by dense clouds of legend, we can still glimpse quite a few figures behind the clouds, including important poets, profound and independent-minded thinkers, and men obsessed with divine love. We frequently encounter, especially after Muhȳī 'l-Dīn Ibn al-'Arabī (560-638/1165-1240), Sûfis who embraced the concept of wahda \{unity (of being)\} in the broadest sense. ${ }^{16}$ As the moral and material influence of the 'Abbāsid caliphs in Baghdad waned and sovereignty in various regions passed into the hands of local amīrs, the caliphs, for certain material reasons, began to favor and patronize tekkes and Șūfîs. ${ }^{17}$ Meanwhile, the absence of a single center of political power, and anarchy in the realm, i.e. the breakdown of the basis of the social system, also created a need for mysticism in spiritual life. Later, in the places that were exposed to momentous events like the Crusades and the Mongol invasion, the influence of the tekkes and their shaikhs naturally became stronger, because they promised and indeed provided - anxious people with what they needed most: spiritual and moral tranquility.

The spread of Sunfism in all directions as a result of many material and, especially, spiritual factors, the quasi-official recognition granted by \{the Muslim\} states to the tekkes and tariqas, and the fact that many statesmen and notables, even sultans, became disciples of the great shaikhs all gave enormous spiritual influence to the Șūfì shaikhs. The Șūis had such moral authority over the corporeal dominions of the rulers that they sometimes even intimidated powerful states and forced them to adopt certain important measures. During the period of the Seljuks and Khwārazm-Shāhs, the Șūfì movement became firmly established throughout virtually all the Muslim-Turkish countries and, especially, in the large cultured cities where Muslim-Persian influence was paramount. At that time, when the Islamic world was shaken by continuous and large-scale disorders and anarchy, the great shaikhs, who had thousands of disciples who obeyed them blindly, were able to play important political roles. Consequently, the rulers found it necessary either to use force and threats against them or to treat them with kindness according to circumstances. The legend of Khwāja 'Azīzān, ${ }^{18}$ for example, and then the fact that the Khwārazm-Shāh was compelled to ask his shaikh Najm al-Dīn Kubrā for forgiveness for doing away with the famous Majd al-Dīn Baghdādī19 are certainly significant points in this respect.

After the death of Ahmad Yasawī, the resurgence of political confusion over all of Asia on the one hand and, on the other, the establishment of Süfism as a philosophical system by mystics like Ibn al-'Arabī, who held broad and 
independent views that considered "the essence of God" to be "absolute being," gradually caused the number of Sūfīs to multiply. Moreover, under the rubric of Sunfism, all sorts of people assembled. Even in the time of al-Ghazālī, there were those who spread and popularized ba tịn $\bar{\imath}$ beliefs under the screen of Șufism, ${ }^{20}$ but as time went on their number increased.

This then was the character of the Sūfì movement in the Muslim world when the Oghuz Turks settled in Anatolia. As the Seljuk state in Anatolia became strong and several Muslim-Turkish cities were established, tekkes also appeared in those places, in conformity with the usual pattern in Islamic countries. The dervishes and shaikhs who came to Anatolia from other countries or who grew up there succeeded in awakening a powerful Șūfì movement within the Anatolian milieu. Among them were a number of Șūfìs who came from Iran, Egypt, Iraq, and Syria. There were also a large number of dervishes who had flourished among the Turks of Khurāsān and Transoxiana. There were even some who were members of the tariqa of Ahmad Yasawī. Particularly after the Mongol invasion, as many Șūfîs and scholars in Turkistan, Iran, and Khwārazm fled before this great pagan influx to Muslim countries in the West, quite a few went to Anatolia and settled there. ${ }^{21}$ The Seljuk rulers, like all Muslim rulers, had long shown great respect and favor to Șūfîs and scholars ${ }^{22}$ and so naturally greeted the newcomers in the same cordial fashion. Anatolia, especially in the first half of the seventh/thirteenth century, had become a place of settlement for a number of famous Ṣūīs, the most illustrious of whom was Mawlānā Jalāl al-Dīn Rūmī.

Among the Șūfis who endeavored to propagate tariqqas in Anatolia in the seventh/thirteenth century, we can mention such well known personalities as Awhad al-Dīn Kirmānī in Konya; ${ }^{23}$ Fakhr al-Dīn 'Irāqī,${ }^{24}$ the author of Lama'āt, in Tokat, for whom his disciple and follower Mu'īn al-Dīn Parwāna built a tekke, ${ }^{25}$ Shaikh Najm al-Dīn Dāya, the author of Mirșād al-'ibād, in Kayseri and Sivas, ${ }^{26}$ Ibn al-'Arabī, also in Konya, and Șadr al-Dīn Muhammad b. Isḥāq al-Qūnawī, who, by writing many commentaries on Ibn al-'Arabī's works, spread his philosophy of the unity of being $\{w a h d a t$ al-wuju $d\}$ throughout that region; ${ }^{27}$ and also Mu'ayyad al-Dīn al-Jandī, one of his disciples who also wrote commentaries on some of the works of Ibn al-'Arabī, ${ }^{28}$ and Sa'd al-Dīn Farghānī, who wrote a commentary on the Qașida al-ta'iyya \{Ode on the letter T\} of Ibn al-Fāriḍ. ${ }^{29}$ We can also include Hājjīi Bektash Veli among the Ṣūīs who flourished in Anatolia in the seventh/thirteenth century. He was not able to win as much fame and influence as these others during his lifetime, but later, as a cycle of legends took shape around his name, he was regarded by the people as the founder of a tariqqa.

Among the tariqas that spread in Anatolia between the end of the seventh/ thirteenth century and the early years of the eighth/fourteenth century, we find the Rifā'iyya, to which Ibn Bațutta also gives the name Ahmadiyya. This writer came across Rifā' $\overline{1}$ tekkes and members of the Rifā' țarqua in Izmir and Bergama, in Sonisa $\{$ Sūnusā $\}$ near Amasya, and even as far afield as Majar in the territory of the Golden Horde. Ibn Battututa says that the tarnqa of the famous Shaikh Abū 
'l-'Abbās Aḥmad al-Rifā' $\overline{1}$, whose tomb he visited in the village of Umm 'Ubaida, a day's journey from Wāsit, had spread throughout Iraq and to some degree in the cities of Anatolia, which had very close political and commercial relations with Iraq. Indeed, he adds that at that time a descendant of Ahmad al-Rifā'ī was the head of the religious order in Sonisa, which belonged to the ruler of Iraq. They sometimes went to visit the grave of the $p \bar{\imath} r$, taking with them hundreds of dervishes. Ibn Battututa encountered such a group and wrote that they would enter a blazing fire while dancing, eat fire, and exhibit other very strange behavior. ${ }^{31}$

In that period, the conditions of life in Anatolia ensured the propagation and general acceptance of the Șûfi movement at all levels of society. As I related above while discussing political life in Anatolia at that time, central government had completely collapsed after 'Alā' al-Dīn Kai-Qubād I. Domestic struggles over the succession, the Mongol invasion, and wars with the Byzantines and Armenians had destroyed the prosperity and security of the country. Observing an absence of social order and reeling from these continuous troubles, the people had no other recourse than the tekkes and the shaikhs in order at least to ensure for themselves in the next world the happiness that eluded them in the present. Conforming to this general tendency of the people, the beys \{tribal chiefs, lords\}, who were trying to establish temporary local authority, built tekkes and zāwiyas everywhere and set aside rich endowments for them in order to take advantage of the material and moral influence of the shaikhs. Under such social conditions, one can easily understand how Anatolia became such fertile ground for producing shaikhs and $b \bar{a} b \bar{a} s$. Indeed, a number of works written about the legends of the saints who lived during that period, as well as other historical sources, corroborate this point. ${ }^{32}$

In the first half of this book, I dwelt on the fact that there were many members of the Yasawi tariqa among the dervishes who migrated to Anatolia from Turkistan, Khwārazm, Khurāsān, Syria, and Iraq. For various reasons, however, these ascetics who were sincerely attached to Sunnī beliefs were not able to achieve spiritual authority in the intellectual and religious environment of Anatolia. In the first place, this environment, which included remnants of the old GrecoRoman and Christian intellectual traditions, was capable of accepting, as I mentioned above, broad-minded philosophical views in addition to those that were narrowly ascetic. Second, under the influence of Ibn al-'Arabī, who lived for a rather long time in Konya, and the many important disciples who followed him, the unconstrained intellectual atmosphere of Anatolia became permeated with the philosophy of the unity of being. It was inevitable, therefore, that the ascetic and pious views of the Yasawi dervishes who had come there from Turkistan and Khwārazm would assume a more unconstrained and philosophical character. ${ }^{33}$ Third, ba țiñ beliefs had taken deep root at that time throughout the Muslim world and especially in Syria, which had very close material and spiritual ties with Anatolia. ${ }^{34}$ The matter did not, therefore, end here. Under the screen of Șūfism, and taking advantage of favorable times, all kinds of games were played. 
In the history of Anatolia, the earliest and most important of these heretical and schismatic movements, which were generally accompanied by political objectives and ambitions, was the famous $B \bar{a} b \bar{a}^{\prime} \overline{1}$ incident. In the reign of Sultan Ghiyāth al-Dīn Kai-Khusraw II, Bābā Isḥāq, a disciple of Bābā Ilyās of Khurāsān, collected numerous supporters in the region of Amasya, Tokat, and Sivas, outwardly in the name of his shaikh - but in reality much more for his own sake - and rebelled against the Seljuk state. Benefiting from the current weakness of the Seljuks, he gained considerable power. Indeed, faced with these Bābāîs, Ghiyāth al-Dīn was forced to abandon Konya and retire to the fortress of Qubādiyya with his family and treasure. Bābā Ishāa, while propagating what was virtually a new religion, was able to attract true believers who were ready to sacrifice themselves for his sake, thus causing great turmoil in the Seljuk state and straining its resources. Finally, Mubāriz al-Dīn Armaghān Shāh took him prisoner, after laying siege to Amasya, and executed him (638/1240). ${ }^{35}$

Despite the important place of the Bābā' $\overline{1}$ uprising in the intellectual history of Anatolia, we do not have much clear information about it, so we can only gauge it rather vaguely. Neverthless, I believe it would not be a mistake to regard the Bābā'̄ incident as an important precursor of the heretical and schismatic movements that challenged Sunnīsm in Anatolia, and subsequently of the formation of groups like the Quzılbash and Bektashīs that appeared as a result of various events beginning with the incident of Badr al-Dīn Samāwnāwī and continuing up to recent times. ${ }^{36}$ In analyzing similar later phenomena, one would naturally regard the seeds of heresy and schism surviving from this period to have sprouted under the influence of new factors, even novel ideas coming from abroad; still, the significance of this initial incident can by no means be denied. Indeed, it should not be forgotten that during the seventh/thirteenth century a number of well known Turkish Șūfīs like Barāq Bābā $\bar{a}^{37}$ and Sulaimān Turkmān̄̄ ${ }^{38}$ also spread many wild ideas and beliefs under the screen of Șüfism.

Furthermore, based on both historical sources and the reports of the traveler Ibn Battūtata, we know that in the same century in Anatolia, as in some of the other Turkish countries, there was an important and widespread corporation of unmarried Sūfì craftsmen known as the akhiss and that they played a significant role in the early history of the Ottomans. ${ }^{39}$ These akhīs followed the way of the futuwwa, traced their roots back to the Prophet Muhammad via 'Alī, and wore the trousers $\{$ shalwār $\}$ of the futuwwa, which distinguished them from the other Șūfîs, who wore patched woolen jackets $\{k h i r q a\}$. The $a k h \bar{\imath}$ organization, which also included many $q \bar{a} d \bar{\imath} s$ and madrasa instructors, was not simply a professional grouping or guild. Instead, it should be considered a tariqa that relied on, and spread its beliefs through, this guild structure. ${ }^{40}$

Ibn Battūta says that a significant number of the akhiss were members of the knife-maker guild and that they carried knives on their persons in a very visible manner, but he also says that they included more than knife makers. Indeed, there were artisans of all types among them. According to Tashköprü-Zāde, the tanners' guild considered Akhī Evren to be the pīr of their tañqa, and there are 
details about this in the manāqibnāmes concerning him. ${ }^{41}$ By the early Ottoman period, one encounters quite a few other dervishes with the title akhi and, of course, they too were members of the same organization. ${ }^{42}$

Apparently these akhis were organized in a hierarchy, like those of the presentday Freemasons, and truths were disclosed to the adepts according to their rank. From this point of view, the akhis can definitely be considered to have originated from bătinism. ${ }^{43}$ In fact, the great Turkish poet Gülshehrī, who flourished in the first half of the eighth/fourteenth century - almost a quarter century before Ibn Batțuta - describes the akhīs saying that they were generally ignorant and heedless of the rules of the futuwrwa, and thus he implies that contemporary Sunnī scholars and Șûfis took a dim view of them and more or less regarded akhism as tainted with bātinism. ${ }^{44}$ After 762/1361, the year in which Ankara was taken by the Ottomans, the term $a k h \bar{\imath}$ rarely appears in the sources. But this should not be interpreted to mean that the political importance of the akhiss had disappeared. After the Ottoman Empire established a strong political base in Anatolia, the $a k h \bar{s}$ could not maintain any political significance. Subsequently, the establishment of tariqas like the Bektashiyya left akhism in the form of an ordinary guild organization, and its ba tịn $\bar{\imath}$ character, which was concealed in its foundation, also passed to tariqas like the Bektashiyya. ${ }^{45}$

It is quite natural that a century that produced Mawlānā Jalāl al-Dīn Rūmī and Sulțān Walad would also produce a great Șūī poet like Yūnus Emre. Some brief information will be provided below on the personality and work of Jalāl alDīn Rūmī, who, beginning with Yūnus during that century, and long afterwards, had an enormous influence on Turkish Șûfì life and Turkish literature in general - just as he did on the entire Muslim world and especially on Persian literature. Following this, an outline, in the most general fashion, of the Turkish language and literature of that period will be given. Yūnus Emre's spiritual personality will thereby reveal itself, because every personality - even a genius like Yūnus Emre who endowed a raw and uncultivated language with a divine quality that could profoundly bring to life the emotional subtleties of the human spirit - is unquestionably a product of his social environment. After all these analyses, the distinctions between Aḥmad Yasawī and Yūnus Emre or, more correctly, between Central Asian Turkish Șūfism and the Șūfism that developed in Anatolia, and the various factors that gave rise to those distinctions, will become clear.

\section{Jalāl al-Dīn Rūmī}

Mawlānā Jalāl al-Dīn Rūmī, whom we can consider as perhaps the greatest and most influential representative of pantheism in Persian Șūfì literature, was born in Balkh in 604/1207. His father, Muhammad Bahā' al-Dīn Walad b. Husain al-Bakrī, who was dubbed Sultān al-'Ulamā', was one of the most famous Ṣūî scholars of Khwārazm. He devoted himself to preaching and teaching; and all the leading personalities and notables of the time, sometimes even the ruler himself, attended his majlis. Forced to leave Balkh - according to one story on 
the instigation of Fakhr al-Dīn al-Rāzī because of rivalry and jealousy between them, and according to another because Muhammad Quṭb al-Dīn the KhwārazmShāh feared his spiritual influence - he took his family and fled to Nīshāpūr. Shaikh Farīd al-Dīn 'Aț̣ār, who was still alive at that time, gave his blessing to the young Jalāl al-Dīn and gave him a copy of his Asrārnāme as a gift. From Nīshāpūr, Bahā' al-Dīn went on to Baghdad, Mecca, Damascus, Malatya, Erzincan, and then to Akşehir where he remained for a while in a tekke built by the wife of Malik Fakhr al-Dīn. Later, he went to Laranda, where he stayed for seven years. While in Laranda, Jalāl al-Dīn married Jawhar, the daughter of Lālā Sharaf al-Dīn Samarqandī (622/1225-6). Finally, as a result of repeated and very warm invitations from 'Alā' al-Dīn Kai-Qubād, they all settled in Konya (626/1228). Sulțān al-'Ulamā', to whom the ruler showed great favor, devoted himself to learning and teaching until his final days. He died in 628/ 1231. According to Aflākī, Mawlānā took his father's post. ${ }^{46}$

One of the important and fundamental factors in shaping Mawlānā's Șūfì and poetic personality after his father's death was the period of about nine years that he spent with the Sayyid Burhān al-Dīn Tirmidhī. Acquiring fame under the title Muhaqqiq \{"the Verifier"\}, the Sayyid Burhān al-Dīn was one of the leading khalīfas of Sulțān al-'Ulamā'. After his shaikh's death, he went to Konya and took upon himself the spiritual education of the young Jalāl al-Dīn, who, by that time, had mastered the exoteric sciences, i.e. the canonical $\left\{\operatorname{shar}^{\circ} \bar{\imath}\right\}$ and literary sciences. The Sayyid Burhān al-Dīn, who had met with Shaikh Shihāb al-Dīn al-Suhrawardī and won his respect, later retired to Kayseri where he died. ${ }^{47}$

From both his father and the Sayyid Burhān al-Dīn, Jalāl al-Dīn had acquired strictly ascetic and pious views. Thus, he occupied himself, on the one hand, with teaching and, on the other, with the principles of Șūfism that al-Ghazālī had reconciled with the provisions of the $\operatorname{Shar}^{c} a$. During this time, however, a dervish named Shams \{al-Dīn Muhammad\} Tabrīzī arrived in Konya. His meeting with Mawlānā (according to Aflākī and Jāmī on 26 Jumādā II 642/ November 29, 1244) had a profound and transformative influence on the latter's spiritual outlook. ${ }^{48}$ According to one account, Shams was the son of a venerable family that belonged to the Ismā $\overline{1} l \overline{1}$ madhhab. ${ }^{49} \mathrm{He}$ had wandered from country to country and had been in the service of various Sûfîs. ${ }^{50}$ It is reported that he was a disciple of Bābā Kamāl Jandī and that he even met in his tekke with Fakhr al-Dīn 'Irāqī. ${ }^{51}$ In any case, no matter who the shaikh or shaikhs of this great Șūfi might have been, it is certain that he was a man with the character of a rind or kalandar \{both are terms for unconventional dervishes\} who could experience very intense mystical ecstacy, and that he was a very forceful personality who entertained the most broad-minded mystical notions because of the genuine needs of his spirit. ${ }^{52}$

There are a variety of reports in different sources about the nature and closeness of the relationship between Shams (who according to one story died in 645/ 1247 , but according to other, more reliable, reports left Konya in that year) and Mawlānā. ${ }^{53}$ With respect to the extent and significance of his influence on 
Mawlānā, the material in Sipahsālār is especially worthy of note. Even if we leave aside those aspects of this material that are of a purely legendary nature, those that remain appear to be very significant. These two Șūiss first had friendly discussions for six months in the cell of Shaikh Șalāh al-Dīn Zarkūb and then departed. Following the path of his father and of the Sayyid Burhān al-Dīn, Mawlānā initially had no liking at all for sama $\bar{a}^{`}$, but because Shams made him like it he could no longer live without it. ${ }^{54}$ Shams realized, however, that those in Mawlānā's circle had become hostile to him and so, without notice, he departed for Damascus. Overwhelmed with grief, Mawlānā stopped writing poetry and conducting sama $\bar{a}^{c}$. When a letter arrived one day from Shams informing him that he was in Damascus, Mawlānā was so happy that he recited a number of ghazals and began a sama $\bar{a}^{c}$. He also sent his oldest son Sultān Walad with some of his companions to Damascus specifically to invite Shams back. ${ }^{55}$

When he returned, Mawlānā was overjoyed. Shortly thereafter, in fact, at Shams's request, Mawlānā married him to a young girl named Kīmyā who had been raised in the women's section of his apartment. Because it was winter, they set aside a small place for the new husband and wife in the anteroom of the kitchen. Shams spent the winter there, but during that time a mutual aversion developed between him and Mawlānā's middle son Chelebi 'Alā' al-Dīn. At the latter's instigation, Shams's former enemies and their allies again began to plot against him. Shams said nothing to Mawlānā of what was going on, but he did express his resentment to Sulțān Walad and added that this time he would disappear without a trace. And so it happened. One morning when Mawlānā went to his madrasa, Shams was nowhere to be seen. Mawlānā, who recited many ghazals expressing the pain of this separation, eventually went to Damascus to search for him again. When no trace of Shams could be found, however, he was obliged to return to Konya. ${ }^{56}$

Mawlānā wrote poems with an exuberant passion and sublime inspiration. He dedicated them to the spiritual ideals of Shams Tabrīzī, and they were later known collectively as the Dīwān-i Shams al-haqa' $i q .{ }^{57}$ His ability to reach perhaps the highest degree of pantheism \{in this poetry\} and his profound attraction to sama $\bar{a}^{\prime}$, dance, and music can be attributed above all to the teachings of Shams. With respect to language and versification, these lyrics can be considered quite faulty. With regard to capturing and demonstrating the most profound and exuberant moments of a mystical soul, however, each poem is a living document of the most immediate kind for properly understanding Mawlānā's emotional life. For Mawlānā, who mixed the basic ideas of the ancient Alexandrian school \{i.e. Neoplatonism\} with certain Indian, Persian, and Arab concepts, Șūfism was not an inert collection of rules and beliefs but something to be felt and lived. Thus, it could be apprehended not by mental and sensory discernment but by intuitive discovery, i.e. by inspiration and love. ${ }^{58}$ The divine lyricism in these poems reveals Mawlānā's spirit in all its immediacy, profundity, and nakedness and is sufficient to suggest that he is Persia's greatest mystical poet. It would be a mistake, however, not to recognize Shams Tabrīzī as the largest single factor in 
the origin and development of this lyricism. We have no clear and certain information about the life and personality of Shams, but it is certainly possible to grasp his mystical ideas and views from the Dīwān-i Shams al-haqa' $i q$. This work would prove even more useful than the Mathnaw in shedding light on Mawlānā's mystical path, because it displays points that are clearly reminiscent of his Neoplatonist beliefs. In order to remain within the bounds of my subject, however, it is not possible to go into further details on this matter. ${ }^{59}$

After Shams's disappearance, Jalāl al-Dīn adopted as his companion one of his former disciples, Șalāh al-Dīn Farīdūn of Konya, who was known under the byname Zarkūb (goldsmith). ${ }^{60}$ Long known for his asceticism and piety, this person had been one of the leading disciples of Burhān al-Dīn Muhaqqiq. Early on, he had taken up the profession of goldsmith in Konya and later attached himself to Shams. Adopting such a man, who had virtually no understanding of the religious and literary sciences, as a companion aroused the enmity of a number of other disciples. They spoke out about his lack of knowledge, but Mawlānā, paying no attention to this gossip, increased his favors to, and respect for, this man. Indeed, in order to strengthen his esoteric attachment with an exoteric bond, he married Sulțān Walad to Șalāh al-Dīn's daughter. In this manner, a sincere attachment lasted for ten years until Șalāh al-Dīn became ill and died. In despair and full of grief, Jalāl al-Dīn composed a number of ghazals. ${ }^{61}$ To be sure, Șalāh al-Dīn had had no influence over Mawlānā, as Dawlat-Shāh supposed; on the contrary, he was very much under Mawlānā's influence. ${ }^{62}$ The fact that Mawlānā mentions him with respect and affection in a number of poems in the $D \bar{\imath} w \bar{a} n$ does not constitute a reason to claim otherwise.

Subsequently, Chelebi Husām al-Dīn became Mawlānā’s khal̄̄fa and companion. According to Mawlawī tradition, Chelebi Husām al-Dīn Hasan b. Muhammad b. Hasan b. Akhī Turk was one of the children of Shaikh Abū 'l-Wafä' of Baghdad. ${ }^{63}$ He was bound and devoted to his shaikh through great respect and affection and, in turn, received the same kind treatment from Mawlānā. Chelebi Husām al-Dīn played a significant role in Mawlānā's composition of the Mathnawē. Realizing that didactic works of the type of \{'Atțāar's\} Ilāhīname, Mantiq al-tair, and Muș̄̄atnāme were well liked and widely circulated among the dervishes, Chelebi asked his shaikh to create a mathnaw $\bar{\imath}$ that could teach the dervishes the rules of the order and the mystical truths. Also, because Mawlānā had already written a rather large number of ghazals, Chelebi hoped

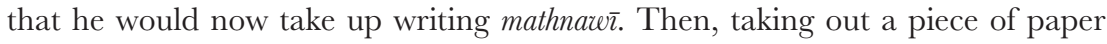
on which were written eighteen couplets from the introduction to the Mathnaw Mawlānā said that he too had thought of doing this. At that point, the composition of the Mathnawẽ began. Mawlānā spoke and Chelebi Husām al-Dīn recorded his shaikh's inspired recitations. After the first volume was finished, there was about a two-year delay in this project because of the death of Chelebi's wife. Subsequently, however, Chelebi implored his shaikh to continue his compositon and convinced him to do so. Therefore, over a period of at least seven or eight years, this monumental work of six volumes came into being. ${ }^{64}$ 
An enormous work of more than 26,000 couplets, the Mathnaw is the most famous product not only of Mawlānā, but perhaps also of all Șūfì literature. ${ }^{65}$ Its influence, which has been very great throughout the Islamic world, especially in India and Iran, was exceptionally powerful on the Anatolian Turks from the time it was written. ${ }^{66}$ Nevertheless, one cannot find in the Mathnaw $\bar{\imath}$ dazzling flashes of brilliance and clear and profound reflections that sweep aside all obstacles and boundaries like those in the Dīwān-i Shams al-haqa ${ }^{\prime} i q$. This is a didactic work of Șûfi ethics written strictly to provide guidance to those on the mystical path. It was written, quite naturally, with mid-level adepts in mind. With respect to language and meter, this work is again quite faulty. Its structure can also be very easily criticized. Adhering to the format of earlier Sūfī poets, Mawlānā expounds every idea, every bit of advice, and every theory with an appropriate story. When he wants to explain, for example, that trusting in providence can be both positive and negative, he begins with a few verses of admonition and then adds a story. Usually, however, before finishing one story, he interrupts it and inserts a second story, and may even insert a third into the second; and after they are completed, the first story is resumed.

The lack of importance given to both the structure and the correctness of language and meter are evidence that Mawlānā was by no means a formalist. In the Dīwān-i Shams al-haqqä'iq, Mawlānā had used poetry as a means of communicating the most profound needs of his spirit, and in the Mathnaw $\bar{\imath}$ used it as an instrument to guide adepts on the mystical path and to expound the principles of the tariqa that he had founded. He never regarded himself as a poet or an artist. ${ }^{67}$ Yet, despite his reluctance to speak with absolute clarity and precision about the realities of the unity of being in the Mathnaw $\bar{\imath}$, he was obliged in many passages to make unintended revelations. Because he himself was aware of this, he also says in the Mathnawn, "If you look at only the form of the expressions, this work seems to lead astray, whereas in reality it guides the right way," and in order to confirm this he relates the following couplet $\{$ vol. 6, 656\}:

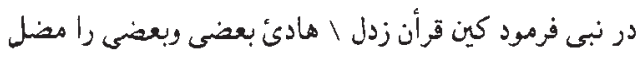

\{n the revelation God says that this Koran / Guides some and leads others astray (cf. Koran 2:26).\}

Strongly influenced by Farīd al-Dīn 'Aț̣ār and Sanā' $\overline{1},{ }^{68}$ as he frequently stated and acknowledged, Mawlānā not only quotes from Kal̄̄la wa Dimna \{on this Indian mirror for princes, see $E I^{2}$, s.v. "Kalīla wa-Dimna" (C. Brockelmann)\}, the legends of Juhā \{on this personage of the popular imagination, see $E I^{2}$, s.v. "Djuhā" \{Ch. Pellat)\}, the stories of Mahmūd Ghaznawe wa $\overline{A y} \bar{a} z$ \{by Fakhr al-Dīn 'Alī Șafī, the son of Husain Wā'iz Kāshifī\}, from Arab stories like Layla wa Majnūn \{see $E I^{2}$, s.v. "Madjnūn Laylā" (Ch. Pellat et al.)\}, and from the qisas al-anbiy $\bar{a}$ ' \{stories of the prophets\} and manāqib al-awliy $\bar{a}$ ' \{legends of the saints, in the generic sense $\}$, but he also portrays, in various passages of his work, life in the palace, or scenes of public life, such as the ceremonial mourning of the Shī $\bar{i}^{\mathrm{i}}$ 
of Aleppo at the Antakya Gate. Indeed, Mawlānā is perhaps too realistic in describing some obscene aspects of life, but this is no reason to criticize him when we take into consideration his personality and the purpose for which he wrote the Mathnaw $\bar{\imath}$. In any case, the influence of the Mathnaw is overwhelmingly obvious in the earliest Turkish works written in Anatolia.

During his last months, Jalāl al-Dīn wrote a number of moving ghazals indicating that the time had come for him to leave this world. In fact, shortly after composing them he became ill. Two well known physicians named Mawlānā Akmal al-Dīn and Mawlānā Ghaḍanfarī attended him, but his illness could not be diagnosed. At sunset on Monday 6 Jumādā II 672/December 18, 1273, Mawlānā died. The next day, after the necessary arrangements, which had been made in advance, for washing and shrouding the corpse were completed, virtually the entire population of Konya participated in the funeral prayer, while Qā ḍi Sirāj al-Dīn acted as imām. Mawlānā was then buried in the tomb where he now rests. With the express wish and approval of his oldest son Sulțān Walad, his khalîfa Chelebi Husām al-Dīn succeeded him. ${ }^{69}$

Mawlānā, whose important followers include such Persian poets as Qiwām al-D̄̄n Sanjānī, Ni`mat Allāh Kūhistān̄̄ \{i.e. Sayyid Ni'mat Allāh Veli\}, and the Sayyid Qāsim al-Anwār, ${ }^{70}$ and who influenced many other poets of the same caliber, and who was long very highly respected and honored by historians, biographers, and Șūfìs, ${ }^{71}$ wrote an important prose treatise entitled Fìhi $m \bar{a} f \hat{\imath} h{ }^{72}$ which he dedicated to Mu'īn al-Dīn Parwāna, and has quite a few other sayings and utterances, but we cannot discuss them here. It is also beyond our subject to discuss Mawlānā as a Persian poet or his influence on Persian literature. Suffice it to say that Mawlānā flourished in an environment that was conducive to unconstrained thought and that appreciated music, art, and literature. With his poetry and mystical ideas, he easily won over the Anatolian cultural scene, pervaded as it was with the philosophy of the unity of being that had been propagated by Ibn al-'Arabī. If the cultural milieu had not been prepared, Jalāl al-Dīn would not have won such great fame while he was still alive and the tariqa that he established would not have spread and developed so readily. But as I made abundantly clear above, the ground had been fully prepared for such a movement. Consequently, Mawlānā's tarīqa, as well as legends about him, began to take shape while he was still alive. Below, we will see how Mawlānā's influence was felt on the earliest Turkish works created in Anatolia. While discussing the works and Șufî ideas of Yūnus Emre, and drawing many comparisons, we will see how this influence spread in a very short time and what important traces it left even on popular Șūfì literature. One fact is incontrovertible: that without a thorough knowledge of Mawlānā, one cannot understand the earliest Turkish works in Anatolia.

\section{E The national $\{$ milli $\}$ language and literature}

The language of the Turks who settled in Anatolia, as adumbrated above, was Western Turkish, which we call the Oghuz or Turkmen dialect. This dialect had 
become the local language of the regions invaded by the Oghuz tribes, especially Anatolia. The Oghuz literary language, which had taken form and developed even before the Oghuz settled in Anatolia, i.e. while they were still living in the Syr Darya area, retained its basic features, although it quite naturally underwent some minor changes in Anatolia. Thus, Western or Southern Turkish, which is known as Seljuk Turkish until the founding of the Ottoman state and Ottoman Turkish thereafter, is simply a developed form of the old Oghuz dialect. ${ }^{73}$

After the establishment of the Seljuk state in Anatolia, Turkish became a written language, but we cannot determine exactly when. Oghuz Turkish had been used for written correspondence even before the Seljuks settled in Anatolia. Like Eastern Turkish, this dialect too had ceased being simply a spoken language. It is quite natural, therefore, that Turkish works began to be written down from the earliest period of the Seljuks, but it is also true that they were very few in number and quite elementary in scope. These works include simple religious tracts meant to expound the principles of Islam, as well as a number of Islamic popular stories like the legends of Batțāl Ghāzī that could satisfy the warlike leanings of the people of Anatolia, which was then an actual field for $j i h \bar{a} d$ \{struggle for the faith $\}.{ }^{74}$ For various historical reasons, virtually nothing has come down to us from the literary creations of this period, but thanks to works that were written later on these subjects, and parts of which have survived, we can get a fairly clear idea about them, because most of these later works are merely updated, embellished, and expanded versions of the earlier ones. The lack of early texts has caused a major gap in linguistic history, but with respect to literary history it is not of such great importance. Such texts, which could not have had much literary value in themselves, could at least have served as a means to help us to understand the intellectual and emotional life of that period as well as its tastes and biases. Although we no longer possess these texts, it is possible to make such an analysis through various other means. \{Köprülü's hypothesizing about nonexistent Turkish literature is problematic. On the history of Turkish literature, see, for example, Alessio Bombaci, Storia della letteratura turca (Milan, 1956).\}

If we take into consideration the general features of the civilization created by the Seljuks of Anatolia, and the intellectual and emotional life of that period, we will immediately understand the extent to which the national language was neglected. The madrasas and tekkes that were built with great elan in almost every corner of Anatolia after the establishment of the Seljuk state were so many hearths that radiated Arabic religious science and, above all, Persian literature. While the nomadic Turkmen satisfied their aesthetic needs with their own folk literature and with remnants of the old Oghuz Destanı, Persian literature prevailed in the cities that welcomed scholars, jurists, and vagabond dervishes who arrived from throughout the Muslim world. At the courts of the learned and artistic rulers who were attracted to the venerable Persian traditions, this foreign language became so influential that it supplanted the national language.

Furthermore, the inclination on the part of the educated class, beginning with the rulers, to pride itself on being distinguished from the common people and 
everything related to them, also kept Turkish far from the courts, belittled works written in Turkish and caused them to be viewed with contempt ${ }^{75}$ - instead creating in Anatolia the most brilliant works of Persian Sūfi literature of this period, such as the Mathnaw $\{$ of Rūmī\} and Lama'āt \{of 'Irāqī . Because the only institutions for training the intellectuals who were going to enter government service were the madrasas, the officials who received their training there under the influence of Persian culture also used Persian in state affairs. This overwhelming domination of Persian as the official language lasted until the ruler of Qaramān, Muhammad Bey, captured Konya. ${ }^{76}$ If the Seljuks had given value and importance to Turkish and tried to develop it, there might have been a rich literature in that language in Anatolia long before the formation of the Ottoman state.

Nevertheless, despite all this neglect and indifference, a Turkish literature - aside from popular religious and heroic works - did develop in Anatolia in the seventh/thirteenth century, partly under the influence of Persian Șūfi literature and partly under the influence of early Turkish popular Șüfi works, such as those of Ahmad Yasawi and his followers. In addition to an early work entitled the Story of Shaikh San' ān, whose author and date are unknown, ${ }^{77}$ we also have the Șūfì poetry of Shayyād Hamza and Sulțān Walad, written quite a bit earlier than that of Yūnus Emre. As for Gülshehrī's \{Turkish\} translation of Mantiq al-tair, the poetry of 'Āshıq Pasha and various compositions of Țūrsūn Faqīh, NaqībOghlu, Mu'arrif Lāziq̄ī, and Ma'ādh-Oghlu Hasan of Baypazar, they were contemporary with, or slightly later than, the works of Yūnus Emre.

Among the Turkish poets who preceded Yūnus Emre - leaving aside Mawlānā, ${ }^{78}$ whose Turkish work consists of about eight or ten lines of poetry, and Shayyād Hamza, ${ }^{79}$ whose Șūfì poems and fame were quickly forgotten - the earliest to produce a noteworthy amount of work was Sultān Walad. This great Șûfì was born in 623/1226 and died in 712/1312 at the age of almost ninety. In Konya and Damascus, he studied the religious sciences with various scholars, especially his father, and also received lessons in spirituality from leading personalities like the Sayyid Burhān Tirmidh̄̄, Shams Tabrīzī, Șalāḥ al-Dīn Zarkūb, Chelebi Husām al-Dīn, and Shaikh Karīm al-Dīn. Sulțān Walad, who, according to sources like \{Ibn Qutlūbughā's\} Tāj al-taräjim and \{'Abd al-Qādir b. Muhammad's\} al-Durra al-mud̦̄'a \{i.e. al-Jawāhir al-mud̦̄’a\}, was, like his father, a great Hanafì faq̄̄ h, was also a fairly noteworthy Șūfì poet in Persian. He has left us three mathnaw̄ works, Ibtidā'nāme, Intiha'nāme, and Rabābnāme, a large anthology of poetry $\{D \bar{\imath} w \bar{a} n\}$, and a prose work called $M a^{`} \bar{a}$ rif.

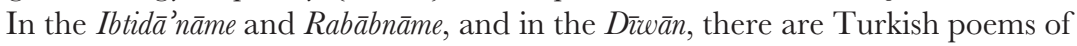
a quantity and quality to allow us to consider Sultān Walad as an early Turkish poet. ${ }^{80}$ I will not go into a lengthy description here of these poems, which were written in a very crude and primitive language and with a very defective and rudimentary versification replete with zihâf \{pronouncing a long vowel short\} and imala \{pronouncing a short vowel long\}. This work, which has still not received the study it deserves, although it has attracted the attention of European scholars for some time, ${ }^{81}$ requires a separate, detailed, linguistic and literary 
analysis. Here I will only make a few brief and general comments about Sulțān Walad and his Turkish poetry in order to indicate his actual place in the general development of Turkish literature in Anatolia.

Sultān Walad, who desired nothing more than to propagate the Șūfì principles that his father had put forward, and whose personality therefore never emerges as distinct from that of his father, tried to compose in Turkish according to the examples of Persian Șūfî literature. Mawlānā's influence on Turkish literature thus begins with him. Sulțān Walad's motivation in writing Turkish poetry, just as it was in composing and reciting Persian poetry, was to raise the religious consciousness of the people of Anatolia, to guide them, and instill in them a sense of the greatness of Mawlānā. The fact that he wrote most of his works in Persian is a consequence of the literary traditions of the period. The fact that he occasionally resorted to Turkish derives from his fear that a large majority, who did not understand Persian, would be deprived of these teachings. ${ }^{82}$ If we set aside the understandably primitive stage of the language and versification, we can say that there is no difference in form, meter, and style between the Turkish poetry of Sulțān Walad and the Persian poetry of Mawlānā. Although there was no widespread use of Turkish as a written language at that time, it is almost certain that Sūfî poems in 'arūd, as well as legends and stories, had been written in Turkish in Anatolia even before Sulțān Walad. ${ }^{83}$ But Sulțān Walad, thanks to his influence as a great Șūî and spiritual teacher, succeeded in establishing 'arüd meters and mathnawi form as the absolute rule for Sūfì-moralistic didactic works. At the same time, however, despite the influence of Sultān Walad and the importance of the Persian 'arüd system, Sūfì poetry written in the syllabic meter, which began with Ahmad Yasawī and continued with popular Șūfìs like Shayyād Hamza, continued to flourish and finally found its greatest representative in Yūnus Emre.

Sultān Walad's first imitator, and a contemporary of Yūnus Emre, was Shaikh Gülshehrī, who expanded upon 'Ațtār's Mantiq al-tair with stories taken from various sources, especially the Mathnawi, and with quite a few discussions and complaints relating to his own time. In this great work, to which he gave a somewhat personal touch, he proved a fine versifier and a very talented artist. ${ }^{84}$ The fame of this poet, who considered himself the direct successor of such great Persian poets as Sanā'î, 'Aț̣āar, Nizāāmī, Sa'dī, Mawlānā, and Sulțān Walad, lasted until the tenth/sixteenth century, after which time he was virtually forgotten, so he was not included in later biographical dictionaries. Nevertheless, many passages from his work are of such excellent literary quality that they can be read with pleasure even today. The work of this poet, who, for his time, had a superb command of the language and a rich imagination - in short, a great artistic sensibility - not only surpasses the Mathnawer, for example, in its composition, but also stands out among contemporary works with regard to its internal aesthetic quality. ${ }^{85}$

After Gülshehrī, the most significant work to appear under the influence of Persian Șūfi literature and of Mawlānā and Sulțān Walad was the Gharībnāme of 
'Ashıq Pasha, whose shorter poems, written under the influence of Yūnus Emre, I will discuss briefly below. ${ }^{86}$ Summing up, in Anatolia before Yūnus Emre, the pervasive influence of Persian culture was present in language and literature as it was in all other aspects of civilization. Indeed, this influence was strong and deep not only with respect to ideas, but also regarding language, form, style, and versification.

\section{F Folk literature}

While the elite who received a madrasa education in the great civilized centers of Anatolia cultivated a taste for the refined products of Persian literature and tried to write works of the same kind, the great mass of the people remained almost total strangers to it. Not only the nomadic Turkmen tribes and the march tribes who guarded the frontiers with Byzantium, Armenia, and Georgia, but also a large part of the urban population could take no pleasure in the literature of a language that they did not understand. Consequently, a number of simple and rudimentary Turkish works of a religious or heroic nature, as well as heroic poems, were written for them. The wandering ozans $\{$ minstrels $\},{ }^{87}$ who for centuries had, with $k o p u z^{88}$ in hand, satisfied the aesthetic needs of the people, kept the old Turkish traditions alive throughout Anatolia in a vigorous and devoted manner.

Beneath a veneer apparently borrowed from Arabic and Persian culture, Turkish life in Anatolia in the Seljuk period was perhaps a bit primitive, but it was completely national, genuine, and widespread. After leaving the banks of the Syr Darya and experiencing a long career of migration filled with adventures and crowned with continuous victories and booty, the Turkmen, who, fighting for their national-religious ideals, settled in Anatolia, saw this as a period of alps \{heroes\}, i.e. as a heroic era. The old national and warlike traditions, which even exerted an influence on the official ceremonies and institutions of the \{Seljuk\} state, developed further among the Anatolian Turks as a natural consequence of unremitting conflict with the Byzantines, Armenians, Georgians, and other Christian peoples. The march tribes in particular, who lived along the frontiers, maintained their customs and pastoral existence and, in their traditions, the harsh and heroic spirit of the early migratory Turkish hordes.

The basic organization of the Seljuk state also had a military cast. Landed estates were parcelled out to the sipāhiss. Officials who possessed large and rich timars were legally bound to raise up a specific number of soldiers. It was a kind of dynastic rule that the rank of sipāh $\bar{\imath}$ pass from father to son. In order for any son to take his father's place, however, he had to prove that he had the qualifications and warlike attributes to be a sipāhi . Gold-embroiderd kutases \{ornaments of yak or horsehair\} were placed on the necks of the horses of the alps who had exhibited great self-sacrifice; tiger tails were attached to the wrists of those who shot a tiger while hunting with a bow and arrow; those who killed a bird with a single shot were allowed to wear its plume. ${ }^{89}$ Alp was a title of very high honor. 'Áshıq Pasha $\{1272-1333\}$, who knew the period of the alps very well, describes 
at length in plain and charming language what was required for one to become an alp. ${ }^{90}$ In this period, Anatolia was so permeated with an atmosphere of heroism that even the Seljuk rulers who were under the demoralizing influence of Persian culture could not give up their attachment to Oghuz customary law \{töre $\}^{91}$ and the old warlike traditions in their own palaces. The sultans' practices of going out to hunt, playing polo with the Oghuz beys, and providing training in hand-tohand combat and archery were all required by Oghuz "custom.",92

The primary native singers of the era of heroes were the ozans. These minstrels, who, from time immemorial, had played the kopuz and sung the old Oghuz legends, i.e. the national epics of the Oghuz Turks, were found without fail in the armies, in the large nomadic tents, in short, wherever there was a gathering. There was never a Seljuk army that was without its minstrels and kopuz players. In the joyful evenings following military victories, kopuz in hand, they would recite heroic poems that would bring to life that day's gestes. ${ }^{93}$ It is a pity that almost nothing from these epics has come down to us. The products of this wonderful era of alps, which certainly included a valuable epic literature, disappeared during subsequent centuries, perhaps because they remained in oral form. Fortunately, we can get an idea of the basic and genuine features of this period, even the completely heroic views of love and women, so different from

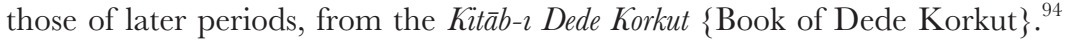

In addition to the ethno-religious didactic works and narratives that were written to expound the principles of Islam, and all of these epic works, the Anatolian Turks also possessed a large body of love poems and folk songs \{s. türkü of a purely lyrical nature. These short poems, which merely expressed individual needs rather than collective feelings and social ideals, were usually couched in the national meters and the traditional forms that had survived from the early ethnic/folk $\{k a v m i\}$ literary period. They had names like türkü, ${ }^{95}$ türkmān $\overline{ },{ }^{96}$ and varsağ ${ }^{97}$ which reveal their ethnic origin, or koşma, ${ }^{98}$ deyiş, ${ }^{99}$ or kayabaşı, ${ }^{100}$ which convey their rustic nature or the requirement of musical accompaniment. Unfortunately, nothing has come down to us of these poems. Moreover, because of the lack of historical documents from this period, the disparagement of, and indifference to, this kind of literary work by the early tezkirecis, ${ }^{101}$ we do not even know the name of a single writer of such poems. Nevertheless, this gap in knowledge is, as I stated above, by no means an obstacle to gaining a clear and definitive idea of the basic features of our literature at that time.

\section{G Oghuznāme}

Like many other peoples in history, the Oghuz Turks had their national epic, the origin of which is lost in time. This epic, which had existed not only as an oral tradition but had also been established in written form, very likely even before the appearance of Islam, ${ }^{102}$ was subsequently called the Oghuznäme because it concerned the Oghuz. Seeing that the early history of every people takes the form of myths and legends, Rashīd al-Dīn \{d. 718/1318\} used this written epic 
for details on the origins of the Oghuz in his famous universal history. ${ }^{103}$ Thus, positive history and myths were mixed together. We also know that this error, which was inescapable for that time, has been continued by our most recent researchers and historians, who still believe that there existed a work describing the early history of the Oghuz under the vague title of Oghuznāme and even search for it. ${ }^{104}$ Although the existence of the Oghuznāme is shown quite clearly and unequivocally in certain historical documents from the ninth/fifteenth and tenth/sixteenth centuries, ${ }^{105}$ and passages from it are even cited in works like the Jām-i jam àȳn and Saljüqnāme, ${ }^{106}$ this evidence is not sufficient to reject the idea that the Oghuznāme was a collective work constituting a national epic that also comprised certain legends relating to the individual Oghuz lineages, and thus was not an early history as has been believed or conjectured. The very clear and detailed discussion of this subject by, above all, Abū Bakr Ibn 'Abd Allāh b. Aybak al-Dawādārī (himself a scion of the Seljuk dynasty \{d. 713/1313\}), who saw an old copy of the Oghuznāme, shows quite definitely that it was not a history

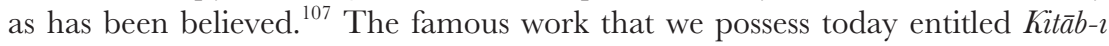
Dede Korkut, if not the complete original Oghuznāme, is, without any doubt, an important and fundamental portion of it. ${ }^{108}$

We cannot give here even a brief account of the Oghuz epic and Kitāb-ı Dede Korkut, both of which need a thorough analysis. Let me simply state, in order to present, as far as possible, a full and accurate picture of life in Anatolia before Yūnus Emre, that the Dede Korkut legends were very widespread among the people at that time and that the Oghuz minstrels recited them with kopuz in hand. ${ }^{109}$ These shared legends of the early heroic periods of the Turks naturally had a special appeal to the unsophisticated and marvel-loving people of those times, when the alp spirit prevailed in Anatolia. The old themes, which had lasted for centuries, did not change, but certain unavoidable novelties appeared in the legends regarding time and place, which aroused even more interest, and had an even more positive influence, on the common people, who had already been enjoying them for a very long time. Compared with heroic legends like those of Battāl Ghāzī and stories like those of the Kitāb-ı Dede Korkut, all the popular works, i.e. ethico-religious exhortations and stories, of that time were very dull and ineffective. If we were to summarize this in one sentence, we could say that one can see in this work, in a most striking fashion, all the aesthetic and ethical features of the alp period of Anatolia. Some of the stories that were told under the title of Oghuznāme, such as the famous legend of Tepegöz, which has attracted the most attention - and which has been seen by various European scholars as having a strong connection with the cyclops in the Greek myths - still survive in some Anatolian villages.

\section{H Conclusion}

Having provided this long summary showing the general but distinct features of the spiritual and literary life in Anatolia before Yūnus Emre in order to 
characterize the milieu in which he flourished, I can now lay out the issue to my readers in a briefer and more synthetic manner. It is obvious from the above sketch that the primary sentiments that animated the Turks of Anatolia were those of religion and heroism. The religious feelings, which were chiefly manifest in mystical form, were not of the type that would paralyze the social structure by confining the Turks of Anatolia to tekkes or mosques, because the Turks, who frequently endured the campaigns of the Crusaders and were continuously on guard against them, had long possessed the warlike qualities that the geopolitical conditions of Anatolia demanded of them. Because warfare was essentially a religious command, religious feelings and feelings of heroism coalesced, indeed complemented each other, among the Turks as they did among other nations who fought religious wars in the Middle Ages. If the Șūin legends that flourished in this era of alps were analyzed even superficially, the following point would become quite obvious: There is an enormous difference between the warlike Turkish Șūîs in these legends - who battle against unbelievers with wooden swords, crush huge enemy armies with a handful of disciples, capture fortresses, and spread Islam to the lands of the infidels by the power of the sword ${ }^{110}-$ and the Arab and Persian Șūiss who spent tranquil lives in the tekkes. The erens \{saints, Șūfì spiritual leaders $\}$ of the era of alps were, as 'Ashıq Pasha quiet rightly stated, "hero saints" \{alp erenler\}.

In light of these cursory remarks, the aesthetic elements that constituted Anatolian literature at that time should be readily apparent. The works that were to satisfy the needs of this religio-heroic life were naturally to arise as a result of the coalescence of two kinds of sentiments, i.e. from a combination of religious and heroic feelings. And this is, in fact, what happened. The literary works of this period comprise legends of religious heroes who had acquired a national character or national heroes who had taken on an Islamic hue; didactic works devoted to religious etiquette; and, to some extent, Șūfì poetry. After the frontier had slowly advanced toward the west, and the eastern areas of Anatolia ceased to be a battlefield and were made secure, scholars who were preoccupied with translating and imitating Persian literature, and contemplative Șūfīs who lived in a deep state of mystic rapture in their tekkes, began to flourish there. But on the frontiers, the alp erens, i.e. dervishes engaged in jiha $\bar{d}$, still flourished. Indeed, even the collapse of political centralization, the lapse of Anatolia into widespread anarchy, and the outbreak of heretical uprisings under the screen of Șūfism in the midst of these disorders could not prevent this. It is during the early period of the foundation of the Ottoman state that the legendary memory of the alp erens, who conquered fortresses with wooden swords and provided leadership to the armies, is attested in our histories. ${ }^{11}$

In addition to the old religio-national heroic legends, Șūfì poetry, treating such subjects as the transitoriness of the world and the philosophy of the unity of being, also began to increase during the seventh/thirteenth century. The Șūfîs who wrote this poetry wanted to spread their beliefs among the common people and thus usually tried to introduce the philosophical element, which was foreign 
to them, in a manner that suited their taste. Consequently, they endeavored to clothe their ideas in a national garment with respect to language, style, form, and meter. This task was relatively easy, because the 'arü ' metrical system, i.e. Persian influence, had not yet penetrated very deeply and was unable to make much progress among the mass of the people. Also, those early poets had before them, as a model, the hikmats of Ahmad Yasawi and his imitators.

It is quite natural, therefore, that while the madrasa-educated class, who had been captivated by Persian literature, were busy translating the classical Persian works, many Șūfis, who were closer to the popular taste, wanted to spread their own beliefs among the people in a national form. Among those who undertook this task was, for example, Shayyād Hamza. The milieu necessary for success, and the elements from which the new artistic form would be created, were essentially present, but they still lacked a genius who would bring them together. It was Yūnus Emre who combined this foreign philosophical element with the national element, according to the peculiar genius of the Turkish aesthetic, and created a Turkish Șūfi literature that accorded with popular taste and, aesthetically speaking, was completely different from that of Persian Șūfì works. The role of Yūnus Emre in the birth of this distinctive literature, which flourished vigorously in the bosom of the nation for centuries and was rooted in it, was to understand with the genius of a national artist the need of the milieu and to combine and synthesize with overwhelming success a number of different elements that the centuries had brought forth. Thus, he was able to epitomize the national taste for centuries.

\section{NOTES}

1 Ibn al-Athīr $\{a l-K a \bar{m} i l\}$. The same historian states that these Oghuz had by that time already entered the milieu of Islam, but this began only in the fourth/tenth century as Barthold quite rightly claims. Furthermore, \{Zakariyyā' b. Muhammad\} al-Qazwīni's $\{$ d. 682/1283\} report suggests that the Oghuz had accepted Christianity at an early date $(\{\bar{A} t h \bar{a} r$ al-bila $d$,$\} ed. F. Wüstenfeld \{Göttingen, 1848; reprinted$ Wiesbaden, 1967\}, vol. 2, p. 394). Barthold states that these Oghuz were the people who had succeeded in unifying all the Turkish tribes from China to the Black Sea in a nomadic empire in the sixth century $\mathrm{CE}$ and that the Toquz Oghuz in the Orhon Inscriptions of the eighth century CE were, in fact, these people (see his article "Ghuzz" in $E I^{I}$ ). The Orientalist Radloff had already understood this point quite well before these inscriptions were discovered (Das Kudatku Bilik, p. 78). G. Ramstedt had claimed that these Oghuz were related to the Mongol Oirats and in like manner B. Munkácsi had claimed that they were related to the Uighurs, but it is simply impossible to accept these claims from the linguistic point of view. Nevertheless, Thomsen, like the Orientalists Barthold and Radloff, also categorically states that the Toquz Oghuz and the ancient Uighurs were the same people and that they were the ones who founded the early Uighur empire (Inscriptions de l'Orkhon, pp. 147-8). In the early Arabic sources, the name Tokuz-Guz, i.e. Toquz Oghuz, is last found in al-Ṭabarī $\left(\left\{\right.\right.$ Ta’ $^{\prime} \bar{k} k h$ (Leiden, 1879-1901),\} vol. 3, p. 1044; \{English trans. under the general editorship of Ehsan Yarshater as The History of al-Tabarn (Albany, NY, 1985-), see vol. 32, trans. C. E. Bosworth as The Reunification of the 'Abbassid Caliphate 
(1987), p. 107\}) in connection with their conquest of the region of Ushrūsana in 205/820-1. Subsequently, in the Western regions only Oghuz are mentioned, and these Oghuz, after becoming Muslims, are usually called Turkmen, which had the meaning of Muslim Turk. I have given information above (Chapter 5, p. 150, n.23) on this title, which we found first in al-Muqaddasī (de Goeje edn, p. 274), then in \{al-Kāshgarī’s\} Dī̌uān lughāt al-turk and \{Niz̄ām al-Mulk's\} Siyāsatnāme. In my view, the various etymological explanations of this word, which were first made by Arab and Persian historians and, afterwards, which have been proposed since Nashrī $\{$ d. before 926/1520\} up to the present time in both the East and West, are completely unacceptable and have no scientific basis. \{See Golden, "The Migrations of the Oğuz," and An Introduction to the History of the Turkic Peoples.\}

2 The Syr Darya Oghuz had quickly accepted Islam because they had a common border with Muslim countries and were in continuous contact with Muslims, Khazar Turks, and Qipchaqs. They had already departed Transoxiana before the Seljuks as various tribes and appeared, after passing through northern Iran, in Azerbaijan and Arrān, i.e. along the frontier of the Byzantine Empire, and began to conduct raids. Nomadic Oghuz tribes were also frequently found in Transoxiana and Khurāsān in the fifth/eleventh century. Those in Khurāsān had been transferred there from Transoxiana as a skillful political expedient on the part of Sultan Mahmūd of Ghazna. For various reasons, they also went to the Byzantine frontier and joined the other Oghuz who had established themselves there. However, neither Transoxiana nor Khurāsān remained completely free of Turks. A number of new Turkish tribes appeared from beyond the Syr Darya and descended upon those same regions. They mixed with the other Turks who were there and became a source of strength for the Seljuks. Transoxiana in particular, because of continuous migration up to that time, became rather Turkified and, to a considerable extent, lost its ancient Persian character \{clearly a Turkish nationalist assertion\}. While the most important ethnographic factor in this respect was the Qarluqs, the role of the Oghuz cannot be considered wholly without significance. In any case, within a short period of one or two centuries, under the command of the Seljuk rulers, the Oghuz who were established on the Byzantine frontier achieved the complete Turkification of Anatolia. Before the Mongol invasion, Oghuz tribes were found in the regions of Transoxiana, Khurāsān, northern Iran, the southern Caucasus, Azerbaijan, Kurdistan, and al-Jazīra. The Mongol invasion drove them toward the west and encouraged a renewed Oghuz migration into Anatolia in the Il-Khānid period. They later formed the states of the Aq Qoyunlu and Qara Qoyunlu. Even the Turks who later returned to the east and formed the basis of power of the Safavid state were all Oghuz. After the Mongol invasion, we no longer find the Oghuz in Transoxiana and Khurāsān. Let me simply add, as I mentioned briefly above (pp. 177-8), that the tribes presently living in the broad Turkmen area encompassed by the Caspian Sea, Iran, Khīva, and Bukhārā are the descendants of the Oghuz who had originally gone there and of the other Oghuz who joined them as a consequence of the Mongol invasion. Even this brief summary clearly demonstrates the huge extent of the ethnographic region that the Oghuz Turks had occupied before the founding of the Ottoman state in Anatolia.

3 The capital of the Saltuqid state, which was founded by 'Alī b. Abū 'l-Qāsim, a Turkmen bey, was Erzurum. This state, which often struggled against the Georgians, came to an end in 598/1202, after first coming under the protection of the Seljuks of Anatolia and then becoming directly subject to them. The Mengüchekid state, which was also founded by a Turkmen amīr \{synonymous with bey\}, Mengüj Ghāzī, possessed Erzincan, Kemah, Konya, Sharkī Karahisar, and Divriği, and their surrounding regions. Erzincan was the capital. The Mengüchekids fought for a long 
time against the Georgians, Abkhāzians, and Byzantines. In 625/1227-8, after the collapse of the Dānishmendid state, they handed the territory over to the Seljuks of Anatolia. The date of the end of the Divriği branch is not entirely clear. As for the Dānishmendid state, which was established by the famous Malik Aḥmad Dānishmend Ghāzī, it took control of the entire region of Cappadocia by conquering Sivas, Amasya, Tokat, Niksar, Osmancık, Çorum and their surrounding areas and then expanded across the Kızıl Irmak and incorporated Kangirı and Kastamonu and their environs. This state showed a great capacity for expansion at the time of its foundation, but the subsequent struggles over succession and disputes with the Seljuks of Anatolia served only to postpone somewhat the Turkification of Anatolia. With the collapse of the Sivas branch of the Dānishmendids in 569/1174 and the Malatya branch in 573/1178, their territory passed to the Seljuks of Anatolia. The AkhlātShāhs, who founded a state in 486/1093-4 and were extinguished by the Ayyūbids in 604/1207, often struggled against the Georgians. Akhlāt passed from the Ayyūbids to Jalāl al-Dīn the Khwārazm-Shāh and then back to the Ayyūbids. The Mongols later completely destroyed this city and massacred its population. Nevertheless, with the help of the Seljuk ruler 'Alā' al-Dīn Kai-Qubād I, it was revived to become one of the major eastern cities of the Seljuks of Anatolia. The Saltuqid, Mengüchekid, and Dānishmendid states were all founded by amīrs under the command of Alp Arslan after his great and decisive victory at Malāzgird. \{For recent work on these states, see the references in their respective sections in Bosworth, The New Islamic Dynasties (New York, 1996).\}

4 The political structures of the states established by Turks who had accepted Islam derived partly from the 'Abbāsids, i.e. from the old Sāsānid traditions, and partly from pre-Islamic Turkish traditions. The Seljuk state in Anatolia remained much more faithful to the old ethnic traditions than did the other Seljuk states. For example, it maintained such ancient institutions as the şölen (public banquets) and sı̆ğr (public hunts \{more properly "royal battue"\} in addition to a structure based on the twenty-four Oghuz clans and the clan beys, and even the kurultay \{great assembly\}. (For information on these subjects, see my article "Türk edebiyatı'nın menşe'i.") The reason for this, so it would appear, is that the Turks came to Anatolia in great masses, and these great masses allowed them to maintain the traditions and institutions that they brought with them. Anatolia was, in fact, already a "dār al-jih $\bar{a} d "$ \{abode of war\} at the time of Toghril Bey and Alp Arslan. Not only large groups but also many individual adventurers hastened there (Nizāam al-Mulk, Siyāsatnāme). In short, Oghuz traditions, which were called the Oghuz töre among the Seljuks of Anatolia, remained strong until the end of the dynasty and had a great influence on political and administrative structures. When the government organization of the Seljuks of Anatolia is studied historically in a comparative manner, the nature of their view of the state can be very clearly understood. The ancient Göktürk state was a compound structure composed of $i l s$ territories\}, and the ruler possessed a kind of patrimonial guardianship over them \{allusion to Max Weber, The Theory of Social and Economic Organization, trans. A. M. Henderson and Talcott Parsons (New York, 1947), pp. 346-54\}. Among the Qarakhānids, who suceeded the Sāmānids, the country was considered to be the property not just of the ruler but of the entire ruling family. Consequently, it was divided into many parts that were governed separately. Some of them in fact were independent of the central authority. The same state of affairs is encountered in the early Seljuk period. Because the ruler alone did not represent the state, in some cities of Khurāsān the khutba \{Friday sermon\} was recited in the name of Toghrl Bey, while in other cities it was recited in the name of $\mathrm{Da}$ ' $\bar{u} d$ \{i.e. his brother Chaghr Bey\}. The concept of state advanced \{i.e. became more rational in the Weberian sense $\}$ during the reigns of the successors of Toghrll Bey and the 
Seljuks of Anatolia, who definitely did not tolerate sharing such things as the khutba or coinage, which were perquisites of sovereignty. Even some neighboring states that were subordinate to the Seljuks were forced to mention on their coinage the name of the Seljuk sultan to whom they were subject. Nevertheless, the Seljuks still regarded it as legitimate for the ruler to divide the country among his children, so it is obvious that the concept of the indivisability of the state had not yet taken hold. In light of all this, it should now be clear that, among the Seljuks of Anatolia, there was another form of guardianship distinct from the ruler's patrimonial guardianship and that the state of the Seljuks of Anatolia had already abandoned, from its inception, the \{notion of an il-khānate, i.e. a composite entity in which the ruler possessed a patrimonial guardianship, and had become a sultanate. Still, it should not be forgotten that this sultanate could not be considered complete and perfect in every aspect of its formation and that a number of institutions, such as the twenty-four clans, sölen, and division of the territory among the individual family members, which dated from the early period of the Il-Khānate, survived until the end of the dynasty. As more research is done on the political structures of the Turkish states that were formed up to that time, these points will be elucidated. \{Cf. Köprülü's "Selçukiler zamanında Anadoluda Türk medeniyyeti," Leiser trans. pp. 48-9.\}

5 The military and political organization of the Seljuks of Anatolia reached its most developed form during the reign of 'Alä' al-Dīn Kai-Qubād I. Not only was the machinery of centralized government properly established, but the administrative apparatus in the provinces was also clearly defined and regularized. There were $q \bar{a} d \bar{\imath} s$, muffīs, subaşıs \{police chief, constable\}, and tax collectors everywhere. The fundamental organization of the Seljuk state, as of all the other Turkish states, was of a military nature. The land was parcelled out to the sipāhis \{cavalry soldiers\}, and high officials possessing large and rich timars \{military land grants\} maintained a set number of troops. The officials of the central government, 'ulama', sayyids, and muqarrabs \{court favorites\} also had timars that provided them with set incomes. On the frontiers, however, the timars were given mainly to ghāzis \{warriors, warriors for the faith \} and alps \{heroes\}. Being a sipāhn was a kind of dynastic right that passed from father to son. But the son first had to prove that he was a warrior in order to take his father's place. Indeed, all folk traditions had a war-like quality. The alps held a very important place among the people. On all the frontiers, there were usually march $\{u c\}$ beys who were charged with protecting the border. In the capital, the Seljuks of Anatolia had substantial standing military forces; and extensive training quarters were established, in the capital in particular, in order to prepare them for war. (For rather more detailed information on the political relations, civil and military organization, palace life, and many other special features of the Seljuks of Anatolia, and comparisons with similar institutions of the other Turkish states, see my article "Selçukiler zamaninda Anadoluda Türk medeniyyeti." \{Currently the most authoritative work on the Seljuks of Anatolia is Osman Turan, Selçuklular zamaninda Türkiye tarihi, 2nd edn (Istanbul, 1984); still useful is Cl. Cahen, Pre-Ottoman Turkey (New York, 1968). See EI' , s.v. "Saldjūkids" (C. E. Bosworth), section III, part 5, "The Saldjūks of Rūm."\}

6 Some of the sources that were consulted for this brief summary about the Turks in Anatolia were mentioned above. The major sources that were not mentioned are the following: Müneccim-başı's history \{ fāmi al-duwal, Turkish trans. Ahmad Nedim as Sahä' if al-akhbār (Istanbul, 1285/1868-9); the original Arabic section on the Ottomans has been published with a modern Turkish trans. by Ahmed Agirakça (Istanbul, 1995)\}, Hayrullâh Efendi's history \{Tarih-i âl-i osmân (Istanbul, 1271-92/1854-75), 'Ālī's Kunh al-akhbār, \{Husain\} Hezārfenn's Tanqūh tawārīkh \{al-mulük\} \{in MS in Köprülü's private library, see $E I^{2}$, s.v. "Husayn Hezarfenn" (V. L. Ménage)\}, \{Diyarbekirli\} Sa'īd Pasha's Mir'ät al-ibar \{Istanbul, 1304/1886-7\}, Ibn al-Athīr 
\{al-Kāmil\}, \{Mīrkhwānd's\} Rawḍtat al-șafāa, Juvainī’s Jahān-Gushā (vol. 2), Hammer's translation \{Geschichte der Ilchane (Darmstadt, 1842-3)\}, the \{Turkish\} translation of \{Ibn Nizām al-Husainī’s\} al-'Urāda \{fì al-hikāya al-saljūqiyya, ed. K. Süssheim as Das Geschenk aus der Seldschukengeschichte (Leiden, 1909), partial Turkish trans. Şerefeddin Yaltkaya, MTM, 1 (1331/1915), 257-304, 481-96\}, the text on the history of the Seljuks published by Houtsma \{he published both Ibn Bībī's al-Awämir al-'alä'iyya and Yazıcı-oğlu's Turkish translation (Leiden, 1889-1902)\}, Ph. Le Bas' Asie mineure \{Paris, 1864\}, İsmail Galip's Takvîm-i meskûkât-i selçûkiyye \{Istanbul, 1309/1891\}, Ahmed Tevhid's Meskûkât-i kadîme-i islâmiyye kataloğu \{Istanbul, 1321/1903-4\} (vol. 4), Necib Âsım and Mehmed Ârif's Osmanl tarihi, and the various articles published in TOEM by Halil Edhem and Ahmed Tevhid.

7 With regard to all the elements constituting their civilization, the most conspicuous influence on the Seljuks of Anatolia was primarily that of Iran. We will see this great influence more clearly below while discussing the Șūfì movement, Mawlānā Jalāl al-Dīn Rūmī, and the disaffection exhibited toward the national language and literature in Anatolia before the Ottomans. The Anatolian Turks did not undergo a great intellectual transformation as a result of their contact with Greeks and Armenians and saw no need to change their old views regarding science, philosophy, and art. Greco-Roman and Christian civilization was bound to have no effect on the Turks of Anatolia as long as their world-views remained unchanged. Moreover, the Muslim Turks did not see the civilization of these defeated \{Christian\} nations as superior to Islamic civilization. To the contrary, they considered it to be inferior in every respect. It was thus impossible for the Turks to escape the influence of Islamic civilization, which was a unified structure embracing every aspect of life. This civilization was not inferior to Western civilization in all of its particulars; rather, it was superior to it in many respects. Based on such considerations, I am of the opinion that Byzantine influence on the Anatolian Turks was very slight and superficial and that the contrary view cannot be defended historically. \{Köprülü later returned to this subject in his "Bizans müesseselerinin osmanlı müesseselerine te'siri hakkında bâzı mülâhazalar," Türk Hukuk ve İktisat Tarihi Mecmuast, 1 (1931), 165-313, English trans. Leiser as Some Observations on the Influence of Byzantine Institutions on Ottoman Institutions (Ankara, 1999). There was much greater cultural exchange between the Turks and Christians in Anatolia than Köprülü allows here. Indeed, he later qualified his views in the aforesaid work. See now in particular Speros Vryonis, The Decline of Medieval Hellenism in Asia Minor and the Process of Islamization from the Eleventh through the Fifteenth Century (Berkeley, CA, 1971).\}

8 The Anatolian Seljuk rulers Kılıch Arslan II, and then Ghiyāth al-Dīn Kai-Khusraw I and 'Alā' al-Dīn Kai-Qubād I, had very close relations with the Byzantines. Indeed, they were familiar with their traditions from living in Byzantium. The famous $q \bar{a} d \bar{\imath}$ al-Tirmidhī issued a strong fatwā saying that Kai-Khusraw was not suitable to be sultan because he had taken refuge with the Byzantine ruler and had done various things that were religiously prohibited. Later, when the sultan assumed the throne in Konya, he took revenge by putting him to death. Nevertheless, we know that in order to calm public opinion, which had been agitated over this incident - for the execution of a $q \bar{a} d \bar{\imath}$ was an unheard of event - the sultan granted a large number of favors to his heirs. Ibn Bībī interprets public opinion quite well by writing that, simply because of the inauspiciousness of this unjustified shedding of blood, the vineyards and gardens of Konya produced no crops for three years (Ibn Bībī, \{Yazıcı-oğlu's\} trans., p. 80). Now, this rather unconstrained behavior of the Seljuks of Anatolia was not, of course, condoned in the fanatical milieu of the neighboring courts. It was asked whether the Seljuks had returned to the old idolatry or Zoroastrianism. Indeed, the ruler of Aleppo, the famous Nūr al-Dīn al-Zangī, who, in the 
early books of ethics, such as \{Kınalı-Zâde 'Ali Chelebi's\} Akhlāq-i 'alä'i \{Būlāq, $1248 / 1833\}$, is presented as a model ruler with respect to his Muslim zeal, justice and integrity, wanted Kılıch Arslan II, whom he did not think was a true Muslim, to renew his faith in the presence of his envoy (Huart, Konia $\{$ La Ville des derviches tourneurs $\}$ [Paris, 1897], p. 215). Because the Seljuks of Anatolia used images of living things as decoration on public buildings, had figures and scenes carved in relief on the walls of fortresses, saw no harm in having three-dimensional statues made, and even had a cavalryman in the shape and person of Saint George on some of their coins, used the falcon and double-headed eagle on their weapons and coats of arms, and had images carved on their tombstones - practices that were never regarded as \{religiously\} lawful by the Sunn̄is - it is easy to understand how such doubts could arise about them. Yet the Seljuks of Anatolia were true Muslim-Turkish rulers, far removed from every kind of fanaticism. The religious zeal that they showed in response to the attacks of the Crusaders and the effort they expended to turn Anatolia into a Muslim country clearly demonstrate this. Indeed, the Turkish tribes that came to Anatolia were also free of every kind of fanaticism.

9 Gustave Mendel, "Les Monuments Seldjoukides en asie mineure," \{ La Révue de l'Art Ancien et Moderne, 23 (1908), 9-24, 113-27,\}, Turkish trans. Vahid as "Anadolu'da selçuk âbîdeleri," in $Y M,\{1917\}$, no. 19, \{369-74\}; no. 20, \{389-91\}; no. 21, $\{409-15\}$.

10 Even before this, however, Persian influence was already clearly evident in all elements of Seljuk civilization in Anatolia. The Mongol invasion also brought to the courts of the Seljuks of Anatolia - as was the case in the other courts of Western Asia that were saved from that onslaught - some poets, Șufîs, and artisans who no longer found it possible to live in Iran, Khwārazm, and Turkistan. As a consequence of this great invasion, some powerful new tribes of the Oghuz also migrated to Anatolia or the Seljuk frontier. It should not be forgotten, however, that even before the Mongol invasion, the ethnographic character and cultural composition of Western Anatolia were in a state of formation and development.

11 The Seljuk rulers who, like all enlightened men of the age, received a literary education and thoroughly knew Persian literature, were also poets in their own right and continuously showered their fellow poets with favors. Indeed, no other kind of behavior could have been expected from such rulers as Sultan Rukn al-Dīn Qāhir (Sulaimān II\}, Ghiyāth al-Dīn Kai-Khusraw I, 'Izz al-Dīn Kai-Kā'ūs I, and 'Alā' al-Dīn KaiQubād I, who were well known for their patronage of literature. When the famous poet Zahīr Fāryābī sent to Sultan Rukn al-Dīn a qașīda, the first verse of which reads

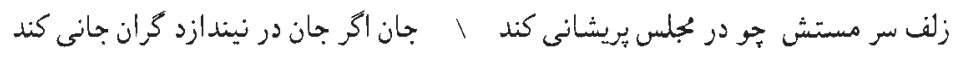

\{When he lets his drunken locks loose in the company / The soul would be sluggish if it did not sacrifice itself for him, $\}$ he received a reward of "five slaves, five slave girls, 2000 pieces of gold, five camels, three horses, and fifty pieces of valuable whole cloth." In like manner, because Niẓāmī Ganjawī composed his famous Makhzan al-asrār for Sultan Rukn al-Dīn and presented it to him, the sultan sent one of his companions to him with "5000 pieces of gold, five horses, sumptuous robes of honor and other gifts," and said that if it had been possible, he would have also given him \{other\} treasures by way of thanks in return for this work that would immortalize his name throughout the world. This information is extracted from my article, only part of which was published, entitled "Selçukîler zamanında Anadolu'da Türk medeniyyeti" \{not in the published part\}. Some critical material on this subject is found in that study. Sultans Rukn al-Dīn Qāhir, Ghiyāth al-Dīn Kai-Khusraw I, and 'Izz al-Dīn 
Kai-Kă' ūs I always discussed and debated issues with the scholars and poets in their councils and granted them royal favors. 'Alä' al-Dīn Kai-Qubād I, who was well versed in various branches of the fine arts, composed some quatrains, mostly in Persian, and took great pleasure in reciting them at wine drinking parties. According to a story of the translator $\{$ Yazıcı-oğlu\} of Ibn Bībī, his palace was truly a place of science and culture, Huzûrunda kasâid ve gazeller okunup, neyler vurulup, sazlar çalmıp, pişrevler pâre edilse, eşârin meânîsi ve nükteleri ve san'atlan ve evzânnndan bahis olunurdu ve makâmât ve durûb ve buhûr tahkikinden söylenirdi. Turrehât ve mâlâya'ni söz söylemezdi ve mecmû́ nedimleri fuzalâ ve üdebâ ve ehl ve şîrin-zebân kişilerdi \{Whenever qașīdas and ghazals were recited, neys and saz' were played, and peşrevs were performed in his presence, the meanings, subtle points, artistry and meters of the poetry were discussed and the modes and rhythmic structures of the music were analyzed. There was no idle talk. All his boon companions were men of culture, letters, and eloquence.\} One sees Persian influence, of course, in all of this.

12 As was explained in my study of the institutions of the Seljuks of Anatolia s see previous note $\}$, Persian influence was very strong in their court life as well as in their administrative organization. As in the old Sāsānid courts, the famous ball and stick \{polo\} game and, as in the oldest Turkish palaces, the battues that were held twice a year - and that were originally religious in character - were very well known in the Seljuk palaces. I hope to publish soon a special study on these public hunts that had great social value in early Iran and among various Turkish dynasties \{never published $\}$.

13 According to Mendel, Seljuk art was not a completely original art because a number of different influences acted upon it. Thus, building plans were Arab or Persian. In architecture, Syrian and Armenian forms mixed with Persian. The columns, capitals, and meanders bear witness to definite Byzantine influence, but limited to certain decorative details and without a significant effect on construction methods. In coverings of multicolored faience, Persian influence is again revealed. Geometric designs, i.e. the manner in which they are treated, and likewise vegetal designs and the arabesque belonged wholly to Islamic art. Finally, the use of depictions of living things in place of \{geometric\} decoration was not unknown to these artisans. Sometimes such different influences existed side by side without mixing and sometimes they blended together more profoundly. In order for a completely original art form to have arisen out of all these elements, the Seljuks of Anatolia would have had to persist under prosperous conditions for a much longer time than that which fate allowed them. As for the Ottomans, their successors, they appreciated beauty that was simple and imposing and for this reason did not especially like the ornamental and flowery motifs that the Seljuk sultans had loved so much in Konya. The real heirs of Kai-Khusraw I and Kai-Qubād I in art were the Qaramānids and Aydınids. The Qaramānid mosques in Qaramān and Konya and the Aydınid mosque of 'İsā Bey in Ayasuluk \{Ephesus\} still bear witness to the fact that Seljuk motifs and forms of ornamentation survived until the beginning of the ninth/fifteenth century (Gustave Mendel, "Les Monuments seldjoukides en Asie mineure," \{pp. 126-7\}. The author \{Saladin\} of the famous work entitled Manuel d'art musulman: l'architecture essentially agrees with Mendel on Seljuk art and its constituent elements.

14 Heinrich Glück, \{Türkische Kunst, a published lecture (Budapest-Constantinople, 1917)\}, Turkish trans. Ahmed Cemal as "Türk san'at1," $Y M,\{1918\}$, no. $59\{129-32\}$; no. $60\{149-52\}$; no. $61\{168-72\}$. An assistant of the famous Prof. J. Strzygowski, the director of the Vienna Institute of Art History, he wrote an important work on Seljuk sculpture in Anatolia that was published in Istanbul in 1917 as the fourth publication of the Müze-i Humâyun \{Imperial Museum\}. The ideas that Prof. Strzygowski first advanced about early Turkish art in his recent and very 
important work Altai-Iran und Völkerwanderung \{Leipzig, 1917\} and \{now $\}$ the studies of Glück challenge everything known to date about Turkish art. The archeologists who have studied Turkish art comprehensively from the earliest times to the present, just as I have done with literature, have quite rightly asserted that early Turkish elements are also found in Seljuk art. This wholly scientific approach, which allows one to analyze an entire series of events successively from beginning to end, has rescued the history of Turkish literature from obscurity during the past six or seven years, and will no doubt be equally productive for the history of art. \{On Turkish art, now see, for example, Oktay Aslanapa, Turkish Art and Architecture (New York, 1971), and Esin Atil (ed.), Turkish Art (Washington, DC, 1980).\}

15 During the time of Saladin $\{564-89 / 1169-93\}$, tekkes and tariqas multiplied in Egypt and Syria to such an extent that he found it necessary to create some structure for them in order to maintain order and to prevent discord and confusion. Thus, he established the tekke of Sa'īd al-Su'adā', which he called the "Duwairat al-Șūfìya" $\{$ Șûi cell $\}$, and then gave the shaikh who was appointed to it a right of supervision over the other shaikhs (\{Zaydān,\} Medeniyyet-i islâmiyye tarihi, vol. 1, p. 239). \{On this facility, see al-Maqrīzī, al-Khitat (Būlāq, 1870), vol. 2, p. 415; and Leonore Fernandes, The Evolution of a Sufi Institution in Mamluk Egypt: the Khanqah (Berlin, 1988).\}

16 The biographies and commentaries, both important and trivial, that have been written in Arabic, Persian, and Turkish about the famous Ibn al-'Arabī, who is considered to be one of the most important and greatest Șūfis to flourish in the Muslim world and who acquired the title the "Greatest Shaikh" and had a powerful influence for centuries on Islamic mysticism through his important works like the Fușus and al-Futühăt, are too numerous to list here even briefly. The fact that no serious and detailed study has yet been produced on the life, works, career, and influence of Ibn al-Arabī truly constitutes a very great shortcoming for the \{study\} of the history of Süfism. [For the most concise information on the research that has been done on Ibn al-'Arabī in the years since this was written, one should see $\dot{I} A$, s.v. "Muhyi-d-Din Arabî" (Ahmed Ateş) \{abridged in his article "Ibn al-'Arabl̄" in $E I^{2}$; now see, above all, William Chittick's works on Ibn al-Arabī, notably those in the bibliography\}.] By the seventh/thirteenth century, there had already developed among Muslim mystics large and powerful movements both for and against Ibn al-'Arabī. On the one hand were proponents of wahdat al-wujüd \{unity of being\} who believed that he had reached the highest stage of Șūfism. On the other there appeared extremist opponents who went so far as to accuse him of unbelief and heresy. \{See Alexander D. Knysh, Ibn 'Arabi in the Later Islamic Tradition: The Making of a Polemical Image in Medieval Islam (Albany, NY, 1999).\} The famous Shaikh Kamāl al-Dīn 'Abd al-Razzāq al-Kāshī, who wrote valuable commentaries on the Fusūs and Manāzil

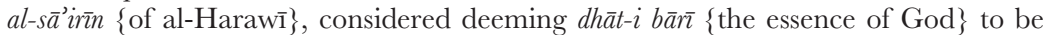
wrijūd-i mutlaq \{absolute being\} to be the most advanced level of his knowledge, but his contemporary Shaikh Rukn al-Dīn 'Alā' al-Dawla \{al-Simnānī\} found this completely unacceptable. Indeed, this issue alone resulted in some correspondence between them (\{Jāmī, $\}$ Nafahāt, \{Turkish\} trans., pp. 537-47). According to the commentator on the Manäzil al-sä'irinn, the last of all the stages was tawhìd. Shaikh Rukn al-Dīn 'Alā' al-Dawla, however, considered tawhìd to be only the eightieth stage and replaced it with devotion to God ('ubüdiyya) as the ultimate, i.e. the hundredth stage. According to him, Devotion to God from the point of view of sanctity means returning to one's initial condition. Indeed, when Sayyid al-Ṭā'ifa al-Junaid alBaghdādī was asked "What is the end of this business?" he answered, الرجوع الى البداية \{Returning to the beginning\}. Shaikh 'Alä' al-Dawla, who had written many quatrains on the theme of tawhīd, said that after placing qidam \{eternal pre-existence of God\} at the end of the stage of tawhind, he realized that these quatrains were in sheer error 
and that to return to God was much better than remaining in falsehood (Nafahăt, \{Turkish\} trans., p. 547).

17 When the influence of the caliphs of Baghdad declined and sovereignty passed into the hands of various Turkish, Dailamī, Kurdish, and Persian amīrs and sultans, these new rulers needed a means of attracting the affection of the people in order to appropriate the religious aura of the caliphs. The easiest way to do this was to favor the poor and honor and respect the 'ulam $\bar{a}$ ' and Șūfìs. Consequently, when a clever and prudent sultan or $a m \bar{\imath} r$ won sovereignty over a city, he first tried to win over its 'ulam $\bar{a}$ ', faq̄īhs, and Șūfìs, to construct mosques, caravansaries, tekkes, and soup kitchens, and to provide for the salaries \{of their employees\} and income \{for their maintenance\}. Nizām al-Mulk showed great skill and energy in this regard. Another reason why such institutions multiplied in a short time was that the amirs and the wealthy people wanted to leave a means of livelihood to their heirs. Anyone who feared that upon his death the ruler would confiscate his wealth would build, for example, a tekke or madrasa, endow it with all his property and then place his children in charge of the administration of the endowment $\{w a q f\}$ and set aside for them an amount that he specified from its income (\{Zaydān,\} Medeniyyet-i islâmiyye tarihi, vol. 3, pp. 397-9). It would be completely incorrect, however, to attribute the creation of such charitable institutions merely to material motives, such as, in particular, the desire of the founder of a waqf to ensure an income for his children. Spiritual and altruistic factors also played a role in this. \{There is a growing literature on waqf in Anatolia. See, for example, Mehmet Köymen, "Selçuklu devri kaynakları olarak vakfiyeler," in Studi preottomani e ottomani (Naples, 1976), pp. 153-63, and S. Bayram, "Selçuklu vakfiyeleri üzerine bazı düşünceler," in IV. Milli Selçuklu kültür ve medeniyeti semineri bildirileri (Konya, 1995), pp. 135-47.\}

18 The famous Șūfì Khwāja 'Azīzān \{more properly known as Khwāja 'Alī 'Azīzān Rāmītanī\}, to whom Mawlānā showed reverence in the couplet

$$
\text { كر نه علم حال فوق قلا بودى كى بدى ل بنده اعيان بخارا خواجئ نساج را }
$$

\{If the science of mystical states $(h \bar{a} l)$ were not superior to standard religious knowledge $(q \bar{a} l)$, why would the notable men of Bukhārā be subservient to Khwāja-i Nassāj (the weaver)\}, left Bukhārā and went to Khwārazm. When he arrived he sent two of his dervishes to the ruler specifically requesting a written permit to reside there. Attributing this to the shaikh's naiveté, the ruler cheerfully granted permission. A short time later, however, so many murids had collected around the shaikh that the ruler became frightened of this large assemblage and, for political reasons, decided to expel the shaikh from the country. But when Khwāja 'Azīzān showed the permit that he had received, the ruler was very embarrassed and, together with the leading state officials, joined the ranks of the shaikh's murids (\{Șafī,\} Rashahät, \{Turkish\} trans., pp. 48-9). This curious incident, which was perhaps altered in transmission, should probably not be viewed as an isolated occurrence. \{The story about Rāmītanī's arrival in Khwārazm, from the Rashahăt, seems to have been a floating anecdote, since much the same story is found about other Șūfìs in Central Asia (and Köprülü left out the interesting part where Rāmītanī is said to have paid people money to become his followers). As for Rūmī knowing about him, according to the Rashahāt Rūmī died nearly a half century before Rāmītanī. The "Khwāja-i Nassāj" referred to in the couplet might be one of two much earlier figures: a Muhammad al-Nassāj of Baghdad, a contemporary of Junaid, or Abū Bakr al-Nassāj of Ṭūs (d. 487/1094). The link with Bukhārā, however, suggests that it might refer to 'Abd al-Khāliq Ghujduwānī, who is also referred to as "a weaver" in some accounts, and is linked in 
several stories with one of the famous șadrs of Bukhārā. There may be something significant about the term "weaver" being applied to several early Khwājagānī saints. In any case, the term used for both Rāmītanī and Ghujduwānī is the Persian one, bäfandah, rather than $n a s s \bar{a} j$. $\}$ Let me mention another important incident from an earlier time in order to show the influence of the shaikhs on the rulers: when Sultan Sanjar went to war against the Khwārazm-Shāh Atsız and entered Khwārazm, the famous Șūfì Zāhid-i Āhū-Pūsh, who was there - and about whom it is reported that he ate deer meat and wore deer skin - "presented himself before Sanjar and after delivering a goodly sermon interceded for the people of the town" (Juvaini, Fahān-Gushā, vol. 2, p. 10 \{Boyle trans., vol. 1, pp. 283-4\}). Such efforts on the part of Sûfīs were generally productive and influential with rulers who were aware of "the Șūfì truths." One can find many such incidents in the history of this period.

19 Birgün Şeyh Mecdü'd-Dîn, dervişlerinden bir cemâatla oturmuştu. Üzerine sekr gâlib oldu, aynttı: Biz bir kaz yumurtası idik, deryâ kenarnda Şeyh Mecdü'd-Din \{error for Necmü'd-Dîn\} bir murg idi; termiyet kanadın üzerimize örttü; tâ kim biz yumurtadan çıktı; bir kaz yavrusu gibi deryâya gittik ve şeyh kenarda kald. Şeyh Mecdü'd-Dîn \{same error as above\} nûr-i kerâmetle ol sözü ma'lûm edindi; zebanlarndan bu sâdır oldu ki: Deryâda olsun \{rather, ölsün\}. Şeyh Mecdü'd-Dîn ân işitib havf eyledi. Şeyh Sa'de'd-Dîn-i Hamevî̀nin önüne geldi ve çok tezarru' eyledi ve aytth: Birgün Şeyh hoş-hâl ola, haber eyle, tâ kim hazretine varb özür dileyim. Bir vakitte sema'da Şeyh hoş-hâl oldu. Şeyh Sa'de'd-Din haber eyledi. Şeyh Mecdü'd-Dîn yalnayak geldi ve bir leğgeni ateşle doldurub ve başı üzerine koyup paşmak çkardıklar yerde durdu. Şeyh Mecdü’d-Dîn âna nazar edib aynttr: Çün dervişler tarikince kelâm-ı perî̧̧ân özrün dilersin, îmân ve dîni selâmete ilettin, ammâ başın verirsin ve deryâda olursun \{rather, ölürsün\} ve biz dahî senin ucundan gideriz ve nice serdârlarn başlan ve mülk-i Hârizm senin ucundan gider ve âlem harabolur. Şeyh Mecdü'd-Dîn, Şeyh' in kademine düstü, az müddet sonra Şeyh' in dediği zuhûra geldi. Şeyh Mecdü'dDîn, Hârizm'de va'z ederdi ve Sultân Muhammed'in anası ânm \{instead of ânm, the original has begâyet cemîle bir hatun idi, Şeyh Mecdü'd-Dînin\} va'znna gelir, ahyânen ziyâretine varrdı.

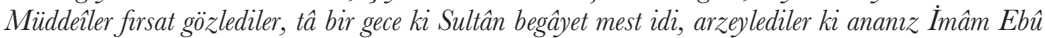
Hanîfe mezhebince Şeyh Mecdü'd-Dîn' in nikâhnna girmiştir. Sultân ziyâde bî-huzur oldu ve buyurdu $k i$, Seyh'i suya \{Dicleye $\}$ atm, attlar. Şeyh Necme'd-Dîn'e haber erişti, mütagayyir oldu, \{in the original followed by ve eyitti: innâ lillâhi ve innâ ileyhi râjï în. Oğlum Mecdü'd-Dîni suya attilar, öldü. Pes\} başın secdeye koydu, bur hayli zamân sonra kaldmp dedi ki: Hazret-i İzzet'ten istedim ki oğlum Mecdü'd-Dîn' in hûn-bahâss için mülkü Sultân Muhammed'den ala, icâbet buyurdu. Sultân'a bundan haber verdiler, begâyet peşiman oldu, piyâde Hazret-i Şeyh'e geldi ve bir leğen dolusu altun getirdi. Üzerine bir knlıç ve kefen koydu ve başsm yaln eyledi ve saff-ı ni'alde durdu ve ayıttı: Eğer diyet gerek işte altun, eğer kisas eyler isen işte kiluç ve baş... Şeyh cevâbinda buyurdu ki, ânin diyeti senin mülkündür, senin başın gider ve çok halkn dahî başı gider, biz dahî sizin ucunuzdan gideriz. Sultân Muhammed nevmîd olup geri döndü ve 'an-karîb Cengiz Han hurûc eyledi. (One day Shaikh Majd al-Dīn was sitting with a group of his dervishes. A sense of intoxication overcame him and he said, "I was a goose egg on the seashore and Shaikh Najm al-Dīn was a bird. He spread over me the wing of training, and I emerged from the egg. I took to the sea like a gosling, while the shaikh remained on the shore." Shaikh Najm al-Dīn, through the light of grace, learned of this remark and the following emerged from his mouth: "Let him die in the sea." Shaikh Majd al-Dīn heard this and was frightened. He came before Shaikh Sa'd al-Dīn al-Hammūyī, very obsequiously humbled himself and said, "One day when the shaikh is in good humor, inform me so that I can go and beg his pardon." Once during a $s a m \bar{a}^{c}$ the shaikh was in a good humor. Shaikh Sa'd al-Dīn informed him. Shaikh Majd al-Dīn came barefoot and filled a large bowl with fire, placed it on his head and stood where they took off their shoes. Shaikh Najm al-Dīn looked at him and said, "Since you ask forgiveness with distraught speech according to the way of the dervishes, you have secured your faith and religion, but you will lose your life and 
die in the sea, and we will also die because of you and many a military commander will die because of you and the dominion of Khwārazm will be lost and the world will go to ruin." Shaikh Majd al-Dīn fell before the foot of the Shaikh and a short time later what the Shaikh said came to pass. Shaikh Majd al-Dīn used to preach in Khwārazm and Sultan Muhammad's mother (who was a very beautiful woman) used to hear him and on occasion she used to visit him. Gossipers watched for an opportunity. One night the sultan was extremely drunk. They said to him "Your mother has married Majd al-Dīn according to the madhhab of Abū Hanīfa." The sultan was very upset and ordered that the shaikh be cast into the water and they cast him in. Word of this reached Shaikh Najm al-Dīn Kubrā and he became very upset. (He said: "We belong to God and to Him we return. My son Majd al-Dīn has been cast into the water and has died." Then) he placed his head on his prayer rug and some time later raised it and said, "I prayed that God take the kingdom away from Sultan Muhammad as the blood-price of my son Majd al-Dīn. And my prayer has been answered." They told the sultan about this and he became extremely remorseful. He went on foot to his excellency the shaikh and he brought a large bowl full of gold. Over it he placed a sword and shroud and he bared his head. He stood by the door where shoes are left on entering and said, "If it is blood money you want, here is the gold. If it is revenge you want, here is the sword and head." The shaikh answered, saying, "The blood money is your kingdom. Your life will be lost and the lives of many people, and I too will lose my life because of you." Sultan Muhammad was in despair. He returned and soon Chingiz Khān burst forth ( $\{$ Jāmī, $\}$ Nafahăt, \{Turkish $\}$ trans., pp. 481-2). This curious legend is recorded in all the sources \{this is not the case\} and is very famous. Dawlat-Shāh attributes the appearance of Chingiz Khān to a similar cause, especially noteworthy in showing the great spiritual influence attributed to the shaikhs: Because there was a great loathing between Sultan Muhammad the Khwārazm-Shāh, who was very proud of his greatness and power, and the 'Abbāsid caliph al-Nāṣir, the sultan obtained fatwās from the 'ulama' and imāms to the effect that the 'Abbāsids did not deserve the caliphate and that it was reserved for the descendants of 'Alī. His intention was to depose and expel the caliph and install in his place one of the sayyids of Tirmidh, Khānizāde 'Alā' al-Mulk, and with this intention he marched on Baghdad. Caliph al-Nāṣir sent the famous Shaikh Shihāb al-Dīn 'Umar al-Suhrawardī with an embassy to the sultan in order to seek a reconciliation. The shaikh met the sultan's army at Nihāwand. When the shaikh entered the sultan's tent, the sultan kept him standing and did not offer him a seat. While on his feet, he told the sultan of the dignity and high rank of the 'Abbāsids and of the harm of becoming the object of their malediction. After a cool exchange of views, the shaikh returned empty handed. Numerous maledictions befell the sultan. Dawlat-Shāh is certain that these imprecations were answered. The same writer reports that whenever Sultan Muhammad the KhwārazmShāh met the Mongols \{in battle\} he heard a voice from among the men of the unseen world say, "Oh, unbelievers! Kill the sinners!" and, being struck with terror, fled. He adds the following anecdote in the same vein: It is reported from the people of unveiling \{saints \} and the great men of religion that they saw a great many men of God as well as Khadir provide guidance at the front of the Mongol army. In the face of this divine wisdom, the discernment of the 'ulam $\vec{a}$ ' and the wisdom of the sages are weak and bewildered. But God is the Almighty and does what He wishes. As a result of this, Shaikh Najm al-Dīn Kubrā recited the following quatrain:

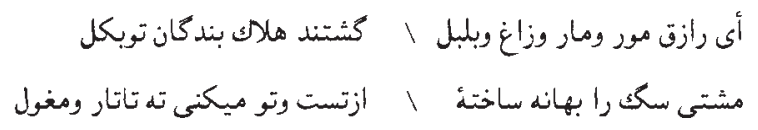


$\{\mathrm{O}$ ! You who provide sustenance to ant and snake and crow and nightingale: All of your servants (= creatures) have been destroyed / You have made a band of dogs the pretext. It is You: You have done it, not the Tatars and the Mongols\} (Dawlat-Shāh, Tadhkira, pp. 133-5). \{See Deweese, "Dog Saints and Dog Shrines," p. 465. \} These curious anecdotes, which go to show that Chingiz Khān was "supported by God" (mu'ayyad min taraf Allāh) and a "great conqueror" (șăhib-khurüj), are obviously later fabrications - the work of politically shrewd Persian historians. Juvainī, who had the best and most intimate knowledge of the history of the Khwārazm-Shāhs, also reports that Sultan Muhammad the Khwārazm-Shāh's behavior toward the caliphs of Baghdad did not bring him good luck (Jahān-Gushā, vol. 2, p. 122). The biography of Shihāb al-Dīn 'Umar al-Suhrawardī and extensive accounts of his exalted position are found in all the Arab and Persian biographical dictionaries and collections of Șûfì legends. It is also known from these works that he wrote a book of travels called al-Risāla al-'assimiyya (C. Fraehn, Indications Bibliographiques \{relatives pour la plupart à la littérature historico-géographique des arabs, des persans et des turcs ... (St Petersburg, 1845)\}, p. 45, n.149). Descriptions of the Khwārazm-Shāhs' relations with the caliphs of Baghdad can also be found in Barthold \{Turkestan\}, Nasawī \{Sìrat al-Sultān Falāl

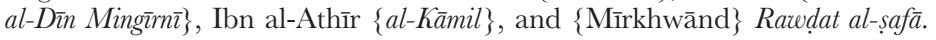

20 Imām al-Ghazālī, in his work al-Tafriqa bain al-islām wa 'l-zandaqa, mentions certain false Șüfiss who claimed they were in a state of divine ecstasy and had no need for the obligations of this world, such as prayer and worship, and he wanted to have them arrested (see Huart, "Les Zindîqs en droit musulman," \{Actes du $11^{e}$ Congrès International des Orientalistes (1897), 3rd section, pp. 69-92,\} citing the MS in the Ayasofya Library, and Jacob, Die Bektaschijje, p. 44 there is an English trans. of al-Tafriqa in R. J. McCarthy, Deliverance from Error . . and Other Works of al-Ghazali (Louisville, n.d.; reprint of Twayne, 1980), pp. 125-49\}.

21 When the Mongols turned toward Khwārazm, Shaikh Najm al-Dīn Kubrā collected his followers. Their number was more than 600. He said to some of them, such as Shaikh Sa'd al-Dīn al-Hammūyī and Raḍī 'l-Dīn 'Alī Lālā, "Arise quickly! A conflagration has appeared from the East and will burn all the way to the West." Some of his followers asked him to pray in order to repel it. "It is not possible," he said. "In that case, you come with us. Let us go to Khurāsān," they said. "I will be a martyr here. I am not permitted to leave the country," he replied. Thereupon a large number of murìds set out for Khurāsān. When the Mongols came to Khwārazm, the shaikh and his remaining murids went out to meet them. He wore a patched cloak $\{k h i r q a\}$ open in front and had filled his arms with stones. Finally, the stones in his hand ran out. An arrow struck his chest. He plucked it out and fell dead (617/1220). Shaikh Najm al-Dīn, who is considered the founder of the Kubrāwiyya tariqqa, was a great Șūfì. There is a tradition that Mawlānā Bahā' al-Dīn Walad \{Rūmī's father\} was one of his murīds. His other leading khalīfas were shaikhs such as Majd al-Dīn Baghdādī, Sa'd al-Dīn al-Hammūyī, Bābā Kamāl Jandī, Raḍī 'l-Dīn 'Alī Lālā, Saif al-Dīn Bākharzị, Najm al-Dīn Rāzì, and Jamāl al-Dīn Gīlī, all of whom held high positions in the Sūfì world. In the famous poem by Jalāl al-Dīn Rūmī that begins

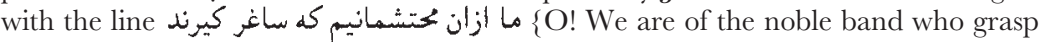
the cup of wine,... (thus in Afzal Iqbal, The Life and Work of Jalal-ud-din Rumi, 3rd rev. edn [Lahore, 1974], p. 46; but in Rūmī’s Kulliyät-i Shams-i Tabrīz, ed. B. Furūzānfar as Kulliyāt-i Shams, ya Dìvān-i kabīr [Tehran, 1977], no. 785, the first words are ما نه زان محتشيمانيم [we are not of the noble band who grasp the cup of wine])\}, there is an allusion to the martyrdom of Najm al-Dīn Kubrā ( $\{$ Jāmī, $\}$ Nafahăt, \{Turkish\} trans., p. 480). \{See EI ${ }^{2}$, s.v. "Kubrā" (Hamid Algar).\}

22 Sultan 'Izz al-Dīn Kai-Kā'ūs I's attachment to his shaikh Majd al-Dīn Isḥāq, and later 'Alā' al-Dīn Kai-Qubād I's and his amīrs' respect and reverence for Shaikh 
Shihāb al-Dīn al-Suhrawardī, who was sent by Caliph al-Nāṣir li-Dīn Allāh, and, as will be seen below, the respect and kindness shown to Sulțān al-'Ulamā' Bahă' al-Dīn Walad and a number of other Șūfis are all evidence of this.

23 Ibn al-'Arabī, who spoke with him, says that this occurred in 602/1205-6 (\{Jāmī, \} Nafahāt, \{Turkish\} trans., p. 409). As a result of this encounter, Awhad al-Dīn Kirmān̄̄ \{d. 635/1238\}, who was associated with Shaikh Abū 'l-Najīb al-Suhrawardī \{d. 563/1168\}, was one of the Sūfîs who şuhûd-i hakikate mezâhir-i suverî ile tevessül eden ve Cemâl-i Mutlak'ı suver-i mukayyedatta gören \{approached the witnessing of Truth by means of the manifestations of form, and saw Absolute Beauty in earth-bound forms\}. Because of this, Shihāb al-Dīn al-Suhrawardī called him an "innovator" (ibid., p. 660). In meetings with Shams Tabrīzī, Shams would ask him what he had done and he would reply, "I saw a bear in the water basin." Shams then alluded to the error into which he had fallen by asking, "If a boil did not erupt on your head, why don't you see it in the sky?" (ibid., p. 520). There are many stories about Awhad al-Dīn Kirmānī's being overly attracted to divine beauty in earthly form \{huṣn-i zanhin̄ $\}$. Mawlānā had great respect for Awḥad al-Dīn Kirmānī, who composed the following quatrain:

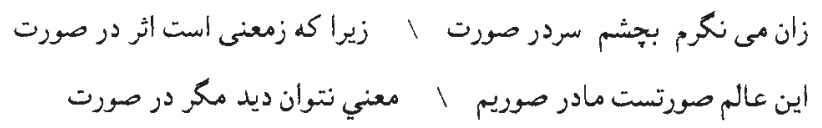

\{I look at the forms with the eyes of my head,

Because in the forms there is a trace of meaning.

This is the world of forms, and we are in the forms:

One canot see meaning except in the forms.\}

The author of the Nafahāt describes the attraction of the great Sūfiss like Shaikh Aḥmad al-Ghazālī, Awhạad al-Dīn Kirmānī, and Fakhr al-Dīn 'Irāqī to earthly beauty as follows: Ekâbirden bâzi cemâat ki cemâl-i mezâhir-i sûñ̂ ve hissî mütâlâasina isstigâl göstermişlerdir; Hüsn-i zan belki sıdk- i itikâd evlâdır ki, onlarn ol mezâhirde Hak Sübhânehu ve Téâlâ'nnn Cemâl-i Mutlak'm mü̧sâhede etmişlerdir ve suver-i hüsn ile mukayyed olmamışlardır ve eğer bâzı küberâdan onlara nisbet inkâr vâkı olduysa ondan maksud oldur ki mahcuplar onu düstur bilmeyeler ve hâllerini onlann hâllerine kyyâs etmeyeler \{With regard to some of the great men who were preoccupied with observing formal, perceptible, outward beauty, it is correct opinion, or rather true belief, that they did witness God's absolute beauty in those manifestations and they were not confined to the (outward) forms of beauty. If certain scholars have repudiated them, their motivation in doing so was to prevent the modest from considering those men as models and judging their own condition by theirs\} (p. 662). Mawlānā's warning كار باكانرا قياس از خود مكير (Do not judge the deeds of the pure by your own (Mathnawn, vol. 1, 263)\} thus applies to such conditions. One should not confuse Awhad al-Dīn Kirmānī, who wrote an imitatio to the famous orthodox \{muwahhidanne, confessing the unity of God\} poem of Sanā's, which begins with the verse

$$
\text { طلب أى عاشقان خوش رفتار ا طرب أى شاهدان شيرين كار }
$$

\{Longing, oh lovely-walking lovers! / Joy, oh sweet-behaving beauties!\} (DawlatShāh, Tadhkira, p. 98), and who also wrote a number of orthodox quatrains (p. 210), with his murīd and disciple Awhad al-Dīn Marāghī. In his section on the famous Sūfī Amīr Sayyid Husainī (d. 718/1318-19), Dawlat-Shāh says that this Sūfì \{apparently 
Husain̄̄ \}, who was a mur̃̄d of Shihāb al-Dīn al-Suhrawardī, retired for religious devotions with Shaikh Fakhr al-Dīn 'Irāqī and Shaikh Awhad al-Dīn \{Marāghī\} (d. 697/1297-8) \{d. 738/1337-8 in $\left.E I^{2}\right\}$ in the tekke of Shaikh Awhad al-Dīn in Kirmān and that during this time 'Irāqī wrote his Lama' $\bar{a} t$, Sayyid Husain̄̄ wrote his Zād al-musāfirnn, and Shaikh Awhad wrote his famous Tarji ' and they presented these works to Awḥad al-Dīn Kirmānī (p. 233). Dawlat-Shāh's statement (p. 210), in his section on Awhad al-Dīn Kirmānī, that he was a murūd of Shihāb al-Dīn al-Suhrawardī is an error that derives from his being associated with Shaikh Abū al-Najīb al-Suhrawardī in this way. \{See Badī‘ al-Zamān Furūzānfar (ed.),

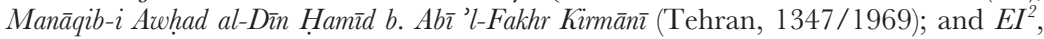
s.v. "Kirmān̄̄" (B. M. Weischer).\}

24 Shaikh Fakhr al-Dīn Ibn Ibrāhīm 'Irāqī, who died in Damascus in 709/1309-10, according to Dawlat-Shāh, or in 688/1289 according to \{Jāmī's\} Nafahăt, holds an important place among the Persian Șūfì poets because of his Lama' $\bar{a} t$ and Dĩwān. Dawlat-Shāh says that he was associated with Shihāb al-Dīn al-Suhrawardī who sent him to India to Shaikh Bahā' al-Dīn Zakariyyā' al-Multān̄̄ \{cf. $E I^{2}$, s.v. "'Irāqī" (H. Massé), versus errors of Dawlat-Shāh\}, whose daughter he married (pp. 21516). In the Nafahāt, it is related that after he returned from India, he visited Mecca and Medina. From there he went to Anatolia and had conversations with Sadr al-Dīn al-Qūnawī. He listened to al-Qūnawī's lectures on \{Ibn al-'Arabī’s\} Fuṣuṣ and wrote the Lama'a $\bar{t} t$ under its influence. We also know that the famous Mu'īn al-Dīn Parwāna was one of his murīds and firmly believed in him and had a tekke built for him in Tokat (Nafahät, pp. $671 \mathrm{ff}$.). This also confirms that the report deriving from Dawlat-Shāh according to which the Lama'a $\bar{t}$ was written in Kirmān and presented to Shaikh Awhad al-Dīn Kirmānī, as mentioned in n.23 above, is not correct. The legendary deeds of this shaikh, who was known for contemplating divine beauty in earthly forms exactly like Awhad al-Dīn Kirmānī, are recorded in the Nafahāt. It seems clear that this shaikh was under the influence of Ibn al-'Arabī and Șadr al-Dīn al-Qūnawī. The Lama'ät is a well known work written in the style of Ahmad al-Ghazālī's Risāla-i Sawāniḥ. The famous sultan Abū 'l-Qāsim Bābur enjoyed reading it very much. The shaikh of shaikhs Șadr al-Dīn Muhammad al-Rawāsī, in response to one of his \{apparently Bābur's \} questions on this work, described the religious works of Shaikh 'Irāqī as "mahd-i $\bar{\imath} q \bar{a} n$ wāssil-i 'irfän" \{pure certainty, a means of attaining spiritual knowledge\} (Dawlat-Shāh, Tadhkira, p. 233 \{the Lama'ät has been translated by William Chittick and Peter Lamborn Wilson as Divine Flashes (New York, 1982)\}).

25 There is extensive information on Mu'īn al-Dīn Sulaimān Parwāna's political life in all the works on the Seljuks of Anatolia. He corresponded with al-Malik al-Zāhir Baibars, the ruler of Egypt who sent this correspondence to Abaqa Khān, and on Abaqa's order he was executed in 676/1277. There is also information on his relations with Jalāl al-Dīn Rūmī in the books of $\{S \operatorname{unfî}\}$ legends. \{See Carole Hillenbrand, "Mu'īn al-Dīn Parwāna: the Servant of Two Masters?" in F. de Jong (ed.), Miscellanea Arabica et Islamica: Dissertationes in Academia Ultrajectina prolatae anno MCMXC (Leuven, 1993), 267-74.\}

26 Najm al-Dīn Rāzī, who had the byname Najm al-Dīn Dāya, was a follower of Najm al-Dīn Kubrā. His training was assigned to Shaikh Majd al-Dīn \{Baghdādī\}. He met both Șadr al-Dīn al-Qūnawī and Jalāl al-Dīn Rūmī, who had gone to Anatolia from Khwārazm during the Mongol invasion. This shaikh, who was the author of Mirșadd al-ibäd and Tafsir r-i bahr al-haqa' $i q$, died in 654/1256, but his place of death is not known for sure. Some assign a grave in Baghdad to him, but it has not been proven to be his. In the second section of the first chapter of Mirșad al-ibād, it is stated that he left Hamadān with some dervishes at the onset of the Mongol invasion in 617/ $1220-1$, that he went to the land of Anatolia $\{\operatorname{Ru} m\}$ via Irbīl the following year, that he resided in Kayseri, which was one of the flourishing Anatolian cities thanks 
to the justice of the Seljuk rulers, that he began to write the Mirșād al-ibād there, and that he finished it in Sivas in 628/1230-1 (\{Jāmī, $\}$ Nafahăt, \{Turkish\} trans., pp. 491-2) \{on the date cf. $E I^{2}$, s.v. "Nadjm al-Dīn Rāzī Dāya" (Hamid Algar); see also William Shpall, "A Note on Najm al-Dīn al-Rāzī and the Bahr al-Haquàiq," Folia Orientalia, 22 (1981-4), 69-80, important for his life and chronology\}. Mirșād al-ibād was translated into Turkish under the title Irshād al-murìd ila 'l-murād by Qāsim b. Muhammad of Karahisar in 825/1421-2 for Sultan Murad II (MSS in the Istanbul University Library, Königlichen Bibliothek in Berlin, and elsewhere \{English trans. by Hamid Algar as The Path of God's Bondsmen from Origin to Return (Delmar, NY, 1982)\}).

27 Shaikh Șadr al-Dīn Muhammad b. Ishāa al-Qūnawī was born in Konya. After Ibn al-'Arabī had come to Konya, Sadr al-Dīn's father died and his mother was widowed. Ibn al-'Arabī married this widow and thus Sadr al-Dīn grew up under his spiritual instruction and was instrumental in spreading the doctrine of the "unity of being" in Anatolia \{cf. $E I^{2}$, s.v. "Șadr al-Dīn al-Kūnawī" (W. C. Chittick), and s.v. "Waḥdat al-Shuhūd" (W. C. Chittick)\}. Indeed, most of his works are devoted to explaining and criticizing the ideas and beliefs of Ibn al-'Arabī. According to \{Jāmī's\} Nafahāt, Kelâm-i Seyh' in nakkâdıdrr. Seyh' in maksûdunu Vahdet-i Vücûd mese'lesinde ve bir vechile ki akl-ü ser'e mutâbık ola, onun tahkîkâtm tetebbu' etmeksizin kemâyenbagî fehmetmek müyesser değildir ve bunlardan dahî musannifâtı vardır. Tefsîr-i Fâtiha, Mefâtihüll-Gayb ve Fusûs

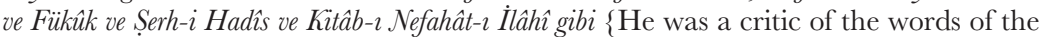
Shaikh. Without studying al-Qūnawī, it is not easy to get a proper understanding of the Shaikh's intention, with regard to the unity of being, in a way that accords with reason and the Shari ${ }^{\prime} a$. He wrote other works in addition to this, such as Tafsir $r-i$

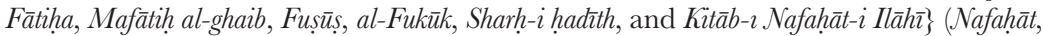
\{Turkish\} trans., p. 632). Șadr al-Dīn al-Qūnawī met the chief khalīfas of Najm al-Dīn Kubrā, like Sa'd al-Dīn al-Hammūyī and Najm al-Dīn Dāya, and had a cordial relationship with Mawlānā. His death was after that of Mawlānā. According to one report, Mawlānā enjoined him to perform his funeral prayer, but according to another, when it came time for him to serve as imām, he was struck by a loud cry and fainted and $q \bar{a} d \bar{\imath}$ Sirāj al-Dīn served as imām (\{Farīdūn b. Aḥmad\} Sipahsālār, \{Manāqib-i hadrat-i Khudāwandikār, Turkish\} trans. \{Midhat Bahârî Hüsâmî (Istanbul, 1331/1913), \} p. 156). By interpreting the works of Ibn al-'Arabī for his disciples and murīds, and devoting his own works to these issues, this great Șūfi, some of whose works are extant in our libraries, performed a great service in spreading the doctrine of the unity of being in Anatolia.

28 Mu'ayyad al-Dīn al-Jandī, whose Arabic Șūfì poetry was in the style of Ibn al-Fāriḍ, and two couplets of which are even mentioned in the Lama' $\bar{a} t$ of Shaikh 'Irāqī, under the influence of Șadr al-Dīn al-Qūnawī, wrote commentaries on the Fușuss, the Mawāa qi' al-nujūm and other works of Ibn al-'Arabī. The main source of virtually every subsequent commentary on the Fususss was that of Mu'ayyad al-Dīn (\{Jāmī, \} Nafahăt, \{Turkish\} trans., pp. 634-5). \{Al-Jandī's Arabic Sharh Fușus al-hikam has been edited by Sayyid Jalāl al-Dīn Āshtiyānī (Mashhad, 1361/1982) and his Persian Nafhat al-rūh va tuhfat al-futūh by Najīb Māyil Haravī (Tehran, 1362/1403/1983).\}

29 Sa'd al-Dīn Farghānī presented Ibn al-Fāriḍ's Qașìda al-tā’iyya with Persian commentary to his shaikh Șadr al-Dīn al-Qūnawī. He also wrote important works on the questions of worship according to the four madhhabs, like Manāhij al-'ibād ilā 'l-ma' âd, which al-Qūnawī liked very much, and on the rules of the order ( $\{J a \bar{m} \overline{1}$,$\} Nafahăt,$ \{Turkish\} trans., pp. 635-6).

30 See the extensive discussions on this matter in the first section of this book (Chapter 2, section H, "The Bektashī Tradition," and Chapter 4, section E, "The Tarīqas that Derived from the Yasawiyya"). According to oral information provided by 
Husām al-Dīn of Amasya, where the endowed properties in the endowment document \{waqfyya\} of Shaikh Sulaimān b. Husain of Kırşehir dated 691/1291-2 are specified, one finds the passage في ناهية المرحوم الخاج بكتاش قدس سرو In the district of the late Hājjī Bektash, may (God) sanctify his secret (a pious phrase used when mentioning a deceased Muslim saint)!\}. This document, which shows that Hājjī Bektash died before this date, corroborates the information that I gave above on the period in which he lived. It would be a major fault not to mention the great Anatolian Ṣūî̀s like Sayyid Maḥmūd Hairānī and Ḥājjī Ibrāhīm in this connection, but I must admit that little is found on them in the written sources at my disposal and that in order to study them properly it would be necessary to carry out local research based on the Shari $a$ records and registers in Anatolia.

31 Ibn Bațtūța, \{al-Rihla, Turkish\} trans., vol. 1, pp. 197, 327, 335, 338, 360 \{see Gibb trans., vol. 2, pp. 273, 436\}. Ibn Batțūṭa encountered an old Rifā'i shaikh from Iraq in the city of Majar on the Kuma River; and sixty or seventy dervishes, married and unmarried, Arabs, Persians, Turks and Greeks, were living in his zāwiya on alms.

32 There are a number of such reports, legendary in part, in the Karaman tarihi, which was originally written in Persian in the style of a shähname and was later translated into Turkish prose by Shikārī of Laranda. Shikārī writes, for example, that when Nūr al-Dīn Bey, one of the Qaramān beys, went to Sivas he paid homage to the famous Bābā Ilyās and that after spending seven years in caves as hrrka-puş̧-i uzlet \{a dervish-cloak wearing recluse\} he took the name Nūr al-Dīn Șūfì. Judging by Shikārî̀s account, shaikhs were definitely present in the consultative councils of the beys, and they were asked to interpret dreams. The same writer also reports at length - with fantastic details appropriate to legend - that the Seljuk ruler always used to confer with Mawlānā; and later, when Qaramān Bey Muhammad captured Konya, that he hastened to the same tekke to humble himself and show his devotion, and that, thanks to Mawlānā's authority, he gave up the plan to destroy the city and massacre the populace (from the copy belonging to Bursalı Tâhir). [This work, which Shikārī translated into Turkish in the tenth/sixteenth century, was published by Mesut Koman (Şikârî tarihi [Konya, 1946]), but it is not a good edition. \{On Shikārī and his work, see Rudi Lindner, Nomads and Ottomans in Medieval Anatolia (Bloomington, IN, 1983), pp. 145-7.\}] There are similar reports in the various legendary works about Mawlānā. It is recorded in Sipahsālār $\{$ Manāqib $\}$ that Shāhzāde Gaykhātū ordered the massacre of the people of Konya after becoming furious over the murder of the ambassador he had sent to Konya by some unruly persons, but after seeing Mawlānā, who had died by that time, in a dream he changed his mind, personally went to Mawlānā's tomb, and made sacrifices and distributed alms (pp. 140ff.).

33 When comparing the Turkish Sunfism of Central Asia with that of Anatolia, these factors should never be lost from view. The constraints of the social environment would naturally have influenced the tariqas that developed in those places. We shall refer to Mawlānā's own statements in order to demonstrate this influence of the environment on the Sūfīs. While discussing his preoccupation with poetry in Konya, Mawlānā reveals that the reason for this is the requirements of the social milieu, thus: "I want to please people so much that when friends arrive, for example, I recite poetry, so that they will not be bored. For a while I stopped reciting poetry, but they wanted me to recite again. Otherwise, what business do I have with poetry! By God, I am disgusted with poetry. In my opinion there is nothing worse than poetry ... A person should see what merchandise is current in a city and immediately buy and sell it, even if it is the most insignificant thing... How much time have I spent acquiring knowledge! How much hardship have I suffered! The reason: in order to offer sublime subjects to the excellent and the learned. God, however, has collected all of that knowledge and brought all of that toil here so that I would be busy with 
this work. He wanted it this way, so what can I do about it? In our country and among our people - i.e. in Khwārazm and among the Khwārazmians \{Köprülü's gloss $\}$ - nothing gives as much shame as being a poet. If I had remained in our own country, I would have lived in accordance with their norms and we would have worked in a manner that they wanted - for example, lecturing, writing and giving sermons and advice" (Sipahsālār, \{Manāqib, Turkish\} trans. citing Fìhi mā fìh, pp. 967 \{English trans. A. J. Arberry as Discourses of Rumi (London, 1961), pp. 85-6; and W. Thackston as Signs of the Unseen: The Discourses of Jalaluddin Rumi (Putney, VT, 1994), pp. 77-8\}). \{In the narrative, we learn that the Yasawi dervishes streaming into Anatolia from Central Asia (a fantasy) were not very committed to their piety and asceticism and dropped them quickly under the influence of Anatolia broadmindedness (another fantasy). Later Köprülü will project this broad-mindedness back onto Central Asia and onto Ahmad Yasawī's shoulders.\}

The traveler Ibn Batțūta, in fact, describes in the following manner the great interest the people of Khwārazm, which was then subect to the state of the Golden Horde, had in religious matters (\{al-Rihla, Turkish trans.,\} p. 405 \{Gibb trans., vol. 3, p. 542\}): "They have a praiseworthy custom with regard to [the observance of] prayer services which I have not seen elsewhere, namely that each of the muezzins in their mosques goes around the houses of those persons neighboring his mosque, giving them notice of the approaching hour of prayer. Any person who absents himself from the communal prayers is beaten by the imām [who leads the prayers] in the presence of the congregation, and in every mosque there is a whip hung up for this purpose. He is also fined five dinars, which go toward the expenses of upkeep of the mosque, or of supplying food to the poor and destitute. They say that this custom has been an uninterrupted tradition among them from ancient times." This last sentence shows that this interest in religious matters was nothing new, that it had continued since ancient times. Thus we can infer that such customs were already found in Khwārazm during the period of the Khwārazm-Shāhs, and Mawlānā's account corroborates this. Such Islamic traditions could not have been formed under the national $\{s i c\}$ and very unconstrained government of the Golden Horde, which had not even dispensed with the yargu \{a kind of court of interrogation\} (ibid., \{Turkish trans.,\} p. 408 \{Gibb trans., vol. 3, p. 545\}).

34 By taking on a thousand different outward guises, Ismāî̀ism and other bätinī ideologies, such as Qarmatianism, which was a branch of it, tried in fact to eliminate all Muslim articles of faith and take over political rule. Whenever one of these ideologies was deemed evil by the people and subjected to severe persecution, the bātinīs who escaped from this persecution would reappear under another name and try to propagate their beliefs in completely new guises. It was thus quite natural for certain men who, in fact, subscribed to bătinī beliefs to conceal themselves under the veil of Sunfism and even pantheism in order to play their role skillfully and successfully. Most of the baținis in Anatolia came from Syria, which had very close intellectual and commercial ties with Anatolia and which had long been a haven for bātini beliefs. As will be seen below, we know that there were, indeed, a number of bātinīs in Syria disguised as Șūfìs. After Hūlāgū captured the fortress of Alamūt and annihilated the Ismā îliss there, a number of bätinīs who had escaped went to Anatolia where they initiated provocations and sedition, naturally under the veil of Șuffism. As will be clear from the explanations given above, the social environment of Anatolia was very conducive to such activity. In this respect, we can consider the Bābā'ī uprising, the institution of the akhīs, the Hurūfí and Bektashī movements and the religious movements that followed them essentially to have originated from bātinism. It should not be forgotten, however, that various secondary factors also combined with this basic factor in each of these movements. We shall discuss later some of the 
movements that bātinī beliefs spawned in Azerbaijan and Khurāsān and some of the poets associated with this ideology.

35 Necib Âsım and Mehmed Ârif, Osmanl tarihi, p. 444. Hammer, citing the historian Janābī, says that Bābā Ilyās and his companion Ishạa were taken captive, but the conquered beguiled the conqueror, and Jalāl al-Dīn and the other Mawlawī shaikhs who were his friends withdrew from the court (\{Geschichte des osmanischen Reichs, Turkish trans., \} vol. 1, pp. 80-1). According to Şâkir Pasha, "At this time a vagabond shaikh named Bābā Ilyās Khurāsānī appeared claiming to be a prophet or to be charged with reforming the world. His followers took the name Bābā's and organized in the area around Amasya. They covered the territory in which they were found with blood and fire. Out of fear, therefore, Ghiyāth al-Dīn Kai-Khusraw II ordered Ertughrul to drive them out and punish them. Ertughrul raided them at a place called Chat near Amasya and routed them completely" (Yeni osmanh tarihi \{Istanbul, 1911-12\}, vol. 1, p. 139). Şâkir Pasha does not, however, clearly state his source for this information. This is reason for not regarding his account as plausible. Indeed, there is nothing in the primary sources to link Ertughrul with this matter. In the $\left\{\right.$ Turkish\} translation of \{Tashköprü-Zāde's al-Shaq $\bar{a}^{\prime} i q$, this shaikh, under the name Bābā Ilyās 'Ajam, and this incident are discussed in the following manner: Amasya'da sâkin idi. Cenâb-ı méâlî nisâbı mazhar-ı kerâmât-ı semiyye olmağın çok kimesne âna irâdet getürüb dervişleri Babah demekle meşhûr oldu; Sultân Gryâsü'd-Dîn b. Alâe'd-Dîn, ol tâifenin hurûcunu ihtimâl verib, sûfillerini katl-i 'âm eyledi. Kendi dahî çok zamân geçmeden kullarnm elinden kuşte olub, nesilleri munkati oldu. Şeyh Muhlis Baba, Yunan'da altr ay padişah olduktan sonra, Baba İlyasin sûfilerinden Nure'd-Dîn ismindeki sûfinin Karaman adli beşy yaşında bir oğlunu Yunan tahtına iclâs eyledi $\{$ He lived in Amasya. He performed sublime miracles that were the prerogative of God and attracted many disciples. His dervishes became known as Bābā'̄is. Sultan Ghiyāth al-Dīn Ibn 'Alā' al-Dīn deemed it likely that the group would rebel, so he massacred all of his Șūfis. Within a short time he was killed at the hands of his slaves and his descendants were cut off. Shaikh Mukhlis Bābā was ruler (padişah) in Yunan [according to Shikārī, Karaman tarihi, p. 4, Yunan = Konya, Larende, and Aksaray; also Tarsus] for six months. Then he placed on the throne of Yunan a five-year-old boy named Qaramān son of Nūr al-Dīn who was one of the Șūfis̄ of Bābā Ilyās\} (p. 23). This report, derived from Janābī's account of the origin of the Qaramānids, is not, in fact, credible. In the same work, in the description of Shaikh Mukhliș Bābā, it is also mentioned in a marginal note that he went to Anatolia during the Mongol troubles and that he was the son of Bābā Ilyās of Khurāsān who settled near Amasya (p. 22). We know that the famous Geyikli Bābā, a shaikh from the period of Sultan Orhan, was a member of the tarīqa of Sayyid Abu 'l-Wafā' - according to al-Shaqā'iq, Sayyid Abū 'l-Wafā-yi Baghdādī - and a murīd of Bābā Ilyās (al-Shaqā’iq, \{Turkish\} trans., p. 32; 'Āshıq Pasha-Zāde, \{Tawārīkh,\} p. 46). In my view, the most reliable information on this matter was collected in \{Müneccim-başı's\} Sahạ̄'if al-akhbār: 637 senesi erişdikde Şumeyşad a'mâlinden Kefersud nâhiyesinde Baba İshâk nâm bir müfsit zuhûra gelib, hurûc eyledi. Bu habis, aslinda izhâr-l zühd ve riyâz ve dünyâdan i' râz sûretinde görünüb Türkman tâifesinden vesâir ehl-i kurâ sâde-dillerinden kendiye vâfir mürîd ve mútekid peydâ eyledi ve bir mikdar hokkabazlık dahî bilüb ol şu'bedeleri kerâmet olmak üzre halka satardi. Sonra Amasya taraflarna vanb ol nevâhîde dağ başında bir mağarada mekân tuttu ve kendi has mürîdlerinden gayri yanna kimseyi getirmez oldu. Bir müddet bu minval üzerine hareket eyleyib âkıbet mürîdlerini irsâl ve halkn igvâ eyleyib, bir gün alem-i şikâk ref'eyledi ve gûya taraf-ı Hak'tan bu hususa mémûr olmak üzre kildr ve başına cem olan evbâs ile hareket eyleyip Amasya ve Tokad nevâhîsine îsâl-i dest-i tearruź eylediler ver erişdikleri memâliki gâret ve mülâkî olduklan ümerâyn münhezim kıldılar. Bu haber sem'-i pâdişaha vüsûl buldukda, Mubârizü'd-Dîn nâm bir mütéayyin Bey' ini irsâ̈l eyledi. Vanb şakî-i merkûmu ahz ve mürîdleri ile salb eyledi. Livâ-yi şekâveti altina cem olan gürûh-i müfsidîn kaziyyeden haberdâr olduklarnda 


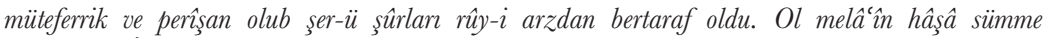
hâşẩ Baba İshâk hakkinda Peygamber'dir diye i'tikâd ederlerdi \{At the beginning of the year 637, a mischief-maker named Bābā Ishāq appeared in the region of Kafarsūd, a dependency of Sumaisāt and rebelled. This scoundrel pretended to be someone who practiced asceticism and turning away from the world. He attracted many muñds and followers from the Turkmens, villagers, and other simple-minded people. Many believed (his) trickery. He pretended to the people that his deceptions were miracles. Later he arrived in the vicinity of Amasya and established himself in a cave at the top of a mountain in that area. He allowed no one except his special murīds to approach him. For a while, he acted in this manner. Finally, he sent out his murinds and led the people astray. One day he raised the banner of rebellion, pretending that this had been demanded by God. He went into action with the rabble who had gathered around him. They made depredations in the areas of Amasya and Tokat. They plundered the country in which they appeared and defeated the beys who met them. When news of this came to the attention of the Sultan, he sent against them a distinguished bey named Mubāriz al-Dīn. He arrived and captured the aforesaid outlaw and hanged him and his murids. When the gang of mischief-makers who had gathered under the banner of villainy learned what had happened, they were in a state of disorder and confusion and the evil of their sedition was erased from the face of the earth. Those cursed ones believed, God forbid, that Bābā Ishāa was a prophet\}

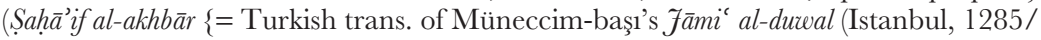
1868-9)\}, vol. 2, p. 568). This report, derived from various sources, shows that Bābā Ilyās was a Șūfì who had left Khurāsān in the wake of the Mongol invasion and was a murīd of Sayyid Abū 'l-Wafă', and that after Sultan Ghiyāth al-Dīn crushed the uprising of the Bābā'îs, which had been incited by Bābā Ishạa, the shaikh was pardoned and had to recognize Mukhliș Pasha as his son. Hüseyin Hüsâmeddin provides an extensive and important account of this subject in Amasya tarihi, but unfortunately he does not clearly specify his sources. According to him, Bābā Isḥāq Kafarsūdī, who prepared the ground for the Bābā's uprising, was originally a Greek convert to Islam. He learned Shī 'ism and bātinism from the qā d̄ of Sivas Abū 'Abd Allāh Muhammad, and after his death he became associated with Bābā Ilyās. This man, who prepared the way for his emergence through various intrigues, appeared in 637/1239-40 and declared that he was amīr al-mu'minin \{ "Commander of the Faithful," a title of the caliphs\}. He marched on Konya. At that time, Sa'd al-Dīn Köpek, a Greek convert and intimate of the Seljuk sultan, had great influence over the sultan. Meanwhile, the king of Trebizond also attacked Seljuk territory. Finally, after the execution of Sa'd al-Dīn, Mubāriz al-Dīn Armaghan-Shāh defeated this false prophet who had invaded the regions of Amasya, Tokat, and Sivas, apprehended him, and put him to death at Amasya. As for Bābā Ilyās, he was, according to \{Şükrullâh's\} Bahjat al-tawārikk \{MS 3059 in the Nuruosmaniye Library in Istanbul\} one of the shaikhs of the Mas'ūdī Khānqāh that was built by the Seljuk Sultan Mas' ūd in 545/1150-1, viz. Shujā' al-Dīn Ilyās b. 'Alī Khurāsānī who won fame after 628/1230-1 and, although he had a hand in the Bābā Ishāq incident, was pardoned and was sent to his estate near Amasya (Amasya tarihi, vols 1 and 2). The manner in which this information was derived and the quality of the sources are unknown, however, so this description is not very credible. In any case, the religio-political nature of this uprising shows that it was a batinin uprising. \{Now see Ahmet Yaşar Ocak, La Revolte de Baba Resul . . (Ankara, 1989); and cf. Mertol Tulum's study of Elvan Chelebi's Menâkibü'l-Kudsiyye, Tarihi metin çalışmalarnda usul (Istanbul, 2000), which is a study of Ocak's primary source.\}

36 Ibn Batțutta states that all the people in the places that he visited in Anatolia were Hanafìs, that there were no Qādirīs, Rāfiḍ̄is, Mu'tazilīs, Khārijīs, or innovators 
among them and that this was a virtue by which God had distinguished them (\{al-Rihla, Turkish trans., $\}$ p. 310, \{see Gibb trans., vol. 2, pp. 416-17\}). This claim is absolutely true with regard to Hanafism in the cities, but it is patently impossible to believe the assertion that there were no members of the Mu'tazili sects in Anatolia, given our knowledge of the important batini $\mathrm{u}$ uprisings in the seventh/thirteenth century. Ibn Batțūta writes that when they were in Sinop, the sultan's deputy suspected that the people of that town were Râfidīs and sent them a rabbit to see if this were true. After he saw that they ate it, his suspicion disappeared (\{Turkish trans., \} p. 357, \{Gibb trans., vol. 2, p. 468\}). The testimony of a foreigner who spent three to five days in the major cities of Anatolia, the language of which he did not understand, can only be so reliable. Bātinism took various Șūî̀ guises in order to escape the attacks of the Hanafis in the cities, and disguised its true nature not only from foreigners, but also from followers who had even been present at the founding of the tariqa. It was quite common and widespread among the nomadic Turkmen in particular, because it sanctioned many of their pre-Islamic customs and traditions. At all events, the urban populace of Anatolia, who were of the Hanafí school, were aware at that time of the existence of certain Rāfidīs who would not eat rabbit. The spread of bātinism was facilitated by the fact that some of the Mongol rulers who maintained political control of Anatolia encouraged, for various reasons, $\mathrm{Mu}^{\prime}$ tazilī movements or else, by observing an old tradition of respect for religious freedom, tolerated, and were indifferent to, those who spread beliefs in opposition to Sunn̄ tenets. Conceivably, the reign of Sultan Muhammad Khudābanda \{Öljeitü, 70316/1304-16\} had great influence in this respect. Aside from that, there were all kinds of battin $\bar{\imath}$ sects in various countries that had relations with the Turks. During the seventh/thirteenth and eighth/fourteenth centuries, when the environs of Latikiyya and Aleppo and the 'Āmiq Plain were almost completely inhabited by Turkmen, there were in those areas, like Sarminn, ahl-i sabb \{"people of the curse"\} who cursed the 'ashara-i mubashshara and thus the number ten. Later \{in this region\} there were members of many other sects, like the Ismā îliss and Nuṣairīs, who lived in various fortresses. The Turkmen residing in 'Irāq al-'Arab and 'Irāq al-'Ajam were also, of course, affected by external influences (Ibn Batțūta, \{Turkish\} trans., pp. 65, 74, $76,79,81,84)$. One should by no means overlook these points in examining the religious history of Anatolia, the Q1zılbash movement, and the beliefs of the presentday Turkmen. As for the Bektashiyya, this tarīqa did not later become corrupted by the infiltration of the Hurūfiyya or lose its original character. Indeed, it came into existence from the appearance, under a new name, of some batinins, perhaps including the Bābā'īs after the true origin of the abdāls and $a k h \bar{s}$, who were very close to them, was for the most part forgotten, as I previously mentioned, and their doctrine was ascribed to Hājjī Bektash Veli, whose legends were widespread among the people. The views of Ishāq Efendi on this subject, and those of all the European researchers who have relied on him, are mistaken.

37 According to the extensive information provided by Hüseyin Hüsâmeddin, citing \{al-'Aynī's\} 'Iqd al-jumān, Barāq Bābā was in fact the khal̄̃fa of Aybek Bābā, the shaikh of the Mas'ūdī Khānqāh, who, while striving to propagate bātinī beliefs in Amasya, was forced to flee to Egypt in 670/1271-2. Because of his suspicious pronouncements in Egypt concerning the indewlling of God \{hulül, see $E I^{2}$, s.v. "Hulūl" (L. Massignon-[G. C. Anawati]) $\}$ and spiritual union with God $\left\{i t t i h \bar{a} d\right.$, see $E I^{2}$, s.v. "Ittihād" (R. Nicholson/G. C. Anawati)\}, he was interrogated by an assembly of religious scholars convened in the presence of the ruler al-Malik al-Zāhir Baibars al-Bunduqdārī and then chastised and flogged. He then left Egypt and joined Abaqa Khān (Amasya tarihi, pp. 405-8). Again citing 'Iqd al-jumān, Hüsâmeddin Efendi also says that Barāq Bābā was originally from Tokat, that he was born around 655/ 
1257-8, that he learned enlightenment in Amasya from Aybek Bābā and Ahmmad Bābā, that he had a large body and was very dirty and roamed from city to city. "He was completely naked above his waist. Below his waist he fastened an apron made of red cloth. He wrapped his head in muslin in the shape of a light-weight red turban. He fastened water buffalo horns to each side of it. In his hand was a very large and long trumpet and a large black begger's cup made from a gourd. He would dance like a bear and speak like a monkey. He was extremely filthy. He had eight or ten companions who dressed and behaved the same way. They carried tambourines with cymbals attached and wherever they went they would stand in a circle and play while Barāq Bābā danced. Barāq Bābā was an absolute heretic. He believed in hulūl and disbelieved in the hereafter. He considered all things forbidden by canon law to be permissible and claimed that God had first been incarnate $\{h u l \bar{u} l\}$ in 'Alī and afterwards was united spiritually $\{$ ittih $\bar{a} d\}$ with Sultan Khudābanda \{Öljeitü\}. He would be overcome by sexual desire, call beautiful women "god" and prostrate himself before them. When he went to Damascus, poets satirized this behavior. Nevertheless, despite this strange state of affairs, it is reported that he was an important Șūin poet. When it became evident to the populace of Damascus that he belonged to the antinomian sect, he was subject to canonical punishment and died in Damascus toward the end of Dhū 'l-Qa'da 706/May 1307 from the injuries suffered from flogging" (Amasya tarihi, pp. 460-4). Certain Șūfì sayings and some other traditions attributed to Barāq Bābā, and his Qalender life style, lead one to conjecture today that he was a popular poet, an ozan, who wrote Sūfì poetry in the popular meter. \{See EIr, s.v. "Barāq Bābā”" (H. Algar); Ahmet Yaşar Ocak, Osmanl İmparatorluğunda marjinal sûfilik: Kalenderîler (Ankara, 1992), index; and Ahmet T. Karamustafa, God's Unruly Friends: Dervish Groups in the Islamic Later Middle Period 1200-1550 (Salt Lake City, 1994), index.\}

38 Shaikh Sulaimān Turkmān̄i, who died in Damascus in 714/1314-15, is a personality strongly reminiscent of Barāq Bābā. This Turkmen Șūfì wore an old and tattered cloak, rarely stood up, said little, and would not fast during Ramaḍān or perform daily prayers, but he did exhibit miraculous powers. In order to explain this strange contradiction, Imām al-Yāfi'i attributed his situation to satr-i hăl \{concealing the (true) state $\}$ and claimed that he prayed when no one saw him and that what he ate in plain sight he did not swallow ( $\left\{\mathrm{Jām}^{2},\right\}$ Nafahăt, \{Turkish $\}$ trans., p. 652). In any case, it is highly likely that this Turkmen shaikh was an adherent of battini beliefs and perhaps was also an Anatolian Bābā' $\overline{1}$. Also in Damascus in the seventh/thirteenth century, we come across a majdhüb \{one obsessed with divine love\} named Shaikh 'Alī Kurdī who behaved contrary to the Sharī'a in several respects, usually even exposing his genitals. Nevertheless, by performing a number of miracles, he beguiled the people of Damascus. Shaikh Shihāb al-Dīn al-Suhrawardī even went out of his way to visit him while on an embassy to Damascus (ibid., pp. 652-3). All of these accounts go to show how strongly battini beliefs were entrenched in Anatolia and Syria in the seventh/thirteenth century. In addition to these leading batitinis who are known to history, there were countless unknown $b \bar{a} b \bar{a} s$ like them who carried out propaganda while wandering among the Turkmen from encampment to encampment. In Sipahsālār's Manāqib, it is recorded that the Seljuk ruler Rukn al-Dīn Qāhir \{Sulaimān II\}, whom Mawlānā used to address as "Child" $\{$ Awlād\}, was goaded by one of his slaves to visit an old Șūfì named Buzāghū \{"Calf"\}, who had just then arrived in Konya and, it was said, every night was attended by jinns. When Buzāghū spoke to the sultan, he addressed him as "Child." Mawlānā was moved by this and said, "In that case, we have to find another Child" (ibid., pp. 117-19). According to Sipahsālār, this old $b \bar{a} b \bar{a}$ named Buzāghū was from among the common people. In my view, this man was one of the batitinis who were so ubiquitous in Anatolia at that 
time. The story found in some histories, according to which Mawlānā, who was touched by this incident, adopted Osman Ghāzī as his spiritual son - and from that time Seljuk grandeur began to decline and the Ottoman dynasty began to rise - is a corruption of this tale and has no historical value. While discussing the Bābā's above, I stated that Janābī and Hammer wrote that "they beguiled the Seljuk ruler and as a result Mawlānā and the Mawlawīs withdrew from the court." Janābī's report may also be a corruption of the aforesaid incident.

39 The most detailed information on the akhi organization in Anatolia is in the book of travels of Ibn Battutta, who traveled in that region in the first half of the eighth/ fourteenth century. Only Turks were found in this mystical professional organization, which had the title Akhiyya-i fityān, i.e. "Youth Fraternity." Ibn Batțutạa encountered $a k h \bar{\imath}$ lodges in various cities of Anatolia, first Antalya and then Burdur, Gölhisar, Ladik, Milas, Barçin, Konya, Niğde, Aksaray, Kayseri, Sivas, Gümüş, Erzincan, Erzurum, Birgi, Tire, Manisa, Balıkesir, Bursa, Görele, Geyve, Yenice, Mudurnu, Bolu, Kastamonu, and Sinop - and also in the port of Azov, which was subject to the Golden Horde - and he was their guest. He gives the following important information about the akhīs with whom he thus had very close contact (Ibn Bațūta, \{al-Rihla, Turkish\} trans., pp. 372-3, \{Gibb trans., vol. 2, pp. 419-20\}): "They exist in all the lands of the Turkmens of al-Rūm, in every district, city, and village. Nowhere in the world are there to be found any to compare with them in solicitude for strangers, and in ardour to serve food and satisfy wants, to restrain the hands of the tyrannous, and to kill the agents of police and those ruffians who joined with them. An Akhī, in their idiom, is a man whom the assembled members of his trade, together with others of the young unmarried men and those who have adopted the celibate life, choose to be their leader. That is [what is called] al-futuwwa also. The Akhī builds a hospice and furnishes it with rugs, lamps, and what other equipment it requires. His associates work during the day to gain their livelihood, and after the afternoon prayer they bring him their collective earnings; with this they buy fruit, food, and the other things needed for consumption in the hospice. If, during that day, a traveler alights at the town, they give him lodging with them; what they have purchased serves for their hospitality to him and he remains with them until his departure. If no newcomer arrives, they assemble themselves to partake of the food, and after eating they sing and dance. On the morrow they disperse to their occupations, and after the afternoon prayer they bring their collective earnings to their leader. The members are called fityan, and their leader, as we have said, is the Akhī. Nowhere in the world have I seen men more chivalrous in conduct than they are." Afterwards, Ibn Batțutta describes the lodge in Antalya (\{Turkish\} trans., pp. 31314, \{Gibb trans., vol. 2, pp. 420-1\}): "We found it to be a fine building, carpeted with beautiful Rūmī rugs, and with a large number of lustres of Iraqi glass. In the chamber there were five [candelabra of the kind called] bais $\bar{s}$; this resembles a column of brass, having three feet and on top of it a kind of lamp, also of brass, in the centre of which is a tube for the wick. It is filled with melted grease, and alongside it are vessels of brass also filled with grease, in which are placed scissors for trimming the wicks. One of their company is put in charge of them; he is called in their language the jarajī \{çracı/çırağcl? $\}$ Standing in rows in the chamber were a number of young men wearing long cloaks, and with boots on their feet. Each one of them had a knife about two cubits long attached to a girdle round his waist, and on their heads were white bonnets of wool with a piece of stuff about a cubit long and two fingers broad attached to a peak of each bonnet. When they take their places in the chamber, each one of them removes his bonnet and puts it down in front of him, but retains on his head another bonnet, an ornamental one, of silk taffeta or some other fabric. In the centre of their hall was a sort of platform placed there for visitors. 
When we had taken our places among them, they brought in a great banquet, with fruits and sweetmeats, after which they began their singing and dancing. Everything about them filled us with admiration and we were greatly astonished at their generosity and innate nobility." When Ibn Battụța was in Ladik, there was some argument between the associates of Akhī Sinān and Akhī TTumān over which party he would lodge with first. Finally, it was decided to cast lots (\{Turkish trans., \} p. 318, \{Gibb trans., vol. 2, p. 426\}). Describing a Ramaḍān procession of Sultan İnanç Bey in Ladik, this traveler gives the following information on the Akhī organization (\{Turkish trans., \} p. 320, \{Gibb trans., vol. 2, pp. 427-8\}): "So we went out to the musallä; the sultan also came out with his troops and the Young akhiss too, all of them fully armed. The members of each trade carried flags, trumpets, drums and fifes, all aiming to rival and outdo one another in magnificence and in perfection of their weapons. Every group of these artisans would come out with cattle, sheep, and loads of bread, and after slaughtering the animals in the cemetery give them away in alms, along with the bread. On coming out they went first to the cemetery, and from there on to the musalla." Again the same traveler, telling us that he stayed in the lodge of Akh̄̄ Amīr 'Alī in Kayseri and describing its importance and wealth, clarifies somewhat the political position of the akhīs (\{Turkish trans.,\} p. 326, \{Gibb trans., vol. 2, pp. 434\}): "It is one of the customs in this land that in any part of it where there is no sultan, it is the Akhī who acts as governor; it is he who gives horses and robes to the visitor and shows hospitality to him in the measure of his means, and his manner of command and prohibition and riding out \{with a retinue $\}$ is the same as that of the princes." In like manner, he shows clearly the nature of the relations between Akhī Chelebi and Amīr 'Alā' al-Dīn Eretna, and the importance of the akhīs of Sivas (\{Turkish trans., \} p. 327, \{Gibb trans., vol. 2, pp. 434-5\}). The first to collect Ibn Bațtuța's information on the akhīs was the Orientalist C. Defrémery (\{“Fragments de géographes et d'historiens arabes et persans inédits relatifs aux anciens peuples du Caucase et de la Russie méridionale,"' $\mathcal{F} A$, 4th series, 16 [1850], 68-70). \{See $E I^{2}$, s.v. "Akhî̀" (Fr. Taeschner); Neşet Çağatay, who tries to prove that the akhi organization was purely a Turkish institution, Bir Türk kurumu olan ahilik (Ankara, 1989).\}

40 This path of the futuwwa that the akhis followed was, according to tradition, traced back to 'Alī and thus to the Prophet. The saying فتى الا على لا سيف الا زو الفقار \{No fatā (youth) except 'Alī, no sword except Dhū 'l-Faqār\}, which was attributed to the Prophet $(\mathrm{H}$. Zotenberg, trans. of \{Persian version of $\}$ al-T Tabarī, \{as Chronique d' Abou Djafer Mohammed b. Djarir Tabari (Paris, 1867-74),\} vol. 3, p. 27 \{EIr, "D̄ ülFaqār" (Jean Calmard)\}), and the proclamation from on high of one of the angels on the day of Badr (\{Muhibb al-Dīn Ahmad al-Ṭabarī $\}$ al-Riyād al-nadira [Cairo, 1327/1909], vol. 2, p. 190) were reasons for deriving this futuwrwa from the Prophet. Over time, this word eventually came to have the meaning of chivalry. The person who first turned the futuwrwa into a code of behavior in this sense was the 'Abbāsid caliph al-Nāṣir li-Dīn Allāh (575-622/1180-1225), who according to \{Ibn al-Ṭiqtaqā's\} Kitāb al-fakhr̄ \{published as Tàn̄kh al-duwal al-islāmiyya (Beirut, 1960), p. 322\}, Abū 'l-Fidā' \{Mukhtașar ta'rīkh al-bashar (Istanbul, 1286/1869-70), vol. 3, p. 142$\}$ and other sources was an Imāmī Shī' $\overline{1}$. \{This claim is, to say the least, rather extreme. See Angelika Hartmann, an-Nāssir li-Dīn Alläh (1180-1225): Politik, Religion, Kultur in der späten 'Abbāsidenzeit (Berlin, 1975) and EI', s.v. "al-Nāṣir li-Dīn Allāh" (Angelika Hartmann)\}. This man, whose relations with the Khwārazmians and Seljuks of Anatolia I mentioned above, had long been especially addicted to findık-endâzlık \{pellet shooting\}, which was a custom that had been adopted from the Persians around the end of the caliphate of 'Uthmān (Ibn al-Athīr, \{al-Kämil, $\}$ vol. 3, p. 90). Around that time, \{the practice of $\}$ this pellet shooting had spread considerably in 
Baghdad and was considered a kind of bravado. Participants had their own special outfit and a distinctive kind of trousers. When al-Nāșir li-Dīn Allāh became caliph, he gave great importance to this. He personally wore futuwwa trousers. Thus - like the freemasons, for example - in order to establish sincere and strong bonds among the members of this professional fraternity, he ordered that those who did not wear the futuwwa trousers and who did not drink from the futuwwa bowl would not be able to do ramy bunduq, i.e. findık-endâzhk \{pellet shooting\}. Having declared himself the patron saint of this tariqa, he accepted whomever he wished. Those who attained this distinction were permitted to inscribe on their weapons the symbol of a bowl or a pair of trousers or both. In 607/1210-11, this caliph wrote to the princes and amins who recognized his caliphate and proposed that they wear the futuwwa trousers, drink from the futuwwa bowl, and consider him the pir in pellet shooting. Those who accepted went to Baghdad where they received from him trousers to wear and futuwwa bowls from which to drink. The pellet shooters in Iraq and other places, like it or not, joined this tarīqa (Ibn al-Athīr, vol. 12, p. 202; Abū 'l-Fidā', vol. 3., pp. 119, 142; Ibn Khaldūn, \{Kitāb al-'ibar, Turkish trans. Subhî Pasha as Miftâh ül-iber (Istanbul, 1276/1859-60),\} vol. 2, p. 535). According to \{Ibn 'Inaba,\} Kitāb 'umdat al-tālib, after the death of al-Nāșir the position of head of this tañqa passed to another family, and al-Naqīb Tāj al-Dīn Muhammad from that family began to wear the khirqa-i tașawrouf \{Ṣūin patched cloak\} at the same time ([Bombay, 1318/1900-1], p. 153). Ibn Jubair also mentions a group in Syria who firmly opposed the Rāfidīs and fully observed the futuwwa oath that they had sworn (\{al-Rihla, ed. de Goeje,\} 2nd edn \{Leiden, 1907\}, p. 280). Ibn Bațūta states (\{al-Rihla, Turkish trans., \} p. 322, \{Gibb trans., vol. 2, p. 430\}): "We lodged there $\{$ Konya in the hospice of its $q \bar{d} d \bar{\imath}$, who is known as Ibn Qalam Shāh; he is one of the Fityan, and his hospice is among the largest of its kind. He has a large body of disciples, and they have a chain of affiliation in the Futuwwa which goes back to the Commander of the Faithful 'Alī b. Abī Țālib (God be pleased with him). The [distinctive] garment of the Futuwwa in their system is the trousers, just as the șufîs wear the patched robe [as their distinctive dress]." Ahmed Âsım Efendi in \{his Turkish trans. of Muhammad Husain Ibn Khalaf al-Tabrīzī's Persian lexicon\} Burhān-i qātic \{Istanbul, 1214/1799-1800\} defines futuwrwa as follows: "It is used for anything worthy of admiration or admirable; it has wider application than word and deed. It is used for anyone who is generous \{mürüvvet\} and public spirited \{ehl-i hamiyyet $\}$. Its application to the chiefs of the craftsmen is derived from this usage" (p. 67). There are important details about futuwrwa in the manuals on Sūfism - like al-Qushairī's Risāla and \{al-Sayyid al-Sharīf al-Jurjānī's\} Tárīfât - and also in the futurerwatnāmes. The violent actions of the members of the futurerwa in Syria against the Rāfidīis should not be attributed to their excessive attachment to the doctrines of Sunnism. Hatred and antagonism were endemic among all the groups that sprang from bātinism, even among the various sub-branches. (For information on the akhīs and the futuwwa, see $E I^{I}$, s.v. "Futuwwa" [C. van Arendok] and especially the work entitled Beiträge zur Kenntnis des islamischen Vereinswessens auf Grund von Madad-et-Taufiq by H. Thorning as part 16 of the Türkische Bibliothéque \{Berlin, 1913\}). \{Much has been done on the futuwrwa. See, for example, Abdülbaki Gölpınarl,, "Les organisations de la futuvvet dans les pays musulmans et turcs et ses origines," Revue de la Faculté des Sciences Économiques de l'Université d'Istanbul, 11 (1949-50), 5-49, and his longer, "İslâm ve Türk illerinde fütüvvet teşkilâtı ve kaynakları," İstanbul Üniversitesi İktisat Fakültesi Mecmuast, 11 (1949-50 [1953]), 3-354; EI ${ }^{2}$, s.v. "Futuwwa" (Cl. Cahen et al.); and Franz Taeschner, Zünfte und Bruderschaften im Islam: Texte zur Geschichte der Futuwewa (Zurich, 1979). On al-Nāșir's role, see P. Kahle, "Die Futuwwa-Bündnisse des Kalifen en-Nāṣir (d. 622/1225)," Theodor Menzel (ed.), Festschrift Georg Facob 
(Leipzig, 1932) pp. 112-27; and Cahen, "Note sur les débuts de la futuwwa d'anNāṣir," Oriens, 6 (1953), 18-22.\}

41 Al-Shaqa'iq, \{Turkish\} trans., p. 33; 'Āshıq Pasha-Zāde, Tawārīkh, p. 200. I think that this $\{$ name $\}$ is nothing other than ören, which is mentioned as an altered form of the word viran in \{al-Kāshgharîs's\} Dīwān lughāt al-turk. Consequently, it is not quite correct to read it as evren with a fatha over the alif. According to all the early historical sources, Akhī Ören was a prominent figure during the reign of Sultan Orhan $\{724$ 61/1324-60\}. [Fr. Taeschner, in his article "Akh̄̄ Ewrān" in $E I^{2}$, gives this name as "Akhī Evren" without commenting on any other pronunciation for it, but as is clear from the text above, Köprülü preferred to read it \{incorrectly\} as Akhī Ören.] \{See Mikâil Bayram, Ahi Evren ve ahi teșkilâtının kurulușu (Konya, 1991), who places his death between 658/1260 and 660/1262, pp. 97-101.\}

42 Such as Akhī Hasan (pp. 29, 36), Akhī Qadam (p. 101), and Akhī Ya'qūb (p. 101), for example, in 'Āshıq Pasha-Zāde, \{Tawārīkh\}. Among them, we know that Akhī Hasan, who had participated in the conquest of Bursa, had a tekke near the Bey Sarayı inside the fortress of Bursa and held an important office at the time of Osman Ghāzī's death \{724/1324\}. Akhī Qadam and Akhī Ya'qūb, who were akhīs in Bursa at the time of the Düzme Muștafā incident, saved that city in an appropriate manner from his attack $\{1421\}$. These points demonstrate that the state organization was still very primitive at that time and that the Akhī organization fulfilled its function to some extent. We also learn from \{Tashköprü-Zāde's\} al-Shaqāiq that Akhī Hasan had a zāwiya near the Dār al-Sa'āda in Bursa and that he was a devotee \{of God\} and an ascetic (al-Shaq $\bar{a}^{\prime} i q$, \{Turkish\} trans., vol. 1, p. 23). We also know that among the shaikhs having the title Akhī was 'Alī Mișrī, who was a murīd of Rukn al-Dīn 'Alä' al-Dawla \{al-Simnānī $\}$ and a notable figure in the eighth/fourteenth century among the shaikhs in Damascus and Anatolia (\{Jāmī, \} Nafahăt, \{Turkish\} trans., p. 500).

43 The source that provides the best information on the etiquette and rules of conduct of the $a k h \bar{\imath} s$, and thus is most important for showing that they were bätinīs, is \{Yahyā b. al-Khalīl's $\}$ Futuwwatnāme MS in Köprülü's private library; ed. Abdülbâki Gölpınarlı as "Burgazi ve Fütüvvetnamesi," İktisat Fakültesi Mecmuası, 15 (1953-5), 76-153; German trans. Fr. Taeschner in Zünfte und Bruderschaften im Islam, using Köprülü's MS \}. The copy of the Futurwwatnāme that I studied with the assistance of Cevdet \{the well-known Muallim Cevdet (Mehmet Cevdet İnançalp)\}, a teacher in the Muallim Mektebi \{Teachers' College\}, belongs to Mehmed Ârif, a member of the Tarih Encümeni \{Historical Society\}, and was written - probably before Ibn Baț̣uța - by Yahyā b. al-Khalīl b. al-Chubān al-Yahyā Fatā 'l-Burghāzī. He states that he was jahil \{unenlightened in faith until age twenty-seven, and then took lessons for a short time from Mawlānā Khwāja Muṣlih al-Dīn of Antalya. When the Franks captured Alexandria, they brought the books that they had acquired there to Anatolia and sold them, including some books on futuwrea, which he bought \{Alexandria was attacked several times during the Crusades, in 1154, 1167, and 1174. Louis IX occupied nearby Damietta in 1249 and Peter I of Cyprus sacked Alexandria in 1365$\}$. He recommends that this work, which he wrote on akhism, not be shown to strangers. The author, who cites some passages from Mawlānā and Nāșir-i Khusraw, also says that he quoted a number of works such as Salwat al-'ārifiñ , \{Ilyās al-Khartaburtī's\} Tuhfat al-wașāyā, Musammā, Manāqib al-'ärifiñ, Tadhkirat al-awliy $\bar{a}^{\prime}$, Qalä'id, and Asrār al-'arifīn. Citing the Tuhfat al-wasāaya, he states that the futuwrea doctrine began with Salmān Fārisī, then passed to the Caliph al-Nāșir li-Dīn Allāh, and from him to Saladin. This information \{in this book\}, which can very easily be accorded with the material that I provided in n.40 in this chapter, reveals quite well the nature of akhism. In this book, it is stated that akhism had 740 rules of etiquette that had been handed down from the time of Nūshīrwān \{i.e. Anūshirwān, 
the Sasanid ruler Khusraw I, 531-79 CE\}, that the shaikhs knew them all, but it was necessary for the $a k h \bar{\imath}$ to know only 124. In addition, citing the Qala ${ }^{\prime} i d$, it is explained that there were two paths of the futuwwa - one deriving from 'Ali and the other from Abū Bakr - called Saifí and Qawlī. Then a lengthy description is given of their customs, ceremonies, and rules of conduct, their costume, the colors of their trousers, and their ranks. The members of the futuwwa were divided into \{groups of \} nine, six being arkān \{pillars\} of the tariqqa and three being așha $\bar{b}$ \{companions\} of the tañqa. Every novitiate had to retain two "brothers of the path" and also a "father of the path." Many conditions had to be met in order to pass from one degree to another, and each degree held different secrets. All of this strongly suggests the bātini character of akhism. With respect to ceremonies and rules of conduct, we find Bektashism and Quzllbashism, which differs very little from Bektashism, to be very similar to akhism. Consequently, in my view, it is not unlikely that around the end of the eighth/fourteenth century, the akhiss took the name Bektashī, ascribed their silsila to Hājjī Bektash Veli, and traced it back to him. Even if this is not accepted, the bătinñ nature of akhism certainly cannot be denied. A thorough analysis of the various sources that I have mentioned above on the futurerwa would thus, I believe, tend to support these hypotheses.

44 The poet Gülsherī, in his translation of, and expansion upon, 'Aț̣āar's Mantiq al-tair, which he completed in 717/1317, asks one of the birds a question about the futuwwa and akhism, and then answers from the mouth of the hoopoe. According to him, the first principle of the akhis is that they should be blameless, the second is that their dining table should be open to all, and the third is that their doors should be open to all. Gülshehrī, who, in addition to these positive attributes, also lists a number of negative attributes, speaks of the need for akhis to be very closely bound to the Shari ${ }^{-} a$, but he eventually complains at length that not even one in a thousand of his contemporary akhīs possessed these positive qualities (see the full description given below on Gülshehrī and his work).

45 [Köprülü planned to expound upon this idea of his in a separate monograph based on the notes that he had collected on akhism over many years, and he announced this in the second edition of Early Mystics, but his untimely death prevented it.] Ahmed Tevhid published a short article on these Ankara akhīs and on akhism in general (\{“Ankarada ahiler hükûmeti,"\} TOEM, no. 19 \{1328/1910\}, pp. 1200-4), but it is obvious that this study, which is based only on Ibn Batțūta and AAhmed Rifat's\} Lughât-i ta'rîkhiyya ve jughrâfyyya \{Istanbul, 1299/1881\}, can have no great importance. However, the information on the Ankara akhis that is cited from a scroll brought from the Mosque of Akhī Sharaf al-Dīn in Ankara is worthy of note. According to it, Husām al-Dīn Husain Efendi, the father of Akhī Sharaf al-Dīn Muhammad, died in 695/1295-6 at the age of seventy and the silsilaname of this man goes as far back as 'Alī. This supports the idea that the futuwrwa code of behavior derived from 'Alī. Akhī Sharaf al-Dīn's three sons, Husain, Hasan, and Yūsuf, and some of the children and grandchildren of the first two, are mentioned in this scroll, but there is no other biographical information. Tevhid says that in the Il-Khānid period the internal affairs of Ankara were probably in the hands of the akhiss, and he rejects the assertion that they were united against the Ottoman state, but he says nothing about the form of government of their \{city\} state. I think the information that I provided above on the akhis of Anatolia can clarify these matters. The reports of Ibn Batțūta and 'Āshıq Pasha-Zāde definitely show that the akhīs of Ankara should not be viewed as constituting a state. The role they played in handing Ankara over to the Ottomans was the same as the one they played in Bursa during the Düzme Muștafā affair, for they took upon themselves this task in places where there was no state organization. 
46 This summary is derived primarily from the works on the legendary deeds of the

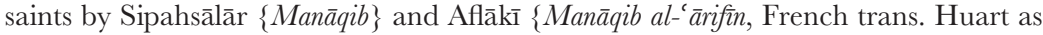
Les Saints des derviches tourneurs (Paris, 1918-22), ed. Tahsin Yazıc1 (Ankara, 1976-80), English trans. John O'Kane as The Feats of the Knowers of God (Leiden, 2002)\} and from \{Jāmī's\} Nafahāt and Dawlat-Shāh's $\{$ Tadhkira\}, but the information given by Dawlat-Shāh is for the most part contrary to that in the other primary sources and incorrect. The Orientalist Nicholson published some selections, with English translation, from \{Jalāl al-Dīn Rūmī's\} Dìvoān-i Shamsi Tabrīz, and in the introduction to this work provided some noteworthy information on the life and works of Mawlānā and the Șūfi path. Hüseyin Dâniş made a summary translation of this information for the section on Mawlānā in his Ser-Âmedân-ı Suhan. Unfortunately Nicholson made no use whatsoever of the most important sources, such as Sipahsālār, and he was completely ignorant of the mathnawiss of Sulțān Walad, which contain many important details on his father, and other sources. Indeed, in his book Nicholson did not even touch on a great many important subjects that need thorough investigation, such as Mawlānā's great influence on Persian, Indian, and Turkish literature, the establishment and development of the Mawlawi tarīqa, the ideas of subsequent generations - i.e. poets, Șūfìs, and jurists - about Mawlānā and the imitators of Mawlānā in Persian and Turkish literature. In addition, because absolutely no research has been done to date on the spiritual climate of Anatolia in the period when Mawlānā flourished, it is not yet possible to depict clearly his personality and influence. The bibliography that Carra de Vaux gives for his article on Jalāl al-Dīn Rūmī in $E I^{l}$ is quite deficient \{cf. $E I^{2}$, s.v. "Djalāl al-Dīn Rūmī" (A. Bausani)\}. For example, he does not mention Nicholson's work at all, nor can he even give sufficient information on Mawlānā's works. Unfortunately, because this subject is beyond the scope of my book, I cannot provide here the Oriental sources concerning Mawlānā, nor the various works in manuscript about him that have not been studied, nor even the briefest account of his own works. [There is valuable information in $\dot{I}$, s.v. "Celâleddin Rumî" (H. Ritter) on the life and works of Mawlānā as well as on his bibliography.] \{Publications on Rūmī have become something of a cottage industry. For an idea see M. Önder, Mevlâna bibliografyasi (Ankara, 1973); Annemarie Schimmel's study of him, The Triumphal Sun (London, 1978); and the recent guide to all things of Rūmī, Franklin Lewis, Rumi, Past and Present, East and West, The Life, Teachings and Poetry of Jalâl al-Din Rumi (Oxford, 2000).\}

47 The information that Dawlat-Shāh provides on the Sayyid Burhān al-Dīn is completely erroneous. According to him, Mawlānā and his father were the Sayyid's murìds. The Sayyid accompanied them on their journeys to Damascus and the Hijāz, died in Damascus, and before his death advised them to go to the land of Rum (Dawlat-Shāh, pp. 193-4). According to \{Jāmī's\} Nafahät, however, the Sayyid was a mur̃̄d of Sultān Bahā' al-Dīn Walad, a descendant of Husain and an inhabitant of Tirmidh. According to legend, he went to Konya on spiritual direction at the death of his shaikh and provided spiritual guidance to Mawlānā for nine years. He used to say, "I gave my mystical state $(h \bar{a} l)$ to Shaikh Șalāh al-Dīn and my teaching $(q \bar{a} l)$ to Mawlānā” \{cf. Aflākī, Manāqib, O'Kane trans., p. 491\}. His tomb is in Kayseri (Nafahāt, \{Turkish trans.,\} pp. 515-16). The passages on the Sayyid Burhān al-Dīn in Sipahsālār's book of legends $\{$ Manāqib $\}$ confirm the Nafahăt. According to that work, when the Sayyid learned of the death of his shaikh he spent a year in mourning. Afterwards, he saw Sulțān al-'Ulamā' \{Mawlānā's father\} in a dream and on his direction went to Konya and took upon himself Mawlānā's spiritual training. This being the case, one could surmise that the Sayyid Burhān al-Dīn went to Konya around 629-30/1231-2 and was with Mawlānā until about 640/1242-3 (Sipahsālār, \{Turkish\} trans., pp. 159-64). 
48 The accounts in $\left\{\mathrm{Jām}^{\prime} \mathbf{s}\right\}$ Nafahāt and Sipahsālār's $\{$ Manāqib $\}$ on the manner and nature of this meeting are basically very similar. According to the Nafahāt, Shams stayed at the Sugar Sprinklers' Inn. Mawlānā left his madrasa accompanied by a group and, while passing that place, he \{Shams\} caught his donkey and asked "Who is greater, Bayezid \{i.e. Abū Yazīd Bistāmī\} or Muhammad?" According to Sipahsālār, Shams stayed at the Rice Dealers' Inn. In the morning, as he sat on the bench in front of the inn, Mawlānā came by and sat opposite him. He then answered Shams's questions. There are lengthy accounts in both of these sources on these questions and answers (Nafahāt, \{Turkish trans.,\} p. 521; Manāqib, \{Turkish trans.,\} p. 170). Abū Yazīd, who said سبحانى مـا اعظم شانى وانا سلطان السلاطين "Glory be to me! How great is my majesty!" and "I am the Sultan of Sultans"\}, quenched his thirst with one gulp; thus he spoke of being sated \{cf. Aflākī, Manāqib, O'Kane trans., p. 425\}. The Prophet, on the other hand, who said ما عرفناك حقي معرفتك W"We have not known you as you ought to be known"\}. His blessed heart, which was as vast as الم نشرح لك صدرك God's earth, had been expanded according to the Koranic verse \{"Have we not expanded your heart for you?"\}; thus he was never sated with water, and so \{he spoke of being thirsty, and \} every day he wished to come closer to God. Discussing the meeting of these two lovers of God, Sultān Walad compared them to two seas embracing each other between pounding waves.

49 Neither \{Jāmī's\} Nafahāt nor Sipahsālār's \{Manāqib\} say anything about Shams al-Dīn Muḥammad b. 'Alī b. Malik-dād al-Tabrīzì. Only Dawlat-Shāh provides some information on this subject, which he took from different sources. According to him, Shams Tabrīzī was the son of Khwānd Jalāl al-Dīn, a descendant of Kiyā

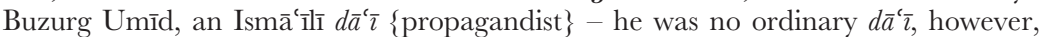
but the successor of Hasan al-Ṣabāh (Dozy, Essai sur l'histoire de l'Islamisme, Turkish trans., vol. 2, p. 403; Hammer-Purgstall, Geschichte der Assasinen \{Stuttgart, 1818\}, French trans., J. Hellert \{as Histoire de l'ordre des assasins\} [Paris, 1833], p. 114; St Guyard, "Fragments relatifs à la doctrine des ismaélis," Notices et Extraits \{des Manuscrits de la Bibliothèque Nationale, 22, i (1874),\} p. 8 \{sic, the article is on pp. 177-428\}). This man reportedly did not accept the things in which his ancestors had believed, burned the books and treatises about the Ismā $\overline{1} 1 \overline{1}$ heretics, and sent his son Shams secretly to Tabrīz so that he would be taught the Islamic sciences. While still a child, Shams was renowned for his exceptional beauty and he learned embroidering from the women of Tabrīz. The author \{Jāmī\} of Silsilat al-dhahab \{Bombay, 1289/1872-3\} disagrees with this, however, and says that Shams Tabrīzī was not the son of Khwānd Jalāl al-Dīn, who had the byname Naw-Musulmān, but was the son of a cloth merchant from Tabrīz - or, according to another report, a cloth merchant from the province of Bā-zer in Khurāsān who had gone to Tabrīz to trade - and was born in Tabrīz. Dawlat-Shāh, saying

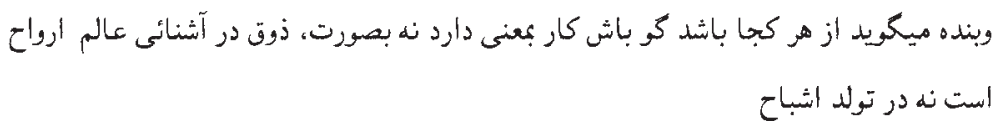

\{Wherever he may be from, deeds are judged by meaning not by form, and mystical discernment lies in knowing the world of spirits not in producing bodies\}, refrains from advancing any definite opinion on this matter (\{Tadhkira, $\}$ p. 195). At the end of the edition of \{Jalāl al-Dīn Rūmī's\} Kulliyyatt-i Shams-i Tabrīz that was published in India $\{$ Lucknow, 1302/1885\}, there is a simple biography that merely repeats the account in the Nafahāt and a death date cited from \{Lāhawrîs\} Khazīnat al-asfy $\vec{a}^{\prime}$, which also tells us little. 
50 According to Dawlat-Shāh, he was the mur̃̄d of Rukn al-Dīn Sinjābī (Tadhkira, p. 196). The relational name \{i.e. nisba\} of this shaikh was not, however, as Prof. Browne has reported, Sinjābī, but Sinjāsīi, as all the other sources unanimously state. Nicholson records this name correctly and also includes in his work verbatim the silsilatnāme of the tarīqa that Dawlat-Shāh mentions. Reportedly, Rukn al-Dīn had ordered him to go to Anatolia and inspired him with the fire of love for a theological student there, i.e. Mawlānā. According to \{Jāmī's\} Nafahăt, even before puberty, Shams had fasted for days for the love of Muhammad. According to a widely known report, he became a mystic through \{the teachings of $\}$ Shaikh Abū Bakr Selabāf \{the garment maker\} Tabrīzī, or, according to another report, through Rukn al-Dīn Sinjāsīi, or, according to another report, through Bābā Kamāl Jandī. The most reasonable theory, as the author of the Nafahät also acknowledges, is that this well known dervish met each one of them separately (Nafahāt, \{Turkish\} trans., p. 520).

51 Jāmī's\} Nafahät records the following incident that occurred while he was in the company of Bābā Kamāl: Her keșf-ü feth ki Şeyh Fahre'd-Dîn 'Irâkîye yüz gösterirdi, ân nazm ve nesr libâssnda izhâr ederdi ve Baba Kemâl' in nazarna eriştirirdi. Şeyh Şemse'd-Dîn ândan hiç nesne izhâr etmezdi. Birgün Baba Kemâl âna eyitti: Oğlum Şemse'd-Dîn, ol esrâr ve hakâyzktan ki oğlum Fahre'd-Din izhâr eyler; sana hiç nesne lâyih olmaz mi? Eyitti: Ândan ziyâade müşâhede düşer, amma şol sebepten ki ânm bâzı mustalahat má lûmu olmuştur, Kâdir' dir ki ânlara mahcûb \{mahbûb in the original\} libâsta cilve vere ve bende ol kuvvet yoktur. Baba Kemâl buyurdu ki: Hak Sübhânehû ve Ta'âlâ sana bir musâhib rûzî kıla ki, evvelîn ve âhirînin maârif ve hakâyıkn senin adına izhâr ede ve hikmet ırmaklan ânn kalbinden lisânmna cârî ola ve harf ve savt libâsina gire ve ol libâssn trrâzı senin adına ola \{Every mystical illumination and revelation that occurred to Shaikh Fakhr al-Dīn 'Irāqī, he revealed in the garb of poetry and prose, and brought it to the attention of Bābā Kamāl. Shaikh Shams al-Dīn never revealed anything. One day Bābā Kamāl said to him, "My son Shams al-Dīn, does nothing ever occur to you of those secrets and truths that my son Fakhr al-Dīn reveals?" He replied: "Even more than him. But because he knows the right terminology, he is able to clothe them in a lovely dress. I do not have that capacity." Bābā Kamāl said, "May God provide you with a companion who will reveal in your name (i.e. under your auspices) the teachings and truths of the ancients and the moderns, may the rivers of wisdom flow from his heart to his tongue and enter the garb of letters and sounds, and may the tira $z$ \{embroidery\} of that garb be in your name"\} (Nafahăt, \{Turkish\} trans., pp. 520-1). \{Jāmī's source for this story was, in fact, the Jawāhir al-asrār of Husain Khwārazmī, the fifteenth-century shaikh in the lineage of Bābā Kamāl Jandī. See the edition by Muhammad Javād Shar̄̄at (Isfahan, 1360/1981), p. 131.\} As will be seen below, Mawlānā's creation of Dīwān-i Shams al-haqa'iq was attributed to this miracle and prayer of Bābā Kamāl.

52 Nicholson describes his personality in the following manner: "He was comparatively illiterate, but his tremendous spiritual enthusiasm, based on the conviction that he was a chosen organ and mouth-piece of Diety, cast a spell over all who entered the enchanted circle of his power. In this respect, as in many others, for example, in his strong passions, his poverty, and his violent death, Shamsi Tabrīz curiously resembles Socrates; both imposed themselves upon men of genius, who gave their crude ideas artistic expression; both proclaim the futility of external knowledge, the need of illumination, the value of love" (Dīvāni Shamsi Tabrīz, p. xx).

53 According to an exceptionally widespread report, Shams Tabrīzî̀s death occurred in a very horrible manner. And the manāqib books add to it a mysterious twist. One night while Shams was sitting with Mawlānā, someone called him outside. Shams went out, saying that they were summoning him to be killed. An ambush awaited outside \{the original says: Seven people had conspired and had laid an ambush\}. They were about to kill him by attacking him with knives. Shams gave a shout, 
however, and the assassins, among whom was Mawlānā's middle son 'Alā' al-Dīn, fainted. When they came to, they saw a few drops of blood on the ground, but no other trace of Shams was ever found. According to one account, he was buried next to Mawlānā Bahā' al-Dīn Walad, but according to another the murderers threw his body into a well. One night he appeared to Sulțān Walad in a dream and told him where he could be found. So he went in the middle of the night with his intimate companions and buried him next to Amīr Badr al-Dīn, who had built Mawlānā's madrasa ( $\{\mathrm{J} \bar{a} m \overline{1}$,$\} Nafahăt, \{Turkish\} trans., p. 523). It is recorded in Sipahsālār,$ however, that he suddenly disappeared and that Mawlānā even went as far as Damascus to search for him (\{Manāqib, $\}$ p. 179). Dawlat-Shāh also says that he withdrew to Damascus from Konya (\{Tadhkira, $\}$ p. 197). When we take into consideration Mawlānā's search, and the fact that there is absolutely nothing about this terrible murder in Sipahsālār, which is a very trustworthy source on these matters, then the account of the Nafahät, according to which he was murdered, becomes very dubious. Therefore, in my opinion, Nicholson's acceptance of the account of the Nafahāt is mistaken. If he had seen Sipahsālār and if he had known that Mawlānā had searched for Shams after his disappearance, he could not have concluded that Shams was murdered. Evliyā Chelebi says that he visited the head of Shams Tabrīzī in Khūy \{in Iranian Azerbaijan\} (Seyāhatnāme, Book 2, fo. 307b).

54 Dancing and whirling $\left\{\right.$ sam $\left.\bar{a}^{\top}\right\}$, which were strictly forbidden to ordinary people who gave in to their carnal appetites, were always regarded as permissible to 'ásh $q$ s and Șūfìs. Indeed, many treatises were written on this subject. Many of the great Șūfìs, in response to a need that arose from their spirit, practiced the sam $\bar{a}^{c}$ and considered it to be a means of reaching mystical ecstasy. For example, Yūsuf b. al-Husain, whom the jurists of Rayy accused of being a heretic, used to perform the sama $\bar{a}^{c}$. The great Șūfî poet Shaikh Abū Sa'īd Ibn Abī 'l-Khair was a frequent practitioner of the $s a m \bar{a}^{c}$. During that time, he would be carried away by mystical ecstasy and tear apart his clothing. Shaikh Najm al-Dīn Kubrā first denounced the $\operatorname{sam}_{\bar{a}}{ }^{\prime}$, but later became a frequent practitioner of it. Shaikh Majd al-Dīn Baghdādī also did the $s a m \bar{a}^{\prime}$. The great Șūfì contemporaries of Mawlānā, such as Șadr al-Dīn al-Qūnawī and Sa'd al-Dīn al-Hammūyī, did the samā as well (\{Jāmī, $\}$ Nafahăt, \{Turkish $\}$ trans., pp. 378, 385, 402, 478, 483, 486). Mawlānā began the sam $\bar{a}^{`}$ instructed by Shams Tabrīzī and continued to practice it for the rest of his life. Indeed, he adopted the sam $\bar{a}^{c}$ as a religious ceremony and \{part of \} the mystical path. There are many passages in Mawlānā's poetry to the effect that "the $\operatorname{sam}_{\bar{a}}$ is the nourishment of the lovers that allows one to imagine union with the Beloved," and others regarding the rules and conduct of the samā'. A chapter in Sipahsālār's book of Șūfì legends is devoted to a description of the true $\operatorname{sam}_{\bar{a}}$, its rules and conduct (\{Manāqib,\} pp. 91-5). While many religious scholars have declared the Sūfi sama $\bar{a}^{`}$ to be permissible and have advocated it, others up to the present time have persistently considered it to be forbidden.

55 The following couplets, which are very significant, are found in one of the ghazals that Mawlānā sent to Damascus (Sipahsālār, \{Manāqib, Turkish\} trans., p. 174):
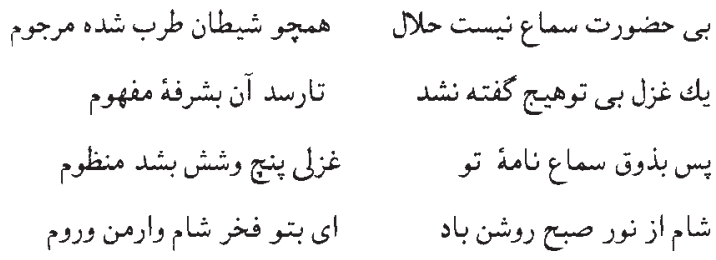
\{Without your presence, $s a m \bar{a}^{c}$ is not lawful.

Joy, like satan, has become the victim of stoning.

Without you, not one ghazal has been uttered

That attains the dignity of understanding.

So, for the pleasure of hearing $\left(\operatorname{sam} \bar{a}^{c}\right)$ your name

Some five or six ghazals have been composed.

May the night (Shām) be illuminated with the light of dawn,

Oh you who are the source of pride for Damascus (Shām) and

Armenia and Rūm (cf. Aflākī, Manāqib, O’Kane trans. pp. 488-9).\}

56 Sipahsālār, \{Manāqib, Turkish $\}$ trans., p. 179. Dawlat-Shāh says nothing in his Tadhkira about Mawlānā going to Damascus, p. 197:

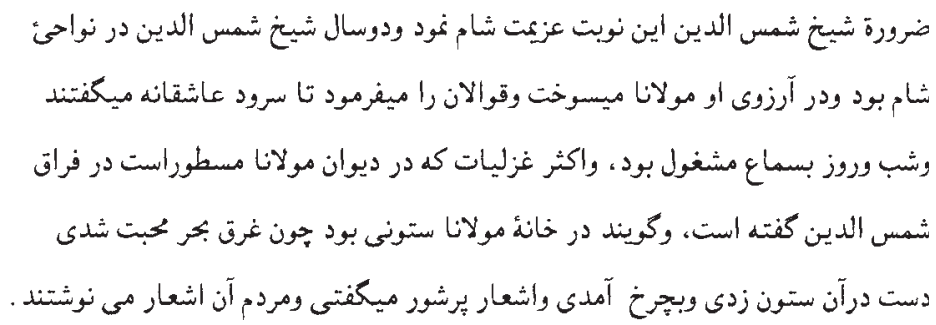

\{At this juncture Shams al-Dīn had to go to Damascus, where he remained for two years, during which Mawlānā burned with desire for him. He ordered the musicians to compose love songs, and night and day he engaged in $\operatorname{sam}^{c}$. Most of the ghazals contained in Mawlānā's dīwān were composed in separation from Shams al-Dīn. It is said that Mawlānā's house had a column, and whenever he was drowned in the sea of love, he would grasp that column and turn round about it, reciting poems with great excitement, and others would write those poems down.\}

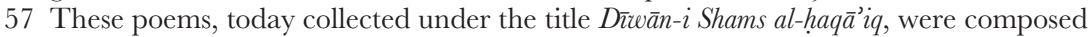
in different periods. Nicholson is correct in believing that a large number were written after the departure of Shams. Hüseyin Dâniş writes that Dawlat-Shāh states that they were written in Damascus after Shams had disappeared (Ser-Amedân-ıSuhan, p. 343), but this is completely mistaken, for he cites verbatim the passage of Dawlat-Shāh on this matter, which is given above in the previous note. Dawlat-Shāh says that Mawlānā wrote most of the ghazals in the Dīwān after Shams went to Damascus for the last time, and this is also what Nicholson claims. \{These collected poems are known under several titles. See the bibliography.\}

58 Even in the brief forward that he wrote to the Dĩvani Shamsi Tabrīz, Nicholson shows quite clearly and categorically the major relationships between Mawlānā's Ṣūî̀ views and Neoplatonist ideas. This ancient philosophical system, which based the question of takwin \{creation\} on love \{ $i s h q\}$ and was in harmony with Pantheism, was no different from the principles taught by Jalāl al-Dīn Rūmī. This is fairly well described in E. J. W. Gibb's History of Ottoman Poetry \{vol. 1, Chapter 2\}. While discussing below the Sūfí ideas of Yūnus Emre and the overwhelming similarity between his works and those of Mawlānā, I will give a brief account of Neoplatonist thought, which constitutes, in fact, the basis of our Sūfì literature.

59 Such an endeavor, which would lay the foundation for a strictly philosophical study, would be extremely important and very useful with respect to literary history, but it 
is outside my field and belongs to specialists in Islamic philosophy. The brief notes given below do not even form the basis for such an effort.

60 One day Mawlānā was passing in front of the jewelry shops in Konya. While passing before the shop of Șalāh al-Dīn, he became exalted with the rhythm of the hammer and began the samác. He then recited a poem that began with the following verse:

$$
\text { يكى كنجى بلديد آمد در اين دكان زر كوبي \ زهى صورت، زهى معنى، زهى خوبى، زهى خويى }
$$

\{A treasure has appeared in that gold-beater's shop. / Such form! Such essence! Oh beauty! Such beauty! (Aflākī, Manāqib, O’Kane trans. p. 495).\} As soon as he realized what was happening, Șalāh al-Dīn continued to strike his hammer without thinking about the damage he was doing to the gold that he was beating. A little later, he left his shop on Mawlānā's invitation and offered him his services (Sipahsālār, \{Manāqib, Turkish\} trans., p. 181; \{Jāmī,\} Nafahāt, \{Turkish\} trans., p. 523). We know that Salāh al-Dīn had already attached himself to Mawlānā before Shams arrived (Sipahsālār, Manāqib, p. 171). And after the departure of Shams, Mawlānā adopted Șalāh al-Dīn as his companion and assuaged his grief with him. Sultān Walad describes at length how Mawlānā valued and respected him and, indeed, how the other muñds were jealous of him:

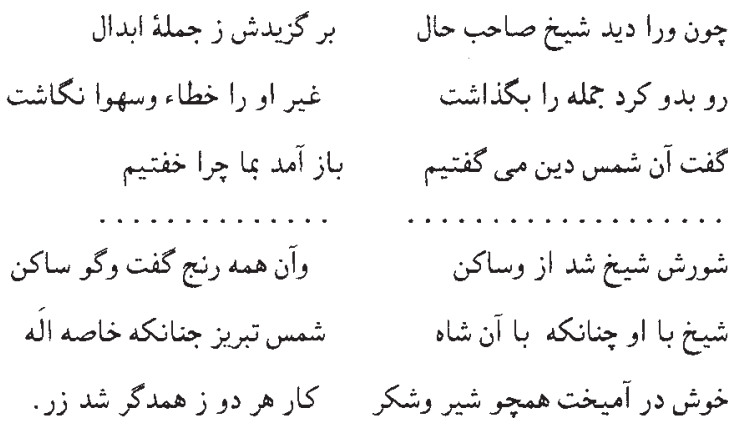

\{When that mystic Shaikh saw Salāh al-Dīn

He chose him from among the ranks of saints.

Turned his face towards him, put all else aside,

Reckoned all others in error, in the wrong.

"That Shams-i Dīn of whom we always spoke

Has come back to us! Why do we slumber?"

Because of him the Shaikh's agitation was stilled.

All the pain of talk and gossip was stilled.

The Shaikh was with him as he had been with that king,

Shams-i Tabrīz, just as God's intimate friend.

They mingled pleasantly, like milk and sugar.

They made gold out of one another. (Cf. Lewis, Rumi, p. 206.)\}

61 On the occasion of his death, Mawlānā recited a ghazal that began with the following verse (Sipahsālār, \{Manāqib, Turkish trans., \} p. 189): 


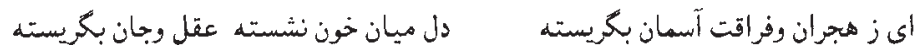

\{Oh you at whose departure the heavens wept in pain! / The heart wallowed in blood, while mind and soul wept. (Ed. Furūzānfar, no. 2364. See Aflākī, Manāqib, O'Kane trans. p. 510.)\} Furthermore, in \{Mawlānā's\} Dĩ̌ān-i kabīr, there are many ghazals that are addressed to him or that describe his exalted spiritual rank, such as the ghazals that include the following couplets:

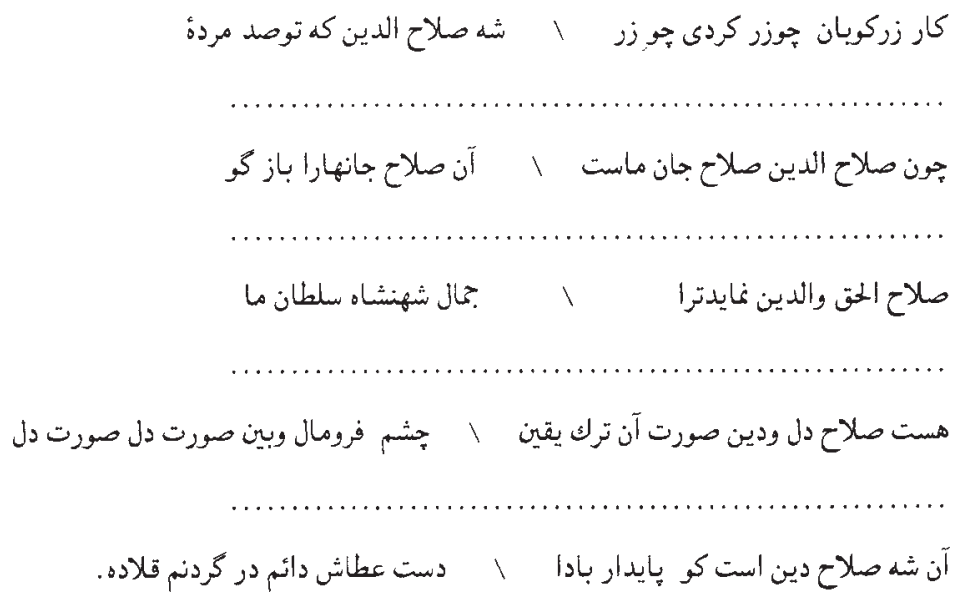

\{You have made the gold-beaters' work golden, golden,

Oh king, Șalāh al-Dīn, you are (worth) a hundred men. $\cdots$

Because Șalāh al-Dīn is the well-being (șalāhn) of our soul Reveal that well-being of souls.

Șalāh al-Haqq wa 'l-Dīn shows to you

The beauty of the King of Kings, our Sultan. $\cdots$

The face of that Turk is surely the well-being of heart and religion.

Rub your eyes and see the face of the heart, the face of the heart.

$\cdots$

That is the king, Salāh al-Dīn, may he live forever!

May his hand of favor always be a necklace on my neck.

62 Dawlat-Shāh, \{Tadhkira,\} p. 195, states that Mawlānā Jalāl al-Dīn Rūmī received the khirqa-i sulük \{patched cloak of his order\} through several intermediaries from Shaikh al-Shuyūkh Șalāh al-Dīn Zarkūb who was associated with Dịā̄ al-Dīn Abū 'l-Najīb al-Suhrawardī, but this is completely mistaken.

63 The Sayyid Abū 'l-Wafā-yi Baghdādī, who died in 501/1107-8 and was known by the byname Tāj al-'Ārifîn, was a very great Șūfì. For information on him, one can 
consult the famous work Manāqib-i Tāj al-'ÁArifin (MS in my private library). Sipahsālār, who is the most credible source on this matter, says, \{Manäqib, Turkish trans., \} p. 191, that Chelebi Husām al-Dīn was a descendant of this shaikh. The same source is cited in this regard in \{Jāmì's\} Nafahāt, \{Turkish\} trans., p. 525. \{On Baghdādī, see Alya Krupp, Studien zum Menāqybnäme des Abu l-Wafä' Tāă al-'Arifīn, part 1, Das historische Leben des Abu l-Wafä' Täğ al-Árifin (Munich, 1976).\}

64 Hüseyin Dâniş provides the following information on this without naming the source: "It has not been determined exactly when the Mathnawi began to be written. It is composed of six large sections and a total of 2666 couplets \{sic, probably 12,666 couplets or 26,000 verses $\}$. The second section began to be composed two years after the completion of the first, i.e. in 1263 ce However, because Hasan Husām al-Dīn, Jalāl al-Dīn's excellent student, who was preoccupied with writing the Mathnawe directly from his master's dictation, died at that time, the task of writing this work was interrupted" (Ser-Âmedân-ı Suhan, p. 342). As for the number of couplets in the Mathnawē, Dawlat-Shāh says (\{Tadhkira,\} p. 197):

$$
\text { مثنوى را جهل وهشت هزار بيت كفته اند وبعضى زياده وبعضى كم كفته اند }
$$

\{They say that the Mathnawi contains 48,000 couplets. Some say more, some less\}, but this is an exaggeration. I cannot go into detail here on the question of the seventh volume of the Mathnawē, which did not belong to Mawlānā but was later attributed to him. Let me simply state here that Hüseyin Dâniş's attempt to show that Chelebi Husām al-Dīn died after finishing the first volume of the Mathnawē does not conform to any of the historical sources and is a very serious mistake. The one who died was his wife. The death of Chelebi Husām al-Dīn was actually twelve years after that of Mawlānā.

65 In India, Iran, and Turkey, where Persian culture was very widespread, the Mathnaw had an almost sacred character. The opinion that it was "the heart of the Koran" $\{m a g h z-i$ Qur'ān $\}$ is quite old. Indeed, Mawlānā's Dīwān, like that of Hāfiz, was used for telling fortunes ( $\{$ Jāmī, Nafahăt, \{Turkish\} trans., p. 423). If all the different assessments and views that have been presented of the Mathnaw since a very early time were collected, they would form a rather long treatise. It is claimed that this work has not had a direct influence on the great mass of the Turkish people and that its influence has been confined to the Mawlawīs and those under the spell of Persian literature, but its indirect influence on the great mass of the Turkish people has, in fact, been much greater than has been thought.

66 This spiritual influence, which began with Gülshehrī, took very clear form with 'Āshıq Pasha. The latter's Ghañbnāme, which is very famous among the Turks, is virtually a Turkish Mathnawē. As for Yūnus Emre, the influence of the Dīwān-i Shams al-haqa $\vec{i} q$ is much more striking.

67 I have discussed above, citing his Fìhi mā fìh, why and for what purpose Mawlānā wrote poetry (see n.33 of this chapter). Mawlānā distinguished himself from ordinary poets with such laments as

$$
\text { شعر جهل باشتد بر من تاكه زنم لاف ازو \ هست مرا فن دكر غير فنون شعرا، }
$$

\{What is poetry to me that I should boast of it? I have another art, different from the arts of the poet $\}$ and

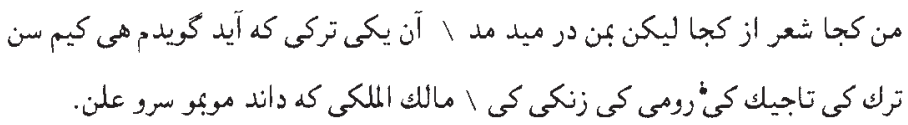


\{What have I to do with poetry? But it breathes within me.

When a Turk comes along, he says to me, Hey kim sen "Hey who are you?"

Who is Turk, who Tajik? Who is Rūmī, who Zangī?

Who knows the Kingship, hair by hair, hidden and manifest?

Sultān Walad put forth an excellent and quite correct opinion of the poetry of Mawlānā: "The 'āshrq, i.e. the true Șūfì, and the poet are distinct from each other. The Koranic dictum \{26:224\} والثعراء يتبعه الغاورن As for the poets: the erring follow them\} concerns the latter, for while the poetry of the 'asshq is a commentary on the words of God, that of the poet is like the odor of garlic. The poetry of the ' $\bar{a} s h q$ is the result of wonder and intoxication \{with the love of God\}, but that of the poet is the product of the self." In various poems, Mawlānā requests from God the tongue of $h \bar{a} l$ \{mystical state\} and opposes the tongue of $q \bar{a} l$ \{speech of the religious scholars\}:
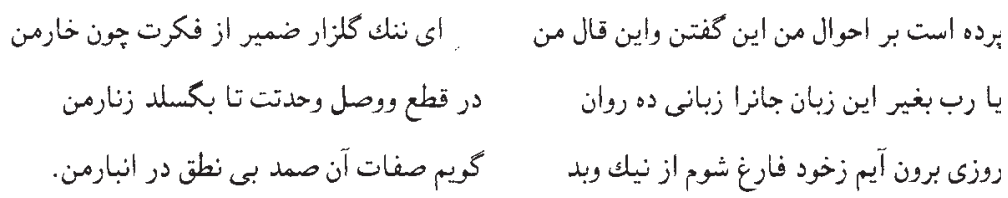

\{This talk of mine is a curtain covering my inner states.

What a disgrace: the rose-garden of conscience comes from my thornlike thoughts.

Oh Lord, give my soul a fluent tongue other than this tongue,

So that in cutting through to union with Your oneness, my zunnār (Christian belt) will break off.

One day I shall go outside myself, go beyond good and evil;

I shall utter the attributes of that Eternal One in the storehouse of my heart, without speech.\}

Ziya Pasha's saying, Şâir dimen öyle ehl-i hâle / İâs-i nakîsedir kemâl'e \{Don’t call a mystic a poet / That is to attribute imperfection to perfection\} in the Kharābāt \{his Harâbât (Istanbul, 1291-2/1874)\}, results from such ideas. In order to understand better this difference between the works of ordinary poets and the poetry of Șūfìs, see the section below on the poetry of Yūnus Emre.

68 In many places in the Mathnawi, Hakīm Sanā'̄i and, to a lesser degree, 'Atțār are mentioned. There are also a great many allusions to them in the Dĩwān. Mawlānā considered himself to be a follower of Sanā'ì and 'Ațtār. In his works, especially in the Mathnaw, their influence is strikingly obvious.

69 Chelebi Husām al-Dīn, who, while Mawlānā was still alive, was his khal̄ fa for nine years, died in 684/1285-6 (Sipahsālār, \{Manāqib, Turkish trans., \} pp. 197-201). If we consider that the arrangement of the Mathnaw $\bar{\tau}$ was begun in 662, then we must also push back Chelebi Husām al-Dīn's career as a khalîfa to Mawlānā to that date. Chelebi Husām al-Dīn's being instructed to begin recording the Mathnawi must have occurred after he became a khalīfa of Mawlānā. If we consider that the period during which he served as a khalif $f$ was between 662 and 672 , then it appears that 662 must be the date when he began the Mathnawi, for this cannot be regarded as the beginning date of the second volume. Consequently, Hüseyin Dâniş's statement \{in his

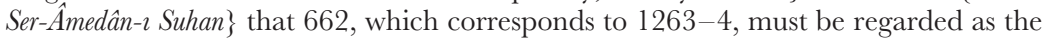


beginning date of the second volume and that the first book was completed in 660, i.e. 1261-2, is evidently mistaken. It is for this reason that I stated above that this great book was written within a period of seven or eight years. Dawlat-Shāh believes that Ibn Akhī Turk and Chelebi Husām al-Dīn were two different persons and says that Mawlānā "dest-i irâdeti Çelebînnin dâmen-i terbiyetine vurduğunu" \{applied the hand of will power to the skirt of Chelebi's training\} (\{Tadhkira, $\}$ p. 195). The historical facts given above suffice to confirm the error of these two claims.

70 Extensive information can be found in Dawlat-Shāh \{Tadhkira\}, \{Jāmī's\} Nafahāt, $\{$ Turkish\} trans., and in various other sources on these personalities, who occupy an important place in Persian Șūfì literature because of their poems imbued with mystical excitement. It is beyond the scope of my work to treat in detail all of these Șūfìs who possess dīwāns, some of which have been published.

71 One day they asked Șadr al-Dīn al-Qūnawī his opinion of Mawlānā. He replied, "Bâyezîd ve Cüneyd bu zamânda olsalard, bu merdler merdinin gâşsiyesini görtürmeyi cânlarna minnet bilirlerdi" " If Abū Yazīd and Junaid were alive, they would realize that to carry the horse blanket of this excellent man would bestow a blessing on their souls ( $\{\mathrm{Jāmi}$,$\} Nafahăt, \{Turkish trans., \} p. 520). Similar examples could fill many pages.$

72 Hüseyin Dâniş mentions the existence of Fìhi mā fìh, based on Nicholson's account, and then says, "This work must be rather rare today" (Ser-Âmedân-ı Suhan, p. 343). Carra de Vaux says that this work was completely unknown in Iran, $E I^{I}$, s.v. "Djalāl al-Dīn Rūmī." However, this small work is quite famous among the Mawlawīs in Istanbul. There are manuscript copies of it in our public libraries and in private hands. \{Ed. Badī‘ al-Zamān Furūzānfar (Tehran, 1338 sh./1959), English trans. A. J. Arberry as Discourses of Rumi (London, 1961), and Thackston as Signs of the Unseen: The Discourses of Falaluddin Rumi (Putney, VT, 1994).\}

73 It is quite clear from the statements of al-Kāshgharī on this matter that some works were written in the Oghuz dialect before the Turks came to Anatolia. The idea that there were two separate dialects called Seljuk Turkish and Ottoman Turkish has no historical or linguistic basis. There is no need to mention here the useless information of the nineteenth-century Orientalists on this matter because work like theirs is not even worthy of scholarly criticism. Nevertheless, because the Hungarian Orientalist Jozef Thúry has recently advanced extremely erroneous views on this important problem, let me use him as an example to show briefly how poorly our linguistic history has been studied to date. According to Thúry, "The most important masses of Turks who came to Anatolia were the Seljuks in the second half of the eleventh century and the Qayı in the first half of the thirteenth century. Because they were both from the Oghuz, there was a close blood and linguistic relationship between them. The Seljuks were not, however, a distinct ethnic group. They were composed of a number of ethnic groups who had broken away and come from different linguistic regions in various places in Central Asia" "“Ondördüncü 'asır sonlarına kadar Türk dili yâdıgârları," pp. 100-2). I have adequately discussed above the emigration of the Turks to Anatolia, so the erroneousness of this assertion is obvious. The mass of the Turks in Anatolia were composed of Oghuz, i.e. Turkmen. The migration of the Qayl and their role in founding the Ottoman state are only of significance from a political perspective, not because they brought to Anatolia an ethnic block who spoke a different dialect - for their number was extremely limited and their dialect was also that of the Turkmen. The aforesaid article by Thúry contains, from beginning to end, mistaken conclusions derived from very defective and very erroneous analyses.

74 Batțāl Ghāzī was a legendary Turkish hero who, according to legend, was named Abū Muḥammad Ja'far b. Sulțān Husain b. Rabī' b. 'Abbās al-Hāshimī, was born in Malatya, and lived 900 years ago. Al-Ṭabarī, however, mentions a historical figure 
named 'Abd Allāh al-Bațtāl who died a martyr in 122/739-40. Janābī and Hezārfen carelessly confuse these two accounts, i.e. the legendary with the historical. Even Halil Edhem, citing \{Yāqūt's\} Mu'jam al-buldān, vol. 8, p. 195, is not able to escape this error, which was also shared by Kātib Chelebi and Evliyā Chelebi (Kayseriye şehri \{Istanbul, 1334/1915-16\}, p. 131). The legend of Batțāl Ghāzī, which had both an heroic and religious quality, lay behind the creation of many works about him $\{$ Batțalnammes\}, both in verse and in prose, since the earliest period of the Seljuks. Thus, the Orientalist H. Ethé quite rightly asserts that, basically, this work was written to prepare soldiers for the conquest of Anatolia. Whoever originally wrote it, and for whatever purpose, this work, which reflects the shared feelings of the Turks in those days, won great fame among the common people. Indeed, it spread as far as eastern Turkistan where there are a number of legends about this legendary hero; even his tomb is to be found there, in Aksu. According to legend there, Baț̣āl Ghāzī was the fourth grandson of Muhammad Ibn al-Hanafiyya - who in fact died in Medina in 81/700-1 and was buried in Baqī - and was known by the name Imām 'Abd al-Raḥmān 'Alawī (Tảñ̄kh-i Sairāmē \{i.e. Mullā Mūsā b. Mullā 'Īsā Sairāmī's Ta'rikh-i amañyya (Kazan, 1905),\} p. 254). This important subject, about which we Turks have not yet done any research, was first studied in detail by H. Fleischer (Kleinere Schriften \{Leipzig, 1885-8\} vol. 3, pp. 226ff.). Ethé later translated this legend into German (Die Fahrten des Sajjid Batthâl [Leipzig, 1871]). There is also important information on this in the $Z D M G$ \{i.e. A. D. Mordtmann's "Die Dynastie der Danischmende,"\} 30 \{1876\}, pp. 468-9; and Georg Hüsing's work \{Beiträge $\}$ zur Rostahmsage (Sajjid Battall) (Leipzig, 1913), is worthy of note. Yet, despite all these studies, it cannot be claimed that this subject has been adequately investigated. What is certain is that the legend was first written down at the time of the Seljuks. The tomb attributed to the famous Sayyid Baț̣āl Ghāzī south of Eskişehir is greatly venerated in that region and a Bektashī tekke, mosque, and soup kitchen are also found nearby (see $E I^{I}$, s.v. "Batțāl" [editors]). There are important details in Evliyā Chelebi on Bațtāl Ghāzī (Seyāhatnāme, Book 3, fo. 7a, Book 4, fos 192b, 196a) and I have collected extensive information from various sources for the analytical work that I am preparing on the Bektashīs and abdāls, on his place among the Bektashīs and, especially, the abdāls, and on the history of the Sayyid Ghāzī Tekke. For now, see my article "Abdal" in Türk halk edebiyat ansiklopedisi (Istanbul, 1935). [For additional material and bibliographical information on both the historical and legendary figures of the Sayyid Batțāl, as well as on other related matters, see $\dot{I} A$, s.v. "Battal" (Pertev N. Boratav), and $E I^{2}$, s.v. "al-Baț̣āal" (M. Canard and I. Mélikoff).] \{For English trans. and Turkish transcription of the legend of Batțāl Ghāzī, see Y. Dedes, Battalname (Cambridge, MA, 1996). See also Hasan Köksal, Battalnâmelerde tip ve motif yapısı (Ankara, 1984), and Saim Sakaoğlu, "Battal-nâme," Türk Dili Araştırmalar Yillı̆̆r: Belleten, 1992, 67-74.\}

75 The following couplets by 'Āshıq Pasha suffice to show how much Turkish was denigrated even in the eighth/fourteenth century:

Türk diline kimsene bakmaz idi

Türkler'e hergiz gönül akmaz idi

Türk dahi bilmez idi bu dilleri

Ince yolu ol ulu menzilleri.

No one cared for the Turkish language.

No one had affection for the Turks.

Even the Turks did not known their own language

The narrow path, the great way-station. $\}$ 
Thanks to various documents, we know very well that this point of view was maintained even in the ninth/fifteenth and tenth/sixteenth centuries. It would be beyond our subject to go into further detail on this matter here.

76 "Afterward the governing council was established. Because all records and orders had been written in Persian, Turkish had almost disappeared. Consequently, all documents that were to be read in the council were to be in Turkish and conversing in other languages was strictly forbidden. Because the registers and other account books had been written up to that time in Arabic and Persian, Turkish was written with difficulty and everyone who wrote in the registers used a different spelling" (Hayrullâh Efendi, Tarih-i âl-i osmân, vol. 1, p. 110). It is very uncertain how long this important action, which occurred after the Qaramānids took de facto control of Konya on 10 Dhū 'l-Hijja 676/May 5, 1278, remained in effect. Nevertheless, this event is enough to show that Turkish had reached a level of development whereby it could replace Persian and Arabic as the official language of that period. This event also definitely confirms that works were produced in Turkish in Anatolia since the very first arrival of the Seljuks. \{Köprülü implies that Persian was the language of instruction in the madrasas, but provides no evidence of this. Traditionally Arabic was the language of instruction in these schools of Islamic law. All the major relevant texts were in that language. Cf. his note 87 below. $\}$

77 The poet Gülshehrī recounts at length \{Mantiq al-tair, facsimile edn [Ankara, 1957], p. 51, and MSS in the Istanbul Archeology Museum Library and the Hâlis Efendi Library in the Süleymaniye in Istanbul $\}$ the famous story of Shaikh Șan'ān under the heading Dāsitān-i 'Abd al-Razzāq in the first part of his work and at the end of it he states:

Bir kişi bu dâstân eylemiş

İla lafżn gey çepürdük söylemiş

Vezniçün lafżn gidermiş harfinı

Artuk eksük söylemiş söz sarfin

Şimdi Gülşshrî giyürdi bu aya

Lefgeri tonlar ki benzedi baya

Anber ile saçı ördi sünbülün

Gönlegin atlasdan eyledi gülün

Söz hurûfin artuk eksük kılmadı

Alim anladı vï câhil bilmedi

Tanrinun kudretlerin yâd eyledi

Mustafầnun cânım şẩd eyledi

Böyle rengîn böyle datlu böyle ter

Husrev-û Şî̀ñ sözü old meğer.

\{Someone told this story,

but made the words very complicated

He left out letters for the sake of the meter, and added or subtracted word endings.

Now Gülshehrī has clothed this moon

in Livorno (?) garments, so it resembles a rich man.

He plaited the hyacinth's locks with ambergris, and made the rose's dress out of satin. 
He did not add or subtract letters.

The wise understood, the foolish did not know.

He recalled God's powers

and gladdened Muhammad's soul.

His words have such color, such taste, such freshness,

that they might very well be Khusraw and Shīrin.\}

It is evident from this that before Gülshehrī, i.e. in the sixth/twelfth or seventh/ thirteenth century, a poet had written about this subject in verse, but because his language was coarse and primitive and his use of meter was naturally very defective, Gülshehrī felt it necessary to rewrite it. This information is of historical value in showing that the 'arüd meters had begun to be used by the Turks of Anatolia much earlier than has been thought, and in showing how old subjects were taken up again by later poets.

78 There are some fragments of poetry in Greek and Turkish in Mawlānā's Dīwān-i $k a b \bar{\imath}$, \{the latter are not of a quality or quantity that would permit us to consider him a Turkish poet. Some of these fragments, which are mainly macaronic \{mulamma $\}$, sometimes satirical, and occasionally consist of complete passages, were included in Necib Âsım's Türk tarihi \{Istanbul, 1316/1898-9\}, pp. 439-42, citing a treatise by Veled Chelebi. In addition, two lines of poetry not found there appear in Fâik Reşad's book, Tarih-i edebiyat-ı osmâniyye \{Istanbul, 1329/1911\}, p. 30. The Turkish passages from Mawlānā, however, do not consist of $\{$ just $\}$ these fragments. Moreover, there are even great differences in the form in which they appear in different copies of the Dīwan. The publication of the requisite commentary on, and explanation of, this poetry by Veled Chelebi, who has a truly profound knowledge of this subject, is awaited with great anticipation \{see Şerefeddin (Yaltkaya), "Mevlânâ'da türkçe kelimeler ve türkçe şiirler," TM, 4 (1934), 111-67\}. Ziya Pasha did not mention Mawlānā as a Turkish poet, and Namık Kemal in his Tahrîb-i harâbât \{Istanbul, 1301/1883-4 and again in 1304/1886-7\} found fault with this, but Namık Kemal's judgment is not altogether correct. In order to give an idea of this poetry and the variants found in the manuscripts, I can cite verbatim from an old anthology another version of a ghazal in the Türk tarihi \{Turkish words underlined\}:

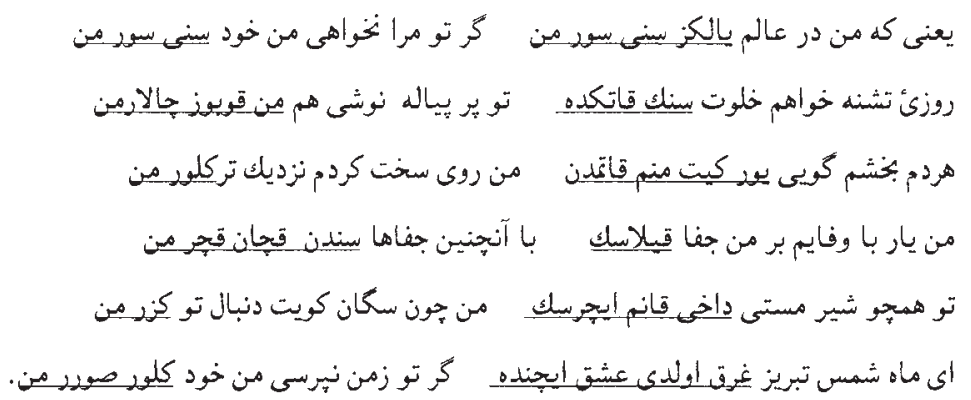

\{It means that I in the world, I only love you. If you do not want me, still I love you.

On the day of thirst, I want to be alone at your side.

You'll drink a full goblet and I'll play the kopuz. 
Every moment you say in anger: Go, depart from my side. I become obstinate and nearer $\underline{\text { I come }}$.

I am the loyal lover; you act cruelly toward me. With such acts of cruelty, how can I flee from you?

You are like a raging lion and you drink my blood. I am like the dogs of your street, $\underline{I \text { follow after you. }}$

O moon of the sun of Tabrīz, he is drowned in love. If you do not ask for me, I'll come myself and ask.

79 In Hacı Kemal's Jāmic al-nază’ir \{MS in the Beyazıt Umumi Library in Istanbul\}, which includes works of the earliest Anatolian poets, the names of whom are not even mentioned in the tadhkiras, there is an ethical Sūfì poem written in simple language and elementary 'arū $d$ meter by a poet named Shayyād Hamza. Its language, subject, and form of versification clearly reveal that it is an early work. There is an account of this man, who is not mentioned in any of the tadhkiras or biographical dictionaries, in Lāmi'î's Lața' if, which states that he was a contemporary of Nașr al-Dīn Khwāja and was a Șūfì who performed miracles. If we bear in mind that Nașr al-Dīn Khwāja died in 683/1284-5 (Köprülü, Nasrettin Hoca [Istanbul, 1918], p. 3), we may assert that Shayyād Hamza was also a figure of the seventh/thirteenth century \{Bayram identifies Nașr al-Dīn Khwāja with Akhī Evren, Tarihin ış̧̌̆ında Nasreddin Hoca ve Ahi Evren (Istanbul, 2001), with a death date between 658/1260 and $660 / 1262$, see n.41 above . Indeed, the nature of his work corroborates this. With the following couplets,

Ecel tutmış elinde bir ulu câm

Ki ol câmın içi dolu ser-encâm

Kime ayak sunar, kime içürmiş

Kimi esrük yatar toprakta müdâm

Ki bir bir içer ol sâkî elinden

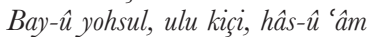

Zehî şerbet ki bir kez andan içen

Ne subh olduğunu bilür ne ahşâm

\{Death has a large cup in his hand.

The cup is full of the end.

He offers the cup to some people and lets them drink.

Some lie drunk in the earth forever.

One by one they drink from the hand of that cupbearer.

Rich and poor, great and small, elite and common folk.

What beverage is this that he who drinks it once,

Knows not whether it is morning or evening\}

found at the end of a poem of nineteen couplets which begins by complaining of the transitory nature of this world, the poet tries to awaken the heedless. He also states that favor and benefaction from the mercy of God reached his own heart, and that he was otherwise innocent of the poetic arts:
Bu sâkî cümlesin esrüdiserdir
Ne cemâat geliserdir, ne îmâm
Ne gül-ruh kurtuhsar, ne şeker-leb
Ne 'anber-hat kahsar, ne gül-endâm
Bu gafletten niçin uyanmadin sen 


\begin{abstract}
Niçin gâfil yatırsin sen ey 'âvâm
Şeyyâd Hamza'nn gönlüne her dem

Gelir Hak rahmetinden lutf-ü in'âm

$\mathcal{N}$ e'arûz bilir ol ne nahv-ï tasinf

Ne kâfiye, redîf ne tecnis-i tâm.
\end{abstract}

\{This cupbearer will make everyone drunk.

No congregation will come and no imām.

Neither the rose-checkered one will escape, nor the sugar-lipped;

Neither the one with perfumed beauty-spot nor the one with rose-like body.

Why then have you not awakened from this heedlessness?

Why do you lie heedless, O foolish folk?

To Shayyād Hamza's heart at every moment

Comes grace and favor from God's mercy.

He does not know metrics or grammar,

He does not know rhyme or radîf or figures of speech.\}

It can plausibly be inferred that Shayyād Hamza, who reveals with this short poem that he was not an artist but an ordinary Șūfi, must have written more hymns in the syllabic meter than such poems in the 'arüd meter, but they were later forgotten. The difference in time between this Șūî poet, whose work was probably in circulation up to the tenth/sixteenth century, and Gülshehrī, was at the most - as a best guess about half a century. [Köprülü was the first to introduce Shayyād Hamza to the literary world. See his "Anatolische Dichter in der Seldschukenzeit, i. Šjjād 'Hamza," Körösi Csoma Archivum, 1 (1921-5), 183-90. This article appeared in Turkish translation in Türk Yurdu, 1 (1340/1921-2), 27-34. One should also consult $\dot{I} A$, s.v. "Şeyyad Hamza" (Sâdettin Buluç) on the subsequent writings of Köprülü and the articles and texts published by Mecdut Mansuroğlu and other writers concerning this poet.] \{Now see EI ${ }^{2}$, s.v. "Sheyyād Hamza" (Kathleen Burrill). Metin Akar has shown that Shayyād Hamza lived in the first half of the fourteenth century, i.e. after Yūnus Emre. See his article "Şeyyad Hamza hakkında yeni bilgiler," Türklük Arastrmalan Dergisi, 2 (1986), 1-14, and Semih Tezcan, "Anadolu Türk yazınının başlangiç döneminde bir yazar ve çarh-name'nin tarihlendirilmesi üzerine," Türk Dilleri Araştrmalan, 3 (1994), 75-88.

80 Sultān Walad's Turkish poetry consists only of this. The poetry attributed to Sultān Walad in \{Ziyâ Pasha's\} Harâbât does not belong to him, and the poem that begins with the famous line "Ben bilmez idim gizli 'iyân hep sen imişsin" \{I did not know that, visible and invisible, all is You \}, which Namık Kemal has attributed to him as well, belongs to Naw'ī. It was translated from Jāmī's quatrain that begins \{You have been visible but I was negligent\}. Thúry gives considerable importance to the passages in the Harâbât and also is of the opinion that "This poem has fourteen syllables per line and the rhyme scheme is abab, whereas Seljuk verse has eleven syllables per line and consists of rhymed couplets" ("Ondördüncü 'asır sonlarına kadar Türk dili yâdıgârları," p. 105). This is very odd. First of all, it is certain that, with respect to their language and versification, these verses cannot belong to that period. Second, the works of Mawlānā and Sultān Walad were not, as he believed, written in the syllabic meter. Third, there are passages in both Mawlānā and Sulțān Walad written in various 'arūd meters and in different styles, i.e. in ghazal as well as mathnaw style. I believe that this brief critique suffices to show how poorly the Hungarian academician has studied this subject. \{See $E I^{2}$, s.v. "Sulțān Walad" (Gudrun Schubert), and Franklin Lewis, Rumi, index.\}

81 This poetry was first published in 1829 in Vienna \{by Hammer\} in the fahrbücher der Literatur. Subsequently, all sorts of opinions have been expressed about it, and it 
has been translated into various languages from this edition. Radloff has published separately the Turkish part, 156 couplets, in his \{ "Über alttürkische Dialekte: (1) die seldschukischen Verse im\} Rebâb-Nâmeh," \{Mélanges Asiatiques, 10 (1890-4), 17-77\} and Ignaz Kúnos has also translated these texts in his \{"Egy ó-török nyelvemlek," $\}$ Nyelvtudományi Közlemények, 22 \{1892\}, 480-97. On this subject, see the bibliographies in C. Salemann \{ "Noch einmal die seldschukischen Verse: (Sultan Veled, Rebabname),"' Bulletin Scientifique de l'Académie Impériale des Sciences de St Pétersbourg \{n.s., 2 (= 34, 1892), 293-365, also in Mélanges Asiatiques, 10 (1894), 173-245\}, in V. D. Smirnov, \{"Les vers dits 'seldjouk' et le christianisme turc,"\} in Actes du $11^{e}$ Congrès International des Orientalistes (1897), \{third section, 143-57\} published in Paris in 1899, and in K. Foy's article \{ "Die ältesten osmanischen Transscriptionstexte in gothischen Lettern; zugleich eine Beitrag zur altosmanischen Literature" $\}$ in Berlin Universität, Seminar für Orientalische Sprachen, Mitteilungen, Westasiatische Studien, \{4 (1901), 235\}. There are many valuable manuscripts of these works in our libraries, so that it is possible to collect all of Sultān Walad's Turkish writings. Veled Chelebi has collected them, but unfortunately he has not yet published them. In the sixth volume of E. J. W. Gibb's \{ History of Ottoman Poetry\}, there are about sixty-seven couplets from the Rabābname and also a few short fragments of verses from Sultān Walad's Dīwān (pp. 1-5).

82 The few couplets given below suffice to show that Sultān Walad pursued this goal and did not think that even his Turkish was adequate for this (Rabābnäme) \{Mecdut Mansuroğlu, Sultan Veled'in Türkçe manzumeleri (Istanbul, 1958), pp. 24-5, = Rabābnāme, lines $97-100\}$ :

\author{
Türkçe bilseydüm ben eydeydüm size \\ Sirlan kim Tañndan değdi bize \\ Bildüreydüm sözile bildüğümi \\ Bulduraydum ben size bulduğum \\ Dilerem kim göreler kamu an \\ Cümle yoksullar ola benden gani \\ Bildürem dükeline bildüğ̈̈mi \\ Bulalar ulu kiçi bulduğumı
}

\{If I had known Turkish, I would have told you

The secrets that God has imparted to me.

I would have informed you in words of what I know

And let you find what I have found.

I wish that all could see that (truth)

And that all the poor would be rich because of me;

That I would inform all of what I know

And let great and small find what I have found.\}

83 See above on the story of Shaikh Șan'ān, the Qaramānid Muhammad Bey's attempt to make Turkish the official language, and Shayyād Hamza. Because historians who recorded Seljuk history did not wish to attribute any literary quality to the basic works written in that period on a popular level, they claimed that "there was not yet any Turkish poetry in that period" (Mukhtasar Saljūqnāme trans., p. 216 \{i.e. Yazıcı-oğlu 'Alī's Turkish trans. of Ibn Bībī's al-Awāmir al-'alā'iyya\}). Later, Ottoman historians and tezkirecis \{biographers\}, as a result of a lack of knowledge combined with this literary prejudice, held the same opinion. 'Āshiq Chelebi says, "There was no Turkish poetry at the time of Orhan Ghāzī $\{1324-60\}$. At the time of Murad I, only one poet, named Ahmad, translated from Persian an epic called Suhail wa naw-bahār in the shähnamme meter. While it is Turkish in manner, it does have certain 
peculiarities of style, but copies of it are rare" (Tadhkira \{i.e. his Mash'̄'ir al-shu'arä'\}, fo. 24). Similarly, 'Ālī says, Hafi olmaya ki Osman Han ve Orhan Han ve Sultân Murad Han zamânlarnnda şu'arâdan kimse zuhûru mâlum değildir. Mücerred sâde nazma kâdir bâzı varsağl-gûlar dahî şöhret bulmamıstır; zirâ ol zamânda sükkân-i mülk-i Rûm ekseriyâ guzât-ı Etrâk ve Tatar idügi mâlûm ve sâir ahâlî merz-ü bûm ise evlâd-ı kefereden zuhûr etmiş bir bölük sâde-levh idügleri mefhûm olmağgn içlerinde şi ír-şinâslan bile ma'dûm idi \{ It is not known if any poets appeared during the time of Osman Khān, Orhan Khān and Murad Khān. Even folk singers, who were capable of simple, plain verse, did not achieve fame; for it is known that at that time most of the inhabitants of the kingdom of Rūm were Turkish and Tatar ghāziss. The rest of the people of the country were a bunch of simpletons who were descendants of infidels, so it is obvious that there were none among them who knew poetry\} (Kunh al-akhbār, vol. 5, p. 115). He thus expresses an opinion quite the opposite to reality. The documents in our possession today clearly demonstrate that the early historians and tezkirecis were definitely unable to acquire an adequate knowledge of the first stages of Ottoman literature. Consequently, it is necessary to regard the similar accounts of the Seljuk historians \{about early Seljuk literature\} as equally unreliable, although few documents have come down to us.

84 Gülshehrī's version of Mantiq al-tair is dated 717/1317. There is one manuscript, copied in Egypt at the beginning of the tenth/sixteenth century, in the Hâlis Efendi \{Library in Istanbul\} and another, defective, manuscript in the Müze-i Humâyûn Library \{Istanbul Archeological Museum\}. There is no information on Gülshehrī at all in the tadhkiras \{biographical works\}. We only know that this poet first wrote a work in Persian called Falaknāme and also wrote ghazals and qașidas in addition to the Mantiq al-tair. Three ghazal-like didactic Șūì poems are found in \{Hac1 Kemal's\} Fāmic al-nazā'ir. Gülshehrī, who in the Mantiq al-tair reveals himself to be a follower of the great Persian Șūî̀s and, especially, Mawlānā and Sulțān Walad, mentions that he had exceptional authority in \{the town of \} Gül-Shehrī and was not the shaikh of any village or town, as was often the case at that time, so it was necessary to regard him as a great Șūfi whose fame had spread in all directions. If we take into consideration the fact that Gülshehrī was Kırshehrī, as recorded in the Velāyetnāme of Hājjī Bektash Veli, then it would appear that this great Șūfì poet was from Kurshehir \{Kırşehir\}. At the end of a Persian commentary on the Arabic Amthila \{paradigms for the conjugation of verbs\} registered as number 4837 in the Ayasofya Library, it is recorded that it was written by Shaikh Mas'ūd b. 'Uthmān, who was associated with the small town of Gülshehrī in Anatolia, on 4 Muharram 741/July 1, 1340. I wonder if this Shaikh Mas'ūd b. 'Uthmān Gülshehrī is the same man as our Gülshehrī. If not, must we conclude, based on the difference in date of composition of these two works, that they are two different persons? Or there is a third possibility: because Shaikh 'Uthmān Gülshehrī was the father of Shaikh Mas' ūd Gülshehrī, perhaps the former was the author of the Mantiq al-tair translation and the latter the author of the Amthila commentary. For now, nothing definite can be said about this. In a very valuable work by Shaikh-oghlu dating from the early years of the ninth/fifteenth century and including poetry from quite a few, mostly unknown, poets of the eighth/ fourteenth century, I came across several passages attributed to Khwāja Mas'ūd as well as two hemistichs belonging to Khwāja Gülshehrī (from the Kanz al-kubarä', a unique copy in my private library written in the author's hand). As likely as it is that these two verses and the Mantiq al-tair translation and the poems in the Famic al-naz $\bar{a}$ 'ir belong to the well known poet named Gülshehrī who lived at the end of the seventh/thirteenth and the beginning of the eighth/fourteenth century, it is equally likely that there is no connection between this and the author of the Amthila commentary and Khwāja Mas' ūd. At any rate, it is difficult to believe that Gülshehrī, 
who must have been a man of mature age when he wrote the Mantiq al-tair, would have composed the Amthila commentary twenty-four years later. Also, Shaikhoghlu, who undoubtedly had a good knowledge of the men of this period, carefully distinguishes between Khwāja Gülshehrī and Khwāja Mas'ūd and shows them to be two different poets. In the manuscript in the Hâlis Efendi Library, there is the following entry: Kïtāb-i Mantiq al-tair min kaläm-i shaikh al-muhaqqiq̄̄n murshid al-tälibīn al-'ämil al-fädil al-shaikh Ahmad al-Gülshehrī the book of Mantiq al-tair by Shaikh ... Ahmad al-Gülshehrī\}, which clearly shows that our Gülshehrī was Ahmad Gülshehrī and corroborates the ideas that I have proposed. \{See $E I^{2}$, s.v. "Gülshehr $\overrightarrow{1}$ " (Fr. Taeschner).\}

85 Gülshehrī, who by the standards of that period paid serious attention to purity of language and faultlessness of versification, and who achieved considerable success, shows that he was a true artist. In contrast to his contemporaries, who generally thought of nothing other than propagating an idea and a goal, there is a perceptible lyricism in the works of this poet who paid close attention to the aesthetic effect that his work would have. Even while giving the most abstract moral advice, he can convey to the reader an aesthetic delight. Then, while describing scenes of nature, he possesses a rather artful and lively style that is at once very colorful and very simple. Artistically, there is a great difference between the poetry of Gülshehrī and the works of Shayyād Hamza or Ṭūrsūn Faqīh, Naqīb-oghlu, Mu'arrif of Ladik, Hasan of Beypazar and even Sultān Walad, which are dry, dull, and devoid of artistic concern. Gülshehrī, who had a good idea of his own worth, claimed that his translation of the Mantiq al-tair was not inferior to 'Aț̣ār's original version - having given it, along with many additions, a quality that was richer and more personal than the original - and that before him no work of such beauty had been written in Turkish. He is not completely unjustified in saying this. (I hope to publish soon a study devoted to Gülshehrī and his work. See that study for abundant details useful for comparing him with his contemporaries and the Persian poets \{never published $\}$.)

86 This enormous didactic Șūfì work that 'Āshıq Pasha, the grandson of the famous Bābā Ilyās Khurāsān̄̄, wrote in Kırşehir in 730/1330 is a kind of Mathnawē in Turkish. It is written in the same meter and form, and is divided into ten chapters of ten sections each. In this long didactic work, which was written for the religious purpose of teaching the rules of the order to Turks who did not know Persian, there are many quotations from Persian Șūin poets and, especially, from Mawlānā. Despite extensive research, I was able to find in this huge work only very few passages that reveal the particular features of life in Anatolia at that time. 'Āshıq Pasha, who, in one passage, expresses his longing for the misty mountains of Turkistan, is much inferior to Gülshehrī artistically. Still, this huge work also deserves a comprehensive study with respect to lingustic history. My study of 'Āshıq Pasha and his son Elvan Chelebi is almost ready for publication. [For considerable information on both 'Āshıq Pasha and his son Elvan Chelebi, one should see $\dot{I} A$, s.v. "Âşıłk Çelebi" (M. F. Köprülü). The critical bibliography in this article is a valuable guide for those working on this subject. In addition, see also Semavi Eyice, "Çorum'un Mecidözü'nde Âşı Paşa-Oğlu Elvan Çelebi zâviyesi,” TM, 15 (1969), 211-44.] \{See $E I^{2}$, s.v. "ĀAshı Pasha” (Fahir İz), and Kemal Yavuz (ed.), Assık Paşa, Garib-nâme (Istanbul, 2000).\}

87 These ozans were the earliest priest-sorcerer-poets of the Oghuz. The men who held the same position among the Tunguz were called shamans, among the Altay Turks kam, and among the Qirghiz bakhshi. These men, who combined in themselves a number of functions, including sorcerer, dancer, musician, and physician, had great importance among the people. The extent of this importance, their costume, musical instruments, and the kind of tasks they performed differed, of course, in time and 
place. Nevertheless, their duties included such things as making sacrifices to the sky gods, sending the souls of the dead to the underworld, preventing evils from demons, and preserving the memory of the dead. There were separate ceremonies for each of these things. Some of these practices are still current among the Altay Turks and the Qirghiz. The ozans would enter an exuberant state during these ceremonies, recite poems, and play the kopuz to accompany them. These literary recitals, which were accompanied by music and had a magical effect, are the earliest form of Turkish poetry. Although the Turks of various regions and in different periods were subject to the influence of Chinese, Indian, Persian, or Islamic civilization, the social function of these ozans was constant. Their social influence was especially great in those places and times in which the primitive national religion was preserved. Later, of course, their importance decreased. Still, in the early armies of the Turks, as far back as that of Attila, the ruler was invariably accompanied by an ozan. Their heroic poems, which they recited to the accompaniment of the kopuz, flattered the sensibilities of an entire people. We know quite well from Latin sources what a profound effect these epic poems had on the audience in Attila's military camp. The ozans did not confine themselves to composing poems about recent events and heroic legends, or elegies in praise of the dead; they also sang the old poems belonging to the Oghuz Destam . Even after falling under the influence of Islam, these ozans did not disappear. As a result of the social division of labor in the great centers, the professions of poet, fortune-teller, sorcerer, astrologer, and physician became separate from one another. Illnesses were treated by physicians; musical instruments were played by musicians; poetry and literature became the preserve of scholars who studied Arabic and Persian religious and literary topics in the madrasas; and the legends of the old bakhshi-ozans were taken up by the Sūfîs. Yet the ozans survived as Muslim folk poets. We find them in Anatolia until the ninth/fifteenth century. Afterwards, 'ashiqs take the place of ozans (for more information, see my "Türk edebiyatının menşe'i," pp. 12-27). [After extensive research on the word ozan, Köprülü published a study on it under the heading "Ozan" in the book Türk dil ve edebiyatr hakknda araştrmalar (Istanbul, 1934), pp. 273-92. This was reprinted in his collection of articles entitled Edebiyat araştırmalan (Ankara, 1966), pp. 131-44.] \{See $E I^{2}$, s.v. "Ozan" (P. N. Boratav).\}

88 Every nation has a national instrument especially used for accompanying its primordial national songs. This instrument is incorporated into the nation's tales and legends, and memory of it is preserved for centuries. The oldest musical instrument that the earliest Turkish popular poets, i.e. the precursors of the bakhshi-ozan, used in relgious ceremonies and later in assemblies of an artistic nature was the kopuz. This instrument, which resembles the ' $\bar{u} d$ \{lute\} of the Arabs, has been continuously found over the centuries from the earliest times in various Turkish countries. In all the legends in which we find the ozan, he has, without fail, a kopuz in his hands. We encounter this in the earliest Uighur texts, in Central Asia from the fifth/eleventh century on, and in Anatolia since the early Seljuk period. The kopuz is mentioned in the works of Mawlānā, Yūnus Emre, and Gülshehrī. Indeed, in the Seljuk period and in the courts of the rulers, there were also, in addition to the ozans, kopuz players who were distingushed from them. For considerable information on this instrument, which is also found among the Hungarians and the Ukrainians, see my article "Türk edebiyatının menşe'i," pp. 57-63. I am also preparing a brief study of this subject. [For concise information on the kopuz, see İA, s.v. "Kopuz" (Mirza Bala).]

89 "Selçukîler zamanında Anadolu'da Türk medeniyyeti," pp. 213-14, \{Leiser trans., pp. $50-1$.$\} .$

90 A passage of sixty-four couplets in the ninth chapter of his Gharībnāme mentions the etiquette of the alps and the requirements \{for being an alp\}. It begins: 
Kanı ol kim ister alp'lk adım

Almak ister düsmeninden dâdım

Dïsmeni kahreyleyip basmak diler

Başın at yanına asmak diler

Gelsün işitsün ki alp'llk nicedür

Alp'larn sermâyesi gör kim nedür

Eydeyim bir bir sana ahvâlini

Kim bilesin Alp-erenler hâlini

\{Where is he who desires the name of alp?

He who wishes to punish his enemy?

He who wants to subdue and trample the foe,

And to hang his head at his horse's side?

Let him come and hear what being an alp means.

See what is the stock and capital of the alps.

Let me tell you their qualities one by one,

So you will know the status of the alp-erenler.

This fine passage goes on to say that nine things are required of the alps: "a stout heart, a strong arm, zeal, a good horse, a special garment \{i.e. armor\}, a bow, a good sword, a lance, and a suitable companion" (Gharībnāme, Beyazit Umumi Library, MS 333 \{see the Yavuz edn, vol. 2/2, p. 549, lines 8487-90\}). [Köprülü dwelt on this subject in his Les Origines de l'empire ottoman. See index under "alp." He also published an original philological and historical study of this word in $\dot{I} A$, s.v. "Alp."] \{See $E I^{2}$, s.v. "Alp" (O. Pritsak).\}

91 This, like alp, ozan, etc., is part of the romantic view of the Turkish past to which Köprülü adhered.\}

92 "Selçukîler zamanında Anadolu'da Türk medeniyyeti," p. 214, \{Leiser trans., p. 51$\}$.

93 Erbâb-ı gnâ ve melâhîyi hâzır ettiler, Şâhinşâh Hazretlerinnin fütûhi üzerine elhân-ı cân-perverle gûyendelik ettiler ve alplık ve bahâdrrlı zikrini ki asâkir-i mansûre ol gün takdim kilmışlard,, ozan'lar ve kopuzcu'lar elfâz-ı garrâ birle bir sebil hikâyet ayıttılar \{They prepared the singers and entertainers. They sang inspiring songs about the conquests of His Excellency the King of Kings and the alp-like and heroic deeds that the victorious soldiers had accomplished that day. And the ozans and kopuz players, with brilliant words, narrated.\} (Mukhtașar Saljüqnāme-i Ibn Bībū, \{Yazıcı-oğlu 'Alī, Turkish\} trans., p. 348.) The same source also informs us that the poets in the courts of the Seljuk rulers were also influenced by the era of the alps, for they took a great interest in the subject

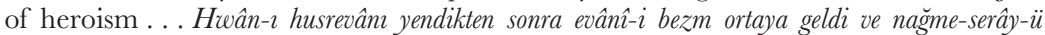
gam-zidây mutribler küffâr devleti nevbetinin firō-daşt çün dil-pezīr ve tarab-engîz pâre ve pîşrevler ber-daşt ettiler ve şu'arâ kasâid-i kâmrânîyi sahâif-i Mâni üzerine nakşedip mutribler bahâdırlarn dilâverliklerin, düsman kahrettiklerin ve pehlevanlar cengin hûb elhân-ü âheng ve kavl-i rast birle hâzrrlar sem'ine iriştirdiler (After the imperial feast was consumed, drinking vessels were brought out, singers of songs and care-dispersing musicians offered heart-pleasing and joyous pieces and peshrevs \{a musical form \} on the occasion of putting an end to the state of the unbelievers. Poets inscribed felicitous qașidas upon painted pages of Mani (a celebrated Persian painter and founder of Manichaeism, d. 274, 276, or $277 \mathrm{CE}$; his name epitomized great art). With elegant tunes and melodies and perfect words, the musicians conveyed to the listeners' ears the heroes' valorous deeds, their defeat of the enemy, and the combat of the champions"\} (ibid., p. 366). All these details show that we must consider that period of Anatolian history to be a time of alps. \{On minstrels and kopuz players, see Karl Reichl, Turkic Oral Epic Poetry 
(New York, 1992) and Singing the Past: Turkic and Medieval Heroic Poetry (Ithaca, NY, 2000). $\}$

94 Women like Seljān Khātūn and Bānī Chichek Khātūn in the stories in the Kitāb-ı Dede Korkut are nothing more nor less than alps. When Kanlı Koja wants to marry off his hero son Kān TTurālı, his son replies, Baba, çün meni iverim dirsin, mana lâyık kız nice olur? Baba, men yerimden durmadin evvel durmuş ola, men karakoç atıma binmedin evvel binmiş ola, men kanl kâfir iline varmadin ol varmıs, mana baş getirmiş ola, dedi \{Father, you want to have me married, but can you find a girl who would be my match? Father, I want a girl who must get up before I do. She must be able to mount her horse before I mount my black stallion. She must be able to reach the bloody land of the infidels before I do, and she must bring me an enemy head" (\{ed. Kilisli Rifat (Istanbul, 1332/1916), p. 96, \{English trans. Geoffry Lewis, p. 117; the standard edition of the Dede Korkut is by Muharrem Ergin, Dede Korkut Kitâbr (Ankara, 1964), the best is the recent edition by Semih Tezcan and Hendrik Boeschoten, Dede Korkut Oğuznameleri (Istanbul, 2001)\}). This shows very clearly the general conception of women at the time of the alps. The kind of woman that Kān Turālı, i.e. the alps of that period, wanted was not a beloved of the type that the later minstrels imagined but was a heroine with exactly the same martial qualities as the men. Indeed, the women of the era of the alps, i.e. the time of the ozans, could only have had such heroic traits.

95 The türkü is a folk song with a musical setting peculiar to the Turks. Türküs were composed in the manner of modern-day art-songs $\left\{s_{s} a r k\right\}$. What distinguished them was not the literary form but the musical setting. In other words, this genre was not of a literary character but was completely musical. Indeed, because these türküs are unique to the early periods when music and poetry could not yet be distinguished, the fact that they differed from each other musically is quite natural. \{See $E I^{2}$, s.v. "Türkü" (Edith Ambros).\}

96 The türkmañ is a folk-song with a musical setting peculiar to the Turkmen. There is no difference in form between it and other türküs. The difference is strictly in the musical setting.

97 The varsağ is originally a kind of folk-song with a musical setting peculiar to the Varsaks. In addition to the various accounts of the Varsaks in our historical works, Pavet de Courteille provides considerable information on them in the notes at the end of his \{French\} translation of \{Ibn Kamāl or Kemāl Pasha-Zāde's $\}$ famous Mohaçnāme, p. 164. These Varsak Turks, who came to Anatolia early on and settled in the Tarsus region, continually caused difficulties for the Ottoman state. They even participated in the uprising of the Qaramānids during the reign of Sultan Murad I. Varsak was also the name of the stony region west of Tarsus where they originally lived. Varsağıs composed to be recited with a musical setting peculiar to them became famous in Anatolia and Azerbaijan at a very early time. Not only does 'Âlin, for example, mention a number of those who sang varsağgs in the early Ottoman period, but 'Âshıq Chelebi also says that Yūnus Emre wrote works in the varsağı style ('Āshıq Chelebi, Tadhkira \{i.e. his Mashā'ir al-shu'arä'\}). We know that Mehmed Beg, a poet with the pen name Shamsi who flourished in Azerbaijan in the tenth/sixteenth century, was well known for singing varsağıs in that region (Șādiqī Kitābdār, Tadhkira, Nuruosmaniye Library, MS 3720), that Sultan Murad IV wrote a varsağ for his companion Mūsā Chelebi, and that Evliyā Chelebi sang it in his presence (Evliyā Chelebi, Seyāhatnāme, Book 1, fo. 70a). With respect to meter, the rule for the varsağrs is not very strict. Sometimes our 'äshrqs composed varsağgs of eleven syllables per line, but most often used eight. As for form, they were composed of four-line stanzas \{quatrains\}, just like koşmas \{see the following note\}, türkïs, and türkmāniss, with the fourth lines rhyming. Varsağıs had to be written in somewhat coarse and masculine language and in a dâğ $\grave{\imath}$ manner a vocal musical work having the character of uzun 
hava, i.e. no rhythmical pattern\}. In this regard, Qaraja-oghlan can be considered superior to virtually all other minstrels. From the fact that $\mathrm{Na}^{\prime} \mathrm{i} m \overline{\mathrm{a}}$ used the word türkï to designate the frontier folk-song that \{Ibrâhîm\} Pečewī $\{$ Peçevî\} recorded as a varsağg, we know that varsă̆g, which differed from the koşma, türkü, and türkmān forms only in musical setting, had long been used synonymously with türkü ( $T a^{\prime}$ rinkhi Na'ìmā [Istanbul, 1280/1863-4], vol. 1, p. 158; Hammer, \{Geschichte des Osmanischen Reichs, Turkish\} trans., vol. 7, p. 216).

98 The koşma, or koşug as it was known among the Eastern Turks, is one of the oldest and most popular forms in the syllabic meter. We can accept that the kosug, which is defined as rajaz, qașīda in \{al-Kāshgarī's\} Dīwān lughät al-turk, is one of the earliest surviving forms of Turkish poetry, belonging to the time when there was no distinction between words and music. The word koşmak, in fact, means "to add a musical setting to a text." The koşma of the 'äshrq type is an independent and much used verse form with a specific musical setting and sung in a special way. The kosmas sung with this musical setting have, in recent centuries, usually been of eleven syllables per line and composed as quatrains. But in the past, koşmas were sung in various meters (for a discussion of the koşma and other verse forms in 'äsh $q$ literature, see my series of articles in the newspaper İkdam, "Sazşâirleri," I-II; April 3, 7, 11, 16, 19, 25; May 2, 7, 9, 31; June 6, 1914.)

99 We know the antiquity of deyiş \{a folk poem or song\}, which means approximately "singing," from one of Mawlānā's Turkish verses: Hem men çakur içer men, hem men teyiş bilir men \{I also drink wine and I also know teyiş. $\}$ This shows that deyişes were already quite famous by Mawlānā's time. This is also a rudimentary form in which musical setting and text were not yet distinguished.

100 As will be easily understood from its name, this was also a simple, primordial and "rustic" from of verse that definitely was sung. The poet Vehbi, while satirizing at length popular poetry and popular poets in the famous Sukhan \{poetry\} qașida, speaks disparagingly of these forms as well:

\section{Kimi mânî kimisi vâdi-i Türkmânîde \\ Kara-oğlan Kaya-başısı yellellâ-yi suhan.}

\{Some write mânर (folk quatrains); some, in the valley of türkmani,

Write kayabaşı of Qara Oghlan with the refrain: yellellâ.

Cf. translation in Kemal Silay, Nedim and the Poetics of the Ottoman Court (Bloomington, IN, 1994), p. 131, verse no. 46.\}

101 For a comprehensive treatment of this strange attitude and the psychological factors that gave rise to it, see my article "Türk edebiyatında âşık tarzının menşe' ve tekâmülü," pp. 5-46. In the view of the old madrasa-educated class, who reserved for themselves a privileged place in society and regarded everything belonging to the common people to be, invariably, base and trivial, "Mevzû-i ilm-i edeb, kelâm-i Arab'drr" \{the subject of the science of literature is the Arabic language\} (\{Tashköprü-Zāde, \} Mawdü ät al-'ulüm, \{Turkish trans. (Istanbul, 1313/1895-6),\} vol. 1, p. 334 \{the title of the Arabic original is Miftăh al-sa'a ada while Mawdī' att al-ulumm is the title of the Turkish translation by his son Kemal al-Dīn\}). Consequently, let alone preserving and appreciating what remained of that early national literature, they vehemently denigrated it, considering works that even hinted at popular taste to be "meaningless and worthless." Unfortunately, we find that this medieval mentality has endured to the present day.

102 See my discussion of this matter above in Chapter 1, p. 17, n.31. When we take into consideration the fact that this national epic, which was translated from Persian into Arabic in 211/826-7, was originally translated into Persian from a work composed 
in Turkish, it is quite evident that the Turkish national epic - as Klaproth quite rightly stated \{apparently referring to his Asia Polyglotta\} - was already established before Islam and that both the Persians and the Chinese made use of it. \{See $E I^{2}$, s.v. "Oghuz-nāma" (Irène Mélikoff).\}

103 The information that we have in Rashīd al-Dīn's fämic al-tawārnkh, which is a primary source for early Turkish history, clearly reveals this \{see Karl Jahn's German trans., Die Geschichte der Oġuzen des Raš̀d ad-Dīn (Vienna, 1969)\}. When Rashīd al-Dīn began to write this enormous work at the order of Ghazan Khān, there were learned men from various ethnic groups in his retinue and they made use of the earliest sources for the history of their own peoples. (On this subject, see the edition of $\bar{f} \bar{a} m i^{\circ}$ al-tawärikh published \{ed. and Russian trans.\} by I. Berezin \{of the introduction on Turkish and Mongol tribes and the history of Chingiz Khān in ZVO, 5 (1858), 7 (1861), 13 (1868), 15 (1888)\}, Abū 'l-Ghāzī \{Bahādur Khān's\} Shajara-i Turk \{ed. and French trans. J. J. P. Desmaisons as Histoire des Mogols et des Tatars (St Petersburg, 1871-4)\}, and especially the excellent work that E. Blochet published as the introduction to Fāmi' al-tawā̄inkh under the title Introduction à l'histoire des mongols in the Gibb Memorial Series, old series \{(London, 1911), now see the introduction to Thackston's English trans. as Rashiduddin Fazlullah's Fami'u't-tawarikh = Compendium of Chronicles, part one (Harvard University Department of Near Eastern Languages and Civilizations, 1998). For various editions of the Jāmi al-tawārīkh, see The Cambridge History of Iran, vol. 5, ed. J. A. Boyle (Cambridge, 1968), p. 705\}.) All of these sources clearly show that Rashīd al-Dīn, while writing the section on the Turks and Mongols, benefited from a certain Amīr Pūlād Chingsang, and also obtained information from reports and documents preserved in the treasury. Reference to this is also found in Shams al-Dīn Kāshānī's work in verse Shāhnāme-i Chingīzī, which cites the Jāmi al-tawārkhh (Hamidiye Library, Lala Vakfi MS 354 nnow in the Süleymaniye Library in Istanbul\}). \{On Kāshān̄̄'s versified history of the Mongols, see the Russian translation by Iu. Ė. Bregel' of C. A. Storey's Persian Literature as Persidskaia literatura: Bio-bibliograficheskii obzor (Moscow, 1972), vol. 2, pp. 767-8, vol. 3, p. 1463.\}

104 It appears that Necib Âsım and Mehmed Ârif, for example, in their unfinished Türk tarihi-i umûmisi (Istanbul, 1325/1907), p. 4, believed that the Oghuznāme was some kind of history. Alî Emîrî Efendi, in the introduction to \{Beyâtî Shaikh Mahmûd's\} Fām-i jam āynn, also thought that the Oghuznamme was a history of the ancient Turks, Fām-i jam āȳn (Istanbul, 1331/1913), p. 5 \{a modern Turkish trans. of Beyâtî's work is included in Atsız, Osmanl tarihleri (Istanbul, 1949)\}. Bursalı Tâhir Bey was of the same opinion, stating, "In light of certain evidence that we possess, the Oghuzname must be considered the most valuable of the national histories written about the tribes constituting the Turks. It has been established, based on certain documents, that this great history existed in the area of Azerbaijan up to around $1000 \mathrm{AH}$, but it is no longer extant" (\{“Aşı Paşa,"\} Türk Derneği, no. $1\{1327 / 1911\}$, p. 12).

105 In the Bahjat al-tawāinkh, a brief history of Islam - which also mentions the Ottomans up to the accession of Muhammad II - composed by the historian Shükrullâh and dedicated to the famous Mahmūd Pasha, one of the viziers of Muhammad II, the following important note is found attesting to the existence and nature of the Oghuznäme (Nuruosmaniye Library \{in Istanbul\}, MS 3059):

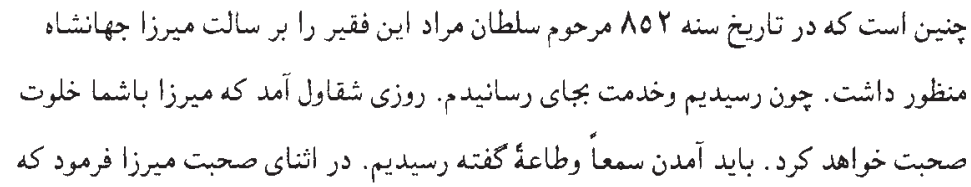




$$
\begin{aligned}
& \text { سلطلنمراد برادر اخروى منست وغير از برادرى خويش منست. سبب خويشى را يرسيده شد. . } \\
& \text { فرمود كه مولانا اسماعيل تواريخ خوان را بخوانتد وهم تواريخ اوغوز بيارند . مولانا اسماعيل }
\end{aligned}
$$

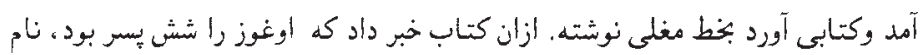

$$
\begin{aligned}
& \text { ايشان كوك آلب، يبه آلب، دكز آلب، كون آلب، آى آلب، ييلديز آلب. ميرزا فرمود كه نسب } \\
& \text { برادرم سلطلن مراد بكوك آلب بن اوغوز مى رسد ونسب قره يوسف بدكز آلب مى رسد. }
\end{aligned}
$$

\{In the year 852, the late Sultan Murad sent me on a mission to Mīrzā Jihānshāh (the Qara Qoyunlu ruler in Tabrīz, reigned 841-72/1438-67). After I had arrived and paid my respects, one day the officer in charge of foreign envoys came and said that the Mīrzā wished to meet with me in private audience. "To hear is to obey," I replied, and went. In the course of the conversation the Mīrzā said: "Sultan Murad is my other-worldly (spiritual) brother, but he is also a brother by kin." When I asked him to explain kinship, he ordered the chronicle-reciter Mawlānā Ismā'îl to be summoned and that he should bring the History of the Oghuz. Mawlānā Ismā'îl came and brought a book written in Mongol (i.e. Uighur) script. From that book he reported that Oghuz had six sons: Gök Alp, Yer Alp, Denīz Alp, Gün Alp, Ay Alp, and Yıldız Alp. The Mīrzā said: "The lineage of my brother Sultan Murad goes back to Gök Alp. The lineage of Qara Yūsuf (Qara Qoyunlu ruler, reigned 791823/1389-1402) goes back to Denīz Alp." A Turkish trans. of the section of Bahjat al-tawāinkh on the Ottomans is included in Atsiz, Osmanh tarihleri, while the Persian text of the same section and a German trans. are provided by Theodor Seif in his "Der Abschnitt über die Osmanen in Š̈urullāh's persischer Universalgeschichte," Mitteilungen zur osmanischen Geschichte, 2 (1923-6), 63-128.\} I think Tâhir based his assertion that "the Oghuznäme existed in the area of Azerbaijan up to around 1000 AH" on this source. This copy of the Oghuznāme, written in Uighur script, was either the digest of a national epic that included legends belonging to the Oghuz lineages, or a historical work that began with the legend of Oghuz Khān and then included historical information on one or more branches of the Oghuz and bore the name Oghuznāme because it concerned the Oghuz. If we consider that the traditions about the early period of every nation are much more legendary than historical, it is not surprising that the men of that time did not distinguish historical events from legends. In the Ottoman period, they called the general histories of the Turks, which went as far back as Oghuz Khān and included the Seljuks, oghuznāme by extension because they were pan-Oghuz in character. The Oghuzname of the famous Lûtfî Pasha is, in fact, such a work. The original Oghuznāme, however, was a collection of legends. Searching for another great historical work, aside from these two, entitled Oghuznāme is a fantasy arising from a misunderstanding of the true nature of the Oghuznāme. Curiously, our recent historians have been deceived in this matter.

106 In his Saljūqnäme, Yazıcı-oğlu 'Alī says, "The narrative of the lineages of the Turks was recorded in the Oghuznamme in Uighur script from the tales of their sages and esteemed story tellers" (Topkapı Sarayı MS). In this statement, he shows that some parts of his work were extracted from the Oghuznāme written in Uighur script. In addition, while mentioning Oghuz Khān and Gün Khān, the author \{Beyâtî Shaikh Mahmûd\} of the Fām-i jam āy $\bar{n}$, which was written in 886/1481-2, attributes the information on them to the Oghuznāme (p. 21). Furthermore, in \{Yazıc1-oğlu 'Alī's translation of Ibn Bībī's Saljūqnāme, 'Alā' al-Dīn Kai-Qubād is described as "knowing well the Oghuzname and other histories" (p. 217). In my view, all these statements 
concern the general histories of the Oghuz, which started with the Oghuz legend, as I have stated in the note above, and not a genuine original Oghuzname that was a collection of legends. I will mention one more conclusive piece of evidence to show that all the various kinds of Turk-Oghuz histories were called oghuznames and that oghuznāme was not the name of a single work as our recent historians imagine. The Oghuznāme in the possession of Jihānshāh considered the Ottoman rulers to be descendants of Gün Khān, but the J̄amm-i jam āyznn, which is also based on an oghuznāme, shows them to be of the dynasty of Gök Khān. This means that the "Oghuznāme" is not a single, specific work, but was a name commonly given to all Turk-Oghuz histories.

107 This author wrote an abridged general history in Arabic entitled Durar al-tīj $\bar{a} n$, which included events up to 709/1309-10. It is arranged chronologically and mainly discusses events in Egypt and occasionally other related matters. It is dedicated to the famous \{Mamlūk sultan\} al-Malik al-Nāṣir Muḥammad b. Qalāwūn. While describing the events of 628/1230-1, the author gives a long introduction on Chingiz Khān, part of which he cites as follows from the Oghuznāme: "I intend to mention here the first time this people \{the Mongols\} burst upon the scene and their origins. The noble Shari $a$ cannot, however, approve of certain aspects of this subject. This information was taken from their book $\bar{U} l \bar{u} K h \bar{a} n$ Aț Bitigjì. The name of this book means Great King Father. This is a book with which the Mongols and Qipchaqs, who are descendants of the ancient Turks, are pleased and happy. This book is greatly revered by them, just as among the Oghuz Turks there is a book called the Oghuzname that circulates from hand to hand. The origins of the Oghuz and all of their early rulers are mentioned in this book. The Turks are called Oghuz, for one of their great leaders was named Oghuz. In this book called the Oghuznāme, an account is given of a certain Depegöz (Tepegöz). This Tepegöz destroyed the countries of the early Turks and killed their great leaders. According to their tradition, he was an ugly and loathsome man. He had a single eye in his forehead. His mother was a sprite from the ocean. He was immune to sword and lance. His father's hat, which completely covered his head, was made of the hide of ten rams. The Oghuz have many famous tales about Tepegöz. These tales are still current. Wise men and sages among the Oghuz memorize these tales and recite them while playing their kopuz. Finally, the esteemed, famous, and powerful Basat son of Urus (Uruz), who grew up among the Turks, killed this Tepegöz. As to the reason for killing him, there was a girl who grew up among the Oghuz whom no one could surpass in marksmanship. This girl goaded Basat to kill Tepegöz. Basat's father also played a role; for when Basat overcame this girl, carried her off \{i.e. married her\} and brought the good news to his father, his father said, 'I thought that you had killed Tepegöz.' For these reasons, when Basat heard about Tepegöz he conceived many cunning plans, carried them out, and killed him. Such things occurred between Basat and Tepegöz that are impossible to believe. They are among the superstitions of the Turks. I wrote this introduction so that the readers of the book would understand that I know many things about the Turks" (Damad Ibrahim Paşa Library, MS 913). This Turkish writer, whose account of Tepegöz shows that he was familiar with the stories of Dede Korkut, has made one minor error in this matter. There is no girl in the story of Tepegöz. \{See U. Haarmann, "Turkish Legends in the Popular Historiography of Medieval Egypt," Proceedings of the VI Congress of Arabic and Islamic Studies... 1972 (Uppsala, 1975), pp. 97-107.\}

Muallim Cevdet also mentions the notes on the Oghuznāme by the Egyptian writer Zakī Pasha, who cites a copy of this work in the Khedival Library in Cairo. I have cited these above in Chapter 1, p. 17, n.33. Let me also cite from Cevdet's article the author's account of how and where he saw the MS and his description of it: "The 
other Turks also have a book, which is called the Oghuznāme. This work is the history of the first rulers of the Turks, the most famous of whom bore the name Oghuz. I am familiar with both books. My knowledge of them allows me to affirm that I have perfectly comprehended the history of the Turkish people and allows me to state that the stories that I will relate about this people can be regarded as very reliable. My father was the amir of Sharqiyya province \{in Egypt\} in the year $709\{1309-10\}$. The capital of this province is Bilbays. One of my friends, Amīn al-Dīn Hamdī, brought me a manuscript after following a discussion with some 'ulama' about the Tatars. He said that he had acquired this work from the late Amīn al-Dīn Bāysarī and that it was unique. Its paper was made in Baghdad and was of silk. It was written in the hand of a pupil of the famous 'Alī b. Hilāl al-Bawwāb. Its text included gilded decorations. Its binding was very refined and woven of yellow silk, and it had a gold case. My friends al-Hammūyī, Jalāl al-Dīn Ibn Zaitūn, and Manșūr al-'Abbās and I got together and studied this book. We read it together and I copied out the things that we were able to understand. We could not understand certain passages. The author wrote that his name was Jibrā'îl Ibn Bakhtīshū', that he was a physician, and that after this book had originally been translated from Turkish into Persian he had translated it from Persian into Arabic in the year $211\{826-7\}$. This book came from the treasury of Abū Muslim Khurāsānī. In fact, the author claims that Abū Muslim was descended from Bakhtu Khān and claims that he inherited this book" (Muallim Cevdet, "Oğuz-nâme - Kitâb-1 Dede Korkut," in the special issue of $Y M$ commemorating Çanakkale \{Gallipoli\}, March 5, 1331, vol. 2, pp. 89-91). This Jibrā̄il Ibn Bakhtīshū' was from a Syriac \{speaking\} family of physicians who won great fame in the 'Abbāsid period. Like his father and grandfather, he served as

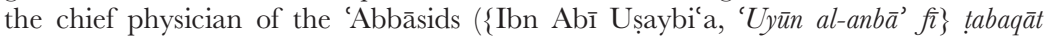
al-atibb $\vec{a}$ ' \{Cairo, 1299/1882\}, vol. 1, p. 127). Because Cevdet did not mention his source, we don't know the work from which Zakī Pasha took this information. Zakī Pasha also states, however, that the unique copy of the Durar al-tījān is in Istanbul \{now ed. Gunhild Graf as Die Epitome der Universalchronik Ibn ad-Dawadaris (Berlin, 1990)\}, and so it would probably be a mistake to believe that Cevdet cited this passage from a second copy of that work in Egypt (Ahmad Zakī, Mémoire sur les moyens propres à déterminer en Egypte une renaissance des lettres arabes [Cairo, 1910], pp. 13-14) \{this was indeed the source; see Ibn al-Dawādārī, Kanz al-durar, vol. 7, ed. Sa'īd 'Abd al-Fattāh 'Āshūr (Cairo, 1972), pp. 218-19\}. If the Kanz al-durar wa jāmi' al'ibar \{or al-ghurar $\}$, which is an abridgement of the Durar al-tīj $\bar{a}$ n and of which volumes 1, 2, 4, and 5 are in the Ayasofya Library and volumes 3, 6, 8, and 9 are in the Topkap1 Sarayı Library, were properly studied, the subject of early Turkish mythology would certainly be much better illuminated.

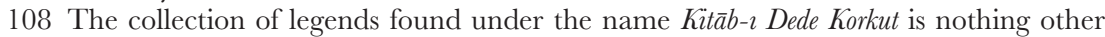
than the Oghuznāme that Abū Bakr Ibn \{'Abd Allāh b.\} Aybak al-Dawādārī saw. The edition published in Istanbul based on the unique copy in Dresden contains twelve separate legends, each of which is also called an oghuznäme. The first Ottoman historian to see this Kitāb-ı Dede Korkut was Rūhī. The following narrative is cited from him in Müneccim-başı's Fāmi` al-duwal: Kadîmü'z-zamânda Türkmen kabâiili beyninde Korkut Ata nâm bir ehl-i hâl azîz vardi; birgün buyurdu ki saltanat âkıbet Oğuz-Han'ın vasuyyeti üzre Oğlu Kayn-Han evlâdina nakledip ilâ âhiri'z-zamân ber-devâm olur \{In olden times there was a saint named Korkut Ata among the Turkmen tribes. One day he said, "Sovereignty will eventually, according to the will and testament of Oghuz Khān, transfer to the descendants of his son Qāyı Khān and will last until the end of time" (Jāmic al-duwal, \{Turkish\} trans., vol. 3, p. 267) \{cf. Geoffry Lewis trans. The Book of Dede Korkut, p. 3; Orhan Gökyay, Dedem Korkudun kitabı (Istanbul, 1973), p. lxviii\}. This tradition is taken almost verbatim from the Kitäb-ı Dede Korkut. Barthold has also 
provided some brief information on this work, which first attracted the attention of H. O. Fleischer and then J. H. von Diez in Europe and was partially translated (see $E I^{I}$, s.v. "Ghuzz"). This valuable collection of legends, which, judging from the proper names in it, evidently belongs to the Turks living in the region of Azerbaijan, Bayburt, and Georgia, i.e. in the region of the Eastern Oghuz, which we call the "Azerī language area," needs a thorough linguistic and historical analysis. Some of these popular legends - such as the story of Bey Beyrek - which the ozans have sung for centuries accompanied by the kopuz, exist in other written versions. Others, such as that of Tepegöz, are still current orally among the people. Indeed, the figure of Dede Korkut is encountered among the Turkmen of Azerbaijan and in the Syr Darya region. This saint, who, according to one legend, went to Arabia to learn about Islam and, after meeting Abū Bakr, became a Muslim, is not a historical person as K. Inostrantsev believes \{see Gökyay (ed.), p. IX\}, but a completely legendary figure. In my view, the Ulug Turk in the Uighur Oghuz legend published by Radloff, the Irkıl Ata in Rashīd al-Dīn, and this Dede Korkut represent the same figure and clearly show the religio-artistic position of the ozans in early Turkish society. Finally, let me say that I have also encountered among Turks other than the Oghuz stories written in the same manner and style as those in the Kitäb-ı Dede Korkut, i.e. in the same kind of metrical prose \{or free verse\}.

109 Shaikh Süleyman Efendi gives the following information on the words ozan and

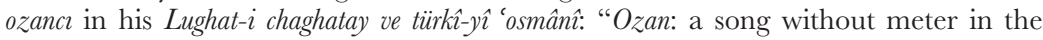
mân $̂$ style that was sung in the story and epic of Qara Khān and Oghuz Khān. Ozancr: a man who plays the drum $\{$ davul $\}$ and tambourine $\{d e f\}$ while singing an ozan, i.e. mân $\hat{\imath}$ and song." The definition in the Chaghatay-Persian lexicon of the Budapest Academy is as follows:

$$
\text { يكطور خوانتد كى باشد درميان اتراك، در نقل اوغوز خان وقراخان كويند }
$$

\{A kind of singing among the Turks which is sung in the story of Oghuz Khān and Qara Khān.\} The famous Pavet de Courteille somehow misunderstood this in his Dictionnaire Turc-Oriental and says "The invention of this was attributed to Oghuz Khān and Qara Khān," which is a mistake. This word, which is not found in Vambéry's Cagataische Sprachstudien, appears among the Yakut in the form of oyun, meaning "shaman." In any case, the definitions given by Süleyman Efendi show that ozans were well known for singing, above all, the epic of the Oghuz and that this epic was "a song without meter in the mânî style," which exactly characterizes the stories of Dede Korkut. \{See İlhan Başgöz, "From Gosan to Ozan," International Journal of Central Asian Studies, 2 (1997), 5-13; on mânî, see $E I^{2}$, s.v. "Māni" (P. N. Boratav).\}

110 A number of legends - coming from many different sources - that constitute the Bektashī tradition reveal this feature very clearly. Sarı Saltık, for example, was not an ordinary dervish, but a hero who conquered countries with a wooden sword and spread the faith.

111 The famous Geyikli Bābā, for example, mounted a gazelle in front of the army besieging Bursa and went into battle with a sword weighing 60 okkas $\{1=1.28 \mathrm{~kg}\}$. In like manner, Abdāl Murad carried out many heroic deeds with a wooden sword that was four arşıns $(68 \mathrm{~cm})$ in length. Hammer considers Geyikli Bābā to be the Saint George of the Ottomans, or to be the furious Roland \{Orlando Furioso $\}$ who was the subject of so much heroic poetry in Western literature - a very good analogy. As a sign of respect, Süleyman the Magnificent cut off one-third of his sword and had it placed in the royal treasury (for accounts of this, see the first volume of Hammer's \{Geschichte des osmanischen Reichs\}; \{Tashköprü-Zāde's\} al-Shaqä’iq, 
\{Turkish\} trans.; \{Sa'd al-Dīn's\} Tāj al-tawā̄inkh; 'Āshıq Pasha-Zāde's \{Tawārīkh-i $\bar{a} l-i$ 'uthmān $\}$; \{İsmâ'îl Belig Bursalı's\} Güldeste-i riyâz-ı irfân; 'Ālî̀'s \{Kunh al-akhbār $\}$;

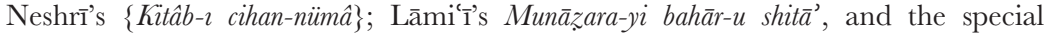
histories written about Bursa). \{Cf. Heath Lowry, "The 'Sword of Roland' and the 'Sword of Abdal Murad': A Note on the History of Brusa (Bursa) in the Light of Six Centuries of Travellers' Accounts (1325-1925)," in Çiğgdem Kafescioğlu and Lucienne Thys-Şenocak (eds), Essays in Honour of Aptullah Kuran (Istanbul, 1999), p. 241. Lowry finds Köprülü's remarks confusing, but Köprülu is not concerned with a particular sword or sword legend.\} 


\section{THE LIFE OF YŪNUS EMRE}

\section{A Bektashī tradition}

There is considerable information about Yūnus Emre in Bektashī tradition, which sought to present virtually every one of the early great Șūis who flourished in Anatolia as a disciple and follower of Hājjī Bektash. Consequently, before I provide historical information on the life of Yunus Emre, it is useful to present his portrait in exactly the way it is given in Bektashī tradition. This tradition took shape in the ninth/fifteenth century - in a somewhat forced manner - and is, for the most part, highly contrary to historical reality because of the time in which it was established. Nevertheless, it is still possible to extract some historical information from it by subjecting it to serious and rigorous criticism.

According to this Bektashī tradition, when Hājj̄ī Bektash arrived in the lands of Rūm \{Anatolia\}, among a number of great Șūfiss who were there, such as Sayyid Maḥmūd Hairānī, Jalāl al-Dīn Rūmī, and Hạajjīi Ibrāhīm Sulțān, ${ }^{1}$ was a shaikh named Emre who "possessed great holiness." Hājjī Bektash summoned all the erens of Anatolia. But this shaikh, for some reason, did not accept the invitation. The other erens of Anatolia informed Hājjī Bektash that he did not want to come. Hājjī Bektash then sent his dervish named Sarı Ismā î̀, ${ }^{3}$ who had previously joined him along with Qaraja Ahmad, ${ }^{4}$ to Emre to summon him. He asked him the reason why he had not come previously. Emre said that a hand, appearing from behind a curtain, had granted him permission to enter the Șūfi path, and that he had never seen anyone called Hājji Bektash at that banquet of erens that he had attended. When Hājjī Bektash asked whether that hand had a mark on it, he said that he saw a green mole on the palm. Hājjī Bektash immediately extended his hand. Emre was astonished to see the green mole on his palm, and when he realized that he was in the presence of the spiritual guide \{murshid\} who had previously given him his hand, in amazement he uttered three times, "Tapduk padişahım" AAt your service my Padishah\}! $!^{5}$ From that day forth, his name was Tapduk Emre. ${ }^{6}$

In one of the surrounding villages, there was a very poor man named Yūnus who earned his living as a farmhand. One year, there was a famine and Yūnus's poverty intensified. Finally, it occurred to him to go to Hājj̄̄ Bektash - having 
heard of his many miracles and graces - and ask for help. He loaded some medlars on his ox and went to the dargāh \{dervish convent [of Hājjj̄i Bektash]\}. Prostrating himself at the feet of the $p \bar{\imath} r$, he gave him his gift and requested some wheat in exchange. Hājjī Bektash treated him with kindness and had him as a guest for several days in his dargāh. But Yūnus was anxious to return. When the dervishes told the $p \bar{\imath} r$ that Yūnus wished to leave, he sent word, saying "Does he want wheat or the miraculous influence \{himma\} of the erens?" The heedless Yūnus asked for the wheat. When Hājj̄̄ Bektash learned this, he again sent word, saying "If he wishes, let me blow on each medlar fruit." Yūnus continued to insist on the wheat. Hājjī Bektash sent word a third time, saying "If he wishes, let me exert my miraculous influence for each seed \{in the medlar fruit\}." When Yūnus again insisted on the wheat, he finally ordered that they give it to him.

Yūnus left the dargāh and set out for home. He had not gone far, however, before he realized that he had made a big mistake. Greatly regretting it, he immediately returned and admitted his blunder. Hājjī Bektash then told him that he had given Yūnus's "lock" to Tapduk Emre and, therefore, if he wished \{to open it\}, he should go to him. As soon as Yūnus heard this, he rushed to Tapduk's dargāh and told him what had happened. Tapduk appointed Yūnus to gather firewood for his dargāh. During the fully forty years in which this devoted dervish carried out this task, he was never seen to bring in a bent or damp piece of wood.

One day, after these many years, an assembly of erens was held. The woodcutter Yūnus was present with his shaikh. Also present was a very well known composer of hymns named Yūnus the Singer. In the assembly, Tapduk Emre entered a state of mystical ecstasy and addressed Yūnus the Singer, saying "I am filled with love. Come, sing a little!" He tried several times, but no sound emerged from his lips. Finally, Tapduk Emre turned to the woodcutter Yūnus and said "Well, the time has come. Your lock has been opened. The words of Hājjī Bektash have been fulfilled. Don't stand there! Sing!" At this, the veil was removed from Yūnus and the lock was opened and he immediately began to compose skillful and eloquent orations and hymns. ${ }^{7}$

\section{B His life}

If we put aside the legend and examine the life and personality of Yūnus Emre from a strictly historical and positivist point of view, we will be confronted with a number of major problems that, to some degree, are impossible to solve, because the information on him provided by the earliest historical sources is often inadequate or contradictory, and even mixed somewhat with legends. There are, to be sure, several hints and clues to the life of Yūnus Emre in his own works, but as will become quite clear from the following chapter on his Dīwān, they too must be used with great caution. Faced with these meager and conflicting materials, we must admit right away that the information that we will give on his life cannot be regarded as positively established. 
Yūnus Emre - or, as he is usually called in his poetry, Qul Yūnus, 'Āshıq Yūnus, or Yūnus Emrem ${ }^{8}$ - was a simple dervish who lived in the second half of the seventh/thirteenth century and the beginning of the eighth/fourteenth century. Some biographical works place his death date as late as 843/1439-40, as expressed by the chronogram gulshan-i tawhīd \{actually amounts to 828 \}, but neither this claim nor the attempt by Tashköprü-Zāde to show that he was a shaikh during the reign of Bayezid I $\{791-804 / 1389-1402\}$ is correct. ${ }^{9}$ Some recent scholars, like Melioransky, hold such opinions, but even in light of the inadequate documents that we possess today, they can very easily be rejected. ${ }^{10}$

First of all, the Bektashī tradition is very strong evidence on this point. If Yūnus Emre died in 843/1439-40, as was claimed, or if he lived into the early years of Bayezid I, the Bektashī tradition, which is virtually confined to the Șūfiss belonging to the second half of the seventh/thirteenth century and the early years of the eighth/fourteenth century, could not have appropriated him. In order to include him in the Bektashī tradition, which was certainly established by the end of the eighth/fourteenth century or the beginning of the ninth/ fifteenth century, it would have been necessary for Yūnus Emre to have lived at a much earlier time and for his historical character to have subsequently been more or less forgotten. ${ }^{11}$

Second, 'Ashıq Pasha-Zāde, who provides fairly accurate and reliable information on the shaikhs and religious scholars of these early periods, such as Hājjī Bektash, considers Yūnus Emre to have been contemporary with such Șūfis as 'Āshıq Pasha, Akhī Ören \{Evren\}, Qaraja Aḥmad, and Geyikli Bābā, and writes that they were among the leading personalities of the reign of Orhan $\{c .724-$ 61/1324-60\} and that some of them reached as far as the time of Murad I $\{761-91 / 1360-89\} .{ }^{12}$ It is more reasonable that Yūnus Emre, who was considered to be a contemporary of 'Āshiq Pasha, lived in the second half of the seventh/thirteenth century than that he died in 843/1439-40.

Third, the fact that several of 'Ashiq Pasha's poems are listed in \{Hacı Kemal's Jāmi al-nază'ir as imitations $\left\{n a z \bar{a}{ }^{\prime} i r\right\}$ of those of Yūnus Emre, shows that Yūnus lived some time before him. ${ }^{13}$

Fourth, a foreigner named Mühlbacher who was taken prisoner by the Turks in 841 or 842/1438 and later, after spending about twenty years in Edirne, Bergama, Bursa, and Chios \{incorrectly given as Cyprus in the 1st edn\}, returned to his country, copied down two of Yūnus's hymns in Gothic letters and translated them into Latin. If Yūnus Emre belonged, in fact, to the eighth/fourteenth or ninth/fifteenth centuries, it would have been impossible for his poems to have been so widespread at that time. It would appear, therefore, that Yūnus Emre lived only into the early years of the eighth/fourteenth century and that his hymns had spread throughout Anatolia and Rumelia by the time of Mühlbacher's captivity. ${ }^{14}$ In light of this historical evidence, the view put forward by Melioransky that Yūnus Emre lived at a later time than we suppose - can hardly be defended. ${ }^{15}$

Yūnus Emre was a Turkmen peasant who lived in the second half of the seventh/thirteenth century in a village close to Sivrihisar, or one of the villages 
dependent on Bolu, near the Sakarya River. ${ }^{16}$ It is apparent from the literary works in his Dĩwan that he tried for a long time to set out on the mystic path, but he was unsuccessful in achieving this goal until he became a disciple of Tapduk Emre. ${ }^{17}$ It is also clear from Bektashī tradition that this man, whom 'Âshıq Pasha-Zāde mistakenly presents as eminent during the reign of Sultan Orhan, and whom Tashköprü-Zāde presents as eminent during the reign of Bayezid I, was one of many well known shaikhs who filled Anatolia in the seventh/ thirteenth century; he lived a solitary life in a village near the Sakarya River. ${ }^{18}$ The legendary reports according to which he was a blind shaikh belonging to the Qādirī tarnqa are not based on any historical evidence. ${ }^{19}$ The information that I have given \{above on Sūfī life in Anatolia at that time renders it likely that Tapduk Emre belonged not to the Qādirī but rather to the Bābā' tariqa; and the fact that there are a number of features that would not be welcomed by the Sharī' $a$-minded in Yūnus's belief system also supports this conclusion. And while, as I will show at length in the next chapter, it would not be correct to consider Yūnus's Șūî̀ personality to have been formed solely under the influence of Tapduk Emre, it would be equally incorrect to believe that he completely escaped his influence. When the personality of Yūnus Emre is studied in the context of the Șūfì movements in seventh/thirteenth-century Anatolia, the spiritual figure of Tapduk Emre also becomes more or less clear. There is a tradition that has long existed among the Anatolian dervishes according to which Tapduk Emre received spiritual instruction from a certain Sinān Efendi, or Sinān Ata, a Central Asian Turkish shaikh who went to Anatolia from Bukhārā following the Mongol invasion. This tradition goes far to explain the influence of Ahmad Yasawī on Yūnus Emre. ${ }^{20}$

Tapduk Emre, who, according to the translator of \{Tashköprü-Zāde's\} al-Shaqẩiq, Müddet-i ömründe halk âleminden uzlet ve intıkấ üzre olup silâh-ı salâh ile habl-i alâkayn kat'etmi ve şîme-i kerîme-i aktâb üzre seccâde-i irşâda cülûs eyleyib, kerâmât-ı âliye izhâr eylemis \{ spent his life in isolation and cut off from the world, severed the cord of worldly ties with the sword of righteousness, sat on the carpet of spiritual learning with the chief saints of the noble qualities, and performed sublime miracles $\}$, was a famous Șūfì who acquired enormous spiritual influence throughout the Sakarya region. It was especially during that confused period, which corresponds with the decline of the Seljuks, that the influence of the Sūfīs over the people increased markedly. Yūnus Emre also succumbed to this widespread spiritual state and followed Tapduk Emre's path of religious instruction. Yūnus spent a lengthy period practicing austerities. In order to complete his religious training, he labored for years with an enthusiasm unique to the dervishes. Summer and winter, he carried wood to the darga $h$ from the Sakarya forests. His being thus occupied collecting wood in the mountains naturally led to the creation and spread of many stories about him among the people. These legends have even come down to our time. One day, according to tradition, Tapduk Emre looked at the wood that Yūnus had brought and noticed that it was all straight and dry. "Is there no bent wood left in the mountains?" he asked, feigning ignorance. 
"There is a lot of crooked wood in the mountains," Yūnus replied, "but at your gate it is not proper for anything to be bent, even the wood." ${ }^{.21}$ In any case, among the adherents of the tariqa, Yūnus was known for centuries as the model of a dervish who was able to reach the highest levels of spirituality by showing absolute devotion to his spiritual guide. We frequently find passages in his Dīwān that show his deep and very sincere affection for, and devotion to, Tapduk Emre. ${ }^{22}$

All the stages of Yūnus's life after his association with Tapduk Emre are shrouded in darkness. According to legend, he completed his religious training after serving his shaikh for a full forty years - because it was not possible to do this in less than forty years ${ }^{23}$ - and reached the level of enlightenment. At that point, he began to write his hymns. Another legend relates that, on the order of his shaikh, he wandered from country to country for forty years and only then reached the stage of enlightenment. ${ }^{24}$ Whatever the case, some of the poems in his $D \bar{\imath} w \bar{a} n$ indicate that both Mawlānā and his shaikh Emre Sultān died before he did, ${ }^{25}$ and that he went to Damascus for a while on the order of his spiritual guide, stopped in 'Ayntāb en route, and delivered a number of orations there. ${ }^{26}$ Indeed, there are even some poems in his $D \bar{\imath} w \bar{a} n$ that imply that he went to Mecca to visit the $\mathrm{Ka}$ 'ba \{i.e. make the pilgrimage\}. ${ }^{27}$

It appears, therefore, that 'Āshıq Yūnus labored for years in his shaikh's tekke; after he obtained spiritual maturity and after legends of his miraculous deeds spread among the people, he departed from there - with Tapduk's permission, naturally; he visited various countries and then became chief of a dervish order $\{$ sajjäda-nishīn $\}$ - in all likelihood in a place different from that of his shaikh. One poem in his Dīwān alludes to his leaving Tapduk's dargāh and going to other countries, ${ }^{28}$ while another poem states that "dervishes came to him from the country of his shaikh." 29 It is evident from all this that Yūnus Emre was his shaikh's most renowned khalifa and that after his shaikh's death his dervishes flocked around Yūnus. Thus, Yūnus Emre, about whom legends spread throughout Anatolia during his lifetime, lived a rather long time and, after writing many hymns and orations and seeing them spread among the people, died some time after $707 / 1307 .{ }^{30}$ Given the documents in our possession, it is, unfortunately, not possible to determine precisely the date of his death.

\section{G Yūnus Emre's illiteracy}

Based on all the documents currently in our possession, we must consider Yūnus Emre to have been an illiterate dervish. The translator of \{Tashköprü-Zāde's al-Shaqā'iq states, Zâhir-i hâlde okumağa dili varmayıb, hâme gibi hurûf-ı teheccînin edâsında kâsır olduğu \{ his tongue could not read in a clear fashion and, like a reed pen, he lacked the ability to pronounce the letters of the alphabet\}. And 'Āshiq Chelebi alleges that Okumak kasdettiği hâlde, hurûf-ı teheccîyi ikmâle dili dönmediği \{he tried to read, but his tongue did not properly pronounce the letters of the alphabet ${ }^{31}{ }^{31}$ E. J. W. Gibb, who was unable to add any more to this and reports it verbatim, also concluded that he was illiterate, but Melioransky disagreed and claimed that 
Yūnus certainly knew how to read and write. ${ }^{32}$ This issue cannot be resolved until proper research is done on similar phenomena in the history of Șufism and on the meaning and nature of illiteracy according to the Șûfis.

In the view of the Sûfìs, knowledge was divided into two kinds: exoteric knowledge, or the knowledge of the $\operatorname{Sharin}^{-} a$, and esoteric knowledge, or knowledge of truth. The Șûfis referred to the latter with the special term 'irfān \{spiritual knowledge\}. The first kind, i.e. primary knowledge, is mediated by the senses or the intellect and can be transmitted. The source of spiritual knowledge, on the other hand, is divine inspiration $\{$ ilha $\bar{m}\}$. The madrasas were the centers of exoteric knowledge or the knowledge of canonical law, while the tekkes were the centers of spiritual knowledge, which was obtained from spiritual guides $\{$ s. murshid $\}$ through divine inspiration. This is why the people of the Shari' $a$ were called "the people of words" $\{a h l-i q \bar{a} l\}$, while the people of true knowledge $\{a h l-i$ haqũ $q\}$ were called "the people of mystical states" $\{a h l-i, h \bar{a} l\} .{ }^{33}$ Just as anyone could be a legal scholar or physician without being ahl-i 'irfān, i.e. possessor of mystical ecstasy, so anyone, despite inability to read and write, could become 'ärif bi'llāh - a knower of God, a mystic. Although some Șûfis among the religious scholars tried to show that exoteric knowledge was a necessary basic foundation for esoteric knowledge ${ }^{34}$ still all the great Șūfis unceasingly opposed the ahl-i $q \bar{a} l .{ }^{35}$ Indeed, if one were to study the history of Șūfism, one would find many great Șūfiss who were famous for being "illiterate," yet had spiritual knowledge. The countless examples of this phenomenon suffice to prove that Yūnus Emre was by no means exceptional in this respect. ${ }^{36}$

In one of his poems, Yūnus Emre speaks boastfully of his illiteracy, saying Yûnus Emrem öldü fakî / Ecel öfkesini \{ensesini in 1st edn\} dokur / Gönül kitabrndan okur / Eline kalem almadı \{My Yūnus Emre died a dervish / Death struck him on the neck / He read from the book of the heart / He did not take pen in hand; this ghazal is not in the standard editions by Gölpınarlı, Yunus Emre: Risâlat al-nushiyya ve Dî̀ân (Istanbul, 1965) and Faruk Timurtaş, Yûnus Emre Divan, 3rd edn (Ankara, 1986)\}. And in one of his hymns, he reveals the pride he felt in being illiterate as opposed to the ahl-i qāl, saying Erenlerin sohbeti artırn márifeti / Câhilleri sohbetten her dem süresim gelür \{Company with the erens increases knowledge / I would like to drive away the ignorant ones from the company\}. But was Yunus Emre in fact such an illiterate dervish that "he could not pronounce the letters of the alphabet"? Did he not know how to read and write at all? We cannot accept at face value Yūnus Emre's confession that he did not take pen in hand, or the reports in the early sources on this matter. It may have been possible for a completely illiterate dervish to write short hymns, but not a long mathnaw $\bar{r}$ of almost 500 couplets, such as the one at the beginning of Yūnus Emre's Dīwān.

Still, even though his claim that he could not pronounce the letters of the alphabet may be an exaggeration, it would also be going too far to regard this simple dervish as a man who was fully literate and who had a madrasa education. As I will explain in the next chapter, there are very clear indications in his work that he knew well the legends of the prophets and saints, old Iranian mythology, 
even the general concepts of the religious knowledge $\left\{{ }^{\prime} i l m\right\}$ of his day. Yūnus Emre was not one who delved deeply into Arabic or Persian literature or into the madrasa sciences. He had neither the Persian eloquence of Jalāl al-Dīn Rūmī nor the profound knowledge of 'Āshıq Pasha. Nevertheless, although this very simple Turkish dervish, who said Mescid ve medresede çok çok tấat kılmışam / Aşk od'una yanuben andan ben kâl'e geldim \{I performed a great many acts of piety in the mosque and madrasa / I was burned in the fire of love and then I came to speech\}, did not have a firm knowledge of the rules of Persian literary style, he surely knew Persian literature sufficiently to enjoy Mawlānā's poems. Otherwise, the strong and clear influence of Mawlānā on his work would not be so obvious.

This man, who grasped the Șūî philosophy that was prevalent in Anatolia in his time with a spiritual facility in no way inferior to that of Jalāl al-Dīn Rūmī and who succeeded in expressing it in the simplest terms with unmatched power, certainly did not "lack the ability to pronounce the letters of the alphabet." In order to raise the level of his spirituality to a higher plain, the translator of \{Tashköprü-Zāde's\} al-Shaqā'iq and 'Âshıq Chelebi related this report \{of his illiteracy\}, which arose from the popular imagination, with full sincerity and conviction, because if this were the case then his poetry could be considered to derive from an altogether divine source. ${ }^{37}$

\section{His burial place and tomb}

There is also considerable confusion about the burial place of Yūnus Emre, whose place and date of death are unknown. In Muslim countries, even prominent figures whose burial places are well known may have various grave sites or tombs - and not just persons like Yūnus Emre whose place of death is uncertain. People everywhere wanted important Șūfìs \{to be buried $\}$ in their own region so that they could benefit from their spirituality and holiness. In the East, therefore, there have been many disputes over such sites. The following are the major burial places and tombs in Anatolia said to belong to Yūnus Emre.

1. In Bursa, in the dargāh of 'Abd al-Razzāq of the Sa'dī tarīqa in the Şibli Quarter between \{the districts of Ghelebi Sultan Mehmet and Emir Sultan, there are three tombs in the names of Yūnus Emre, 'Āshıq Yūnus, and 'Abd al-Razzāq, along with an inscription. Shaikh Ahmad 'Izz̄̄-Zāde Sayyid 'Abd alLațîf briefly mentions this tomb \{of Yūnus Emre\} in his work Khulāsat al-wafayāt, ${ }^{38}$ and Rızâ Tevfik, who visited it, also gives some details about it. ${ }^{39}$ According to tradition, this burial place was originally determined by Muhammad Niyāzī Mișrī based on a spiritual revelation. There are many reasons why it cannot be accepted as Yūnus Emre's true burial place. First, various authors, such as Evliyā Chelebi, İsmâ'îl Belig, and Lāmi`̄i Chelebi, who, before Niyāzī, discuss those buried in Bursa and the türbes found there, say nothing of such a türbe. Furthermore, not only is it likely that Yūnus Emre died before the conquest of Bursa, but there is also absolutely no record of his being present at the conquest of that city or 
visiting it afterward. In fact, we know quite well the early Șūfīs who lived in Bursa during the years following its conquest. If a renowned Șūî like Yūnus Emre had lived and died there, the authors whom I have mentioned, as well as the older historians, would surely have recorded this fact. In addition, there is a report that Yūnus Emre had a khalîfa named 'Āshıq Yūnus. But this is a dubious tradition of no historical value, because there is no mention of it in the older historical sources and because it spread among the people at most a century ago. ${ }^{40}$

2. In the province of Manisa, in a village named Emre, composed of seventy houses lying between the districts of Kula and Sâlihli \{i.e. the village of Yunus Emre about twenty kilometers west of the town of Kula\}, there is a stone türbe. Inside are the graves of Tapduk Emre, his children and grandchildren, and, in front of the threshold, the grave of 'Âshıq Yūnus \{see photographs, p. 276\}. There are no inscriptions on the graves; there is only a small ax carved on the grave of 'Āshıq Yūnus. ${ }^{41}$ Mehmed Tâhir, who visited this site, says that this particular gravestone is at most fifty or sixty years old. In my view, an ax is a symbol related to the famous legend about the firewood that I mentioned above. According to a tradition widespread among the villagers, Yunus, who showed great reverence for his shaikh, specifically willed that he be buried at the threshold to his tomb, so that those who visited the shaikh would have to tread upon and step over his own grave. The fact is, it cannot be claimed by any means that this burial place belongs to Yūnus Emre's shaikh or to Yūnus Emre.

3. An hour and a half from Erzurum, at the foot of the Palandöken Mountains, is the village of Dutcu, which overlooks the Erzurum plain from the east. In this village is the türbe of Tapduk Emre and Yunus Emre. It is protected by a wall and furnished with a thick wooden railing. The village and the lands around it were established as a pious foundation for the dargāh of 'Alī Bābā. After prayers, the villagers of Dutcu always dedicate a Fätiha to the spirit of Yūnus Emre and in summer many people come from Erzurum to visit his tomb and recite the hymn Yemen illerinde Veyse'l-Karanî. ${ }^{42}$ However, we have no historical evidence that Yūnus Emre went to, or settled in, that region. And because we know that Tapduk Emre lived as a hermit in the Sakarya region, it is impossible to consider this grave to be Yūnus Emre's true burial place.

4. According to a report \{told by $\}$ İsmâ îl Hakkı $\{$ d. $1137 / 1725\}$, the graves of Yūnus Emre, his shaikh Tapduk Emre, and his shaikh Sinān Efendi are under a dome Kiçiborlu kasabası kurbündeki gadîr-i 'azîmin cânib-i şarkîsinde olan puşte tarafinda bir karyede in a village by a hill east of a large pond near the town of Kiçiborlu $\}{ }^{43}$ This report, which is not found in any other historical source, is not worthy of any credence. We possess no historical evidence to corroborate it.

5. It therefore remains to prefer and accept the fifth and last possibility, namely the report in Lāmi'ī Chelebi's translation of \{Jāmī's\} Nafahāt and its supplement $\{$ Dhail $\}$ that Yūnus Emre is buried at the confluence of the Porsuksuyu and the Sakarya. While this report has not been positively proven, it certainly seems more plausible than the others. ${ }^{44}$ However, when we recall that 


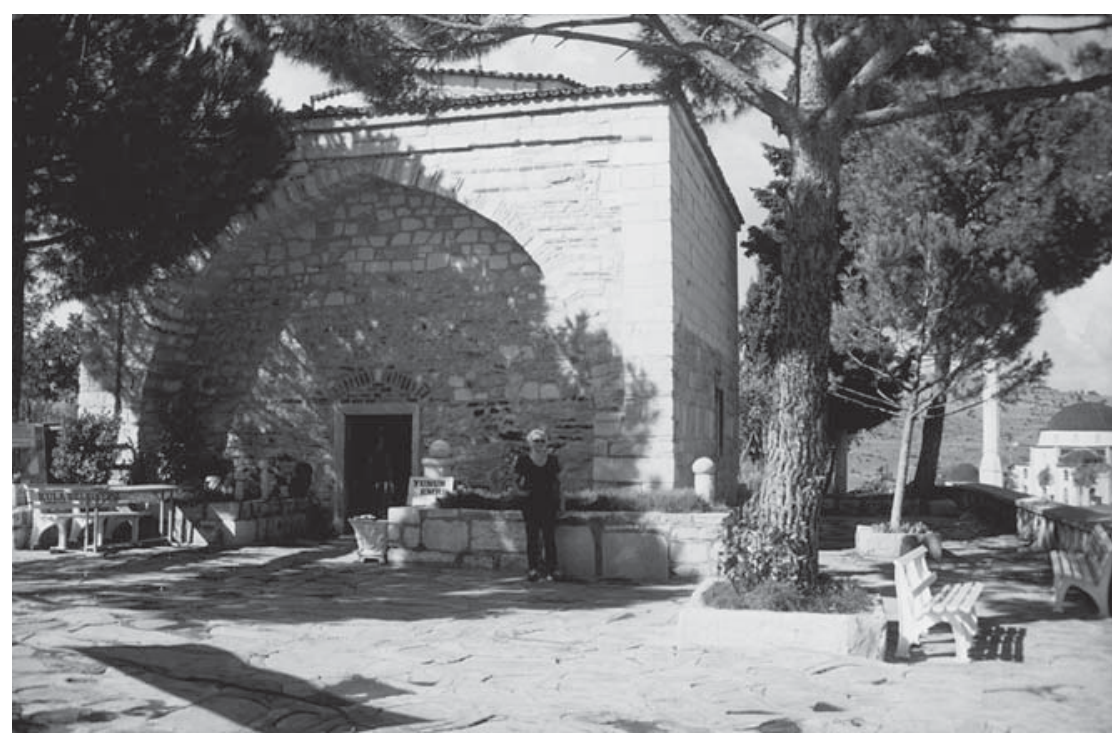

Figure 3 One of the reputed burial sites of Yūnus Emre, east of Izmir in the province of Manisa, Turkey. Yūnus's grave is in the foreground. Tapduk Emre and relatives are inside. (Photo courtesy of Berrin Dirim.)

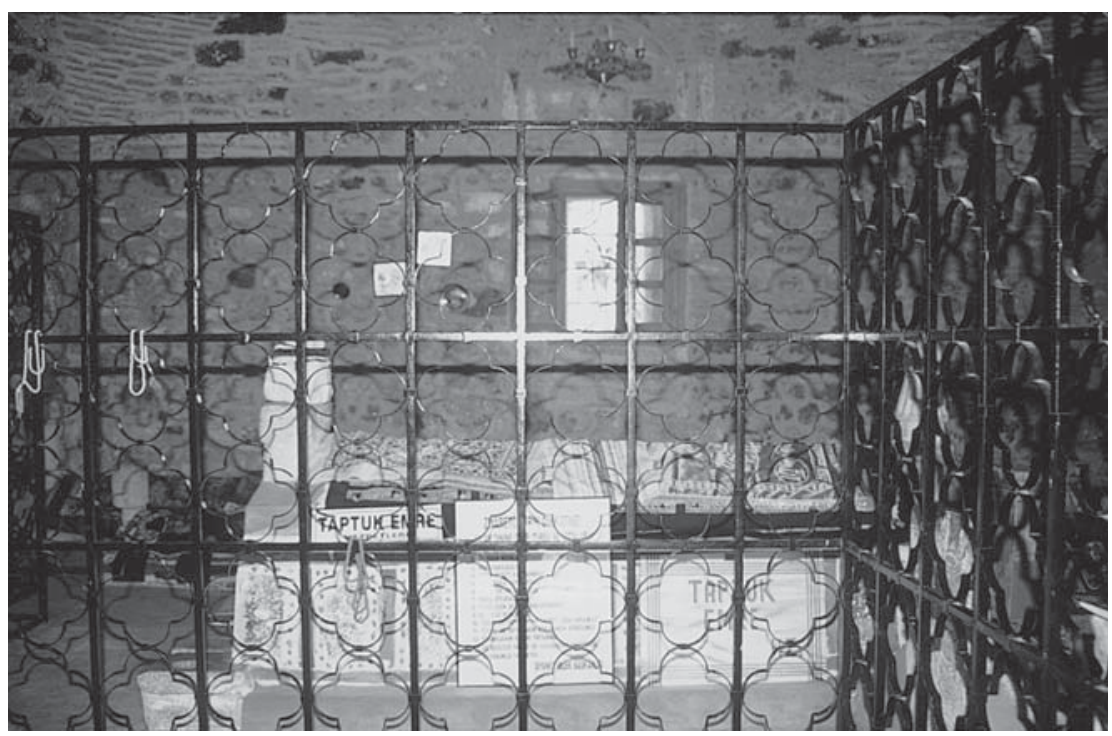

Figure 4 The cenotaph of Tapduk Emre in the tomb next to the grave of Yūnus Emre. (Photo courtesy of Berrin Dirim.) 
Yūnus Emre established a zāwiya in a different place from his shaikh's residence, this strengthens the likelihood that Tapduk Emre is buried in the place specified by Lāmi' $\overline{1}$ and that Yūnus Emre was buried in the place mentioned by Shaikh İsmâcîl Hakkı. The intimacy between shaikh and disciple surely prevented the separation of the two in the popular imagination, so that one could not help but believe they were buried in the same place. In any case, the many graves of Yūnus Emre scattered about the vast area of Anatolia are very significant indications of the sanctity ascribed to him by the people. Mehmed Tâhir also states, in addition to the above, that Yūnus has another burial place in Karaman, but he gives no details about it. ${ }^{45}$

\section{E His fame}

After Yūnus Emre's death, he was not quickly forgotten, as were other popular Șūfîs who were his contemporaries or predecessors. To the contrary, his fame spread throughout Anatolia and Rumelia and lived on for centuries among people of all classes. From this point of view, we can certainly regard him as a representative of the Turkish genius. In the last chapter, I will explain how this great folk poet created a new type of literature, or, more accurately, how he combined an old type with his own personality and gave it new life. Therefore, instead of going into literary details here, I would like to prepare the ground for an internal and literary analysis of his work by showing - to the extent that the few documents in our possession allow - how Yūnus Emre was viewed by people of different classes after his death. For this purpose, let me first examine the extent of his fame among the Șufīs, then his fame among the popular masses who were directly influenced by these Sūfīs, and finally the views of him held by the classic $\{$ Turkish $\}$ poets who imitated Persian models.

By the beginning of the eighth/fourteenth century, Yūnus Emre had already acquired many important and respected followers, such as 'Āshıq Pasha and Qayghusuz Bābā. His fame continued unabated among the Șūfìs in the ninth/ fifteenth century. I have described above, citing the Velāyetnāme, the important place that was given to him in the Bektashī tradition, which had been fixed in that century. We also find Yūnus Emre mentioned among the great Bektashīs in the Khadirname, which records and confirms the same tradition. ${ }^{46}$ Beginning with histories like that of 'Āshıq Pasha-Zāde \{d. after 889/1484\}, which started to be written in the tenth/sixteenth century, and then in \{Tashköprü-Zāde's\} al-Shaqā’iq, \{Sa'd al-Dīn's\} Tāj al-tawārīkh, the translation of \{Jāmī’s\} Nafahāt, \{'Âlì's\} Kunh al-akhbār, and later histories and biographical dictionaries, Yūnus is always described as a great Șūfì. Indeed, even Tashköprü-Zāde could not refrain from mentioning the famous legend about the firewood, which passed into Bektashī tradition.

This evidence, however, no matter what its value, cannot be considered as important as the views advanced by genuine Șūfīs. For example, there is a curious report in $\{$ Hüdā's's $\}$ Wāqi $\bar{a} t$ Uftäda that shows what great importance 
Yūnus Emre had among the Șüfis of the tenth/sixteenth century. Supposedly, Jalāl al-Dīn Rūmī confirmed the high rank \{of spirituality\} that he had reached by saying, "Whatever levels of spirituality I advanced to, this Turkman elder, Yūnus, preceeded me." ${ }^{37}$ This legend cannot, of course, be accepted from a historical point of view, but it is nevertheless quite significant. On the other hand, according to this source, the ascetic and devout man Shaikh Uftāda, while influenced by Ibn al-'Arabī, was generally hostile to Yūnus's broad-minded and free-thinking views. ${ }^{48}$ The famous Olanlar Shaikhi Ibrāhīm Efendi, the author of the Dil-i Dânâ \{MS in Köprülü's private library\}, who died in 1066/1655-6, was an admirer of Yūnus Emre and he used to say Lisân-ı kadîm üzre mánâ icrâ eylemis er, Yûnus Emre Hazretleri'dir (The man (or, saint) who expressed spiritual meaning in the old language was his excellency Yūnus Emre $\}{ }^{49}$ Similarly, the famous Muhammad Niyāzī Miṣrī, the founder of the Miṣrī branch of the Khalwatiyya tarīqa who died in 1105/1694, honored and glorified Yūnus Emre in some of his poems..$^{50} \mathrm{He}$ also wrote a commentary on his famous hymn that begins with the verse Çrktım erik dalna anda yedim üzümü / Bostan ısı kakıyub der ne yersin kоzumu \{I climbed up a plum branch and there ate grapes / The owner of the garden became angry and said "Why are you eating my walnuts?" ${ }^{51}$ İsmấ̂îl Hakkı of Bursa, a Șūfì writer who appeared after Niyāzī, also cited and commented on several of Yūnus Emre's couplets in his commentary on the Muhammadiyya \{of Yazıcı-oğlu Mehmed\} and had much praise for him..$^{52}$ And in a separate work, following Niyāzī, he wrote a detailed commentary on Yūnus Emre's \{aforementioned\} hymn. ${ }^{53}$ All of this material shows that Yūnus Emre acquired great fame among the Sūfis beginning in the eighth/fourteenth century and that, rather than being forgotten, he was glorified and admired more ardently in each succeeding period.

Yūnus Emre's great renown among the Șūiss also explains how it is that the fame he acquired among the popular masses - who were, for the most part, directly under the influence of the Șüfis - flourished unabatedly since the eighth/ fourteenth century. Indeed, the presence of his shrines in various places in Anatolia and the proliferation of legends about him over the centuries fully support this contention. We can clearly see the extent of the influence of Yūnus Emre's hymns on the people by leafing through the old collections of folk poetry (cönk \{see n. 54$\}$ ). We invariably find Yūnus's poems in all these miscellanies, which span various periods and belong to people of different cultural levels. ${ }^{54}$ Just as the testimony of the captive Mühlbacher in the ninth/fifteenth century shows that the hymns of Yūnus Emre were already popular during his time, \{Hacı Kemal's\} Fāmi al-nazà $i r$, which belongs to the early years of the tenth/sixteenth century, indicates the importance of these works in the following century. The works of Yūnus Emre, which we can regard as a native production with respect to incorporating artistic elements that appealed to the Turkish national taste, not only had a great influence on the Bektashīs, because they adumbrate a broad-minded and free-thinking Sūfì philosophy, but were also deemed significant among the Q 1 zilbash Turkmen from an early date. One of Khațầ'̄'s \{i.e. the Safavid Shāh 
Ismā'îl I, 907-30/1501-24\} poems clearly reveals Yūnus's spiritual influence on these simple Turkmen already at that time. ${ }^{55}$

The Persian-imitating poets, seeing that Yūnus's hymns written in the syllabic meter were read with great pleasure among the people, feigned indifference to his work, or belittled it, or showed their spite by considering it to be outside the sphere of poetry. Some of those who wrote biographical dictionaries of poets, and whom we can call our first literary historians, such as Sehî Bey \{d. 955/ 1548-49, see $E I^{2}$, s.v. "Sehī Bey" (G. A. Tekin)\} and Lațîfī \{d. 990/1582, see $E I^{2}$, s.v. "Lațîfî" (M. Çetin)\}, did not find it necessary to mention Yūnus Emre, although they discussed many other shaikhs and Șūîs who wrote in the 'arūd meter. 'Āshıq Chelebi did devote seven or eight lines to him, following TashköprüZāde, but could not refrain from considering his work to be Șūfì hymns rather than poetry. Because an ancient classification made a sharp distinction between the poet and the 'asshq, i.e. between the artist who was preoccupied with non-religious subjects and the one who took his inspiration from religion and mysticism, ${ }^{56}$ the fact that Yūnus was known by the Șūî̀s as a great ' $\bar{s} h \imath q$ was a highly respected view. But this notion, in the biased view of the Persian-imitating poets, was somewhat belittling, and many of the biographers would not even describe him as a Șūfi. These points suffice to show that the early poets did not have a very good opinion of him. The author of the Dih-murghname, even though he was a poet whose work is full of Șūfì ideas, could not use respectful language with regard to Yūnus Emre. ${ }^{57}$ Similary, Vehbî spoke of his hymns with downright ridicule and scorn. ${ }^{58}$ Yet even this attitude, expressed in various periods, is significant historically as pointing to Yūnus's unshakable fame among the people.

Thus, despite the inadequate documentation in our possession, it is clear that Yūnus Emre exercised enormous influence for centuries over the Turks in Anatolia, Rumelia, and even Azerbaijan; and his fame has survived up to the present, overcoming all the vicissitudes of his time. This influence, whose causes and consequences I will try to explicate in the last chapter, was not confined to just one period, one milieu, or a certain class, but was propagated from the highest intellectual and cultural level down to the lowest and, therefore, we must recognize Yūnus Emre - after Ahmmad Yasawī - as the most renowned poet to appear among the countless Turkish poets who flourished over the centuries and the one whose work has been the most enduring. The influence of Yūnus Emre on the Anatolia Turks and their mystical folk literature was of the same nature and extent as that of Ahmad Yasawī on the Eastern Turks. In the following pages, I will also show the relationship and similarities between the two. The cry of Yemen illerinde Veyse'l-Karanî, which is raised most evenings in the poor and almost deserted streets of Istanbul and Anatolia in a lonesome and melancholy strain, and the simple and beautiful hymns that issue from the large, broken, iron-grilled windows of the neighborhood schools, and are always recited with special melodies in the mevlid assemblies \{generally in a mosque or a private home $\}$ and in the tekkes, show that Yūnus Emre is still very much alive among 
the people and that he still dominates the popular spirit. Our biographers, who considered art to consist of imitation and artificiality, did not appreciate the importance of this popular Șūfì poet because he wrote according to the popular taste in the folk meters and language. But, in fact, he is a most worthy figure of study in our literature. A man whose work is still recited, after six centuries, among all classes of people and in all parts of the country with passion and enthusiasm must surely be considered a rare representative of the national taste. ${ }^{59}$

\section{NOTES}

1 I have provided some information above on the nature of the Bektashī tradition, on the period of its formation, and on its firm establishment (Chapter 4, pp. 102-5). The Bektashīs tried to increase the prestige of this tradition by mixing historical personalities, such as Sayyid Maḥmūd Ḥairān̄i, Jalāl al-Dīn Rūmī, and Ḥājjī Ibrāhīm Sultān, who had won fame in Anatolia in the seventh/thirteenth century, into their own legends. Not only are legends about these figures found in the velayetnāmes, they are also mentioned in a long poem entitled Khadirnāme that \{the Bektashī saint\} Muhȳī 'l-Dīn wrote in 880/1475-6 \{MS in Köprülü's private library\}. The waqf document of Sayyid Mahmūe Hairānī, which was drawn up in 655/1257-8, and that of Hājjjī Ibrāhīm Sulțān, which was drawn up in 665/1266-7, have survived to the present and are still in force. Consequently, the historical nature of these personalities and their time is fairly well known. Here I only want to point out, in particular, that those Șūfìs who were genuine historical figures and were mentioned as having a relationship with Hājjī Bektash lived in either the seventh/thirteenth or early eighth/ fourteenth century.

2 Unfortunately, the linguistic research that has been done to date on the word emre has not yielded anything very definite. Let me simply describe the various theories that have been proposed on this matter and indicate the one that I support. Hammer read this word as a variant of imre in his famous Geschichte der osmanischen Dichtkunst \{bis auf unsere Zeit (Pest, 1836-8)\} and wanted to equate it with the same word in Hungarian meaning ' $\bar{a} s h q$. He indicates this by translating it into German as emmerich. Necib Âsım says that this word, which was used in the form amrak, emre in Turkish and imre in Hungarian, means 'áshıq. Rizâ Tevfik also simply accepts Hammer's theory, saying "There is no doubt that imre means ' $\bar{a}$ sh $q$, that is, "poet'; other meanings are random conjectures that can be easily rejected," (\{Yûnus Emre hakkında biraz daha tafsilât,"\} Büyük Duygu, nos 10-13, \{1 (1331/1913), \} p. 178). However, as Karl Foy has quite rightly objected, this is a very whimsical explanation that is based on no evidence whatsoever ("Die ältesten osmanischen Transscriptionstexte in gothischen Lettern," p. 237). Indeed, as Foy also very correctly writes, the forms emre or emrem are found in all the early texts having vowel marks, but the form imre is not. J. H. Mordtmann agrees with this and gives the following noteworthy information on this subject: "The exact meaning of the word emre is not known. The former owner of the copy of T. Bianchi's dictionary \{Dictionnaire Turc-Français (1835; reprinted Paris, 1871)\} that is in my possession records next to this word that it meant 'brother' in old Turkish, but he does not give an example. I can give one, however. In the introduction to the ferman \{edict\} given to Ghāzī Evrenos Bey, and published by Diez \{'Murat I, Sultan of the Turks. Abschrift [und Text] der Stiftungs- und Statthalterschafts-Urkunde ...,' Denkwürdigkeiten von Asien, 2 (1815), 101-32\}, the word occurs in the meaning of 'brother,'” (\{“Türkisches zu Foy’s 'älteste osmanische Transscriptionstexte,'” Berlin Universität, Seminar für Orientalische Sprachen, Mitteilungen, Westasiatische Studien, 5 (1902),\} 
p. 168). Mordtmann goes on to say that this word was written in different ways - such as emrem, emirem, emir, emre - in various copies of this ferman. It is found, in fact, as emre in the copy of this ferman in Ferîdûn Bey's Münşeat (Münşeat-ı selâtîn \{Istanbul, 1274/ 1857-8\}, vol. 1, p. 87); as emir in a manuscript copy that appears to have been written in the eleventh/seventeenth century and is in my private library; and as emrem in a berat \{sultanic diploma, letter-patent\} in the Königlichen Bibliothek zu Berlin \{now the Staatsbibliothek\} and published by F. Kräelitz (\{"Ilk osmanlı padişahlarının ısdar etmiş oldukları bazı beratlar,"\} TOEM, no. $28\{1330 / 1912\}$, p. 246). In a footnote, Kräelitz states that this word is a mistake for emirem, but this is a strictly subjective interpretation. If we refer to the opinions of the early writers on this matter, we find that the author \{Mehmed b. Ahmed Nişânci-Zâde\} of Mir'ät al-kä'ināt \{MS 2420 in the Nuruosmaniye Library in Istanbul $\}$ says that the word emre means "eldest brother," thus supporting Mordtmann's opinion. In my view, the opinion of Shaikh Ismā'îl Haqqī Bursawī \{Bursalı Shaikh İsmâ'îl Hakkı, d. 1137/1725, see $E I^{2}$, s.v. "Ismā̄îl Hakkị”" (Günay Kut)\} is perhaps closest to the truth. He says, Emre zâhir budur ki Türkìde elkâb-ı medihdendir. Etrâk arasinda Atabeg ve Rûmiyân meyânnda lala ve emsâli gibi \{Evidently emre is an honorific title in Turkish, similar to atabeg among the Turks and to lala and the like among the Ottomans\} (Şerh-i Rumûzât-ı Yûnus Emre, copy in my private library). This explanation of the word emre shows rather clearly that the word emrem in the berat \{in this case granted by Bayezid I (1389-1402)\} of Evrenos (Evren-uz) \{this etymology is dubious; see $E I^{2}$, s.v. "Ewrenos" (Irène Mélikoff)\} Bey, was used instead of atabeg-i devlet \{"father bey of state," minister\} and indeed meant "elder brother." We know that in addition to titles like ata and $b \bar{a} b \bar{a}$ for Turkish shaikhs, the word akhi was especially used at that time in the meaning "brother." It is very likely that the words emre and emrem were the Turkish equivalents of the titles akh and $a k h \bar{\imath}$. Despite all my research to date, I have found no additional information to shed light on this subject, in either the major contemporary linguistic sources, such as \{Abū Hayyān al-Gharnāț̣̄s\} Kitāb al-idrāk li-lisān al-aträk \{712/1313\}, \{the anonymous\} Tarjumān-i turkī wa' arab̄̄ $\{743 / 1343$, ed. Houtsma as Ein türkisch-arabisches Glossar $\}$, and \{the anonymous\} al-Tuhfa al-zakiyya fì'l-lugha al-turkiyya \{eighth/fourteenth century, ed. T. Halasi-Kun as La Langue des Kiptchaks (Budapest, 1942),\} or in \{al-Kāshgarī’s\} Dĩwān lughāt al-turk \{begun in 464/1072 and completed in 469/1077\}. If the seventh/ thirteenth- and eighth/fourteenth-century works from Anatolia that are in our possession were subjected to lengthy and detailed linguistic analysis, or if valuable new documents from that period were to appear, perhaps this minor linguistic problem, like a great many others, could be more definitely solved. The views that I have advanced are the most defensible based on our current knowledge.

3 Sarı Ismā'îl was very famous in the Bektashī tradition. He was one of the leading khalîfas of Haājjī Bektash. One comes across a great many legends concerning him in the velāyetnāmes, but unfortunately we have no information on his \{true\} historical existence. But if we consider how the Bektashi tradition was created by blending the available legends, we can grant the possibility that a dervish with this name lived in western Anatolia in the seventh/thirteenth century or early years of the eighth/ fourteenth century.

4 According to the Bektashī velāyetnāmes and the Khadirnāme, Qaraja Ahmad was one of the great saints of Anatolia who received spiritual enlightenment from Hājjī Bektash. \{Tashköprü-Zāde's\} al-Shaq a’iq also mentions him among the high officials during the reign of Orhan. According to that source, his father was a king of the country of the Persians. He himself went to Anatolia because he was overwhelmed by mystical rapture. He lived and died near Akhisar. Subsequently, his tomb gained fame among the people for curing the ill (al-Shaq $\bar{a}^{\prime} i q$, \{Turkish\} trans., vol. 1, p. 33). Citing Bektashī tradition, 'Ālì also describes his importance, Ol tarihte Rûm-erenleri'nin kutb-ı nâm-dân 
Karaca Ahmed Sultân idi; Sivrihisar'da sâkin Seyyid Nûre'd-Dîn nâm 'umde-i vâsılîn terbiyesiyle seccâde-nişîn olmuştu, asrnnda elliyedi bin mürîd-i hidâyet-nüvîd, Karaca Ahmed Sultân' in taht-ı hükmünde bedid idi \{At that time, the most famous of the saints of Anatolia was Qaraja Ahmmad Sulțān. He became the chief of a religious order under the tutelage of a leading mystic named Sayyid Nūr al-Dīn, who lived in Sivrihisar. During his time, 57,000 disciples seeking spiritual guidance appeared under the authority of Qaraja Ahmad Sulțān\} (Kunh al-akhbār, vol. 5, p. 55). E. J. W. Gibb thought that there was good reason to doubt the veracity of 'Âlî's information on the shaikhs of this early period. Of course, if he had known that this information derived from the Bektashī velāyetnāmes, he would not have given it any credence.

5 Lexicons such as \{Abū Hayyān al-Gharnāțīs $\}$ al-Idrāk, \{the anonymous\} al-Tuhfat al-zakiyya, and \{the anonymous\} Tarjumān-i turki wa' arabī, which are the most important linguistic sources for this period, give the following definitions: tapmak = to find; tapışmak = to get together, to meet; tapşrmak = to bring people together, to have people meet; tapu, tabu = service; serving God, worship; tapu eylemek = to serve; tapuci, tabuci $=$ servant. The semantic development through which this word - which today we also use to mean "to worship" - gradually passed appears here very clearly. This word was first used simply with the meaning "to seek out." Then it gradually began to express the concept "to seek out God, to reach God, to adore and worship God." Mehmed Tâhir Bursawī \{Bursalı Tâhir\} says that in the vicinity of Erzurum the word tapdak is used to mean "smooth, even" \{düz, ânzasiz\} (Osmanl müellifleri \{Istanbul, 1334-43/ 1916-25\}, p. $194\{s i c$; it is unlikely that this has anything to do with tapduk\}). The explanation given here suffices to indicate the meaning of tapduk during the period in question $\{$ i.e. served, worshipped .

6 Veläyetnāme-i Häjji Bektash Velī, fo. 30 (cited from the copy in my private library \{see the Gölpınarlı edn, p. 21\}). This is also mentioned in the section entitled \{ وربيان آمدن حاجى بكتاش بروز باجازت خواجد اتمد يسوى Bektash in Anatolia by permission of Khwāja Aḥmad Yasawī $\}$ in the versified version of the Velāyetnāme \{also in Köprülü's private library\}. Originally written in prose by Firdevsī $\{-i$ Rumi, d. after 1500$\}$, this work was later versified in approximately 6000 couplets by a novice poet with the pen name Nihānī at the behest of Faiḍ Allāh Efendi, a descendant of Hājjī Bektash. The historian 'Ālī also mentions this legend in his history, citing the Velàyetnāme (Kunh, vol. 5, p. 56).

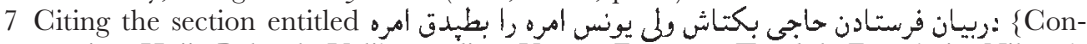
cerning Hājjī Bektash Veli's sending Yūnus Emre to Tapduk Emre\} in Nihān̄̄'s versified version of the Veläyetnāme. The historian 'Âli also briefly reports this story of the Velāyetnāme in the sentence Yûnus Emre hizmet-i âlîlerinde iken terbiyetini Tapduk Emre'ye bunlar buyurmuşlarder \{While Yūnus Emre was in the service of the exalted one (i.e. Hājjīi Bektash), he ordered him to receive his training from Tapduk Emre $\}$ (\{Kunh, vol. 5,$\}$ p. 57). In the prose version of the Velayetnāme, there are a few more minor details on this subject that were ignored when this work was rendered into verse. According to this text, Yūnus was occupied with plowing and sowing at a place called Sar1-göl north of Sivrihisar; and after he entered the service of Tapduk Emre, he carried wood on his back for fully forty years for the convent (Veläyetnäme, fo. 68 ssee the Gölpinarlı edn, pp. 48-9\}).

8 In addition to these, we also find in the poetry of Yūnus Emre the pen names Miskīn Yūnus, Dervish Yūnus, Koja Yūnus, or simply Yūnus. We encounter the same kind of thing; that is, a poet using various forms of his pen name, with Ahmad Yasawī. No historical authority can be given to the reports that Yūnus Emre had a khalîfa named 'Āshıq Yūnus. While discussing the burial places and graves of Yūnus Emre below, I will state the source of this report, which appears at the beginning of the published edition of his Dīwān. The Russian Orientalist Melioransky also mentions an 'Āshıq 
Yūnus as a disciple of Yūnus Emre, but this results from his uncritical acceptance of this report in the Dīwān ("K voprosu o znachenii i proiskhozhdenii slov 'chäläb" (chalap) i 'chäläbi' v turetskom iazyke," \{ZVO, (St Petersburg), 15 (1902-3), pp. 36$43\})$. The $m \bar{m} m(\hat{p})$ at the end of the word emre'm is the possessive pronoun like that at the end of the words paşam and hactm. It is not part of the original word. Indeed, we know of various examples of contemporary Sūfīs who had such additions to their names. Thus, 'Āshıq Pasha-Zāde mentions 'Āshıq Pasham and Kochum Seydî (\{Tawārn̄kh-i a $\bar{l}-i$ 'uthmān,$\}$ p. 199). Another well known example is Hājjim Sulțān, a khalîf $f$ of Hājjī Bektash, many of whose legends have been recorded and even published.

9 Al-Shaq $\vec{a}^{\prime} i q$, among the personalities of the fourth tabaqa, published on the margins of Ibn Khallikān, p. 119 \{i.e. published on the margins of the Būlāq edition of the Wafayat in 1300/1882\}. Al-Shaq $\bar{a}^{\prime} i q$, \{Turkish\} trans., and supplement $\{$ Hada' $i q\}$, vol. 1, p. 78.

10 Based on the couplet Tarih dahi yediyüz yedi idi / Yûnus cân bu yolda kodı idi \{The date was 707 (1307-8) / when Yūnus set his heart on this path\}, which is found in Yūnus Emre's Dīwān and to which Walad Chelebi first drew attention, the Orientalist E. J. W. Gibb considers him to be a Șüfi who lived at the end of the seventh/thirteenth and beginning of the eighth/fourteenth century (A History of Ottoman Poetry, vol. $1\{$, p. 165\}). Mehmed Tâhir and Necib Âsım agree with this (Mehmed Tâhir, Aydin vilâyetine mensûb ricâlin terâcim-i ahvâli \{(Izmir, 1324/1906), new ed. M. Akıf Erdoğru (Izmir, 1994)\}, the section on Yūnus Emre; Osmanh müellifleri, vol. 1, p. 193; Âsım, Millî arûz, [Istanbul, 1329/1911], p. 7). Melioransky, who was aware of studies on Yūnus Emre by Gibb, Foy, and Mordtmann and who also had recourse to \{Tashköprü-Zāde's al-Shaqā'iq and \{Shams al-Dīn Sāmī's\} Qāmūs al-a'lām, gives the following opinion in order to defend the information on Yūnus Emre provided by al-Shaq $\bar{a}^{\prime} i q$ and refute Gibb: "Reading these couplets, Mr Gibb concludes that the date given by TashköprüZāde is mistaken and that Yūnus Emre lived a hundred years before that date. In my view, however, such a deduction is baseless. The problem arises from the fact that, shortly before these couplets, there are other couplets praising uprightness. Consequently, in my view, we are completely justified in saying that what this couplet states is that Yūnus Emre should be included among the murìds of Tapduk Emre, who is called Șăhib-i irshād \{the one who guides on the right path\} by Tashköprü-Zāde. How old could Yūnus have been when he set out on this path? I cannot answer this question directly, but it is worthy of note that the Central Asian Șūfìs joined the tarīqas at a very young age. As Gibb has stated, for example, the famous Khwāja Aḥmad Yasawī, who has some points in common with Yūnus Emre, says several times that he entered the service of Shaikh Arslan Bābā at the age of seven. Thus, there is some basis for us to conclude that Yūnus Emre was a child when he entered the tañqa in $707\{1307-8\}$. In that case, he could undoubtedly have lived until the early years of the sultanate of Bayezid I. If we were eventually to learn that 707 was simply Yūnus Emre's date of birth, I personally would not be the least surprised" (Melioransky, " $\mathrm{K}$ voprosu o znachenii"). Hammer's discussion of this matter is very confusing and erroneous. In one place in his book \{Geschichte der osmanischen Dichtkunst\}, he writes, without giving a source, that he was a poet during the reign of Süleyman the Magnificent (926-74/1520-66), while in another he indicates that he was a poet of the eleventh/seventeenth century. Similarly, he mentions these two Yūnus Emres in the index as the same person, but he says nothing about when they lived. G. Flügel also considers him to be a poet of the tenth/sixteenth century (Mordtmann, "Türkisches zu Foy's").

11 Indeed, in this tradition, which was fixed in such works as the Velāyetnāme and Khadimāme, he is always mentioned among Șūfis of the seventh/thirteenth century. A few of these, such as Qaraja Ahmad and Yūnus Emre, could have lived into the eighth/fourteenth 
century. In my opinion, this evidence of the Bektashī tradition is very valuable and worthy of credence in determining the time when Yūnus Emre lived.

12 'Āshıq Pasha-Zāde, Tawärīkh-i äl-i'uthmān, pp. 199-200.

13 If there were no other evidence, by itself this would mean nothing, for it is also occasionally reported, mistakenly, in the $\mathcal{F} \bar{a} m i^{`}$ al-naz $\bar{a}$ ir that an earlier poet composed imitations $\left\{n a z \bar{a}^{\prime} i r\right\}$ of another poet who came after him. But when this is added to the other evidence, Hacı Kemal's testimony on this matter gains additional value.

14 Foy, "Die ältesten osmanischen Transscriptionstexte in gothischen Lettern," 4 (1901). In this work, entitled Tractat, which appeared in the fifteenth century, had many readers as late as the seventeenth century, and was published in many editions, there is, among some miscellaneous information on the Turks, the text of two hymns by a poet named Yūnus. They are written in Gothic letters and are accompanied by a Latin translation. Foy devoted extensive research to these hymns (ibid., 4 [1901], 5 [1902]), especially with regard to linguistic history. They also attracted the attention of J. H. Mordtmann, M. Hartmann, Brockelmann, and Houtsma. Foy did not believe that these hymns belonged to Yūnus Emre, but they must in fact be his, as Mordtmann and Hartmann conceded. Anyone who is somewhat familiar with the works of Yūnus Emre will conclude that, linguistically and stylistically, the passages that I will include in the next chapter can only be attributed to Yunus Emre. Furthermore, in that period, there was no other Șūfì poet named Yūnus to whom it might be possible to attribute these works. The anonymous recorder of these hymns, who was only fifteen or sixteen years old when taken prisoner at the Ottoman capture of the fortress of Mühlbach and who remained among the Turks a full twenty years, being sold seventeen times, states that he knew Turkish language and literature very well and that Turkish khwäjas \{masters, religious scholars\} even took lessons from him. If Yūnus Emre, who lived in one corner of Anatolia, had died in 843/1439-40 - that is, one year before Mühlbacher was taken prisoner - his works would not have been sufficiently widespread and famous for him to know about them and to record and translate in preference to other works of this kind. To my way of thinking, this problem can be solved very easily. It is quite natural that the hymns of Yūnus Emre, who lived one century earlier than Melioransky conjectured, whose legends were famous enough to enter Bektashī tradition, whose historical personality had been forgotten, and whose works had spread in all directions, would have been recorded and translated by Mühlbacher in preference to other such works. On the one hand, this reveals the fame of Yūnus Emre at that time and, on the other, it supports Mühlbacher's claim that he knew the contemporary literature of the Turks fairly well. Hammer also mentions Mühlbacher's captivity and his work, which was first printed in 1530 (Hammer, \{Geschichte des osmanischen Reiches, Turkish\} trans., vol. 2, pp. 205, 350).

15 In certain poems in the various printed and manuscript copies of Yunus Emre's $D \bar{\imath} w \bar{a} n$, one finds praise and veneration of, or else allusions to, some of the great Șūfis who came after Yūnus Emre, such as Hājjī Bayram Veli or Amīr Sulțān. In the hymn with the refrain Bize dervişler geldi \{The dervishes came to us\}, for example, Hājjj̄ Bayram is mentioned.

\section{Hacı Beyram-İlinde Bergüzâr var elinde Şeker damlar dilinde Bize dervişler geldi}

\{n the province of Hājjī Bayram, With gifts in their hands, With sugar dripping from their tongues, The dervishes came to us.\} Now, Hājjī Bayram died in 833/1429-30. Similarly, there are passages in Yūnus Emre's Dĩwann that describe Shaikh Shams al-Dīn Muḥammad b. 'Alī Husain al-Bukhārī, known as Amīr Sulțān, who died in the same year, such as the poems that end with the following couplets: 
Bahr-i isyândan halâs olmağ için ihlâs ile Sidk ile Sultân Emîr'in eteğini tutalım

Yûnus Emre söyler sözü, âşı olmuş gönlü gözü Unutman duâdan bizi Emîr Sultân Türbesinde

Yûnus sana cândan tutmustur özü

Hem mübârek rûhuna sürer yüzü

Efendim ceddine ulaştr bizi

Yeşil tonlu Emîr Sultân merhabâ

\{To be rescued from the sea of rebellion, with sincerity,

With honesty, let us grasp the skirt of Sultān Amīr.

Yūnus Emre says the words. His heart and eyes have become lovers.

Do not forget us in your prayers, in the tomb of Amīr Sultān.

From his heart Yūnus clings to you,

And rubs his face (in the dust) at your blessed spirit.

My lord, convey us to your ancestor.

Amīr Sultān with the green cloak: Greetings!\}

In addition to this Amīr Sulțān, on whose behalf the poet Ạ̣mad Pasha wrote the famous eulogy containing the stanza Ey âlem-i Velâyete Sultân olan Emîr / Ve'y mülk-i Rûm'a Rahmet-i Rahmân olan Emîr \{Oh Amīr, who is sultan of the realm of saintliness / Oh Amīr, who is compassion of the Compassionate to the Kingdom of Rūm\}, there are other Amīr Sultāns buried in Izmir and Üsküb, but the poems in Yūnus Emre's Dĩwān evidently relate to the original and famous Amīr Sulțān. Would not the fact that Yūnus Emre recited poetry about these Șūfìs who died in 833 confirm the view that he died in 843 rather than the idea advanced by Melioransky that he was born in 707? \{Still, $\}$ as I will demonstrate in detail when speaking of Yūnus Emre's Dīwān in the next chapter, the Dǐwan currently in our possession is not composed entirely of passages belonging to Yūnus Emre. The works of a number of subsequent poets even including other poets with the pen name Yūnus - are mixed into it. Therefore, we can definitely conclude that neither the passages concerning Hājjji Bayram nor those concerning Amīr Sultān were written by Yūnus Emre.

16 It is clearly stated in the Bektashī tradition that he was from Sivrihisar. The translator of \{Tashköprü-Zāde's\} al-Shaqā'iq writes that he was from Bolu (p. 78), whereas the author of that work does not specifically state where he was from, but simply states that he was a disciple of Tapduk Emre (on the margins of Ibn Khallikān, \{Wafayāt, $\}$ vol. 1, p. 119). Shams al-Dīn Sāmī indicates that he lived at the confluence of the Sakarya and Porsuk rivers, but Melioransky disagrees and claims that this resulted from emending the information provided by Tashköprü-Zāde on Tapduk Emre. The truth is that this account in Sāmī's Q Qāmūs al-a'lām derives from the material about the tomb of Yūnus Emre given in Lāmi î̀s supplement to his \{Turkish\} translation of \{Jāmī's\} Nafahăt (Nafahāt trans., p. 691). Because I will discuss his tomb at length below, I will not go into the subject here. Let me simply say that, although it is not possible to assert with certainty where Yūnus Emre was from, it could not be far wrong to believe that he was born in the vicinity of Bolu.

17 In the works of Yūnus Emre, there are quite a few passages showing this. Shaikh \{Shams al-Dīn\} Muḥammad Niyāzī Miṣrī \{d. 1105/1694, see $E I^{2}$, s.v. "Niyāzī" (F. Babinger); Baha Doğramacı, Niyazi-yi Misri hayat ve eserleri (Ankara, 1988); Mustafa Kara, Niyazi-i Misri (Ankara, 1994); and Derin Terzioğlu, "Sufi and Dissident in the Ottoman Empire: Niyazi-i Misri (1618-1694)," dissertation, Harvard University, 1999\}, for example, also supports this notion in the commentary that he wrote on the poem 
Çıktı erik dalına anda yidim üzümü / Bostan ısı kakıyıb der ne yersin kozumu \{I climbed up the plum tree branch and there ate grapes / The garden's owner became angry and said, "Why are you eating my walnuts?"', which was very famous among the Sūfiss: İmdi Azîz'in bu beyitten muradlar, mürşîdsiz ben şarîat ve tarikat ve hakikati kendi bildiğgimin ile indîce sülûk edüb vâsıl-ı Hak olurum dìy sa'y edenlerin ahvâlini temsîl tarikiyle beyân etmektir. Yâni, böyle eden kimsenin hâl-ü şân, kang meyve ne șecerden bittiğin bilmeyib, gönlü üzüm istedikte, erik ağacondan biter dive erik ağacondan arayan, gönlü erik istedikte ceviz ağacondan erik biter dive ceviz ăgacina çıkan bî-akl kimseler gibi olur. Meselâ, ámâ olan kimse cümle renkleri siyah sandiğg gibi ... Azîz, bu hâli kendisine nisbet eylese câizdir; bir zamân böyle mürşî̉siz çalı̧ııı birşey hâsıl edemeyib, sonra mürşid-i kâmile mukârin olmus ola \{Now what the saint intended by this couplet was to express allegorically the condition of those who try to teach Divine Truth without a spiritual guide, merely following subjectively what they know concerning the Sharĩ a (sacred law), tarīqa (mystical path), and haqūqa (truth). In other words, the condition of someone who does this is like that of those who do not know what fruit grows from which tree. They are like ignorant ones who, desiring grapes, look for them on a plum tree because that is where they think they grow, or desiring plums climb up a walnut tree because that is where they think they grow. This is like someone who is blind thinking that all colors are black. The saint must have compared this situation to his own. He once exerted himself in this way without a spiritual guide, but he was unable to achieve anything. Then he attached himself to a perfect guide (and was successful)\} (commentary \{Sharh-i nutuq-i Yünus Emre\} published on the margins of the Dīwān of Yūnus Emre \{Būlāq, 1254/1838-9\}).

18 'Āshıq Pasha-Zāde, Tawārīkh-i āl-i 'uthmān, p. 200; \{Tashköprü-Zāde,\} al-Shaqā'iq, p. 119; al-Shaqa’’iq, \{Turkish\} trans., vol. 1, p. 78; \{Sa'd al-Dīn,\} Tāj al-tawārīkh, vol. 2, p. 429. Shaikh İsmâ'îl Hakkı says both Tapduk Emre and Yūnus Emre Anadolu'da Keçiborlu nâm kasaba kurbünde olan gadîr-i 'azîm'in cânib-i şarkîsinde olan puşte tarafinda bir karyede neşv-ü nemâ bulduklarm \{grew up in a village by a hill east of a large pond near a town named Keçiborlu in Anatolia\} (from the commentary Sharh-i rumüzät-i Yünus Emre\} that he wrote on the poem Craktrm erik dalina, fo. 12 in the MS in my private library). I will discuss this problem below while dealing with the burial places of Yūnus Emre.

19 This is a legendary report that is widespread among the dervishes, but it has no historical value. One or two hymns in the Dĩwān of Yūnus Emre, which have the refrains Abdü'l-Kâdir gibi bir er bulunmaz \{There is no er like 'Abd al-Qādir\} and Meded et Sultânm Şeyh Abdï'l-Kâdir \{Shaikh 'Abd al-Qādir is my helper and sultan\}, have given rise, I think, to the belief that both Yūnus Emre and his shaikh were Qādirīs (Mehmed Tâhir, Osmanlı müellifleri, vol. 1, p. 192). We have no knowledge, however, of the presence of the Qādiriyya in Anatolia at that time. There were then Rifā' $\overline{1}$ tekkes in Anatolia, so it would be more reasonable to assert that they were Rifầis. As will be seen from the discussion in the next chapter on Yūnus's D $\bar{\imath} w \bar{a} n$, it is virtually certain that these hymns do not belong to Yūnus Emre. \{On the hymn with the former refrain, see Mustafa Tatçı, Aş̧ı Yunus ve diğgr Yunuslarn şïrleri (Ankara, 1991), p. 61.\}

20 Shaikh İsmâ'îl Hakkı gives the following important account on this matter: Nezîl olduğum Bursa'dan bitariki'l-hac Antakya tarafina sevk-ı esb-i 'azîmet edib kasaba-i mezbûre nevâhîisinden mürurumda orada mâder-zâd olan ehl-i tarikatten birine mülâkî oldum. Kavl-i mervâridvârm bu vechile âvîze-i gûş̧um eyledi ki: Mukaddemâ Buhâra cânibinde istilâ-yı etrâktan sarsar-ı

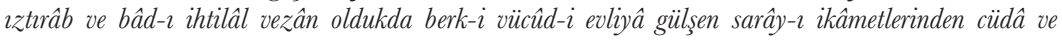
perî̧an oldukda ez-cümle Şeyh Sinan Efendi nâm bir 'azîz-i enâm sahrâ neverd-i sefer olarak Şeyh Yûnus Emre karyesine firukeş edib Tapduk Emre'yi irşâd eylemiş, ba'de'z-zamân Yûnus Emre zuhûr edib ol dahî zâhiren ve bâtmen Tapduk'a tapu kılmış ve yedinden câm-i ser-şâr-ı feyz nûş etmiş, nitekim buyurur: Yûnus bir doğan idi / Kondu Taptuk eline / Av ve şikâre geldi / Bu yuva kuşu değil \{ I set out on horse from Bursa, where I was stopping, toward Antakya on the 
pilgrimage road and passed through the region of the aforesaid town. I met a member of the tariqa who was native to that place and I lent an ear to his pearl-like words. He said: "A long time ago, when the storm-wind of disquiet and suffering blew in the region of Bukhārā from the invasion of the Turks (i.e. Mongols) and the petals of the saints were blown helter-skelter from the rose-garden palace of their residence, one of them, a saint of mankind named Shaikh Sinān Efendi, traveling in the wilderness of wandering, sojourned in the (future) village of Shaikh Yūnus Emre and became the spiritual guide of Tapduk Emre. Some time later, Yūnus Emre appeared and served Tapduk outwardly and inwardly, drinking from the cup of abundant enlightenment. As he states: 'Yūnus was a falcon / he alighted on Tapduk's hand / he went hunting and in search of prey / this was not a nesting bird' "\} (commentary \{Sharh-i rumūza $\bar{t}-i$ Yünus Emre\} on the same ghazal, same folio). Although this dervish tradition, recorded two centuries ago, is not to be found in any other source, that is no reason to completely discount its importance. The time when Tapduk Emre was alive corresponds quite well with the time when Shaikh Sinān of Bukhārā arrived in Anatolia after migrating because of the Mongol invasion. According to the account that I gave in the first part of this book on the spread of the Yasawiyya, it is quite likely that this shaikh was a Yasawī dervish. We cannot exclude the possibility that the influence of Ahmad Yasawī, which is frequently encountered in the works of Yūnus Emre, can be partially ascribed to this event.

21 Tashköprü-Zāde records this in particular,

$$
\text { ولم يوجد فيها حطب معوج أصلا فساله الشيخ عن ذلك فقال لا يليق بهذا الباب شئ معوج }
$$

\{There was not a single piece of bent firewood. When the shaikh asked him about this, he said, "Nothing crooked is worthy of this gate," al-Shaq a'iq, Furat edn p. 57\}. The translator also cites this, embellishing it with a stroph of Persian that discusses the benefits of uprightness. In the history of Șüfìsm up to the time of the Bektashī tradition, one often finds incidents similar to this story of the firewood. In the legends of certain Yasawi shaikhs, it is stated that they reached the rank of spiritual guide by carrying wood to the dervish dargāh (\{Hazīnī, \} Fawähir, p. 279). Similar things are found in the legends of other Șūfis. When Shaikh Abū 'l-Ghaib Jamīl al-Yamanī went out into the open country to collect wood, a lion ate his donkey. As punishment, he loaded his wood on the lion and brought it in (\{Jāmī,\} Nafahăt, \{Turkish\} trans., p. 641). Similarly, Sayyid Ahmad al-Bukhārī was the wood gatherer for the famous İlâhî-i Simâvī dargāh (ibid., p. 466). \{It is curious that Köprülü did not link this story with the accounts of Hakīm Ata.\}

22 Thus, in various copies of his Dĩwann, I have come across such passages as the follow-

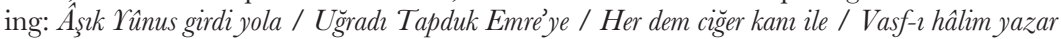
oldu \{The lover Yūnus entered upon the path / He visited Tapduk Emre / Every moment with his heart's blood / He writes the attribute "the Forbearing" \}; Yûnus eydür azıklyım / Tapduk’umuz dost yüzüdür / İşte bu söze inanmayan / Bunda bulsun ettiğini \{Yūnus says: I am provided for the journey / Our Tapduk is the face of the Friend / Those who do not believe these words / Will find what they have done here (i.e. will get their just deserts in this world?)\}; Yûnus Emre'm sen tek otur / Da'vâ-yn ma'nâyı bitür / Tapduk'leyin bir er getür / Câna başa kalmaz ola \{Yūnus Emre, you sit quiet / Finish your claim to (spiritual) meaning / Bring a man (or, saint) like Tapduk / Let nothing remain (?) for soul and head\}; Yûnus sen Tapduk'a kılg̨l duâlar / Aş̧ılar meydân 'arş'dan uludur \{Yūnus, recite benedictions for Tapduk / The field of the lovers is bigger than God's throne\}; Miskin Yûnus bu sözü cân içinde söyledi / Söyleyen de b̂̀-haber Tapduk Emre kârnder \{Miserable Yūnus said these words in his soul / The sayer was unaware that it was the work of Tapduk Emre\}; Yûnus sen Tapduk'una kıl duâlar / İ̧me sen zehr-i kâtil aşk 
elinden \{Yūnus, recite benedictions for Tapduk / Do not drink lethal poison from the hand of Love\}; Aşk sultân Tapduk'tur, Yûnus gedâ ol kapuda / Gedâlara lûfteylemek kâidedir Sultâna \{The sultan of Love is Tapduk and Yūnus is a beggar at the gate / Kindness to beggars is a rule for sultans\}; Yûnus'tur bunu söyleyen / Tapduk'a kulluk eyleyen / Din yoksulun bay eyleyen / Ol Subhâna'llâh değil mi \{It is Yūnus who says this / Who serves Tapduk / Is it not that Praise of God / Who makes rich the one who is poor in religion?\}; Tûnus yine esrüdi Tapduk yüzün görelden / Meğer anin elinden bir cur'a şerbet içmiş \{Again Yūnus has been intoxicated, ever since he saw Tapduk's face / Perhaps he has drunk a cup of wine at his hand\}; Miskin Yûnus bilişeli / Cân-ü gönül verişeli / Tapduk'uma erişeli / Gizlü râzzm açar oldum \{Ever since miserable Yūnus became acquainted / Ever since he gave up heart and soul / Ever since I attained Tapduk / I have begun to reveal my secrets\}; Sorun Tapduk'lu Yûnus'a bu dünyâdan ne anladı / Bu dünyânnn karan yok, sen ne imiş, ben ne imiş \{Ask Tapduk's Yūnus what he understands of this world / This world has no stability. What are you? What am I?\}; Yûnus esriüiben düstü sokakta / Çağrrr Tapduk'una 'âr gerekmez \{Yūnus got drunk and fell in the street / He calls Tapduk - no need to be ashamed!\}; Şeyh-ü dânişmend-ü velî / Cümlesi birdir er yoli \{Shaikh and sage and saint / All are one (on?) the saint's path\}; Yûnus'tur deroişler kulu / Tapduk gibi serveri var \{Yunus is slave of the dervishes / He has a commander such as Tapduk\}; Aşktrr bunca âvâzlar / Dediüim mánâ sözler / Tapduk Yûnus'u gözler / Bu vilâyet içinde \{Love is so many voices / The meaning I utter is words / Tapduk has his eye on Yūnus / Within this sainthood\}; İsrâfîl Sûr'in uncak / Her bir sûret nefsim dìye / Ben anmayam hiç Yûnus'u / Tapduk köle oldum dile \{When Isrāfîl blows his trumpet / Every form will assert itself / I will not recall Yūnus at all / Tapduk, I am your slave, command me!\}; Emre’m bir doğan idi kondu Tapduk eline / Av ve şikâre geldi, bu yuva kuşu değil \{Yūnus was a falcon. He alighted on Tapduk's hand / He came to hunt. This is no nesting bird\}. Shaikh İsmấ̂̂l Hakkı cites this last couplet in a passage of his commentary on the Muhammadiyya \{i.e. his Farah al-rüh (Şerh ül-muhammediye ül-mevsum bi ferah ür-ruh), a commentary on Yazıcı-oğlu Mehmed's Muhammadiyya (Būlāq, 1252/ 1836), see $E I^{2}$, s.v. "Yazidji-oghlu" (Edith G. Ambros)\} and comments on it as follows: بقال العارف صيد الحق ولا يكون للصيد صيد IIt is said: the knower of God is the prey of divine Truth; and the prey has no prey.\} In other words, Arifi-billâh olan Hak teâlâ

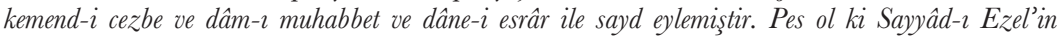
şikârndrr, âna başka şikâr olmaz. Suâl olunursa ki, Mesnevînnin ve Yûnus Emre’nin bu beyitlerinden

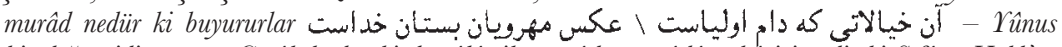

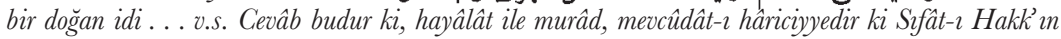
aksi ve eseridir, evliyâ ve 'urefâya dâm olduğu budur ki, her biri bir ismin ve bir sifâtın mazhar olmağla, basîret ehli âna nazar eylese bir nevi' şuhûd saydeder. Pes 'ârifin bu saydr şikâr etmesi hakikatte kendinin sayd-i Hak olduğundander \{God hunts the knower of God with the lasso of Attraction and the snare of Love and the grain of Mystery. Thus, he who is the prey of the Eternal Hunter has no other prey. If one inquires: What then is the meaning of the verse in the Mathnaw (Book 1, line 72; trans. Nicholson) "Those phantasies which ensnare the saints are the reflection of the fair ones of the garden of God"; and Yūnus Emre's verse, "Yūnus was a falcon ... etc.," the answer is: by "phantasies" (khayāāt) he means external reality, which is the reflection and the trace of the divine attributes; by "snare of the saints and the mystics" he means that each one is the locus (= place of manifestation) of one of His names and attributes, so that if people of insight look at it, that is a kind of hunting for witness (of the divine). The mystics' hunt for this prey actually results from he himself being the prey of God (= divine Truth) $\}$ (commentary on the Muhammadiyya, p. 111).

23 While commenting on a couplet in the Muhammadiyya, İsmâcîl Hakkı says, Nâzımın kelâmmnda işâret varder ki كن mazmûnu üzre bu yolun yetîmi ola. Suâl olunursa ki, Şeyh Hacı Bayram Velî irşâdin bulan nice yetîm olur ve Uveysî-meşreb kalur, cevâb budur ki sâlik 
ol sülûkten kirk sene gâyetine dek terbiyeye muhtâçtr. Hacı Bayram'in terbiyesi ise bu gâyete resîde olmamıştrr. Nitekim Şeyh Üftâde-i Bursavî dahî eğerçi sekiz sene kadar Hizır Dede ile sohbet etmiştir ve lâkin Hizur Dedénin vefâtondan sonra ser-menzil-i murâda erince ne zahmetler çekmiștir ve kezâlik Şeyh Hûdâŷ̂ dahî mezkûr Üftâde’nin vefâtnndan sonra bisyâr ibtilâ görmüşür. Nitekim

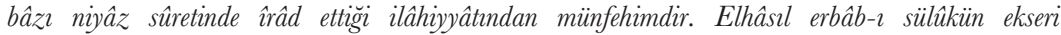
yetîm kalmıştır ve, lâkin meşreb-i pâk ehlinden cür'ảnûş olmağla irşâd-i Hakk'a mazhar olub

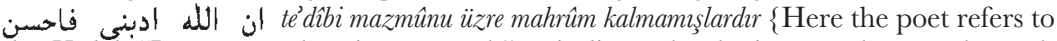
the Hadith: "I was an orphan in my youth" to indicate that he is an orphan on the path [i.e. having no spiritual guide]. If the question is asked, how can one who found the spiritual guidance of Shaikh Hājj̄i Bayram be an orphan and stay uveysi-meșreb [i.e. be of the "school" of Uways al-Qaranī, a contemporary of the Prophet who lived in Yemen and reached illumination without a guide, see Schimmel, Mystical Dimensions of Islam (Chapel Hill, NC, 1975), pp. 28, 89, 105], the answer is this, that the follower of a mystic path needs guidance on that path for as long as forty years. As for the guidance of Hājjī Bayram, it did not last that long. Similarly, Shaikh [Muhyī 'l-Dīn Muhammad] Uftāda Bursawī remained in the company of Hizır Dede for about eight years, but after Hizir Dede's death, when he reached the last desired stage [of spiritual development], he suffered great difficulties. And again, after the aforesaid Uftāda died [988/1580], Shaikh [Mahmmūd b. Faḍl Allāh b. Maḥmūd] Hüdā’̄̄ [his khalêfa, d. 1038/1628-9, see $E I^{2}$, s.v. "Hüdā'î"' (I. Beldiceanu-Steinherr)] also encountered many tribulations, as one gathers from some hymns that he recited in the form of entreaty. In short, most of the men of the mystic path remained orphans, but because they had drunk at the hand of men of pure character they became the object of God's spiritual guidance and were not deprived of the chastisement referred to in the maxim, "God chastised me and did well" [in other words, God punished me and it was an act of kindness on His part to do so] \} (commentary on the Muhammadiyya, p. 255). It appears that Yūnus Emre was fortunate: by spending forty years with his shaikh, he successfully completed all the stages of the path, and so did not remain an orphan.

24 In several of Yūnus's poems, we find passages showing that he traveled in this way from country to country. For example: Gel ey Yûnus-ı bîçâre / Var derdine eyle çâre / Gezin şöyle şardan şara / Yoktur garīb benciliyin \{Come, oh helpless Yūnus / Go, find help for your ailment / Wander thus from city to city / There is no homeless one like me\}. As a rule among the Șūfìs, except for those who preferred solitude and seclusion, it was an old custom to visit various places and travel abroad. Among the people of Anatolia, there is a widespread legend about Yūnus Emre. Supposedly, his shaikh, for some reason, ordered him to travel for forty years. After wandering about for a full forty years, he returned to his shaikh's dargāh. Finding Ana Baji - that is, his shaikh's wife - he asked her his shaikh's opinion of him. She said, "Tomorrow at the time of the morning prayer, lie down on the shaikh's path. The shaikh, of course, will ask me who you are. I will say to him, 'Yūnus.' If he asks, 'Is this our Yūnus?' understand that your ordeal has finally come to an end." The next morning Yūnus took this advice and lay down on the path. When his shaikh asked, "Is this our Yūnus?" he understood that his ordeal had finally come to an end, and as a gesture of thanks he fell at his shaikh's feet. From that day forward, by order and permission of his shaikh, he began to recite those famous hymns. This legend, which is quite reminiscent of an earlier legend concerning Zangī Ata and Sayyid Ata in the first part of this book, Chapter 4, pp. 89-94, and the Bektashī legend in section A of this chapter agree in showing the poetry of Yūnus Emre to be completely of divine origin. 
Yûnus sen de ölürsün, kara yere girersin

Mürşidlerin ulu'su ol Emre Sultân yatur

\{The saints of truth have gone from this world, every one

In Konya the lordly Mawlānā lies buried

You too will die, Yūnus, and enter the black earth

The great one of the murshids, that Emre Sultān lies buried.\}

Emr-i mürşid ile oldum Şâm’a revâne

Ne mümkindir gide Şâm’a böyle dîvâne

Murâd olan Anteb imiş çıtı beyâne

Yûnus bir nutuk söyledi Anteb’de (!?)

\{By order of my murshid, I went to Shām (Syria or Damascus)

How is it possible for such a madman to go to Shām?

It turned out that by Shām he meant 'Ayntāb

So Yūnus delivered an oration in 'Ayntāb.\}

27 As, for example, in the poems that begin: Rûm'dan çıtım yürüdüm, mûm olup sızdım eridim / Şükür Hakk'a yüzler sürdüm ne güzel Ka'be yollan \{I set out from Rūm and walked, I became a candle and melted / Thanks to God, I rubbed my face (in the dust of) the roads to the Ka'ba the beautiful\} and Edïb niyyet gittik Ka'be iline / Vardik tavaf ettik El-hamdü li'llâh / Ol cennetten çkan Hacer (-i) esved’e / Yüzümüzü sürdük El-hamdü li'llâh \{We made the resolution and went to the country of the Ka'ba / We arrived and performed circumambulation - praise be to God! / Upon that black stone which emerged from Paradise / We rubbed our face - praise be to God!\}. As I will explain below, however, there is always the possibility that these couplets do not belong to Yūnus Emre, and consequently that he did not visit the Ka'ba.

28 Vardiğgmı illere, şol safâh güllere

Baba Tapduk mánâsin aldık El-hamdü li'llâh

Açduk evi kuşladık çok hayrrlar işledik

Uş̧ bahar oldu geri gọ̈ttük El-hamdü li'llâh

Derildik pinar olduk, ayrildik trmak olduk

Şol akar sular olduk şükür El-hamdü li'llâh

Tapduk'un tapusunda, kul olduk kapusunda

Yûnus miskîn çiğ idik, piştik El-hamdü li’llâh

$\{$ To the countries where we went, to those happy roses,

We took Bābā Tapduk's spiritual message - praise be to God!

We set up house and spent the winter. We performed many good deeds.

As soon as it was spring, we migrated back - praise be to God!

We gathered together and became springs. We broke asunder and became rivers.

We became those flowing streams. Thanks to God, praise be to God!

In Tapduk's service, we became slaves at his gate.

Miserable Yūnus, we were raw. We became cooked - praise be to God!\}

29 Dost bağcesi gülünden, şükür antn dilinden

Yûnus şeyhin ilinden bize dervişler gelür

\{From the rose of the Friend's garden, thank God! From His tongue, Yunus, from the shaikh's country the dervishes come to us.\} 
30 In the long mathnawe at the beginning of Yūnus's Dĩwān, there are two separate references to this date; taken together, they must be considered definitive evidence that Yūnus died after this date (MS in my library).

Söze tarih yediyüz yedi idi

rûnus câm bu yolda fedâyidi

\{The date for this discourse was 707

Yūnus's soul was pledged upon this path

Yûnus cân doğruluğa kildr kodı

Anın çin tarîhi yediyüz yedi

\{Yūnus pledged his soul to uprightness (?)

The true date of that was 707.$\}$

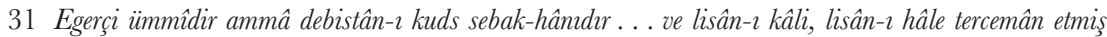
abdal ve ebrârdander ve lisân-ı gaybla, [izhâr-ı] mâ-fi'z-zamîr eden ashâb-ı esrârdandır. Mervîdir ki her bâr ki okumak kasdetmiş, hurûf-ı teheccîyi ikmâl etmeye dili dönmemiş ve âyine-i kalbi küdûrât-ı nukûş-u hutût ile donmamıs. Bedîheten bu beyti demiş: Nazar eyle ebteri, bâzâr eyle götürü / Yaradılan hos gör, Yaradan'dan ötürü \{Although he was illiterate, he was a student of the school of holiness. He translated the language of words into the language of states. He was an $a b d \bar{a} l$ and a righteous person. He was one of the people of mysteries who reveal what is in the heart with the tongue of the unseen world. It is related that, whenever he tried to read something, he could not get his tongue around the letters of the alphabet and the mirror of his heart was not darkened by the turbidities of inscriptions and writings. He recited the following couplet extempore: Nazar eyle ebteri bâzâr eyle götürü / Yaradılan hoş gör, Yaradan'dan ötürü (Regard "the one cut off" [cf. Koran, 108:3, referring to enemies of the Prophet]. Do business wholesale. / Be tolerant toward creatures, for the sake of the Creator)\} ('Āshıq Chelebi, Tadhkira \{i.e. Mashā'ir al-shu'arā'\}, the entry on Yūnus Emre \{we used the Meredith-Owens edn, 98b \}). The translator of \{Tashköprü-Zāde's\} al-Shaqä'iq agrees with this, saying: Zâhir-i hâlde okumağa dili varmaynp, hâme gibi hurûf-i teheccinin edâsinda kâsır idi; ammâ debistân-ı kudsün hurûf-i maârif-i ledünnîyesinde mâhir idi \{It was obvious that he could not bring himself to read. Like a reed pen, he was cut short to produce the letters of the alphabet. But he was expert in the letters of the sciences of the knowledge of the consciousness of God learned in the school of holiness $\}$ (p. 78). This claim of illiteracy, however, is found neither in the original Arabic version of al-Shaq $\bar{a}^{\prime} i q$ nor in Sa'd al-Dīn, who, for the most part, cites it (Tāj al-tawārinkh, vol. 2, p. 429). This is additional evidence for the legendary nature of this claim. Nevertheless, there is frequent reference to his illiteracy in the $D \bar{\imath} w \bar{a} n$, as in the following:

Ol dost bana ümmî demiş, hem adımı ümmî komuş

Dilim şeker, gövdem kamış, bu söyleyen nemdir benim

Ümmî benem Yûnus benem, dokuz atam dörttïr anam

Aşk odu’na düşüb yanam sûk-u bâzâr nemdir benim

\{That Friend called me illiterate (ummī) He gave me the nickname "Ummī."

My tongue is sugar, my body is reed. What does all this talk have to do with me?

I am Ummī. I am Yūnus. I have nine fathers and four mothers.

I fall into the fire of love and burn. What do getting and spending have to do with me?\} 
32 A History of Ottoman Poetry and Melioransky's aforesaid study \{apparently his "K voprosu o znachenii" .

33 In Șüfism, the followers of the path must be inwardly illiterate even if outwardly they are learned. Outwardly, the effect of their knowledge is behavior in accordance with the stipulations of the Shari $a$; inwardly the effect of their illiteracy is to receive knowledge directly from God. For, as long as one is not simple and pure of heart, the book of the heart cannot be exposed to divine manifestations. Consequently, it is more difficult for the learned to enter upon the mystic path. This is why it was said of the Prophet that he was both illiterate and learned. He was illiterate for the sake of spiritual Truth but learned for the sake of the $\operatorname{Shañ}^{-} a$, for, although he did not learn knowledge of spiritual Truth from anyone, he acquired the Shari' $a$ from Gabriel. There is a difference between mediated and unmediated knowledge. Mediated knowledge is knowledge that can be expressed; \{unmediated knowledge is knowledge that can be (this phrase seems to be missing in the text)\} pointed to. The knowledge that Moses learned from Khadir was such "pointed to" knowledge. Unmediated knowledge is pure Truth. Therefore it is necessary for the followers of the path to acquire "expressed" knowledge from a master of the outward, i.e. a mudarris, and to acquire "pointed to" knowledge from a master of the inward, i.e. a murshid. \{The 'ulam $\bar{a}$ ' have knowledge that can be expressed in words, 'ibarra. The Șūfîs have knowledge that can only be indicated or shown, ishāra. See $E I^{2}$, "Ishāāra" (P. Nwiya); al-Kalābādhī, Ta'arruf li-madhhab ahl al-tasawereuf, English trans. Arberry as The Doctrine of the Sufis (Cambridge, 1935; reprinted Lahore, 1966), p. 76; William Chittick, The Sü ü Path of Knowledge (Albany, NY, 1989), pp. 245-6.\}

34 Thus, İsmâ'îl Hakkı, giving the example of the Prophet's receiving knowledge of the Shari' $a$ from Gabriel, states that one should not look down on masters of outward knowledge, that is, religious scholars $\{$ 'ulam $\vec{a}\}$ : . . Y Yalmz mescid ve medresede olan tâ'at ve ibâdet ile vǘûd kal olmaz ve gönül te'ayyünâttan fenâ bulmaz. Bil ki insân-ı kâmil sohbeti ve dilde zevk-ı mahabbet hâleti lâzımdır; ammâ ol ki bu zamânede bâzı ümmîler ilm-i zâhire müteallik zebân-dırâzlık ederler, yerinde değildir; bil ki hatâ-yı mahzdır. Kïşinin zâhiri âlim ve bâtın ümmî gerektir. Ol mainâya ki levh-i dil cümle nukûștan sâde olmadıkça, esrâr-ı ilâhiyyeye mahal olamaz. İste, bu bidâyet hâlidir, nihâyette ise zâhir ve bâtm bütün ilim olur \{One's body does not become refined merely by acts of piety and worship in the mosque or madrasa, nor does one's heart gain annihilation in God from performing obligatory acts. Rather, one must keep company with spiritual masters and taste love in one's heart. But the fact that in this age some illiterates are abusive in their talk about outward knowledge is not proper. Rather, it is pure error. A man should be outwardly learned and inwardly illiterate. The reason is that if the tablet of the heart is not completely blank, it cannot become the locus of the divine mysteries. This is the beginning state. As for the final state, outward and inward become total knowledge) (commentary on the Muhammadiyya, p. 114). The same author also explains the words of those who were opposed to qāl ("words") in the following manner: Nâzzmın bu ma'nâyı kâl' terk ile emirden sonra zikrettiğinin vechi budur ki, kâl'de emr-i şer î dâhil değildir. Bil ki emr-i şer î hâl denilen ma'nâya vusûle vesîledir. Vesîle dahî makâsıda mülhaktrr. Pes kangı sûfî-sûretin ki zâhirinde emr-i şer $\hat{\imath}$ riâyeti olmaya, elbette hâl-ehli olmaz \{The reason that the poet mentioned this ma'na after declaring that $q \bar{a} l$ be abandoned is that Shari $a$ matters are not included in $q \bar{a} l$. Rather, Shari $\bar{\imath}^{\prime} a$ matters are a means of arriving at the $m a^{\prime} n \bar{a}$ called ha $\bar{l}$. The means is also dependent upon the objectives. Therefore, any would-be Șūfì who does not outwardly observe the Shari $a$ definitely cannot become possessor of $h \bar{a} l$ (mystical states)\} (ibid., same part, p. 216). The early Ṣūî Abū 'Abd Allāh Mukhtār b. Muhammad b. Aḥmad al-Harawī said, Ubûdiyyetin ash oldur ki, zâhirde şöyle olasın ki senden cemic şer zâhir ola ve bâtında şöyle olasin ki, zikrin gaym anda siğmaya \{The essence of devotion to God is that you should behave outwardly such that your behavior conforms completely to 
the law of God; and you should behave inwardly such that your behavior contains nothing but dhikr (remembrance of God) \} ( $\{\mathrm{Jām} \overline{1}\}$ Nafahăt, \{Turkish $\}$ trans., p. 391). However, the true ecstatics and possessors of $h \bar{a} l$, the pantheist Süfiss, were not very devoted to the outward appearances.

35 Hundreds, indeed, thousands, of examples of this can be found in Mawlānā, Hāfiz, Jāmī, and the Turkish Șūfì poets.

36 Citing Kharqānī, Shaikh al-Islām al-Harawī says that the famous Ṣūfì Khwāja Khayirja was so illiterate that he could not pronounce al-hamdu li-llāh \{praise be to God\} but that nevertheless he was ghawth-i rūzgār \{ "Help of the age," i.e. the highest Șūfì spiritual authority or "pole" $\}$ ( $\{\mathrm{Jām} \overline{1}$,$\} Nafahāt, \{Turkish \}$ trans., p. 378). Similarly, Shaikh al-Islām Abū Naṣr Ahmad al-Jāmī, known for several of his works, was illiterate. At the age of twenty-two, he retired to the mountains. After eighteen years of mortification of the flesh, he returned and, when he mixed with the people, the doors of 'ilm-i ladunn $\bar{\imath}$ \{knowledge imparted directly by God through mystic intuition \} were opened to him (ibid., p. 392). Shaikh Berke al-Hamadānī also knew nothing apart from the Fattiha and a few süras, and he could not even recite these properly. Nevertheless, the famous 'Ayn al-Quḍāt al-Hamadānī \{i.e. 'Abd Allāh b. Abī Bakr al-Miyānajī, d. 526/1131, see $E I^{2}$, Supplement, s.v. both names (J. K. Teubner)\} admitted that this dervish, who did not know what qăla yaqūlu \{past and present forms of the Arabic verb "to say," i.e. the first thing about Arabic grammar was, knew the Koranic truths much better than he did, and that he greatly benefited from him in this respect (ibid., p. 473). The famous shaikh Șadr al-Dīn al-Khiyāwī al-Shirwānī was also completely illiterate, and made his living as a weaver (ibid., p. 572). So, those who truly deserve the title of hakim \{sage\} are these illiterate 'ärifs \{mystics who had attained true knowledge of God\}. In determining what is meant by wisdom $\{$ hikma $\}$ in the Arabic \{We gave Luqmān wisdom, Koran 31:12\}, the religious scholars differed. According to the Șūfiss, hikma means to be aware of the reality of things and to act accordingly; and to know the most sublime of things, who is God, through divine knowledge. If someone knows all things but does not know God through divine knowledge, he cannot be called hakim. But those who are 'ârifs, even if they are ignorant of the formal and exoteric sciences, deserve this attribute. Because Ibn Sinna, for example, tried to reach God through reason, the Sūfìs do not consider him to be a hakim.

37 The renowned Ummī \{illiterate\} Sinān, who is known for the hymns that he wrote in the manner of Yūnus Emre, and was the founder of the Sināniyya branch of the Khalwatiyya, was in fact an 'álim, but he adopted the nickname Ummī as a result of a dream that he had. Aside from this famous Sūfì who died in 958/1551-2, Elmalılı Shaikh Muhammad Sinān - the murshid of Niyāzī - who was from the Yiğit Başı \{i.e. Ahmmad Shams al-Dīn b. 'Īsā al-Marmarawī Yigitbashī, d. 910/1504\} branch of the Khalwatiyya, is also known by the byname Sinān-i Ummī. This Șūfì poet died in $1075 / 1664-5\left\{1069 / 1658\right.$ in $E I^{2}$, s.v. "Niyāzī," p. 65$\}$.

38 In Khulāsat al-wafayāt, concerning Bursa, that this individual wrote based on \{TashköprüZāde's\} al-Shaq à iq, \{İsmâ'îl Belig's\} Güldeste-i riyād-i 'îfān, \{Mehmed b. Mustafâ\} Baldırzâde's \{Rawdat-i awliy $\bar{a}$, more popularly known as Ta'rīkh-i wafayāt or Wafayāt, for MSS see Babinger, Die Geschichtsschreiber der Osmanen und ihre Werke (Leipzig, 1927), no. 171 \}, Dhail-i rid̄a anot further identified\}, and his own Rawdāt al-muflihün \{of which Khulāsat al-wafayāt is probably an abridgement\}, we find the following description in the section devoted to türbes: Yûnus'lar: Emîr Sultân yolunda Şibli Önüne karî̉ mahalle

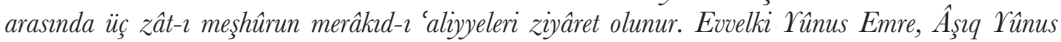
ikinci, üçüncü Abdu’r-Razzâk Ser-bülend deyu ta'rifflerinde şuarâdan biri ebyât inşâd edüb, türbe kapısı üzerinde nakş olunmuştur \{Yūnuses: on the Amīr Sulțān road, in the district near Şiblī Önü, one may visit the exalted resting places of three famous men: Yūnus 
Emre, 'Āshıq Yūnus, and 'Abd al-Razzāq Ser-bülend. Some verses describing them are inscribed over the door of the türbe\} (MS in the library of the late Hâşim Paşa). Mehmed Tâhir also briefly mentions this shrine of Yūnus Emre (in the entries on Yūnus Emre in his Ayden vilâyetine mensûb ricâlin terâcim-i ahvâli and Osmanh müellifleri).

39 "If you turn to the right just before reaching the mosque of Amīr Sultān and enter a small street, you will immediately come to a tiny square. This place is the Qara 'Abd al-Razzāq district. To the right of that little square there is a ruined house and in the wall there is a tiny window, partially overlooking the garden of that house, and covered with an iron grill. Just opposite that courtyard, the grand Yūnus Emre is buried along with two of his companions. I carefully read the inscription over the window and copied it in my notebook. Aside from Yūnus Emre and 'Āshıq Yūnus, it also mentions someone called 'Abd al-Razzāq. The Qara 'Abd al-Razzāq who gave his name to this district is this person. I give the inscription verbatim:

\author{
Asl-ı sütûde gevherïll-Hak Yedekci-zâde \\ Cû̉d-ü keremle yektâ zât-i cihân-pesendi \\ Rağbet edüb bu câyz ihyâya kaldr hikmet \\ Üçler makâmın icrâ etti gören beğendi \\ Evvelki Yûnus Emre, Assck Yûnus ikinci \\ Üçüncü Abdürr-Razzâk $U_{s ̧ s ̧ \hat{a} k-\imath ~ s e r-b u ̈ l e n d \hat{\imath}}$ \\ Hayrât-ı pâki olsun makbûl-i kurb-i Bâri \\ Ola şefẩatiyle bânisi behre-mendi \\ İlhâm olundu geldi bir zât dedi tarîh \\ $\ddot{U}_{c}$ kabri kıldı ma'mûr li-llâh 'Alì Efendi
}

\{God's jewel, of blessed origin, Yedekci-Zâde

Unique in generosity, one with whom the world is pleased

Desired to restore this place and did it with wisdom.

He made the shrine of the three saints, which pleased those who saw.

First Yūnus Emre, second 'Āshiq Yūnus,

Third 'Abd al-Razzāq, Lovers with head held high.

May his pure good deed be acceptable with the Creator.

May he who built it partake of His intercession.

Someone was inspired and came up with this chronogram:

"Ali Efendi renovated the three tombs for the sake of God."

"It is evident from this that a certain charitable individual named Yedekci-Zâde Alî Efendi repaired and restored the tombs of these three venerable men. According to the abjad method of reckoning \{enumeration by letters of the alphabet\}, the chronogram indicates exactly $1252 / 1836-7$. There is also a puzzle here, for this means that it had been repaired in 1252, that is, 77 \{mistakenly given as 114 in 3rd edn\} years ago. But according to my research, Yūnus Emre's tomb was completely in ruins for some time and so inconspicuous that its location was not evident. The famous Niyāzi became especially interested in this tomb and determined its true location" (Rizâ Tevfik, his article "Yûnus Emre'yi ziyâret" in Peyâm ilâve-i edebiyyesi \{literary supplement to the newspaper Peyâm\}, June 19, $1329\{1911\}$ ). I am of the opinion that there is no basis to the report, which was widespread among the leading members of the tarīqa in Bursa, that Niyāzī discovered this tomb of Yūnus Emre, because İsmâ'îl Hakk1, who, just like Niyāzī, held the works of Yūnus Emre in high regard, says nothing at all about the tomb of Yūnus Emre in Bursa in his Sharh-i rumūzāt-i Yünus Emre, which he wrote thirteen years after Niyāzî̀s death, that is, in 1118/1706-7. Instead, he indicates that he was buried in a town near Kiçiborlu. If Niyāzī had really 
discovered this place, İsmấ̂̂l Hakkı would certainly have mentioned this claim, even if he did not accept it.

40 In $n .8$ of this chapter, I stated that there was no historical basis to the report that there was also an 'Āshiq Yūnus who was a khalîfa of Yūnus Emre. The source of this report is the tombs in Bursa that are at most a hundred years old and have no historical value. When the $D \bar{\imath} w \bar{a} n$ was published, 'Āshıq Yūnus was also mentioned, based of course on this report. When we realize that this new story, which has been around for only a hundred years, is not found in any of the various historical sources written over so many earlier centuries, and cannot be traced back even as far as the time of Niyāzī, then no historical and positive significance can be attributed to it. The errors of Melioransky and Rızâ Tevfik on this point derive from their accepting every report they saw without subjecting it to critical inquiry.

41 The section on Yūnus Emre in Mehmed Tâhir's Aydnn vilâyeti'ne mensûb ricâlin terâcim-i ahvâli and Osmanl müellifteri.

42 One of my students from Erzurum gave me this information. And Rızâ Tevfik, citing a friend from Erzurum in his article in Peyâm, corroborates it. It was told by a secondhand book-dealer, an old man from Erzurum, that there was an old and very large copy of Yūnus Emre's Dī̌ān in that türbe. The works and legends of Yūnus Emre were very well known and widespread in all of those regions. \{The hymn Yemen illerinde Veyse'l-Karanî (Uways al-Qaranī in the lands of Yemen) refers to Uways al-Qaranī, a legendary or semi-legendary contemporary of the Prophet Muhammad. He supposedly lived in Yemen and corresponded with the Prophet by telepathy. He became a prototype of the Șūfi guided solely by divine grace. See Schimmel, Mystical Dimensions of Islam, p. 28; $E I^{2}$, s.v. "Uways al-Karanı̄" (J. Baldick); for the text of the hymn with the aforesaid refrain, see Tatç1, Aşı Tunus, pp. 182-4.\}

43 İsmâ' ̂̂l Hakk1, from the aforesaid MS of his Sharh-i rumūzāt-i Yūnus Emre.

44 Nafahăt, \{Turkish\} trans., p. 691; Eskisehir-Ankara yolu üzerindeki istasyonlardan Sanköy istasyonunda bu zât adına bir ziyâret-gâh varder ki, Lâmi î Çelebînnin beyân ettiğg yerdir \{At the Sarıöy station, on the road between Eskişehir and Ankara, there is a place of pilgrimage dedicated to this man. It is the place mentioned by Lāmi'ī Chelebi\}

45 Ibid. (\{Mehmed Tâhir,\} Osmanl müellifleri, p. 194).

46 In the section of \{Muhȳī 'l-Dīn's\} Khadirnāme with the heading Beyân-ı seyrân-ı derûn-i bahr ve 'acâyibhâ-yn o ve musâhabet-i mahlûkât ki der ka'r-ı deryâ sû be-sû \{Concerning a Journey to the Bottom of the Sea and its Marvels and the Creatures that he consorted with there\}, Yūnus Emre is mentioned in the following manner:

Geldi erenler cem` ile gösterdiler ucdan uca

Tapduk San Saltuk bile gösterdi hem ucdan uca

Hem Yûnus Emrem geldiler çün bir yire ilettiler

Bir ak denize attlar gösterdi hep ucdan uca

\{The saints gathered together and showed (?) from end to end

Even Tapduk and Sarı Saltuk showed from end to end

And Yūnus Emre came: When they brought him to a place,

They tossed him into a white sea (or, a Mediterranean). He showed from end to end.\}

In the following section Beyân-ı cem'iyyet-i kübrâ ve sohbet-i heme evliyâ \{Concerning a Great Assembly and a Meeting of All the Saints\}, we again come across the name of Yūnus Emre among a number of early Șūiss, such as Hājjī Bektash, Sayyid Mahmūd Hairānī, Șadr al-Dīn al-Qūnawī, Mawlānā, Sulțān Walad, Faqīh Aḥmad, Shams Tabrīzị, Șalāh al-Dīn Zarkūb, Rasūl Bābā, Sayyid Bațāal Ghāzī, Sulțān Shujāé, Malik 
Ghāzī, Akhī Ören \{Evren\}, Sarı Saltuk, and Amīr Sayyid, along with some whose names we don't recognize:

\section{Aşsı Beşe Tapduk Beşe geldi Killç Abdal bile \\ Hem Yûnus Emrem de bile bir gine görsem yüzlerin \\ \{'Āshıq Beshe and Tapduk Beshe came with Kılıch Abdāl \\ And also Yūnus Emre - I wish I could see their faces once again.\}}

47 The words of the Jilwatī shaikh Muhȳi 'l-Din Uftāda of Bursa, who died in 988/ 1580-1, were recorded by his khaliffa Shaikh Hüdā'i \{on the Jilwatiyya, see $E I^{2}$, s.v. "Djilwatiyya" (Abdülbâkî Gölpınarlı)\}, so this large Arabic work is called Wāqi'āt Uftäda. There are MSS of this work, some parts of which have been translated into Turkish, in the libraries of the Hüdā'̄ Dergâh \{apparently the Hüdâiyye Tekkesi, now known as the Cafer A $\breve{g}$ a Mosque in Istanbul\}, Atlama Taşı \{i.e. the Hacı Halil Mosque in Istanbul\}, Bayezid Mosque, the Great Mosque \{i.e. Ulu Cami in Bursa?\}, and in other places. If we take into consideration the date of Mawlānā's death, it is clear that this statement has only legendary value and cannot be accepted historically.

48 What İsmâ'îl Hakkı says on this subject is quite significant: ve bu makûle kelimât ekser esnâ-i şevk ve galebe-i hâlde sâdır olmağla kadh ve cerhe sâlih değildir; zîrâ sâhibi mázûrdur ve lâkin mümkün oldukça ibârette edebe riâyet etmek gerektir. Annn için Yûnus Emrènin bu makâlesini ki buyurur: Cennet cennet dedikleri birkaç köle birkaç hûri / İsteyene versin ân bana seni gerek seni. Afdalü'l-müteahhirin ve emselü'l-müteeddibîn Şeyh Üftâde hoş görmeyib, hakknda ليس كما ينبغى buyurmuşlarder ve nice müftîler dahî cenneti istihkâr tarikiyle bu kelimâtr okuyan cehele-i sûfiyyeyi ikfâr etmişlerdir \{This kind of utterance, which usually emerges while in a state of ecstasy and $h \bar{a} l$ (mystical experience), is not subject to criticism, for the one who utters it is excused. Nevertheless, in the expression (of such utterances), one must observe propriety as far as possible. Thus, concerning the following utterance of Yūnus Emre: "Paradise - what they call Paradise - A few slaves, a few houris / Let him give it to the one who wants it, I need You, You." Afḍal al-Muta'akhkhirīn (the best of the later ones [S़̄ūìs]), Amthal al-Muta'addibīn (the epitome of the well cultured ones) Shaikh Uftāda was not pleased and said, "It is not proper! And many a mufti has deemed foolish Șūfìs, who recite this utterance in order to express their scorn of Paradise, to be (guilty of) kufr (unbelief)"'\} (commentary on the Muhammadiyya, p. 75). Indeed, the men of the madrasas, who are blindly suspicious of any ascetic or Șūfì, have never hesitated to use the weapon of takfir \{accusation of unbelief $\}$ against such unrestrained views.

49 Ghaibī, one of the khalîfas of Ibrāhīm Efendi, collected the Sūfī sayings of his murshid in a work entitled Suhbatnāme-i Ghaibī. In it we find the following opinions about Yūnus Emre: Lisân-i kadîm üzre ma'nâ icrâ eylemiş er Yûnus Emre Hazretleri'dir ki bu siyakta bizim bu suâlimize ki: Dervis dilinde söyleyen kim idigin bilir misin / Ya kulağrnda dinleyen kim idigin bilirmisin kelâmıder ki ânlarn / Bu dilimde söyleyen kendisidir va’llâhi / Kulağımda dinleyen kendisidir va'llâhi / Gördüm iki âdemdir biri sen ve biri ben / Hakîkatte sen ben yok kendisidir va'llâhi \{The saint who expressed spiritual truth in the old language was his excellency Yūnus Emre. I asked him the following question: "Do you know who it is who speaks with the dervishes' tongue? / Do you know who it is who listens with the dervishes' ear?" He answered appropriately, saying, "The one who speaks with my tongue is Himself, by God! / The one who listens with my ear is Himself, by God! / I saw that among men one is you and one is me / In truth, there is no you and I; there is Himself, by God!"' (Suhbatnāme-i Ghaibī, MS in Hâşim Pasha Library \{in the Süleymaniye Library in Istanbul $\}$ ).

$50 \mathrm{As}$, for example, in the following couplet found in his Dīwān: Bassszz kabak gibi sen tekerleme söz ile / Yûnus'leyin Niyâzî̀ irfân arzularsin \{Talking nonsense like a headless 
squash / You desire the spiritual knowledge of someone like Yūnus and Niyāzī \}. This $D \bar{\imath} w a \bar{n}$ is widely known among the Sūfiss. Various editions have been published, but the most reliable one was published in Cairo \{Būlāq\} in 1254/1838-9. \{Now see Kenan Erdoğan (ed.) Niyazî-i Misrî ve Divan (Ankara, 1998), where the verse is on p. 169.\}

51 There exist several MSS of this commentary \{Sharh-i nutuq-i Yünus Emre\} and it was printed on the margins of Yūnus Emre's Dǐwān. Niyāzì exhibits a great and sincere respect and affection for Yūnus Emre in this commentary. \{See the edn of this commentary by Neclâ Pekolcay and Emine Sevim, Yunus Emre şerhleri (Ankara, 1991), pp. 137-52, and the discussion of it in Schimmel, Mystical Dimensions of Islam, pp. $334-5$.

52 İsmâ'îl Hakkı claims that, because it is not possible to attain God rationally, such people - even the likes of Ibn Sinna - cannot be called hakims. He then advances the notion that Yūnus Emre was a "mystic sage" \{hakim-i ârif\}: Diyâr-ı Rûm'da Anadolu'da medfûn olan Yûnus Emre demekle şöhret-yâb olan böyle değil iken yine Lisânüll-Gayb'dor ve ânn nazmettiği maârif, Lisân-ı Türkî üzre kimseye makdûr olmamıştır ve cümle ândan sonra gelib nazm-

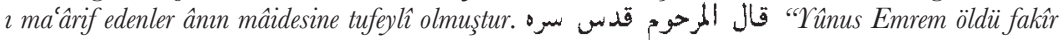
/ Ecel öksesini \{sic, ensesini in 1st edn\} dokur / Gönül kitâbindan okur / Eline kalem almadr." Pes bu makûleye hakikatta hakim denilir; zirâ ecell-i ma'ârif ile muttasıftır. Felâsifenin hikmet tesmiye ettiği makûlât, hakikatte hikmet değildir; zîrâ mü'min ve kâfir anda müsâvidir ve âfet-i vehm-ü hayâl ş̧evâibinden hâli değildir. Bir ma'nâ ki kesb-i fikir ile hâsıl olmuş ola, zannîdir ve bir emir ki keşf-i Hak'la vücûd bulmuş ola, kat îdir. Vahy'illahhi nice mevhibe-i enbiyâ ise, hikmet dahî mevhibe-i evliyâdir \{While the man known as Yunus Emre, who is buried in the lands of Rūm, in Anatolia, is not such a one, still he is lisān al-ghaib (spokesman of the invisible world). And the mystical doctrines that he versified were not vouchsafed to anyone in Turkish (other than to him). And all those who came after him and versified mystical doctrines were parasites at his table. The late (Yūnus Emre), may (God) hallow his secret (said of deceased Muslim saints), said, "Yūnus Emre died a dervish / Death struck him on the neck / He read from the book of the heart / He did not take pen in hand." This sort of person truly deserves to be called hakim, for he is endowed with the noblest of sciences. The doctrines that the philosophers called hikma (wisdom) are not in fact hikma, for the believer and unbeliever share in them equally, and they are not free from the defeats of harmful fancy and conjecture. A notion that is obtained by exercising the mind is conjectural; and a command that occurs by divine revelation is certain. Just as divine inspiration is granted to the prophets, hikma is granted to the saints\} (commentary on the Muhammadiyya, vol. 1, p. 82). It is obvious that İsmâ'îl Hakkı has recognized Yūnus Emre as the greatest of our Șūfì folk poets and their leader.

53 One of his commentaries is an explanation of the hymn Çaktım erik dalina anda yedim ӥzӥmӥ \{I climbed up a plum branch and there ate grapes\}, which Niyāzī had also previously commented on. It was written in 1118/1706-7. Another was a commentary on the hymn Çıktım bâdem dalina anda yedim üzümü \{I climbed up an almond branch and there ate grapes $\}$. It was written in 1123/1711-12. Both are unpublished. Mehmed Tâhir mentions the commentary on only one of Yūnus Emre's ghazals among the works of İsmâ'îl Hakkı (Osmanl müellifleri, vol. 1, p. 29). As I have indicated, İsmâ'îl Hakkı wrote separate commentaries on these two ghazals. There is a MS of each in my private library \{see the editions of these commentaries in Pekolcay and Sevim, Yunus Emre şerhleri, pp. 153-81\}. At the end of his commentary on the second ghazal, while explaining the line Kul çalmadan uyandım hem çalarm sazım \{I awoke without striking anyone, all my striking was on my saz\}, he expounds Yunus's perfection in the following manner: ve bundan, şeyh-i mezbûrun ekâmil-i nâstan olduğu bâhir oldu. Ânn için kelimâtr, kemâle dâirdir; yoksa beyne'l-Cemâl ve'l-Celâl mütereddid değildir, sâir kelimât-ı 'uş̧âk gibi \{ It is evident from this that the aforesaid shaikh was among the most perfect of 
men. Therefore his words are about perfection. But he does not waver between the beauty of God and the awesome might of God, as is the case with other 'ashrqs (the implication being that he chose beauty) .

54 In the past, everyone who had some literary taste, no matter what his social class, possessed miscellanies (s. majmī $\bar{u}^{\prime}$ ) and collections of folk poems \{s. cönk\}. Cönk, meaning memorandum book, is a majmu $\bar{u}^{c} a$ that opens lengthwise. These miscellanies contain, according to the taste of their owners, bits and pieces of poetry, letters, wise advice, pleasantries, and a thousand other such things. Some of these majmü'as simply consist of hymns belonging to the dervishes. Among such majmü'as that reveal the Șūfì temperament of their owners, there is hardly any that does not include Yūnus Emre's poems. \{See Orhan Şaik Gokyay, "Cönkler üzerine," Folklor ve Etnografya Araștirmalari, 1984, 107-65; also the series of short studies by M. Sabri Koz, the first three of which are "The Dervish Cönk," "An Istanbul Cönk," and "Two Cönks from the First Half of the 19th Century," 4th Floor, The Bulletin of the Kapu Kredi Sermet Çifter Research Library, no. 1 (2001), 18-23, no. 3 (2001), 16-22, no. 4 (2002), 10-16. Koz uses some cönks from Köprülü's library.\}

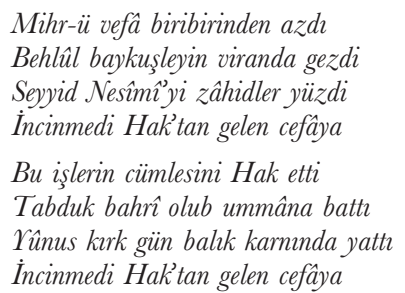

\{Love and loyalty strayed from each other

Bahlūl wandered amidst ruins like an owl

Sayyid Nesīmī was flayed by ascetics

He was unharmed by the cruelty that came from God.

God brought about all of these things

Tapduk became a kingfisher and plunged in the ocean

Yūnus lay forty days in the fish's belly

He was unharmed by the cruelty that came from God, \}

(from the unique MS in my private library of the work entitled Manāqib al-asrār, bahjat al-ahrār, which the Safavid Shāh Ismā'îl \{supposedly\} wrote under the pen name Khațā' in order to disseminate the rules and protocols of his own tariqqa). This work attributed to Shāh Ismā'îl, a collection of whose poetry in excellent Turkish is found in the British Museum (Charles Rieu, Catalogue of Turkish Manuscripts in the British Museum (London, 1888)\}, no. 205), has been completely unknown up to now \{see Minorsky, "The Poetry of Shāh Ismā̄īl I," Bulletin of the School of Oriental (and African) Studies, 10 (1940-2), 1007-53; and Tourkhan Gandjeï, Il Canzoniere di Š̈h Isma $\bar{a}^{\top} \bar{\imath}$ Hat $\bar{a}^{\prime} \bar{\imath}$ (Naples, 1959)\}. This work contains the religious beliefs of the Quzlbash, and is thus very valuable with respect to our religious history. It also includes a significant number of poems in the syllabic meter by both Shāh Ismā'îl and certain Qizllbash poets who preceded him, and so it is also a very important source for our literary history. From a careful study of Manāqib al-asrār, bahjat al-ahrār, I have reached the firm conclusion that it does not, in fact, belong to Shāh Ismā̄îl \{on his poetry, see $E I^{2}$, s.v. "Ismā̄îl I: His Poetry" (T. Gandjeî)\}. Nevertheless, this does not lessen its importance. I have benefited from it greatly in my studies of the religious history of Anatolia. 
56 The poets of pre-Islamic Arabia, the Jāhiliyya \{i.e. time of ignorance\}, had a religiomagical aura and very great influence among the people. Consequently, in order to undermine their influence, the Koran naturally contains a number of \{divine\} judgments against poetry and poets. Still, because poetry and eloquence had acquired great importance in Arab life (see \{Zaydān, \} Medeniyyet-i islâmiyye tarihi, vol. 3, p. 49, citing such sources as \{al-Suyūțīs $\}$ Muzhir, Bulügh al-arib \{?\} and \{Ibn 'Abd Rabbihi's \} al-'Iqd al-farid; Brockelmann's and Huart's histories of Arab literature \{respectively Geschichte der arabischen Litteratur, 2nd edn (Leipzig, 1909), not to be confused with Brockelmann's multi-volume catalogue of Arabic works with the same title, and $A$ History of Arabic Literature (London, 1903)\}, the Prophet treated very favorably the poets who had accepted Islam. He had poetry recited in his presence and even encouraged Hassān b. Thābit to write satirical poetry about polytheists. Ka'b b. Mālik once asked whether or not it was legitimate to satirize unbelievers. The answer he received from the Prophet was "satirizing unbelievers is like shooting arrows at them with the tongue and thus is tantamount to fighting $\{\ddot{i} h \bar{a} d\}$ for the sake of God" (Surūrī $\{$ d. 969/1562\}, at the end of Bahr al-ma'ariff, from the MS in my private library \{on this writer see $E I^{2}$, s.v. "Surūrî" (Edith Ambros)\}; there are very important materials concerning the permissibility of poetry and its benefits in Naw's's \{apparently the Ottoman poet, $d$. 1007/1599, and not the Persian poet, d. 1019/1610\} famous letter \{?\}, and especially in the introduction to 'Āshıq Chelebi's Tadhkira \{i.e. Mashā'ir al-shu'arä'\} and Hashmet's $\{$ d. $1181 / 1768\}$ Sanad al-şu'ara $\bar{a}^{\prime}, \mathrm{MS}$ in my private library \{on the latter, see $E I^{2}$, s.v. "Hashmet" (Mehmed Kaplan)\}. For poetry to be acceptable, in this manner, the upholders of religious law and the Sūfis subsequently restricted it to such subjects as tawhīd \{profession of the unity of God\}, na't \{praising the Prophet\}, and akhläqiyyāt \{ethics\}, and for a long time any other, non-religious, poetry was viewed with disfavor. Taking advantage of this, the Șūfìs distinguished between the poetry of 'asshqs, i.e. themselves, and that of the poets in order to separate true love, with which they were preoccupied, from physical love, about which the other poets sang. We saw above how Sultān Walad - conforming to this old Șūi view - distinguished the poetry of the 'asshrq from that of the poet. Sinān Pasha \{d. 891/1486\} too, after criticizing poets at length in his Tadhkirat al-awliy $\bar{a}$, explains the difference between them and Șūfìs: .. . Ammâ sakn bu sözden Hoca 'Attâr, Şeyh Irâkî emsâlini şâir sanma, Hazret-i Mevlânâa gazeliyyâtm bu kabilden addeyleme; ânlarn kelimâtı derd-i dildir ki söylerler ve ânlar gazellerini harâret-i aşkla takrîr eylerler. Ânlarn Dî̀ân'lan dûde-i safâ - vü dâd ile tahrîr ve tertîb olunubdur ve ânlarn mecmû́alan tılaa-yn hüsn-i i'tikâd ile tasvîr ve tezhîb olunubdur. Ânlarn sözleri aşk meclisinin sazı olur ve ânlarn neşî̉elerinin bir dürlü âvâzı olur \{ . . . But from what I have said you should not suppose that Khwāja 'Atțār, Shaikh 'Irāqī, and the like, were poets. Nor should you consider the ghazals of Mawlānā to belong to this class. Their utterances are expressions of heartache. They recite their ghazals with the fever of love. Their dīwans are composed with the lampblack of purity and justice. Their majmǘas are illuminated with the gold of firmly held belief. Their songs (söz) are the musical instruments (saz) of the assembly of love ('ishq) and their verses have a kind of echo $(\hat{a} v \hat{a} z)$ \} (Tadhkirat al-awliy $\bar{a}^{\prime}, \mathrm{MS}$ in the Beyazit Umumi Library in Istanbul \{now ed. Emine Gürsoy (Ankara, 1987), and see EI ${ }^{2}$, "Sinān Pasha, Khodja" (Christine Woodhead)\}). Lațifî, in order to give value in this way to poets whose work has no mystical character whatsoever, alleges in his Tadhkira that even non-religious subjects also definitely have a mystical import (pp. 10-12), but this allegation by no means conforms to reality. Therefore, despite the claim by writers like Lațîfi and Nawā' (Mạhbüb al-qulüb, \{ed. Vefik Pasha (Istanbul, 1889), sections published by M. Belin in Caractèrs, maximes et pensées de Mir Ali Chîr Névâii (Paris, 1860)\}, pp. 30-3) that all poets should be considered mystics, we must accept the Șūfis' distinction between the 'āsh $q$ and the poet. 
57 The Dih-murghnāme, which was influenced by 'Ațtār's Manțiq al-tair, was written in 919/1513-14 by a poet known as Ishıq Shamsī or Dervish Shamsī. He was a contemporary of Sultan Selim I, to whom he presented this work (on this poet, see Lațîfi, \{Tadhkira,\} p. 209; 'Āshıq Chelebi, \{Mashā'ir, $\}$ vol. 5, p. 42; \{Kınalı-Zâde\} Hasan Chelebi, \{Tadhkirat al-shu'arā', MS TY 1737 in Istanbul University Library; ed. İbrahim Kutluk (Ankara, 1979-81),\} p. 112. According to Lațifî, he was from Sivrihisar, but according to 'Âshıq Chelebi and Hasan Chelebi he was from Iran. Lațîfi's report that he died at the end of Selim I's reign is mistaken, because he says in his own work that he reached the reign of Süleyman the Magnificent. \{Now see Idris Güven Kaya, Derviş Şemsi ve Deh Murg Mesnevisi [Cambridge, MA, 1997].\}) The following passage,

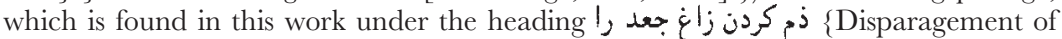
the Ill-favored Crow and shows that contemporary Șûfìs continuously recited the hymns of Yūnus Emre, is very worthy of note:

Sûfîdir yâni kuşun benden kaçar

Şöyle zâhiddir ki saldurmaz geçer

Günde halk içinde açtıkçâ dehân

Kendüden gayn Müsülmân yok hemân

Yûnus Emre sözlerin tekrâr ider

Subh oluncâ nâ-bedîd olur gider

Dâimâ kavli budur sâfîlerin

Zühdü yoktur şimdiki sûfîlerin

$\{$ He is a Șūfi - I mean, your bird - he flees from me

He is such an ascetic that he passes by without attacking.

During the day when he opens his mouth in a company

You'd think there was no Muslim beside himself.

He repeats the words of Yūnus Emre.

At dawn he disappears.

The words of the pure are always thus.

The Șūfìs nowadays have no asceticism.\}

58 In his famous Lutfyyy, Vehbī \{Sünbülzâde Vehbî, d. 1224/1809\}, speaking of beggars, says the following:

Bed-sadâ böyle dilenciye tamâm

Har gedâ der zurefâ-yi aćcâm

Bâzı cerrâr da şâir geçinür

Cerr-i eskalda mâhir geçinür

Dağıder halka müzeyyef tarîh

Olarak lâyzk-ı levm-ü tevbîh

İsiten Yûnus ilâhîsi sanur

Bu edâsin gören âdem usanur

\{All beggars are in bad repute

The beggar is a donkey amidst the refined and witty Persians

Some beggars pass as poets

They are skilled at lifting weights

They broadcast contemptible chronograms

Being worthy of blame and reproach

The listener thinks it is a hymn of Yūnus

The man who sees this behavior is disgusted.\} 
59 [In the fifty-six years that have passed since the publication of the first edition of Early Mystics \{i.e. between the first and third (1976) editions\}, much has been written on Yūnus Emre. Indeed, in September 1970 an international seminar was organized on him in Istanbul. Nevertheless, apart from certain details, there has been little advance beyond the framework that Köprülü established. For recent publications on Yūnus Emre and his Dīwān, see Faruk K. Timurtaş, Yunus Emre divan (Istanbul, 1972), pp. 38-42.] [Now see, for example, the studies on Yūnus Emre by Ahmet Yaşar Ocak collected in his Türk sufîliğine bakışlar; and $E I^{2}$, "Yūnus Emre" (Edith G. Ambros).\} 


\title{
9 \\ THE WORK OF YŪNUS EMRE
}

\begin{abstract}
A His work
Yūnus Emre's only work is his famous Dīwān, which includes ghazals and hymns composed in the syllabic meter $\left\{h u r \bar{u} f-i\right.$ hija $\left.\bar{a}^{\prime}\right\}$. Before analyzing this text, which was first published lithographically in 1302/1884-5 \{in Istanbul as Divân-ı âşık Yûnus Emre $\}$ and again in 1320/1902-3, we need to understand how reliable it is and, if it is a faithful text, whether or not Yūnus composed any other work. To be sure, the analysis that I made above of the Diwann-i Hikmat, which has long been attributed to Ahmad Yasawī, has shown the erroneousness of several points that researchers up to the present time have generally accepted as axiomatic (Chapter 5, pp. 127-9). But the surviving work of Yūnus Emre, along with contemporary linguistic and literary products, considerably facilitates our research on this topic.

As with the Dīwān-i Hikmat, manuscript copies of Yūnus Emre's Dīwān are quite numerous. Nothing could be more natural for a poet whose hymns reached the most remote corners of Anatolia and Rumelia and were well known for centuries among the people. Yet, despite all my research, I have not been able to find a copy of this Dīwan dating from the eighth/fourteenth or ninth/fifteenth century. The manuscripts in our possession are, in fact, all products of recent centuries. The reason for this is that Yūnus Emre's Dĩwān was compiled and arranged centuries after his death by a dervish who was very devoted to him. ${ }^{1}$

As far as we know, the oldest texts belonging to Yūnus Emre are the hymns published by Mühlbacher. ${ }^{2}$ After these hymns, which were written down in the first half of the ninth/fifteenth century, we can consider a few hymns recorded and identified by Hacı Kemal of Eğridir, the author of $\mathcal{F} \bar{a} m i^{\prime} a l-n a z \bar{a}^{\prime} i r$, to be the oldest text belonging to him. ${ }^{3}$ Subsequently, hymns recorded in the name of Yūnus Emre appeared in various poetic anthologies compiled at various periods, and later on, whoever it was who compiled the Dīwān made use of them. Consequently, it is obvious that we cannot fully attribute to Yūnus Emre the printed version of his D $\bar{\imath} w \bar{a} n$ or the various manuscript copies of it that belong to later periods, nor can we reject the possibility that he wrote some hymns in addition to those in the $D \bar{\imath} w \bar{a} n$. A casual examination of the printed Dīwān suffices to
\end{abstract}


confirm this. This Dīwān, consisting of 10,000-12,000 verses, contains many passages that do not belong to Yūnus Emre ${ }^{4}$ and, at the same time, it lacks many items that we know definitely do belong to him, such as the passages published by Mühlbacher. The variation among the manuscript copies of the work derives from the fact that, in the absence of any reliable early copy, each compiler included, according to his own understanding, whatever poems \{of Yūnus Emre\} he happened to come across. Apparently Yūnus recited many hymns without intending for them to be compiled into a dīwa $n ;^{5}$ the Dīwān was later compiled from those hymns that had been recorded, with a number of differences, in various anthologies. This is why the same hymns appear in such different versions in various works ${ }^{6}$ and also why we cannot regard either the published version of the Diwwann or the manuscript copies that we possess as reliable documents with respect to linguistic history. To compile a reliable version of Yūnus Emre's Diwa an , it is necessary - keeping in mind the basic points that I have outlined above - to collect the passages of his work scattered among the various manuscripts and anthologies and then subject them to a rigorous comparative linguistic critique according to the characteristics of contemporary Anatolian Turkish, and produce a new Dīwān by the method of reconstitution philologique. Still, from the point of view of literary \{as opposed to linguistic\} history, we can say that the most basic historical critique will suffice to show the place of Yūnus Emre in our literature and the literary character of his work. ${ }^{7}$

\section{B Linguistic character}

Our discussion of Yūnus Emre's Dīwān has shown that long preparatory work would be required in order to make a linguistic analysis of it. Indeed, a thorough linguistic analysis is beyond the scope of this book, but we do possess sufficient information to give a general idea about the linguistic and dialectical features of the Dīwān. Because we find in Yūnus Emre's works exactly the same linguistic characteristics as in the works of Shayyād Hamza, Sultān Walad, Gülshehrī, 'Āshıq Pasha, and other contemporary writers, we can consider them to be among the oldest \{Turkish\} works in Anatolia. Although no scholarly analysis has been made to date on these works with respect to phonology and lexicon, this old Anatolian Turkish, which immediately strikes one as being closely akin to the Azeri dialect, ${ }^{8}$ is nothing but a later and more developed form of the old Oghuz Turkish. ${ }^{9}$

This Oghuz Turkish, which very early had become a written language, continued as such after the Turks settled in Anatolia, although it underwent certain changes under the influence of environment and other factors. Relatively few works, including some books, produced in this language - those that I have mentioned above - have come down to us, but thanks to them we have a fairly good understanding of Anatolian Turkish in the seventh/thirteenth and eighth/ fourteenth centuries. The linguistic characteristics of Anatolian Turkish that are peculiar to these early periods, and that are rather different from those that 
appeared later, after the conquest of Constantinople, are later found as well in Yūnus Emre's Dīwān, so one naturally includes it within this same domain. Although it is likely that there were some insignificant local variations between it and the other old works belonging to the same periods, research on this topic, as I stated above, requires a complete rearrangement and restoration of the text of the Divwān according to its earliest form. To be sure, such a study may be of greater value to linguistic than to literary history. In any case, the language of Yūnus Emre is, like that of other contemporary Anatolian works, despite some archaic features, pure Anatolian Turkish. ${ }^{10}$

\section{G Literary character}

Yūnus Emre's Dīwān is composed of several mathnawñs and numerous ghazals and strophic poems (musammats). It contains altogether some 5000-6000 couplets, most of which are in the syllabic meter.

The mathnaw $\bar{r}$, which constitute a minor part of the work, about 600 couplets, and which come after a short prose introduction at the beginning of the Dĩwann, ${ }^{11}$ actually form a unit that is divided into the following sections: Dāstān-i rūh wa nafs wa mā yatáallaqu bihimā min al-ahwāl \{Poem of the spirit and carnal soul and the conditions concerning them\}, Dāstān-i qanā'at \{Poem of contentment\}, Dāstān-i ghadab \{Poem of wrath\}, Dar-bayān-i ahwāl-i șabr wa hikāyat-i Yūsuf 'alayhi's-salām \{Concerning patience and the story of Joseph, upon him be peace\}, Dar-bayann- $i$ hạlāt-i bukhl \{Concerning avarice\}, Dar-bayān-i ahwwāl-i Qārūn \{Concerning Korah\}, and Dar-bayān-i dāstān-i 'aql \{Concerning the intellect\}. These mathnaw $\bar{\imath} s$, which discuss the conditions of the spirit and the carnal soul and such moral issues as avarice, contentment, patience, and generosity, are inspired by the rules of Șūfi ethics; and the influence of 'Ațtāar, Sanā' $\overline{1}$, and Mawlānā on them is immediately apparent. In a manner replete with allusive symbols that were very popular among the Șūfiss, Yūnus expounds the distinctions of reason and faith, the nature of the four elements \{earth, water, air, and fire\}, the merciful and satanic powers that govern the world of the heart, the temptations of the carnal soul, and the importance of contentment and patience. Occasionally, in order to emphasize and clarify a point, he will illustrate it by means of a simple story, such as the greed of Korah, or Joseph's patient trust in God when he was in the well, and show the dangers \{awaiting one\} on the Day of Judgment.

His descriptive style is generally quite artful. For example, after the Emperor of Intellect captures the Land of Greed, he raises Contentment to the throne. But there is a bandit on the road leading to that land. He dwells at the top of the mountain and never descends from it. Those who follow this rebel, whose name is Pride, never consider that the long rope of death will reach them wherever they are. Yūnus Emre advises them to implore Intellect, a great man who possesses Justice. Intellect orders Humility to drive Pride from the top of the mountain. Then Humility takes the form of a river and flows into the sea. Those who dive into that sea under the guidance of Intellect find there unheard of pearls, coral, 
garnets, and rubies. When Intellect learns that Pride has been defeated with the help of Humility and Contentment, he joyfully thanks God. This does not, however, end the disorders in the kingdom of the body. Two antagonists, Comfort and Pleasure, are about to appear again. Intellect learns about this through his spies and orders Patience to oppose them. Patience successfully puts an end to these difficulties. Nevertheless, the roads are long and dangerous. There are enemies like Avarice, Envy, Hatred, and Slander who prevent one from reaching the goal. But Intellect finds a means to overcome them: Righteousness. When one puts on the honorable robe of Righteousness, i.e. when one attains divine Truth, the torch of faith burns brightly; the thief in the house of the body, that eternal seducer of mankind, comes into the open and can no longer hide. ${ }^{12}$

Written in 707/1307-8, this rather long mathnawe, which forms a unit, shows that Yūnus Emre was not an illiterate poet as has been claimed, but, to the contrary, can be regarded as a Șūfi inspired by the mystical moralist poets of Iran. Anyone who briefly studies our literary works that were produced between the second half of the seventh/thirteenth and the first half of the eighth/fourteenth century may easily judge that this mathnaw exactly fits this period with respect to its subject, world view, and form of expression. Composing this mathnaw in the Persian 'aru $\bar{d}$ meter is also completely in accordance with the literary traditions of that period, because contemporary Anatolian poets, under the influence of the great Persian Șūfiss, had accepted the Persian 'arū the mathnaw form. Yet, because the \{Turkish\} language was still not suitable for the 'arü meter, the words could by no means be read naturally. Instead, they had to be lengthened or shortened. And because artistic excellence could not be achieved, the rhymes are almost always faulty. Therefore, those who have studied the work of Yūnus Emre up to the present have usually regarded this mathnawi as written in the syllabic meter. ${ }^{13}$ This moralistic poem, of a more or less didactic nature, is technically very defective and cannot be compared aesthetically to Yūnus's other works, because it was nearly impossible to add something of his own personality to such didactic versifying. The need to remain bound to a foreign technique to which neither he nor the language was accustomed was also a factor in this.

After this long mathnaw $\bar{\imath}$, there appears a short invocation $\{m u n \bar{a} j \bar{a} t\}$, awkwardly

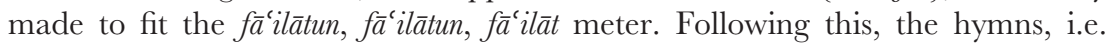
Yūnus Emre's original, important, and personal works, are arranged in a series according to the last letters of the rhyming element. Indeed, the most popular of Yūnus Emre's works for centuries have been these hymns or orations \{s. nutuq\} (in Bektashī terms, nefes \{hymn\}). As one finds generally among the Muslim mystics, some of these works express views that are broad and lofty - i.e. that defend honor and dignity - or are even quite humanistic. Others are orations urging the need for prayer and fasting. Most of them are exuberant poems concerning the philosohy of wahdat al-wujüd \{unity of being\}. All of them breathe a profound and pure excitement, a divine impulse combined with purity of heart and sincerity. This singer of hymns, who only cried out to offer sincere worship 
to his creator and to expound to the heedless the great divine Truth that he had attained, was, in his own words, Hakk tecellîsini şâir dilince eden bu âşık koca \{this enraptured old man who poetically described the self-disclosure of God\}. He knew perfectly all the stories and traditions of ancient history and the scientific and philosophical views and systems of the time. In various places in the Dīwān, there are eloquent references to Islamic and Persian traditions, such as the sultanate of Solomon, the treasure of Farīdūn, and the treasure of Nūshirwān; to all the stages in the history of the prophets; to the legends of the great Șūfìs, such as al-Hallāj and Dhū 'l-Nūn; and to contemporary intellectual and philosophical systems. After reviewing them, it is absolutely clear that the tradition of Yūnus Emre's illiteracy can by no means be considered historically correct.

In a state of mystical rapture and pious reverence, 'Āshıq Yūnus Emre sometimes speaks of a love that is sublime and replete with mysteries, or else of the fearful clamor of the Day of Judgment, or the rivers of milk in Paradise and the divine nightingales' singing of the unity of God. Yet like all Turkish mystics, he could not be completely indifferent to nature. Just as there is an enthusiasm for, and attraction to, nature in the early Turkish poetry in \{al-Kāshgharī's Dīwān lughāt al-turk and in \{Yūsuf Khāṣs Hājib's\} Kutadgu Bilig, ${ }^{14}$ there also exists a certain pleasure in nature in the works of Yūnus Emre, who wandered about the forests of the Sakarya obsessed with divine love. Yet, because his eyes could not escape from the depths of the inner world, even in the very few scenes of nature in the Diveann one is again struck by colors and degrees of spirituality; and the result appears in a completely unexpected manner, i.e. either as moralistic advice or as a mystical aphorism. ${ }^{15}$ In this respect, it would be quite subjective and mistaken to try to establish a connection between Yūnus Emre's works and his milieu. ${ }^{16}$

Also, compared to the moralistic and philosophical poems in the Dīwann, there is very little of a mystical-satirical nature. Poems of this genre, which were also written by conscientious Șûfis in imitation of the utterances of certain of those obsessed with divine love $\{$ majdhu $b\}$, had a very clear meaning to those who were sufficiently familiar with Șūfì symbols, although the ahl-i qāl \{conventional religious scholars\}, who could not penetrate their depth of meaning, regarded them as utter nonsense. Yūnus Emre's poems, such as his famous hymn Çıktrm erik dalna anda yedim üzümü \{I climbed the plum branch and there ate grapes\}, are exactly of this type, and extensive commentaries have been written about some of them. ${ }^{17}$

The meter and form of Yūnus Emre's works are also worthy of study. Up to now researchers have concluded that he used only the syllabic meter, but the fact is that he used both 'arü $d$ and the national \{i.e. syllabic\} meter. I described briefly above how the 'arü Anatolian poets of that time (Chapter 7, p. 209). In this respect, it should be seen as very natural that Yūnus Emre, who was by no means an illiterate dervish, used the 'arü $d$ meter, although he lived among the people and addressed himself to them. Just as it is obvious that some of the poems in the Dīwann that were composed perfectly in the 'arüd meter do not belong to Yūnus Emre, it is equally 
certain that the 'aru $d$ works written in primitive form in Turkish - and usually in such a defective manner that they are indistinguishable from \{works in $\}$ the syllabic meter - do belong to Yūnus Emre. Basically Yūnus Emre employed the simple 'arüd meters that were the most compatible with the syllabic meter. ${ }^{18}$

Although Yūnus Emre used the 'arü $d$ meter, he wrote a significant number of his hymns - and naturally the most beautiful and original of them - in the syllabic meter. The major factor in this was his desire to address the popular masses, among whom he grew up, more effectively by using a cadence to which they were accustomed. In addition, his desire not to differ from other such popular works, which were surely written before him under the influence of Aḥmad Yasawī and his imitators, played a strong role in this. A Șūfī poet who understood the affection and attachment that the people had for such works would certainly, in the famous words of Mawlānā, offer the same kind of goods to his readers. Still, it should not be forgotten that, at that time, in addition to all of these factors, the foreign 'arü nature, whereas in lyrical works the artist tended to the national meter in accordance with his disposition. Yūnus Emre, who was quite unconcerned with art or artistry and composed his poems simply by divine impulse, quite naturally conformed to the natural and national cadence that was stored in his conscience. One encounters virtually every form of the syllabic meter in the Dīwān, namely, $6 ; 7 ; 8 ; 5+5=10 ; 6+5=11 ; 6+6=12 ; 7+7=14 ; 8+8=16$. Among these, the ten- and twelve-syllable forms are quite rare in our literature. While one observes that Yūnus was not bound to the caesura in these forms, or that he was indifferent to various deficiencies, generally speaking he was very successful in his use of these meters.

In addition to the Persian mathnawe and ghazal forms in the Dīwān, there is also the old koşma form, which we may also call quatrains or musammats. Yūnus Emre's most beautiful poems are arranged above all in this latter form. As I stated above while discussing Aḥmad Yasaw̄i, the koşma or quatrain form is the oldest and most widespread form in Turkish folk literature. Yūnus Emre preferred this form not because he was imitating Persian quatrains or musammats, but simply because he was under the strong influence of folk literature. ${ }^{19}$ Thus, it is clear that Yunus Emre did not depart from the popular taste with respect to either meter or form and that he unconsciously took advantage of the aesthetic source that the popular spirit had accumulated over the centuries.

\section{Yūnus Emre the moralist}

As I mentioned above, some of Yūnus Emre's mathnawēs and hymns are of a didactic nature. With them he tried to propagate a type of Șūfì morality. There is no doubt that some of these works are of poor quality and lack originality compared to his genuine Șūfì works. In other words, the moralist persona of Yūnus Emre that we are going to examine here was very undistinguished compared to his Șūfi persona. In any case, in order not to exclude from our study of Yūnus 
Emre even the most insignificant aspects of his life, let me briefly describe the bases of the Șūfi morality that he tried to expound. ${ }^{20}$

The Sūfī morality that Yūnus Emre propagated is first of all a genuine summons to conform to the teachings of the Koran and Hadith and to respect the principles of the Shart ‘ $a$, even to the most minor details, because the Shari ‘ $a$ is the essential foundation of the tariqa. Those who do not respect it are threatened with eternal punishment. Second, there are several negative and positive moral principles that are required by the Prophet's Sunna \{al-sunna al-muhammadiyya\}. These are so well known that there is no need to repeat them here. In quite a few of his poems, Yūnus expounds at length the need to remain bound by them: patience, contentment, generosity, benevolence, and so forth. But these are all general points that constitute the moral bases of Islam. True Șūfì morality begins after this. While it includes much more serious obligations, it is also more refined and more humane $\{$ ins $\bar{a} n \bar{\imath}\}$.

Yūnus begins this propaganda with an invitation to the Șūfi way. Many of his hymns instill the notion that "without attaching oneself to a perfect guide on the mystical path, one cannot reach the goal." ${ }^{21}$ But this way, this Șûfî way, is very demanding. The difficulties to be undergone are not of the sort that could be endured by those subject to the physical self and carnal passion, which are closely bound to this world. For this reason, it is first necessary to make the adepts aware of these difficulties. Thus many of Yūnus Emre's hymns are explanations of these difficulties. Being a dervish does not simply mean being a disciple and wearing the cap $\{t \bar{a} j\}$ and patched cloak $\{k h i r q a\}$. One must put all this aside and, allowing oneself to be the target of arrows of censure $\{$ maläma , eliminate all sense of shame and honor so that genuine \{divine\} love may be established \{in one's heart\}. Only then, thanks to the power of this love, can duality \{of the self and the divine $\}$ be transcended and only then will the secret of divine unity be revealed. There is no other way, for this will not occur by studying the religious sciences. ${ }^{22}$

As I will explain below when discussing the Șūfì beliefs of Yūnus Emre, such a view of existence requires one to trust in God and submit to Him \{tawakkul wa tastim $\}$ and to renounce, abandon, and divest oneself completely from worldly affairs. At that point, the dervish must tolerate everything and consider it good. Once he has attained this state, he no longer makes distinctions among people, whether good or bad, Muslim or $m \bar{a} j \bar{u} s \bar{\imath}$ \{fire-worshipper\}. Indeed, he even treats kindly those who have treated him badly. ${ }^{23}$ It is for this reason that the ascetic Yūnus Emre, who, in some of his hymns, makes the most grave accusations against "one who has never prayed," reveals a broad, humane compassion in some of his most valuable compositions propagating the principles of Șūî morality, and goes as far as to say that he who does not look at the seventy-two sects as equal, he who makes distinctions among them, even if he is a religious instructor, he is still in fact a sinner. ${ }^{24}$

It is, therefore, very clear that this Șūfi morality, the basic principles of which I have tried to establish, was not something peculiar to Yūnus Emre but was 
something that the great Persian Șūi moralists had promulgated. ${ }^{25}$ While Yūnus Emre's style is weak and insipid in some of his poems where he defends the principles of an orthodox pietistic asceticism, he comes across as a forceful, sincere, and distinctive individual in those passages that instill a very broad and humane Șūfì morality. It is also quite obvious from this that Șufism is not, according to this early Turkish Sūfī, a lifeless thing composed of terminology and a code of rules. Instead, just as with Abū Sa'̄̄d Ibn Ab̄̄ 'l-Khair and Mawlānā, it is something living and to be lived, a spiritual need, a divine impulse.

\section{E Yūnus Emre the Șūfì}

Yūnus Emre's Șūfî views, like those of all the early Anatolian Șūfi poets, are either directly borrowed from Jalāl al-Dīn Rūmī or virtually identical to his. In order to understand the Șūfì ideas of Jalal al-Dīn Rūmī, to which we can give the name panthéisme idéaliste \{i.e. wujūdiyya-i khayāliyya\}, it would first be necessary to explain the principles of the Neoplatonists, especially the late Neoplatonists. But in order not to go beyond the scope of my work, which is merely a literary and historical study, I will be content to cite and elucidate briefly the Șūfì principles that are very beautifully summarized in the work of the Persian Șūfì poets, such as Mawlānā and Jāmī. ${ }^{26}$ The basic principle is that of the unity of being \{wahdat al-wujūd\} or panthéisme idéaliste, which is common to all Muslim Ṣūîs and is expounded in perhaps its most perfect and refined form by Muhỵī 'l-Dīn Ibn al-'Arabī. ${ }^{27}$

\{n the following three paragraphs, Köprülü paraphrased E. J. W. Gibb, A History of Ottoman Poetry, vol. 1, pp. 16-19, but we have used Gibb's text.\}

God is Absolute Being. He therefore necessarily comprises within Himself all apparent existences whatsoever; and Absolute Good, therefore necessarily Absolute Beauty, Beauty being one side or aspect of Good. Such is the Divine Nature; and having learned this, we may perceive how the phenomenal universe came into existence. Ere yet time was, God dwelt alone in unrevealed loveliness and glory; alone in solitary radiance shone Absolute Beauty; no eye was there to gaze enraptured on Its unspeakable fairness, no heart to thrill in ecstasy at Its all-perfect harmony. A marked characteristic of Beauty, whatever be the form it may assume, is an innate desire of self-manisfestation. This is very clearly expressed in a famous Hadis or "Apostolic Tradition," continually on the lips of the poets, in which God, in answer to a question of David as to why He had created man, replies, "I was a Hidden Treasure, therefore was I fain to be known, and so I created creation in order that I should be known."28

But how was this manifestation thus demanded by the Divine nature to be brought about? It is an axiom that things can be known only through their opposites or negations. Now the opposite or negation of 
Absolute Being, which is one and the same with Absolute Beauty and Absolute Good, is necessarily Not-Being, Not-Beauty, Not-Good. But such can have no real existence, for all real existence is of necessity comprised in Absolute Being, of which this is the negation. Not-Being is then only a phantasm evoked for a season and for a special purpose. As Absolute Being could be known only through Its negation Not-Being, so Absolute Good could be known only through Its negation Not-Good; and as Absolute Being and Absolute Good are one, so also are Not-Being and Not-Good. Evil has therefore no real existence; there is no Absolute Evil as there is Absolute Good; by its very nature Evil is temporary and limited, it is but an illusion which the conditions of manifestation have rendered necessary for a while.

The process of manifestation was accomplished thus. When NotBeing became opposed to Being there appeared on the former, as in a mirror, a reflection or shadow of the latter. This reflection, which partakes of the nature of both Being and Not-Being, is called Contingent Being, and is none else than the phenomenal universe. ${ }^{29}$ Some Șūiss liken this to the reflection of the sun on a still lake. As the universe is thus the image of Absolute Being, that is of God, reflected in the mirror NotBeing, so, they continue, is man the eye in that image, and as when we look in a mirror, we perceive a small image of ourselves reflected in the pupil, so is the image of God reflected in this eye which is man. Thus is God revealed unto Himself and unto man, and thus moreover does man contain in himself the image of God. ${ }^{30}$

\{In the following paragraph, Köprülü paraphrased Gibb, vol. 1, pp. 19-21; again we have used Gibb's text.\}

Man, like the phenomenal universe in which he finds himself, and of which he presents an epitome, is double-natured, partaking at once of Being and Not-Being, of Good and Evil, in other words, of the elements of existence and non-existence. This Divine particle in man, this spark of Pure Being, is ever seeking, consciously or unconsciously, to be reunited to its source; but so long as the phenomenal state lasts, the presence of the element of Not-Being holds it back. Man's business then is to eliminate, so far as may be, this element of Not-Being, and to attain to that union with God, that absorption into the Divine, which though to be fully achieved only after death of the body, is possible in a certain measure even in this present life. Those who learn the mystery of \{ Die before you die\} have successfully done this. The way to do this is to conquer self; for self, which seems so real, is in truth the supreme illusion as it is the cause of all our woe. We have no self; whatever we have of Real Being is God's not ours; the rest is mere nothingness, the negation of Being, the negation of Good, to hug which 
can bring only sorrow. Thus, Love \{ $i s h q$, ecstatic love of God\} is necessary to conquer the physical self. By Love, and by Love alone, can the dark shadow of Not-Being be done away, can the soul of man win back to its Divine source. Human love is not itself the end, it is but the means to the end; it is the "Bridge" across which the pilgrim of the Truth must pass. But fair as the Bridge may be, the pilgrim must beware of lingering thereon, lest haply he should fail to reach his journey's end. Once across, his eyes are opened, his heart is made clairvoyant through Divine Love; wherever he turn his gaze he sees the Face of God. If he turn his eyes inward and look into his own heart, there he can read letter by letter the very heart of God. For he has now become one with God, knowing and feeling that there is naught beside God. Thus the annihilation in God which is called "becoming Truth with the True," i.e. to perish in absolute being, is this. Al-Manșūr's \{al-Hallāj's $\}$ statement "I am the Truth," and Abū Yazīd Bistāmī's exclamation "There is none other than God within my cloak" are exact expressions of this. ${ }^{31}$

What is needed for this is ecstasy $\{w a j d w a h \bar{a} l\}$. I have discussed above the Șūfì stages that follow this, i.e. baq $\vec{a}$ ' \{subsistence\}, which comes after fan $\vec{a}^{\prime}$ \{annihilation\}, and the final state, which is 'ubüdiyya \{servanthood\} and rujū' ila 'l-bidāya \{returning to the beginning; on these terms see Chittick, The Sufi Path of Knowledge, pp. 219, 310-11, 105$\}$.

After briefly expounding these basic beliefs, which are found not only in Yūnus Emre but in virtually all Turkish and Persian Ṣūfī poets, it will be much easier to understand Yūnus Emre's Șūfì poems. As appears clearly and categorically in many places in his Dīwān, this great Turkish Șūfì was influenced by the work of Jalāl al-Dīn Rūmī, ${ }^{32}$ and like him was very closely attached to the path of wujüdiyya-i khayāliyya = panthéisme idéaliste, which I have explained above. Sometimes, by saying that he could not further expound the truth because he revered the discipline of the $\operatorname{Sharin}^{-} a$, he provides teaching that suits the upholders of religious law and the ascetics. But usually he leaps beyond this boundary with divine rapture, ${ }^{33}$ admitting that the path of love is true religion; that the followers of the Sharī'a cannot attain that station; that his \{i.e. Yūnus Emre's $\}$ religious community is different from every other, and his religion and piety are exceptions to existing religions; and that even without ritual prayer and ablutions he has attained the prayer-niche of the divine Friend. ${ }^{34}$ Yunus gives the following categorical and eloquent response to the objections to this by the "externalists" $\{z a ̂ h i r ~ e h l i\}$ - the legal scholars and jurists:

Bana nâmâz kulmaz diyen, ben kuluram nâmâzımı

Kilur isem kılmaz isem ol Hak bilür niyâzım

Hak'tan artık kimse bilmez kâfir, müsülmân kimdürür

Ben kıluram nâmâzımı Hak geçirdiyse nâzımı 
Ol nâz dergâhından geçen mánâ şarâbından içen

Hicâbsız cân gözin açan ol bilür benim sözümü

\{They say that I do not pray - but I do pray.

And whether I pray or not, God knows my supplication.

Only God knows who is an infidel, who a Muslim.

I do pray, if God has forgiven my pride.

He who passes beyond the court of pride, who drinks the wine of Spiritual Meaning,

Who opens the eyes of his soul without a veil - he knows what I am saying.\}

It is obvious that Yūnus Emre has no business with the legal scholars and jurists, those concerned with the external or superficial meaning of scripture, i.e. the established religious authorities, because they claim to know truth simply by means of the intellect. Using only the intellect and the senses on this dangerous path cannot be productive. For this, ecstasy (wajd, hăl) is required; but those are people who understand religion and God from books $(q \bar{a} l)$ :

Hakikat bir denizdir şerî‘ at ann gemisi

Çoklar gemiden çıkı denize dalmadılar

Dört Kitâb’ ı şerheden hakîkatte âsîdir

Zîrâ tefsîr okuyup mánâsm bilmediler

\{Truth is a sea, and the Sharic $a$ is a boat.

Many never leave the boat and plunge into the sea.

Those who expound the Four Books are sinners in truth:

They read exegesis, but do not know the meaning of what they read.\}

Because Yūnus Emre entered this path with Love, his Dīwān is replete with cries of Love. Just as Love occupies the prime place in Plato, Plotinus, and later in Mawlānā, so it does in Yūnus Emre. He shouts "Ever since I drank the wine of Love, I don't know what I am. In order to reach You, I passed beyond my own existence (i.e. I overcame the physical self and thus eliminated the element of non-existence). Now see me!" And he finally understands the nature of this Assembly of Love $\{$ aşk meclisi $\}$ :

Bir sâkîden içtik şarâb 'arştan yüce meyhânesi $i^{35}$

Ol sâkînin mestleriyüz cânlar anm peymânesi

Bunda dâim yananlarn küllî vücûdü nûr olur

Ol od bir od'a benzemez hiç belürmez zebbânesi

Bu meclisin mestlerinin Ene 'l-Hak demleri olur

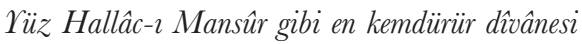


Ol meclis kim bizde olur anda ciğer kebâb olur

Ol şem'a kim bizde yanar ay ve güneş pervânesi

Ol meclisin bekrîleri İbrâhîm Edhem gibidir

Belh şehrince yüzbin ola her kösede bir dânesi

Aşk şarâbın içenlere gel bir nazar eyleyi-gör

Bunca yuldır nice döner ol meclisin piyâlesi

Yûnus bu cezbe sözlerin câhillere söylemegil

Bilmez misin câhillerin nice geçer zamânesi

\{We drank wine at the hands of a Cupbearer whose tavern is higher than the heavenly throne.

We are drunkards of that Cupbearer, our souls are His wine cup.

Here those who constantly burn are wholly transformed into light.

That fire is unlike any fire: there are no flames to be seen.

Those drunk in this assembly only sing: I am Truth.

Like a hundred Hallājes, the lowliest of them is mad.

In that assembly of ours the heart (lit.: liver) is the kebab.

Of that candle which burns in us the sun and moon are moths.

The drunkards of that assembly are like Ibrāhīm b. Adham:

In a single corner are as many as a hundred thousand in the city of Balkh.

Come take a look at those who have drunk the wine of Love:

In so many years, how often the wine cup has made its rounds.

Yūnus: don't utter these words of rapture to the ignorant.

Don't you know that the time of the ignorant will pass?\}

This path of Love is undoubtedly not an easy one. Many dangers must be overcome and many hardships must be met before one reaches the goal. ${ }^{36}$ Yet once one has attained Truth on this path, all difficulties - ugliness, evil, and non-existence - disappear and the traveler sees God everywhere. He finds everything consumed in absolute being.

Ma'nâ bahrine daldık Vücûd seyrini kuldık

İki-Cihân ser-teser cümle Vücûd'da bulduk

Gece ile gündüzü gökte yedi ynlduzı

Levh'te yazllan sözü cümle Vücûd'da bulduk

Mûsâ çıktı̆ğ Tûr'u gökte Beytü'l-Mámûru

İsrâfil'deki Sur'u cümle Vücûd'da bulduk 
Tevrât ile İncîl'i Furkân ile Zebûr'u

Bunlardan hem beyânı cümle Vücûd'da bulduk

Yedi gök yedi yeri dağlan denizleri

Uçmak ile tamuyu cümle Vücûd'da bulduk

Yûnus'un sözleri Hak cümlemiz dedik sadak

Kande ister isen bak cümle Vücûd'da bulduk

\{We plunged into the sea of (spiritual) meaning. We made a tour of Being. We found in Being the totality of both the worlds, from end to end.

Night and day and the Seven Stars in the sky (= Big Dipper),

The words written on the celestial Tablet - we found all of them in Being.

Mount Sinai which Moses ascended, the Frequented House in Heaven, And Isrāfîl's trumpet - we found all of them in Being.

Torah and Gospel, Koran and Psalter,

Together with their explanation - we found all of them in Being.

The seven heavens and seven earths, the mountains and the seas, Paradise and Hell - we found all of them in Being.

Yūnus's words are Truth. We all said: "He has spoken truly."

Look wherever you will - we found all of them in Being.?

After seeing everything in the universe consumed in absolute being, after the element of non-existence is utterly destroyed, and after not separating himself from it \{absolute being\}, the follower of this path obtains absolute happiness. Therefore, in contrast to those who seek God outside oneself, Yūnus Emre's saying Hak cihâna doludur kimseler Hakk'ı bilmez / Kendinden istesene ol senden ayn olmaz \{The Truth (or, God) fills the world, but no one knows the Truth. / Why don't you seek Him in yourself? He will not be apart from you \} rings true, for according to this idea, even absolute being, which is the uniquely true existence and by means of which everything exists, is reflected within human consciousness. The following poem perfectly expounds this conviction:

İstediğimi buldum âşkâre cân içinde ${ }^{37}$

Taşra isteyen kendin kendi pinhân içinde

Kâimdir ol mlmaz ansız kimse dirilmez

Adım adım yer ölçer hükmü revân içinde

Bu trlısm bağlayan cümle dili söyliyen

Yere göğe sı̆̆mayan girmiş bir cân içinde

Girdim gönül sehrine daldim anin bahrine

Aşk ile seyrederken iz buldum cân içinde 
Şâh oluben oturur kula buyruk tutturur

Fermânın buyurur kendi fermân içinde

\{I found what I was seeking plainly evident in my soul.

He who seeks his self outside himself is himself hidden within.

He is everlasting and never departs. Without Him no one comes to life.

He measures the earth step by step. His reign is in the soul.

He who has cast this spell, who speaks in every language,

Who is not comprised by heaven and earth - He has entered inside a single soul.

I entered the city of the heart. I plunged into His sea.

While touring with Love, I found the trace inside my soul.

He is king and sits on his throne, giving commands to His subjects.

He gives His command, but He Himself is in the command.\}

This should never be understood, however, as a form of incarnation \{hulül, indwelling of God in a creature $\}$ or union $\{i t t i h \bar{a} d\}$, because in order for incarnation or union to be possible another being is required in addition to God. The Șūfì belief, however, accepts nothing but absolute being, as I mentioned above. ${ }^{38}$ The hymn below, which reveals Yūnus Emre's concept of emanation $\{s \underline{u} \bar{u} r\}$ and self-disclosure of God $\{$ tajall $\bar{\tau}$, shows that he did not differ from the other great Șūfis in this matter as well; and that is why we can by no means attribute the above words to incarnation or union.

Oradan gönderildim aşk ile bile geldim ${ }^{39}$

Bu âleme çıkcak bir aceb hâle geldim

Gör ne yuvadan uçtum halka râzımı açtım

Aşk tuzağına düşüm tutuldum ele geldim

Geldim us yine varam yine Rahmân'ım bulam

Sanurlar beni bunda davara mâla geldim

Kudret sûret yapmadan firişteler tapmadan

Âlemi halk tutmadan ilerü yola geldim

Çün dost açtr yüzümü gösterdi kendözümü

Gönlümdeki râzım söyledim dile geldim

Tuzaktayım ne gülem ne hâldeyim ne bilem

Bir garîbçe bülbülem ötmeğe güle geldim

Tuzağa düşen gülmez âşık hiç râhat olmaz

Kimse hâlimden bilmez bir aceb ile geldim 
\{I have been sent from there. I have come with Love.

When I emerged into this world, I came into a wondrous state.

See from what a nest I have flown. I divulged my secret to the people.

I fell into Love's trap. I was caught and now I am in the hands of others.

I come, and lo! I will return. I will find my Merciful One again.

They think that I have come here looking for cattle!

Before divine power made the forms, before the angels worshipped,

Before the world was created, I came forth on the way.

When the Friend uncovered my face and made me manifest, I spoke and revealed the secret in my heart.

I'm in the trap: why should I laugh? How do I know what state I'm in? I'm a nightingale far from home. I have come to the rose to sing.

One who falls in the trap does not laugh. The lover is never at ease.

No one knows of my condition. I have come to a wondrous country.

In saying here "The lover is never at ease," Yūnus means that lovers have no peace in this transitory world, because they wish to obtain divinity immediately and go quickly to their original abodes. The divine bird of the heart, which has flown from the nest, keeps fluttering in order to return to its nest as soon as possible. This is why Mawlānā said: مرغ دلم ميطيِ هيبح سكونى نداشت The bird of my heart is fluttering. It never rests. It has seen its original abode. It has found rest there.\}

The externalists do not know the condition of lovers, nor understand their language. Thus, it is a torment for lovers to live amidst creatures not of their own kind, in a world that does not belong to them. ${ }^{40}$ This is what Yūnus Emre expresses with these moving cries. They are a commentary on Plato's principle, "to die is to live."

Ben bunda garîb geldim ben bu ilden bezerem ${ }^{41}$

Bu tutsaklık tuzağın demi geldi üzerem

Yetmişiki millete suçum budur hak dedim

Kirkı hiyânet durur ya ben niçin kızaram

Bir çeşmeden akan su acı tath olmaya

Edebdir bana yirmek bir lüleden sizaram

Şerîa erenleri nice yol ide bana

Hakîkat deryâsinda bahrî oldum yüzerem

Çü ben suçumu bildim cümlesin bende buldum

Mansûr'em dâre geldim kül oluben tozaram 
\{I have come here as a stranger. I am weary of this country.

The time has come for me to break this trap where I am held captive.

I said to the seventy-two religious communities: "This truly is my fault."

Forty of them are treachery - so why should I get angry?

Water flowing from a fountain is not bitter or sweet.

The proper thing for me is to tear it apart (?) and let me ooze out through a pipe.

How can the men of the Shari' $a$ make a way for me?

I am a kingfisher in the sea of Truth - let me swim!

Because I acknowledged my fault, I find them all in me.

I am al-Hallāj and have come to the gallows. I am ashes - let me be blown away!

I stated above the reason for honoring man, that he was created as the most perfect form $\{$ ahsan-i taqwīm $\}$ and that divine attributes are manifest in him. ${ }^{42}$ The major reason for his moral exaltedness is the heart. Some of Yūnus Emre's poems on the heart, and especially the hymn below, are no less precious than the most beautiful passages of the Persian Șūfiss on this subject.

Ak sakall bir koca hiç bilmez kim hâl nice

Emek vermesin hacc'a bir gönül ynkar ise

Sağır işitmez sözü gece sanur gündüzü

Kördür münkirler gözü âlem münevver ise

Gönül Çalab'm tahtr Çalap gönüle bahd

Dört Kitâb'in ma'nâsı budur ĕger var ise

\{An old man with a white beard who does not know what ecstasy is:

Let him make no effort to go on the Hajj, if he is going to break a heart.

He is deaf and cannot hear speech. He thinks day is night.

The deniers' eyes are blind, although the world is brightly lit.

The heart is God's throne. God has regard for the heart.

If the Four Books mean anything, this is what they mean.\}

I described above the kinds of moralistic conclusions that could be derived from this mystical theory. According to the Șūiss, if man, i.e. the perfect man who overcomes the element of non-existence and attains divine Truth, is so important then naturally the most sublime knowledge also belongs to him. Because our primary task is to know God, and knowing Him occurs through knowing ourselves, the most important science, or, more correctly, the fundamental science is that which teaches the mysteries of man. This cannot be found in books like 
the science of conventional religious scholars. It can only be found via the path of Love and by means of a spiritual guide, in other words by the science of mysticism. Yūnus Emre also knows this reality, but he favors stating it not to jurists and religious scholars who are heedless of it, but to lovers.

İm okumak bilmektir hem kendüyü bilmektir ${ }^{43}$

Çünkü kendin bilmezsen bir hayvândan betersin

Yûnus işbu sözleri âşık'a di âşık'a

Gir gönüle yararsa birkaç dahi katarsin ${ }^{44}$

\{Knowledge is knowing how to read, and also knowing one's self.

Because if you don't know yourself you are worse than an animal.

Yūnus: utter these words to lovers, to lovers.

Enter the heart. If it suits, you will add even more (?). $\}$

Just as the idea of the perfect man arises from the theory of emanation and self-disclosure \{of God\} in Șüfì philosophy, so does the idea of dawr \{the cycle of existence passing out from the Divine Reality down through the Arc of Descent and then back into the Godhead in the form of the Perfect Man\}, which is related to it. Hence, we have creation poems $\{$ dawriyyas\}, which are very famous in Șūfì literature. According to the theory of emanation and self-disclosure that I described above, something that comes into existence in this material world, which is the lowest of the existing worlds, is first manifest in the form of an inanimate object, then as a plant, animal, and man, and finally it enters the form of the perfect man and reaches God. This then is the secret of منه بدأ الامر واليه يعود \{Existence originates from $\mathrm{Him}$ and returns to $\mathrm{Him}$ \}, i.e. existence emerges from absolute being, descends to this world, leaves it again, and returns to the source. The Sūfīs likened this cyclical movement to a circle and divided it into the arc of descent and the arc of ascent.

The divine light, which emerges from absolute being, passes in a sequence from Universal Intellect $\{\mathrm{God}\}$ to the nine intelligences, to the nine souls, to the nine celestial spheres, to the four natures \{heat, cold, wetness, and dryness $\}$ and as far as the earth to the four elements \{earth, water, fire, and air\}; this is the origin of the arc of descent. Following this, the same light passes from earth to mineral, then to plant, then to animal, then to man and then to the perfect man and returns again to its source. This second cycle is called the return or arc of ascent. ${ }^{45}$ Mawlānā depicts this cyclical movement very well in one of his famous lyric poems ${ }^{46}$ and there are also passages that touch on this celebrated Șūî doctrine in the Mathnaw ${ }^{47}$ Nāṣir-i Khusraw \{d. between 465 and $471 / 1072$ and 1078\}, ${ }^{48}$ Ibn Yamīn \{d. 769/1368\}, ${ }^{49}$ Faiḍ-i Hindī, ${ }^{50}$ and $\{$ Maḥmūd Shabistarī's\} Gulshan-i $r \bar{a} z{ }^{51}$ This teaching, which Turkish Șūîs used with great skill as a subject of poetry, is essentially Neoplatonic. The doctrine of metempsychosis, on the other hand, is found neither in the great Șūfîs nor in Yūnus Emre. ${ }^{52}$ 
So, just as we find dawriyyas in the poetry of the great Persian Șūfìs, Mawlānā in particular, we also find quite a few in Yūnus Emre's Dīwān, usually penned with great freedom and excitement. Yūnus writes in fervent language that in the beginning he was together with the Beloved, i.e. absolute being; then he became mineral, plant, animal, and man; then he took the form of Moses and went up Mount Sinai, he became Abraham and wanted to sacrifice Ishmael, he became the ram that was sacrificed, he became Joseph and was sold, he became the one who purchased him, he became Jesus and went up to heaven, and he was present at the Prophet's ascension ... etc. From this it is evident that Yunus was not afraid of the chastisement of the Shari $a$, despite his admission to the contrary. The description that I have given above of the spiritual state of Anatolia at that time, suffices to show how Yūnus Emre could have had such unrestrained ideas and, more importantly, how he did not hesitate to express them. Let me give as an example one of the most unrestrained dawriyyas that he wrote:

Ol Kâdir-i kün feyekûn lutf edici Rahmân benem ${ }^{53}$

Kesmeden nzkim veren cümlelere Sultân benem

Nutfadan âdem yaratan yumurtadan kus dürüden

Kudret dilini söyleten zikreyleyen Subhân benem

Kimisini zâhid kulan kimisine fisk işleten

Ayzlarmı örtücü ol Delîl ve Burhân benem

Benem ebed benem bekâ ol Kâdir-i Hak - mutlakâ

Yarn Hizır ola sakâ anı kılan gufrân benem

Et ve deri, sögük ve cân, ten perdelerini tutan

Kudret işim çoktur benim hem Zâhir u 'Ayân benem

Hem bâtinem hem zâhirem hem evvelem hem âhirem

Hem ben Ol'um hem Ol benem Ol Kerîm-i Subhân benem

Yoktur arada tercemân andagı is bana beyân

Oldur bana veren lisân ol deniz ve ummân benem

Bu yeri gökü yaratan bu 'arş ve kürsî devriden

Binbir adı vardır Yûnus ol sâhib-i Kur'ân benem

\{I am He with power over "Be and it was," the Beneficent, the Merciful.

I am Sultan over all, who gives their nourishment without stint.

I am He who created Adam from semen, who produces birds from eggs,

Who gives speech to the tongue of Power, the reciter of praise and the

One who is praised.

I am He who makes some ascetics and others fornicators.

And who conceals their faults; I am the Evidence and the Proof. 
I am the Eternal, the Powerful, absolute Truth.

Tomorrow Khadir will provide you with water: I am He who forgives him.

I am He who keeps body and soul together, flesh and skin and bones.

I have many deeds of Power. I am the Apparent, the Evident.

I am the Hidden and the Apparent, the First and the Last.

I am He and He is I. I am that Generous one who is praised.

There is no interpreter between us. Whatever He does is evident to me.

It is $\mathrm{He}$ who gave me a tongue. I am the ocean and the sea.

I am He who created heaven and earth, who turns the heavenly throne.

He has a thousand and one names, Yūnus. I am the possessor of the Koran.\}

From these accounts, to which many more examples could be added, it is clear that Yūnus Emre grasped with great intuitive power - a power no less than that of Jalāl al-Dīn Rūmī - the most extensive and refined Șūfì philosophy that prevailed in Anatolia at that time and succeeded in expressing it with astounding force and eloquence using the primitive Turkish of that period. While we can by no means consider Yūnus Emre to be an illiterate dervish, we may not fault him because he was not able to create a wholly individual philosophical system. He appropriated to himself entirely the broad and unrestrained views of Muhȳi 'l-Dīn Ibn al-'Arabī, Jalāl al-Dīn Rūmī, and their disciples. In his spirit a mystic, in his character he was a great and genuine artist. A number of leading Persian poets and Șūfis had adopted Neoplatonism in its Islamic form while making no attempt to create an individual system; and Yūnus Emre followed their lead. Yet he succeeded in expressing all the Sūfì principles in the simplest language and in such an artistic manner, and he made his works live so vigorously among the people that his like has never been seen in our literature or in Persian literature. Yūnus Emre was not a great philosopher, but he was a sincere, enthusiastic, and genuine Sūfī and above all a poet of genius. After Aḥmad Yasawī, one encounters no other Șūî poet in all Turkish literature who had as much influence as Yūnus Emre. ${ }^{54}$

It would be totally incorrect to regard Yūnus Emre as a bātinin, i.e. "as a follower of the creeds that did not conform to the official doctrines," he did not go beyond the principles found in Muhyȳ 'l-Dīn Ibn al-'Arabī and Jalāl al-Dīn Rūmī, principles that were not even regarded as contrary to the $\operatorname{Shari}^{\prime} a$ - albeit interpreted allegorically - even by a large segment of the orthodox religious establishment. ${ }^{56}$ If Muhȳī 'l-Dīn Ibn al-'Arabī, Jalāl al-Dīn Rūmī and their followers are to be considered as bātinīs, then Yūnus Emre would also have to be included among them, but Muslim scholars never understood the term bātiniyya in this fashion. 


\section{F Yūnus Emre and Ḥurūfism}

Hurūfism is a creed that was spread by Faḍl Allāh al-Na'̄immī Astarābādh̄̄ in the eighth/fourteenth century and penetrated Anatolia in the ninth/fifteenth and tenth/sixteenth centuries. Its fundamental beliefs and the reasons for its appearance have been very well studied. ${ }^{57}$ Although a number of Turkish Șūfi poets like Nesīmī, Rafì̄ $\overline{1}$, and Tamannāyī adopted this creed, ${ }^{58}$ no one to date has made the slightest suggestion that Yūnus Emre was a Hurūfí; neither the old historians and biographers nor modern researchers have spoken of such a likelihood. Rızâ Tevfik, probably believing Yūnus Emre was a ninth/fifteenth-century poet, was the first to conclude from certain passages he saw in the Dīwān that he was a Hurūfī. ${ }^{59}$ The information I provided in the previous section on the life of Yūnus Emre showed that it is virtually certain that he died long before the appearance of Faḍl Allāh Astarābādhī and thus to regard him as a Hurūfī is completely without foundation. Indeed, no evidence whatsoever has come to light indicating that he was in fact a Hurūfi. Some things do exist in his work pertaining to Arabic letters and their secrets, ${ }^{60}$ but they are common to all the great Șūis and are a part of Șūì Islam, not as a fundamental principle but as an appendage, and it is impossible to attribute Hurūfism to those Șūfīs who speak of them. ${ }^{61}$ If one were to consider everyone who believed in the secrets of the Arabic letters to be a Hurūfì, then one would have to accept that Hurūfism was established long before Faḍl Allāh. But because it is certain that the strange and childish system that we know under the name Hurūfism originated with this figure, such a claim is untenable. ${ }^{62}$ In short, because all Sunfīs believed in the secrets of the letters, and because this belief has no connection with Hurūfism, nothing further need be said on this matter. Rızâ Tevfik apparently ignored the importance that Muslim mystics gave to the Arabic script and never considered whether Yūnus Emre came before or after Faḍl Allāh. He created the issue of Yūnus Emre's Hurūfism out of nothing and tried to include him among the Hurūfì poets. In light of this brief discussion, it is obvious how baseless and fanciful this claim is.

\section{G Conclusion}

In Chapter 7 of this book, I outlined the spiritual and literary character of Anatolia before Yūnus Emre and described the milieu in which he flourished. After providing descriptions of Yūnus Emre's poetry with respect to its linguistic and literary character and its ethical and mystical features, I would now like to draw the threads together and make some brief general remarks concerning his artistic achievement and his similarity to Aḥmad Yasawī.

First, was Yūnus Emre an artist, and what inherent value does his work have from a strictly aesthetic perspective? From the time of our early biographers, whose elementary and limited views of art we know quite well, to the present which has naturally been influenced by these same elementary views - Yūnus Emre has never been thought of as an artist. Indeed, as I have shown above, 
Yūnus Emre, who was an ardent Șūfi, was not concerned in the least with art and artistry. He simply sang of his soul and his spiritual excitement, his needs and inspirations. As with all Șūiss, the single external factor that drove him in this matter was his desire to assist people by giving them spiritual guidance. Nevertheless, his lack of concern for art, his disregard of the regularities of language and rhymes, were never obstacles to his becoming an artist, indeed a great artist. To the contrary, if he had been preoccupied with artistry according to the conception of that time, he would not have been able to avoid an affectation of style, i.e. the rules of old classical literature, and consequently he would not have been able to pour out his soul with such sincerity. The basis of art is personality, and the most powerful personalities are those who are the most sincere. In other words, the fact that Yūnus Emre was ignorant of his own artistry is by no means an obstacle to considering him a great artist.

Yūnus Emre's art was a completely popular, i.e. a completely Turkish, art, so that when we analyze it we discover two major fundamental elements. First, the Islamic-Neoplatonist element gave Yūnus Emre his mystical and ethical principles. This constitutes the matter in his work. Second, the Turkish popular element provided his language, style, meter, and verse-form. This constitutes the form of his work. Because form and matter cannot be separated from each other - and can only be analyzed by abstraction - these two elements have coalesced in Yūnus Emre's personality, resulting in art that is completely national, i.e. completely Turkish with respect to taste. Expressing this metaphorically, we could say that Yūnus dissolved these two elements in the crucible of his personality and brought forth brand new material possessing completely different and distinctive qualities. Yūnus Emre's power - or, to use a more forceful and more accurate expression, his genius - derives from this capacity. And essentially this form of genius is also completely Turkish. ${ }^{63}$

Yūnus Emre created this national art form and imprinted it - in a manner so forceful that it would not fade over the centuries - with the seal of his personality. The distinctive qualities of this art form are purity, sincerity, simplicity, clarity, and power. While reading Yūnus, we sense that a simple ingenuous dervish, with eyes full of compassion and love, is singing to us in divine language. In his addresses and pleas to God, this dervish, who opens his soul to us like an old friend, shouts, weeps, or protests, or else, always with a most natural purity, simplicity, and sincerity, sings in a state of rapture. His work has no trace of anything artificial, ostentatious, ceremonial, or in conformity with rules of etiquette. The simplicity of his soul is reflected transparently in all his hymns. Yūnus Emre speaks about the most profound and difficult metaphysical questions with amazing clarity. Even those who know nothing about the subtleties of Islamic mysticism or the doctrines of the Neoplatonist school become spiritually acquainted with these subjects by reading his hymns, for they will have perceived in their hearts the riddles of existence. Yūnus Emre had the ability to instruct the people by making them sense these mysteries - albeit in the simplest manner with the purity and directness of an illiterate. He expressed himself forcefully and 
convincingly and his way of presenting the most intractable problems was straightforward. Indeed, his ingenuous boldness in expounding the most sublime truths is too personal and sublime to be found even among the greatest Persian Sūfìs.

\section{Sirât kuldan incedir kuluçtan keskincedir \\ Varp anon üstüne evler yapasim gelir \\ Altında gayyâ vardır içi nâr ile pürdür \\ Varp ol gölgelikte biraz yatasim gelir \\ Ta'n eylemen hocalar hatorniz hoş olsun \\ Varuben ol tamuda biraz yanasim gelir}

\{ Sirât (the eschatological bridge over hell) is thin as a hair and sharp as a sword:

I would like to go there and build houses on it.

Below it is the inferno, blazing with fire:

I would like to go and lie down a while in that shade.

Don't blame me, teachers - please think well of me -

I would like to go and burn in hell a while.\}

This manner of expression, which the reader finds astounding and convincing at the same time, is so natural that we would almost think we were hearing it from the mouth of the famous illiterate shepherd whom Moses encountered. ${ }^{64}$ But Yūnus Emre was not illiterate like this shepherd. He was familiar with all the contemporary \{intellectual\} systems. Still, it is marvellous how he can resolve the most abstruse metaphysical questions with such purity of heart and simplicity and with such a sense of the popular taste, while lending them the sincerity of an illiterate. The primary features that we found in Yūnus Emre's art - simplicity, clarity, power - we also see clearly in other branches of Turkish art - for example, in architecture - which is its most exemplary branch. ${ }^{65}$ This too shows that Yūnus's literary genius was completely national and typical.

This brief analysis of Yūnus's art also makes clear why his works have flourished for centuries among the people. The first of the two elements that shaped Yunnus Emre's art, i.e. the Islamic-Neoplatonist element, has hardly diminished during the six centuries that have elapsed since his time. To the contrary, it has persisted, and indeed continually increased in importance right up to modern times. The intellectual heritage of the ancient Greeks, which was studied in the madrasas, and later the rich and valuable works of the Persian Sūfîs, which were read in the tekkes, reinforced this manner of feeling and thought and spread it to the masses. As these views, which slowly spread from the upper classes to the common people, eventually became pervasive among the public, it became impossible, of course, for the hymns of Yūnus Emre to be forgotten. Above all, the fact that this element was presented in new dress with forms wholly derived from the people and in a manner that suited their taste, and thus the most sublime and difficult metaphysical doctrines were expressed in a national form that was simple 
enough to be understood by the people, gave a very prominent place to Yūnus Emre's hymns among even the simplest folk.

As I said above while analyzing the reasons for the success of Ahmad Yasawī, the general conservativeness of popular literature over the centuries, i.e. the lack of a major change in the popular taste, was another factor contributing to the popularity of his work for centuries. In addition, one must also search for Yūnus's artistic success, which endured for centuries, not only in the lack of a significant intellectual and spiritual change in the milieu that his art addressed, but also somewhat in his personality, in his genius. If this were not the case, our great intellectual \{Gökalp\} would not have tried to imitate the national and sincere style of Yūnus Emre's hymns in a number of his own hymns written during the recent years of revolution in which great importance has been given to research on the national taste. ${ }^{66}$

Those who read separately my ideas about Ahmad Yasawī and Yūnus Emre could easily make for themselves a comparison between the two. In order to save them the trouble, it will suffice for me to briefly list certain important differences between them. First, it is certain that Ahmad Yasawī and his followers influenced Yūnus Emre and his predecessors in Anatolia. Even the artistic elements of Aḥmad Yasawī and Yūnus Emre are virtually identical. In Yūnus Emre, however, the philosophical element becomes broader and more sublime, assuming an explicit form of pantheism \{wujüdiyya-i khayaliyya . At the same time, the expression is no longer dry and didactic, but acquires a lyrical and lively form. The difference between them cannot be explained simply as the result of period and milieu. Yūnus Emre apparently never gave a thought to founding a tarīqa and so never gained the spiritual influence of the founder of a tariqa. Nevertheless, he had a much more sensitive temperament than Ahmad Yasawī and was a much more individual artist. He was also a more exuberant and vigorous Ṣufî̀ than Aḥmad Yasawī. In all of Turkish literature, from its origin to the present, no greater Șūī poet has ever appeared.

\section{NOTES}

1 We possess no clear documentation on this matter, but the fact that all copies of the $D \bar{\imath} w \bar{a} n$ belong to recent centuries leads us to accept this notion. Otherwise, because the works of this early poet were so well known and widespread, we should certainly find an early copy of his D $\bar{\imath} w \bar{a} n$ written in the eighth/fourteenth or ninth/fifteenth century. The lack of a dīwān is the reason why early anthologies $\left\{m a j m \bar{u}^{\prime} a s\right.$ and cönks\} are full of Yūnus Emre's hymns. I mentioned above that true Sūfiss who sang simply for the sake of the divine, without any concern for artistry, and without any desire for fame, rarely recorded and arranged their works into dīwanns and that even the Dīwān-i Hikmat was collected and arranged by an enthusiastic murī long after the death of Ahmad Yasawī. It is clear that the works of Aḥmad Yasawī and Yūnus Emre are quite similar in this respect.

2 Foy, who made a number of extensive linguistic analyses of the two texts that Mühlbacher published, cites them in Arabic script as follows, transcribed here, with certain corrections, as early texts of Yūnus Emre \{"Die ältesten osmanischen 
Transscriptionstexte in gothischen Lettern," with further emendations based on recent studies by Talât Tekin, "Yunus Emre'nin gotik harfleriyle iki manzumesi," Erdem, 3 (1987), 367-92, and Heidi Stein, "Das türkische Sprachgut im 'Tractatus de Moribus, Condictionibus et Nequicia Turcorum' (1481) des Georg von Ungarn," Archivum Ottomanicum, 14 (1995/6), 39-78; 15 (1997), 89-118\}:

Gâfl olma aç gözünü

Kötülük etme dünyâda

Niceler yatır düsüben

Sümükleri saçışuban

Kim âh edüb kulır zân

Göcmüs yatır pîr u kar

Sorma hâlin kimisine

Kim isini gövdesine

Hanı Muhammed Mustafâ

Dünyâ kime kuld vefâ

Aldanma mâla davara

Sevik ile bile vara

Yûnus bu sözleri çatar

Kendisi nekadar dutar
Hâline bak öleni gör

razuklarn dileni gör

Girm ilan, çiyan üşüben

Çürüyen ovulan gör

Günâhdur elinde varn

Miskînleri güleni gör

Inanma yaramasina \{?\}

Ulşup yeni ynlan gör $\{$ ? $\}$

Hüküm etti Kaf'tan kaf'a

Aldamben kalan gör

Kulluk eyle Hakk'a yara

Bâkî yoldaş olan gör

Halka márifet satar

Söylediği yalan gör

Yanar içim göner özüm

Ben ölümü anç̧ag

Ölüm endîşesi ne hoş

Ululara danıçag

Öliseriz belli beyân

Teneşir üstüne konup

Gizli içimiz olur ayân

Halk önünde yunçag

Hiç bilmezem ben nice idem

Yakasiz don giyem gidem

Hangi yana sefer idem

Başsiz ata biniçeg

Gele bana kavum kardaş

Kim olısar bana hâldaş

Ola sine degi yoldas

Ben sin'imde kahçag

Kalam ben 'amelim ile

Her niceyse hâlim ile

Gide kavum güle güle

Evden yana döniçeg

Sana eydirem ey paşa

Kimi isiden bağrr pise

Neler geliserdur başa

Kim şarâba kamçag

Yarn siyâset kurula

Cümle halâynk dirile

Kimi isiden yanı̧ag

'Amelsize olur 'itâb

Bunda âzâd olı̧ag

'Amel verer onda cevâb

Şol kişiye olmaz azâb

Utanmayasin doğru bak

Yûnus imdi kul yarak

Cümle halâynk dirile

\{Don't be neglectful: open your eyes; consider your condition; see the dying.

Don't do evil in this world; seek forgiveness for your sins.

How many have fallen and lie in the grave, with swarms of worms, snakes and centipedes, 
Their bones scattered. See how they decay and turn to dust.

Some sigh and moan: everything is sin in their hands.

The elders have passed on and lie in the grave. See how the miserable sinners laugh.

Ask no one of his condition, trust not one who is contrary (?).

He who was warm in his body (?) - see how he howls and expires.

Where is Muhammad Mustafā who ruled the world from end to end?

To whom has the world been faithful? See those who are left deceiving themselves.

Do not be deceived by worldly wealth. Worship God.

Go together with the Beloved (Prophet). See who is the eternal wayfellow.

Yūnus puts these words together. He sells wisdom to the people.

But how much does he hold to it himself? See what lies he is telling!

$$
\text { * * * }
$$

My innards burn when I recall death.

How pleasant is the anxiety of death when I marvel at the great ones.

We shall die, that is clear. What is hidden within us will be plain to see.

When we are placed upon the bier and we are washed before the people.

I don't know at all what I should do, which direction I should go.

I'll wear the garment without a collar (i.e. shroud) when I mount the horse without a head (i.e. bier).

My people and kin will come to me and be my wayfellows as far as the grave. Who will be my companion when I am left in my grave?

I'll be left with my deeds, with my condition, whatever it may be.

My people will go back laughing, when they return home.

I will tell you, o pasha, what things will befall me:

Some will have their livers cooked by the heat (in hell), while some quench their thirst with the wine (of paradise).

Tomorrow punishment will be meted out; all creatures will be gathered together.

Some amīs (?) protected by shade, while some burn in the heat.

Our good deeds will answer for us there. He who lacks good deeds will be punished,

That man will not be tormented who is noble in this world.

Yūnus make provisions now. Don't be ashamed, look straight ahead.

All creatures will be gathered together and each one will be counted by name.\}

The language of these texts reveals their antiquity quite well. For example, we encounter Sulțān Walad's concept of mâl davar \{worldly goods\} in his line Yoğ idi mâlm tavarm kim virem \{I had no worldly goods to give $\}$ here in the line aldanma mâla davara $\{\mathrm{Be}$ not deceived by worldly goods $\}$. We also come across such adverbial and verbal forms as geliben, kaliben, geliser, and kahser, belonging to the early periods of Turkish and found in the works of Sultān Walad, 'Āshıq Pasha, and Gülshehrī. Similarly, sin in the line Ben sin'imde kahı̧ag means "grave." We also find this word in \{al-Kāshgharī's\} Dīwān lughāt 


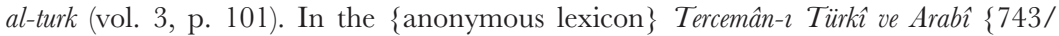
1343 , which belongs to that period, this word is also found having the meaning "grave" and "statue." It is very likely that this refers to the statue placed on the grave according to a well known custom among the early Turks. While Foy's linguistic explanations need to be criticized in many respects, I will not mention them here. I will say, however, that these texts, despite Foy's claim to the contrary, definitely belong to Yunus Emre. The second of these two poems has another characteristic that we find in our earliest folk poetry and in the work of Ahmad Yasawī, namely, that the fourth verse, which serves as a refrain, is always one syllable short compared to the main verses. In other words, the poem is mainly in $4+4$ meter while the refrains have seven syllables (on this subject see Chapter 5, pp. 160-1, nn.44 and 45).

3 There are a number of poems belonging to Yūnus Emre in the $\mathcal{F} \bar{a} m i^{\prime}$ al-naża $\bar{a}^{\prime} i$, which was collected and arranged by Hacı Kemal from Eğridir in 918/1415-16 on the latter, see $E I^{2}$, s.v. "Mukhtārāt" (Günay Kut), p. 531\}. I will cite one of them here verbatim in order to give an idea of their linguistic nature:

Düsmüşsem elden ayağa Şâhh-u Sultânm meded Dertliyem geldim kapuna derde dermânm meded

Sen hakikat serveri ben bir kemine kul senin Hizmete geldim kabûl et ben kulun Hân'in meded

Sendedir mühr-î Süleymân sana fermân ins-ü cân Yeryüzünü tuttu dî̀ler ey Süleymân'rm meded

Fikr-ü zikrindir hemîşe gönlümün eğlencesi Kimse yâr olmaz bana hiç tendeki cânmm meded

Yanahdan nâra bağgrm aşknna Ceyhûn gibi

Durmaz akar gözlerimden yaş ile kanm meded

Kâfileden ayn düştüm ey Emîr Hâcim benim 'Âsi hurma berkesinde kald kârvânum meded

Aşk ile geldi kapuna Tapduk'ım Yûnus senin

Gice gündüz endîşem Tapduk'um-ü cânm meded

This ghazal, which is not found in the published Dīwann, but is also in a manuscript copy $\{$ of the $D \bar{\imath} w \bar{a} n\}$ in my private library, is corrupt in many respects.

4 There is no question that there are many poems in the printed and manuscript copies of Yūnus Emre's Dīwān that do not belong to him. For example, the hymn that mentions him in the couplet Yûnus idi pişsevimiz Asşı Paşa Küşterîmiz / Ol demde oku İsmấ̂l Miskîn niyâminda idi \{Yūnus was our forerunner, 'Āshıq Pasha our Kushterī / Recite at that time, Ismā̄īl: Miskīn was asleep (?)\} - which shows that Yūnus had precedence followed by 'Āshıq Pasha and Shaikh Kushterī \{d. c.767/1366\} - clearly appears to have been written by a Șüfi poet with the pen name Ismāîl and cannot possibly be attributed to him. Similarly, other hymns written by someone with the pen name Amīr Sayyid do not belong to him. In addition, it would be incorrect to assume that all the hymns by writers with the pen names Yūnus, 'Āshıq Yūnus, Dervish Yūnus, Miskīn Yūnus, Qul Yūnus, and Yūnus Emrem can be attributed to him. As I mentioned above while discussing Ahmmad Yasawī, poems that a number of unknown dervishes who had the pen name Yūnus wrote in imitation of those by Yūnus Emre, which had for them a sacred quality, have been mixed with his genuine poetry. Given Yūnus Emre's great fame, hymns belonging to others could also have been attributed to him as they were copied from one anthology to another. For example, the famous 
hymn Abdu'l-Kâdir gibi bir er bulunmaz \{There is no saint like 'Abd al-Qādir\}, which has been presented as belonging to Yūnus Emre, is attributed to Eşrefoğlu \{d. 873/1469, see $E I^{2}$, s.v. "Eshrefoghlu" (Fahir İz) $\}$ in an anthology in my possession. In my discussion above of Ahmad Yasawī's Dīwān-i Hikmat, I dwelt on the factors that gave rise to this phenomenon.

5 One comes across traditions mixed with all sorts of superstitions that point to the large number of Yūnus Emre's hymns among the dervishes. According to these traditions, Yūnus Emre recited improvised hymns - or, to use another well known term, orations $\{$ nutuq\} - wherever he stopped and there were so many of them that some were sung by animals, some by humans, and some by angels. Such traditions are very significant for showing the place and influence of Yūnus Emre among the people.

6 For example, the hymn quoted above $\{$ in n. 3$\}$ that was taken from $\{\mathrm{Hac1}$ Kemal's $\mathcal{F} \bar{a} m i^{\prime}$ al-nază ${ }^{\prime} i r$ appears in the following form in the manuscript copy in my private library:

Düşmüs (em) elden ayaga şâh(u) sultânmm meded Dertliüüm geldim kapuna derde dermânm meded

Sen hakikat severisin ben kemine kemterin

Kulluğa geldim kapuna ben kula hânm meded

Sendedir mühr-i Süleymân sana fermân ins-ü cîn

Yir yüzini tuttı dîvler hey Süleymân'm meded

Tanahdanberi bağrnm aşknna Ceyhûn gibi

Durmaz akar gözlerimden yaş ile kanm meded

Kâfileden ayn düştüm ey Emîr Hâci’m benim

'Âsi hurma berkesinde kaldr kârbânm meded

Kulluğa bel bağlayub Tabdûk'a Yûnus (?!) gibi

Gice gündüz endîşem câna cânanm meded

One may also find different versions - often quite confused - of the same hymn in various places in one $D \bar{\imath} w \bar{a} n$.

7 There are numerous manuscript copies of Yūnus Emre's Dīwān. \{In Turkey\} copies are found in many libraries, including the Galata Mevlevî-hânesi Library (no. 608) and the Âtıf Efendi Library \{in Istanbul\} (no. 1047). Many other copies are found in the libraries of Europe. One frequently comes across not only the Dīwann but also anthologies containing the works of Yūnus Emre in Flügel's manuscript catalogue for Vienna, in Pertsch's catalogue for Berlin, and in catalogues of other libraries. In addition to a fairly good manuscript copy in my private library, I have been able to examine five or six other copies of the Diwe $\bar{a} n$ in private hands. In an anthology in the Esad Efendi Library \{in the Süleymaniye Library in Istanbul\}, quite a few hymns of Yūnus Emre are given together with the names of the composer. My private library also includes many anthologies that contain works of Yūnus Emre. In any case, those who wish to make linguistic analyses of his $D \bar{\imath} w a \bar{n}$ will be able to find numerous such manuscripts of it as well as anthologies.

8 For the close relationship between Azerī dialect and early Anatolian Turkish, see $\dot{I} A$, s.v. "Âzerî" (M. F. Köprülü).

9 On the classification of Turkish dialects in the fifth/eleventh century, see the long discussion above \{in Chapter 5, pp. 130-4\} concerning the dialect in which Ahmad Yasawī wrote.

10 E. J. W. Gibb compares the language of Yūnus Emre and Sultān Walad and reaches the following conclusion: "The language, though naturally abounding in longobsolete words and forms, is considerably more Ottoman than that of the Rebáb-Náme 
verses. This may probably be in some measure owing to the 'corrections' of successive copyists, but it is no doubt chiefly attributable to the fact that the author was a northern Turk" (A History of Ottoman Poetry, vol. 1, \{p. 167\}). I definitely cannot accept the idea that there was such a great difference, with regard to language, between the works of Yūnus Emre and Sultān Walad. If we possessed an early and reliable copy of Yūnus Emre's Dīwān, I could very easily prove my contention. But even without such a copy - thanks to other works from Anatolia from those periods - I can assert very strongly that morphologically and phonetically there is no significant difference between the works of Yūnus Emre and Sultān Walad and that their poetry should be included in the same linguistic parameters. The fact that Gibb provides no evidence for his claim reveals its weakness. If Gibb had seen early contemporary copies of these works, he would not have attributed such a great difference to the works of Sultān Walad. I could strengthen my contention with considerable evidence if necessary.

11 In the printed edition of the Dīwann, and in most manuscript copies, this prose introduction is laid out as verse. On closer examination, however, it is obvious that it is not verse but a kind of rhymed prose. I have only found this laid out as prose in some good and carefully written manuscripts.

12 In the printed Dīwann, this mathnaw $\bar{\imath}$ is found in a very corrupt and completely unreliable form. The manuscript copy in my private library, however, is in the proper and correct form. It is written in the mafā $\bar{\imath} l u n$, maf $\bar{a}^{c} \bar{\imath} l u n, f a^{c} \bar{u} l u n$ meter and has more or less preserved its early linguistic features \{see Gölpinarlı edn, pp. 2-37\}.

13 Veled Chelebi \{İzbudak\}, in an article that he wrote in 1313/1895-6 for a special joint issue of Tercümân-ı hakikat-Servet-i fünûn \{i.e. the daily newspaper Tercümân-ı hakikat and the illustrated weekly Servet-i funun $\}$, is of the same opinion. E. J. W. Gibb, who perhaps follows him, also agrees: "All this verse is written in the Turkish metres, which is doubtless what Tashköpri-záde means when he speaks of Yúnus' words being in the 'ballad style.' . . . Yúnus' verse is rugged beyond that of any other Turkish poet; this is in part owing to the fact that he alone used exclusively the uncultivated Turkish metres; Sultán Veled... and Yúnus' contemporaries and immediate successors... wrote in one of the established Persian metres" (A History of Ottoman Poetry, vol. 1, $\{$ pp. 167, 168\}). Melioransky, in his treatise that I mentioned above \{ $\mathrm{K}$ voprosu o znachenii"\}, also says "The language of Yūnus Emre is purer and sounder than the language of subsequent Ottoman poets. His meter is the syllabic meter. These two features, which were viewed unfavorably by Ottoman men of letters and historians, give, in my opinion, much greater value to his work." The reason for this mistaken idea must be sought not only in the lack of a critical attitude, but in the unreliability of the text of the printed $D \bar{\imath} w \bar{a} n$ and in the fact that even 'Āshıq Chelebi and TashköprüZāde indicate that he wrote only in the syllabic meter.

14 In Chapter 1 (pp. 11-12), I touched on the feelings for nature in our early folk poetry. For more on this subject, see my Türk edebiyat tarihi (Istanbul, 1928), pp. 87, 184, 194ff. In the Kutadgu Bilig, there are some passages that sincerely describe nature, such as in the introduction to the ode about Bughrā Khān. See the text published by Radloff \{Das Kudatku-Bilik; and see Dankoff's Eng. trans., pp. 41-3, and his study "On Nature in Karakhanid Literature," Journal of Turkish Studies, 4 (1980), 27-35\}.

15 As, for example, in the passages:

Gitti bu kuş zulmeti geldi bahâr nâz ile Yeni nebâtlar bitti cünbüs oldu yaz ile

Yine merg-zâr oldu uş yeni gülzâr oldu Ter nağme düzer oldu mûsıkî de sâz ile

Hoş haber geldi dosttan bezendi bâ̆ğ-ü bostân Ötüşür hezâr destân bülbülleri râz ile 
Kim görmüş̧ür baykuşu gülsitâna girdiğin

Leylekler zikredemez bir latîf âvâz ile

Nice mâh saklar isen dürdâne gevher olmaz

Leylek leylekle uçar hemîşe bâz bâz ile

El kuşu elden ele gül kuşu gülden güle

Baykuş vîrâne sever şâhînler pervâz ile

\{Winter's darkness is gone. Coyly spring has come.

Plants have sprouted again exuberantly with the coming of spring.

The meadow is green again, the roses are in bloom.

The air is filled with fresh melody and song.

Good news has arrived from friends. The gardens are all decked out.

A thousand nightingales sing and coo.

Who saw the owl enter the rose garden?

The storks can recite no litanies with a delicate voice.

No matter how many months you keep it, the pearl will not become

a jewel.

Stork always flies with stork and hawk with hawk.

Bird of hand from hand to hand, bird of rose from rose to rose.

Owls love ruins, falcons love to fly.\}

It is clear that nature is not the basic subject here. The poet, using artistic language, is interpreting its manifestation in a completely mystical fashion. Other such nature poetry found in the Dīwān is generally of the same kind. For a true Sūfì who finds what he is searching for wholly and exclusively in his own conscience, this should be considered normal.

16 In a short monograph entitled Millî arûz, Necib Âsım attributes the ghazal Müsülmânlar gönül şehri açılmaz key alâmet var / nazar eylen bu dünyâya aceb dürlü melâmet var \{Muslims: the city of the heart will not open. There is a good sign. / Look at this world: there are wondrous kinds of blame\}, which I very much doubt belonged to Yūnus Emre, to the confused time at the end of the Seljuk period and tries to establish an artificial relationship between the works of this dervish, who was indifferent to the outside world, and his milieu. The poetic inspiration of the Șūfîs, however, is dependent only on their own inner nature and conscious universe and is remote from any concern with time and place. The unity that is perceptible amidst the endless variety of phenomena in the universe and the existence that is concentrated in selfconsciousness are the only stock-in-trade of a true Sūfi. The adorer of unity who finds absolute being, which is the greatest reality, in the conscience would not deign to complain about his time in the following manner: Ne kâdî adl-ü dâd eyler ne kayguluyu şâd eyler / Ne ümmî itikâd eyler ne imâmda imâmet var \{The qāậ̀ neither practices justice nor cheers the distressed. / Neither does the illiterate have faith nor does the prayerleader lead the prayer\}. There are stories that persist among the people about the evil, oppression, and irreligion of every period, government, and government official and there are various ballads and poems of this kind that we can consider an outward manifestation of this spiritual condition, but they have no Șūî significance whatsoever. On the whole, the Șūfis are not pleased with this world and are opposed to it. But this displeasure does not result from good times, bad times, or times of public disorder, or from any such material reasons. Instead, it arises simply from the desire to attain immediately the "original abode" \{maskan-i aș $\bar{\imath}$, i.e. God\}. 
17 Shaikh Jamāl al-Dīn Lūrī, who was in Shīrāz when Abū Bakr \{the Salghurid, 62858/1231-60\} was the Atabeg of that city, was a Sūfì obsessed by divine love. From time to time, he recited satirical verse. Using these satirical verses as a pretext, some religious scholars issued a fatwa for his execution and wanted an authorization from the ruler to carry out the fatwā. The ruler said that he would not grant such an authorization as long as Shaikh Najīb al-Dīn Buzghush and Mu'īn al-Dīn did not declare him to be an infidel. They concluded that because he was overcome by divine love, he could not be declared an infidel and he was therefore saved ( $\{$ Jāmī, $\}$ Nafahăt, \{Turkish\} trans., pp. 533-4). Some Șūfìs, while not being obsessed by divine love but imitating those who were, did not hesitate to recite, from time to time, satirical verses of a Șūfì character. We have, for example, the following ghazal by Jalāl al-Dīn Rūmī, for which Shams al-Dīn Sīwāsī provided a commentary \{Sharh-i ghazal-i Maweīnā, MS in Köprülü's private library\}:

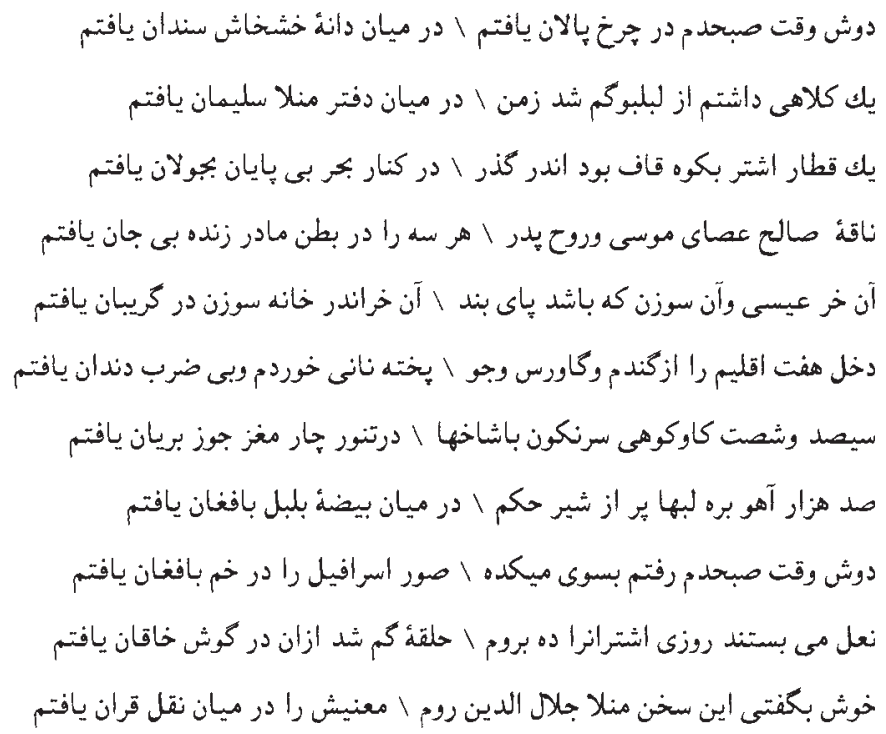

\{Yesterday at dawn I found a pack-saddle in the wheel;

I found an anvil in the middle of a poppy seed.

I had a hat made of chickpeas. I lost it.

I found it in the middle of Mullā Sulaimān's register.

A camel train on Mount Qāf was in the pass:

I found it wandering at the shore of the boundless sea.

Șālih’s she-camel, Moses' rod, father's soul:

I found all three alive and dead in mother's belly.

Jesus' donkey and the needle that is a fetter:

I found that donkey in the house and that needle in the collar.

I ate a piece of boiled bread made from wheat and millet and barley,

And without striking my teeth, I found the income of the seven climes. 
I found 360 mountain-cows with their horns head down

In the oven of a roasted walnut.

I found a hundred thousand fawns, their lips full of the milk of wisdom, Moaning in the middle of a nightingale's egg.

Yesterday at dawn I went to the tavern.

I found Isrāfil's trumpet moaning in a barrel.

Ten camels in Rūm were shod one day.

One ring was lost: I found it in the Khāqān's ear.

You have spoken these words nicely, Mullā Jalāl al-Dīn Rūmī.

I have found their meaning while transcribing the Koran.\}

According to the Sūfìs, this kind of satirical verse, which is also found in the Dīwān of Yūnus Emre, can be interpreted in several ways. It seems that Yūnus Emre, as I will explain below, agreed with Mawlānā in this matter as in many others. We often find such satire in subsequent imitators of Yūnus Emre, such as Qayghusuz, who wrote this kind of hymn, and in many Bektashī poets right up to recent times. It would be wrong to dismiss such poems as nonsense based on their outward form alone, without taking into account their true meaning from the Sūfì point of view. In the first line of Mawlānā's ghazal, for example, by dûş \{yesterday\} he means 'ālam-i alast \{primordial world \}, by subhdem \{dawn\} he means tajalth-i af' $\bar{a} l$ \{self-manifestation of acts\}, by pâlân \{pack-saddle\} he means rūh \{soul\}, by dâne-i haşhaş \{poppy seed\} he means shay'-i haquir \{insignificant thing\}, and by sindân \{anvil\} he means nafs-i ammāra \{soul that commands evil\}. Thus the meaning of this first couplet becomes clear.

18 This is an important characteristic that is noticeable not only in Yūnus Emre but also in almost all the poets of that period. In periods when the language was still unable to accommodate the 'arüd system, our poets could only use those 'arüd meters that were very close to the syllabic meter. For the most part, they did this so poorly that, as I stated above, several scholars have not been able to tell if they were writing in the 'arüd or the syllabic meter. The errors of Thúry, E. J. W. Gibb, and even Veled Chelebi on this subject have resulted from this. Indeed, 'arüd patterns like fā'ilātun,

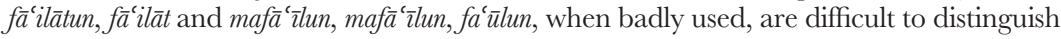
from the eleven-syllable pattern.

19 E. J. W. Gibb expresses the following opinion in this matter: "Yet Yúnus had practically no model; though inspired by Jelál, he did not, like the early mesneviwriters, copy the Persian masters, and there was no lyric poetry in Western Turkish. There was nothing but some rude folk-songs and popular ballads; and it was in the way of these that Yúnus fashioned his verses. He may indeed have seen or heard the Díwán-i Hikmet of Khoja Ahmed-i Yeseví, which has much in common with his own both in manner and matter; but this is in Eastern, not Western, Turkish" ( $A$ History of Ottoman Poetry, vol. 1, \{p. 169\}). Also, "In most of the ghazels there is present, in greater or less measure, the favourite Turkish arrangement of a thrice-repeated internal sub-rhyme, an arrangement which, as has been said before, works out into practical identity with what in more literary poetry is known as musemmat verse" (ibid. \{p. 167\}). The accounts that I have given above show that Gibb was in error on many points. First, Yūnus Emre imitated the Iranian masters in the composition of mathnawīs. Second, poets like Shayyād Hamza used the 'arüd meter and ghazal form before Yūnus Emre. Third, on the relationship between Aḥmad Yasawī and Yūnus Emre, I will shed further light below in addition to what I stated above. For the relationship between him and Jalāl al-Dīn Rūmī, see the sections below on the ethics and philosophy of Yūnus Emre. 
20 Muslim mystics advanced certain ideas about ethics in general and always regarded the issue of ethics as a complementary aspect of their system. Al-Ghazāil was a consummate teacher of ethics and Shihāb al-Dīn al-Suhrawardī's \{d. 632/1234\} 'Awärif al-ma'ärif is an excellent handbook of Șūfì ethics \{German trans. Richard Gramlich as Die Gaben der Erkenntnisse des 'Umar as-Suhrawardī (Wiesbaden, 1978)\}. These ethics are a unified system that took shape not only from Neoplatonist doctrines but also from the Koran, Sunna, and the traditions of the great Șuffis. It is beyond the scope of our subject to analyze them here. I will simply provide some information to show the relationship of Yūnus Emre with other Șūfì teachers of ethics. Șūfism, according to some Sūfiss, is founded on three virtues: adherence to poverty; persistent exertion; and abandoning contention and willfulness. Al-Suhrawardī distinguishes between poverty and Șūfism, but says that according to a noble hadīth love for the needy and wretched is the key to paradise. The same writer shows humility - in Yūnus Emre's term, alçaklı \{lowliness\} - as the first principle of Șūfì ethics. Others include sociability, offering assistance and condolence, forgiveness, kindness, justice, and compassion. Concerning kindness, Sufyān al-Thawrī \{d. 161/778\} said, "Kindness is doing good to someone who does bad to you, because reciprocating good for good is like paying for something you have purchased in the market." Al-Suhrawardi describes the importance of compassion in the Șûfì view in the following manner: "If people loved each other and appreciated the benefits of compassion, there would no longer be a need for courts. Justice is the handmaiden of compassion. It is used where compassion is lacking." For the Șūfī, "Observing the principles of compassion is better than observing the principles of pious asceticism because observing compassion is inward whereas observing the acts of worship is outward." It is clear that Sūfî ethics were of a lofty and humane nature. As the basis of personal ethics, this system promotes the cleansing of one's mind of evil thoughts, and of the humbling of the self; and as a basis of social ethics it promotes meeting evil with good by loving one's fellows with a love and compassion acquired from divine love. Generally speaking, these are the basic principles of Yūnus's ethics as well. It is clear, therefore, that the goal of Șūfì ethics is to attain divine Truth as "the perfect man."

21 Like, for example, the hymn with the refrain Bir kâmil mürşide varmaynnca olmaz \{Nothing can be achieved without a perfect guide\}.

22 As in the following hymn, for example \{Cf. Gölpınarlı, Yunus Emre: Risâlat al-nushiyya ve Dîâan, p. 74\}:

İkilikten geçemedin, hâli kâl'den seçemedin

Hak'tan yana uçamadon fakîhlik oldu sana fak

Cübbe ve horka taht u tâc versen gerektir aşka bâc

Dörtyüz mürîdle elli hac terk eyledi Abdü'r-Razzâk

Anın gibi dîn ulusu haç öptï çaldı nâkûsu

Sen dahi brrak nâmûsu gel berü putun oda yak

Asşı ma'şûk birdir bile aşktan gelir her söz dile

Bî-çâre Yûnus ne bile ne kara okudu ne ak

\{You have not gone beyone duality. You have not distinguished spiritual state $(h \bar{a} l)$ from doctrine $(q \bar{a} l)$.

You have not flown toward divine Truth. Legalism has become a trap for you.

You have to give up your Șūî̀ attire (patched cloak, etc.) as a toll to love.

'Abd al-Razzāq (Shaikh Șan'ān in 'Aț̣āar's Language of the Birds) gave up 400 disciples and fifty pilgrimages. 
Such a great Muslim pietist kissed the cross and rang church bells. You too, forget your "honor," come here and set fire to your idol.

Lover and beloved are one together. Every word comes to the tongue out of Love.

What should helpless Yūnus know? He has read neither black nor white.\}

There is an allusion here to the story of Shaikh Șan'ān, which was very well known among the Șūfìs.

23 The following lines of Yūnus Emre, which are very much in harmony with the ethics of the Gospels, are worthy of note:

Kim bize taş atar ise güller nisâr olsun ana

Urmaklğ̆a kasdedenin düşem öpem ayağın

Her kim bana söğer ise her dem duâ kılam ana

Çarâğma kasdedenin Hak yandirsun ocağım

\{If someone throws stones at us, let us shower him with roses.

If someone wants to strike me, let me fall down and kiss his feet.

If someone curses me, let me respond with a blessing.

If someone wants to take away my lamp, may God kindle his hearth.\}

The poem below also reveals the bases of Șūfì ethics and how humane they were but how difficult to follow:

Döğene elsiz gerek, sögene dilsiz gerek

Derviş gönülsüz gerek, sen derviş olamazsin

Derviş bağrn baş olur, gözü dolu yaş olur

Koyundan yavaş olur, sen derviş olamazsin

Muhammed darlmazdi, sen yine darlirsin

Bu darlmak sende var, sen derviş olamazsin

Derviş Yûnus sen dahi her gördïgüü kakırsin

Bu kakimak sende var, sen dervis olamazsm

\{To one who strikes you, you should be handless (not retaliate); to one who curses you, you should be tongueless (dumb, silent).

The dervish should be heartless (not take offense?) - you cannot be a dervish.

The dervish should have wounds in his breast; his eyes should be full of tears;

He should be as gentle as a lamb - you cannot be a dervish.

Muhammad never took offense, yet you still do.

As long as you take offense, you cannot be a dervish.

Dervish Yūnus: you too get angry at whatever you see.

As long as you get angry, you cannot be a dervish.\}

Here Yūnus Emre bases Șūî̀ ethics squarely on the Sunna. This great Turkish Șūfì poet did not hesitate to freely reveal these broad humane views in many of his other poems as well. In one poem, he states the need to honor and serve guests, i.e. strangers, whether they be Muslim or Christian; and in various other poems he also mentions the importance of the heart, which is the house of God, and the value of 
pleasing others. These principles have several ethical consequences. In one poem, he says \{cf. Gölpınarlı, Tunus Emre: Risâlat al-nushiyya ve Dî̀ân, p. 144\}:

Dürüs kazan ye yedir bir gönül ele getür

Bin Ka'be'den yegrekdur bir gönül 'imâreti

\{Strive and earn, eat and feed others; take one heart into your hand (i.e. be kind to one person).

Cultivating a single heart is better than a thousand Ka'bas.\}

Elsewhere he states it even more beautifully:

Gönül Çalab'in tahtı Çalab gönüle bahtı

İki cihân bedbahtı kim gönül yıkar ise

Sen sana ne sanursan ayruğa hem am san

Bir ma'nâ Dört-Kitâb'tan budur eğer var ise

\{The heart is God's throne. God pays regard to the heart.

It is the misfortune of both the worlds if someone breaks a heart.

Whatever you think of yourself, think the same of others.

If the Four Books have any meaning, this is it.\}

These lines forcefully express a sublime principle of Șūfî ethics. Compared to them, we can rate as rather uninspired Jāmì's famous poem:

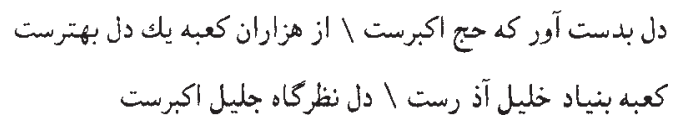

\{Win a heart - that is the greatest Hajj.

One heart is better than a thousand Ka'bas.

The Ka'ba is the shrine of Abraham;

The heart is the shrine of the Glorious One.\}

We also find this influence of Yūnus Emre in the following fine quatrain by Khatạầ:

Hatāŷ̉ hâl çağında

Hak gönül alçağrnda

Yüzbin Kábe yapmaktor

Bir gönül al çağgnda

\{Khațā' is is in a mystic state.

Truth is in a humble heart.

Building a hundred Ka'bas

Is in winning a single heart (?).\}

Many other such examples of aphorisms concerning Sūfì ethics can be found in Yūnus Emre's hymns. This is an important and broad subject that deserves its own thorough study.

24 The following poem is one of the best examples to show Yūnus Emre's Șūfi ethics \{cf. Gölpınarlı, Yunus Emre: Risâlat al-nushiyya ve Dîvân, p. 49\}: 
Söylememek harcısı söylemenin hâssidır

Söylemenin harcısı gönüllerin pasıdır

Gönüllerin pasin ger sileyin der isen

Şol sözü söylegil kim sözün hulâsasidır

Sözü doğru diyene kuli'l-hak dedi Çalab

Bunda yalan söyleyen yarn utanasidrr

Yetmişiki millete bir göz ile bakmayan

Halka müderris olsa hakîkatte âsîdir

Şeri`atin haberin şerhile diyem işit

Şerîa bir gemidir hakikat deryâsıdır

Ol geminin tahtas nekadar muhkem ise

Deniz mevo uruncağız soyub uşadasıdır

Bundan içerü haber dinlegil benden ey yâr

Hakikatin kâfiri şer'in evliyâsidir

\{The expense of not speaking is the income of speaking.

The expense of speaking is rust on the heart.

If you wish to wipe away the rust on your heart,

Speak only those words that are the epitome of speech.

To one who speaks truth, God has said: "Say: the truth ..." (Koran, 18:29).

He who speaks false today will be ashamed tomorrow.

He who does not consider the 72 religious communities as equal

Is a sinner in truth, though he be a religious instructor to the people.

Listen and I'll inform you about the Shari $a$ along with the commentary:

The Shar $\bar{r}^{\prime} a$ is a boat in the sea of Truth.

No matter how firm the planks of that boat,

When the waves of the sea strike it, they will shake it to pieces.

Now listen, my friend, and I'll inform you of the hidden meaning:

The infidel of Truth is the saint of the $\operatorname{Shari}^{-} a$. $\}$

25 In order to demonstrate the degree to which the ethics propagated by the Muslim mystics are based on Neoplatonism, it is necessary to touch on Plotinus' conception of ethics. According to Plotinus, because God is absolute perfection, every created thing is perfect in its kind and degree. Nothing occurs subject to accident. Everything, every phenomenon, has an ultimate cause. This theory of ultimate cause, which Plotinus explains in great detail, naturally leads to optimism. His defense of the argument against the existence of evil is very strong. "Evil does not exist of its own accord; it only coexists with good. Inequality is a condition of order and regularity. To be sure, when evil is abstracted and exists in isolation, it is evil, not good. For example, ugliness is ugly, not beautiful; but if every part were beautiful, the whole could not be beautiful." He expresses the refutation of pain and death more clearly and elegantly than Seneca and all of the Stoics. Death is so insignificant that on festival days people gather to watch it. It is a kind of stage play and cannot be taken seriously. What suffers pain or dies is not our soul but our material existence. The only correct thing in life is duty. The cries and sobs that fill the world do not prove the existence of evil, but the cowardice of mankind. Plotinus, who was a panthiest and fatalist, should have confused duty with nature and nature with necessity. But, while denying free will, he 
speaks of it as though not denying it (for, like Spinoza, he accepts the existence of free will only on condition of observing the laws of nature and agrees that actions based on perception and intelligence and without compulsion are voluntary). The ethics of Plotinus, like those of Plato, are pure, severe, and take divine perfection as the goal. The influence of the Stoics on Plotinus in this respect is also quite obvious. According to Plotinus, prudence, courage, and temperance are the virtues of man as a political animal, i.e. the bases of social ethics. As for the virtues required for the philosophers, they comprise not only these virtues, to which the people are confined, but also the purifying and inspiring virtues that save us from this world and prepare us for ecstacy, i.e. justice, knowledge, and love. These are the bases of individual ethics. For Plotinus, like Plato, knowledge is a virtue that elevates mankind and generates love. Finally, above all these ethical virtues there is mystical ecstasy, union with God, which is the ultimate goal of ethics as well as the ultimate goal of metaphysics \{except for the first sentence, Köprülü translated this footnote to this point from Adolphe Franck (ed.), Dictionnaire des sciences philosophiques, 2nd edn (Paris, 1875), s.v. "Plotin," (Jules Simon), p. 1349\}. If we compare Plotinus' ethical principles with Șūfì ethics, we can readily see that Șüfi ethics have a close relationship with Muslim tradition, although we find in it the influence of all the Greek ethical systems. The principles of social ethics in particular are broader, more humane, and stronger in Șūfì ethics than in those of Plotinus.

26 This great movement, which is famous in the history of philosophy under the general name of Neoplatonism, and which continued strongly for a full three centuries from the second to the sixth century CE, was basically inspired by Platonic doctrine. The original founder of this movement was Ammonius Saccas, a Christian, and it arose as a system of thought in Alexandria. If we take into consideration the status of Alexandria at that time, we can more or less account for the basic features of this system. Alexandria was then a place where various philosophies and religions were found. In addition to hosting disciples of Plato and Pythagorus, various Jewish sects that prepared the ground for the cabala by interpreting the Bible or else tried to combine Philo and Greek philosophy with Judaism, and Gnostics who claimed a connection with Zoroaster, it was home to a Christianity that had established a strong center of activity there with Saint Athanasius and sought to oppose Greek philosophy. A complex spiritual state resulted from this mixture of creeds. Critical skepticism and naive superstition reigned side by side. The destruction and transformation of customs produced an ascetic reaction in all of these beliefs. The three basic qualities of Neoplatonism - eclecticism, mysticism, and asceticism - can be explained quite well as a result of the influence of this environment. The greatest representative of this system of belief was Plotinus. This philosophical system, which constituted the last active stage of ancient Greek philosophy and formed a link between the ancient scientific mentality and the medieval mentality, ultimately acquired a completely mystical nature with Iamblichus and his students. (For more information on these subjects, see the following works: Étienne Vacherot, Histoire critique de l'école d'Alexandrie, 3 vols, \{1846-51; reprinted Amsterdam, 1965\}; Jules Simon, Histoire de l'école d'Alexandrie, 2 vols, [Paris, 1845]; Jules Barthélemy Saint-Hilaire, De l'école d'Alexandrie; \{rapport à l'Académie des sciences morales et politiques, précédé d'un essai sur la méthode des Alexandrins et le mysticisme, et suive d'une traduction de morceaux choisis de Plotin\}, [Paris, 1845]. One can consult La Grande Encyclopédie and Adolphe Franck's Dictionnaire des sciences philosophiques on each of the individuals and subjects found in these works. In the article on Plotinus in the latter work, there is an adequate account of the French translation of this work.) E. J. W. Gibb defends the connection of Muslim mysticism with Neoplatonism as follows: "Many Orientalists consider Súfiism to be an offshoot from the Vedánta philosophy of India. My reasons for preferring to regard it as a development of 
Neo-Platonism are: Firstly, the practical identity of the two systems, except, of course, where coloured by the prevailing positive religion; Secondly, the circumstance that Súfiism as a system is first heard of in Syria, the country of Iamblichus, where Neo-Platonist ideas were widely spread; ... ; Thirdly, the fact that the other side of Muhammedan philosophy is beyond question derived from the Neo-Platonist exponents of Aristotle" (A History of Ottoman Poetry, vol. 1, p. 53, n.2). I mentioned above (Chapter 7, p. 244, n.58) that Nicholson explained this subject very well in his introduction to the Dīwān Shams al-haqā’iq \{i.e. Selected Poems from the Dīvāni Shamsi Tabrīz\}.

27 'Azīz b. Muhammad al-Nasafî's account of wahdat al-wujūd is as clear as it is brief:

$$
\begin{aligned}
& \text { اهل وحدت ميكويند كه يكى بيش نيست وآن وجود خداست تعالي وتقدس، وبغير از وجود خداى } \\
& \text { تعالى وجود ديكر نيست وامكان وجود ندارد كه باشد. وديكران ميكويند كه اكر وجوديكى بيش نيست، } \\
& \text { اما اين وجود ظاهرى دارد وباطنى دارد. جون اين مقدمات معلوم كردى، اكتون بدانكه اهل وحدت } \\
& \text { ميكويندكه باطن اين وجود يك نوراست كه جان عالمست وعالم مالامال اين نوراست. واين نور نوريست } \\
& \text { نا محدود ونا متناهى وبحريست بيى بايان وبى كران. حيات وعلم وارادت وقدرت باين نوراست. بينايي } \\
& \text { وشنوايى وكويايى وروايئ اشيا از اين نوراست. بلكه خود همه اين نوراست. طبيعت وخاصيت وفعل اشيا } \\
& \text { درين نوراست. اكرجه صفات وافقل واسلمئ اشيا از اين نوراست، امل اين نور يكى بيش نيست وافراد } \\
& \text { مويجودات بيكبار مظاهز اين نورند وهريك دريجه اند. وصفات اين نور از اين دريجها بيرون تافته } \\
& \text { است. اي درويش، اين نور اول وآخر ندارد، وفنا وعدم را بوى راه نيست. دريجهاى نوميشوند وكهنه } \\
& \text { مى كردند وبخاك ميروند واز خاك باز مى آيند وخود مى باشند وخود ميرويند وخود ميزايند ـ هريك } \\
& \text { آنبهه ما لابد أيثانست تا بكمال خود رسند با خود دارند واز خود دارند . واين نور بدين مظاهر خود } \\
& \text { عاشق است از جهت آن كه اين نور ورين مظاهر خود كمال خود را مى بيند, وصفات واسامئ خود را } \\
& \text { مشاهده ميكند . واز اين جاست روح آدمى بر جسم خود عاشقست، از جهت آنكله جسم آدمى مظهر صفات } \\
& \text { روح آدميست وروح جسم خود را مى بيند وصفات واسامئ خود را مشاهده ميكند . واز أين جاست كفته } \\
& \text { اندكه خود را بشناس تا خدايرا بشناسى، كنون دانستى كه إين نوراست كد خود رأمى شناسد . واين } \\
& \text { نوراست كه جان عالمست وافراد عالم .جله ومظاهر اين نورند . . . . }
\end{aligned}
$$

\{The people of unity say that existence is one and no more, and that is the existence of God. There is no other existence than the existence of God, nor is any other possible. Others say that while existence is one and no more, this existence has an outer and an inner aspect. Furthermore you should know that the people of unity say that the inner aspect of this existence is a light that is the soul of the world. The world is full of this light, which is unbounded and infinite, a sea without a shore. Life and Knowledge and Will and Power exist by virtue of this light. Sight and hearing and speech and the beauty of things are from this light, or rather they are this light. Nature and quality and the activity of things are in this light. Although the attributes 
and actions and names of things are from this light, still this light is one and no more. The individual existing things are all together manifestations of this light, or they are so many windows, and the attributes of this light shine out from these windows. $\mathrm{O}$ dervish! This light has no beginning and no end, and there is no way for it to cease existing. New windows appear and grow old and go into the ground and re-emerge out of the ground; they appear and grow and reproduce of their own accord. Each one possesses whatever it needs in order to attain its own perfection. And this light is in love with these manifestations of itself, because in them it sees its own perfection and witnesses its own attributes and names. For this reason, man's soul loves its body, because the human body is a manifestation of the attributes of the human soul: the soul sees its own body and witnesses its own names and qualities. And for this reason, it is said: Know yourself, so that you may know God. Now you may understand that this is the light that knows itself and that is the soul of the world, and the individual things of the world are all manifestations of this light\} (cited from al-Nasafî's Zubdat al-haqa' 'iq as found in Ferid Bey's work entitled Vahdet-i vücûd [Istanbul, 1331/1913], pp. 80-1 \{the Zubdat has been edited by A. E. Bertel's in Piat' filosofskikh traktatov na temu 'Áfāq va anfus' (O sootnoshenïakh mezhdu chelovekom i vselennor) (Moscow, 1970), pp. 90-207, and by Haqq-virdī Nāșirī (Tehran, 1405/1363/1985)\}). Because of the simplicity of the passage, I have simply cited the text \{without translating it!\}.

28 I will touch here on the way in which the Sūfîs resolved the problem of creation, which is always the weakest aspect of any philosophical system. According to Sūfiss, the cause of creation and emanation is Love. The poet who said Kendi hüsnün hûblar şeklinde peydâ eyledin / Çeşm-i âşıktan dönüp sonra temâşâa eyledin \{You revealed your own beauty in the form of beautiful (beings) / Then contemplated it with the eyes of lovers $\}$ expressed this as a very succinct principle. Many Șūiss, however, including Jāmī, the author of Salamān wa Absäl, explained the important subject of creation in terms of a more explicit Neoplatonism that corresponds almost perfectly to Plotinus' theory of emanation. From it arose the view of Hadarät-i khams, i.e. Beş 'âlem \{the five worlds\}, which are not separate worlds in separate places, but constitute different stages of the same existence as they recede in a balanced relationship from wuju $d-i$ haqqiq $\bar{\imath}$ \{true existence, i.e. God\} and descend stage by stage. As summarized by 'Abd Allāh Bosnawī \{d. 1054/1644, in his commentary on Ibn al-'Arabī's Fusūs al al-hikam, i.e. Tajalliyāt 'ară'is al-nușuss (Būlāq, 1252/1836-7); English trans. Bulent Rauf et al. as Ismail Hakki Bursevi's Translation of, and Commentary on, Fusus al-hikam by Muhyiddin Ibn 'Arabi (attributed to 'Abd Alläh Bosnawñ) (Oxford, 1986)\}: above and beyond the universe is the divine world that is the source of everything. It is not included in the other five hadarat. The first of the five hadarat is hadrat-i ghaib-i mutlaq \{the world of the absolutely invisible\}, or hadrat $i$ 'ama \{world of nebulosity\}. This is the world of immutable entities (a'yann-i thäbita, which is essentially the same as Plato's ideas). The second hadra is ghaib-i muda $\bar{a} f$ \{world of the relatively invisible\} and is the world of intellects \{'uqū $l$ \} and souls $\{a r w \bar{a} h\}$. They call this the world of domination $\left\{{ }^{\prime} \bar{a} l a m-i\right.$ jabarüt $\}$. The third hadra is 'älam-i mithāl \{world of images\} or the world of sovereignty \{'alam-i malaküt, see Chittick, The Self-Disclosure of God (Albany, NY, 1998), pp. 259-60\}. They also call this the intermediate world ' 'alam-i barzakh, between the spiritual and corporeal; see Chittick, The Sufi Path of Knowledge, pp. 14, 117-18\}. The fourth hadra is 'älam-i shahäda \{visible world, see Chittick, ibid., p. 114\} or 'ālam-i mulk \{corporeal world, see Chittick, ibid., p. 282\}. This is the world in which we act. The fifth hadra is 'alam-i insān \{world of mankind\}, which sums up and comprises all the others, for mankind is the microcosm ('ālam-i șughrā) \{on these worlds, cf. E. J. W. Gibb, A History of Ottoman Poetry, vol. 1, pp. 55-6\}. These worlds are sometimes classified as 'ālam-i ghaib - 'ālam-i barzakh'ălam-i shuhūd, but usually 'älam-i ghaib - 'älam-i shuhüd. Thus the concept of the five worlds, which gradually become more complex as they precede from the Unified 
Essence $\{\mathrm{God}\}$ and fall from grace, is actually an application to Islam of the theory of emanation $($ tajall $\bar{\imath})$, which was peculiar to the school of Alexandria. Their meaning of 'aql-i kull \{universal intellect (God)\} and 'aql-i awwal \{first intellect\} for nash'at-i üla wa thaniya \{first and second existence\} was also under the influence of Plotinus' nous \{"The original Being first of all throws out the nous, which is a perfect image of the One and the archetype of all existing things. It is at once being and thought, ideal world and idea. As image, the nous corresponds perfectly to the One, but as derived it is entirely different. What Plotinus understands by the nous is the highest sphere accessible to the human mind, and, along with that, pure thought itself," Encyclopaedia Britannica (1955), s.v. "Neoplatonism" (Adolf van Harnack; John Malcolm Mitchell)\}. As in Mawlānā's couplet \{Mathnawē, Book 2, line 978\}

$$
\text { اين جهان يك فكرتست از عقل كل \عقل جون شاهست صورتها رسل }
$$

\{This world is one thought (emanating) from the Universal Intellect / The Intellect is like a king, and the ideas (are his) envoys; Nicholson trans.\} these Neoplatonist beliefs are quite obvious in 'Āshıq Pasha's didactic mathnawi, Gharībnāme. Let me briefly describe the concept of $a^{i} y \bar{a} n-i$ thäbita \{immutable entities; see Chittick, The Sufi Path of Knowledge, pp. 83-6\} in order to finish this account of the hadarāt. A'yān-i thābita "are the possibile realities that exist in God's knowledge and do not smell the fragrance of existence." Because existence is more inclusive than immutability, not every immutable thing requires the quality of existence. Thus, they are also immutable with respect to non-existence and are not qualified by existence. There are two aspects to a $a^{c} \bar{a} n-i$ thäbita. On the one hand, they are divine realities, based on the consideration that names and attributes are formal \{i.e. take the visible form\}. On the other hand, they are possible realities and supports \{mustanad, phenomena of this world as "supported" by names; see Chittick, ibid., p. 37\}. According to the first hypothesis, immutable entities are the equivalent of bodies for souls and according to the second hypothesis are the equivalent of souls for bodies. The immutability in God's knowledge of a'y $\bar{a} n-i$ thābita results from "the most sacred spiritual effusion $\{$ faid-i aqdas $\}$," while the external appearance of the form-taking possibilities of the entities $\left\{a^{i} y \bar{a} n\right\}$ results from "the sacred spiritual effusion \{faid-i muqaddas\}." Because $a^{c} y \bar{a} n-i$ thābita do not exist externally, they are not qualified by creation $\left\{\mathrm{ja}^{c} l\right\}$. Those things that exist are forms of the $a^{c} y \bar{a} n$ that appear because of sacred spiritual effusion in mirrors of the $a^{c} y \bar{a} n$. All the forms of existing things and manifestations of the contingent world are the forms of the a'yān-i thäbita or the divine names and attributes (Fususus sharhā, p. 15). \{See $E I^{2}$, s.v. "Ālam" (Tj. de Boer and L. Gardet)\}.

29 While describing al-Ghazālī's ideas about Possible Existence in his note on Jalāl \{divine majesty\}, Gelenbevî İsmâ'îl Efendi provides important information on wahdat al-wujūd. I consider it useful to cite it briefly in order to summarize clearly the subject of the self-disclosure of God $\left\{\operatorname{tajall}_{\bar{\imath}}\right\}$ : "What exists in reality is ascribed in the mind to something that exists thanks to existence itself. The Șūfîs considered it self-evident that there is no true existence apart from God. The ascription of existence to possibilities \{of realities\} is based on the connection of manifestation, for there are not various numerous existences of which some subsist with the Necessarily Existent $\{\mathrm{God}\}$ and others with the possibilities. There is only one existence and that is God. To say that possibilities exist is not to say that existence subsists with them but to say that possibilities have a certain relationship to the Necessarily Existent that exists by itself and subsists by its own essence. This attachment occurs at the moment of the selfdisclosure of God in the immutable entities. And the immutable entities are the divine sapiential forms that are the opposite of the capacity \{for subsistence in God\} as required by the mutually divine names like qäbid \{Contractor\}, bāsit \{Expander\}, 
rahīm \{Merciful\}, and qāhir \{Compellor\}. No one except God knows how this selfdisclosure occurs. The immutable entities, which are in mutual opposition with regard to the need and capacity for the Necessarily Existent $\{d h \bar{a} t-i w \bar{j} j i b\}$, are the manifestations of the divine self-disclosures. The essence and attributes of God appear in them by means of that capacity for manifestation and appear in the form of mutually opposed existence because of the difference in capacity. Now multiplicity comes into existence from capacity. For example, there are many mirrors but the image of one man is reflected in them. According to the capacity of the mirrors, that man appears differently in each one but none of these \{different\} accidental qualities and attributes exists in him. There is one true existence, but with its appearance during the selfdisclosure of God, it expands over the existing possibilities. However, it does not mix with possibilities and is not incarnated in them. While this attachement remains, the possibilities are figuratively called existing by virtue of the attainment of manifestation. When attachment is stopped, there can be no attribution of existing either in reality or figuratively. Thus, the existing possibilities consist of immutable entities on condition of attainment of the self-disclosure of God. This means that nothing exists subsisting in itself. Therefore, existing cannot in fact be attributed to them. They are non-existent in past and future eternity. Therefore, it is said that immutable entities do not smell the fragrance of existence" (cited from Ferid Bey's treatise Vahdet-i vücûd, pp. 101-6). Certain aspects of this are explained in greater detail below.

30 According to Șûfì beliefs, the universe culminates in man, who is the central point. The things that exist in the universe can only reflect one or another of the divine attributes. Man, however, is the place of manifestation of all of them, for he is the manifestation of the greatest name $\{$ ism-i a'zam\}. As 'Abd Allāh Bosnawī, the commentator on the Fusūss states, "The universe is the aggregate of the individual objects through which are manifested the Divine Names; but as it was incapable of receiving the form of the Divine Totality, and as the manifesting of the manifestation of universality was not obtainable therethrough, God created Man, who is its soul, after the Divine image; so Man is the theatre of the Divine Names and the meeting-point of the Divine Attributes" \{we have used Gibb's translation, A History of Ottoman Poetry, vol. 1, p. 62\}. Because of this, man has collected in himself the personal reflections of the divine attributes that are scattered throughout the universe. He is thus also the perfect mirror of the image of God. Because man is the sum and epitome of the macrocosm outside himself, and its miniature, he is called the microcosm. A number of Șūfis go beyond this, however, regarding man as the macrocosm and the universe as the microcosm. This lofty status of man is due to the heart, for the divine attributes are reflected there. Thus, in order to know God, one must first know oneself. The Șūfī principle من عرف نفسه فقد عرف ربه \{Who knows himself knows his Lord\} is derived from this $\{$ Köprülü again follows Gibb here, vol. 1, pp. 62-3\}. Many examples of this can be found in the Persian and Turkish poets, in Jalāl al-Dīn Rūmī, Faiḍ-i Hindi, then Yūnus Emre, Ghaibī, Nesīmī, Olanlar Shaikhī Ibrāhīm Efendi, etc.

31 This ecstasy or rapture, which our Sūfis call $h \bar{a} l$ \{the mystical state\}, has a very important place in Neoplatonism. Plotinus accepts the givens of the senses, but he places reason above them and above reason places ecstasy. Only this discloses Absolute Unity $\{\mathrm{God}\}$, which the laws of reason do not have the ability to discover. Ecstasy is unification. In other words, it is the disappearance or the withdrawal of plurality, consciousness, and personality. It is the momentary absorption of the individual and the variable in absolute existence. In this state, the spirit, which is united with God, is no longer in the body. Indeed, in any ecstatic state, one is also separated from the soul, which drives and illuminates the body. The human body is then like an empty palace that is subject to the laws of organic nature. Therefore, ecstasy is a death in advance \{of dying\}, or, more correctly according to Plato's mystical principle of "to 
die is to live," it is a life in advance \{of living\}. The problem now remains to discover its generative causes. Is it brought about through intellectual effort, or will, or love? The answer is quite simple. Love, which receives the help of intellectual effort and will, is the generative cause of ecstasy. Intellectual effort, by scattering some of the clouds that hide our spirituality, brings us face to face with unity. Will tries hard to escape from plurality and tear down the final cover that conceals absolute existence. And Love, which finally discovers the sole thing that will nourish it, leaps out like a flame and thus unification occurs. It is virtue and prayer that allow us to reach this ultimate happiness. Prayer, according to Plotinus, is the directing of an energetic and absolute love toward its object. In later Neoplatonism, as inspiration weakened, prayer and then mystical rites gradually took the place of Love. The lofty theories of Plotinus degenerated into superstition at the hands of Iamblichus (Franck (ed.), Dictionnaire des sciences philosophiques, s.v. "Plotin" \{Jules Simon\}, p. 1347). Saint-Hilaire also critically analyzes the characteristics of this system (De l'école d'Alexandrie, p. xxxv). It appears from this entire account that the Neoplatonists' views of ecstasy are virtually identical with our Șūfìs' views of hăl.

In al-Qushairī's al-Risāla, there is a noteworthy description of our Șūfìs' views of hāl \{cf. Michael Sells (trans. and ed.), Early Islamic Mysticism, (New York, 1996), p. 103; Rabia Harris (trans.), pp. 74-5\}. According to the Șūfìs, hăl means "a feeling of joy and sorrow, contraction and expansion, ardor and awe, that reaches the heart as a gift bestowed by God." In this, human attainment and effort have no part. The stages \{s. maqām, level of enlightenment\}, however, are acquired by intellectual effort and ascetic exercises. The second distinguishing characteristic of $h \bar{a} l$ is transformation \{tahawwul\} and variegation \{talawroun\}, i.e. instability. "Stages," on the other hand, are stable. So it is clear that the unstable and rarely appearing ecstasy that Plotinus presented as the product of love in particular is basically the same as the mystical "state" $\{h \bar{a} l\}$ of our Șūfiss. Our Șūîs only expand on what Plotinus hinted at. They reject - in accord with Plotinus' idea of soul - the influence of intellectual effort and ascetic discipline \{in attaining ecstasy and designate not one ecstatic state but different degrees of $h \bar{a} l$. Some of them, however, do teach the permanence and persistance of $h \bar{a} l$, and consider those who dabbled in mystical experience as "not having attained the points of departure of the mystical states." According to most Șūfis, however, hăl has no permanence other than the existence of time. In the opinion of the religious scholars, it is analogous to something accidental \{'arad\}. Ibn al-'Arabī explains this in Chapter 192 of his Futūhăt. As expounded by the majority of the Șūfìs, this view is completely in accord with that of Plotinus, for he taught that ecstasy is momentary and fleeting. Thus, the mystical state that al-Junaid describes in the couplet

$$
\text { طوراق انوار تلوح |ز| بدت \فتظهر كتمانا وتخبر عن جتع }
$$

\{Sudden gleams of light / when they appear, apparitions, / Revealing a secret,/ telling of union (Sells, trans. in Early Islamic Mysticism, p. 105)\} is no different than the ecstasy of Plotinus (al-Qushairī, al-Risāla, \{Turkish\} trans., pp. 14-18).

32 The careful study of both of their dīwanns clearly shows this. For example, there is a great similarity between Yūnus Emre's ghazal

Bir sâkîden içtik şarâb 'arştan yüce meyhânesi

Ol sâkînin mestleriyüz cânlar ann peymânesi

\{I drank wine at the hands of a cupbearer whose tavern is higher than the heavenly throne.

We are drunkards of that Cupbearer, our souls are His wine cup, \} 
and Mawlānā's ghazal that begins with the verse

$$
\text { بيش ازان كاندر جهان باغ رز وانكور بود \از شراب لا يزالم جان ما مخمور بود }
$$

\{Before vineyard and grape were yet in the world,

Our souls were drunk with the wine of everlastingness.

In like manner, Yūnus Emre's hymn beginning with the verse Bî-mekânem bu cihânda menzilim durağım anda / Bunda seyreyleyu geldim băğģe ve bâğrm anda \{cf. Gölpınarlı, Tunus Emre: Risâlat al-nushiyya ve Divân, p. 123; I have no place in this world: my abode is there / I have come here to sojourn: my garden is there\} and Mawlānā's famous ghazal

$$
\text { دلا جهل بستهُ اين خاكدان بر كنذرانى ازين حظيره برون ير كه مرغ عالم جانى }
$$

$\{\mathrm{O}$ heart, why art thou a captive in the earth that is passing away? / Fly forth from this enclosure, since thou art a bird of the spiritual world; Nicholson (trans.), Selected Poems from the Dìvanni Shamsi Tabriz, p. 175, \} have almost the same meaning. Moreover Yūnus Emre's hymn Ey âşskân ey âşıkân aşk mezhebi dîndir bana / Gördü gözüm dost yüzünü yas kamu düğ̈̈ndür bana \{cf. Gölpmarl, ibid., p. 41; O lovers, O lovers; the creed of Love is my religion / My eyes have seen the loved one's face: for me funerals are weddings\} has the same meaning as Mawlānā’s poem اي عاشقان اي عاشقان \{O lovers, O lovers; Nicholson (trans.), Selected Poems, p. 141\}. On this subject, for which many other examples could be given, one should bear in mind that this influence originates from Mawlānā's general personality and outlook, not from this or that poem.

33 I stated above that those obsessed by divine love were not responsible for the deeds and words that issued from them. Aq Shams al-Dīn \{d. 863/1459, see H. J. Kissling, "Aq S̆ems ed-Dīn: Ein türkischer Heiliger aus der Endzeit von Byzanz," Byzantinische

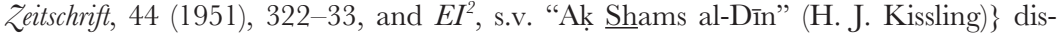
cusses this subject in a treatise and says that for the Sūfiss it is not permitted to reveal the $\{$ spiritual $\}$ truths to the people. He excludes those obsessed by divine love from this and says, "If obsession ( $j a d h b a$ ) is overpowering then it is manifest involuntarily. Such majdhübs (those obsessed by divine love) are those in whom God is acting freely. They witness the pole of the world. The pole of the world commands them. Whatever in the world is or will be, they are first to go about that task," (Risāla-i Aq Shams al-Dīn, from the MS in the Hâlis Efendi Library \{in the Süleymaniye Library in Istanbul\}). There is also a useful and succinct discussion of majdhūbs in the Thamarāt al-fu'a $\bar{d}$ \{Istanbul, 1288/1871\} of Sarı 'Abd Allāh Efendi \{d. c.1071/1661, see $E I^{2}$, vol. 3, p. 711, and s.v. "Sarı 'Abd Allāh Efendī (Cl. Huart [Kathleen Burrill])\}. In much of the poetry of Yunus Emre, the notion that \{spiritual\} truths cannot be revealed to the common people is repeated, but it is curious that he could not refrain from doing so.

34 This view is consistently found in all the Șūfiss from Abū Sa'īd Ibn Ab̄̄ 'l-Khair, who said in a quatrain

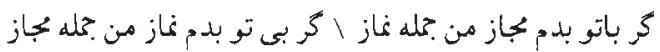

\{With you my figurative speech becomes prayer / Apart from you my prayer becomes a mere figure. Muhammad b. Munawwar, The Secrets of God's Mystical Oneness, trans. John O'Kane, p. 514\}, to Mawlānā. The following passage from Mawlānā expresses the same meaning as the aforesaid quatrain of $\mathrm{Abu} \mathrm{Sa}^{\mathrm{i}} \overline{\mathrm{T}} \mathrm{d}$ : 


$$
\text { زاكر نه روى دل اندر برأبرت دارم \من اين نماز حساب نماز نشمارم }
$$

\{If the face of my heart is not directed toward you

I do not consider this prayer to be prayer.

I direct my face toward the qibla out of love for your face;

Otherwise, I have nothing to do with prayers and qiblas.\}

We also constantly find passages with this meaning in Yūnus Emre. It appears that in such great Șūfìs as these, as in Plotinus, love \{'ishq, ecstatic love of God\} comes before everything and is the true goal of everything. Such passages as these express this notion; they do not mean that prayer and the other religious duties are unnecessary. Because Șūfìs subsequently gave more importance to asceticism and religious exercises, the importance of love has declined somewhat - as was the case in the last periods of decline of the Neoplatonists.

35 \{Cf. Gölpınarl, Yunus Emre: Risâlat al-nushiyya ve Dîvân, p. 203.\}

36 There is much in the poetry of Yūnus Emre on love and the difficulties of love, as in, for example, the hymns beginning Âşı-ûu mest-ü harâb etti bizi cânânemiz / Âlem içinde bu gün hos söylenür efsânemiz \{Our Beloved made us lovers and drunkards, and ruined us / Today in the world our story is nicely told\}; or Gerçek âşık olanlarn işi âh ile zâr olur / Hasretinden ol dilberin gözü yaşı pinar olur \{The task of true lovers is to sigh and moan / Their tears flow like springs out of longing for the Beloved\}; or Dürlü dürlü cefânnn admo aşk komuşlar / Bu cefâya katlanan dosta halvet irmişler \{ "Love" is the name given to all sorts of cruelty / Those who bear this cruelty attain privacy with the Beloved\}. Mawlānā, who says

$$
\text { عمر كه بى عشق رفت هيجّ حسابش مكير \آب حيات است عشق در دل وجانش يذير }
$$

\{Do not count a life as anything that has gone without Love / Love is the water of life: accept it into your heart and soul\}, also reveals the difficulties of love in the following strophe:

$$
\begin{aligned}
& \text { اي بهر هناكامه دام عشق تو هناكُامه كير \ وى جكيده خون ما بر راه رهرو را نشان } \\
& \text { صد هزاران زخم بر سينه نه زخم تير عشق \ل صد شكارى خسته و نه تير بيد انه كمان }
\end{aligned}
$$

$\{\mathrm{Oh}$ you who conjure love in every assembly,

And on whose path our blood drips to mark the road for travelers:

A hundred thousand wounds are in our breast, not wounds of Love's arrow;

A hundred fall prey, while there is no arrow visible and no bow.\}

Because men who enter the field of love consider their own physical existence to be nothing and sometimes even give up their lives on that field, the Șūfis frequently use the comparison of "ball and stick" \{i.e. being knocked about like a ball\} in regard to this subject. In a beautiful poem Mawlānā describes quite eloquently the ecstasy of those who drink the wine of \{spiritual\} love from the cup bearer of eternity. Other versions of this concept are frequently found in Yūnus Emre. 


$$
\begin{aligned}
& \text { جِه تدبير اي مسلمانان كه من خود را تميدانم \نه ترسا نه يهودم من نه كبرم نه مسلمانم } \\
& \text { نه شرقيم نه غربيم نه بريم نه بحريم \ نه از كان طبيعيم نه از افلاك كردانم } \\
& \text { نه از خاكم نه از آبم نه از بادم نه از آتش ل نه از عرشم نه از فرشم نه از كونم نه از كانم } \\
& \text { نه از هندم نه از جينم نه از بلغار وسقسينم \ نه از ملك عراقينم نه از خاك خراسانم } \\
& \text { نه از دنيى نه از عقبى نه از جنت نهاز دوزخ \ نه از آدم نه از حوا نه از فردوس ورضوانم } \\
& \text { مكانم لا مكان باشد نشانم بى نشان باشد \نه تن باشُ نه جان باشد كه من از جان جانانم } \\
& \text { دوئ از خود بدر كردم يكى ديدم دو عالمرال \يكى جويم يكى دانم يكى بينم يكى خوانم } \\
& \text { هو الاول هو الاخر هو الظاهر هو الباطن \لجز يا هو ويا من هو كسى ديكر نيدانم } \\
& \text { زجام عشق سر مستم دو عالم رفته از دستم \لجز رندى وقلاشى نباشد هيج سامانم } \\
& \text { اكر در عمر خود روزى دمى بى توبر آوردم \ازان وقت وازان ساعت زعمر خود يشيمانم } \\
& \text { اكر دستم دهد روزى دمى باتو درين خلوت \ دو عالم زير باى آرم همى دستى بر افشانم } \\
& \text { الا اي شمس تبريزى هنين مستم درين عالم \كه جز مستى وقلاشى نباشد هيج دستانم }
\end{aligned}
$$

\{What is to be done, O Moslems? for I do not recognize myself.

I am neither Christian, nor Jew, nor Gabr, nor Moslem.

I am not of the East, nor of the West, nor of the land, nor of the sea;

I am not of Nature's mint, nor of the circling heavens.

I am not of earth, nor of water, nor of air, nor of fire;

I am not of the empyrean, nor of the dust, nor of existence, nor of entity.

I am not of India, nor of China, nor of Bulgaria, nor of Saqsīn;

I am not of the kingdom of 'Irāqain, nor of the country of Khorāsān.

I am not of this world, nor of the next, nor of Paradise, nor of Hell;

I am not of Adam, nor of Eve, nor of Eden and Rizwān.

My place is the Placeless, my trace is the Traceless;

'Tis neither body nor soul, for I belong to the soul of the Beloved.

I have put duality away, I have seen that the two worlds are one;

One I seek, One I know, One I see, One I call.

$H e$ is the first, He is the last, He is the outward, He is the inward;

I know none other except ' $Y \bar{a} H \bar{u}$ ' and ' $Y \bar{a}$ man $H \bar{u}$.'

I am intoxicated with Love's cup, the two worlds have passed out of my ken;

I have no business save carouse and revelry.

If once in my life I spent a moment without thee,

From that time and from that hour I repent of my life.

If once in this world I win a moment with thee,

I will trample on both worlds, I will dance in triumph for ever.

O Shamsī Tabrīz, I am so drunken in this world,

That except of drunkenness and revelry I have no tale to tell.

Nicholson (trans.), Selected Poems from the Dīvāni Shamsi Tabrīz, pp. 125, 127 (Köprülü omitted the fifth and seventh verses).\} Yūnus Emre's famous poem that includes the 
couplet Zâhir suya girmedin el ayak depretmedin / Başsecdeye varmadin kılınur tấatimiz \{Our worship takes place without ablutions, without bodily movements, without bowing the head [Gölpınarlı, Yunus Emre: Risâlat al-nushiyya ve Divân, p. 169]\} is basically identical with this.

The following $r u b \bar{a}^{c} \imath$ is very important for showing the nature of spiritual love in Șūfìsm and is very beautiful:

$$
\begin{aligned}
& \text { از شبنم عشق خاك آدم كل شد \ شوزى بر خاست فتنهُ حاصل شد } \\
& \text { سر نشتر عشق بر ركك روح رسيد \يك قطره از وجكيد ونامش دل شد }
\end{aligned}
$$

\{From the dew of Love, Adam's clay turned to mud;

A tumult arose, a commotion broke out.

The blade of the lancet touched the vein of the spirit,

One drop fell from it: it was named "heart."

According to Yūnus Emre, in order "to go beyond duality and to distinguish $q \bar{a} l$ \{book-learning\} from $h \bar{a} l$ \{mystical ecstasy\}," the only way is love. Mawlānā, who says in the Mathnaw $\{$ Book 5, line 588\}:

$$
\text { عشق آن شعله است كوجون بر فروخت \ هر جه جز معشوق باقى .جله سوخت }
$$

\{Love is that flame which, when it blazes up, / Consumes everything else but the Beloved; Nicholson trans.\}, subsequently explains how unity is manifest in plurality \{Book 4, line 408, and Book 2, lines 184-7\}:

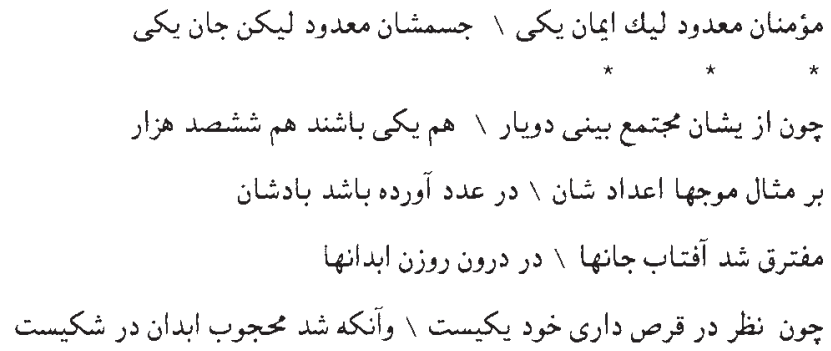

\{Believers are numerous, but belief is one. Bodies are many, but the soul is one.

When you see two friends joined, they are both one and six hundred thousand.

Their number is like waves: it is wind that has brought them forth in number.

The sun of souls is separate inside the window of bodies,

When you look at the sun disc, it is one: but he who is screened by bodies is in doubt.\} 
37 \{Cf. Gölpınarl, Yunus Emre: Risâlat al-nushiyya ve Dî̀ân, p. 119.\}

38 Pes her şey ki zâtta vech-i küllî̀ ve icmâli üzre münderic ola, pes ol şey insân-ı kâmilde vech-i küllî ve icmâli üzre münderictir ve ilm-i Hak-ta vech-i cüz'î ve tafsîl üzre zâhir olan şey pes ilm-i insân-ı kâmil'de vech-i cüz'î ve tafsîl üzre zâhirdir. Bil ki Hakk'n ilmi, insân-ı kâmil' in ilmidir ve ânın zâtı, insân-ı kâmil'in zâtıdır, ittihâd ve hulûlsuz; zîrâ ittihâd ve hulûl mevcûdînden hâsıl olur ve hulûl dahî böylecedir; zîrâ Vücûd-ı vâhid'den gayn vücûd yoktur; zîrâ esyâ Hakk'n vücûdi ile mevcûde, kendi nefsleriyle ma'dûmedir. Pes Hak'la nice müttehid olur şol şey ki ânn vücûdiyle mevcûd ola ve kendi nefsi ile ma'dûm ola \{Everything that is incorporated in the divine essence totally and in general is incorporated in the perfect man totally and in general, and everything that appears partially and in particular in the knowledge of God appears partially and in particular in the perfect man. Know that the knowledge of God is the knowledge of the perfect man and His essence is the essence of the perfect man, without "union" and without "incarnation" (see $E I^{2}$, s.v. "Hulūl" [L. Massignon-(G. C. Anawati)]). For union and incarnation result from those who exist, and incarnation is also like this; because there is no existence other than the existence of the One; because things exist by virtue of the existence of God and in themselves are non-existent. How could something be united with God which exists only by virtue of His existence and which by itself is non-existent?\} ('Abd Allāh Bosnawī, commentary on the Fusūss, p. 16). Some conventional religious scholars \{'ulama'\} have accused Ibn al-'Arabī, and many of the great Șūîs who accepted his ideas, of hulül \{incarnation, indwelling\}, but this allegation is completely false. Hulül is sometimes understood as resulting naturally and sometimes as subsisting with a thing itself; whereas God, being pure existence, cannot subsist through another. Ibn al-'Arabī fully explains this point and then says, Nûr-i şems, bedr'de tecelli ettiğginde sâir gecelerdekinden başka olduğu gibi, iktidâr-i ilâhîde 'abdde tecellî ettiḡi vakitta halktan birtakum ef'âl zuhûr eder. Bu her nekadar iktidâr-i ilâhî ile ise de, hükmü muhteliftir; zîrâ bu tecellî-i ilâhî, âyine gibi meclâ vâsstasiyle olmuştur; aklen mâlum olacağ̀ üzre, kamerin taayyününde kendisinde nûr-i şemsten hiçbir ş̧ey yoktur ve şems âna bizâtihâ intikâl dahî etmemiştir; ancak, kamer ona meclâ olmuştur. 'Abd de bunun gibi olur, Hâlık'ndan kendisinde hiçbir şey olmadiği gibi, ânda hulûl dahî eylememişstir; ancak, o Hâlık'n hassaten meclâ ve mazhârîdir. Şurasin da bilmeli ki, birșeyin diğer şeye meclâ olması, onun mahalli olması değildir; zîrâ mirâttan zâhir olan, bizâtihî mir'âttan değildir; fakat mahalle nisbetle hâl böyle değildir; zîrâ hâl mahalde hâsıldır. Zuhûr, hulûl değildir $\{$ Just as the light of the sun is different each night when it is manifest on the moon, so when divine power is manifest in man numerous actions appear from mankind. While all manifest divine power, the effect is different, for this divine manifestation occurs by means of reflection like a mirror. As is known by reason, the moon is visible only because the light of the sun is on it. The sun does not transfer anything of itself to it; the moon is only a mirror of it. Man is just like this. Not only is there nothing of the Creator in him, so there is no divine indwelling in him. Only he is especially the reflection and manifestation of God. Furthermore, the fact that something can be reflected in something else does not mean that it takes its place, because that which appears in the mirror is not in itself of the mirror, which is not the case with respect to place. To be manifest is not to be indwelling (cf. Chittick, The Self-disclosure of God, pp. 84-5)\}. This is why Ibn al-Arabī says الحتق خلق وما الخلق حق God is a cre-

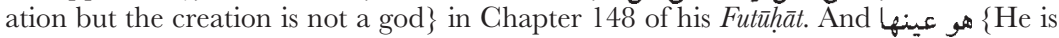
their essence\} in the expression سبحان من اظهر الاشياء وهو عينها \{Praise be to Him who reveals things, He being their essence $\}$ is a true affirmation of this, for this means that

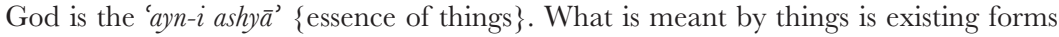
$\{$ suwar-i marejū $d a\}$. And this is absolute existence, in relation to one of the special features $\{k$ husususiyya $\}$ that are necessary for the immutable entities. (Misunderstanding this, some have asserted that God is la bi-shart-i shay' \{not conditioned by things\}, that $\mathrm{He}$ is the same as the existence of things; but what is intended by absolute existence 
here is "the totality of the absolute bound to the intrinsic special feature." Consequently, the statements of some - for example, Jāmī's statement in the Muqaddima-i sharh-i Fusūs, citing \{Dāvūd\} Kayserī - that God is the essence of everything in descending order, i.e. in the great chain of being $\{C e n a ̂ b-i$ Hakk'n mertebe-i tenezzülde ayn-i essyâa, are unacceptable, because to explain the words هو عينه هو عين ما هيتها $\{\mathrm{He}$ is the essence of their essence\} is to contradict Ibn al-'Arabī, who explained that "the immutable entities that are the essences of all things do not exist in nature but are the others in immutability \{mâhiyât-ı esyâ olan a'yân-ı sâbite’nin tabî̀ vücûtta değgl, fakat sübûtta agyâr olduğunu, see Chittick, The Sufi Path of Knowledge, p. 91\}. How is it possible that Ibn al-'Arabi would assert that the thing he said was "other" was the "same"? 'Alā' al-Dawla Simnānī's many objections to this chapter disappear in light of this elucidation. In another work, Ibn al-'Arabī also rejects union $\{i t t h \bar{a} d\}$. He says that union is absurd, because the one next to you, with whom you want union, still says "I," and that is not union. Rather, it is not you who speaks, but He through you. Also, when you say نانانت أنانت

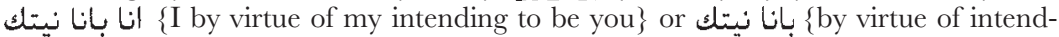
ing to be you\}. If you have said بانا نيتك $\{$ by virtue of intending to be you\}, there is no union with respect to either meaning or forms. Because this is the way that most conventional religious scholars have understood this, they have attacked Șûfìsm. Abū Sa'īd Ibn Ab̄̄ 'l-Khair, the author \{not further identified\} of Bustān al-'ārifiñ , and Imām al-Suyūṭ̂̄ both defended Ibn al-'Arabī against the conventional religious scholars on this point. In addition, Imām al-Ghazālī says in his Munqidh that the followers of the Șûfi path have progressed to the point that their words could be attributed to indwelling and union, but to accuse them of this would be a mistake. Qāḍ̂̄ Mu'īn al-Dīn Husain Yazdī \{i.e. Muhammad Yazdī, d. 789/1387, see $E I^{2}$, s.v. "Mu'īn al-Dīn ... Yazdī" (Angelika Hartmann)\} and Qāḍ̄ Yūnus 'Abd al-Mālik assert that those who relate the doctrines of Șüfism to indewlling and union are mistaken. Yūnus Emre's hymn Sen'inle dirliğim Sen'den aynlmaz / Hayât Sen'inledir Sen'siz dirilmez \{ I live through you, not separate from you / Life is through you: without you there is no life $\}$ reveals complete conformity with Ibn al-'Arabī's view.

39 \{Cf. Gölpinarl, Yunus Emre: Risâlat al-nushiyya ve Dîâan, p. 97.\}

40 İsmâ ̂̂l Hakkı explicates this hymn by Yūnus Emre as follows: Yuvadan maksadı âsiyâne-i ezelî ve âlem-i vahdettir ki, oradan bu âlem-i ebede ve kesrete pervâz eyleyib Tabduk

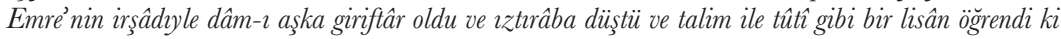
bu kesret ilinde âm ehl-i vahdetten gayn kimse fethetmedi; zîrâ Yemen bâzirgânnmn getirdï̆ dürr-ü cevâhirin kuymetini karevî olanlar bilmez ve boncuk kadar rağbet kılmaz. Pes cümle ehl-i hakikatin kelimâtn dahî böyledir. Annn çin bu zevka mazhar olanlar ve bu sirn bilenler na-ehle râz açmazlar ve nâdân yanndan geçmezler \{ By nest ( yuva) he means pre-eternal home, the world of unity. He soared from there to the world of post-eternity and multiplicity and with the guidance of Tapduk Emre became caught in the snare of love and suffered anguish. He learned a language like a trained parrot, so that in this region of multiplicity no one but a member of the people of unity conquered him, for peasants (karevî) do not know the value of pearls brought by the Yemeni merchant - and do not desire them as much as beads. Moreover, the words of all the people of the truth (Șūfìs) are like this. Therefore, those who are exposed to this blissful perception of God's presence (zevk) and who know this secret do not reveal the mystery to the undeserving and do not associate with the ignorant\} (commentary on the Muhammadiyya, bakiyye-i cildi evvel \{remainder of volume 1\}, p. 112). Khujandī's couplet

$$
\text { باناصح بى ورد نكويم غم عشق \بيهوده سخن محرم آن راز نباشد }
$$

\{I do not tell the pain of love to the unfeeling advisor: / The speaker of nonsense is not a confidant of that mystery expressess the same meaning. These bird and nest 
similes are quite famous among the Șūfìs. The following poem by Mawlānā is a very eloquent example of such comparisons:

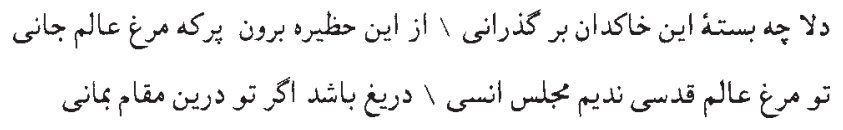

$\{\mathrm{O}$ heart, why art thou a captive in the earth that is passing away?

Fly forth from this enclosure, since thou art a bird of the spiritual world.

Thou art a bird of the whole world, a boon-companion in the assembly of Love;

If thou wilt remain here, 'tis a pity

Nicholson trans., Selected Poems from the Dīvāni Shamsi Tabrīz, p. 175\}.

41 \{Gölpınarl, Tunus Emre: Risâlat al-nushiyya ve Dî̀ân, p. 85.\}

42 Ibn al-'Arabī records his thoughts on this matter in the Bezel of Adam \{Chapter 1 of Bezels of Wisdom (Fușus al-hikam)\} in particular. Bosnawi \{in his commentary\}

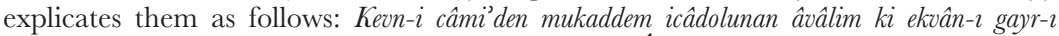
câmi“ann câmi'dir, insânsız şebh-i vücûdî gibi icâdolunmuştu. Ânn mezâhirinde olan rü’yet-i esmẩ îdir; hâlbuki kevn-i câmi' mazharnda esmâ'-i hüsnânn a'yâm rü'yetine meşiyyetin teallûkundan evvel Hak Teâlâ âlemin küllisini şebh-i müsevvâ gibi ki ânda rûh yoktur, icâdetmiş̧i. Pes âlem cilâ olunmamıs âyîne gibi idi: zîrâ kevn-i câmi' in icâdından mukaddem icâdolunan âlemin küllîsi, a' lâ ve esfeli, zulmânî ve nûrânîsi ve âlem-i emri ve halkr olsun esmẩi ilâhiyye mezâhiridir ... İnsânsız âlemin kemâl-i zuhûra kâbiliyyeti yoktur, zâten ve sûreten ve cem'an ve tafsîlen, zâhiren ve bâtınen Hakk' in kemâl-i mazhariyyetinden kâsir olduğundan ötürü. Pes insândan evvel, âlem-i zuhûr-i küllî, insân rûhu için tesviye olunmuş bir cesed gibi idi ve insânnn vücûdü cilâsı ile cilâ olunmağa kâbil cilâ olunmamış bir âyîne gibi idi... Pes Emr-i ilâhî ve Hükm-i Rabbânî, âlem mir'âtmnn cilâsm ıktzzâ eyledi; pes âdem ol mir'ât cilâsmm ayni ve ol şebh-i müsevvâ sûretinin rûhu oldu; zîrâ âdem esmâ'-i ilâhiyye cem'iyyetini câmi olan Hazret-i ilâhiyyetin mazhander. Pes Hazret-i ilâhiyye, esmẩ $i$ ilâhiyyeyi câmic a olub, ânmnla zât beyninde vâsita olmadı̆̆g gibi hazret-i insâniyye dahî esmẩ $i$ ilâhiyye'yi câmi'a olub zât-ı ehadiyyet ile ânn beyninde vâsita yoktur. Hazret-i ilâhiyyet'te olan

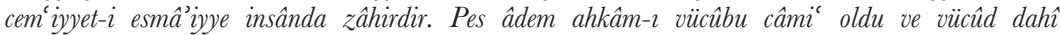

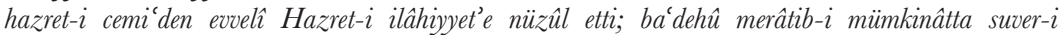
nev'iyye-i imkâniyye üzre fâiz olub, cemi' merâtib ile munsabrg olduğu hâlde, insâna müntehî oldu. Pes insân-ı kâmil cemi‘ merâtib-i imkâniyyenin zübdesini câmi‘ olmağla, ahkâm-ı imkâniyyeyi dahî câmic oldu. Pes âlem ile kemâl bulub, ekmel sûrette Hak Teâlâ âlem üzre zâhir oldu; zîrâ âlem Sûret-i Hak üzre olan âdemin sûreti üzredir. Pes âlemin netîcesi ve semeresi âdemdir, zuhûr ciheti ile ... \{ The cosmos, which was created before the all-comprehensive thing (see Chittick, The Self-disclosure of God, p. 171, the perfect human being), is that which comprehends the non-comprehensive engendered things. It was created without man, like the corporeal form. In its manifestations is found the perception of the divine names, whereas, in the manifestation of the all-comprehensive thing are found the essences of the beautiful names of God. Before any connection with the desire to perceive it, God created the cosmos like an undifferentiated body, without a soul. Thus, the world was like an unpolished mirror; for the cosmos, which was created before the creation of the all-comprehensive thing, is the manifestation of the divine names - including highest and lowest, dark and light, the world of command and the world of creation (see Chittick, ibid., pp. 250ff.) . . . The world without man has no capacity for perfect appearance because it is incapable of the perfect manifestation of God, whether in essence or in form, whether in whole or in part, whether outwardly or inwardly. Thus, before man, the cosmos was like a body prepared for the human soul. It was like an unpolished mirror capable of being polished with the polish of the existence of 
man ... Then the divine command and divine judgment necessitated the polishing of the mirror of the world. Adam is identical to the polishing of that mirror and is the soul of that undifferentiated body. Adam is the manifestation of the divine presence that comprehends all of the divine names. Just as the divine presence comprehends the divine names and there is no intermediary between it and the essence (of God), so the human presence also includes the divine names and there is no intermediary between it and the dhatt-i ahadiyyat (essence of unity). All of the names that are in the divine presence are manifest in man. Thus Adam became the totality of the properties of necessity. Existence first descended from the collective presence (of bringing together; cf. Chittick, ibid., p. 179) to the divine presence and then became abundant according to the possible specific attributes in the stages of possible things. Existence was tinged with (has the appearance of) all the stages, but culminated in man. Thus, the perfect man included the quintessence of all the possible stages and also the possible properties. Thus he found perfection with the world and God appeared upon the world in the most perfect form, because the world (macrocosm) is in the form of man (microcosm) who is the image of God. Thus the end result and product of the world is man, from the point of view of appearance... A After this Ibn al-'Arabī speaks at length about man being God's vicegerent and says that, if the perfect man were detached from the treasurehouse of the world, nothing would be left in the world that God would treasure with Himself. The reason that the all-encompassing thing is called man is due to the generality of his creation and the fact that he comprises the totality of the truths. The collective creation of the cosmos is summed up in man's creation, and man's creation is differentiated in the collective creation. The greatest barzakhiyya \{intermediary realm\} comprises all divine, created, and intermediary $\{$ barzakh $\bar{\imath}\}$ truths with the truth of the unity of the cosmos.

43 \{Cf. Gölpinarl, Yunus Emre: Risâlat al-nushiyya ve Dîvân, pp. 107-8.\}

44 It is clear that Yūnus Emre considered esoteric knowledge and not exoteric knowledge to be important. The reason for this dichotomy in knowledge is that God is both apparent and hidden. The dichotomy is necessary according to the Șüfis because the apparent can only be known by the apparent and the hidden by the hidden. Those who regard only exoteric knowledge to be important cannot see God "with essential perception in rational degrees \{madārik\} and essential stages"; and those who regard only esoteric knowledge as important cannot see God "who is apparent in cosmic phenomena and sensory manifestations." Because the perfection of Muhammad is in the joining of the apparent and hidden, and this is possible in the stage of $q \bar{a} b$-i qaresain \{being very close; see Chittick, The Self-disclosure of God, pp. 233-6\}, which is the stage of the vicegerency \{see Chittick; The Sufi Path of Knowledge, p. 286\} and the perfect man, naturally it is not vouchsafed to everyone. Nevertheless, the Sūfì poets acted coldly and contemptuously not only toward the conventional religious scholars but also toward exoteric knowledge. Mawlānā’s statement مرد خدانيست فقيه از كتاب the man of God is not learned from books; Nicholson (trans.), Selected Poems from the Dĩvanni Shamsi Tabriz, p. 29 \} expresses this precisely.

45 The subject of dawr is explained briefly and quite well in the introduction of İbrâhîm Hakkı's Márifatnâme \{Istanbul, 1294/1877\}, pp. 27-9. For greater detail, see \{'Abd Allāh Bosnawī's commentary on the Fusūus, especially the first faș \{segment\}. This subject is also briefly discussed in Sarı 'Abd Allāh Efendi's Thamarāt al-fu'a $\bar{d}$ (p. 10). Creation poems \{dawriyyas\} dealing with the arc of descent \{transformation of the divine light into the four elements\} are termed "of the carpet" \{farshiyya, i.e. earthly\} and the others "of the throne" \{'arshiyya, i.e. heavenly\}. Niyāzī Mișrī's Dawriyya-i 'arshiyya and Üsküdarlı Hâshim Baba's Dawriyya-i farshiyya are very famous in our literature. In addition, there are many dawriyyas by the tekke poets beginning with Nesīmī and including those such as Ibrāhīm Efendi \{i.e. Olanlar Shaikhi\} and Qayghusuz, 
and also in Bektashī poetry. There is a simple commentary on this theory in Qayghusuz's 'Abdālnāme \{MS in Köprülü's private library\}, p. 16.

$$
\begin{aligned}
& \text { بانه يدر در هر فلك يكجيند دوران كرده ام. \با اختران دو بر جها من سالها كرديده ام. } \\
& \text { يكجِند نا بيدا بدمبا او بهم يكجا بدم \در ملك اوادنى بدم ديدم هر آنجه ديده ام } \\
& \text { مانتد طفل اندر شكم من ثرورش دارم زحق \ليكبار زايد آدمى من بارها زائيده ام }
\end{aligned}
$$

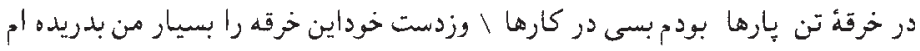

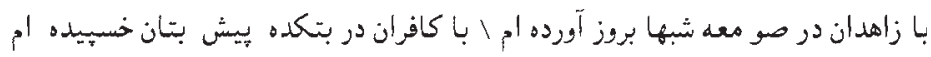

$$
\begin{aligned}
& \text { عمم دزد عياران منم هم رنج بيماران منم \هم إبرو هم باران منم در باغها با ريده ام } \\
& \text { بردا منم كرد فنا نتشست هر كز اي كدا \در باغ وبستان بقا كلها فراوان جيده أم }
\end{aligned}
$$

\{I turned a little in every sphere with the Nine Fathers

(F. Steingass, Persian-English Dictionary [1892; reprinted Beirut, 1975], p. 1437: the seven planets with the dragon's head and tail)

I turned for years in the constellations with the stars.

For a while I disappeared. I was at one place together with him.

I was the lowliest in His kingdom. I saw whatever I saw.

I get nourishment from divine Truth (God) like an embryo in the womb.

A man is born once: I have been born many times.

In the torn cloak of the body I was involved in many deeds,

And with my own hand I often tore this cloak apart.

I spent nights with monks in their cell.

I slept with infidels in their idol temple, next to the idols.

I am a thief of the rogues. I am the suffering of the sick.

I am both cloud and rain: I have rained into the gardens.

The dust of annihilation never settled on my shirt, O beggar!

I have picked roses in abundance in the garden of eternity.\}

47 In Mawlānā's Dīwān, there is a ghazal beginning

$$
\text { عو نقش راكه ديدى جنسش زلا مكانست \كّر نقش رفت غم نيست اصلش جو جاودانست }
$$

\{Every design that you see has its type in the One Without Place (God). / No matter if the design disappears: its original is eternal.\} Here Mawlānā tries to explain the daw theory in the following verses:

$$
\begin{aligned}
& \text { اول بحاد بودى آخز نبات كشتى \آنكه شدى تو حيوان اين بر توجون نهانست } \\
& \text { كشتى ازان بِ انسان با علم وعقل وايمان \بنكر جه كل شد آن تن كو جزؤ خاكدانست }
\end{aligned}
$$


\{First you were mineral, then vegetable.

You then became animal. How is this hidden from you?

Then you became human, with knowledge, reason, and faith.

See how that body, which is a part of the earth, turned into a rose.\}

In his Mathnawr, Mawlānā presents this clearly as well \{Book 4, lines 3637-9, and Book 3, lines 3901-6\}:

$$
\begin{aligned}
& \text { أمده اول باقليم جحاد \ وزبحادى در نباتى او فتاد } \\
& \text { سائها اندر نباتى عمر كرد \ وزجمادى ياد ناورد لز نبرد } \\
& \text { وز نباتى عجون بحيوانى فتاد \نا مدش حال نباتى هيج ياد } \\
& \text { از بحادى مردم ونامى شدم \ وز نما مردم بحيوان سر زدم } \\
& \text { مردم از حيوانى وآدم شدم \ بس جه ترسم كى زمردن كمشدم } \\
& \text { جملة ديكر بمير از بشر \تابر آرم از ملاكك بال وير } \\
& \text { وز ملك هم بايدم جستن زجو \كل شئ هالك الا وجهه } \\
& \text { بار ديكر از ملك قربان شوم \آنجه اندر وهم نايد آن شوم } \\
& \text { يس عدم كردم عدم هون ارغنون \كويدم كانا اليه راجعون }
\end{aligned}
$$

$\{$ He came first to the mineral realm.

From a mineral he turned into a vegetable.

He lived in the vegetable state for years,

And because of the opposition (between them) remembered nothing of the mineral state.

Then from a vegetable he turned into an animal,

And remembered nothing of the vegetable state.

$\cdots$

I died as a mineral and became a plant.

I died as a plant and appeared as an animal.

I died as an animal and became a man.

So why should I fear that from dying I will be diminished?

Let me die completely as a man,

So that I may put forth angel's wings.

From the angels I must leap out of the air:

"Everything passes away exept His face" (Koran, 55:22).

Once again, as an angel, I will be sacrificed,

So that I may become what has never been imagined.

Then I will become non-being. Non-being says loud as an organ:

"To Him we shall return" (Koran, 2:156).\} 
48 In Nāṣir-i Khusraw's poem that begins

$$
\text { بكذشت زهجرت يس سيصد نود وجار \بنهاد مرا ها در بر مركز غبرا }
$$

\{Three hundred ninety-four years had passed since the Hijra, / When my mother placed me in the center of the earth $\}$ this belief in dawr is quite obvious.

49 The famous strophe of Ibn Yamīn, the author of Muqatta' āt \{Calcutta, 1865\}, which begins

$$
\text { زدم از كتم عدم خيمه بصحراي وجود \ وزبحادى بنباتى سفرى كردم ورفت }
$$

\{From the concealment of non-being, I pitched a tent in the plain of being. / I journeyed from being mineral to being vegetable, $\}$ fully describes this theory.

50 Faid-i Hindī's Markaz al-adwār is a good example of a dawriyya.

51 In the Gulshan-i rāz, the subjects of this daw and the perfect man, and then that of the emanation and the self-disclosure of God, are clearly presented in a manner suitable to a didactic work. In order not to go beyond our subject, I will not cite it here.

52 I believe that the descriptions that I have given above of the views of the Muslim mystics on the subject of creation have shown that they could not include a belief in metempsychosis $\{$ tanāsukh - just as they could not include a belief in indwelling $\{h u l \bar{u} l\}$ or union $\{i t t i h \bar{a} d\}$. The author of Gulshan-i rāz thus rejects any possible imputation $\{$ of this $\}$ by saying

$$
\text { تناسخ نبود اين از روى معنا \ظهور أتيست در عين تجلا }
$$

\{These circuits are not transmigrations of souls, for verily / They are manifested in the visions of Epiphanies; Whinfield (trans.), line 367, and in a footnote he explains "In metempsychosis one body perishes and another succeeds it as a receptacle of the soul, but in these circuits the truth may be manifested in teacher and disciple at once." $\}$. We also find the belief in metempsychosis, which we first encounter as a philosophical view in Pythagorus and Plato, in the Neoplatonists. Their theory of emanation and self-disclosure of God did not lend itself to the belief in metempsychosis, because, in their opinion, the soul is an idea and matter is a negation. Consequently, the notion of metempsychosis entered Neoplatonism not as a corollary of their system, but as a remnant of the Pythagorean theories.

The first to try to reconcile this with the Neoplatonist system was the Syrian Porphyry $\{233-c .304\}$. According to him, the reason why our souls wear the garment of the physical body is punishment for sins that we committed in a previous life. The envelope that covers our soul is proportionally thick or thin according to our offense and punishment. Thus, some souls have been placed in an aerial body and some in the human body. They fulfill their duties with resignation and thus slowly approach God. This view is clearly nothing more than the extension of Plato's spiritualism indiscriminately to all mankind. Porphyry believed that animals possessed a soul, perception, and reason, but he did not include them in this system. Furthermore, in contrast to this ascending ladder that goes from man to God, he also accepts a descending ladder that goes from man to hell.

Among the cabalists, we find this theory assuming more of an ethical and spiritual quality. According to them, it is predestined for souls, like all existing things on the face of the earth, to return to the divine substance. In order to do this, it is necessary for the indestructible germ of perfection within the souls to acquire all the perfect 
qualities. If the soul cannot acquire them in the first life, then it begins, in turn, the second and third and finds in each the means of reaching perfection that it was not able to find in the previous one. Finally, when our soul reaches such perfection that it perceives the bliss of divine unity, this cycle ends. Moreover, if we persist in not turning away from our sins, this cycle will continue until the day of resurrection \{Köprülü's description of metempsychosis here is essentially a summary of an extract from Franck (ed.), Dictionnaire des sciences philosophiques, s.v. "Métempsychose" (Adolphe Franck), pp. 1096-7\}. It is clear that among the cabalists the cycle is restricted to humans.

In light of this entire account, the nature of the differences between our Sūfis and the Neoplatonists and the cabalists on the subject of the cycle is easily understood. Our Șūfìs included in the cycle not only mankind but also inanimate objects, plants, and animals. The view of some Sunfiss that the "soul is brought down to the corporeal world in order to find perfection through life experience" is somewhat compatible with the ideas of Porphyry and the cabalists, but differs from them with respect to the system. The great Șūfis basically explain the descent of the soul not in this manner but as "the divine will's desire to manifest its essence." All the Sūfì poets accepted this. İbrâhîm Hakkı's explanation of this in his Ma'rifatnâme is somewhat reminiscent of Porphyry and the cabalists, but when the Sūfì system of Ibn al-'Arabī and Jalāl al-Dīn Rūmī - and that of İbrâhîm Hakkı who follows them - is carefully examined, it becomes quite obvious that there is absolutely no inclination toward accepting the theory of metempsychosis. With respect to the origin of the belief in dawr, it did pass from the Neoplatonists and cabalists to our Șūfìs, but they changed its nature broadening and refining it - and escaped from metempsychosis, which was not very compatible with their views. The manifestations of the beliefs in indwelling and union and metempsychosis in Islam constitute a separate subject that is of great importance.

53 \{Cf. Gölpınarl, Munus Emre: Risâlat al-nushiyya ve Dîvân, p. 179; Mustafa Tatçı, Yunus Emre Divân (Ankara, 1990) p. 161.\}

54 There is this difference, namely that Ahmad Yasawi was much more of an upholder of the religious law and a moralist, and had the spiritual influence of the founder of a tarìqa, while Yūnus Emre was only a mystic, a simple dervish who was influential for centuries as a passionate poet. Indeed, Yūnus Emre was superior to Aḥmad Yasawī not only as an artist but also as a Șūfí.

55 In his commentary \{on Ibn al-'Arabī's Fușūs\}, 'Abd Allāh Bosnawī provides a brief but fairly detailed description of how the Șüfìs perceive God (p. 11). If we compare it with Plotinus' theory of the three hypostases (i.e. unity, intelligence, and power) and his ideas about the essence of God and the creation of the universe, it becomes clear not only that our Sunfis have essentially accepted the theory of Neoplatonism, but also how they have modified and deepened it within the framework of Islam. Yūnus Emre, who lamented Ben bir kitâb okudum kalem onu yazmadı / Mürekkep eylerisem yetmeye yedi deniz I I read a book not written with a pen. Seven seas of ink would not suffice for it\}, maintained a view that was no different from that of Mawlānā, who cried out م نهeware! If you see me, tell no one. I have seen (Him)\}, and Ibn al-'Arabī. And he wrote orations that could be easily reconciled with Sharīa principles. Only by ignoring the rather subtle interpretations of Islamic mysticism and many of its other features can one consider Yūnus's beliefs contrary to those of the Sunnīs.

56 Rızâ Tevfîk says in an article, "Yūnus Emre was similar to other bātinīs. I consider them all to be proponents of religious doctrines that do not conform to conventional beliefs. His verse Hakikatin kâfiri şer in evliyâsudır \{The infidel of divine Truth is the saint of the Sharī $a$ \} justifies including this beloved Turkish poet among this group, based on his own admission. His beliefs were no different from those of the Șüfis of Iran and 
India" ("Yûnus Emre hakkında biraz daha tafsilât," p. 183). As I have explained above, it would be completely mistaken to consider Yūnus Emre a battinī, because he never went beyond a clear limit that, by means of interpretation, could be reconciled \{with orthodoxy\}. As for the above verse, it must be interpreted in a completely different sense. Otherwise, we must also not consider Mawlānā, if we take his words literally, to be a Muslim. The absurdity of this is obvious. If we do not carefully study the special features of Islamic mysticism and simply accept it as an imitation of Neoplatonism, we cannot escape such errors. A lengthy discussion here of these important Șūfì issues is beyond my expertise.

57 See the Hurūfí texts published by Huart, \{Textes persans relatifs à la secte des houroufis (Leiden, 1909)\}. There is a fairly detailed account of this in Khwāja İshak Efendi's Kâsififi'l-esrâr ve dâf' ‘̈̈l-eşrâr \{Istanbul, 1290/1873-4\}. There is also some information in \{Karakaşzâde Ömer Efendi's\} Nûrü̈l-hüdâ li-men ihtadâ \{Istanbul, 1286/1869-70\} and Rifat Ahmed Efendi's Mir'âtü'l-makâsid \{Istanbul, 1293/1876\}. Rızâ Tevfik's study is disorganized and full of historical gaps and errors, but it is still useful. The Hurūfis, who accept epiphany, i.e. the appearance of God in the form of the sect's founder Faḍl Allāh, are one of many similar bătinin sects that arose from the bosom of Islam. In its origins, it is a curious and rudimentary mixture of Jewish cabala and Neoplatonist beliefs, plus a few religio-mystical traditions. Simply comparing it to other bātinī sects does not suffice to properly understand it. In addition, one should fully comprehend the milieu in which it developed, the places to which it spread, and its connection and relationship with other similar sects. Then a full explanation of it would be possible and its historical development would be discernable. I am preparing a study that will include some important notes, especially from the historical point of view, on the Hurūfìs among various other unorthodox tañqas and groups that were spread among the Anatolian Turks for centuries. \{This was never published. Köprülü was supposed to prepare something on this subject for the supplement to the $\dot{I} A$, see bibliograpy, s.v. "Hurûfilik" (ed.). Now see $E I^{2}$, s.v. "Hurūfiyya" (A. Bausani), and especially the works of Gölpınarlı listed in the bibliography of his Hurûfilik metinleri kataloğu, and Bashir's "Enshrining Divinity."\}

58 There are a fair number of Hurūfi poets in our literature. The aforementioned study will also include details on them. It would be a mistake, however, to consider every poet whose work included allusions to asrär-i hurüf \{the secrets of the letters\} to be a Hurūfî.

59 In the Dīwān of Yūnus Emre, who said, Ne elif okudum ne cîm ne varlktandır kelecim / Okumaz yüzbin müneccim tâli ‘im yllduzdan gelür \{I have read neither alif nor jìm, nor do my words concern the world / A myriad astrologers cannot read it: my horoscope comes from the stars (cf. Gölpınarl, Yunus Emre: Risâlat al-nushiyya ve Divân, p. 51),\} there are some important references to this issue of the letters. The following passages are examples of such references:

Tigirmisekiz hece okursun ucdan uca

Sen elif dersin hoca mánâsı ne demektir

\{You read the twenty-eight letters from end to end

You say alif, teacher; but what does it mean?\}

$\cdots$

Dört Kitâb' in ma'nâsı tamâmdır bir elifte

Bâ dedirmeniz bana ben bu yoldan azarm

Yedi Mushaf mainâsn okudum tamâm kıldım

Ya ne için karayı ak üstïnde yazarm 
\{The entire meaning of the Four Books is in a single alif.

When you make me say $b \vec{a}$, I go astray.

I have read completely the meaning of the seven variant readings (of the Koran).

So why do I write black on white?\}

Rızâ Tevfik says, "According to authorities, there are clear references to the fact that Yūnus Emre was a Hurūfi." He uses two of these couplets as evidence of this and explains them as follows: "In these expressions, \{the letter\} alif is Adam. $B \vec{a}$ ' is the beginning of $b^{\prime}$ ismillath \{the invocation, in the name of God\}, so that the dot beneath it is the source of existence, which is the origin of all letters. The meaning of yedi mushaf \{seven variant readings of the Koran is the seven basic facial lines of Adam. The expression ak üstünde kara yazı \{writing black on white\} is an allusion to hutût-i ümmiyye \{the maternal lines\} and hututt-i ebiyye \{the paternal lines\}. These are some of the fundamental beliefs of the Hurūfiss. There are many examples, references and explanations in my published work.” Apparently Rızâ Tevfik considers Yūnus Emre to be a disciple of Faḍl Allāh Hurūfì. It is absolutely mistaken, however, to explain these four verses by Yūnus Emre, who lived a century before Faḍl Allāh, according to Hurūfì beliefs. The quatrain below, which belongs to the famous Sūfì Shaikh 'Izz alDīn Mạ̣mūd al-Kāshī, who wrote a commentary on \{Ibn al-Fārị̣'s\} Qașīda-i tă iyya and translated \{al-Suhrawardī's\} 'Awärif al-ma'arifi, has the same meaning as Yūnus Emre's line Dört Kitâb' mn ma'nâsı tamâmdır bir elifde \{The entire meaning of the Four Books is in an alif $\}$.

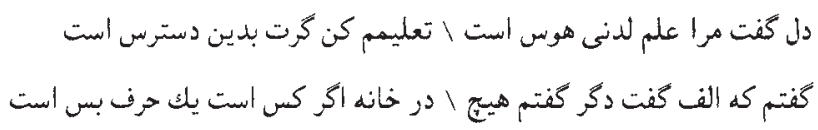

\{My heart said to me: "I desire divine knowledge.

Instruct me if you have attained it."

"Alif," I said. "What else?" he asked. "Nothing," said I.

If someone is in the house, one word is enough.\}

This Șūfī, who was definitely not a Hurūfí, also considered spiritual knowledge to be concentrated in the letter alif. This shows that it would be completely mistaken to attribute the aforesaid words of Yūnus Emre to Hurūfism and explain them in its terms.

60 In addition to the passage that I have mentioned, there are a few trifling things in the Dĩwan concerning the secrets of the letters, but none of them bears the slightest evidence of Hurūfism or fadl \{i.e. Faḍl Allāh\}.

61 To demonstrate the importance that genuine Șüfis gave to the secrets of the letters, I will give verbatim the account of the commentator \{'Abd Allāh Bosnawī $\}$ on the Fusūs - by Ibn al-'Arabī - concerning hurūf \{letters\} and kalimāt \{words\}: Hurûf ile kelimât iki kussm üzredir. Birisi hurûf-i ilâhivye ve kelimât-i ilâhiyye, birisi hurûf-i vücûdiyye ve kelimât-i vücûdiyye. Pes hurûf-i ilâhiyye; gaybı, gayb-ı guyûbda kâmin olan şân-i zâtîdir, nevât içinde şecere gibi. Pes şû̂nât-i ilâhiyye téayyunât-i Hakk'n a'lâ merâtibi olduklan i'tibâriyle ve

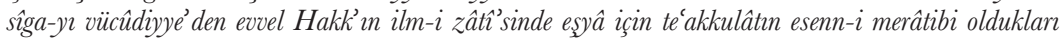
i'tibâriyle ânlardan her bir şs'n hurûf-i gaybî ile tesmiye olunur. Sîga-yn vücûdiyye' den evvel her bir şe’ni ânm levâzimi ile te'akkul etmek i'tibâriyle ol şèn kelime-i gaybiyye ile tesmiye olunur ve ol șèn ile Hakk' in zuhûru ve ânn levâzimi i'tibârîsiz Hakk' nn tecellîsî hükmünün insihâbi i'tibâriyle ol șe’n harf-i vücûdî ile tesmiye olunur ve ol tecellî hükmünün ol șe’n üzre ve ânn levâzimi üzre insihâab̂ิ 
itibâriyle ol şse’n kelime-i vücûdiyye ile tesmiye olunur. Pes hurûf-i gaybiyye şû̂n-i zâtiyye olduğu ¿'tibâr üzre Hakk'in aynidir, şecere, nevâtta, nevâtın ayni olduğu gibi téayyun ilmi ile hurûfun téayyunu ve téaddüd-i nisbî ile hurûfun téaddüdü i'tibâriyle ve hurûf-i essyânn hakâynk ve üsûlu ve

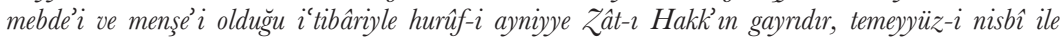
ândan mütemeyyizedir, temeyyüz-i hakikî ile değil. Pes hurûf-i gaybiyye, eşânnn téayyünâtı için mebâdî-i vâki'a olur ve 's-selâm \{Letters and words are divided into two catagories: one is divine letters and divine words and one is existing letters and existing words. Divine letters pertain to the invisible world. They are of the quality of the divine essence that is concealed in the most invisible of the invisible worlds. They are like the tree inside the seed. By virtue of the fact that the divine tasks are the highest stages of the entifications of God, and that before the existent form the oldest stages of comprehension for everything are in the divine essence of the knowledge of God, every divine task is named with the invisible letters. And by virtue of the fact that every divine task before the existent form is comprehended with its requirements, it is named with the invisible word. With respect to that task and the appearance of God being without regard to its requirements and the self-disclosure of God being with regard to the withdrawal of his property, that task is named with the existing letter. And with respect to that property of self-disclosure of God being withdrawn for that task and its requirements, that task is named with the existing word. With regard to the invisible letters being tasks of divine essence, they are the same as God, just as the tree in the seed is the same as the seed. With regard to the knowledge of entification and the entification of letters and relative multiplicity and the multiplicity of letters, and with regard to the letters of things being their true realities and their origin, beginning and source, the essential letters are different from God. They are distinguished from Him by relative distinction, not by true distinction. Thus, the invisible letters are the beginning occurrences for the entifications of things (commentary on the Fususs, p. 17). The visible and hidden letters of the word God $\{$ Alla $h\}$ and the symbols that they denote are explained at length in this commentary: . . . Kezâlik nefes-i Rahmânî elif' $i$ tecellî îcâdr bed'inde téayyün-i evvel' in kalbi bâtmnndan mümted olub, ilm-i zâtîde ehadiyyet cem ${ }^{\prime}-i$ hazretinde olan cemic şû̂n-i zâtiyye ve a'yân-ı ilmiyye-i gaybiyye ve hakâyı-ı fi'liyye'yi ilâhiyye üzre Hazret-i imkân' in gâyetine müntehî olunca mürûr etti. Pes tecellînin téayyünü için bir mahall-i tâm olmadiğr eclden yine mebdéi olan téayyün-i evvel'in bâtmna rucû́ etti. Pes devre-i tecellî tamâm oldu ve nefes-i Rahmânî elif'i hakâyık-ı vücûbiyye ve imkâniyyeyi ihâta edüb âhiri evveline muttasıl oldu. Pes Allâh Té âlâ ilmen ve vǘcûden esyânnn küllisinini muhît oldu \{... Similarly, the divine breath was extended from the hidden heart of the first entification at the first manifestation of the creation of the alif. The oneness of God in the knowledge of the divine essence continued over all the tasks of the divine essence, the invisible and knowable entities, and the divine actual realities, which are in the total divine presence, culminate in the divine possibility. Then, because there is no perfect place for the entification of self-disclosure, it returned to the hidden part of the first entification, which is also its origin. Then the cycle of self-disclosure was complete and the divine breath encompassed the necessary and possible realities of the alif and its end is joined to its beginning. Thus God encompassed all things, both in knowledge and in being\} (p. 27). All of this goes to show that the mystery of the letters was also included in the Muslim system of mysticism - as was the case in all other systems of mysticism beginning with those of India. İsmâ'îl Hakkı summarizes the significance of am the dot under the (Arabic) letter "b") by citing Shaikh 'Alī's Aswalat al-hikam and other such books acceptable to the (conventional) religious scholars. His account also corroborates and further elucidates my views: Vücûdun dört mertebesi vardrr. Evvelkisi

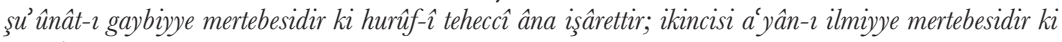
ebced'e varnnca olan hurûf-i mürekkebe âna işârettir; ü̧̧üncüsü âlem-i ervâh mertebesidir ki ebced âna işârettir; dördüncüsü âlem-i ecsâm mertebesidir ke sâir mürekkebât-ı kelâmiyye âna işârettir. Sibyân ve 
ânlarn hükmünde olan ricâlin ibtidâ elif'ten bed' ettikleri Âlem-i zât karîb olduklan cehetten nefes-i Rahmânî-ye işârettir ki ol nefes-i elif gibi cemic a'yân-i mümkinât üzerine mümted olmuştur ... Velhâsıl imtidâd-ı nefes-i Rahmânî ile ibtidâ téayyün-i zâtî vücûde geldi ki bẩ in tahtrnda olan nokta-i muvahhede âna işârettir ve sâniyen te'ayyün-i sifâtî vücûde geldi ki tânnn febkinde olan noktateyn âna işârettir. Sâlisen te'ayyün-i ef'âlî sübût buldu ki sầnn fevkinde olan nikât-i selâse âna işârettir, yâni elif' in müşârün ileyhi olan imtidâd-ı nefes-i Rahmânî ile hâsıl olan téayyünât üç mertebe olmağla nokta dahî üç aded oldu; iki veya dört olmadr ve elsine-i sûfyyede dâir olan âlem-i nûn noktaya işârettir ol âleme Ummü'l-Kitâb dahî derler; zîrâ asıl Kitâbï̀l-vücûd'dür. Ol nûn'da midâd-i mevadd-i nukîş-i âlem müctemi` olmuştur. Pes Hazret-i Alî, Taht-i bẩ da olan nokta benim buyurduğu cemîi merâtib-i ilâhiyye ve kevniyye’nin cem'inden ibâret olan insân-ı kâmil lisânnndandır, gerek neb̂̀ gerek velî olsun; zîrâ hakikat-i Muhammediyye'nin téayyün-i evvel olması, hakikat-i 'aliyyenin té ayyün-i evvel olmasm mâni' değildir, zîrâ insân-ı kâmil in cümlesi saff-i evveldendir ve Vücûd'da müttehittir \{There are four stages of existence. The first is the stage of invisible tasks. Spelling of the letters is an allusion to it. The second is the stage of noncorporeal entities. The composite letters as far as the abjad (an order of the alphabet, see $E I^{2}$, s.v. "Abdjad" [G. Weil-(G. S. Colin)]) formula are an allusion to it. The third is the word of souls. The abjad is an allusion to it. The fourth is the stage of the world of corporeal bodies. All composed words are an allusion to it. Because youths and men who are equivalent to them are near the world of divine essence, which they began from alif, they are an allusion to the divine breath of the All Merciful. Like the breath of the alif, they are extended to all possible entities.... In short, the first entification of the divine essence came into being with the extension of the divine breath. The single dot under the $b \vec{a}^{\prime}$ is an allusion to it. Second, the entification of the attributes came into being. The two dots over the $t \bar{a}^{\prime}$ are an allusion to it. Third, the entification of the acts was established. The three dots over the tha $\bar{a}^{\prime}$ are an allusion to it. In other words, the entifications that occur with the extension of the divine breath, which is the aforesaid alif, are three stages and the dots also number three. They are not two or four. The world of the $n \bar{u} n$, which is found on the tongues of the Sūfìs, is an allusion to the dot. That world is also called umm al-kitäb (mother of the book), because it is the original book of existence. In that $n \bar{u} n$ is the ink of the matter for designing the world. It is on the tongue of the perfect man, who is the collective totality of all the divine and engendered stages, that his excellency 'Ali said: "I am the dot below the $b \bar{a}$," whether one be prophet or saint. The fact that the reality of Muhammad was the first entification does not prevent the reality of 'Alī being the first entification, because the totality of the perfect man is of the first rank and is united in existence (commentary on the Muhammadiyya, vol. 1, part 2, pp. 132-3). In the couplet Kudret, sûret yapmadan firiştehler tapmadan / Âlemi halk tutmadan ileri yola geldim \{Before power and form were made, before the angels worshipped, / Before creation seized upon the world, I came to the forward path\}, Yūnus Emre uses "the forward path" (ileri yol) to mean the world of the dot that is the collective whole of the divine and engendered stages and the copy of the objective and subjective worlds. It is as meaningless to consider Yūnus Emre to be a Nuqțawī \{one who believed the earth was the starting point, nuqta, of all things; see $E I^{2}$, s.v. "Nuktawiyya" (H. Algar)\} based on this as it is to consider him a Hurūfì based on the couplets given above. \{See "On Letter Symbolism in Sufi Literature" in Schimmel, Mystical Dimensions of Islam, pp. 411-25.\}

62 Comparable to some other bātinī beliefs, Hurūfism was a creed that held, in effect, that God was manifest in the form of Faḍl Allāh Hurūfì. In order to reach this absurd conclusion, however, the Hurūfìs advanced all kinds of lengthy preliminaries, which one encounters explicitly or implicitly in all Hurūfì literature from \{Faḍl Allāh's Fāwidān \{MS in Köprülü's private library\} to the works of Firishte-oghlu \{d. 874/ $1469\}$, 'Alī 'l-A'lā \{d. 822/1419\}, and the Hurūfì poets. This system includes several 
points that are basically held in common with Islamic mysticism. For example, the secrets of the letters, the perfect man, the dawr, and esoteric interpretation $\left\{t a^{2} w \bar{l} l\right\}$ were not inventions of Faḍl Allāh Hurūfi. They were taken from Islamic mysticism, but were absurdly stuck together with such things as metempsychosis, indwelling, and union, which cannot be reconciled with it, and with a number of childish interpretations $\left\{t a^{\prime} w \bar{l} l\right\}$ that go to show that Faḍl Allāh is God. In this respect, Hurūfism was set up very awkwardly on the premises of Islamic mysticism and so, removed from the mooring of a consistent philosophical system, can be considered a hodgepodge of childish beliefs without any philosophical and ethical value. Putting its premises to one side, the fundamental belief of this system is as follows: God, who is manifest in the form of speech, is known with the letters. All of these letters have been made evident in the face of the perfect man. Therefore, it is possible to see in the face of man the twenty-eight letters that are the original elements of all created things. The highest knowledges teach us this. In the face of man are the seven maternal lines - four eylashes, two eyebrows, one hair line - which they call sawa $\bar{d}-i$ a $z a m$ \{the greatest mass\}. There are also seven paternal lines that appear later: two beard whiskers, whiskers on the other side of the lines, two moustache whiskers and one whisker under the lip. Seven and seven make fourteen. If we multiply this with regard to condition and place, it makes twenty-eight. Faḍl Allahh, adding to them the Persian letters 5 increased the number to thirty-two. The Hurūfîs interpret everything with this twenty-eight and thirty-two. Then, after removing the twenty-eight consonants occurring in the ambiguous verses of the Koran, they \{Hurūfìs $\}$ call the remaining seventeen letters the incontrovertible letters and the others the ambiguous letters. They consider the verses that ordinary religious scholars consider ambiguous to be incontrovertible and the ones that these scholars consider incontrovertible to be ambiguous and they pretend to comment on them at length and in a childish manner. They make a great many strange interpretations. They say, for example, that "That is the bounty of God," Koran, 5:54, 57:21, 62:4\} and "God is the possessor of bounty abounding," Koran, 2:105, 3:74, 8:29, 57:21, 57:29, 62:4\} refer to Faḍl Allāh Hurūfī; the mi'rāj \{Muhammad's ascension to heaven $\}$ refers to looking at the lines in the human face; the sidrat al-muntaha \{the lotus tree in seventh heaven\} refers to the nostrils of Faḍl Allāh seen in the countenance of Adam; the shäbb-i amrād \{beardless youth\} who appeared to the Prophet in the micra $\bar{j}$ was Faḍl Allāh, and so forth. Such interpretations, which are usually forced, concerning the number and secrets of the letters are so childish and ridiculous that there is no need to comment on them. With such additions and interpretations, the Hurūîs were also far removed from the philosophical views that constituted a basis for their system (summary of İshak Efendi's Kâşsifül-esrâr and the works of Firishte-oghlu). Absolutely no such childish ideas are found in the poetry of Yūnus Emre, who was a genuine Șūfì like Jalāl al-Dīn Rūmī.

63 Stryzgowski and his students, such as Glück, in their valuable studies on Turkish art have reached the same conclusions as I have on this feature of the Turkish artistic genius. In architecture, for example, the Turks adopted local elements, combined them with their own personalities, and then created completely new styles of art of a wholly unique nature. Many valuable works that in the past were assumed to have belonged to the milieu of Iranian art, and then Seljuk and Ottoman art, reveal these qualities in the full sense. Innovation means, in fact, not to create something from nothing, but to arrange existing elements in a new style according to a new sense of appreciation. This general character of early Turkish art was unknown until Stryzgowski, so that the products of that art were attributed to the Iranian milieu or, as was the case with Seljuk art, their originality was denied. Unfortunately, until now, no light has been shed on the originality of our popular Șūi literature, of which 
Yūnus Emre was the most powerful representative, and its distinctive features. Indeed, it too has been denied.

64 This story of the shepherd is described at length in the second volume of the Mathnawi. When Moses first encounters him, the shepherd is searching for God as follows:

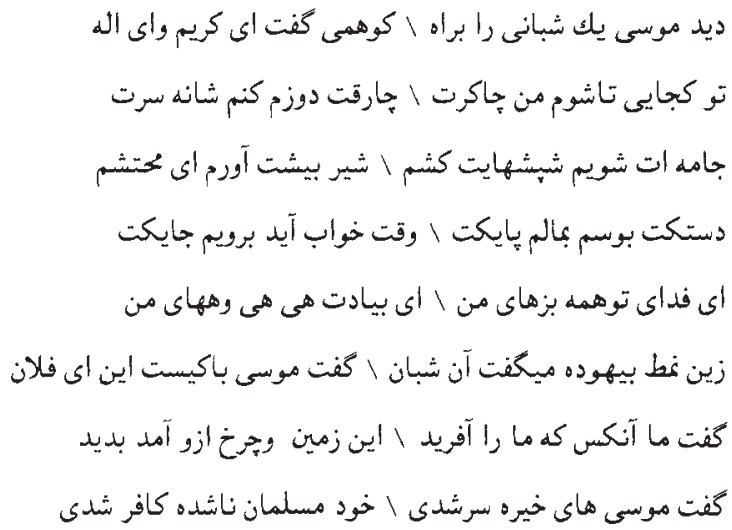

\{Moses saw a shepherd on the way, who was saying, "O God who choosest (whom Thou wilt),

Where art Thou, that I may become Thy servant and sew Thy shoes and comb Thy head?

That I may wash Thy clothes and kill Thy lice and bring milk to Thee, $\mathrm{O}$ worshipful One;

That I may kiss Thy little hand and rub Thy little foot, (and when) bedtime comes I may sweep Thy little room,

O Thou to whom all my goats be a sacrifice, O Thou in remembrance of whom are my cries of ay and ah!"

The shepherd was speaking foolish words in this wise, Moses said, "Man, to whom is this (addressed)?"

He answered, "To that One who creates us; by whom this earth and sky were brought to sight."

"Hark!" said Moses, "you have become very backsliding (depraved); indeed you have not become a Moslem, you have become an infidel."

\section{The Mathnawi, Book 2, lines 1720-7, Nicholson trans.\}}

This shepherd worshipped God with the cry, "O my God! Where are you? Let me serve you! Let me sew your sandals! Let me comb your hair! Let me wash your clothes! Let me bring you milk! When you are sleepy, let me make your bed! All of my hue and cry is for you." When Moses reproved him and accused him of unbelief, the poor shepherd rent his shirt collar from emotion and fled to the wilderness. But the word of God came at once to Moses: "You have separated one of my slaves from me. While you had come to unite \{with me\}, you have parted from me. Words and phrases have no importance. Look at the fire of love in the heart."

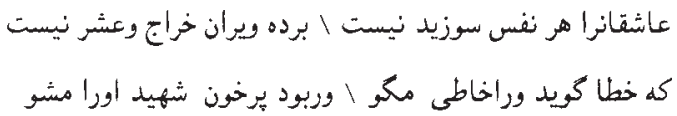




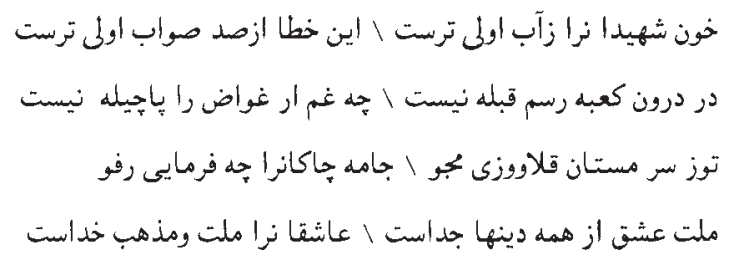

\{To lovers there is a burning (which consumes them) at every moment: tax and tithe are not (imposed) on a ruined village.

If he (the lover) speak faultily, do not call him faulty; and if he be bathed in blood, do not wash (those who are) martyrs.

For martyrs, blood is better than water: this fault (committed by him) is better than a hundred right actions (of another).

Within the Ka'ba the rule of the qibla does not exist: what matter if the diver has no snow-shoes?

Do not seek guidance from the drunken: why dost thou order those whose garments are rent in pieces to mend them?

The religion of Love is apart from all religions: for lovers, the (only) religion and creed is God.

The Mathnawe, Book 2, lines 1765-70, Nicholson trans.\} Full of pain and grief as a result of this, Moses found the shepherd and gave him the good news in the following manner:

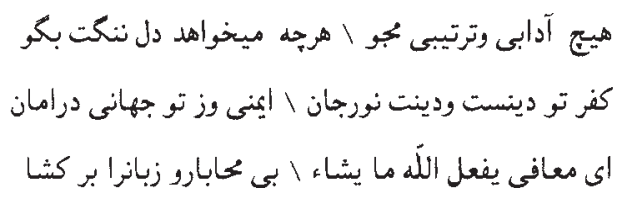

\{Do not seek any rules or method (of worship); say whatsoever your distressful heart desires.

Your blasphemy is (the true) religion, and your religion is the light of the spirit: you are saved, and through you a (whole) world is in salvation.

O you who are made secure by God doeth whatso he willeth, go loose your tongue without regard (for what you say).

The Mathnawi, Book 2, lines 1784-6, Nicholson trans.\} This shepherd is a symbol of the sincere mystics who have gone beyond ordinary norms. If there are those who see thoughtlessness in certain passages of Yūnus Emre, the aforesaid words of Mawlānā are an excellent response to them.

65 All the specialists who have properly studied Turkish and Ottoman architecture are virtually unanimous in finding these qualities in it.

66 Read the hymns of Ziyâ Gökalp in his Yeni hayât \{Istanbul, 1918\}. The influence of Yūnus Emre is immediately apparent in them. With respect to inspiration and power of expression, they are examples that most closely approach the hymns in the most masterly style of Yūnus Emre. Because the style of Yūnus Emre is "inimitable simplicity," it is very difficult to imitate it successfully. 


\section{YŪNUS EMRE'S INFLUENGE ON TURKISH LITERATURE AND HIS IMITATORS}

\section{A Yūnus Emre's influence}

The religious life in Anatolia from the seventh/thirteenth century to around the end of the tenth/sixteenth century offers a very important field of study. In this milieu - in which numerous great Șūfìs and Șūfì poets, beginning with Yūnus Emre, flourished - many sects and tarīqas that could be included in the battini group took form and spread, including those of the Bābā'īs, Abdāls, Bektashīs, Hurūfīs, Quzılbashes, Qalandarīs, and Haidarīs. In addition, there occurred the uprising of the supporters of Badr al-Dīn \{Ibn Qāḍ̄i \} Samāwnā, which was a reprise of the previous Bābā'̄ uprising, and subsequent religio-political uprisings or isolated incidents of the same kind. During these four centuries, therefore, the Anatolian Turks experienced a life of continuous crisis. False prophets and new creeds, for which a great many adherents risked their lives, flourished. Because these events were influenced by many different factors and took many different forms, it would not be prudent to advance unreservedly a general and definitive idea about them. ${ }^{1}$ The religio-Șūfì life, which, on the one hand, gave rise to battini currents like these that were contrary to the clear stipulations of the $\operatorname{Sharin}^{-} a$ and, on the other, created with the same strength and vigor new tariqas that conformed perfectly to Shari' $a$ principles, spread to every corner of the Ottoman Empire, indeed, as far as the borders of Rumelia and Bosnia. Simply for this reason, this period of Ottoman history reveals two contradictory phases. On the one hand, there were religious uprisings, sectarian movements led by isolated individuals, punitive actions \{against rebellions\}, killings, and executions. On the other hand, there were shaikhs who enjoyed the honor and respect of the most fanatical members of the official religious establishment and the palace, whose saintly charisma spread among the people, and who exercised great spiritual influence. Indeed, these two contradictory phases were the result of the same event, two different manifestations of the same thing. They reveal the importance of, and high regard for, the Șūfì movement among the people. In short, in the region of Anatolia, from the time of the Turkish settlement until the end of the tenth/ sixteenth century, the Șûfì movement in various guises gradually increased in strength. Indeed, it never subsided and has continued up to the present. 
The Șūfì poetry of Yūnus Emre spread very quickly in Anatolia and in a short time some rather important imitators appeared. Until the ninth/fifteenth century, Ottoman literature was under the influence of Persian Șūfi literature, and thus was thoroughly mystical in nature. Under the spell of Mawlānā, Sulțān Walad, 'Atțār, Sanā'̀̃, and Sa'dīi, it adopted, with a success that grew daily, the Persian meters and \{literary\} forms. At the same time, however, it could not abandon the national style that Yūnus Emre had invigorated with his powerful personality. Thus it also followed his path. Yūnus Emre played a great role in the following of two such different courses of Șūfi inspiration, both of which derived from the same source. If he had not reinvigorated the national style and stamped it with his genius, our literature would have followed the other course exclusively and would have been influenced only by the great Persian Șūfīs. In fact, because no national genius like Yūnus Emre flourished in non-religious literature, that field was neglected for centuries and no national literature of the originality and esteem of the Șūfì literature that we call the Yūnus Emre style ever appeared in it.

We find the influence that Yūnus Emre vigorously maintained in contrast to the Persian Șūfi poets, \{i.e.\} the fact that the Șūfì inspiration followed two such different paths, first in 'Āshıq Pasha, the son of a Turkish family from Khurāsān. ${ }^{2}$ This poet, whose Gharibname was completed in 730/1329-30 under the direct influence of the Mathnaw $\bar{l}$, also wrote hymns in which the influence of Yūnus Emre is striking. But because he almost completely lacked the artistic genius of Yūnus Emre, his works are virtually indistinguishable from Yūnus's ordinary hymns, which incorporate none of his true artistic personality. The ability of an ordinary dervish like Yūnus Emre to have this much influence on such a Șūî poet, who was directly under the influence of the Persian Șüfìs and especially Mawlānā, is very worthy of note. ${ }^{3}$

The earliest poet to understand the charm of Yūnus Emre's style and to write hymns in the same manner was Qayghusuz Abdāl, the khalîfa of Abdāl Mūsā. The Bektashīs consider him, like many other poets, to be a member of their tariqqa. Although the legends and poetry of this man, whom the Egyptians call 'Abd Allāh Maghārawī because he was buried in a cave \{maghāra\} in Egypt, have been established and are well known, his historical personality, indeed, whether or not he actually wrote the beautiful poetry attributed to him, still have not been determined with scholarly precision. ${ }^{5}$ But whoever he was and whenever he lived, we must consider those fine poems of his that have come down to us to be among the most valuable works of the special expressive style that we call the style of Yūnus Emre. Exactly as with Yūnus Emre, his poems, which were written in the national meter and style, are characterized by being clearly and very forcefully expressed with a profound purity and sincerity that accords with their simplicity. ${ }^{6}$

The next oldest imitator of Yūnus Emre was the famous Hājjī Bayram Veli. ${ }^{7}$ After him, the influence of Yūnus Emre became pervasive. On one hand, we find the imitators of Yūnus Emre among the members of the tañqas that conformed 
to $\operatorname{Shari}^{-} a$ principles and, on the other, we find them among the members of the tarīqas that, in fact, could be included among the esoteric maslaks \{paths\}. We even find them outside the tariqas among the saz poets or 'ashrqs, the continuators of the old Turkish minstrels. It is not possible to discuss here one by one and at length, or even briefly, all these imitators of Yūnus Emre. Instead of undertaking such an ambitious task, which would require a completely separate study, and which would not, with respect to scholarship, be useful compared to the effort required, I find it sufficient, and also necessary within the general framework of my book, to synthesize and describe briefly, and in global fashion, all of what we know about this influence.

\section{B Tekke poetry}

Beginning in the eighth/fourteenth century, i.e. after the death of Yūnus Emre, a number of tariqas of various sizes were established throughout the Turkish regions \{and spread among the Turks of Anatolia\}. \{At the same time, tariqas founded in other regions also spread among the Turks of Anatolia. It would require a completely separate and lengthy study to determine historically when these different tariqqas were founded, how they entered our country, and the extent to which they spread there. Hammer does give some rather brief information in his history on when the various tariqas were established, but it cannot be regarded as wholly trustworthy. In any case, as tekkes and zāwiyas were thus founded throughout the Turkish regions and the principles of Sūfism were spread among the people, it was necessary to create a distinctive literature for each tarīqa. Indeed, one finds today in virtually every tarīqa works written for its members and describing its rules of etiquette and basic regulations, Șūfì principles, and the legends and miracles of its early shaikhs. In order to spread the Suufī paths among the people and to win supporters among them, the Șūfis resorted without fail to the medium of poetry - as was the case in almost the entire Muslim world, including the Arabs, Persians, and Central Asian Turks. ${ }^{8}$ The notion of taking advantage of the popular affection for poetry encouraged the shaikhs to create an intellectual and artistic milieu in the tekkes in order to make them more appealing. For this reason, poetry, like music, occupied an important place in the religious services of the tarīqas.

I have stated above that Ahmad Yasawī and his imitators wrote religious poems $\{$ hikmats $\}$ in order to arouse the people's love for Yasawism; that Jalāl al-Dīn Rūmī composed his Mathnawē only for his disciples; and that later Sulțān Walad and 'Āshıq Pasha resorted to Turkish in order to propagate Șûfì doctrine among the Turks who did not know Persian. Subsequent Șūfīs also wished to compose poems, hymns, and books for the same reason. They then found before them the pure, simple, powerful hymns of Yūnus Emre that he had written in the popular meter and language. These works, for which the people had great affection and respect because they were suited to their own taste, and also the 
fact that both the people and the Șūfis considered Yūnus Emre to be a "spokesman of the unseen world," encouraged later Șūfìs to follow suit. In this manner, they would both observe a semi-sacred tradition and would present works in a style understood and enjoyed by the mass of the people. The fact that, after 'Ashiq Pasha and Qayghusuz, a great shaikh like Hājjī Bayram wrote a number of poems in the style of Yunus Emre caught the attention of the tekke poets, so that later Șûfiss, indeed, right up to the present, wrote the great majority of their hymns in this style. Almost all these Șūfīs were men who understood Persian literature and were able to write almost faultless works in the 'ar $\bar{u} d$ meter. Indeed, many of them did write in this style as well. But writing unlettered, simple, and insightful poems in the style of Yūnus Emre had become such a firmly rooted tradition in all the tekkes that it was virtually impossible to avoid. The fact that the national meter and forms won such a prominent and important place among our Șūfì poets, indeed, the fact that even some poets whom we could not really consider to be true Șūfìs occasionally wrote only on Șūfì subjects, are consequences of this. ${ }^{9}$ The style of Yūnus Emre, which inspired many imitators, was well received in all the tariqas that flourished in the Ottoman Empire except the Mawlāwiyya. It was not, compared to the others, able to win a place in Mawlawī tekkes. We can attribute this to the supremacy of Persian over Turkish language and culture in those circles because of \{Jalāl al-Dīn Rūmī’s\} Mathnaw̄ and Dīwān-i kabīr. ${ }^{10}$

There are many tekke poets who wrote hymns in the style of Yūnus Emre, but few whose works are somewhat reminiscent of his. Beginning with Eşrefoğlu Rūmī of Iznik (d. 873/1469), ${ }^{11}$ son-in-law of Hājjī Bayram Veli, author of Muzakkī 'l-nufüs, and founder of the Eşrefiyye branch of the Qādiriyya tariqqa, the poets whose works more or less call to mind Yūnus Emre are Ibrāhīm Ummī Sinān (d. 958/1551-2), ${ }^{12}$ founder of the Sināniyya branch of the Khalwatiyya tariqa; Aḥmad Sārbān (d. 952/1545-6) ${ }^{13}$ of the Malāmiyya-i Bayramiyya; Eroghlu Nūrī Efendi of Elmalı; ${ }^{14}$ Idrīs Mukhtafì (d. 1024/1615-16), ${ }^{15}$ a member of the Malāmiyya-i Bayramiyya; Sayyid Saif Allāh Khalwatī (d. 1010/1601-2); ${ }^{16}$ Naqshī Aq Kirmānī (d. 1062/1651-2); ${ }^{17}$ Ibrāhīm Efendi (d. 1066/1655-6), ${ }^{18}$ known as Olanlar Shaikhi; and his disciple Șunu' Allāh Ghaibī (d. after 1072/1661-2), ${ }^{19}$ author of the famous dawriyya known as Kashfal-ghitä'. Because each of them had his own personality, one should not consider them merely as imitators of Yūnus Emre. Still, it can definitely be claimed that none of them was able to approach the artistic level of Yūnus Emre. There are many other tekke poets, such as Uftāda \{d. 988/1580-1\}, Hüdā'̄i \{d. 1038/1628-9\}, and Niyāzī \{d. 1105/1694\}, but Yūnus's influence on them is not as obvious as it is on those mentioned above. As a final observation, we can say that the influence of Yūnus Emre's style on tekke poetry, with few exceptions, was confined to form and meter, i.e. to its external nature, and was not able to affect its true spirit to the same extent. ${ }^{20}$ Those who understood the true features of this style, its true taste, and appropriated it were the Bektashīs, Hurūfîs, and Qııılbashes. 


\section{G Bektashī poetry}

I have stated above that the Bektashiyya, which was founded and took root in the ninth/fifteenth century, acquired a batinin character in the very early years of its establishment. It was a tariqa that came into existence from a mixture of three different Șüfì sects, namely those of the Bābā'īs, Akhīs, and Abdāls, and then fell under the influence of Hurūfism. It acquired no other features. ${ }^{21}$ It is just because the poetry of Yūnus Emre was clearly expressed in an unrestrained and bold manner and was able to reach the lowest level of society that it became very important in the eyes of the Bektashīs, who reserved a major place for Turkish even in their rituals and litanies. The Bektashī $b \bar{a} b \bar{a} s$, like the other shaikhs, did not receive an extensive madrasa education and the Bektashī dervishes were also, for the most part, plain and simple souls who grew up among the people. ${ }^{22}$ For this reason, they held the national language and literature in high regard instead of prizing and slavishly imitating Persian language and literature. It is for this reason too that the poets who thrived among them - most of whom had no madrasa education but were cognizant of the national taste - had a mentality capable of subtle and elegant thought, yet primitive to the extent of gullibility, and superstitious; and while they usually employed the 'arü $d$ meter and forms in a very poor and defective manner, ${ }^{23}$ they wielded the national meter and forms in a manner perfectly suited to the Turkish taste. These Bektashī $b \bar{a} b \bar{a} s$, whose taste was not corrupted by the awe and enthusiasm that we feel toward sublime examples of Persian literature and who thus preserved the simplicity and originality unique to the people, naturally had the best sense of Yūnus Emre's taste and were the most successful in approaching it.

The original and truly esteemed examples of Bektashī poetry written in the national meter and forms are known as nefeses and are recited in the tekkes with specific melodies, analogous to the $i l \bar{a} h \bar{\imath} s$ hymns\} and nutuqs \{orations $\}$ in the other tariqqas, and the hikmets among the Yasawīs. There are also eulogies, elegies, dastāns, and dawriyyas concerning 'Alī or other members of the family of the Prophet Muhammad, all composed in the syllabic meter. For example, the dawriyya of Shīrī \{'Alī Bey Hersek-Zāde, $f$ l. first half of tenth/sixteenth century\}, the dastān of Mir'àtī Bābā and the nefeses of dervishes from various periods, such as Turābī, Sham`̄̄, Ajrī, Perīshānī, Pīr Sulțān, Qalandar Abdāl, Qul Nasīmī, Hamdī, Delī Shükrü, Shāhī, Ibrāhīm Bābā, Niyāzī, Güvench Abdāl, Saḥar Abdāl, Kemterī, Khatāà̄, Qul Himmat, Rumūz̄ì, and Veli Bābā, are in the syllabic meter and in a style modeled completely after that of Yūnus Emre, or even more lively, allusive, and refined. To be sure, it is virtually impossible to make precise assertions about the time, place, ideas, and beliefs of these poets. Some of them, such as Khatāà ${ }^{24}$ Qul Himmat, Rumūzī, and Veli Bābā, not only accepted Hurūfism and the divinity of Faḍl Allāh Hurūfì, but also associated with many poets who belonged to the Quzllbash, who were distinct from, but connected with, the Bektashīs. Qalandarī and Haidarī poets were also associated with them. So, while we are discussing Bektashī poetry and poets, 
we have to discuss at the same time those who wrote Q1zilbash ${ }^{25}$ Qalandarī, Haidarī, and Hurūfĩ ${ }^{26}$ poetry in the national meter, and the influence of Yūnus Emre on them. These bātini sects held a number of basic beliefs more or less in common, so that the poetry of one of them was always accepted and read with pleasure by the others.

In these poems, which we call Bektashī poetry and which in fact provide commentary and musical expression for a mélange of obscure beliefs - including

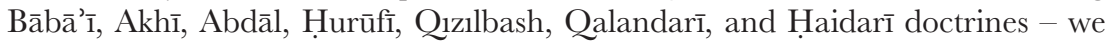
find much concerning love \{ish q, mahaabba , the trinity of God, Muhammad, and 'Alī, $\bar{A} l-i$ 'Abā' \{the people of the cloak, Muhammad and his family\}, the divinity of Faḍl Allāh Ḥurūfì, the secret meanings of the letters, Hājjī Bektash Veli being indistinguishable from Muhammad and 'Alī, the difficulties of the mystic path, ritual ceremonies, the legendary deeds of Pîr-i Abdālān and Sayyid Ghāzī, and of the great Bektashīs like Qızıl Deli Sulțān, and Bālım Sulțān, and the abominable deeds of Yazīd. With respect to style, the influence of Yūnus Emre is so pervasive that one sometimes comes across the same topics, indeed, even the same lines of verse. Nevertheless, Bektashī poetry is generally more unrestrained, more elegant, more subtle and refined than his. Yet this poetry lacks the power of conviction that is found in Yūnus Emre. It is not only less convincing but also conveys flashes of profound irony $\{i s t i h z \bar{a}\}$ mixed with skepticism. ${ }^{27}$ Yūnus Emre possessed a lofty Sūfî philosophy, as did Muhyȳ 'l-Dīn Ibn al-'Arabī and Jalāl al-Dīn Rūmī. The Bektashīs, on the other hand, held a number of childish beliefs - such as metempsychosis, indwelling, and union that are barely reconcilable and far from a coherent system. This could account for their irony and skepticism. But however little value this mixture of beliefs has as a system of Șūfì thought, with regard to method, taste, and style Bektashī poetry is the branch of literature that is certainly the most Turkish and perhaps the most influenced by Yūnus Emre. ${ }^{28}$ Perhaps more than anything else, this plain beautiful poetry, which suited the national taste and was simple enough for everyone to understand, helped to spread so forcefully the strange ideas that appeared under the names of Bektashism, Quzılbashism, and Hurūfism among the people.

\section{D'Āshıq literature}

I discussed above \{in Chapters 6 and 7$\}$ the ozans, the earliest popular poets of the Turks, and especially the popular literature that they created as they sang to the accompaniment of the kopuz. These saz poets, who were the principal minstrels of the Turks of Anatolia from their first appearance in that region, continued their poetic activities during the eighth/fourteenth and ninth/fifteenth centuries. In the course of the ninth/fifteenth century, we find that, even in the palaces, an important place was still given to the ozans. After the tañqas had multiplied and the Șūfi movement had spread and became thoroughly established among the people, almost all the ozans attached themselves to a pir and tried to 
give a Șūfi flavor to their work. At that point, instead of using the name ozan, which conjured up the pre-Islamic period, i.e. the memory of Korkut Ata and the traditions of the Oghuznāme, they adopted the title of ' $\bar{a} s h r q$, which meant Șūi poet, and the term ozan began to be used to mean a "prattler." 29 One could strongly argue that this differentiation took place in the second half of the ninth/ fifteenth century, or, more likely, in the tenth/sixteenth century. By that time, significant works of 'äshrq literature, the particular forms and rules of these works, important and famous ' $\bar{a} s h q q$, the ' $\bar{a} s h q q$ life and 'Âsh $\imath q$ organization, and the place of 'ashıqs in public life are all very well known. Because I have published a detailed study on this special style of literature, I will not mention here even briefly the many aspects of this broad topic. ${ }^{30}$

This 'ashrq literature, which was established to fulfill the artistic needs of a certain class by a kind of division of labor, is completely separate from classical literature, tekke literature, and even folk literature, which is included in the analytical framework of folklore. Although it derived its original tradition from the older folk literature, a number of elements from both the Persian-style classical literature, which fulfilled the needs of the upper class, and Șüfi literature, which thrived in the tekkes, mingled with it; 'ashıq literature, or what we call saz literature, was created from all these elements. In its early period of development, it conformed completely to the old folk literature with respect to meter and form. Later, however, after Fudūlī $\{$ d. 963/1556\}, it also tried to apply the rules of Persian versification - in a very defective and elementary manner - under the influence, on one hand, of classical literature and, on the other, of tekke literature, which had been subject to strong Persian influence. However, because it was a literature that spoke directly to the popular masses and to the popular taste, the rules of Persian poetry could not make it neglect the Turkish tradition. The national meter and national forms remained as a fundamental element of 'àshıq literature.

The influence of Yūnus Emre on 'asshqq literature was indirect rather than direct. Because virtually all 'āshrqs were associated with tañqas, indeed, because most of them were in fact Bektashīs who flourished among the janissaries, 'asshq literature was very strongly influenced by the national Sūfì poetry of the Bektashī poets and thus they \{i.e. ' $\bar{a} s h q$ and Bektashī literature\} had many features in common. I have already discussed at length the relationship of the 'ashrqs with the Bektashīs and the causes and consequences of this very close relationship. Now, as I explained a moment ago, Yūnus Emre had a striking influence on Bektashī poetry with regard to spirit and style. This influence, passing through that particular literary style into ' $\bar{a} s h q$ literature, reveals itself in the ' $\bar{a} s h q$ poetry that has a more or less Șūfì nature, and even in some tekerlemes \{jingle, playful formula used in folk narratives $\}$ that are reminiscent of Yūnus's satirical writings. This influence is obvious to various degrees according to the personality and level of mystical capacity of each great 'ashrq. Therefore, while studying a given 'āshıq, one should never disregard the influence of Yūnus Emre among the elements that contributed to his art. 


\section{E Conclusion}

I have described how popular Șūfĩ literature, by combining elements from various sources, appeared among the Turks in a form that was peculiar to the people. I have done so by examining at length the causes and consequences of this process from the origins of the Sûfì movement among the Central Asian Turks and Ahmad Yasawī, who was our first great popular Șūfì poet, to Yūnus Emre, the greatest Șūfì poet of the Western Turks, and his imitators. Now, having reached the end of my investigation, it may be useful to pause a moment and reflect on the long and difficult road that we have traveled. We can thus recapitulate, albeit briefly, in synthetic fashion and with greater clarity, the entire scope of my study. The many secondary details that I have given while passing from point to point may have tired my readers and my lengthy analyses may have made it somewhat difficult for a general synthesis to emerge in their minds.

We have seen that a Șūfi literature whose major elements derived from popular literature and the national taste began with Ahmad Yasawī and continued to Yūnus Emre, and beyond him to the present day in the form of a long chain connecting one poet to another. This literature, which won the favor of the people from its first appearance because it was very closely related to our preIslamic popular literature, helped to spread the principles of Sunfism among the Turks. The development of Șūfì sentiments and perceptions among the Turks later caused this literature to thrive for centuries among the people, and it has maintained its initial spiritual influence even today among the Central Asian Turks who have not yet undergone a renaissance or entered the modern world. The literature, and the Șûfi movement that brought it forth, took a broader, more unrestrained, and more profound form as soon as it entered the milieu of the Western Turks and was transformed from a system of asceticism and piety into a philosophy of divine love. This difference did not simply result from the differences between the personalities of Aḥmad Yasawī and Yūnus Emre. The free environment of Anatolia, which was conducive to the philosophy of panthéism idéaliste \{worjüdiyya-i khayāliyya under the influence of two such great Sūfìs as Muhyī 'l-Dīn Ibn al-'Arabī and Jalāl al-Dīn Rūmī, cast the well defined, dry, orthodox, and pietistic views of Ahmad Yasawī into a broad, fluid system of divine love and unity of being characteristic of Yūnus Emre. While Ahmad Yasawi was basically the founder of a great taniqa and a legal scholar almost completely lacking in poetic ability, Yūnus Emre, to the contrary, was an inspired poet and a simple dervish who embraced Șūfism out of his spiritual need. This explains the dignified, rather dull and dry style of the one and the simple and unlettered sincerity of the other.

If we compare the inherent value of their works, i.e. with respect to their aesthetic nature, we can say that Yūnus Emre was an artistic genius and that his work can be read with pleasure even today, whereas Aḥmad Yasawìs Dĩ Hikmat can only be read by dervishes who believe in its sanctity. It is clear that although Yūnus Emre was directly or indirectly under the spiritual influence of 
this early Turkish saint from the steppes of Kirgizistan, he greatly surpassed him as a literary genius. But if we leave aside this measure of inherent value and compare only the external influences of Ahmad Yasawī and Yūnus Emre, it is impossible not to be astounded by the greatness of both men. First of all, Ahmad Yasawī, who founded a vigorous tariqa that spread to all the countries of the Turks, created a popular Sūfì literature, a style of religious poems \{hikmat\}, within the literature of Central Asia and thus set an example for the Sūfì poets of that region who have flourished up to the present. In other words, he created a tekke literature that bore the stamp of his own personality. The primary centers of this literature are the tekkes of the Naqshbandīs. As for Yūnus Emre, unlike his master he did not found a new tariqa, but like him he created an original literature, a Șūfì popular literature called the Yūnus style that we still read with pleasure and that still affects us. This literature was a major factor in \{the development of all tekke poetry, in Bektashī poetry, and even in ' $\bar{a} s h q$ literature. In contrast to the hikmat style, which prevails mainly in the Naqshbandī dervish convents in Central Asia, the preference for the Yūnus style is most striking in Bektashī poetry. The artistic genius of Yūnus Emre in particular created a special, and the most national and original, form of Turkish literature, the like of which never appeared in the other Islamic literatures. This form, which was able to represent the epitome of national taste for centuries, has an incomparable value for the history of Turkish literature. Those who, faced with the contemporary progress of the positive sciences, find no pleasure in Șüfì philosophy, or those who, for whatever reason, wish to cut the ties to the past, may claim that they are not affected by the works of Ahmad Yasawī and Yūnus Emre. After all, everyone is free to enjoy whatever literature he wishes. Still, it is impossible to deny that these two great personalities exerted an unparalleled influence on the general development of Turkish literature. These two names, Aḥmad Yasawī and Yūnus Emre, will live forever as immortal chapters in the history of Turkish literature.

\section{NOTES}

1 Unfortunately, these phases of the religious history of the Anatolian Turks have hardly been studied. Among the sects mentioned here - Abdālism, Bektashism, Hurūfism, Qalandarism, and Haidarism - only two, Bektashism and Hurūfism, have attracted the attention of the Western scholarly world and have been studied to some degree. But even these studies, as I have shown in various connections in this book, are very defective. In fact, with respect to Bektashism, they are completely erroneous. By not doing serious studies on the Bābā'ìs, Akhīs, Yasawīs, and Abdāls, indeed, by not even seeing the need to acknowledge their existence, these researches on Bektashī history, undertaken with the few limited sources that are available, are doomed to failure. In what milieu did Bektashism arise and what factors influenced it? To what changes was it subject? How was it viewed? What status did it acquire across the centuries with respect to the extent of its development and spread? With what tariquas did it have connections and ties? In order to comprehend properly all such questions, one has to study the Șūfì systems and doctrines in Anatolia and Băținism as a whole. In this regard, we can say that the studies of Dr Jacob and others on Bektashism are very 
defective and erroneous, and that on Hurūfism no historical study has been done at all. I plan to publish gradually the studies that I am preparing on these unanswered questions concerning Bektashism and Hurūfism as well as those on Akhism, Abdālism, Qalandarism, and Haidarism. I hope that these studies, whatever shortcomings they may have, will prepare a new foundation for the synthetic works that will be written in the future on the religious history of Anatolia, and, by correcting current errors, will also provide a sound and reliable course for such studies. For now, see "Misir'da bektaşîlik," TM, 6 (1936-9), 13-40, and İA, s.v., "Bektâş" \{M. Fuad Köprülü\}. \{As mentioned earlier, Köprülü's work on the Hurūfîs was never published. See the studies by Gölpınarlı listed in the bibliography of his Hurûfilik metinleri kataloğu. Much work has recently been done on Șufism and heterodoxy in Anatolia. On the Bābā'īs and Qalandarīs, see Ocak, Osmanh İmparatorluğunda marjinal sûfilik: Kalenderîler and Ahmet Karamustafa, God's Unruly Friends. On Akhism, see Çağatay, Bir Türk kurumu olan ahilik. See also Ocak, Osmanl topumunda zindiklar ve mülhidler (15.-17. yüzynllar) (Istanbul, 1998). On Badr al-Dīn Ibn Qāọ̄ī Samāwnā, see Michel Balivet, Islam mystique et révolution armée dans les Balkans ottomans: vie du Cheikh Bedreddîn le "Hallâj des turcs" (1358/9-1416) (Istanbul, 1995).\}

2 Because he was the child of a family that came from Khurāsān, Rızâ Tevfik considered this poet to be of Iranian origin. This claim is completely erroneous. Many Turks, especially Oghuz Turks, lived scattered about, or in large groups, sometimes as tribes, in several places in Khurāsān. I have discussed this subject in various places in the present work, so there is no need to repeat it here. It is in this respect that we must consider 'Āshıq Pasha to be an Oghuz Turk. There is considerable information on 'Āshıq Pasha in the early Ottoman histories, in Lațîfi's Tadhkira, \{Tashköprü-Zāde's\} al-Shaq a' iq, the introduction to 'Āshıq Pasha-Zāde's Tawārn̄kh-i āl-i'uthmān, in Mehmed Tâhir's article \{“Aşı Paşa" $\}$ in the first issue of Türk Derneği \{1327/1911, pp. 12-19\}, and in E. J. W. Gibb's \{A History of Ottoman Poetry, vol. 1, pp. 176-200\}, but a detailed analysis of the literary and linguistic nature of his work has not been done. The poems that Mehmed Tâhir attributes to 'Āshıq Pasha-Zāde Elvan Chelebī in his Osmank müellifleri all belong to Shaikh Elvan Shīrāzī, the \{Turkish\} translator of \{Mahmmūd Shabistarī's Gulshan-i rāz. Thúry also confused these two Elvan Chelebīs. The only samples of the poetry of 'Āshıq Pasha-Zāde Elvan Chelebī to come down to us are in \{Hacı Kemal's\} Fāmi al-naża $\vec{a}$ ir \{see $E I^{2}$, s.v. " "Āshık Pasha” (Fahir İz) and the introduction to Ocak and Erünsal (eds), Menâkrbu 'l-Kudsiyye\}.

3 In his $\mathcal{J} \bar{a} m i^{c}$ al-nază'ir, Hacı Kemal of Eğridir records a number of hymns of 'Āshıq Pasha as imitations of the poetry of Yūnus Emre. Even without this explicit reference, however, the influence is easy to see.

4 In his Osmanl müellifteri, Mehmed Tâhir also accepts this theory of the Bektashīs and considers both him and Abdāl Mūsā to be early Bektashīs. Because the Bektashī tarñqa had not been established at that time, this claim does not conform to reality. As can be understood from their names, they belonged to the group of Abdāls who were rather widespread in Anatolia at that time. Qayghusuz's Abdālnāme also shows this \{better known as Budalānāme, ed. Abdurrahman Güzel in Kaygusuz Abdal'ın mensur eserleri (Ankara, 1983), pp. 49-74\}. There is no reference to the Bektashism of Abdāl Mūsā in either 'Āshıq Pasha-Zāde's \{Tawārīkh-i a al-i 'uthmān\} or \{Tashköprü-Zāde's\} al-Shaqa'iq. During the establishment of Bektashism in the ninth/fifteenth century, when it borrowed elements from Akhism, Bābā'ism, and Qalandarism, it also appropriated many features of the tañqa of the Abdāls, which was a branch of Bābā'ism. It is for this reason that Abdāl Mūsā and his khalîfa were considered to be Bektashīs. I have described in various places above how Bektashism appropriated to itself those individuals whose legends and miracles were famous among the people, even though they did not have a close relationship with it. I will provide extensive details in the 
study that I mentioned on Abdālism and its relationship to Bektashism. \{See his article "Abdal" in Türk halk edebiyat ansiklopedisi.\}

5 There is detailed information in the legends of Qayghusuz Abdāl about his relationship with Abdāl Mūsā and how he later went to Egypt (MS of Manāqib-i Qayghusuz Abdāl in my private library). At the end of this collection of legends there is also a very famous poem that is a kind of satire in which Qayghusuz mimics Yūnus Emre. As an example of Qayghusuz's work, we can give this famous passage that best describes his personality:

\section{Yücelerden yüce gördüm Âlem okur kelâm ile $\hat{A} \hat{s} \hat{\imath}$ kullar yaratmuşsın Anlan koymuş orada Kildan köprü yaratmıssin Hele biz şöyle duralm}

\{Highest of the high, I have seen: The world recites with speech: You created rebellious servants, You put them there

You created the bridge, as thin as a hair,

Well, let us stay here

\author{
Erbâbsin Sen koca Tann \\ Sen okursun hecâ Tann \\ Varsin şöyle dursun deyu \\ Sen çıkmışsin uca Tann \\ Gelsün kullar geçsün deyu \\ riğit isen geç a Tann
}

You are the Lord, mighty God.

You recite letters, O God.

sending them on their way;

and went out to the edge, O God.

and told Your servants to come across.

and You cross if You're so brave, O God! \}

This poem, the latter parts of which are too unrestrained to ever please the conventional upholders of religious law, is obviously somewhat livelier and bolder than the style of Yūnus Emre, but it is still under his influence. Qayghusuz's influence on later Bektashī poets, or, more correctly, on establishing the special style that we call Bektashī poetry, is very great \{see $E I^{2}$, s.v. "Kayghusuz Abdāl" (Fahir İz)\}.

6 There is a noteworthy point in this respect. Ahmad Sārbān, whom I will discuss briefly below, also had the byname Qayghusuz. Like Yūnus Emre, he had a broad view of unity of being. Although he did produce works along these lines, his style is very different from that of the older Qayghusuz.

7 See the following sources for the biography of this great Sūfì - who was the founder of the Bayramiyya tariqa and died in 833/1429-30 - and for the characteristics of his tar̄qq: \{Tashköprü-Zāde's\} al-Shaqä’iq, \{Turkish\} trans.; İsmâ'îl Hakkı's Silsilanāme-i jalwat̄ \{lithograph edn, n.p., 1291/1874\}; Jām̄̄'s Nafahāt, \{Turkish\} trans.; La' līzāde 'Abd al-Bāqī’s Risāla-i malämiyya-i bayrāmiyya \{Istanbul, n.d.\}; \{Harīrī-Zāde's\} Tỉbyān$i$ wasāil al-haqā’iq; Aq Shams al-Dīn's Risālat al-nūriyya \{or Risâle-i Akșemseddin\} and Sharh-i Aqwāl-i Hǟj̄̄ Bayrām Wal̄̄ Ibrāhīm Tennūrī's poem Gulzār-i ma'naw̄̄ \{ see Ali Karabulut and Ramazan Yıldız, Gülzâr-i ma'nevi ve İbrahim Tennuri (Kayseri?, 1978)\}; 'Abd al-Rahīm Bayrāmī's treatises Munyat al-abrār and Wahdatnāme; the tarīqatnāmes of Du'āci Oghlu and Himmat Dede; the second and third volumes of Evliyā Chelebi's Seyāhatnāme; and Tâhir's Osmanh müellifleri and treatise entitled Hǟj̄̄ Bayrām Wal̄ \{Istanbul, 1329/1911\}. \{See $\dot{I A}$, s.v. "Bayramiye" (Abdülbâki Gölpınarlı), and $E I^{2}$, s.v. "Hāadjdjī Bayrām Walī” (V. L. Ménage).\} Hāājī Bayram’s three major hymns are well known. The first begins Bilmek istersen seni cân içinde ara câmı / Geç cânnndan bul An sen seni bil sen seni \{If you wish to know yourself, seek the Soul within the soul / Give up your soul and find Him. Know that you are you \}. The second begins $\mathrm{Hic}$ kimse çekebilmez güçtür felekin yayı / Derdine gönül verme birgün götürür vâyn \{No one can draw the bow of fate, it is too hard / Do not give your heart over to grief: one day He will remove your sighs\}. His most famous hymn was the third, for which İsmâ'îl Hakkı, Muḥammad Șuhufī al-Brusawī, 'Abd al-Hayy Üsküdârî, and Sayyid Khwāja 
Muhammad Nūr al-'Arabī all provided commentaries. In order to give an idea of its form and style, I will cite it verbatim.

Çalabım bir şâr yaratmus iki cihân arasında Bakucak dî̀âr görünür ol şârn kenâresinde

Nâgehân ol şâr'a vardim ol şâr' yapılır gördüm

Ben dahi bile yapildm taş u toprak arasinda

Ol şâr' dan oklar atılır gelir ciğere batıler

Ârifler sözü satzlır ol şâr'in bâzâresinde

Şâkirdleri taş yonarlar yonup üstâda sunarlar

Çalab'in ismin anarlar o taşin her pâresinde

Bu sözü ârifler anlar câhiller bilmeyib tanlar

Hacı Bayram kendi bânlar ol şâr'in menâresinde

$\{$ My Lord created a city between the two worlds.

If you look you'll see His face at the edge of that city.

At once I went to that city and saw that it was built.

I too was built together with it, in the midst of stone and mortar.

Arrows are shot from that city and penetrate the heart.

The words of mystics are sold in that city's marketplace.

Apprentice masons carve stones and present them to the master.

On every piece of stone, they carve the Lord's name.

Mystics understand these words; fools are bewildered by them.

Ḥājjī Bayram himself gives the call to prayer in that city's minaret.\}

It is obvious that this style is identical with that of Yūnus Emre.

8 The traveler Ibn Batțūta says that when he was a guest in the zāwiya of Saif al-Dīn Bākharzī in the suburb of Fath Ābād in Bukhārā, the shaikh of the zāwiya Yahyā al-Bākharzī, a descendant of Saif al-Dīn, arranged a banquet for him and invited the leading men \{of the city\}. The Koran readers recited, the preachers gave sermons, and songs were sung melodiously in Turkish and Persian (Seyähatnāme, \{Turkish trans., \} vol. 1, p. 416 \{Gibb trans., vol. 3, p. 554\}). Indeed, if we consider the Islamic world at that time, we see that literature, music, and free thinking could only find refuge in the tekkes in opposition to the dry and cold fanaticism of the ascetics. The tekkes and Șufism provided a place of refuge and a source of intellectual and artistic activity for the Islamic world for centuries. The Mawlid gatherings \{to celebrate the birthday of the Prophet\}, in which religious poetry and music coalesced, were extremely popular among the Turks in particular because of the people's nostalgia for the old şölens, i.e. for aesthetic assemblies. In contrast to the fanatical asceticism and piety represented by the madrasas, the tekkes provided an outlet where one could breathe an atmosphere of artistic and intellectual freedom. This is why the Șūfìs and poets attacked the conventional religious scholars and the madrasas, which represented them, for centuries. \{Mawlid gatherings do not appear to be attested among the Turks in the eighth/fourteenth century. See N. Kaptein, Muhammad's Birthday Festival: Early History in the Central Muslim Lands and Development in the Muslim West until the 10th/16th Century (Leiden, 1993).\}

9 Sultan Murād III $\{1574-95\}$, for example, who was disposed to Ṣūfism, wrote a famous hymn in the syllabic meter beginning Uyan ey gözlerim gafletten uyan \{Awake, my eyes, from heedlessness, awake!\} (Müstaqūm-Zāde mecmuası, MS 3397 in the Esad Efendi 
Library, now in the Süleymaniye Library in Istanbul). In addition, it is known that Mehmed Giray IV, the khān of Crimea who died in 1085/1674-5, wrote some hymns and some poetry in the syllabic meter under the pen name 'Ārif. I chanced upon an example in an anthology in my library (Gülbün-i khānān - al-sab' al-sayyār \{Istanbul, 1287/1870-1\}). This poem, beginning Bu dehrin hâline eyledim nazar / Her biri bir derde giriftâr ancak / Kemâle erince hâr ile gülzâr / Bülbülün âdeti âh-u zâr ancak \{I considered the state of the present age / Everyone is in bondage to some concern / When thorn and rose reach perfection / The nightingale's preoccupation is with sighs and moans $\}$, is a fine work expressing mystical ecstasy. We should not forget, however, that such examples are relatively rare. [Köprülü later published the remainder of this poem \{in "XVII. asır saz şairlerinden kâmil kırım hanı IV. Mehmet Giray"\} in Hayat Mecmuası, 1928, no. 134, an article in which he pointed out that the pen name of Mehmed Giray IV was not 'Ārif but Kāmil. This article was reprinted in Orhon F. Köprülü (ed.), Köprülü'den seçmeler, pp. 93-8.]

10 Although the Mawlawī tarīqa was established by a Turk in a Turkish milieu, it acquired a clearly Iranian hue under the influence of Jalāl al-Dīn Rūmī. Mawlawī litanies $\{w i r d\}$, orations, and most of the major works of the tariqqa are in Persian. Later, beginning with Jalāl Arghūn, poets who wrote in Turkish also flourished, but all of them strove to apply the Persian meters and forms. Thāqib Dede, in his Safina-i mawlawiyān \{or Sefine-i nefise-i mevleviyan (Cairo, 1283/1866)\}, and Esrār Dede \{d. 1211/1796-7\}, in his Tadhkirat-i shu'ara' (MS in my private library), both of which discuss the leading Mawlawī personalities and poets, provide a clear view of this. Among the great Mawlawīs, the only one who held the national style in high regard was the famous Ādem Dede. Safă'î̀ \{d. 138/1725\}, the author of the Tadhkira, mentions his hymn beginning Dert ehli libâsım aşk ile given gelsün / Zehrini şeker gibi zevk ile yiyen gelsün \{Let him come who wears the cloak of the people of pain, with Love / Let him come who eats its poison like sugar, with pleasure 3 and reports that

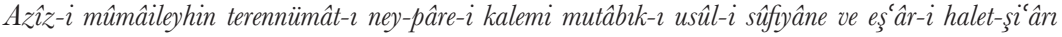
bîtekellïf ve âşıkane \{the songs of the aforesaid saint were in conformity with the Sūfì style; and his poetry was characterized by a lack of formality and ecstatic love of God\} (Șafā'ī, Tadhkira, MS. 2549 in the Esad Efendi Library). In Thāqib Dede's book there is also a hymn with the refrain Kurtar bizi nefs elinden \{Save us from the clutches of the carnal self \} (Safinna-i mawlawiyān, vol. 2, p. 50). Esrār Dede says of this Sūfí, who died in Egypt while performing the pilgrimage to Mecca in 1063/1652-3: "Most of his poetry consists of hymns and divinely inspired orations \{ilhâmât $\}$; his beste hymns in the Șūfì style are now employed for dhikrs and Șūfì litanies" (Tadkhira, pp. 4-6). He also mentions his fine poetry written in the 'arū $d$ meter and even some noteworthy poems in Persian.

11 In addition to his published Muzakkī 'l-nufüs \{Istanbul, 1281/1865\} and unpublished Țañqātnāme, Eşrefoğlu, who received instruction first from Ḥājji Bayram Veli and then from Husain Hamawī, a descendant of 'Abd al-Q̄ādir Jilānī, also has a dīwān printed in Istanbul in 1286 \{see $E I^{2}$, supplement, s.v. "Eshrefoghlu" (Fahir İz)\}. Even a superficial examination of this $D \bar{\imath} w a \bar{n}$, which, on the basis of manuscript copies, is rather defective, shows that he was under the influence of Yūnus Emre. This Dīwān, despite the unreliability of the imprint, recalls Yūnus Emre in several of its linguistic and stylistic features. It reveals Eşrefoğlu to us as a pantheist Șūfì completely under the influence of Yūnus Emre and 'Āshıq Pasha. The passages written in the 'arūd meter are very defective, exactly like those of 'Āshıq Pasha. As for those written in the syllabic meter, while lacking Yūnus's sincerity and power they nevertheless show a striking resemblance to his work. As is the case with Yūnus Emre's Dīwann, this one too includes unrestrained dawriyyas, exhortations on the need for ecstatic love of God and spiritual knowledge, and counsels on the need to be attached to a shaikh. In Eşrefoğlu, 
however, there are passages indicating that he was the shaikh of a tariqa and summoning the people to him.

Aş̧ sayrusu olanlara gelsinler tîmâr eyleyem

İcürem aşk şerbetini dosttan haberdâr eyleyem

Açar bâtmî gözünü göre kendi kendözünü

Dosta döndürem yüzünü âlemden bîzâr eyleyem

Söyündürem nefsi od'zn bozam trlssmmn bendin Götürem benliği seddin ol dosta yular eyleyem

Ol taş olmus gönüllere vuram aşkn külünküni

$\hat{A} b$-i hayât' $\imath$ akıtam gönlünde pinar eyleyem

Ben dostu görüp gelmişem devrânım sürüp gelmişem

Dost dostlara gelsün dedi geldim ki haber eyleyem

\{Let those come who are sick with Love: I will treat them.

I'll give them love potion to drink. I'll inform them of the Beloved.

He shall open his inward eye and see himself.

I'll turn his face to the Beloved and make him sick of the world.

I'll put out the fire of his carnal self. I'll break the talismanic spell.

I'll remove the barrier of his self and make him a halter (?) for the Beloved.

I'll strike Love's pickaxe upon those hearts turned to stone.

I'll cause water-of-life to gush forth from his heart.

I've seen the Beloved and come back. I've spent my time of fortune and come back.

The Beloved told the lovers to come: I've come to tell the others.

It is clear that this work is also completely in the style of Yūnus Emre. Among the factors that shaped the personality of Eşrefoğlu, the influence of Yūnus Emre is strikingly greater than that of 'Āshıq Pasha. Eşrefoğlu's language is somewhat more technical than that of Yūnus Emre because of the difference in time between them, but given his complete lack of consideration for art, his use of half rhyme for the most part instead of rhyme, and his subject matter, Eşrefoğlu is Yūnus's most faithful imitator. With the exception of Qayghusuz, we can consider him to be the most important imitator of Yūnus Emre. In the following passage from one of his dawriyyas, the influence of Yūnus Emre is immediately apparent:

Gâh denizlere düşerem mevc urup taşra taşaram

Nâdân eline düsserem kem bahâya alınuram

Gâh çkaram bu göklere dönerem çarh ile bile

Gâh ay ile bedr oluram gâh gün ile dolanuram

Gâh 'Arafât'a çıkaram lebbeyk urub baş açaram

Gâh kurbân yerine gelüp koç olub boğazlanuram

Gâh hânkâhta sûfîyem gâh meyhânede fâsıkam

Gâh raksa girüb dönerem gâh sâz olub çalinuram

Gâh onaram gâh azaram bu halk içinde gezerem

Gâh şâh olub şahbâz olub şikâr edüb avlanuram 
Gâh deniz gâh göl oluram gâh sultân gâh kul oluram

Gâh bahâr gâh gül oluram elden ele yelinürem

Ne menzil vardir ne makâm ne vücud vardır ne 'adem

Hak'tan gayn yok ve'sselâm ya ben kande dolanuram

\{Now I plunge into the sea and emerge as a wave,

Or I fall in the hands of a fool and am sold at a small price.

Now I rise up to heaven and turn with the spheres;

I am crescent moon or full moon, or I turn with the sun.

Now I go out to Arafat as a pilgrim and bare my head,

Or come to the place of sacrifice as a ram and am slaughtered.

Now I'm a Sūfi in the dervish convent, or a reprobate in the tavern,

Or I twirl in the dance, or become a saz and am strummed.

Now I go aright, now astray: I wander amidst the people.

Now I am king, or else the king's falcon in the hunt.

Now I'm the sea, or a lake; now sultan, or slave.

Now spring, or a rose passed from hand to hand.

Neither halting-place nor station, neither being nor non-being:

Nothing but God, that is all: so where shall I turn now?

12 The following hymn of Ummī Sinān is completely reminiscent of Yūnus Emre's style:

Erenlerin sohbeti ele giresi değil

Ikrâr ile gelenler mahrûm kalası değil

Ümmî Sinan yol 'ayân olubdur her şey beyân

Dervişlik yolu hemen tâc ve hrrkası değil

\{Conversing with the saints cannot be brought under control.

Those who come confessing will not be left deprived.

Ummī Sinān, the way is clear and everything is evident.

The way of the dervish is not just tall cap and patched cloak.

13 Many of the hymns of this person, who sometimes used the pen name Ahmadi and sometimes Qayghusuz in his poetry, are recorded in Müstaqīm-Zāde's treatise

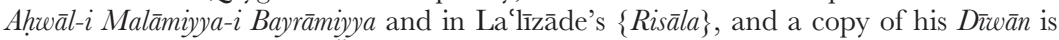
in the Selim Agga Library in Usküdar. In order to give an idea of the hymns in the syllabic meter of this Șūfì, who also wrote quite a few poems in the 'arüd meter, I will cite a very noteworthy and personal work of his concerning his view of the $\{$ spiritual $\}$ pole $\{q u t b\}$.

Evliyâya ĕgri bakma

Mülke hükmün süren oldur

Sen an şöyle sanursun

Evliyẩnn strr vardır

\{Do not look askance at the saints:

It is they who govern the kingdom:

You should consider each of them

The saints have a secret:

\section{Kevn ü mekân elindedir}

İki cihân elindedir

Sencileyin bir âlemdir

Gizli 'ayân elindedir

the universe is in their hands.

both the worlds are in their hands.

as a world equivalent to you (?).

the concealed and the evident are in their hands. 
Rızâ Tevfik believed the original Qayghusuz Abdāl and Aḥmad Sārbān were the same person and deduced a number of things from this (\{article in the literary supplement to the newspaper\} Peyâm, no. 35, 8 May, 1330/1912); but this is clearly mistaken. The doctrine and mystical ideas of Ahmad Sārbān and Qayghusuz are both well known and their writing styles are noticeably different.

14 This person who is buried in the village of Eroğlu between the districts of Kula and

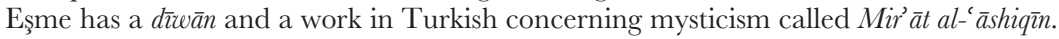
His hymn, beginning Nidâ ettim gelsin âşı olanlar / Hakk'a gidenlerin yoludur Tevhîd / Aşkn dersin bundan aldr alanlar / Hem ledün ilmin nin dilidir Tevhîd \{ I summoned those who are lovers / Tawhid is the path of those going to divine Truth / Those who learned the lesson of Love learned it from this / Tawhìd is the language of the science of divine nearness \}, is only slightly reminiscent of Yūnus Emre. This man is not, in fact, a particularly important personality (\{Mehmed Tâhir,\} Osmanlı müellifleri, vol. 1, p. 26).

15 Originally from Trrhala, he came to Istanbul and trained a number of great personalities, including Sarı 'Abd Allāh Efendi, the commentator on the Mathnawẽ. His hymns vaguely recall those of Yūnus Emre. His famous oration beginning $\dot{I}_{S}$ bu dem'e erince üç kez doğgdum anadan \{Until I reached this moment, I was born again three times\} was expounded upon by several shaikhs (\{Mehmed Tâhir, \} Osmanlı müellifleri, vol. 1, p. 24).

16 This person, whose $D \bar{\imath} w \bar{a} n$ has been published, has many other works, most notably a famous treatise entitled Miftāhl-i wahdat-i wujūd. He was a khā̄̄fa of Ummī Sinān. In addition to a number of poems in the 'arüd meter, he wrote hymns in the style of Yūnus Emre. The following passage from one of his hymns is reminiscent of Yūnus Emre:

Kiyamazsan başa câna Bu meydânda nice başlar

Bak şu Mansûr'un işine

Ene'l-Hakk' in firâş̧ına

Seyfu'llâh sözünde mesttir

Dî̀ânerâ kalem nîstdir
Irak dur girme meydâna

Kesilir hiç sorar olmaz

Halkı üşürmüs başına

Dïşenlere tîmâr olmaz

Şeyhinden aldiğ dest'dir

Ne söylese kanar olmaz

\{If you cannot sacrifice your life, do not enter the arena.

In this arena many heads are cut off and no one questions it.

Look what happened to Manșūr al-Hallāj: the people gathered against him.

There is no treatment for those who enter the sick bed of "I am the Truth."

Saif Allāh is intoxicated in his speech: It is the permission he received from his shaikh.

Madmen have no pens: Whatever they say does not convince.\}

Some shaikhs have written commentaries on this hymn.

17 He was from Divriği and was a leading member of the Khalwatī tarīqa. Because he went to Aq Kirmān to provide mystical guidance and was buried there, he is known as Aq Kirmānī. In addition to his published $D \bar{\imath} w a \bar{n}$, which was printed under the mistaken title of Dǐwān-i Shāh Naqshband, he has a number of Șūfì works in verse and prose. I will cite as an example a hymn in the syllabic meter, although much of his poetry is in 'arüd.

Aş̧kn şarâbrn içmeyen

Zincîr-i aşka düsmeyen

Akut gözlerinden yaşı

Kul olur ise bir kişi
Mest olub hayrân olur mu

Soyunub uryân olur mu

Gör kimdir işleyen işi

Bu mülke sultân olur mu 
Aşka ciğerin yakmayan

Bahr-i Muhît'e akmayan

Gönül gel geçirme çağ̀n

Gülleri bitmeyen bağın

Nakşî açıldr çün gözün

Lâkin bilmem uş bu sözün
Mürşide doğru bakmayan

Göl iken ummân olur mu

Ko yansin yürekte yağgn

Bülbülü nâlân olur mu

Hakk’ görür oldu özün

Münkire îmân olur mu

\{One who does not drink wine and become drunk: can he be amazed?

One who does not suffer the chains of Love: can he strip and be naked?

Let the tears flow from your eyes. See who is doing the deed.

If a man is a slave, can he be sultan of this kingdom?

One who does not kindle his heart with Love; one who does not look toward his spiritual master;

One who does not flow toward the sea, but remains a lake: can he become the sea?

Come, heart, do not waste your days. Let the fat on your heart burn off. If roses do not bloom in the garden, will nightingales sing?

When Naqshī opened his eyes, he seemed to see God in himself.

But I don't know whether these words of his will be a creed for one who denies.\}

18 This person wrote two famous poetic works, Dil-i dāna and Mufid-u mukhtasar. He was a khal̄̃fa of HaqīqīZāde Osman Efendi, a khal̄̃fa of Sayyid Saif Allāh Efendi. In addition, he studied under Hüdā's', 'Abd al-Ahad Nūrī and Husain Lāmekān̄i. According to Ghaibī, who was a khalīfa of Ibrāhīm Efendi and collected accounts of his legendary deeds and his sayings in a work entitled $B \bar{\imath}^{\prime}$ atnäme or Suhbatnāme, he also was a khalîfa of Țab Ṭab Shāh 'Alī, a khalîfa of Ahmad Sārbān. In addition to the poems that he wrote in the 'arūd meter, he composed quite powerful works in the style of Yūnus Emre, but in slightly more artful and technical fashion.

Tayan yerde ne gezersin gel âdeme ir bu deme Hayvân gibi ne yelersin gel âdeme ir bu deme

Nüsha-i Vahdet âdemdir nefha-i kudret bu demdir

Âdemden gayn 'ademdir gel âdeme ir bu deme

Ayine-i Hak âdemdir gören görünen bu demdir

Her nefes İsm-i a'zam'dor gel âdeme ir bu deme

Bu ilmin beyânm bir kâmil insândan sor

Cânum cân haberini cân içinde cândan sor

Yarn ne olacağgn bugün bilmek istersen

Uykuya vardiğinda gördüğ̈ün seyrândan sor

Târin zülfü içinde ne başlar oynadiğın

Erenler meydâninda top ile çevgândan sor

Geçen hod geçti gitti geleceği neylersin

Her nefesin neş'esin bu demle bu ândan sor

İbrâhim' in gönlünün gönkleğini bilmeğe

Cân ile tâlib isen gel 'Arș-ı Rahmân'dan sor 
\{Walker, why do you walk on the ground? Come to Adam, to Adam's breath. Runner, why do you run like an animal? Come to Adam, to Adam's breath.

Adam is the copy of Unity; his breath is the afflatus of power.

Aside from Adam is non-being. Come to Adam, to Adam's breath.

Adam is the mirror of Truth: his breath is what sees and what is seen.

Every breath is the Greatest Name. Come to Adam, to Adam's breath.

Inquire the explanation of this science from a perfect man.

My dear: inquire for news of the soul from the soul within the soul.

If you wish to know today what will be tomorrow.

Go to sleep and inquire of your dream.

What heads are dangling in the Beloved's locks?

Inquire of the polo stick and ball in the arena of True Men.

What's past is past, and what can you do about what's to be?

Inquire the joy of every breath from every passing moment.

What is the shirt on the bosom of Abraham?

If you really want to know, inquire of the Throne of the Merciful.\}

In these poems Ibrāhīm Efendi is clarifying the theory of the "Perfect Man" and Mawlānā's notion of "breath," which he expounded in the couplet \{Mathnawē, Book 1, line 133$\}$

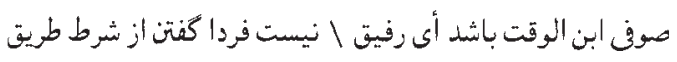

\{The Șūî is the "child of the moment," my friend.

It is not the rule of the Way to say "Tomorrow."

Another of his poems is reminiscent of some passages from Yūnus Emre that I cited above:

Âlimem dersin ammâ âlemden bî-habersin

$B u$ ândan bu nefesten bu demden bî-habersin

Söze gelince gerçi eylemişsin kul gibi

Kalbine Hak'tan olan hemdemden bî-habersin

Bu esrân duymağa gerçekler nazarnda

Âriflerin dediği nağmeden bî-habersin

Dört Kitâb' 1 okursan yine bilmiş olmazsin

Benim cânm mâdam ki âdemden bî-habersin

\{You say, "I know," but you know nothing of the world.

You know nothing of this moment, this breath.

When you start to talk, you split hairs, but

You know nothing of your breath that God has provided as companion to your heart.

To hear these mysteries, in the view of realities, (?)

You must know the song sung by the mystics: You know nothing about it. 
Even if you read the Four Books you still will know nothing, My dear, as long as you know nothing of Adam (or, Man).\}

In his work on Hurūfism, Rızâ Tevfik says that this Ibrāhīm Efendi was known as Oğlan Shaikh and that during the reign of Süleyman the Magnificent he was condemned to death while only twenty-two years old by a fatwa from Ibn Kemāl (Études sur la religion des Houroûfis [Leiden, 1909], p. 254); later in an article that he published on Sūfî literature in the literary supplement \{to the newspaper\} Peyâm, he repeats that he was a shaikh during the reign of Süleyman. We can conclude from this that Rızâ Tevfik confused Olanlar Shaikhi and the famous Oğlan Shaikh with each other. This poet Ibrāhīm Efendi lived long after the reign of Süleyman, so he was not the one who was executed. Oğlan Shaikh Ismā'îl Ma'shūqī, who was executed along with twelve of his muñds in front of the fountain at the Hippodrome on the authority of Ibn Kemāl's fatwāa, was the son of Pīr 'Alī Efendi of Aksaray, a Bayramī shaikh. He was born in 914/1508-9 and was killed in 935/1528-9 (for details, see \{Hâfiz Hüseyin Ayvansarayî,\} Hadīqat al-jawāmic \{Istanbul, 1281/1864\}, vol. 1, pp. 35, 253, vol. 2, p. 125 English trans. Howard Crane as The Garden of the Mosques: Hafiz Hüseyin al-Ayvansarayî's Guide to the Muslim Monuments of Ottoman Istanbul (Leiden, 2000)\}; La' 'īzāde, Risāla, pp. 27-9; the supplement to \{Tashköprü-Zāde's\} al-Shaqā’iq, vol. 1, p. 89; and Ghaibī, Suhbatnāme, the most important source on Olanlar Shaikhi). La' līzāde says that Oğlan Shaikh also composed a number of hymns.

19 Ghaibī was the khalêfa of Olanlar Shaikhi. In addition to the Suhbatnāme and Kashf al-ghit $\bar{a}^{\prime}\{\mathrm{MS}$ in Köprülü's private library\} he wrote a number of short treatises, poetry in the 'arūd meter, and many elegant and sincere hymns in the style of Yunus Emre. Among the imitators of Yūnus Emre, Ghaibī was a great poet superior even to his shaikh Ibrāhīm Efendi. For some reason, Rızâ Tevfik, again in his work on the Hurūfìs, presents Ghaibī as a Hurūfì poet, but this claim is based on absolutely no evidence, only on hearsay. Ghaibī, who was absolutely faithful to the system of panthéism idéaliste \{wrijüdiyya-i khayāliyya\}, was, exactly like Yūnus Emre, a genuine Sūfì and especially an esteemed poet. The following example can give us an idea of his art and his personality:

Tâc márifet tâcudır sanma gayri tâc ola Taklid ile tok olan hakîkatte ac ola

Düse düşüp aldanma kendin hayrete salma Senden özke ne varder ta'bire muhtâc ola

Sana âlem görünen hakikatte Allâh’tır Allâh birdir va'llâhi sanma ki birkaç ola

Bir ağaçtır bu âlem meyvesi olmuş âdem

Meyvedir maksûd olan sanma ki ağaç ola

Bu âdem meyvesinin çekirdeği sözündür

Sözsüz bu âdem âlem bir ânda târâc ola

Bu sözlerin méâli kişi kendin bilmektir Kendi kendin bilene hakikat Mi' râc ola

Hak denilen özündür özündeki sözündür Gaybî özin bilene rübûbiyyet tâc ola

\{The crown (or, dervish cap) is the crown of mystical knowledge: don't think there is any other.

One who is replete with imitation is in truth hungry. 
Don't deceive yourself with dreams. Don't let yourself go in bewilderment. Whatever exists beside yourself requires interpretation.

What seems to you to be the world is in truth God. God is One: by God, don't think that He is many.

This world is a tree and Adam (or Man) is its fruit. The goal is the fruit: don't think it is the tree.

The nut (or core) of the fruit of Adam (or Man) is your speech. If Adam is speechless, the world is pillaged in an instant.

The sum of human speech is that a man should know himself. To know oneself is to earn the true Ascension.

What is called "Truth" is yourself, your speech in your self. To know Ghaibī's self is to earn the crown of Lordship.\}

This fine poem, which explains the secret of من عرف \{reference to the Hadith "who knows himself knows his Lord"; see, for example, Annemarie Schimmel, Mystical Dimensions of Islam, p. 189\} and the theological notions common to all Șūîs, could never be interpreted according to Hurūfì beliefs.

20 The poets of the other tekkes, apart from a very small number, like Qayghusuz, Ghaibī, and Ibrāhīm Efendi, were bound to much more ascetic and pious views and could not display the same sincerity and broadmindedness as Yūnus Emre. Indeed, even the language of Ghaibī and Ibrāhīm Efendi is more technical and their style is less sincere. Yūnus Emre's mode of expression, both clear and allusive, can be seen only among the Bektashī poets.

21 See the various explanations that I have given of this matter in different places in this book. For more detailed information on these subjects, see my series of articles entitled "Anadolu'da islâmiyet: \{Türk istilâsından sonra Anadolu tarih-i dinîsine bir nazar ve bu tarihin menbalar,," in Dârülfuinûn Edebiyat Fakültesi Mecmuast, 2 (1922), 281-311, 385-420, 457-86; English trans. Gary Leiser as Islam in Anatolia after the Turkish Invasion (Salt Lake City, 1993).\}

22 A detailed account of this phenomenon and analysis of the various factors that gave rise to it are outside our subject. The Abdāls were also of this nature. This was a major factor in both their influence and that of the Bektashīs on the popular masses. Because they flourished among the people, the Bektashī $b \bar{a} b \bar{a} s$ knew their psychology better than anyone and, indeed, in many respects were no different from them, and thus had all the qualities necessary to spread Bektashi propaganda among the broadest masses of the people. Detailed accounts of this subject will be found in my \{forthcoming\} work \{never published. See his article "Bektaş" in $\dot{I} A$.

23 The works of the Bektashi poets, which were long written in the 'arü d meter - beginning with \{Muhȳī 'l-Dīn's\} poem Khadirnāme which I mentioned briefly above - are for the most part faulty and defective, in short, they are very inept. That is the rule, with very rare exceptions. This fact is immediately obvious when looking through anthologies \{s. cönk\} of poems belonging to Bektashīs. Also in these cönks are a number of works by Hurūfì poets like Nesīmī and Shīì poets like Fuḍūī \{d. 963/1556\}, all of which should not be included within the scope of Bektashī literature. It is beyond our subject to go into detail here on Bektashī poets, the form and nature of Bektashī poems,

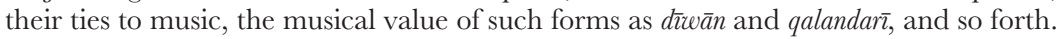
\{For collections of Bektashī poetry, see Sadettin Nüzhet Ergun, Bektaşi edebiyat antolojisi (Istanbul, 1955-6) and Gölpinarl, Türk tasavvuf şïri antolojisi (Istanbul, 1972).\}

24 According to the common tradition in all the biographies of the poets, Khațā' $\overline{1}$ was the pen name of the Safavid Shāh Ismāīil. One should not, however, conclude that all 
works attributed to Khatậ'̄i belong to Shāh Ismā'îl. Just as among our classical poets several men may have the same pen name, so it is among these tekke poets. Because of the paucity of historical documents on the Bektashīs in particular, it is not possible to resolve such problems completely. I stated above that even the names Yasawi and Yūnus were used by all kinds of people - whose personalities are unknown - and I gave the reasons for this.

25 There were a great many Quzllbash poets, beginning with Shāh Ismā'îl, but it is virtually impossible to do a thorough historical study of them. Nevertheless, because we have in our possession various works of several Quzlbash poets, we can definitely state that this literature is no different from that of the Bektashīs.

26 I mentioned that a large proportion of the Bektashī poets who wrote these kinds of works in the national meter and under the influence of Yūnus Emre's style were Hurūfìs. But the Hurūfîs had an important literature in the 'arüd meter even before this style was established. I hope to publish in the future a separate study on this literature which includes several important poets, beginning with Nesīmī and Rafî̀ $\overline{1}$, the author of the Bashäratnāme. For now suffice it to say that Bektashī literature adopted the 'arü meter and that style of poetry from the Hurūfiss and Qalandarīs and the syllabic meter and the style of Yūnus Emre and Qayghusuz from the Abdāls. The latter won much greater esteem and importance among the people and had greater prestige in Bektashī poetry. Thus the products of Bektashī-Hurūfî literature that were in the 'arū $d$ meter, while at first having greater esteem and importance, subsequently lost pride of place. The fine poem of Qayghusuz Abdāl given below is one that belongs wholly to the Abdāls. It also passed to the Bektashīs, and, in fact, Bektashī poetry was able to acquire its distinctive features via the influence of Abdāls such as Qayghusuz.

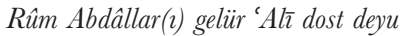

Hırka giyer abâ deyu post deyu

Hastalara gelür dermân isteyu

Sağlar gelür Pîrim Abdâl Mûsầya

Hind'den bâzirgânlar gelür yaymur

Aşı olan bu meydânda soyunur

Pişer lokmalan aşlar toyunur

Toklar gelür Pîrim Abdâl Mûsầya

Ikrârder koç-yiğitin yulan

Fakîhleri çeksem gelmez ileri

Ak-prnar'in yeşil gülliü sular

Çağlar gelür Pîrim Abdâl Mûsầya

\{The Abdāls of Rūm (Anatolia) come crying " "Alī! Friend!"

They don the patched cloak and call it $a b \bar{a}$ and post.

They come to the sick seeking a cure.

They come in health to my Pīr Abdāl Mūsā.

From India merchants come and disperse.

The Lover strips in this arena.

He is cooked, and gobbets of him are consumed.

Those who are full come to my Pīr Abdāl Mūsā.

His confession is the champions' halter.

If I pull the legal scholars they won't come forward.

The streams of Aq-pinar with their green roses

Come flowing to my Pīr Abdāl Mūsā.\} 
When I publish my future studies on the Abdāls, I will provide detailed information on the other works of Qayghusuz \{as mentioned, never published.\}. All of Bektashī literature clearly shows the influence of Qayghusuz Abdāl. Nothing resembling his style, which is completely Turkish exactly like that of Yūnus Emre, is found in Persian or Arabic literature.

27 This feature derived directly from the influence of Qayghusuz. The resulting mixture of beliefs of Bektashism, which were filtered through many different sources, naturally perpetuated this influence among Bektashī poets. The poem given below is a HurūfīBektashī composition that shows the unity of God, Muhammad, 'Alī, and Faḍl Allāh Hurūfi. There are many like it.

\begin{tabular}{|c|c|}
\hline $\begin{array}{l}\text { Gönlüme gözüme gelen surûru } \\
\text { Cemâline muştâk grlmân ve hûrî }\end{array}$ & $\begin{array}{l}\text { Fazl Hak Muhammed 'Alìden bildim } \\
\text { Fazl Hak Muhammed 'Alì'den bildim }\end{array}$ \\
\hline $\begin{array}{l}\text { Tâlibine lutfet ey kerem kânı } \\
\text { Adâlet etmenin geldi zamânı }\end{array}$ & $\begin{array}{l}\text { Lebin kevseriyle gel kander cân } \\
\text { Fazl Hak Muhammed 'Al⿳亠丷厂 den }\end{array}$ \\
\hline
\end{tabular}

\{The joy that comes to my heart and my eyes I know is from Faḍl, God, Muhammad, 'Alī.

The male and female denizens of paradise who long for Your beauty I know are From Faḍl, God, Muhammad, 'Alī.

Show favor to Your seeker, O mine of generosity. Come quench the soul with the Kawthar (name of a river in Paradise) of your lips.

The time has come to do justice. I know it from Faḍl, God, Muhammad, 'Alī.\}

Likewise, the following passage taken from one of Khatâa's's poems also has this meaning and is clearly Hurūfî in nature:

Şerí at yolunu Muhammed açtı

$B u$ dünyâdan yüzbin erenler geçti

Şâh Hatây'm eydür sirrn duyurma

Yalancı dünyâda hiç sağrm deme
Tarîkat gülünü Şâh 'Alî seçdi Anlar ittifâkta Mehdî yoldadır

İde-gör niyâzı kazâya koma

Muhammed Fazlu'llâh şimdi yoldador

\{Muhammad opened the path of the Sharī'a. Shāh 'Alī selected the rose of the Tariqa.

Myriads of saints have passed through this world: they are, by agreement, on the path of the Mahdī.

Shāh Khațā'̄̄ says: Do not divulge your secret. Perform the supplication, do not postpone it.

In this false world don’t say: "I am true." Muhammad and Faḍl Allāh are now on the way.

It is obvious that the notions of indwelling and union are continuously encountered in Bektashī poetry.

28 This nefes is an example of the most beautiful and sincere passages of Bektashī poetry:

Vardim kurklar meydânna gel beri hey cân dediler

$\dot{I}_{z z e t}$ ile selâm verdim geç otur hey cân dediler

Kirklar yerinde durdular yerlerinden yer verdiler

Meydâna sofra serdiler lokmaya sun cân dediler 
Kirklarn gönlü uludur mü'minler kalbin eridir Gelisin kanden beridir söyle be hey cân dediler

Kalk semấda bile oyna silinsün pâk olsun ayna Kirk ynl bir kazanda kayna dahi çeksin cân dediler

Düsme dünyâ kisvetine tâlib ol Hak Hazreti’ne $\hat{A} b-\imath$ Kevser şerbetine parmağın ban dediler

Gördïgünü gözün ile beyân etme sözün ile Bir gececik bizim ile olasin mihmân dediler

Şâh Hatây'm nedir hâlin Hakk'a şükret kaldır elin Kese-gör grybetten dilin olasin sultân dediler

\{I went to the field of the Forty. They said: "Come this way, O soul!" I paid my respects. They said: "Come, sit down, O soul!"

The Forty stood up and gave me a place among them. They laid out a spread in the field and said: "Help yourself, O soul!"

The Forty have a great heart that causes the believers' hearts to melt. They said: "Where are you from? Tell us, O soul!"

"Get up and join us in the mystical dance $\left(s a m \bar{a}^{c}\right)$. Let the mirror (of your heart) be wiped clean.

Boil in a cauldron for forty years and let your soul suffer," they said.

"Do not put on the garment of this world. Be one who seeks Divine Truth. Dip your finger in the sherbet of the stream of Kawthar," they said.

"What you see with your eyes do not utter with your lips.

Be our guest for a single night," they said.

"Shāh Khațā'î: what is your condition? Raise your hands and give thanks to God.

Keep your tongue from calumny and you will be the Sultan," they said.\}

Poems of an ethical nature like this are also common among the Bektashīs. The ethical view of the Bektashīs is very important with respect to both its nature and sources. (There is a long chapter on this subject in my work on the Bektashīs \{again, never published\}.)

29 We find that the word ozan was used in the tenth/sixteenth century, in Lāmi ${ }^{i} \overline{1}$, for example, with the meaning of "talkative," "garrulous," "prattler."

30 In my full-length article entitled "Sazşâirleri: Türklerde âşık edebiyatı'nın menşe' ve tekâmülü," some parts of which were published in abbreviated form \{in the newspaper Ikdam, see bibliography\}, there is detailed information on this subject and many examples are given. For further information, see my Türk sazşâirleri (Istanbul, 1940; reprinted Ankara, 1962-5), vol. 1, pp. 9-49. 


\section{APPENDIX 1}

Chains of authority 


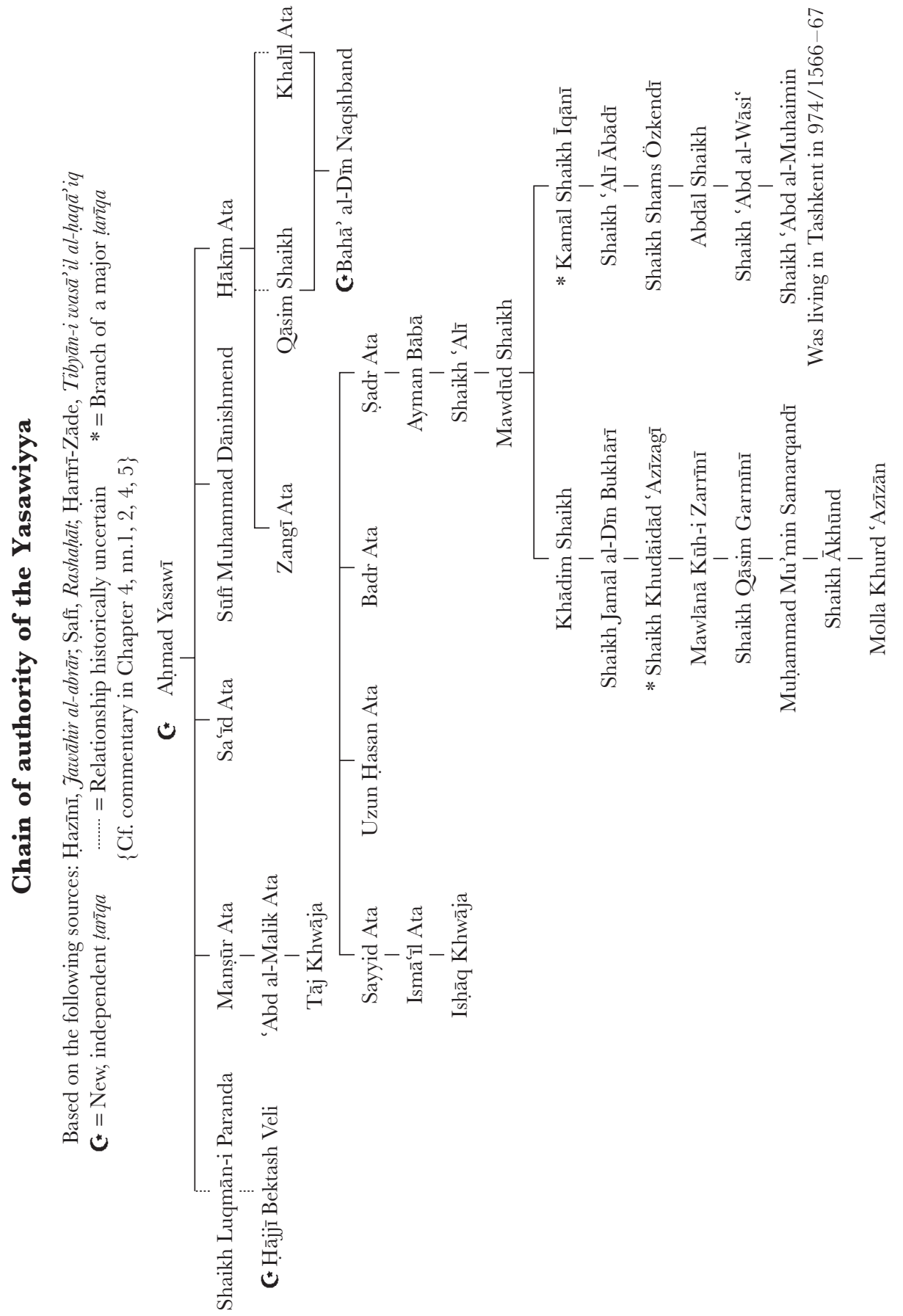




\section{Chain of authority from Zangī Ata}

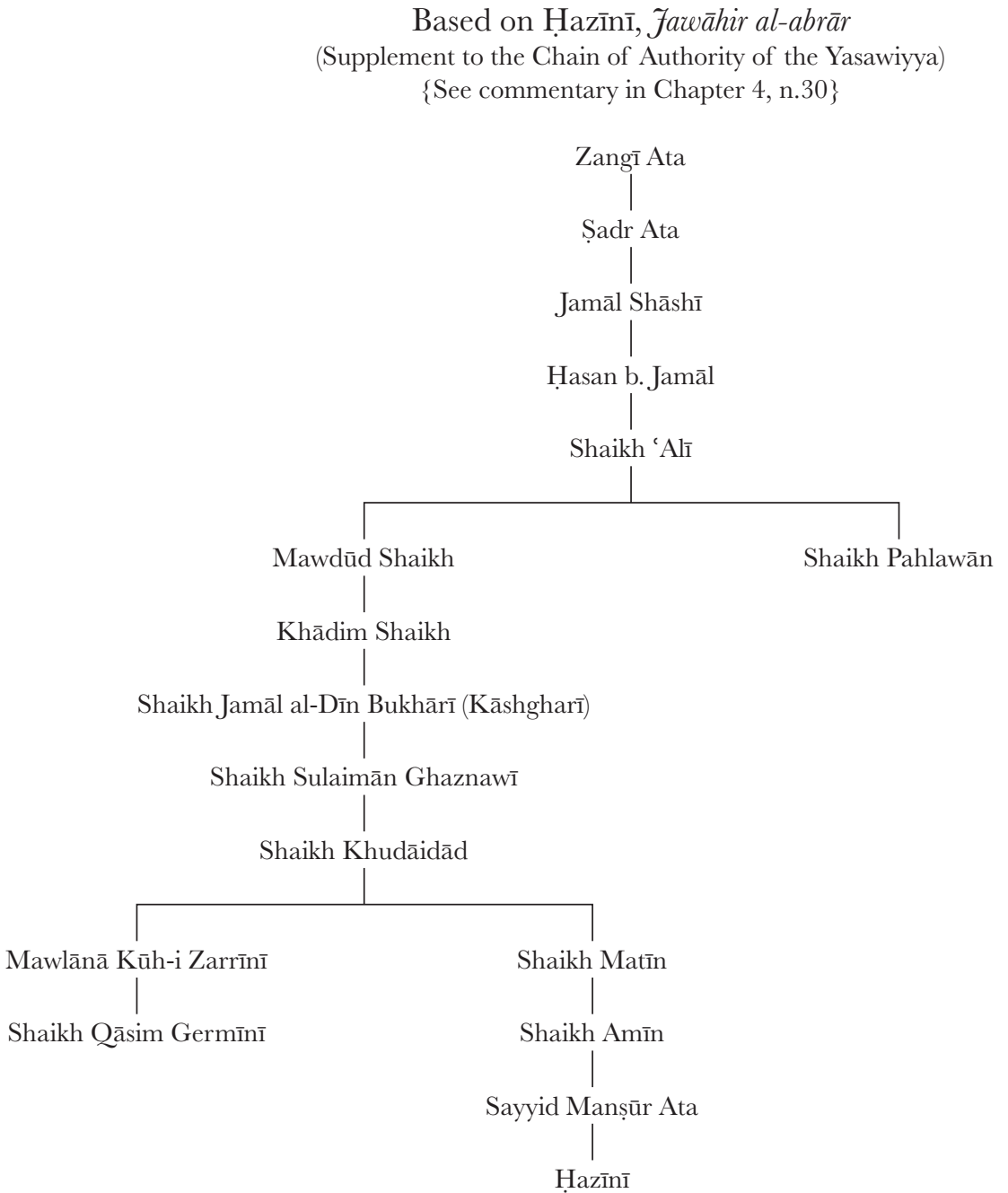




\section{APPENDIX 2 \\ Some hymns of Yūnus Emre}

These hymns of Yūnus Emre were, according to Köprülü, still sung in the tekkes. We have followed the 1st edn, which differs very slightly from the 3rd edn, because of the rhyme.

Number 1

Hicaz İlâhî

Rhythmic pattern: Düyek

Composer unknown
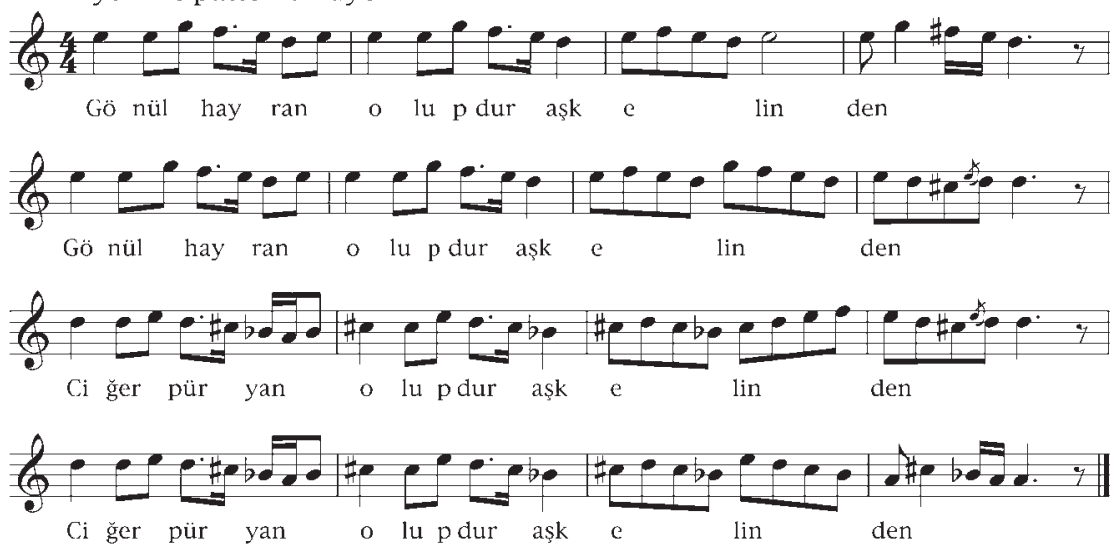

Gönül hayran olupdur aşk elinden Ciğer püryan olupdur aşk elinden
The heart is wonderstruck because of love The liver is roasted because of love 


\section{Uşşak İlâhî}

Rhythmic pattern: Düyek

Composer unknown
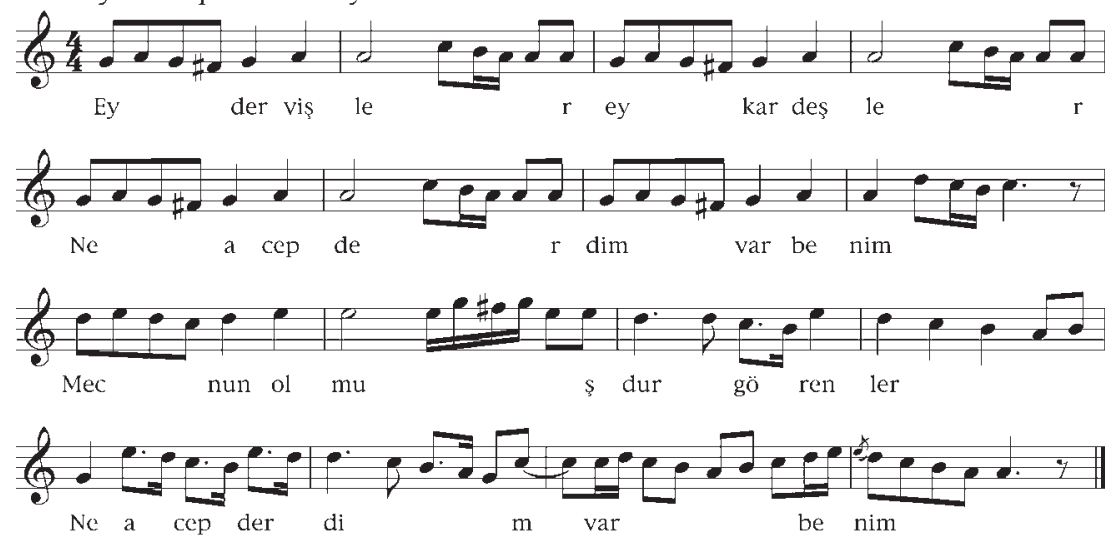

Ey dervişler ey kardeşler

Ne acep derdim var benim Mecnun olmuşdur görenler
Oh dervishes, oh brothers

What a strange pain of love I feel

Those who have seen have gone mad

Number 3

Nevrûz İlâhî

Rhythmic pattern: Evsat
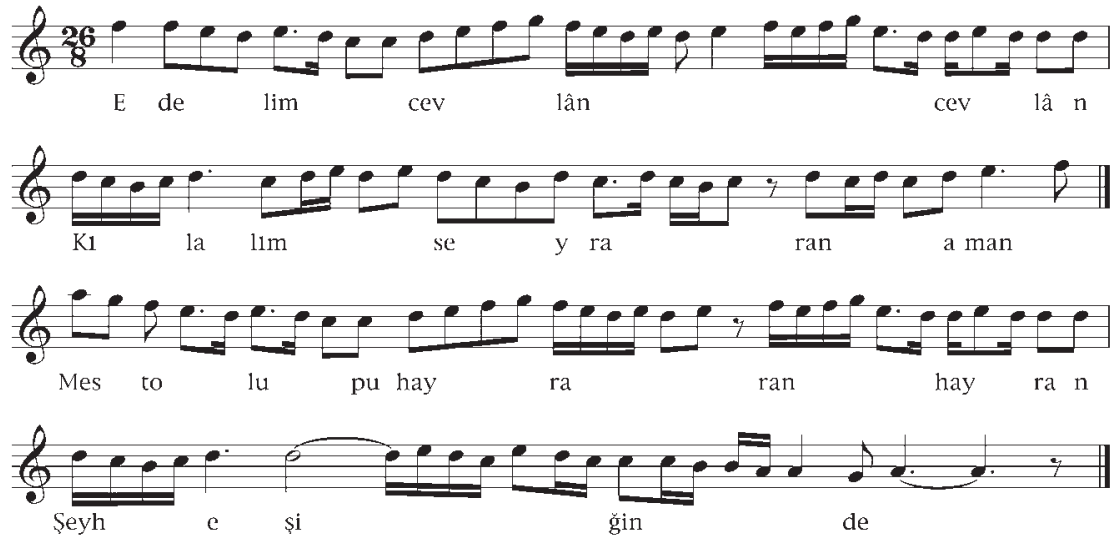

Edelim cevlân cevlân Kılalım seyran aman Mest olup hayran hayran Şeyh eşiğinde
Let us wander around

Let us stroll about

Intoxicated, wonderstruck

At the threshold of the shaikh 
Rhythmic pattern: Nimevsat
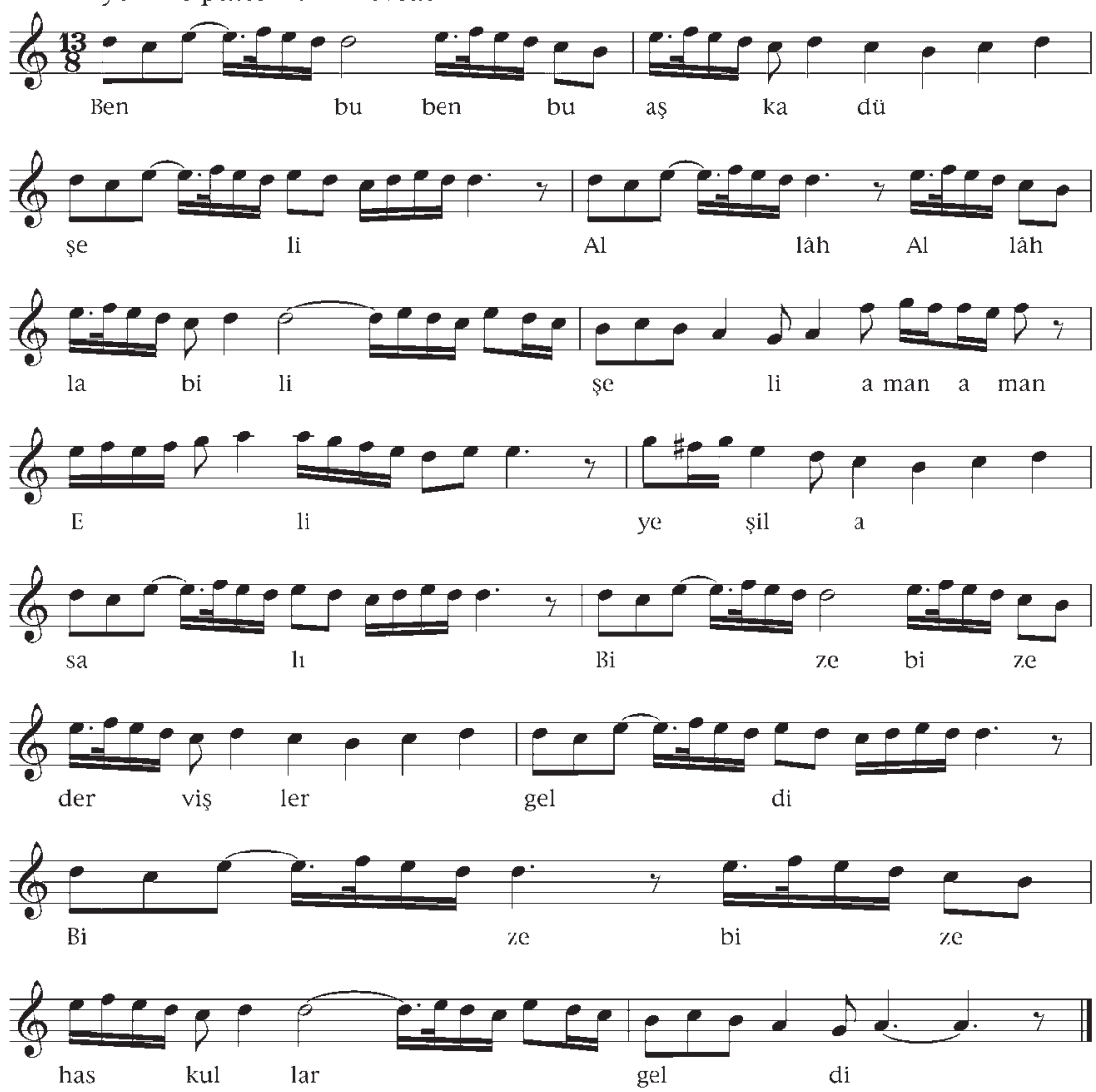

Ben bu aşka düscli Allâhla bilişeli

Eli yeșil asalı

Bize dervişler geldi

Bize has kullar geldi
Ever since I fell into this love

Ever since I became acquainted with God With green staves in their hands The dervishes have come to us God's special slaves have come to us 


\section{Evç İlâhî}

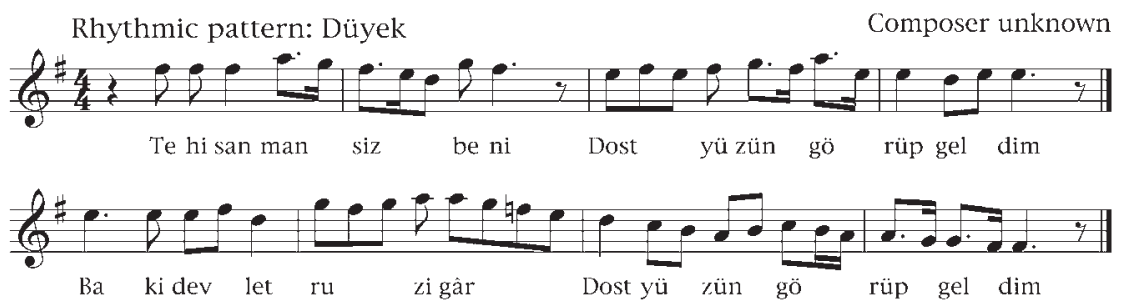

Tehi sanman siz beni Dost yüzün görüp geldim Baki devlet ruzigâr
Don't consider me lightly

I have come having seen the face of the Friend Time is fortune everlasting

Number 6

\section{Uşşak İlâhî}

Rhythmic pattern: Düyek

Composer unknown

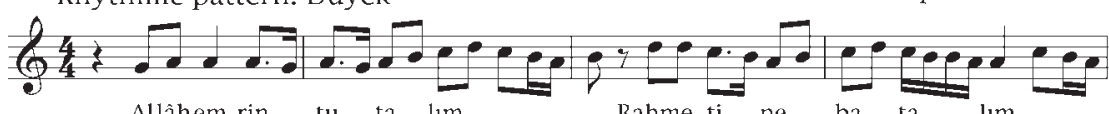

Allâhem rin tu ta $\lim$

Rahme ti ne

ba ta lim
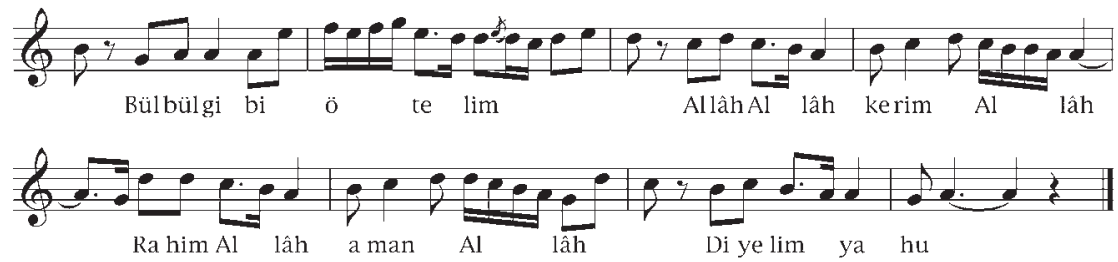

Allâh emrin tutalım

Rahmetine batalım

Bülbül gibi ötelim

Allâh Allâh kerim Allâh

Rahim Allâh aman Allâh

Diyelim yahu
Let us keep God's command

Let us sink into His mercy

Let us sing like nightingales

God, God, generous God

Merciful God, o mercy God

Let us say "Oh He!" 
Rhythmic pattern: Düyek
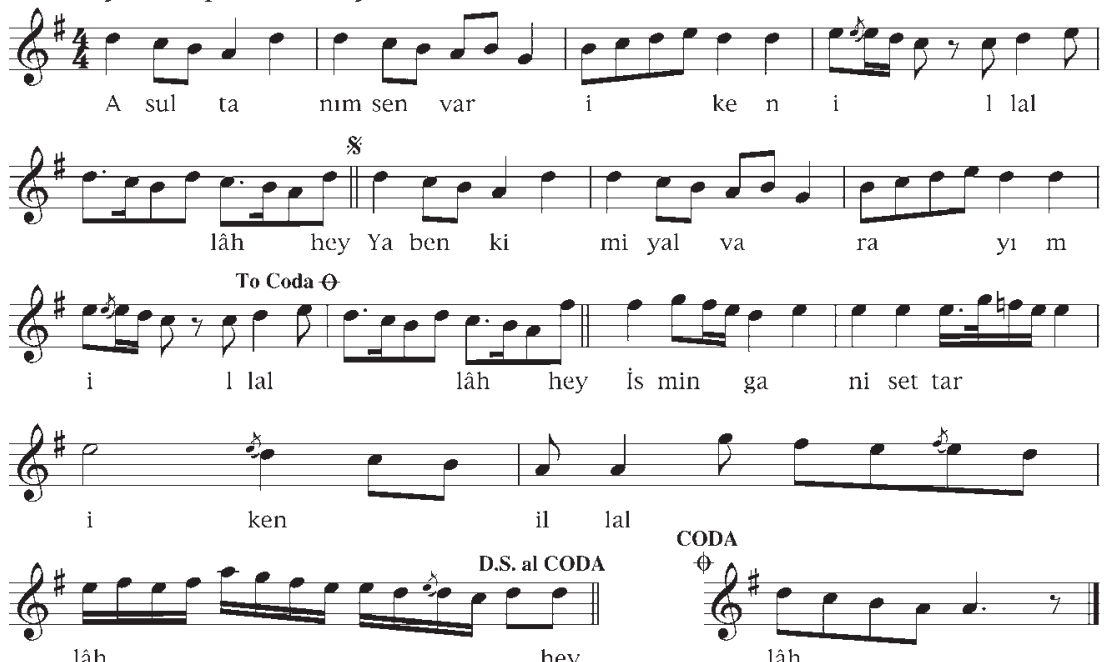

lâh

hey

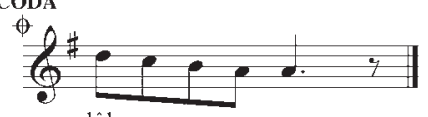

A sultanım sen var iken Ya ben kimi yalvarayım İsmin gani settar iken [Ya ben kimi yalvarayım]
Oh my Sultan, while You exist

Whom else should I implore?

While Your name is All Possessor and Veiler of Sins [Whom else should I implore?]

Number 8

\section{Beyâtî İlâhî}

Rhythmic pattern: Sofyan

Composer unknown
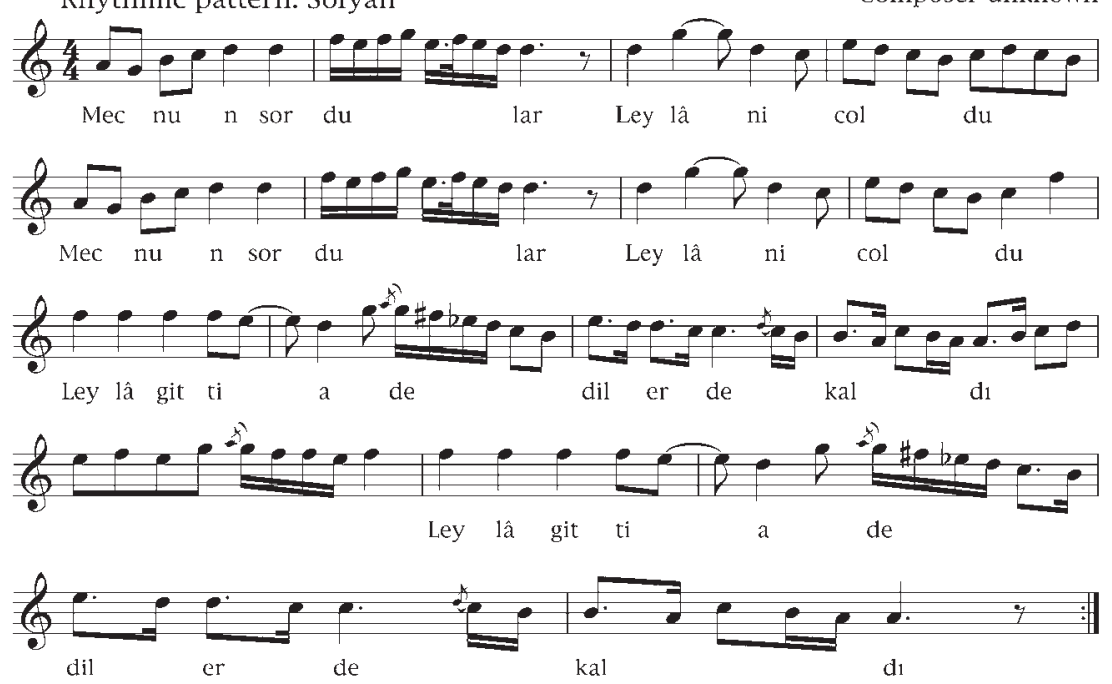

Mecnun sordular Leylâ nic'oldu Leylâ gitti a dediler de kaldı
They asked Majnūn, "What happened to Laylā?" "Laylā went away," he said and sighed 
Rhythmic pattern: Düyek
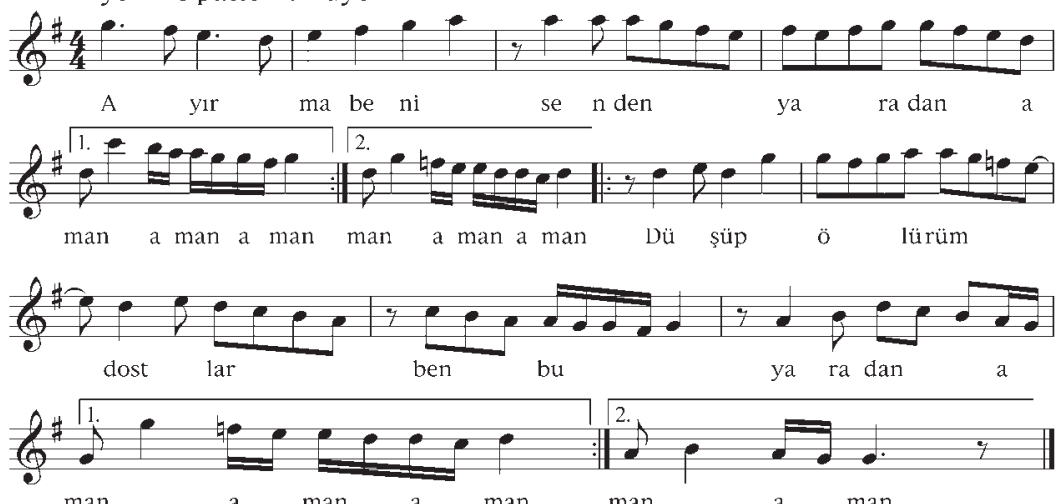

Ayırma beni senden yaradan

Do not separate me from You, my Creator Düșüp ölürüm dostlar ben bu yaradan

On friends, I will fall and die from this wound

Number 10

\section{Mâhûr İlâhî}

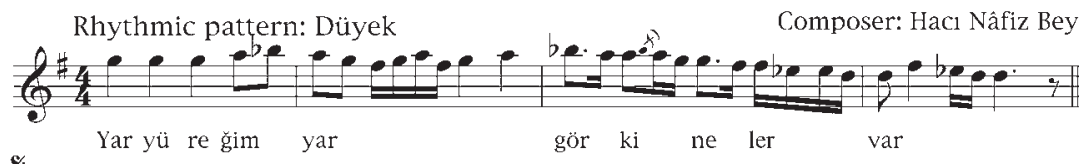

$\$$
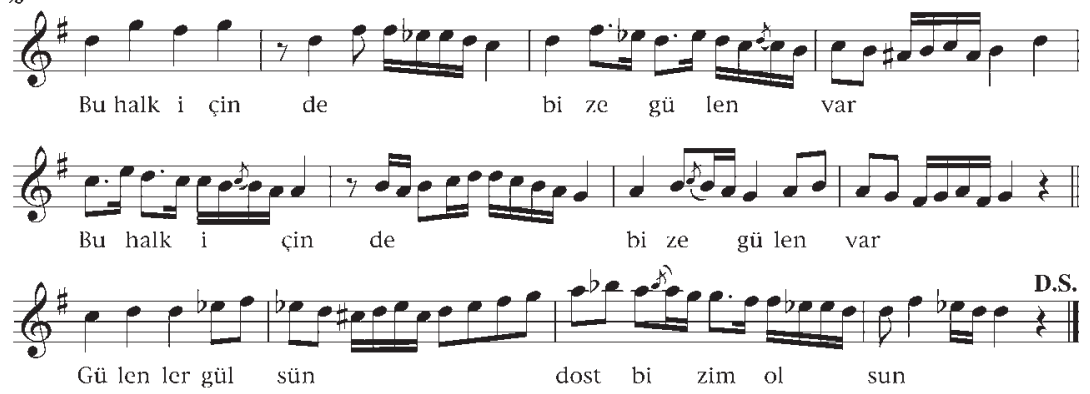

Yar yüreğim yar gör ki neler var Bu halk içinde bize gülen var Gülenler gülsün dost bizim olsun
Split my heart, Beloved, and see what is there Among these people are those who laugh at us Let them laugh, as long as the Friend is ours 
Rhythmic pattern: Evsat
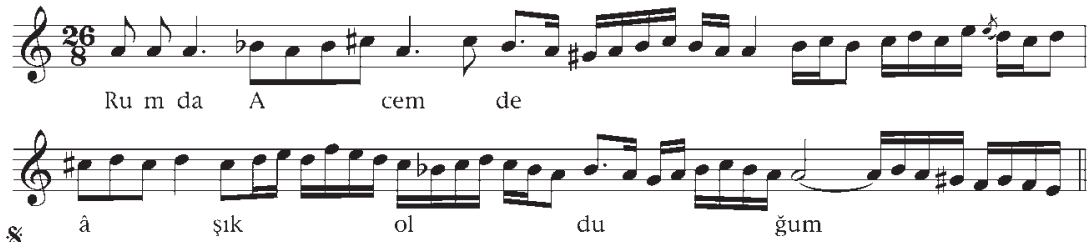

$\%$
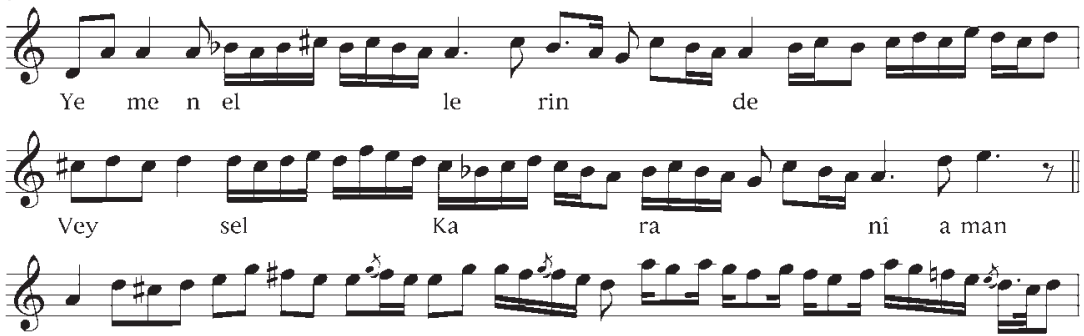
Al lâ
ha
bî
bi

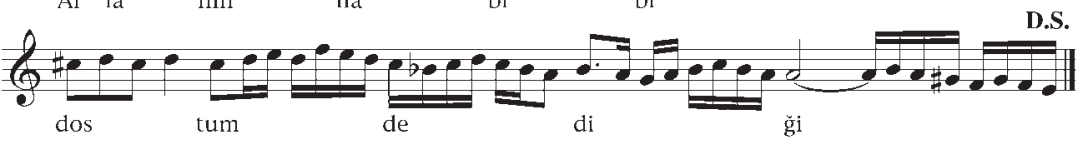

Rumda Acemde âşık olduğum Yemen ellerinde Veysel Karanî Allâhın habîbi dostum dediği
He whom I love, in Turkey, in Persia Uways al-Qarani in the country of Yemen

God's beloved, whom He has called his friend

\section{Acempuselik İlâhî}

Rhythmic pattern: Düyek

Composer: Balat Şehyi Kemal Efendi
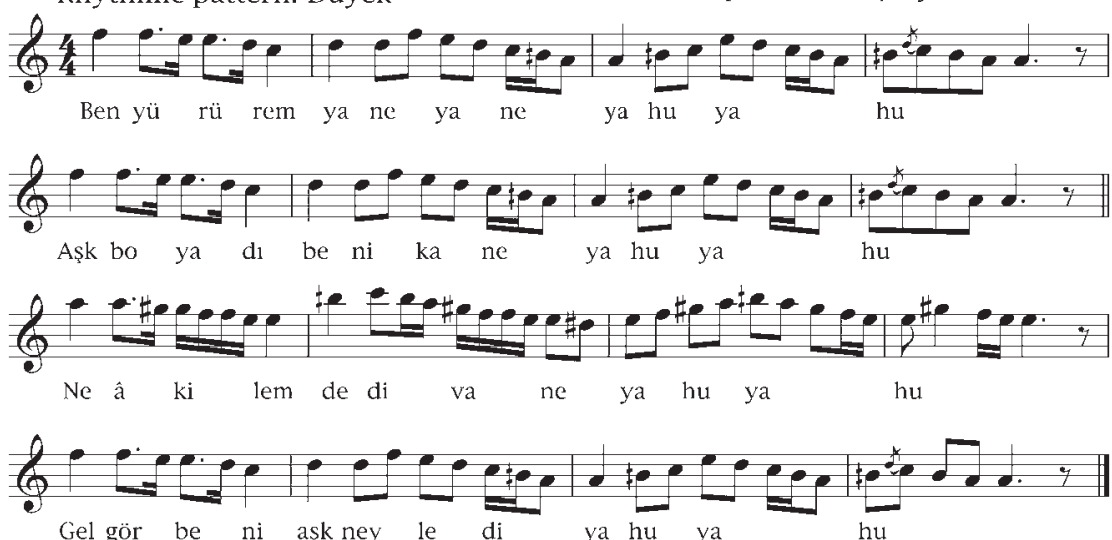

Ben yürürem yane yane

Aşk boyadı beni kane

Ne âkilem de divane

Gel gör beni așk neyledi
I wander burning

Love dyed me with blood

I am neither rational nor mad

Come see what love has done to me

\{Grace Smith, The Poetry of Yūnus Emre (Berkeley, CA, 1993), p. 138\} 


\section{GLOSSARY}

\begin{tabular}{|c|c|}
\hline $\bar{a} d \bar{a} b$ & rules, etiquette, protocol \\
\hline$a b d \bar{a} l$ & dervish \\
\hline$a k h \bar{\imath}$ & $\begin{array}{l}\text { member of a mystical professional organization (cf. } \\
\text { futuwrwa) }\end{array}$ \\
\hline 'alam & standard, badge \\
\hline 'älim, pl. 'ulama' & religious scholar \\
\hline alp & hero \\
\hline$a m \bar{\imath} r$ & commander, officer \\
\hline $\operatorname{arba} a^{\prime} \bar{m}$ & forty, i.e. forty-day retreat for religious exercises \\
\hline 'ârif, pl. 'urafä' & knower of God, mystic (cf. ma'rifa) \\
\hline 'arüd & the Arabo-Persian quantitative metrical system \\
\hline 'āshrq & lover of God; minstrel, saz poet \\
\hline$b \bar{a} b$ & spiritual leader \\
\hline$b \bar{a} b \bar{a}$ & "father," honorific title used especially in dervish circles \\
\hline bakhshi & saint, sorcerer, popular poet \\
\hline bātinī & 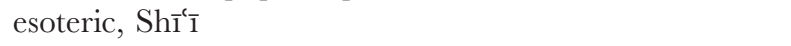 \\
\hline bey & tribal chief, lord \\
\hline chilla-khāne & $\begin{array}{l}\text { place where religious devotees shut themselves up for a } \\
\text { forty-day retreat (= chilla) }\end{array}$ \\
\hline cönk & miscellany, anthology of folk poetry \\
\hline dargāh & dervish convent \\
\hline dastān & a type of long strophic poem; ballad or epic \\
\hline dawr & cycle of existence \\
\hline dawriyya & creation poem \\
\hline dhikr & remembrance of God; Șūī séance \\
\hline$d \bar{\imath} w \bar{a} n$ & collection of poems of a poet \\
\hline er & man, saint \\
\hline erenler & saints, Șūfì spiritual leaders \\
\hline fana $\bar{a}^{\prime}$ & $\begin{array}{l}\text { annihilation, passing away from self and its replacement } \\
\text { by a pure consciousness of God }\end{array}$ \\
\hline faq̄̄h & jurist \\
\hline faq $\bar{\imath} r$ & dervish \\
\hline
\end{tabular}




\section{GL O S S A R Y}

\begin{tabular}{|c|c|}
\hline Fātiha & opening süra of the Koran \\
\hline fatwo & religious opinion, judicial order \\
\hline futuwwa & $\begin{array}{l}\text { a semi-religious fraternity with a chivalrous code of } \\
\text { behavior, often associated with guilds (cf. } a k h \bar{\imath})\end{array}$ \\
\hline$g h \bar{a} z \bar{\imath}$ & warrior, warrior for the faith \\
\hline Hadith & Prophetic tradition \\
\hline hākim & judge \\
\hline$h \bar{a} l$, pl. ahwwāl & mystical state \\
\hline haqa'iq & realities of God \\
\hline hikmat & $\begin{array}{l}\text { "wisdom": name given to quatrains in the Yasawiyya } \\
\text { poetic tradition }\end{array}$ \\
\hline hukm, pl. hukūm & religious norms \\
\hline hulül & indwelling of God in a creature \\
\hline$h \bar{u} r \bar{\imath}$ & female denizen of paradise \\
\hline iḩrām & garb of pilgrims going to Mecca \\
\hline$\ddot{j} \bar{a} z a$ & permission to teach a work on the authority of its author \\
\hline$i l \bar{a} h \bar{\imath}$ & hymn \\
\hline imām & $\begin{array}{l}\text { supreme leader of Twelver Shī'ism; founder of one of the } \\
\text { four Sunnī madhhabs }\end{array}$ \\
\hline$i q t \bar{a}^{\mathrm{c}}$ & estate, land grant \\
\hline ‘ishq & ecstatic love of God \\
\hline ittihāed & union with God \\
\hline jihād & struggle for the faith, war against unbelievers \\
\hline kalām & scholastic theology \\
\hline karāma & saintly miracle \\
\hline khalīfa & deputy or spiritual successor of a shaikh/pīr \\
\hline khalwa & solitary religious devotions \\
\hline$k h \bar{a} n$ & ruler \\
\hline khānqāh & dervish convent \\
\hline khilāf & divergences in law \\
\hline khirqa & dervish patched cloak \\
\hline khutba & Friday sermon \\
\hline$k h w \overline{a j} a$ & master \\
\hline kopuz & ancestor of the $s a z$ \\
\hline koşma & a type of strophic verse \\
\hline márifa & experiential knowledge of God (cf. 'ārif) \\
\hline madhhab & school of law; sect \\
\hline madrasa & Islamic law school \\
\hline mahabbat & love \\
\hline mahd $\bar{\imath}$ & an eschatological figure similar to a messiah \\
\hline majdhūb & one obsessed with divine love \\
\hline majlis & religious assembly, course of instruction \\
\hline$m a j m \bar{u}^{\prime} a$ & miscellany, anthology \\
\hline manāqib & legendary deeds of Șūfì saints \\
\hline
\end{tabular}




\begin{tabular}{|c|c|}
\hline manzūma & poem, verse \\
\hline maqām, pl. maqāmāt & $\begin{array}{l}\text { stage on the mystical path; musical mode; tomb; a } \\
\text { literary genre }\end{array}$ \\
\hline maslak & path, especially mystical path \\
\hline mathnawe & rhymed couplets \\
\hline mihrāa & prayer niche indicating the direction of Mecca \\
\hline mudarris & professor of law at a madrasa \\
\hline muftī & one who gives formal legal opinions ( fatwās) \\
\hline mulamma & macaronics, half in one language and half in another \\
\hline mulhid & heretic, unbeliever \\
\hline munājāt & extempore prayers, intimate conversations with God \\
\hline murìd & novice, disciple \\
\hline murshid & spiritual guide \\
\hline nefes & $\begin{array}{l}\text { "breath": name given to religious poems in the Bektashī } \\
\text { tradition }\end{array}$ \\
\hline ozan & troubadour poet-singer \\
\hline$p \bar{\imath} r$ & (s.v. shaikh) Șūfì master, elder \\
\hline post & sheepskin, symbol of spiritual succession \\
\hline$q \bar{a} l$ & speech, doctrine, book-learning \\
\hline qubba-i alif-tāj & dome-shaped Bektashī headgear \\
\hline $\operatorname{rad} \bar{\imath} f$ & repetition of word or phrase at the end of each couplet \\
\hline Rāfị̂̀ & $\operatorname{Sh}_{\overline{1}}^{-} \overline{1}$, heretic \\
\hline Rūm & Anatolia, Byzantium \\
\hline$s a b q$ & precedence \\
\hline sadr & paramount person, leader \\
\hline sagu & elegy \\
\hline säjā $d a$ & prayer rug \\
\hline $\operatorname{sam} \bar{a}^{c}$ & Șūfì séance with music \\
\hline sancak & district \\
\hline saz & Turkish stringed instrument \\
\hline shaikh & Șūfì master, elder \\
\hline $\operatorname{Sharī}^{`} a$ & Islamic law \\
\hline siğgr & "hunt," royal battue \\
\hline sipāh $\bar{\imath}$ & cavalry soldier \\
\hline silsila & chain of authority, genealogy of spiritual affiliation \\
\hline sofra & tablecloth \\
\hline şölen & public banquet \\
\hline subaşı & police chief, constable \\
\hline șudūr & emanation \\
\hline sunna & any saying or action of the Prophet \\
\hline sūra & chapter of the Koran \\
\hline $\operatorname{tafs\overline {r}r}$ & exegesis, especially Koranic \\
\hline$t \bar{a} j$ & crown, dervish headgear \\
\hline tajalli & the self-disclosure of God \\
\hline
\end{tabular}




\begin{tabular}{|c|c|}
\hline takwīn & creation \\
\hline tarīqa & Șūfì brotherhood, path \\
\hline tawhị $\bar{d}$ & proclaiming the unity of God \\
\hline tekke & dervish lodge \\
\hline tezkireci & Ottoman biographer \\
\hline timar & military land grant \\
\hline töre & customary law (cf. yasa) \\
\hline türbe & mausoleum \\
\hline türkü & folk song \\
\hline 'ulamà' & religious scholars \\
\hline uṣul al-fiqh & the "roots" or bases of Islamic jurisprudence \\
\hline 'uzla & withdrawal for religious exercise \\
\hline wahda & unity (of God) \\
\hline wahdat al-wujūd & $\begin{array}{l}\text { unity of being (the metaphysical system associated with } \\
\text { Ibn al-'Arabī) }\end{array}$ \\
\hline waqf & pious endowment \\
\hline wujūdiyya khayāliyya & panthéism idéaliste \\
\hline yargu & court of interrogation \\
\hline yarlı̆ & edict \\
\hline yasa & law, tribal custom (cf. töre) \\
\hline zāwiya & Șūfì lodge \\
\hline zind̄̄q & heretic \\
\hline
\end{tabular}




\section{BIBLIOGRAPHY}

As described at the beginning of this book, the third edition of Early Mystics did not include a proper bibliography. Instead, selective works were incorporated in the index, sometimes by title and sometimes by author. In some cases this bibliographic information was incomplete, and in other cases it was combined with annotations. The bibliography given below includes all works cited in the text. We have retained those annotations that might still be of interest. All works cited by Orhon Köprülü or Fevziye Tansel in their prefaces, or added to the text by Orhon Köprülü, are in brackets []. All works added by the translators are in braces \{\}. All Turkish works published before 1929 are in the Arabic alphabet. English translations are given of the titles of all Turkish works published after 1900, of all Russian works, and of one Qazaq work. Finally, it should be noted that Köprülü's private library is now in the possession of Yapı Kredi Bankası. Much of it is housed and catalogued in the Yapı Kredi Sermet Çifter Kütüphanesi, İstiklal Caddesi, No. 285 Beyoğlu, Istanbul.

'Abd Allāh Anșāāī al-Harawī. Munājāt. Istanbul, 1301/1883-4. \{English trans. Lawrence Morris and Rustam Sarfeh as Munājāt: The Intimate Prayers of Khwajīh 'Abd Allāh Anșārī. New York, 1975.\}

'Abd Allāh Bosnawī. Tajalliyāt 'arā' is al-nușūs. Commentary in Turkish on Ibn al-'Arabī's Fuṣuṣ al-hikam. Būlāq, 1252/1836-7. Also Istanbul, 1873. \{English trans. Bulent Rauf et al. as Ismail Hakki Bursevi's Translation of, and Commentary on, Fusus al-hikam by Muhyiddin Ibn 'Arabi (attributed to 'Abd Alläh Bosnawī). 4 vols. Oxford, 1986.\}

'Abd al-Ghaffār b. Hasan Kirimī. 'Umdat al-tawā̄inkh wa 'l-akhbār. Unique MS 2331 in the Esad Efendi Library in the Süleymaniye in Istanbul. According to Köprülü, this abridged work, which is composed of 327 folios, on each page of which are twenty-three lines of about fourteen words each, is a general history of Islam. The author, who states that he was a member of the 'ulam $\vec{a}$ ', incurred the wrath of Selim Giray b. Kaplan Giray, the Khān of Crimea, in 1157/1744-5. He was banished first to the village of Șafā Qongrati, which was his farm, from there to his home in the small town of Qānșū, and from there to the fortress of Soghujaq. In the latter, he wrote his history during the reign of Sultan Maḥmūd b. Mușțaā. This work, which includes bits of important information on history and literature $\{$ in general $\}$, is primarily a detailed account of the history of Crimea, and in this respect is without equal. Beginning on folio 294, the author describes Devlet Giray and in the course of this description mentions the wars in which he was engaged and the circumstances in which he was killed in battle (martyred). The information that he gives on the well known poet Thābit, for example, 


\section{B I B L I O G R A P H Y}

is very valuable. The following are the works that he says were his sources: al-Tabarī, Shāhnāme, Fihānnumā, Ibn Shihna's Rawdat al-munāzarā, Rawdat al-șafā, Murūj al-dhahab, Taqwīm al-buldān of Sulțān 'Imād al-Dīn al-Hamawī, Zubdat al-ta'rīkh, 'Ālī’s Kunh

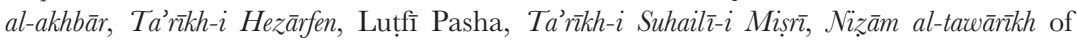

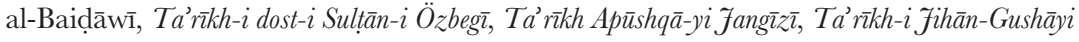
of 'Alī 'l-Yazdī, Fam'iyyāt-i Khair al-Dīn-zāde Muhammad al-Shīrn̄ī. Because the 'Umdat al-tawāinkh is based on these sources, some of which are very useful and unknown to us, it is a very important work for Turkish history.

'Abd al-Hamīd Lāhawrī. Pādishāhnāme. 3 vols. Calcutta, 1866-72.

Abū 'l-Fidā. Mukhtașar ta'n̄̄kh al-bashar. 2 vols. Istanbul, 1286/1869-70.

Abū 'l-Ghāzī Bahādur Khān. Shajara-i Turk. According to Köprülü, J. J. P. Desmaisons collated various MSS of this work and then published an annotated edition of the text and a French translation as Histoire des Mogols et des Tatars. 2 vols. St Petersburg, 1871-4. Ahmed Vefik Pasha translated part of it into Turkish. Subsequently, Riza Nur published an abridged Turkish translation of the first part of the French translation.

Abū Ḥayyān al-Gharnāṭ̄i. Kïtāb al-Idrāk li-lisān al-atrāk. Istanbul, 1309/1893. \{Superseded by Ahmed Caferoğlu's edn. Istanbul, 1931; and especially A. Melek Özyetgin as Ebb̂ Hayyân, Kitâbu'l-İdrâk li Lisâni'-Etrâk. Ankara, 2001.\}

Abū 'l-Wafā-yi Baghdādī. Manāqib-i Tāj al-'Árifīn. MSS in Köprülü's private library and MS 2427 in the Esad Efendi Library in the Süleymaniye in Istanbul.

Aflākī. Manāqib al-'ārifīn. French trans. Cl. Huart as Les Saints des derviches tourneurs. 2 vols. Paris, 1918-22. \{Ed. Tahsin Yazıcı. 2 vols. Ankara, 1976-80; English trans. John O'Kane as The Feats of the Knowers of God. Leiden, 2002.\}

(Ağa) Aḥmad 'Alī Aḥmad. Risāla-i tarāna. Calcutta, 1867.

Aḥmad 'Izzī-Zāde Sayyid 'Abd al-Lațîf. Khulāsat al-wafayāt. MS in the Hâşim Pasha Library in the Süleymaniye in Istanbul. Not further identified.

Ahmad Yasawī. Dī̌ān-i Hikmat. Istanbul, 1299/1881-2. 3rd Kazan edn, 1311/1893-4. \{Ed. Hayatı Bice. Ankara, 1993. Facsimile edn. Yusuf Azmun. Istanbul, 1994.\}

Aḥmad b. Jalāl al-Dīn al-Kāsānī. See Makhdūm-i A'ẓam.

Aḥmad b. Mạ̣mūd Yüknekī. 'Atabat al-haqā'iq. Ed. Necib Âsım inder the mistaken title of Hibetül'-Hakânnk. Istanbul, 1334/1918. \{Superseded by R. R. Arat (ed.) as Atebetü'lhakayn. Istanbul, 1951.\}

Ahmed Rifat. Lughât-i ta'rîkhiyya ve jughrâfyyya. 7 vols. Istanbul, 1299/1881.

Ahmed Vefik Pasha. Lehce-i osmânî. 2nd edn. Istanbul, 1306/1890.

\{Akar, Metin. "Şeyyad Hamza hakkında yeni bilgiler" [New information on Shayyād Hamza]. Türklük Araştrmalan Dergisi, 2 (1986), 1-14.\}

\{Akhmetgaleeva, Ia. S. Issledovanie tiurkoiazychnogo pamiatnika "Kisekbash kitaby" [Research on the Turkic-language monument "Kisek-bash kitabï"]. Moscow, 1979.\}

Aq Shams al-Dīn. Risāla-i Aq Shams al-Dīn. MS in the Hâlis Efendi Library in the Süleymaniye in Istanbul. Same work under the title Risālat al-nūriyya MS 989 in the Millet Library in Istanbul.

\{Algar, Hamid. "The Naqshbandī Order: A Preliminary Survey of Its History and Significance." Studia Islamica, 44 (1976), 123-52.\}

\{__ "A brief history of the Naqshbandî order." Marc Gaborieau, Alexandre Popovic, and Thierry Zarcone (eds), Naqshbandîs: cheminements et situation actuelle d'un ordre mystique musulman. Istanbul, 1990, pp. 3-44.\}

\{__ "Kubrā." $\left.E I^{2}.\right\}$ 
$\left\{\right.$ _— "Nadj̣m al-Dīn Rāzī Dāya." $\left.E I^{2}.\right\}$

\{_ "Nakshband." $E I^{2}$.

$\left\{-\right.$ "Nukțawiyya." $E I^{2}$. $\}$

\{__ "Sayf al-Dīn Bākharzī." $E I^{2}$.

\{__ "Barāq Bābā." EIr.\}

\{_—_Bektāš." EIr.\}

\{—— "Bektāšīya." EIr.\}

\{Algar, Hamid et al. "Nakshbandiyya." $E I^{2}$.

[Alî Emirî. "Cevap." A response to a letter by Alî Rızâ criticizing Köprülü's Yeni Osmanh tarihi-edebiyat (Istanbul, 1916) in Tarih ve Edebiyat Mecmuası, year 3, no. 25, March 31, 1336/1918, pp. 635-49.]

'Ālī, Mușțafā b. Aḥmad. Kunh al-akhbār. 5 vols. Istanbul, 1861-9.

'Alī Ra'̄̄is b. Husain, Sayyidī. Mir'āt al-mamālik. Istanbul, 1313/1895-6. \{English trans.

A. Vambéry as The Travels and Adventures of the Turkish Admiral Sidi Ali Re'is in India, Central Asia and Persia in the Years 1553-1556. Edn of 1899. Reprinted Lahore, 1975.

New edn Mehmet Kiremit. Ankara, 1999.\}

\{Alpay, Günay. "Hakīm Ata." $E I^{2}$.\}

\{Ambros, Edith. "Surūrī." $\left.E I^{2}.\right\}$

\{_ "Türkü." $\left.E I^{2}.\right\}$

$\left\{-\right.$ "Yazıdj1-oghlu." $E I^{2}$.\}

$\left\{\_\right.$"Yūnus Emre." $E I^{2}$. $\}$

Amīn al-Dīn Bābā b. Dā'ūd Faqīh. Risāla-i qudsiyya. Unique MS in the possession of Kilisli Rifat Bey.

Andreas, F. C. The Book of Mainyo-i-khard . . Kiel, 1882.

\{Andrews, Walter. An Introduction to Ottoman Poetry. Minneapolis, 1976.\}

\{Arat, R. Rahmeti. "Kutadgu Bilig." $\dot{I} A$.

van Arendok, C. "Futuwwa." EI $I^{1}$

'Āshıq Chelebi. Mashā'ir al-shu'arā'. Also referred to as his Tadhkira. MS in Köprülü's private library. \{Ed. G. M. Meredith-Owens. London, 1971.\}

'Āshıq Pasha. Ghañ̄bāme. MS 333 in the Beyazıt Umumi Library in Istanbul. \{Ed. Kemal Yavuz as Assık Paşa, Garib-nâme. 4 vols. Istanbul, 2000.\}

'Āshıq Pasha-Zāde. Tawārikhh-i āl-i 'Uthmān. Ed. 'Ālī Bey. Istanbul, 1332/1914. \{Ed. H.

Nihal Atsız as Tevarih-i âl-i Osman, Âşıkaşaoğlu tarihi. Ankara, 1985.\}

Âsım, Necib. Türk tarihi. Istanbul, 1316/1898-9.

— Millî arüz [The national (literary) meter]. Istanbul, 1329/1911.

Âsım, Necib and Mehmed Ârif. Türk tarihi-i umûmisi [A general history of the Turks]. Istanbul, 1325/1907.

Osmanl tarihi [A history of the Ottomans]. Istanbul, 1335/1916-17.

\{Aslanapa, Oktay. Turkish Art and Architecture. New York, 1971.\}

[Ateş, Ahmed. "Muhyi-d-Din Arabî." İA.] \{Abridged in $E I^{2}$ as "Ibn al-'Arabī."

\{—_Senâ'î." $\dot{I} A$. $\}$

\{Atil, Esin (ed.). Turkish Art. Washington, DC, 1980.\}

'Atțār, Farīd al-Dīn. Tadhkirat al-awliy ă'. Ed. R. A. Nicholson. London, 1905-7.

- Mantiq al-tair. Köprülü used an edition published in Iran. In his time all Turkish translations were in MS. \{English trans. Afkham Darbandi and Dick Davis as The Conference of the Birds. London: Penguin Books, 1984.\}

'Awfī, Muḥammad. Lubāb al-albāb. Ed. E. G. Browne and M. Qazvīnī. 2 vols. London, 1903-6. 


\section{B I B L I O G R A P H Y}

\{Babadžanov, Baxtiyor, M. "On the History of the Naqšbandīya Muğaddidīya in Central Māwarāannahr in the Late 18th and Early 19th Centuries." Michael Kemper, Anke von Kügelgen, and Dmitriy Yermakov (eds), Muslim Culture in Russia and Central Asia from the 18th to the Early 20th Centuries. Berlin, 1996, pp. 385-413.\}

\{Babinger, F. Die Geschichtsschreiber der Osmanen und ihre Werke. Leipzig, 1927.\}

\{_ "Nesīmī." $\left.E I^{2}.\right\}$

\{—_Niyāzī." $\left.E I^{2}.\right\}$

Bābur, Zahīr al-Dīn. Dīwān. MS in Köprülü's private library. Partially published by Köprülü in "Zahiruddin Muhammad Bâbur Şah'ın 'Risâle-i vâlidiye"” [The Risāla-i wālidiyya of Zahīr al-Dīn Muhammad Bābur Shāh]. MTM, 1 (1331/1915), 113-24, 235-56, 464-80, and 2 (1331/1915), 308-26. \{Ed. Bilâl Yücel as Bâbür Dîvân. Ankara, 1995. This edn includes Bābur's verse translation of the Risāla-i wälidiyya, pp. 95-119. English trans. A. J. E. Bodrogligeti as "Bābur Shah's Chaghatay Version of the Risāla-i Vālidīya: A Central Asian Turkic Treatise on How to Emulate the Prophet Muhammad." Ural-altaische Fahrbucher, 56 (1984), 1-61.\}

- Bāburnāme. Facsimile ed. A. S. Beveridge as The Bábar-náma. Leiden, 1905. \{Ed. Eiji Mano as Bâbur-nâma (Vaqâyi') I: Critical Edition Based on Four Chaghatay Texts; II: Concordance and Classified Indexes. 2 vols. Kyoto, 1995-96. English trans. Wheeler Thackston. Oxford, 1996.\}

Badā’ūn̄̄, 'Abd al-Qādir. Muntakhab al-tawārn̄kh. Calcutta, 1868. \{Partial English trans. of the 1925 Calcutta edn by George Ranking et al. 3 vols. Karachi, 1976-8.\}

Bahr al-wilāya. MS in Hâlis Efendi Library in the Süleymaniye in Istanbul. According to Köprülü, this is an elementary work of no importance.

[Bala, Mirza. "Kopuz." İA.]

Al-Balādhurī. Futūh al-buldān. Leiden, 1866. \{English trans. Philip Hitti and F. C. Murgotten as The Origins of the Islamic State. 2 vols. New York, 1914-24.\}

\{Baldick, J. "Uways al-Karanī." $E I^{2}$.

\{Balivet, Michel. Islam mystique et révolution armée dans les Balkans ottomans: vie du Cheikh Bedreddîn le "Hallâj des turcs" (1358/59-1416). Istanbul, 1995.\}

[Banarl, N. S. Resimli Türk edebiyatı tarihi (An illustrated history of Turkish literature). Istanbul, 1948.]

Barbier de Meynard, G. A. (ed.). Dictionnaire géographique, historique et littéraire de la Perse et des contrées adjacentes. Paris, 1861.

—L Le Boustan, ou Verger; poem persan de Saadi; traduit pour la premièr fois en français . . . Paris, 1880.

Barthold, W. Turkestan down to the Mongol Invasion. Russian edn 2 vols. St Petersburg, 1898-1900. \{English trans., 1928; revised, London, 1968.\}

__ "Balāsāghūn." $E I^{1}$.

"Bukhārā." $E I^{I}$.

"Burhān." EII.

"Fārāb." $E I^{1}$.

"Ghuzz." $E I^{I}$.

\{Barthold, W. and B. Spuler. "Awliyā Ata." $E I^{2}$.

\{_—_Farāb." $\left.E I^{2}.\right\}$

\{Başgöz, İlhan. "From Gosan to Ozan." International Fournal of Central Asian Studies, 2 (1997), 5-13.\}

\{Bashir, Shahzad. "Enshrining Divinity: The Death and Memorialization of Fażlallāh Astarābādī in Hurūfì Thought.” Muslim World, 90 (2000), 289-308.\} 
\{Bausani, A. "Djalāl al-Dīn Rūmī." $\left.E I^{2}.\right\}$

\{— "Hurūfiyya." $E I^{2}$.\}

\{Bayram, Mikâil. Ahi Evren ve ahi teşkilâtınn kuruluşu [Akhī Evren and the establishment of the Akhī organization]. Konya, 1991.\}

\{- Tarih ışı̆ğnda Nasreddin Hoca ve Ahi Evren [Nāṣir al-Dīn Khwāja and Akhī Evren in the light of history]. Istanbul, 2001.\}

\{Bayram, S. "Selçuklu vakfiyeleri üzerine bazı düşünceler" [Some thoughts on Seljuk waqfiyyas]. In IV. Milli Selçuklu Kültür ve Medeniyeti Semineri Bildirileri. Konya, 1995, pp. 135-47.\}

\{Baysun, Cavid. "Evliya Çelebî." İA.\}

\{Beldiceanu-Steinherr, I. "Hüdā'̄i." EI ${ }^{2}$.

Berezin, I. Recherches sur les dialectes musulmans. Kazan, 1848.

\{Bernardini, Michele. "Solțan Jomjome et Jesus le Paraclet." Benjamin Lellouch and Stéphane Yerasimos (eds), Les traditions apocalyptiques au tournant de la chute de Constantinople. Paris, 1999, pp. 35-53.\}

Beyâtî Shaikh Mahmûd. Jām-i jam āyàn. Composed from the Oghuznāme. Pub. Alî Emîrî Efendi. Istanbul, 1331/1913. \{A modern Turkish trans. is included in Atsiz, Osmanli tarihleri. Istanbul, 1949.\}

Bianchi, T. Dictionnaire Turc-Français. 2 vols. Paris, 1871.

\{Blachère, R. et al. "Ghazal." $E I^{2}$.

Blochet, E. Introduction à l'histoire des mongols. Gibb Memorial Series, Old Series vol. 18. London, 1911.

"Études sur l'histoire religieuse de l'Iran: (1) De l'influence de la religion mazdéenne sur les croyances des peuples turcs. (2) L'ascension au ciel du prophète Mohammed." RHR, 38 (1898), 26-63; 40 (1899), 1-25, 203-36. Turkish trans. of the first part as "Mazda'izmin Türk kavimlerinin i'tikadları üzerinde tesiri." MTM, 1 (1331/1913), $125-61$.

\{_— "Christianisme et mazdéisme chez les Turks orientaux." Revue de l'Orient Chrétien, 27 (1929-30), 31-125.\}

\{De Boer, Tj. and L. Gardet. "Ālam.” $E I^{2}$.\}

\{Bombaci, Alessio. Storia della letteratura turca. Milan, 1956.\}

[Boratav, Pertev. "Battal." í.

$\left\{-\right.$ "Māni." $E I^{2}$. $\}$

\{— "Ozan." $\left.E I^{2}.\right\}$

\{Borovkov, A. K. "Ocherki po istorii uzbekskogo iazyka (Opredelenie iazyka khikmatov Akhmada Iasevi)" [Studies on the history of the Uzbek language (Determination of the language of the hikmats of Ahmad Yasawī]. Sovetskoe vostokovedenie [Soviet Oriental Studies], 5 (1948), 229-50.\}

\{Bosworth, C. E. The New Islamic Dynasties. New York, 1996.\}

$\left\{\_\right.$"Saldjukids." $\left.E I^{2}.\right\}$

\{—_ "Sighnāk.." $\left.E I^{2}.\right\}$

$\left\{-\right.$ "Tarāz." $\left.E I^{2}.\right\}$

\{__ "Asfijāab." EIr.\}

\{__ "Balāsāgūn." EIr.\}

[Bouvat, L. "La Presse Ottomane." Revue du Monde Musulman, 38 (1920), 217-44.]

\{Böwering, G. "Abū Sa'̄îd . . Abìill-Kayr." EIr.\}

\{_— "Baqā̄' wa Fanā'." EIr. $\}$

\{Bregel, Yu. "Mangishlak." $E I^{2}$.\} 


\section{B I B L I O G R A P H Y}

Brockelmann, G. Geschichte der arabischen Litteratur. 2nd edn. Leipzig, 1909.

__ 'Ali's Qissa' i Jusuf, der älteste Vorläufer der osmanischen Litteratur. In Abhandlungen der Königlichen Preussischen Akademie der Wissenschaften, no. 5. Berlin, 1917.

\{__ "Newa' is Biographien türkischer und zeitgenössischer Mystiker." J. Fück (ed.),

Documenta Islamica Inedita (Festschrift R. Hartmann). Berlin, 1952, pp. 221-49.\}

$\left\{-\right.$ "Kalīla wa-Dimna." $E I^{2}$.

\{De Bruijn, J. T. P. "Sanā'̄." $E I^{2}$.

\{Buhl, Fr. "Muḥammad Ibn al-Hanafiyya." $E I^{2}$.\}

[Buluç, Sâdettin. "Şeyyad Hamza." İA.]

Al-Burghāzī, Yaḥyā Ibn al-Khalīl. Futuwewatnāme. MS in Köprülü's private library.

Another in the possession of Mehmed Ârif.

\{Burrill, Kathleen. "Sheyyād Hamza." $E I^{2}$.\}

\{Çağatay, Neşet. Bir Türk kurumu olan ahilik [The akhiss, a Turkish association]. Ankara, 1989.\}

Çaghatay-Farsî lugati. MS in the Istanbul University Library copied from a MS in the Pest Academy Library.

\{Cahen, Cl. Pre-Ottoman Turkey. New York, 1968.\}

\{__ "Note sur les débuts de la futuwwa d'an-Nāșir." Oriens, 6 (1953), 18-22.\}

\{-et al. "Futuwwa." $E I^{2}$.

$\left\{-\right.$ et al. "Ghuzz." $\left.E I^{2}.\right\}$

Cahun, Leon. Introduction à l'histoire de l'asie, les turcs et les mongoles. Paris, 1896.

\{Calmard, Jean. "Dū'l-Faqār." EIr.\}

\{Calmard, J. et al. "Ṣadr." $E I^{2}$.

[Canard, M. "Al-Batțāl." $E I^{2}$.]

Capus, G. A travers le royaume de Tamerlan . . . Paris, 1892.

Carra de Vaux, Bernard. Avicenne. Paris, 1900. \{Reprinted Amsterdam, 1974.\}

_ Gazali. Paris, 1902.

"Djalāl al-Dīn Rūmī." EI .

Cemâlü'd-Dîn Velidî Efendi. Tatar edebiyatınn banş̧ [The reconciliation of Tatar literature]. Orenburg, 1912.

\{Çetin, Nihad M. "Lațīfî." $E I^{2}$.\}

Chavannes, E. Documents sur les Tou-Kioue (Turcs) occidentaux. St Petersburg, 1903.

\{Chittick, William. The Sufi Path of Knowledge. Albany, NY, 1989.\}

\{-The Self-disclosure of God. Albany, NY, 1998.\}

\{—_Ṣadr al-Din al-Kūnawī." $E I^{2}$.

\{—_Waḥdat al-Shuhūd." $E I^{2}$.

\{Cler, J. "Saz." $E I^{2}$.\}

\{Cunbur, Müjgân. "Evliyâ Çelebi Seyâhatnâmesi'nde Ahmed Yesevî" [Ahmad Yasawī in the Seyāhatnāme of Evliyā Chelebi]. Erdem, vol. 7, no. 21 (1995), 887-917.\}

\{Dankoff, Robert. An Evliya Çelebi Glossary. Department of Near Eastern Languages and Civilizations, Harvard University, 1991.\}

\{_ "Kāshgharī on the Tribal and Kinship Organization of the Turks." Archizum Ottomanicum, 4 (1972), 23-43.\}

\{__ "Three Turkic Verse Cycles Relating to Inner Asian Warfare." Harvard Ukranian Studies, 3-4 (1979-80), part 1, pp. 151-65.\}

\{__ "On Nature in Karakhanid Literature.” Journal of Turkish Studies, 4 (1980), 27-35.\}

\{__ "Yūsuf Khāṣṣ Hāâjib." EI $I^{2}$.\}

Darmesteter, J. Les Origines de la poésie persane. Paris, 1887. 
Davids, Arthur Lumley. A Grammar of the Turkish Language. London, 1832. French trans. Sarah Davids as Grammaire turke. London, 1836.

Dawlat-Shāh. Tadhkirat al-shu'ară’. Ed. E. G. Browne. London, 1901.

Dede Korkut (or Korkut Ata). Kitāb-ı Dede Korkut. Ed. Kilisli Rifat. Istanbul, 1334/1916. \{Ed. Muharrem Ergin as Dede Korkut Kitâbı. Ankara, 1964. Best edn Semih Tezcan and Hendrik Boeschoten as Dede Korkut Oğuznameleri. Istanbul, 2001. English trans. Geoffrey Lewis as The Book of Dede Korkut. Harmondsworth, 1974.\} According to Köprülü, the Rifat edition was copied from the Berlin MS. He adds that it is obvious that Korkut Ata was not a historical figure and that this book can be considered a remnant of the old Oghuz Destan. Only tradition attributes it to Dede Korkut. He states that after ordering a copy of the original Dresden MS of Kitab-ı Dede Korkut, he had wanted to publish a corrected version of it together with one or two other sections of the Oghuzname that he had obtained. Indeed, he had done the necessary preliminary work for this, writing a long introduction that included extensive historical information on the Oghuz Destan and a detailed bibliography. He had also prepared a separate glossary of the old Turkish words in this work. Unfortunately, he was never able to complete this project.

\{Dedes, Y. Battalname. English trans. and Turkish transcription. Cambridge, MA, 1996.\}

Defrémery, C. "Fragments de géographes et d'historiens arabes et persans inédits relatifs aux anciens peuples du Caucase et de la Russie méridionale." FA, 4th series, 13 (1849), 457-522; 14 (1849), 447-513; 16 (1850), 50-75, 153-201; 17 (1851), 105-62.

\{DeWeese, Devin. Islamization and Native Religion in the Golden Horde: Baba Tükles and Conversion to Islam in Historical and Epic Tradition. University Park, PA, 1994.\}

\{_ "Yasavian Legends on the Islamization of Turkistan." Denis Sinor (ed.), Aspects of Altaic Civilization III. Bloomington, IN, 1990, pp. 1-19.\}

\{_ "Bābā Kamāl Jandī and the Kubravī Tradition among the Turks of Central Asia." Der Islam, 71 (1994), 58-94.\}

\{_ "The Descendants of Sayyid Ata and the Rank of Naqīb in Central Asia." Journal of the American Oriental Society, 1115 (1995), 612-34.\}

\{_— "The Mashā'ikh-i Turk and the Khojagān: Rethinking the Links between the Yasavī and Naqshbandī Sufi Traditions." Journal of Islamic Studies, 7 (1996), 180-207.\}

\{__ "Yasavi Šayhs in the Timurid Era: Notes on the Social and Political Role of Communal Sufi Affiliations in the 14th and 15th Centuries." Michele Bernardini (ed.),

La civiltà timuride come fenomeno internazionale. Rome, 1996, pp. 173-88.\}

\{_ "The Politics of Sacred Lineages in 19th-century Central Asia: Descent Groups Linked to Khwaja Ahmad Yasavi in Shrine Documents and Genealogical Charters." International Fournal of Middle East Studies, 31 (1999), 507-30.\}

$\left\{\_\right.$"The Yasavī Order and Persian Hagiography in Seventeenth-century Central Asia: 'Ālim Shaykh of 'Alīyābād and his Lamahāt min nafahāt al-quds." Leonard Lewisohn and David Morgan (eds), The Heritage of Sufism, vol. 3, Late Classical Persianate Sufism (15011750), The Safavid and Mughal Period. Oxford, 1999, pp. 389-414.\}

\{_ "Dog Saints and Dog Shrines in Kubravī Tradition: Notes on a Hagiographical Motif from Khwārazm." Denise Aigle (ed.), Miracle et karāma: Hagiographies médiévales comparées. Turnhout, Belgium, 2000, pp. 459-97.\}

\{_ 'Sacred Places and 'Public' Narratives: The Shrine of Ahmad Yasavī in Hagiographical Traditions of the Yasavī Sufi Order, 16th-17th Centuries." Muslim World, 90 (2000), 353-76.\}

\{__ "Ahmad Yasavī and the Dog-Men: Narratives of Hero and Saint at the Frontier of Orality and Textuality." Proceedings from a conference on "Theoretical Approaches 


\section{B I B L I O G R A P H Y}

to the Transmission and Edition of Oriental Manuscripts" (Orient-Institut der Deutschen Morgenländischen Gesellschaft, Istanbul. Forthcoming.\}

\{Doğramacı, Baha. Niyazi-yi Mısri hayatı ve eserleri [Niyāzī Miṣrī, his life and works]. Ankara, 1988.\}

Dozy, R. Essai sur l'histoire de l'Islamisme. Leiden, 1879. \{Reprinted Amsterdam, 1966.\}

Turkish trans. Abdullah Cevdet as Tarih-i islâmiyet. 2 vols. Cairo, 1908.

Dubeux, Louis. Tartarie, Béloutchistan, Boutan et Népal. Paris, 1848.

Edhem, Halil. Kayseriye şehri [The city of Kayseri]. Istanbul, 1334/1915-16.

Editors. "Battāal." EI $I^{I}$.

[Editors. "Hurûfîlik." İA.]

\{Elwell-Sutton, L. P. “"arūż.” EIr.\}

\{Eraslan, Kemal. Ahmed-i Yesevî, Dîvân-ı Hikmet'ten seçmeler [Selections from the Dīwān-i Hikmat of Ahmad Yasawī]. Ankara, 1983.\}

\{———ûsuf Hâs Hâcib." İA.\}

\{Ergun, Sadettin Nüzhet. Bektaşi edebiyat antolojisi [Anthology of Bektashī literature]. 3 vols. Istanbul, 1955-6.\}

\{Ernst, Carl W. Words of Ecstasy in Sufism. Albany, NY, 1985.\}

Eşrefoğlu. Muzakkì 'l-nufūs. Istanbul, 1281/1865. \{Modern Turkish trans. Abdullah Uçman as Müzekki'n-Nüfûs. Istanbul, 1996.\}

Dìwān. Istanbul, 1286/1869-70.

\{Esin, Emel. "Ahmed Yesevî Külliyesi" [The Ahmad Yasawī complex]. Türkiye Diyanet Vakfi İslam Ansiklopedisi. Istanbul, 1988.\}

Esrār Dede. Tadhkirat-i shu'arā'. MS in Köprülü's private library.

Ethé, H. Die Fahrten des Sajid Battâl. 2 vols. Leipzig, 1871.

- Catalogue of Persian, Turkish, Hindustani and Pushtu Manuscripts (in the Bodleian). Part 13, vols 1, 3. Oxford, 1889-1954.

Evliyā Chelebi. Seyāhatnāme. 6 vols. Istanbul, 1314-18/1896-1900. \{Books 1-3, Bağdat Köşkü MSS 304-5, Topkapı Sarayı, Istanbul.\}

\{-Evliya Çelebis Anatolienreise aus dem dritten Band des Seyahatname. Ed. and German trans. Korkut Bugday. Leiden, 1996.\}

[Eyice, Semavi. "Çorum’un Mecidözü’nde Âşık Paşa-Oğlu Elvan Çelebi zâviyesi”" (The zāwiya of 'Āshıq Pasha-Oghlu Elvan Chelebi at Mecidöz near Çorum). TM, 15 (1969), 211-44.]

Faḍl Allāh Hurūfî. Fāwidān. MS in Köprülü's private library.

Fâik, Reşad. Tarih-i edebiyat-ı osmâniyye [A history of Ottoman literature]. Istanbul, 1329/ 1911.

\{Fakhr al-Dīn 'Irāqī. Lama'āt. English trans. William Chittick and Peter Lamborn Wilson as Divine Flashes. New York, 1982.\}

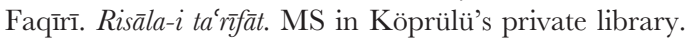

\{Farah, C. E. "Ibn al-Nadjdjār." $E I^{2}$.\}

\{Faroqhi, Suraiya. Der Bektaschi-Orden in Anatolien. Vienna, 1981.\}

\{ "The Life Story of an Urban Saint in the Ottoman Empire." Tarih Dergisi, 32 (1979), 655-78.

\{Feldman, Walter. "Interpreting the Poetry of Mäkhtumquli."Jo-Ann Gross (ed.), Muslims in Central Asia: Expressions of Identity and Change. Durham, NC, 1992, pp. 167-89.\}

Ferid Bey. Vahdet-i vücûd [Unity of being]. Istanbul, 1331/1913.

Ferîdûn Bey. Müseat-ı selâtin [The writings of the sultans]. 2 vols. Istanbul, 1274/1857-8. \{Fernandes, Leonor. The Evolution of a Sufi Institution in Mamluk Egypt: the Khanqah. Berlin, 1988.\} 
Fïdawsī. Shāhnāme. Text and French trans. J. Mohl as Le Livre des rois . . 7 vols. Paris, 1838-78. Translation alone, 1876-8.

Fīrūzābādī, Muhammad b. Ya'qūb. Al-Q̄āmūs al-muhñit. Turkish trans. Ahmed Âsım Ayintabi

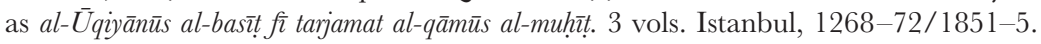

Fleischer, H. Kleinere Schriften. 3 vols. Leipzig, 1885-8.

\{Flemming, Barbara. "Yūsuf and Zulaykhāa," part 2, Turkish Literature. $E I^{2}$.\}

\{Fletcher, J. "Aḥmad K'ājagī b. Jalāl-al-Dīn.” EIr.\}

Flügel, G. Die arabischen, persischen und türkischen Handschriften der Kaiserl.-Königl. Hofbibliothek zu Wien. 3 vols. Vienna, 1865-7.

\{de Fouchecour, C.-H. et al. "Rubāî̀." $E I^{2}$.\}

Foy, K. "Die ältesten osmanischen Transscriptionstexte in gothischen Lettern; zugleich eine Beitrag zur altosmanischen Literatur." Berlin Universität, Seminar für Orientalische Sprachen, Mitteilungen, Westasiatische Studien, 4 (1901), 230-77; 5 (1902), 233-93.

Fraehn, C. Indications bibliographiques relatives pour la plupart à la littérature historico-géographique des arabs, des persans et des turcs... St Petersburg, 1845.

Franck, Adolphe. Dictionnaire des sciences philosophiques. 2nd edn. Paris, 1875.

\{Frank, Allen J. Islamic Historiography and "Bulghar" Identity among the Tatars and Bashkirs of Russia. Leiden, 1998.\}

\{_ "Islamic Shrine Catalogues and Communal Geography in the Volga-Ural Region: 1788-1817." Journal of Islamic Studies, 7 (1996), 265-86.\}

\{Franke, Patrick. Begegnungen mit Khidr. Beirut, 2000.\}

Galib, İsmail. Takvîm-i meskûkât-i selçukiyye [Catalogue of Seljuk coins]. Istanbul, 1309/1891.

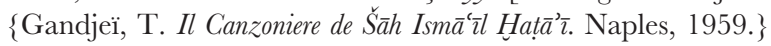

$\left\{-\right.$ "Ismā'îl I: His Poetry." $E I^{2}$.

Ghaib̄i, Șun' Allāh. Suḥbatnāme-i Ghaib̄̄. MS in Hâşim Pasha Library in the Süleymaniye in Istanbul.

Kashf al-ghița'. MS in Köprülü's private library.

Ghujduwān̄̄, 'Abd al-Khāliq. Maqāmāt-i Yūsuf Hamadāñ̄. Appended to Harī̄ī-Zāde's Tibyānn$i$ was $\vec{a}^{\prime} i l$ al-haq $\vec{a} i q$. Ibrahim Ağa MS 432 in the Fatih Library in the Süleymaniye in Istanbul.

Gibb, E. J. W. A History of Ottoman Poetry. 6 vols. London, 1900-9. Turkish trans. Fuad Raif five folios of the first volume as Eş'âr-i osmânîye tarihi. Abdü'l-Ahad Dâvud translated the section on Yūnus Emre.

Giese, F. "Türk elsine ve tarihine dâir bazı yeni alman neşriyatı" [Some recent German publications on Turkish languages and history]. Dârülfünûn Edebiyat Fakültesi Mecmuası, 1 (1332-4), 286-94.

Glück, Heinrich. Türkische Kunst. Budapest and Constantinople, 1917. Turkish trans. Ahmed Cemal as "Türk san'atı." $Y M, 1918$, no. 59, pp. 129-32; no. 60, pp. 149-52; no. 61, pp. $168-72$.

Gobineau, J. A. Les Religions et les philosophies dans l'asie centrale. Paris, 1866. \{Reprinted Paris, 1953.\}

de Goeje, M. J. Bibliotheca Geographorum Arabicorum. 8 vols. Leiden, 1870-94.

Gökalp, Ziyâ. Yeni hayât [Modern life]. Istanbul, 1918.

\{Gökyay, Orhan. Dedem Korkudun kitabı [The book of Dede Korkut]. Istanbul, 1973.\}

\{_ "Cönkler üzerine" [On cönks]. Folklor ve Etnografya Araştrrmalan, (1984), 107-65.\}

\{Golden, Peter. An Introduction to the History of the Turkic Peoples. Wiesbaden, 1992.\}

\{__ "The Migrations of the Oğuz." Archivum Ottomanicum, 4 (1972), 45-84.\}

$\left\{-\right.$ "Sayrām." $\left.E I^{2}.\right\}$ 


\section{B I B L I O G R A P H Y}

\{Gölpınarlı, Abdülbâki. Yunus Emre: Risâlat al-nushiyya ve Divvân [Yūnus Emre: the Risalāt al-nushiyya and Dīwān]. Istanbul, 1965.$\}$

\{—- Türk tasavouf şïri antolojisi [Anthology of Turkish mystical poetry]. Istanbul, 1972.\}

[— Hurûfilik metinleri kataloğu (Catalogue of Hurūfì texts). Ankara, 1973.]

\{__ "Les Organisations de la Futuvvet dans les Pays Musulmans et Turcs et ses Origines."

Revue de la Faculté des sciences économiques de l'Université d'Istanbul, 11 (1949-50), 5-49. Longer version as "İslam ve Türk illerinde fütüvvet teşkilâtı ve kaynakları." İstanbul Üniversitesi Iktisat Fakültesi Mecmuası, 11 (1949-50 [1953]), 3-354.\}

\{_ "Hurûfîlik ve Mîr-i 'alam Celâl Bek'in bir mektubu" [Hurūfism and a letter of Mīr-i 'ālem Jalāl Bek]. TM, 14 (1965), 93-110.\}

$\left\{\_\right.$"Bayramiye." $\left.\dot{I} A.\right\}$

$\left\{-\right.$ "Djilwatiyya." $\left.E I^{2}.\right\}$

La Grande Encyclopédie. 31 vols. Paris, 1886-1902.

Grenard, F. Le Turkestan et le Tibet. Part 2 of J.-L. Dutreuil de Rhins (ed.), Mission scientifique dans la haute asie. 3 vols. Paris, 1897-8.

__ "La légende de Satok Boghra Khân et l'histoire." FA, 9th series, 15 (1900), 5-79.

\{Gross, Jo-Ann. "Multiple Roles and perceptions of a Sufi Shaikh: Symbolic Statements of Political and Religious Authority." Marc Gaborieau, Alexandre Popovic, and Thierry Zarcone eds. Naqshbandîs: cheminements et situation actuelle d'un ordre mystique musulman. Istanbul, 1990, pp. 109-21.\}

\{Gross, Jo-Ann and Asom Urunbaev. Letters of Khwäjah 'Ubayd Alläh Ahrār and His Associates. Leiden, 2002.\}

de Guignes, J. Histoire général des huns, des turcs, des mongols et des autres tartares occidentaux. 4 vols. Paris, $1756-8$.

Gülbün-i khānān. Istanbul, 1287/1870-1.

Gülshehrī. Mantiq al-tair. MSS in the Istanbul Archeology Museum Library and Hâlis Efendi Library in the Süleymaniye in Istanbul. Facsimile edn Ankara, 1957.

Guyard, St. "Fragments relatifs à la doctrine des ismaélis." Notices et Extraits des Manuscrits de la Bibliothèque Nationale, 22 i (1874), 177-428.

\{Güzel, Abdurrahman. Kaygusuz Abdal'nn mensur eserleri [Qaygusuz Abdāl's prose works]. Ankara, 1983.\}

\{-Abdal Mûsâ Velâyetnâmesi. Ankara, 1999.\}

\{Haarmann, U. "Turkish Legends in the Popular Historiography of Medieval Egypt." Proceedings of the VI Congress of Arabic and Islamic Studies . . 1972. Uppsala, 1975, pp. 97107.\}

Habîb Efendi. Düstûr-i suhan. Istanbul, 1309/1891-2.

Hacı Kemal. Jāmi` al-nază’ir. Unique MS in Beyazit Umumi Library in Istanbul.

\{Hacıeminoğlu, M. Necmettin. Kutb'un Husrev ü Şirin'i ve dil hususiyetleri [The books of Khusraw and Shīrīn and their linguistic features]. Istanbul, 1968.\}

Hâfiz Hüseyin Ayvansarayî. Hadīqat al-jawāmir. 2 vols. Istanbul, 1281/1864. \{English trans. Howard Grane as The Garden of the Mosques: Hafiz Hüseyin al-Ayvansarayı̂s Guide to the Muslim Monuments of Ottoman Istanbul. Leiden, 2000.\}

Ḥāfiz-i Abrū. Zubdat al-tawān̄̄kh (or Majma' al-tawān̄ikh). MS in Damad Ibrahim Pasha Library in the Süleymaniye in Istanbul.

Hājjīi Bektash Veli. Velāyetnāme-i Hǟjōi Bektash Veli. MS in Köprülü's private library. \{German trans. E. Gross as Das Vilâyet-nâme des Haggi Bektasch. Leipzig, 1927. Ed. A. Gölpınarlı as Manakib-i Hacı Bektaş-i Veli "Vilâyet-Nâme." Istanbul, 1958.\} Versified version by Nihān̄̄ also in Köprülü's library. 
Hājjjim Sulțān. Velāyetnāme-i Häjjim Sulțān. Ed. R. Tschudi as Das Velayet-name des Hadschim Sultan. Leipzig, 1914.

Hakîm Ata. See Sulaimān Ata.

Hakîm Ata kitâbr. (Anonymous). Kazan, 1901.

\{Halasi-Kun, Tibor. La Langue des Kiptchaks d'après un manuscrit arab d'Istanbul. Budapest, 1942.\}

Al-Hallāj, Manșūr. Kitāb al-Ṭawāsīn. Ed. L. Massignon. Paris, 1913. French trans. by Massignon in vol. 3 of his La Passion d'al-Husayn-ibn-Mansour al-Hallāj. Paris, 1922.

Hạd Allāh Mustawfī Qazwīnī. Ta’rn̄kh-i guzīda. Facsimile ed. E. G. Browne. Leiden, 1910. \{New edn 'Abd al-Husayn Navā'̄i. Tehran, 1362/1983 or 1984.\}

von Hammer(-Purgstall), Joseph. Geschichte der Assasinen. Stuttgart, 1818. French trans.

J. Hellert as Histoire de l'ordre des assasins. Paris, 1833.

Geschichte des osmanischen Reiches. 10 vols. Budapest, 1827-35. Turkish trans. Mehmet Ata as Devlet-i osmaniyye tarihi. 10 vols. Istanbul, 1329-37/1911-19.

- Geschichte der osmanischen Dichtkunst bis auf unsere Zeit. 4 vols. Budapest, 1836-8.

Geschichte der Ilchane (a trans. of Juvainī). 2 vols. Darmstadt, 1842-3.

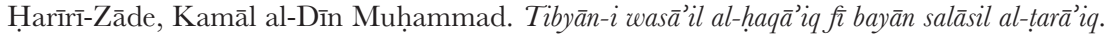
Ibrahim Ağa MSS 430-2 in the Mulhak Fatih Library in the Süleymaniye in Istanbul. Arabic MS in three large volumes. The author's biography and his works are given in Bursalı Tâhir's Osmanlı müellifleri, vol. 1, pp. 155-9. According to Köprülü, this is a very valuable work that gives the biographies of the pīrs of some 150 Șūî tarīqas and describes the nature of the tariqas that they founded. If published, it would be a fundamental source for the history of Șūfism.

\{van Harnack, Adolf and John Malcolm Mitchell. "Neoplatonism.” Encyclopaedia Britannica, 1955.\}

\{Hartmann, Angelika. an-Nāssir li-Dīn Alläh (1180-1225): Politik, Religion, Kultur in der späten 'Abbāsidenzeit. Berlin, 1975.\}

$\left\{-\right.$ "Mu'īn al-Dīn . . Y Yazdī." $E I^{2}$.

\{__ "Al-Nāṣir li-Dīn Allāh." EI $I^{2}$.\}

Hartmann, M. "Der čaghataische Diwan Huwedas herausgegeben und übersetzt von M. Hartmann." Berlin Universität, Seminar für Orientalische Sprachen, Mitteilungen, Westasiatische Studien, 5 (1902), 132-55.

\{_ "Mešreb der weise Narr und fromme Ketzer: Ein zentralasiatisches Volksbuch." Der islamische Orient. Vol. 5. Berlin, 1902.\}

Hashmet. Sanad al-shu'arā'. MS in Köprülü’s private library.

Hātifī. Tìmūrnāme (or Zafarnāme). Many MSS. Köprülü says he describes the author and his work in his Timurlular devrinde orta-asya Türk edebiyat [Central Asian Turkish literature in the Tīmūrid period], but no work under that title was ever published. \{See StoreyBregel', Persidskaia literatura, vol. 2, pp. 808-12.\}

Hayrullâh Efendi. Tarih-i âl-i osmân (rather, Dawlat-i 'aliyya-i 'uthmāniyya ta'rīkhi). 18 vols. Istanbul, 1271-92/1854-75.

Hazīn̄̄. Fawāhir al-abrār min amwāj al-bihāar. Unique MS in the Hâlis Efendi Library in the Süleymaniye in Istanbul nnow in the Istanbul University Library, MS TY 3893\}. \{Ed. Cihan Okuyucu. Kayseri, 1995.\} According to Köprülü, this work is a primary source on Ahmad Yasawī, and even more on the special rules of etiquette of the Yasawiyya, but was completely unknown to date $\{1918\}$ to the scholarly world. He goes on to state that this important work is not mentioned in Kâtib Chelebi's Kashf al-zunūn. The manuscript was copied in a beautiful thulth style by Mạ̣mūd b. Hasan b. 
Shaikh al-Naqshbandī. He completed it on a Saturday in Rabī' al-awwal 1002/1593. It is a book composed of 324 large pages and is divided into two sections. One section of 221 pages is in Turkish. The other, some pages of which are missing, is in Persian. This work was written during the reign of Murad III $\{1574-95\}$ by a Yasawī Dervish named Hazīnī. Both sections are on the same subject. This work describes the legendary deeds of Ahmad Yasawī, the rules of etiquette of his tariqqa, and then of his Șūfì path $\{$ suluk\}. The first part of the Persian section is written completely in verse. According to what Köprülü gleaned from this work, Hazīn̄̄ was in fact a Turkistan̄̄ Turk. He lived at a time when the Șûfi movement was at the height of its strength in Central Asia and he was overcome with mystical ecstasy when only twelve years old. Shortly thereafter he met Sayyid Manșūr Qashıq-tırâsh and studied under him. He read the legendary deeds of the Șūfì saints and learned the rules of the Șūfì path. Finally, when he was nineteen years old, he received permission from his shaikh to don the $t \bar{a} j$ \{dervish headgear\}, kemer \{girdle\}, and khirqa \{dervish patched cloak\} and to write the legends of the saints. In the Persian section, there are many legends and stories about this Sayyid Manșūr al-Balkhī, then \{thumma\} al-Hișārī and al-Bukhārī \{i.e. he had resided in each of these places\}, who, indirectly, had been a murid of Shaikh Süleyman Ghaznawī. Hazīn̄i lived in various places in Transoxiana but then, for some reason, decided to leave. In the reign of Selim II, he went to Istanbul and settled there. Aware of the esteem and respect given to the Șūfìs during the reign of Murad III, Hazīn̄̄ wrote this book in order to present it to the sultan. Köprülü did not find him mentioned in any source from that period. According to Köprülü, Hazīn̄i also states that the title of the book, Fawāhir al-abrār min amwāj al-bihāar, points to the date of writing it (i.e. constitutes a chronogram). In any case, this work is an extremely important source for our subject. Köprülü attached to the present work a chart showing Hazīnīss chain of authorities for the Yasawī tarīqa starting with Zangī Bābā.

Мecmua-i Hazînî. Tashkent, 1329/1911.

Hezārfenn Husain. Tanqūh tawārīkh al-mulūk. MS in Köprülü's private library. \{See $E I^{2}$, s.v. "Husayn Hezarfenn" (V. L. Ménage).\}

\{Hillenbrand, Carole. "Mu'īn al-Dīn Parwāna: the Servant of Two Masters?" F. de Jong (ed.), Miscellanea Arabica et Islamica: Dissertationes in Academia Ultrajectina prolatae anno MCMXC. Leuven, 1993, pp. 267-74.\}

\{Hillenbrand, Robert. "The Mausoleum of 'A' 'isha Bibi and the Central Asian Tradition of Funerary Architecture." Journal of Turkish Studies, 18 (1994), 111-20.\}

\{Hofman, H. F. Turkish Literature, a Bio-bibliographical Survey. Section III. Moslim Central Asian Turkish Literature Being in the Main a List of "Chaghatayan" Authors and Works in "Chaghatay" as Registered in Professor M. F. Köprülü's Article: "Clagatay edebiyat,," IA. Vol. 3 (270-) with some additions (Navà'̄āna, however, excepted). Utrecht, 1969.\}

\{__ "Makhdūm Kụūi." $E I^{2}$.\}

Houtsma, Th. (ed.) Tarjumān-i turk̄̄ wa'arab̄̄ as Ein türkisch-arabisches Glossar. Leiden, 1894. "Ein alttürkisches Gedicht: (eine vorislamische Bearbeitung des biblischen Romans von Joseph und Zulaika; aus der Dresdner Handschrift herausgegeben und überstetzt)." ZDMG, 43 (1889), 69-98.

Howorth, H. History of the Mongols. 4 vols. London, 1880-8.

Huart, Cl. Konia: La Ville des derviches tourneurs. Paris, 1897.

Histoire de la littérature arab. Paris, 1902. \{English trans. A History of Arabic Literature. London, 1903. Reprinted Beirut, 1966.\}

Textes persans relatifs à la secte des houroufis. Leiden, 1909. 
Histoire des arabes. 2 vols. Paris, 1912-13.

"Les Zindîqs en droit musulman." Actes du $11^{e}$ Congrès International des Orientalistes (1897), 3rd section, pp. 69-92.

"Perse." La Grande Encyclopédie.

— A review of R. A. Nicholson, The Kashf al-mahjúb. The Oldest Persian Treatise on Șifism. FA, 11th series, 3 (1914), 186-8.

[—_Les Anciens derviches turcs" (a review of Early Mystics). Fournal des Savants, new series, 20 (1922), 5-18. Turkish trans. Râgip Hulûsî in TM, 1 (1925), 267-80.]

[- Another review of Early Mystics. 7A, 202 (1923), 146-50.]

\{Huart, Cl. and Kathleen Burrill. "Șarı 'Abd Allāh Efendi." EI ${ }^{2}$.\}

[Hulûsî (Sayman), Şerif. Ord. Prof. Dr Fuad Köprülünün yazılan için bir bibliyografya (1913-1934) (A bibliography of the writings of Ordinarius Prof. Dr Fuad Köprülü [1913-1934]). Istanbul, 1934. 2nd edn as Ord. Prof. Dr Fuad Köprülü’nün yazzlan için bir bibliyografya (1912-1940). Istanbul, 1940.]

Ḥusām al-Dīn Muslimī. Risāla-i tawārākh-i bulghäriyya. Kazan, 1902. According to Köprülü, it was written in the tenth/sixteenth century and it is composed entirely of legends. Şihabü'd-Dîn Mercânî severely criticized it in his Mustafād al-akhbār, vol. 1, pp. 210-24. Husām Kātib. Hikāyat-i jamjama sultạn (Kesikbaş hikâyesi). Versified in Chagatay in 777/ 1375-6. MS in Köprülü's private library.

Hüseyin Dâniş. Ser-Âmedân-ı Suhan. Istanbul, 1327/1909.

Hüseyin Hüsâmeddin. Amasya tarihi [The history of Amasya]. 5 vols. Istanbul, 1328/1910. Hüsing, Georg. Beiträge zur Rostahmsage (Sajid Battâl). Leipzig, 1913.

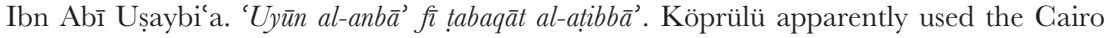
edn, 1299/1882.

Ibn al-Athīr. Al-Kāmil fì 'l-ta' rīkh. Thornberg (ed.). 12 vols. Cairo, 1303/1885-6.

Ibn Battūța. Al-Rihla. Turkish trans. Şerîf Pasha as Seyāhatnāme. 3 vols. Istanbul, 1333-5/ 1914-17. Köprülü also cites the edn by C. Defrémery and B. R. Sanguinetti, Voyages d'Ibn Batoutah. 4 vols. Paris, 1853-8. \{English trans. H. A. R. Gibb as The Travels of Ibn Battūta. 3 vols in 2. Cambridge, 1956-72.\}

Ibn Bībī. See Yazıcı-oğlu 'Alī.

Ibn al-Dawādārī. Ta'rn̄kh-i mukhtașar. MS 913 Damad Ibrahim Pasha Library in the Süleymaniye in Istanbul.

— Durar al-tijān. MS in Istanbul. \{Ed. Gunhild Graf as Die Epitome der Universalchronik Ibn ad-Dawadaris. Berlin, 1990.\}

\{—Kanz al-durar. Vol. 7. Ed. Sa'īd 'Abd al-Fattāh 'Āshūr. Cairo, 1972.\}

Ibn al-Faq̄īh al-Hamadānī. Kitāab al-buldān. Ed. M. J. de Goeje. Leiden, 1885.

Ibn Hawqal. Al-Masālik wa 'l-mamālik. Ed. M. J. de Goeje. Leiden, 1873. \{Superseded by J. H. Kramer's edn. Leiden, 1938-9.\}

Ibn 'Inaba. Kitāb 'umdat al-țălib. Bombay, 1318/1900-1.

\{Ibn al-Jawzī. Șafwat (Șifat) al-șafwa. 2 vols. Cairo, 1411/1991.\}

Ibn Jubair. Al-Rihla, 2nd edn. M. de Goeje. Leiden, 1907.

Ibn Kamāl. See Kemāl Pasha-Zāde.

Ibn Khaldūn. Muqaddima. Turkish trans. Pirî-Zâde Mehmed Sâhib Efendi. Beginning through the fifth chapter, 2 vols. Cairo, 1275/1858-9. With sixth and final chapter trans. Ahmet Cevdet, 3 vols. Istanbul, 1277/1860-1. \{English trans. Franz Rosenthal. The Muqaddimah. 3 vols. Princeton, NJ, 1967.\}

Kitāb al-'ibar (Ibn Khaldūn's history that follows the Muqaddima). Turkish trans. Subhî Pasha as Miftâh ül-iber. 2 vols. Istanbul, 1276/1859-60. 


\section{B I B L I O G R A P H Y}

Ibn Khallikān. Wafayāt al-âyān. Būlāq, 1299/1881-2. \{Ed. Iḥsān 'Abbās. 8 vols. Beirut, 1968-72. English trans. MacGuckin de Slane as Ibn Khallikān's Biographical Dictionary. 4 vols. Paris, 1842-71.\}

Ibn Niz̄ām al-Husaini. Al-'Urāda fì 'l-hikiāya al-saljūqiyya. Ed. K. Süssheim as Das Geschenk aus der Seldschukengeschichte. Leiden, 1909. Partial Turkish trans. Şerefeddin Yaltkaya. MTM, 1 (1331/1915), 257-304, 481-96.

\{Ibn al-Ṭiqțaqā. Kitāb al-fakhrī. Published as Ta'rīkh al-duwal al-islāmiyya. Beirut, 1960.\}

Ibn Yamīn. Muqatta'a àt. Calcutta, 1865.

İbrâhîm Hakkı. Márifatnâme. Istanbul, 1294/1877.

Ibrāhīm Tennūrī. Gulzār-i ma'nawē. \{See Ali Karabulut and Ramazan Yıldız, Gülzâr-i ma'nevi ve İbrahim Tennûri. [Kayseri?], 1978.\}

\{Iqbal, Afzal. The Life and Work of Jalal-ud-din Rumi, 3rd rev. edn. Lahore, 1974.\}

\{Isfarā’in̄̄, Nūr al-Dīn 'Abd al-Rahmān. Le Révélateur des mystères (Kâshif al-Asrâr). Ed. Hermann Landolt. Paris, 1986.\}

İshak Efendi. Kâşifíl'l-esrâr ve dâfi' ï’l-eşrâr. Istanbul, 1290/1873-4.

Ishıq Shamsī. Dih-mürgnāme. According to Köprülü, this was written during the reign of Selim and subsequently presented to Süleyman the Magnificent after a few changes and some additions were made. One of the two copies in our possession was written during the reign of Selim and the other during the reign of Süleyman. The information given in the biographical dictionaries \{tadhkiras\} on this work is mistaken.

İsmâ'îl Belig Bursalı. Güldeste-i riyâz-ı irfân. Bursa, 1302/1884.

İsmâ'îl Hakkı Bursalı. Sharh-i rumūzāt-i Yūnus Emre. MS in Köprülü's private library.

Farah al-rūh (Sharh al-muhammadiyya al-mawūum bi-Farah al-rūh). Commentary on Yazıc1oğlu Mehmed's Muhammadìya. Būlāq, 1252/1836.

_ Silsilanāme-i jalwatī. Lithograph edn. n.p., 1291/1874.

Iștakhrī. Masālik al-mamālik. Ed. M. de Goeje. Leiden, 1870. \{Reprinted Leiden, 1927.\}

\{Ivanov, A. A. "O bronzovykh izdeliiakh kontsa XIV v. iz mavzoleia Khodzhi Akhmeda Iasevi" [On the bronze articles from the end of the fourteenth century from the mausoleum of Khwāja AḥmadYasawī]. B. A. Litvinskii (ed.), Sredniaia Azïia i ee sosedi v drevnosti $i$ srednevekov'e [Central Asia and its neighbors in Antiquity and the Middle Ages]. Moscow, 1981, pp. 68-84.\}

\{İz, Fahir. 'A $\underline{\text { shik }}$ Pasha." $E I^{2}$.\}

\{—— "Dede Korkut." EI ${ }^{2}$.\}

\{__Eshrefoghlu." EI ${ }^{2}$, Supplement.

\{_— "Kayghusuz Abdāl." EI ${ }^{2}$.\}

'Izzī-Zāde Sayyid 'Abd al-Lațîf, Shaikh. Khulāṣat al-wafayāt. MS in the Hâşim Pasha Library in the Süleymaniye in Istanbul.

Jacob, Georg. Die Bektaschïje im ihrem Verhältnis zu verwandten Erscheinungen. Munich, 1909.

\{Jahn, Karl. Die Geschichte der Ogizzen des Raš̀d ad-Dīn. Vienna, 1969.\}

Jalāl al-Dīn Rūmī. Dīwān-i kabīr (or Kulliyyāt-i Shams-i Tabrīz or Dīwān-i Shams al-haqāìq). Lucknow, 1302/1885 and Jawnpore, 1912. \{Ed. Badī' al-Zamān Furūzānfar as Kulliyatt-i Shams, ya Dīvān-i kabīr. 10 Vols. Tehran, 1977.\} English trans. R. A. Nicholson as Selected Poems from the Dīuanni Shamsi Tabriz. Cambridge, 1895. \{Reprinted Cambridge, 1952.\}

Mathnawē. Ed. and English trans. R. A. Nicholson. 8 vols. London, 1925-40.

- Fìhi mā fìh. \{Ed. B. Furūzānfar. Tehran, 1338 sh./1959. English trans. A. J. Arberry as Discourses of Rumi. London, 1961; and W. Thackston as Signs of the Unseen: The Discourses of Jalaluddin Rumi. Putney, VT, 1994.\} 
Jāmī. Nafahāt al-uns. Calcutta, 1859. Turkish trans. by Lāmi' $\overline{1}$, who made some additions to the text. Istanbul, 1289/1872-3. \{Maḥmūd 'Ābidī ed. Persian text. Tehran, 1370/ 1991.\}

- Silsilat al-dhahab. Bombay, 1289/1872-3. At the end of Nafahāt al-uns.

\{Jandī, Mu’ayyad al-Dīn. Sharh Fușūs al-ḥikam. Ed. Sayyid Jalāl al-Dīn Āshtiyān̄̄. Mashhad, 1361/1982.\}

\{—_ Nafahāat al-rūh. Ed. Naj̄̄b Māyil Haravī. Tehran, 1362/1403/1983.\}

\{Jaubert, Amódée. "Notice d'un manuscrit turc, en charactèrs ouigours, envoyé par M. de Hammer à M. Abel-Rémusat." fA, 6 (1825), 39-52, 78-95.\}

$\{$ Jürgen, Paul. Die politische und soziale Bedeutung der Naqšbandiyya in Mittelasien im 15. Fahrhundert. Berlin, 1991.\}

\{__ "Scheiche und Herrischer im Khanat Čagatay." Der Islam, 67 (1990), 278-321.\}

Juvain̄̄. Tản̄̄kh-i Jahān-Gushāa. Ed. Mīrzā Muhammad Qazvīnī, Gibb Memorial Series vol. 16. 3 vols. London, 1912-37. \{English trans. J. A. Boyle as The History of the World Conqueror. 2 vols. Manchester, 1958.\}

\{Kahle, P. "Die Futuwwa-Bündnisse des Kalifen en-Nāṣir (d. 622/1225)." Theodor Menzel (ed.), Festschrift Georg Facob. Leipzig, 1932, pp. 112-27.\}

\{Al-Kalābādhī. Ta'arruf li-madhhab ahl al-tașawreuf. English trans. A. J. Arberry as The Doctrine of the Sufis. Cambridge, 1935. Reprinted Lahore, 1966.\}

Kamāl al-Dīn Husain Tabas̄i Gāzurgāhī, Amīr. Majālis al-'ushshāq. Jawnpore, 1897 and MS 4238 in the Aya Sofya Library in Istanbul.

\{Kaplan, Mehmed. "Hashmet." $E I^{2}$.

\{Kaptein, N. Muhammad's Birthday Festival: Early History in the Central Muslim Lands and Development in the Muslim West until the 10th/16th Century. Leiden, 1993.\}

\{Kara, Mustafa. Niyazi-i Misri. Ankara, 1994.\}

Karakaşzâde Ömer Efendi. Nûrü'l-hüdâ li-men ihtadâ. Istanbul, 1286/1869-70.

\{Karamustafa, Ahmet T. God's Unruly Friends: Dervish Groups in the Islamic Later Middle Period 1200-1550. Salt Lake City, 1994.\}

Al-Kāshgharī, Mạ̣mūd. Dĩūann lughāt al-turk. 3 vols. Istanbul, 1333-5/1915-17. \{English trans. Robert Dankoff and James Kelly as Compendium of the Turkic Dialects. 3 vols. Cambridge, MA, 1982-5.\}

Kāshifî. See Șafī.

\{Katanov, N. "Materialy k izuchniiu kazansko-tatarskago narechiia" [Materials for the study of the Kazan Tatar dialect]. Uchenye zapiski Kazanskago Universiteta, 7-8 (1898).\}

Kātib Chelebi. Fihān-numā. Istanbul, 1145/1732. \{Reprinted Istanbul, 1967.\}

Kashf al-zunūn. According to Köprülü, the Būlāq edition of 1274/1857 in 3 vols is more reliable than the subsequent Istanbul edition.

\{Kaya, Idris Güven. Derviş Şemsi ve Deh Murg Mesnevisi [Dervish Shamsī and his Deh Murg Mathnawī]. Cambridge, MA, 1997.\}

Kemāl Pasha-Zāde. Mohaçnāme (book 10 of his Tarih-i āl-i osman). Ed. and French trans. Abel Pavet de Courteille as Histoire de la campagne de Mohacz par Kemal Pachazadeh. Paris, 1859.

Kemal, Mehmed Nâmı. Tahrîb-i harâbât. Istanbul, 1301/1883-4 and again in 1304/ 1886-7. A criticism of the first vol. of Ziya Pasha's anthology Harâbât (Istanbul, 12912/1874).

\{Kemper, Michael. Sufis und Gelehrte in Tatarien und Baschkirien, 1789-1889: Der islamische Diskurs unter Russischer Herrschaft. Berlin, 1998.\}

"Khalwa," an article signed by "T" and published in the Russian journal Shūra (Orenburg) in March, 1914. 


\section{B I B L I O G R A P H Y}

Khațā̄ì (Shāh Ismā'īl I). Manāqib al-asrār, bahjat al-ahrār. MS in Köprülü’s private library. Köprülü states that this work, which includes very important information on the beliefs of the Q1zilbash, does not in fact belong to Shāh Ismāềl.

Khuda Bakhsh, S. "Saifuddīn Bākharzī." ZDMG, 59 (1905), 345-54.

Khwāndamīr. Habīb al-siyar. 4 vols. Bombay, 1273/1857. \{Partial English trans. Wheeler Thackston as Habibu's-siyar, Tome Three. The Reign of the Mongol and Turk. 2 vols. Department of Near Eastern Languages and Civilizations, Harvard University, 1994.\}

Khwārazmī. Mahabbatnāme. MSS in the Alî Emirî Efendi Library, which is in the Fatih Millet Library in Istanbul, and in the British Museum. \{Ed. A. M. Shcherbak as Oguznāme. Mukhabbat-nāme (in Russian). Moscow, 1959.\}

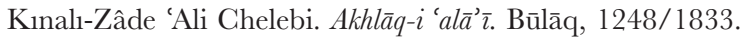

Kınalı-Zâde Hasan Chelebi. Tadhkirat al-shu'ară'. MS TY 1737 in the Istanbul University Library. \{Ed. İbrahim Kutluk, Ankara, 1979-81.\}

\{Kirmān̄i, Awḥad al-Dīn Ḥāmid b. Ab̄̄ 'l-Fakhr. Manāqỉb. Ed. Badī‘ al-Zamān Furūzānfar. Tehran, 1347/1969.\}

\{Kissling, H. J. "Aq Šems ed-Dīn: Ein türkischer Heiliger aus der Endzeit von Byzanz." Byzantinische Zeitschrift, 44 (1951), 322-33.\}

\{—_Ak Shams al-Dīn." $E I^{2}$.

\{Knysh, Alexander D. Ibn 'Arabi in the Later Islamic Tradition: The Making of a Polemical Image in Medieval Islam. Albany, NY, 1999.\}

\{Köhbach, M. "Vom Asketen zum Glaubenskampfer: Geyiklü Baba. Ein Beitrag zur osmanischen Hagiographie." Journal of Ottoman Studies, 3 (1982), 45-51.\}

\{Köksal, Hasan. Battalnâmelerde tip ve motif yapıs [The formation of types and motifs in the Batțālnāmes]. Ankara, 1984.\}

\{Komaroff, Linda. The Golden Disk of Heaven: Metalwork of Timurid Iran. Costa Mesa, CA, 1992.\}

\{“Köprülü, Mehmed Fuad.” Türk Dili ve Edebiyat Ansiklopedisi [Encyclopaedia of Turkish Language and Literature]. Istanbul, 1982-98.\}

Köprülü, M. Fuad. Nasrettin Hoca. Istanbul, 1918.

- Türk edebiyat tarihi [The history of Turkish literature]. Istanbul, 1920-1, again in 1926 \{and reprinted Istanbul, 1981.\} Köprülü cites a 1928 edn.

[— Türk dil ve edebiyat hakknda araştırmalar (Research on Turkish language and literature). Istanbul, 1934.]

[—Les Origines de l'Empire Ottoman. Paris, 1935. Turkish trans. as Osmanle devletinin kuruluşu. Ankara, 1959.] [English trans. Gary Leiser as The Origins of the Ottoman Empire. Albany, NY, 1992.\}

Türk sazşâirleri [Turkish saz poets]. 3 vols. Istanbul, 1940. \{Reprinted Ankara, 1962-5.\}

[—_ On the Way to Democracy. Trans. Tibor Halasi-Kun. London, 1964.]

[—Edebiyat araștirmalan (Research on [Turkish] literature). Ankara, 1966.] \{2nd edn Ankara, 1986.\}

[__ "Şeyh Gâlibe" (Shaikh Gâlibe). Mehâsin Mecmuası, issue no. 1, Sept. 1324/1908.]

[_ "Türk edebiyatı tarihinde usûl" (Method in the history of Turkish literature). Bilgi Mecmuası, 1 (1329/1913), 3-52.]

"Ahmed Yesevî ve çagatay ve osmanlı edebiyatları üzerinde te'sirleri”" [Ahmad Yasawī and his influence on Chagatay and Ottoman literature]. Bilgi Mecmuası, 1 (1330/1914), 611-45. 
"Sazşâirleri: Türklerde âşık edebiyatı'nın menşe' ve tekâmülü" [Saz poets: the origin and development of minstrel poetry among the Turks]. Some parts abridged and published in the newspaper İkdam, April 3, 7, 11, 16, 19, 25; May 2, 7, 9, 31; June 6, 1914. The introduction was published in MTM, 1 (1331/1915), 5-46. See the next entry.

" "Türk edebiyatında âşık tarzının menşe' ve tekâmülü hakkında bir tecrübe" [An essay on the origin and development of Turkish minstrel poetry]. MTM, 1 (1331/ 1915), 5-46. \{Reprinted in his Edebiyat araştrmaları.\}

"Türk edebiyatının menşe'i" [The origin of Turkish literature]. MTM, 2 (1331/ 1915), 5-78. \{Reprinted in his Edebiyat araştrmalar.\}

"Türk edebiyatı tarihine medhal" [Introduction to the history of Turkish literature]. No such work was ever published, but the first part of it appeared as "Türk edebiyatının menşe'i." Köprülü also refers to this as a book. See the preceding entry.

"Selçukiler zamanında Anadoluda Türk medeniyyeti." MTM, 2 (1331/1916), 193232. English trans. Gary Leiser as "Turkish Civilization in Anatolia in the Seljuk Period." Mésogeios, 9-10 (2000), 37-82.\}

"X. asır hayatına âit bir vesika" [A document on life in the tenth century]. Ikdam newspaper, June 10, 12, 1332. Reprinted as "Onuncu asıra âit vesikalar: Fakîri'nin Risâle-i tarîfâti”" [Documents on life in the tenth century: Faqīî̀'s Risāla-i ta'rñfät]. Hayat Mecmuast, 1 (1927), 22-3.

"Harâbât" [The tavern, in the mystical sense of where a novice becomes absorbed in God's glory]. $Y M, 1$ (1917), 186-8.

"Islâm edebiyatında mersiye" (real title "Bizde mersiye ve mersiyecilik" [Elegies and elegy composition among us]). $Y M, 1$ (1917), no. 16, 305-8; no. 17, 324-8; no. 18, $344-8$; no. 19, 364-7; no. 20, 384-6.

"Osmanlı edebiyatının başlangıçı" [The beginning of Ottoman literature]. $Y M, 3$ (1918), 85-8.

"Anadolu'da islâmiyet: Türk istilâsından sonra Anadolu tarih-i dinîsine bir nazar ve bu tarihin menbaları" [Islam in Anatolia: A review of the religious history of Anatolia after the Turkish invasion and the sources for this history]. Dârülfünûn Edebiyat Fakültesi Mecmuast, 2 (1922), 281-311, 385-420, 457-86. \{English trans. Gary Leiser as Islam in Anatolia after the Turkish Invasion. Salt Lake City, 1993.\}

[__ "Anatolische Dichter in der Seldschukenzeit, i. Šejjād 'Hamza." Körösi Csoma Archivum, 1 (1921-5), 183-90. Turkish trans. in Türk Yurdu, 1 (1340/1921-2), 27-34.]

[—_ "XVII. asır saz şairlerinden Kâmil Kırım Hanı IV. Mehmet Giray" (Kāmil, the Crimean Khān Mehmet Giray IV, a seventeenth-century saz poet). Hayat Mecmuası, 1928, no. 134. Reprinted in Köprülüden sę̧meler (Selections from Köprülü), ed. Orhan Köprülü. Istanbul, 1972, pp. 93-8.]

- "Bizans müesseselerinin osmanlı müesseselerine te'siri hakkında bâzı mülâhazalar." Türk Hukuk ve İktisat Tarihi Mecmuası, 1 (1931), 165-313. \{English trans. Gary Leiser as Some Observations on the Influence of Byzantine Institutions on Ottoman Institutions. Ankara, 1999.\} __ "Mısır'da bektaşîlik" [Bektashism in Egypt]. TM, 6 (1936-39), 13-40.

\{_ "Osmanli İmparatorluğunun etnik menşei mes'eleleri" [Poblems of the ethnic origin of the Ottoman Empire]. Belleten, 7 (1943), 219-313.\}

[—_ "Anadolu selçukluları tarihinin yerli kaynakları" (Local sources for the history of the Seljuks of Anatolia). Belleten, 7 (1943), 379-458.] \{English trans. Gary Leiser as The Seljuks of Anatolia: Their History and Culture According to Local Muslim Sources. Salt Lake City, 1992.\} 
\{_ "Kay kabilesi hakkında yeni notlar" [New notes on the Qay tribe]. Belleten, 8 (1944), 421-52.\}

[—_ "Gürcü âlimlerine cevap - I. Tarih, yalancı şâhit olmaz" (A reply to the Georgian scholars - I. History does not give false testimony); "II. Tarih değil, efsâne" (II. Not history, myth); "III. Efsâne değil, tarih" (Not myth, history). A series of articles in the newspaper Vatan, December 17, 19, 20, 1946, respectively.]

[_ "Türk onomastique’i hakkında" (On Turkish onomastic). İstanbul Üniversitesi Edebiyat Fakültesi Tarih Dergisi, 1 (1950), 221-36.]

\{_- "Orta-Asya Türk dervisliği hakkında bazı notlar" [Some notes on Turkish dervishes in Central Asia]. TM, 14 (1964), 259-62.\}

"Abdal." Türk halk edebiyatr ansikopedisi. Istanbul, 1935.

[__ "Abdal Mûsâ." Türk halk edebiyatr ansiklopedisi. Istanbul, 1935. Second part in Köprïlïden şę̧meler. Istanbul, 1972. Reprinted in Türk Kültürü, 11 (1973), 198-207.]

[—_ "Ahmed Yesevî." İA.]

[—_Alp." İA.]

\{_ "Arûz" (Iran and Türk). İA.\}

[— "Âşı Çelebi." IA.] "Âzerî." $\dot{L} A$.

[—_Bahş1." "LA.]

[_ "Bektaş." 'LA.]

[C "Cagatay edebiyatı." $\dot{I} A$.

Review of the Turkish trans. of Khwāja Ghiyāth al-Dīn Naqqāsh's 'Ajāi ib al-lațā'if: Hatây (i.e. Khațā'ī) seyâhatnâmesi by Çelebi-Zâde Âsım. MTM, 2 (1331/1915), 351-68.

[Köprülü, Orhan. "Tarihî kaynak olarak XIV. ve XV. asırlardaki bâzı Türk menâkıbnâmeleri" (Some legendary deeds of Turkish of saints of the fourteenth and fifteenth centuries as historical sources). Dissertation, Istanbul University, 1951.]

\{—_ Fuad Köprülü. Ankara, 1987.\}

[_ "Prof. Fuad Köprülü için yazılmış bibliyografyalar ve bunlara bâzı ilâveler" (Bibliographies of [the works of] Prof. Fuad Köprülü and some additions to them). Türk Kültürü, 8 (1970), 616-20.]

[—_ "Fuad Köprülü bibliyografyasına yeni ilâveler" (Recent additions to the bibliography of [the works of] Fuad Köprülü). Türk Kültürü, 10 (1972), 1242-5.]

[__ "Köprülü bibliyografyasında yeni gelişmeler" (Recent developments in the bibliography of [the works of] Koprülü). Türk Kültürü, 14 (1975), 52-5.]

Kouznietsov, Pierre. La Lutte des civilizations et des langues dans l'asie centrale. Paris, 1912.

\{Köymen, Mehmet. "Selçuklu devri kaynakları olarak vakfiyeler" [Waqfiyyas as sources for the Seljuk period]. In Studi preottomani e ottomani. Naples, 1976, pp. 153-63.\}

\{Koz, M. Sabri. "The Dervish Cönk," "An 'Istanbul' Cönk," and "Two Cönks from the First Half of the 19th Century." 4th Floor, The Bulletin of the Yapr Kredi Sermet Ciffter Research Library, no. 1 (2001), 18-23; no. 3 (2001), 16-22; no. 4 (2002), 10-16.\}

Kräelitz, F. "İlk osmanlı padişahlarının ısdar etmiş oldukları bazı beratlar" [Some berats issued by the first Ottoman sultans]. TOEM, no. 28 (1330/1912), 242-50.

$\left\{\right.$ Krenkow, F. and G. Lecomte et al. "Kașīda." $E I^{2}$.\}

\{Krupp, Alya. Studien zum Menāqubnāme des Abu l-Wafā' Tăăg al-'Ārifin, part 1, Das historische Leben des Abu l-Wafă' Tä̆g al-'Árifin. Munich, 1976.\}

[Kufralı, Kasım. "Gucduvânî." İA.]

\{von Kügelgen, Anke. "Die Entfaltung der Naqšbandīya Muğaddidīya im mittleren Transoxanien vom 18. bis zum Beginn des 19. Jahrhunderts: Ein Stück Detektivarbeit." 
Anke von Kügelgen, Michael Kemper, and Allen J. Frank (eds), Muslim Culture in Russia and Central Asia from the 18th to the Early 20th Centuries, vol. 2, Inter-Regional and Inter-Ethnic Relations. Berlin, 1998, pp. 101-51.\}

Kúnos, I. "Egy ó-török nyelvemlek." Nyelvtudományi Közlemények, 22 (1892), 480-97.

\{Kut, Günay. "Ismā'īl Haḳḳ̄i." $E I^{2}$.\}

\{_- "Mukhtārāt." EI $I^{2}$.\}

Kuun, Géza (ed.). Codex Cumanicus. Budapest, 1880. \{Reprinted Budapest, 1981.\} According to Köprülü, in light of Bang's criticism, this edition is not reliable.

__ "Gurdēzī a törökökröl." Keleti Szemle, 2 (1901), 1-5; 3 (1902), 32-44, 81-94, 253, 61; 4 (1903), 17-40, 129-41, 257-83; 5 (1904), 130-52.

Lagus, J. J. W. (ed.). Ijmāl-i ahwwāl-i āl-i saljūq ber müj̈b-i naql-i oghuznāme-i Sayyid Luqmān. Helsinki, 1854. For a MS in Vienna, see Flügel's catalogue.

Lāhawrī, Ghulām Sawar Muhammad. Khazinnat al-asffyā'. Lucknow, 1322/1904-5.

La'līzāde, 'Abd al-Bāqī. Risāla-i malāmiyya-i bayrāmiyya (or Tarikat-i bayramiyyeden taife-i melâmiyyenin an'ane-i iradetleri). Istanbul, n.d.

\{Landolt, H. "Khalwa." $E I^{2}$.

Lațîfi. Tadhkira. Ed. Ahmed Cevdet as Tadhkira-yi Laț̄ît. Istanbul, 1314/1896.

Lavisse, E. and Rambaud, A. L'Europe féodale, les croisades, 1095-1270 and Formation des grands états, 1270-1492, which are vols 2 and 3 respectively of Histoire générale du IV siècle à nos jours. 12 vols. Paris, 1893-1901.

Le Bas, Ph. Asie mineure. Paris, 1864.

\{Leiser, Gary. "Ṣarı Șalțūk Dede." $E I^{2}$.\}

\{Lentz, Thomas and Glenn Lowry. Timur and the Princely Vision: Persian Art and Culture in the Fifteenth Century. Los Angeles, 1989.\}

Levshin (or Levchin), A. I. Description des hordes et des steppes des Kirghiz-Kazaks ou KirghizKa'issaks. Trans. from the Russian by Ferry de Pigny. Paris, 1840.

\{Lewis, Franklin. Rumi, Past and Present, East and West. The Life, Teachings and Poetry of Jalâl al-Din Rumi. Oxford, 2000.\}

\{Lindner, Rudi. Nomads and Ottomans in Medieval Anatolia. Bloomington, IN, 1983.

\{Lowry, Heath. "The 'Sword of Roland' and the 'Sword of Abdal Murad'; A Note on the History of Brusa (Bursa) in the Light of Six Centuries of Travellers' Accounts (1325-1925)." In Çiğdem Kafescioğlu and Lucienne Thys-Şenocak (eds) Essays in Honour of Aptullah Kuran. Istanbul, 1999, pp. 233-52.\}

Lykoshin, N. "Premudrost' Khazrat-Sultana Arifin-Khodzha-Akhmada Iassavi (mogila ego v mecheti g. Turkestana)" [The Wisdom of Haḍrat Sulțān al-'ārifīn Khwāja Aḥmad Yasawi (whose grave is in the mosque of the city of Turkestan)]. Sbornik materialov dlia statistiki Syr-Dar'inskoi oblasti [Collection of materials for the statistics of the Syr-Darya district], vol. 9, part 2, 1901, pp. 76-105. Mentioned by Barthold on p. 44 of "Russische Arbeiten über Westasien. Jahresberichte für 1901." Berlin Universität, Seminar für Orientalische Sprachen, Mitteilungen, Westasiatische Studien, (1902), 25-47.

\{Madelung, Wilferd. "Yūsuf al-Hamadān̄̄ and the Naqšbandiyya." Quaderni de Studi Arabi, 5-6 (1987-8), 499-509.\}

Maḥmūd Shabistarī. Gulshan-i rāz. Ed. and English trans. E. H. Whinfield as Gulsha I Raz: The Mystic Rose Garden of Sa'd Ud Din Mahmud Shabistari. London, 1880. \{Reprinted Lahore, 1978. According to Köprülü there was a Turkish trans. by Shaikh Elvan Shīrāzī. He adds that there are many Persian and Turkish commentaries on this work, which was written to answer the questions of the famous Sūfì Husainī Sādāt Amīr. 


\section{B I B L I O G R A P H Y}

Makhdūm-i A'ẓam (Ahmad b. Jalāl al-Dīn al-Kāsānī). Risāla-i bāburiyya. MS in the Bağdadlı Vehbî Library in the Süleymaniye in Istanbul.

\{Man’kovskaia, L. Iu. "K izucheniiu priemov sredneaziatskogo zodchestva kontsa XIV v. (mavzolei Khodzhi Akhmada Iasavi.” Iskusstvo zodchikh Uzbekistana, 1 (1962), 93-142. Paraphrased English trans. Lisa Golombek as "Towards the Study of Forms in Central Asian Architecture at the End of the Fourteenth Century: The Mausoleum of Khvāja Ahmad Yasavi." Iran, 23 (1985), 109-27.\}

\{Mansuroğlu, Mecdut. Sultan Veled'in türkçe manzumeleri [The Turkish verses of Sulțān Walad]. Istanbul, 1958.\}

\{Manz, Beatrice Forbes. The Rise and Rule of Tamerlane. Cambridge, 1989.\}

\{Al-Maqrīzī. Al-Khitat. 2 vols. Būlāq, 1870.\}

Marquart, J. "Ğuwaini's Bericht über die Bekehrung der Uiguren." Sitzungsberichte der Preussischen Akademie der Wissenschaften, 1 (1912), 486-502.

"Über das Volkstum der Komanen." Chapter 2 of Marquart and W. Bang, Osttürkische Dialektstudien, which is vol. 13 of Abhandlungen der Königlichen Gesellschaft der Wissenschaften zu Göttingen. Berlin, 1914.

\{Massé, H. "Irāḳ̄i." $E I^{2}$.\}

\{Massignon, Louis. The Passion of al-Halläj. English trans. Herbert Mason. Princeton, NJ, 1982.\}

\{Massignon, L. and G. C. Anawati. "Hulūl." $E I^{2}$.\}

\{Massignon, L. and F. Radtke. "Tașawwuf." $E I^{2}$.

\{Masson, M. E. Mavzolei Khodzha Akhmeda Iasevi [The Mausoleum of Khwāja Aḥmad Yasawi]. Tashkent, 1930. Reprinted in K. M. Baipakov (ed.) Goroda Turkestana: Sbornik nauchnykh statei [The City of Turkestan: A collection of scholarly articles]. Almaty, 1999, pp. 9-29.\}

\{McGarthy, R. J. Deliverance from Error ... and Other Works of al-Ghazali. Louisville, KY, n.d.; reprint of Twayne, 1980.\}

Mehmed Alî Aynî. Hüccetü'l-islâm-ı Gazâlı. With additions and corrections to Carra de Vaux's book Gazali. Istanbul, 1908.

Mehmed Şâkir Pasha. Yeni osmanh tarihi [Modern Ottoman history]. 2 vols. Istanbul, 1911-12.

\{Meier, Fritz. Abū Sa'̄d-i Abū l-Hayr (357-440/967-1049): Wirklichkeit und Legende. Leiden, 1976.\}

\{Mélikoff, Irène. Hadji Bektach un mythe et ses avatars. Leiden, 1998.\}

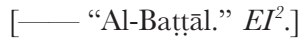

\{_ "Ewrenos." $\left.E I^{2}.\right\}$

\{__ "Oghuz-nāme." $E I^{2}$.\}

Melioransky (Melioranskii), P. "K voprosu o znachenii i proiskhozhdenii slov 'chäläb' (chalap) i 'chäläbi' v turetskom iazyke" [On the question of the meaning and origin of the words "chalab" (chalap) and "chalabi" in the Turkish language]. ZVO. (St Petersburg), 15 (1902-3), 36-43.

—Ahmed Yesewī." $E I^{1}$.

\{Ménage, V. L. "Hāạdjjī Bayrām Walī." $E I^{2}$.\}

Mendel, Gustave. "Les Monuments Seldjoukides en asie mineure." La Révue de l'Art Ancien et Moderne, 23 (1908), 9-24, 113-27. Turkish trans. Vahid as "Anadolu'da selçuk âbîdeleri," $Y M, 1917$, no. 19, 369-74; no. 20, 389-91; no. 21, 409-15.

[Menzel, Th. "Die ältesten türkischen Mystiker." ZDMG, new series, 4 (1925), 269-89.] 
[Meriç, Rıfkı Melûl. "Hurûfîlik" (Hurūfism). Graduate thesis, Istanbul University, Edebiyat Fakültesi, 1936, library no. 305.]

\{Minorsky, V. Abū Dulaf Mis'ar ibn Muhalhil's Travels in Iran (circa AD 950): Arabic Text with an English Translation and Commentary. Cairo, 1955.\}

\{_ "The Poetry of Shāh Ismā'îl I." Bulletin of the School of Oriental (and African) Studies, 10 (1940-2), 1007-53.\}

Mir-Salikh-Bekchurin. "Opisanie mecheti Azreta, nakhodiashcheisia v Turkestane." Voennyi sbornik, 9/8 (1866), 209-19. French trans. L. Leger as "Description de la Mosquée de Hazret (Khodja Ahmed Yessevy)" in Recueil d'itineraires et de voyages dans l'Asie Centrale et l'Extrême-Orient. Paris, 1878, pp. 245-58.

Mīrkhwānd. Rawdut al-șafā. Ed. Riḍā Qulī-Khān. 6 vols. Tehran, 1270-4/1853-6. \{New edn, 10 vols. Tehran, 1338-9 sh./1960.\}

\{Mojaddedi, Jawid A. The Biographical Tradition in Sufism: The Tabaqāt Genre from al-Sulamī to F̄āmin. Richmond, Surrey, 2001.\}

Mordtmann, A. D. "Die Dynastie der Danischmende." ZDMG, 30 (1876), 467-86.

Mordtmann, J. H. "Türkisches zu Foy's 'älteste osmanische Transscriptionstexte.'” Berlin Universität, Seminar für Orientalische Sprachen, Mitteilungen, Westasiatische Studien, 5 (1902), $161-9$. "Evliyā Čelebi." EI $I^{I}$.

[—_ Review of Köprülü's Early Mystics. Orientalistische Literaturzeitung, 26 (1923), 122-9. Turkish trans. Mübârak Galib in TM, 1 (1925), 281-7.]

Muallim Cevdet. "Oğuz-nâme - Kitâb-1 Dede Korkut." In special issue of $Y M$ on Çanakkale (Gallipoli), 5 March, 1331, pp. 89ff.

Muhammad Husain Ibn Khalaf al-Tabrīzī. Burhān-i qātịi. Turkish trans. Ahmed Âsım. Istanbul, 1214/1799-1800.

Muḥammad Șāliḥ. Shaibāñ̄nāme. Ed. and German trans. A. Vambéry as Die Shëbaniade. Vienna, 1885. \{New ed. E. Shādīev, Tashkent, 1989.\}

Muhammad b. Munawwar. See John O'Kane.

Muḥȳi ‘l-Dīn. Khadịnāme. Unique MS in Köprülü’s private library. Mullā Mūsā b. Mullā 'İsā Sairāmī. Ta'rn̄kh-i aman̄yyya. \{Prepared by N. N. Pantusov under the title Taarikh-i èmènie, Istoriia vladetelei Kashgarii: Sochinenie Mully Musy, ben Mulla Aisa, Sairamtsa.\} Kazan, 1905.

Müneccim-başı. Fāmic al-duwal. MS 131 in the Beyazıt Umumi Library in Istanbul, an excellent Arabic text. According to Köprülü, the Turkish translation by a committee that included Ahmed Nedîm, as Sahä'if al-akhbār, Istanbul, 1285/1868-9, is not as reliable as the Arabic text $\{$ it is considerably abbreviated\}. \{The section on the Ottomans from the Arabic original has been published with a modern Turkish trans. by Ahmed Agirakça. Istanbul, 1995.\}

Al-Muqaddasī. Ahsan al-taqāsīm fì márifat al-aqātīm. Ed. M. de Goeje. 2nd edn. Leiden, 1906. \{English trans. Basil Anthony Collins as The Best Divisions for Knowledge of the Regions. Reading, UK, 2001. The English trans. is not always reliable. Cf. André Miquel's partial trans. as La Meilleure répartition pour la commaissance des provinces. Damascus, 1963.\}\}

\{Mustafina, R. M. Predstavlenïa, kul'ty, obriady u kazakhov (V kontekste bytovogo islama v Iuzhnom Kazakhstane v kontse $X I X-X X$ vv.) [Conceptions, cults, and rites among the Qazaqs (In the context of everyday Islam in Southern Kazakhstan in the late nineteenth and twentieth centuries]. Alma-Ata, 1992.\} 
Müstaqīm-Zāde. Müstaqūm-Z̄̄ade mecmuası. MS 3397 in the Esad Efendi Library in the Süleymaniye in Istanbul.

\{Naficy, S. "Ghudjduwānī." $E I^{2}$.

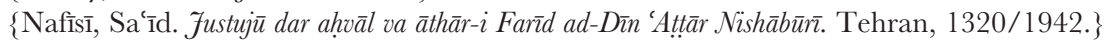

\{—- (ed.) "Risalāh-i șāhịibīyah." Farhang-i İrān-zamīn. 1 (1332/1953), 70-101.\}

Nā’ib al-Ṣadr Shīrāzī, Muhammad Ma'șūm. Tară’iq al-haqā’ iq. Tehran, 1318/1900.

Na'īmā. Ta'rīkh-i Na'īmā, 2nd edn. Istanbul, 1280/1863-4.

Najm al-Dīn Rāzī Dāya. Mirșād al-'ibād. Turkish trans. Karahisarlı Qāsim b. Muhammad as Irshäd al-murīd ilā 'l-murād for presentation to Murad II. MSS in the Istanbul University Library, the Königlichen Bibliothek in Berlin, and elsewhere. \{English trans. Hamid Algar as The Path of God's Bondsmen from Origin to Return. Delmar, NY, 1982.\}

\{Nāmah-i dānishvarān. 9 vols. Tehran, 1338/1959-60.\}

\{Nasafì. Zubdat al-haqa'iq. A. E. Bertel's edn in Piat' filosofskikh traktatov na temu "Āfāq va anfus" (O sootnosheniiakh mezhdu chelovekom $i$ vselennoi) [Five philosophical treatises on the theme of "Áfāq wa anfus" (On the correlations between man and the universe)]. Moscow, 1970, pp. 90-207. Also Haqq-virdī Nāșirī edn. Tehran, 1405/1363/1985.\}

Nāṣirī, 'Abd al-Qayyūm. Fawāgih al-julasā'. Kazan, 1884.

Nașr Allāh Efendi. Risāla-i bahä’iyya. Istanbul, 1328/1910.

Nawā'̄̄, 'Alī Shīr. Maḥbūb al-qulūb. Ed. Vefik Pasha. Istanbul, 1889. Selections published by M. Belin in Caractèrs, maximes et pensées de Mir Ali Chîr Névâii. Paris, 1860.

\{-Nasä’im al-mahabba. Ed. Kemal Eraslan. Istanbul, 1979. 2nd edn, Ankara, 1996.\}

Németh, J. Critique of C. Brockelmann's Ali's Qissai Jusuf. Túrán, 2 (1918), 111-18.

[— Review of Köprülü's Early Mystics. Körösi Csoma-Archivum, 1 (1924), 330-2. Turkish trans. Ahmed Cemal in TM, 1 (1925), 288-9.]

New'î-Zāde 'Ațā'ī. Khamsa. MS in Köprülü's private library.

— Kitäb-i nafahăt al-azhār der jawāb-i mahzan al-asrār. MS in Köprülü’s private library.

\{Nicholson, R. and G. G. Anawati. "Ittihāē." $E I^{2}$.

Nişânci-Zâde, Mehmed b. Ahmed. Mir'ät al-kă'ināt. MS 2420 in the Nuruosmaniye Library in Istanbul.

Nithārī Bukhārī, Bahā’ al-Dīn Ḥasan. Mudhakkir-i aḥbāb. According to Köprülü, an important Persian biographical dictionary describing the poets of Central Asia after Nawā'̄i. Excellent MS in the Königliche Bibliothek in Berlin. \{Ed. Najīb Māyil Haravī. Tehran, 1377/1999.\}

Niyāzī Miṣrīi, Muḥammad. Dī̌ān. Būlāq, 1254/1838-9. \{Ed. Kenan Erdoğan as Niyazî̀-i Misni ve Divanı. Ankara, 1998.\}

Commentary on the margins of Yūnus Emre's Dīwān, Sharh-i nutuq-i Yūnus Emre.

Nizāām al-Mulk. Siyāsatnāme. Ed. and French trans. Ch. Schefer. 2 vols. Paris, 1891-3. \{English trans. H. Darke as The Book of Government, or Rules for Kings. London, 1960.\}

\{Noyan, Bedri. Firdevsi-i Rûmi, manzûm Hacı Bektâş Veli Vilâyetnâmesi [Firdawsī-i Rūmī, the versified version of the Velāyetnāme of Hājjī Bektash Veli]. Aydın, 1986.\}

Nūr Allāh al-Shustarī. Majālis al-mu’minīn. Tehran, 1268/1851-2.

\{Nurmuhammedoğlu, Naim-Bek. Hoca Ahmed Yesevî türbesi [The türbe of Khwāja Ahmad Yasawī]. Ankara, 1991.\}

\{Nwiya, P. "Ishāra." $\left.E I^{2}.\right\}$

\{Ocak, Ahmet Yaşar. İslâm-Türk inançlarnnda Hizrr yahut Hızır-Illyâs kültü [The cult of Khaḍir or Khaḍir Ilyās in Turco-Islamic beliefs]. Ankara, 1985.\}

\{—- Türk folklorunda Kesik Baş [Kesik Baş in Turkish folklore]. Ankara, 1989.\}

\{—L La Revolte de Baba Resul . . . Ankara, 1989.\} 
\{—— Osmanl İmparatorluğunda marjinal sûfilik: Kalenderîler [Marginal Șūfism in the Ottoman Empire: the Qalandarīs]. Ankara, 1992.\}

\{— Türk sufiliğine bakışlar [Interpretations of Turkish Sufism]. Istanbul, 1996.\}

\{-Osmanh toplumunda zindıklar ve mülhidler (15.-17. yüzyllar) [Heretics and unbelievers in Ottoman society (15th-17th centuries) ]. Istanbul, 1998.\}

\{- San Saltk. Ankara, 2002.\}

\{_- "Un cheik Yesevī et Babaī dans la première moitié du XIII ${ }^{e}$ siècle en Anatolie:

Emīrci Sulțān (Şerefu'd-Dīn İsma'īl b. Muhammed).” Turcica, 12 (1980), 114-24.\}

\{Ocak, Ahmet Yaşar and İsmail Erünsal (eds) Elvan Chelebi's Menâkıbu'l-Kudsiyye. 2nd edn, Ankara, 1995.\}

\{O'Kane, John. Trans. The Secrets of God's Mystical Oneness or the Spiritual Stations of Shaikh Abu Sa'id [Asrār al-Towhid fi maqāmāt al-šeyk Abi Sa'id] by Mohammad Ebn-e Monavvar. Costa Mesa, CA, 1992.\}

Olanlar Shaikhi Ibrahim Efendi. Dil-i Dânâ. MS in Köprülü's private library.

\{Önder, M. Mevlâna bibliografyasi [A bibliography of works about Mawlānā]. Ankara, 1973.\}

Ouseley, G. Biographical Notices of Persian Poets. London, 1846.

[Özderim, S. N. “F. Köprülü’nün yazıları, 1908-1950” (The works of F. Köprülü, 19081950). Hasan Eren and Tibor Halasi-Kun (eds) Türk dili ve tarihi hakkında araştrmalar -I (Research on Turkish language and history). Ankara, 1950, pp. 159-248.]

[__ "Bibliografya - F. Köprülü’nün yazılarına ek ve bâzı düzeltmeler" (A supplement and some corrections to the bibliography of the works of F. Köprülü). Belleten, 30 (1966), 661-5.]

\{Park, George. "The Life and Writings of Mehmet Fuad Köprülü.” Dissertation, Johns Hopkins University, 1975.\}

Pārsā, Muhammad. Faṣl al-khițāb. MS in the Istanbul University Library.

Pavet de Courteille, Abel. Dictionnaire Turc-Oriental. Paris, 1870.

Mirâdj-nâmeh: Récit de l'ascension de Mahomet au cièl. Paris, 1882. \{Reprinted Amsterdam, 1975.\}

\{Pekolcay, Neclâ and Emine Sevim. Yunus Emre şerhleri [Commentaries on Yūnus Emre]. Ankara, 1991.\}

\{Pellat, Ch. "Djuhāa." $\left.E I^{2}.\right\}$

\{Pellat, Ch. et al. "Madjnūn Layla." $E I^{2}$.

Pertsch, W. Verzeichniss der türkischen Handschriften der Königlichen Bibliothek zu Berlin. Berlin, 1889.

\{Pritsak, O. "Alp.” EI².\}

\{Privratsky, Bruce G. Muslim Turkistan: Kazak Religion and Collective Memory. Richmond, Surrey, 2001.\}

Qayghusuz. 'Abdālnāme. MS in Köprülü's private library.

— Manāqibi-Qayghusuz Abdāl (Sulțān). MS in Köprülü's private library. \{Ed. Abdurrahman Güzel as Kaygusuz Abdal (Alâeddin Gaybî) menâkıbnamesi. Ankara, 1999.\}

Al-Qazwīnī, Zakāriyyā’ b. Muhammad. Āthār al-bilād. Ed. F. Wüstenfeld. 2 vols. Göttingen, 1848. \{Reprinted Wiesbaden, 1967.\}

\{Qoylaqï, Safi ad-Din Orïn. “Nasab-nama.” Ed. Äshirbek Qŭrbanŭli Muminov and Zikiriyä Zamankhanŭlï Jandarbekov. Turkistan, 1992.\}

Quatremère, É. "Notice de l'ouvrage qui a pour titre Mesalek Alabsar fi Memalek Alamsar, Voyages des yeux dans les royaumes de différentes contrées." Notices et Extraits des Manuscrits de la Bibliothèque du Roi, 13 (1838), 151-348. 


\section{B I B L I O G R A P H Y}

Al-Qushairī. Al-Risāla. Turkish trans. Nâfî Efendi as Risâle-i Kuşayrîye. Istanbul, 1307/ 1889-90. \{Ed. 'Abd al-Halīm Mạ̣mūd et al. as al-Risāla al-Qushairiyya. 2 vols. Cairo, 1966; English trans. Rabia Harris as The Risalah: Principles of Sufism. Distributed by KAZI Publications [Chicago], 2002.\}

Radloff, W. (or Radlov, V). Proben der Volkslitteratur der türkischen Stämme Süd-Siberiens. 10 vols. St Petersburg, 1866-70. \{Reprinted Leipzig, 1965.\}

Das Schamanenthum und sein Kultus, eine Untersuchung. Leipzig, 1885.

"Über alttürkische Dialekte: (1) die seldschukischen Verse im Rebâb-Nâmeh.” Mélanges Asiatiques, 10 (1890-4), 17-77.

Rashīd al-Dīn. Jāmi al-tawā̄inkh. Ed. and Russian trans. I. Berezin of the introduction on Turkish and Mongol tribes and the history of Jenghiz Khan in ZVO, 5 (1858), 7 (1861), 13 (1868), 15 (1888). Berezin's work is old and defective. E. Blochet corrected Berezin and translated the introduction into French in the GMS. London, 1911. See above. \{Ed. A. A. Alizade. Moscow and Baku, 1957-80. Also ed. Bahman Karīmī. Tehran, 1338/1959-60. English trans. W. Thackston as Rashiduddin Fazlullah's Jami'u't-tawarikh - Compendium of Chronicles. Part 1. Harvard University Department of Near Eastern Languages and Civilizations, 1998.\}

Rāzī, Amīn Aḥmad. Haft iqtīm. MS in the Hâlis Efendi Library in the Süleymaniye in Istanbul. \{Ed. Javād Fādili, 3 vols. Tehran, 1960.\}

Reclus, É. (ed.) Nouvelle géographie universelle. 19 vols. Paris, 1881-94.

\{Reichl, Karl. Turkic Oral Epic Poetry. New York, 1992.\}

\{_- Singing the Past: Turkic and Medieval Heroic Poetry. Ithaca, NY, 2000.\}

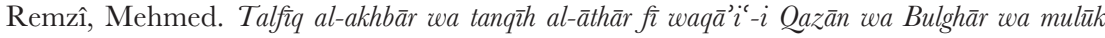
al-tätār. 2 vols. Orenburg, 1325/1907. In Arabic.

Riḍā Qūī Khān. Safarnāme-yi Khwārazm. Ed. and French trans. Ch. Schefer. Paris, 1879.

Rieu, Charles. Catalogue of Turkish Manuscripts in the British Museum. London, 1888.

Rifat Ahmed Efendi. Mir'âtül-makâsıd. Istanbul, 1293/1876.

Risāla-i bektāshiyya. Minor Bektashī treatises of unknown authorship. Several MSS in Köprülü's private library.

[Ritter, H. "Celâleddin Rûmî." İA.]

\{—_Aț̣āar." $E I^{2}$.\}

Rızâ Tevfik. Études sur la religion des Houroûfis. Leiden, 1909.

"Yûnus Emre'yi ziyâret" [Visiting the tomb of Yūnus Emre]. In the literary supplement to the newspaper Peyâm, June 19, 1329/1911.

Unidentified article in the literary supplement to the newspaper Peyâm, no. 35, May 8, 1330/1912.

"Yûnus Emre hakkında biraz daha tafsilât" [A few more details on Yūnus Emre]. Büyük Duygu, nos 10-13, 1 (1331/1913).

\{Saadi, A. "Novyi material po istorii tatarskoi literatury drevnei èpokhi" [New material for the history of Tatar literature in the ancient (sic) period]. Vestnik nauchnogo obshchestvo tatarovedeniia, no. 7 (1927), 149-56.\}

Sa'd al-Dīn. Täj al-tawārīkh. 2 vols. Istanbul, 1280/1863-4.

Șādiqī Kitābdār. Tadhkira (Majma' al-khawāṣṣ). MS 3720 in the Nuruosmaniye Library in Istanbul. According to Köprülü, this work was written around the end of the tenth/ sixteenth century and describes the poets, calligraphers, and painters who lived in Azerbaijan, Turkistan, and especially in the area under the control of Iran. The author Șādiqī (or Sâdıkî) was the librarian of Shāh 'Abbās. He wrote in beautiful Chagatay 
and in imitation of Nawā' $\overline{1}$. \{Ed. and Persian trans. 'Abd al-Rasūl Khayyāmpūr. Tabriz, 1327/1948. See Hofman, Turkish Literature, vol. 5, pp. 273-7.\}

Șafā'̄̄. Tadhkirat al-shu'ară'. MS 2549 (Köprülü gives this number in the text, but gives MS 1750 in his index) in the Esad Efendi Library in the Süleymaniye in Istanbul.

Șafì, 'Alī b. Husain Wā'iz Kāshifì Baihaqī. Rashahāt-i 'ain al-ḥayāt. Lucknow, 1308/1890. \{Ed. 'A. A. Mu'īniyān. Tehran, 2536/1977-8.\} According to Köprülü this work, which describes the Naqshbandī Khwāja 'Ubaid Allāh Ahrār, is very famous among the Naqshbandīs. There are many MSS of it. Written in 903/1497-8, it was, according to Kātib Chelebi, translated into Turkish with additions by Mehmed Ma'rūf of Trebizond while he was $q \bar{a} d \bar{\imath}$ of Izmir in 993/1585. Then it was presented to Sultan Murad.

Turkish translation of the Rashahāt. Istanbul, 1291/1874. According to Köprülü, it was first published in Egypt (i.e. Būlāq) in 1236/1820-1. There is also a Kazan edition. According to the MS in his private library, "in 1149/1736-7, when Mawlānā Niyāz, who was called Shāh-i Mashāyikh \{King of the shaikhs\}, Shaikh al-Islām Naqshband, Chagatay Bey and more than 500 Hindī, Sindī, Özbeg, and Afghan abdāls arrived on the pretext of going to Anatolia, the Khwārazm Sultan Muhammad Bahādur Khān had this work translated into Turkish because it was in Persian." Nevertheless, adds Köprülü, this cannot be considered trustworthy. He goes on to say that we possess various copies of Ma'rūf Efendi's translation, but even if we did not, Kātib Chelebi's testimony would suffice to reject the aforesaid assertion.

Sa ${ }^{\prime} \bar{d}$ Pasha (Diyarbekirli). Mir'āt al-íibar. Istanbul, 1304/1886-7.

Saint-Hilaire, Jules Barthélemy. De l'école d'Alexandrie; rapport à l'Academie des sciences morales et politiques, précédé d'un essai sur la méthode des Alexandrins et le mysticisme, et suive d'une traduction de morceaux choisis de Plotin. Paris, 1845.

\{Sakaoğlu, Saim. "Battâl-name.” Türk Dili Araştırmalan Yillı̆̆ı: Belleten, (1992), 67-74.\}

Sakib Dede. See Thāqib Dede.

Şâkir Pasha. Yeni osmanl tarihi [Modern Ottoman history]. Istanbul, 1911-12.

Saladin, Henri. Manuel d'art musulman: I. L'Architecture. Paris, 1907.

Șalāh al-D̄̄n Ibn Mubārak al-Bukhārī. Maqāmāt Muhammad Bahā’ al-D̄̄n Naqshband. Turkish trans. Süleyman Azmî. Istanbul, 1328/1910. \{Actually entitled Anīs al-țālibīn. Ed. Khalīl Ibrāhīm Șārī Oghlī. Tehran, 1371/1992.\}

Salemann, C. "Noch einmal die seldschukischen Verse: (Sultan Veled Rebabname)." Bulletin Scientifique de l'Académie Impériale des Sciences de St Pétersbourg, N.S., 2 (= 34, 1892), 293-365. Also in Mélanges Asiatiques, 10 (1894), 173-245.

Salmon, Georges. "Soufisme." La Grande Encyclopédie.

Al-Sam‘ān̄̄. Al-Ansāb. Facsimile (ed.), D. S. Margoliouth. London, 1912. \{Ed. Al-Mu'allimī et al. 13 vols. Hyderabad, Deccan, 1952-82.\}

Samoilovich, A. N. "Materialy po sredneaziatsko-turetskoi literature" [Materials on Turkish literature in Central Asia]. ZVO, 19 (1909), 1-30; 22 (1913-14), 127-53; ZKV, 2 (1927), $257-74$.

\{Sapabekŭlï, Sadïq. "Türkı̌standaghï tarikhi ziyarat” [A historical pilgrimage in Turkistan]. Ed. Khamid Imanzhanov and R. Zhüzbaeva in the collective vol. Yäsaui taghilimi [Yasawī’s teaching]. Ed. Mekemtas Mirzahmetǔli. Turkistan, 1996, pp. 123-32.\}

Sarı 'Abd Allāh Efendi. Thamarāt al-fu'àd. Istanbul, 1288/1871.

\{Scharlipp, Wolfgang. Die frühen Türken in Zentralasien. Darmstadt, 1992.\}

\{Schimmel, Annemarie. Mystical Dimensions of Islam. Chapel Hill, NC, 1975.\}

\{-The Triumphal Sun. London, 1978.\} 
\{Schmitz, Andrea. Die Erzählung von Edige: Gehalt, Genese und Wirkung einer heroischen Tradition. Wiesbaden, 1996.\}

\{Schubert, Gudrun. "Sulțān Walad." $E I^{2}$.\}

Schuyler, Eugene. Turkistan, Notes of a Journey in Russian Turkistan, Khokand, Bukhara, and Kuldja, 6th edn. 2 vols. London, 1877. \{Abridged reprint London, 1966.\} Turkish trans. Ahmet Efendi as Musavvar Türkistan tarihi ve seyâhatnâmesi. Istanbul, 1294/1878.

\{Sells, Michael. Early Islamic Mysticism. New York, 1996.\}

Şerefeddin (Yaltkaya), Mehmed. "Eski Türk memleketlerinde" [In the countries of the ancient Turks]. YM, no. 59, August 29, 1918, 134-6.

" "Sencer ve Gazzâlî [Sanjar and al-Ghazālī]. Darülfünûn İlâhiyat Fakültesi Mecmuası, 1 (1341/1925), 39-57.

"Selçukiler devrinde mezâhib" [Muslim sects in the Seljuk period]. TM, 1 (1925), $101-8$.

\{—_ "Mevlânâ'da türkçe kelimeler ve türkçe şïrler" [Turkish words and poetry in Mawlānā]. TM, 4 (1934), 111-67.\}

\{Şeşen, Ramazan. İslâm coğrafyacılarna göre Türkler ve Türk ülkeleri [The Turks and Turkish countries according to Muslim geographers]. Ankara, 1985.\}

\{Shafî', Moḥammad. "Ratan." $\left.E I^{2}.\right\}$

Shahrastānī. Al-Milal wa 'l-nihal. Turkish trans. Nūh b. Muștafā. Cairo, 1263/1847 and Istanbul, 1279/1862. \{French trans. D. Gimaret et al. as Livre des religions et des sectes. 2 vols. Louvain, 1986-93.\}

Shaikh Süleyman. Lughat-i chaghatay ve türkî̀ŷ́ 'osmânî. Istanbul, 1298/1882.

Shaikh-oghlu. Kanz al-kubarā'. Unique autograph MS in Köprülü's private library. According to him, this work is very important with respect to Turkish linguistic and literary history.

Shams al-Dīn Ibn Qays al-Rāzī (or Shams-i Qays). Al-Mu'jam fì ma'āȳ̄r ash'ār al-'ajam. Leiden, 1909. \{Ed. Muhammad Qazvīnī et al. Tehran, 1314/1935.\}

Shams al-Dīn Muḥammad b. Nūr Muḥammad al-Ṭāhirī. Köylü îmân [Peasant faith]. Kazan, 1903.

Shams al-Dīn Sāmī. Qāmūus al-a' lām. 6 vols. Istanbul, 1889-98. \{Reprinted Ankara, 1996.\}

Shams al-Dīn Sīwāsī. Sharh-i ghazal-i Mawelānā. MS in Köprülü's private library.

Shams Kāshānī. Shahnāme-i Chingīzī. Lala Vakfi MS 354 in the Hamidiye Library in the Süleymaniye in Istanbul. According to Köprülü, this is an excellent copy embellished with valuable miniatures. He adds that Edgar Blochet, in his Introduction à l'histoire des Mongols de Fadl Allah Rashid ed-Din, mistakenly claims that this work exists only in a single copy in the Bibliothèque Nationale in Paris. Kătib Chelebi also saw this work. He reported it under the title Ta'nikh-i Ghāzann Khān and adds that the poet of this work died around 730/1329-30 during the reign of Abū Sa'īd. \{See Storey-Bregel', Persidskaia literatura, vol. 2, pp. 767-8.\}

Sharā'it al-īmān. Kazan, 1901.

Al-Sha'rānī, 'Abd al-Waḥhāb. Al-Ṭabaqāt al-șūfyya. Cairo, 1305/1887-8. \{Published as al-Ṭabaqāt al-kubrā, Cairo, 1898. Reprinted Cairo, 1965.\}

Shaw, Robert Barkley. A Sketch of the Túrki Language as Spoken in Eastern Tưrkistán Káshghar and Yarkand, Together with a Collection of Extracts. Lahore, 1875.

Shikārī. Karaman tarihi (or Şıkâri tarihi). Turkish trans. by Shikārī of Āl-i Qaramān shāhnāme, a Persian poem of unknown author. MS in the possession of Tâhir al-Brusawi. [Ed. Mesut Koman. Konya, 1946.] 
\{Shpall, William. "A Note on Najm al-Dīn al-Rāzī and the Bahrr al-Haqū’iq." Folia Orientalia, 22 (1981-4), 69-80.\}

\{Silay, Kemal. Nedim and the Poetics of the Ottoman Court. Bloomington, IN, 1994.\}

Simon, Jules. Histoire de l'école d'Alexandrie. 2 vols. Paris, 1845.

"Plotin," in Adolphe Franck (ed.) Dictionnaire des sciences philosophiques, 2nd edn. Paris, 1875.

Sinān Pasha. Tadhkirat al-awliy $\vec{a}$. MS in the Beyazıt Umumi Library in Istanbul. \{Ed. Emine Gürsoy. Ankara, 1987.\}

Sipahsālār, Farīdūn b. Aḥmad. Manāqib-i hadrat-i Khudāwandigār. Turkish trans. Midhat Bahârî Hüsâmî. Istanbul, 1331/1913. According to Köprülü, this work had not attracted the attention of Western scholars. It is the oldest source for Mawlānā and the early Mawlawīs. \{Ed. Sa'īd Nafìsī as Risāla-i Sipahsālār. Tehran, 1325/1947.\}

Smirnov, V. D. "Les vers dits 'seldjouk' et le christianisme turc." Actes du $11^{e}$ Congrès International des Orientalistes (1897). Paris, 1899, 3rd section, pp. 143-57.

\{Soysal, M. Orhan. Eski Türk edebiyatı metinleri [Early Turkish literary texts]. Ankara, 1978.\}

Spencer, Herbert. The Principles of Sociology, 3rd rev. edn. New York, 1890.

\{Stein, Heidi. "Das türkische Sprachgut im 'Tractatus de Moribus, Condictionibus et Nequicia Turcorum' (1481) des Georg von Ungarn." Archivum Ottomanicum, 14 (1995/ 6), 39-78; 15 (1997), 89-118.\}

\{Steingass, F. Persian-English Dictionary. 1892; reprinted Beirut, 1975.\}

\{Storey, C. A. Persian Literature. Russian trans. Iu. È. Bregel' as Persidskaia literatura: Biobibliograficheskii obzor. Moscow, 1972.\}

Strzygowski, J. Altai-Iran und Völkerwanderung. Leipzig, 1917.

Șūfi Allāhyār. Fawz al-najāt. Istanbul, n.d., and Kazan, 1895.

Al-Suhrawardī, Shihāb al-Dīn. 'Awārif al-ma'ārif. 2 vols. Būlāq, 1289/1872-3. On the margins of al-Ghazālì's Ihyā'ulüm al-dīn. \{Cairo, 1973. German trans. Richard Gramlich as Die Gabender Erkenntnisse des 'Umar as-Suhrawardī. Wiesbaden, 1978.\}

Şükrullâh. Bahjat al-tawārnkh. MS 3059 in the Nuruosmaniye Library in Istanbul. According to Köprülü, this work was written for Mạ̣mūd Pasha, a vizier of Mehmet II. It is a brief but noteworthy history of Islam that describes the Ottomans up to the reign of Mehmet II. \{A modern Turkish trans. of the section on the Ottomans is included in Atsiz, Osmanl tarihleri. Istanbul, 1949. The Persian text of the same section and a German trans. have been published by Theodor Seif as "Der Abschnitt über die Osmanen in Š̈urullāh's persischer Universalgeschichte." Mitteilungen zur osmanischen Geschichte, 2 (1923-6), 63-128.\}

Sulaimān Ata Bāqirghān̄̄ (Hakīm Ata). Bāqirghān kitābr. Attributed to Sulaimān but actually the work of later Yasawī poets. Kazan, 1857. Reprinted Kazan, 1883-4. \{New eds Ibrahim Häqqul and Säyfiddin Räf'iddin. Tashkent, 1991.\}

Surūrī. Bahr al-ma'ārif. MS in Köprülü's private library.

Al-Ṭabarī. Ta'rn̄kh (Ta'n̄kkh al-rusul wa 'l-mulük). Leiden, 1879-1901. The abridged Persian version was translated into Turkish. L. Debeux and then after his death H. Zotenberg translated the Persian version into French as Chronique d'Abou Djafer Mohammed b. Djarir Tabari. 4 vols. Paris, 1867-74. \{English trans. of the original Arabic under the general editorship of Ehsan Yarshater as The History of al-Tabari. 39 vols. Albany, New York, 1985-. We have cited vol. 32, trans. C. E. Bosworth as The Reunification of the 'Abbāsid Caliphate. 1987.\} 


\section{B I B L I O G R A P H Y}

Al-Ṭabarī, Muhibb al-Dīn Aḥmad. Al-Riyāe al-nadira. 2 vols. Cairo, 1327/1909.

\{Taeschner, Fr. Zünfte und Bruderschaften im Islam: Texte zur Geschichte der Futuwwa. Zurich, 1979.\}

$\left\{-\right.$ "Akhī." $E I^{2}$. $\}$

[—_A "Ahī Ewrān." EI ${ }^{2}$.]

\{—_Gülshehrī." $E I^{2}$.\}

Tâhir, Bursalı Mehmed. Aydnn vilâyetine mensûb ricâlin terâcim-i ahvâli [Biographies of notables associated with the province of Aydın]. Izmir, 1324/1906. \{Ed. M. Akıf Erdoğru as Aydrn vilâyetine mensûb meşâyih, ulemâ, şuarâ, müverrihin ve etibbânn terâcim-i ahvâli [Biographies of shaikhs, 'ulam $\vec{a}$ ', poets, historians, and physicians associated with the province of Aydın]. Izmir, 1994.\}

Hā̄jō Bayrām Wat̄. Istanbul, 1329/1911.

Osmanl müellifleri [Ottoman authors]. 3 vols. Istanbul, 1334-43/1916-25.

"Aşık Paşa." Türk Derneği, 1 (1327/1911), 12-19.

[Tansel, Fevziye Abdullah. "Memleketimizin aci kaybı Prof. Dr Fuad Köprülü" (A painful loss for our country, Prof. Dr Fuad Köprülü). Belleten, 30 (1966), 633-5.]

[__ "Prof. Dr Fuad Köprülü yazıları için basılmış bibliyografyalar" (Published bibliographies of the writings of Prof. Dr Fuad Köprülü). Türk Kültürü, 6 (1968), 543-56.]

\{_ "Cümcüme Sultan: Ottoman Translations of the Fourteenth Century Kipchak Turkic Story." Archivum Ottomanicum, 2 (1970), 252-69.\}

\{Taşağıl, Ahmet. Gök-Türkler. Ankara, 1995.\}

Tashköprü-Zāde. Al-Shaqā'iq al-nu'māniyya. On the margins of Ibn Khallikān's Wafayāt al-a'y ān. Būlāq, 1300/1882. Turkish trans. Mecdî, Istanbul, 1269/1852-3. Supplements,

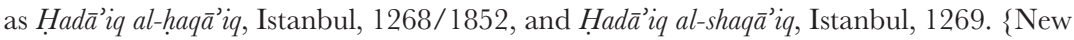
edn of the original Arabic, Ahmed Furat. Istanbul, 1985.\}

—Mawdü'ät al-'ulūm. Turkish trans. Istanbul, 1313/1895-6. \{The title of the Arabic original is Miftāh al-sa'a da.\}

de Tassy, Garcin. La Poésie philosophique et religieuse chez les persians d'après le Mantic uttaïr . . . Paris, 1860.

- Histoire de la littérature hindoui et hindoustani, 2nd rev. edn. 3 vols. Paris, 1870-1.

\{Tatç1, Mustafa. Yunus Emre Divân. 2 vols. Ankara, 1990.\}

$\{-$ Asşck Yunus ve diğger Yunuslarn şïrleri [The poetry of 'Āshıq Yūnus and the other Yūnuses]. Ankara, 1991.\}

\{Tekin, G. A. "Seh̄̄ Bey." $E I^{2}$.\}

\{Tekin, Talât. "Yunus Emre'nin gotik harfleriyle iki manzumesi" [Two verses by Yunus Emre in Gothic script]. Erdem, 3 (1987), 367-92.\}

\{Terzioğlu, Derin. "Sufi and Dissident in the Ottoman Empire: Niyazi-i Misri (16181694)." Dissertation, Harvard University, 1999.\}

\{Teubner, J. K. "“Abd Allāh b. Abī Bakr al-Miyānadjīi." EI $I^{2}$, Supplement.\}

\{__ “Ayn al-Kựāt al-Hamadhān̄i." EI ${ }^{2}$, Supplement.\}

Tevhid, Ahmed. Meskûkât-i kadîme-i islâmiyye kataloğu [Catalogue of early Islamic coins]. Vol. 4. Istanbul, 1321/1903-4.

"Rum selçuki devletinin inkiraziyle teşekkül eden tevâif-i mülûkdan Kara Hisar-i Sahibde Sahib Ata Ogulları" [One of the petty states that arose with the collapse of the Seljuk State of Rum: the Sahib Ata-Oghullari at Kara Hisar-i Sahib]. TOEM, 9 (1327/ 1909), 563-8.

"Ankara'da ahiler hükûmeti" [The government of the akhīs in Ankara]. TOEM, no. 19 (1328/1910), 1200-4. 


\section{B I B L I O G R A P H Y}

\{Tezcan, Semih. “Anadolu Türk yazınının başlangıç döneminde bir yazar ve çarh-name’nin tarihlendirilmesi üzerine" [Concerning an author of the initial period of Anatolian Turkish literature and the dating of the Çarh-name]. Türk Dilleri Araştrrmalan, 3 (1994), 75-88.

Thāqib Dede (or Sakib Dede). Safinna-i mawlawizyān (or Sefine-i nefise-i mevleviyan). Cairo, $1283 / 1866$.

Tholuck, F. A. D. Sufismus. Berlin, 1821.

Thomsen, V. "Inscriptions de l'Orkhon déchiffrées." Mémoires de la Société Finno-ougrienne. Helsinki, 5 (1896), 1-224.

"Sur le système des consonnes dans la langue ouïgoure." Keleti Szemle, 2 (1901), 241-59.

- "Ein Blatt in türkischer 'Runen' Schrift aus Turfan.” Sitzungsberichte der (Berliner, d.h.) Preussischen Akademie der Wissenschaften, 1910, pp. 296-306.

Thorning, H. Beiträge zur Kenntnis des islamischen Vereinswesens auf Grund von Madad-et-Taufiq. Published as part 16 of Türkische Bibliothèque. Berlin, 1913.

Thúry, Jozef. "Ondördüncü 'asır sonlarına kadar Türk dili yâdıgârları" [Monuments of the Turkish language up to the end of the fourteenth century]. Trans. from the Hungarian by Râgip Hulûsî in MTM, 2 (1331/1913), 81-133.

\{Tietze, Andreas and Talât Tekin. "Tarama Sözlüğü üzerine bazı açıklamalar" [Some clarifications concerning the Tarama Sözlügüi]. Erdem, 5 (1989), 285-93.\}

[Timurtaş, Faruk. Yûnus Emre Divanı. Istanbul, 1972.] \{3rd edn, Ankara, 1986.\}

Togan, Ahmed Zeki Velidi. Türk-Tatar tarihi. Vol. 1, Kazan, 1912. Vols 1-2, Kazan, 1915-17.

\{—_ "Yeseviliğe dair bazi yeni malûmat" [Some new information on the Yasawiyya]. In Osman Turan et al. (eds) 60 Doğum ynl münâsebetiyle Fuad Köprülü armağanı (Mélanges Fuad Köprülü). Istanbul, 1953, pp. 523-9.\}

\{__Gazan-Han Halil ve Hoca Bahaeddin Nakşbend." In Necati Lugal armağanı. Ankara, 1968, pp. 775-84.\}

[—_Balasagun." $\dot{I} A$. $]$

\{Tosun, Necdet. "Yesevîliğin ilk dönemine âid bir risâle: Mir'âtü'l-kulûb" [A treatise from the early period of the Yasawiyya: Mir'ät al-qulüb]. ILAM Araştrma Dergisi, 2 (1997), 41-85.\}

\{Troitskaia, A. L. "Zhenskii zikr v starom Tashkente." Sbornik Muzeia antropologii e ètnografii AN SSSR, 7 (1928), 189-92.\}

Tschudi, R. "Bektāsh.." EI $I^{1}$.

\{Tulum, Mertol. Tarihi metin çalı̧smalarnda usul: Menâkıbu'l-Kudsiyye üzerinde bir deneme [Method in the study of historical texts: an essay on the Manāqib al-Qudsiyya (of Elvan Chelebi)]. Istanbul, 1989.\}

\{Turan, Osman. Selçuklular zamaninda Türkiye tarihi [A history of Turkey in the Seljuk period]. 2nd edn, Istanbul, 1984.\}

[—_ "Fuad Köprülü'nün ilmî neşriyat”" (Fuad Köprülü’s scholarly publications). In Osman Turan et al. (eds) 60 Doğum ynlı münâsebetiyle Fuad Köprülü armağann (Mélanges Fuad Köprülü). Istanbul, 1953, pp. xxvii-1.]

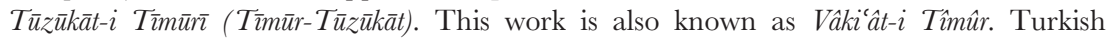
trans. Qāộ̄ Makhdūm Nab̄̄ Jān Khāṭif Khujandī. Tashkent, 1308/1890-1. It was translated from Chagatay to Persian under the title Malfüzăt-i Tìmūiñ. French trans. L. M. Langlès as Institutes politiques et militaires de Tamerlan, proprement appellé Timour . . Paris, 1787. \{English trans. and Persian text by Major Davy as Institutes, Political and Military. 
1783. Reprinted Tehran, 1342/1963.\} See W. Pertsch, Verzeichniss der persischen Handschrifen der Königlichen Bibliothek zu Berlin, vol. 4. Berlin, 1888. \{See Storey-Bregel', Persidskaia literatura, vol. 2, pp. 791-7.\}

Ujfalvy, C. Le Syr-Daria ... Paris, 1879.

Üsküplü 'Ațā. Tuhfat al-'ushshāq. MS in Köprülü's private library.

\{Usmanov, M. A. Tatarskie istoricheskie istochniki XVII-XVIII vo [Tatar historical sources of the seventeenth-eighteenth centuries]. Kazan, 1972.\}

Vacherot, Étienne. Histoire critique de l'école d'Alexandrie. 3 vols. Paris, 1846-51. \{Reprinted Amsterdam, 1965.

Vambéry, Arminius (Hermann). Cagataische Sprachstudien. Leipzig, 1867.

Voyages d'un faux derviche dans l'asie centrale de Téhéran à Khiva, Bokhara et Samarkand. 2nd edn, Paris, 1873. \{English trans. as Travels in Central Asia. London, 1864. Reprinted New York, 1970.\}

History of Bokhara, 2nd edn. London, 1873. \{Reprinted New York, 1973.\}

"Eine legendäre Geschichte Timurs." ZDMG, 51 (1897), 215-32.

\{_ "Muhammadanism (in Central Asia)." Encyclopaedia of Religion and Ethics. Reprinted New York, 1961. Vol. 8, pp. 885-8.\}

Veled Chelebi \{İzbudak\}. Unidentified article in a special joint issue of the Istanbul daily newspaper Tercümân-ı hakikkat and the illustrated weekly Servet-i fünun, 1313/18956.

Visdelou, C. Bibliothèque orientale de messieurs C. Visdelou et A. Galland contenant les observations sur ce queles historiens arabes $\&$ persiens rapportent de la Chine $\&$ de la Tartarie dans la Bibliothèque orientale de M. d'Herbelot. Maestricht, 1780.

\{Vryonis, Speros. The Decline of Medieval Hellenism in Asia Minor and the Process of Islamization from the Eleventh through the Fifteenth Century. Berkeley, CA, 1971.\}

\{Weber, Max. The Theory of Social and Economic Organization. Trans. A. M. Henderson and Talcott Parsons. New York, 1947.\}

\{Weil, G. and G. S. Colin. "Abdjad." $E I^{2}$.\}

\{Weischer, B. M. "Kirmānī." $E I^{2}$.\}

\{Wensinck, A. J. "Khadir." $E I^{2}$.\}

\{Woodhead, Christine. "Sinān Pasha, Khodja." $\left.E I^{2}.\right\}$

Al-Yāfi'ī, 'Abd Allāh b. As'ad. Mir'āt al-janān wa 'ibrat al-yaqzan fì ma'rifat hawāadith al-zamān. 9 vols. Hyderabad, 1337-9/1918-21. \{Beirut, 1984.\}

Yaltkaya. See Şerefeddin.

Yahyā b. al-Khalīl b. al-Chūbān al-Yahyā Fatā 'l-Burghāzì. Futuwwratnāme. MS of \{the historian\} 'Ârif Bey. According to Köprülü, another MS of this work had come into his possession. It differed somewhat from the other following the section on the Akhīs. It was in his private library. He promised to provide extensive and critical information on these MSS in a special analytical work that he was preparing on the Akhīs, but it never appeared. \{Ed. Abdülbâki Gölpınarlı as "Burgazi ve Fütüvvetnamesi." İktisat Fakültesi Mecmuası, 15 (1953-5), 76-153. German trans. by Fr. Taeschner in Zünfte und Bruderschaften im Islam, using Köprülü's MS.\}

Yāqūt. Mưjam al-buldān. Ed. F. Wüstenfeld. 6 vols. Leipzig, 1866-73.

Yazdī, Sharaf al-Dīn. Zafarnāme-i T̄̄mūr. 2 vols. Calcutta, 1887-8. Chagatay trans. Muhammad 'Alī b. Darwīsh 'Alī Bukhārī, MS 3268 Nuruosmaniye Library in Istanbul. French trans. of the Persian MS Pétis de la Croix as Histoire de Timur-Bec, Paris, 1722. \{English trans. as The History of Timur-Bec . . London, 1723; new Persian ed. Muhammad 'Abbāsī. Tehran, 1336/1957.\} 


\section{B I B L I O G R A P H Y}

Yazıcı-oğlu 'Alī. Saljūqnāme (Mufașsal Saljūqnāme). MS in the Topkapı Sarayı Revan Köşkü Library. There is another good MS in the Hâlis Efendi Library in the Süleymaniye in Istanbul. According to Köprülü, Necib Âsım began to publish this work, but was not able to finish it. Ed. Th. Houtsma as vol. 3 of Recueil de textes relatifs à l'histoire des seldjoucides. Leiden, 1902.

Yūnus Emre. Dī̌ān-ı 'āshıq Yūnus Emre. Istanbul, 1320/1902-3. MS in Köprülü’s private library. Commentary on his hymn Çıktım erik dalnna by Bursalı Ismā̄îl Hakkı. MS in Köprülü's private library. Commentary on the same by Niyāzī Miṣrī as Sharh-i ghazal-i Yünus on the margins of Yūnus's Dīwān.

\{Yurt, Ali. Akşemseddin, 1390-1459: hayatı, eserleri [Ak Shams al-Dīn, 1390-1459: His life and works]. Istanbul, 1994.\}

\{Yūsofì, G. H.̣. "Abū Moslem ... Korāsānī.” EIr.\}

Yusuf Khāṣ̦ Hājib. Kutadgu Bilig. Text and German trans. W. Radloff as Das KudatkuBilik. . . 2 vols. St Petersburg, 1891-1910. [Ed. and Turkish trans. R. R. Arat. Ed. Istanbul, 1947; trans. Ankara, 1959.] \{English trans. Robert Dankoff as Wisdom of Royal Glory. Chicago, 1983.\}

\{Zajaczkowski, Ananiasz. Najstarsza wersja turecka Husräv u Š̀̀ñn Qutba. 3 vols. Warsaw, 1958-61.\}

Zakī Pasha, Ahmad. Mémoire sur les moyens propres à déterminer en Égypte une renaissance des lettres arabes. Cairo, 1910.

\{Zaleman, K. G. (ed. and trans.). "Legende pro Khakim-Ata." Izvestiia Akademii nauk (SPb.), 9/2 (1898), 105-50.\}

\{Zarcone, Th. "Zangī Ātā." $E I^{2}$.\}

\{—_ "Khwādjagān." $E I^{2}$, Supplement.\}

Zaydān, Jurjī. Medeniyyet-i islâmiyye tarihi [The history of Islamic civilization]. Turkish trans. of the Arabic original. 5 vols. Istanbul, 1328-30/1910-12.

Ziyâ Pasha (ed.). Kharābāt (or Harâbât). 3 vols. Istanbul, 1291-2/1874. 


\section{INDEX}

'Abbāsids 5, 9, 17n30, 197

'Abd Allāh Baraqī 60-3, 73n9, 77n30

'Abd al-Qādir al-Jìlānī 7

Abdāl Mūsā 31, 49n50, 363, 371n4, 372n5

Abū Sa'īd Ibn Abī 'l-Khair 8, 139, 166n55, 343n34, 348n38

Abū Sa'î̀d Mīrzā 29

Abū Yazīd al-Bistāmī 7, 118n42, 241n48 ahl-i hāl 273

ahl-i qāl 273, 306

Ahmmad Sārbān 365, 376n13, 378n18

Aḥmad Yasawī: in Bektashī legend 32-5; children and grandchildren 64-5; in his chilla-khāne 26-8, 63; compared with Yūnus Emre 369-70; death date xvii, $62,7 \ln 3$; early fame 22-4; family xvii; historical childhood 57-8; khaliffas 24-6, 89-94; khaliffas among the Qipchaqs 30-1; khaliffas among the Western Turks 31-2; legendary childhood 20-2; life as Șūfì teacher xviii, 136-40; life in Yasī 61-4; literary influence of 171-5; miracles 22-4, 26-8, 47n42; miracles after his death 28-30; poetry xix-xxiii; shrine $8 \ln 49$, 82n51, 83n53, n56-7, 86n61; and Soviet ideology vii, xiv, xxiii; spiritual training xviii; tañqas originating from 102-5; türbe and mosque 65-70; and the Yasawi order xix

akhī(s) 200-1, 230n34, 235n39, 238n43, 239n44-5, 281n2, 364

Akhī Ören (Evren) 270

Āl-i Burhān 58

'Alī 8, 20, 7 ln5

'Alī Lālā, Shaikh 62, 78n32, n34, 79n35
'Ālī, Mușțafā xv

'Ālim Shaikh of 'Alīyābād xii alp 210-11, 213, 258n90, 260n94

Amīr Sulțān 284n 15

Amu Darya 4-5

Anatolia 37, 104, 107, 123n62, 177-8, 198-200, 206-10, 213, 216n3-4, 230n34, 235n39, 257n86, 268, 281n4, 286n19, 362-4, 321; see also Rūm

'Anbar Ana 89, 91-4, 108n3, 111n15

Ankara 239n45

$\operatorname{Arab}(\mathrm{s})$ 4-5, 9

Argu 130-1, 133, 155n33, 157n35

'ärif 22

Arslan Bābā xvii-xviii, 8, 20-1, 38n3-4, 39n5, 40n10, 46n32, 57-8, 70n1, 92, $108 \mathrm{n} 1$

'arüd meter xxvi n16, lii, 9-10, 135, 159n42, 173-5, 181n8, 209, 252n77, 254n80, 279, 305-7, 332n18-19, $38 \ln 23,382 \mathrm{n} 26$

'āshrq 174, 178, 183n17, 258n87, 279, 367-8

'Āshıq Pasha 210, 247n66, 250n75, 257n86, 270, 277, 326n2, 327n4, 340n29, 363, 371n2-3

Avshar Bābā 31

Azerbaijan 31, 37, 191 ñ 3

Azerī 177-8, 182n12, 186n27, 266n108, 303, 328n8

$b \bar{a} b, b \bar{a} b \bar{a} 7-8,366$

Bābā Māchīn 24-5, 39n4, 43n18, 128

Bābā'̄̄ uprising 200, 230n35

Badakhshān 34

Baghdad 58-9, 74n12 
Bahā' al-Dīn, Shaikh 26

bakhshi 174, 177, 182n10, n12, 185n21

Balāsāghūn 6, 133, 153n26, 154n28, $155 \mathrm{n} 33,156 \mathrm{n} 34$

Balkh 4

Bāqirghān 90-2, 109n5, 110n9, 112n17

Bâqirghân kitâbr 175, 183n17, 184n18

Barāq Bābā 200, 233n37, 234n38

Bashqird 130-1

Basmil 130

bātiñ̄ 230n34, 232n35-6, 234n38, 239n43, 320, 354n56, 362

Battāl Ghāzī 207, 249n74

Bayrāsh b. Ibrāsh Șūfī 30

Bektashī, Bektashiyya xvi, xix, 39n8, 49n50, 53n66, 54n68, 55n72, 56n73, 102, 104, 120n54, 122n60, 123n62, 233n36, 239n43, 257n87, 268-70, 277, 280n1, 281n4, 366-8, 370n1, 371n4, $382 \mathrm{n} 26$

Bughrā Khān 10-11, 30, 89-91, 111n15, 156 n34

Bukhārā 5, 7-8, 22, 28, 36, 43n19, 58-61, 63, 72n8, 73n9, 74n12, 77n28, n30, 93, 132, 146n14, 191

Bulghar Turks 36

Burhān al-Dīn Tirmidhī 202-4, 208, $240 \mathrm{n} 47$

Chaghatay, 130, 134, 157n39, 159n41, 177-8, 179n2, 184n19, 185n20

Charuq 130-1

Chelebi Ḥusām al-Dīn 204, 206, 247n64, 248n69

Chigil 130-1

China 4-5, 9, 11, 17, 50n52, 147n15, $150 \mathrm{n} 21,152 \mathrm{n} 24$

Chomul 130-1

creation: Șūfì view of 339 n28

dastān 17n31, 160n45

dawriyya 318-19, 350n45, 366, 375n11

Dede Korkut 15n19, 18n33, 187n27, 211-12, 264n107, 265n108, 405

deyis $211,26 \ln 99$

Dĩwān of Yūsuf Emre 302-3, 324n1, 327n4, 328n7; linguistic character of 303-4; literary character of 304-7

Dīwān-i Hikmat xix-xxiv, 127-30, 137-8, 159n41, 171-3, 175-7, 179n2, 180n3; date of $141 \mathrm{n} 4$; editions of $142 \mathrm{n} 6$; linguistic character of 130-4; literary character of 134-6; manuscripts of $142 n 4$

elegies 11

erens 213; of Khurāsān 23, 33-5

Eşrefoğlu 365, 374n11

ethics 333n20, 334n23, 335n24, 336n25

existence: Sūfì view of $34 \ln 29$

Evliyā Chelebi xv, 31-2, 64

Faḍl Allāh al-Na '̄imī Astarābādhī Hurūfī 321, 358n62; see also Hurūfī

fan $\bar{a}^{\prime} 14 \mathrm{n} 9,117 \mathrm{n} 40,311$

Fārāb 6, 154n28, 132

Farghānā 4-8

Farīd al-Dīn 'Atțār 15n18, 28, 139-40, $16 \ln 47,167 n 56,168 n 57,202,248 n 68$

folk literature 210-11

futwrwa 200, 235n39, 236n40, 238n43

Gawhar Shahnāz 20, 57, 64

Geyikli Bābā 31, 49n49-50, 231n35, 266n111, 270

ghazal 9, 220n11

al-Ghazālī 7, 198, 348n38

Ghaibī, Șunu' Allāh 365, 378n18, 380n19

Ghujduwānī, 'Abd al-Khāliq xviii, 22, 4ln12, 47n43, 59-61, 73n9, 75n20, 77n24, n30, 103-4, 119n49, 222n18

Gijgij Dede 32

Göktürks 4, 132, 146n14, 147n15, 151n23, 152n24; see also Qarakhānids

Gülshehrī 209, 239n44, 251n77, 256n84, 257n85, 326n2

Gurgān 5

Hac1 Kemal 302, 327n3, 328n6

Hadrat-i Turkistan 30, 57; see also Yas̄̄

Ḥājjī Bayram 284n15, 289n23, 363, 365, $372 \mathrm{n} 7$

Hāijī Bektash 32-5, 37, 39n8, 48n47-8, 49n50, 50n51, n53, 51n61, 52n65-6, 54n68-9, 55n71, 104, 121n59, 122n60, 123n61, 198, 229n30, 239n43, 268-70, $201 n 3$

Hāijjim Sulțān 35

Hakīm Ata, Sulaimān xii, xiv, 24-7, 42n17, 87n65, 89-92, 108n4-5, 109n7, 110n13-14, $11 \ln 15,112 \mathrm{n} 17,128,173$, 175-6, 183n17, 287n21

Hakīm Sanā'ī 74n18, 79n34, 139, 167n56, 168n57, 248n68 
hăl 342n31

al-Ḥallāj 7, 22, 137, 163n50, 311

Hamadān 58, 73n9

Hanafì, Hanafism 8, 58-9, 63, 75n20, 77n28, 79n37, 137, 232n36; and the Turks $15 \mathrm{n} 17$

Ḥasan Andāqī, Khwāja 60, 63, 73n9, $77 \mathrm{n} 30$

Hasan-oğlu 178, 186n25-6

Hazīn̄̄ xi, xiii, xv, xvii, xix, 37n1, 40n10, 116n31, 169n58, 409

Herat 7, 43n19, 51n61, 59, 74n14

Hidāyat Allāh Āfāq 31, 47n40

Hindal Mīrzā 29

Horos Dede 31, 50n51

Hubbī Khwāja 91-2

Humāyūn 29, 46n33, 107

Hurūfí, Hurūfism 104, 123n62, 230n34, 321, 355n57, 356n59, n61, 358n62, 367, 370n2, 382n26, 383n27; see also Faḍl Allāh al-Na'īmī Astarābādhī Hurūfì

Hüveyda, Chimyanlı 134, 175

Ibn al-'Arabī 197-9, 221n16, 309, 320, 348n38, 350n43, 356n61

Ibn al-Fārid 198

Ibn al-Najjār 59, 74n15, n19

Ibrāhīm Efendi 365, 378n18; see also Olanlar Shaikhi

Ibrāhīm Sulțān, Ḥājjī 268, 280n1

Idrīs Mukhtafì 365

Imām Marghuḍī 24-6

İqāniyya 105, 120n54

'Irāqī, Fakhr al-Dīn 198, 202, 227n24, 242n 51

Isfijāa 5, 133, 155n32

Isḥāq Khwāja xii-xiii

Jahriyya 30-1

Jāmī xv

al-Jandī, Mu'ayyad al-Dīn 198, 228n28

Fumjuma sulțān 177, 185n20

Kademli Bābā Sulțān 31

Kamāl Shaikh 94, 101

Kāmil Shaibān̄̄, Shaikh 26, 43n19

Kāshghar 6, 10-11, 130-1

kayabaşı 211, 261n100

Khadir 20, 23, 26, 28, 39n6, 4ln12, 60, 73n9, 90, 101, 119n49, 175, 183n16 khalq liii, lvii n2 khalwa 99-100, 118n44

Khalwatiyya 293n37

Khāqāniyya Turkish 131-3, 146n14, 149n19, 151n23, 153n26, 156n33, $158 \mathrm{n} 39$

kharābāt 170n59

Khațāî̀ (Shāh Ismā̄îl I) 278, 266, 298n55, 366, 381n24

Khudāidād xiii

Khurāsān 4, 7-11, 23-4, 29, 33-7, 48n47-8, 50n52, 53n67, 59, 62, 76n22, 77n28, 90, 104, 107, 132, 193

Khwājagān(六) xii, xviii

Khwārazm 23, 25, 37, 78n32, 89, 107, 112n17, 201, 230n33

Kirmānī, Awḥad al-Dīn 198, 226n23-4

Konya 208, 228n27, 229n32

Köprülü, M. F.: academic and scholarly career xxviii-xxxi; method and approach to research xiv-xvii

kopuz 3, 12, 185n21, 210-11, 258n87-8, 264n107, 367

Korkut Ata 8; see Dede Korkut

koşma 211, 260n97, 261n98, 307

Kutadgu Bilig 10-12, 16n27-8, 127, 133-5, 140, 153n26-7, 157n39, 159n42, 174, 179n2, 306

Lāhawrī, Ghulām Sarwar xvii

love: Șūfì view of 311, 344n34, n36, 346n 36

Luqmān-i Paranda 33-4, 51n61, 122n59

madrasa $11-12$

Mahabbatnāme 177, 184n19

Mahmūd of Ghazna 17n31, 215n2

Mahmūd Hairānī 268, 280n 1

Mahmūd al-Kāshgharī 130-3, 306

Maḥmūd Shabistarī 164n50, 170n59, 318, 353n52

Makhdūm Qulī 177, 186n24

Manșūr Ata 29, 46n32, 89

Marw 4, 7, 25, 58-9, 74n18

Mathnawī (of Rūmī) 205-6, 209, 247n64-5, 248n69, 318

mathnaw $10-11$

Mawlānā see Rūmī

metempsychosis 318,353 n52

Muhammad Baghdādī, Shaikh 26, $43 n 19$

Muhammad Dānishmend 24-5, 27, 42n17, 90, 109n7, 118n42 
Muhammad Ibn al-Hanafiyya 33, 35, 57, 66, 70n1, 7ln5, 87n66, 116n32, $250 \mathrm{n} 74$

Muhammad Sharīf of Bukhārā xiii

Mühlbacher 270, 278, 284n14, 302-3, $324 n 2$

Mu'īn al-Dīn Parwāna 198, 206, 227n24-5

al-Mu'tașim 5-6

Mu'tazilìi(sm) 8

Najm al-Dīn Dāya 198, 227n26

Najm al-Dīn Kubrā 43n19, 47n43, 62, 78n32, 197, 223n19, 225n21, 227n26, $243 n 54$

Naqshbanī(yya) xi-xii, xix, 36-7, 51n61, 56n73, 65, 73n9, 75n20, 77n31, 80n44, n46, 94, 102-4, 106-7, 120n54, $125 \mathrm{n} 70, \mathrm{n} 75$

Naqshī Aq Kirmānī 365, 377n17

al-Nāṣir li-Dīn Allāh 236n40

Nāṣir-i Khusraw 318

Nawā'̄̄, 'Alī Shīr xii, xxi, 134, 158n39, 172-4, 181n8

Neoplatonism 203, 244n58, 309, 318, 336n25, 337n26, 341n31, 353n52

Nesīmī 321, 381n23, 382n26

Nīshāpūr 7, 33, 43n19

Nithārī Bukhārī, Hasan xi, 38n4, 64, 108n1

Niyāzī Miṣrī 278, 285n17, 294n39, 297 n51

Oghuz 5-6, 39n7, 131-3, 145n13, 149n19, 150n23, 153n27, 154n28, 155n29 ก̃ 30, 156n34, 186n27, 191-3, 195, 207, 211-12, 214n1, 215n2, 257n87, 264n106, 264n107, 303

Oghuz menkabesi 12, 17n33

Oghuznāme 18n33, 185n21, 211-12, 262n104, 263n105-6, 264n107, $265 \mathrm{n} 108$

Olanlar Shaikhi 278, 365, 380n18-19; see also Ibrahim Efendi

Orhan, Sultan 31, 49n49, 48n46-7, 50n53, 52n66, 255n83, 270

Orkhon Inscriptions 132, 146n14, $15 \ln 23,153 n 27,214 n 1$ ozan $8,174,185 n 21,210-11,257 n 87-8$, 266n108, 266n109, 367-8, 384n29

Pantheism 244n58, 309 perfect man 318, 347n38, 349n42
Persian literature 9-11, 135, 159n42, 174, 207-8, 214, 219n11, 363

Pīr Dede 31

poets 299 n56

Qādirī (tañqa) 271, 286n19

qasīda 9, 220n11

Qara Khițāy 58

Qarachuq Mountain 21-2, 39n7, 154n28

Qaraja Ahmad 268, 270, 281n4, 283n11

Qarakhānids 8, 10-11, 17n31, 58, 77n28; see also Göktürks

Qarluqs 5-6, 132, 145n13, 148n16, 150n23-4, 152n25-6, 155n29, n33, 156n34, 157n35, 158n39, 215n2

Qay 130, 146n15

Qayghusuz 49n50, 277, 332n17, 350n45, 363, 365, 372n5, 374n11, 377n13, 383 n26-7

Qayı 146n15

Qāzān Khān 27

Qazaqs 31, 36, 69-70, 85n60, 87n67, 88n69, 113n17, 125n76, 127, 173

Qipchaqs 18n33, 30, 130-1, 133, 149n19, 153n27, 155n29, 158n39, 173, 177, 185n21

Q1zulbash 201, 278, 362, 365, 367, 382 n25

al-Qūnawī, Șadr al-Dīn 198, 227n24, n26, 228n27, n29, 243n54, 249n71

al-Qushairī, Abū 'l-Q̄āsim 7

Qutaiba b. Muslim 4-5

Quṭb al-Dīn Haidar 52n62

Qutham Shaikh 103, 121n55

Rashīd al-Dīn 17n33, 262n104

Rifā'ī 198, 233n36, 286n19

Rūm 35-6, 45n30, 48n46-7, 49n50, 50n52, 53n67, 268; see also Anatolia

Rūmī, Jalāl al-Dīn 161n46, 162n48-9, 163n50, 165n52, 167n56, 170n59, 201-6, 222n18, 227n26, 228n27, 229n32, 235n38, 240n46, 243n53-5, 244n56, 245n60-1, 247n67, 256n84, 261n99, 274, 278, 280n1, 309, 311, $316,318,320,33 \ln 17,340 \mathrm{n} 28$, 343n32, 345n36, 349n40, 351n47, 360n64

Sa'd al-Dīn, Shaikh 26

Sadr Ata 93-4, 113n18

Ṣadr-i Jihān 58 


\section{IN D E X}

Șadrs of Bukhārā 77n28

sagu 160n45

Sa'̄id Ata 89

Saif Allāh Khalwatī 365, 377n16, 378n18

Saif al-Dīn Bākharzī 26, 43n17, n19, 62

Sairām 20-2, 57, 70n1, 114n21, n26, 133, 145n12, 150n20, 155n32

Sakarya River 270-1, 275, 285n16

sama $\bar{a}^{`} 203,243 \mathrm{n} 54$

Sāmānids 5-6, 77n28, 130

Samarqand 4, 8, 23, 29, 36, 45n28, 58, 60-1, 64, 73n91, 76n20, 76n23, $145 n 14$

Sanjar, Sultan 60-2, 76n22, 77n28, 132, $223 n 18$

Sarı Ismā'ìl 268, 28ln3

Sarı Saltuk 35-6, 53n68, 55n72, 266n1 10

Sāsānids 4, 6, 9

Savrān 27, 44n25, 69, 154n28, 155n29

Sayyid Ahmad (Ata) 93-4, 104, 111n16, $112 \mathrm{n} 17,114 \mathrm{n} 23$

Sayyid Manșūr 29, 46n32, 115n30

Sayyidī 'Alī Ra'̄is 64-5, 104n17

saz 3, 174, 178, 182n12, 270n11, 364, $367-8$

Seljuk(s) 8, 15n17, 17n30, 77n28, 191-5; art 220n13; civilization in Anatolia 195-6, 210, 216n4, 217n5; court 258n88, 259n91

Shāh Ismā'îl I, see Khațā'̄

Shaikh Ibrāhīm 20-2, 57

Shaikh Nușrat 32

Shams al-Dīn Tabrīzī 202-4, 226n23, 24ln48-9, 242n52-3

Sharı $^{`}$ and the Șūfîs 273, 292n33-4, 308, 311

Shāsh 5-6, 36, 110; see also Tashkent

Shayyād Hamza 208, 253n79, 257n85

Shīī (sm) 8, 15n18, 77n28, 162n49

sigir 3, 216n 4

Sivrihisar 270, 282n7, 285n16, 300n57

Soghdia 4-6, 145n14

şölen 3, 110n12, 216n4

Șūfì movement 197-201

Șūfîs 166n54, 168n57; biographies of $14 n 10$

Sūfism in Turkistan 7-9; origins of 7

al-Suhrawardī, Shihāb al-Dīn xvii, 7, 118n44, 224n19, 226n23, 234n38, 333 n20

al-Suhrawardī al-Maqtūl 7

Sulaimān Turkmānī 200, 234n38

Sultān Ibrāhīm-i Thānī 34
Sulțān Walad 208-9, 245n60, 248n67, 254n80, 255n82, 256n84, 257n85, $326 \mathrm{n} 2,328 \mathrm{n} 10$

Șūrī 27, 45n26

syllabic meter xxvi n16, 3-4, 135, 160n44, 181n8, 209, 254n80, 261n98, 302, 305, 307, 329n13

Syr Darya 5, 8, 36-7, 39n7, 62, 65, 69, 107, 132-3, 145n14, 152n25, 154n28, 191

tajalli 315, 340n29

Talas 5, 72n6, 146n14, 150n20, 152n25, 154n28, 155n32, 155n33

Tapduk Emre 268-9, 271-2, 275, 277, 282n5, n7, 286n18, 287n20, n22

TTarāz see Talas

Tashkent 29, 62, 65, 92-4, 107, 113n20, 114n23, 132; see also Shāsh

Tatars 130

tekke 110n8; poetry 364-5, 373-8

Tīmūr 28, 36-7, 65-8, 81n47-8, 82n51, $83 n 57$

Tokhsi 130-1

Toquz Oghuz 5, 132, 145n13, 148n16, 152n26, 191, 214n1

Transoxiana 4-5, 7, 9-10, 23-4, 58-9, $77 \mathrm{n} 28,94,104,107$

T’u-chüeh 148n15, 155n32; see also Turks, Eastern

Türgesh 5

Turkish literature 255n83, 258n87, 261n98; influence of Iran on 9-11; popular literature 11-12, 159n43; pre-Islamic 3-4; Western Turkish literature 206-10, 369-70

türkmāñ 211, 260n96, 261n97

Turks 215n2; in Anatolia 191-5, 250n74; as described by Maḥmūd al-Kāshgharī 130-4; Eastern 4-5, 37, 41n14, 64, 127, 149n16-17, 153n27, 156n33; Islamization of 4-5; Northern 31, 36-7, 47n43, 69, 89, 127, 177; pre-Islamic 4-5; pre-Islamic survivals of 110n12, 111n14, 118n46, 259n91; Western 4-6, 31-2, 37, 52n66, 53n68, 152 n25

türkü 17n31, 178, 186n26, 211, 260n95, $26 \ln 97$

'Ubaid Allāh Ahrār 29, 93-4, 101, 105, 114n23, 119n51 
Uftāda, Shaikh 278, 296n47-8, 365

Ughraq 130-1

Uighur(s) 9, 11, 17n30, 130-2, 146n15, 150n21, 152n24, n26, 154n28, 157n39, 179n2, 184n19, 214n1, 263n105-6; see also Toquz Oghuz and Turks, Eastern Umayyads 5

Ummī Sinān 365, 376n12

Urgench 25

Ushrūsana 6

Uways al-Qaranī 289n23, 295n42

'uzla 118n44

varsağ 211, 260n97

wahdat al-wujūd 221n16, 305, 309-11, 338n27, 340n29

Yabaqu 130

Yaghma 130-1

Yarkand 31

Yasawī tarīqa: and Bektashī tradition xix; presence in Anatolia xix; rules of 94-9

Yas̄i 22-3, 25-7, 29, 36, 44n25, 57, 61-2, 64-5; present-day 69-70, 70n1, 72n6
Yedi-Su 5

Yimak 130-1

yoğ 3

Yūnus Emre: and 'āshrq literature 367-8; in Bektashī tradition 268-9; and Bektashī poetry 366-7; compared with Ahmad Yasawī 369-70; early life of 269-72; his burial place 274-7; his fame among Sūfîs and others 277-80; his influence $362-4$; his illiteracy 272-7, 291n31, 306; his work 302-3; and Hurūfism 321; as moralist 307-9; origin of his name 280n2; as Șūfì 309-20; and tekke poetry 364-5

Yūsuf Hamadānī xviii, 22-3, 4ln12, 73n9, n11-12, 74n15-19, 75n20, 77n27, 79n34, 104, 119n49, 122n59, 124n64, 165n51; in Bukhārā 58-61; his khaliffas 63

Yūsuf Khāṣs Ḥājib 10-11; see also Kutadgu Bilig

Yūsuf u Zulaikhā 173, 181n8

Zangī Ata (Bābā) 42n17, 89, 92-4, $11 \ln 15,113 \mathrm{n} 20,289 \mathrm{n} 24$

Zarkūb, Șalāh al-Dīn 203-4, 245n60 